\title{
Melhoria contínua aplicada a edificações de tipologia padronizada: a gestão do conhecimento no contexto do portfólio de ativos de uma organização
}

Tese apresentada à Faculdade de Arquitetura e
Urbanismo da Universidade de São Paulo para a
obtenção do título de Doutor em Arquitetura e Urbanismo

Área de concentração: Tecnologia da Arquitetura

Orientadora: Profa. Dra. Sheila Walbe Ornstein

São Paulo

2016 
Autorizo a reprodução e a divulgação total ou parcial deste trabalho, por qualquer meio convencional ou eletrônico, para fins de estudo e pesquisa, desde que citada a fonte.

EXEMPLAR REVISADO E ALTERADO EM RELAÇÃO À VERSÃO ORIGINAL, SOB RESPONSABILIDADE DO AUTOR E ANUÊNCIA DO ORIENTADOR.

O original encontra-se disponível na sede do programa.

São Paulo 20 de julho de 2016.

e-mail da autora: alimongi@usp.br

Catalogação da Publicação

França, Ana Judite Galbiatti Limongi

F814m Melhoria contínua aplicada a edificações de tipologia padronizada: a gestão do conhecimento no contexto do portfólio de ativos / Ana Judite Galbiatti Limongi França. -- São Paulo, 2016.

495 p. : il.

Tese (Doutorado - Área de Concentração: Tecnologia da Arquitetura) - FAUUSP.

Orientadora: Sheila Walbe Ornstein

1.Edificações (Desempenho) 2.Modelagem da informação 3.Gestão do conhecimento I.Título

CDU 69 


\section{DEDICATÓRIA}

Ao pequeno Pietro, recém-chegado e companheiro de incontáveis madrugadas. 


\section{AGRADECIMENTOS}

À Profa. Dra . Sheila Walbe Ornstein, minha orientadora durante o longo processo, que começou em 2007, quando fui sua aluna especial e perdurou até a conclusão da presente tese. Obrigada, por suas contribuições ao longo desta etapa tão importante de minha formação pessoal, acadêmica e profissional, durante o Programa de Pós-Graduação da FAUUSP, bem como no desenvolvimento das demais atividades acadêmicas.

À Universidade de São Paulo e, especialmente, aos professores, funcionários e colegas do Departamento de Tecnologia da Arquitetura da Faculdade de Arquitetura e Urbanismo, que me proporcionaram a vivência acadêmica fundamental para o desenvolvimento desta pesquisa.

Aos funcionários da Biblioteca da Faculdade de Arquitetura e Urbanismo, por sua sempre gentil colaboração e, em especial, à Bibliotecária Maria José Polleti.

Ao Prof. Dr. Marcelo Eduardo Giacaglia e ao Prof. Dr. Silvio Burrattino Melhado, pelas pertinentes contribuições dadas durante o exame de qualificação.

Ao Prof. Dr. Norberto Moura, cujos subsídios quanto à aplicação da tecnologia da informação à construção civil foram fundamentais para os resultados obtidos.

Aos professores e colegas do grupo de pesquisa CNPq Qualidade e Desempenho no Ambiente Construído, pelas importantes trocas de experiências quanto aos aspectos relacionados ao desempenho de edificações em uso.

Ao Prof. Eduardo Toledo Santos e à Profa. Dra. Regina Ruschel, pelas contribuições à pesquisa, quanto aos aspectos da modelagem da informação da construção.

À OTEC, na pessoa de seu Diretor de Desenvolvimento David Douek, pelo suporte ao desenvolvimento desta pesquisa. Aos estimados colegas de empresa, pela criação de um fértil ambiente para troca de experiências quanto ao desempenho do ambiente construído. À Arq. Ms. Maíra André pelas contribuições para as simulações de conforto térmico realizadas para o modelo.

À Nosyko AS, pela licença educacional concedida para o aplicativo de Banco de Dados dRofus, fundamental para o desenvolvimento da pesquisa. Ao Arq. David Patera, pelo treinamento e orientação necessária à utilização da ferramenta.

À Solibri e ao Eng. David Oliveira, da empresa CAD Technology, pela 
concessão da licença do programa computacional Solibri Model Checker.

À Autodesk, pela licença educacional do programa computacional Revit e do plug-in DB link (versões 2012, 2013 e 2014). Ao Arq. Ricardo Bianca, pela entrevista concedida. À equipe da BestSoftware, pelo suporte técnico.

Ao Rodolfo Jambas Guilherme e ao Tiago Sathler, da Bentley Systems, Incorporated, por terem fornecido informações necessárias à etapa exploratória das soluções tecnológicas.

À Diretora Associada da Smithsonian Institution, Sylvia Kendra, por ter gentilmente compatilhado material técnico referente à experiência da instituição quanto à modelagem da informação e à gestão de seus ativos.

Ao Arq. Luiz Augusto Contier, da Contier Arquitetura, à Eng. Arq. Joyce Paula Martín Delatorre, da Método Engenharia, ao Eng. Marco Antonio Nascimento da Mota, Gerente Setorial de Projeto e Suprimento da Sede da Unidade de Operações da Bacia de Santos (UO-BS) Petrobrás, ao Arquiteto Henrique Cambiaghi, da Cambiaghi Arquitetura, à Arq. Dra. Maria Beatriz Pestana Barbosa e ao Coordenador de Manutenção Civil Carlos Adriano Perez Pinto, da Companhia do Metropolitano de São Paulo, pelas entrevistas concedidas.

Ao Tenente-Coronel Washington Gutenberg de Moura Lüke, do Exército Brasileiro, pelos esclarecimentos prestados, referentes ao Sistema OPUS.

Ao arquiteto Leandro Hideki Okamoto, por ter contribuído para a elaboração do modelo tridimensional.

À Fundação para o Desenvolvimento da Educação, por possibilitar acesso às edificações educacionais, durante o período entre 2008 e 2011.

A meu marido Sergio, a meu pequeno Pietro, a minha mãe Eliná, a minha tia Elza e a meu irmão Carlos Otávio, pelo apoio e compreensão, ao longo deste processo.

A todos que, de alguma maneira, contribuíram para o êxito desta pesquisa, meus sinceros agradecimentos, na certeza de que, sem sua colaboração, os resultados aqui apresentados não teriam sido possíveis. 


\section{RESUMO}

Muitas vezes, o setor da construção civil brasileira sofre com a falta de formalização dos processos necessários às fases de concepção, construção, operação e manutenção de um empreendimento. Entretanto, a gestão eficiente da informação relacionada ao ambiente construído pode contribuir para o aprendizado quanto às experiências pregressas. Isso é importante, pois se espera que os resultados de diagnósticos, quanto ao desempenho de um edifício em uso, possam orientar revisões quanto às orientações para projeto futuros. A presente tese objetiva propor um modelo metodológico de gestão para os edifícios de tipologia padronizada, existentes e futuros. No caso de edificações de tipologia semelhante, essa abordagem permite melhorar de modo contínuo o desempenho de edificações, pelo aprimoramento das diretrizes para especificações. Considerando estes aspectos, Avaliações Pós-Ocupação (APOs) foram aplicadas a escolas públicas paulistas, voltadas ao ensino fundamental e médio, no período entre 2008 e 2011. Com base na análise dos resultados obtidos, foi verificada a pertinência quanto à revisão das orientações de projeto e dos procedimentos de manutenção. Visto que estas edificações compartilham de programas de necessidades e de especificações para componentes e sistemas construtivos, verificou-se ser oportuno formalizar um processo para a gestão do conhecimento. Deste modo, pode-se embasar a comunicação das informações relacionadas a uma edificação, de forma estruturada e acessível, para os atores envolvidos nos processos de construção e de gerenciamento do edifício. O presente estudo apresenta proposições, quanto à revisão de processos e discute os recursos tecnológicos necessários para que o desempenho aferido das edificações sob a gestão de uma mesma organização seja eficientemente documentado, a fim de possibilitar, inclusive, a comparação entre os edifícios. Nesse contexto, aspectos da gestão do conhecimento são aventados, ao longo do ciclo de vida da edificação, com o objetivo de melhorar seus níveis de qualidade ambiental, bem como manter a vida útil prevista em projeto para seus componentes e sistemas construtivos, visando à promoção da qualidade no ambiente construído. 
Palavras-chave: Desempenho no ambiente construído, Modelagem da Informação, Edificações, Gestão do Conhecimento. 
The Brazilian construction industry is often affected by the lack of formalization for the design, construction, operation and maintenance processes. However, the efficient information management can improve the sharing of lessons learned from previous results regarding building performance. This is important, because it is expected that this information is used for reviewing new construction requirements. In the case of similar buildings, this approach allows improving the built environment performance, by continuously reviewing the design guidelines. Considering these aspects, Post-Occupancy Evaluations (POEs) were applied to São Paulo public educational facilities, in the period between 2008 and 2011. From these results analysis, the design guidelines and maintenance procedures review was considered relevant. Since these buildings are standardized and share functional programming and specifications for building systems and components, it was considered appropriate to formalize a process for the information management. Therefore, the information related to a building can be managed in a structured manner, accessible for the players engaged in the building design and facility management. This research shows an approach regarding the knowledge management and discusses the technological resources required for the performance of buildings assessed under the management of one organization, in order to be efficiently documented. These procedures also aim to promote the quality in the built environment, by enabling comparisons between similar buildings, in order to improve their performance and maintainability levels, throughout the expected service life of the building components and construction systems.

Keywords: Built Environment Performance, Information Modeling, Knowledge Management. 


\section{LISTA DE FIGURAS}

Figura 1. Modelo de gestão vigente na FDE para a construção de edificações escolares. ...........................10

Figura 2. Procedimentos metodológicos para elaboração da tese ........................................................13

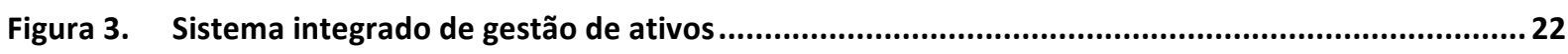

Figura 4. Ciclo do processo "planejar, executar, avaliar e corrigir" .......................................................25

Figura 5. Modelo do processo construtivo e seus controles de qualidade, conforme Meseguer.................30

Figura 6. Processo intelectual de projeto..................................................................................41

Figura 7. Fluxograma do processo de tomada de decisões visando à gestão da qualidade ........................51

Figura 8. Procedimentos para a avaliação do desempenho dos edifícios ...............................................52

Figura 9. Diferença entre estratégias de desenho manual e CAD. ........................................................60

Figura 10. Modelo de relações entre as etapas do processo de projeto. ............................................62

Figura 11. Estrutura de modelagem da informação georreferenciada em um empreendimento .............74

Figura 12. Relações entre o inventário de equipamentos e a gestão financeira das instalações e da organização ..................................................................................................................... 80

Figura 13. Abordagem sistêmica para a gestão de projetos..........................................................82

Figura 14. Desvio entre os requisitos do proprietário e as soluções de projeto .....................................84

Figura 15. Fluxo de processo para projeto no qual arquitetos e subcontratados compartilham um modelo BIM 86

Figura 16. Evolução do processo de projeto, em função das práticas de colaboração............................87

Figura 17. Processo de projeto convencional comparado ao processo de projeto integrado ...................89

Figura 18. Recursos da BIM que contribuem para apresentar respostas ao aumento de pressão sobre o processo de projeto

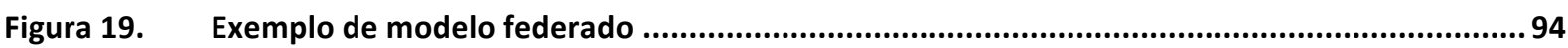

Figura 20. Aspectos fundamentais do processo colaborativo de modelagem da informação...................96

Figura 21. Representação esquemática da relevância da informação da construção, por tipo, ao longo da vida útil da edificação.

Figura 22. Representação esquemática da organização de diferentes níveis de informação em um modelo 107

Figura 23. Requisitos dos usuários para a troca de informações....................................................108

Figura 24. Organização das informações em um arquivo COBie .........................................................111

Figura 25. Exemplos de atributos em modelo de entes e relacionamentos ..........................................120

Figura 26. Processo de projeto proposto pela SI ..........................................................................142

Figura 27. Exemplos de parâmetros disponíveis nos templates da SI ............................................. 143

Figura 28. Exemplo de visualização de informação georreferenciada de instalações prediais do complexo gerido pela SI. 
Figura 29. Exemplo de leiaute para página de consulta de informações técnicas referentes ao NASM...145

Figura 30. Mapa da linha ferroviária Crossrail .............................................................................148

Figura 31. Gestão da informação, ao longo do ciclo de vida, no contexto do projeto Crossrail...............150

Figura 32. Informações relevantes à representação do ativo, no contexto do projeto Crossrail .............150

Figura 33. Exemplo de modelagem da informação do ativo no empreendimento Crossrail.....................151

Figura 34. Vista de parte do projeto da Crossrail no contexto da malha urbana e das instalações

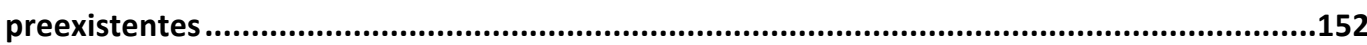

Figura 35. Vista tridimensional da Tottenham Court Road Station.....................................................153

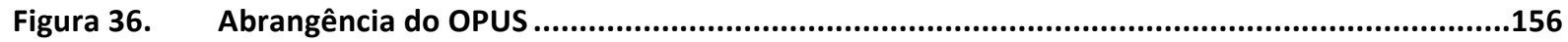

Figura 37. Aspectos gerenciados por meio do sistema OPUS ...................................................157

Figura 38. Interface do sistema OPUS para a elaboração de planejamento estratégico .........................158

Figura 39. Exemplos de georreferenciamento de informações contempladas pelo sistema OPUS..........159

Figura 40. Exemplo de informação georreferenciada modelada no sistema OPUS................................159

Figura 41. Exemplos de recursos para o monitoramento de obras - Sistema OPUS ..............................160

Figura 42. Vistas tridimensionais do modelo federado BIM da Sede Administrativa da UO-BS ..............162

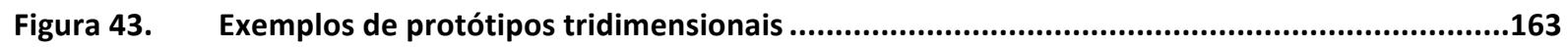

Figura 44. Fluxograma referente à modelagem da informação para o projeto da Sede Administrativa da UO-BS

Figura 45. Detalhes de sistemas prediais modelados para o projeto da Sede Administrativa da UO-BS. 164

Figura 46. Exemplo de lista de material de acabamento ................................................................165

Figura 47. Esforços relacionados aos processos de projeto tradicional e BIM ....................................173

Figura 48. Modelo de relações entre as etapas do processo de projeto proposto..................................175

Figura 49. Símbolos para a elaboração de fluxogramas ...................................................................177

Figura 50. Fluxo de informações simplificado do projeto..................................................................178

Figura 51. Recursos resultados das etapas do ciclo de vida de unidades da construção, considerando a abordagem da pesquisa ...............................................................................................179

Figura 52. Esquema simplificado do processo proposto..........................................................180

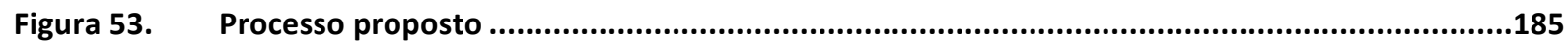

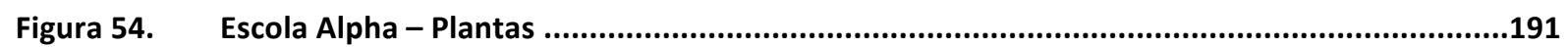

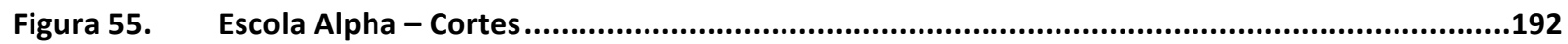

Figura 56. Exemplo de propriedades consideradas para a elaboração do Banco de Dados.....................196

Figura 57. Entes e relacionamentos, no âmbito de uma organização ..................................................198

Figura 58. Critérios da legenda, para identificação de um elemento do Modelo, quanto à localização geográfica.

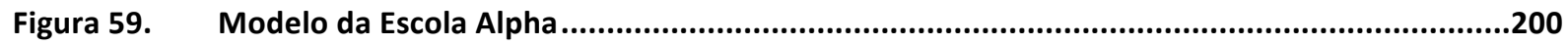

Figura 60. Detalhe da modelagem do componente no modelo BIM.................................................201

Figura 61. Detalhe do diagnóstico elaborado durante o processo de APO para o componente EF-06.....202

Figura 62. Aspecto do Banco de Dados consolidado por meio da utilização da plataforma dRofus .........203 
Figura 63. Arquitetura simplificada do sistema 204

Figura 64. Representação esquemática do acesso de vários projetos ao Banco de Dados comum 205

Figura 65. Exemplo de interface para a atribuição de responsabilidades...........................................206

Figura 66. Exemplo de classificação de componentes em grupos para orçamentação ........................... 207

Figura 67. Apresentação hierárquica das informações ............................................................... 208

Figura 68. Representação esquemática da arquitetura do sistema ....................................................209

Figura 69. Exemplo de ficha de componente configurada para o projeto da Escola Alpha .....................212

Figura 70. Exemplo de pesquisa de ocorrência de componente e respectiva localização no modelo. .... 213

Figura 71. Exemplos de componentes inseridos em ambientes internos, modelados para a Escola Alpha 214

Figura 72. Exemplo de compatibilização entre os componentes especificados na ficha de ambientes e o projetado

Figura 73. Lista de componentes especificados para uma sala de aula. .224

Figura 74. Exemplo de ambiente modelado e lista de componentes sincronizada com o Banco de Dados .225

Figura 75. Exemplo de componente inserido no modelo, sincronizado com o Banco de Dados .... .226

Figura 76. Exemplo de componente atribuído a uma unidade administrativa . 227

Figura 77. Exemplo de lista de ambientes que compartilham fichas de requisitos para o projeto... 228

Figura 78. Exemplo de propriedades configuradas em fichas técnicas de ambiente ..............................2229

Figura 79. Exemplo de lista de ambientes organizado por conjunto funcional....................................2230

Figura 80. Exemplo de visualização de lista de ambientes para a Escola Alpha.................................... 231

Figura 81. Aspecto da interface gráfica referente às informações relacionadas ao ambiente. ............... 232

Figura 82. Exemplo de ficha de ambiente gerada a partir da plataforma de Banco de Dados ................ 233

Figura 83. Exemplo de ficha de ambiente gerada a partir da plataforma de Banco de Dados ............... 234

Figura 84. Exemplo de interface gráfica para acesso às premissas de projeto e aos requisitos do proprietário

Figura 85. Exemplo de tela para a inserção dos aspectos críticos identificados, relacionados a um ambiente 237

Figura 86. Modelo tridimensional elaborado para uma sala de aula. .238

Figura 87. Exemplo de especificação não compatível com o executado 240

Figura 88. Exemplo de componente modelado projetado sob medida, que apresentou desempenho insatisfatório.

Figura 89. Modelagem do componente exaustor (EX-01) 244

Figura 90. Exemplo de evidência de aspectos críticos identificados por meio da aplicação de questionários, durante processo de APO

Figura 91. Exemplo de pesquisa para a verificação de alterações referentes a uma ficha de ambiente. 248 Figura 92. Exemplo de inclusão de informações relacionadas a diferentes edificações no BD. 255 
Figura 93. Conceituação de desempenho efetivo

Figura 94. Exemplo de menu configurado no Banco de Dados para a determinação dos requisitos do proprietário

Figura 95. Processo para a consolidação de um sistema de indicadores para edificações de tipologia construtiva semelhante

Figura 96. Menu disponível no programa computacional Revit v. 2014 para a elaboração de análises de desempenho da envoltória

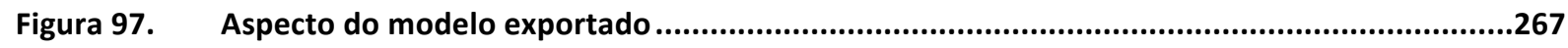

Figura 98. Exemplo de falta de elementos construtivos de divisão interna entre ambientes..................268

Figura 99. Exemplo de falta de elementos construtivos com geometria alterada (cobogós)..................268

Figura 100. Exemplo de falta de elementos construtivos (janelas) ..................................................269

Figura 101. Exemplo de elemento exportado com características diferentes das modeladas..................269

Figura 102. Exemplo de pesquisa utilizando a localização geográfica como critério ................................272

Figura 103. Escola Alpha: localização geográfica determinada por meio do software Terraview V. 4.2.2 e modelo relacionado.

Figura 104. Exemplo de análise comparativa referente a resultados de desempenho de edificações do portfólio

Figura 105. Níveis de organização das informações - configuração inicial 


\section{LISTA DE FOTOS}

Foto 1. Vizinhança típica de escola estadual situada na Região Metropolitana de São Paulo 8

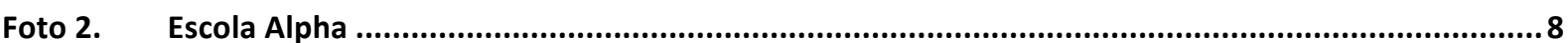

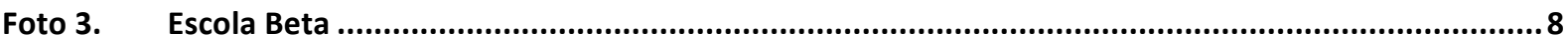

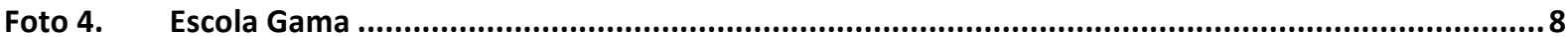

Foto 5. Evidência da instalação de elemento improvisado, fixado à janela, para controle de incidência solar

Foto 6. Evidência do desempenho inadequado de fechadura ......................................................239

Foto 7. Evidências relacionadas à manutenção predial ................................................................240

Foto 8. Evidência relacionada à manutenção predial ....................................................................... 240

Foto 9. Exemplo de detalhamento estrutural a ser revisto: pilar metálico em contato direto com o piso cerâmico

Foto 10. Exemplo de corrimão tubular desenvolvido sob medida para o projeto 242

Foto 11. Evidência de situação existente em desacordo com o previsto em projeto (degraus) ................243

Foto 12. Evidência de ocorrência associada ao componente exaustor (EX-01)..................................... 245

Foto 13. Evidência de ocorrência associada ao componente banco (BC-17)........................................246 


\section{LISTA DE GRÁFICOS}

Gráfico 1. Período de utilização da tecnologia BIM - comparação entre o Brasil e os demais participantes da pesquisa. 131

Gráfico 2. Nível declarado de conhecimento, quanto aos recursos de BIM . 133

Gráfico 3. Número de não conformidades quanto ao desempenho (ABNT, 2013) ..............................249

Gráfico 4. Temperaturas médias diurnas utilizadas na simulação ...................................................... 265

Gráfico 5. Relatório de temperaturas internas (anual) ...............................................................266

Gráfico 6. Escola Alpha - Comportamento térmico da Sala de Aula 15 ..............................................2 270 


\section{LISTA DE QUADROS}

Quadro 1. Comparação de recursos da tecnologia para BIM, quando comparada à tecnologia convencional. 91

Quadro 2. Normas desenvolvidas pelo NIBS para a padronização de troca de informações modeladas ....... 109

Quadro 3. Tabelas de terminologia OminiClass ......................................................................... 112

Quadro 4. Estrutura de classes proposta pela NBR 15.965:2011 ..................................................... 114

Quadro 5. Níveis de detalhamento da informação modelada.............................................................. 115

Quadro 6. Nível de Maturidade da informação relacionada à gestão de ativo ......................................... 118

Quadro 7. Níveis de Maturidade BIM, conforme Succar (2009) ............................................................. 118

Quadro 8. Sumário das principais iniciativas para a regulamentação de BIM ......................................... 124

Quadro 9. Guias de diretrizes para BIM, publicados pela GSA. ........................................................ 137

Quadro 10. Ficha técnica: Smithsonian Institution ...................................................................... 141

Quadro 11. Usos a serem considerados pela SI para a modelagem da informação ..................................147

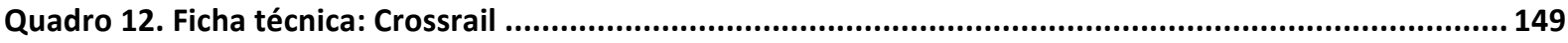

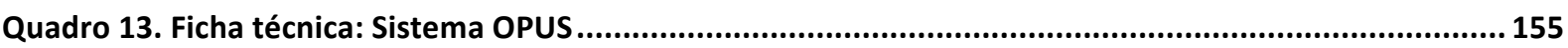

Quadro 14. Ficha técnica: Sede Administrativa da UO-BS................................................................. 161

Quadro 15. Principais programas para modelagem da informação utilizados nos processos dos exemplos

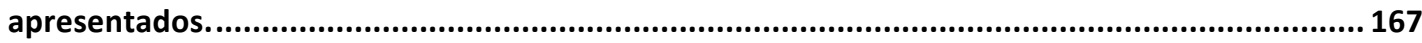

Quadro 16. Matriz de responsabilidades para o processo proposto ......................................................... 188

Quadro 17. Especificações de projeto da Escola Alpha ...................................................................... 190

Quadro 18. Dados de Ocupação para a Escola Alpha ......................................................................... 190

Quadro 19. Ambientes e respectivas áreas - Escola Alpha ................................................................. 192

Quadro 20. Análise dos ambientes e usos identificados na Escola Alpha ................................................. 194

Quadro 21. Exemplo de organização das especificações técnicas correspondentes ao catálogo de componentes instalados na Escola Alpha

Quadro 22. Exemplo de organização das especificações técnicas correspondentes ao catálogo de serviços executados na Escola Alpha

Quadro 23. Exemplo de organização das especificações técnicas correspondentes a ambientes da Escola Alpha

Quadro 24. Exemplo de organização das especificações técnicas correspondentes às diretrizes de acessibilidade em ambientes, para a Escola Alpha

Quadro 25. Informações modeladas para a ocorrência ....................................................................... 236

Quadro 26. Exemplo de informações modeladas - ocorrência associada ao uso inadequado .......................244

Quadro 27. Exemplo de informações modeladas - ocorrência associada ao uso inadequado .......................246

Quadro 28. Exemplo de matriz de diagnóstico de aspectos críticos referentes à Escola Alpha .................... 251

Quadro 29. Exemplo de classificação da informação e de análise de recorrência de falha ..........................260 
ABNT - Associação Brasileira de Normas Técnicas.

ACADIA - Association for Computer-Aided Design in Architecture.

ACCV - Análise do Custo do Ciclo de Vida.

ACV - Análise do Ciclo de Vida.

AEC - Arquitetura, Engenharia e Construção.

AGC - The Associated General Contractors of America.

$A G I$ - The Association for Geographic Information.

AIA - American Institute of Architects.

ANAC - Agência Nacional de Aviação Civil.

ANSI - American National Standards Institute.

ANVISA - Agência Nacional de Vigilância Sanitária.

ANTAC - Associação Nacional de Tecnologia do Ambiente Construído.

AP- Anteprojeto.

API - Application Program Interface.

APO - Avaliação Pós-Ocupação.

ASCE - American Society of Civil Engineers.

ASQC - American Society for Quality Control.

AQUA - Alta Qualidade Ambiental.

ASHRAE - American Society of Heating, Refrigerating and Air-Conditioning Engineers.

AVAC - Sistemas de Aquecimento, Ventilação e Ar-condicionado.

BAMie - Building Automation Modeling information exchange (troca de informações modeladas, referentes à automação predial).

BAS - Building Automation System (Sistema de Automação Predial).

BBSR - Bundesinstitut für Bau-, Stadt- und Raumforschung.

$B C A$ - Singapore Building and Construction Authority.

BD - Banco de Dados.

BIC - Institute for BIM in Canada.

BIM - Building Information Modeling (Modelagem da Informação da Construção).

BIMMS-N - Building Information System for Maintenance and Management 
Support in National Government.

BIMNET EB - Rede BIM do Exército Brasileiro.

BIMSie - Service Interface exchange (Aplicativo de Interface de troca).

BLIS - Building Life Cycle Interoperable Software.

Bpie - Building Programming information exchange (troca de informações modeladas, referentes ao programa arquitetônico).

BPMN - Business Process Model and Notation (Notação para a Modelagem de Processos de Negócio).

BSI - The British Standards Institution.

BTC - Banco de Tecnologias Construtivas.

CAD - Computer-Aided Design (Desenho Assistido por Computador).

CAFM - Computer-Aided Facility Management (Gestão de Facilidades Assistida por Computador).

CapEx - Capital Expenditure (Investimento em Bens de Capital).

CBIC - Câmara Brasileira da Indústria da Construção.

CDHU - Companhia para o Desenvolvimento Habitacional e Urbano do Estado de São Paulo.

CERL - Construction Engineering Research Laboratory.

CHPS - The Colaborative for High Performance Schools.

CIB - Conseil International du Bâtiment - International Council for Research and Innovation in Building and Construction.

CIBSE - The Chartered Institution of Building Services Engineers.

$\mathrm{CIC}$ - Construction Industry Council.

CIE - Commission Internationale de L'Éclairage.

CIFE - Center for Integrated Facility Engineering.

CMMS - Computerized Maintenance Management System (Sistema de Gestão de Manutenção Automatizado).

CNPq - Conselho Nacional de Desenvolvimento Científico e Tecnológico. COBie - Construction-Operations Building information exchange (troca de informações modeladas, referentes à construção e à operação da edificação). CONESP - Companhia de Construções Escolares do Estado de São Paulo. CONMETRO - Conselho Nacional de Metrologia, Normalização e Qualidade Industrial. 
CPIC - Construction Project Information Committee.

CPOS - Companhia Paulista de Obras e Serviços.

CSTB - Centre Scientifique et Technique Du Bâtiment (Centro Científico e Técnico da Edificação).

CTECH - Comitê Nacional de Desenvolvimento Tecnológico da Habitação.

DDC - New York City Department of Design and Construction.

DEC - Departamento de Engenharia e Construção do Exército Brasileiro.

DECONCIC - Departamento da Indústria da Construção.

DNIT - Departamento Nacional de Infraestrutura de Transportes.

DOM - Diretoria de Obras Militares do Exército Brasileiro.

DOP - Departamento de Obras Públicas.

Dpatr - Diretoria de Patrimônio.

DPL - Densidade de Potência Luminosa.

DXF - Drawing Exchange Format.

EB - Exército Brasileiro.

EDIF - Divisão de Projetos do Departamento de Edificações da Prefeitura Municipal de São Paulo.

EDRA - Environmental Design Research Association.

ENTAC - Encontro Nacional de Tecnologia do Ambiente Construído.

EP- Estudo preliminar.

EPA - United States Environmental Protection Agency.

ERDC - United States Army Engineer Research and Development Center.

ERIC - Education Resources Information Center.

ERP - Enterprise Resource Planning (Planejamento de Recursos Empresariais).

ESRI - Environmental Systems Research Institute.

ETC- Equivalente a Tempo Completo.

EV - Estudo de viabilidade.

EVO - Efficiency Valuation Organizations.

FAUUSP - Faculdade de Arquitetura e Urbanismo da Universidade de São Paulo.

FDE - Fundação para o Desenvolvimento da Educação.

FECE - Fundo Estadual de Construções Escolares. 
FIESP - Federação das Indústrias do Estado de São Paulo.

GAE - Grupo Ambiente - Educação da Faculdade de Arquitetura e Urbanismo da Universidade Federal do Rio de Janeiro.

GBXML - Open Green Building eXtensible Markup Language.

GEPA - Grupo de Estudos e Inter-ações Pessoa Ambiente do Departamento de Arquitetura da Universidade Federal do Rio Grande do Norte.

GESC - Governo do Estado de Santa Catarina.

GSA - United States General Services Administration.

GRP - Government Resource Planning (Planejamento de Recursos Públicos).

HA - Hong Kong Housing Authority.

HIS - Habitação de Interesse Social.

HKIBIM - Hong Kong Institute of Building Information Modelling.

HM Government - Her Magesty's Government.

HVACie - Heating, Ventilation and Air Conditioning information exchange (troca de informações modeladas, referentes a sistemas de aquecimento, ventilação e ar condicionado).

IAI - International Alliance for Interoperability.

IAM - The Institute of Asset Management.

IAPS - International Association People-Environment Studies.

IBC - Institute for BIM in Canada.

IBGE - Institudo Brasileiro de Geografia e Estatística.

iBIM - Integrated Building Information Modeling (Modelagem Integrada da Informação da Construção).

IDF - Input Data File.

IFC - Industry Foundation Classes.

IFMA - International Facility Management Association.

INPE - Instituto Nacinal de Pesquisas Espaciais.

IEA - International Energy Agency.

IEC - International Eletrotechnical Commission.

IP - Internet Protocol.

ISO - International Organization for Standardization.

ITM - International Technical Management Committee.

IU - Indiana University. 
IUG- buildingSMART International User Goup.

LABAUT - Laboratório de Conforto Ambiental e Eficiência Energética do Departamento de Tecnologia da Arquitetura da Faculdade de Arquitetura e Urbanismo da Universidade de São Paulo.

LABEEE - Laboratório de Eficiência Energética em Edificações da Escola de Engenharia Civil da Universidade Federal de Santa Catarina.

LACCD - Los Angeles Community College Distric.

LBNL - Lawrence Berkeley National Laboratory.

Lcie - Life Cycle information exchange (troca de informações modeladas, referentes ao ciclo de vida).

LEED - Leadership in Energy and Environmental Design.

LV - Levantamento.

MCE - Medida de Conservação de Energia.

MDIC- Ministério do Desenvolvimento, da Indústria e Comércio Exterior.

MEC - Ministério da Educação e Cultura.

METRÔ - Companhia do Metropolitano de São Paulo.

M\&V - Medição e Verificação.

MILT - Ministry of Land, Infrastructure, Transport and Tourism of Japan.

MOLIT - Ministry of Land, Infrastructure and Transport in Korea.

MPOG - Ministério do Planejamento, Orçamento e Gestão.

NASM - National Air and Space Museum.

NATSPEC - Australia National Building Specification.

ND - Nível de Desenvolvimento.

NBIMS-US - National BIM Standard - United States.

NIBS - National Institute of Building Sciences.

NIST - United States National Institute of Standards and Technology.

NORIE - Núcleo Orientado para a Inovação da Edificação da Universidade Federal do Rio Grande do Sul.

NTU - National Taiwan University.

NUTAU - Núcleo de Pesquisa em Tecnologia da Arquitetura e Urbanismo da Universidade de São Paulo.

NYC - New York City.

OCCS - OmniClass Construction Classification System. 
ODBC - Open Database Connectivity.

OECD - Organisation for Economic Co-Operation and Development.

OM - Organizações Militares do Exército Brasileiro.

OMG - Object Management Group.

OpEx - Operational Expenditure (Despesas Operacionais).

OPUS - Sistema Unificado do Processo de Obras.

PAC - Programa de Aceleração do Crescimento.

PAS - Public Avaliable Specification (especificação de domínio público).

PB - Projeto Básico.

PBS - Public Building Services.

PBQP - Programa Brasileiro da Qualidade e Produtividade.

PBQP-H - Programa Brasileiro da Qualidade e Produtividade do Habitat.

PDOM - Plano Diretor de Organização Militar do Exército Brasileiro.

$P E$ - Projeto para execução.

PEO - Plano de Execução de Obras.

PGE - Plano de Gestão do Empreendimento.

PIB - Produto Interno Bruto.

PMI - Project Management Institute.

$\mathrm{PL}$ - Projeto Legal.

PN - Programa de necessidades.

PPS - Korea Public Procurement Service.

PR - Pré-execução.

PROCEL - Programa Nacional de Conservação de Energia Elétrica.

PROLUGAR - Grupo Qualidade do Lugar e Paisagem, da Faculdade de Arquitetura e Urbanismo da Universidade Federal do Rio de Janeiro.

PROPUR - Programa de Pós-Graduação em Planejamento Urbano e Regional da Universidade Federal do Rio Grande do Sul.

PSPP - Projeto Simultâneo do Produto e de sua Produção.

PSU - Pen State University.

Qtie - Quantity Takeoff information exchange (troca de informações modeladas para a elaboração de quantitativos).

QUALIHAB - Programa da Qualidade da Construção Habitacional do Estado de São Paulo. 
RDC - Resíduos de Construção e Demolição.

RIBA - Royal Institute of British Architects.

RIOURBE - Empresa de Urbanização Municipal da Cidade do Rio de Janeiro. SBD - Sistema de Banco de Dados.

SBQP - Simpósio Brasileiro de Qualidade de Projeto no Ambiente Construído.

SECOVI/SP - Sindicato das Empresas de Compra, Venda, Locação e Administração de Imóveis Comerciais e Residenciais do Estado de São Paulo.

SEE - Secretaria da Educação do Estado de São Paulo.

SEHAB/SP - Secretaria Municipal de Habitação de São Paulo.

SI - Smithsonian Institution.

SIG - Sistemas de Informação Geográfica.

SINAPI - Sistema de Preços, Custos e Índices.

SINAT - Sistema Nacional de Aprovações Técnicas.

SindusCon - Sindicato da Indústria da Construção Civil.

SisPatr - Sistema Gerencial de Acompanhamento e Controle Patrimonial do Exército Brasileiro.

SITdA - Società Italiana della Tecnologia dell' Architettura.

Sparkie - Electrical System information exchange (troca de informações modeladas, referentes a sistemas elétricos).

Spie - Specifiers' Properties information exchange (troca de informações modeladas, referentes a especificações técnicas de um produto).

SS - Secretaria Estadual da Saúde de São Paulo.

SSI - Swedish Standards Insitute.

STA - Swedish Transportation Administration.

TI - Tecnologia da Informação.

TIC - Tecnologias de Informação e Comunicação.

UE - União Europeia.

UFBA - Universidade Federal da Bahia.

UFC - Universidade Federal do Ceará.

UFPR - Universidade Federal do Paraná.

UFF - Universidade Federal Fluminense. 
UFRGS - Universidade Federal do Rio Grande do Sul.

UFV - Universidade Federal de Viçosa.

UNICAMP - Universidade Estadual de Campinas.

UO-BS - Unidade Operacional da Bacia de Santos da Petrobrás.

UPM - Universidade Presbiteriana Mackenzie.

USACE - United States Army Corps of Engineers.

USC - University of Southern California.

USGBC - United States Green Building Council.

USP - Universidade de São Paulo.

VA - Department of Veterans Affairs.

VA (CFM) - The United States Veterans Affairs Office of Construction and Facilities Management.

WALLie - Wall information exchange (troca de informações modeladas, referentes a propriedades de paredes).

WBDG - Whole Building Design Guide.

Wsie - Water System information exchange (troca de informações modeladas, referentes a sistemas hidráulicos). 
RESUMO VII

ABSTRACT IX

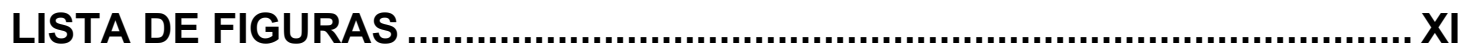

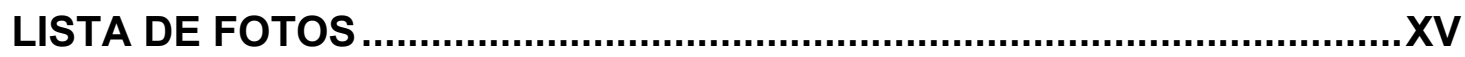

LISTA DE GRÁFICOS .......................................................................

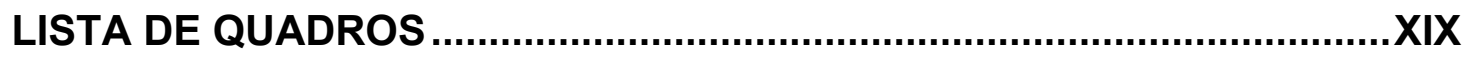

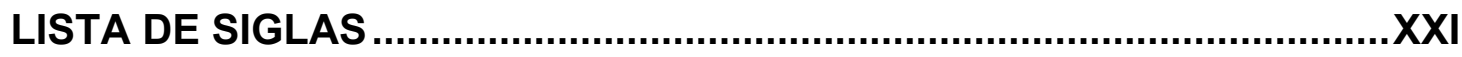

1 INTRODUÇÃO

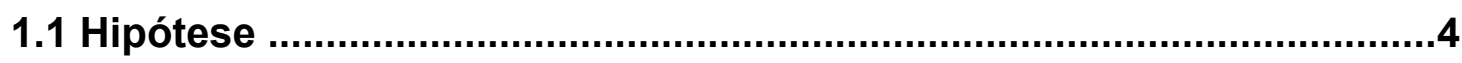

1.2 Estrutura da tese e descrição dos capítulos .........................................

2 APRESENTAÇÃO DO PROBLEMA

2.1 Caracterização da organização objeto de estudo .................................

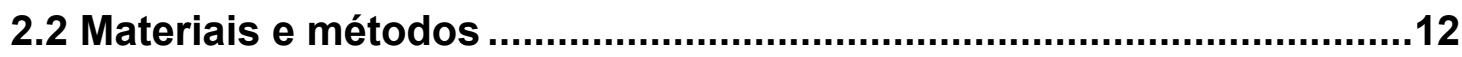

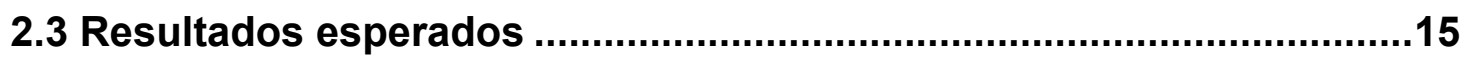

3 MELHORIA CONTÍNUA APLICADA ÀS EDIFICAÇÕES SOB A GESTÃO

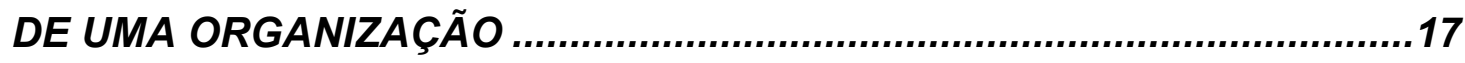

3.1 Conceituação de qualidade, desempenho e processo ........................17

3.2 Gerenciamento de edificações de tipologias semelhantes, no contexto de um portfólio. .20

3.3 Abordagem sistêmica e a melhoria contínua .23 
3.5 A formalização de processos e a indústria da construção civil brasileira

3.6 Processos integrados e gestão da informação para o suporte à produção e à operação do edifício

3.7 Boas práticas para a verificação e o monitoramento do desempenho no ambiente construído 47

3.7.1 Avaliação Pós-Ocupação (APO). 47

3.7.2 Processo de Comissionamento. .53

3.7.3 Avaliação e monitoramento do desempenho energético da edificação em uso

4 RECURSOS TECNOLÓGICOS PARA A GESTÃO DA INFORMAÇÃO... 55

4.1 Considerações sobre o projeto auxiliado por computador 59

4.2 Building Information Modeling (BIM) 64

4.3 Possíveis aplicações para a modelagem da informação 71

4.3.1 Georreferenciamento da informação. .71

4.3.2 Simulação de desempenho do projeto .75

4.4 Gestão da informação aplicada à edificação em uso 76

4.5 Recursos de modelagem da informação como catalisadores de alterações no processo de projeto.

\section{ASPECTOS RELEVANTES PARA O PLANEJAMENTO DA} MODELAGEM DA INFORMAÇÃO 101

5.1 Diretrizes para a normalização da informação modelada

5.2 Níveis de Desenvolvimento 115

5.3 Níveis de maturidade da modelagem da informação e seu impacto 
nos processos de projeto e de produção

5.4 Produtos do processo de projeto para permitir a gestão da informação

\section{PRINCIPAIS INICIATIVAS PARA O INCENTIVO DAS PRÁTICAS DE} MODELAGEM DA INFORMAÇÃO.

6.1 Abrangência dos recursos tecnológicos para a modelagem da informação 130

6.2 Exemplos de atores líderes em modelagem da informação 134

6.2.1 United States General Services Administration - GSA

6.2.2 The U. S. Veteran Affairs Office of Construction \& Facilities - VA(CFM) 138

6.3 Exemplos de boas práticas de modelagem da informação 139

6.3.1 Smithsonian Institution (SI)

6.3.2 Crossrail.

6.3.3 Exército Brasileiro (EB). 154

6.3.4 Sede Administrativa da Unidade Operacional da Bacia de Santos (UO-BS) da Petrobrás S. A.

6.3.5 Considerações sobre os exemplos apresentados. 166

\section{MODELAGEM DA INFORMAÇÃO APLICADA AO ESTUDO DE} CASO

7.1 Proposição de um processo para a gestão da informação em edificações de tipologia padronizada. 174

7.2 Caracterização da Escola Alpha 189

7.3 Conceitos e procedimentos adotados para a modelagem 196

7.4 Proposição de indicadores para verificação de desempenho .249

7.5 Definição de indicadores de desempenho. .252

7.6 Simulação do desempenho em projeto - oportunidades e limitações 
técnicas

7.7 Possibilidades de análises, utilizando informações georreferenciadas

7.8 Outros aspectos de interoperabilidade enfrentados durante o processo de modelagem

8 CONCLUSÕES E CONSIDERAÇÕES FINAIS

WEBSITES

APÊNDICES

APÊNDICE A - Lista de propriedades configuradas para a ficha de ambiente na plataforma de Banco de Dados

APÊNDICE B - Exemplos de fichas de diretrizes de projeto para ambientes, elaboradas por meio da plataforma de Banco de Dados dRofus v. 1.8 para a Escola Alpha.

APÊNDICE C - Relatório de aspectos críticos identificados na Escola Alpha, elaborado por meio da plataforma de Banco de Dados dRofus v. 1.8

APÊNDICE D - Exemplos de Ficha de especificações de componentes

APÊNDICE E - Considerações sobre os recursos tecnológicos e as ferramentas computacionais utilzadas 483

APÊNDICE F - Informações utilizadas para a modelagem: 485

ANEXOS

ANEXO A - Exemplo de ficha técnica de ambiente modelo FDE 489 
ANEXO B - Lista de classes IFC disponíveis para exportação, por meio do programa Autodesk Revit V. 2014 493

ANEXO C - Lista de tabelas que não são importadas pelo plug-in DB link... 


\section{INTRODUÇÃO}

Algumas organizações, públicas e privadas, são responsáveis por administrar um conjunto de edificações de tipologia semelhante, quanto a seus usos e perfis de operação, tais como: escolas, sedes corporativas, hospitais, redes metroferroviárias, redes aeroportuárias, centros comerciais e hotéis. Nesses casos, muitas vezes, são adotadas diretrizes para a padronização de seus projetos e soluções construtivas, de modo a tornar mais eficiente a gestão, durante seu período de vida útil.

Além disso, observa-se que, usualmente, não há um processo sistematizado para a avaliação de seu desempenho. Tampouco, verifica-se a proposição de melhorias, baseadas em um aprendizado organizacional.

Mesmo quando as edificações são submetidas a processos para avaliação de desempenho, e os respectivos resultados são divulgados às partes responsáveis, a desejada realimentação de projeto ainda não acontece de maneira sistematizada (FRANÇA, ORNSTEIN, 2014).

A presente pesquisa propõe-se a discutir o processo de projeto de uma edificação, considerando o compromisso com seu desempenho, quando em uso. Para tanto, é adotado como estudo de caso para a discussão do problema, um conjunto de edificações escolares da rede pública paulista, que apresenta as mencionadas características de padronização.

O desejo de se estabelecer um sistema de melhoria contínua para as edificações com características em comum não é novo. A respeito dessa questão, Wolfgang F. E. Preiser afirma, referindo-se à necessidade de que sejam avaliados ambientes construídos em uso:

Este processo é visto não somente como sendo linear, considerando um produto como objetivo, como por exemplo, a edificação completa e ocupada, mas, sim, como uma evolução cíclica, a qual tem como objetivo o aprimoramento contínuo da qualidade das edificações. Esse objetivo só pode ser alcançado se a avaliação for conduzida ao longo do processo de entrega da edificação e se: 
- a avaliação acontecer de maneira sistemática e rigorosa;

- a informação obtida alimentar bancos de dados e entidades, de modo que seja utilizado por gerações futuras de edificações; e

- houver continuidade no fluxo de informações. (PREISER, 1989, p. v, tradução nossa)

No discurso de Preiser (1989), fica claro que, já nos últimos anos da década de 1980, havia a percepção de que é necessário estabelecer um fluxo contínuo de informações entre as fases do ciclo de vida da edificação. Isso, em tese, também deveria acontecer entre os atores participantes dos processos decisórios pertinentes ao planejamento, ao projeto e ao uso do ambiente construído. No entanto, essa prática vem se mostrando desafiadora.

À medida que os processos de produção da edificação e de gestão de facilidades se formalizam, apoiados na evolução dos recursos tecnológicos, torna-se mais viável a prática de avaliações sistemáticas de sua eficiência, bem como o acesso a seus resultados. Portanto, os aspectos necessários para viabilizar a troca confiável de informações entre as fases do ciclo de vida dos edifícios, bem como entre edificações, devem ser explorados de maneira a consolidar o conhecimento acumulado.

Como marcos iniciais para a presente pesquisa, foram determinadas as seguintes premissas:

- a informação proveniente das avaliações aplicadas às edificações em uso não são incorporadas de modo sistemático a novos projetos;

- embora as edificações avaliadas apresentem aspectos relevantes de padronização, quanto a: programa de necessidades, tecnologia construtiva e especificações de componentes, foi observada a incidência de aspectos críticos recorrentes, tais como resistência de materiais e níveis de conforto ambiental inadequados, em várias edificações; e

- para a gestão da informação de uma edificação não se deve adotar 
abordagem fragmentada, restrita às fases de projeto e construção, mas sim, ser parte de um processo contínuo, que inclui todas as fases de seu ciclo de vida. A fragmentação pode implicar perdas quanto a sua confiabilidade e prejudicar um processo de aprendizado e melhoria contínua, o qual deve considerar os resultados referentes ao desempenho das soluções empregadas.

Por meio da proposição de um modelo metodológico de gestão para os edifícios de tipologia padronizada existentes e futuros, pretende-se contribuir para a manutenção da qualidade e do desempenho do ambiente construído, ao longo da vida útil de um conjunto de edificações com características semelhantes adotando, para tal, a incorporação de métodos sistemáticos. Faz parte de seu escopo a proposição de um processo que permita:

- planejar a edificação, com base em informações completas, organizadas e atuais (estudo de viabilidade, planejamento e elaboração do programa de necessidades);

- gerir a qualidade do projeto e da construção;

- verificar o desempenho do ambiente construído em uso; e

- sistematizar a informação, quanto aos resultados obtidos, tornando-a acessível a novo planejamento (seja nova edificação ou requalificada).

Desta forma, a abordagem proposta visa a formalizar os processos de avaliação do desempenho de cada etapa e, consequentemente, a identificação de aspectos críticos e de ações corretivas, de modo a embasar o estabelecimento de um ciclo de melhoria contínua. 
As atividades de projeto, produção e operação vêm sendo tratadas, no Brasil, como etapas estanques, de modo que a transferência de informações entre estas fases do ciclo de vida de uma edificação implica importantes perdas, relacionadas ao retrabalho para seu levantamento e validação, bem como a riscos associados a sua confiabilidade.

Por esse motivo, justifica-se uma abordagem integrada dos processos pertinentes às diversas fases da vida útil do ambiente construído. Também são propostas soluções para o acesso às informações, de modo a promover o conhecimento organizacional.

Isso apresenta fundamental importância para a promoção de seu desempenho, uma vez que, à medida que soluções são especificadas, implantadas e avaliadas de forma integrada e sistemática, é possível promover a gestão do conhecimento organizacional.

\subsection{HIPÓTESE}

É possível formalizar um processo para a gestão do conhecimento, de modo a incrementar a qualidade da construção civil no ambiente construído. Por meio da adoção de métodos e técnicas visando à avaliação sistemática e continuada de edifícios em uso, cujos sistemas construtivos e programas de necessidades são semelhantes, é possível tornar mais eficazes os processos de planejamento, projeto e construção. Nesse contexto, a gestão do conhecimento, consolidada por experiências pregressas pode contribuir para o melhor desempenho, do ponto de vista ambiental, funcional e financeiro, ao longo de toda a vida útil de um ambiente construído. 


\subsection{ESTRUTURA DA TESE E DESCRIÇÃO DOS CAPÍTULOS}

No Capítulo 2, é apresentado o problema, a saber, a questão da transferência eficiente da informação entre os atores responsáveis pela tomada de decisões, ao longo das diferentes fases do ciclo de vida de uma edificação. Para tanto, são apresentados os materiais e os métodos adotados. Também são apresentadas as condições pregressas, que levaram à identificação desta condição, pela aplicação de Avaliações Pós-Ocupação (APOs) a edificações geridas pela organização objeto de estudo. Esta não dispunha, à época dos levantamentos (2008-2010), de um processo sistemático e formal de retroalimentação de projeto.

O Capítulo 3 propõe-se a discutir o estado da arte dos métodos e técnicas da gestão da qualidade, bem como sua aplicação, no contexto da construção civil brasileira. Além disso, pretende-se apresentar uma discussão sobre os conceitos e recursos necessários para análise dos aspectos críticos, cujas aplicações são pertinentes a edificações de tipologia construtiva padronizada.

Considerando-se que as atividades relacionadas à construção, muitas vezes, sofrem com a falta de formalização dos processos necessários às fases de concepção, construção, operação, manutenção e retroalimentação, a incorporação de procedimentos para a gestão da qualidade pode contribuir para: maior eficiência, redução de desperdícios e melhor controle do desempenho do ambiente construído entregue ao usuário.

Ainda no Capítulo 3 , com vistas a incorporar a efetiva prática da melhoria contínua aos edifícios, objeto de discussão pela presente pesquisa, são discutidas as abordagens a serem incorporadas a seu processo de produção, de modo a permitir a padronização de critérios de avaliação. A formalização desses critérios é necessária para garantir a integridade da informação, uma vez que esta consiste em subsídios para a realização de tarefas e tomada de decisões.

Assim sendo, no Capítulo 4, são debatidos aspectos sobre os principais recursos tecnológicos pertinentes à gestão eficiente da informação, durante as diferentes fases do ciclo de vida de uma edificação. Também são feitas considerações quanto a seus impactos nos processos de produção e operação de uma edificação, no contexto de um conjunto de edificações com características semelhantes, gerido por uma organização. 
No Capítulo 5, é feita uma reflexão sobre os desafios relacionados à incorporação dos conceitos apresentados no Capítulo 4. Com base no exposto, são discutidas as alternativas e as boas práticas para sua implantação.

De modo a consolidar o arcabouço teórico relacionado ao escopo da tese, no Capítulo 6, são apresentadas iniciativas identificadas para a disseminação da matéria no âmbito mundial. São identificados atores líderes e exemplos relevantes de sua aplicação, bem como são discutidas as práticas adotadas.

Com base na adoção de recursos da tecnologia da informação, como uma alternativa para o desenvolvimento de processos, no Capítulo 7, é proposto um processo para a modelagem da informação. São discutidas as soluções tecnológicas adotadas, de modo a permitir a troca de informações entre as fases do ciclo de vida da edificação. Também é apresentado um modelo de gestão do conhecimento adquirido apoiado nas experiências pregressas no âmbito do portfólio da organização, à medida que proporcionam subsídios para a formalização das atividades e contribuem para melhorar a comunicação entre os diversos atores.

Finalmente, no Capítulo 8, são elaboradas as conclusões sobre a aplicabilidade do processo proposto, de modo a corroborar a hipótese formulada para a pesquisa. Também são recomendados novos temas, para possíveis desdobramentos da pesquisa. 


\section{APRESENTAÇÃO DO PROBLEMA}

A presente investigação partiu da análise crítica dos processos de diagnóstico e da resposta obtida, por parte dos stakeholders ${ }^{1}$, com base nas APOs aplicadas a escolas públicas paulistas. Pressupõe-se que o modelo atualmente praticado não apresente configuração propícia para o acesso sistemático à informação. Desta forma, a investigação em curso pretende avaliar como a reformulação de processos envolvendo o planejamento, o projeto, a construção e a operação da edificação pode impactar as boas práticas da gestão da informação e dos métodos para a gestão da qualidade. Pretende-se avaliar também a relevância dos recursos tecnológicos disponíveis, para auxiliar no atendimento a essas metas.

\subsection{CARACTERIZAÇÃO DA ORGANIZAÇÃO OBJETO DE ESTUDO}

De modo que se possa processar os dados referentes a uma edificação e seus respectivos resultados de avaliação de desempenho, foram consideradas, como estudo de caso, as edificações escolares públicas paulistas, construídas a partir de 2003.

Nesse período, as escolas construídas na Região Metropolitana de São Paulo, foram edificadas a partir de diretrizes de projeto que incluiam a adoção de um sistema estrutural predominantemente em concreto armado e aço estrutural (este último com menor frequência, por apresentar custo mais alto do que o concreto armado), com o objetivo de permitir a elaboração de projetos de edificações de ensino-aprendizagem que apresentassem projetos diferenciados (SERAPIÃO, 2004).

Uma vez que gerir a qualidade da construção de edifícios públicos, apresentase como um grande desafio para seu planejamento e sua construção, a Fundação para o Desenvolvimento da Educação (FDE) desenvolveu um processo de padronização tipológica de seus edifícios escolares (FRANÇA, 2011). A formalização de um catálogo de componentes, serviços e ambientes (disponíveis

${ }^{1}$ Responsáveis pelas decisões durante o processo de projeto e de construção de um empreendimento. 
em: <http://fde.sp.gov.br>, acesso em 20 abr. 2014) e a adoção do sistema em estrutura pré-fabricada foram resultados de um longo processo de evolução de soluções de projeto e programas de necessidades (FERREIRA, MELLO, 2006).

Geralmente inseridas em áreas carentes de infraestrutura urbana, estas escolas ocupam terrenos com áreas restritas e, não raro, adotam a verticalização como solução para a acomodação do programa de necessidades, adquirindo um aspecto monumental, em meio a construções informais comumente existentes no entorno (Foto 1).

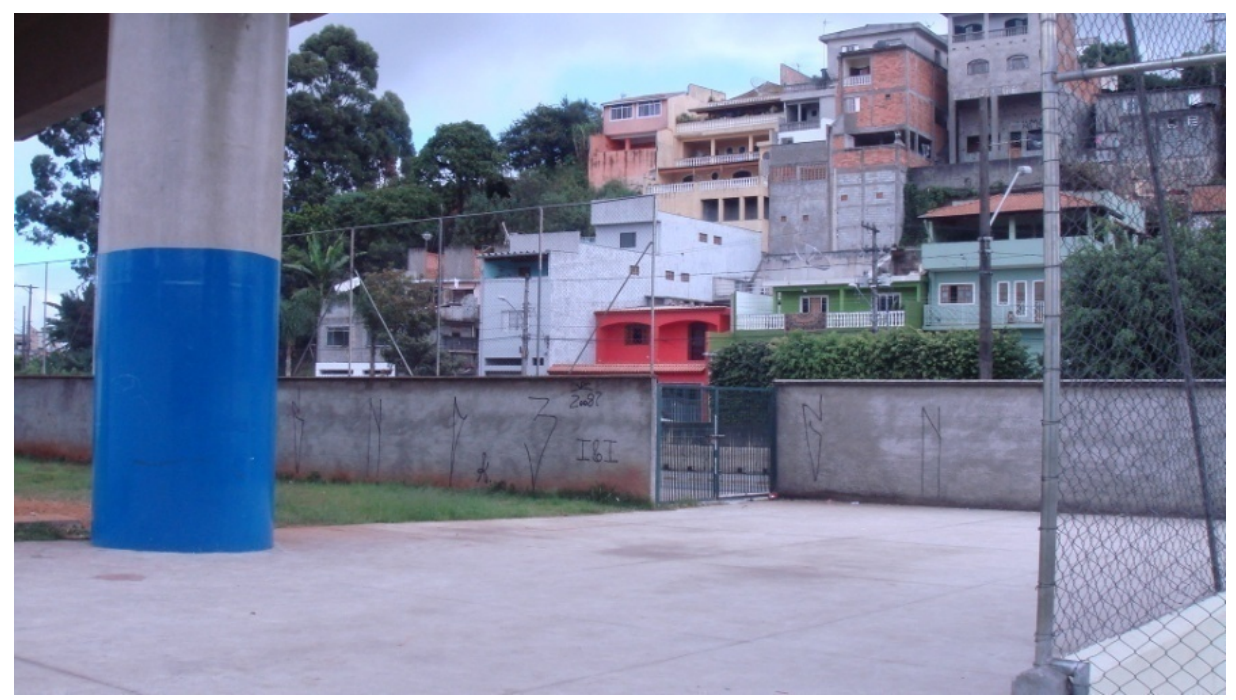

Foto 1. Vizinhança típica de escola estadual situada na Região Metropolitana de São Paulo Fonte: Acervo da pesquisadora.

A repetição desta tipologia construtiva foi determinante para que exista uma unidade arquitetônica facilmente identificável visualmente, conforme pode ser observado nas Fotos 2, 3 e 4.

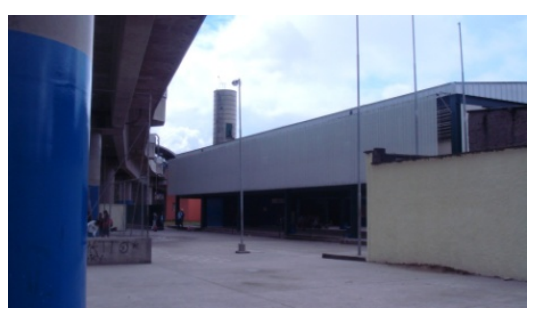

Foto 2. Escola Alpha Fonte: Acervo da pesquisadora.

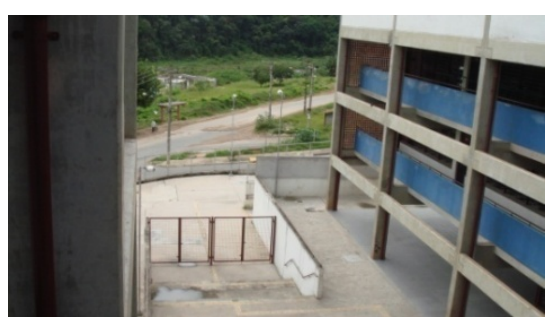

Foto 3. Escola Beta Fonte: Acervo da pesquisadora.

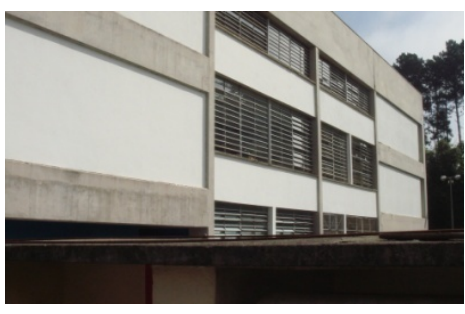

Foto 4. Escola Gama

Fonte: Acervo da pesquisadora. 
As diretrizes elaboradas sob a gestão da Secretaria de Estado de Educação (SEE) são apresentadas nos seguintes documentos: catálogo de serviços, catálogo de componentes, catálogo de ambientes, além de orientações para a apresentação de projetos arquitetônicos, de paisagismo, de instalações, bem como para construção (orientações para o canteiro de obras) e manutenção (uso e conservação dos elevadores, segurança contra incêndio e conservação de edifícios) (DURAN; ESTEVES, 2006; FDE, 2014).

Estas edificações, construídas e operadas pelo Governo do Estado de São Paulo eram, à época da realização dos levantamentos (2011) planejadas em escala. Para tal, compartilham diretrizes de projeto e programas de necessidades (FRANÇA; ORNSTEIN, 2009; FRANÇA; ORNSTEIN, 2010; FRANÇA; ORNSTEIN, 2010b; KOWALTOWSKI; DELIBERADOR, 2010; RHEINGANTZ, 2010; FRANÇA; ORNSTEIN; ONO, 2011). O modelo de gestão vigente destacava-se pela característica centralizada, que delega à Fundação para o Desenvolvimento da Educação (FDE), as decisões referentes ao planejamento, construção e administração da edificação, ao longo de sua vida útil, conforme o apresentado na Figura 1. 

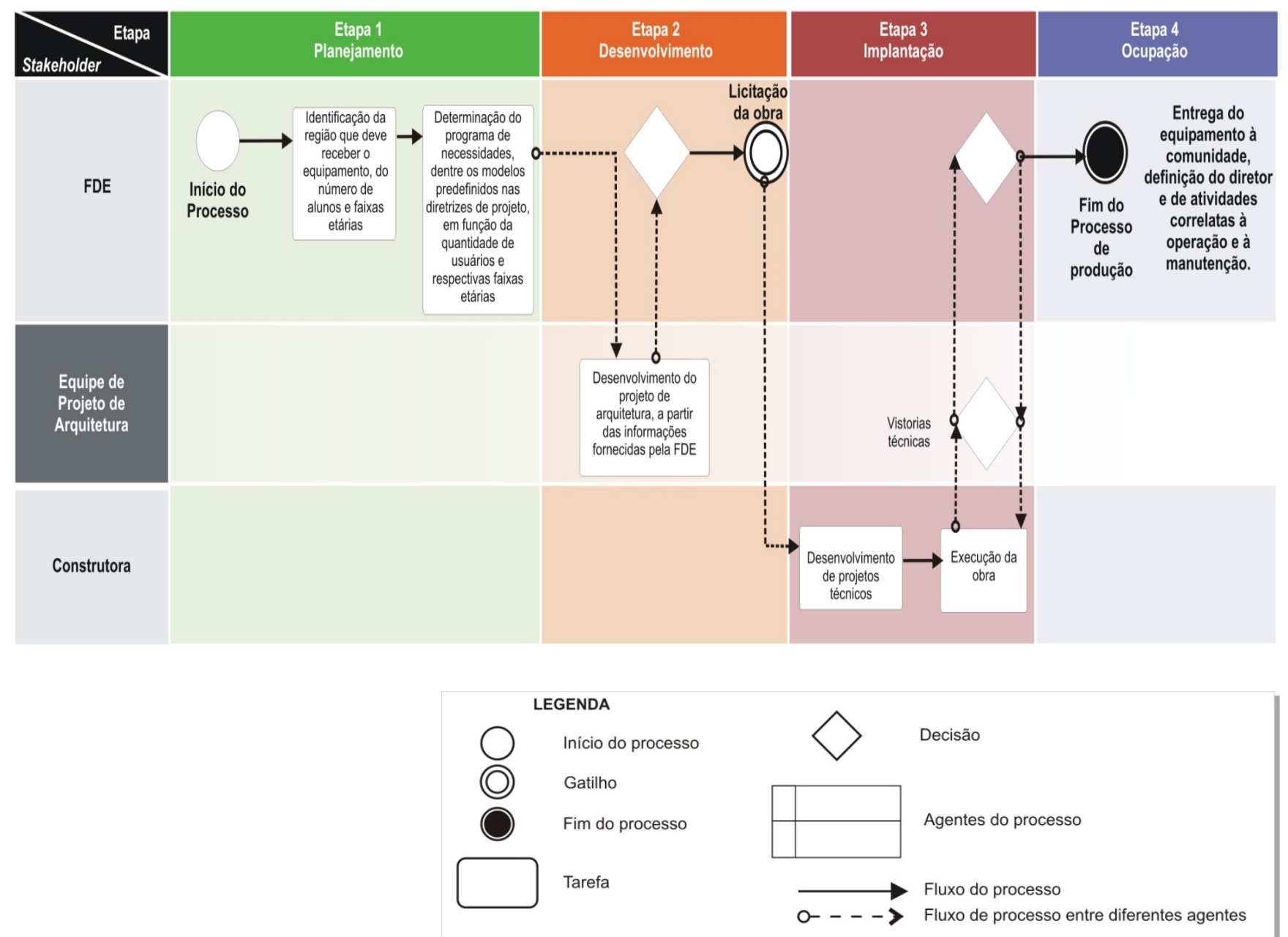

Figura 1. Modelo de gestão vigente na FDE para a construção de edificações escolares. Fonte: Elaborado pela pesquisadora, apoiado nas informações apresentadas em ORNSTEIN et al. (2009).

No modelo verificado (FRANÇA, 2011), é possível observar que o fluxo das informações acontecia de forma linear e a equipe de projeto de arquitetura iniciava seu contato com a edificação na Etapa 2 (Desenvolvimento), encerrando-o na Etapa 3 (Implantação).

Também observou-se que, no modelo descrito, não existia um sistema de alimentação formal das informações, sobre as edificações semelhantes em uso, nem um aprofundamento quanto aos desejos e necessidades específicos da comunidade local em relação ao novo equipamento público que irá receber.

Em razão das oportunidades para a racionalização dos custos e da facilidade de incorporação de soluções de projeto, a Etapa 1 representa uma fase importante do desenvolvimento de um projeto. Durante essa fase, a incorporação das 
informações aferidas em experiências pregressas pode ser facilmente absorvida e proporcionar benefícios representativos, por meio da identificação e da correção precoce dos aspectos negativos relacionados às soluções de projeto. Além disso, os custos para a correção de aspectos críticos nas fases iniciais de projeto, representam impacto menor, quando comparados às demais etapas de produção e de uso da edificação.

Conforme o projeto avança, iniciam-se as etapas de execução e de ocupação, as possibilidades decrescem, em função dos custos de implantação da solução e de seus efeitos em outros aspectos já implantados do projeto (MELHADO, 2005).

No Modelo avaliado, apenas após a definição do programa de necessidades, ocorria o envolvimento da equipe de projeto de arquitetura. Esta se limitava a aplicar no projeto as orientações constantes das diretrizes e instruções da FDE (disponíveis em: <http://fde.sp.gov.br>, acesso em 20 abr. 2014) e não participava ou recebia, de maneira sistemática, informações relacionadas ao desempenho em uso do projeto do edifício que realizou.

O contato entre os usuários e a edificação ocorria apenas na Etapa 4. É nesse momento, que também iniciava-se o envolvimento do diretor (e, efetivamente, o administrador do equipamento público) com a comunidade, da qual espera-se que estabeleça um vínculo com a nova escola e desenvolva um sentimento de pertencimento.

A construtora contratada para a obra tinha seu envolvimento com a edificação restrito à Etapa 3, exceto em situações previstas em contrato que merecessem garantia quanto à qualidade dos componentes e dos sistemas implantados na edificação.

Por meio da aplicação de APOs, foram identificadas situações em que essa possível garantia não apresentava a eficácia desejada (THOMAZONI et al., 2007; RESENDE et al., 2007; ISSA, 2008, POLTRONIERI, 2008; BARBOSA et al., 2008, GROTTI, 2009; NAMBU, 2010; NOVASKI, 2010, KOWALTOWSKI, DELIBERADOR, 2010, FRANÇA, 2011). Os estudos de caso avaliados mostraram, por exemplo, que portas, fechaduras e dobradiças inadequadas ao uso intenso permaneciam com avarias mesmo em situações nas quais a responsabilidade da construtora ainda estava vigente. Além disso, aspectos relacionados à necessária declividade de pisos, drenagem e descolamento de acabamentos permaneciam sem solução. 
Após a ocupação (Etapa 4), conforme o modelo vigente, a direção da escola acabava por adotar um papel determinante para o ambiente construído, à medida que era responsável por administrar uma verba restrita para a execução de pequenos serviços de manutenção. Nesta etapa, à época dos levantamentos (2009) não havia a adoção de um procedimento sistemático que permitisse a revisão das diretrizes a serem seguidas por futuros projetos, à luz da experiência adquirida durante a operação (FRANÇA; ORNSTEIN; ONO, 2011). Notou-se também que não eram realizadas avaliações para a verificação dos níveis de conforto ambiental do ambiente construído (BARBOSA et al., 2008; FRANÇA, 2011, KOWALTOWSKI, 2011).

Além disso, não haviam sido determinadas metas às escolas, para a redução do consumo de água e energia, sendo os respectivos consumos encaminhados diretamente às diretorias de ensino (agentes de administração regional da Fundação), sem que os gestores da escola sequer tivessem conhecimento dos respectivos consumos (FRANÇA; ORNSTEIN, 2010b).

Deste modo, a elaboração de um modelo de gestão do conhecimento no âmbito da corporação pode contribuir para que se estabeleçam procedimentos sistemáticos para o planejamento, a construção e o uso dessas edificações, visando à melhoria contínua dos níveis de qualidade e do desempenho do ambiente construído.

\subsection{MATERIAIS E MÉTODOS}

Para a análise de problemas complexos, Yin (2005) sugere a abordagem sistêmica, de modo a possibilitar o entendimento dos aspectos relevantes e a interrelação entre seus atores.

Dessa forma, para a aplicação da metodologia proposta, foi escolhida, dentre os casos previamente estudados, uma edificação para a validação das proposições apresentadas. O processo de validação consistiu na modelagem tridimensional da geometria da edificação e na configuração, em um sistema de Banco de Dados, de seus respectivos parâmetros (propriedades e características), relevantes à condução de avaliações de desempenho. Com base nas informações modeladas, foram consolidados procedimentos para que informações críticas pudessem ser acessadas 


\section{por equipes de projetos. Nas informações apresentadas na Figura 2 são destacados os procedimentos metodológicos para a elaboração da tese e suas inter-relações.}

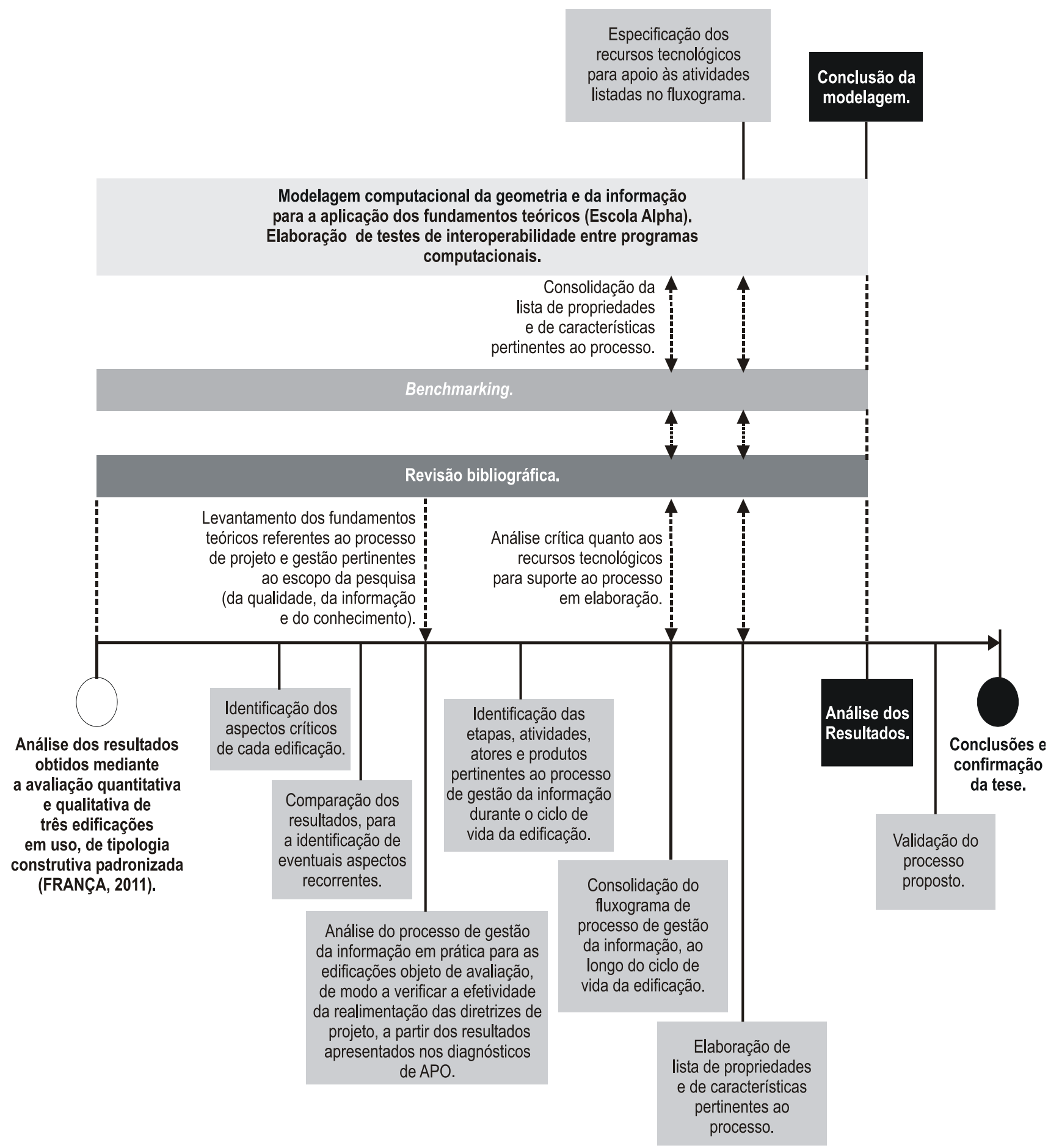

Figura 2. Procedimentos metodológicos para elaboração da tese Fonte: Acervo da pesquisadora. 
Dado que a presente tese pretende propor um Modelo para a gestão de informações pertinentes a edificações de tipologia semelhante, nas diferentes fases de seu ciclo de vida (a saber: projeto, produção, operação e demolição), os seguintes materiais e métodos foram adotados:

a. avaliação do estado da arte, quanto aos conceitos adotados para embasamento da pesquisa, o que inclui a revisão da bibliografia pertinente aos processos de projeto, operação e manutenção no ambiente construído, bem como recursos tecnológicos que possam contribuir para a matéria;

b. aplicação do proposto a uma edificação existente, visando à avaliação da pertinência das soluções formuladas. Para tal, foram incorporados os resultados de levantamentos de campo referentes a estudo de caso representativo (FRANÇA, 2011). Com base nestes resultados, quanto ao comportamento de uma edificação em uso, foram comparados os aspectos críticos de suas causas e consequências; e c. verificação: avaliação da eficácia do modelo proposto, revisão dos aspectos críticos identificados e elaboração do Modelo em sua versão final. 


\subsection{RESULTADOS ESPERADOS}

Por meio da presente pesquisa, pretende-se sistematizar procedimentos que embasem a desejada realimentação de diretrizes para edificações semelhantes, proposta quando da formulação da hipótese. Este deve ser aplicável a todo o ciclo de vida da edificação, de modo que seja possível sistematizar a análise de informações, por parte dos stakeholders, para prover subsídios à tomada de decisões;

Assim, são almejados os seguintes resultados:

- proposição de um processo de gestão do conhecimento, aplicável a edificações de tipologia construtiva padronizada (não apenas restrito às edificações de ensino-aprendizagem, mas também pertinente a outros usos);

- discussão dos recursos tecnológicos necessários para suporte ao processo proposto; e

- verificação das condições de troca de informações entre programas computacionais, necessários ao emprego de recursos tecnológicos utilizados durante o processo proposto (interoperabilidade).

Com base nestes resultados, espera-se prover subsídios a corporações públicas e privadas, para que possam gerir as informações relacionadas às edificações sob sua administração de modo mais eficiente e promover o aprendizado por experiências pregressas.

Desta forma, a partir da avaliação das diretrizes e práticas para a padronização das informações e sua modelagem, com o auxílio de programas computacionais, espera-se propor um processo de melhoria contínua a portfólios de edificações sob a gestão de uma organização. 


\section{MELHORIA CONTÍNUA APLICADA ÀS EDIFICAÇÕES SOB A GESTÃO DE UMA ORGANIZAÇÃO}

É esperado que um edifício apresente características adequadas para atender às necessidades conscientes (como o desejo de visualizar o ambiente externo, para maior satisfação e conforto visual) e inconscientes (por exemplo, condições de segurança no uso durante o acionamento de componentes móveis em esquadrias, se podem causar danos à integridade física) de seus usuários.

Para que se possa utilizar e operar plenamente um ambiente construído, é importante, portanto, que este apresente níveis de qualidade apropriados e que seu desempenho seja compatível com o esperado.

\subsection{CONCEITUAÇÃO DE QUALIDADE, DESEMPENHO E PROCESSO}

Produzir produtos de qualidade é de suma importância, não só no âmbito da indústria da construção civil, como também no contexto dos ambientes empresariais e industriais. Quanto ao conceito de qualidade, Fabricio (2002) destaca, dentre outros, os seguintes aspectos:

- propriedades de um elemento, de modo a atingir um efeito pretendido;

- atendimento a normas de produção; e

- estratégia de gestão, com vista à eficiência da produção.

Por conseguinte, gerir a qualidade de determinado produto ou serviço visa a garantir o projeto, a produção e a entrega ao usuário um produto o mais econômico, útil e satisfatório, conforme os requisitos de desempenho determinados. Sendo assim, seu processo de gestão apresenta uma metodologia sistemática para determinar metas, avaliar e gerir os aspectos relevantes, de modo a assegurar um nível mínimo de qualidade adequado ao uso previsto.

Roméro e Ornstein (2003) definem o termo qualidade, como as características de um produto ou serviço cujo desempenho é adequado para satisfazer as necessidades do usuário. Para tanto, é fundamental que critérios de desempenho (ou seja, o comportamento desejado de um elemento ou conjunto de elementos, 
considerando um uso específico) estejam definidos, na ocasião da elaboração de um projeto. Também é preciso que seu processo de desenvolvimento e construção esteja apresentado de modo claro a todas as equipes envolvidas.

Além disso, Fabricio; Ornstein e Melhado (2010) avaliam que, sendo a qualidade um aspecto relacionado às expectativas criadas em relação a algo, não é possível mensurá-la de modo direto, dependendo esta da identificação das características de elementos, coisas ou pessoas. Deste modo, a aferição da qualidade de algo pode se dar tanto por meio da avaliação de seu desempenho físico como da verificação dos níveis de satisfação daqueles que o utilizam.

Considerando a verificação da qualidade aplicada ao projeto do ambiente construído, vários aspectos devem ser observados, tais como: funcionalidade e construtibilidade das soluções de projeto, representação gráfica adequada e interação eficiente entre as equipes de projeto (SALGADO, 2010a).

Complementarmente a estas pesquisas, que avaliam a gestão da qualidade aplicada a diversos atores do processo construtivo, Abiko e Ornstein (2002) destacam a importância dos esforços, no sentido de incorporar melhorias à cadeia produtiva da construção civil, pelo desenvolvimento de normas técnicas e de incorporação prática, visando à gestão da qualidade.

Finalmente, para que os resultados aferidos possam ser efetivamente incorporados, como recomendações para novos projetos ou para a proposição de uma eventual requalificação, a implantação de um processo formalizado pode contribuir para que diagnósticos e APOs (ORNSTEIN et al., 2009; ORNSTEIN; ONO, 2010) sejam elaborados de modo sistemático.

No que diz respeito à qualidade do projeto, Fabricio; Ornstein e Melhado (2010) destacam a necessidade de que seja observada a adequação das soluções de projeto previstas para o empreendimento ao programa de necessidades, considerando os critérios de desempenho determinados pela norma NBR 15.575, cuja versão preliminar foi publicada em 2008, posteriormente tendo sido revista em 2013 (ABNT, 2013). Também são aspectos a serem observados: a qualidade dos serviços associados ao projeto (tais como consultorias, quantitativos, projetos de manutenção e orçamentos), a apresentação gráfica e a gestão do processo de projeto.

Corroborando a necessidade de que o desempenho efetivo do ambiente seja 
observado no processo de produção da edificação, o Department of Trade and Industry (1998) destaca os seguintes procedimentos, previstos no processo de desenvolvimento de um produto, que podem ser aplicados à construção civil:

- compreensão das necessidades do consumidor;

- desenvolvimento de produtos que excedam às expectativas do cliente;

- definição dos requisitos de um produto da construção civil e como estes interferem na especificação de sistemas e componentes;

- determinação de metas claras de desempenho para o produto;

- incorporação de condições no processo construtivo que possibilitem a assimilação destas metas pelas equipes envolvidas;

- avaliação sistemática dos projetos finalizados e do respectivo nível de satisfação de seus clientes; e

- desenvolvimento de um trabalho junto aos fornecedores, de modo a possibilitar a incorporação de inovações sem que haja risco de perder a confiabilidade nos resultados finais.

O desempenho do ambiente construído é definido, portanto, como o atendimento a um conjunto de requisitos pela edificação pronta e em uso. Entretanto, este conceito é, muitas vezes, erroneamente limitado à avaliação da qualidade dos sistemas e dos processos construtivos, em detrimento do resultado final (BORGES, SABBATINI, 2008). Somente determinar requisitos e implantar a avaliação da qualidade e do desempenho no ambiente construído não garante seu bom resultado final. Para que isso ocorra, devem ser adotadas medidas para formalizar, por meio de um processo formal, a transferência dos resultados obtidos entre os atores dos processos de produção e operação da edificação, bem como entre suas fases.

Sendo assim, devem ser determinados procedimentos para o monitoramento desse desempenho pretendido, com base na medição dos resultados, visando à melhoria da eficiência e incorporação das correções necessárias.

Portanto, para gerir a qualidade em edificações de modo sistematizado, é necessário formalizar procedimentos, ou seja, um conjunto de ações e métodos, isto 
é, o trabalho sistemático de busca para questões formuladas.

\subsection{GERENCIAMENTO DE EDIFICAÇÕES DE TIPOLOGIAS SEMELHANTES, NO CONTEXTO DE UM PORTFÓLIO}

Quando se adota a compreensão de que várias edificações fazem parte de um conjunto, sob uma determinada administração, entende-se que estes correspondem a um portfólio de ativos, ou seja: conjunto dos bens, direitos, valores, créditos e outros elementos semelhantes, que compõem o patrimônio de uma entidade, seja ela uma empresa, uma pessoa ou uma instituição (FULGENCIO, 2007).

Desta forma, passa-se a perceber as tarefas e as decisões tomadas, relacionadas a esse conjunto de edificações, em um contexto maior e integrado, compondo assim o portfólio de ativos de uma organização (IAM, 2013).

A gestão eficiente de ativos pressupõe a compreensão global de seus aspectos críticos e valores, em função das expectativas determinadas, que podem ser técnicas ou financeiras (WOODHOUSE, 2011). Love et al. (2015), apresentam a seguinte definição sobre a questão:

Gestão de ativos refere-se ao equilíbrio dos custos, oportunidades e riscos, em função do desempenho esperado para os ativos, de modo a cumprir os objetivos do proprietário (LOVE et al., 2015, tradução nossa)

Isso inclui a análise integrada dos impactos das decisões tomadas durante as etapas de investimento inicial na criação ou na aquisição de cada ativo do sistema (CapEx), considerando seus custos, riscos e benefícios. Além disso, também são considerados o desempenho em uso e as despesas operacionais (OpEx). Para tanto, pressupõe-se que sejam feitas recorrentes avaliações de desempenho, durante o ciclo de vida do ativo.

Muitas vezes, durante a fase de planejamento de um projeto, as avaliações de custos são elaboradas considerando o investimento na construção, enquanto os custos de operação são negligenciados. Essa abordagem mostra-se crítica, pois os maiores custos de um empreendimento estão relacionados à operação, ao longo de 
sua vida útil. Para que se tenha uma referência da relevância dos custos operacionais de uma edificação, conforme aponta Teicholz (2010), 80\% (oitenta por cento) dos valores gastos ao longo do ciclo de vida de um empreendimento correspondem à fase de operação e manutenção.

As Normas ISO 55.000:2014 (ISO, 2014b); ISO 55.001:2014 (ISO, 2014c) e ISO 55.002:2014 (ISO, 2014d) formalizam, respectivamente, os conceitos, os requisitos e as diretrizes para a gestão dos ativos de uma organização, em consonância com a norma PAS 55-1 (BSI, 2008).

Já a Norma ISO 15.686 (ISO, 2002, 2011; 2012, 2014a) visa a orientar o processo decisório para o planejamento de uma construção ou elemento construtivo, considerando seu comportamento, ao longo de sua vida útil. Dentre os aspectos abordados, estão a realização de auditorias e revisões para a adequação do desempenho (ISO, 2002), bem como os processos necessários para a modelagem da informação. Deste modo, espera-se que a informação modelada possa ser utilizada durante a vida útil do elemento construtivo em questão, o que pode contribuir para estender sua vida útil e reduzir os riscos associados à sua operação (ISO, 2014).

No esquema apresentado na Figura 3, é representado um Sistema Integrado de Gestão de Ativos. No modelo proposto, cada ativo interfere no desempenho global do portfólio e também pode impactar no desempenho de outros sistemas. Desta forma, um determinado componente de uma edificação (por exemplo, uma janela que não apresente estanqueidade adequada à chuva) poderá comprometer o funcionamento de um item de mobiliário (como uma mesa). Isso pode, inclusive, comprometer um eventual aproveitamento futuro desse componente em outra edificação, caso a ocorrência comprometa sua vida útil. 


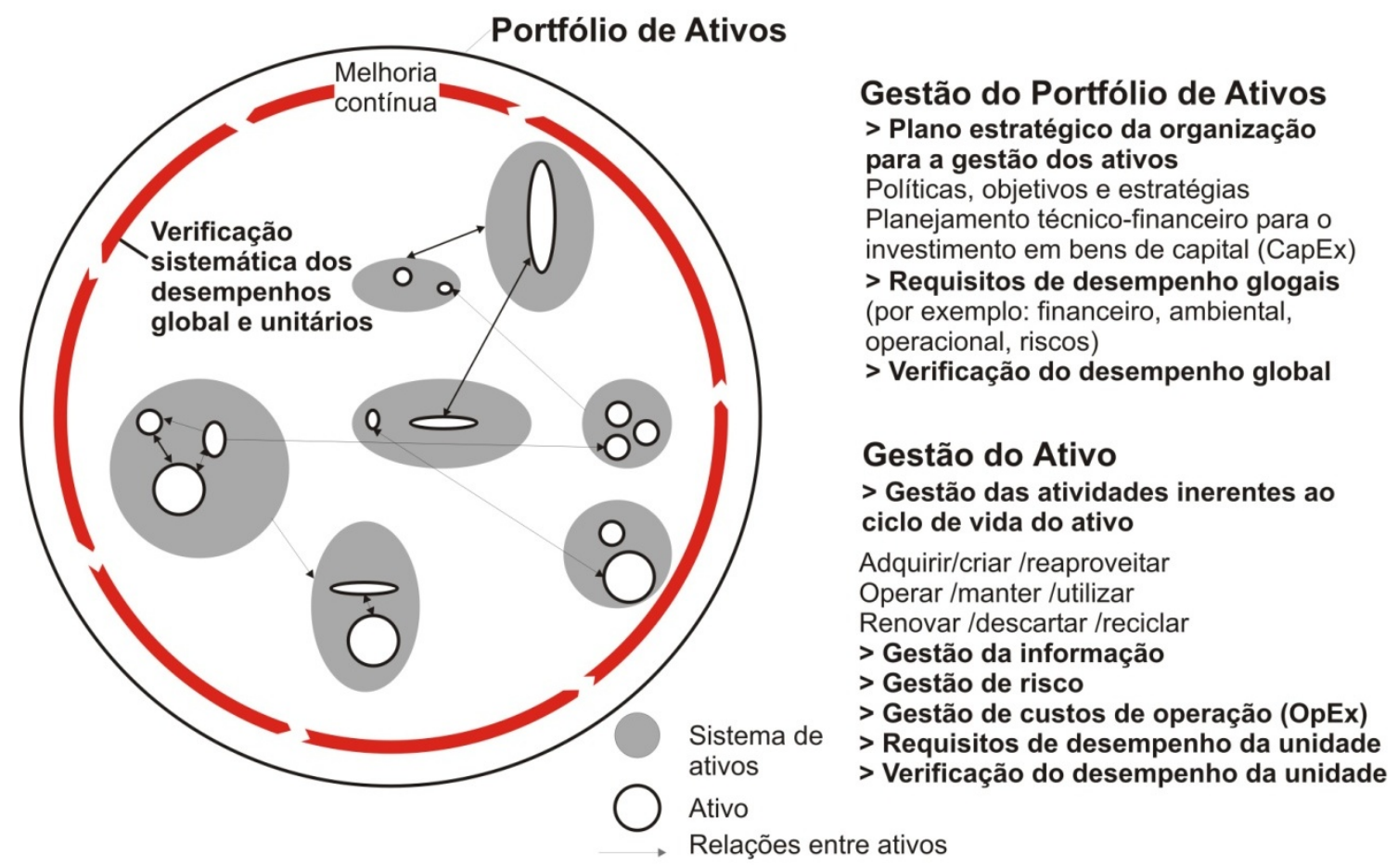

Figura 3. Sistema integrado de gestão de ativos

Fonte: Elaborado pela pesquisadora, com base em: LOVE et al. (2015, p. 283); WOODHOUSE, (2011, pp. 9-10); BSI (2008, pp. 7-4).

Deste modo, para que se possa colocar em prática essa visão sistêmica e integrada, fundamental para a gestão eficiente do portfólio de ativos, devem ser previstos procedimentos eficientes para a verificação sistemática do desempenho de cada unidade integrante do sistema, bem como avaliações periódicas do desempenho global do conjunto.

Isso só será possível à medida que se adotem estratégias para o gerenciamento integrado da informação, o que pressupõe a adoção de recursos tecnológicos, de modo a documentar e prevenir a perda de informação correspondente às modificações que ocorrem durante seu ciclo de vida, ou seja, pratique-se a gestão do conhecimento, seja ele tácito ou explícito (NONAKA; TAKUSHI, 1997; DALKIR, 2005).

A gestão do conhecimento corresponde à sistematização de objetivos, estruturas e processos de uma organização com o objetivo de promover a inteligência organizacional, com vistas a gerar, codificar apropriar e disseminar o conhecimento (DALKIR, 2005). Isso inclui a gestão dos seguintes aspectos (LEINSTER, 2010): 
- know-how (por exemplo: experiências e boas práticas);

- know-who (tais como: ativos de conhecimento, competências, capital intelectual); e

- Meios para sua comunicação e disseminação.

Se forem planejadas corretamente também, melhoram 0 acesso à informação, aumentando a eficiência das ações relacionadas à manutenção e à operação desses ativos, assim valorizando-os financeiramente.

Portanto, para que seja possível gerenciar o conhecimento, no contexto de um portfólio de ativos, é preciso adotar recursos que permitam realizar análises estratégicas das informações, considerando os custos, as oportunidades e os riscos envolvidos, em função dos objetivos de uma determinada organização. Isso se aplica a todas as etapas do ciclo de vida de determinado ativo que, no contexto da presente pesquisa, corresponde a uma edificação e seus componentes.

\subsection{ABORDAGEM SISTÊMICA E A MELHORIA CONTÍNUA}

Para que se possa compreender a natureza e a evolução histórica dos conceitos relacionados à sistematização de processos, a seguir, é apresentada uma breve revisão bibliográfica.

No fim do século $X X$, o conceito de gestão da qualidade encontrava-se mundialmente difundido, tendo sido incorporado por organizações de diferentes setores econômicos, tais como: fábricas, hospitais, redes varejistas, órgãos governamentais, instituições educacionais e empresas do terceiro setor (HACKMAN; WAGEMAN, 1995), inclusive, as atividades da construção civil (FABRICIO; MELHADO, 2002).

Os métodos e as técnicas para a gestão da qualidade foram desenvolvidos em meados do século $X X$, inicialmente restritos a ambientes industriais e militares, mas ganharam espaço também nos setores de comércio e de serviços, frente à necessidade de eficiência organizacional e de competitividade em mercados globalizados (JURAN,1998).

Nesse contexto, os Estados Unidos da América e o Japão destacaram-se 
como vetores desta revolução do sistema produtivo, conforme será apresentado nos itens subsequentes.

Durante a Segunda Guerra Mundial (1939-1945), o setor industrial dos Estados Unidos da América encontrou-se diante do desafio de produzir grande quantidade de produtos militares. Embora muitos desses produtos manufaturados incorporassem importantes avanços tecnológicos, o processo de produção, até então, permaneceu praticamente inalterado. Porém, após 1945, com o término da Segunda Guerra Mundial, as fábricas daquele país depararam-se com a necessidade de aumentar sua competitividade, em razão da perda de mercado frente aos produtos importados.

Juran (1998) destaca a crise dos anos 1980 e os grandes avanços, com relação à qualidade, obtidos pelas fábricas japonesas no período, como importantes vetores para o desenvolvimento dos modelos para a gestão da qualidade nos Estados Unidos da América, em razão do aumento da competição e da consequente necessidade de redução do desperdício (como por exemplo, perdas de matériaprima e horas trabalhadas relacionadas a retrabalho) nos processos industriais.

Os pesquisadores Deming (1986; 1990) e Juran (1998) contribuíram de modo fundamental para a consolidação de práticas de qualidade, formalizando conceitos e procedimentos que, posteriormente, foram amplamente difundidos e aplicados, inclusive, aos processos inerentes a diversas atividades da construção civil, como, por exemplo, a fabricação de componentes construtivos e a produção de edificações propriamente ditas (FORMOSO et al., 2003).

Os preços competitivos e a melhor qualidade dos bens manufaturados importados obrigaram a implantação de medidas para aumentar eficiência do processo produtivo, com a consolidação do conceito de "custo da má qualidade", segundo o qual empreender esforço para produzir com qualidade superior, na realidade, é menos representativo que despender recursos relacionados com ineficiência, falhas e perdas de matéria-prima. Nesse período, Juran estimou que cerca de 1/3 (um terço) dos esforços de produção das empresas eram dedicados ao retrabalho (JURAN, 1998).

O entendimento das necessidades dos consumidores de produtos, de modo a estabelecer metas, verificar o desempenho e corrigir as situações não conformes, é resumido por Deming (1986) e Shewhart (apud OAKLAND, 2003) no método de 
"planejar, executar, avaliar e corrigir", conforme o esquema apresentado na Figura 4.

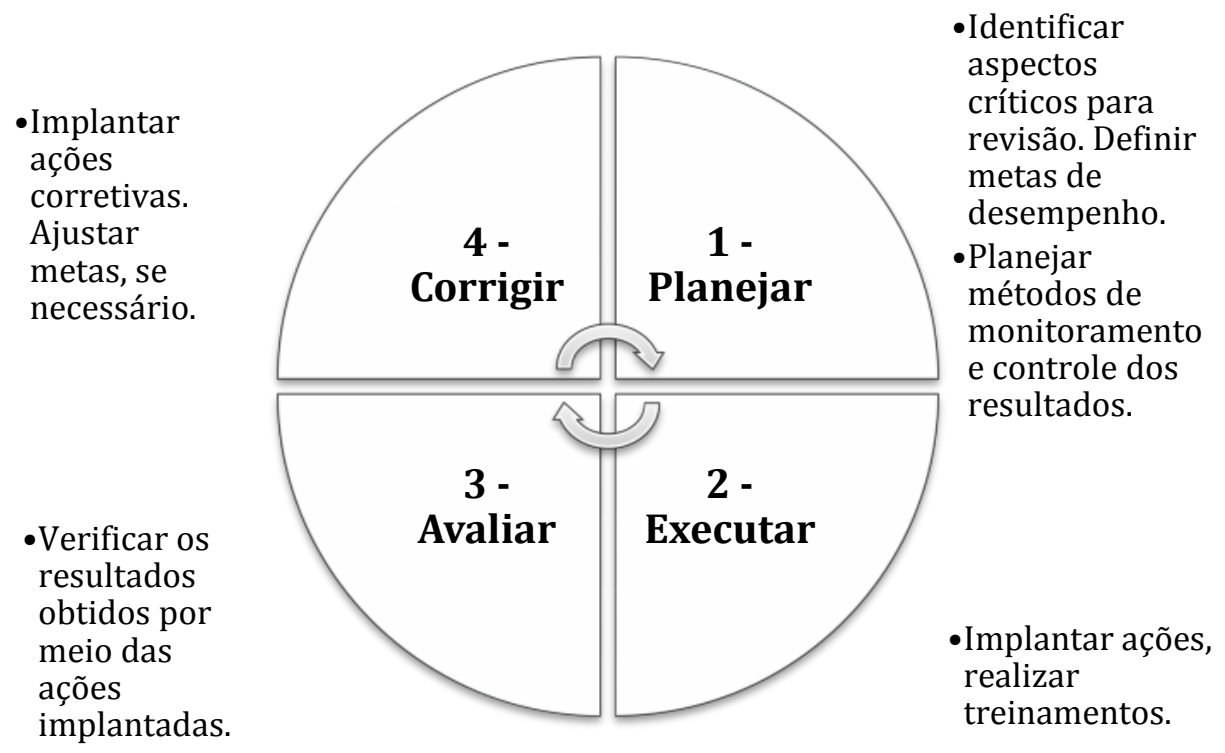

REPETIR O CICLO CONTINUAMENTE.

Figura 4. Ciclo do processo "planejar, executar, avaliar e corrigir"

Fonte: Adaptado pela pesquisadora de DEMING (1986, p. 88).

Considerando o processo de melhoria contínua pretendido, quando da aplicação de uma abordagem integrada aos processos de produção e gestão da edificação em uso, merecem destaque os seguintes aspectos:

- definição de critérios e metas de desempenho;

- observação a normas técnicas pertinentes;

- identificação de aspectos críticos; e

- proposição de ações para a solução destes.

Portanto, organizar o processo de avaliação de desempenho e a realimentação de projeto do edifício, conforme as boas práticas da gestão da qualidade, podem contribuir para a maior clareza durante as fases de concepção e execução, bem como melhorar a confiabilidade dos resultados obtidos, considerando a edificação em uso e seu nível de adequação às necessidades do usuário. 
Assim sendo, é necessário determinar um método para a gestão da informação e a avaliação dos níveis de qualidade de um ambiente construído, conforme os seguintes aspectos (ROMÉRO; ORNSTEIN, 2003; FABRICIO; ORNSTEIN; MELHADO, 2010; FRANÇA, 2011):

- qualidade das características funcionais (desempenho técnico-funcional, adequação ao uso pretendido);

- qualidade das características temporais (disponibilidade, manutenibilidade, confiabilidade e durabilidade);

- qualidade de conformação;

- qualidade dos serviços associados ao produto (instalação, diretrizes para conservação, assistência técnica);

- qualidade da interface entre o produto e o meio (relações do produto com o meio-ambiente e com o usuário);

- qualidades subjetivas (estética, qualidade percebida); e

- custo do ciclo de vida do produto para o usuário.

Oakland (2003) destaca a necessidade de planejamento prévio para a identificação dos aspectos de interesse para a coleta de dados, a utilização de procedimentos para aferir os resultados e a atribuição de responsabilidades às equipes envolvidas, para a implantação de um sistema de gestão da qualidade.

A informação de interesse pode ser expressa, por exemplo, em horas trabalhadas, volume produzido, do resultado financeiro ou em função do nível de atendimento aos critérios de desempenho pertinentes (FRANÇA, 2011), no caso da presente pesquisa.

Sendo assim, a confiabilidade dos dados obtidos está diretamente relacionada aos resultados da análise crítica. Inconsistências no protocolo de medição e no tratamento das informações coletadas podem exigir que seja conduzido um novo processo de monitoramento do desempenho, para que sejam tomadas decisões estratégicas apoiadas em premissas fidedignas. 


\subsection{SISTEMATIZAÇÃO DOS PROCESSOS NA CONSTRUÇÃO CIVIL}

Koskela (1992) propõe a aplicação de dois conceitos, difundidos na área de gestão da qualidade, ao processo construtivo, de modo a proporcionar vantagens relacionadas à produtividade, à qualidade e à eficiência financeira.

Dentre os aspectos que podem ser considerados como catalisadores para a sistematização de processos de produção do edifício estão: a redução de custos, por meio da restrição dos esforços com produção, transporte e armazenagem. A resposta passa a ser sob demanda contratada, deixando-se a produção antecipada e a estocagem de matéria-prima e de produtos (HIROTA; FORMOSO, 2001). Deseja-se também o envolvimento dos colaboradores, tanto nos níveis operacionais como nos níveis mais altos, de modo a permitir que o sistema de gestão englobe todas as suas operações, possibilitando a gestão do processo como um todo.

São aspectos relacionados à adoção das práticas de gestão da qualidade na construção civil (KOSKELA, 1992; GREEN, 1999; SULLIVAN, 2011):

- manutenção preventiva - de modo a manter os equipamentos envolvidos no processo em ótimas condições operacionais, para que possam suportar a demanda de produção;

- envolvimento dos funcionários - resposta rápida a aspectos críticos relacionados à equipe e realização de acompanhamento permanente, mantendo-a continuamente motivada;

- melhoria contínua - praticar o aprimoramento contínuo, por meio de melhorias graduais de baixo impacto;

- benchmarking - avaliação do desempenho, em comparação às boas práticas de mercado;

- redução da energia dedicada às atividades que não agregam valor ao processo;

- redução do desperdício de matérias-primas;

- redução da variabilidade;

- redução de prazos; e

- entendimento de todas as etapas do processo, seu fluxo e suas 
relações, o que permite suprimir etapas e conexões desnecessárias e melhorar sua eficiência.

No prefácio elaborado para o documento Rethinking construction - the report of the Construction Task Force, publicado em 1998, John Egan destaca a necessidade de mudanças nas práticas relacionadas à construção civil:

Aprendemos que a melhoria contínua e sustentada é possível, se focarmos esforços para atender às necessidades de nossos clientes e se estivermos preparados para enfrentar os desperdícios e a baixa qualidade, decorrentes de nossas estruturas e práticas de trabalho existentes. (EGAN, 1998, p. 3, tradução nossa)

Além disso, observa-se a existência de aspectos críticos, tais como: redução das margens de lucro, deficiências no treinamento dos trabalhadores envolvidos na cadeia da construção civil e escolha de profissionais de projeto e construção considerando prioritariamente o critério de preço (KOSKELA, 1992; DEPARTMENT OF TRADE AND INDUSTRY, 1998).

Conforme o Project Management Institute (PMI, 2008), existem cinco grupos de processos relacionados à gestão de projeto:

- atividades preliminares;

- planejamento;

- execução;

- monitoramento e controle; e

- conclusão.

Ao organizar as atividades relacionadas à construção de um edifício em um fluxograma, considerando como critérios de avaliação: custo, valor agregado ao projeto e desempenho final do produto, Koskela (1992), por sua vez, identifica dois principais processos pertinentes: 
- processo de projeto, no qual as necessidades e os desejos dos futuros usuários são transformados em requisitos, e estes, no detalhamento de um projeto; e

- processo de construção, composto por fluxos de materiais no canteiro e atividades das equipes de execução.

O pesquisador cita, ainda, processos secundários, relacionados aos dois principais citados acima:

- gestão do processo pelo proprietário;

- gestão do processo de projeto e compatibilização dos projetos técnicos pelo gerenciador; e

- gestão do processo da produção da obra (coordenação de atividades do canteiro).

Destaca-se, como um aspecto crítico, a dificuldade em determinar critérios de medição comuns, para a determinação de indicadores, que permitam a elaboração de comparações e a definição de metas. Esta condição pode estar relacionada à natureza única de muitos projetos, nos quais não é possível estabelecer um padrão de repetição, à dificuldade de coletar informações relacionadas ao ambiente construído (ou seja, ao produto finalizado e em uso) e à falta de padrões para os procedimentos de coleta de informação (HIROTA; FORMOSO, 2001).

No processo de produção da edificação elaborado por Meseguer, apresentado na Figura 5, é proposta a aplicação de procedimentos para a gestão da qualidade. Nota-se a cisão entre as fases de produção e operação do edifício. 


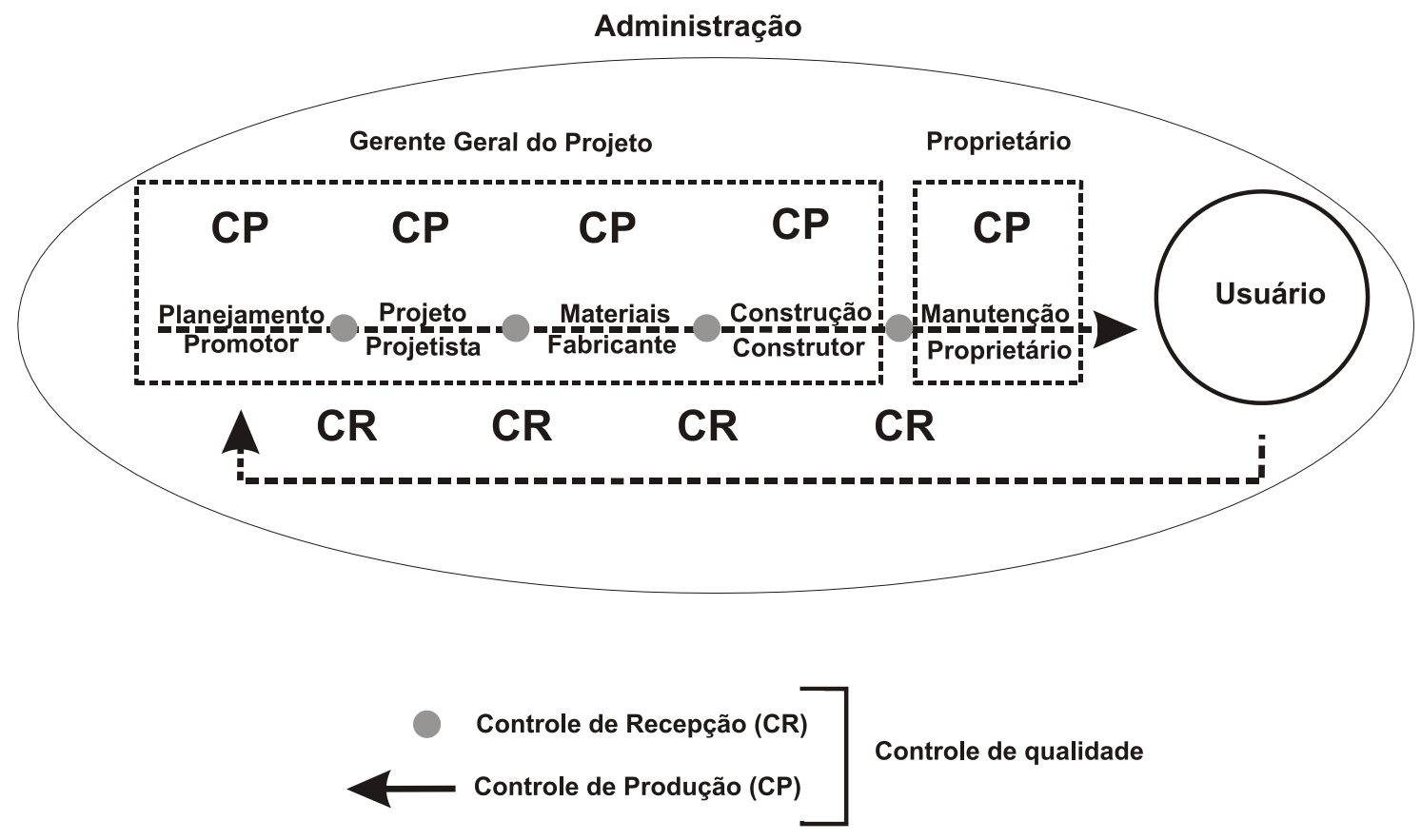

Figura 5. Modelo do processo construtivo e seus controles de qualidade, conforme Meseguer Adaptado de: MESEGUER (1991, p. 17), pela pesquisadora.

Além disso, observa-se que, embora incorpore mecanismos para o monitoramento do processo, a abordagem proposta pelo pesquisador prevê uma administração centralizada e um processo linear, no qual não são observados mecanismos de controle entre agentes (por exemplo, o controle dos projetistas sobre os materiais presentes na obra ou o resultado da construção).

Por sua vez, Melhado (1999) e Melhado (2005) destacam a importância da sistematização do processo de projeto, no qual devem ser contemplados os seguintes aspectos:

- atribuição de responsabilidades;

- elaboração de um manual que documente o sistema de gestão;

- estabelecimento de critérios para análise de documentos e contratos;

- determinação de meios e critérios para a documentação das atividades relacionadas aos projetos;

- orientações para inspeção, medição e ensaios, bem como para a documentação dos resultados;

- adoção de técnicas estatísticas, pertinentes à análise dos resultados; 
- definição de procedimentos, mediante a identificação de nãoconformidades;

- determinação de rotinas para a adoção de ações corretivas;

- estabelecimento de diretrizes para a documentação dos registros relacionados à qualidade;

- apresentação de orientações para a condução de auditorias; e

- proposição de meios de comunicação e treinamento dos envolvidos.

Ainda, conforme os mesmos pesquisadores, todas as etapas da produção devem ser documentadas, de modo que possam ser rastreadas e auditadas, ou seja: submetidas a um processo sistemático independente, para identificar se e quais critérios de desempenho pertinentes estão sendo atendidos.

Com vistas à gestão da qualidade no ambiente construído, Melhado (2000) propõe que seja elaborado um Plano de Gestão para o Empreendimento (PGE), no qual cada empreendimento deve corresponder ao projeto de um novo produto industrializado, estando vinculado diretamente aos manuais da qualidade de cada agente envolvido no processo, podendo ser desdobrado em função das seguintes etapas: projeto; execução, uso e operação e manutenção.

Além do PGE e do Projeto Simultâneo (denominado pelo pesquisador como Projeto Simultâneo do Produto e de sua Produção - PSPP), Melhado (2001) destaca a importância de que seja elaborado um Plano de Qualidade do empreendimento, no qual devem ser listados os procedimentos a serem adotados, os recursos disponíveis e a atribuição de responsabilidades e prazos. Como consequência, o pesquisador apresenta um conjunto de "métodos de gestão", composto pelo PGE, pelo PSPP, pelo Plano de Qualidade e também pela Preparação da Execução de Obras (PEO), na qual devem ser identificados os principais conflitos que podem ocorrer no projeto e as ações relacionadas a estes.

Também fazem parte do processo de gestão da qualidade aplicado aos processos de produção da edificação: a definição de metas de desempenho e a identificação de benchmarks, ou seja, a elaboração de uma avaliação comparativa que permita balizar os resultados obtidos, em um ciclo de melhoria contínua.

No que diz respeito ao desenvolvimento de produtos para a construção civil, 
Tzortzopoulos e Formoso (2003) destacam a importância da gestão da qualidade como aspecto que interfere diretamente na vida útil das edificações, bem como promove o aumento da transparência do processo de produção e a comunicação mais eficiente entre seus participantes. Mas, para que isso ocorra, é preciso que estes agentes tenham uma visão integrada e geral de todas as atividades e etapas relacionadas a um empreendimento, de modo a interagirem e contribuírem mutuamente.

Alves e Formoso (2000) observam que a abordagem sistêmica pode ser adotada para a resolução de qualquer problema, independente do grau de complexidade relacionado a ele. Este entendimento aplica-se também aos processos praticados na construção civil brasileira.

Além disso, levando-se em conta que edifícios usualmente são concebidos em meio a restrições financeiras e sofrem pressão para sua conclusão em prazos restritos, faz-se fundamental que os processos de projeto, construção, operação e manutenção sejam claros, bem como os mecanismos de verificação, de modo que possam ser eficientemente retroalimentados.

Outro aspecto fundamental, relacionado ao sistema de gestão, é a formalização de um sistema de garantia de qualidade, o qual deve contemplar claramente requisitos, condições de operação e procedimentos para manutenção preventiva e corretiva (THOMAZ, 2001).

No contexto do sistema de gestão de uma construção, Ohnuma e Cardoso (2006) avaliam a relevância da contribuição dos subempreiteiros, de modo que se faz pertinente a formalização de um sistema de gestão, que contenha diretrizes para os processos de qualificação, contratação, treinamento, avaliação e qualificação, gestão de contrato e pagamento, a fim de formalizar os procedimentos de planejamento e controle de serviços executados por subempreitados.

Em suma, observa-se que todo o conjunto de atividades da construção civil pode adotar procedimentos de gestão, de modo a produzir um produto conforme determinados critérios de desempenho, o que possibilita um maior domínio do sistema de produção. Portanto, verifica-se que as práticas de gestão de qualidade podem ser aplicadas com sucesso às diferentes atividades e etapas da construção, projeto e uso de uma edificação, com vantagens quanto à qualidade e ao desempenho do ambiente construído. 
Isso posto, observa-se que, em teoria, os principais marcos determinados para o processo de projeto baseiam-se nos conceitos de "planejar, executar, avaliar e corrigir", tal como foi proposto por Deming (1986). Apesar disso, verifica-se que, na prática, muitas vezes é adotada, efetivamente, uma abordagem linear e fragmentada.

\subsection{A FORMALIZAÇÃO DE PROCESSOS E A INDÚSTRIA DA CONSTRUÇÃO CIVIL BRASILEIRA}

A cadeia produtiva da construção civil representa uma importante atividade econômica no Brasil. Sua contribuição correspondeu, no primeiro trimestre de 2015, a uma participação estimada de $10,1 \%$ do Produto Interno Bruto Brasileiro ${ }^{2}$ (DECONCIC, 2015). Por conseguinte, iniciativas para incrementar sua produtividade podem apresentar um impacto positivo relevante na economia do País.

No início dos anos 1990, uma importante fase de desenvolvimento econômico tem início, datando desse período a criação do Programa Brasileiro da Qualidade e Produtividade (PBQP) e a maciça difusão dos conceitos e práticas da gestão da qualidade, não só no setor industrial, como também junto a outros setores da economia. O avanço do governo democrático nos anos anteriores, a abertura econômica e maior acesso ao capital estrangeiro, bem como a influência externa no que diz respeito a produtos, serviços e informação tecnológica, foram aspectos fundamentais para tal (BETIN, 1998).

No Brasil, observa-se a disseminação tardia dos conceitos e das práticas de gestão da qualidade, nos diversos setores da economia. Isso também se aplica ao setor da construção. Frente ao processo de globalização, concomitante à última década do século XX, Fabricio e Melhado (2002) avaliam seus impactos, como sendo marginais, se comparados com os verificados em outros setores da economia.

No entanto, foram relevantes o bastante para aumentar a competitividade entre as empresas prestadoras de serviços envolvidas com a cadeia produtiva da

${ }^{2}$ Participação equivalente a $R \$ 142.673 .000 .000,00$ (cento e quarenta e dois bilhões, seiscentos e setenta e três reais) (DECONCIC apud FIESP, 2015). 
construção, o que obrigou alterações em seu processo de gestão, tanto na área administrativa, como na de produção de edificações. A respeito da importância da existência de referências normativas e de processos padronizados na construção civil, Silva e Souza (2003) observam:

Todo esforço de melhoria na qualidade de uma empresa, de um setor industrial e de um país começa com a normalização de produtos, projetos, processos e sistemas. Sem normas e padrões não há controle nem garantia, nem certificação de qualidade.

No âmbito das empresas, as normas técnicas e procedimentos padronizados exercem o papel de especificar os produtos de acordo com as necessidades do consumidor e estabilizar os processos, fazendo com que todos os insumos sejam processados sempre da mesma maneira, racionalizando o uso de materiais, da mão de obra e equipamentos e reduzindo os custos de produção. (SILVA; SOUZA, 2003, p. 53)

Para a disseminação das boas práticas da gestão da qualidade, a formalização de programas foi fundamental, por parte do governo federal brasileiro e de governos estaduais, sobretudo, aqueles destinados à habitação de interesse social (HIS). Dentre estas iniciativas, destacam-se:

- Programa Brasileiro da Qualidade e Produtividade do Habitat - PBQP-H é um programa de adesão voluntária, instituído pelo governo federal em 1998, pela Portaria $n^{\circ} 134$ (disponível em: <http://www.cidades.gov.br/pbqp-h/pbqp_baselegal.php>, acesso em 05 fev. 2013). Por meio da implantação de mecanismos de gestão e do incentivo ao desenvolvimento tecnológico, o objetivo de sua instituição foi melhorar os níveis de qualidade e produtividade na construção civil;

- iniciativa QUALIHAB - Programa da Qualidade da Construção Habitacional do Estado de São Paulo, instituído em 1996 pela Companhia 
de Desenvolvimento Habitacional e Urbano do Estado de São Paulo CDHU (disponível em: <http://www.cdhu.sp.gov.br/producaonew/qualihab.asp>, acesso em 5 fev. 2013), pelo do Decreto n. ${ }^{\circ} 41.337$, com o objetivo de promover a qualidade em construções habitacionais de baixa renda. Para tanto, foram constituídas três frentes distintas, formalizadas em comitês, a saber: Comitê de Projetos e Obras, formado por empresas de construção e projetos, o Comitê de Materiais e Sistemas Construtivos, composto por fornecedores de insumos para as construções e o Comitê Interno, com a atribuição de implantar e praticar um sistema de gestão da qualidade na $\mathrm{CDHU}$;

- Sistema Nacional de Aprovações Técnicas (SINAT), que é integrante do PBQP-H e tem por objetivo incentivar a inovação e suprir a carência de normas técnicas específicas referentes ao desempenho de sistemas construtivos e de materiais. Para tal, é dedicado a estabelecer diretrizes de avaliação para verificar o desempenho dos sistemas construtivos inovadores ou que não disponham de regulamentação específica (disponível em: <http://www.cidades.gov.br/pbqp-h/projetos_sinat.php>, acesso em 10 ago. 2013);

- Programa Minha Casa Minha Vida (Lei no 11.977 de 2009, alterado pelo Decreto $\mathrm{n}^{\circ}$ 7.825, de 2012), que foi instituído pelo governo federal brasileiro, como integrante do Programa de Aceleração do Crescimento PAC (disponível em: <http:// www.pac.gov.br>, acesso em 30 jan. 2013), uma iniciativa visando à construção intensiva de moradias voltadas a famílias de baixa renda e à facilitação do acesso destas famílias a financiamentos, com o objetivo de reduzir o deficit habitacional brasileiro. Para que as empresas construtoras possam aprovar os financiamentos de seus projetos junto à Caixa Econômica Federal, é pré-requisito que participem do PBQP-H; e

- Norma NBR 15.575: edificações habitacionais - desempenho (ABNT, 2013), publicação que oferece parâmetros quantitativos e qualitativos para a avaliação do desempenho construtivo de edificações habitacionais, bem como sugere a vida útil esperada dos elementos construtivos e apresenta diretrizes para o estabelecimento de prazos de garantia (CBIC, 2013). 
Além disso, foi criado o Comitê Nacional de Desenvolvimento Tecnológico da Habitação (CTECH), destinado a oferecer suporte e incentivo a inovações tecnológicas no setor de habitação, com o intuito de facilitar o fluxo de informações entre os agentes do setor, tais como: entidades de normalização, associações de profissionais, iniciativas público-privadas e pesquisadores envolvidos na área da habitação (disponível em: <http://www.abc.habitacao.org.br/index.php/participacaoinstitucional/ctech/>, acesso em 1 fev. 2013).

A respeito do programa QUALIHAB, Santos e Melhado (2004) observam que as propostas dos sistemas de gestão então praticadas tiveram fundamentação semelhante às preconizadas pela série de Normas ISO 9.000 (ABNT/ISO, 2005; 2008). Os pesquisadores destacam, entretanto, que a composição de um plano de qualidade aplicado às obras públicas habitacionais avaliadas é mais restrita que em empreendimentos privados, pois sua abrangência, usualmente, inicia-se ao término da elaboração dos projetos.

Apesar dos avanços para a gestão da qualidade em habitações de interesse social (HIS), observa-se que, nem sempre, foram efetivamente implantados os procedimentos de gestão propostos pelo QUALIHAB. Quando da avaliação da eficácia do programa, Jesus e Cardoso (2006) avaliaram que, em relação ao setor de obras, os planos de gestão da qualidade elaborados na ocasião não haviam sido implantados nas empresas construtoras de modo eficaz, embora estas apresentassem certificados de participação do programa. Como possível solução, foi sugerido que se promovesse a motivação dos responsáveis pelos programas de qualidade dessas empresas, por meio da mensuração de ganhos efetivos, em função do atendimento a metas e indicadores.

Especificamente, em relação às iniciativas conduzidas pela CDHU, para a construção de moradias de baixa renda, Fabricio (2002) observa que, embora os projetos padronizados e com alto nível de repetição possibilitem ao projeto um maior grau de industrialização (em razão da escala da produção), verifica-se que pouco da inovação tecnológica disponível é incorporada efetivamente ao mercado da construção habitacional. Nesse caso, o desenvolvimento do projeto avança pouco além do necessário para a elaboração do projeto para submissão à aprovação na Prefeitura Municipal, insuficiente, portanto, para implantação de um processo formal 
de produção.

Em sua análise, Hino (2001) destaca, ainda em relação aos resultados obtidos pelo QUALIHAB, a importância da verificação dos níveis de satisfação do usuário, o que, no caso da construção civil, pode ser feita pela verificação do nível de atendimento a critérios de desempenho e aplicação de Avaliações Pós-Ocupação (APOs).

Não obstante o representativo conjunto de iniciativas visando à gestão da qualidade de HIS apresentado, ainda não se observa um processo efetivo de retroalimentação para a melhoria do desempenho do ambiente construído. Palermo (2013) destaca que embora haja um grande número de APOs aplicadas na dinâmica de produção de HIS, a realimentação do projeto não é considerada. Isso se dá, dentre outros aspectos, em função da escassez de recursos financeiros, de pessoal e pela falta de políticas públicas que possibilitem a continuidade dos programas de habitação popular.

Além disso, merecem destaque, como aspectos críticos, os diferentes instrumentos e critérios para a aplicação das citadas APOs, o que dificulta a análise dos diagnósticos e resultados em escala (PALERMO, 2013).

Para Reis e Lay (2002) e Galvão; Ornstein e Ono (2013), apesar das limitações para a aplicação de processos de APOs a HIS, sua prática constituiu-se em uma importante contribuição para 0 incremento da qualidade desses empreendimentos.

Kowaltowski et al. (2013) destacam a importância de que sejam conduzidas avaliações do desempenho de HIS, como parte do processo de produção habitacional. Observam também que, nessas edificações avaliadas, verifica-se a repetição de formas e soluções de implantação, em oposição aos poucos aspectos à humanização da arquitetura.

Villa (2013) evidencia a importância do atendimento aos critérios de desempenho das edificações habitacionais, de modo que atendam às expectativas dos futuros usuários, sendo para tal pertinente a aplicação de métodos e técnicas de APO.

Para Leite (2013), o desenvolvimento de uma iniciativa pela Secretaria Municipal da Habitação (SEHAB/SP) para a aplicação da APO à HIS, denominada Programa 3R, pretende promover a avaliação de empreendimentos em uso, cujos 
condomínios foram constituídos. Para tal, pretende-se determinar indicadores de qualidade, a fim de permitir a compreensão dos aspectos críticos relacionados aos condomínios residenciais constituídos. Conforme os pesquisadores, tendo as experiências iniciais sido implantadas satisfatoriamente, pretende-se adotar a prática de aplicação da APO, de modo sistemático e geral nos empreendimentos sob a gestão da SEHAB/SP, como meio de monitoramento do desempenho dos programas de política habitacional desta secretaria.

Roman e Bonin (2003) comentam que a melhoria da qualidade construtiva no País, por meio da aplicação de procedimentos, visando à eficiência na troca de informações e gestão da qualidade, pode proporcionar maior confiabilidade dos produtos da construção civil e no relacionamento entre fornecedor e consumidor, além de auxiliar na redução dos custos de produção e consumo e proporcionar mais condições de segurança à construção.

Corroborando a abordagem de Roman e Bonin (2003), Oliveira (2005) avalia que, para que se possa definir uma estratégia de gestão da qualidade, é necessária a determinação de indicadores de comportamento da produtividade, como por exemplo, a velocidade de produção das equipes, a sequência de execução dos serviços ou a quantidade de insumos consumidos em um determinado período de tempo, de modo a buscar uma maior eficácia no desempenho das atividades necessárias à construção.

Também merece menção a iniciativa para a disseminação e incorporação das metodologias da qualidade aplicadas a edificações com vistas ao desenvolvimento de um Sistema de Indicadores de Qualidade e Produtividade para a Construção Civil, elaborado pelo Núcleo Orientado para a Inovação da Edificação (NORIE) da Universidade Federal do Rio Grande do Sul, cujo objetivo era permitir aos gestores dos projetos o acesso a informações que embasassem a tomada de decisões e a identificação de ações relacionadas às melhorias necessárias à operação de uma empresa da construção (COSTA et al., 2005).

Outro vetor importante para o amadurecimento do setor da construção civil em relação a seu compromisso com a qualidade e com o desempenho do ambiente construído foi a entrada em vigor do conjunto normativo 15.575 (ABNT, 2013), que dispõe sobre o comportamento em uso dos componentes e dos sistemas construtivos de edificações, ao longo dos anos. Com isso, foram alteradas as 
relações de consumo até então existentes, à medida que são atribuídas responsabilidades aos projetistas, aos fornecedores, aos construtores, aos incorporadores e aos usuários (ABNT, 2013; CBIC, 2013). Essa iniciativa, embora dedicada formalmente a edificações habitacionais, vem sendo importante promotora de discussão de aspectos da qualidade no ambiente construído, também no âmbito de edificações de outros usos e tipologias construtivas.

\subsection{PROCESSOS INTEGRADOS E GESTÃO DA INFORMAÇÃO PARA O SUPORTE À PRODUÇÃO E À OPERAÇÃO DO EDIFÍCIO}

Para Melhado (1999) e Fabricio e Melhado (2002), a abordagem que considera a evolução continuada do processo de construção deve incluir a racionalização construtiva, o desenvolvimento tecnológico e a incorporação de inovações, aplicáveis a todas as etapas de um empreendimento, de modo a auxiliar na evolução das práticas adotadas.

Isso é importante, pois a falta de formalização dos procedimentos envolvidos e de suas inter-relações no processo construtivo convencional dificulta a gestão da qualidade do ambiente construído. Além disso, a gestão dos processos que englobam o projeto e a construção de uma edificação, representa um desafio, uma vez que deles fazem parte várias etapas e, usualmente, participam muitos atores (FABRICIO; MELHADO, 2002).

De modo a prover níveis de qualidade adequados a um empreendimento, é necessário, portanto, que seja implantado um sistema de gestão da informação, permitindo assim formalizar os processos e identificar, de maneira lógica, a respectiva sequência de tarefas, bem como as informações necessárias e as interações organizacionais (OLIVEIRA, 2013).

Por sua vez, Tang et al. (2008) discutem a importância de que as informações necessárias à execução do projeto sejam objeto de planejamento. Para tanto, devese considerar que o excesso de informação não relevante é potencialmente tão prejudicial quanto sua falta. Os pesquisadores destacam que a informação estratégica pode ser processada de modo que sejam atingidos objetivos, constituindo-se em um ativo valioso. No entanto, especificar corretamente os dados e as propriedades para os usos pretendidos em determinado processo consiste em 
um equilíbrio delicado, uma vez que o desenvolvimento tecnológico facilita o armazenamento de um grande volume informações, podendo se constituir em uma armadilha, em razão da falta de critérios adequados.

Assim, é fundamental separar a informação relevante no universo dos dados disponíveis, referentes a um certo contexto. A isso, soma-se a importância de que o entendimento acumulado, proveniente de análises aplicadas aos dados e às informações seja eficientemente transmitido (BSI, 2003). Procedimentos para a documentação e a transferência, tanto da informação como do conhecimento, devem ser formalizados, de modo a, efetivamente, promover a melhoria contínua.

O planejamento da gestão da informação inclui a identificação dos requisitos, bem como a coordenação das necessidades e expectativas dos stakeholders, ao longo do processo de produção do edifício. Para tanto, deve-se considerar proceder à permanente avaliação dos seguintes aspectos: escopo, qualidade, prazos, orçamento, recursos e riscos (PMI, 2008).

Isso pressupõe gerir os processos complexos, que englobem uma grande quantidade de tarefas, a serem desempenhadas por vários atores. Apesar disso, é comum a falta de formalização de suas atividades, dos procedimentos envolvidos e de suas inter-relações, mesmo em projetos de edificações complexas, o que dificulta a verificação dos resultados obtidos (FABRICIO; MELHADO, 2002).

O processo de projeto constitui-se na criação e caracterização das informações necessárias à sua fabricação, pressupondo, portanto, aspectos intelectuais e técnicos (FABRICIO; MELHADO, 2002). Nele, as informações são avaliadas, organizadas, qualificadas e comunicadas, de modo a embasar a execução do objeto em questão, conforme o apresentado na Figura 6. 


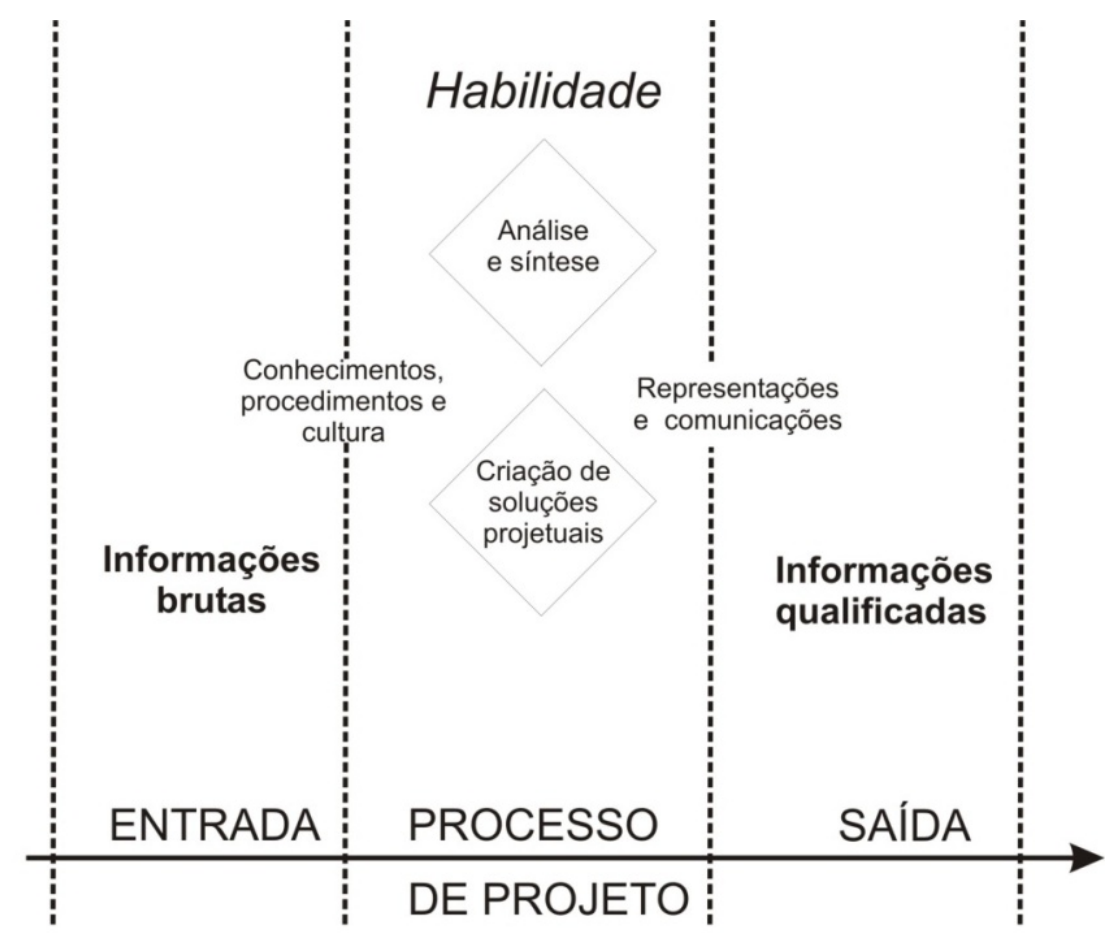

Decisão

Figura 6. Processo intelectual de projeto.

Adaptado de: FABRICIO (2002, p. 118), pela pesquisadora.

$O$ projeto e a construção de uma edificação são compostos por tarefas complexas que se desenvolvem ao longo de várias etapas, a saber (SILVA; SOUZA, 2003):

- planejamento do empreendimento;

- concepção do produto;

- desenvolvimento do produto (anteprojeto, projeto legal, projeto préexecutivo, projeto executivo e detalhamento, projeto de produção);

- entrega final do projeto; acompanhamento da obra; desenvolvimento de projeto como o construído;

- elaboração do manual do usuário; e

- avaliação da satisfação do cliente final. 
Dentre os aspectos que podem contribuir para a ineficiência e o desempenho inadequado do ambiente construído estão: a grande variedade de stakeholders e as especificidades pertinentes a cada projeto, o que dificulta a formalização de procedimentos comuns. Destacam-se, entre as consequências desta falta de padronização: a colaboração ineficiente e a falta de comunicação, o que implica desperdício de recursos (ANTÓN; DÍAZ, 2014). Os pesquisadores estimam que, por volta de $60 \%$ (sessenta por cento) do tempo do projeto é gasto de forma ineficiente pelos motivos citados.

Soma-se a isso a natureza multidisciplinar da produção da edificação, que pressupõe a participação de profissionais de diferentes especialidades, como arquitetura, engenharia civil, engenharia hidráulica, engenharia elétrica, engenharia mecânica, entre outras, a variar em função da tipologia do empreendimento.

Deste modo, para que o projeto da edificação possa atingir níveis adequados de qualidade, é necessário que as informações sejam adequadamente documentadas e divulgadas durante e entre as diferentes fases de projeto e execução.

Por isso, quanto maior a complexidade do projeto em questão maior será também a importância de que existam sistemas de gestão e de coordenação eficientes, de modo que sua formalização seja fundamental para a redução das incertezas relacionadas às soluções apresentadas pelas equipes, bem como para a análise mais eficiente das interações entre os sistemas construtivos e prediais a serem instalados e operados. Espera-se também o aproveitamento eficiente da capacidade de produção e a diminuição dos esforços envolvidos com o processamento da informação (ZEGARRA, CARDOSO, 2001).

Também quanto ao atendimento das necessidades do proprietário e do usuário, Nascimento e Santos (2001) lembram ser importante a implantação de mecanismos de gestão aos processos do projeto e da construção, visto que permite o controle mais eficiente dos requisitos pertinentes a cada uma das etapas do processo de produção de uma edificação, por meio da incorporação de mecanismos de avaliação e controle, que incluem a atribuição clara das tarefas e das responsabilidades às equipes envolvidas (HIROTA; FORMOSO, 2001).

Estes aspectos têm importância reforçada, quando se pretende incorporar ao empreendimento o processo simultâneo de projeto, que implica a interação 
multidisciplinar dos inúmeros agentes envolvidos, de modo a agregar competências específicas e experiências de diversas naturezas. Assim sendo, a gestão eficiente da informação não só contribui para a qualidade final do empreendimento, possibilitando sua utilização de modo mais adequado, bem como práticas de operação e manutenção mais eficientes (FABRICIO; MELHADO, 2000).

A prática da engenharia simultânea surgiu na década de 1990 e prevê a colaboração consistente entre indivíduos, equipes e empresas, envolvidos no processo. Inicialmente, esta prática estava restrita às áreas automobilística e da aeronáutica. Sua aplicação à construção civil, entretanto, apresentou desafios, pelo alto grau de informalização, normalmente observada nos processos de projeto e construção. Portanto, sua aplicação deu-se com maior sucesso nos casos dos projetos com maior nível de industrialização (FERREIRA, 2007).

Em relação ao conceito de projeto simultâneo, Fabricio (2002) ressalta a importância quanto à elaboração de um modelo do processo de projeto dividido em fases de concepção, o que possibilita a organização formal das etapas, possibilitando a troca organizada de informações entre os membros de uma equipe multidisciplinar.

Assim sendo, para a efetiva prática da colaboração simultânea, é necessária a organização sequencial do desenvolvimento do empreendimento, anteriormente ao início do desenvolvimento da arquitetura. Desta forma, faz-se necessária a mudança de cultura, no sentido de estabelecer uma maior parceria entre os agentes de um projeto.

Fabricio (2002) destaca ainda que a coordenação entre as diferentes disciplinas da arquitetura e da engenharia, desde o início do processo de projeto, é fundamental para a eficiência das soluções embora, efetivamente, ainda se observe uma clara hierarquização entre o projeto de arquitetura e os projetos de engenharia e especialidades. Estes últimos são realizados em paralelo, porém a integração das informações ainda permanece limitada.

Portanto, pode-se apreender que a adoção das práticas de gestão da qualidade está diretamente relacionada com a formalização e a clareza das fases do processo envolvido, a atribuição de responsabilidades e a incorporação de mecanismos eficientes para sua retroalimentação. Para tanto, é necessário que seja praticada também uma gestão eficiente da informação para o gerenciamento de 
projetos, ou seja, atividades relacionadas à geração, à coleta, à documentação, ao acesso e à distribuição das informações pertinentes a cada fase de projeto (FAGUNDES; TRISKA; MENDES JUNIOR, 2005).

Além disso, quanto maior o porte do projeto em questão e, por conseguinte, mais representativa a complexidade causada pelo grande número de equipes e etapas envolvidas e inter-relacionadas, mais relevante será a incorporação formal e sistemática dos preceitos da gestão da informação.

Reforçando este ponto de vista, Salgado (2010b) relata que um dos aspectos críticos da gestão da qualidade aplicada à construção civil refere-se ao alto nível de informalidade na organização das empresas de projeto, tendo observado que, mesmo quando há uma proposta de organização, falta treinamento para os colaboradores, e o fluxo de informação é inadequado. Deste modo, é comum a não apreensão, por parte das equipes, dos métodos propostos, em prejuízo dos resultados pretendidos para o processo.

Ferreira e Salgado (2007) também identificaram como desafiadora a implantação de processos sistemáticos a escritórios de arquitetura e constataram que, embora uma maior formalização do processo de projeto tenha trazido vantagens a estas empresas, pelo maior controle sobre as informações recebidas (por meio da determinação de procedimentos de registro, de armazenamento de informações e da formalização de ações e etapas, o que auxilia no treinamento e na capacitação da equipe), foi observado que as equipes tiveram dificuldade em coordenar as atividades de documentação. Como aspecto crítico observado para tal, verificou-se a necessidade de tempo adicional dos funcionários, além daquele dedicado às atividades profissionais.

Neste contexto, Bertezini e Melhado (2007) observaram dificuldades, por parte das empresas de projeto para estabelecer métodos para uma avaliação eficiente e implantar melhorias no processo. Alguns dos aspectos críticos foram apontados: a ineficiência na retroalimentação do processo, a inexistência de indicadores de referência e a falta de monitoramento adequado do desempenho.

Portanto, com base nos resultados obtidos pelas pesquisas citadas, é possível identificar que, embora a formalização de processos por equipes de projeto tenha trazido benefícios, há desafios observados, relacionados à escala de produção reduzida e à usual falta de formalização das tarefas (ABRAMOVICZ; 
ORNSTEIN, 2004; FERREIRA; SALGADO, 2007; BERTEZINI; MELHADO, 2007; SALGADO, 2010b). Esses aspectos são críticos, à medida que processos precisam ser formalizados, antes de serem incorporados a um sistema de gestão de informações.

Desta forma, as ferramentas computacionais podem contribuir para a formalização das tarefas, desempenhando, inclusive, o papel de um repositório de informação digital. Entretanto, acessar a informação requerida pode se tornar uma tarefa complexa, em razão da grande quantidade de informações, gerando perdas referentes às horas técnicas dos profissionais envolvidos na pesquisa desse volume de informações e a seus custos de armazenamento.

Conforme o apresentado por Fabricio (2002), o planejamento necessário à gestão da informação durante o processo de projeto deve contemplar soluções para evitar os seguintes aspectos:

- fluxo da informação desvinculado do fluxo de projeto;

- falta de mecanismos de monitoramento do fluxo de informação;

- dificuldade de acesso à informação, em função do grande volume de dados coletados de forma não sistemática; e

- falta de critérios para a avaliação da relevância das informações.

Uma vantagem na implantação das ferramentas computacionais para suporte tecnológico é a facilitação quanto à implantação do processo de desenvolvimento integrado do projeto. Este processo pressupõe o trabalho integrado de profissionais de diferentes competências, ao longo de todas as fases de seu desenvolvimento, de modo a apresentar soluções mais eficientes, considerando aspectos técnicofinanceiros (AIA, 2007).

Nesse contexto, a adoção de um repositório de informações produzidas pelos diferentes participantes, se estruturadas adequadamente, podem permitir que a informação da construção seja organizada em um único Banco de Dados. Nesse caso, o acesso às informações deve ser eficiente, a exemplo do observado em atividades industriais manufatureiras, que se beneficiaram pela implantação de sistemas de informação para gerir processos sistêmicos e estruturados.

Essa iniciativa pode aumentar a confiabilidade das informações trocadas 
entre equipes, assim como reduzir a necessidade de retrabalho de modelagem para adequação a seu uso em diferentes programas computacionais utilizados como apoio às tarefas desempenhadas. Sendo assim, Berard e Karlshoej (2012) destacam a importância do desenvolvimento de novos processos de projeto, possibilitados pelo desenvolvimento tecnológico, nos quais várias tarefas permitem a automação.

Além disso, com base na adoção de recursos tecnológicos, é possível melhorar a qualidade dos produtos da indústria da construção civil (edificações, componentes e sistemas construtivos), já que facilitam a comunicação entre os atores envolvidos no processo, permitem a integração com os fornecedores da obra e possibilitam a implantação de um sistema de gestão eficiente, sendo, portanto, um importante instrumento para a promoção da qualidade (LUCIANO; LUCIANO, 2005).

De modo análogo, a falta de implantação de um sistema integrado que permita gerenciar as tarefas, ao longo dos processos de projeto e de execução da edificação, pode representar riscos, relacionados à falta de validação dos resultados e à transmissão ineficiente das soluções e especificações de projeto.

Kerzner (2011) conclui que o gerenciamento de riscos de um empreendimento é, muitas vezes, falho, ficando o desempenho real aquém das expectativas do cliente. Para tanto, dois aspectos são determinantes: a má gestão dos riscos e a incapacidade técnica dos atores envolvidos.

As Normas ISO 31.000:2009 (ISO, 2009) e ISO/IEC 31.010:2009 (ISO/IEC, 2009) determinam procedimentos para a gestão de riscos, visando à elaboração de uma matriz de impacto, de modo que possam orientar o processo decisório.

Dentre os aspectos que podem expor o empreendimento a riscos de perdas, estão (OLIVEIRA, 2011):

- erros de projeto ou de execução;

- desperdício de materiais;

- ineficiência na execução dos serviços; e

- perda da confiabilidade das informações, durante as etapas de operação da edificação.

Em suma, etapas de produção fragmentadas e com tarefas não formalizadas comprometem a transmissão e a confiabilidade das informações relacionadas à 
execução e à operação de uma edificação, ao longo de seu ciclo de vida. Deste modo, são potencializados os riscos de perdas financeiras e relacionados aos impactos ambientais da construção civil, pelo desperdício de materiais e em razão do retrabalho necessário à adequação da edificação (MELHADO; MESQUITA, 2005; 2006).

Portanto, devido à quantidade e complexidade das informações necessárias ao processo de produção do empreendimento, é fundamental garantir a confiabilidade na transmissão dessa informação entre programas computacionais e entre etapas de seu ciclo de vida, sobretudo se essa transferência ocorrer de modo automatizado (JACOSKI; LAMBERTS, 2003).

\subsection{BOAS PRÁTICAS PARA A VERIFICAÇÃO E O MONITORAMENTO DO DESEMPENHO NO AMBIENTE CONSTRUÍDO}

Para Mallory-Hill; Preiser e Watson (2012), a avaliação de desempenho aplicada a uma edificação permite que seja verificada a pertinência das soluções adotadas durante o projeto, levando-se em consideração o comportamento humano, no contexto do ambiente construído.

Melhado e Mesquita (2006) observam que, no Brasil, não é comum que exista contato entre os arquitetos e engenheiros envolvidos no projeto e a edificação construída, após sua entrega e ocupação. Por este motivo, não raro, projetistas envolvidos com a concepção de edificações semelhantes não realimentam o processo criativo, permanecendo alheios a aspectos críticos relacionados a seu uso, operação ou manutenção e repetindo, por vezes, soluções ineficientes em novos projetos (MESQUITA, 2007).

\subsubsection{AVALIAÇÃO PÓS-OCUPAÇÃO (APO)}

Para a elaboração de um projeto, Imai (2013) observa que devem ser consideradas as seguintes etapas: identificação das características dos futuros usuários; determinação de suas necessidades; elaboração de um programa arquitetônico inicial; validação deste ao longo da elaboração do projeto, pelos usuários e projetistas; desenvolvimento dos elementos de representação gráfica; 
verificação do produto e avaliação de seu desempenho em uso, por meio da aplicação de uma APO.

A avaliação de desempenho tem a função de prover informações que embasem as decisões de projeto, visando à qualidade durante as etapas de concepção, construção e operação, de modo a retroalimentar o processo. Desta maneira, pode ser concebido um ciclo no qual uma equipe de projeto com acesso às informações sobre o desempenho de construções similares pregressas em uso permite a tomada de decisões de projeto embasadas por experiências anteriores (PREISER; VISCHER, 2005).

Sendo assim, a aplicação do conhecimento adquirido por meio da aplicação de APOs a edificações de tipologia construtiva semelhante constitui uma das possibilidades para a determinação das soluções de projeto adequadas às metas de desempenho. Portanto, sua realização pressupõe a adoção de métodos claros de pesquisa e julgamento, de modo a identificar os padrões que provejam subsídios para mensurar a qualidade, sejam estes relativos ou absolutos.

De modo resumido, a adoção dos conceitos da gestão da qualidade em um processo construtivo no qual está prevista uma APO, permite uma abordagem mais sistemática para a coleta de informações, identificação de situações críticas, determinação das causas e aspectos críticos prioritários e a aplicação de soluções corretivas (MELHADO, 2005), o que pode contribuir para a efetiva melhoria contínua do ambiente construído.

Outro aspecto importante, relacionado à elaboração sistemática e padronizada destas avaliações, é a possibilidade de consulta de seus resultados por agentes envolvidos na concepção de novas edificações, inclusive de modo a prover subsídios para a elaboração e revisão de normas técnicas, diretrizes de boas práticas e atualização de metas de desempenho e benchmarks.

Preiser e Schramm (2005) identificam seis fases de avaliação interativa do desempenho da edificação, a saber: planejamento estratégico, elaboração de programa, projeto, construção, ocupação, adaptação para reúso ou reciclagem.

As APOs vêm sendo aplicadas no Brasil, desde a década de 1980 (ORNSTEIN, 2006; ORNSTEIN; MOREIRA, 2008; ORNSTEIN et al., 2009), com o objetivo de aferir o desempenho do ambiente construído em diferentes tipologias de edificações e compreender como o usuário percebe e relaciona-se com a edificação. 
Desde então, os métodos e técnicas adotados para sua aplicação sofreram evoluções sucessivas (ORNSTEIN, 1996; KOWALTOWSKI; PIÑA, 2001; ROMÉRO; ORNSTEIN, 2003; ELALI, 2010; RHEINGANTZ, 2010; FRANÇA; ORNSTEIN; ONO, 2011; ORNSTEIN et al., 2012). Também foram objeto de debates em ambientes acadêmicos e fóruns dedicados ao estudo da engenharia e da arquitetura, como os promovidos pelo NUTAU (Núcleo de Pesquisa em Tecnologia da Arquitetura e Urbanismo da Universidade de São Paulo) e pela ANTAC (Associação Nacional de Tecnologia do Ambiente Construído), dentre outros.

Neste cenário, o trabalho de grupos de pesquisa, tais como: Qualidade e Desempenho no Ambiente Construído (Faculdade de Arquitetura e Urbanismo da Universidade de São Paulo), Processo de Projeto em Arquitetura: da teoria à tecnologia (Departamento de Arquitetura e Construção da Faculdade de Engenharia Civil da Universidade Estadual de Campinas, GAE e ProLUGAR (Faculdade de Arquitetura e Urbanismo da Universidade Federal do Rio de Janeiro), GEPA (Grupo de Estudos Interação Pessoa-Ambiente, do Departamento de Arquitetura da Universidade Federal do Rio Grande do Norte), PROPUR (Programa de PósGraduação em Planejamento Urbano e Regional da Universidade Federal do Rio Grande do Sul) e MORA (Grupo de Pesquisa em Habitação da Faculdade de Arquitetura, Urbanismo e Design da Universidade Federal de Uberlândia) merecem destaque.

Entretanto, observa-se que, embora 0 ambiente acadêmico dedique importantes esforços à questão, a aplicação efetiva dos métodos e técnicas da APO junto à indústria da construção civil ainda não é uma realidade no Brasil, à época da conclusão da presente pesquisa (2015).

Além disso, o extenso Banco de Dados referente a ambientes construídos em uso, elaborado pelas diferentes equipes de pesquisa na área de ambiente e comportamento, carece de padronização e de um fluxo eficiente de informação, que possibilite o acesso aos aspectos identificados e respectivas medidas corretivas adotadas, o que é fundamental para a realimentação do processo de projeto. Uma possibilidade visando a proporcionar maior fluidez e melhor acesso a esses dados seria a elaboração de uma norma técnica para a aplicação de APOs, a apresentação e a documentação dos resultados obtidos por meio destas.

Especificamente, considerando o caso de edificações escolares públicas, 
Kowaltowski (2011) avalia:

Uma análise dos estudos de ambientes físicos de escolas públicas no Brasil demonstra que os prédios escolares apresentam qualidade arquitetônica pouco expressiva e nível de conforto mínimo. (...)

As intervenções de melhoria são possíveis nos casos de problemas de conforto ambiental encontrados na maioria dos estudos, com a possibilidade de soluções simples em muitas escolas. As reformas e ampliações, por sua vez, necessittam de avaliações de custo/benefício e planejamento cuidadoso, para evitar inadequações, comuns nas escolas públicas. As modificações simples podem trazer melhorias significativas para um aspecto, porém, se mal planejadas, podem trazer prejuízos em outros aspectos. (KOWALTOWSKI, 2011, p.156)

Considerando um nível de formalização suficiente para que os processos de projeto e de execução possam ser claramente mapeados, faz-se possível aplicar a estes processos de avaliação os conceitos de gestão da qualidade, tal como o apresentado por França e Ornstein (2015) para orientar a tomada de decisões de projeto, conforme o fluxograma proposto na Figura 7. 


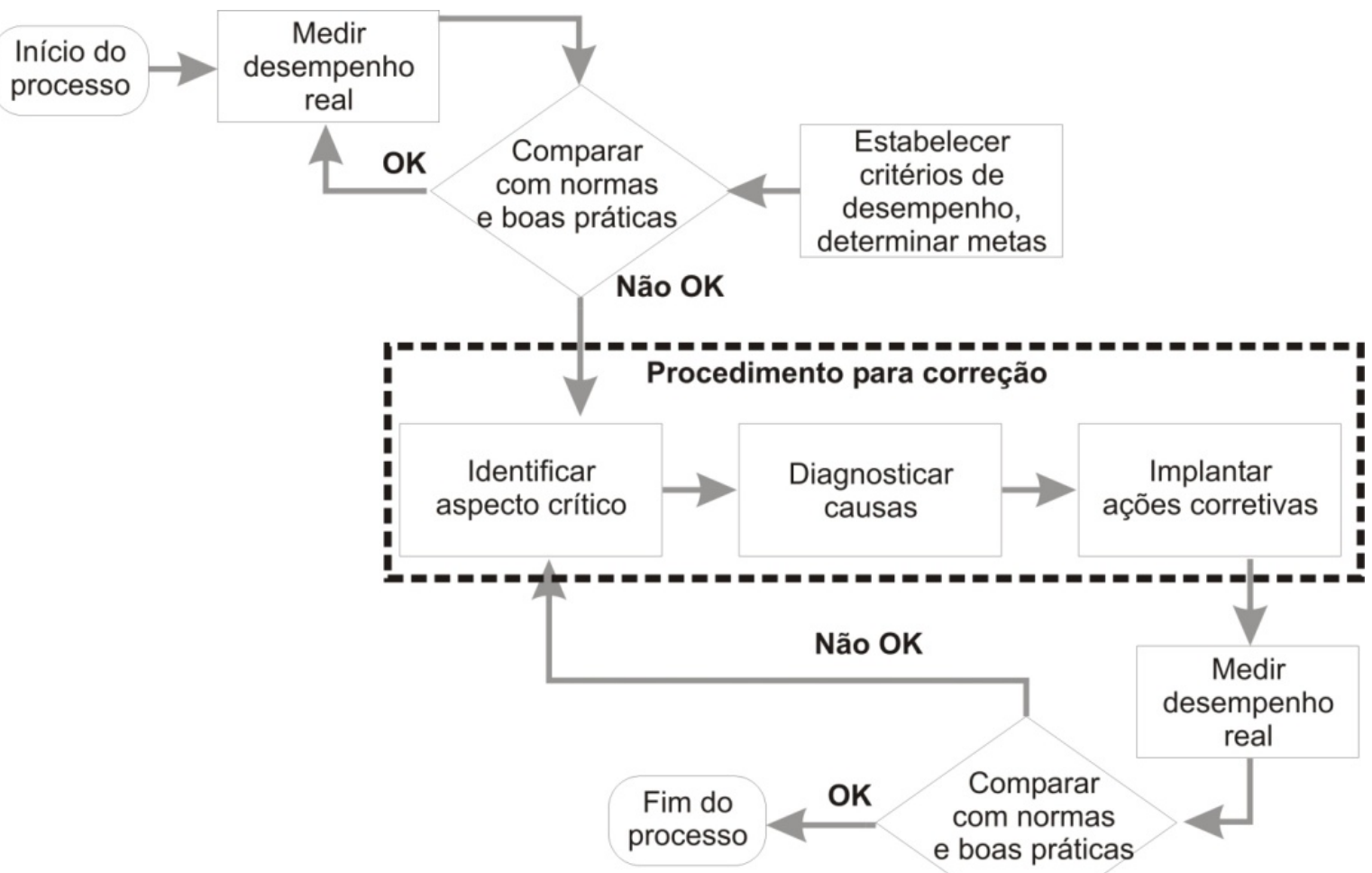

Figura 7. Fluxograma do processo de tomada de decisões visando à gestão da qualidade Fonte: FRANÇA, ORNSTEIN (2015).

No esquema da Figura 8, as etapas de projeto são apresentadas em função da realimentação cíclica, com base nos resultados da edificação em uso ao longo de sua vida útil, possibilitada pela aplicação de uma APO. Desta forma, podem ser elaborados planos de requalificação, revisão de procedimentos para a manutenção, a operação e a revisão de diretrizes para novos projetos. 


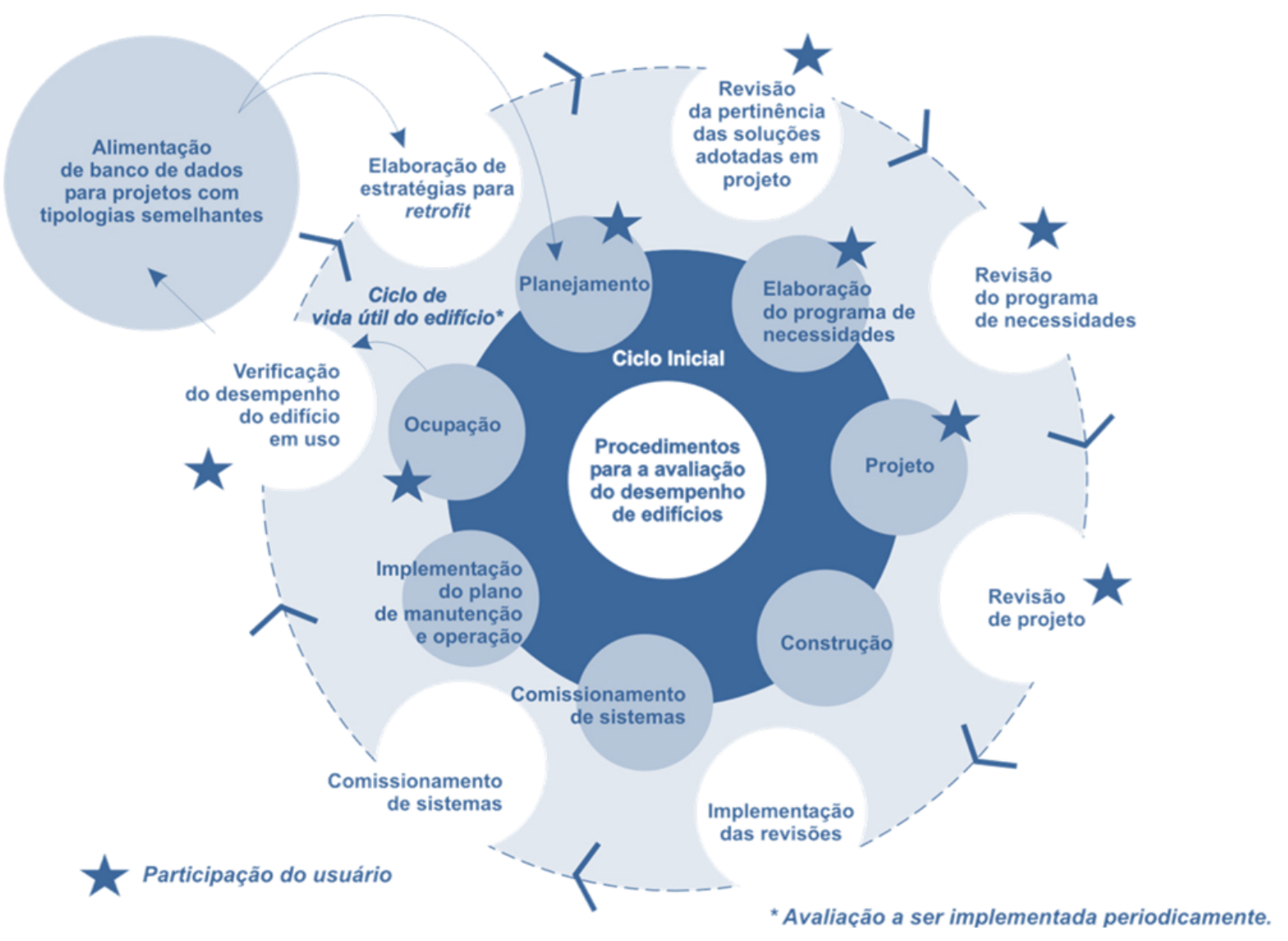

Figura 8. Procedimentos para a avaliação do desempenho dos edifícios Fonte: FRANÇA (2011, p. 12).

Alguns exercícios vêm sendo feitos, com o intiuto de automatizar os resultados obtidos por meio da aplicação de APOs. Sales e Ruschel (2014) sugerem a incorporação dos resultados das APOs ao modelo tridimensional, no formato de tabelas. Por sua vez, Freitas e Ruschel (2015) propõem o emprego de soluções tecnológicas de realidade aumentada para a incorporação dos resultados de APOs ao modelo, de modo que a imagem da situação existente possa ser renderizada, sobreposta à imagem do protótipo tridimensional.

Entretanto, para que essa informação seja efetivamente útil, é preciso determinar quais procedimentos e recursos tecnológicos são necessários para o acesso aos dados e a que atores estes diagnósticos interessam, no contexto de um processo de gestão do conhecimento (SOUZA, MELHADO, 2008).

Por exemplo, gestores de facilidades, usualmente, são proficientes na análise de tabelas, porém, não apresentam domínio do programa computacional utilizado 
para modelagem em 3D. Também as licenças desses programas de uso específico de engenharia e de arquitetura não costumam estar disponíveis nos ambientes administrativos nos quais são tomadas as decisões gerenciais referentes ao empreendimento.

Por esse motivo, entende-se, no âmbito da presente pesquisa, que as informações provenientes de diagnósticos de APO, para efeito de uma realimentação eficiente de projeto, devem estar disponíveis aos stakeholders, em ambiente que permita a fácil consulta e não obrigue à equipe o domínio de programas computacionais de modelagem tridimensional.

\subsubsection{PROCESSO DE COMISSIONAMENTO}

Outra prática de grande importância para a validação do desempenho no ambiente construído é o processo de comissionamento (ANSI/ASHRAE, 2005), que consiste em:

Processo sistemático de se assegurar, por meio de verificação e de documentação, desde a fase de projeto até, no mínimo, um ano após a construção, que todos os sistemas da edificação integrados apresentam desempenho em conformidade com a documentação de projeto e seus objetivos, de acordo com as necessidades operacionais do proprietário, o que inclui 0 treinamento da equipe operacional. (GSA, 2005, p. 7)

A GSA (GSA, 2005) destaca que o escopo do processo de comissionamento aplica-se à edificação como um todo, e não deve se restringir a sistemas de AVAC e outros consumidores de energia, que mais usualmente são objeto de validação.

Portanto, o processo de comissionamento tem por objetivo assegurar a qualidade do ambiente construído, seja ele novo ou objeto de requalificação. Para tal, deve ser aplicado ao longo de toda a vida útil da edificação, desde a fase de planejamento, por meio da validação dos requisitos do proprietário e das premissas de projeto, até a fase de pós-ocupação, quando da verificação das condições de operação dos ambientes e de seus sistemas em uso. 


\subsubsection{AVALIAÇÃO E MONITORAMENTO DO DESEMPENHO ENERGÉTICO DA EDIFICAÇÃO EM USO}

Durante a fase de projeto, a simulação energética é utilizada como um recurso para a verificação do desempenho das soluções propostas. Mas, além da simulação de desempenho energético elaborada durante o projeto, é importante monitorar os níveis reais de eficiência energética da especificação, para verificar se o desempenho real está coerente com o projetado.

Para tal, é adotado o Protocolo Internacional de Medição e Verificação do Desempenho Energético da edificação, que apresenta procedimentos que permitem quantificar as economias reais obtidas pela implantação de medidas de conservação de energia (MCEs) implantadas em um projeto. Uma das alternativas propostas pelo protocolo consiste na calibração do modelo computacional de simulação do consumo energético elaborado para o projeto, considerando os padrões efetivos de operação e ocupação (EVO, 2010). 


\section{RECURSOS TECNOLÓgICOS PARA A GESTÃo DA INFORMAÇÃO}

Considerando os processos $\mathrm{e}$ as boas práticas relevantes para o desenvolvimento da presente pesquisa, foi verificada a necessidade de identificação e de avaliação de recursos tecnológicos, que embasassem o processo sistemático a ser proposto.

Para a efetiva integração dos processos relacionados à produção de uma edificação, é fundamental adotar uma abordagem que integre os agentes envolvidos (AIA, 2007). Fabricio (2002) e Fabricio e Melhado (2003) destacam, em sua discussão sobre o desenvolvimento do projeto simultâneo, as vantagens obtidas pelas interfaces com mercado/usuário, especialidades pertinentes aos projetos $\mathrm{e}$, finalmente, entre o projeto e a produção.

Scheer, Bollmann e Stumm (2005) discutem a aplicabilidade de ambientes colaborativos para a arquitetura e a engenharia civil. Os pesquisadores destacam que a interoperabilidade proporcionada pela integração de profissionais de múltiplas competências específicas, bem como o uso simultâneo de diferentes programas computacionais, ao longo do desenvolvimento do projeto, permitem reduções de custos e prazos relacionados ao projeto e à construção de uma edificação.

Para o sucesso do trabalho simultâneo em equipe, entretanto, deve-se considerar a elaboração detalhada do escopo de projeto e o planejamento das atividades relacionadas à fase de desenvolvimento. Portanto, é necessário que seja estabelecido um processo eficiente de gestão da informação.

A prática efetiva de projeto em ambiente colaborativo, entretanto, ainda não se mostrou plenamente concretizada, à época do desenvolvimento da presente pesquisa (2015).

Isso ocorre, pois, não se verificam, na prática, as alterações necessárias no processo de desenvolvimento de projeto. Neste sentido, Corrêa e Ruschel (2010) observam que o mercado da construção civil brasileira passou a incorporar, desde 2003, conceitos de projetos participativos, com o uso da internet. Esta prática disseminou-se, sobretudo, entre as incorporadoras e as empresas de infraestrutura, cujo ambiente propício é relacionado com o alto grau de terceirização e 
descentralização. No entanto, nesses casos, não foram incorporadas alterações significativas no processo de projeto então existente.

Para Moeckel (2000), o sistema colaborativo de trabalho auxiliado pelo computador permite aos participantes o acesso simultâneo às informações de projeto. Em geral, na construção civil, esta comunicação vem sendo possibilitada pelo uso de uma extranet, ou seja, uma rede de computadores que permita o acesso controlado de usuários externos, como, por exemplo, os participantes da equipe de projeto de um empreendimento.

Pelo desenvolvimento de projeto integrado, busca-se antecipar, para a fase de projeto, todas as decisões referentes às expectativas dos integrantes de sua equipe multidisciplinar, sob os aspectos dos requisitos técnicos e da qualidade, inclusive considerando o custo e o tempo correspondentes às soluções adotadas (OLIVEIRA, 2005).

Ao integrar as informações de projeto, por meio da Tecnologia da Informação (TI), observa-se um aumento representativo no fluxo das informações, que são trocadas entre os membros das equipes envolvidas por meio de extranets, ou seja, redes de computadores que possibilitam o acesso remoto às informações. Esta dinâmica potencializa o fluxo das informações, podendo gerar sobrecarga e perda de dados importantes, caso não sejam definidas regras de comportamento para seu envio e validação (FABRICIO; MELHADO, 2002; SCHEER et al. 2009).

Também, os ambientes de extranets permitiram o gerenciamento de projetos e sua utilização para a proposição de propostas, bem como a realização de compras via rede, integrando também aspectos financeiros e administrativos aos recursos tecnológicos disponíveis (NASCIMENTO; SANTOS, 2003).

Nem sempre, o investimento em tecnologia da informação apresenta benefícios mensuráveis. $\mathrm{E}$, ainda, nem todas as organizações adotam planos claros para a verificação de eventuais benefícios obtidos por meio dos recursos tecnológicos implantados. Ashurst; Doherty e Pettard (2008) alertam para a importância da questão e sugerem que o planejamento dos sistemas de informação e de seu respectivo suporte tecnológico seja feito com vistas aos benefícios a serem obtidos, bem como sejam adotados critérios para a avaliação sistemática de seu atendimento.

Nascimento e Santos (2001) observam que a popularização da utilização das 
extranets de projetos proveem suporte e tornam comum o gerenciamento dos agentes envolvidos no processo de projeto, pela utilização da internet.

Scheer et al. (2007) destacam ainda a importância do uso da extranet como um repositório de arquivos e para suporte ao sistema de comunicação do projeto. Por meio da extranet, é possível compartilhar informações referentes a arquivos de projetos, especificações, orçamentos, cronogramas e demais documentos, necessários à produção do edifício, disponíveis em uma base de dados centralizada (FABRICIO; MELHADO, 2002). Na ocasião, os pesquisadores observaram que o principal meio para o acesso e atualização das informações ocorria pelos uploads e downloads, não sendo possível que dois ou mais projetistas trabalhassem ao mesmo tempo no mesmo arquivo.

Entre as vantagens relacionadas ao uso da extranet em projetos para a gestão de informações e arquivos estão: a criação de um Banco de Dados dos documentos do empreendimento; o controle de versões e atualizações; a facilidade de acesso às informações pela equipe de projeto e melhor fluidez da informação; a redução das trocas de informações por meio físico, o que representa a redução de custos e do tempo relacionado e o melhor controle do acesso às informações.

Entretanto, ainda há desafios a serem vencidos, tais como: dificuldades de compatibilização entre os fluxos de informação dos processos de projeto e organizacionais; necessidade de controle de processos para evitar a produção da informação desnecessária e para manter a informação organizada, de modo que esta possa ser acessada adequadamente pelos membros das equipes envolvidas. Além disso, é importante que exista um mecanismo para o monitoramento do processo, que permita garantir que este opere de modo adequado ( $F A B R I C I O$, MELHADO, 2002).

Portanto, incorporar os conceitos de projeto participativo e seus necessários recursos tecnológicos às práticas da produção e da gestão do edifício consiste em um desafio, para o qual é preciso que se deixe a zona de conforto, para repensar as práticas de projeto e o processo de gestão da informação.

O ambiente colaborativo pode se utilizar de uma extranet, ou seja, uma rede de computadores que permita o acesso externo, como ambiente para o repositório de arquivos. Nesse contexto, dois aspectos são fundamentais: a formalização do fluxo de processo, de modo a possibilitar a identificação dos atores, tarefas e 
responsabilidades e as diretrizes para o fluxo da informação e procedimentos para sua validação, em cada estágio do processo (SCHEER et al, 2007).

Por sua vez, Scheer et al. (2009) comentam que, para o processo de projeto colaborativo, é necessária a formalização de um Plano de Comunicação, no qual sejam listados os responsáveis, atribuídas as responsabilidades e especificados os protocolos de validação das informações. Os pesquisadores apontam, como vantagens dessa abordagem, a possibilidade de visualização das atualizações de projeto, o monitoramento mais eficiente e a maior confiabilidade das soluções, uma vez que se torna mais fácil a identificação das não conformidades.

Para Andery e Arantes (2015), o uso do gerenciador de arquivos proporciona maior agilidade na interação entre os atores de um determinado empreendimento, uma vez que, dentre os recursos disponíveis, possibilita o envio de notificações automáticas das alterações realizadas no ambiente da extranet, tais como a publicação de novos arquivos. Verificou-se também maior comprometimento dos projetistas, no cumprimento dos prazos das tarefas. Entretanto, os pesquisadores concluem, no âmbito dos estudos de caso avaliados que, em razão do planejamento prévio ineficiente, os benefícios dos ambientes virtuais acabam se limitando a determinados contextos (como, por exemplo, projeto e construção), não se refletindo positivamente de forma mais ampla, entre os agentes envolvidos nos demais processos relacionados à produção e à operação da edificação, bem como aos agentes envolvidos com fluxos de trabalho interdependentes, tais como escopos da área financeira e jurídica.

Scheer et al. (2009) destacam que, dentre as principais vantagens de se adotar um processo colaborativo de projeto, com o suporte de recursos tecnológicos, encontra-se a possibilidade de reduzir os erros de projeto, pela simulação do comportamento das soluções especificadas. Isto aplica-se tanto para verificação da geometria proposta quanto para avaliação do desempenho de elementos construtivos, relacionados às diferentes disciplinas da construção. 


\subsection{CONSIDERAÇÕES SOBRE O PROJETO AUXILIADO POR COMPUTADOR}

Até a década de 1980, não se notou um grande impacto dos recursos da $\mathrm{TI}$ aos processos de projeto, uma vez que a tecnologia encontrava-se restrita a procedimentos administrativos de empresas de grande porte. Ao longo da década de 1980, observou-se a popularização dos computadores pessoais, concomitantemente à disseminação do uso de sistemas de desenho assistido por computador (CAD) junto às empresas de projeto (NASCIMENTO; SANTOS, 2003).

O desenvolvimento deste ambiente propiciou possibilidades de integração entre os programas computacionais, adotados para o desenvolvimento de projeto, durante a década de 1990. No caso dos arquivos elaborados utilizando tecnologias para CAD, tornou-se possível exportar desenhos no formato neutro DXF (Drawing Exchange Format), que permitiu a troca de informações entre diferentes programas de autoria. Além disso, editores de textos passaram a permitir a inserção de planilhas eletrônicas e gráficos criados em programas específicos (NASCIMENTO; SANTOS, 2003).

A partir da disseminação destas práticas, deu-se o amadurecimento da utilização de programas computacionais para auxílio das tarefas inerentes aos processos de projeto e construção do edifício. Esse aspecto pressupõe a troca de informações entre atores do processo de produção do edifício que utilizem diferentes programas computacionais

Observa-se que a popularização dos recursos de informática em escritórios de projetos ocorre, concomitantemente, à adoção em escala de métodos para a gestão da qualidade nessas mesmas empresas, o que se dá em dois níveis: gestão da qualidade dos serviços prestados no escritório e da qualidade das soluções propostas em projeto, conforme foi abordado no Capítulo 3.

Especificamente no campo da TI aplicada ao desenvolvimento de projetos, foram observadas grandes transformações, a partir dos anos 1990. Nesse período, programas CAD, empregados para a elaboração de desenhos assistidos por computador, passaram a ser amplamente utilizados para elaborar desenhos, croquis e projetos. Inicialmente, não houve uma compreensão adequada das ferramentas disponíveis, tendo sido observada a aplicação dos programas computacionais de um 
modo ineficiente, praticamente como um instrumento de desenho. Observou-se, na ocasião, que o uso da ferramenta computacional ocorria de forma análoga ao desenho elaborado na prancheta, quase como se o programa de computador correspondesse a uma régua "T" (FLEMMING, 1997).

Entretanto, para que a adoção dos programas CAD representasse um ganho real de produtividade, foi necessário repensar e planejar o processo de desenho (BHAVANI, JOHN, 1997).

No esquema apresentado na Figura 9, são demonstradas as diferenças entre os raciocínios envolvidos para a elaboração de uma mesma forma geométrica, considerando o desenho manual e o desenho em CAD.

\section{Estratégia para desenho manual}

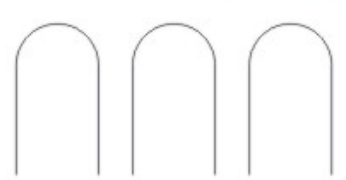

1. Desenhar os arcos
2. Desenhar as linhas verticais

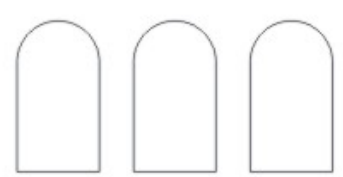

2. Desenhar as linhas horizontais

\section{Estratégia para desenho em CAD}

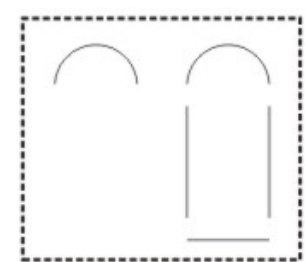

1. Desenhar o arco

2. Desenhar as linhas

Detalhamento

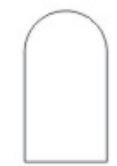

3. Agrupar as linhas

Agrupamento

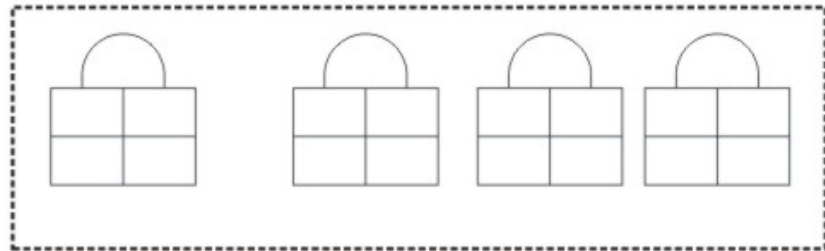

4. Modificar a forma

5. Copiar a forma

Manipulação

Figura 9. Diferença entre estratégias de desenho manual e CAD. Adaptado de BHAVNANI; JOHN (1997, p. 10) e FLEMMING (1997, p. 359). Tradução nossa.

Em continuidade à tecnologia $\mathrm{CAD}$, surgiram ferramentas mais complexas, com base nas quais se extrapola o uso do computador, como meio de representação da geometria. Isto ocorre pela incorporação de informações 
referentes ao desempenho dos componentes e ambientes modelados e permite a elaboração de projeto em ambiente digital.

Dentre manifestações destas tecnologias, observou-se, por exemplo, o desenvolvimento de projeto baseado em desempenho. Essa prática consiste na elaboração de um modelo geométrico, cujas soluções de projeto são verificadas, por meio de simulações computacionais. Com base nestas análises, procede-se à modificação e à geração de formas arquitetônicas, com o objetivo de obter-se um determinado desempenho pretendido (OXMAN, 2008).

Os modelos apresentados na Figura 10 demonstram a evolução das relações presentes em um processo de projeto elaborado em papel e, portanto, sem o auxílio de recursos digitais (Modelo 1 ), bem como a evolução das inter-relações, correspondentes ao projeto desenvolvido em ambiente CAD (Modelo 2) e a evolução referente ao projeto baseado em desempenho, elaborado com o auxílio do ambiente computacional (Modelo 3).

Nota-se que, no Modelo 1, as relações referentes à geração, à avaliação e ao desempenho são implícitas e dependem diretamente do projetista. Considerando a evolução para o Modelo 2, observa-se que a mudança fundamental está relacionada à forma de representação, que passa a ser digital e, por conseguinte, pressupõe uma abordagem diferente, quando comparada ao desenho em papel. Entretanto, os aspectos relacionados à avaliação, ao desempenho e à geração da geometria continuam implícitos e dependentes, diretamente, das decisões do projetista.

As relações dos projetos modelados em computador são representadas no Modelo 3. Neste caso, observa-se que as relações inerentes à representação e à avaliação passam a ser implícitas e sujeitas a interações com o projetista. Apesar disso, a geração e a verificação do desempenho ainda se constituem em relações não digitais e dependentes das decisões dos atores responsáveis pelo desenvolvimento do projeto. 

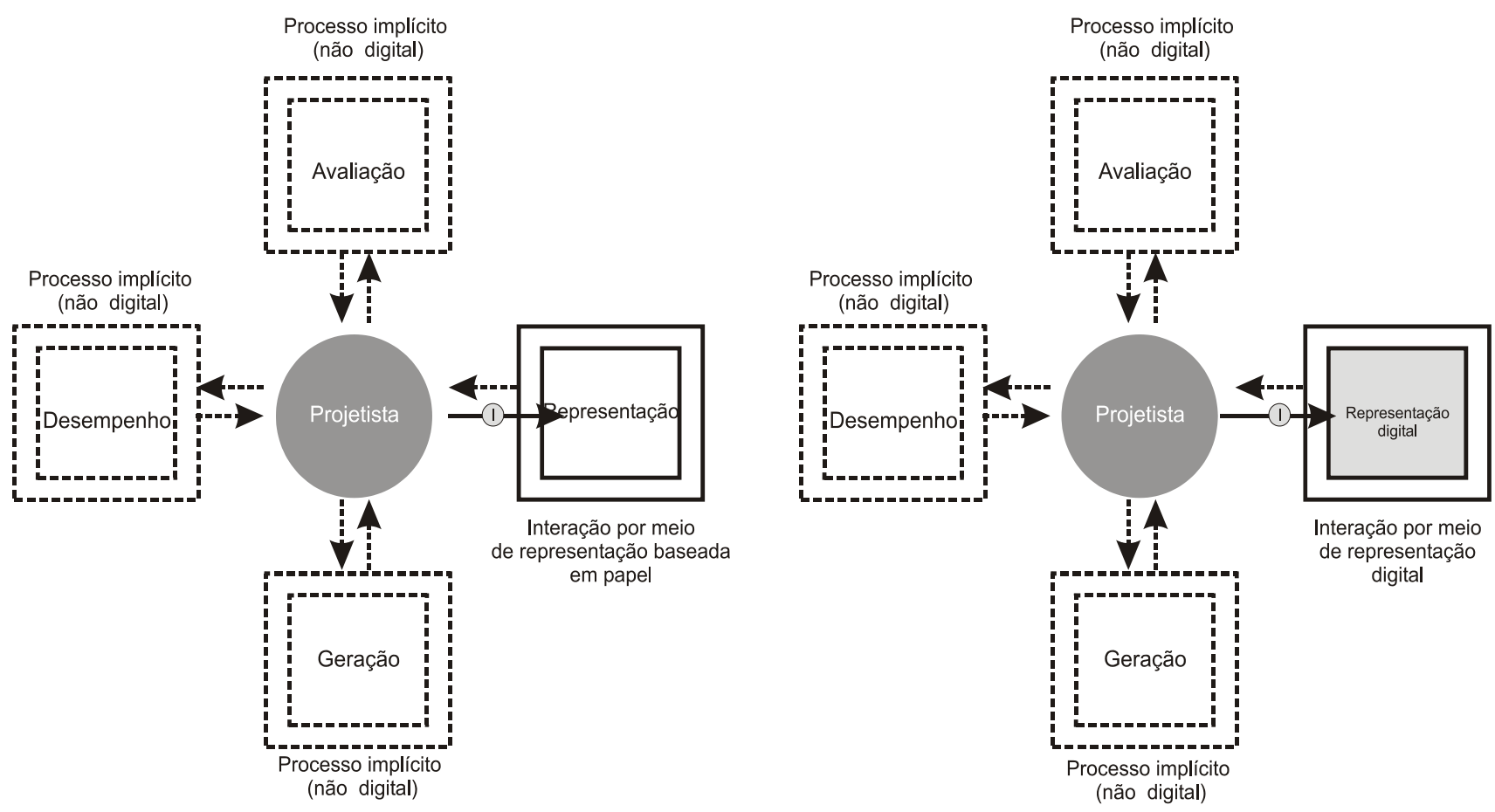

3 - Modelo - Projeto baseado em desempenho

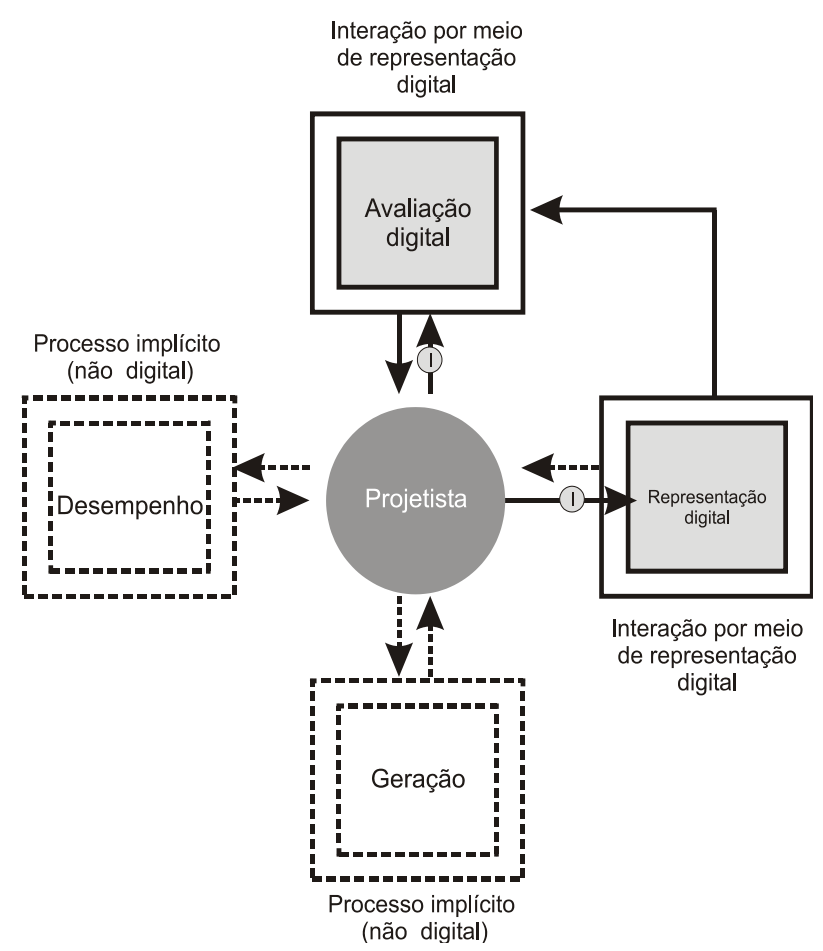

Figura 10. Modelo de relações entre as etapas do processo de projeto.

Adaptado de: OXMAN (2006, p. 245, 247 e 248), pela pesquisadora. 
O surgimento de tecnologias de modelagem da informação altera, novamente, as relações entre as etapas de projeto e seus atores. Um aspecto importante desta abordagem é a possibilidade de que sejam relacionados dados e propriedades de componentes de uma edificação ao modelo computacional, inclusive considerando as modificações que, eventualmente, ocorrem durante seu ciclo de vida. Assim, passou a ser possível incluir, em um modelo computacional, informações de diferentes naturezas, tais como: produtos, processos e respectivos registros, representações gráficas, especificações, características de desempenho e informações sobre manutenção (RUSHEL et al., 2010).

Quanto aos recursos da tecnologia digital aplicados ao projeto, Crespo e Ruschel (2007) observam que o uso de ferramentas de modelagem da informação permite a elaboração de um mockup digital, no qual os elementos construtivos são codificados, admitindo uma representação geométrica dos componentes do edifício real a ser construído. Esse protótipo pode ser relacionado a um Banco de Dados, o que torna possível o gerenciamento de informações, inclusive durante o período de operação da edificação.

Apesar disso, embora os recursos proporcionados pela evolução da TI tenham permitido maior capacidade de armazenamento e processamento de informações, Panizza e Ruschel (2005) observam que, em muitos escritórios, as interações multidisciplinares ainda ocorrem de modo precário e o sistema de desenho eletrônico, muitas vezes, atue apenas como um substituto do desenho convencional feito em papel. 


\subsection{BUILDING INFORMATION MODELING (BIM)}

Como discutido no Capítulo 3, em um projeto, encontra-se implícita uma grande quantidade de informações. Verificam-se também relações complexas entre elas, uma vez que podem ser necessárias às etapas de projeto, construção, operação e manutenção, bem como a diferentes disciplinas, tais como: arquitetura, engenharia civil, engenharia mecânica, engenharia elétrica, engenharia hidráulica.

Além disso, a elaboração da análise de ciclo de vida de componentes e a avaliação da viabilidade financeira são pertinentes ao processo decisório para as soluções apresentadas, de modo que a integração destes aspectos consiste em um desafio. Como uma possível abordagem para a questão, apresenta-se a adoção de tecnologias para a Modelagem da Informação da Construção (Building Information Modeling - BIM) (ASHRAE, 2009).

Portanto, a BIM consiste em um processo integrado de modelagem e de gestão da informação, para o planejamento, o projeto, a construção e a manutenção da edificação. Para tanto, são utilizados recursos tecnológicos, que permitem a representação computacional de informações geométricas (tais como tamanho, volume, formato, altura e orientação); e não geométricas (como informações sobre o desempenho de componentes e ambientes, informações sobre sistemas, resultados quanto ao atendimento a requisitos normativos, especificações, quantitativos e custos) (BCA; 2012). Seu produto é o protótipo digital de um ambiente construído, de modo que seja possível especificar, comunicar e analisar as propriedades de uma edificação e o inter-relacionamento destas (EASTMAN et al., 2011; BIMFORUM, 2015).

Aos processos de BIM, portanto, é inerente a troca de informações da construção associadas a representações tridimensionais parametrizadas ou estáticas (IBRAHIM, KRAWCZYK, 2003). A quantidade e a natureza das informações da construção que serão atribuídas ao modelo variam conforme o processo proposto para determinado projeto. Por exemplo, podem estar associadas a suas características (como: cor, material, preço) ou a seu desempenho (térmico, acústico, estrutural, consumo energético, vida útil, entre outros). Esse processo de informatização da informação é semelhante ao observado na indústria manufatureira (HVAM, 1999). 
Para Nascimento e Santos (2003), a indústria da construção civil adotou tardiamente as novas tecnologias da informação, quando comparada a outros setores industriais. Um dos motivos possíveis, destacados pelos pesquisadores, foi a sobrecarga de informações relacionadas a um processo de construção típico, mesmo que seja de baixa complexidade. Isto ocorre pois, são muitas as informações necessárias para produção do edifício, dentre as quais estão: desenhos, memorandos, fotos, especificações e memoriais descritivos, quantitativos e orçamentos. Desse modo, a adoção de tecnologias para BIM corresponde a um ganho importante do ponto de vista da gestão e da produtividade.

BIM é definido como a criação e o uso de informações coordenadas, consistentes e computáveis referentes a uma edificação em projeto - informação paramétrica é utilizada para a tomada de decisões de projeto, produção de documentos de construção de alta qualidade, predição de desempenho da edificação, estimativa de custos e planejamento da construção. (KRYGIEL; NIES, 2008, p. 27, tradução nossa)

Para Crespo e Ruschel (2007), a modelagem em BIM corresponde à codificação digital dos componentes da edificação, que os descrevem e representam.

Por sua vez, Lee; Sacks e Eastman (2006), descrevem a BIM como sendo um processo para a especificação e a gestão de informações relacionadas a uma edificação, de modo a garantir sua reutilização e a possibilitar a interoperabilidade entre programas computacionais, pertinentes a diferentes disciplinas.

Portanto, um modelo BIM consiste na representação digital de um projeto, considerando-se suas características físicas e funcionais. O modelo é composto por elementos, que podem ser componentes, sistemas ou conjuntos de componentes. Sendo assim, a utilização de tecnologias para BIM permite (AIA, 2008):

- elaboração das representações gráficas necessárias ao projeto de arquitetura e aos projetos técnicos;

- $\quad$ elaboração de simulações de desempenho dos modelos representados; 
- $\quad$ registro e organização dos resultados obtidos por simulações;

- $\quad$ registro de dados coletados correspondentes à aferição do desempenho real;

- $\quad$ tratamento estatístico das informações;

- documentação do histórico de resultados e ações implantadas; e

- $\quad$ a partir da consulta aos resultados, a retroalimentação do processo.

Em suma, os projetos desenvolvidos em BIM, além das informações geométricas tridimensionais (3D), podem apresentar as seguintes informações: tempo (4D), custo (5D) e gestão de facilidades (6D) (RIBA, 2012).

Além disso, para Eastman et al. (2011), a modelagem da informação da construção permite a representação digital de componentes da edificação, associada atributos e a regras paramétricas.

O comportamento paramétrico de um elemento corresponde à habilidade de um determinado componente em responder a um estímulo. Nesse contexto, componentes da edificação, tais como: paredes e elementos estruturais, respondem de modos diferentes a estímulos, quando compatibilizados com elementos construtivos. Por exemplo, um cano pode atravessar uma parede, mas deve desviarse de uma viga. Ou ainda, uma parede pode receber uma porta ou janela (LEE; SACKS; EASTMAN, 2006).

Consistem em variáveis do sistema paramétrico (EASTMAN et al., 2011):

- definições geométricas associadas a dados e regras;

- integração da geometria, de modo a garantir que não haja representações redundantes;

- existência de hierarquias que permitam fazer associações entre objetos representados (por exemplo: um elemento representando uma "porta" será automaticamente inserido em um elemento caracterizado como "parede");

- possibilidade de agregar objetos em diferentes níveis, de modo a permitir a edição de parâmetros de todos os elementos com a mesma classificação automaticamente;

- definição de regras relacionadas à viabilidade de um elemento (como, por 
exemplo, uma porta cuja altura seja maior que a parede onde será inserida); e

- interface para a exportação de tabelas de atributos relacionados às informações do projeto e seus componentes.

Sendo assim, uma das principais características do modelo elaborado é a possibilidade de que sejam atribuídas propriedades e características para determinar o comportamento de um elemento gráfico modelado, bem como estabelecer relações entre elementos de um determinado modelo (EASTMAN et al., 2011).

Dentre os componentes que podem ser modelados como objetos paramétricos, estão: paredes, elementos estruturais, portas, janelas, entre outros. A estes, podem ser atribuídas características geométricas (por exemplo: largura, altura, espessura); comportamentais, de modo a permitir sua interação com outros objetos do modelo (por exemplo, uma porta, ao ser inserida, pode remover a porção de parede correspondente ao tamanho do vão necessário a sua instalação) e informações técnicas (como orientações para instalação, manutenção e demolição).

É possível modelar famílias de elementos construtivos, como por exemplo, uma família de portas de mesmo material e configuração de batentes e guarnições, que apresentem diferentes tamanhos de folhas (MONTEIRO, 2011).

Para a modelagem eficiente, as características podem ser atribuídas a objetos específicos ou automaticamente, a um conjunto de elementos construtivos (por exemplo: todos os elementos modelados como paredes podem ser relacionados às características de um determinado tipo de alvenaria).

Além disso, um elemento construtivo está relacionado a um conjunto de propriedades, que devem ser listadas, analisadas e orçadas, tais como (AGC, 2006):

- especificações do material pertinente a sua produção;

- indicadores de desempenho e comportamento (propriedades acústicas, transmitância térmica e refletâncias);

- informações relacionadas ao comissionamento, manutenção e ciclo de vida dos materiais e dos sistemas;

- características físicas (cores, cargas, comportamento estrutural); e

- informações relacionadas à manutenção preditiva e corretiva, o que contribui 
para a manutenção de seu desempenho, ao longo da vida útil da edificação.

Além de ser possível atualizar um modelo para uso durante a construção, bem como continuamente, ao longo da vida útil da edificação, desde as fases de concepção do projeto até sua ocupação e manutenção. Além disso, as informações do modelo BIM permitem que o proprietário e as equipes de manutenção compreendam os sistemas de edificação e os padrões de operação previstos, bem como embasem alterações, renovações e ampliações (ASHRAE, 2009).

Tanto os processos de BIM como o desenvolvimento de projeto em CAD 2D/3D geram arquivos digitais. Entretanto, as informações relacionadas a cada um são de natureza bastante diferente, visto que ao elaborar um modelo BIM, além da representação geométrica em três dimensões, estas são relacionadas ao projeto informações sobre a edificação e seus componentes, que formam uma base de dados para embasar a tomada de decisões (ASHRAE, 2009).

Assim, um projeto elaborado utilizando tecnologias para BIM está relacionado a uma quantidade maior de informações do que as possíveis de serem atribuídas à tecnologia CAD, em razão da mencionada parametrização de elementos construtivos (em função da altura do pé-direito, por exemplo), à exportação de suas características para programas de simulação de desempenho, à consistência da modelagem (uma alteração feita em planta é automaticamente atualizada em uma vista, corte ou perspectiva) e à interação de diversos usuários no mesmo arquivo (para a inclusão, por exemplo, do sistema estrutural e das instalações). Essa abordagem permite à equipe de projeto interagir de modo colaborativo, ao longo de todo o desenvolvimento de projeto (EASTMAN et al., 2011).

Quanto às etapas relacionadas ao processo de modelagem, Succar (2010b) propõe que sejam estabelecidos três estágios, a saber: modelagem dos objetos e de suas propriedades (modelagem paramétrica em três dimensões de disciplinas específicas individualmente); colaboração técnica entre as equipes responsáveis pelas diferentes disciplinas, como por exemplo, projetos técnicos e de arquitetura ou ainda entre fases diferentes do ciclo de vida quando, por exemplo, a equipe de engenharia de manutenção ou da APO oferece contribuições às equipes de projeto e integração em rede, nos quais os modelos desenvolvidos são integrados, compartilhados e mantidos de modo colaborativo, ao longo do ciclo de vida da 
edificação.

Além disso, o pesquisador destaca que fazem parte de cada etapa os respectivos recursos tecnológicos (aplicação prática do conhecimento científico, inclusive os programas computacionais, os equipamentos de hardware e os sistemas de rede necessários à execução do processo), políticas (diretrizes para a tomada de decisões e atribuição de responsabilidades) e processos (organização sequencial das atividades envolvidas) (SUCCAR, 2009).

Scheer e Ayres Filho (2009) propõem quatro níveis de informações para a modelagem BIM:

- Supermodelagem: atividade multidisciplinar, com a participação de várias equipes e foco nos processos;

- Metamodelagem: processo de criação dos modelos neutros, nos quais a estrutura das informações é definida. O modelo aceito adota os padrões da IFC, conforme o proposto pela Norma Internacional ISO 16.739:2013;

- Modelagem: processo de elaboração dos objetos que representam os sistemas construtivos a serem adotados em um determinado projeto de edificação; e

- Micromodelagem: processos de criação dos elementos de um projeto de edificação e atribuição das informações relacionadas a estes.

Outro aspecto pertinente à tecnologia BIM refere-se à integração entre as equipes envolvidas no projeto. Succar; Sher e Williams (2013) consideram que, para o sucesso da incorporação da tecnologia BIM, devem ser formalizados fluxos de trabalho e o processo de projeto, considerando os conhecimentos especializados e a competência de cada membro da equipe envolvida, pela atribuição clara de atividades e tarefas.

Com base na atribuição clara das responsabilidades, também torna-se possível realizar avaliações do desempenho do processo, considerando a nova tecnologia incorporada (SUCCAR, 2010b).

Portanto, o modelo criado utilizando tecnologias para BIM permite que a colaboração entre as equipes ocorra desde o início do processo. Além disso, quando comparado à abordagem tradicional, é possível considerar que, teoricamente, pode- 
se ter acesso a informações consistentes. Isto permite que sejam realizadas análises e tomadas decisões para a otimização do desempenho do projeto, desde sua fase inicial de desenvolvimento, uma etapa na qual os custos relacionados à realização de alterações são muito menores.

Nesse sentido, a adoção dos critérios de análise do ciclo de vida (ACV) em modelos pode oferecer suporte à avaliação das soluções de projeto propostas para a edificação. Entretanto, a maior parte dos projetos elaborados, utilizando tecnologias de modelagem, ainda restringe as informações especificadas às propriedades e aos dados necessários para sua construção, bem como limita sua abrangência ao período anterior ao da ocupação da edificação (RIST, 2011).

A respeito da comunicação no ambiente da modelagem da informação da construção, Giacaglia; Lara e Moura (2011) observam que:

Arquitetos e engenheiros civis, ao adotarem a automação na construção e manufatura digital, não podem esperar lidar com o mesmo tipo de trabalhador encontrado na construção artesanal. Eles se comunicarão com trabalhador qualificado e bem treinado, tais como os encontrados em ambientes de fábrica modernos, uma comunidade acostumada com a terminologia precisa e rigorosa da linguagem de projeto, ao longo do desenvolvimento e produção (GIACAGLIA; LARA; MOURA, 2011, p. 181, tradução nossa)

Quanto ao estado de arte da tecnologia, embora os recursos tecnológicos tornem possível a prática da modelagem da informação, ainda há obstáculos quanto à interoperabilidade entre os programas computacionais, o que reduz a compatibilidade e a confiabilidade das informações. Além disso, ainda apresenta restrições quanto à prática integrada da modelagem, com base em processos automatizados (SEBASTIAN, 2010).

Estes aspectos são críticos e traduzem-se em perdas, relacionadas ao fluxo de informações não eficientes, a saber: o tempo de espera pela informação, o tempo gasto para a validação da informação, o tempo gasto pelo retrabalho necessário para a adequação da informação aos requisitos do projeto e, finalmente, o tempo 
necessário para que a equipe de projeto tome ciência da informação. Também não basta apenas o acesso à informação, como é importante o entendimento de seu histórico e de como esta deve ser aplicada. Também o acesso às alterações de projeto, a transparência e a clareza na comunicação são fatores fundamentais para o fluxo satisfatório das informações, bem como a capacidade de interpretação, por parte das equipes (MANZIONE, 2013).

No processo de projeto, a importância da gestão da informação pode ser percebida quando se analisa seu impacto nas causas das falhas identificadas nas edificações. Josephson (1998) identificou o aspecto informação como sendo responsável por $12 \%$ (doze por cento) do total dos custos relacionados diretamente às falhas nas edificações construídas. Entretanto, o pesquisador ressalta que a falta de informação pode estar indiretamente relacionada aos erros causados pela desmotivação da equipe, aspecto que representou $55 \%$ (cinquenta e cinco por cento) do custo total estimado, assim como o conhecimento inadequado, associado a $29 \%$ (vinte e nove por cento) do custo total estimado.

Isso posto, fica claro o entendimento que a reengenharia dos processos e o treinamento adequado das equipes envolvidas são aspectos fundamentais para o sucesso do desenvolvimento de projeto em ambiente colaborativo.

\subsection{POSSÍVEIS APLICAÇÕES PARA A MODELAGEM DA INFORMAÇÃO}

Os recursos tecnológicos disponíveis para a gestão dos processos de projeto, execução e gestão, objetos desta pesquisa, não se limitam à incorporação da modelagem da informação de uma edificação, sendo pertinente também incorporar as seguintes práticas: georreferenciamento, consolidação de Banco de Dados, simulação de desempenho e gestão de facilidades, que serão apresentadas nos itens 71 subsequentes.

\subsubsection{GEORREFERENCIAMENTO DA INFORMAÇÃO}

Os sistemas computacionais que possibilitam que os dados geográficos sejam armazenados, manipulados e consultados denominam-se Sistemas de Informação Geográfica (SIG) (LISBOA FILHO, 2000). Seu propósito de utilização é a 
análise de dados georreferenciados, por meio da utilização de programas, equipamentos, metodologias, dados e indivíduos, integrados de modo a permitir a análise de informações, considerando sua localização geográfica (LISBOA FILHO, IOCHPE, 1996).

(...) O termo Geoprocessamento denota a disciplina do conhecimento que utiliza técnicas matemáticas $\mathrm{e}$ computacionais para o tratamento da informação geográfica e que vêm influenciando de maneira crescente as áreas de Cartografia, Análise de Recursos Naturais, Transportes, Comunicações, Energia e Planejamento Urbano e Regional. As ferramentas computacionais para Geoprocessamento, chamadas de Sistemas de Informação Geográfica (SIG), permitem realizar análises complexas, ao integrar dados de diversas fontes e ao criar bancos de dados geo-referenciados. Tornam ainda possível automatizar a produção de documentos cartográficos.

Pode-se dizer, de forma genérica, "Se onde é importante para seu negócio, então Geoprocessamento é sua ferramenta de trabalho". Sempre que o onde aparece, dentre as questões e problemas que precisam ser resolvidos por um sistema informatizado, haverá uma oportunidade para considerar a adoção de um SIG. (CÂMARA et al., 2001, p. 1)

As tecnologias de SIG são utilizadas para analisar a informação geospacial. Historicamente, a prática do georreferenciamento de informações estava associada a projetos de infraestrutura. Mas, sua aplicação no auxílio tecnológico da gestão de facilidades cresceu recentemente, à medida que os sistemas computacionais tornaram-se mais acessíveis. Nesse processo de amadurecimento da tecnologia, seu uso tornou possível a análise de informações georreferenciadas, inclusive em empreendimentos de pequeno porte, para a avaliação de áreas específicas, pertinentes à gestão dos sistemas e instalações prediais. Nesse contexto, vem se mostrando eficiente o mapeamento de componentes da edificação e de incidentes, 
para que sejam analisadas, por exemplo, ocorrências, conforme sua localização (WITTS JR., 2013).

Este recurso tecnológico vem sendo aplicado a edificações e a seus ambientes internos, tornando possível a gestão de vários aspectos, dentre os quais (TEICHOLZ, 2010):

- espaços e respectivos usos;

- áreas locadas;

- elaboração de planos de segurança patrimonial, por meio do estabelecimento de zonas de acesso restrito;

- determinação de áreas de evacuação e avaliação de rotas de fuga;

- demarcação de rotas acessíveis;

- condução de avaliações de segurança contra incêndio;

- elaboração de inventários e identificação da localização de ativos;

- atividades de manutenção e mapeamento de ocorrências;

- verificação e monitoramento das condições de operação e uso da edificação;

- modelagem dos resultados de alterações propostas em reformas e ampliações; e

- planejamento de redistribuição de leiaute.

Observa-se, desta forma, a consolidação das práticas de modelagem da informação da edificação, considerando todo seu ciclo de vida.

Além disso, os sistemas administrativos e prediais de um empreendimento podem ser integrados a bancos de dados com informações georreferenciadas, à medida que a localização é aspecto necessário para o processo decisório (TEICHOLZ, 2010).

Dentre os sistemas pertinentes de integração, estão: os sistemas de automação da edificação (building automation systems - BAS), o sistema de planejamento de recursos empresariais (enterprise resource planning - ERP) e o sistema de gerenciamento do local de trabalho, que consiste em uma plataforma que permite a integração das informações de planejamento, projeto, gestão, 
operação e desconstrução dos ativos de uma organização. Isso inclui o portfólio imobiliário, bem como propriedades e dados referentes à infraestrutura e às instalações. O intuito desta integração é apoiar atividades, tais como: gestão de projetos, de ambientes e de atividades de manutenção e administração de áreas locadas (KELLER, 2013; IFMA, 2014ª).

Na Figura 11, é apresentado um esquema da estrutura e os principais usos da informação georreferenciada no empreendimento.
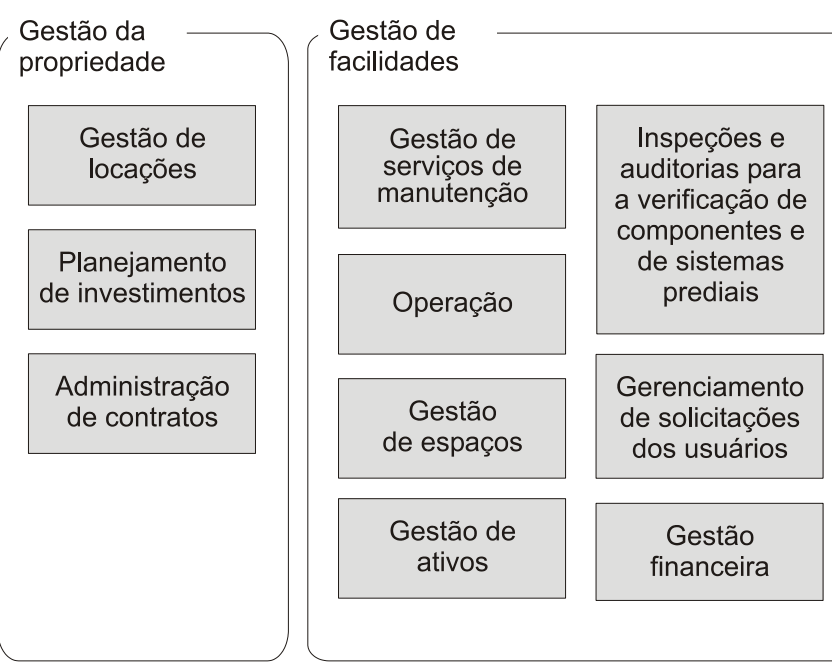

Gerenciamento de solicitações dos usuários
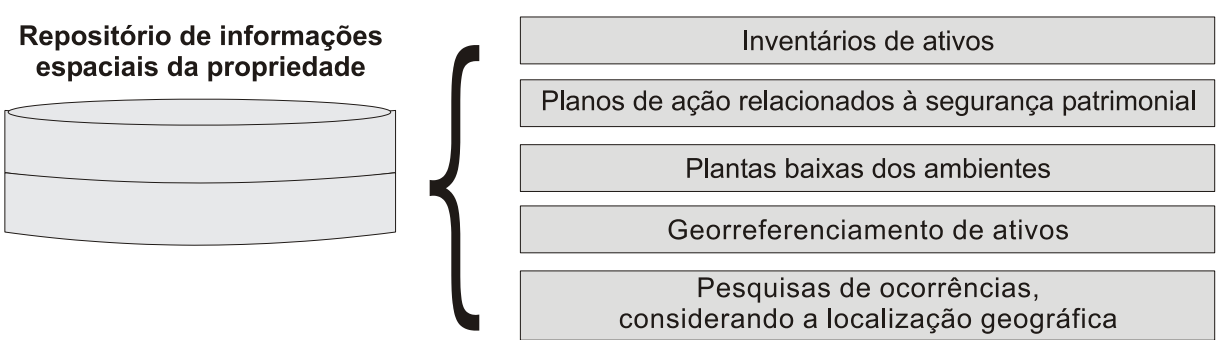

Figura 11. Estrutura de modelagem da informação georreferenciada em um empreendimento Fonte: Adaptado pela pesquisadora de TEICHOLZ (2010, p. 12).

Observa-se, portanto, que a consolidação de um repositório de informação georreferenciada corresponde a um importante recurso para a gestão de edificações em uso, especialmente, se estas fizerem parte de um portfólio de ativos. 


\subsubsection{SIMULAÇÃO DE DESEMPENHO DO PROJETO}

Uma das vantagens do uso de tecnologias para BIM é que o modelo desenvolvido pode ser utilizado para a elaboração de avaliações de desempenho, para o projeto proposto (SEDERA; ROSEMANN; GABLE, 2001).

Dentre as possibilidades de uso de BIM para a elaboração de análises estão: avaliação do impacto da orientação da geometria e do impacto da envoltória, análises das condições de iluminação natural, simulações de consumo energético, do desempenho de sistemas de energia renovável e de armazenamento de água das chuvas (AZHAR et al., 2011).

Para tanto, é preciso que as informações modeladas sejam exportadas para programas computacionais tais como: o EnergyPlus, o Ecotect, o Green Building Studio e o Integrated Environmental Solutions, que permitem a elaboração de simulações, com base na geometria modelada, para a verificação do desempenho energético e dos níveis de conforto ambiental.

Laine; Hänninen e Karola (2007) avaliam que a utilização da BIM torna mais eficiente a geração do modelo de simulação e a geração do arquivo para a importação pelo EnergyPlus. Isso faz com que o processo de avaliação seja mais dinâmico, quando comparado à maneira tradicional, que prevê métodos de cálculo estáticos. Por sua vez, a simulação a partir do modelo BIM possibilita a verificação do desempenho em diferentes fases do projeto, desde as etapas preliminares e, inclusive, permite a verificação do desempenho efetivo da edificação, durante a etapa de operação e manutenção.

Além disso, a adoção desta prática, durante o processo de projeto, permite a análise dos níveis de conforto ambiental em edificações de geometria complexa com maior precisão, quando comparada às análises convencionais (AZHAR; BROWN; FAROOQUI, 2009).

Portanto, a integração precoce entre os processos de modelagem da informação e de simulação de desempenho permitem que os resultados obtidos embasem as decisões de projeto, desde a etapa de estudo preliminar. Assim, as equipes de projeto podem adotar estratégias para atingir os níveis de desempenho pretendidos (AUGENBROE; SANGUINETTI; EASTMAN, 2009).

Também é possível quantificar materiais com maior precisão, reduzindo o 
desperdício, bem como avaliar o desempenho ambiental dos mesmos (proporções de materiais reciclados ou recicláveis em sua constituição), impacto das emissões atribuídas ao transporte, inclusive considerando seu impacto por meio de cálculo dos volumes a serem utilizados na construção (AZHAR et al., 2011).

Desta forma, o uso de tecnologias de modelagem da informação permite, ao menos em teoria, que sejam feitas análises de desempenho das soluções apresentadas desde as fases iniciais de projeto.

\subsection{GESTÃO DA INFORMAÇÃO APLICADA À EDIFICAÇÃO EM USO}

À medida que as edificações passam a dispor de sistemas prediais complexos, o desempenho de sua operação precisa ser entendido, considerando o conjunto dos equipamentos e dos componentes em uso, bem como suas interrelações (ANTONIOLI; GRAÇA, 2004).

Assim sendo, os recursos tecnológicos para a gestão da informação da edificação podem ser adotados durante seu uso, com muitas vantagens. Fabricio (2002) lembra que os ciclos de vida dos edifícios estendem-se por décadas e englobam, tanto as fases de execução e operação, como as de demolição ou de reabilitação (ABNT/ISO, 2010). Ao longo desse período, as necessidades a serem supridas pela edificação modificam-se, bem como as instalações.

Também o consumo energético da edificação ganha relevância, quando avaliado ao longo de seu período de uso (FRANÇA; ORNSTEIN, 2015). Outro aspecto a ser considerado é a durabilidade dos sistemas construtivos e dos componentes especificados e a manutenção necessária para mantê-los durante a vida útil da edificação (ABNT, 2013).

Para tanto, um sistema de gestão de facilidades assistida por computador (Computer-Aided Facility Management - CAFM) integrado ao sistema de BIM pode ser adotado, para dar suporte às atividades inerentes à gestão de facilidades (IFMA, 2014b), bem como àquelas relacionadas à administração e infraestrutura de uma edificação. Assim, é possível utilizar as informações da construção modeladas durante as fases de projeto e de execução. Esta interação com as fases anteriores aumenta a transparência e a precisão, relacionadas às etapas de operação e manutenção, bem como contribui para eliminar a redundância das informações 
(ABEL; LENNERTS, 2005).

Dentre os recursos que podem ser adotados por meio da integração entre BIM e CAFM estão (OZAN; CLAYTON; NOME, 2009):

- monitoramento dos usos e perfis de ocupação dos ambientes;

- monitoramento de consumos, tais como: água, energia e gás;

- informações atualizadas sobre os sistemas da edificação;

- inventário dos equipamentos;

- $\quad$ suporte aos planos de manutenção e qualidade do ar;

- elaboração e atualização de projetos 'como o construído';

- monitoramento do desempenho dos sistemas e instalações;

- monitoramento de atividades de manutenção corretiva e preventiva; e

- suporte a projetos de requalificação e análise de retorno financeiro.

Embora a tecnologia de modelagem da informação seja mais usualmente adotada nas fases de projeto e construção, seus recursos ainda são subutilizados nas fases posteriores, relativas ao ciclo de vida da edificação (CHECCUCCl; PEREIRA; AMORIM, 2013).

O modelo atualizado pode dar suporte às atividades da edificação até o final de sua vida útil, inclusive para efeitos de planejamento do processo de demolição e gestão de resíduos da construção civil e demolição (RCD). Pode, por exemplo, ser utilizado para a determinação dos volumes de resíduos de alvenarias e quantificação de elementos para reúso, tais como portas, janelas, equipamentos hidrossanitários e equipamentos de iluminação, entre outros (CHENG; MA, 2013).

Durante a fase de operação e manutenção de uma edificação, a utilização da tecnologia BIM também pode permitir a verificação das condições de suas instalações de forma remota, o que aumenta a eficiência dos procedimentos de manutenção preventiva e possibilita o acesso, via rede, da documentação técnica referente a seus componentes. Espera-se que, por meio da disponibilização de um inventário atualizado continuamente, no qual se possa identificar todos os componentes da edificação consumidores de energia, programar suas atividades de manutenção e monitorar seu desempenho, seja possível obter um retorno de 
investimento de $3 \%$ (três por cento) no consumo de energia elétrica de um empreendimento, conforme o levantamento elaborado pela United States General Services Administration (GSA, 2012).

Também permite reduzir custos associados à elaboração de uma nova documentação para a fase de ocupação e reduz as pesquisas necessárias para a elaboração de renovações (GSA, 2012).

Para sua implantação, é preciso que sejam identificados, ainda durante as fases iniciais de projeto, os processos pertinentes à fase de operação e as informações necessárias a este. Dentre as informações a serem documentadas, estão: interfaces e recursos tecnológicos necessários; sistemas e equipamentos a serem instalados (por exemplo: mecânicos, hidráulicos, de segurança patrimonial, de irrigação, de proteção e combate a incêndio), mobiliário e respectivas especificações. Também devem ser definidas, para os componentes, tais como: localização, vida útil, garantia, necessidade de manutenção (GSA, 2012). Esse planejamento prévio deve ser observado quando da elaboração do Plano de Execução BIM.

Vêm sendo verificados benefícios quanto ao uso da BIM para a gestão de facilidades, tais como maior acesso às informações, confiabilidade, mitigação de riscos e retorno de investimento (BECERIK-GERBER; JAZIZADEH; LI; CALIS, 2012).

Entretanto, Volk, Stengel e Shultmann (2014) observam que os processos de BIM vêm se popularizando entre novas construções, embora a maioria dos empreendimentos não os adote para a operação, o planejamento de reformas e de alterações de leiautes nem para a desconstrução. Por esse motivo, os pesquisadores concluem que a incorporação do processo de modelagem e de gestão da informação a todas as etapas do ciclo de vida da edificação ainda constitui-se em um desafio.

Dentre os aspectos críticos a serem vencidos, está a fragmentação dos processos de operação do edifício, uma vez que as equipes responsáveis pela manutenção e pelas atividades de desconstrução, usualmente, estão de modo formal alocadas separadamente em determinada organização. Por esse motivo, não têm acesso aos aspectos gerenciais, técnicos e legais já abordados nas fases anteriores do ciclo de vida da edificação. 
Nesse contexto, Hartmann (2011), avalia que, na renovação de projetos complexos, é preciso estabelecer uma abordagem integrada para o planejamento, na qual seja possível a participação de especialistas que detenham conhecimentos específicos. Por exemplo, em projetos de reforma hospitalar, além do conhecimento específico de engenharia também são necessárias informações quanto aos requisitos de cada ambiente, no que diz respeito a aspectos médicos e de segurança, uma vez que as soluções arquitetônicas e de engenharia irão impactar no desempenho da prática médica. Nesses casos, além de incorporar o estabelecimento de requisitos ao processo, é necessário prever mecanismos eficientes de busca e de validação da informação.

A tecnologia para a automação da gestão de facilidades ainda se encontra em desenvolvimento, e é usada na troca de informações via rede. Seus avanços ocorrem conforme são desenvolvidas melhores soluções de interoperabilidade, no sentido de integrar tecnologias como SIG e sistemas de automação das edificações (KELLER, 2013).

Entretanto, Keller (2013) destaca como desafios para a implantação desse conjunto integrado de tecnologias: o comportamento entre fabricantes, no sentido de proteger a tecnologia de autoria e a falta de unidade entre os departamentos dentro das próprias empresas de programação.

Para Hoffmann (2013), a habilidade de integrar diferentes dispositivos automatizados de uma edificação, por meio de um sistema centralizado, desenvolveu-se na década de 1980. Sua popularização ocorreu por volta de 1995, em razão da redução dos custos dos equipamentos. Nesse período, difundiu-se também o entendimento de interoperabilidade, pois os equipamentos de diferentes disciplinas (tais como: iluminação, ar condicionado e sistemas industriais) deveriam estar conectados a um dispositivo central de visualização, controle e comando, por meio de uma rede.

No início dos anos 2000, pôde-se observar, por parte dos fabricantes de dispositivos de automação, o uso de protocolos abertos, desenvolvidos ao longo da década de 1990, além da adoção do protocolo IP (Internet Protocol), popularizando o uso da TI por meio da internet, como suporte à operação de edificações.

Os inventários de equipamentos instalados em uma edificação constituem-se na base de muitas atividades necessárias à gestão de facilidades, a saber: avaliação 
das condições das instalações, controle das atividades de manutenção e das garantias, planejamento de requalificações, estimativas de custos de projetos, de reformas e mão de obra, controle e elaboração de planos de contenção (KEADY, 2009; GSA, 2012). Em suma, constituem o subsídio necessário ao planejamento de CapEx e de Opex em uma organização. Na Figura 12, são representadas as relações entre o inventário dos equipamentos e a gestão financeira da organização, cujo entendimento é compartilhado pela GSA.

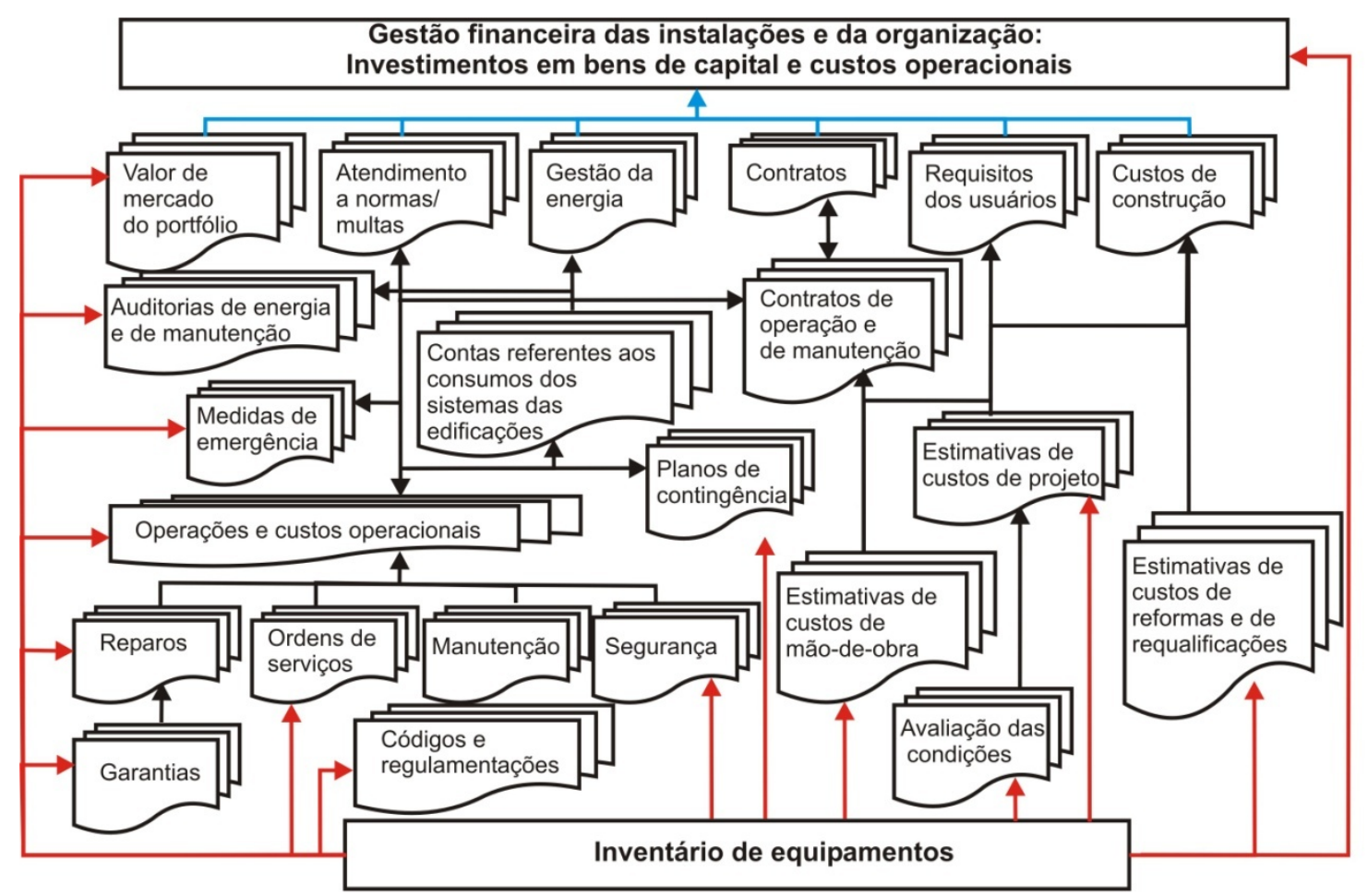

Figura 12. Relações entre o inventário de equipamentos e a gestão financeira das instalações e da organização Fonte: KEADY (2009, p. 1), tradução nossa.

No fluxograma proposto na Figura 12, nota-se que as atividades de projeto, de construção e operação e manutenção estão inseridas em um contexto maior e integrado, que envolve decisões financeiras estratégicas.

À época da presente pesquisa (2015), a atuação via rede de sistemas de automação encontrava-se consolidada, inclusive para o gerenciamento remoto e o georreferenciamento de ativos. 
Dentre suas aplicações, destacam-se: limitação e gerenciamento da demanda energética do empreendimento, gestão de recursos financeiros e monitoramento e validação de requisitos de desempenho. Mas, sua integração ao modelo tridimensional de modelagem da informação da construção ainda está restrito a poucos empreendimentos e o custo desta integração, muitas vezes, ainda inviabiliza sua implantação.

Uma das dificuldades a se enfrentar para a adoção da tecnologia de modelagem da informação para o gerenciamento de facilidades é que, dadas as especificidades dos sistemas prediais e dos padrões de operação, é necessário considerar diferentes requisitos e de fluxos de trabalho em uma edificação. Por esse motivo, há dificuldade em se padronizar parâmetros e procedimentos para a automatização de processos.

Além disso, a gestão de facilidades pressupõe interação com os usuários da edificação, o que também contribui para a personalização dos procedimentos de operação (SABOL, 2013).

\subsection{RECURSOS DE MODELAGEM DA INFORMAÇÃO COMO CATALISADORES DE ALTERAÇÕES NO PROCESSO DE PROJETO}

Uma vez que as atividades da construção civil são fundamentadas em conhecimento, seu desenvolvimento pressupõe a participação de diversos atores, com competências específicas, trabalhando em conjunto, para criar uma solução (AHANKOOB; MANLEY; STEINHARDT, 2015). Mas, os meios de comunicação complexos e a informação fragmentada dificultam a desejada produção do conhecimento.

Fabricio e Melhado (2002) constataram que a incorporação da tecnologia nos escritórios de projeto pressupõe mudanças profundas nas práticas e metodologias profissionais. Apesar disso, com a popularização dos computadores de uso pessoal, é difícil identificar escritórios de projeto que não tenham incorporado recursos de $\mathrm{TI}$ em seus processos de produção.

O processo de produção de edifícios apresenta caráter multidisciplinar, já que depende das competências específicas de diferentes profissionais (SCHEER; AYRES FILHO, 2009). 
Por esse motivo, Kerzner (2011) destaca a importância de que seja adotada uma abordagem sistêmica de gestão do conhecimento, de modo a integrar e a unificar as informações de diferentes disciplinas, para solucionar problemas considerando o contexto geral do projeto, conforme o apresentado na Figura 13.

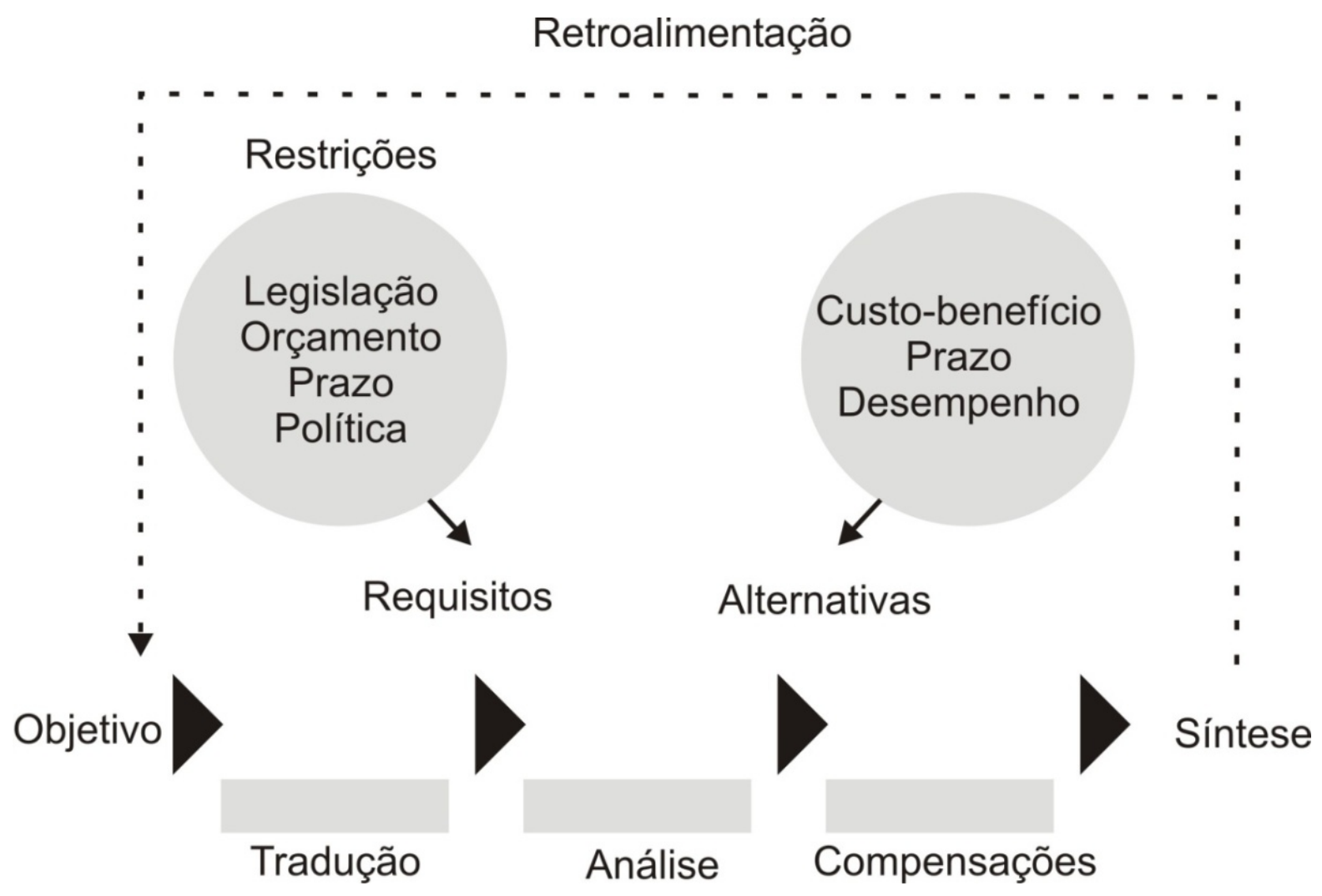

Figura 13. Abordagem sistêmica para a gestão de projetos

Fonte: Adaptado pela pesquisadora de: KERZNER (2011, p. 53).

O pesquisador destaca ainda que, embora teorias que preguem essa abordagem existam desde a década de 1950, ela ainda enfrenta resistência para sua implantação, por parte dos profissionais envolvidos. Entretanto, o aumento da complexidade das edificações está relacionado a um processo de especialização dos atores envolvidos, de forma que se reforce a necessidade de consolidação dos métodos de planejamento, programação e controle eficientes (KERZNER, 2011).

$\mathrm{Na}$ abordagem sistêmica desejada, há quatro fases de desenvolvimento para a resolução de problemas: tradução (objetivos do problema, critérios e restrições a serem observadas); análise das abordagens possíveis para solução; compensações, 
ou seja, restrições e critérios de seleção aplicáveis às alternativas listadas e síntese ou o resultado obtido pelo processo de análise.

A respeito da importância das boas práticas para a gestão da informação, adotadas durante a fase de projeto, Andery; Campos e Arantes (2012) avaliam:

O processo de projeto é uma etapa estratégica do empreendimento com relação aos gastos de produção e à inserção da qualidade ao produto. O projeto tem a capacidade de subsidiar as atividades de produção em canteiro de obras com informações detalhadas e que não poderiam ser igualmente geradas no ambiente da obra. A partir de um projeto completo, detalhado para a obra, torna-se possível elaborar um planejamento e uma programação mais eficientes, assim como um programa efetivo de controle da qualidade para materiais e serviços. (ANDERY; CAMPOS; ARANTES, 2012)

Para a formalização do processo de projeto, Romano (2003) destaca que, inicialmente, é preciso que seja definida a lista de atividades pertinentes a seu desenvolvimento. Posteriormente, estas devem ser organizadas em sequência lógica, de modo a destacar suas relações de interdependência, bem como os produtos esperados para cada etapa.

Outro aspecto fundamental para a gestão satisfatória do processo de projeto é a formalização de requisitos. Isso é relevante, à medida que seu atendimento deve ser avaliado, frente às soluções de projeto propostas (KIVINIEMI, 2005). Desta forma, o processo de projeto integrado, com o suporte de recursos computacionais para a modelagem da informação permite verificar a pertinência das soluções de projeto continuamente, frente aos requisitos determinados pelos proprietários, conforme o apresentado na Figura 14. 

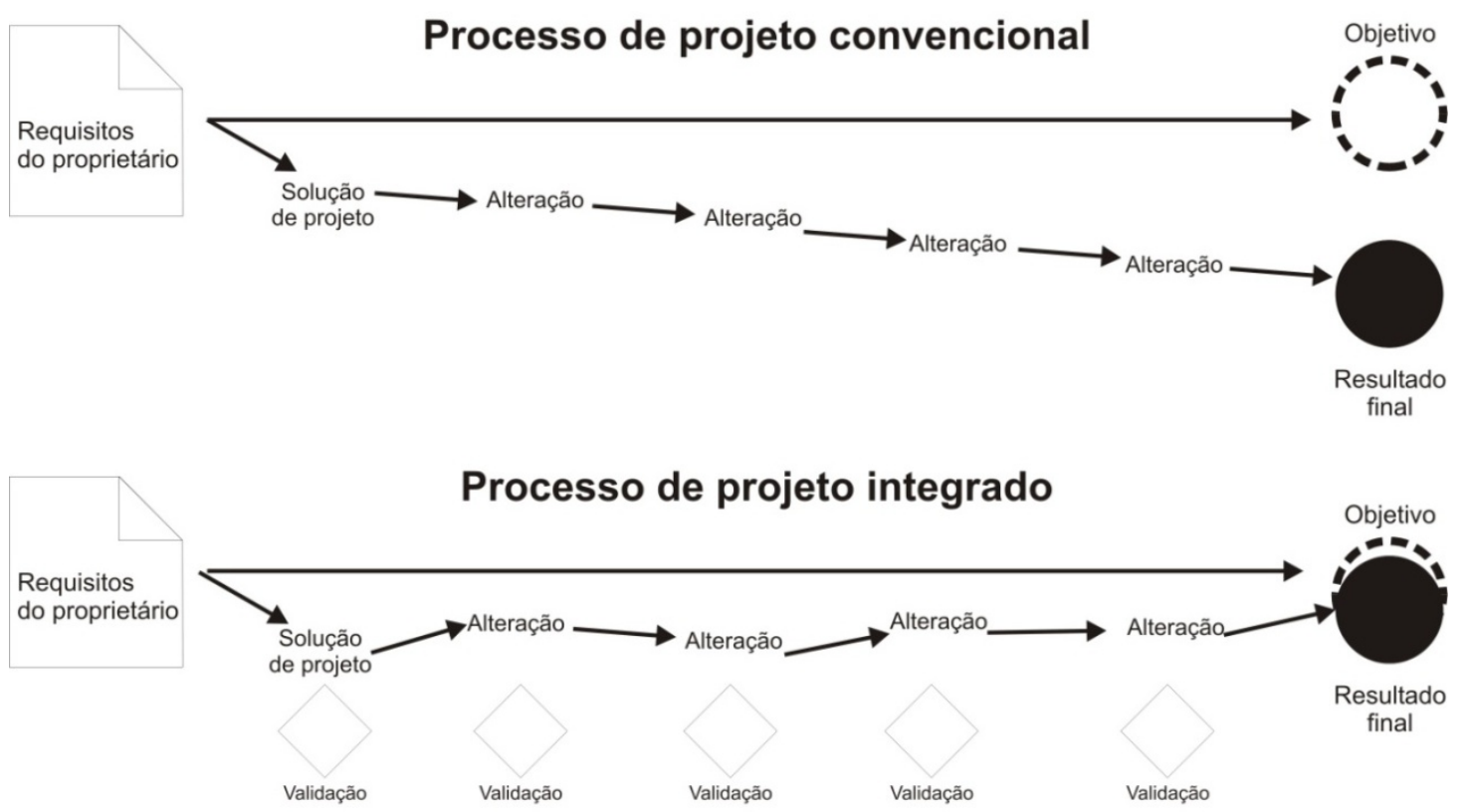

Figura 14. Desvio entre os requisitos do proprietário e as soluções de projeto

Fonte: Adaptado pela pesquisadora, baseado em KIVINIEMI (2005, P. 5).

Ao adotar essa prática, espera-se reduzir o desvio dos objetivos iniciais para o empreendimento, como ocorre, comumente, ao longo do processo de projeto.

Dentre as vantagens de aplicação dos processos de BIM para a gestão da informação na construção, Ahankoob; Manley e Steinhardt (2015) destacam maior acurácia nas estimativas de custos e na projeção de resultados quanto ao desempenho das soluções propostas, o estabelecimento de um ambiente de trabalho transparente, de modo a promover o entendimento mútuo entre as equipes participantes.

Além disso, a incorporação dos resultados relacionados ao desempenho do projeto, por meio de simulações elaboradas com base no modelo e na compilação dos resultados obtidos durante o período de pós-ocupação, permite uma compreensão mais extensa do processo de modelagem, na qual além da incorporação das informações de projeto ao modelo que representam a construção também podem ser incorporadas informações sobre a gestão e operação Modelagem da Informação e dos Resultados de Avaliação da Construção e Gestão (DEPARTMENT FOR BUSINESS, INNOVATION AND SKILLS, 2011b).

Para tal, Coelho e Novaes (2008) entendem que a adoção de recursos da 
modelagem da informação ao processo de projeto pressupõe a revisão das interações entre os atores envolvidos com a gestão, o desenvolvimento do projeto e a construção, destacando-se dentre as vantagens que envolvem a elaboração do modelo BIM: colaboração, simulação e documentação.

Tobin (2008) destaca a importância da elaboração de um único modelo que possa ser compartilhado e atualizado por toda a equipe, já que permite um processo mais eficiente de projeto. Essa abordagem apresenta ainda a vantagem de reduzir os riscos de interferências entre os projetos técnicos, o que se faz fundamental em projetos de grande complexidade.

Ainda conforme o pesquisador, o modelo BIM deve corresponder ao que se pretende construir, a fim de eliminar ainda na fase de projeto aspectos críticos que possam ser antecipados, evitando os custos maiores de fazê-lo durante a fase de construção.

Também a avaliação da eficiência e a valorização financeira são aspectos fundamentais da implantação de um sistema de elaboração de projetos baseado na tecnologia BIM.

Para o Department for Business, Innovation and Skills do Reino Unido (2011a, 2012), que consolidou uma iniciativa para a aplicação de modelagem BIM em escala, para as edificações institucionais a serem projetadas em seu território, são objetivos da incorporação desta tecnologia:

- promover a integração entre projeto, construção, operação e avaliação;

- embasar a revisão das diretrizes de projeto e a elaboração de benchmarking;

- reduzir o desperdício de materiais de construção;

- melhorar o desempenho do ambiente construído;

- documentar e avaliar as informações referentes ao ciclo de vida dos componentes e materiais;

- diminuir o prazo de elaboração de projeto e de execução; e

- reduzir custos e riscos financeiros.

Nem sempre, porém, a noção de projeto participativo está amadurecida entre os pesquisadores que se dedicam ao estudo da BIM. Eastman et al. (2011) 
apresentam um processo para a elaboração de projeto utilizando a tecnologia BIM ainda centralizada, na figura de um consultor, que seria responsável pela elaboração de modelos contendo as informações pertinentes aos projetos técnicos e sua compatibilização. Isso se dá pois, na proposta apresentada no fluxograma, representado na Figura 15, ainda não são incorporados os conceitos de projeto simultâneo.

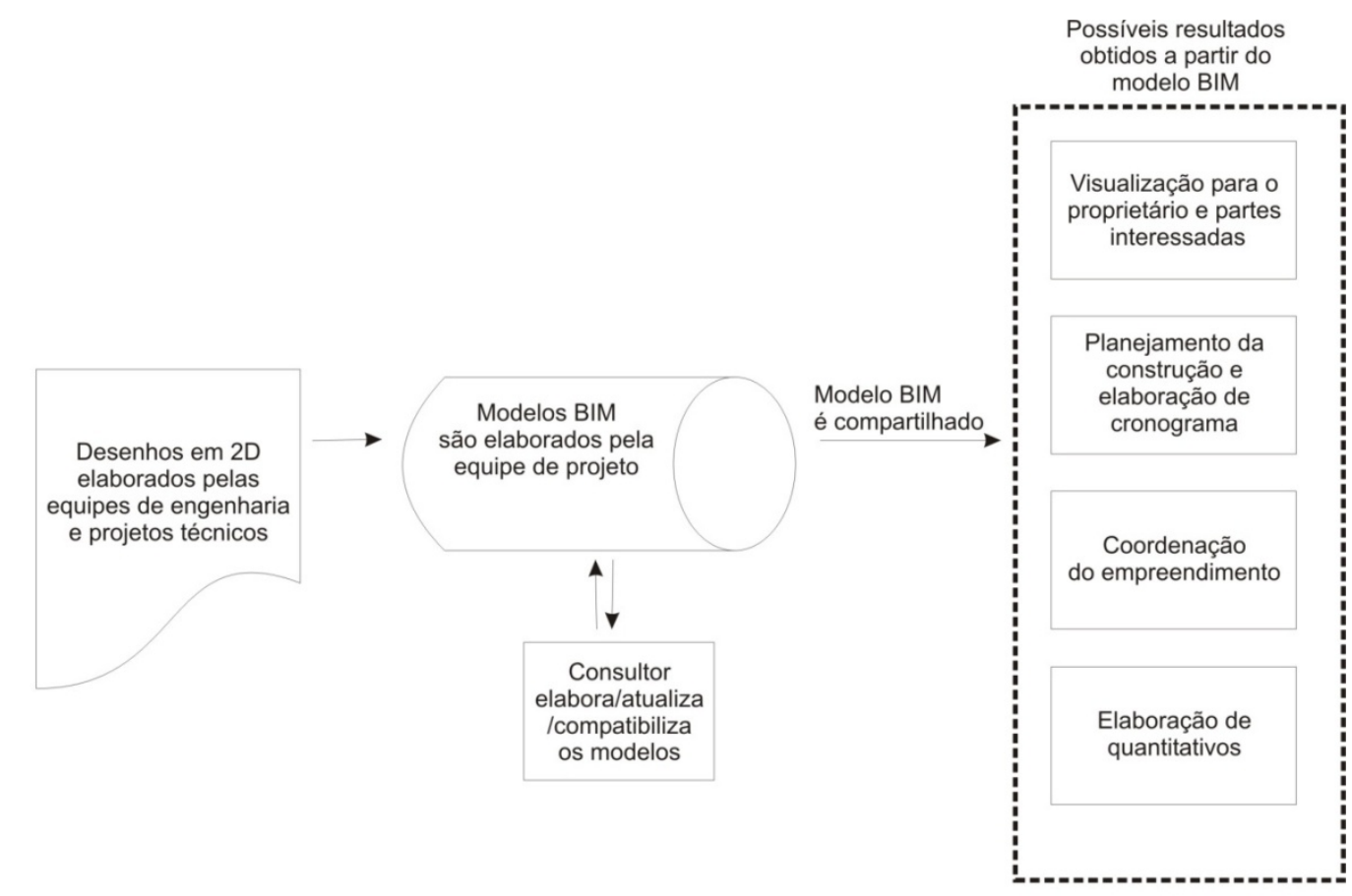

Figura 15. Fluxo de processo para projeto no qual arquitetos e subcontratados compartilham um modelo BIM Fonte: Adaptado de: Eastman et al. (2011, p. 271), pela pesquisadora.

Mas, Ruschel et al. (2010) ressaltam que a adoção de tecnologia BIM modifica a dinâmica do desenvolvimento de projeto, à medida que contribui para desenvolver, comunicar e avaliar os processos relacionados à construção de uma edificação, o que pode propiciar a implantação efetiva de práticas de projeto simultâneo (MELHADO, 2001), de modo a dar suporte à interoperabilidade e à gestão, em todas as fases do ciclo de vida da edificação (CHECCUCCI, 2014).

Ao criar condições para que projetistas e especialistas de diversas áreas estejam integrados, por meio da modelagem paramétrica, é possível incorporar aspectos inerentes às respectivas disciplinas (RUSCHEL et al., 2010), o que contribui para enriquecer o processo de projeto. 
No fluxograma apresentado na Figura 16, Corrêa e Ruschel (2010) propõem um de processo de projeto considerando seu desenvolvimento utilizando tecnologia BIM, em ambiente colaborativo.

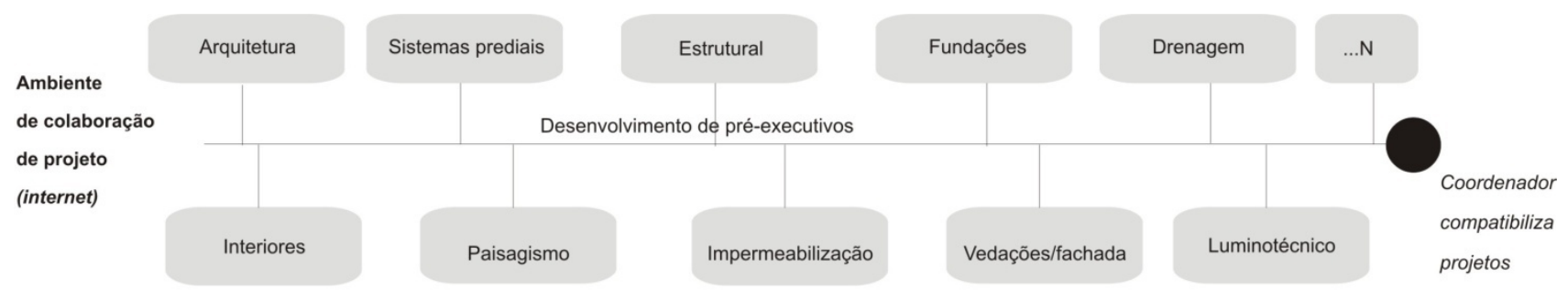

Projeto colaborativo convencional

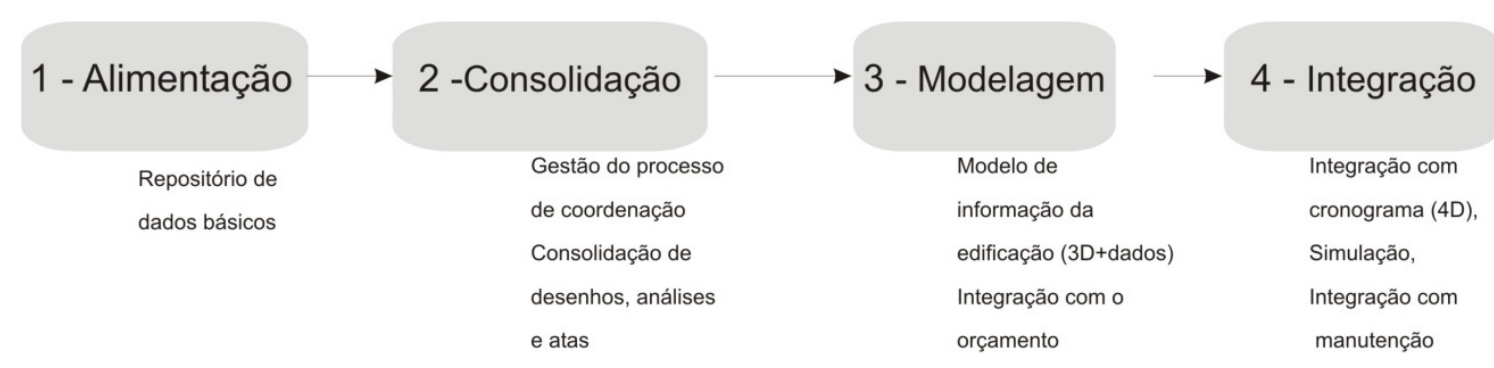

Evolução do processo de projeto, em função das práticas de colaboração

Figura 16. Evolução do processo de projeto, em função das práticas de colaboração.

Fonte: Adaptado de CORRÊA; RUSCHEL (2010, 87e. 122-123), pela pesquisadora.

Mendes (2012) também destaca as vantagens da utilização da BIM como uma ferramenta colaborativa, que dê suporte à interoperabilidade, possibilitando a diferentes equipes editar e consultar as informações de projeto.

É de fundamental importância que os métodos de gestão de um empreendimento considerem aspectos de como serão projetados, construídos e utilizados e mantidos (KUNZ; FISCHER, 2012). Sendo assim, Jernigan (2008) destaca quatro fases de integração de projeto:

Fase inicial - de planejamento e atribuição de responsabilidades, que é crítica para o sucesso do processo. Nessa etapa, a revisão dos dados preliminares é fundamental para evitar que erros sejam replicados. Também é nesta fase que são compreendidas as necessidades do projeto, definidos os aspectos contratuais, softwares e são determinados os recursos de comunicação a serem utilizados, bem como os critérios de organização das informações de projeto. 
Fase de projeto - Nesta etapa, o modelo é elaborado, sendo fundamental que as informações preliminares sejam revisadas, para garantir sua precisão. É quando as equipes de projeto técnico são selecionadas e capacitadas. Em alguns casos, informações de projeto entregues em $2 \mathrm{D}$ deverão ser convertidas para que sejam integradas ao modelo.

Fase de construção - Esta fase tem foco nas ferramentas para monitorar a evolução da obra. Por isso, é fundamental que a comunicação seja efetivamente eficiente. Com base na validação de orçamentos e cronogramas, devem ser determinados recursos para o monitoramento dos prazos e custos reais. Também devem ser conduzidos procedimentos para a checagem de conflitos, por meio do suporte do modelo 4D. Finalmente, o projeto modelado deve ser validado na ocasião da entrega da obra.

Fase de gestão - O modelo BIM deve ser integrado a um sistema de gestão de facilidades. As equipes de operação e manutenção e o proprietário devem ser envolvidos no processo, capacitados e treinados.

Embora, na teoria, a questão da integração entre as fases do empreendimento; na prática, muitas vezes, ainda prevalece a visão segmentada da matéria, por parte dos atores do processo. Reforçando essa percepção, Kunz e Fischer (2012) ponderam que:

BIM atualmente permite que muitos profissionais da indústria da construção apresentem melhor desempenho. Entretanto, mesmo utilizando as mais adequadas práticas de BIM, os projetos geralmente não abrangem a modelagem, a visualização ou a análise da organização e de seus processos de modo preciso e eficiente, e métodos para a gestão e a comuniação de informações e de processos multidisciplinares permanecem adhoc. (KUNZ; FISCHER, 2012, 88e.7-8)

Na Figura 17, são apresentadas as diferenças entre o processo de projeto convencional e o processo integrado que, para sua prática, conta com o auxílio de ferramentas computacionais. 
Proccesso de

Proccesso de Projeto Convencional

Projeto Integrado, utilizando tecnologia BIM
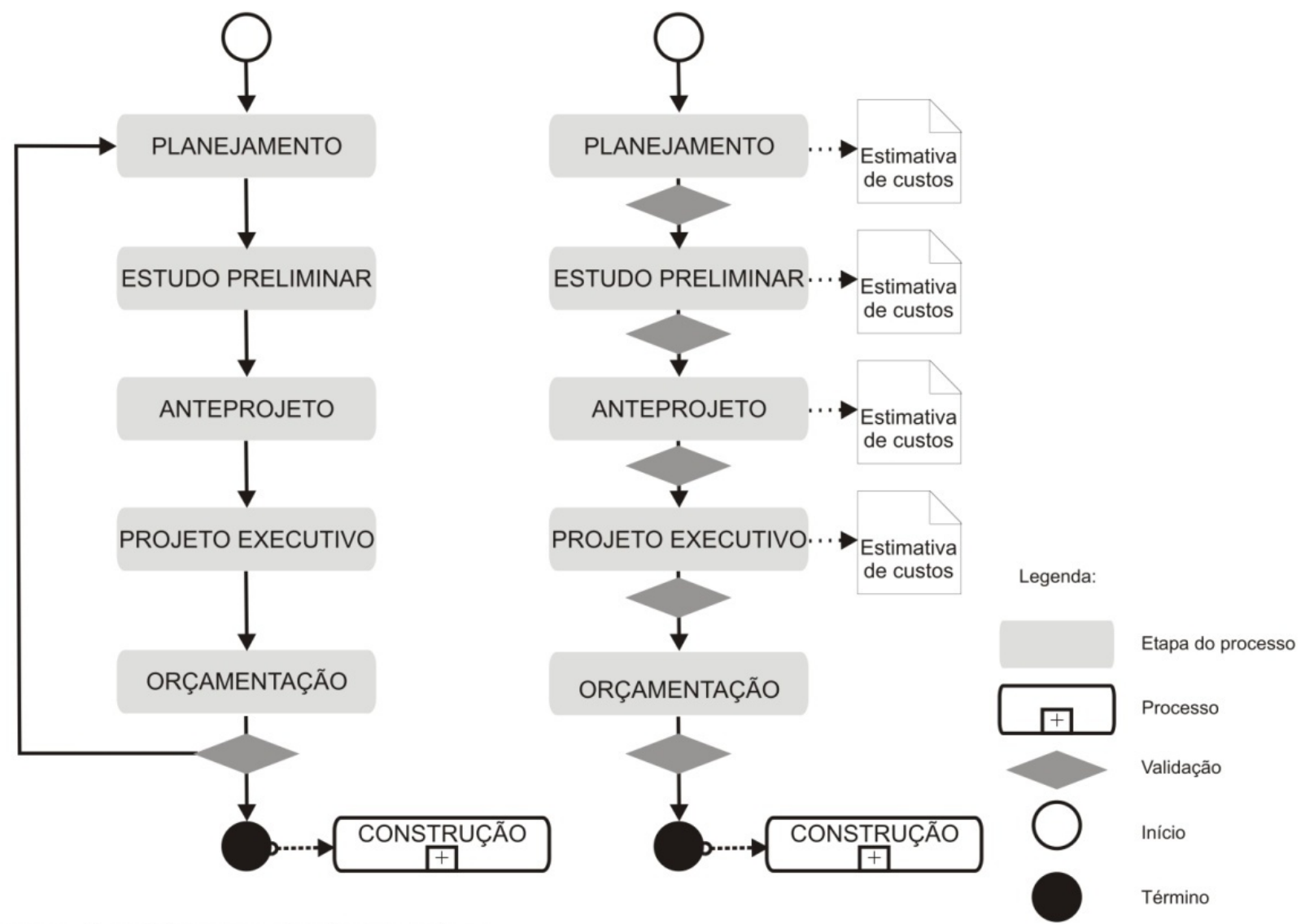

Figura 17. Processo de projeto convencional comparado ao processo de projeto integrado Praticado com o suporte de tecnologia BIM Fonte: Adaptado pela pesquisadora de: REINHARDT; WIDLEY (2010, p. 2-20).

Fischer (2006) destaca os seguintes usos pertinentes à modelagem da edificação, considerando um projeto cujas decisões sejam baseadas em desempenho, cuja operação considere o desempenho ao longo do ciclo de vida:

- análise do desempenho ambiental (ACV)

- avaliação do investimento, considerando a análise do custo do ciclo de vida (ACCV);

- gerência de facilidades;

- monitoramento dos consumos e do desempenho da edificação em uso;

- elaboração de quantitativos;

- orçamentação; 
- visualização de modelos combinados, para a avaliação de interferências;

- simulações computacionais: de iluminação, conforto térmico, consumo de energia, ventilação;

- realidade virtual; e

- alimentação e visualização de informações referentes aos ambientes do projeto.

Especificamente, no que diz respeito à $A C V$ e à $A C C V$, é fundamental que esses aspectos sejam incluídos, como critérios de desempenho a serem considerados nas decisões de projeto (AIA, 2010).

Projeto e construção tridimensional: o projeto tridimensional permite a visualização, conforme o que será construído, não dando margens a simplificações que, potencialmente, possam vir a se transformar em erros durante a execução (CPIC, 2011). Sendo assim, os componentes inseridos, provenientes de bibliotecas disponibilizadas por fornecedores, apresentam dimensões e as informações técnicas validadas pelo fabricante. Para a especificação, podem ser consultadas, inclusive, informações quanto a seu desempenho durante a fase de operação e manutenção.

Portanto, pode-se citar, dentre os aspectos que se constituem em benefícios da adoção da tecnologia BIM, estão:

- a criação de modelos de visualização e maior possibilidade de acesso à informação não geométrica, o que contribui no processo decisório dos stakeholders;

- maior possibilidade de interação entre as equipes;

- possibilidade de integração entre o modelo geométrico e a gestão de facilidades; e

- maior confiabilidade das informações, em razão de recursos para a conferência automatizada.

Desta forma, é possível tornar o processo de projeto mais eficiente, além de reduzir riscos e incertezas associados às soluções adotadas. 
No Quadro 1 é apresentado um resumo comparativo entre os processos tradicional e baseado em recursos de tecnologia para BIM.

\begin{tabular}{|l|l|l|}
\hline \multicolumn{2}{|c|}{ Quadro 1. Comparação de recursos da tecnologia para BIM, quando comparada à tecnologia convencional. } \\
\hline Propriedade & Tecnologia para BIM & Tecnologia convencional \\
\hline $\begin{array}{l}\text { Validação da informação da } \\
\text { construção. }\end{array}$ & $\begin{array}{l}\text { Tarefa automatizada, permite a } \\
\text { visualização tridimensional. }\end{array}$ & $\begin{array}{l}\text { Tarefa manual (sujeita, portanto, ao } \\
\text { erro humano e à imprecisão } \\
\text { dimensional). }\end{array}$ \\
\hline $\begin{array}{l}\text { Verificação da consistência das } \\
\text { informações }\end{array}$ & $\begin{array}{l}\text { Deteç̧ão de interferências, } \\
\text { checagem do modelo e elaboração } \\
\text { de quantitativos automatizadas. }\end{array}$ & $\begin{array}{l}\text { Conferência e quantificação de } \\
\text { projeto manuais. }\end{array}$ \\
\hline $\begin{array}{l}\text { Desenvolvimento das especificações } \\
\text { de projeto }\end{array}$ & $\begin{array}{l}\text { Desenvolvimento gradualmente } \\
\text { complementado, conforme o } \\
\text { andamento do projeto (BIMFORUM, } \\
\text { 2015). }\end{array}$ & $\begin{array}{l}\text { Manual, com menor controle do } \\
\text { nível de desenvolvimento. }\end{array}$ \\
\hline $\begin{array}{l}\text { Distribuição da informação de } \\
\text { projeto entre as equipes }\end{array}$ & $\begin{array}{l}\text { Sistema pode ser configurado para } \\
\text { tornar a informação disponível, } \\
\text { conforme o acordado pelas equipes. }\end{array}$ & $\begin{array}{l}\text { Requer procedimentos para a } \\
\text { solicitação de informações e a } \\
\text { emissão de relatórios de andamento } \\
\text { periódicos. }\end{array}$ \\
\hline
\end{tabular}

Fonte: Adaptado pela pesquisadora de: REINHARDT; WIDLEY (2010, p. 2-3).

Para o Department for Business, Innovation and Skills do Reino Unido (2011b), também estão relacionados benefícios em relação à incorporação da tecnologia BIM para a redução da incerteza relacionada à elaboração de contratos e à atribuição de direitos autorais, bem como para elaboração de apólices de seguros. Dentre os contratos que podem ser firmados com maior precisão, estão os que levam em consideração o desempenho energético previsto para a edificação (AUTODESK, 2007, 2009).

Para efeitos do desenvolvimento de projeto simultâneo e da garantia da confiabilidade das informações de projeto, é importante que seja clara a atribuição das responsabilidades de cada equipe, de modo a identificar as partes responsáveis, por exemplo, pela autoria e validação das informações, elaboração de componentes, e atribuição de direitos de acesso de edição relacionados às diferentes informações técnicas e equipes envolvidas (AIA, 2008).

Embora a produtividade das equipes de projeto inicialmente sofra um decréscimo, em razão da incorporação do novo processo de projeto que incorpora a tecnologia BIM, passada a etapa de implantação, há um ganho significativo de 
eficiência, no médio prazo (AUTODESK, 2007), sobretudo se a equipe desenvolver projetos que reutilizem componentes e sistemas construtivos.

Assim como se viu, nos primórdios da incorporação dos programas CAD ao desenvolvimento de projeto (FLEMMING, 1997), os ganhos em desempenho e retornos de investimento relacionados à incorporação da nova tecnologia dependem da adoção de um novo processo para a elaboração de projetos e, portanto, da exclusão das equipes envolvidas de sua zona de conforto.

Entretanto, para o sucesso dos procedimentos relacionados à aplicação da BIM, Coelho e Novaes (2008) lembram ser fundamentais a organização e a padronização adequadas das informações, de modo a permitir que diferentes agentes envolvidos no projeto possam compreender, avaliar e contribuir para o processo, com base na produção das demais equipes. Assim, quanto maior o nível de industrialização do projeto em questão, mais eficiente será o processo de modelagem.

Andrade e Ruschel (2009) observam que a BIM permite reunir e filtrar, de forma eficiente, grandes quantidades de informações características de projetos complexos, de forma que sejam úteis para embasar a solução de problemas, permitindo a comunicação das soluções de projeto, bem como a consulta das informações.

Além disso, dentre as vantagens de incorporação desta tecnologia, Romero e Scheer (2009) destacam que, no caso de aprovações e análises de projetos públicos, a modelagem da informação possibilita maior agilidade no processo e reduz as incertezas relacionadas ao detalhamento de projeto. Para Scheer et al. (2007), a maior precisão e o melhor detalhamento construtivo proporcionados pela adoção do sistema de modelagem BIM permitem antever as interferências projetuais e reduzir os erros de execução na obra.

Eastman et al. (2011) destacam os aspectos da BIM que podem auxiliar a gerenciar o aumento das pressões que o mercado imprime sobre o processo de projeto, conforme o apresentado na Figura 18. 


\section{Pressões sobre o processo de projeto e de construção}

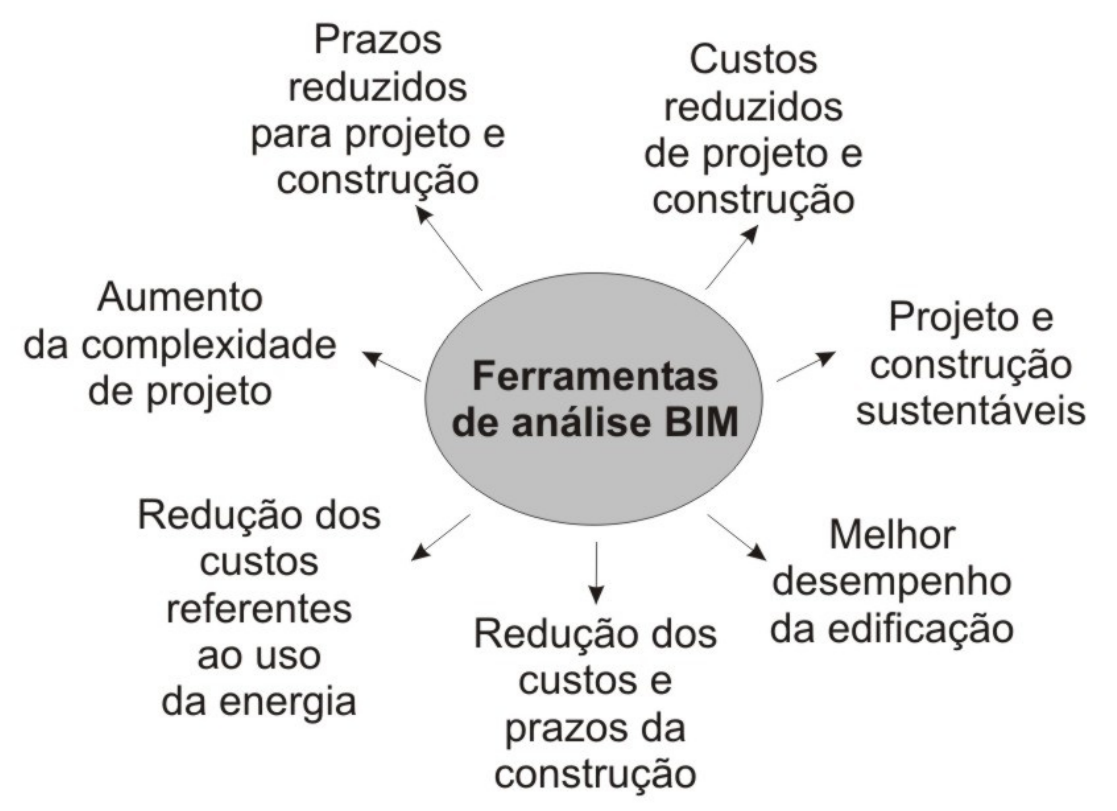

Figura 18. Recursos da BIM que contribuem para apresentar respostas ao aumento de pressão sobre o processo de projeto Fonte: Adaptado, pela pesquisadora, de Eastman et al. (2011, p. 20).

Além disso, Souza; Amorim e Lyrio (2009) concluem que a BIM é uma ferramenta para a integração dos processos, que permite diminuir as ineficiências e redundâncias gerando, desse modo, melhor produtividade. Lima; Fabricio e Firmino (2007) destacam ainda que o uso da BIM e dos demais recursos da TI, em projetos públicos contribui para o aumento da transparência em processos de aprovação. Mas, para que funcione adequadamente é preciso que os processos relacionados sejam racionalizados e que as equipes envolvidas estejam tecnicamente capacitadas.

Entretanto, Beber; Scheer e Wille (2007) entendem que a fluência das informações e os protocolos de comunicação nos escritórios de arquitetura e entre equipes de projetos técnicos representam desafios ainda a serem superados, pois dependem de um sistema de gestão formal, o que ainda precisa ser absorvido e incorporado pelas equipes de projeto.

Kymmell (2008) destaca como vantagens o aumento da produtividade, melhor precisão da documentação e a compatibilização de projeto por meio da composição de um Modelo Federado.

No documento ConsensusDOCS-301 (CONSENSUSDOCS, 2011), o modelo 
federado é definido do seguinte modo:

Um Modelo Federado corresponde a um Modelo composto por Modelos de Componentes associados, porém distintos, derivados de Modelos, textos e de outras fontes de informações, os quais não perdem sua identidade ou integridade por serem associados, de modo que uma mudança de uma mudança associada a um Modelo de Componente em um Modelo Federado não promove uma mudança em outro Modelo de Componente deste Modelo Federado. (CONSENSUSDOCS, 2011, p. 3, tradução nossa)

Esta abordagem permite um processo de projeto mais eficiente, uma vez que oferece condições para a visualização das instalações e suas interferências no modelo, conforme o apresentado na Figura 19.

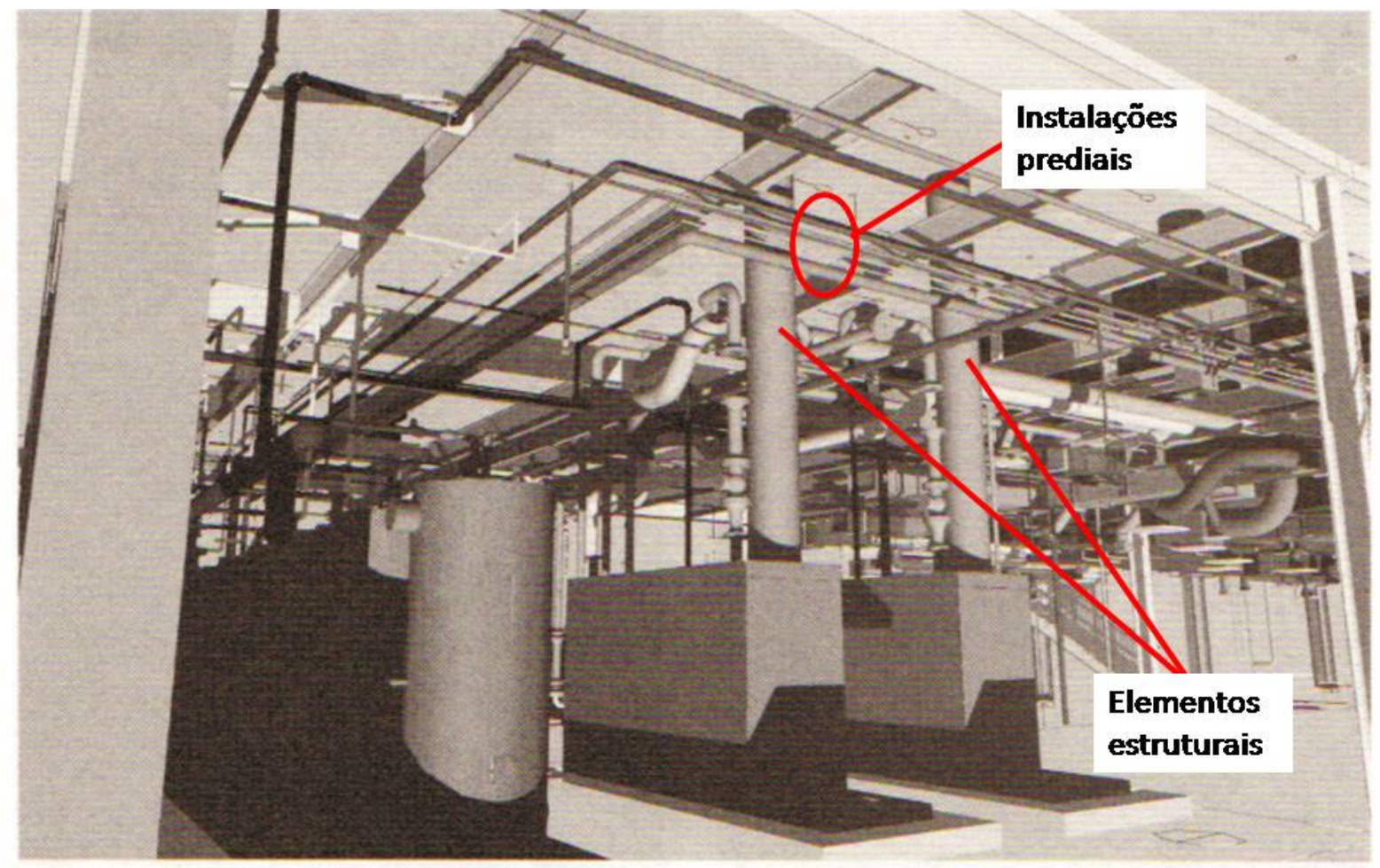

Figura 19. Exemplo de modelo federado

Fonte: Adaptado pela pesquisadora de: KYMMELL (2008, p. 73). 
A coordenação de projeto por meio de processos embasados pela tecnologia de BIM oferece, portanto, grandes vantagens, em relação ao processo tradicional (GOES, SANTOS, 2011), contribuindo para uma compatilização de projeto mais eficiente e precisa.

Quanto aos ganhos quantitativos obtidos pela implantação da tecnologia BIM ao processo de projeto, Jernigan (2008) estima que, em estudos de caso adotados para avaliar a produtividade BIM, foram constatadas economias entre $8 \%$ (oito por cento) e $15 \%$ (quinze por cento) em projetos novos e de até 35\% (trinta e cinco por cento) em projetos de requalificação relacionadas à adoção de um modelo BIM. As vantagens econômicas aplicaram-se tanto aos arquitetos e projetistas como aos proprietários.

No esquema apresentado na Figura 20 , são destacados os aspectos fundamentais para a prática do processo de projeto colaborativo, baseado na modelagem da informação. 


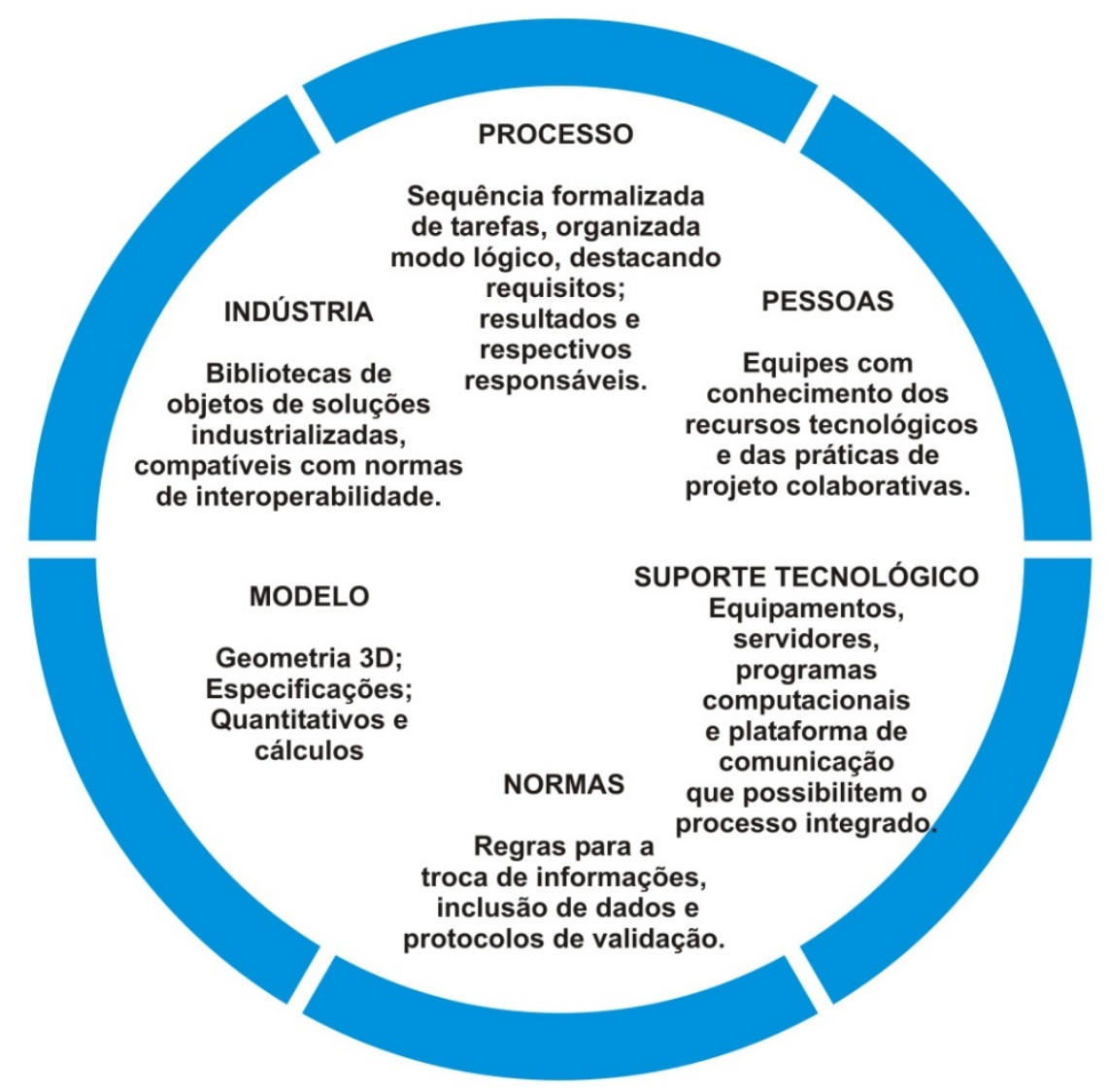

Figura 20. Aspectos fundamentais do processo colaborativo de modelagem da informação Fonte: Adaptado pela pesquisadora de: SEBASTIAN (2010, p. 179).

O projeto e a construção virtuais permitem que se possa avaliar, desde as fases iniciais de concepção, o desempenho das propostas elaboradas pelas diferentes disciplinas envolvidas no projeto, bem como sua interação (FISCHER, 2006). Nesses casos, a validação acontece de forma mais eficiente e confiável, visto que permite a visualização e a aplicação de rotinas automatizadas para a identificação de aspectos críticos e de interferências. Também é possível melhorar a confiabilidade e a eficiência das soluções de projeto, considerando seu desempenho ao longo da vida útil da edificação.

Os benefícios de se incorporar processos automatizados potencializam-se em empreendimentos de grande porte ou de maior complexidade. As pesquisas do Center for Integrated Facility Engineering (CIFE), da Universidade de Stanford, destacam-se na formalização do conhecimento quanto ao projeto cujas decisões são baseadas em desempenho. 
Esse entendimento parcial dos recursos da BIM dificulta a compreensão de sua utilização em um contexto mais amplo, que realmente ofereça suporte ao ativo imobiliário durante sua vida útil, restringindo os benefícios obtidos por aqueles que se propõem a incorporar seus recursos tecnológicos.

Alterações tão substanciais nos processos de projeto envolvem riscos. Dentre estes, há aqueles relacionados à modelagem. Para sua mitigação, devem ser considerados procedimentos para o controle de versões, fluxo de informações e de comunicação e atribuição de responsabilidades para validação e realização de alterações (AGC, 2006; SUCCAR, 2010ª).

Outra vantagem da implantação de tecnologias da BIM para o processo de projeto é a automação da elaboração de quantitativos e de orçamentos, visto ser possível calcular volumes e quantidades dos componentes modelados, bem como atribuir custos aos materiais de construção especificados (BASSETTE; MORAIS; RUSCHEL, 2012).

Observa-se, portanto, que no caso de edificações que apresentem tipologia construtiva e programa de necessidades padronizados, vencidos os desafios iniciais de implantação, quando as equipes envolvidas deverão deixar sua zona de conforto e assimilar novos processos para o projeto, a execução e a manutenção das edificações, a tecnologia BIM poderá ser implantada com grandes vantagens, permitindo mais agilidade e maior controle do desempenho e da qualidade do ambiente construído.

Dentre os principais obstáculos para a prática de um processo integrado de BIM, Sebastian (2010) destaca: o imediatismo dos stakeholders, quanto aos benefícios da implantação da tecnologia, as alterações profundas na matriz de responsabilidades e nas formas de contratação e pagamento, incertezas quanto ao direito da propriedade intelectual de soluções apresentadas nos modelos e a inexistência de um consenso quanto à proteção da informação em um ambiente colaborativo. Os riscos ainda não bem definidos, associados a essas alterações de processos e à atribuição das responsabilidades, também se constituem um desafio para a popularização da prática.

Olatunji e Sher (2010) observam que a migração ambiente digital colaborativo envolve a quebra do paradigma do processo segmentado, que é amplamente praticado pelas equipes de projeto. Nesse contexto, a prática colaborativa está 
condicionada a um novo conjunto de instrumentos jurídicos compatíveis, que atribuam, de forma clara, as responsabilidades e direitos de cada membro da equipe, não só em relação aos produtos entregues como também no que diz respeito à segurança da informação.

Além disso, como estão implícitos o conceito de ciclo de vida da edificação e o contexto multidisciplinar de modelagem, as informações devem ser modeladas considerando essa perspectiva. Olatunji (2014) destaca, por exemplo, que há poucos documentos disponíveis para orientar a gestão de projetos em BIM. Dentre estes, estão: E202 (AIA, 2008) e ConsensusDOCS-301 (LOWE; MUNCEY, 2009; CONSENSUSDOCS, 2011).

Desta forma, entregar como resultado do processo de projeto, um modelo, produto de trabalho multidisciplinar, vem se mostrando um objetivo desafiador, visto que a indústria da construção e o arcabouço jurídico que envolve suas atividades ainda não se encontram suficientemente maduros para absorver as práticas multidisciplinares do processo integrado de BIM (OLATUNJI, 2014).

$O$ processo colaborativo exige a reestruturação dos papéis e das responsabilidades de seus participantes. A falta de clareza quanto a esse aspecto se constitui-se em um importante empecilho para sua prática. Embora o conceito de projeto colaborativo seja bastante conhecido pelas equipes, observa-se que, na prática, os projetistas apresentam pouca experiência quanto à sua aplicação. Além disso, as estruturas organizacionais sedimentadas não são ambientes propícios para a prática colaborativa com suporte em BIM (SEBASTIAN, 2010).

Com base no exposto, pode-se apreender que a BIM pressupõe a existência de processos para a gestão da informação da construção, desta forma, impactando profundamente o processo de projeto de um empreendimento. Apesar disso, é, muitas vezes, entendida erroneamente como o uso de determinada ferramenta de modelagem.

Corroborando esse entendimento, Manzione et al. (2011b) observam que a BIM, na maioria das vezes, ainda é compreendida de forma simplificada, como uma mera ferramenta de projeto, não sendo suas possibilidades de desenvolvimento do projeto integrado efetivamente exploradas.

O ambiente colaborativo proporcionado pelo uso dos recursos da BIM (MANZIONE; MELHADO, 2015) introduz desafios quanto aos limites contratuais de 
cada membro da equipe. Também pode expor os envolvidos a riscos, caso os procedimentos para arquivamento e atualização dos arquivos não estejam adequadamente formalizados.

Além disso, os dados dos próprios modelos utilizados para análises podem, potencialmente, expor colaboradores a riscos, caso as informações inseridas nos modelos não estejam adequadamente validadas. Considerando que há múltiplas equipes responsáveis pela alimentação dos dados, uma equipe terceira que venha a utilizá-lo (como por exemplo, especialista em simulação energética) pode ser induzida a obter resultados inadequados. Neste contexto, alguns conceitos precisam ser colocados em prática para o sucesso do processo, a saber (HURTADO, 2010):

- risco compartilhado: em equipes multinacionais, é comum que as equipes façam um seguro de responsabilidade civil cruzada, como forma de mitigar os riscos relacionados a prejuízos por erros de projeto;

- prevenção de litígio, pela elaboração de contratos transparentes, que pressuponham boa fé entre as partes envolvidas;

- gestão de arquivos do modelo; e

- planejamento adequado da modelagem.

Apesar da discussão apresentada, quanto aos riscos inerentes às alterações de processos, inerentes à adoção de uma abordagem integrada, baseada no uso de tecnologias de BIM, no âmbito de um portfólio de ativos, sua prática apresenta vantagens. Pode, por exemplo, embasar decisões estratégicas para o proprietário de ativos, extrapolando seu valor como um recurso tecnológico para o gerenciamento de informações.

Para isso, porém, é preciso que o planejamento para a utilização da informação durante a etapa de gestão do ativo, seja feito durante a fase de planejamento de projeto. São aspectos a serem considerados quando da utilização das informações durante o ciclo de vida da edificação: governança, gestão de alterações, monitoramento do desempenho e planejamento estratégico (LOVE et al., 2014).

Portanto, os recursos tecnológicos da BIM vêm sendo adotados para a gestão não só do projeto, como dos ativos imobiliários de uma organização. Uma 
contribuição da presente tese é que, no caso de organizações que apresentem, em seu portfólio de ativos de edificações de tipologia padronizada, as informações referentes ao desempenho em uso das soluções de projeto sejam incorporadas ao Banco de Dados, de modo que possam ser facilmente consultadas.

Esta abordagem integrada para a informação não só contribui para a melhoria contínua do projeto como também consolida o aprendizado da organização, permitindo a efetiva gestão de seu conhecimento.

BIM pode significar tantas coisas diferentes que não utilizamos este termo em nossa documentação contratual. Nós adotamos 'gestão da informação' ou 'modelagem da informação'. (TAYLOR, 2014ª p.39, tradução nossa)

Isso posto, em um portfólio integrado, e ao longo do ciclo de vida, há informações referentes a diferentes aspectos dos ativos, não devendo a modelagem da informação ficar restrita à construção, mas, sim, ser vista em um sentido mais amplo, de modo que a modelagem contemple a integração do modelo (B)IM aos recursos para (A)IM (asset information management), que dependem da fase do ciclo de vida no qual se encontra o empreendimento. Desta forma, a informação deve permanecer consistente, conforme os critérios que proporcionem confiabilidade aos dados modelados, independente da fase na qual o empreendimento encontra-se (planejamento, produção ou uso).

Por conseguinte, observa-se, que o ciclo de vida da informação, no contexto do portfólio de ativos imobiliários de uma organização, extrapola o ciclo de vida da edificação. Por isso, é pertinente que sejam adotadas as medidas de gestão necessárias para incrementar o aprendizado organizacional, a fim de evitar que o conhecimento se perca ou limite-se à experiência profissional dos colaboradores. 


\section{ASPECTOS RELEVANTES PARA O PLANEJAMENTO DA MODELAGEM DA INFORMAÇÃO}

Em projetos complexos, é preciso gerenciar as diferentes necessidades de cada equipe participante do processo de projeto multidisciplinar. Conforme as etapas do ciclo de vida da edificação avançam, observa-se que as informações necessárias às equipes envolvidas diferem-se, conforme a representação esquemática apresentada na Figura 21. Deste modo, a informação geométrica, muito relevante durante as etapas de projeto e de construção, apresenta menor relevância durante a fase de operação de um empreendimento (TEICHOLZ, 2013).

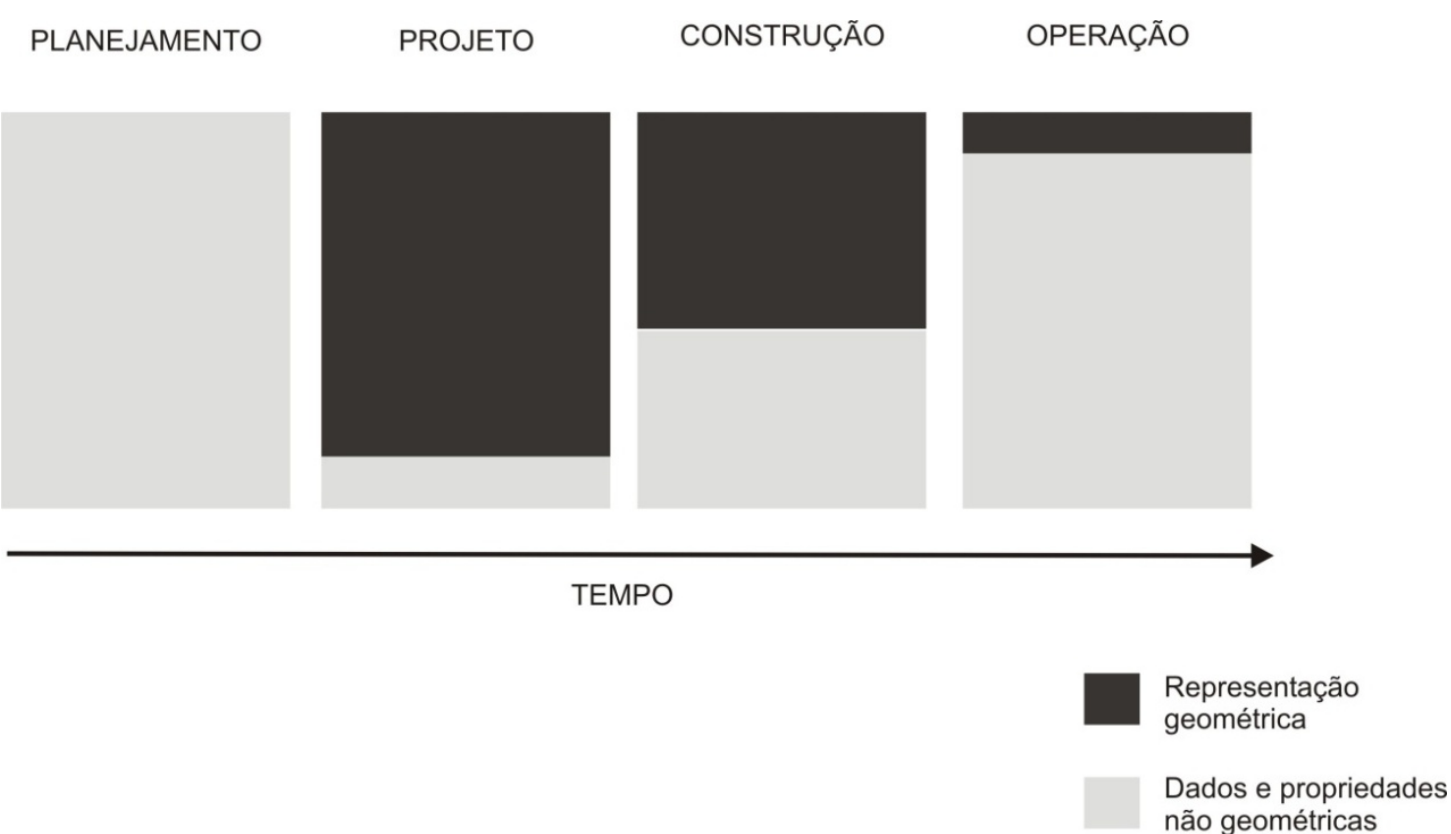

Figura 21. Representação esquemática da relevância da informação da construção, por tipo, ao longo da vida útil da edificação. Fonte: Adaptado pela pesquisadora de: TEICHOLZ (2013, p. 7).

No caso de uma edificação nova, enquanto na etapa de planejamento ainda não há praticamente informação geométrica disponível - ficando esta restrita a levantamentos preliminares - durante a fase de projeto e de construção, sua importância é destacada, em conjunto com os dados e as propriedades pertinentes às especificações de projeto. Quando da edificação em uso, por sua vez, a relevância da informação não geométrica (datas de instalação, especificações, 
condições de garantia, por exemplo) destaca-se em relação à informação geométrica (TEICHOLZ, 2013).

Nascimento e Santos (2003) destacam, como crítica para a implantação dos recursos tecnológicos ao processo de projeto, a falta de procedimento formal de validação de produtos projetados, tarefa que, por vezes, é delegada a colaboradores de nível operacional.

Outro desafio a ser vencido é que, normalmente, cada equipe trabalha conforme uma metodologia de trabalho própria e, para seu suporte, utiliza recursos tecnológicos específicos, gerando um processo fragmentado. Além disso, gestores e administradores, normalmente, têm pouca familiaridade com o ambiente digital, faltando uma visão estratégica a ser incorporada ao processo de projeto e de construção com a utilização da TI (NASCIMENTO; SANTOS 2001).

Para Owen et al. (2010), usualmente, as empresas não possuem normas para a gestão do conhecimento. Quando as possuem, as diretrizes costumam ser determinadas considerando apenas os vieses administrativos e jurídicos, sem que uma reflexão mais aprofundada quanto a incentivar que seja dado o adequado retorno, quanto ao desempenho obtido.

Os pesquisadores destacam, ainda, que o conhecimento costuma ficar restrito a grupos e, raramente, é distribuído entre equipes da organização, inclusive com o intuito de preservar uma suposta vantagem competitiva. Dessa forma, o uso do conhecimento quanto a projetos pregressos, usualmente, está restrito ao reaproveitamento da equipe (OWEN et al., 2010).

A importância do conhecimento para o processo de projeto é destacada por Fabricio e Melhado (2002). Durante seu desenvolvimento, diversos projetistas apresentam proposições referentes às disciplinas específicas e sua validação é feita em função do interesse dos diversos agentes. Desta forma, são promovidos aprimoramentos sucessivos do entendimento do problema inicial e do aprimoramento de soluções propostas.

Por esse motivo, o planejamento do processo de modelagem deve incorporar soluções que permitam que as informações desenvolvidas pelas diferentes equipes responsáveis pelo processo de produção da edificação sejam normalizadas de modo que possam ser utilizadas, inclusive, em outras etapas do ciclo de vida da edificação. 
Por conseguinte, vem se disseminando o entendimento de que precisa ser adotada a melhor ferramenta para cada abordagem específica, o que aumenta a necessidade de que as informações possam ser encaminhadas de um programa computacional a outro de modo eficiente. Daí, a importância de soluções de integração abertas, que não estejam restritas ao domínio de um programa computacional específico.

Por exemplo, um aspecto importante da interoperabilidade da informação entre programas computacionais é permitir a gestão financeira dos ativos, pela integração das informações de projeto com os sistemas ERP.

Essa funcionalidade permite que a informação modelada seja utilizada para a gestão dos processos de fabricação, transporte e entrega, dos recursos humanos e do inventário de ativos e aspectos financeiros relacionados (CHEN, 2001).

Nesse sentido, há uma grande quantidade de plug-ins (ou seja, programas que podem ser instalados em outros, com o objetivo de adicionar funções) que se propõem a oferecer a conectividade desejada (SCHLEUSNER, 2014).

A troca de informações entre programas é suscetível à perda de consistência, durante os processos de importação e exportação. Além disso, programas de autoria geram arquivos com terminações específicas, que não são, necessariamente, lidos por programas terceiros. Os efeitos desta limitação técnica podem comprometer o sucesso do compartilhamento da informação modelada.

Para tal, no início do projeto, os critérios para a modelagem devem ser determinados, para as etapas do ciclo de vida pertinentes, considerando os usos pretendidos para o modelo, os produtos esperados para cada fase e suas relações. Deste modo, os recursos tecnológicos, os padrões de interoperabilidade, os atores envolvidos e as respectivas responsabilidades são definidos, bem como os protocolos de segurança e as regras de documentação, comunicação e validação. A documentação deste planejamento é denominada Plano de Execução BIM (AGC, 2006).

Em suma, para que o sistema de gestão da informação possa abranger as diferentes fases do ciclo de vida do empreendimento, espera-se obter, por meio da adoção do padrão único e aberto, suporte à troca de informações ao longo do ciclo de vida do ambiente construído, entre disciplinas e entre aplicações técnicas (LIEBICH, 2009). Para tanto, deve-se trabalhar em equipe, com diferentes 
programas computacionais e versões, escolhidos em função das especificidades de cada disciplina envolvida, de modo que sua integração é crítica para o processo de projeto.

Para que se tenha a dimensão do impacto dos aspectos da interoperabilidade para a gestão da informação, um estudo conduzido pelo National Institute of Standards and Technology (NIST), no contexto do mercado da construção civil e da gestão de facilidades dos Estados Unidos da América, foi realizado, em 2002. Nesta pesquisa, foi estimado que os custos correspondentes a perdas de oportunidades em razão de aspectos de interoperabilidade correspondiam a US\$ 15,8 bilhões (quinze bilhões e oitocentos milhões de dólares dos Estados Unidos da América), sendo que $2 / 3$ (dois terços) destes custos foram gerados durante a fase de operação e manutenção das edificações (NIST, 2004).

Frente a esse cenário, há um esforço conjunto, promovido por diversos agentes da indústria da construção (do qual fazem parte software houses e fabricantes de produtos da construção), no sentido de promover a comunicação entre os programas para modelagem da informação, independentemente do fabricante ou de sua aplicação durante os processos de projeto, construção e operação.

Em 1995, uma iniciativa internacional denominada International Alliance for Interoperability foi constituída, como organização sem fins lucrativos e empreendida pela indústria da construção civil. Seu objetivo era promover um protocolo neutro de comunicação das informações modeladas durante os processos inerentes à produção do ambiente construído, independente do aplicativo de BIM adotado, que pudesse ser aplicado ao longo do ciclo de vida do objeto modelado. Em 2005, a organização foi rebatizada como buildingSMART.

A entidade buildingSMART propõe-se a promover, no âmbito internacional, normas que possibilitem a troca de informação aberta, aplicáveis a projetos de ativos da construção civil e de infraestrutura, durante seu ciclo de vida (BUILDINGSMART, 2014a).

À época da presente pesquisa (2015), a buildingSMARTcontava com 16 (dezesseis) comitês regionais, organizados da seguinte forma: Austrália, Canadá, China, França, Alemanha, Hong Kong, Itália, Japão, Coréia, Holanda, Países Nórdicos (Finlândia, Dinamarca e Suécia), Estados Unidos da América (como um 
Conselho do National Institute of Building Sciences), Noruega, Singapura e Reino Unido.

Também merece destaque o OpenBIM Programme, um programa de iniciativa da buildingSMART, que se propõe a promover a comunicação universal das informações modeladas ao longo do processo BIM, bem como fornecer suporte técnico e educacional para tal (OPENBIM, 2012).

Com base no trabalho desses grupos de entidades e especialistas, foi desenvolvida a norma internacional para o compartilhamento das informações geradas utilizando a tecnologia BIM, cujo produto é um arquivo em extensão Industry Foundation Class (IFC) (BUILDINGSMART, 2014b).

Em 1999, em razão do interesse de que fosse popularizado o uso do IFC, um grupo de fabricantes de software, dentre os quais as empresas, Microsoft, Timberline Software e Graphsoft, constituiu o Building Life Cycle Interoperable Software (BLIS). Este grupo demonstrou ser viável o compartilhamento de informações entre diferentes programas computacionais, para a elaboração de análise energética, quantitativos e verificação do atendimento a normas técnicas. Entretanto, as soluções apresentadas para tais fins ainda se demonstravam parciais e fragmentadas (ROE, REINA, 2001).

IFC consiste em uma norma de compartilhamento de informações da construção, de modo a permitir as diferentes aplicações necessárias ao uso da arquitetura, da engenharia e da gestão de facilidades. É um esquema de informações, sedimentado em definições de classes, como, por exemplo, componentes da edificação, propriedades e espaços. (BAZJANAC; CRAWLEY, 1997; BUILDINGSMART, 2013).

O arquivo IFC armazena dados referentes ao projeto, porém, estes dados por si só não fazem algum sentido quando estão codificados (ilegíveis, abstratos ao usuário). Portanto, faz-se necessário o uso de uma camada intermediária (software) para manipular estes dados de arquivos IFC. O software é uma aplicação responsável por extrair e padronizar estes dados de acordo com os arquivos IFC. Desta forma, é possível transformar dados codificados em linguagem IFC em outros 
tipos de dados e também transformá-los em informação em nível de usuário. (JACOSKI; LAMBERTS, 2003, p. 4)

A Norma IFC, à época da presente pesquisa (2015), apresentava a versão IFC4 (ISO 16.739:2013) e foi desenvolvida com o intuito de dar suporte, inclusive, à modelagem de projetos de infraestrutura complexos, tais como rodovias, túneis e pontes.

A utilização dos arquivos IFC para a troca de informações em processos de BIM, embora ainda apresente limitações quanto aos parâmetros disponíveis, permite que sejam formalizadas relações geométricas complexas. Em geral, para a importação em um programa, é preciso utilizar uma API (ou seja, um conjunto de protocolos e rotinas que especifiquem como os componentes do programa devem interagir), uma vez que a maioria dos programas não suporta muitas das aplicações do formato IFC (SCHLEUSNER, 2014).

Desta forma, é possível, por meio da exportação em formato IFC, que um programa computacional, diferente daquele em que o arquivo foi gerado, reconheça os objetos e as informações e execute suas tarefas específicas, complementando as informações iniciais (ROE; REINA, 2001).

A discussão sobre os aspectos da interoperabilidade é fundamental, pois o compartilhamento das informações é condição para o sucesso do processo de modelagem da informação da construção, conforme o conceito de produção de projeto integrado (IDP) (AIA, 2007). Isso se dá, pois a informação deve estar acessivel a todas as disciplinas, tais como: arquitetura, engenharia de sistemas prediais, engenharia civil, gestão de facilidades, gestão de projeto, gestão dos requisitos do proprietário, elaboração de quantitativos, orçamentação e gestão de propostas comerciais para a aquisição e a manutenção dos componentes modelados, independente do programa computacional no qual foram geradas.

Desta forma, ficam claros os benefícios proporcionados pela exportação da informação da construção em formato aberto e compatível com os vários programas computacionais adotados no processo de produção e operação do edifício, de modo a possibilitar o acesso e a atualização das informações, ao longo da vida útil do objeto modelado.

Para que as informações necessárias e seus fluxos possam ser padronizados 
por tipo de uso, existem diretrizes a serem observadas, por meio da elaboração de Manuais de Distribuição da Informação. Esses documentos são compostos por diretrizes formais para a gestão das informações, que ofereçam suporte a todos os requisitos de atividades da construção pertinentes a determinado empreendimento, durante todos seus ciclos de vida (WIX; KARLSHØJ, 2010).

Os processos para sistemas de informações podem ser classificados, considerando os seguintes critérios (BERNARD, 2012): sequência das tarefas a serem realizadas, identificação das informações necessárias, interações organizacionais e lógica pertinente à realização das tarefas.

A representação esquemática, apresentada na Figura 22, descreve, de forma não técnica, os processos pertinentes e as respectivas informações necessárias para cada tarefa (SEBASTIAN, 2010; MANZIONE, 2013).

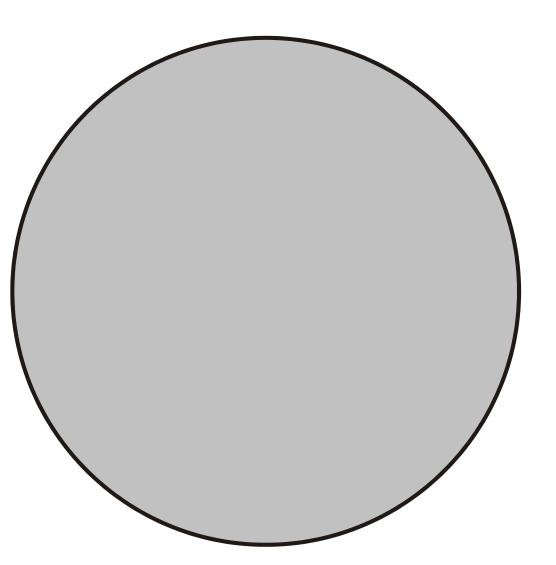

Todas as informações do modelo, relacionadas a parâmetros IFC.

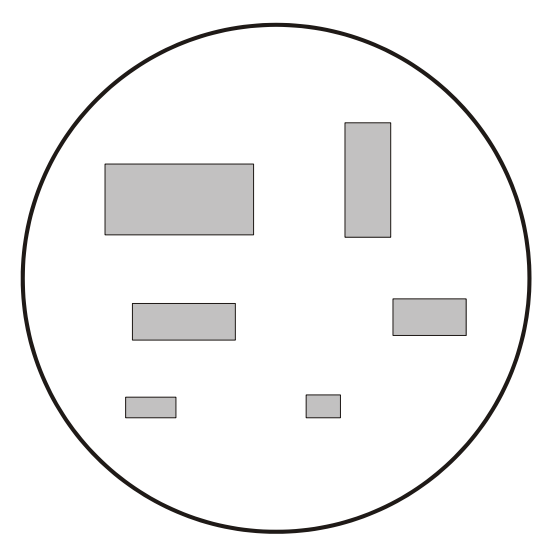

Manuais de distribuição da informação

Método para definir os requisitos de informações referentes a um uso específico, em uma data etapa do desenvolvimento de projeto.

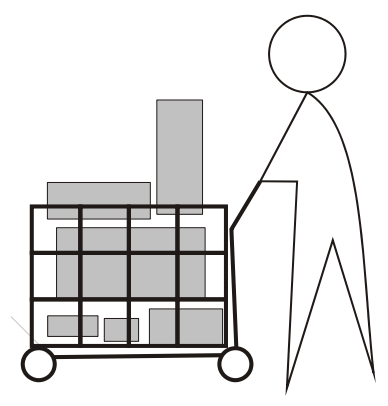

Definição de vista do modelo Subgrupo de informações, necessárias para atender a requisitos específicos.

Figura 22. Representação esquemática da organização de diferentes níveis de informação em um modelo Fonte: Adaptado pela pesquisadora de: WIX; KARLSHøJ (2010, p. 14).

O processo de elaboração de um Manual de Distribuição da Informação envolve, pelo menos, dois programas computacionais e a informação que deve ser trocada entre eles. Para sua normalização, é necessário formalizar o processo de 
integração entre os programas computacionais e os requisitos das informações a serem trocadas (BERNARD, 2012).

Em suma, do universo de informações modeladas, é necessário identificar qual a informação da construção que cada ator do processo precisa e quais os parâmetros modelados a ela relacionados, conforme o esquema apresentado na Figura 23.

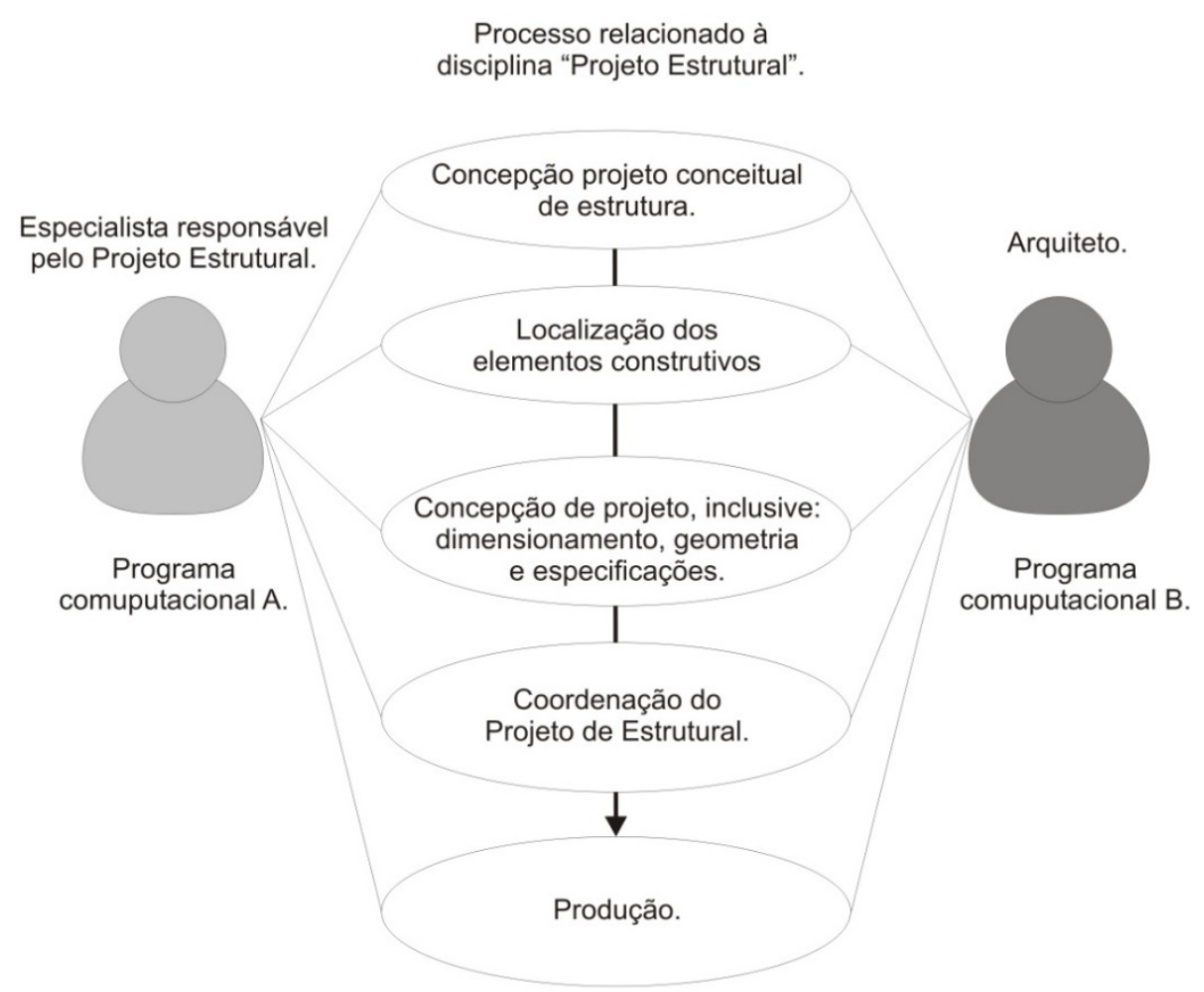

Figura 23. Requisitos dos usuários para a troca de informações

Fonte: Adaptado pela pesquisadora de: WIX; KARLSH $\emptyset \mathrm{J}(2010$, p. 10).

Com o intuito de que se tenha clareza quanto aos requisitos e atores envolvidos, é preciso consolidar um mapa de processo que permita esclarecer o fluxo das atividades, de modo a proporcionar a toda a equipe uma compreensão completa das etapas do processo, ações a serem realizadas e produtos a serem entregues.

Em cada tarefa a ser cumprida durante o processo, apenas algumas classes de informações do modelo são necessárias. Deste modo, são criados subconjuntos de dados do IFC, em função das necessidades específicas de cada atividade 
envolvida no processo de modelagem da informação. Estes subconjuntos, denominados vistas, são descritos nas 'vistas de informação do modelo' (WIX; KARLSHØJ, 2010).

Para prover a interoperabilidade desejada, deve-se ter claro quem deverá modelar as informações requeridas, seu uso previsto, em que fase do projeto deverão ser acessadas, quais são os dados e propriedades necessários para tal. Também é preciso determinar-se para quem as informações serão encaminhadas e quais as disciplinas envolvidas na troca (WIX; KARLSHØJ, 2010).

De modo a suprir essa necessidade, merece menção uma série de normas que objetivam padronizar a troca de informações para diferentes usos encontramse em desenvolvimento, conforme o apresentado no Quadro 2. A nomenclatura destas normas apresenta a terminação 'ie', que caracteriza seu uso como de troca de informação (information exchange), em função dos diferentes usos pretendidos.

Quadro 2. Normas desenvolvidas pelo NIBS para a padronização de troca de informações modeladas

\begin{tabular}{|c|c|c|c|}
\hline Sigla & Nome por extenso & Objetivo do projeto & Situação \\
\hline BIMSie & $\begin{array}{l}\text { Service Interface } \\
\text { exchange }\end{array}$ & $\begin{array}{l}\text { Automatizar a interação entre aplicativos } \\
\text { BIM operados em rede, por meio de uma } \\
\text { API de código aberto. }\end{array}$ & $\begin{array}{l}\text { Submissão à NBIMS } \\
\text { pendente. }\end{array}$ \\
\hline BAMie & $\begin{array}{l}\text { Building Automation } \\
\text { Modeling exchange }\end{array}$ & $\begin{array}{l}\text { Apresentar os requisitos necessários para } \\
\text { possibilitar a integração da informação } \\
\text { modelada com os sistemas de } \\
\text { automação, para todo o ciclo de vida do } \\
\text { empreendimento. }\end{array}$ & $\begin{array}{l}\text { Submissão à NBIMS } \\
\text { pendente. }\end{array}$ \\
\hline Bpie & $\begin{array}{l}\text { Building Programming } \\
\text { information exchange }\end{array}$ & $\begin{array}{l}\text { Determinar a informação necessária à } \\
\text { consolidação do programa arquitetônico. }\end{array}$ & $\begin{array}{l}\text { Submetido à } \\
\text { NBIMS-US V3. }\end{array}$ \\
\hline COBie & $\begin{array}{l}\text { Construction- } \\
\text { Operations Building } \\
\text { information exchange }\end{array}$ & $\begin{array}{l}\text { Designar as características e propriedades } \\
\text { necessárias à gestão de facilidades, } \\
\text { inclusive as relacionadas aos espaços e } \\
\text { aos equipamentos e componentes. }\end{array}$ & $\begin{array}{l}\text { NBIMS-US V2, } \\
\text { atualizado para } \\
\text { NBIMS-US V3. }\end{array}$ \\
\hline HVACie & $\begin{array}{l}\text { HVAC information } \\
\text { exchange }\end{array}$ & $\begin{array}{l}\text { Especificar os requisitos relacionados aos } \\
\text { componentes, equipamentos e sistemas } \\
\text { de AVAC. }\end{array}$ & $\begin{array}{l}\text { Submetido à } \\
\text { NBIMS-US V3. }\end{array}$ \\
\hline Lcie & $\begin{array}{l}\text { Life Cycle information } \\
\text { exchange }\end{array}$ & $\begin{array}{l}\text { Estabelecer as informações necessárias } \\
\text { para a gestão de produtos que compõem } \\
\text { determinado modelo, durante seu } \\
\text { respectivo ciclo de vida. }\end{array}$ & $\begin{array}{l}\text { Submetido à } \\
\text { NBIMS-US V3, } \\
\text { como um anexo da } \\
\text { Norma COBie. }\end{array}$ \\
\hline
\end{tabular}

Continua... 
...continuação.

\begin{tabular}{|l|l|l|l|}
\hline Qtie & $\begin{array}{l}\text { Quantity Takeoff } \\
\text { information exchange }\end{array}$ & $\begin{array}{l}\text { Determinar os requisitos } \\
\text { necessários para a elaboração de } \\
\text { quantitativos, a partir de um } \\
\text { modelo. }\end{array}$ & Em desenvolvimento. \\
\hline Sparkie & $\begin{array}{l}\text { Electrical System } \\
\text { information exchange }\end{array}$ & $\begin{array}{l}\text { Especificar os requisitos } \\
\text { relacionados aos componentes, } \\
\text { equipamentos e sistemas elétricos. }\end{array}$ & $\begin{array}{l}\text { Submetido à NBIMS-US } \\
\text { V3. }\end{array}$ \\
\hline Spie & $\begin{array}{l}\text { Specifiers' Properties } \\
\text { information exchange }\end{array}$ & $\begin{array}{l}\text { Criar arquivos-modelo que } \\
\text { permitam aos fabricantes exportar } \\
\text { as informações referentes a seus } \\
\text { produtos em formato aberto. }\end{array}$ & Em desenvolvimento. \\
\hline WALLie & $\begin{array}{l}\text { Wall information } \\
\text { exchange }\end{array}$ & $\begin{array}{l}\text { Padronizar, de forma explícita, as } \\
\text { características e propriedades } \\
\text { necessárias à construção de } \\
\text { paredes, por meio da } \\
\text { padronização de layers, de } \\
\text { abrangência internacional. }\end{array}$ & Em desenvolvimento. \\
\hline Wsie & $\begin{array}{l}\text { Water System } \\
\text { information exchange }\end{array}$ & $\begin{array}{l}\text { Especificar os requisitos } \\
\text { relacionados aos componentes, } \\
\text { equipamentos e sistemas } \\
\text { hidráulicos. }\end{array}$ & V3. \\
\hline
\end{tabular}

Fonte: Elaborado pela pesquisadora, a partir de NIBS (2015å). Disponível em <https://www.nibs.org/?page=bsa_infoexchange>. Acesso em 20 out. 2015.

Dentre as normas apresentadas, destaca-se a COBie (ConstructionOperations Building information exchange, em português: troca de informações modeladas, referentes à construção e operação da edificação). Esta norma propõe uma solução para uma situação recorrente. É comum, ao final da construção, que a informação necessária aos serviços de manutenção, operação e gestão de ativos esteja incompleta ou desatualizada. Assim sendo, consiste em um esquema de estruturação de dados e propriedades de componentes que, por ser aberto, pode ser utilizado por diferentes programas de autoria, conforme o apresentado na Figura 24. 


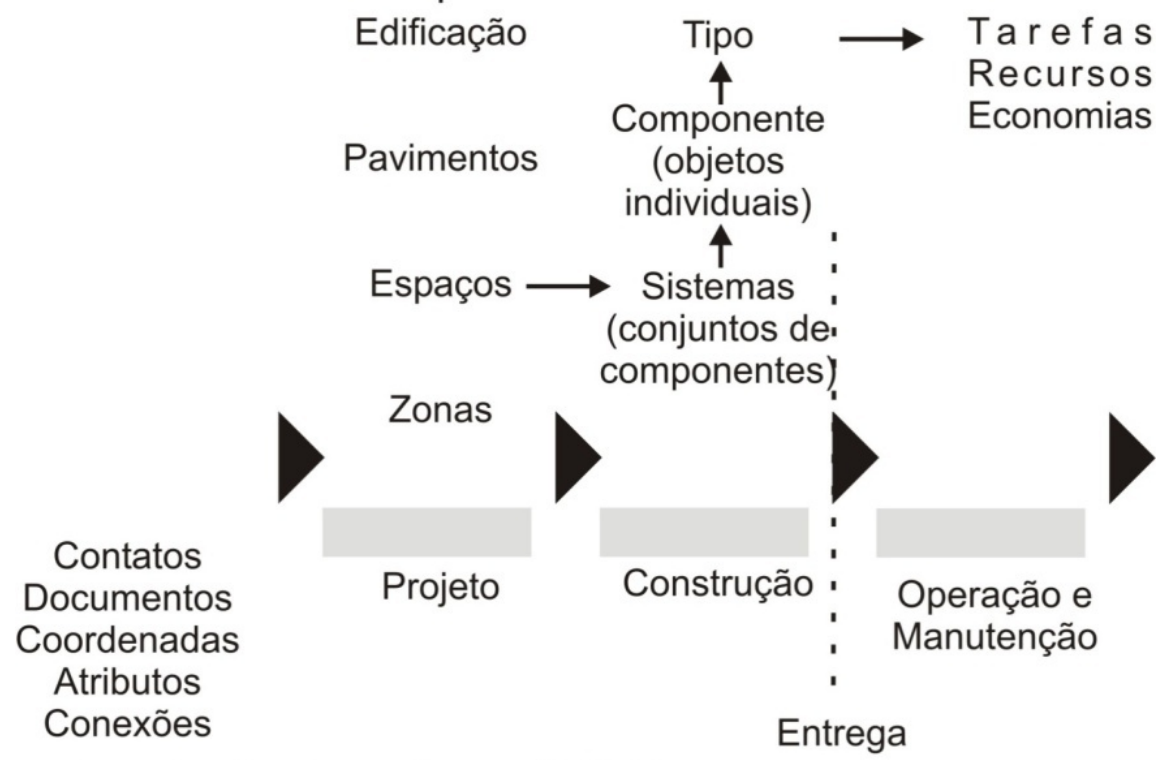

Figura 24. Organização das informações em um arquivo COBie

Fonte: Adaptado pela pesquisadora de: SABOL (2013, p. 33).

Seu formato pretende permitir que as informações referentes a componentes modelados em projeto sejam usadas para atividades de operação, manutenção e gestão de ativos, inclusive especificações técnicas e informações sobre vida útil e garantia, tais como: números de série, instruções, especificações técnicas e manuais (SABOL, 2013).

Um exemplo de sua aplicação é a elaboração de listas de peças de reposição e de atividades de manutenção preventiva. Para que tais informações sejam adequadamente modeladas, é preciso determinar quais propriedades são relevantes ao empreendimento, ainda na fase de seu planejamento. Nos casos em que o empreendimento será mantido por meio de um sistema de gestão da manutenção com suporte computacional, a condição ideal é de que a informação seja automaticamente fornecida, ao final da construção (ERDC/CERL, 2007).

É importante ressaltar que, apesar dos recursos oferecidos pelo formato aberto, a solução proposta pela Norma IFC não abrange todas as propriedades que precisam ser exportadas, obrigando ainda a busca de soluções complementares para que se possa, efetivamente, integrar as informações, ao longo do ciclo de vida da edificação. 


\subsection{DIRETRIZES PARA A NORMALIZAÇÃO DA INFORMAÇÃO MODELADA}

Para que seja viável que diferentes equipes acessem um mesmo arquivo, bem como incluam e editem informações de modo a permitir a compreensão dos demais, faz-se fundamental que sejam adotados critérios para a padronização da informação.

Sendo assim, deve-se padronizar a terminologia adotada durante os processos a serem integrados. No intuito de suprir essa necessidade, o sistema de classificação da informação da construção OMNICLASS (OCCS), estabelece 15 (quinze) tabelas para a padronização da terminologia pertinente à indústria da construção (OCCS, 2012), cujo conteúdo é apresentado no Quadro 3.

Quadro 3. Tabelas de terminologia OminiClass

\begin{tabular}{|c|c|c|}
\hline Tabela & Conteúdo & Comentários \\
\hline 11 & Entes, por função & $\begin{array}{l}\text { Unidades que compõem o ambiente construído contidas em elementos. } \\
\text { Relacionadas a espaços e caracterizadas pela função exercida (OCCS, 2012) }\end{array}$ \\
\hline 12 & Entes, por forma & $\begin{array}{l}\text { Entes que compõem o do ambiente construído caracterizadas, conforme } \\
\text { sua forma (OCCS, 2012) }\end{array}$ \\
\hline 13 & Ambientes, por função & $\begin{array}{l}\text { Unidades do ambiente construído, circundados por um limite físico ou } \\
\text { abstrato, classificadas conforme sua função. }\end{array}$ \\
\hline 14 & Ambientes, por função & $\begin{array}{l}\text { Unidades do ambiente construído, circundados por um limite físico ou } \\
\text { abstrato, classificadas conforme sua forma (OCCS, 2012). }\end{array}$ \\
\hline 21 & Elementos & $\begin{array}{l}\text { Elementos que compõem o ambiente construído, que apresentam, por } \\
\text { exemplo, as seguintes funções: estrutural, fechamento, manutenção e } \\
\text { equipamento (OCCS, 2012). }\end{array}$ \\
\hline 22 & Resultados & $\begin{array}{l}\text { Consiste no produto de um ou mais processos da construção, e utiliza-se } \\
\text { de, pelo menos, um recurso da construção (ABNT, 2011). }\end{array}$ \\
\hline 23 & Produtos & $\begin{array}{l}\text { Recurso da construção a ser incorporado de modo permanente ao } \\
\text { ambiente construído (ABNT/ISO, 2010). }\end{array}$ \\
\hline 31 & Fases & $\begin{array}{l}\text { Etapa do ciclo de vida do ambiente construído, identificada pelas } \\
\text { características dos processos a ela inerentes (ABNT/ISO, 2010). }\end{array}$ \\
\hline 32 & Serviços & $\begin{array}{l}\text { Qualquer processo da produção do ambiente construído que ocorre ao } \\
\text { longo do ciclo de vida do empreendimento (ABNT/ISO, 2010). }\end{array}$ \\
\hline 33 & Disciplinas & $\begin{array}{l}\text { Área de atuação dos agentes envolvidos em processos desenvolvidos } \\
\text { durante o ciclo de vida do ambiente construído (ABNT/ISO, 2010). }\end{array}$ \\
\hline
\end{tabular}




\begin{tabular}{|c|c|c|}
\hline 34 & Funções organizacionais & $\begin{array}{l}\text { Posições técnicas ocupadas pelos agentes da construção (ABNT/ISO, } \\
\text { 2010). }\end{array}$ \\
\hline 35 & Ferramentas & $\begin{array}{l}\text { Recursos utilizados para o desenvolvimento do projeto e da construção, } \\
\text { não incorporados permanentemente ao ambiente construído } \\
\text { (OMNICLASS, 2010). }\end{array}$ \\
\hline 36 & Informação & $\begin{array}{l}\text { Toda a informação necessária para o desenvolvimento dos processos } \\
\text { relacionados à construção (ABNT/ISO, 2010). }\end{array}$ \\
\hline 41 & Materiais & $\begin{array}{l}\text { Insumos utilizados para o processo construtivo, que não se constituem em } \\
\text { um produto (ABNT/ISO, 2010). }\end{array}$ \\
\hline 49 & Propriedades & $\begin{array}{l}\text { Características relacionadas a todos os elementos construtivos (ABNT/ISO, } \\
\text { 2010). }\end{array}$ \\
\hline
\end{tabular}

Fonte: Elaborado pela pesquisadora, com base nas informações disponíveis em OCCS (2012).

O sistema de classificação OCCS visa a promover padronização, por meio de critérios de classificação, para organizar bibliotecas de materiais e informações de projeto relacionadas à indústria da construção civil. Para sua consolidação, foram considerados os conceitos determinados pela International Organization for Standardzation (ISO) e International Construction Information Society (ICIS) e apresenta listas detalhadas de componentes e elementos construtivos, com respectivos códigos, cada qual representando uma classe de informação da construção.

Os termos apresentados nessas tabelas são aplicáveis à organização de bibliotecas de materiais, informações de projeto e estruturação de bancos de dados. Seu conteúdo incorpora outros sistemas de classificação em uso (OCCS, 2006), tais como: MasterFormat (para os resultados da construção) (disponível em: <http: //www.masterformat.com>. Acesso em 20 mai. 2015) e Uniformat (para os elementos construtivos) (disponível em: <http: //www.uniformat.com>. Acesso em 20 mai. 2015) (OCCS, 2012).

Observa-se que, a cada elemento qualificado, corresponde um número de referência que permite a posterior aplicação de filtros, nos casos de edição ou pesquisa.

Algumas das tabelas OCCS tiveram as terminologias adaptadas à realidade 
brasileira. As seguintes normas foram publicadas pela ABNT e apresentam a versão regionalizada da terminologia: NBR 15.965-1:2011: Sistema de classificação da informação da construção: parte 1 - terminologia e estrutura (ABNT, 2011). Esta estabelece os critérios de terminologia e estrutura para a modelagem da informação da construção, conforme o apresentado no Quadro 4.

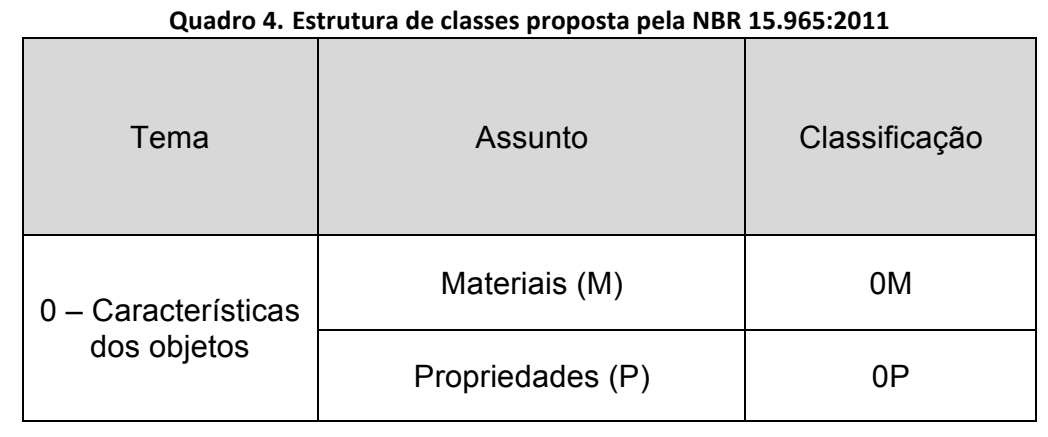

\begin{tabular}{|c|c|c|}
\hline \multirow{2}{*}{1 - Processos } & Fases $(\mathrm{F})$ & $1 \mathrm{~F}$ \\
\cline { 2 - 3 } & Serviços (S) & $1 \mathrm{~S}$ \\
\cline { 2 - 3 } & Disciplinas (D) & $1 \mathrm{D}$ \\
\hline
\end{tabular}

\begin{tabular}{|c|c|c|}
\hline \multirow{2}{*}{$2-$ Recursos } & Funções $(\mathrm{N})$ & $2 \mathrm{~N}$ \\
\cline { 2 - 3 } & Equipamentos $(\mathrm{Q})$ & $2 \mathrm{Q}$ \\
\cline { 2 - 3 } & Componentes ISSO & $2 \mathrm{C}$ \\
\hline
\end{tabular}

\begin{tabular}{|c|c|c|}
\hline \multirow{2}{*}{$\begin{array}{c}\text { construção } \\
\text { conultados da }\end{array}$} & Elementos (E) & $3 \mathrm{E}$ \\
\cline { 2 - 3 } & Construção ISSO & $3 \mathrm{R}$ \\
\hline
\end{tabular}

\begin{tabular}{|c|c|c|}
\hline $4-\begin{array}{c}\text { Unidades e } \\
\text { espaços da } \\
\text { construção }\end{array}$ & Unidades (U) & $4 U$ \\
\cline { 2 - 3 } & Espaços (A) & $4^{\mathrm{a}}$ \\
\hline
\end{tabular}

\begin{tabular}{|c|c|c|}
\hline $\begin{array}{c}5-\text { Informações da } \\
\text { construção }\end{array}$ & Informação (I) & $5 \mathrm{I}$ \\
\hline
\end{tabular}

Fonte: Adaptado de ABNT (2011, p.5), pela pesquisadora.

Também merece menção a NBR/ISO 12.006:2010 (ABNT/ISO, 2010), que recomenda os títulos e as nomenclaturas para a definição de tabelas, considerando 
as etapas, os recursos e os resultados da construção, bem como as classes da construção pertinentes.

Por conseguinte, a gestão da informação pressupõe que sejam compreendidos determinados requisitos da informação necessários, e que estes sejam normalizados, de modo a dar suporte a todas as atividades desempenhadas pelos atores participantes de determinado processo.

\subsection{NÍVEIS DE DESENVOLVIMENTO}

Um aspecto fundamental para o trabalho no ambiente de modelagem é a determinação de quais informações devem ser fornecidas, por membro da equipe, em cada etapa do processo. Para a padronização deste requisito, foi estabelecido o conceito de Nível de Desenvolvimento (ND) que, por vezes, é denominado como nível de detalhamento.

Uma vez que não se trata, porém, da quantidade de detalhes representada em projeto, e sim do Nível de Maturidade da representação geométrica e da informação necessária para possibilitar a fabricação da edificação e de seus componentes (BIMFORUM, 2015), o termo Nível de Desenvolvimento foi adotado, no contexto da presente pesquisa.

As informações apresentadas no Quadro 5 descrevem os níveis de detalhamento da informação modelada, correspondentes a cada ND.

\begin{tabular}{|c|c|c|c|}
\hline \multicolumn{4}{|c|}{ Quadro 5. Níveis de detalhamento da informação modelada } \\
\hline ND & Informação geométrica & Informação não geométrica & $\begin{array}{c}\text { Exemplo (pilar em estrutura } \\
\text { metálica) }\end{array}$ \\
\hline 100 & $\begin{array}{l}\text { Símbolo ou outra } \\
\text { representação } \\
\text { genérica. }\end{array}$ & $\begin{array}{l}\text { Propriedades relacionadas ao } \\
\text { componente podem ser derivadas de } \\
\text { outros elementos (como, por } \\
\text { exemplo, custo por } \mathrm{m}^{2} \text { ). }\end{array}$ & \\
\hline 200 & $\begin{array}{l}\text { Representação como } \\
\text { um elemento genérico. } \\
\text { Quantidades, forma, } \\
\text { localização e } \\
\text { dimensões } \\
\text { aproximadas. }\end{array}$ & $\begin{array}{l}\text { Propriedades correspondentes ao } \\
\text { componente. }\end{array}$ & \\
\hline
\end{tabular}




\begin{tabular}{|c|c|c|c|}
\hline 300 & $\begin{array}{l}\text { Representação como } \\
\text { um elemento } \\
\text { específico do modelo. } \\
\text { Quantidades, forma, } \\
\text { localização, orientação } \\
\text { e dimensões e } \\
\text { materiais precisos. }\end{array}$ & $\begin{array}{l}\text { Propriedades correspondentes ao } \\
\text { componente. }\end{array}$ & \\
\hline 350 & $\begin{array}{l}\text { Representação como } \\
\text { um elemento } \\
\text { específico do modelo, } \\
\text { juntamente com } \\
\text { outros sistemas da } \\
\text { edificação. } \\
\text { Quantidades, forma, } \\
\text { localização, orientação } \\
\text { e dimensões e } \\
\text { materiais precisos. }\end{array}$ & $\begin{array}{l}\text { Propriedades correspondentes ao } \\
\text { componente. }\end{array}$ & \\
\hline 400 & $\begin{array}{l}\text { Representação como } \\
\text { um elemento } \\
\text { específico do modelo. } \\
\text { Quantidades, forma, } \\
\text { localização, orientação } \\
\text { e dimensões e } \\
\text { materiais detalhados } \\
\text { conforme o necessário } \\
\text { para a fabricação. }\end{array}$ & $\begin{array}{c}\text { Propriedades correspondentes ao } \\
\text { componente. }\end{array}$ & \\
\hline 500 & $\begin{array}{c}\text { Detalhamento } \\
\text { executivo, conforme o } \\
\text { construído. }\end{array}$ & $\begin{array}{l}\text { Propriedades de acordo com o } \\
\text { construído. }\end{array}$ & \\
\hline
\end{tabular}

Fonte: Adaptado pela pesquisadora de: BIMFORUM, 2015.

Leite et al. (2011) avaliam que um maior ND não necessariamente corresponde a um esforço proporcional de modelagem, embora corresponda à melhora da precisão das estimativas de orçamentos e facilite as atividades de gestão, reduzindo os riscos e as demandas por complementação de informações.

Sendo assim, é preciso planejar, antes do início do projeto, as informações pertinentes às diferentes disciplinas, em cada fase da produção do ambiente construído. 


\subsection{NíVEIS DE MATURIDADE DA MODELAGEM DA INFORMAÇÃO E SEU IMPACTO NOS PROCESSOS DE PROJETO E DE PRODUÇÃO}

Amor e Owen (2011) destacam que há duas tendências quanto ao desenvolvimento de projetos em BIM. A primeira assimila a modelagem da informação de uma forma simplificada, no contexto de um recurso tecnológico. A segunda, por sua vez, pressupõe o trabalho colaborativo entre equipes multidisciplinares (qualificada como iBIM - integrated building information modeling) - sendo esta opção a que apresenta, efetivamente, maiores vantagens do ponto de vista financeiro.

Esta última pressupõe um processo de projeto integrado e apresenta três aspectos obrigatórios para seu sucesso: colaboração entre equipes, processos de trabalho integrados e interoperabilidade quanto às soluções tecnológicas (OWEN et al., 2010).

Entretanto, a adoção integral do processo de projeto integrado pressupõe profundas mudanças, quanto às práticas adotadas pela indústria da construção civil. Uma vez incorporadas, porém, essas mudanças têm o potencial de proporcionar melhores resultados quanto à qualidade das edificações, bem como contribuir para reduzir o desperdício causado pelo desenvolvimento de tarefas que estejam disponíveis as informações adequadas (KOSKELA, 2004).

Lucas; Bulbul e Thabet (2013) ressaltam a necessidade de que, em um trabalho multidisciplinar, seja estruturado um sistema para planejamento e execução, de modo que estejam apresentadas, de forma objetiva, todas as entradas de informações necessárias para cada etapa e seus respectivos responsáveis. Essas informações devem ser pré-requisito para a execução das tarefas, sob pena de que o processo desenvolva-se de forma inadequada.

O desenvolvimento de tarefas, considerando informações incompletas ou inadequadas, não raro, estimula a equipe a fazer suposições e obriga uma validação posterior, o que pode induzir a erros e, potencialmente, aumentar a frequência de eventos de retrabalho. O desenvolvimento de tarefas, com base em informações inadequadas ou incompletas, é aspecto relevante para que ocorra desperdício, nos processos de projeto e construção (KOSKELA, 2004).

Pelos motivos apresentados, portanto, a prática do processo de projeto 
integrado cria possibilidades de que seja agregado valor ao projeto, na forma de economia de tempo, mão de obra e materiais, além de permitir melhor controle sobre a qualidade da edificação. Isso inclui a redução dos riscos assumidos, no caso de soluções personalizadas, uma vez que o processo prevê validações de seu desempenho durante o desenvolvimento do projeto.

As características esperadas para um modelo, em função do Nível de Maturidade pretendido, são apresentadas no Quadro 6.

Quadro 6. Nível de Maturidade da informação relacionada à gestão de ativo

\begin{tabular}{|c|c|c|}
\hline Nível & Características do modelo & Escopo \\
\hline 0 & $\begin{array}{c}\text { CAD; } \\
\text { Agentes apresentam separadamente as } \\
\text { informações mais relevantes do ativo em papel. }\end{array}$ & Informação de projeto . \\
\hline 1 & $\begin{array}{c}\text { Agentes apresentam separadamente o } \\
\text { conjunto de informações do ativo, por meio de } \\
\text { documentos eletrônicos semiestruturados. }\end{array}$ & Informação de projeto. \\
\hline 2 & $\begin{array}{c}\text { Um modelo tridimensional federado concentra } \\
\text { informações de projeto e da construção do } \\
\text { empreendimento, desenvolvida por diferentes } \\
\text { atores. Suporte tecnológico parcialmente } \\
\text { automatizado. }\end{array}$ & Informação de projeto. \\
\hline 3 (iBIM) & $\begin{array}{c}\text { Informação eletrônica totalmente integrada e } \\
\text { automatizada. Armazenamento dos dados é } \\
\text { feito com o apoio de um sistema integrado por } \\
\text { rede. Gestão da informação aplica-se a todo o } \\
\text { ciclo de vida do ativo*. }\end{array}$ & Informação de projeto + \\
& $\begin{array}{c}\text { informação do ativo. } \\
\end{array}$ & \\
\hline
\end{tabular}

*o ciclo de vida do ativo compreende: concepção/construção/aquisição; operação/uso/manutenção; modificação/ substituição/melhoria; descarte/demolição/venda.

Adaptado pela pesquisadora de RIBA (2012); BSI (2013); BSI (2014).

Por sua vez, Succar (2009), aborda os níveis de maturidade conforme o apresentado no Quadro 7.

Quadro 7. Níveis de Maturidade BIM, conforme Succar (2009)

\begin{tabular}{|c|c|}
\hline Nível de maturidade & Características \\
\hline Pré-BIM & Desenvolvimento de projeto em CAD 2D ou 3D. \\
\hline Estágio 1 & Modelagem baseada no objeto. \\
\hline Estágio 2 & $\begin{array}{c}\text { Modelagem, com colaboração entre equipes para a execução } \\
\text { do modelo. }\end{array}$ \\
\hline Estágio 3 & $\begin{array}{c}\text { Modelagem, com colaboração, em ambiente conectado por } \\
\text { rede. }\end{array}$ \\
\hline Processo integrado de Projeto (IPD) & $\begin{array}{c}\text { Desenvolvimento de projeto simultaneamente, por equipe } \\
\text { multidisciplinar. }\end{array}$ \\
\hline
\end{tabular}

Fonte: Adaptado pela pesquisadora de: SUCCAR (2009). 
Nota-se que as definições de Níveis de Maturidade apresentadas no Quadro 7 ainda não contemplam a integração de dados entre equipes multidisciplinares. Usualmente, são entregues como produto do processo de projeto pranchas de desenho e, por vezes, um modelo tridimensional para visualização.

No Quadro 6, entretanto, verifica-se que a definição de Nível de Maturidade 3 pressupõe a consolidação de um Banco de Dados para se gerenciar o desempenho do projeto, ao longo de sua vida útil. Apesar disso, a comparação sistemática do desempenho entre edificações ainda não seja considerado.

Por esse motivo, a presente discussão representa uma contribuição ao estado da arte, pois, não só propõe que seja promovida a gestão da informação da construção ao longo do ciclo de vida da edificação, como também sugere que seja considerada a sistematização da apresentação das informações sobre o desempenho pretendido e o efetivo. Estas iniciativas possibilitam a efetiva consulta pelas equipes responsáveis pelo planejamento e desenvolvimento do projeto, de modo a consolidar um ciclo de melhoria contínua.

\subsection{PRODUTOS DO PROCESSO DE PROJETO PARA PERMITIR A GESTÃO DA INFORMAÇÃO}

A proposição de uma reestruturação do processo, de modo a permitir a gestão da informação da edificação, quando em uso, altera os produtos de projeto pretendidos (ou entregáveis). Em lugar de se obter, ao final do processo, desenhos e memoriais descritivos, o resultado do processo passa a ser um Banco de Dados (BD), que permite a elaboração de pesquisas e a impressão de desenhos e tabelas sob demanda.

Um BD corresponde a uma estrutura de armazenagem de dados, necessária a aplicações complexas, que permite a realização de atividades, tais como análises e consultas. Para o suporte às ações relacionadas ao banco, é preciso um Sistema de Gerenciamento de Banco de Dados (SGBD). Este deve permitir: a definição do BD (tipos, estruturas e restrições dos dados), a construção do Banco de Dados (armazenamento controlado de informações), a manipulação das informações modeladas (inclusive as operações de inclusão e exclusão de dados, mantendo sua 
integridade) e as consultas a serem elaboradas pelo usuário (LISBOA FILHO, 2001).

Para a elaboração de um Banco de Dados devem ser observadas a análise dos requisitos do $\mathrm{BD}$ e a elaboração de um esquema conceitual (modelo de entes e relacionamentos).

A elaboração de um modelo de entes e relacionamentos (CHEN, 1976) é fundamental para o planejamento de uma metodologia de análise sistemática, que permite a organização formal idealizada, conforme o exemplo apresentado na Figura 25. Também é preciso que sejam identificadas as etapas do processo e as relações de dependência entre entes.

$1: 1$

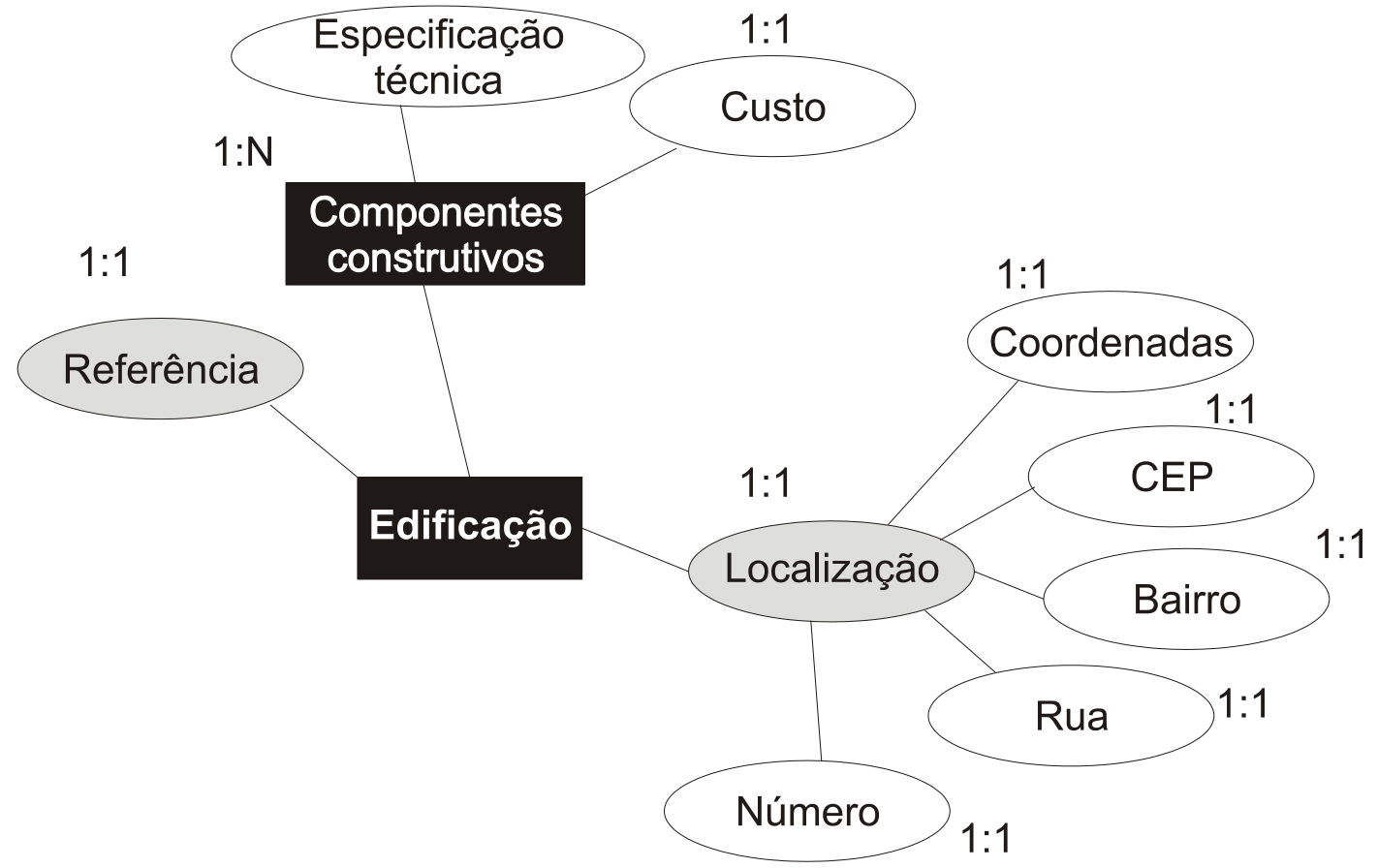

Figura 25. Exemplos de atributos em modelo de entes e relacionamentos Fonte: Elaborado pela pesquisadora, baseado em CHEN (1976).

Portanto, as informações geradas, aferidas e gerenciadas, referentes a um conjunto de edificações, devem ser organizadas, por meio da consolidação de um Banco de Dados que permita seu armazenamento, a realização de consultas e a elaboração de análises. 


\section{PRINCIPAIS INICIATIVAS PARA O INCENTIVO DAS PRÁTICAS} DE MODELAGEM DA INFORMAÇÃO

No âmbito mundial, são países pioneiros na instituição de iniciativas públicas para a regulamentação de BIM por meio da publicação de guias de diretrizes para a elaboração de projetos em BIM, que ocorreram em 2007: os Estados Unidos da América $^{3}$ (GSA, 2006; GSA, 2007a; GSA, 2007b; GSA, 2009a; GSA, 2009b, GSA, 2012; GSA, 2015b; GSA, 2015c, NIBS, 2015b), o Reino Unido (BSI, 2007) e a Finlândia (SENATE PROPERTIES, 2007), tendo essas recomendações sido revisadas e complementadas posteriormente (BBSR, 2013; CHENG, LU, 2015).

Em comum, os citados documentos de diretrizes de modelagem são dedicados a determinar requisitos básicos para o planejamento do processo, inclusive quanto aos usos pertinentes aos modelos, à modelagem e à interoperabilidade das informações entre equipes, destacando a necessidade de que os programas computacionais adotados sejam compatíveis com formato International Foundation Class (IFC).

Mais recentemente, merece menção a iniciativa da União Europeia, no sentido de promover a qualidade do ambiente construído (UE, 2011) e a modelagem da informação (UE, 2014).

O Regulamento (UE) N ${ }^{\circ}$ 305/2011 do Parlamento Europeu e do Conselho, de 9 de março de 2011 (UE, 2011) estabelece requisitos comuns de desempenho para os produtos da construção civil e expõe a necessidade de que se faça o controle quanto ao desempenho das soluções ao longo do processo de projeto, o que incentiva a prática colaborativa para que se possa garantir o desempenho do conjunto. No Apêndice I do referido regulamento, são apresentados os seguintes requisitos de desempenho para o ambiente construído:

- resistência mecânica e estabilidade;

- segurança contra incêndio;

- qualidade ambiental (higiene, saúde e ambiente);

3 Os documentos que se encontram referenciados na bibliografia correspondem às versões revisadas das normas mencionadas. 
- segurança e acessibilidade;

- conforto acústico;

- conforto térmico e eficiência energética; e

- utilização responsável dos recursos naturais.

Para o atendimento ao preconizado por este dispositivo legal, a utilização de recursos tecnológicos de BIM contribui para que sejam possíveis as validações necessárias ao processo (ZANCHETTA et al., 2014).

Além disso, o Parlamento Europeu recomenda, por meio da Diretiva 2014/24UE, que todas as obras públicas a serem executadas na UE observem princípios de transparência, acessibilidade e confiabilidade das informações, por meio da utilização dos recursos tecnológicos disponíveis, a partir de 2016 (UE, 2014).

No que respeita aos contratos de empreitada de obras públicas e aos concursos de concessão, os Estados-Membros podem exigir a utilização de instrumentos eletrónicos específicos, tais como instrumentos de modelização eletrónica de dados de construção ou similares. Nesses casos, as autoridades adjudicantes devem oferecer meios alternativos de acesso, conforme previsto no n.o 5, enquanto esses instrumentos não estiverem geralmente disponíveis na aceção do n.o 1, primeiro parágrafo, segundo período. (UE, 2014, p. 107)

Dentre as publicações dos países analisados, destaca-se a meta estabelecida para 2025 pelo Reino Unido, que pretende, a partir da adoção dos processos de modelagem da informação para todo o ciclo de vida da edificação, reduzir os custos iniciais (CapEx) e os custos operacionais (OpEx) em 33\% (trinta e três por cento); reduzir a emissão dos gases de efeito estufa em $50 \%$ (cinquenta por cento) e o tempo de desenvolvimento de projeto e de execução de construções novas e existentes em 50\% (cinquenta por cento) (HM GOVERNMENT, 2013). Estas metas demonstram a relevância dos processos de modelagem da informação para a eficiência das atividades inerentes à construção civil.

Para tanto, sugere-se que as iniciativas pública e privada trabalhem em 
conjunto, com vistas ao desenvolvimento do conhecimento, da tecnologia e das oportunidades de negócio (HM GOVERNMENT, 2013).

Se forem considerados os impactos estimados, referentes às alterações de processos e tecnologias para o desenvolvimento de empreendimentos, é possível dimensionar os efeitos da produtividade da cadeia da construção civil do mercado brasileiro (DECONCIC apud FIESP, 2015).

Outros países adotaram medidas regulatórias para BIM mais recentemente, como é o caso da França, que designou, em 2014, o Presidente do Centro Técnico CSTB, Beltrand Delcambre, como "Embaixador Digital para a Indústria de Edificações", com o objetivo de desenvolver uma política digital de modelagem da informação, bem como um programa para sua implantação junto à indústria da construção civil. No caso deste país, pretende-se que a BIM seja exigida para obras públicas progressivamente, a partir de 2017 (KASSEM, LEUSIN, 2015).

No Quadro 8 é apresentado um resumo das principais iniciativas identificadas para implantação de BIM. 
Quadro 8. Sumário das principais iniciativas para a regulamentação de BIM

\begin{tabular}{|c|c|c|c|c|c|c|}
\hline 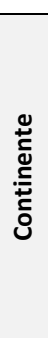 & $\frac{\bar{d}}{\frac{\bar{d}}{\delta}}$ & 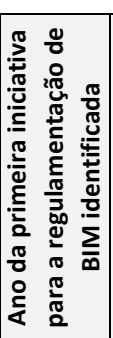 & 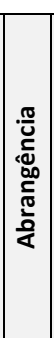 & Organização(ões) & 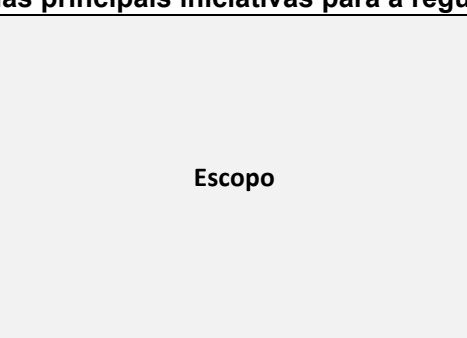 & Exemplos de documentos \\
\hline \multirow{5}{*}{ 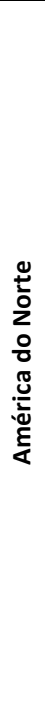 } & \multirow{4}{*}{ 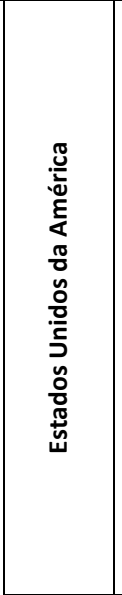 } & \multirow{4}{*}{ ¿̊̀ } & $\begin{array}{l}\bar{\pi} \\
\stackrel{\pi}{0} \\
\frac{\pi}{2} \\
2\end{array}$ & $\begin{array}{l}\text { NIBS, USACE, GSA, VA, } \\
\text { AIA, NIST, AGC. }\end{array}$ & $\begin{array}{l}\text { Estabelece a adoção de BIM para o } \\
\text { desenvolvimento de projetos. } \\
\text { Determina normas para a elaboração } \\
\text { de projetos. }\end{array}$ & $\begin{array}{c}\text { NBIMS-USTM (NIBS, 2015b), GSA BIM Guide Series } \\
\text { 01-08 (GSA, 2006; GSA, 2007a; GSA, 2007b; GSA, } \\
\text { 2009a; GSA, 2009b, GSA, 2012; GSA, 2015b; GSA, } \\
\text { 2015c). }\end{array}$ \\
\hline & & & 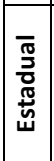 & $\begin{array}{l}\text { Wisconsin, Ohio, } \\
\text { Tennessee, entre } \\
\text { outras. }\end{array}$ & $\begin{array}{l}\text { Estabelece a adoção de BIM para o } \\
\text { desenvolvimento de } \\
\text { projetos.Determina normas para a } \\
\text { elaboração de projetos. }\end{array}$ & State of Ohio BIM Protocol (OHIO DAS, 2011). \\
\hline & & & 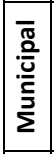 & $\begin{array}{l}\text { New York, Seattle, } \\
\text { entre outras. }\end{array}$ & $\begin{array}{l}\text { Estabelece a adoção de BIM para o } \\
\text { desenvolvimento de projetos. } \\
\text { Determina normas para a elaboração } \\
\text { de projetos. }\end{array}$ & NYC BIM Guidelines (DDC, 2012). \\
\hline & & & 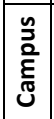 & $\begin{array}{l}\text { PSU, LACCD, IU, USC, } \\
\text { entre outras. }\end{array}$ & $\begin{array}{c}\text { Apresenta critérios para o } \\
\text { desenvolvimento de projetos em BIM. }\end{array}$ & USC BIM Guidelines (USC, 2012). \\
\hline & $\begin{array}{l}\frac{\pi}{0} \\
\pi \\
\pi \\
\mathbb{\pi} \\
0\end{array}$ & $\stackrel{\text { ¿ }}{\stackrel{n}{2}}$ & \begin{tabular}{l|}
$\frac{\pi}{\pi}$ \\
$\frac{0}{0}$ \\
$\frac{0}{\pi}$ \\
2
\end{tabular} & IBC. & $\begin{array}{c}\text { Apresenta critérios para o } \\
\text { desenvolvimento de projetos em BIM. }\end{array}$ & $\begin{array}{l}\text { IBC 100-2014 BIM Contract Appendix (BIC, 2014a), } \\
\text { IBC 201-2014 LOD, Authorized Uses and Model } \\
\text { Element Table (BIC, 2014b). }\end{array}$ \\
\hline \multirow{7}{*}{ 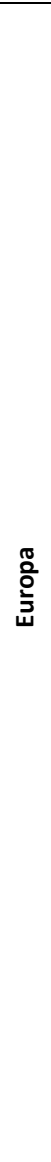 } & 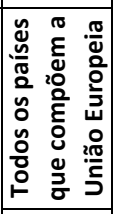 & 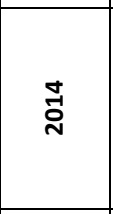 & 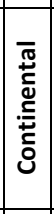 & Parlamento Europeu. & $\begin{array}{l}\text { Estabelece a adoção de BIM para o } \\
\text { desenvolvimento de projetos. }\end{array}$ & Diretiva 2014/24UE (UE, 2014). \\
\hline & 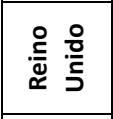 & ¿े & 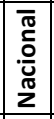 & $\begin{array}{l}\text { BSI, CIC, RIBA, BIM } \\
\text { Task Group, AEC-UK. }\end{array}$ & $\begin{array}{l}\text { Estabelece a adoção de BIM nível } 2 \\
\text { (RIBA, 2012, BSI, 2013, BSI, 2014) para } \\
\text { todos os projetos públicos, até } 2016 .\end{array}$ & PAS 1192-2 (BSI,2013), PAS 1192-3 (BSI,2014). \\
\hline & 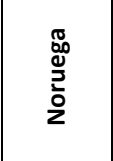 & 유 & $\begin{array}{l}\bar{\pi} \\
\frac{\pi}{0} \\
\frac{0}{2} \\
\frac{\pi}{2}\end{array}$ & Statsbygg. & $\begin{array}{l}\text { Estabelece a adoção de BIM para } \\
\text { edificações públicas (STATSBYGG, } \\
\text { 2013). Determina normas para a } \\
\text { elaboração de projetos. }\end{array}$ & Statsbygg BIM Manual (STATSBYGG, 2010). \\
\hline & 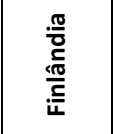 & ¿્̀ & $\begin{array}{l}\bar{\pi} \\
\frac{\pi}{2} \\
\frac{0}{2} \\
\frac{\pi}{2}\end{array}$ & $\begin{array}{l}\text { Senate Properties, } \\
\text { Common BIM } \\
\text { Requirements. }\end{array}$ & $\begin{array}{l}\text { Requer o uso de BIM em projetos } \\
\text { públicos. Determina normas para a } \\
\text { elaboração de projetos. }\end{array}$ & $\begin{array}{l}\text { Senate Properties BIM Requirements. (SENATE } \\
\text { PROPERTIES, 2007) ; Common BIM } \\
\text { Requirements** (2012). }\end{array}$ \\
\hline & 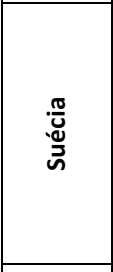 & 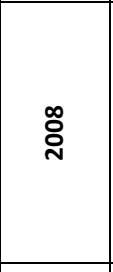 & $\begin{array}{l}\bar{\pi} \\
\frac{\pi}{0} \\
\frac{0}{2} \\
\frac{\pi}{2}\end{array}$ & $\begin{array}{l}\text { Trafikverket (STA), } \\
\text { SSI. }\end{array}$ & $\begin{array}{l}\text { Determina o uso de BIM em todos os } \\
\text { projetos, de acordo com as seguintes } \\
\text { metas: } 2015 \text { - BIM em projetos de } \\
\text { investimentos e manutenção; } 2030 \text { - } \\
\text { informação referente a todo o ciclo de } \\
\text { vida, acessivel a todos os atores } \\
\text { envolvidos nos processos*. }\end{array}$ & $\begin{array}{l}\text { Bygghandlingar } 90 \text { (SSI, 2008); BIM in STA } \\
\text { (MALMKVIST, 2013). }\end{array}$ \\
\hline & $\begin{array}{l}\frac{\pi}{0} \\
\frac{\pi}{\frac{\pi}{0}} \\
\frac{0}{1}\end{array}$ & 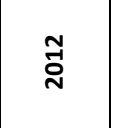 & $\begin{array}{l}\bar{\pi} \\
\frac{\pi}{0} \\
\frac{0}{2} \\
\frac{\pi}{2}\end{array}$ & Rijksgebouwendienst. & $\begin{array}{c}\text { Apresenta critérios para o } \\
\text { desenvolvimento de projetos em BIM. }\end{array}$ & $\begin{array}{l}\text { Rgd BIM Norm v1.1 (RIJKSGEBOUWENDIENST, } \\
\text { 2012). }\end{array}$ \\
\hline & 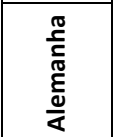 & $\stackrel{n}{\stackrel{n}{n}}$ & $\begin{array}{l}\bar{\pi} \\
\stackrel{0}{0} \\
\frac{\pi}{0} \\
\frac{\pi}{2}\end{array}$ & $\begin{array}{l}\text { Bundesinstituts für } \\
\qquad \text { Bau, Stadt } \\
\text { und Raumforschung. }\end{array}$ & $\begin{array}{c}\text { Apresenta critérios para o } \\
\text { desenvolvimento de projetos em BIM. }\end{array}$ & BIM- Leitfaden Für Deutschland (BBSR, 2013). \\
\hline
\end{tabular}


...continuação.

\begin{tabular}{|c|c|c|c|c|c|c|}
\hline 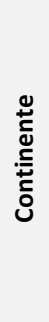 & $\frac{\bar{y}}{\frac{n}{\pi}}$ & 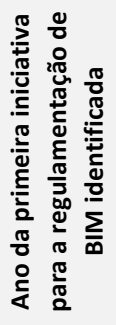 & 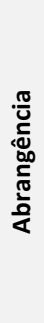 & Organização(ões) & Escopo & Exemplos de documentos \\
\hline \multirow{4}{*}{$\frac{\pi}{4}$} & 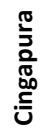 & $\stackrel{\infty}{\circ}$ & $\begin{array}{l}\bar{\pi} \\
\stackrel{0}{\frac{0}{6}} \\
\frac{\pi}{2}\end{array}$ & BCA. & $\begin{array}{c}\text { Apresenta critérios para o } \\
\text { desenvolvimento de projetos em BIM. }\end{array}$ & Singapore BIM GUIDE (BCA, 2012). \\
\hline & $\begin{array}{l}\overline{3} \\
0 \\
0 \\
0 \\
\frac{\pi}{0} \\
\frac{0}{0}\end{array}$ & 옹 & $\begin{array}{l}\bar{\pi} \\
\frac{\pi}{0} \\
\frac{\pi}{2} \\
\frac{\pi}{2}\end{array}$ & PPS. & $\begin{array}{l}\text { Meta de adoção de BIM em todas as obras } \\
\text { públicas, até } 2016 .\end{array}$ & PPS BIM Guidelines (apud LEE, 2014).** \\
\hline & 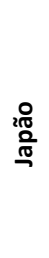 & ำ & $\begin{array}{l}\bar{\pi} \\
\stackrel{0}{\frac{0}{6}} \\
\frac{\pi}{2}\end{array}$ & MILT. & $\begin{array}{l}\text { Apreseta critérios para o desenvolvimento } \\
\text { de projetos em BIM, bem como o } \\
\text { aplicativo BIMMS-N, para a aplicação nos } \\
\text { procedimentos de gestão de facilidades } \\
\text { dos prédios públicos . Requer o uso de } \\
\text { BIM para os prédios públicos dos XXXII } \\
\text { Jogos Olímpicos, em Tokio (2020). }\end{array}$ & $\begin{array}{l}\text { Government Building Services (MILT, 2014), } \\
\text { Japan Chapter Status Report (YAMASHITA et al., } \\
\text { 2014). }\end{array}$ \\
\hline & 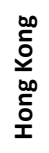 & ஜ & $\begin{array}{l}\bar{\pi} \\
\stackrel{0}{\frac{0}{u}} \\
\frac{\pi}{2}\end{array}$ & $\begin{array}{l}\text { HA, HKIBIM, } \\
\text { MOLIT. }\end{array}$ & $\begin{array}{c}\text { Apresenta critérios para o } \\
\text { desenvolvimento de projetos em BIM. } \\
\text { Requer o uso de BIM em projetos da } \\
\text { agência governamental MOLIT, até } 2019 \text {. }\end{array}$ & $\begin{array}{l}\text { HKIBIM BIM project Specification (HKIBIM, } \\
\text { 2011), Plano de implantação BIM do MOLIT } \\
\text { (KIM, 2014). }\end{array}$ \\
\hline 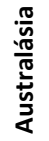 & 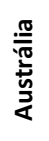 & : & $\begin{array}{l}\bar{\pi} \\
\stackrel{0}{0} \\
\frac{\pi}{\pi} \\
\frac{\pi}{2}\end{array}$ & $\begin{array}{l}\text { BEIIC, AMCA, } \\
\text { NATSPEC. }\end{array}$ & $\begin{array}{l}\text { Requer o uso de BIM em projetos } \\
\text { públicos, apartir de } 2016 \text {. Determina } \\
\text { normas para a elaboração de projetos. }\end{array}$ & NATSPEC National BIM GUIDE (NATSPEC, 2011). \\
\hline \multirow{3}{*}{ 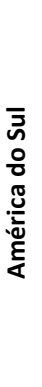 } & \multirow{3}{*}{$\underset{\overline{\frac{5}{0}}}{\frac{\overline{0}}{\infty}}$} & \multirow{3}{*}{$\stackrel{m}{\stackrel{2}{2}}$} & \multirow{2}{*}{$\begin{array}{l}\bar{\pi} \\
\frac{0}{0} \\
\frac{\pi}{2}\end{array}$} & ASBEA. & $\begin{array}{c}\text { Apresenta critérios para o } \\
\text { desenvolvimento de projetos em BIM. }\end{array}$ & $\begin{array}{l}\text { Guia de boas práticas em BIM - Fascículos } 1 \text { e } 2 . \\
\text { (ADDOR, 2013; ADDOR, 2015). }\end{array}$ \\
\hline & & & & ABNT.*** & $\begin{array}{l}\text { Apresenta sistema de classificação de } \\
\text { terminologia de componentes da } \\
\text { construção civil, a ser adotada para a } \\
\text { modelagem da informação. }\end{array}$ & $\begin{array}{l}\text { NBR 15.965-1:2011 - Sistema de Classificação da } \\
\text { Informação da Construção (ABNT, 2011). }\end{array}$ \\
\hline & & & 疍 & $\begin{array}{l}\text { Governo do Estado } \\
\text { de Santa Catarina. }\end{array}$ & $\begin{array}{c}\text { Estabelece a adoção de BIM para o } \\
\text { desenvolvimento de projetos a partir de } \\
2018 \text {. }\end{array}$ & $\begin{array}{l}\text { Termo de referência para o desenvolvimeno de } \\
\text { projetos com o uso de BIM (GESC, 2014). }\end{array}$ \\
\hline
\end{tabular}

Fonte: Elaborado pela pesquisadora, a partir de CHENG; LU (2015); KARLSHøj (2014).

* Relatório da STA apresentado à BuildingSMART. Documentos de diretrizes e de regulamentação não localizados .

** Relatório apresentado à BuildingSMART. Documentos de diretrizes e de regulamentação não localizados.

Informações referentes a 2015.

Nota-se, portanto, uma grande evolução, em relação ao levantamento realizado por Succar (2009), tanto no que diz respeito à quantidade de iniciativas e 
sua distribuição, em nível mundial, como em relação à atualização do conhecimento dos recursos tecnológicos e, por consequência, quanto à adoção da modelagem da informação, em diferentes fases do ciclo de vida da edificação.

No Brasil, à época da conclusão da presente pesquisa (2015), estava em desenvolvimento a normalização referente à modelagem da informação da construção, inclusive sistemas de classificação de elementos e componentes da construção, sob a égide da ABNT/CEE - 134 - Comissão de Estudo Especial de Modelagem da Informação da Construção [(ABNT, 2015), disponível em: <http://www.abnt.org.br/cb-134>, acesso em 04 nov. 2015 ].

Até a data da conclusão do levantamento para a presente tese, a CEE havia publicado três normas: NBR/ISO 12.006-2:2010 - Construção da informação organização da informação da construção. Parte 2: estrutura para a classificação da informação (ABNT/ISO 2010); NBR 15.965-1 - Sistema de Classificação da Informação da Construção. Parte 1: terminologia (ABNT, 2011); e NBR 15.965-2 Sistema de Classificação da Informação da Construção. Parte 2: características dos objetos da construção (ABNT, 2012).

Estas iniciativas são importantes, à medida que determinam critérios para a padronização da informação a ser adotada nos processos inerentes à produção e à utilização do ambiente construído, o que é fundamental para garantir a consistência da informação, durante os processos de modelagem.

Também merece destaque a rede para a articulação de pesquisas acadêmicas relacionadas à modelagem da informação, Rede BIM Brasil (disponível em: <http://www.redebimbrasil.org.br/>, acesso em 04 jul. 2015), constituída em 2008 e apoiada pela ANTAC. Seu objetivo é integrar a produção acadêmica e promover o conhecimento, por meio da cooperação entre as seguintes universidades: UFPR - Universidade Federal do Paraná; USP - Universidade de São Paulo; UFF - Universidade Federal Fluminense; UFBA - Universidade Federal da Bahia; UNICAMP - Universidade Estadual de Campinas; UFV - Universidade Federal de Viçosa; UFRGS - Universidade Federal do Rio Grande do Sul; UPM Universidade Presbiteriana Mackenzie; UFC - Universidade Federal do Ceará. Além da participação da comunidade acadêmica, a RedeBIM foi aberta, em 2012, para contribuições dos profissionais de empresas do mercado da construção civil.

Quanto à determinação de diretrizes de modelagem pelo poder público, a 
Secretaria da Saúde do Governo Estadual de Santa Catarina elaborou o Termo de Referência para Desenvolvimento de Projetos com o Uso de Modelagem da Informação da Construção - BIM (GESC, 2014). Os objetivos do caderno de diretrizes são estabelecer regras para a modelagem de projetos, utilizando tecnologias para BIM, o que pretende ser requisito para editais de licitações e contratos de projetos. Em seu conteúdo, são apresentados os requisitos e as condições para a modelagem da informação da Construção em projetos públicos do Estado de Santa Catarina. Dentre outros aspectos, são determinados os níveis de desenvolvimento esperados para cada fase de projeto e as respectivas propriedades a serem especificadas, pertinentes a cada disciplina de projeto. Também são apresentados critérios para nomenclaturas, utilização de cores e formatos de arquivos que deverão ser entregues em formato IFC.

Outro aspecto que interfere na relevância dos processos de modelagem dos projetos brasileiros é o recente compromisso com o desempenho do ambiente construído (ABNT, 2013). Sendo assim, o Brasil, em consonância com o entendimento comum ao mercado da construção civil da União Europeia, dispõe da Norma NBR 15.575:2013 (ABNT, 2013), que determina requisitos de desempenho para o ambiente construído, embora seu escopo ainda seja restrito a casas e apartamentos. A abordagem proposta torna necessário que o desempenho do conjunto das soluções de projeto seja validado, de modo análogo, incentivando o desenvolvimento de projeto integrado suportado por recursos tecnológicos interoperáveis.

Com base na revisão bibliográfica apresentada, é possível apreender que:

- As iniciativas para a adoção da modelagem da informação estão se difundindo por diferentes países, à medida que se verifica o amadurecimento das diretrizes e boas práticas; e

- O setor público representa um importante papel nesse processo. Cheng e Lu (2015), identificaram seis aspectos fundamentais da participação do Estado: na pesquisa, no desenvolvimento de diretrizes, na regulamentação de normas, em iniciativas para a educação, na divulgação dos resultados e do conhecimento acumulado e, como agência de financiamento. 
Dentre estes aspectos, merece destaque sua atuação na promoção de oportunidades de negócio pelo poder público, cujo impacto pode mobilizar a indústria da construção civil, como podem ser avaliados nos exemplos apresentados como benchmarks, no contexto da presente pesquisa (vide Item 6.2).

A partir das informações apresentadas no Quadro 8, verifica-se que as medidas para a regulamentação de BIM difundem-se mundialmente, muitas vezes, em função das exigências dos respectivos governos quanto à implantação dos recursos tecnológicos de modelagem para obras públicas.

Observa-se, ainda, ao analisar as diretrizes e os requisitos publicados que, nos casos em que as práticas de modelagem encontram-se mais consolidadas, as exigências deixam de se limitar ao desenvolvimento de projeto e às informações necessárias para a produção, passando a adotar uma visão integrada para todo o ciclo de vida do empreendimento. Isto inclui, portanto, as informações técnicas necessárias para a gestão dos sistemas e das edificações durante seu uso, para oferecer suporte às atividades de operação e manutenção, como é o caso dos Estados Unidos da América (GSA, 2012) e do Reino Unido (BSI, 2013; BSI, 2014).

Especificamente, no caso do Brasil, ainda não foram identificadas iniciativas de âmbito nacional, no sentido de restringir a contratação de projetos públicos, obrigando que seu desenvolvimento incorpore tecnologias para a modelagem da informação.

O Ministério do Desenvolvimento, da Indústria e do Comércio Exterior (MIDIC), em ação em conjunto com o Ministério do Planejamento, Orçamento e Gestão (MPOG) contrataram uma análise das condições de desenvolvimento da tecnologia BIM no País e sua comparação com a situação da União Europeia, quanto a esse aspecto.

Por meio desse estudo, denominado BIM - Building Information Modeling no Brasil e na União Europeia (KASSEM; LEUSIN, 2015), o uso das tecnologias de BIM foi entendido como um importante recurso para a melhora do desempenho dos projetos e a previsibilidade dos resultados. Foi recomendada a exigência do desenvolvimento de projeto, considerando o processo colaborativo, utilizando tecnologias para a modelagem da informação, bem como sua ampla adoção em obras públicas, destacando-se em importância, entre estas, as HIS, as escolas e os 
hospitais.

Como desafios à sua efetiva implantação, em nível nacional, foram destacados os seguintes aspectos: a amplitude geográfica brasileira, a grande quantidade de órgãos e departamentos governamentais que assinam os contratos públicos e a cisão entre os processos de concepção e execução em obras públicas brasileiras, com a de processos de licitação pelo menor preço ofertado. Nos projetos desenvolvidos no Brasil, em que os processos de modelagem da informação foram bem-sucedidos, em geral, predomina o Regime de Contratação Diferenciada, que se adapta mais convenientemente aos processos de BIM, pois permite que o projeto seja desenvolvido pelo contratado (KASSEM; LEUSIN, 2015).

O aspecto contratual é importante para a difusão das práticas da modelagem da informação pois, os padrões e os protocolos adotados atualmente no Brasil, a saber, a Portaria $n^{\circ} 2.296$, de julho de 1997, que descreve os métodos para projeto, orçamentação e controle dos serviços de construção em nível federal (BRASIL, 1997) e os Manuais de Escopo (SECOVI/SP, 2006), apresentam orientações elaboradas considerando um ambiente tecnológico anterior ao emprego de tecnologias de BIM e, por esse motivo, carecem de revisão (KASSEM, LEUSIN, 2015).

Além disso, em 2010, o Governo Brasileiro, por intermédio do Ministério do Desenvolvimento, Indústria e Comércio Exterior - MDIC e da Agência Brasileira de Desenvolvimento Industrial - ABDI contratou o desenvolvimento de uma biblioteca para o programa "Minha Casa Minha Vida" (MCMV), desenvolvida pela Contier Arquitetura e pela GDP - Gerenciamento e Desenvolvimento de Projetos (KASSEM, LEUSIN, 2015). Essa biblioteca, disponível em: <http://contier.com.br/downloads> (acesso em 10 abr. 2015), vem sendo amplamente adotada e tem desempenhado importante papel na popularização do uso de tecnologias de BIM.

Como uma ação de relevância envolvendo a elaboração de projetos, utilizando tecnologias de BIM, pode-se citar a licitação, publicada em 2014, para a elaboração de 270 aeroportos, organizada pela ANAC - Agência Nacional de Aviação Civil (KASSEM; LEUSIN, 2015).

Outras iniciativas que estão em desenvolvimento no Brasil, envolvendo a aplicação de BIM a projetos que merecem menção são conduzidas pela Companhia do Metropolitano de São Paulo (METRÔ, 2012), que adotou a tecnologia BIM para a 
modelagem das estações da linha 17-Ouro e a carta de intenções publicada pelo DNIT - Departamento Nacional de Infraestrutura de Transportes, conforme a qual se pretende passar a exigir a entrega de todos os projetos licitados pela entidade em BIM (DNIT, 2012).

\subsection{ABRANGENCIA DOS RECURSOS TECNOLÓGICOS PARA A MODELAGEM DA INFORMAÇÃO}

A abrangência do uso das tecnologias de modelagem vem se popularizando progressivamente nas empresas de projetos de engenharia e de arquitetura, bem como junto às construtoras (MCGRAW-HILL, 2014).

Nos Estados Unidos da América, por exemplo, a abrangência do uso da BIM pelas empresas da indústria da construção civil passou de 17\% (dezessete por cento) em 2007 para 71\% (setenta e um por cento), em 2012 (MCGRAW-HILL, 2012).

De acordo com a pesquisa, conduzida pela McGraw-Hill Construction, uma entidade de pesquisa e de análise de informações relacionadas à indústria da construção civil, foram avaliados mercados de relevância no contexto mundial, para o desenvolvimento da tecnologia BIM (MCGRAW-HILL, 2014). A seguir, são apresentados os países e o respectivo número de empresas participantes da mencionada pesquisa: Japão (30), Alemanha (32), França (31), Canadá (39), Brasil (40), Austrália (83), Nova Zelândia (36), Estados Unidos da América (291), Reino Unido (54) e Coréia do Sul (91).

Dentre os aspectos destacados pelos respondentes como os maiores benefícios obtidos pela adoção da tecnologia BIM estavam: a redução de erros e informações faltantes, opção assinalada por $41 \%$ (quarenta e um por cento) dos respondentes, maior colaboração entre proprietários e empresas de projetos, 35\% (trinta e cinco por cento), melhora da imagem corporativa, 32\% (trinta e dois por cento), redução de retrabalho, 31\% (trinta e um por cento) e redução dos custos de construção, 31\% (trinta e um por cento). Os resultados apresentados indicam que, no Brasil, $85 \%$ (oitenta e cinco por cento) das construtoras ${ }^{4}$ inquiridas reportaram

${ }^{4}$ Os resultados da pesquisa correspondem às respostas fornecidas por 
uma taxa de retorno de investimento positiva. Ainda de acordo com a mesma, o retorno de investimento em BIM estimado ficou entre 10\% (dez por cento) e $25 \%$ (vinte e cinco por cento).

Quando comparadas com as demais empresas participantes, as empresas brasileiras demonstraram ter adotado os recursos tecnológicos de modelagem mais recentemente, conforme os dados apresentados no Gráfico 1.

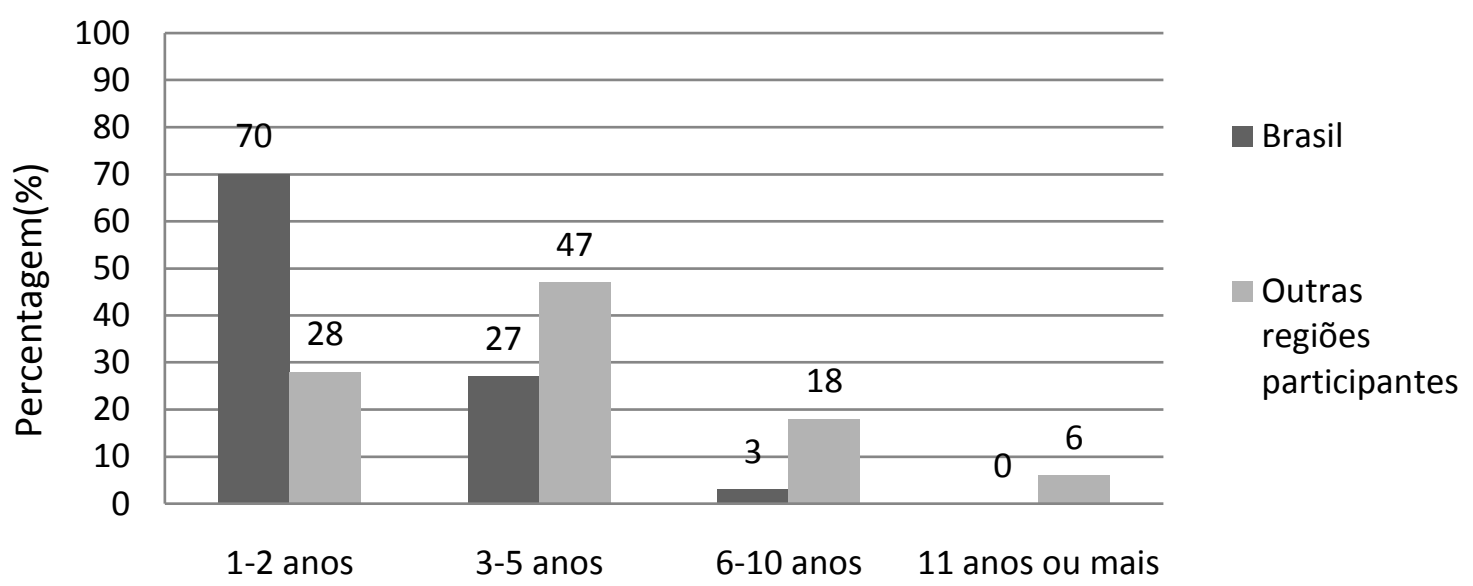

Gráfico 1. Período de utilização da tecnologia BIM - comparação entre o Brasil e os demais participantes da pesquisa.

Fonte: Adaptado pela pesquisadora de MCGRAW-HILL (2014, p. 46).

Ainda, a referida pesquisa apresentou um Índice de Envolvimento da empresa com a tecnologia BIM, que levou em consideração: a experiência (em anos de uso da tecnologia BIM); o nível de conhecimento e a percentagem de projetos das empresa que, atualmente, utilizam tecnologias para BIM. O resultado obtido para o Brasil apresentou um total de $55 \%$ (cinquenta e cinco por cento) de empresas, cujo nível de envolvimento era baixo, enquanto $33 \%$ (trinta e três por cento) apresentaram nível médio e, apenas $15 \%$ (quinze por cento), apresentaram nível alto, o que posicionou o País em último lugar, considerando os nove grupos participantes. Como comparação, no extremo oposto, 21\% (vinte e um por cento) das empresas participantes, situadas nos Estados Unidos da América, apresentaram baixo envolvimento, $36 \%$ (trinta e seis por cento), médio envolvimento, $22 \%$ (vinte e general contractors. Embora a organização das empresas de construção civil no Brasil seja diferente da praticada nos Estados Unidos da América, entendeu-se que o termo "construtoras" aplicava-se de modo adequado ao contexto. 
dois por cento) alto envolvimento e, $22 \%$ (vinte e dois por cento), envolvimento muito alto.

A partir da análise dos dados apresentados no Gráfico 2, observa-se que $42 \%$ (quarenta e dois por cento) do total de respondentes declararam ter nível moderado de domínio sobre tecnologias para BIM, e apenas 10\% (dez por cento) consideraram ter um alto nível de especialização em BIM.

Quanto ao tempo de prática de BIM, 70\% (setenta por cento) dos respondentes brasileiros declararam o tempo de utilização com entre 1 (um) e 2 (dois) anos e apenas 3\% (três por cento) entre 6 (seis) e 10 (dez) anos, sendo o país que apresentou o maior número de usuários que utilizavam BIM há menos tempo, dentre todos os grupos respondentes (MCGRAW-HILL, 2014).

Goes e Santos (2011) corroboram as análises do relatório e observam que, embora se verifiquem iniciativas utilizando recursos para BIM em projetos brasileiros, a indústria da construção civil ainda se encontra substancialmente fundamentada na troca de conteúdos desenvolvidos em 2D. Dentre as desvantagens em não se incorporar a modelagem da informação da construção e a representação em 3D estão: maior suscetibilidade a erros de representação (tais como inconsistências e interferências geométricas) e dificuldades na compatibilização dos projetos.

Dentre as principais vantagens da adoção de BIM aos processos de projeto em escritórios de arquitetura brasileiros, destacadas por Souza; Amorim e Lyrio (2009) estavam: a diminuição de erros e o aumento da qualidade dos projetos entregues. Observou-se também o aumento da quantidade das informações de projeto disponíveis.

Outra vantagem destacada foi quanto à possibilidade de se oferecer novos produtos aos clientes, como quantitativos e imagens para a visualização das soluções. Apesar disso, o prazo para a execução dos projetos e o tamanho das equipes não foram reduzidos quando comparados aos projetos desenvolvidos, conforme o processo convencional o que, de acordo com os pesquisadores, pode ser creditado à prática não tão frequente dos processos com suporte em tecnologias para a modelagem da informação (SOUZA; AMORIM; LYRIO, 2009). 


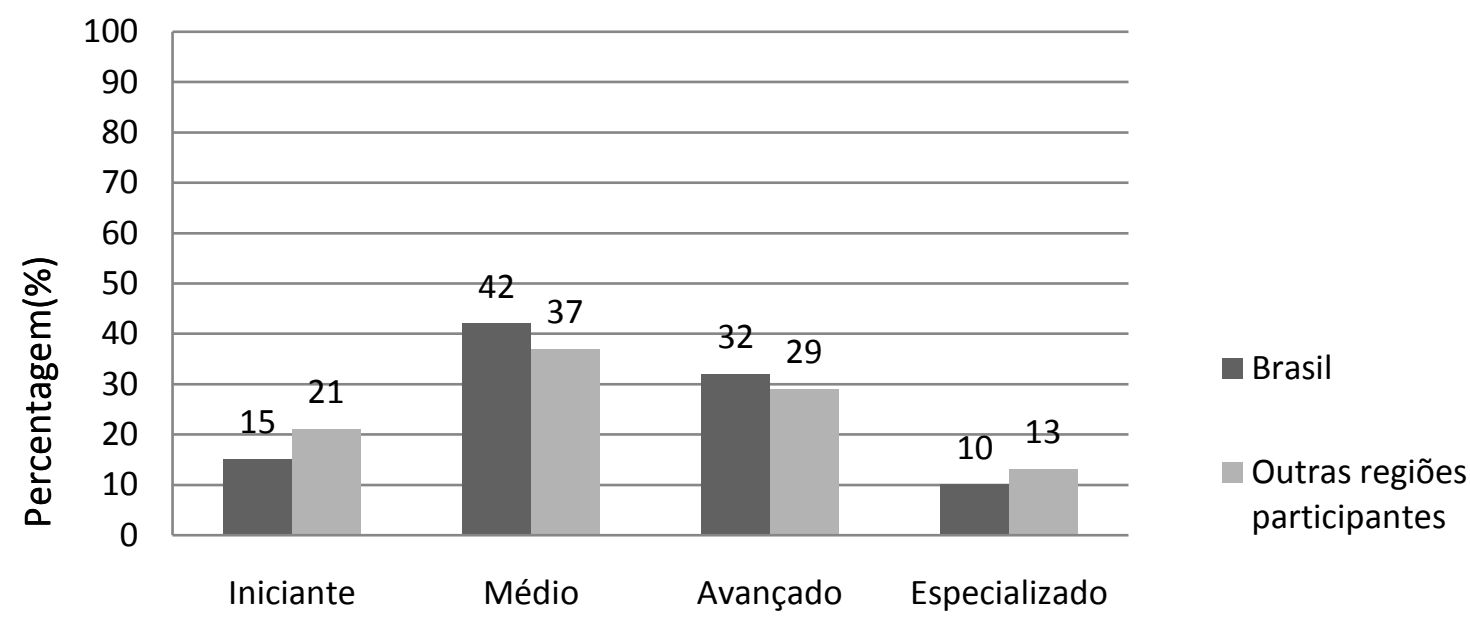

Gráfico 2. Nível declarado de conhecimento, quanto aos recursos de BIM Fonte: Adaptado pela pesquisadora de MCGRAW-HILL (2014, p. 46).

Dentre as empresas respondentes brasileiras, 35\% (trinta e cinco por cento) declararam ter incorporado os processos de BIM a menos de 15\% (quinze por cento) dos projetos do escritório, enquanto $40 \%$ (quarenta por cento) afirmaram aplicá-los a entre $15 \%$ (quinze por cento) e $30 \%$ (trinta por cento) dos projetos. Finalmente, os respondentes declararam planejar investimentos em tecnologias para suporte aos processos de BIM, em 2 (dois) anos, a contar de 2014, data da divulgação da pesquisa. Portanto, há indícios importantes quanto à popularização das tecnologias de modelagem da informação junto a empresas da construção civil brasileira, embora o Nível de Maturidade dos processos de BIM no Brasil ainda seja considerado baixo, quando comparado ao contexto mundial (MCGRAW-HILL, 2014).

Dentre as principais aplicações reportadas entre as empresas que adotam a modelagem da informação para a gestão de facilidades, Becerik-Gerber; Jazizadeh; Li e Calis (2012) destacam; como principais vantagens observadas, a gestão do consumo energético e a gestão de atividades de manutenção, presentes, respectivamente, em $82 \%$ (oitenta e dois por cento) e $79 \%$ (setenta e nove por cento) dos casos. Ainda, dentre os respondentes, $79 \%$ (setenta e nove por cento) declararam utilizar recursos de modelagem da informação para gestão de leiaute e $74 \%$ (setenta e quatro por cento) para controle da qualidade ambiental. 
Quanto às tipologias construtivas de projetos que adotaram recursos para a modelagem da informação, uma pesquisa realizada por pesquisadores da University of Southern California (USC), publicada em 2012 (Apud BECERIK-GERBER; JAZIZADEH; LI; CALIS, 2012), mostrou que, dentre os empreendimentos que efetivamente implantaram a gestão de facilidades com o suporte de tecnologias para a modelagem da informação, destacavam-se: edificações educacionais, que corresponderam a 53\% (cinquenta e três por cento) dos casos pesquisados, edificações administradas por agências governamentais, 13\% (treze por cento), empresas de grande porte no segmento da indústria da construção civil, $9 \%$ (nove por cento) e edificações de prestadoras de serviços de saúde, 5\% (cinco por cento).

Edificações pertencentes a organizações dedicadas à gestão de facilidades representaram 4\% (quatro por cento); enquanto as empresas de comércio varejista e de tecnologia da informação contribuíram com, respectivamente, 3\% (três por cento) cada. Outras tipologias de empresas representaram 10\% (dez por cento) dos respondentes da pesquisa (BECERIK-GERBER; JAZIZADEH; LI; CALIS, 2012). Observa-se, portanto, o papel de liderança exercido pelas organizações educacionais para a disseminação da integração de BIM à CAFM.

\subsection{EXEMPLOS DE ATORES LÍDERES EM MODELAGEM DA INFORMAÇÃO}

Considerando o levantamento das boas práticas de gestão da informação aplicada a processos relacionados à produção e à operação de edificações, foram identificados exemplos de atores líderes, em relação a diferentes aspectos: pesquisa e desenvolvimento e elaboração de diretrizes, como é o caso das organizações do Governo dos Estados Unidos da América: VA (United States Department of Veterans Affairs) (VA, 2010) e GSA (United States General Services Administration) (GSA, 2012).

Estas, além de proverem importantes contribuições para o Estado da Arte da matéria, também desempenham papel de destaque na criação de oportunidades de negócio que incorporem os conceitos especificados, conforme o apresentado nos itens subsequentes. 


\subsubsection{UNITED STATES GENERAL SERVICES ADMINISTRATION - GSA}

A United States General Services Administration - GSA é a maior proprietária de ativos imobiliários dos Estados Unidos da América, sendo responsável pela administração de mais de 34 (trinta e quatro) milhões de metros quadrados de área locável, distribuídos em 9.624 (nove mil, seiscentos e vinte e quatro) edificações de diversas tipologias construtivas, tais como: escritórios administrativos federais, tribunais e postos de fiscalização do tráfego internacional (informações referentes a 2012) (GSA, 2012).

O Office of Design and Construction do United States General Services Administration - GSA, departamento responsável pela gestão dessas propriedades, instituiu, em 2003, um programa de abrangência nacional, denominado 3D-4D BIM Program. Esta iniciativa pretende promover a integração entre os serviços de TI dos prédios públicos, de modo a integrar a tecnologia e os processos para a modelagem da informação a todos os usos pertinentes ao portfólio de edificações administrado pelo Public Building Services (PBS), o que inclui, portanto, todas as fases do ciclo de vida de cada edificação administrada pela agência. Responsável por administrar um orçamento de US\$23,9 bilhões (dado correspondente ao ano fiscal de 2008) e por gerir um portfólio de ativos cujo montante corresponde a US\$500 bilhões, do qual fazem parte 9.600 (nove mil e seiscentas) edificações (adquiridas ou alugadas) (GSA, 2015a), é possível apreender o impacto desta iniciativa para a consolidação de boas práticas na indústria da construção civil dos Estados Unidos da América.

Dentre as diretrizes, é determinado que os projetos sejam elaborados em programas computacionais homologados para interoperabilidade por meio de formato IFC, e os modelos devem incluir geometria 3D associada aos respectivos dados e propriedades pertinentes às especificações de projeto, informações quanto aos prazos (4D), dados de custos $(5 \mathrm{D}$, que correspondem às informações modeladas em 4D, associadas aos respectivos custos), bem como informações geográficas do empreendimento (GSA, 2008).

Por meio da adoção dos processos e da tecnologia para BIM, pretende-se reduzir o desperdício associado ao retrabalho, por meio da compatibilização de soluções de projetos e requisito nas fases iniciais de desenvolvimento (GSA, 2007a). 
O objetivo da (adoção de tecnologias para ${ }^{5}$ ) BIM é tornar a informação de projeto explícita, de modo que os requisitos de projeto e o programa possam ser imediatamente entendidos e avaliados. A abordagem BIM permite a geração de documentos 'sob demanda' (por exemplo: desenhos, listas, tabelas e renderizações em 3D), utilizando um modelo de informação da construção consistente. (...)

Como um recurso para o compartilhamento de conhecimento, a BIM pode reduzir a necessidade de reagrupar e reorganizar as informações. Isso pode resultar em um aumento na velocidade e na precisão da informação transmitida, redução dos custos associados à falta de interoperabilidade, automatização de validações e análises e em embasamento sem precedentes às atividades de operação e manutenção". (GSA, 2007a, p. 2, tradução nossa)

Para orientar a aplicação do 3D-4D BIM Program, foi publicado um conjunto de documentos, que abordam os seguintes aspectos: conceituação, validação do programa arquitetônico, elaboração de levantamentos, utilizando tecnologia a laser, planejamento de execução, desempenho energético e gestão de facilidades. Os respectivos escopos dos guias mencionados são apresentados no Quadro 9.

${ }^{5}$ NT: no original, consta: "o objetivo da BIM". 
Quadro 9. Guias de diretrizes para BIM, publicados pela GSA.

\begin{tabular}{|c|c|c|}
\hline Título & Escopo & Data \\
\hline BIM Guide 01- BIM Overview (GSA, 2007a) & $\begin{array}{l}\text { Conceitos principais de BIM e entendimento da agência } \\
\text { quanto aos objetivos de sua implantação aos projetos do } \\
\text { portfólio. }\end{array}$ & $14 / 5 / 2007$ \\
\hline $\begin{array}{c}\text { GSA BIM Guide } 02 \text { - Spatial Program } \\
\text { Validation (GSA, 2015b) }\end{array}$ & \multirow[t]{2}{*}{$\begin{array}{l}\text { Procedimentos para a validação dos requisitos de } \\
\text { projetos e do programa de necessidades, inclusive, para } \\
\text { o cálculo de áreas e a classificação de ambientes. }\end{array}$} & $21 / 5 / 2015$ \\
\hline $\begin{array}{l}\text { GSA BIM Guide } 02 \text { - Spatial Program } \\
\text { Validation - Appendices (GSA, 2006) }\end{array}$ & & $1 / 11 / 2006$ \\
\hline $\begin{array}{l}\text { GSA BIM Guide } 03 \text { - 3D Laser Scanning (GSA, } \\
\text { 2009a) }\end{array}$ & $\begin{array}{l}\text { Procedimentos para medição ou captura de informações } \\
\text { quanto ao ambiente construído ou natural, por meio de } \\
\text { tecnologia a laser. Define os produtos a serem entregues } \\
\text { quando da contratação deste serviço, em função do nível } \\
\text { de desenvolvimento determinado. }\end{array}$ & $1 / 1 / 2009$ \\
\hline GSA BIM Guide 04 - 4D Phasing (GSA, 2009b) & $\begin{array}{l}\text { Diretrizes para a integração do modelo 3D com as } \\
\text { informações referentes às atividades da construção, } \\
\text { considerando o tempo de execução das tarefas. }\end{array}$ & $25 / 9 / 2009$ \\
\hline $\begin{array}{l}\text { GSA BIM Guide } 05 \text { - Energy Performance } \\
\text { (GSA, 2015c) }\end{array}$ & $\begin{array}{l}\text { Diretrizes para a realização de análises energéticas em } \\
\text { projetos modelados em BIM e normas a serem } \\
\text { observadas para a verificação do atendimento às metas } \\
\text { de consumo. }\end{array}$ & $2 / 6 / 2015$ \\
\hline $\begin{array}{l}\text { GSA BIM Guide } 08 \text { - Facility Management } \\
\text { (GSA, 2012) }\end{array}$ & $\begin{array}{l}\text { Procedimentos para a modelagem da informação para } \\
\text { uso durante a fase de operação e manutenção da } \\
\text { edificação. }\end{array}$ & $25 / 1 / 2012$ \\
\hline
\end{tabular}

Fonte: Acervo da pesquisadora.

O GSA BIM Guide 06 - circulation and security validation é de circulação restrita e aplica-se aos processos de BIM, os requisitos de circulação e de segurança pertinentes às edificações que abrigam os tribunais daquele país (GSA, 2007b).

Há ainda o documento GSA BIM guide 7 - building elements, que pretende identificar as propriedades pertinentes a cada uso do modelo BIM, pertinentes aos componentes da edificação. Este guia encontrava-se em elaboração à época da pesquisa (2015).

Em uma etapa seguinte, espera-se ampliar as recomendações para os seguintes aspectos (GSA, 2007a):

- visualização;

- estimativas de custos;

- elaboração de quantitativos;

- iluminação;

- acústica;

- estrutura;

- elementos construtivos; e 
- rotas de fuga e circulação.

A partir das diretrizes determinadas pelo programa, é possível apreender que, dentre os benefícios esperados, em função da adoção dos critérios especificados pelo programa, estão a redução dos riscos associados a incertezas, ao longo das diferentes fases do ciclo de vida das edificações do portfólio, um melhor controle dos níveis de desempenho durante sua operação, maior confiabilidade das informações documentadas e a redução dos custos associados ao retrabalho e às horas trabalhadas referentes à busca e verificação de informações.

\subsubsection{THE U. S. VETERAN AFFAIRS OFFICE OF CONSTRUCTION \&} FACILITIES - VA (CFM)

O VA (CFM) é responsável por gerenciar construções, projetos e edificações em operação para o United States Department of Veterans Affairs. Tendo assumido como premissas a busca por qualidade no ambiente construído e a eficiência nos custos de operação das edificações sob sua administração; o VA (CFM) adotou uma abordagem de gestão da informação da construção ao longo do ciclo de vida. Também pretende prolongar ao máximo a vida útil dessas edificações.

Para tanto, foi determinado que os projetos desenvolvidos para a organização devem ser elaborados conforme as metodologias de BIM e de desenvolvimento de projeto integrado publicadas no VA BIM Guide (VA, 2010). Como diretriz, para o desenvolvimento de projetos arquitetônicos e de engenharia, devem ser utilizados programas computacionais homologados para a exportação em formato IFC. Também deve ser elaborado um Plano de Gestão de BIM, no qual sejam destacados, conforme os requisitos de projeto determinados pela VA: os recursos tecnológicos a serem adotados durante o processo, as informações pertinentes a cada fase de projeto, os responsáveis por sua produção e validação e os protocolos para a documentação e a comunicação das informações. 


\subsection{EXEMPLOS DE BOAS PRÁtICAS DE MODELAGEM DA INFORMAÇÃO}

Dentre as iniciativas de relevância, na qual foram utilizadas tecnologias de modelagem da informação, foram identificados, como referências para a presente pesquisa os seguintes exemplos, cujas características e complexidade são apresentadas nos itens subsequentes: Smithsonian Institution, Crossrail, Exército Brasileiro e o edifício que abriga a Sede Administrativa da Unidade Operacional da Bacia de Santos, de propriedade da Petróleo Brasileiro S.A..

Para a seleção destes casos, foram considerados os seguintes critérios: relevância do projeto no contexto da construção civil local, complexidade das instalações e incorporação de soluções tecnológicas inovadoras pertinentes à gestão da informação da construção.

\subsubsection{SMITHSONIAN INSTITUTION (SI)}

A Smithsonian Institution - SI é responsável por gerir um portfólio de propriedades imobiliárias de mais de 760 (setecentos e sessenta) prédios e estruturas, pelos quais são distribuídos mais de 20.000 (vinte mil) ambientes de diferentes tipologias. Dentre os principais usos das edificações sob sua gestão, destacam-se museus, laboratórios, estações de campo e telescópios (SI, 2014).

Para tornar a gestão destas propriedades possível, o SI implantou recursos tecnológicos, mesmo antes da difusão das tecnologias de BIM. A instituição dispõe de um Banco de Dados georreferenciado personalizado, denominado SI Explorer, que se constituiu no primeiro recurso para repositório de informações espaciais, inclusive plantas de pavimento e respectivos leiautes. O sistema de arquivamento das informações referentes à gestão de facilidades é o Tririga Facility Center, Banco de Dados responsável pelo armazenamento das informações apresentadas em tabelas, que opera com um plug-in, denominado Tririga CAD Integrator, de modo a possibilitar a sincronização de dados com sistemas de CAD, atualizados sistematicamente, para apresentar as informações correspondentes a edificações novas ou renovadas (SI, 2014).

As tecnologias de CAD e de SIG possibilitaram tornar mais eficiente a gestão 
das informações referentes aos ambientes e seus sistemas. Entretanto, aspectos como tempo dispendido em processos manuais e redundâncias de informações ainda eram identificados como críticos.

A busca por maior eficiência para a gestão das informações referentes aos ativos da SI demandou um esforço para a revisão das tecnologias e dos processos de trabalho. Nesse contexto, foi consolidado um programa estratégico, para a gestão da informação referente aos ativos da instituição, considerando a utilização de BIM em larga escala, para o desenvolvimento dos projetos e das atividades de construção e de gestão de facilidades da edificação.

O programa elaborado pela Smithsonian Institution foi implantado de forma gradual. Inicialmente, foi elaborado um inventário das 23 (vinte e três) construções do portfólio da instituição modeladas e do respectivo nível de desenvolvimento de modelagem da informação para a gestão de facilidades. Nesta etapa, foram contempladas 19 edificações, com área total equivalente a mais de 1.114.836 (um milhão, cento e quatorze mil, oitocentos e trinta e seis) metros quadrados de área construída (SI, 2014).

Também foi adotada a prática da modelagem da informação para a infraestrutura de campi, de acordo com a qual se pretende consolidar uma plataforma de informação digitalizada em 3D, de modo a embasar a gestão de terrenos, paisagismo, infraestrutura urbana e componentes de instalações de edificações. Para tal, foi determinado, como caso piloto o campus do Zoológico Nacional (National Zoo - NZP), o maior campus do portfólio e também o de maior relevância do ponto de vista de planejamento de investimentos. Outro aspecto relevante para a escolha do NZP foi sua grande variedade e complexidade, quanto aos requisitos de informações, tanto no que se referia a tecnologias de BIM, como às tecnologias de SIG (SI, 2014).

No Quadro 10, é apresentada uma ficha técnica correspondente ao programa de modelagem da informação em implantação na SI. 
Quadro 10. Ficha técnica: Smithsonian Institution

\begin{tabular}{|c|c|}
\hline Proprietário & Governo Federal dos Estados Unidos - Smithsonian Institution. \\
\hline País & Estados Unidos da América. \\
\hline Ano de implantação do programa & 2004 \\
\hline $\begin{array}{l}\text { Objetivos buscados por meio da } \\
\text { implantação de recursos tecnológicos } \\
\text { para a modelagem da informação (SI, } \\
\text { 2014). }\end{array}$ & $\begin{array}{l}\text { Durante o desenvolvimento de projeto, elaborar análises preliminares de } \\
\text { desempenho das propostas apresentadas, identificar interferências entre } \\
\text { soluções de projeto, realizar coordenação de projeto, por meio da adoção } \\
\text { de um modelo federado tridimensional. Planejar o cronograma e elaborar } \\
\text { orçamentos. Utilizar a tecnologia BIM como base para a realização de } \\
\text { como um repositório acessível de informações, para inventário. Monitorar } \\
\text { o desempenho e o consumo das edificações em uso. }\end{array}$ \\
\hline Nível de MaturidadeBIM (RIBA, 2012). & 3 \\
\hline $\begin{array}{l}\text { Abrangência da iniciativa (KENDRA, } \\
\text { 2009) }\end{array}$ & 760 edificações e estruturas. \\
\hline Total de edificações (KENDRA, 2009) & 20.003 ambientes. \\
\hline Área construída (KENDRA, 2009) & $1.114 .836 \mathrm{~m}^{2}$ \\
\hline
\end{tabular}

Fonte: Acervo da pesquisadora.

Além disso, há um estudo piloto, referente ao Smithsonian Tropical Research Institute, que pretende migrar a informação da construção digitalizada para um sistema georreferenciado, denominado Modelo de Informação da Construção em Ambientes Internos, um sistema de modelagem de informações georreferenciadas, que permite a gestão e a elaboração de relatórios de informações referentes a ambientes internos (ESRI, 2010).

Ao colocar em prática a meta de praticar a gestão de facilidades utilizando tecnologias de modelagem da informação, a instituição instituiu os seguintes objetivos (KENDRA, 2015):

- desempenhar um papel catalisador junto à indústria da construção civil, de modo a incentivar a gestão das informações de facilidades;

- compatibilizar as diretrizes para BIM, os processos de trabalho e a capacitação das equipes; e

- desenvolver normas e diretrizes que permitam assegurar a entrega de dados confiáveis. 
O entendimento da SI quanto ao processo de projeto é apresentado na Figura 26.

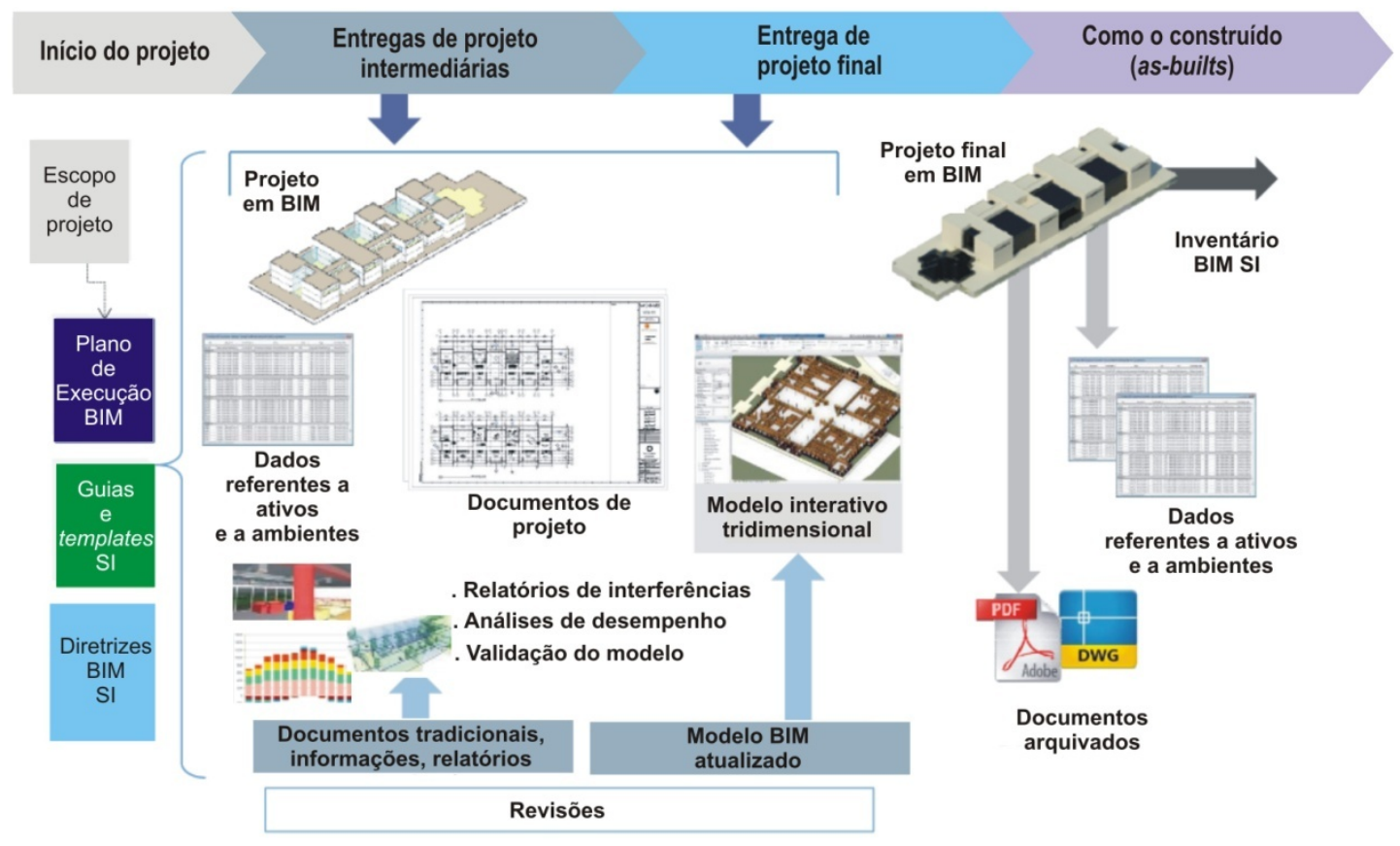

Figura 26. Processo de projeto proposto pela SI

Fonte: SABOL (2015, p. 17). Tradução nossa.

Com vistas à padronização das informações, foram criados arquivos-modelo, para as disciplinas de: arquitetura, instalações de ar condicionado, instalações hidráulicas e sistemas estruturais. Nesses arquivos, foram configurados previamente os campos de dados a serem preenchidos, pertinentes a cada disciplina de projeto.

Na Figura 27, são apresentados exemplos de parâmetros correspondentes a dados e propriedades pertinentes aos usos pretendidos para os modelos elaborados pela instituição. 
Propriedades e

características atribuídas ao ambiente

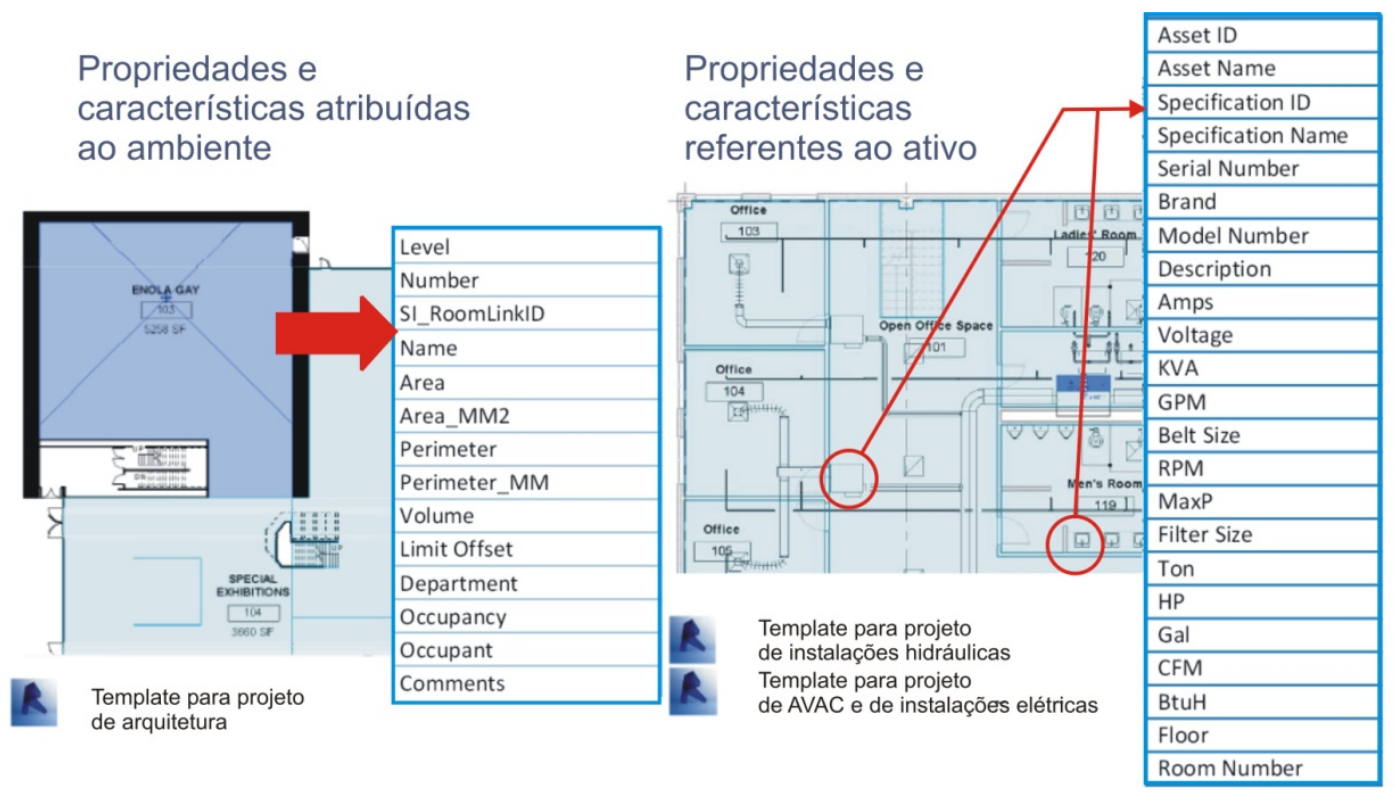

Figura 27. Exemplos de parâmetros disponíveis nos templates da SI Fonte: Adaptado pela pesquisadora de SABOL (2015, p.16).

Por meio do fluxograma apresentado, pretende-se integrar as informações referentes a gestão de facilidades e sistemas de automação, bem como promover seu georreferenciamento, de modo a permitir a gestão de ativos imobiliários, a elaboração do planejamento de investimentos, a gestão das atividades de manutenção, de desempenho energético e de outros aspectos de sustentabilidade, além de consolidar um inventário único, confiável e permanentemente atualizado de todos os ativos da instituição.

$\mathrm{Na}$ Figura 28, é apresentado um exemplo de tela para a visualização da informação georreferenciada no complexo da SI. 


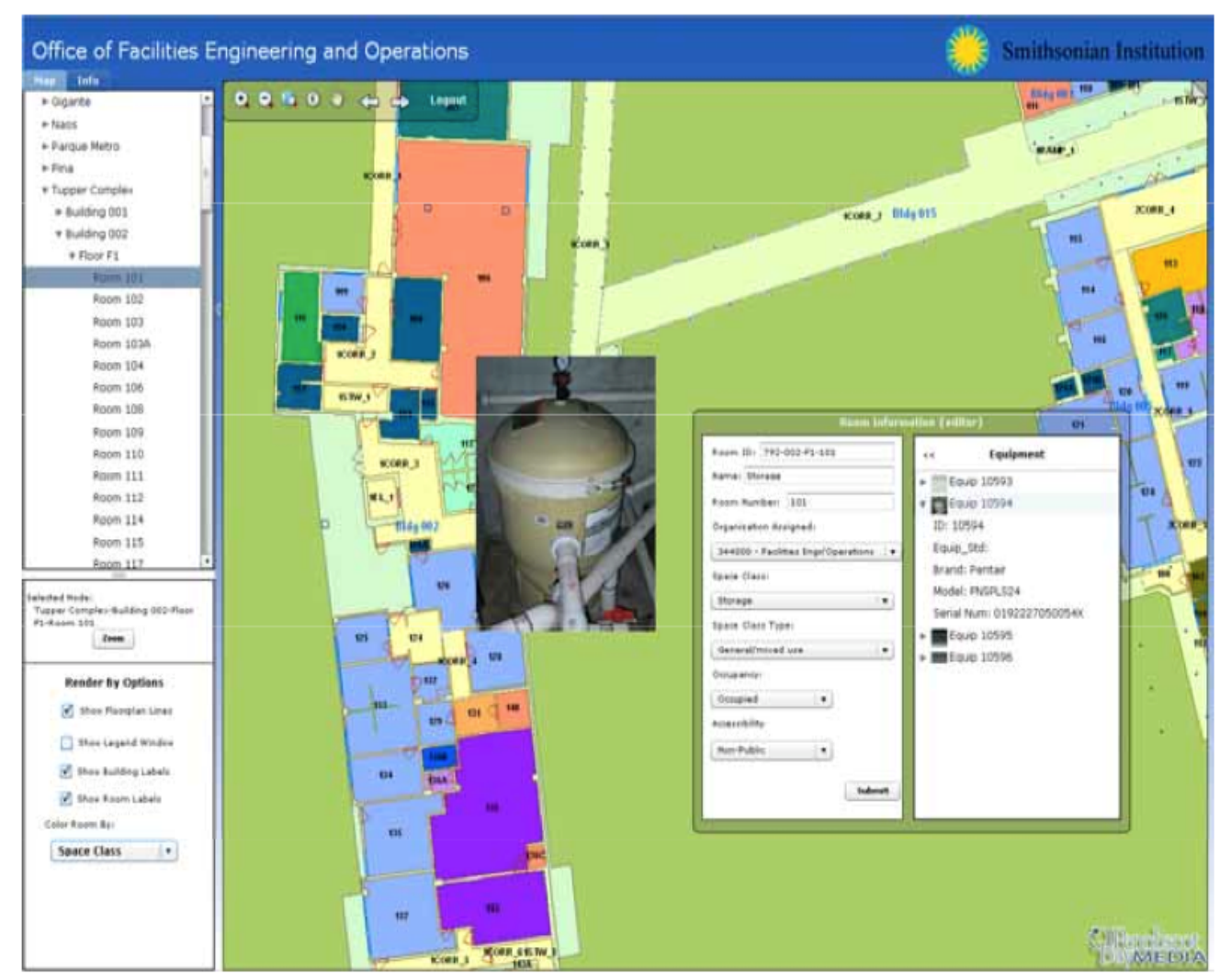

Figura 28. Exemplo de visualização de informação georreferenciada de instalaçães prediais do complexo gerido pela SI.

Fonte: Acervo da Smithsonian Institution.

Uma das metas do projeto é a elaboração de um website, denominado SI BIM Wiki, que pretende possibilitar a consulta das informações técnicas referentes aos sites consultados. Na Figura 29, é apresentado um exemplo de leiaute de uma página do website em desenvolvimento, refente ao National Air and Space Museum (NASM). 

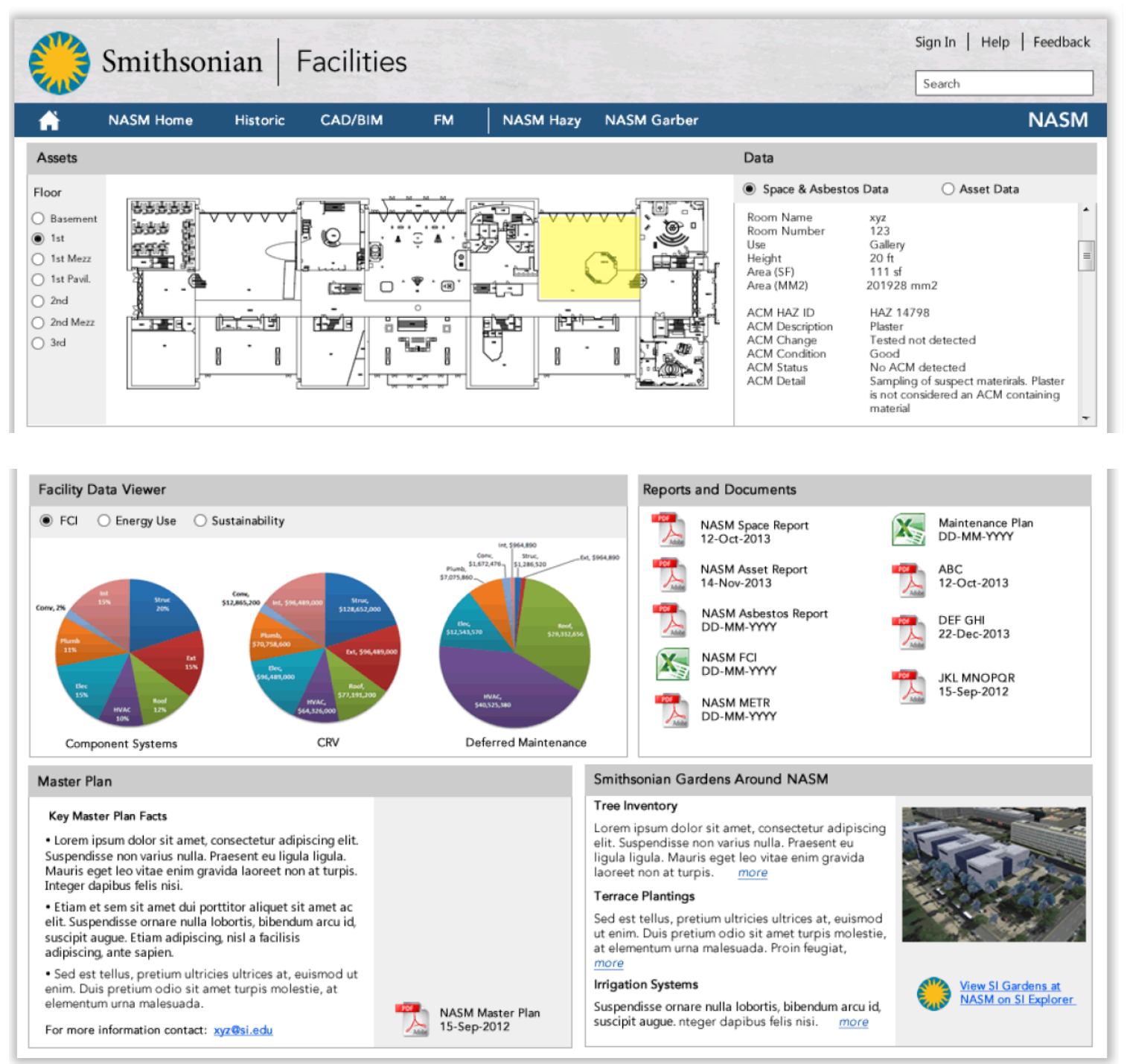

Figura 29. Exemplo de leiaute para página de consulta de informações técnicas referentes ao NASM.

Fonte: SI (2014, p. 35).

Por meio dos recursos tecnológicos implantados, pretende-se que as informações necessárias à gestão de facilidades apresentem consistência e integridade, de modo a permitir análises referentes aos seguintes aspectos integrados (KENDRA; HELLER, 2011):

- Indicador de Condições das Instalações;

- requisitos para o desenvolvimento das instalações; 
- informações sobre atividades de manutenção e reparos;

- plano de gestão de investimentos; e

- adoção dos processos e das tecnologias de modelagem da informação para todos os projetos de construções e de alterações, em conformidade com as diretrizes apresentadas.

O programa implantado pelo Smithsonian indica que a modelagem seja elaborada, considerando os usos apresentados no Quadro 11, organizados por fase do ciclo de vida da edificação. 
Quadro 11. Usos a serem considerados pela SI para a modelagem da informação

\begin{tabular}{|c|c|c|c|c|}
\hline Etapa & Planejamento & Projeto & Construção & Operação \\
\hline & $\begin{array}{l}\text { Elaboração do } \\
\text { programa de } \\
\text { necessidades. }\end{array}$ & Elaboração de projeto. & $\begin{array}{l}\text { Planejamento do } \\
\text { canteiro de obras. }\end{array}$ & $\begin{array}{l}\text { Programação das } \\
\text { atividades de } \\
\text { manutenção. }\end{array}$ \\
\hline & $\begin{array}{l}\text { Análises de } \\
\text { implantação e } \\
\text { volumetria. }\end{array}$ & $\begin{array}{l}\text { Revisões de projeto e do } \\
\text { modelo. }\end{array}$ & $\begin{array}{l}\text { Projetos de sistemas } \\
\text { prediais. }\end{array}$ & $\begin{array}{l}\text { Avaliação do } \\
\text { desempenho das } \\
\text { edificações. }\end{array}$ \\
\hline & $\begin{array}{l}\text { Planejamento de } \\
\text { aspectos de } \\
\text { segurança e de } \\
\text { logística, } \\
\text { utilizando } \\
\text { modelo } \\
\text { tridimensional. }\end{array}$ & $\begin{array}{l}\text { Coordenação e } \\
\text { gerenciamento do } \\
\text { projeto, utilizando um } \\
\text { modelo tridimensional/ } \\
\text { compatibilização de } \\
\text { projeto. }\end{array}$ & $\begin{array}{l}\text { Coordenação e } \\
\text { gerenciamento do } \\
\text { projeto, utilizando } \\
\text { um modelo } \\
\text { tridimensional/ } \\
\text { compatibilização de } \\
\text { projeto. }\end{array}$ & Gestão de ativos. \\
\hline 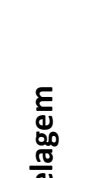 & & Análise estrutural. & Fabricação digital. & $\begin{array}{l}\text { Gestão de espaços } \\
\text { /monitoramento } \\
\text { dos padrões de } \\
\text { ocupação. }\end{array}$ \\
\hline 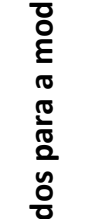 & & $\begin{array}{l}\text { Análise do desempenho } \\
\text { das soluções quanto à } \\
\text { iluminação natural e } \\
\text { artificial. }\end{array}$ & $\begin{array}{l}\text { Planejamento e } \\
\text { controle, utilizando o } \\
\text { modelo } \\
\text { tridimensional. }\end{array}$ & $\begin{array}{l}\text { Planejamento de } \\
\text { medidas } \\
\text { preventivas quanto } \\
\text { a possíveis } \\
\text { desastres. }\end{array}$ \\
\hline 竞 & & $\begin{array}{l}\text { Análise do desempenho } \\
\text { energetic. }\end{array}$ & $\begin{array}{l}\text { Documentação do } \\
\text { modelo. }\end{array}$ & $\begin{array}{l}\text { Documentação de } \\
\text { alterações. }\end{array}$ \\
\hline 흠 & & $\begin{array}{l}\text { Análise do projeto de } \\
\text { sistemas de AVAC. }\end{array}$ & & \\
\hline & & $\begin{array}{l}\text { Outras analises de } \\
\text { engenharia. }\end{array}$ & & \\
\hline & & $\begin{array}{l}\text { Avaliação de desempenho } \\
\text { ambiental (LEED). }\end{array}$ & & \\
\hline & & $\begin{array}{l}\text { Validação de requisitos } \\
\text { normativos. }\end{array}$ & & \\
\hline & $\begin{array}{l}\text { Planejamento de } \\
\text { cronograma de } \\
\text { execução (4D). }\end{array}$ & $\begin{array}{l}\text { Planejamento de } \\
\text { cronograma de execução } \\
\text { (4D). }\end{array}$ & $\begin{array}{l}\text { Planejamento de } \\
\text { cronograma de } \\
\text { execução (4D). }\end{array}$ & $\begin{array}{l}\text { Planejamento de } \\
\text { cronograma de } \\
\text { execução (4D). }\end{array}$ \\
\hline & $\begin{array}{l}\text { Orçamentação } \\
\text { (5D) . }\end{array}$ & Orçamentação (5D) . & Orçamentação (5D) . & $\begin{array}{l}\text { Orçamentação } \\
\text { (5D). }\end{array}$ \\
\hline & $\begin{array}{l}\text { Modelagem das } \\
\text { condições da } \\
\text { edificação em } \\
\text { uso (6D). }\end{array}$ & $\begin{array}{l}\text { Modelagem das } \\
\text { condições da edificação } \\
\text { em uso (6D). }\end{array}$ & $\begin{array}{l}\text { Modelagem das } \\
\text { condições da } \\
\text { edificação em uso } \\
\text { (6D). }\end{array}$ & $\begin{array}{l}\text { Modelagem das } \\
\text { condições da } \\
\text { edificação em uso } \\
\text { (6D). }\end{array}$ \\
\hline
\end{tabular}




\subsubsection{CROSSRAIL}

O Crossrail é um projeto de infraestrutura de grande porte, do qual fazem parte as instalações, os túneis e as estações de uma linha ferroviária que cruza a Grande Londres, conforme o mapa apresentado na Figura 30. Com mais de 100 quilômetros de extensão total, o projeto inclui a construção ou a requalificação de 37 estações conforme as informações disponíveis no Quadro 12. A operação plena do empreendimento está prevista para ocorrer em 2017 (CROSSRAIL, 2014).

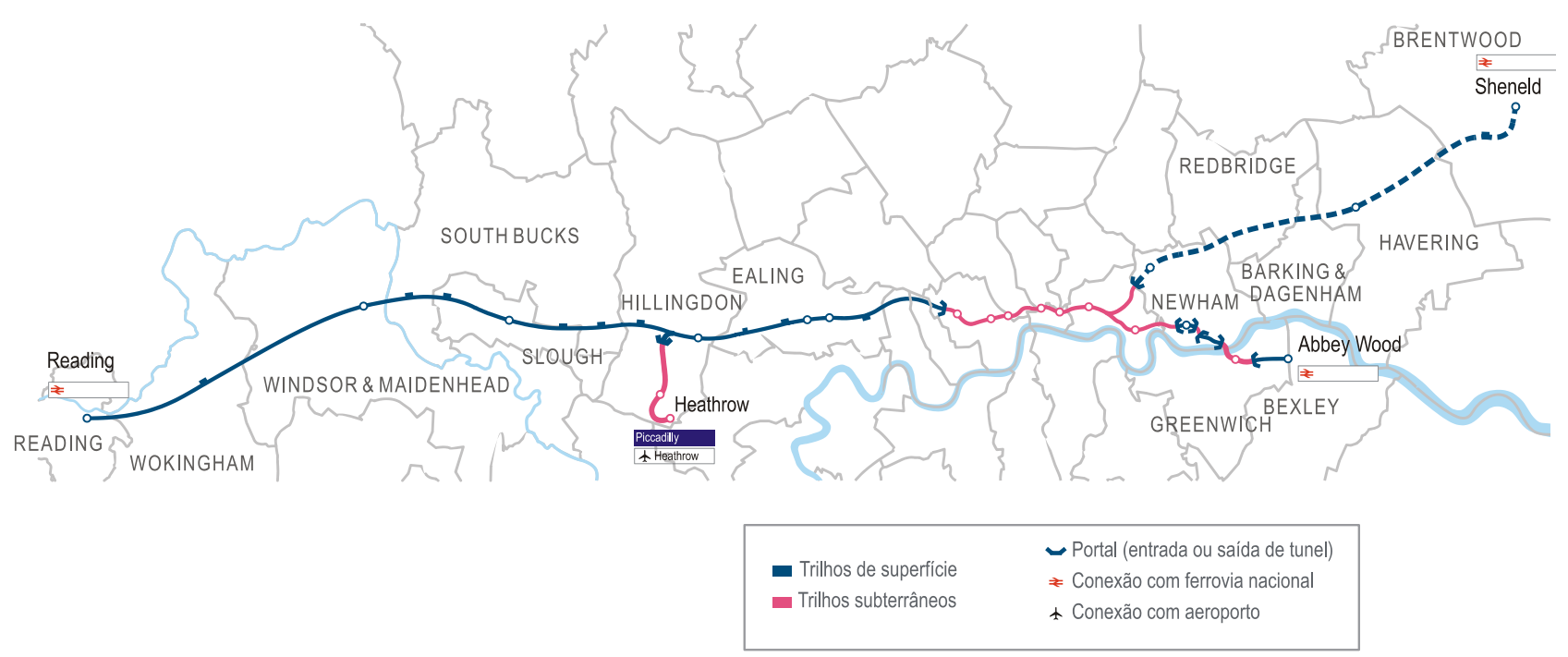

Figura 30. Mapa da linha ferroviária Crossrail

Fonte: Adaptado, pela pesquisadora, de CROSSRAIL (2014).

Trata-se do maior projeto de engenharia civil da Inglaterra e um dos maiores projetos de infraestrutura da Europa, com orçamento total previsto em $£ 14,800,000$ (quatorze bilhões e oitocentos milhões de libras esterlinas) (CROSSRAIL, 2013). Até 2014, foram criados mais de um milhão de arquivos CAD, integrados com o modelo federado de informação (CROSSRAIL, 2014). 
Quadro 12. Ficha técnica: Crossrail

\begin{tabular}{|c|c|}
\hline Proprietário & $\begin{array}{l}\text { Transport for London. Concessão de operação para a empresa MTR Corp, } \\
\text { em } 2014 .\end{array}$ \\
\hline País & Inglaterra. \\
\hline $\begin{array}{l}\text { Ano de início do projeto } \\
\text { (TAYLOR, 2015) }\end{array}$ & 2005. Início da construção: 2009. \\
\hline $\begin{array}{l}\text { Objetivos buscados por meio da } \\
\text { implantação de recursos } \\
\text { tecnológicos para a modelagem } \\
\text { da informação (TAYLOR, 2014b) }\end{array}$ & $\begin{array}{l}\text { Redução de custos, melhor controle de qualidade, minimização de riscos e } \\
\text { acesso às informações atualizadas. Para tanto, obter o mapeamento } \\
\text { georreferenciado das instalações preexistentes e construídas, para o } \\
\text { planejamento, o projeto, a gestão e a operação do empreendimento. } \\
\text { Durante a construção, praticar o processo de projeto colaborativo, realizar a } \\
\text { compatibilização de projeto utilizando informações tridimensionais, de } \\
\text { modo a aumentar a precisão das soluções. Realizar os planejamentos de } \\
\text { cronograma e de custos. Após a construção, utilizar as informações } \\
\text { atualizadas, como o construído, para as atividades de operação e } \\
\text { manutenção. Todas as informações (de projeto e de aspectos } \\
\text { administrativos) devem estar centralizadas em um único Banco de Dados. }\end{array}$ \\
\hline $\begin{array}{l}\text { Nível de MaturidadeBIM (RIBA, } \\
\text { 2012). }\end{array}$ & 3 (meta, em implantação). \\
\hline $\begin{array}{l}\text { Abrangência da iniciativa } \\
\text { (CROSSRAIL, 2014). }\end{array}$ & $\begin{array}{l}\text { Linha ferroviária que se vai de Reading e Heatrow (a oeste de Londres) até } \\
\text { Shenfield e Abbey Wood (situadas a leste), atravessando a área central de } \\
\text { Londres. }\end{array}$ \\
\hline $\begin{array}{l}\text { Total de edificações e de } \\
\text { instalações (CROSSRAIL, 2014). }\end{array}$ & $\begin{array}{l}90 \mathrm{~km} \text { de trilhos de superfície, } 21 \mathrm{~km} \text { de túneis duplos sob a área central de } \\
\text { Londres e } 37 \text { estações, sendo } 10 \text { novas e, as demais, requalificadas. }\end{array}$ \\
\hline Área construída & Área construída total não informada. \\
\hline
\end{tabular}

Fonte: Acervo da pesquisadora.

Todos os ativos do empreendimento dispõem de representação espacial e apresentam mais de 100 atributos no Banco de Dados (TAYLOR, 2015), o que dá referências para estimar a complexidade da iniciativa. No esquema apresentado na Figura 31, é representada a abordagem utilizada no projeto Crossrail, para a gestão da informação, ao longo do ciclo de vida. 


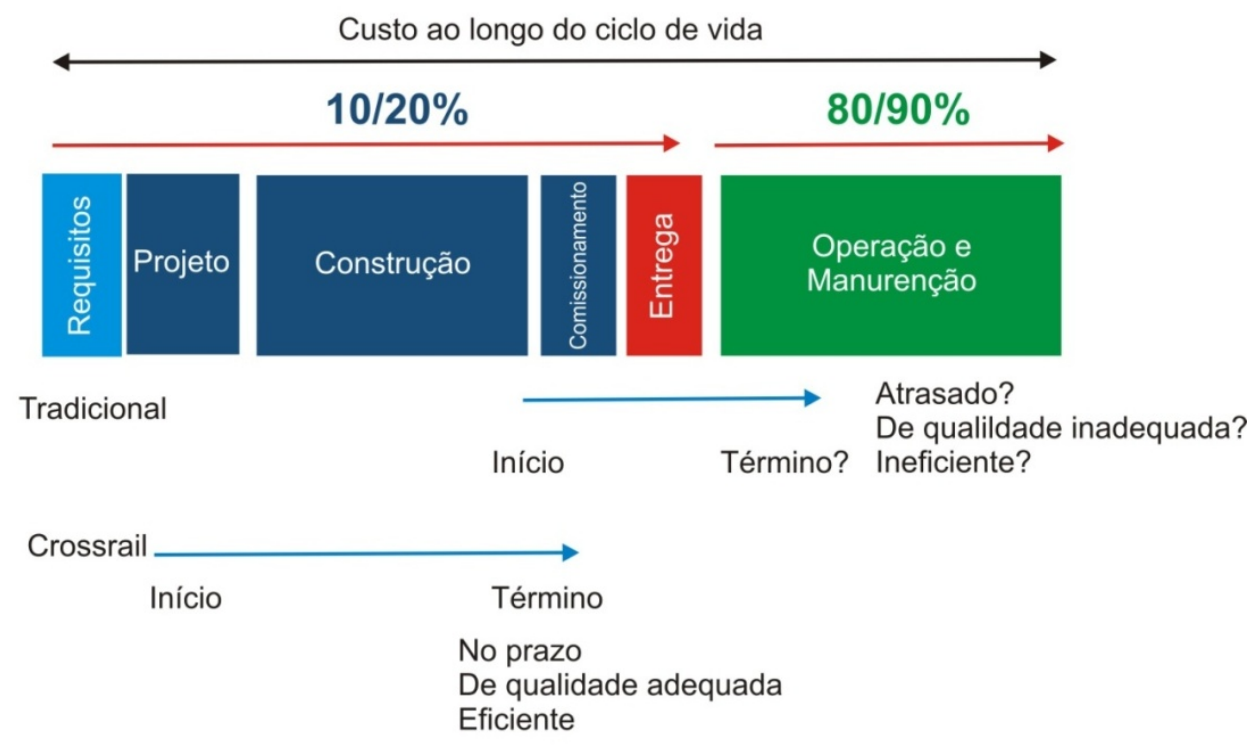

Figura 31. Gestão da informação, ao longo do ciclo de vida, no contexto do projeto Crossrail Fonte: IRWIN (2014, p. 6), tradução nossa.

No exemplo apresentado na Figura 32, são destacadas as propriedades e as características atribuídas aos ativos modelados.

\section{Representação do ativo}

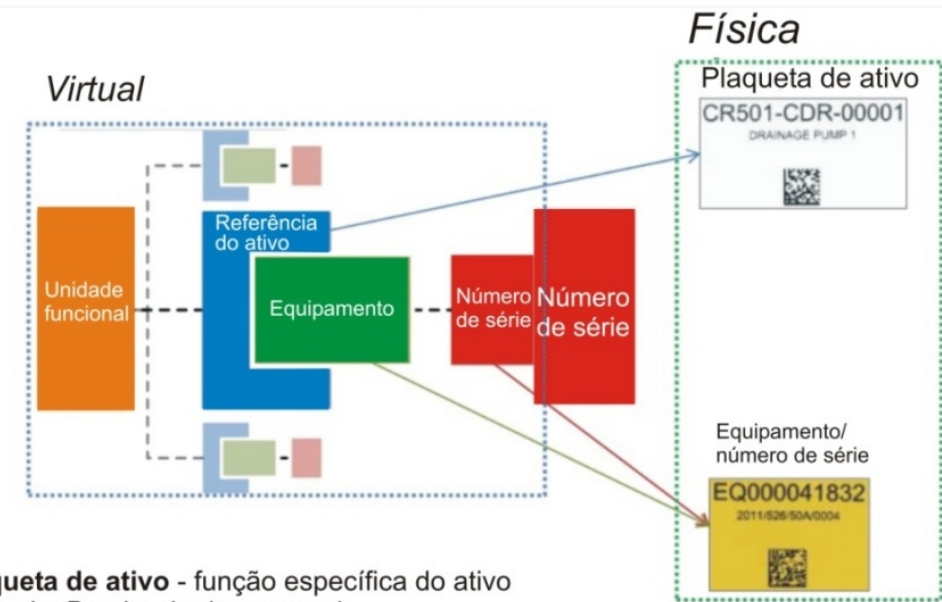

Plaqueta de ativo - função específica do ativo

Exemplo: Bomba de drenagem 1

Equipamento - o item físico desempenhando a função do ativo

Exemplo: Bomba Fabricante Acme, Modelo B

Número de série

- uma instância específica de um equipamento ou lote

Exemplo: 12345

Unidade funcional - um conjunto de ativos identificados por plaquetas,

que trabalham em conjunto, como um sistema

Figura 32. Informações relevantes à representação do ativo, no contexto do projeto Crossrail Fonte: IRWIN (2014, p. 11), tradução nossa. 
O entendimento adotado no empreendimento Crossrail quanto à sua consolidação no Banco de Dados das informações do ativo modeladas, geométricas e não geométricas, é apresentado na Figura 33.

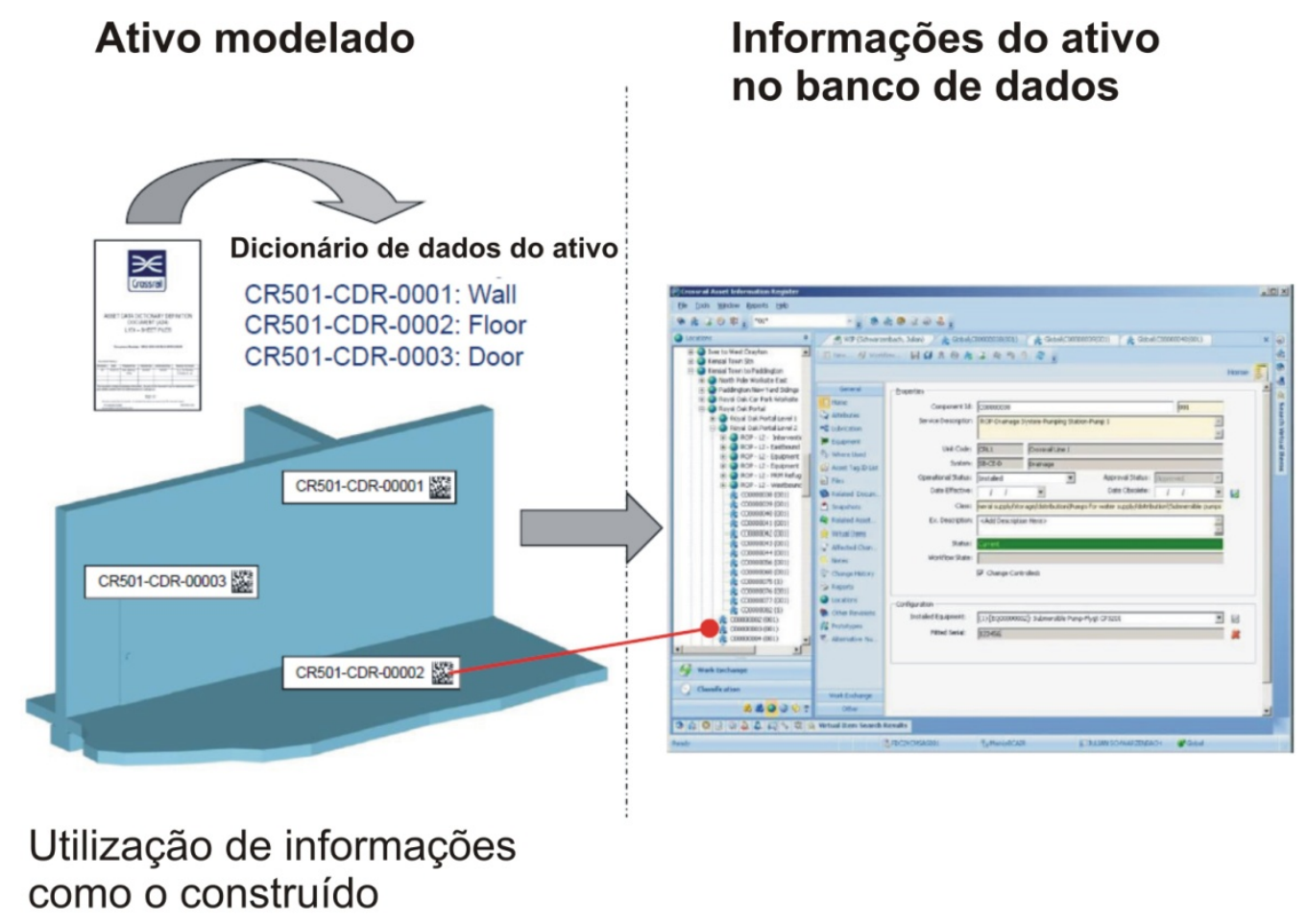

Figura 33. Exemplo de modelagem da informação do ativo no empreendimento Crossrail Fonte: TAYLOR (2013, p. 34).

O processo de projeto atende aos critérios do ambiente integrado definido pelo Nível 2 de Maturidade (BSI, 2013), o que implica a colaboração entre as 60 (sessenta) principais empresas de execução e os 25 (vinte e cinco) consultores de projeto que trabalham em um ambiente compartilhado e, portanto, observam os mesmos processos de trabalho e regras de modelagem (TAYLOR, 2014a).

O projeto da Crossrail propõe-se a solucionar os desafios contratuais e relacionados à adoção do processo de projeto integrado e à gestão das informações dos ativos, ao longo de seu ciclo de vida. Dentre estes, estão os aspectos relacionados à propriedade das informações e à responsabilidade quanto às 
soluções de projeto (TAYLOR, 2014b).

Para seu projeto, o mapeamento tridimensional georreferenciado é de grande importância, pois envolve áreas urbanas consolidadas e densamente ocupadas, como é possível observar na vista tridimensional apresentada na Figura 34. Para os levantamentos das estruturas e estações preexistentes, foi utilizado o levantamento digital a laser (TAYLOR, 2015).

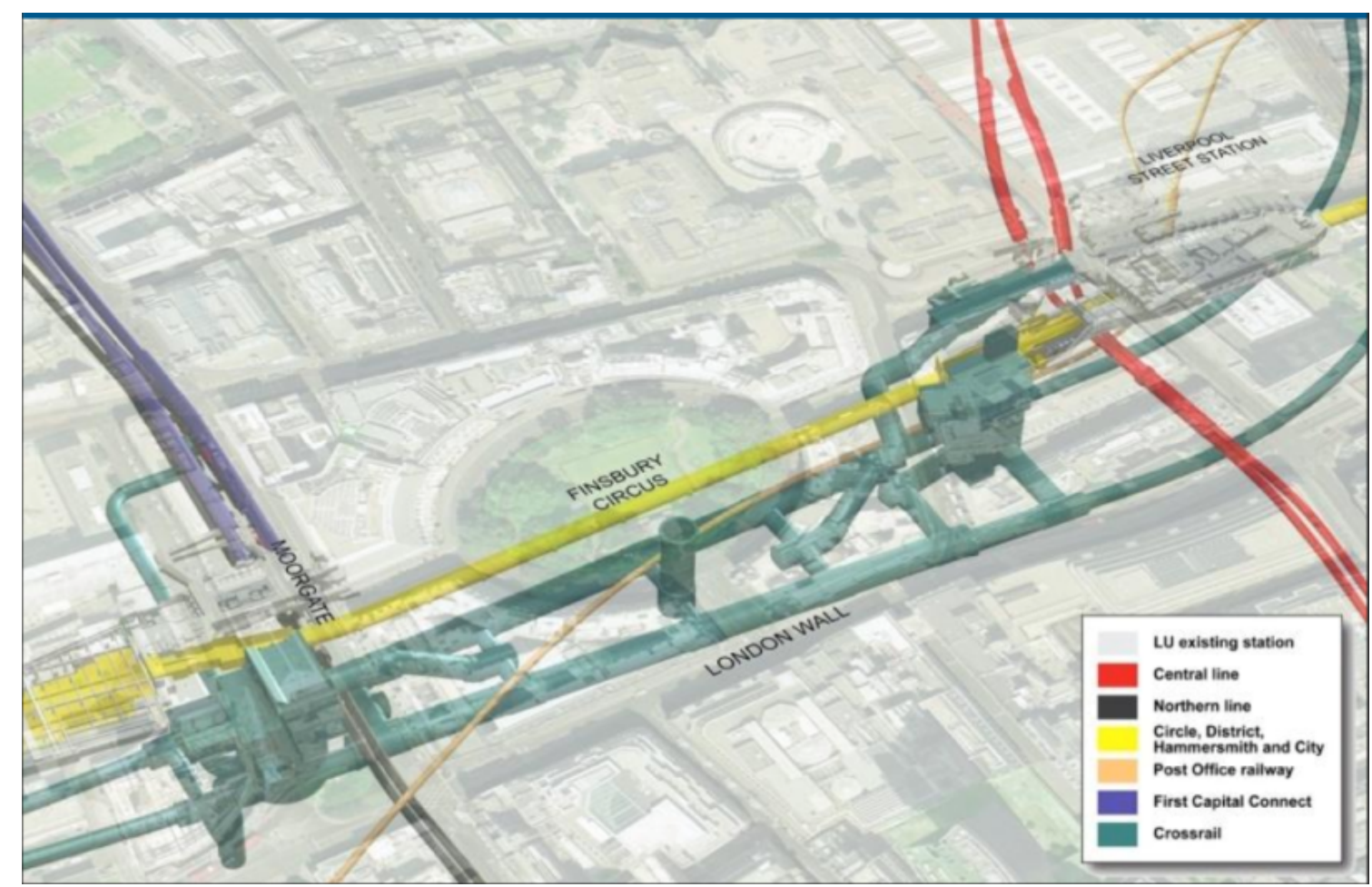

Figura 34. Vista de parte do projeto da Crossrail no contexto da malha urbana e das instalações preexistentes Fonte: TAYLOR (2015, p. 9).

$\mathrm{Na}$ Figura 35, são apresentados os sistemas construtivos e prediais da estação, modelados em tecnologia BIM para a Tottenham Court Road Station e mostram a complexidade das instalações objeto de modelagem. Dentre as informações modeladas, está o mapeamento da infraestrutura urbana existente, para possibilitar a compatibilização com o proposto e minimizar riscos de interferências. 


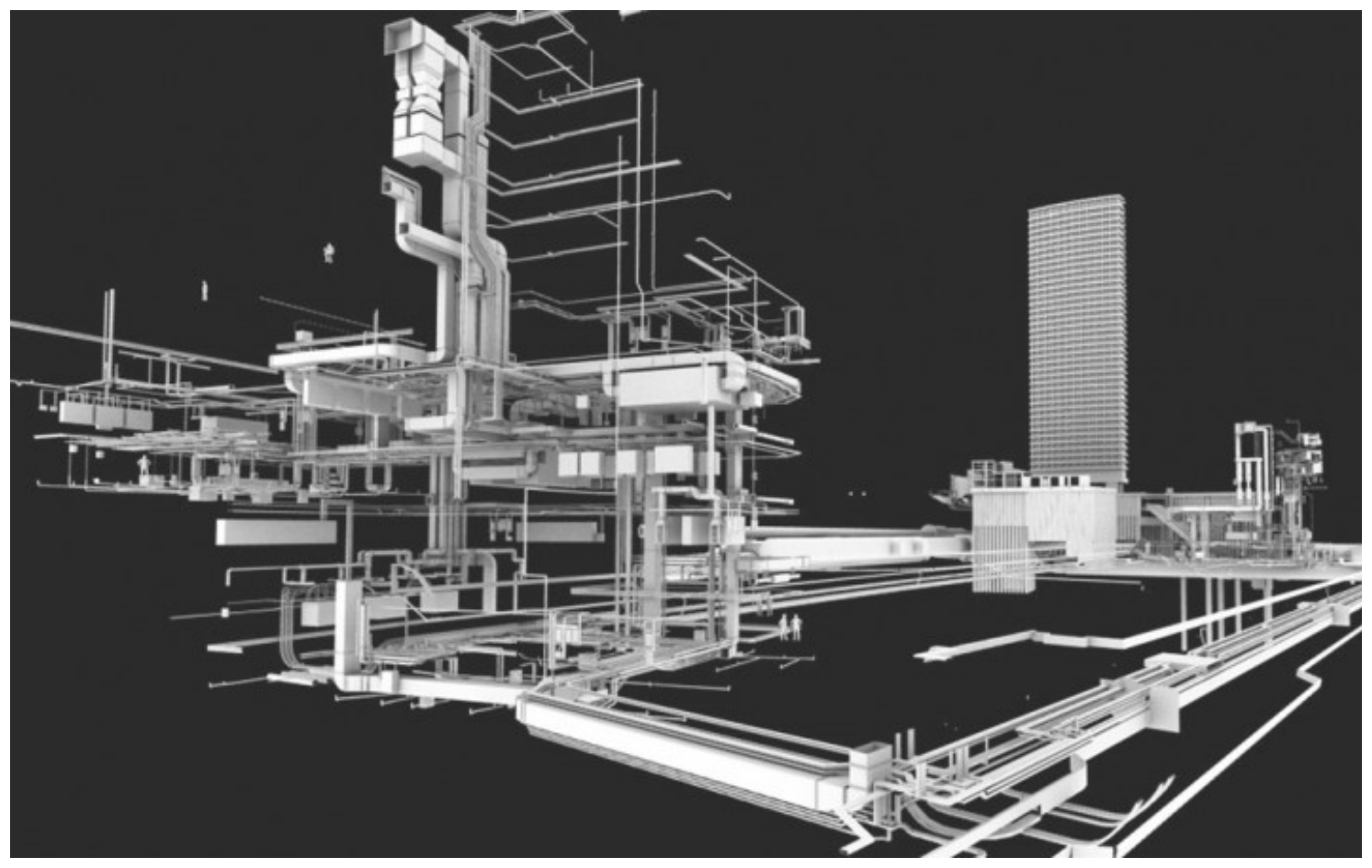

Figura 35. Vista tridimensional da Tottenham Court Road Station

Fonte: CROSSRAIL (2014).

Disponivel em: <http://www.crossrail.co.uk/>. Acesso em 22 set. 2015.

Ao se oferecer ao usuário da interface gráfica pretende-se que sejam possíveis a pesquisa e a visualização de informações, por meio de um mapa intuitivo (BUDDEN, 2011).

Um aspecto relevante do mencionado projeto é que, à época das etapas iniciais de seu desenvolvimento, não havia referenciais normativos que orientassem a modelagem da informação para todo o ciclo de vida do ativo, o que foi suprido, ao longo do processo, pelas Normas britânicas PAS 1192-2:2013 - Specification for information management for the capital/delivery phase of construction projects using building information modelling (BSI, 2013), para a gestão da informação para a fase de construção de bens de capital, utilizando BIM e PAS1192:3 - Specification for information management for the operational phase of assets using building information modelling (BSI, 2014), que apresenta as especificações para a gestão da informação para a fase de operação de ativos, utilizando BIM. A partir de então, tornou-se mais fácil cobrar das equipes envolvidas, que observassem os requisitos determinados, uma vez que passaram a ter embasamento normativo para as 
exigências pertinentes ao empreendimento (TAYLOR, 2014b).

Todos os projetos e os documentos devem estar disponíveis em um ambiente comum, para o compartilhamento de informações. A respeito da importância do Banco de Dados, no contexto de modelagem da informação, Malcolm Taylor, Chefe de Informações Técnicas ${ }^{6}$ da Crossrail, eleva sua importância à equivalência da informação geométrica:

Modelos e bancos de dados são importantes em diferentes fases do ciclo de vida. Quando se constrói algo como a Crossrail, é necessário que se reconheça que os bancos de dados são tão importantes como os modelos em 3D - e, por isso, é necessário que sejam planejados ao mesmo tempo. (TAYLOR, 2014a, p.39, tradução nossa)

Dentre os benefícios obtidos pela implantação dos processos e das tecnologias de modelagem da informação, estão: diminuição de custos, redução do tempo de execução, menor número de interferências no canteiro, maior eficiência, redução da perda das informações, redução dos riscos, por meio de análise 4D, transferência dos modelos dos projetistas à equipe de execução e gestão de ativos eficiente, por meio da conexão entre os modelos e o Banco de Dados (TAYLOR, 2015).

\subsubsection{EXÉRCITO BRASILEIRO (EB)}

Um sistema de uso corporativo, dedicado à gestão patrimonial de todo o portfólio de ativos do Exército Brasileiro está em desenvolvimento, a cargo da Diretoria de Obras Militares (DOM) do Exército Brasileiro (EB). Desse modo, são atribuídas à DOM as atividades de construção, manutenção e conservação relacionadas às obras militares, bem como o controle dos materiais necessários ao desempenho destas funções (NASCIMENTO; LÜKE, 2012).

No Quadro 13, são apresentadas as informações referentes ao escopo do programa implantado pelo EB.

\footnotetext{
${ }^{6}$ Head of Technical Information.
} 
Quadro 13. Ficha técnica: Sistema OPUS

\begin{tabular}{|c|c|}
\hline Proprietário & Diretoria de Obras Militares do Exército Brasileiro \\
\hline País & Brasil. \\
\hline $\begin{array}{l}\text { Ano de implantação do } \\
\text { programa (EB, 2008). }\end{array}$ & 2006. \\
\hline $\begin{array}{l}\text { Objetivos buscados por meio da } \\
\text { implantação de recursos } \\
\text { tecnológicos para a modelagem } \\
\text { da informação (DOM, 2014) }\end{array}$ & $\begin{array}{l}\text { Consolidar um Banco de Dados para a gestão da infraestrutura, ao longo de } \\
\text { seu ciclo de vida que permita gerir os seguintes aspectos: logística, pessoal, } \\
\text { meio ambiente, patrimonial e mobilização. }\end{array}$ \\
\hline $\begin{array}{l}\text { Nível de MaturidadeBIM (RIBA, } \\
\text { 2012). }\end{array}$ & $\begin{array}{l}\text { Não se aplica à classificação sugerida pela BSI, uma vez que a informação do } \\
\text { ativo, ao longo de seu ciclo de vida, está disponível em rede. Mas, à época } \\
\text { dos levantamentos realizados para a presente pesquisa (2014) não foram } \\
\text { identificadas evidências da prática de processo de projeto integrado. }\end{array}$ \\
\hline Abrangência da iniciativa & Todo o portfólio de ativos do Exército Brasileiro. \\
\hline $\begin{array}{l}\text { Total de edificações (DOM, } \\
\text { 2014). }\end{array}$ & $\begin{array}{l}75.787 \text { benfeitorias (edificações), } 1.794 \text { imóveis, distribuídas em } 650 \\
\text { Organizações Militares. }\end{array}$ \\
\hline Área construída (DOM, 2014). & Aproximadamente, $18.630 .719 \mathrm{~m}^{2}\left(^{7}\right)$. \\
\hline
\end{tabular}

Fonte: Acervo da pesquisadora.

Por meio de um sistema denominado OPUS (Sistema Unificado de Processo de Obras), foi consolidado um sistema de gerenciamento de recursos públicos (government resource planning - GRP) para controle de obras e de ativos (DOM, 2015). Por meio de sua utilização, pretende-se modelar informações georreferenciadas, de modo que sejam consultadas para embasar decisões e tarefas quanto aos seguintes aspectos de gerenciamento: logístico, pessoal, meio ambiente, patrimonial e de mobilização (FERREIRA, 2009).

Sistema Unificado do Processo de Obras - OPUS é um Sistema informatizado de apoio à decisão que visa a suportar as funcionalidades de Planejamento, Programação, Acompanhamento, Fiscalização, Controle, Gerência e Execução de Obras e Serviços de Engenharia de todas as atividades dos

7 A área construída de benfeitorias e imóveis administrada pela DOM corresponde a, aproximadamente, $85 \%$ (oitenta e cinco por cento) da área do Estado de Sergipe. A área do Estado de Sergipe considerada para o cálculo é de $21.918 .493 \mathrm{~m}^{2}$ (vinte e um milhões, novecentos e dezoito mil, quatrocentos e noventa e três metros quadrados) (DOM, 2014). 
macroprocessos finalísticos do Sistema de obras Militares (SOM), tanto no nível executivo como gerencial e estratégico. (DOM, 2014)

A representação esquemática apresentada na Figura 36 destaca os aspectos contemplados pelo Sistema OPUS para a gestão dos ativos do Exército Brasileiro.

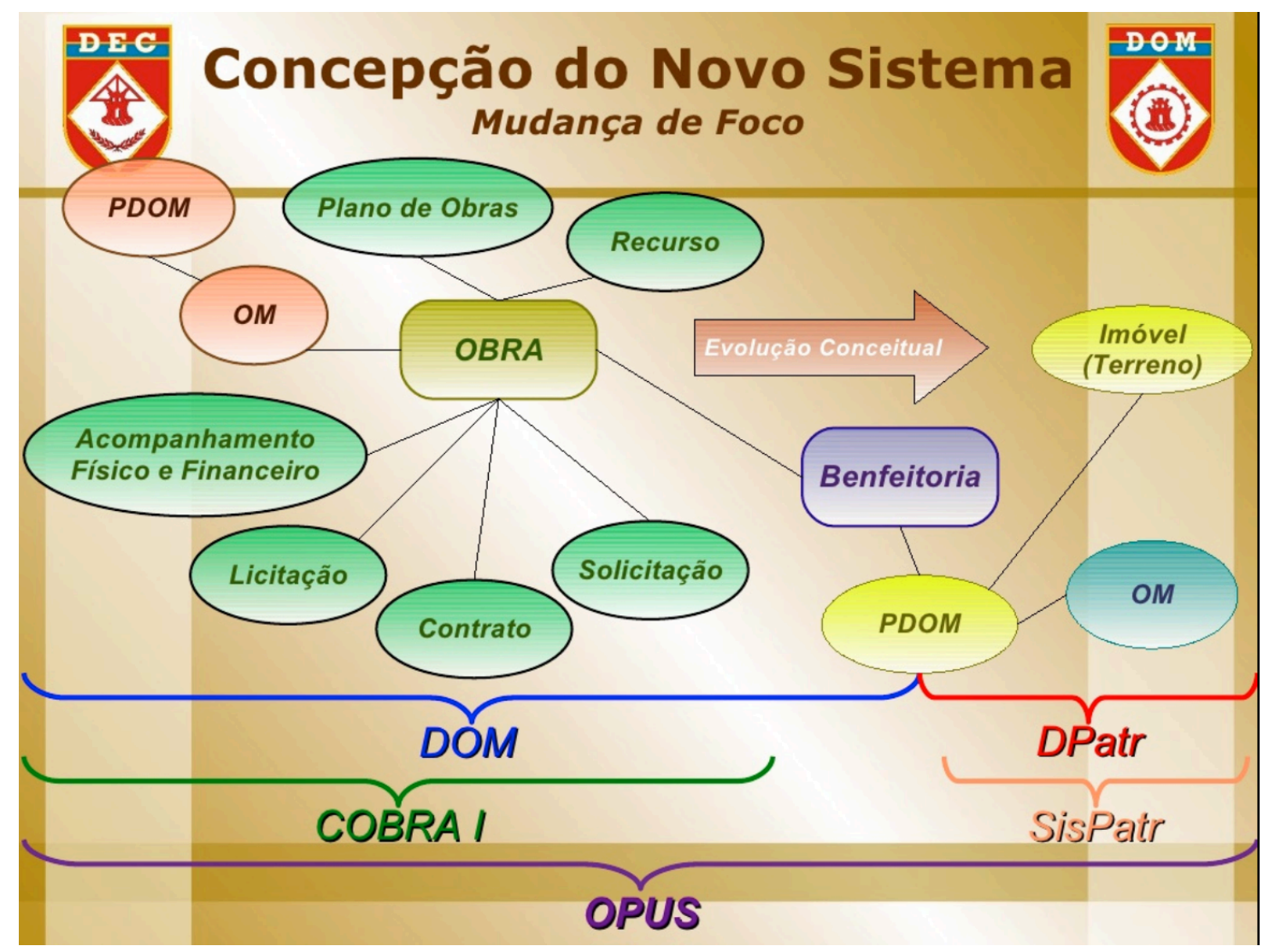

Legenda:

DOM - Diretoria de Obras Militares.

DPatr - Diretoria de Patrimônio.

PDOM - Plano Diretor de Organização Militar do Exército Brasileiro.

OM - Organizações Militares do Exército Brasileiro.

SisPatr - Sistema Gerencial de Acompanhamento e Controle Patrimonial do Exército Brasileiro.

DEC - Departamento de Engenharia e Construção do Exército Brasileiro.

Figura 36. Abrangência do OPUS

Fonte: FERREIRA (2009, p. 7).

Além de permitir gerenciar as atividades e embasar as decisões da DOM, a análise dos dados gerenciados é considerada para que sejam tomadas as decisões 
necessárias à elaboração do plano diretor da instituição (PDOM - Plano Diretor de Organização Militar do Exército Brasileiro). Na Figura 37, são representados os aspectos gerenciados por meio do sistema OPUS.

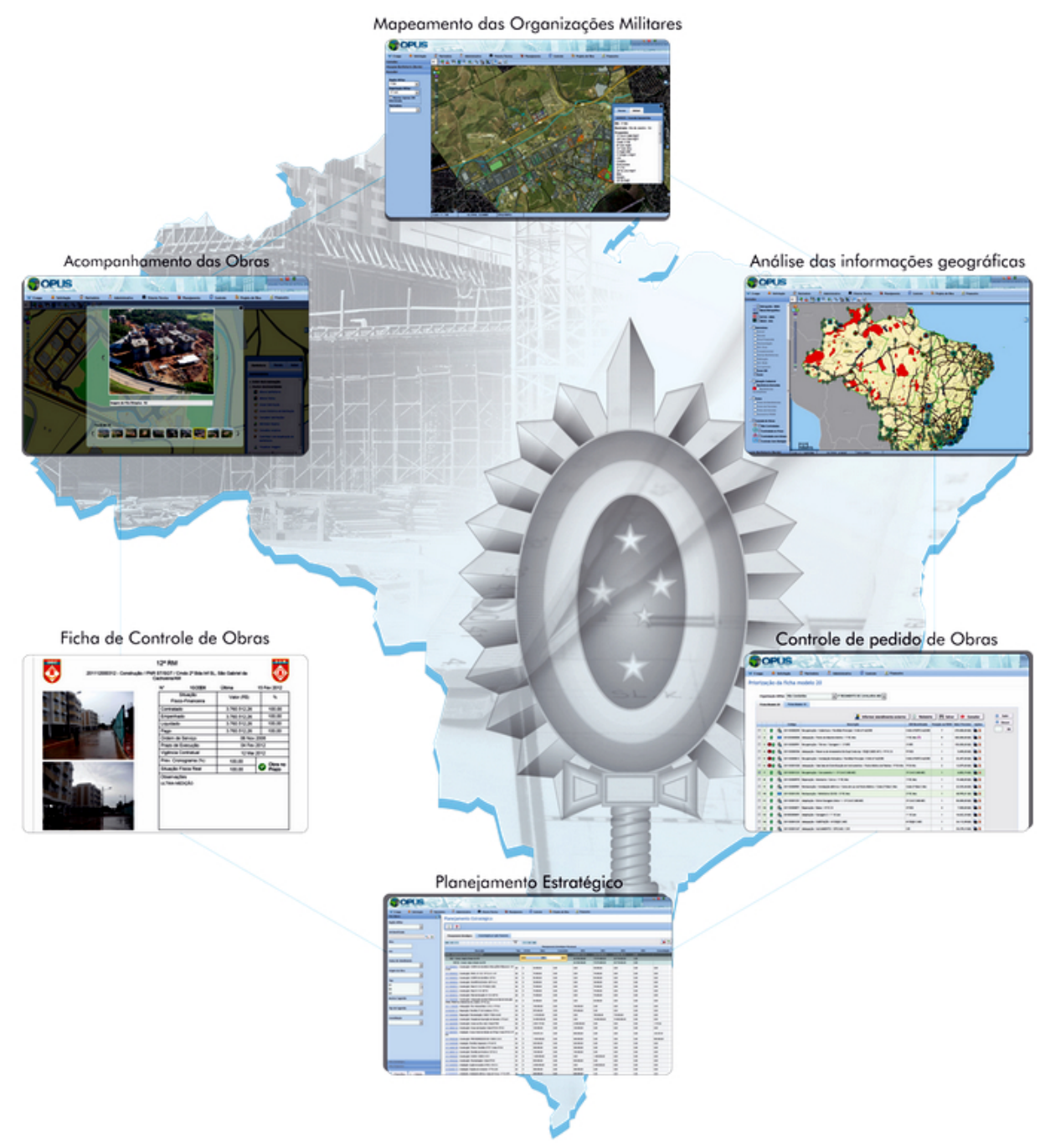

Figura 37. Aspectos gerenciados por meio do sistema OPUS

Fonte: Acervo da DOM do Exército Brasileiro. Disponível em: <http://www.dom.eb.mil.br/?page_id=312>. Acesso em 20 mai. 2015.

A Figura 38 corresponde a um exemplo de menu contendo informações para planejamento estratégico, que apresenta informações disponíveis no sistema, considerando os custos estimados de projeto e os recursos financeiros disponíveis em determinado período. 


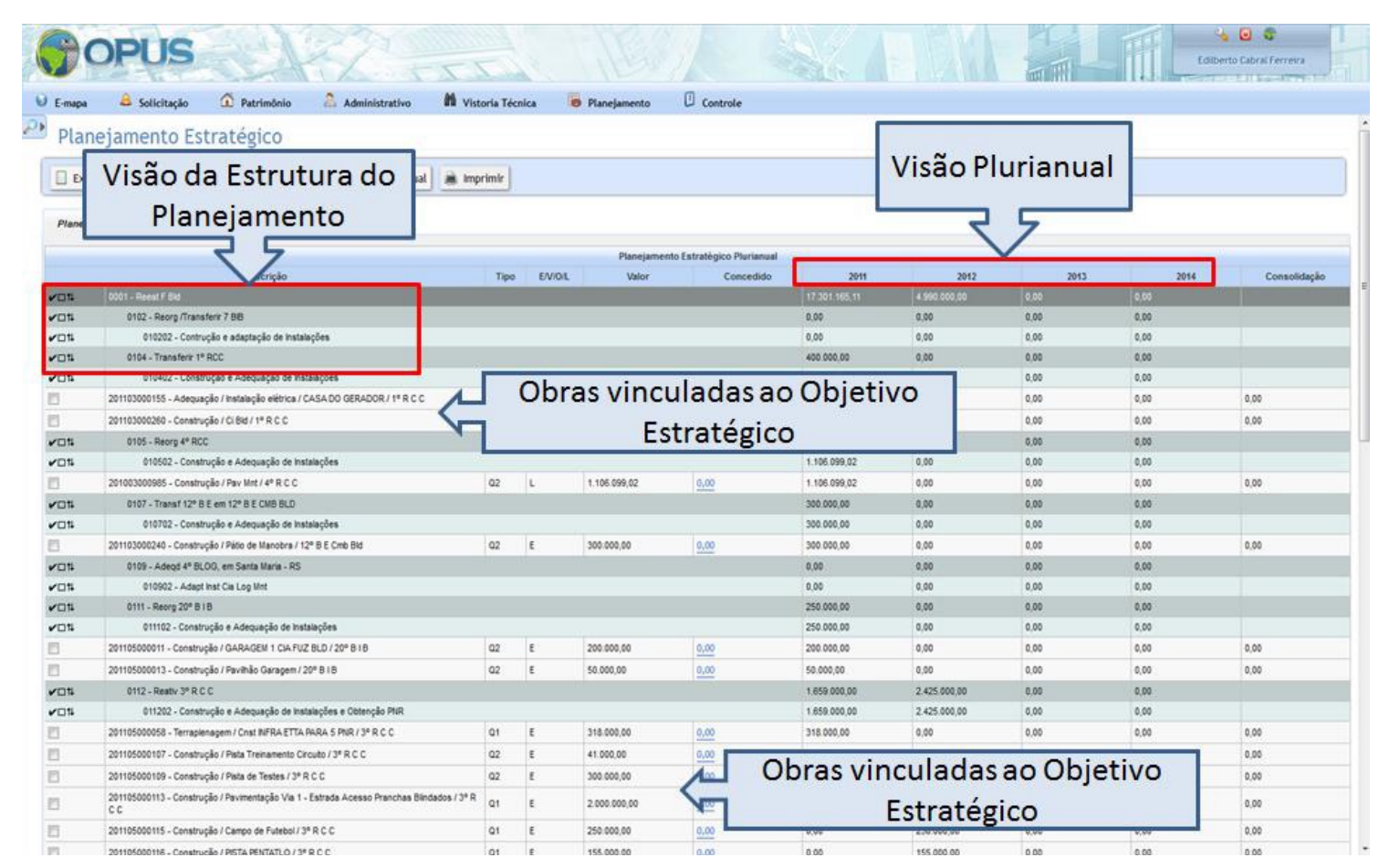

Figura 38. Interface do sistema OPUS para a elaboração de planejamento estratégico

Fonte: NASCIMENTO; LÜKE (2012, p. 35).

Para o geoprocessamento das informações, foram observadas as seguintes etapas (FERREIRA, 2009):

a) levantamento e catalogação - levantamento das plantas de situação de todos os ativos imobiliários do Exército Brasileiro, cujas informações podem estar em papel ou digitalizadas;

b) planejamento das tarefas de vetorização das plantas;

c) estruturação - conversão dos dados e geoprocessamento, de modo a permitir que as informações geométricas sejam vetorizadas;

d) revisão - auditoria das informações geométricas vetorizadas; e

e) migração de bancos - conversão e reagrupamento das informações em tabelas, de modo que estejam reagrupadas, conforme os requisitos do sistema OPUS.

A Figura 39 apresenta exemplos de diferentes níveis de informações objeto de gerenciamento pelo OPUS, que apresentam diferentes níveis, a saber: 
instalações, terreno e edificações.

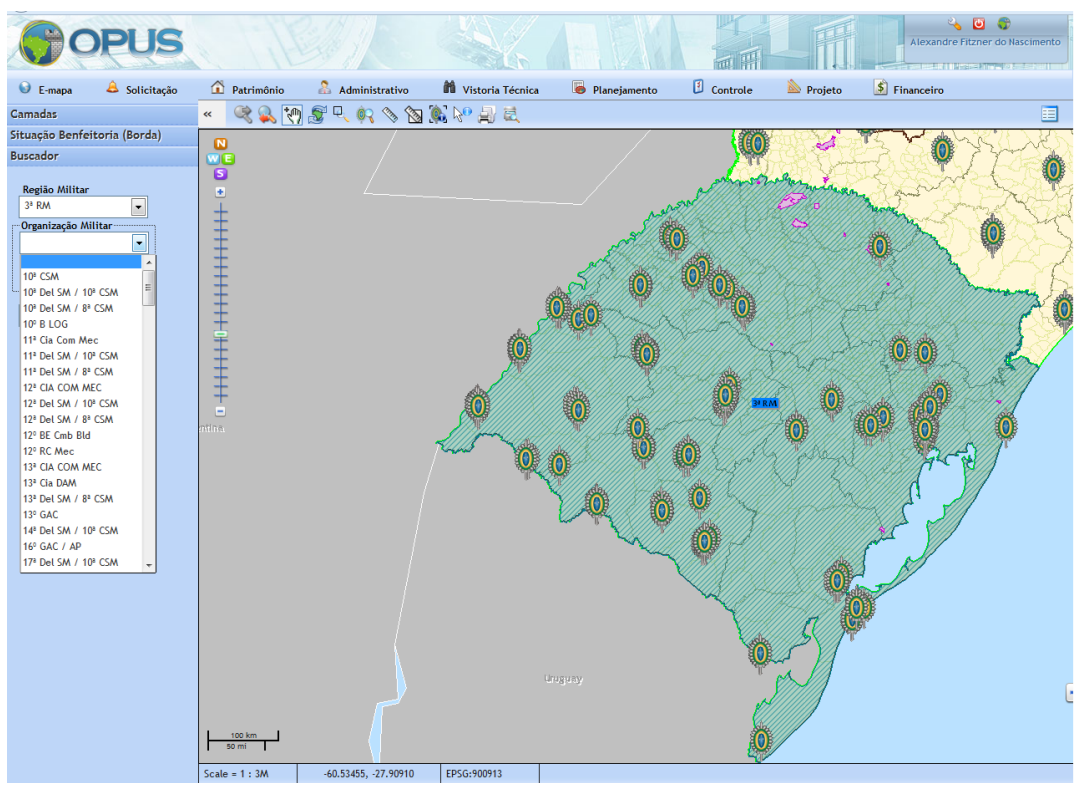

Figura 39. Exemplos de georreferenciamento de informações contempladas pelo sistema OPUS Fonte: NASCIMENTO; LÜKE (2012, pp. 13).

Um exemplo de informação modelada georreferenciada para o sistema pode ser verificado na Figura 40.

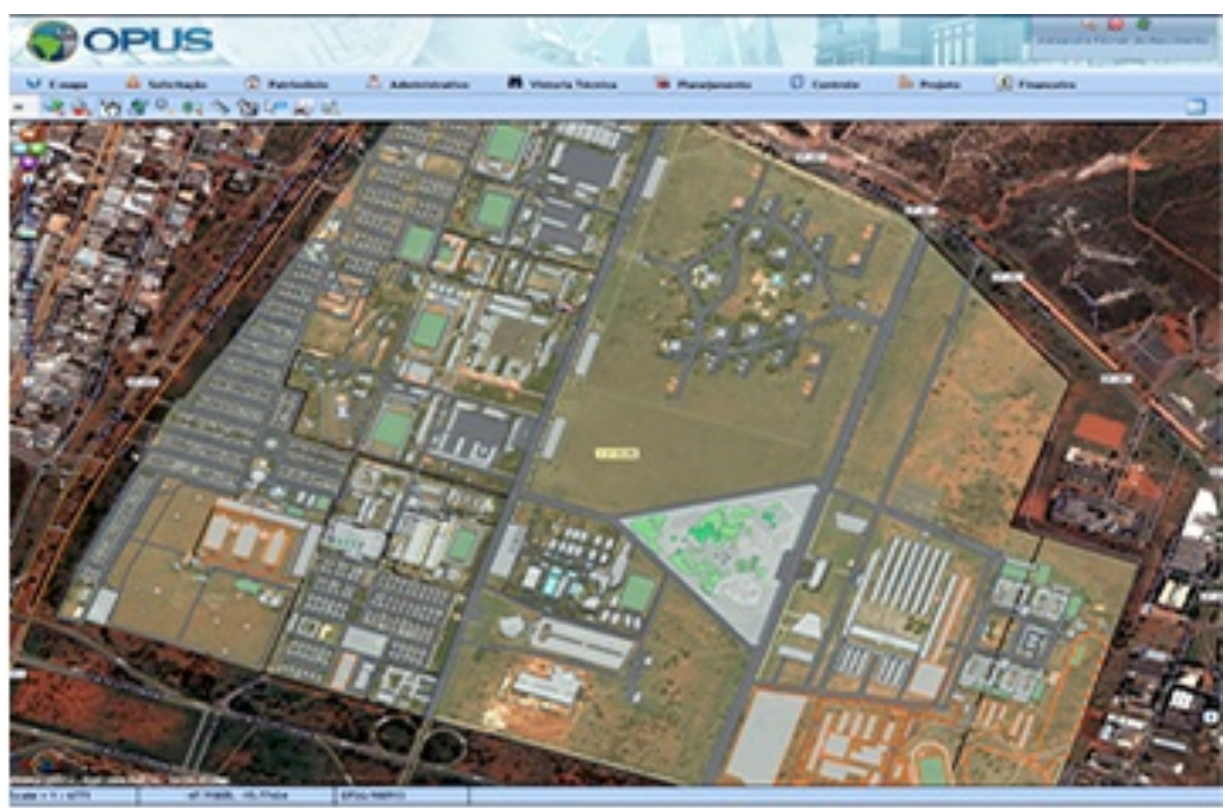

Figura 40. Exemplo de informação georreferenciada modelada no sistema OPUS Fonte: DOM (2014, p. 1). 
Os recursos para o monitoramento das obras no EB disponíveis no OPUS são exemplificados na Figura 41. Às edificações, estão relacionados os ativos ali localizados e as respectivas informações, tais como: especificação, custo e vida útil. Por meio do sistema, é possível gerar ordens de compra e de serviço, por exemplo.

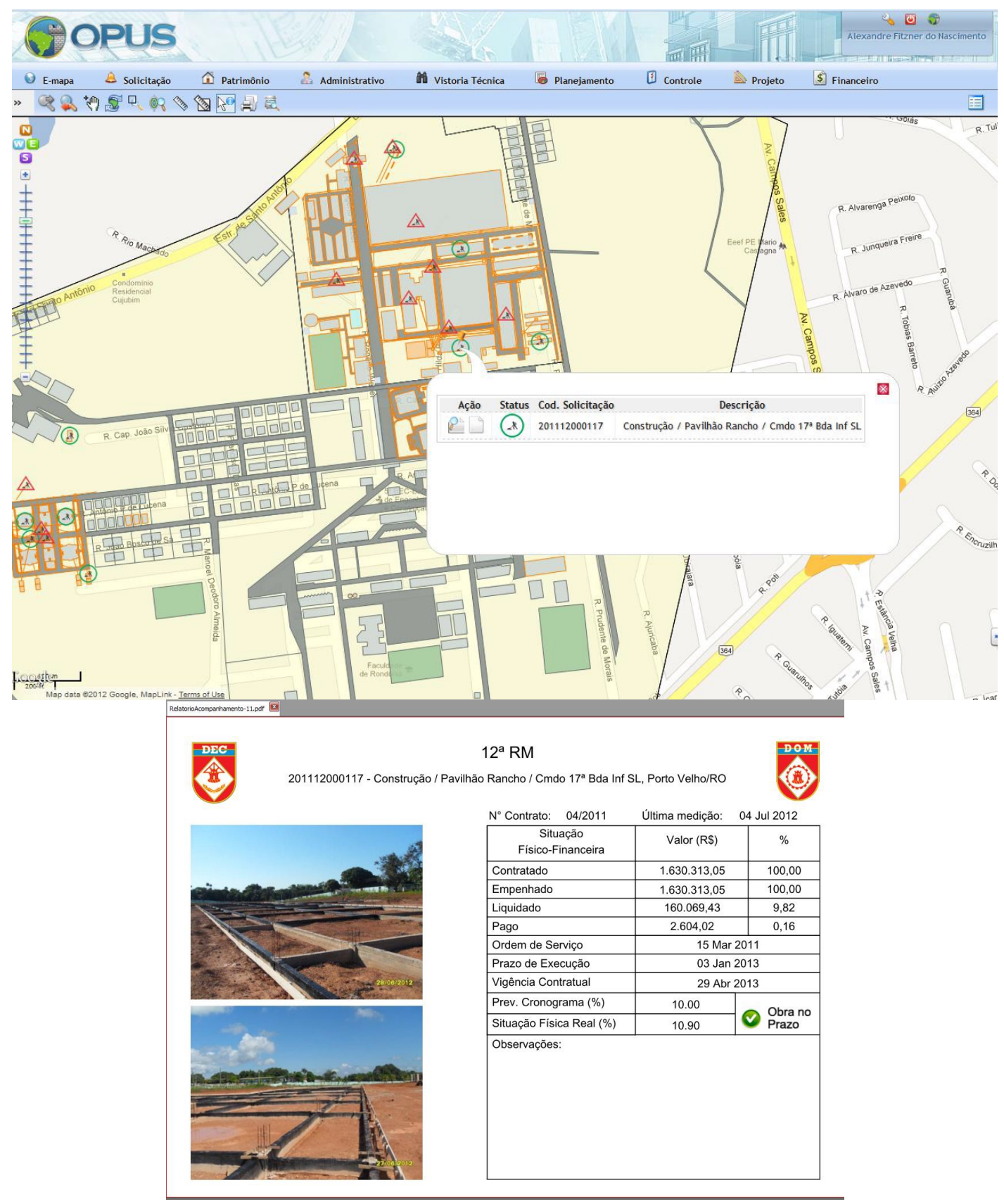

Figura 41. Exemplos de recursos para o monitoramento de obras - Sistema OPUS Fonte: NASCIMENTO; LÜKE (2012, pp. 26-27). 
Os projetos das novas edificações a serem contratados têm como requisito o desenvolvimento em tecnologia BIM. Pretende-se que as informações da construção geradas durante esses processos de projeto sejam gradualmente integradas ao Banco de Dados, de modo a consolidar um portfólio de ativos digitalizado.

\subsubsection{SEDE ADMINISTRATIVA DA UNIDADE OPERACIONAL DA BACIA} DE SANTOS (UO-BS) DA PETROBRÁS S. A.

O projeto da Sede administrativa da Unidade Operacional da Bacia de Santos (UO-BS) da Petrobrás S. A. foi idealizado em três torres, distribuídas por um terreno de $25 \mathrm{mil} \mathrm{m}^{2}$, situado em Santos, São Paulo. A ficha técnica do projeto é apresentada no Quadro 14.

\begin{tabular}{|c|c|}
\hline Proprietário & Petrobrás \\
\hline País & Brasil \\
\hline $\begin{array}{l}\text { Ano de implantação do programa } \\
\text { (MOTA, 2011) }\end{array}$ & 2007 (ano de elaboração do estudo de viabilidade do empreendimento). \\
\hline $\begin{array}{l}\text { Objetivos buscados por meio da } \\
\text { implantação de recursos tecnológicos } \\
\text { para a modelagem da informação } \\
\text { (MOTA, 2011) }\end{array}$ & $\begin{array}{l}\text { Aumento da qualidade dos projetos, integração das informações e } \\
\text { replicação de dados entre as fases do empreendimento (planejamento, } \\
\text { projeto, suprimento, construção e montagem e comissionamento), } \\
\text { automação de processos de engenharia, diminuição de custos de produção. }\end{array}$ \\
\hline Total de edificações (MOTA, 2012) & $\begin{array}{l}1 \text { (correspondente à Fase } 1 \text { do projeto, que prevê três torres no total). } \\
\text { Estão previstas } 3 \text { torres no terreno. }\end{array}$ \\
\hline $\begin{array}{l}\text { Área construída (MOTA, RODRIGUES, } \\
\text { 2012) }\end{array}$ & $\begin{array}{l}25.000 \mathrm{~m}^{2} \text { (Torre Norte). Estão previstas mais duas torres. Área total } \\
\text { prevista para o empreendimento: } 75.000 \mathrm{~m}^{2} \text {. }\end{array}$ \\
\hline
\end{tabular}

Fonte: Acervo da pesquisadora.

A empresa estatal exigiu o seguinte requisito, em seu edital de contratação:

A CONTRATADA deverá desenvolver o projeto executivo por meio de ferramentas de automação de projeto e da tecnologia BIM (Building Information Modeling), com a execução de um modelo 3D paramétrico, de todo o empreendimento, para a extração de documentos de projeto. (MOTA, 2011, p.12) 
Para o atendimento dos critérios de contratação, o escritório Contier Arquitetura, foi o responsável pelo projeto e elaborou um plano tecnológico para a modelagem da informação, cujas vistas tridimensionais são apresentadas na Figura 42. O processo de projeto foi formalizado de modo que fosse possível a prática do processo de projeto colaborativo. Seu desenvolvimento envolveu 26 disciplinas, que trabalharam em conjunto com a equipe de projeto de arquitetura. Durante 0 desenvolvimento de projeto, foram realizadas reuniões semanais para a validação a das soluções apresentadas pelas equipes envolvidas e solução dos aspectos críticos, relacionados às interferências entre os elementos construtivos ${ }^{8}$.
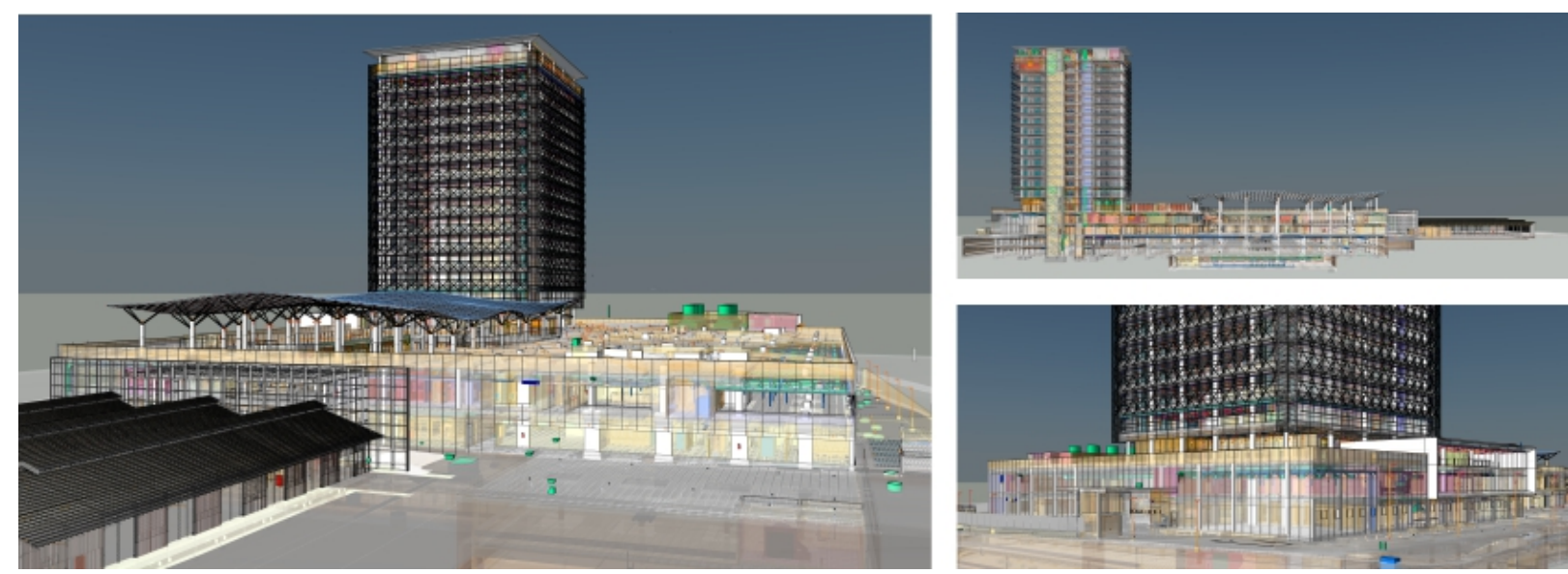

Figura 42. Vistas tridimensionais do modelo federado BIM da Sede Administrativa da UO-BS

Fonte: Acervo da Contier Arquitetura. Disponível em <http:// contier.com.br/edificios-comerciais/edificio-petrobras-sede-bacia-desantos>. Acesso em 01 mar. 2015.

Para que fosse possível atender à demanda quanto aos processos de projeto e considerando a complexidade e a quantidade das informações modeladas, foi necessário adaptar o conjunto de equipamentos a ser utilizado pela equipe de arquitetura para o projeto (CASTANHO, 2012).

A adoção da modelagem da informação para edificações foi uma decisão conveniente, uma vez que a modelagem de protótipos em 3D já é utilizada amplamente pela empresa na área industrial, e seus benefícios são reconhecidos para melhoria da qualidade dos projetos e para redução de riscos inerentes ao

8 Informação obtida por meio de entrevista concedida pelo Arquiteto Luiz Augusto Contier, em 1/9/2014. 
processo de produção ${ }^{9}$.

Exemplos da utilização pregressa da elaboração de modelos tridimensionais de projetos pela empresa, para outros usos que não a arquitetura e a engenharia civil, são apresentados na Figura 43.
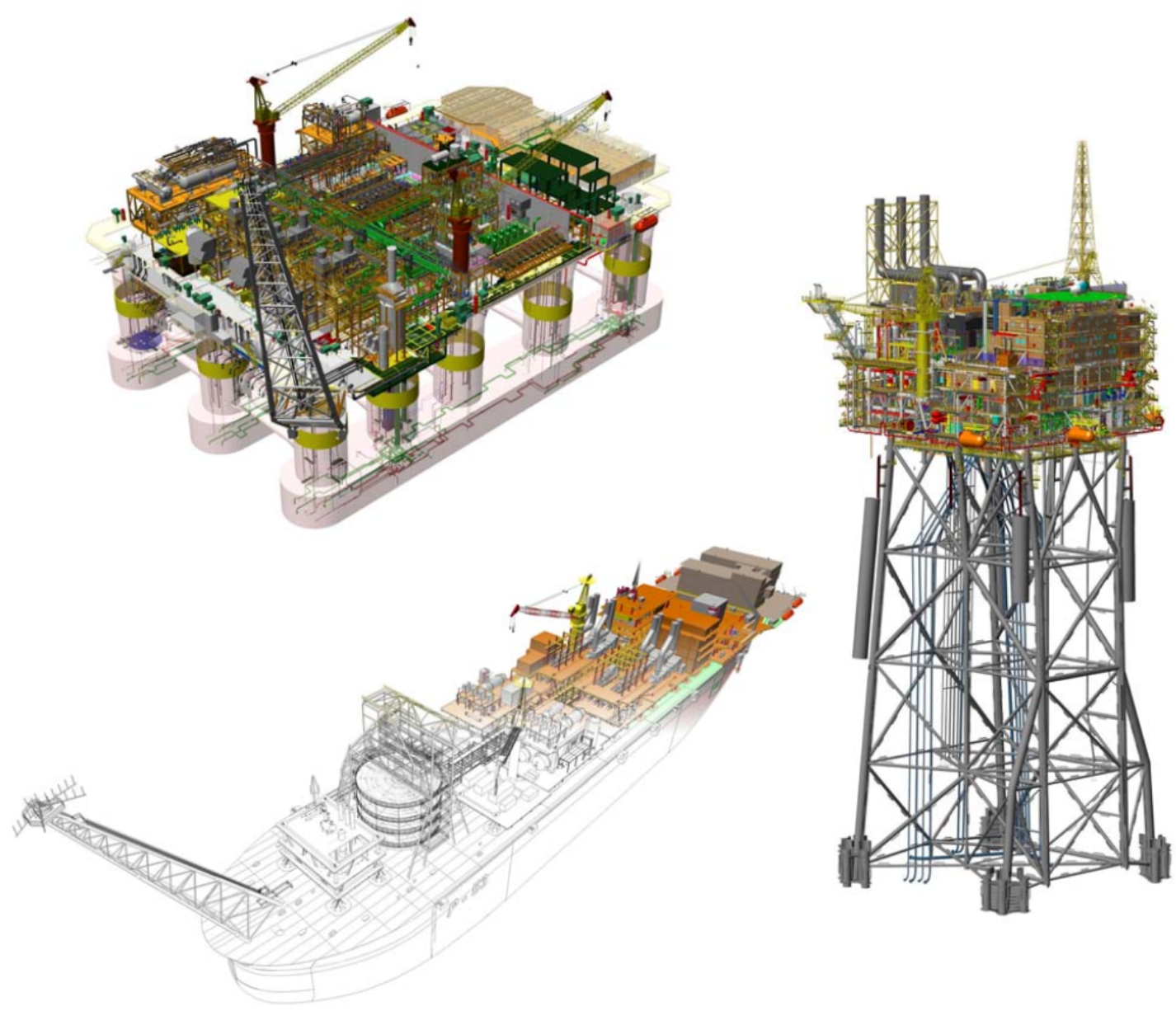

Figura 43. Exemplos de protótipos tridimensionais elaborados para projetos de instalações, plataformas e navios da Petrobrás S. A. Fonte: RODRIGUES (2011, p. 17).

$\mathrm{Na}$ Figura 44, o fluxograma proposto para a modelagem da informação é apresentado, considerando a congregação de todas as informações em um único modelo federado.

${ }^{9}$ Informação obtida por meio de entrevista concedida pelo Gerente Setorial de Projeto e Suprimento da Sede da UO-BS Marco Antonio de Nascimento da Mota, em $11 / 11 / 2014$. 


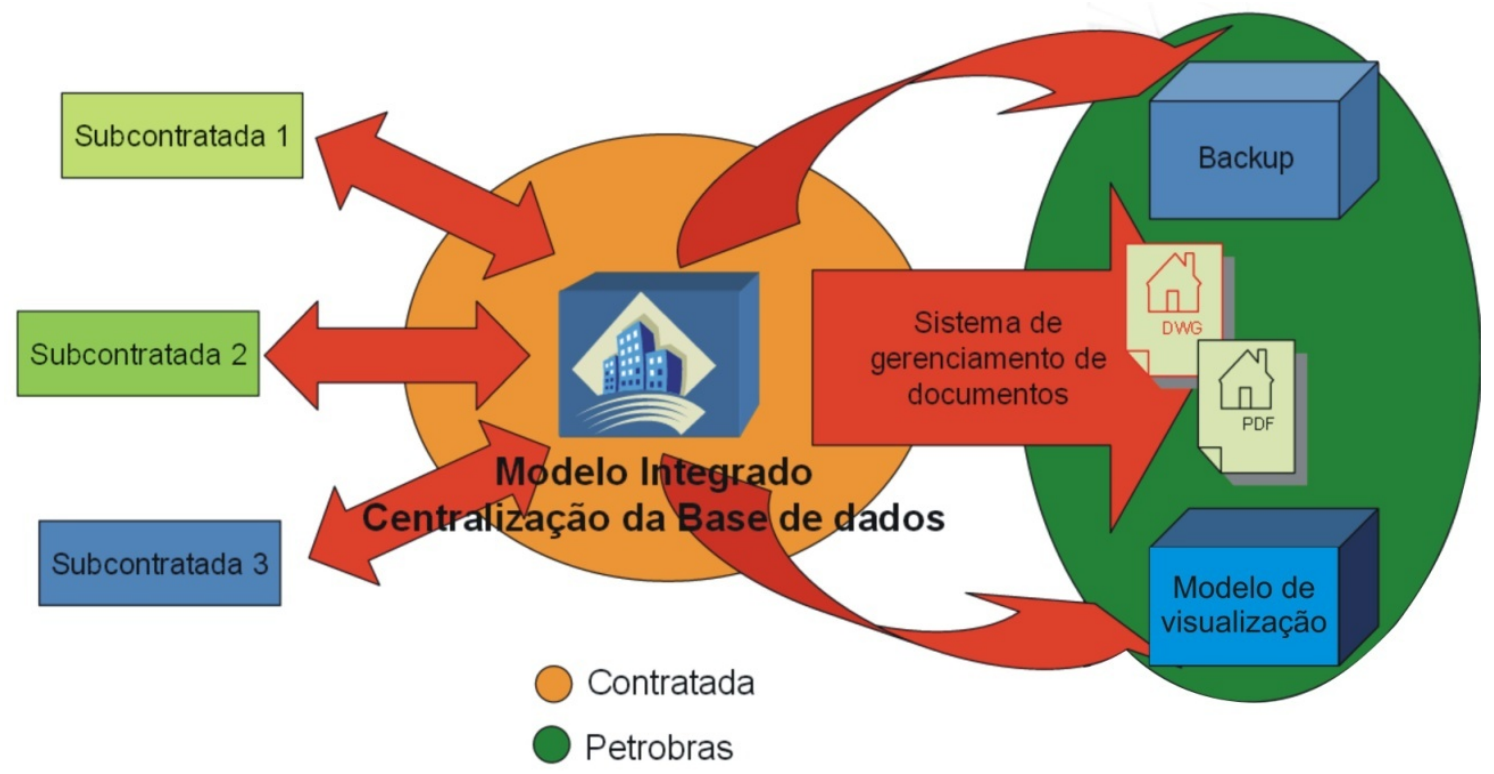

Figura 44. Fluxograma referente à modelagem da informação para o projeto da Sede Administrativa da UO-BS Fonte: MOTA (2011, p. 11).

Dentre os objetivos da implantação de processos de modelagem da informação, estava a possibilidade de integração de dados entre as fases de: planejamento, projeto, suprimento, construção, montagem e comissionamento dos sistemas, referentes ao empreendimento (RODRIGUES, 2011).

Detalhes dos sistemas prediais modelados, importados para um arquivo único, que inclui o projeto de arquitetura, de modo a constituir o modelo federado do projeto são apresentados na Figura 45.

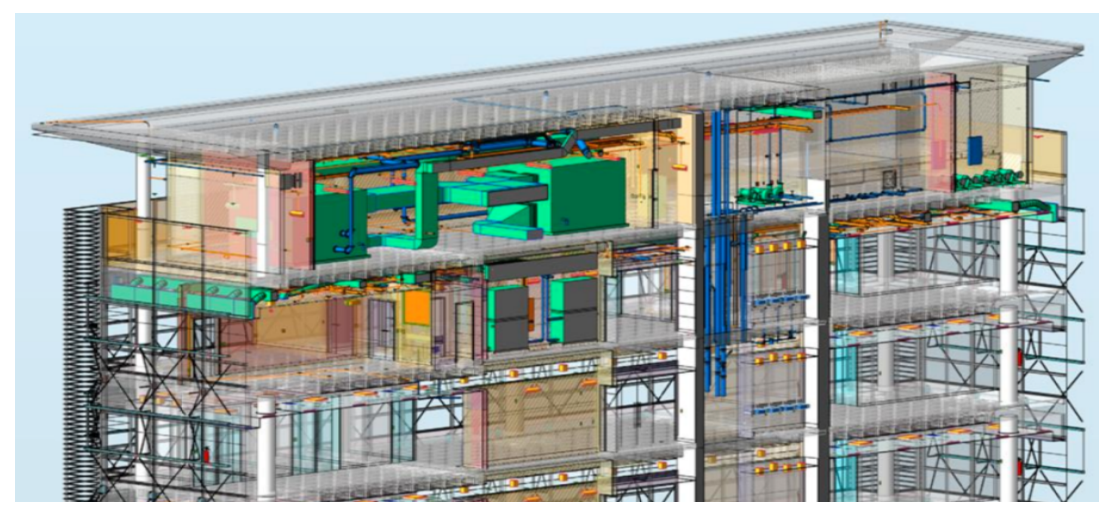

Figura 45. Detalhes de sistemas prediais modelados para o projeto da Sede Administrativa da UO-BS.

Fonte: CONTIER (2014, p. 32). 
Dentre os produtos obtidos pela adoção do processo de modelagem estão informações referentes a quantitativos e orçamentos, como é o caso do exemplo da lista de acabamentos apresentada na Figura 46.

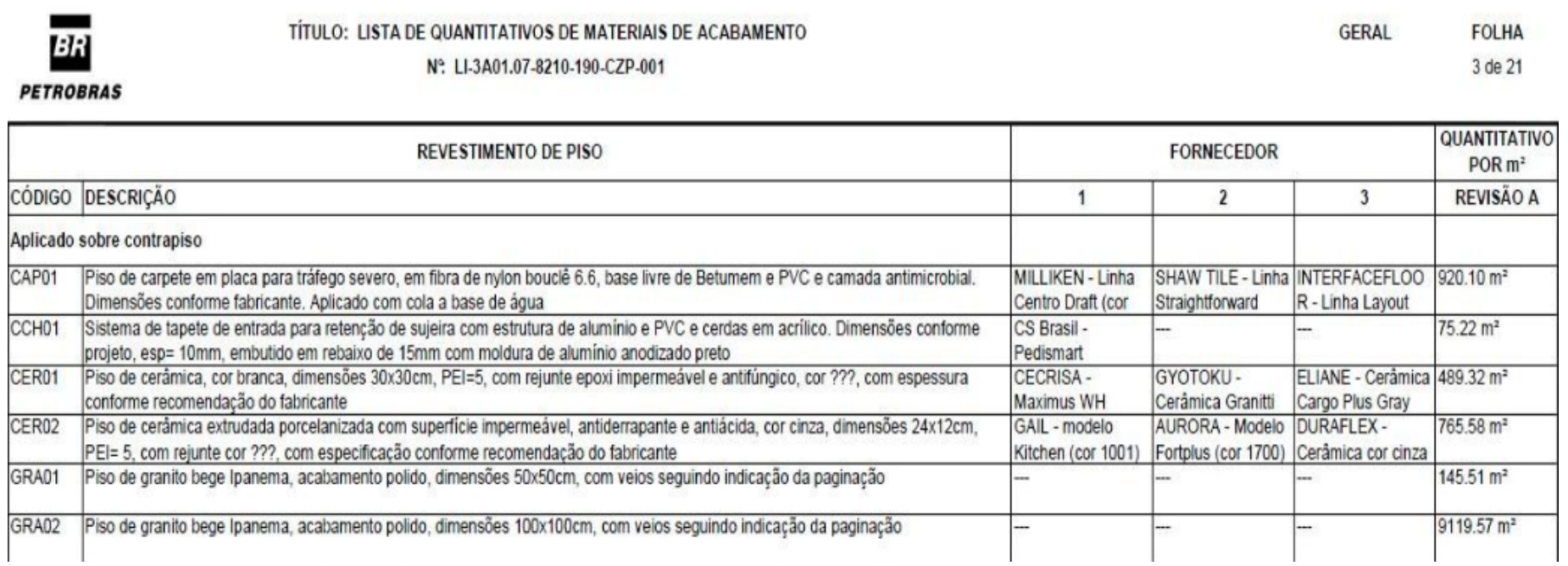

Figura 46. Exemplo de lista de material de acabamento

para o Projeto da Sede Administrativa da UO-BS, gerada por meio de tecnologia BIM Fonte: CONTIER (2014, p. 40).

Embora tenha sido demonstrado o desejo de integrar as informações modeladas para o projeto às tarefas de gestão de facilidades do empreendimento, durante os levantamentos elaborados para a presente pesquisa (2014), esse aspecto ainda não havia sido contemplado ${ }^{10}$.

${ }^{10}$ Informação obtida por meio de entrevista concedida pelo Gerente Setorial de Projeto e Suprimento da Sede da UO-BS Marco Antonio de Nascimento da Mota, em 11/11/2014. 


\subsubsection{CONSIDERAÇÕES SOBRE OS EXEMPLOS APRESENTADOS}

Nos processos adotados para os exemplos discutidos, as equipes utilizaram vários programas computacionais. Observou-se também que foram determinadas regras específicas de modelagem e de exportação de arquivos, com o objetivo de promover a interoperabilidade necessária aos processos.

No Quadro 15, é apresento um resumo dos principais programas computacionais identificados, bem como os usos pretendidos para a informação modelada, nos casos avaliados. 
Quadro 15. Principais programas para modelagem da informação utilizados nos processos dos exemplos apresentados.

\begin{tabular}{|c|c|c|c|c|}
\hline 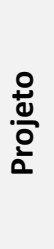 & 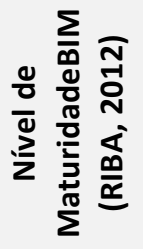 & $\begin{array}{l}\text { Principais programas } \\
\text { utilizados para a } \\
\text { modelagem da } \\
\text { informação }\end{array}$ & $\begin{array}{c}\text { Empresa } \\
\text { desenvolvedora }\end{array}$ & Usos \\
\hline \multirow{2}{*}{ 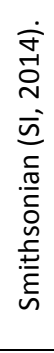 } & \multirow{2}{*}{$\dot{m}$} & Revit. & Autodesk. & $\begin{array}{l}\text { Elaboração de projetos de } \\
\text { arquitetura, estrutura e } \\
\text { instalações. }\end{array}$ \\
\hline & & Tririga. & IBM. & $\begin{array}{l}\text { Banco de dados e } \\
\text { gerenciamento de informações } \\
\text { referentes à gestão de } \\
\text { facilidades. }\end{array}$ \\
\hline \multirow{10}{*}{ 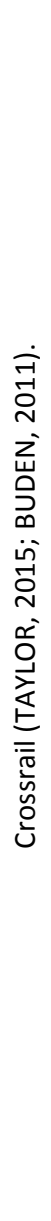 } & \multirow{10}{*}{ 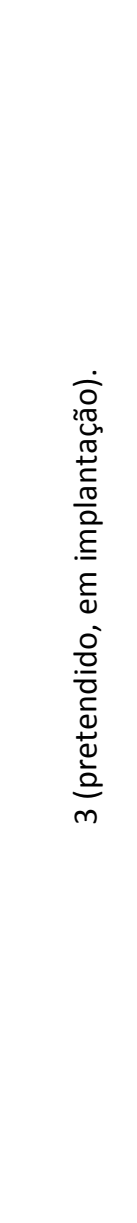 } & ArcGIS. & ESRI. & $\begin{array}{l}\text { Georreferenciamento de } \\
\text { informações. }\end{array}$ \\
\hline & & Bentley Maps. & Bentley. & $\begin{array}{l}\text { Georreferenciamento de } \\
\text { informações. }\end{array}$ \\
\hline & & Web GIS. & Bentley. & $\begin{array}{l}\text { Publicação em rede das } \\
\text { informações } \\
\text { georreferenciadas. }\end{array}$ \\
\hline & & AecoSim. & Bentley. & $\begin{array}{l}\text { Desenvolvimento de projetos } \\
\text { de arquitetura e de instalações. }\end{array}$ \\
\hline & & $\begin{array}{l}\text { eB Insight/AssetWise } \\
\text { (parte da plataforma } \\
\text { Asset Lifecycle } \\
\text { Information } \\
\text { Management -ALIM). }\end{array}$ & Bentley. & $\begin{array}{l}\text { Gestão de informações } \\
\text { referentes às soluções de } \\
\text { projeto, operações, } \\
\text { manutenção e mudanças, } \\
\text { durante o ciclo de vida do } \\
\text { ativo. }\end{array}$ \\
\hline & & ProjectWise. & Bentley. & Gestão de projetos. \\
\hline & & FME. & Safe Software. & $\begin{array}{l}\text { Extração e manipulação de } \\
\text { dados. }\end{array}$ \\
\hline & & SAP. & SAP SE. & ERP. \\
\hline & & Oracle Spatial. & IBM. & Banco de dados. \\
\hline & & MS Access. & Microsoft. & Banco de dados. \\
\hline
\end{tabular}

Continua... 
...continuação.

\begin{tabular}{|c|c|c|c|c|}
\hline$\frac{\stackrel{0}{*}}{\frac{0}{0}}$ & 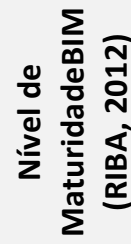 & $\begin{array}{c}\text { Principais } \\
\text { programas } \\
\text { utilizados para a } \\
\text { modelagem da } \\
\text { informação }\end{array}$ & $\begin{array}{c}\text { Empresa } \\
\text { desenvolvedora }\end{array}$ & Usos \\
\hline \multirow{5}{*}{ 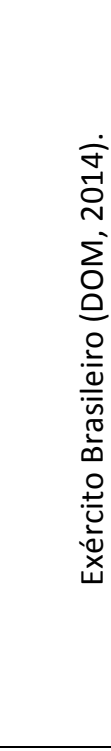 } & \multirow{5}{*}{$\begin{array}{l}* \\
\stackrel{*}{0} \\
.0 \\
0 \\
0 \\
0 \\
0 \\
n \\
0 \\
2 \pi \\
2\end{array}$} & Revit. & Autodesk. & $\begin{array}{l}\text { Elaboração de projetos de } \\
\text { arquitetura e de } \\
\text { instalações. }\end{array}$ \\
\hline & & Showcase. & Autodesk. & $\begin{array}{l}\text { Visualização do modelo } \\
\text { tridimensional. }\end{array}$ \\
\hline & & Navisworks & Autodesk. & Gestão. \\
\hline & & $\begin{array}{l}\text { Infrastructure } \\
\text { Modeler. }\end{array}$ & Autodesk. & $\begin{array}{l}\text { Elaboração de projetos de } \\
\text { infraestrutura. }\end{array}$ \\
\hline & & OPUS. & $\begin{array}{l}\text { Sistema } \\
\text { desenvolvido pela } \\
\text { DOM para uso } \\
\text { específico no } \\
\text { âmbito do EB (EB, } \\
\text { 2008). }\end{array}$ & $\begin{array}{l}\text { Armazenamento de dados } \\
\text { para a gestão dos ativos } \\
\text { do EB. }\end{array}$ \\
\hline \multirow{8}{*}{ 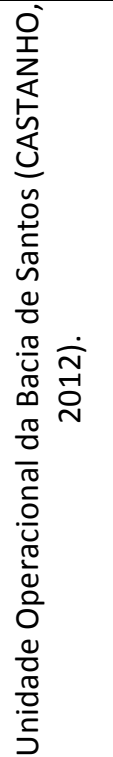 } & \multirow{8}{*}{$\sim$} & $\begin{array}{l}\text { Revit Server } \\
\text { (Windows } \\
\text { Server). }\end{array}$ & $\begin{array}{l}\text { Autodesk/ } \\
\text { Microsoft. }\end{array}$ & Servidor de arquivos. \\
\hline & & $\begin{array}{l}\text { Revit } \\
\text { Architecture. }\end{array}$ & Autodesk. & Arquitetura. \\
\hline & & Navisworks. & Autodesk. & Gestão de projeto. \\
\hline & & TQS. & TQS Informática. & Estrutura de concreto. \\
\hline & & Revit Structural. & Autodesk. & Estrutura metálica. \\
\hline & & Tekla Structures. & Tekla. & Estrutura metálica. \\
\hline & & Sofstik. & Sofstik AG. & Estrutura. \\
\hline & & Revit MEP. & Autodesk. & Instalações. \\
\hline
\end{tabular}

Fonte: Acervo da pesquisadora.

* No caso do Exército Brasileiro, embora o sistema adotado permita a gestão de ativos e a informação seja georreferenciada, não foram identificadas evidências, à época da realização dos levantamentos (2014) da prática de processo de projeto integrado, não sendo possível, portanto, classificar este projeto, conforme os Níveis de Maturidade preconizados pela RIBA (RIBA, 2012). 
Considerando os exemplos apresentados, foi possível apreender a relevância das ações do Estado para o desenvolvimento tecnológico, em razão das dimensões e da relevância de seu portfólio de ativos, tanto no que tange ao montante financeiro empregado como para a mobilização dos fornecedores da indústria da construção civil. Nos quatro casos avaliados, as iniciativas estatais desempenharam um importante papel, como impulsionadoras do desenvolvimento de novas tecnologias para a gestão da informação. Além disso, verificou-se que as instituições governamentais responsáveis pelos projetos atuaram como agentes reguladores, no desenvolvimento de diretrizes e normas que regulamentassem os processos propostos.

$\mathrm{Na}$ indústria da construção civil, o impacto destas iniciativas foi um catalisador, que tornou possível a consolidação dos recursos necessários à aplicação dos processos de gestão da informação de ativos a portfólios de empresas privadas.

São aspectos comuns aos exemplos avaliados:

- múltiplos ativos geridos pela entidade;

- compromisso com o desempenho quando em uso;

- compromisso com o custo quando em uso;

- controle das atividades de operação e manutenção; e

- necessidade de localização e quantificação dos componentes e elementos construtivos.

Portanto, destacam-se ações nas esferas públicas e privadas, que criam um ambiente propício para a adoção da modelagem da informação em escala. $\mathrm{Na}$ esfera pública, o Estado surge como regulador de diretrizes e como criador de oportunidades de negócio. Na esfera privada, nota-se a mobilização de importantes atores da indústria da construção para o desenvolvimento de tecnologias, no sentido de desenvolver e promover as características de interoperabilidade entre os sistemas, necessárias à gestão da informação, ao longo do ciclo de vida do ativo. 


\section{MODELAGEM DA INFORMAÇÃO APLICADA AO ESTUDO DE} CASO

Com base na revisão bibliográfica e na avaliação do estado da arte elaborados, foi possível apreender que as edificações geridas pela organização objeto de estudo podem se beneficiar da implantação de processos sistematizados embasados por recursos tecnológicos, conforme foi apresentado nos Capítulos 3, 4 e 5 .

Além disso, considerando as experiências e os exemplos apresentados no Capítulo 6, verificou-se que a abordagem que considera a gestão integrada dos ativos de um portfólio, utilizando recursos para a modelagem da informação, não só é factível, como também vem se disseminando, gradualmente. Desta forma, é proposta uma alternativa de modelagem de processos e da informação, para a aplicação ao estudo de caso determinado.

Entretanto, para a adoção dos recursos da TI às fases do ciclo de vida de uma edificação, torna-se fundamental rever os processos e práticas a ela relacionados, de modo a instituir um sistema de gestão da informação eficiente, que permita padronizar atividades e procedimentos, bem como evitar a redundância de informações (NASCIMENTO; SANTOS, 2003).

Especificamente, no caso das escolas públicas paulistas, a discussão referente à adoção de recursos tecnológicos para um melhor controle da qualidade de edificações escolares vem sendo objeto de reflexão em pesquisas científicas.

Dentre elas, pode-se citar Graça (2008) que propõe uma metodologia para a avaliação das soluções de projeto determinadas às escolas estaduais paulistas, considerando os aspectos de conforto térmico (localização dos ambientes e sua exposição aos raios solares, circulação de ar), de conforto acústico (disposição de ambientes, com o intuito de amenizar ruídos e uso proposto), de conforto visual (disposição das aberturas) e de conforto funcional (fluxos, acesso a rampas, relacionamento entre ambientes, definição de leiautes). Também são consideradas características da estrutura (pé-direito e espaçamento de vãos), e das instalações (localização de bocais de tubulações e prumadas de sanitários) e propriedades, tais como a localização da edificação, sua implantação, o tamanho do terreno e a 
disposição dos ambientes.

Por sua vez, Kowaltowski (2011) sugere que um conjunto de decisões de projeto deve ser tomado considerando os desempenhos pretendidos, de modo a embasar as decisões de projeto, relacionadas ao conforto ambiental e à funcionalidade. A pesquisadora salienta também que o armazenamento de dados referentes ao desempenho de edificações escolares pode contribuir para a concepção de escolas de melhor qualidade.

Sendo assim, propõe-se uma abordagem dinâmica para a modelagem de informações referentes aos materiais e sistemas construtivos e ambientes, por meio da aplicação da modelagem da informação.

Também é aspecto importante do processo proposto a elaboração de simulações, com base no modelo elaborado, as quais possibilitam a verificação prévia do desempenho da edificação.

Finalmente, considera-se a análise crítica dos resultados obtidos, à luz do conhecimento documentado e organizado, por meio da aplicação de APOs a edificações com características construtivas e de uso similares. Pretende-se, assim, permitir a identificação e a correção dos aspectos críticos ainda na fase de projeto. A consulta ao conhecimento pregresso é importante no contexto do processo de modelagem da informação em edificações de tipologia padronizada, pois pode contribuir para redução dos custos das alterações, conforme pode ser observado na representação dos esforços relacionados ao processo de projeto, de acordo com o apresentado na Figura 47. 


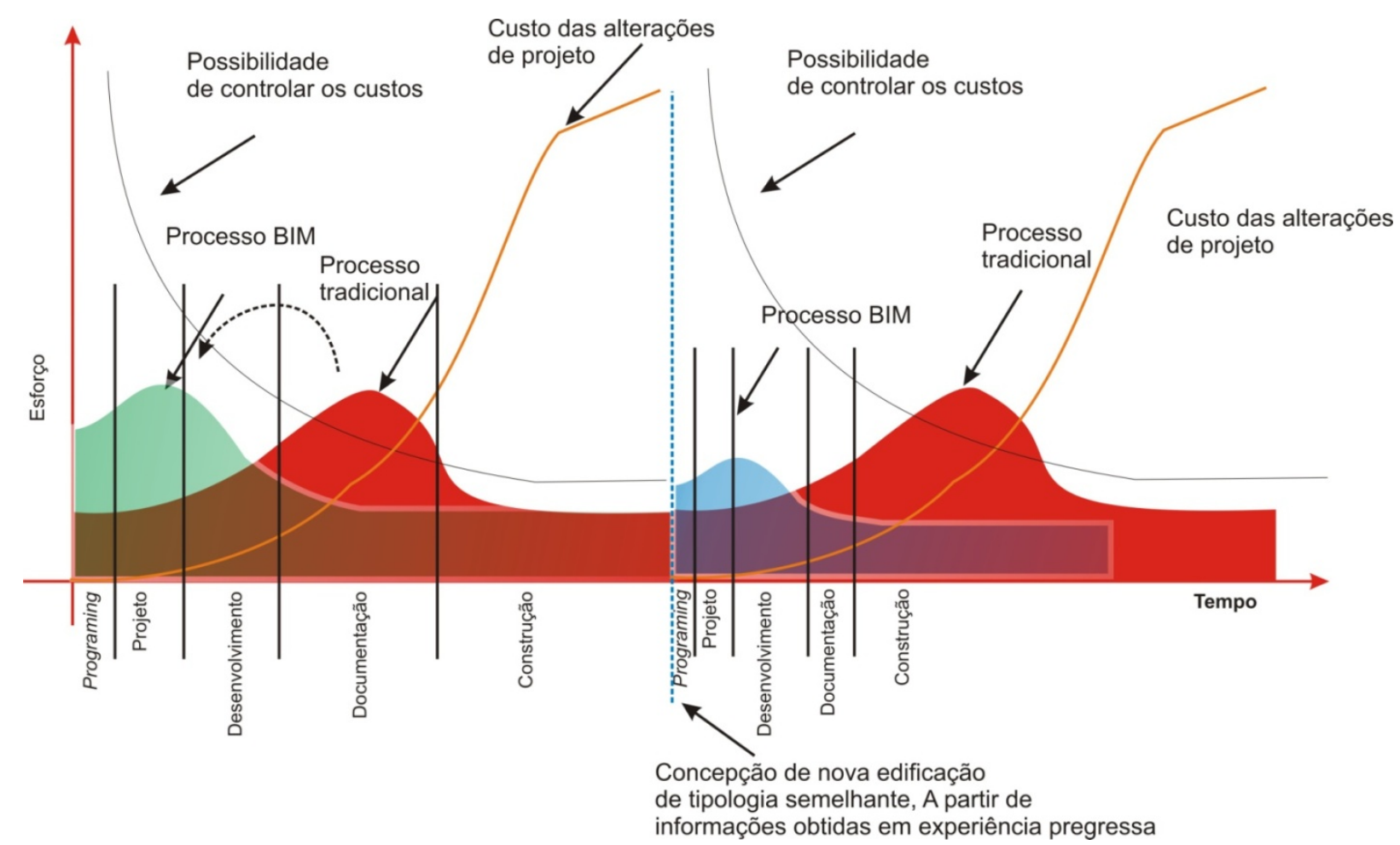

Figura 47. Esforços relacionados aos processos de projeto tradicional e BIM considerando a repetição de projetos de tipologia semelhante Fonte: Adaptado, pela pesquisadora, de HOK apud ASHRAE (2009, p. 9).

A padronização dos procedimentos e dos critérios para a transferência das informações da construção faz-se fundamental, quando da análise objetiva dos resultados de desempenho obtidos para o conjunto de edifícios objeto de estudo. Considerando-se que incorporam elementos construtivos industrializados e que compartilham de tipologia e programa de necessidades padronizados (FRANÇA, 2011), estas edificações podem ser beneficiadas pela incorporação das ferramentas da TI apresentadas.

Dessa forma, o processo proposto pode contribuir para o incremento da qualidade do projeto e da obra, bem como para a obtenção de melhores resultados quanto ao desempenho do ambiente construído, considerando, por exemplo, aspectos de conforto ambiental e eficiência energética (FRANÇA; ORNSTEIN, 2010a) e de operação e manutenção (FRANÇA; ORNSTEIN, 2010b). 
7.1 PROPOSIÇÃO DE UM PROCESSO PARA A GESTÃO DA INFORMAÇÃO EM EDIFICAÇÕES DE TIPOLOGIA PADRONIZADA

Com base na análise das boas práticas para a gestão da informação, é proposta uma metodologia, como objetivo de formalizar o processo de melhoria contínua do projeto, considerando a participação dos muitos atores envolvidos, tais como: projetistas, construtores, gestores e usuários (FABRICIO, 2002).

É fundamental que sejam também adotadas iniciativas para promover a gestão da qualidade e desempenho real de edificações, de modo a incorporar, efetivamente, resultados de avaliações e auditorias aplicadas a edificações em uso (FRANÇA; ORNSTEIN; ONO, 2011).

Para que os resultados aferidos possam ser efetivamente incorporados, na forma de recomendações para novos projetos ou para proposição de uma eventual requalificação da edificação, é importante que a apresentação do diagnóstico seja feita de modo sistemático (ORNSTEIN et al., 2009; ORNSTEIN; ONO, 2010).

Dados esses aspectos, é proposto um processo para a concepção, implantação, avaliação e realimentação de informações referentes à construção e ao uso de edificações.

Manzione et al. (2011a) destacam a importância de que sejam definidos os meios de comunicação e as regras quanto à comunicação entre os atores envolvidos em um projeto, sob pena de que seja perdida a eficiência do processo e a confiabilidade das informações compartilhadas.

Para a consolidação do processo de modelagem da informação, são consideradas as seguintes classes da construção e suas relações, a saber:

- espaços;

- resultados,

- processos,

- recursos,

- propriedades e características; e

- informações. 
O modelo proposto é apresentado na Figura 48, no qual são previstas: a representação digital, a simulação computacional e a modelagem das informações da construção e da operação.

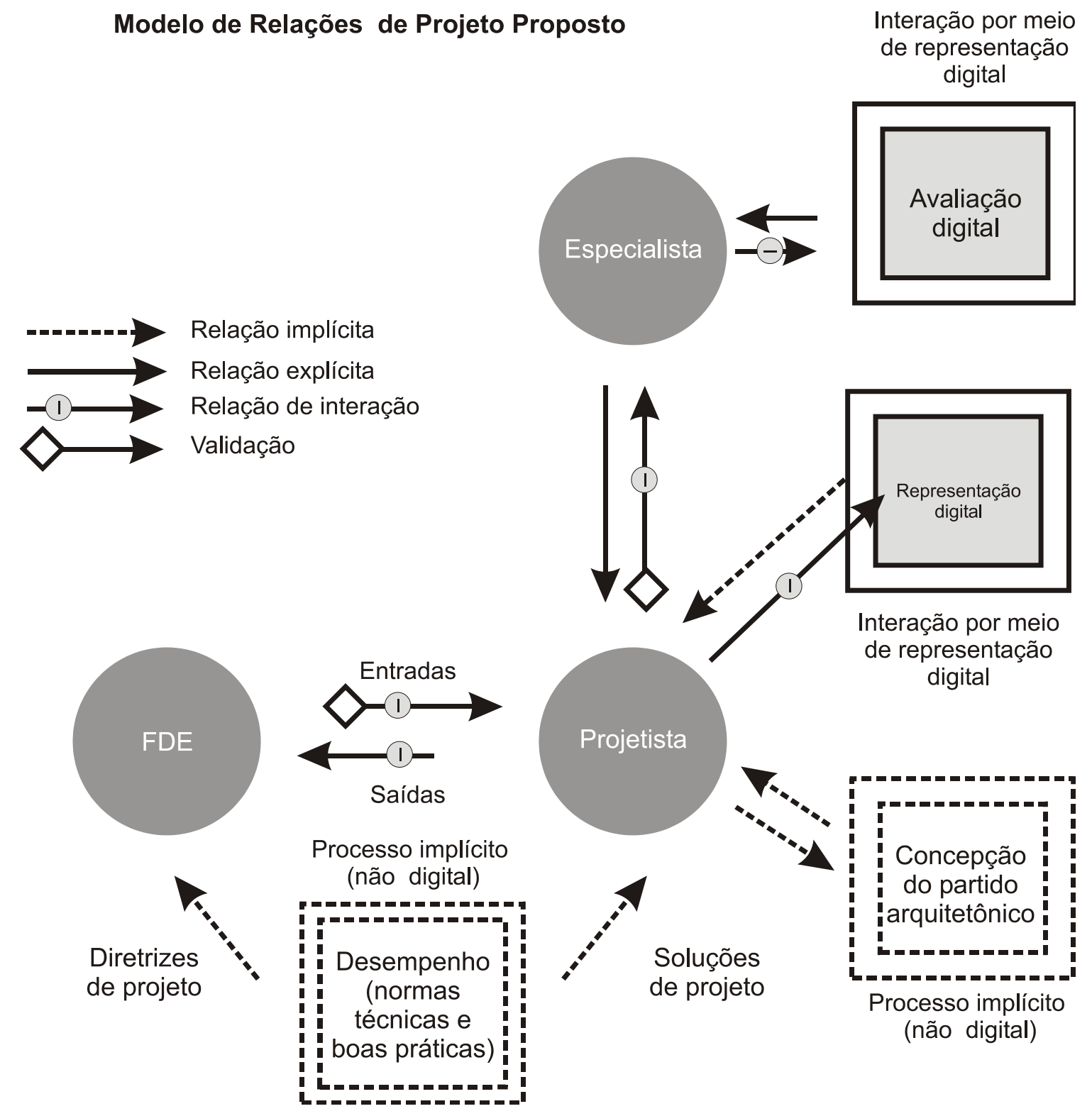

Figura 48. Modelo de relações entre as etapas do processo de projeto proposto. Fonte: Acervo da pesquisadora (baseado em: OXMAN (2006).

Para sua formalização, foi proposto um fluxograma para a representação gráfica sequencial e analítica das tarefas, atores e produtos envolvidos no processo. Esta forma de apresentação permite a identificação das entradas e saídas, modo de documentação, análise e sequência de operações. Para que um projeto atenda aos 
requisitos e às necessidades de seus usuários, é preciso que as informações nele constantes estejam adequadamente qualificadas, representadas e comunicadas.

O fluxograma de processo pretende descrever todas as atividades que fazem parte do processo de um determinado negócio, de modo a embasar a gestão da qualidade. Para sua modelagem, as atividades envolvidas, os responsáveis, os requisitos necessários e os produtos esperados para cada tarefa são destacados em uma sequência lógica (OLIVEIRA, 2013).

A formalização das tarefas permite auditar o processo, avaliar o desempenho de cada etapa, bem como embasar a sugestão de alterações visando à melhoria contínua.

Para a representação do fluxograma proposto, foi usada a notação BPMN, adotada como boa prática pela entidade buildingSMART para a formalização dos processos relacionados às propriedades da Industry Foundation Classes (WIX, 2007; OMG, 2011; BERARD; KARLSHOEJ, 2012). Para a representação do fluxograma, foram incorporados à notação adotada símbolos para a consulta e gravação de informações no banco de dados, conforme os símbolos apresentados na Figura 49. Deste modo, pretende-se padronizar a informação, de modo que todos os atores envolvidos no processo compreendam as tarefas, as responsabilidades e os produtos abordados no processo. 

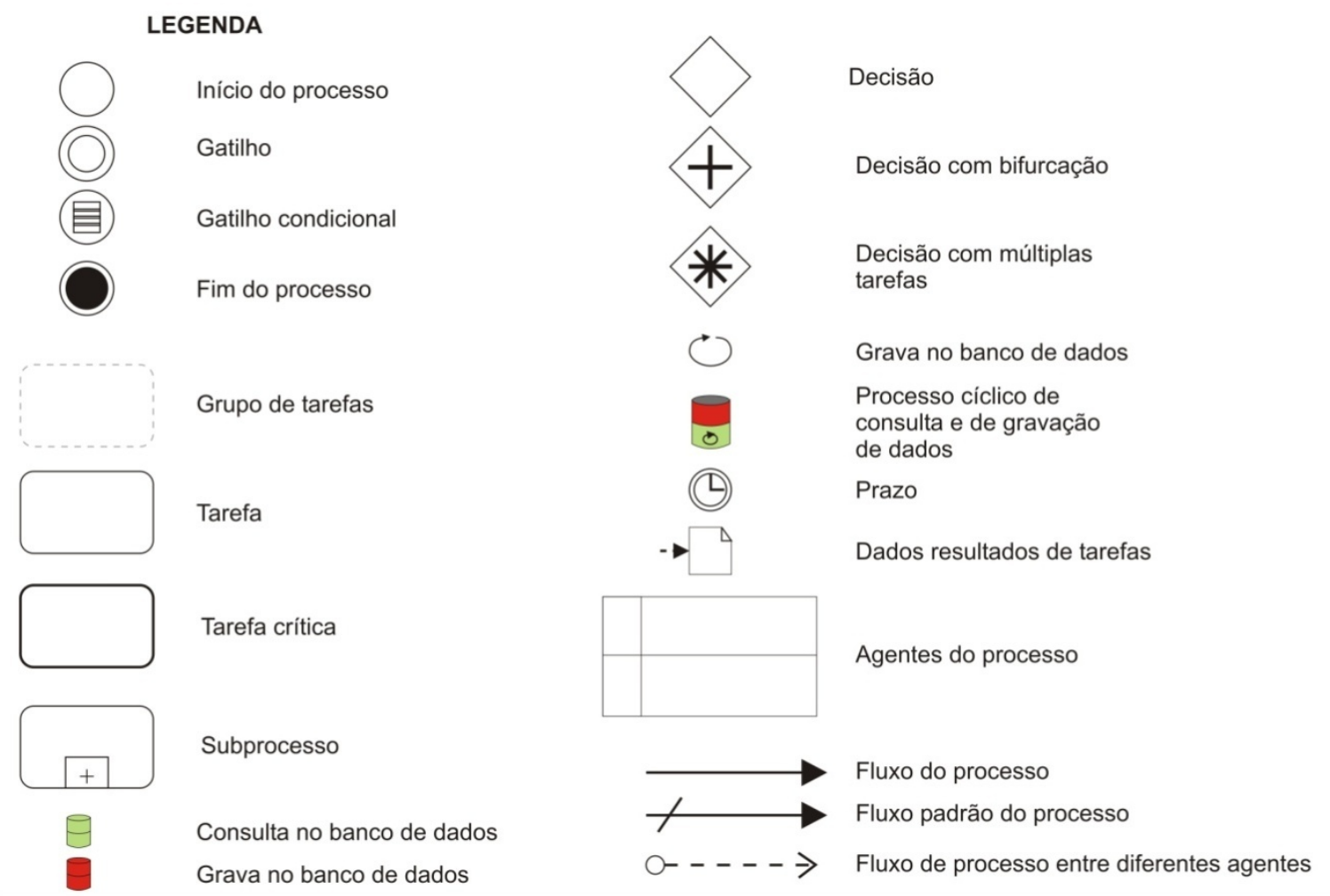

Figura 49. Símbolos para a elaboração de fluxogramas

Fonte: Acervo da pesquisadora. Adaptado de BPMN (2004).

$\mathrm{Na}$ Figura 50, é apresentada uma representação simplificada dos principais aspectos relacionados ao ambiente construído, correspondentes a todo seu ciclo de vida. Usualmente, há fases atribuídas à informação da edificação (projeto, construção e desconstrução/decomissionamento (CaPex) e fases relacionadas à informação do ativo (planejamento e operação), cujas tarefas relacionadas estão vinculadas a recursos financeiros de diferentes naturezas (OpEx). 


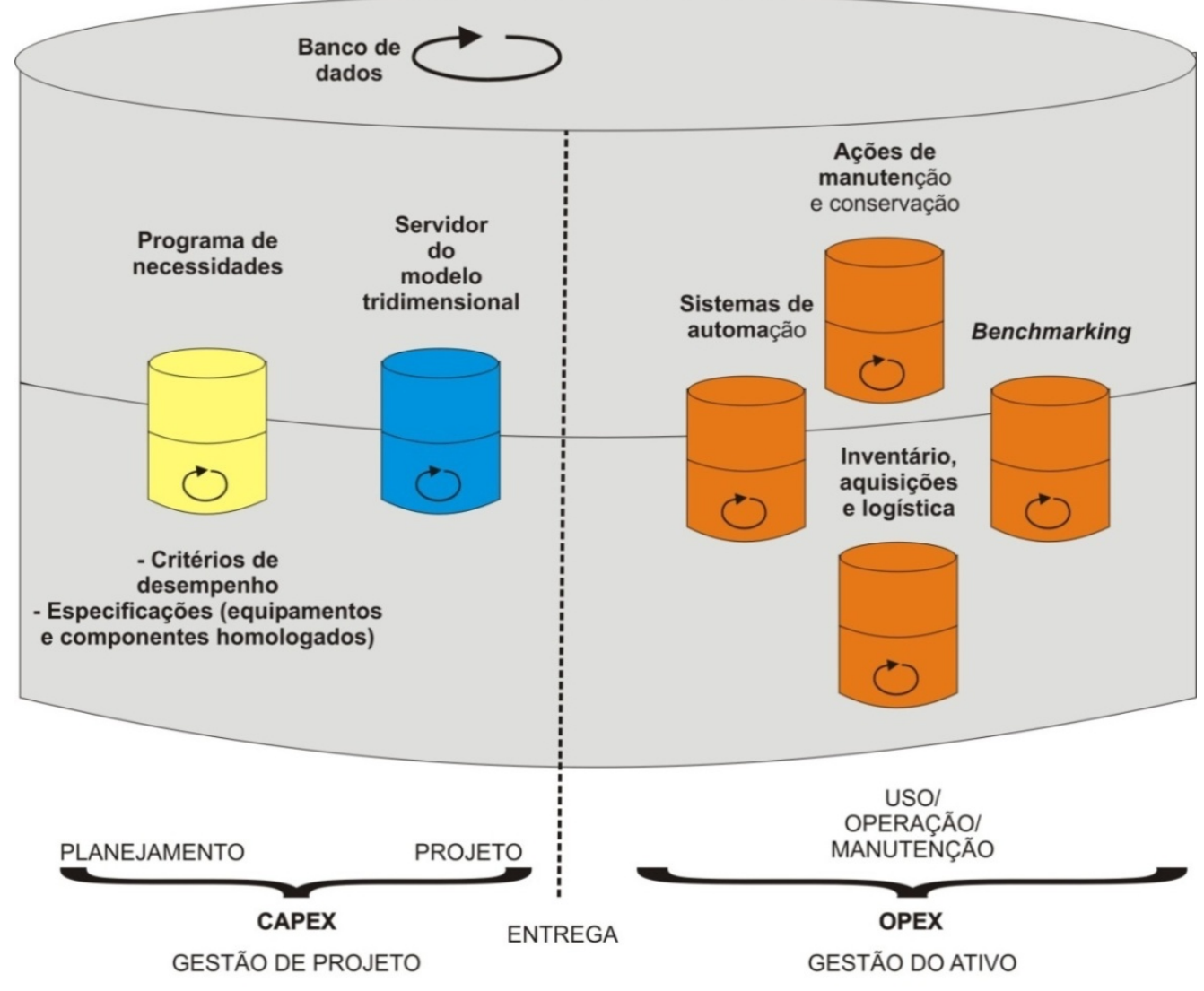

Figura 50. Fluxo de informações simplificado do projeto.

Fonte: Adaptado pela pesquisadora de: SABOL (2013, p. 37).

O modelo proposto destaca a importância de que haja integração entre todas as atividades, independentemente da fase do ciclo de vida da edificação à qual estão relacionadas. Para isso, é fundamental que sejam adotadas regras para a padronização das informações, bem como sua documentação e os recursos para seu acesso.

Na Figura 51, são apresentados os recursos e os resultados considerados como referência para a elaboração do fluxograma, relacionados às fases do ciclo de vida do projeto. 


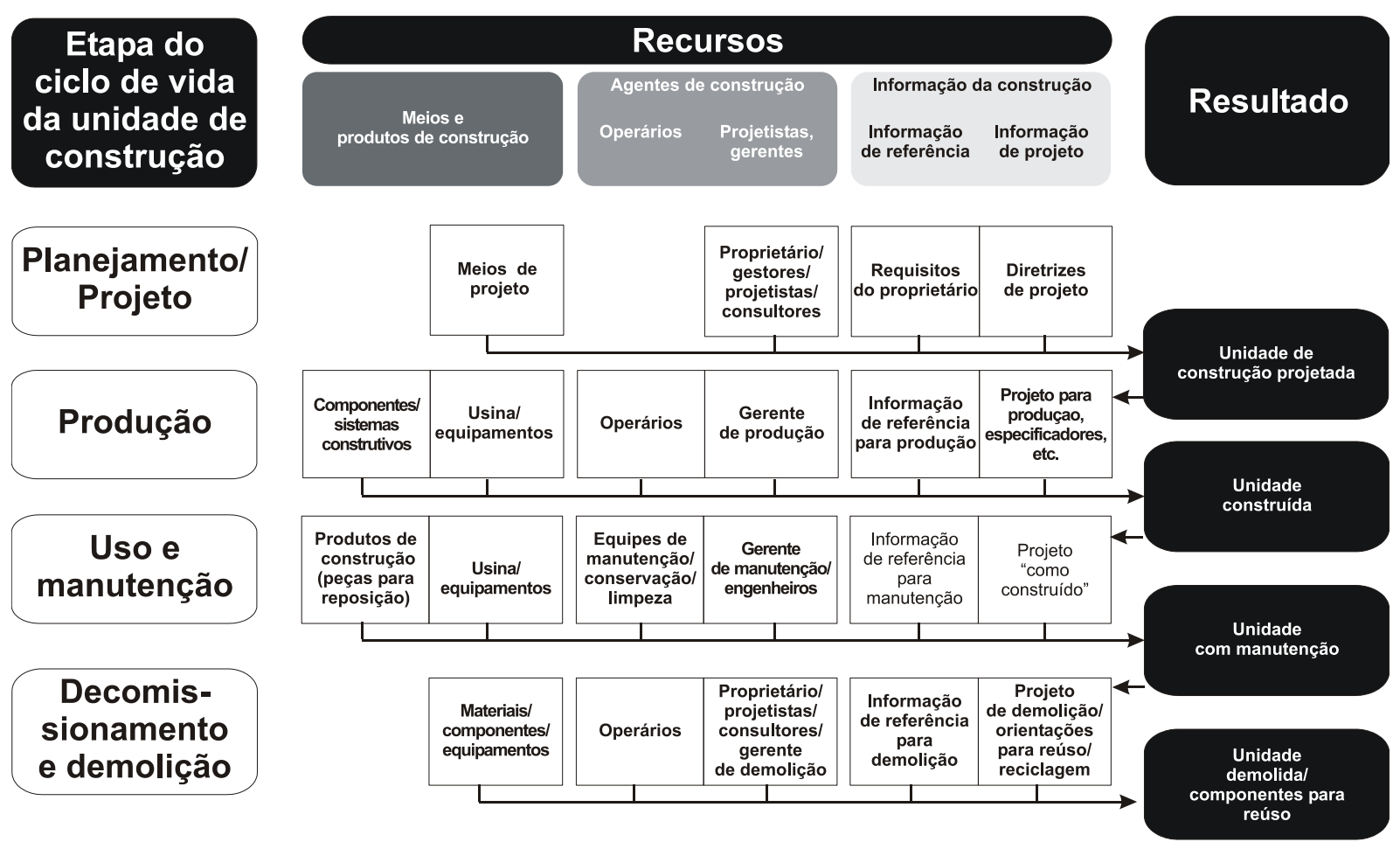

Figura 51. Recursos resultados das etapas do ciclo de vida de unidades da construção, considerando a abordagem da pesquisa Fonte: Adaptado pela pesquisadora de ABNT/ISO (2010, p. 6).

Para a proposição do fluxograma, foram identificadas as equipes e as etapas do desenvolvimento de um processo de produção e o uso de uma edificação padronizada (planejamento, projeto, construção e ocupação), bem como suas interrelações, conforme o esquema apresentado na Figura 52. 


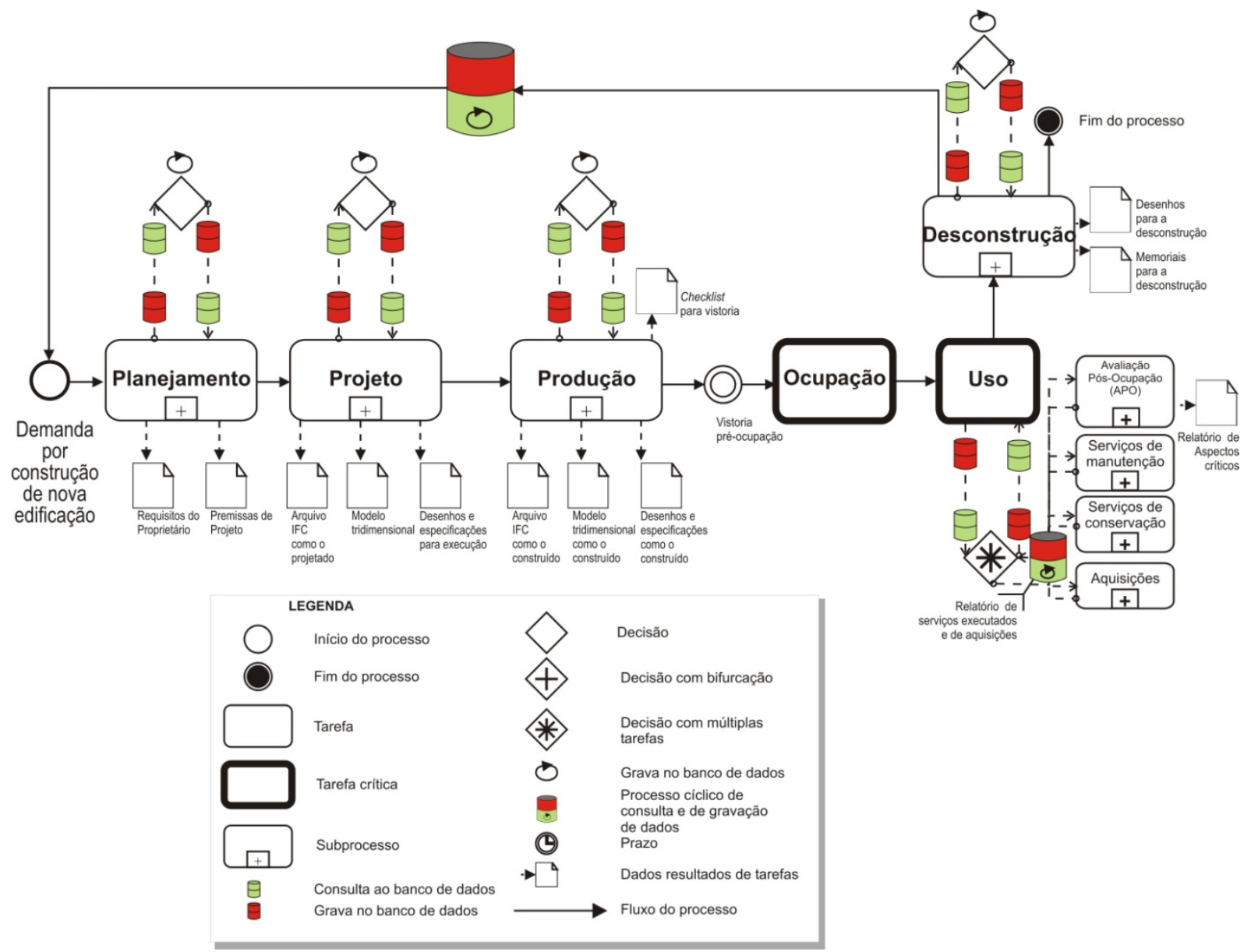

Figura 52. Esquema simplificado do processo proposto Fonte: Acervo da pesquisadora.

O processo foi proposto considerando o acesso contínuo e sistemático às informações relacionadas à edificação, de modo a embasar um ciclo de melhoria contínua. Este foi dividido em fases, conforme a etapa do ciclo de vida à qual corresponde, de acordo com o apresentado na Figura 53.

O intuito da sistematização da informação proposta é possibilitar a realimentação das premissas de projeto, ou seja. Como se pode observar no fluxograma apresentado, os seguintes aspectos são determinantes: o atendimento às premissas de projeto, o nível de adequação aos requisitos do proprietário e o cumprimento de diretrizes ditadas pelas referências normativas, boas práticas e legislação pertinente.

A Etapa 1 corresponde à fase de planejamento. Para tanto, a equipe de 
projeto irá se utilizar de componentes, cujas especificações estão processadas em um Banco de Dados.

Estas especificações apresentadas para os componentes e os serviços, que compõem o BD, devem ser revistas de modo sistemático, podendo ser atualizadas e complementadas continuamente.

A partir da demanda por uma nova edificação, é feita uma consulta ao Banco de Dados para verificação dos indicadores de desempenho pertinentes à elaboração do projeto, à luz dos requisitos, necessidades e solicitações dos usuários, identificados em experiências pregressas. Estas informações irão embasar a análise técnico-financeira e a determinação dos requisitos preliminares como, por exemplo, o número e o perfil de usuários. Com base nestes requisitos, é possível identificar as especialidades que são pertinentes ao projeto, de modo a oferecer suporte ao processo de contratação. Estas atividades, a serem coordenadas pelo Gestor do Empreendimento, devem ser validadas pelo Proprietário e pelo Gerente dos Ativos da organização.

Sendo assim, é na fase de planejamento que são determinados os requisitos do proprietário e as correspondentes diretrizes de projeto. Desde essa etapa e durante todo o desenvolvimento de projeto, a autoridade de comissionamento irá validar as soluções propostas, de forma a verificar se estão compatíveis com os requisitos iniciais.

Durante a Etapa 2, que abrange as atividades de desenvolvimento de projeto, o programa de necessidades é elaborado, bem como os requisitos de projeto são validados, com a participação da Equipe de Projeto de arquitetura e dos demais especialistas.

Cada fase do desenvolvimento de projeto (Estudo de Massas - ND 100, Estudo Preliminar - ND 200/ND 300/ND 350, e Projeto Execultivo - ND 400) deve ser conduzida observando validações periódicas da equipe multidisciplinar de projeto. Para cada fase, a validação das soluções propostas deve incluir resultados de simulações de desempenho em ambientes e áreas de interesse e, quando necessário, incorporar as alterações necessárias, sempre trabalhando sob a validação da Autoridade de Comissionamento, do Gestor de Projeto, do Proprietário e do Gestor de Ativos.

Romano (2003) destaca que a conclusão de uma determinada fase de projeto 
corresponde à conclusão de um produto tangível, passível de validação. Sendo assim, uma vez verificado o desempenho simulado do projeto e incorporadas modificações, se necessário, o projeto será encaminhado para execução. Durante esta fase, as especificações processadas no Banco de Dados podem gerar subsídios a elaboração de checklists, para a condução de vistorias técnicas.

Ao final da fase de projeto, o produto obtido é um Modelo contendo informações geométricas e não geométricas necessárias à sua produção (ND 400). Pranchas de desenhos e memoriais de especificações podem ser produzidos sob demanda para encaminhamento às equipes responsáveis pela obra.

$\mathrm{Na}$ Etapa 3, os responsáveis pelas atividades de produção da edificação beneficiam-se da consulta de informações referentes a resultados de experiências pregressas, por meio do acesso ao banco de dados. Além disso, devem alimentar o Banco de Dados quanto aos aspectos críticos encontrados, identificados por auditorias de comissionamento ou durante aplicações de checklists.

Com base na validação de eventuais alterações de projeto necessárias à solução de aspectos críticos, o Modelo deve ser atualizado, conforme o construído (ND 500).

Após o evento "vistoria pré-ocupação", o construído é validado pela Autoridade de Comissionamento, pelo Gestor do Projeto, pelo Proprietário e pelo Gestor de Ativos. Após a solução de não conformidades e do aceite da obra, dá-se início à etapa pré-ocupação, durante a qual são conduzidos os treinamentos pertinentes às equipes de operação, manutenção e conservação.

A Etapa 4 corresponde à fase de Uso e Manutenção, durante a qual ocorrem o início da operação e a ocupação da edificação. Após um ano de uso do empreendimento, pode ser aplicada uma APO para verificação de seu desempenho (ORNSTEIN et al., 2012), bem como os processos de Medição e Verificação (EVO, 2010) e de Recomissionamento da edificação (GSA, 2005). Com base nos diagnósticos realizados, será possível confirmar a pertinência das diretrizes de projeto vigentes ou providenciar eventuais alterações destas, na base de dados.

Mediante à identificação de que a edificação está inadequada ao uso, deve ser conduzida uma avaliação para identificar se cabe ou não uma requalificação. Em caso positivo, retorna-se à fase de planejamento.

Se a requalificação não for viável, inicia-se a Etapa 5 , na qual o ativo 
imobiliário será desmobilizado. Nesta fase, são elaborados os inventários de ativos e dos elementos que o compõe, de modo a determinar quais componentes e equipamentos poderão ser realocados para outro ativo e quais serão destinados a processos de descarte ou reciclagem.

Cabe destacar que a realimentação do Banco de Dados, durante toda a vida útil do ativo, deverá ser feita pela modelagem de resultados obtidos por meio das diversas ações para verificação do desempenho. São exemplos de instrumentos previstos para tal: checklists de validação de projeto; checklists para vistorias de obras; checklists para APOs; fichas de conformidade e fichas de realimentação do Banco de Dados. 


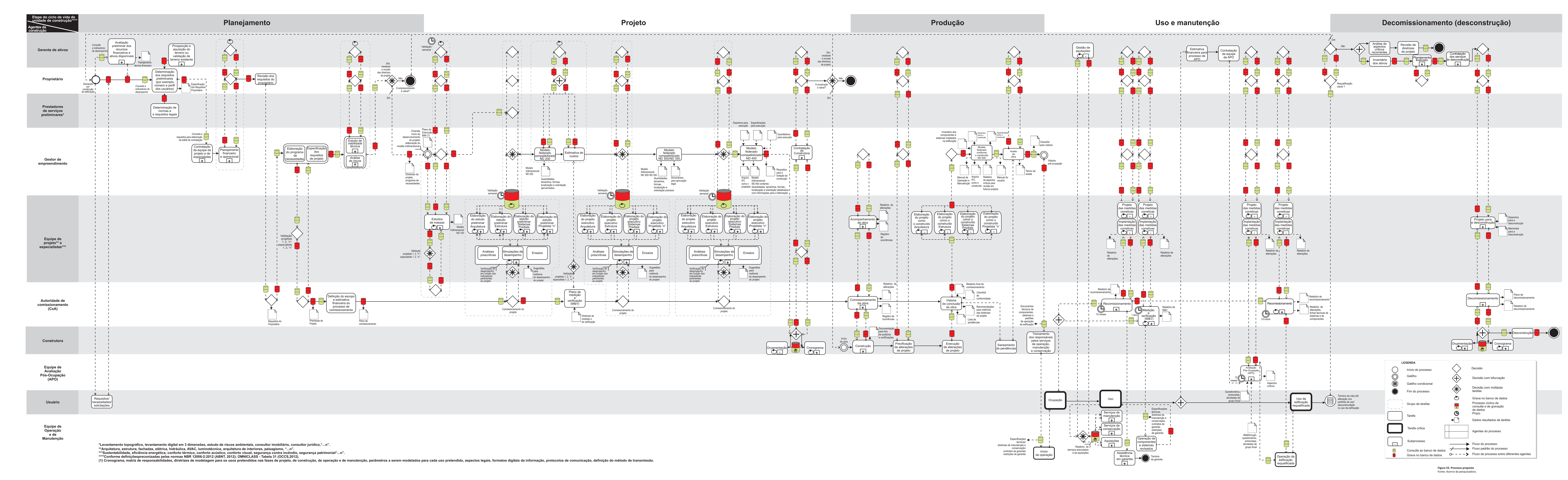


Portanto, considerando a incorporação das etapas apresentadas aos processos de produção e gestão de uma edificação, é possível incorporar, efetivamente, boas práticas identificadas em experiências pregressas, consolidando o ciclo de melhoria contínua. Entretanto, para que isso seja possível, as informações modeladas precisam estar disponíveis aos atores que participam das diferentes fases de seu ciclo de vida.

Por exemplo, considerando-se o conjunto de edificações, no contexto de um portfólio de ativos, verifica-se que proprietários e os gestores de ativos têm maior necessidade das informações da construção do que de suas representações gráficas. Sendo assim, seu acesso às tabelas de especificação, aos preços e aos indicadores de desempenho não só deve ser possibilitado, como também ser atualizado continuamente.

No Quadro 16 é representada a matriz de responsabilidades, relacionada ao modelo proposto. Todos os atores deverão acessar informações modeladas, como subsídio às decisões necessárias às suas atividades. Este Banco de Dados deve ser atualizado continuamente, conforme as etapas do ciclo de vida são cumpridas. 
Quadro 16. Matriz de responsabilidades para o processo proposto

\begin{tabular}{|l|c|c|c|c|c|}
\hline \multirow{2}{*}{ Agente } & \multicolumn{5}{|c|}{ Etapas } \\
\cline { 2 - 6 } & Planejamento & Projeto & Construção & Uso/ Operação & Desconstrução \\
\hline Proprietário & $\mathbf{X}$ & $\mathbf{X}$ & $\mathbf{X}$ & $\mathbf{X}$ & $\mathbf{X}$ \\
\hline Gestor dos Ativos & $\mathbf{X}$ & $\mathbf{X}$ & $\mathbf{X}$ & $\mathbf{X}$ & $\mathbf{X}$ \\
\hline Equipes de projeto & $\mathbf{X}$ & $\mathbf{X}$ & $\mathbf{X}$ & & $\mathbf{X}$ \\
\hline Gestor do Projeto & $\mathbf{X}$ & $\mathbf{X}$ & $\mathbf{X}$ & & $\mathbf{X}$ \\
\hline Gestor de Facilidades & & & & $\mathbf{X}$ & $\mathbf{X}$ \\
\hline $\begin{array}{l}\text { Autoridade de } \\
\text { Comissionamento }\end{array}$ & $\mathbf{X}$ & $\mathbf{X}$ & $\mathbf{X}$ & $\mathbf{X}$ & $\mathbf{X}$ \\
\hline Especialista em APO & & & & $\mathbf{X}$ & \\
\hline Equipe de Manutenção & & & & $\mathbf{X}$ & \\
\hline
\end{tabular}

Fonte: Acervo da pesquisadora.

Dentre as vantagens proporcionadas pela implantação do processo proposto para a gestão da informação, pretende-se agregar valor ao trabalho dos diferentes atores da cadeia produtiva da construção civil. Isso é possível, à medida que os envolvidos no desenvolvimento do projeto podem elaborar suas propostas, tendo à disposição informações sobre os resultados obtidos por edificações semelhantes em uso.

Também têm condições de melhorar sua produtividade e testar, desde as fases iniciais de projeto, o desempenho das soluções propostas. Isso inclui a elaboração de análises no contexto dos demais projetos, por meio da prática do modelo federado.

Em razão da menor quantidade de erros e de inconsistências, bem como da maior confiabilidade das especificações, os construtores podem reduzir seus riscos 
durante a execução e obter maior segurança na elaboração de orçamentos e cronogramas.

Por sua vez, os gestores de facilidades podem se beneficiar dos seguintes aspectos: acesso facilitado aos documentos e às especificações dos componentes e dos sistemas prediais e redução do tempo dedicado à busca e à validação das informações. Também, o acompanhamento do desempenho, durante todo ciclo de vida do ativo, contribui para a elaboração de análises mais confiáveis para tomada de decisões estratégicas.

O gestor dos ativos da organização pode obter menores custos de operação, elaborar um planejamento mais preciso para alocação dos recursos da organização e beneficiar-se de maior confiabilidade e transparência na análise das informações.

Finalmente, o proprietário tem condições de, efetivamente, propagar o conhecimento adquirido em experiências pregressas, sem depender exclusivamente do saber acumulado pelos membros da equipe, de modo a possibilitar que se cumpra o desejado ciclo de melhoria contínua.

\subsection{CARACTERIZAÇÃO DA ESCOLA ALPHA}

A Escola Alpha, exemplo para a aplicação da metodologia considerada para esta pesquisa, corresponde a um dos três edifícios escolares aos quais foram aplicados métodos e técnicas de Avaliação Pós-Ocupação (FRANÇA, 2011). Ela está situada na zona sul da cidade de São Paulo e possui $1142,72 \mathrm{~m}^{2}$ de área construída, distribuída em dois pavimentos, em um terreno de $5861,39 \mathrm{~m}^{2}$.

Suas especificações de projeto são apresentadas no Quadro 17. 
Quadro 17. Especificações de projeto da Escola Alpha

\begin{tabular}{|c|c|}
\hline Sistema Estrutural: & $\begin{array}{l}\text { Aço. Acabamento: Pintura poliuretano acrílico, cor de referência verde-colonial acetinado sobre primer } \\
\text { epóxi poliamida (exceto onde for necessário prever proteção passiva das estruturas metálicas com } \\
\text { argamassa projetada, conforme decreto estadual } 46.076 \text { ). }\end{array}$ \\
\hline Laje: & Pré-moldado de concreto tipo painel, com isopor e=25cm. \\
\hline Vedos: & Alvenaria em tijolo cerâmico e=14cm + revestimento. \\
\hline $\begin{array}{l}\text { Proteção para controle solar } \\
\text { (brises): }\end{array}$ & $\begin{array}{l}\text { Telha de aço, com galvanização eletrolítica ( } 40 \text { micras por face), perfurada } 20 \% \text {, marca Eucatex, modelo } \\
\text { L40, esp }=0.8 \mathrm{~mm} \text {. Acabamento: pintura eletrolítica na cor branca, nas duas faces. }\end{array}$ \\
\hline Estrutura dos brises: & Perfis soldados em aço. Acabamento: pintura galvanizada, na cor branca. \\
\hline Esquadrias: & $\begin{array}{l}\text { Ferro/vidro incolor } 3 \mathrm{~mm} \text { ou fantasia } 4 \mathrm{~mm} \text {, quando utilizado em sanitários e vestiários. Acabamento: } \\
\text { pintura esmalte na cor branca, sobre fundo antioxidante (zarcão). }\end{array}$ \\
\hline Portas: & Madeira sarrafeada. Acabamento: pintura esmalte - cor de projeto: amarelo ouro/cor executada: azul. \\
\hline Escadas (Estrutura): & Aço com pintura cor de referência Suvinl Verde Colonial acetinado, sobre primer epóxi poliamida. \\
\hline Escadas (Degraus): & $E=17 \mathrm{~cm} / P=30 \mathrm{~cm}$. Degrau com bandeja de aço. Piso em concreto desempenado. \\
\hline $\begin{array}{l}\text { Pisos internos e circulação } \\
\text { horizontal: }\end{array}$ & $\begin{array}{l}\text { Revestimento cerâmico } 30 \times 30 \mathrm{~cm} \text { monoqueima de alta resistência (PEI 5). Colocação contínua, sem } \\
\text { soleiras junto às portas. }\end{array}$ \\
\hline Piso quadra descoberta: & Cimentado, com pintura poliesportiva. \\
\hline Piso galpão: & $\begin{array}{l}\text { Ladrilho hidráulico } 20 \times 20 \text { com texturizado. Cor: vermelha/Concreto usinado desempenado, requadros } \\
\qquad 1,80 \times 1,80 \mathrm{~m} \text {, junta plástica cor cinza. }\end{array}$ \\
\hline $\begin{array}{l}\text { Acabamento - paredes } \\
\text { ambientes internos e } \\
\text { circulações: }\end{array}$ & Pintura látex acrílico fosco sobre gesso $(5 \mathrm{~mm})$. \\
\hline
\end{tabular}

Acabamento - guarda-corpo de alvenaria:

Pintura látex acrílico fosco sobre chapisco/emboço e reboco de $2,5 \mathrm{~cm}$.

Acabamento - paredes áreas molhadas:

Azulejo 15 x $15 \mathrm{~cm}$. Cor: branca.

Caixa d'água:

Elementos vazados:
Anéis de concreto. Acabamento: concreto natural, com aplicação de resina acrílica incolor. Bloco Neorex modelo: 97 . Dimensões: $10 \times 10 \times 10 \mathrm{~cm}$. Acabamento: pintura de referência, cor palha.

Telha galvanizada trapezoidal com pintura branca na face externa, e=8mm. I=10\%.Referência: Perflor LR-

$33, \mathrm{H}=40 \mathrm{~mm}$, ou similar.

Cobertura:

Ladrilho hidráulico tátil de alerta $20 \times 20 \mathrm{~cm}$.

Piso tátil:

Fontes: projeto executivo e catálogo de especificações (Acervo da Fundação para o Desenvolvimento da Educação).

À época em que foram realizados os levantamentos (jan/2009), a Escola Alpha apresentava as características de ocupação apresentadas no Quadro 18.

Quadro 18. Dados de Ocupação para a Escola Alpha

\begin{tabular}{ll}
\hline Alunos matriculados * & 1.316 \\
Turnos de funcionamento* & Matutino, vespertino e noturno \\
Professores $^{*}$ & 74 \\
Funcionários da cozinha* & 06 \\
Funcionários de limpeza* & 06 \\
Funcionários da administração* & 03 \\
\hline * Dados correspondentes ao $1^{\circ}$ semestre de 2009. & \\
\hline
\end{tabular}


As plantas e os cortes referentes ao projeto executivo da Escola Alpha são apresentados nas Figuras 54 e 55.

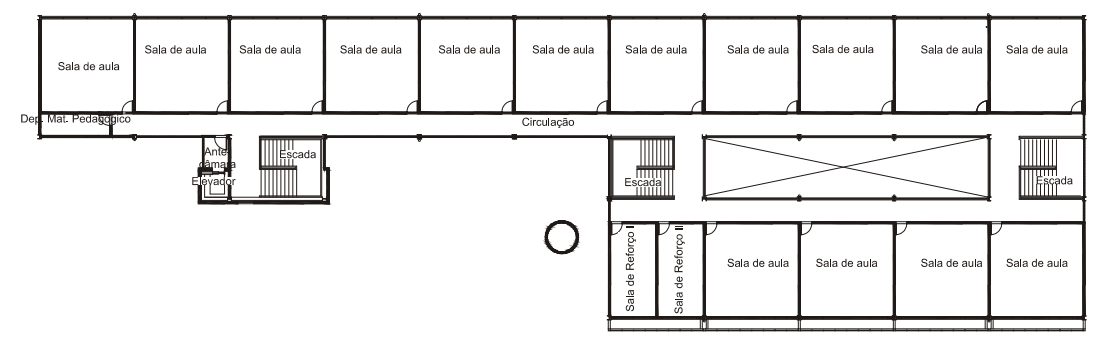

Escola Alpha $-1^{\circ}$ Pavimento

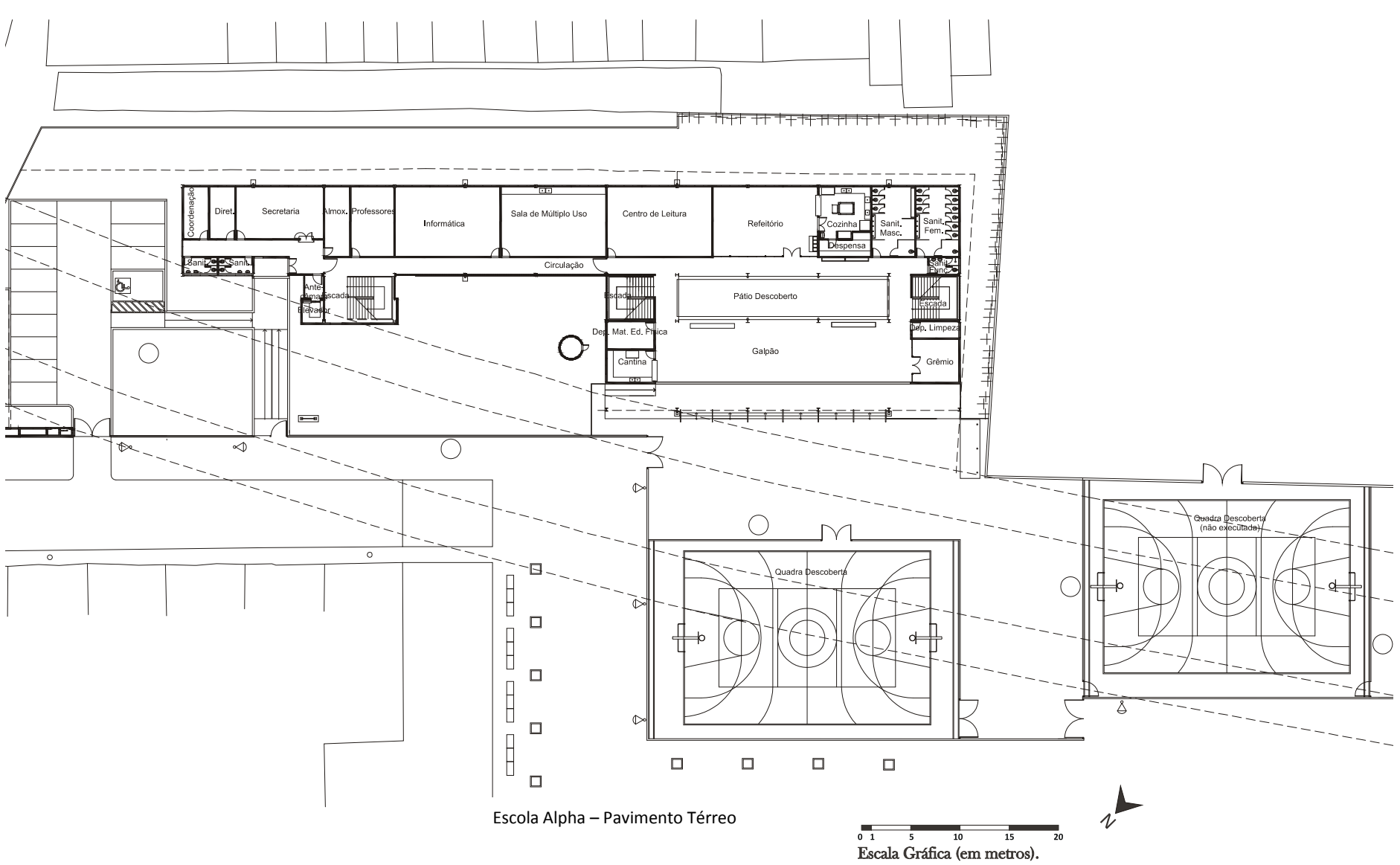

Figura 54. Escola Alpha - Plantas

Fonte: Acervo da Fundação para o Desenvolvimento da Educação.

Plantas correspondentes ao projeto executivo da edificação, extraídas dos arquivos 0059199_01APE0300.dwg e 0059199_01APE0400.dwg.

Esta escola ocupa um terreno remanescente de uma obra realizada pela Companhia do Metropolitano de São Paulo (METRÔ), de modo que sua implantação se dá a uma distância bastante próxima dos trilhos elevados da Linha 5 - Lilás da Companhia. 


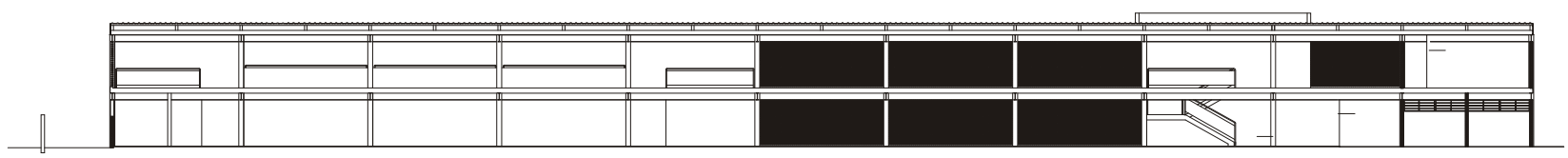

Escola Alpha - Corte Longitudinal

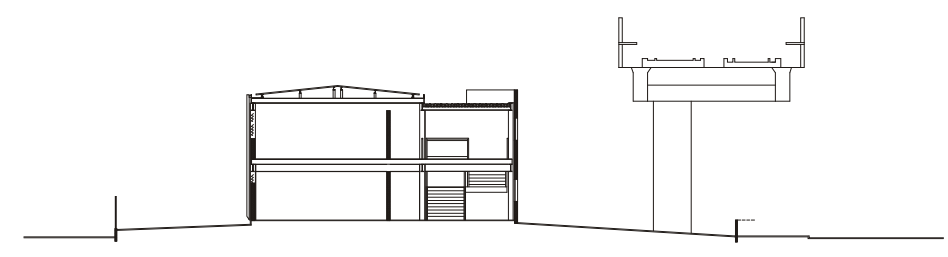

Escola Alpha - Corte Transversal

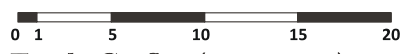

Escala Gráfica (em metros).

Figura 55. Escola Alpha - Cortes

Fonte: Acervo da Fundação para o Desenvolvimento da Educação.

Situados no pavimento térreo, foram localizados os ambientes de vivência e administrativos. As salas de aula foram concebidas no primeiro pavimento, próximas às salas de reforço e ao depósito de material pedagógico.

Com base na leitura dos documentos de projeto e dos levantamentos técnicos feitos no local (FRANÇA, 2011), foram identificados os ambientes (Quadro 19) considerados no projeto.

\begin{tabular}{|c|c|c|}
\hline \multicolumn{3}{|c|}{ Quadro 19. Ambientes e respectivas áreas - Escola Alpha } \\
\hline Ambiente & Uso efetivo & $\begin{array}{c}\text { Área útil unitária do } \\
\text { ambiente }\left(\mathrm{m}^{2}\right)\end{array}$ \\
\hline Estacionamento descoberto & Estacionamento & 294 \\
\hline Coordenação & Vice-diretoria & 13 \\
\hline Diretoria & Diretoria & 13 \\
\hline Secretaria & Secretaria & 46 \\
\hline Almoxarifado & Almoxarifado & 12,7 \\
\hline Conjunto de Sanitários Administrativo & Conjunto de Sanitários Administrativo & 11,02 \\
\hline Circulação Horizontal & Circulação Horizontal & 425,69 \\
\hline Circulação Vertical (escadas) & Circulação Vertical (escadas) & 47,64 \\
\hline Hall Elevador & Hall Elevador & 4,4 \\
\hline Elevador & Elevador & 1,65 \\
\hline Sala dos Professores & Sala dos Professores & 30,1 \\
\hline
\end{tabular}




\begin{tabular}{|c|c|c|}
\hline Ambiente & Uso efetivo & $\begin{array}{l}\text { Área útil unitária do } \\
\text { ambiente }\left(\mathrm{m}^{2}\right)\end{array}$ \\
\hline Sala de Informática & Sala de Informática & 75,32 \\
\hline Sala de Uso Múltiplo & Sala de Aula Acessível & 75,32 \\
\hline Centro de Leitura & $\begin{array}{l}\text { Centro de Leitura e Sala de Jogos } \\
\text { (sobreposição de usos) }\end{array}$ & 75,32 \\
\hline Refeitório & Refeitório & 76,39 \\
\hline Cozinha & Cozinha & 26 \\
\hline Despensa & Despensa & 10,1 \\
\hline Conjunto de Sanitários Alunos & Sanitários para Alunos & 61,9 \\
\hline Sanitário de Funcionários & Sanitário de Funcionários & 4,92 \\
\hline Depósito de limpeza & Vestiário dos Funcionários & 7,79 \\
\hline Grêmio & Sem Uso & 20,4 \\
\hline Galpão & Galpão & 165,96 \\
\hline Depósito de Material de Educação Física & Depósito de Material Geral & 12,99 \\
\hline Cantina & Sem Uso & 15,34 \\
\hline Pátio Descoberto & Pátio Descoberto & 94,48 \\
\hline Quadra Descoberta (construída) & Quadra Descoberta & 613,89 \\
\hline $\begin{array}{c}\text { Quadra Descoberta (prevista em projeto. } \\
\text { Porém, não executada) }\end{array}$ & Sem Uso & 609,08 \\
\hline Depósito de Material Pedagógico & $\begin{array}{l}\text { Depósito de Material Pedagógico e } \\
\text { Almoxarifado }\end{array}$ & 8,4 \\
\hline Sala de Aula & Sala de Aula & 49,3 \\
\hline Sala de Reforço & Sala da Coordenação & 24,15 \\
\hline
\end{tabular}

Após a análise preliminar, foram determinados procedimentos para a organização das informações e determinação das formas de análise dos dados, de modo a orientar a elaboração do modelo.

Posteriormente à identificação dos usos efetivos, foi realizada uma análise comparativa, considerando as diretrizes de projeto $\mathrm{e}$ as áreas efetivamente disponíveis para cada ambiente, conforme o apresentado no Quadro 20. 


\begin{tabular}{|c|c|c|c|c|c|c|c|c|}
\hline \multicolumn{9}{|c|}{ Quadro 20. Análise dos ambientes e usos identificados na Escola Alpha } \\
\hline 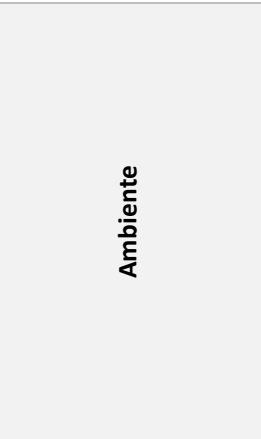 & 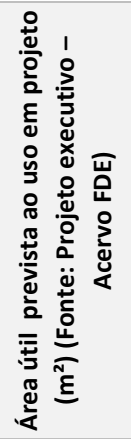 & 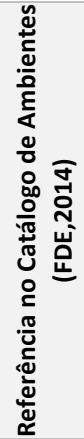 & 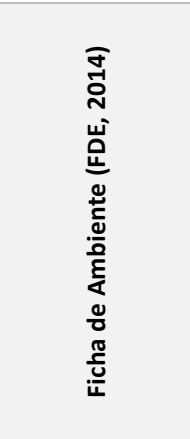 & 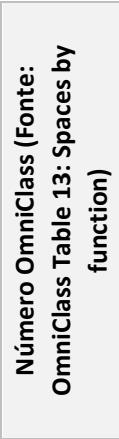 & 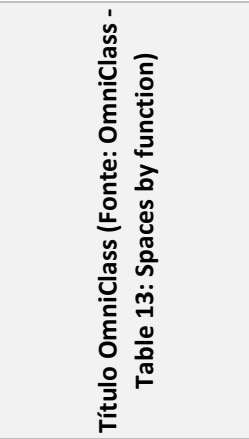 & 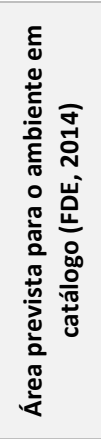 & 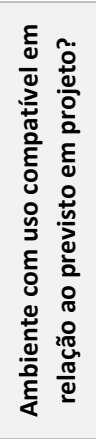 & 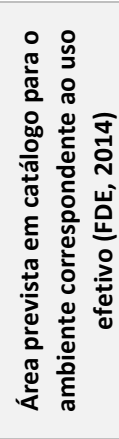 \\
\hline $\begin{array}{l}\text { Estacionamento } \\
\text { descoberto }\end{array}$ & 294 & n.a. & n.a. & $\begin{array}{l}13-21 \\
1100\end{array}$ & $\begin{array}{l}\text { Estacionamento } \\
\text { Externo }\end{array}$ & n.a. & $\operatorname{sim}$ & n.a. \\
\hline Coordenação & 13 & 05B & $\begin{array}{l}\text { Coord. } \\
\text { Pedagógico } \\
\text { M5 - M6 }\end{array}$ & $\begin{array}{l}13-55 \\
1111\end{array}$ & Escritório & 12,96 & não & 12,96 \\
\hline Diretoria & 13 & $01 \mathrm{~A}$ & $\begin{array}{c}\text { Diretor M1 - } \\
\text { M2 - M3 - M4 - } \\
\text { M5 - M6 }\end{array}$ & $\begin{array}{l}13-55 \\
1111\end{array}$ & Escritório & 9,72 & $\operatorname{sim}$ & 9,72 \\
\hline Secretaria & 46 & $03 \mathrm{C}$ & $\begin{array}{c}\text { Secretaria M3 } \\
\text { - M6 }\end{array}$ & $\begin{array}{l}13-55 \\
1111\end{array}$ & Escritório & 45,36 & $\operatorname{sim}$ & 45,36 \\
\hline Almoxarifado & 12,7 & 04B & $\begin{array}{l}\text { Almoxarifado } \\
\text { M2 - M5 }\end{array}$ & $\begin{array}{l}13-63 \\
1321\end{array}$ & $\begin{array}{l}\text { Armazenamento de } \\
\text { suprimentos }\end{array}$ & 12,96 & $\operatorname{sim}$ & 12,96 \\
\hline $\begin{array}{l}\text { Conjunto de } \\
\text { Sanitários } \\
\text { Administrativo }\end{array}$ & 11,02 & 07A & $\begin{array}{c}\text { Conjunto } \\
\text { Sanitário } \\
\text { Administrativo } \\
\text { M1 - M4 }\end{array}$ & $\begin{array}{l}13-23 \\
1700\end{array}$ & Sanitário & 14,58 & $\operatorname{sim}$ & 14,58 \\
\hline Circulação Horizontal & 425,69 & 25 & $\begin{array}{c}\text { Acessibilidade } \\
\text { ao Edifício M1 } \\
\text { - M2 - M3 - M4 } \\
\text { - M5 - M6 }\end{array}$ & $\begin{array}{l}13-25 \\
0000\end{array}$ & Circulação & n.a. & n.a. & n.a. \\
\hline $\begin{array}{c}\text { Circulação Vertical } \\
\text { (escadas) }\end{array}$ & 113,64 & 25 & $\begin{array}{c}\text { Acessibilidade } \\
\text { ao Edifício M1 } \\
\text { - M2 - M3 - M4 } \\
\text { - M5 - M6 }\end{array}$ & $\begin{array}{l}13-23 \\
1100\end{array}$ & Circulação vertical & n.a. & n.a. & n.a. \\
\hline Hall Elevador & 4,4 & 24 & $\begin{array}{c}\text { Circulação } \\
\text { Horizontal e } \\
\text { Vertical M1 - } \\
\text { M2 - M3 - M4 - } \\
\text { M5 - M6 }\end{array}$ & $\begin{array}{c}13-23 \\
111115\end{array}$ & Elevador & n.a. & n.a. & n.a. \\
\hline Elevador & 1,65 & 24 & $\begin{array}{c}\text { Circulação } \\
\text { Horizontal e } \\
\text { Vertical M1 - } \\
\text { M2 - M3 - M4 - } \\
\text { M5 - M6 }\end{array}$ & $\begin{array}{c}13-23 \\
111115\end{array}$ & Elevador & n.a. & n.a. & n.a. \\
\hline Sala dos Professores & 30,1 & 06B & $\begin{array}{l}\text { Professores } \\
\text { M3 - M4 - M5 }\end{array}$ & $\begin{array}{l}13-55 \\
2921\end{array}$ & Sala de Reuniões & 30,1 & $\operatorname{sim}$ & 30,1 \\
\hline Sala de Informática & 75,32 & 12B & $\begin{array}{c}\text { Sala de } \\
\text { Informática } \\
\text { M4 - M5 - M6 }\end{array}$ & $\begin{array}{l}13-31 \\
1711\end{array}$ & $\begin{array}{l}\text { Laboratório de } \\
\text { Computação }\end{array}$ & 77,76 & $\operatorname{sim}$ & 77,76 \\
\hline Sala de Uso Múltiplo & 75,32 & $10 \mathrm{~B}$ & $\begin{array}{l}\text { Uso Múltiplo } \\
\text { M5 - M6 }\end{array}$ & $\begin{array}{l}13-31 \\
1100\end{array}$ & Sala de Atividades & 77,76 & não & 49,52 \\
\hline Centro de Leitura & 75,32 & $11 \mathrm{~A}$ & $\begin{array}{c}\text { Sala de Leitura } \\
\text { M4 - M5 - M6 }\end{array}$ & $\begin{array}{l}13-45 \\
1100\end{array}$ & Biblioteca & 77,76 & não & 77,76 \\
\hline Refeitório & 76,39 & $15 B$ & $\begin{array}{c}\text { Refeitório M2 } \\
\text { - M3 - M5 - M6 }\end{array}$ & \begin{tabular}{|c|}
$13-57$ \\
131511
\end{tabular} & Refeitório & 103,68 & $\operatorname{sim}$ & 103,68 \\
\hline Cozinha & 26 & 14A1 & $\begin{array}{c}\text { Cozinha M1 - } \\
\text { M4 }\end{array}$ & $\begin{array}{l}13-57 \\
1313\end{array}$ & Cozinha & 28,35 & $\operatorname{sim}$ & 28,35 \\
\hline
\end{tabular}

Continua... 
...Continuação

\begin{tabular}{|c|c|c|c|c|c|c|c|c|}
\hline $\begin{array}{l}\stackrel{0}{\stackrel{2}{c}} \\
\frac{d}{0} \\
\frac{\text { है }}{<}\end{array}$ & 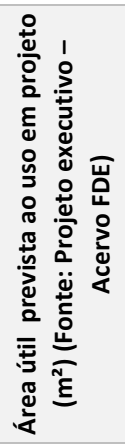 & 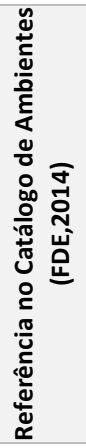 & 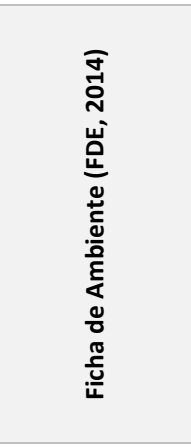 & 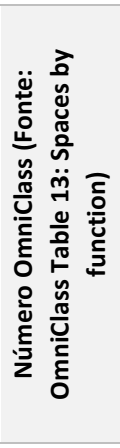 & 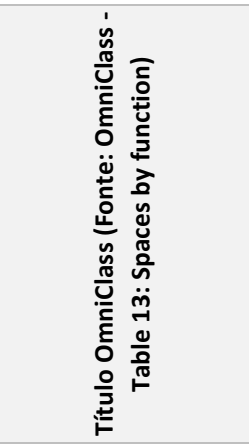 & 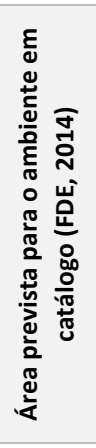 & 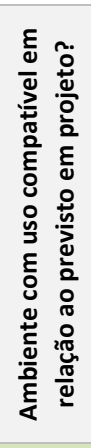 & 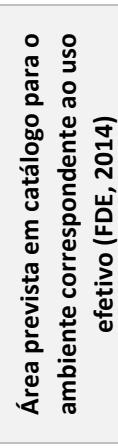 \\
\hline Despensa & 10,1 & 14B1 & $\begin{array}{c}\text { Despensa M1 - } \\
\text { M4 (+ } \\
\text { utensílios) }\end{array}$ & $\begin{array}{l}13-63 \\
1321\end{array}$ & $\begin{array}{l}\text { Armazenamento de } \\
\text { suprimentos }\end{array}$ & 11,34 & $\operatorname{sim}$ & 11,34 \\
\hline $\begin{array}{c}\text { Conjunto de } \\
\text { Sanitários Alunos }\end{array}$ & 61,9 & 17A3 & $\begin{array}{c}\text { Conjunto } \\
\text { Sanitário } \\
\text { Alunos M3 - } \\
\text { M6 }\end{array}$ & $\begin{array}{l}13-23 \\
1700\end{array}$ & Sanitário & 68,85 & $\operatorname{sim}$ & 68,85 \\
\hline $\begin{array}{l}\text { Sanitário de } \\
\text { Funcionários }\end{array}$ & 4,92 & $23 A$ & $\begin{array}{l}\text { Conjunto } \\
\text { Sanitário Func. } \\
\text { M1 - M2 - M3 - } \\
\text { M4 - M5 - M6 }\end{array}$ & $\begin{array}{l}13-23 \\
1700\end{array}$ & Sanitário & 12,96 & $\operatorname{sim}$ & 12,96 \\
\hline Depósito de limpeza & 7,79 & 22B & $\begin{array}{c}\text { Depósito } \\
\text { Material } \\
\text { Limpeza M2 - } \\
\text { M3 - M5 - M6 }\end{array}$ & $\begin{array}{l}13-63 \\
1311\end{array}$ & $\begin{array}{c}\text { Armazenamento de } \\
\text { materiais }\end{array}$ & 9,72 & não & 12,96 \\
\hline Grêmio & 20,4 & 18B & $\begin{array}{c}\text { Grêmio M5 - } \\
\text { M6 }\end{array}$ & $\begin{array}{c}13-55 \\
292115\end{array}$ & Grêmio & 25,92 & não & 25,92 \\
\hline Galpão & 165,96 & $21 \mathrm{A3}$ & $\begin{array}{l}\text { Pátio Coberto } \\
\text { M2-M5 }\end{array}$ & $\begin{array}{l}13-33 \\
0000\end{array}$ & Área recreativa & 194,4 & $\operatorname{sim}$ & 194,4 \\
\hline $\begin{array}{l}\text { Depósito de Material } \\
\text { de Educação Física }\end{array}$ & 12,99 & 19B & $\begin{array}{l}\text { Depósito Mat. } \\
\text { Educação } \\
\text { Física M3 - M6 }\end{array}$ & $\begin{array}{l}13-63 \\
1311\end{array}$ & $\begin{array}{c}\text { Armazenamento de } \\
\text { materiais }\end{array}$ & 12,96 & não & n.a. \\
\hline Cantina & 15,34 & $16 \mathrm{~A}$ & $\begin{array}{l}\text { Cantina M4 - } \\
\text { M5 - M6 }\end{array}$ & $\begin{array}{c}13-57 \\
131531\end{array}$ & Cantina & 16,2 & não & 16,2 \\
\hline Pátio Descoberto & 94,48 & n.a. & n.a. & n.a. & n.a. & n.a. & n.a. & n.a. \\
\hline $\begin{array}{c}\text { Quadra Descoberta } \\
\text { (construída) }\end{array}$ & 613,89 & 20B & $\begin{array}{c}\text { Quadra } \\
\text { Descoberta } \\
\text { M6 }\end{array}$ & $\begin{array}{l}13-33 \\
1100\end{array}$ & $\begin{array}{l}\text { Quadra para } \\
\text { atividade esportiva } \\
\text { recreativa }\end{array}$ & 600 & $\operatorname{sim}$ & 600 \\
\hline $\begin{array}{l}\text { Quadra Descoberta } \\
\text { (prevista em projeto. } \\
\text { Porém, não } \\
\text { executada) }\end{array}$ & 609,08 & 20B & $\begin{array}{c}\text { Quadra } \\
\text { Descoberta } \\
\text { M6 }\end{array}$ & $\begin{array}{l}13-33 \\
1100\end{array}$ & $\begin{array}{c}\text { Quadra para } \\
\text { atividade esportiva } \\
\text { recreativa }\end{array}$ & 600 & não & 600 \\
\hline $\begin{array}{c}\text { Depósito de Material } \\
\text { Pedagógico }\end{array}$ & 8,4 & n.a. & n.a. & n.a. & n.a. & n.a. & não & n.a. \\
\hline Sala de Aula & 739,5 & 08B & $\begin{array}{l}\text { Sala de Aula } \\
\text { M4 - M5 - M6 }\end{array}$ & $\begin{array}{l}13-31 \\
1311\end{array}$ & Sala de Aula & 51,84 & $\operatorname{sim}$ & 51,84 \\
\hline Sala de Reforço & 48,3 & 09B & $\begin{array}{c}\text { Sala de } \\
\text { Recuperação } \\
\text { M4 - M5 - M6 }\end{array}$ & $\begin{array}{l}13-31 \\
1311\end{array}$ & Sala de Aula & 25,92 & não & 25,92 \\
\hline
\end{tabular}

Observa-se, quanto ao atendimento ao programa funcional da Escola Alpha, a ocorrência de alterações de uso em ambientes importantes, tais como: sala de uso múltiplo, sala da coordenação, salas de reforço e centro de leitura. 


\subsection{CONCEITOS E PROCEDIMENTOS ADOTADOS PARA A MODELAGEM}

Para oferecer suporte ao processo proposto, é pressuposta a consolidação de um Banco de Dados, ou seja, uma estrutura de armazenagem de dados, necessária a aplicações complexas (LISBOA FILHO, 2001) aplicada a edificações de tipologia padronizada.

Para a composição do Banco de Dados contendo as informações referentes às diretrizes de projeto, foram considerados os aspectos apresentados na Figura 56.

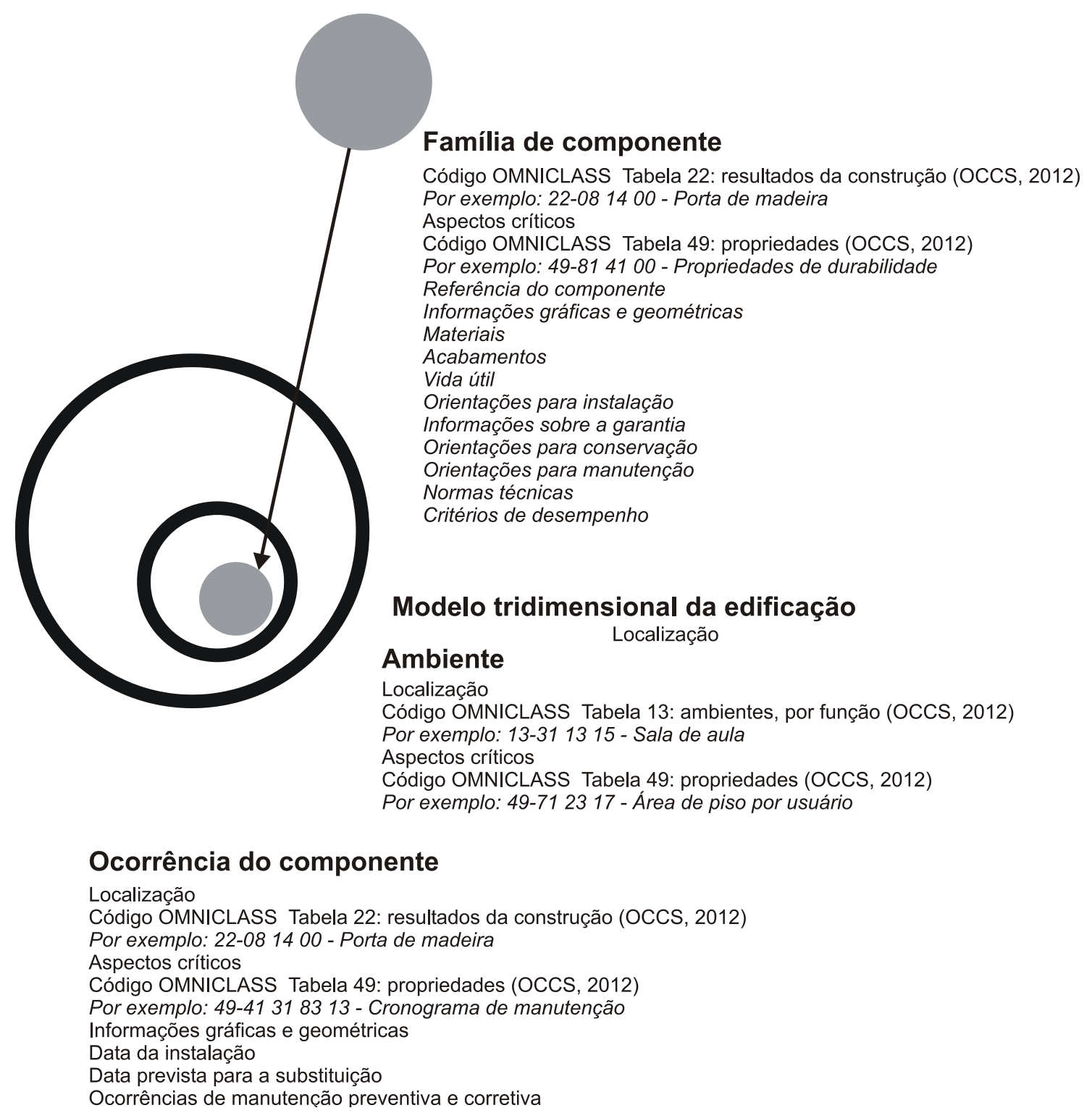

Figura 56. Exemplo de propriedades consideradas para a elaboração do Banco de Dados

Fonte: Acervo da pesquisadora. 
Para que fosse possível identificar a natureza do serviço, material ou elemento construtivo, cada item inserido no Banco de Dados foi qualificado conforme o critério definido pela OmniClass (OCCS, 2012), para a padronização da nomenclatura atribuída às atividades e produtos da construção civil.

Para o planejamento do Banco de Dados, os seguintes objetivos foram determinados:

- organização dos resultados referentes ao desempenho de edificações escolares em uso, obtidos pela aplicação de Avaliações Pós-Ocupação (APO);

- Identificação dos aspectos críticos identificados na APO, respectivas causas, frequência de recorrência e nível de risco relacionado; e

- Realimentação do Banco de Dados, com informações referentes aos componentes construtivos homologados e respectivos desempenhos reais, de modo a aprimorar o repertório técnico das equipes de projeto.

Em um projeto desenvolvido em tecnologia BIM, cujas informações serão usadas na fase de operação e manutenção, a interface gráfica deve dar suporte ao acesso do usuário final às seguintes informações (LOVE et al., 2015):

- localização de uma ocorrência;

- especificações do componente;

- possíveis causas; e

- procedimentos relacionados à sua mitigação.

Também é importante que possam ser identificados e qualificados os riscos e eventuais danos a ela relacionados.

No estabelecimento de relacionamentos (CHEN, 1976) existe uma hierarquia, a saber: a organização engloba a propriedade, que possui a edificação, que tem pavimentos, onde estão dispostos os ambientes. A estes ambientes, estão associados os elementos construtivos (que são compostos por componentes), bem como os equipamentos existentes no empreendimento. Esta hierarquia é importante, 
não só para a formalização dos relacionamentos necessários à modelagem, como também para a análise das informações referentes aos dos aspectos críticos identificados na edificação. Uma representação de entes e relacionamentos, no âmbito de uma organização, é apresentada na Figura 57.

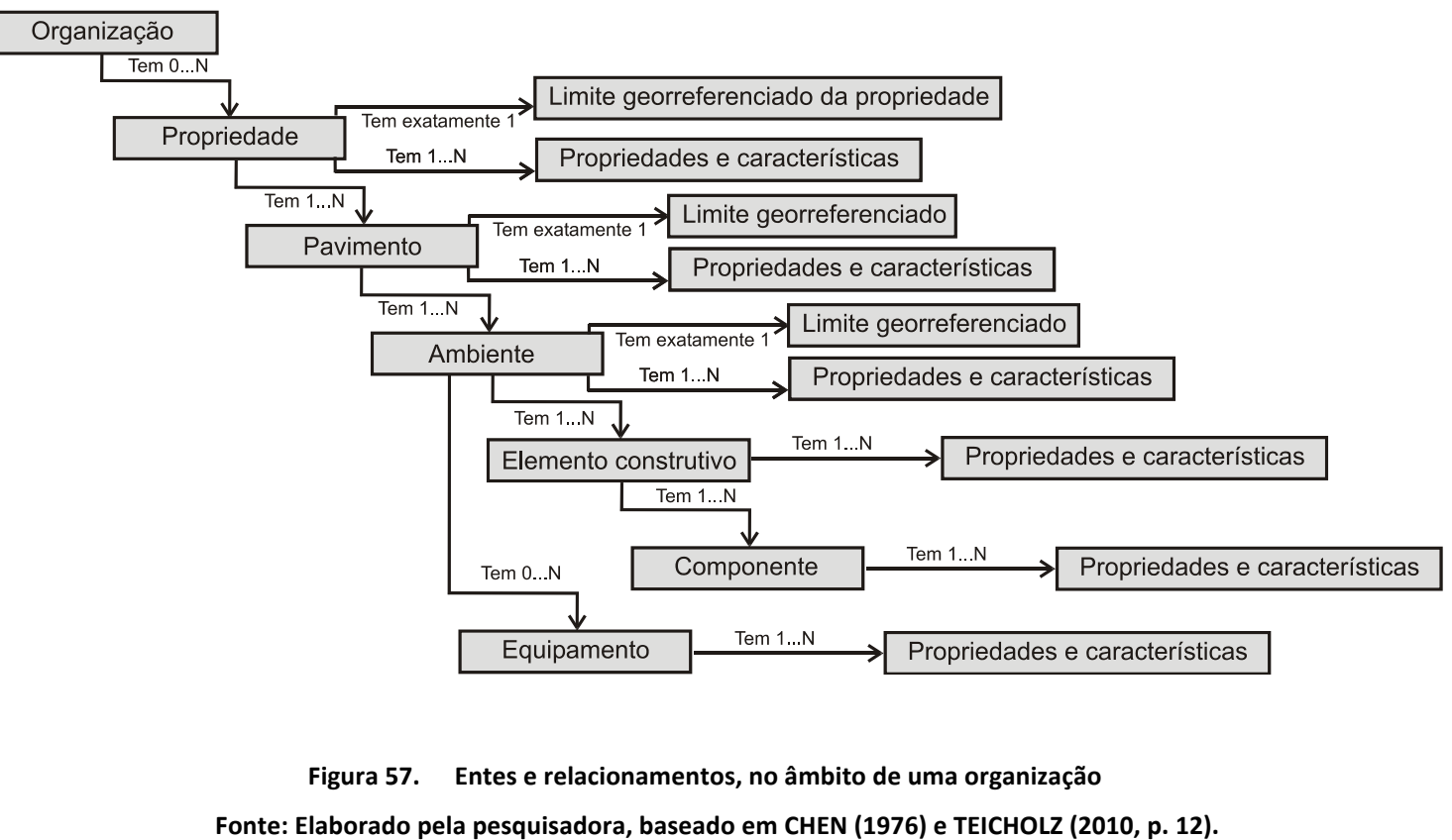

Deste modo, é possível a realização de análises das informações, a partir da utilização de filtros, que podem incluir a informação geográfica da entidade em questão.

Para identificação dos elementos do Modelo elaborado para a Escola Alpha, quanto à localização geográfica, foram adotados os seguintes critérios: coordenadas, pavimento e orientação, conforme o apresentado na Figura 58. Estes dados foram organizados de modo a permitir pesquisas (de aspectos críticos, por exemplo) que utilizem a informação referente à localização da edificação ou orientação de determinado ambiente. 


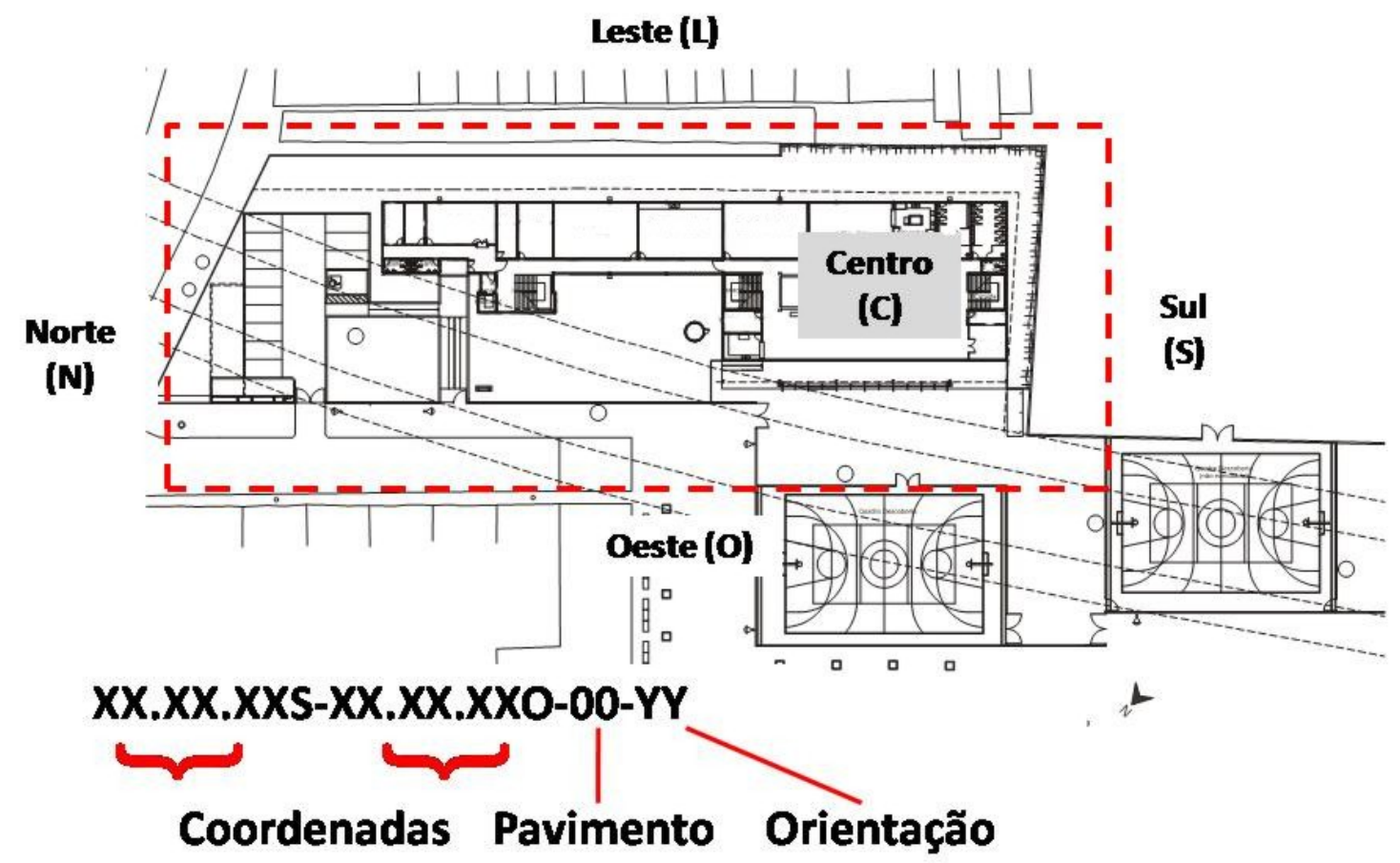

Figura 58. Critérios da legenda, para identificação de um elemento do Modelo, quanto à localização geográfica Fonte: Elaborado pela pesquisadora, baseado em CHEN, 1976 e TEICHOLZ, 2010, p. 12.

Para a elaboração do Modelo para a representação digital do projeto, contendo informações geométricas e não geometricas, a inclusão de suas características físicas e funcionais foi considerada, de modo a oferecer suporte às seguintes atividades: elaboração das representações gráficas necessárias aos projetos técnicos e arquitetônicos; elaboração de simulações de desempenho dos modelos representados; registro e organização dos resultados obtidos pelas simulações e registro de dados coletados correspondentes à aferição do desempenho real (AIA, 2008). A documentação do histórico de resultados e das ações implantadas também foi contemplada, de modo a organizar estas informações em um Banco de Dados, para a retroalimentação do processo e a consulta aos resultados, inclusive de modo a permitir seu tratamento estatístico.

Na Figura 59, é apresentada a renderização do modelo BIM, elaborado para a Escola Alpha. 


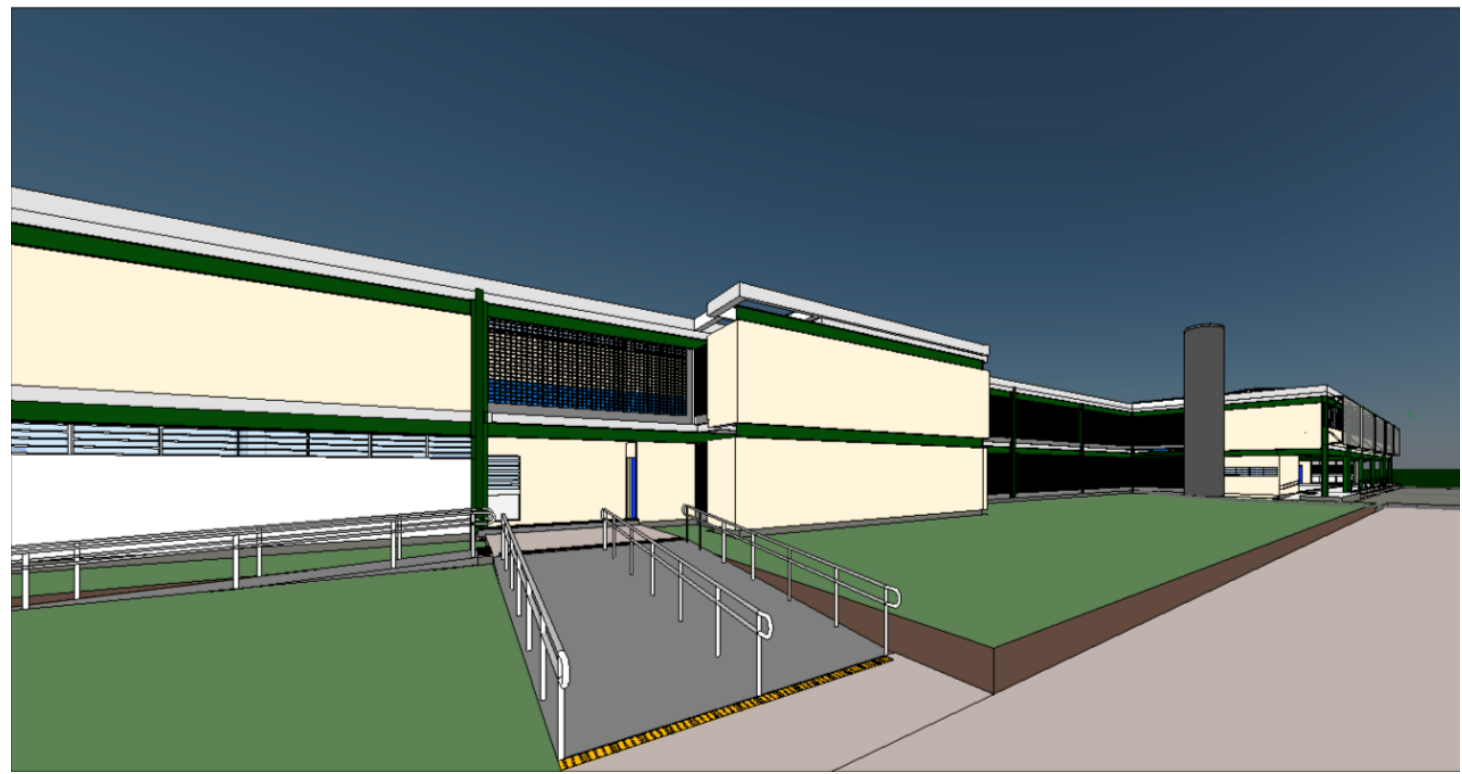

Figura 59. Modelo da Escola Alpha

Elaborado utilizando o software Revit v. 2014, da Autodesk. Fonte: Acervo da pesquisadora.

A abordagem proposta também possibilita relacionar os componentes modelados às respectivas informações da construção (indicadores de desempenho, propriedades acústicas, transmitância térmica, refletâncias, cores, cargas e comportamento estrutural), bem como às informações relacionadas à manutenção preditiva e corretiva, o que contribui para a manutenção de seu desempenho, ao longo da vida útil da edificação (EASTMAN et al., 2011).

$\mathrm{Na}$ Figura 60, é apresentado um exemplo da inserção dos componentes modelados para a Escola Alpha, associados às respectivas especificações. 


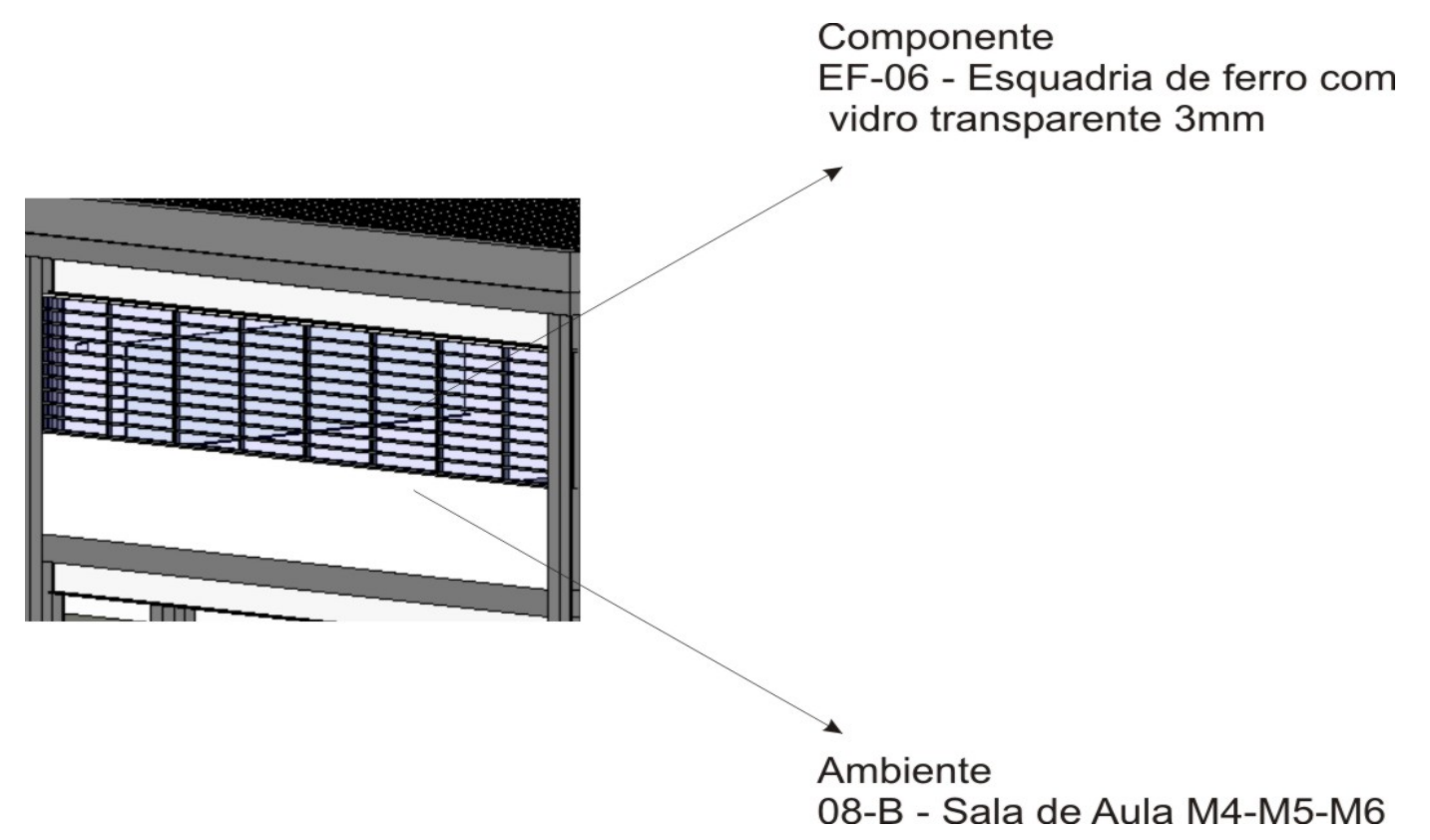

Figura 60. Detalhe da modelagem do componente no modelo BIM

Componente EF-06, inserido no Ambiente Sala de Aula 08-B, elaborado utilizando o software Revit v. 2014, da Autodesk. Fonte: Acervo da pesquisadora.

Deste modo, os componentes modelados podem ser relacionados a seu desempenho aferido, cujos resultados são obtidos com base na avaliação da edificação em uso. Esse procedimento permite identificar e validar as diretrizes de projeto e as especificações associadas a um determinado aspecto crítico avaliado. A Figura 61 apresenta os resultados obtidos pela aplicação de APO e respectivos componentes e ambientes, bem como os respectivos critérios de desempenho, identificados no diagnóstico (FRANÇA, 2011). 

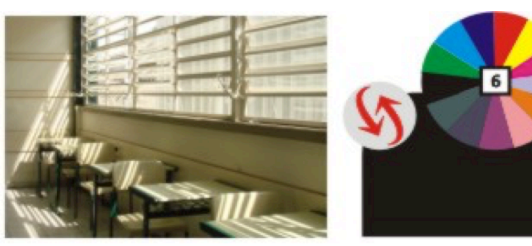

Esquadrias das salas de aula ventilaç̃o insuficiente nos dias quentes, não proporcionam estanqueidade suficiente ao vento nos dias frios nem à água da chuva, não proporcionam isolamento acústico suficiente, apresentam áreas com corrosão.

\section{Normas/ Boas práticas}

NT: NBR 15575:2008 (ABNT, 2008); ISO 15686-1:2000 (ISO, 2000). BP: Revisar os aspectos citados no projeto e na execução de novas esquadrias de padrão semelhante.

Recomendações

Para as esquadrias existentes, avaliar a instalação de borrachas de vedação em frestas, verificar a integridade da massa utilizada para a fixação dos vidros. Em ambientes nos quais é desejável o controle da luminosidade, verificar a viabilidade de uso de persianas. Revisar o projeto e verificar a qualidade da execução de esquadrias em futuros edifícios.Se possível,

incorporar difusores para a iluminação natural.

Resultado da aplicação da APO para esquadrias instaladas nas salas de aula da Escola Alpha. Fonte: FRANÇA, 2011

\section{LEGENDA}

Item correspondente no quadro de diagnósticos

Critério de desempenho

Conforto visual Conforto acústico Conforto higrotérmico Acessibilidade Funcionalidade

Salubridade

Estanqueidad

Durabilidade

Manutenabilidade

Desempenho ambiental

Segurança estrutural

Segurança estrutura

Segurançacontra incêndio

Outros: conforto tátil e ergonomia

Realimentação de projeto

Pertinente a revisão

(1) deste aspecto em futuros

projetos de edifícios

semelhantes/ alimentação

de banco de informações

Fonte: Acervo da pesquisadora.

No Anexo A, pode ser consultado um exemplo de fichas técnicas presentes nos catálogos de ambientes, cujas diretrizes de projeto foram consideradas para a consolidação do Banco de Dados objeto da presente pesquisa. Na Figura 62, é apresentado o aspecto da interface do usuário da Plataforma de Banco de Dados. 
Figura 62. Aspecto do Banco de Dados consolidado por meio da utilização da plataforma dRofus

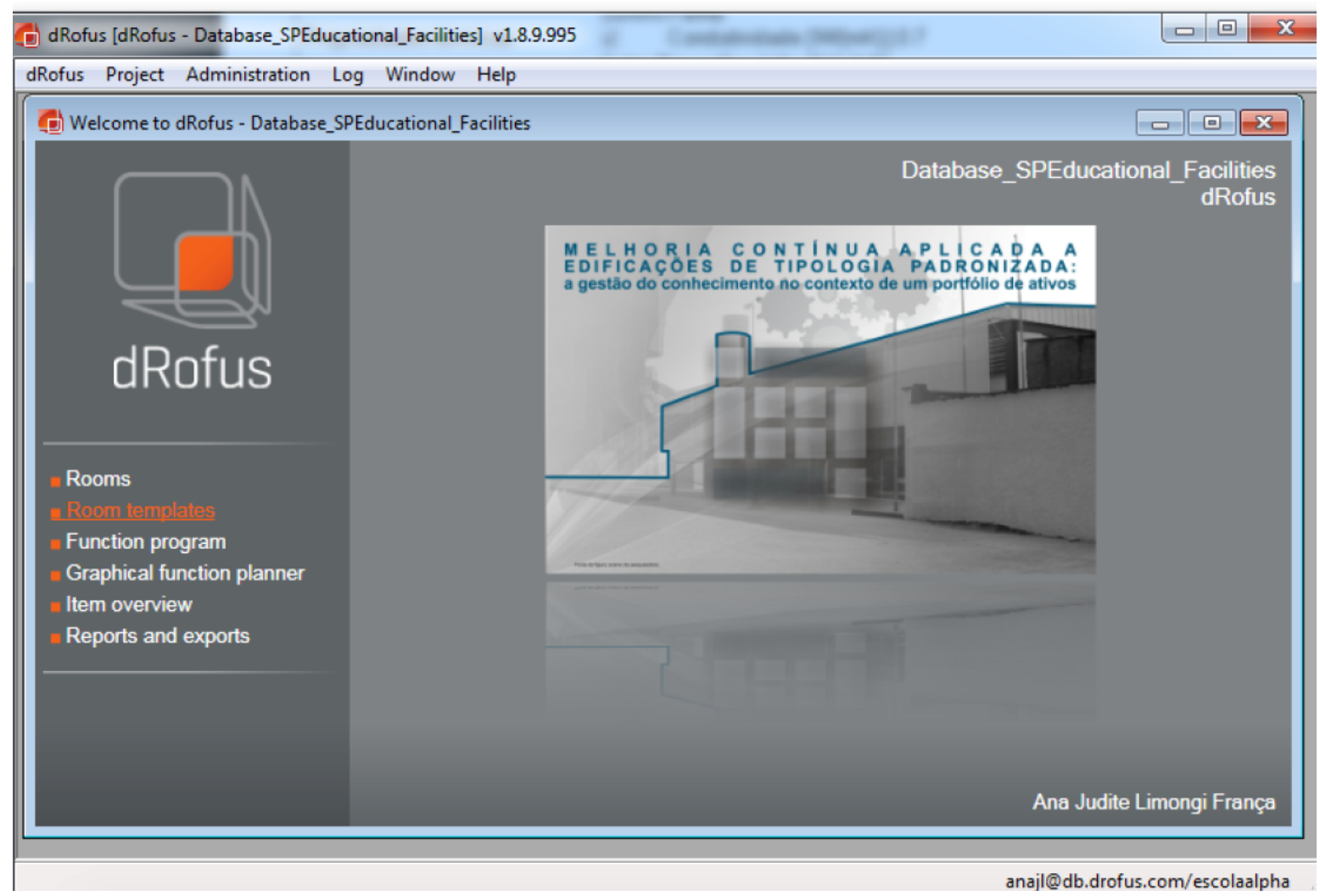

Fonte: Acervo da pesquisadora.

As diretrizes e os requisitos de projeto pertinentes à Escola Alpha foram organizados em diferentes tabelas que contém informações disponíveis no catálogo de especificações FDE, complementadas com requisitos de desempenho identificados pela aplicação de APO à edificação (FRANÇA, 2011), a saber: ambientes, acessibilidade, serviços e componentes. Como chave, ou seja, o código que identifica o item no banco de informações, foi considerada a referência adotada pela FDE na respectiva ficha.

Na Figura 63, é apresentada uma representação esquemática da arquitetura do sistema. A plataforma é composta de um Banco de Dados central, um sistema de administração central baseado em rede e um servidor de relatórios e documentos. $O$ acesso aos dados ocorre por meio de um programa de acesso para cliente (dRofus), que se conecta ao Banco de Dados e, por meio de um plug-in ${ }^{11}$, com o programa

${ }^{11}$ Um programa que pode ser adicionado a outro, com o objetivo de adicionar funções (SCHLEUSNER, 2014). 
utilizado para elaboração do modelo tridimensional - nesse caso, o Autodesk Revit (NOSYKO AS, 2015).

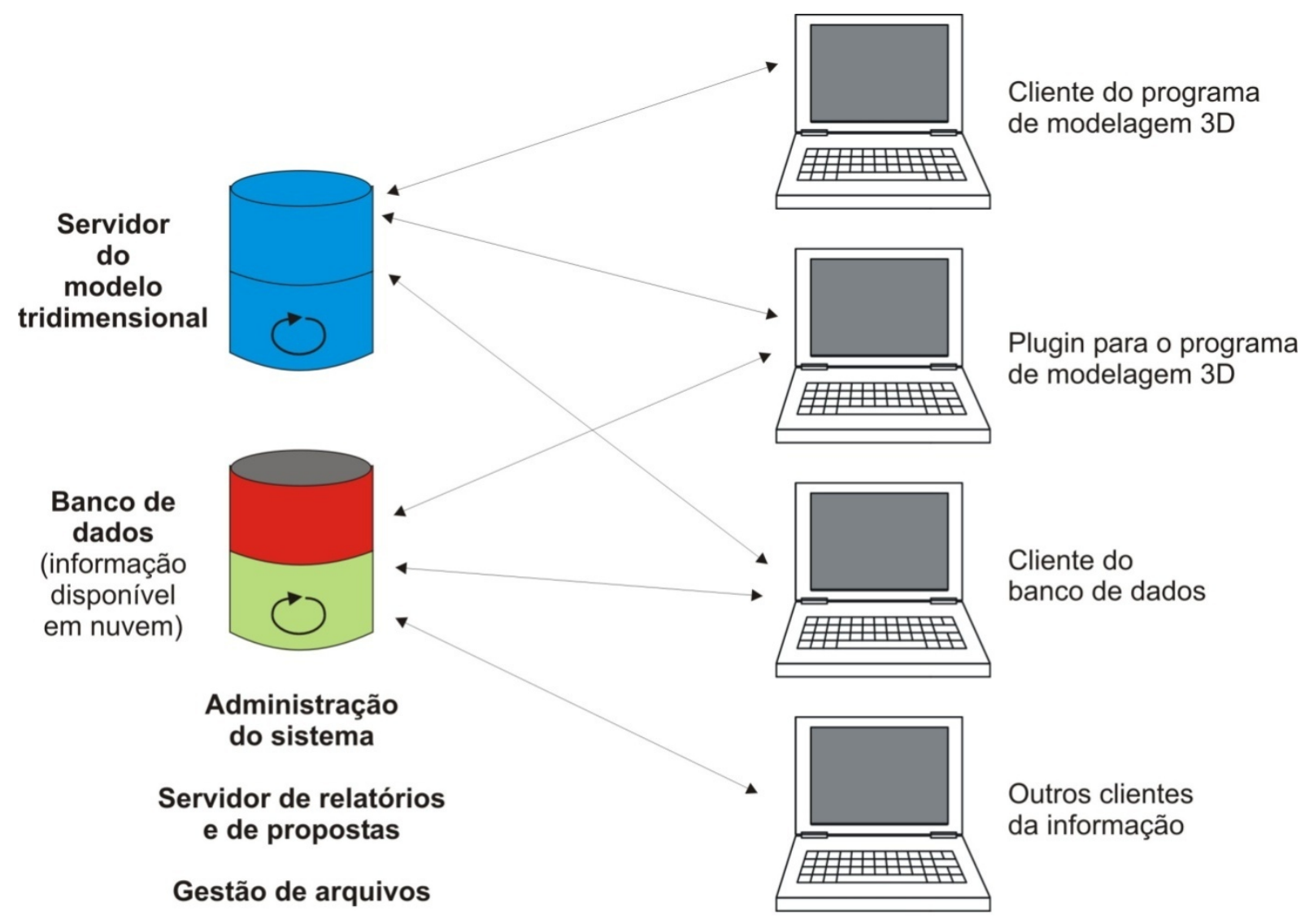

Gestão de conteúdo técnico

Figura 63. Arquitetura simplificada do sistema

Fonte: elaborado pela pesquisadora, a partir de: NOSYKO AS (2015, p. 27$)$.

A plataforma de Banco de Dados pode gerenciar diversos projetos, conforme o representado no esquema apresentado na Figura 64. Isso é importante, pois permite a consulta e a troca de informações entre os projetos, bem como a condução de análises comparativas. 


\section{Gestão de projetos}
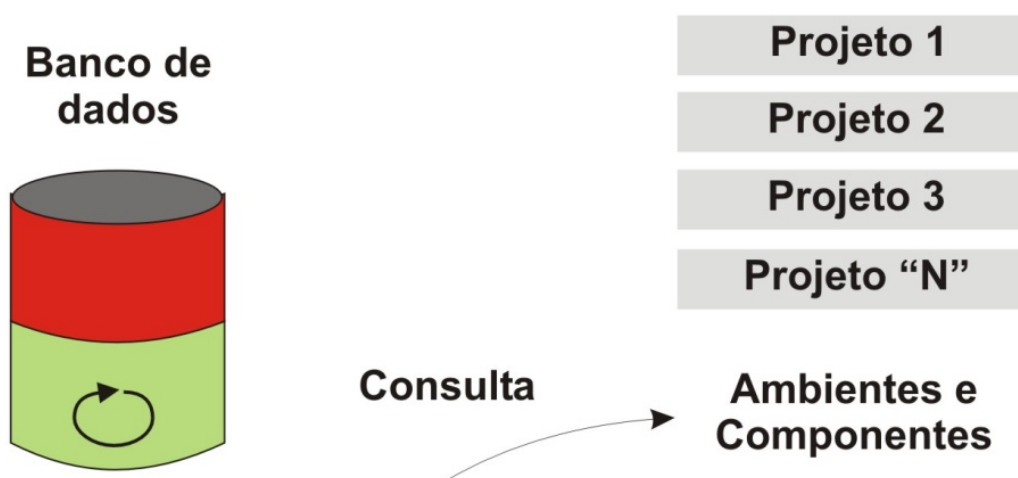

\section{Fichas de ambientes \\ Componentes}

Modelos de listas para aquisição e verificação.

\section{Validação}

Gestão de ativos

\footnotetext{
Figura 64. Representação esquemática do acesso de vários projetos ao Banco de Dados comum Fonte: elaborado pela pesquisadora, a partir de: NOSYKO AS (2015, p. 11).
}

Quanto à utilização da plataforma de Banco de Dados dRofus, Baldauf; Formoso e Miron (2013) destacam que não é prática comum a modelagem de requisitos de projeto em aplicativos BIM durante os estágios iniciais do processo de projeto. Os autores citados sugerem um método para a validação de requisitos em empreendimentos habitacionais de interesse social (HIS) que inclui a identificação e o processamento dos requisitos de projeto, a disponibilização destes requisitos no programa computacional e a verificação de seu atendimento frente às soluções de projeto.

Com base na leitura dos documentos gráficos e das especificações de projeto referentes à Escola Alpha, as informações da construção foram organizadas e tabuladas, preliminarmente à configuração das interfaces do usuário no Banco de Dados.

Um aspecto relevante do recurso adotado constituiu-se na possibilidade de configurar padrões de acesso para os diferentes atores, que podem acessar e/ou editar as informações modeladas, bem como atribuir a responsabilidade pela gestão 
dos componentes instalados.

Na Figura 65, é apresentado um exemplo de uma lista de responsáveis determinados para o projeto, que devem ser associados aos diversos componentes da edificação (a saber: engenheiro civil, projetista técnico, arquiteto, gerente de facilidades, entre outros).

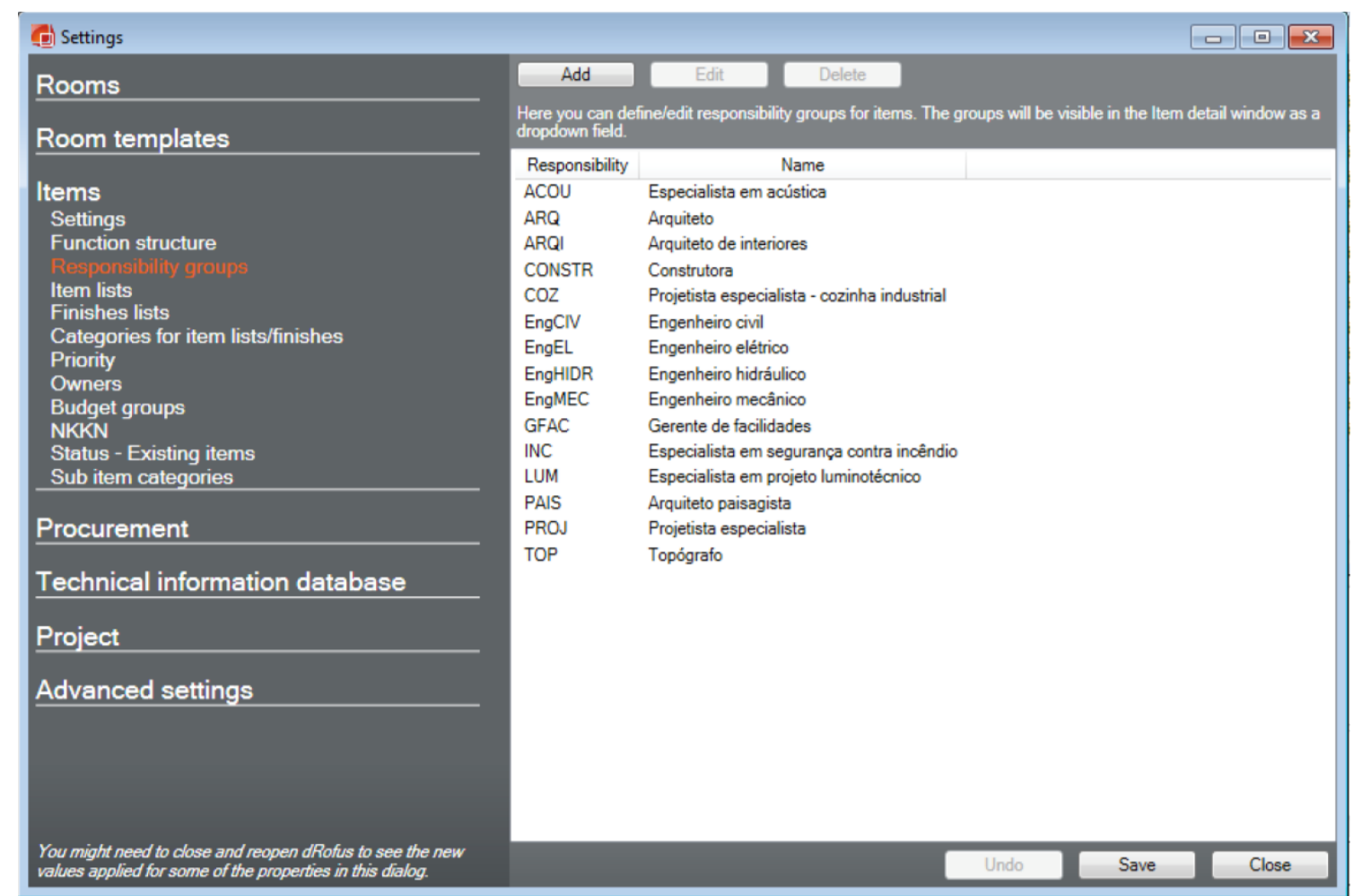

Figura 65. Exemplo de interface para a atribuição de responsabilidades Fonte: Acervo da pesquisadora.

As atribuições de responsabilidade podem ser configuradas, tanto para o projeto como para a fase de orçamentação, conforme o exemplo apresentado na Figura 66. 


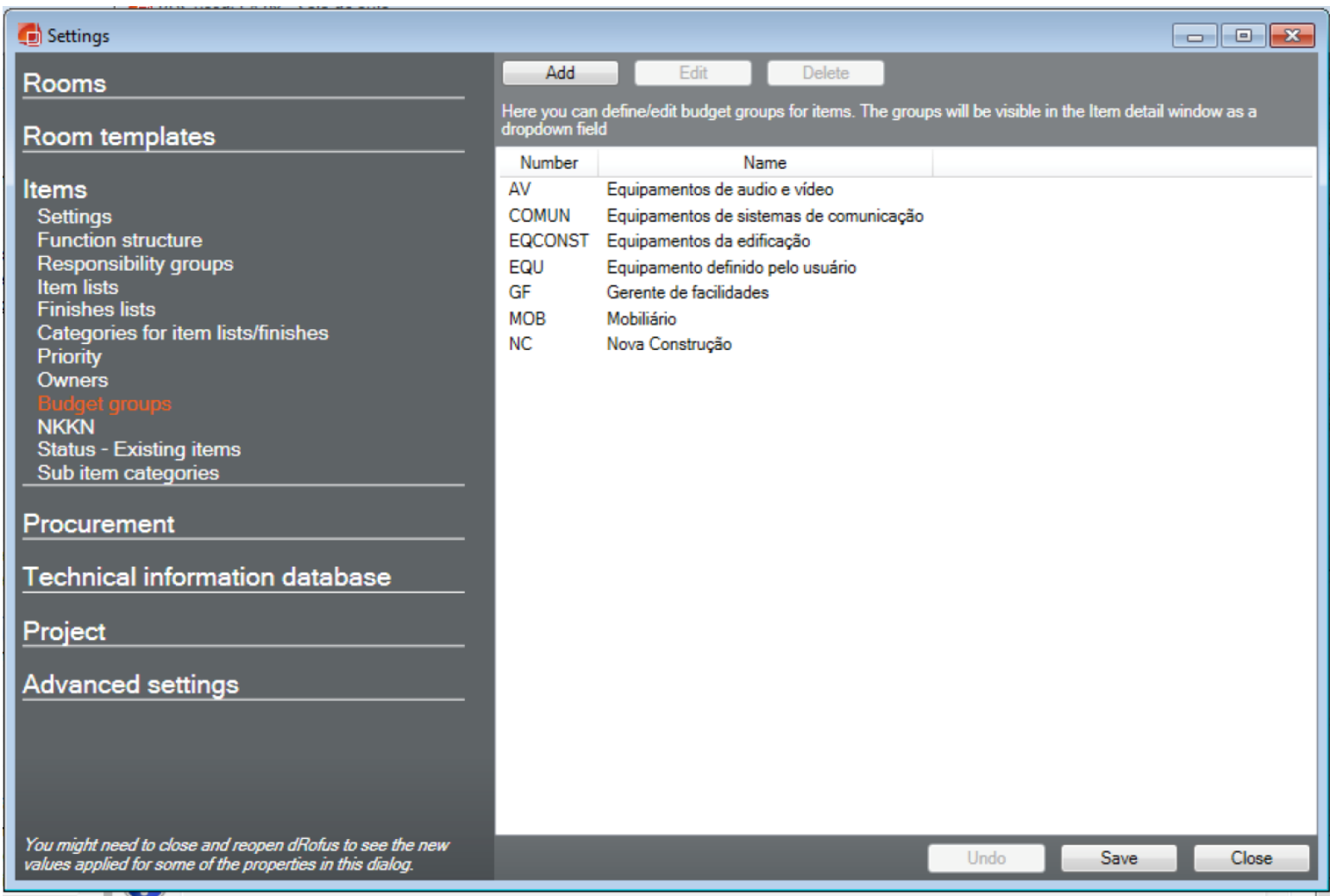

Figura 66. Exemplo de classificação de componentes em grupos para orçamentação Fonte: Acervo da pesquisadora.

Durante a fase de planejamento da modelagem, os componentes foram classificados, conforme a terminologia OCCS, para padronizar sua nomenclatura e determinar referências numéricas que possibilitassem futuras análises.

As etapas de planejamento, análise e de tabulação das diretrizes de projeto possibilitaram que se tivesse clareza quanto aos requisitos relacionados à escola Alpha, em diferentes níveis hierárquicos de informação, conforme apresentado na Figura 67. 


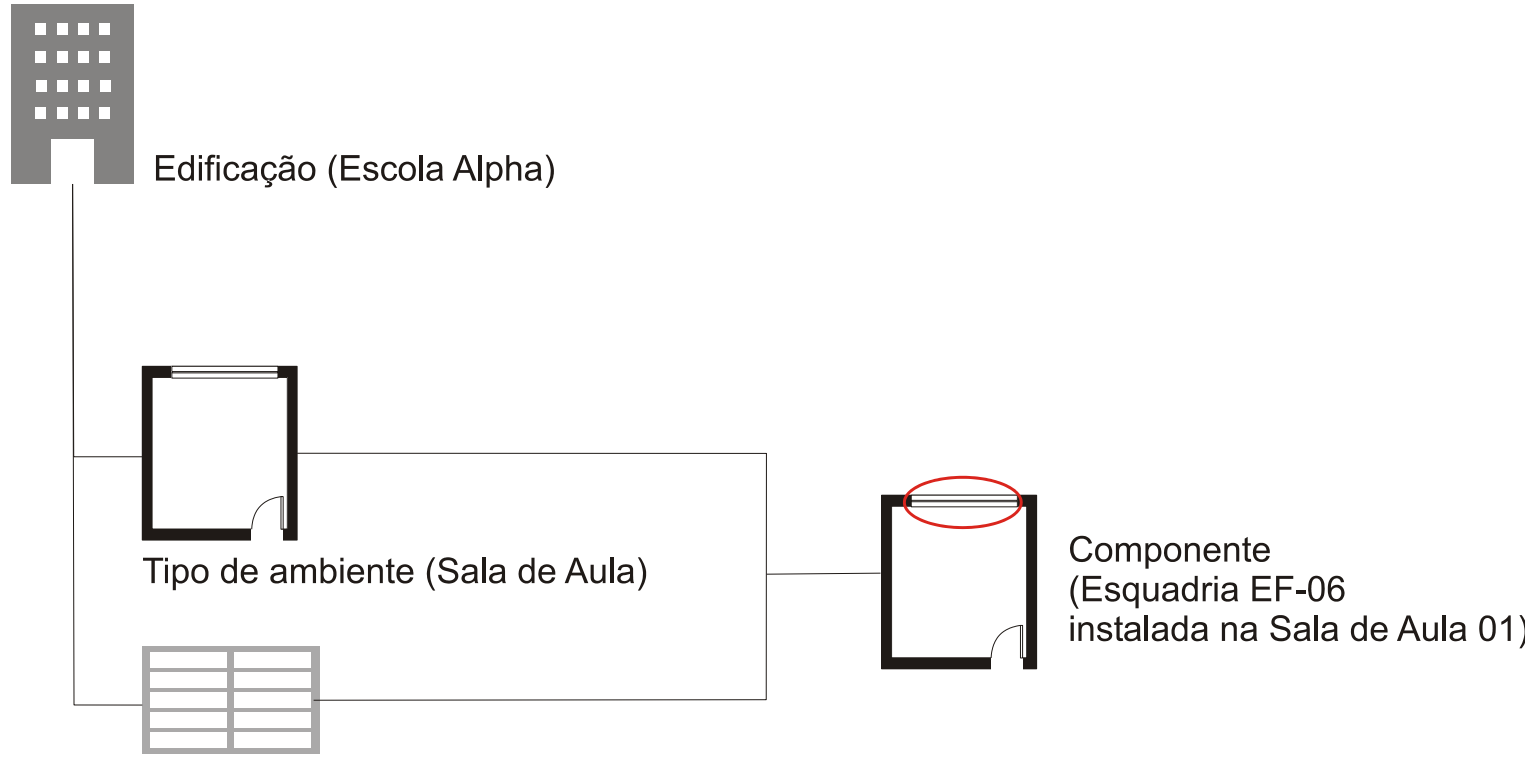

Família de componentes (Esquadrias tipo EF-06)

Figura 67. Apresentação hierárquica das informações Fonte: Acervo da pesquisadora.

Dessa forma, procedeu-se à tabulação das informações e especificações de projeto, de modo a determinar as propriedades importantes para a modelagem da Escola Alpha.

Lee; Chuang e Wu (2011) destacam a grande contribuição dos recursos tecnológicos para a organização e comunicação da quantidade de informações necessárias à produção do edifício, desde que os sistemas adotados pela equipe permitam a operação integrada, de modo a permitir o uso de diferentes aplicativos. O sistema de Banco de Dados adotado pode permitir, inclusive, o acesso por membros da equipe situados em diferentes localizações geográficas. Também é fundamental que os sistemas utilizados apresentem recursos amigáveis para a interação humana no ambiente eletrônico. Por isso, a interface gráfica do sistema com o usuário deve possibilitar seu acesso ágil e adequado à informação e, na medida do possível, ser intuitiva.

A representação esquemática da arquitetura do sistema é apresentada na Figura 68. 


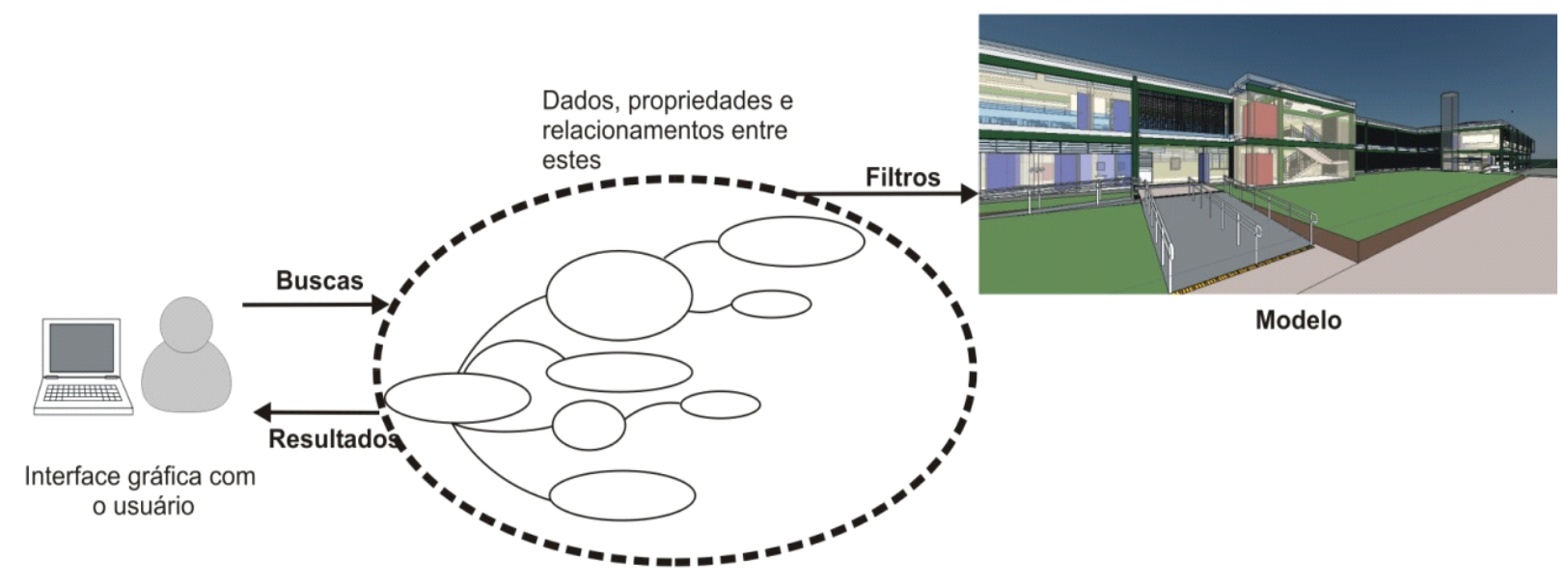

Figura 68. Representação esquemática da arquitetura do sistema Fonte: Adaptado pela pesquisadora, a partir de: LUCAS; BULBUL; THABET (2013, p. 81).

No Quadro 21, são apresentados exemplos das propriedades e características atribuídas aos componentes, modelados para a Escola Alpha, a saber: código FDE, nome da ficha FDE, número e nome OmniClass correspondentes, dimensões, elementos constituintes, acessórios, acabamentos, protótipos comerciais de referência, orientações para aplicação e execução, fichas de referência e componentes relacionados, critérios para recebimento do serviço, itens incluídos no preço, critérios de medição, legislação e normas técnicas citadas, data da elaboração da ficha de diretrizes e respectiva versão. 
Quadro 21. Exemplo de organização das especificações técnicas, correspondentes ao catálogo de componentes instalados na Escola Alpha

\begin{tabular}{|c|c|c|}
\hline $\begin{array}{l}\text { Código de Ficha do } \\
\text { Componente (Fonte: } \\
\text { Catálogo de } \\
\text { componentes FDE) }\end{array}$ & EF-01 & $\begin{array}{l}\text { PM-04 } \\
\text { PM-05 } \\
\text { PM-08 } \\
\text { PM-24 }\end{array}$ \\
\hline $\begin{array}{l}\text { Ficha de Componente } \\
\text { (Fonte: Catálogo de } \\
\text { Componentes FDE) }\end{array}$ & Esquadria de ferro $(90 \times 60 \mathrm{~cm})$ & $\begin{array}{c}\text { Porta de } \\
\text { madeira } \\
\text { sarrafeada } \\
\mathrm{p} / \text { pintura e batente de madeira }\end{array}$ \\
\hline $\begin{array}{l}\text { Número OmniClass } \\
\text { (Fonte: OmniClass } \\
\text { Table 23: Products) }\end{array}$ & 23-17 1313 & 23-17 1115 \\
\hline $\begin{array}{l}\text { Titulo OmniClass } \\
\text { (Fonte: OmniClass } \\
\text { Table 23: Products) }\end{array}$ & Janela de metal & Porta de madeira \\
\hline $\begin{array}{l}\text { Material(is) (Fonte: } \\
\text { Catálogo de } \\
\text { Componentes FDE) } \\
\end{array}$ & $\begin{array}{l}\text { ferro/vidro incolor } 3 \mathrm{~mm} \text { ou fantasia } 4 \mathrm{~mm} \text {, quando } \\
\text { utilizado em sanitários e vestiários }\end{array}$ & madeira sarrafeada \\
\hline $\begin{array}{l}\text { Largura }(\mathrm{cm}) \text { (Fonte: } \\
\text { Catálogo de } \\
\text { Componentes FDE) }\end{array}$ & $90 \mathrm{~cm}$ & 0,82 \\
\hline $\begin{array}{l}\text { Constituintes (Fonte: } \\
\text { Catálogo de } \\
\text { Componentes FDE) }\end{array}$ & $\begin{array}{l}\text { - Contramarcos, básculas e batentes em perfis de ferro, } \\
\text { conforme bitolas especificadas nos desenhos. } \\
\text {-obs.:. Em regiôes litorâneas ou outros locais sujeitos à } \\
\text { atmosfera corrosiva (NBR } 6181 \text { ), todos os perfis deverão } \\
\text { ser galvanizados. } \\
\text { - Alavanca em aço carbono } 1010 / 1020 \text { zincado, } \\
\text { espessura de } 2,65 \mathrm{~mm} \text { e comprimento entre } 140 \mathrm{~mm} \text { e } \\
150 \mathrm{~mm} \text {. } \\
\text { - Vidros planos incolores: transparentes lisos de } 3 \mathrm{~mm} \text { ou } \\
\text { fantasia comum de } 4 \mathrm{~mm} \text {, quando utilizados em } \\
\text { sanitários e vestiários. }\end{array}$ & 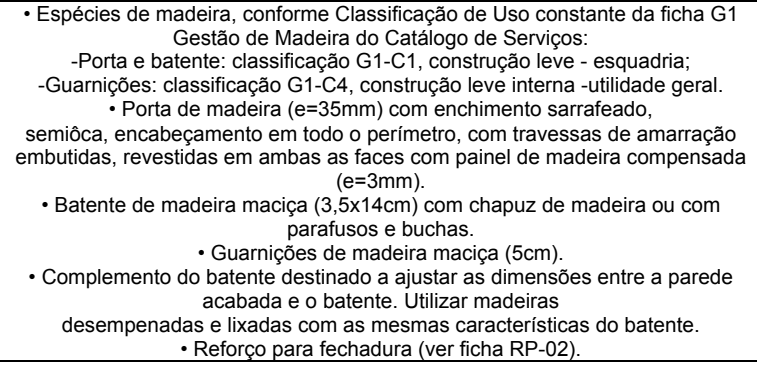 \\
\hline $\begin{array}{l}\text { Acessórios (Fonte: } \\
\text { Catálogo de } \\
\text { Componentes FDE) }\end{array}$ & $\begin{array}{l}\text { - Rebites de ferro cabeça chata (aço inox para regiões } \\
\text { litorâneas ou outros locais sujeitos à atmosfera } \\
\text { corrosiva). } \\
\text { - Parafusos galvanizados de rosca soberba e buchas de } \\
\text { nylon (FISCHER S6). }\end{array}$ & $\begin{array}{l}\text { - Dobradiças tipo média, em aço cromado, com pino e bolas, de } 31 / 2 " \text { x } 3 \text { 3": } \\
\text {-PM-04, PM-05 e PM-24: } 3 \text { (três) unidades; } \\
\text {-PM-0: } 6 \text { (seis) unidades. } \\
\text { - Fechadura de embutir, tipo externa, em aço, distância de broca }=55 \mathrm{~mm} \text {. } \\
\text { - Maçaneta tipo alavanca, maciça, bordas arredondadas, acabamento cromado. } \\
\text { - Roseta com acabamento cromado, acompanha as maçanetas. } \\
\text { - Para PM-08: Fecho de embutir, tipo "unha" ( } 18 \text { a 20cm), com alavanca, em aço } \\
\text { e acabamento cromado: } 2 \text { (duas) unidades. }\end{array}$ \\
\hline $\begin{array}{l}\text { Acabamentos (Fonte: } \\
\text { Catálogo de } \\
\text { Componentes FDE) }\end{array}$ & $\begin{array}{l}\text { - Básculas, batentes e contramarcos: pintura esmalte } \\
\text { sobre base antioxidante (zarcão). } \\
\text {-Obs.: Em regiôes litorâneas ou outros locais sujeitos à } \\
\text { atmosfera corrosiva - conforme NBR } 6181 \text { (ABNT, } \\
\text { 2003), pintura esmalte sob refundo para galvanizados. } \\
\text { - Alavanca: pintura esmalte sobre fundo para } \\
\text { galvanizados. }\end{array}$ & $\begin{array}{l}\text { - Porta, batente de madeira, guarnições e complemento: } \\
\text {-Pintura esmalte ou óleo sobre fundo para madeira, conforme indicação em } \\
\text { projeto. Cores de acordo com especificação em projeto. } \\
\text { • Reforço RP-02: ver ficha RP-02. }\end{array}$ \\
\hline $\begin{array}{l}\text { Protótipo Comercial } \\
\text { (Fonte: Catálogo de } \\
\text { Componentes FDE) }\end{array}$ & $\begin{array}{c}\text { •Alavanca: } \\
\text {-DE TONI: ref. } 34.0 \text { - FZ } \\
\text {-PRENSAL: ref. } 603 \\
\text {-SOPRANO: cód. } 03505.0015 .13 \text { - FZB }\end{array}$ & 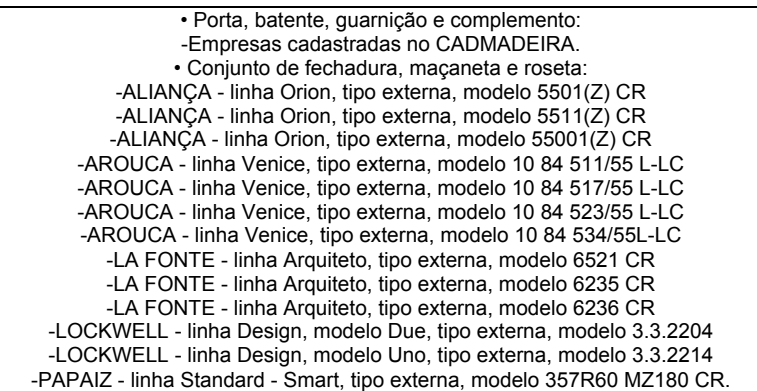 \\
\hline $\begin{array}{c}\text { Aplicação (Fonte: } \\
\text { Catálogo de } \\
\text { Componentes FDE) }\end{array}$ & Em diversos ambientes, conforme indicado em projeto. & - Em ambientes internos, conforme indicação em projeto. \\
\hline $\begin{array}{l}\text { Execução (Fonte: } \\
\text { Catálogo de } \\
\text { Componentes FDE) }\end{array}$ & $\begin{array}{l}\text { - Bater os pontos de solda e eliminar todas as rebarbas } \\
\text { nas emendas e cortes dos perfis. } \\
\text { - Antes da aplicação da base antioxidante ou do fundo } \\
\text { para galvanizados, toda superfíice metálica deve estar } \\
\text { completamente limpa, seca e desengraxada. } \\
\text { - Em regióes litorâneas ou outros locais sujeitos à } \\
\text { atmosfera corrosiva (NBR 6181): } \\
\text {-O componente deve ser montado com perfis } \\
\text { previamente galvanizados e ter os pontos de solda e } \\
\text { corte tratados com galvanização a frio (tratamento } \\
\text { anticorrosivo composto de zinco). }\end{array}$ & 0 \\
\hline
\end{tabular}


...Continuação

\begin{tabular}{|c|c|c|}
\hline $\begin{array}{l}\text { Fichas de Referência } \\
\text { (Fonte: Catálogo de } \\
\text { Componentes FDE) }\end{array}$ & $\begin{array}{c}\text { Catálogo de Componentes } \\
\text { Ficha ME-02 Montante estrutural para esquadrias } \\
\text { (vertical) } \\
\text { ME-03 Montante estrutural para esquadrias (horizontal) } \\
\text { Catálogo de Serviços } \\
\text { Ficha S13.04 Vidro impresso comum } \\
\text { Ficha S13.06 Vidro liso transparente } \\
\text { Ficha S14 Pintura } \\
\text { Ficha S14.09 Tinta esmalte sintético } \\
\text { Ficha S14.17 Galvanização } \\
\text { Ficha S14.18 Fundos para metais } \\
\text { Ficha S14.21 Tinta esmalte à base de água } \\
\text { Ficha S14.23 Fundos para metais e madeira à base de } \\
\text { água }\end{array}$ & $\begin{array}{c}\text { Catálogo de Componentes } \\
\text { Ficha RP-02 Reforço para fechaduras } \\
\text { Catálogo de Serviços } \\
\text { Ficha G1 Gestão de Madeira } \\
\text { Ficha S11.02 Cantoneira de alumínio } \\
\text { Ficha S14 Pintura } \\
\text { Ficha S14.09 Tinta esmalte sintético } \\
\text { Ficha S14.12 Tinta a óleo } \\
\text { Ficha S14.19 Fundos para madeira }\end{array}$ \\
\hline $\begin{array}{l}\text { Recebimento (Fonte: } \\
\text { Catálogo de } \\
\text { Componentes FDE) }\end{array}$ & $\begin{array}{c}\text { • perfis: devem ter, necessariamente, as bitolas } \\
\text { indicadas. } \\
\text { - Alavanca: aferir conformidade às especificações. } \\
\text { • Não serão aceitas esquadrias empenadas, } \\
\text { desniveladas, } \\
\text { fora de prumo ou de esquadro ou que apresentem } \\
\text { quaisquer defeitos decorrentes do manuseio e } \\
\text { transporte. } \\
\text { - Não podem existir rebarbas ou desníveis entre o } \\
\text { conjunto e as esquadrias adjacentes. } \\
\text { - O funcionamento do conjunto deve ser verificado após } \\
\text { a completa secagem da pintura e subsequente } \\
\text { lubrificação; não deve apresentar jogo causado por } \\
\text { folgas. } \\
\text { - Fechado todo o conjunto, lançando-se sobre o mesmo } \\
\text { um jato d'água, a sua estanqueidade deve ser total. } \\
\text { - Em regiôes litorâneas ou outros locais sujeitos à } \\
\text { atmosfera corrosiva, conforme NBR 6181 (ABNT, 2003): } \\
\text {-Exigir certificado de galvanização a fogo, emitido pela } \\
\text { empresa galvanizadora, para todos os perfis e alavanca; } \\
\text {-Verificar o tratamento dos pontos de solda e corte com } \\
\text { galvanização a frio; } \\
\text {-Verificar o uso de parafusos galvanizados e rebites de } \\
\text { aço inox. }\end{array}$ & $\begin{array}{c}\text { • O serviço pode ser recebido, se atendidas todas as condições de } \\
\text { especificação, projeto, fornecimento e execução. } \\
\text { - A aceitação do lote se fará mediante a comprovação documental da origem da } \\
\text { madeira, exigindo-se: } \\
\text {-Notas fiscais; } \\
\text {-Declaração de emprego apenas de produtos e subprodutos } \\
\text { de madeira de origem exótica ou de origem nativa da flora } \\
\text { brasileira adquirida de pessoas jurídicas cadastradas no CADMADEIRA; } \\
\text {-Comprovante de cadastramento do fornecedor perante o CADMADEIRA (a } \\
\text { situação cadastral do fornecedor deverá ser conferida eletronicamente). } \\
\text {-Aferir as especificações de todos os itens. } \\
\text { - Porta, batente de madeira, guarnições e complemento: } \\
\text {-Espécie botânica: } \\
\text { „Conferir a espécie da madeira utilizada, de acordo com a Classificação de Uso } \\
\text { constante da ficha G1 Gestão de Madeira, do Catálogo de Serviços; } \\
\text { „A Fiscalização poderá, a seu critério, requerer a identificação da espécie } \\
\text { botânica da madeira e os resultados de ensaios físico-mecânicos. As amostras, } \\
\text { retiradas aleatoriamente do mesmo lote, deverão ser avaliadas em laboratório. } \\
\text {-Verificar a inexistência de fungos, apodrecimentos ou furos de insetos; } \\
\text { - Verificar encabeçamento em todo o perímetro; } \\
\text {-Verificar, auditivamente, com leves batidas em vários pontos da superfície da } \\
\text { porta, a especificação do enchimento sarrafeado. Não serão aceitas portas ôcas } \\
\text { ou com miolo colmeia; } \\
\text {-Rejeitar peças empenadas, desniveladas, fora de prumo ou de esquadro; } \\
\text {-A folha da porta deverá ser colocada em posição semiaberta e permanecer } \\
\text { parada, caso contrário, será sinal } \\
\text { evidente de desvio de prumo da esquadria. } \\
\text { - Acessórios: Aferir as especificações, verificar a correta instalação e } \\
\text { funcionamento. } \\
\text {-Verificar a ausência de falhas na pintura ou quaisquer defeitos decorrentes do } \\
\text { manuseio. }\end{array}$ \\
\hline $\begin{array}{l}\text { Serviços Incluídos no } \\
\text { Preço (Fonte: Catálogo } \\
\text { de Componentes FDE) }\end{array}$ & $\begin{array}{l}\text { - Esquadria, acessórios e lubrificação das partes } \\
\text { móveis. }\end{array}$ & 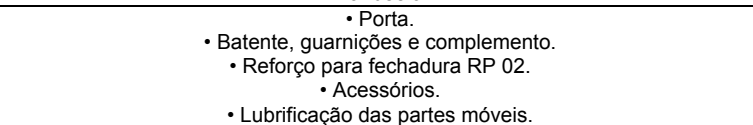 \\
\hline $\begin{array}{l}\text { Critérios de Medição } \\
\text { (Fonte: Catálogo de } \\
\text { Componentes FDE) }\end{array}$ & un. - por unidade instalada. & unidade instalada. \\
\hline Legislação & 0 & $\begin{array}{l}\text { Decreto Estadual n } n^{\circ} 53.047 \text {, de } 02 \text { de junho de } 2008 \text { - cria o CADMADEIRA e } \\
\text { estabelece procedimentos na aquisição de produtos de subprodutos de madeira } \\
\text { de origem nativa pelo Governo do Estado de São Paulo. }\end{array}$ \\
\hline Normas & 0 & NBR 7203:1982 - Madeira serrada e beneficiada. \\
\hline $\begin{array}{l}\text { Data (Fonte: Catálogo } \\
\text { de Componentes FDE) }\end{array}$ & $25 / 9 / 2012$ & $22 / 3 / 2010$ \\
\hline $\begin{array}{l}\text { Revisão (Fonte: } \\
\text { Catálogo de } \\
\text { Componentes FDE) }\end{array}$ & 3 & 9 \\
\hline
\end{tabular}

0 = não há informação disponível para o campo.

Fonte: Acervo da pesquisadora. Elaborado a partir de especifcações disponíveis em FDE (2014). 
A cada componente, foi atribuída uma ficha, contendo suas especificações técnicas, restrições de aplicação, estimativa de vida útil e informações sobre a manutenção e a garantia, conforme exemplo apresentado na Figura 69. A ficha está relacionada com a representação tridimensional do componente, que será inserida nos ambientes escolhidos.

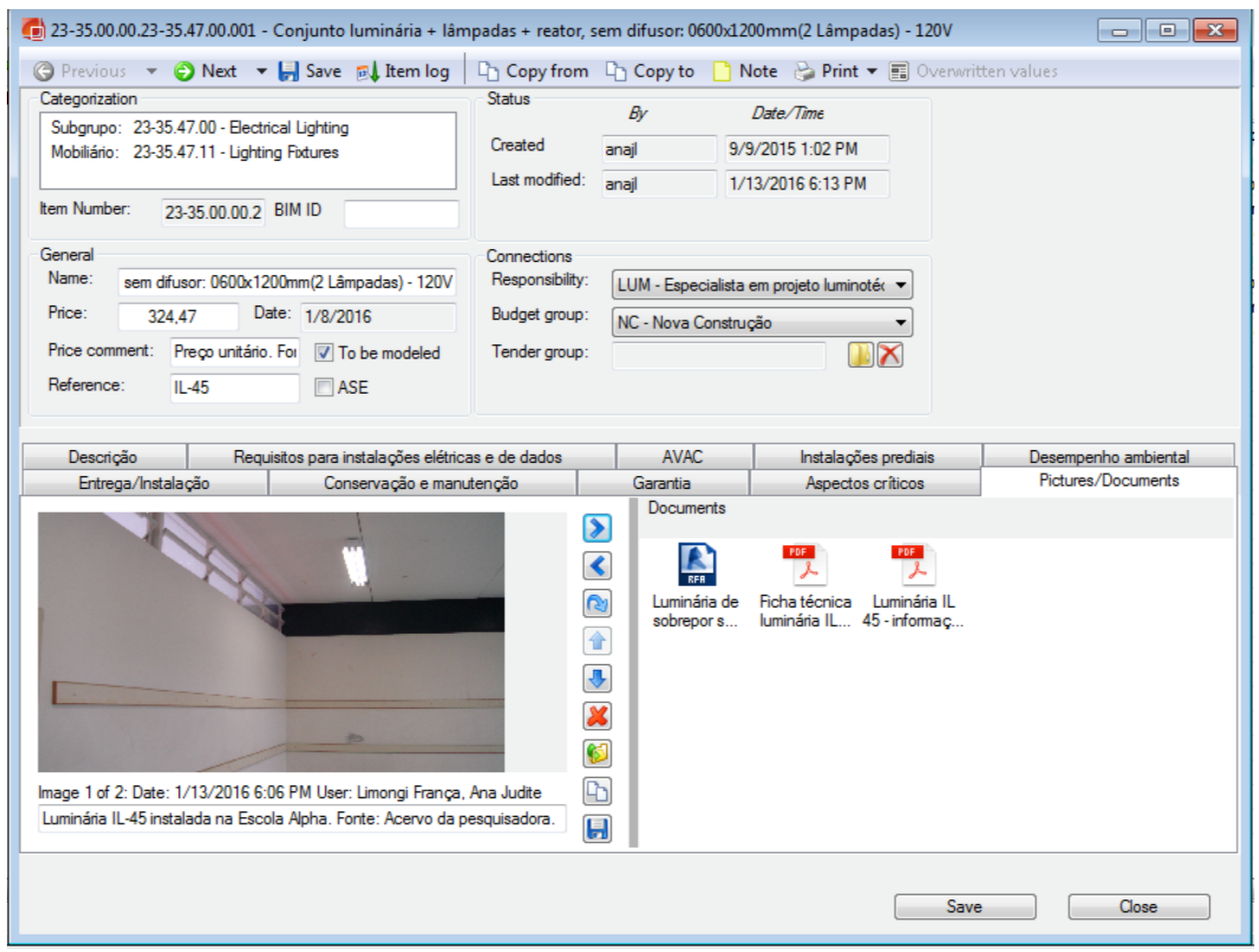

Figura 69. Exemplo de ficha de componente configurada para o projeto da Escola Alpha Fonte: Acervo da pesquisadora.

Os componentes e suas características podem ser rastreados e quantificados, quando inseridos no ambiente, conforme o exemplo apresentado na Figura 70. 


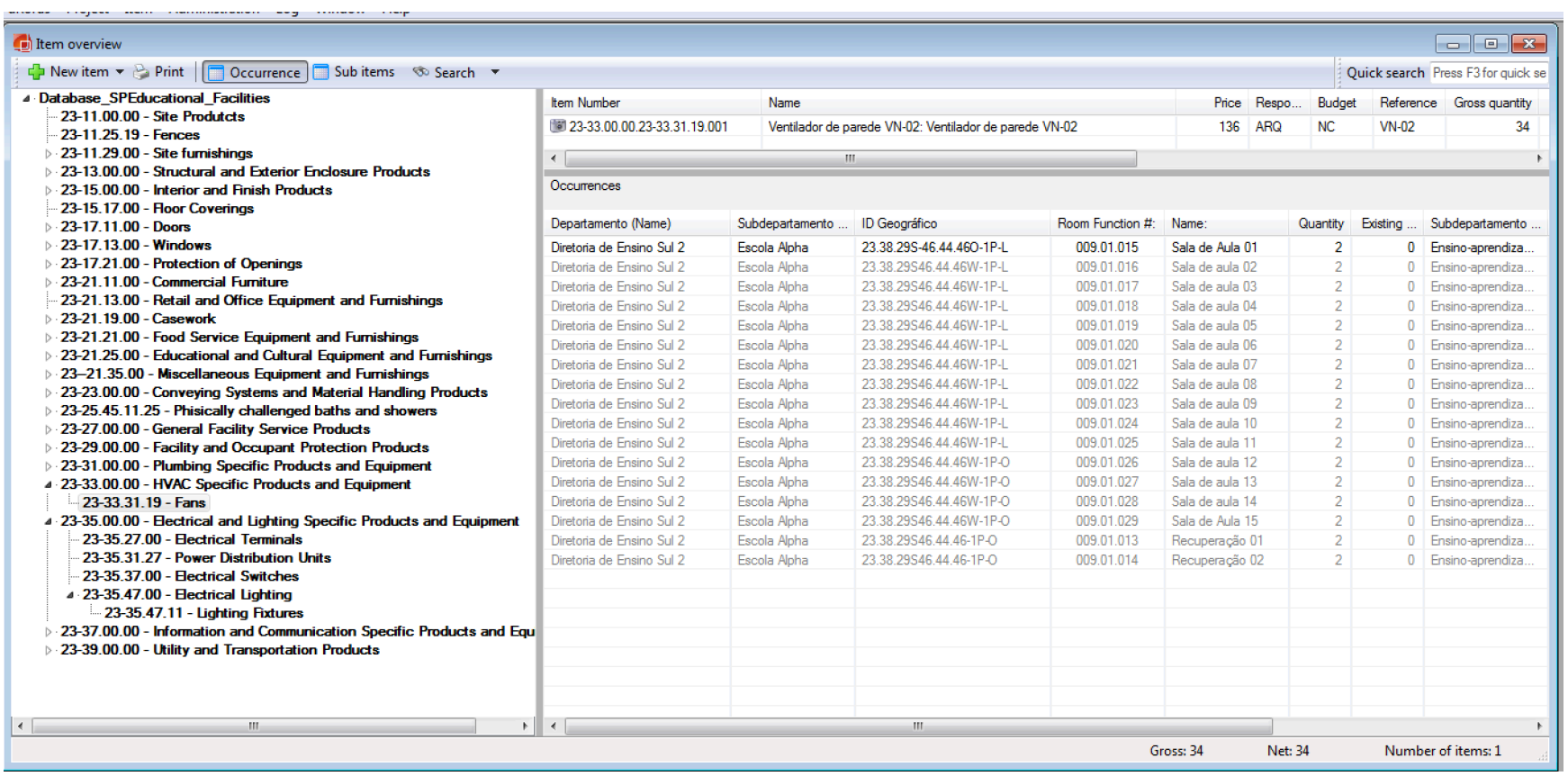

Figura 70. Exemplo de pesquisa de ocorrência de componente e respectiva localização no modelo.

Fonte: Acervo da pesquisadora.

Assim, durante a elaboração do projeto é possível a verificação de quantitativos, por meio da comparação entre o especificado e o existente no modelo, bem como a consulta a especificações e diretrizes de projeto.

$\mathrm{Na}$ Figura 71, são apresentados exemplos de modelagem de ambientes internos e seus componentes. Esses elementos foram objeto de compatibilização com os requisitos determinados para as fichas de especificações técnicas. 

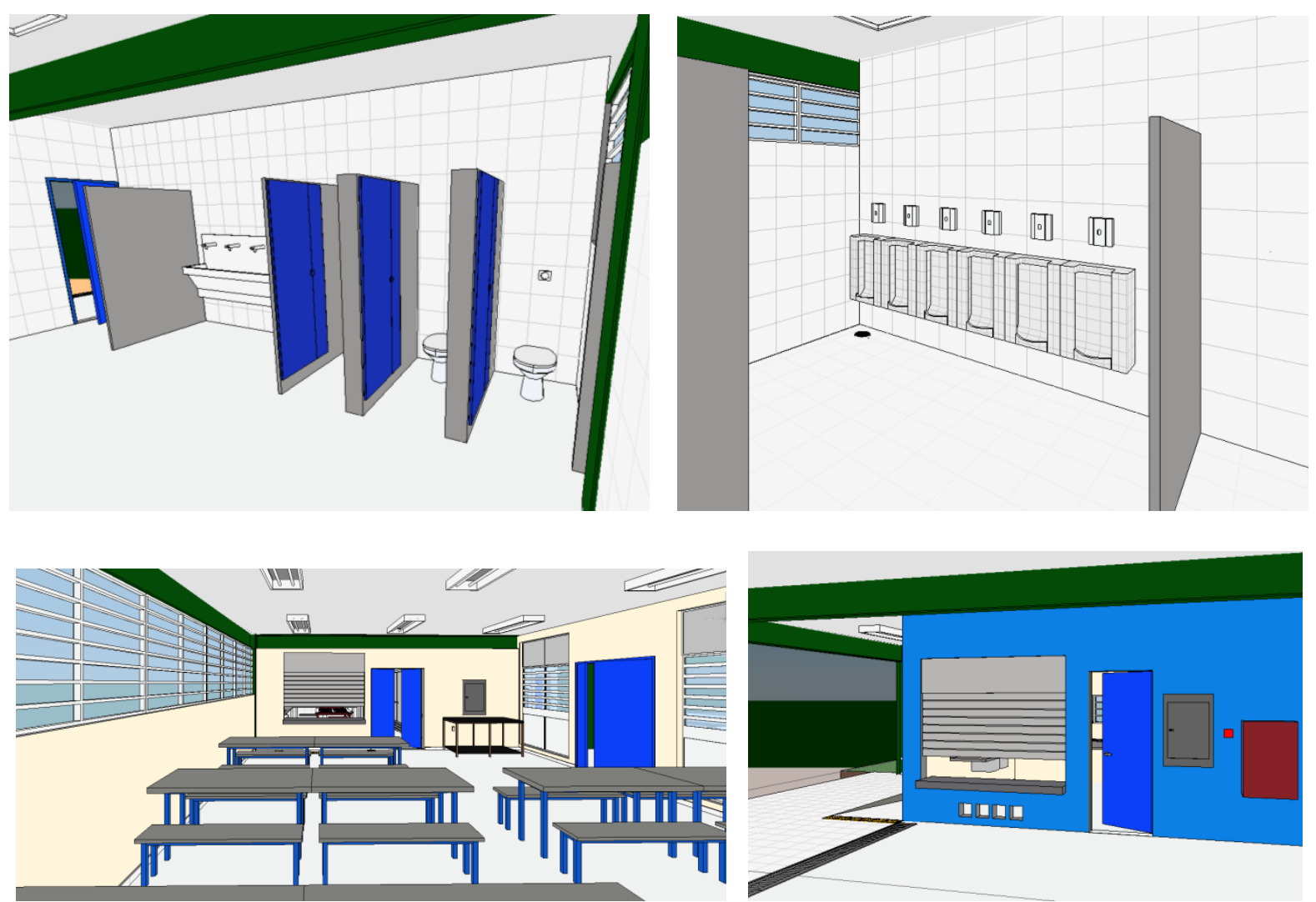

Figura 71. Exemplos de componentes inseridos em ambientes internos, modelados para a Escola Alpha Fonte: Acervo da pesquisadora.

Para a modelagem das propriedades dos componentes construtivos e de elementos de mobiliário, inicialmente, procedeu-se à análise e à tabulação das especificações de projeto, conforme os requisitos determinados pela FDE (FDE, 2014).

No Quadro 22, é apresentada a tabulação da informação referente aos serviços desenvolvidos para a produção da Escola Alpha, a saber: código FDE, nome da ficha FDE, número e nome OmniClass correspondentes (OCCS, 2012), material, etapa da obra correspondente, descrição do serviço, orientações para a aplicação e execução, fichas de referência e componentes relacionados, critérios para recebimento do serviço, itens incluídos no preço, critérios de medição, legislação e normas técnicas citadas, data da elaboração da ficha de diretrizes e respectiva versão. 
Quadro 22. Exemplo de organização das especificações técnicas, correspondentes ao catálogo de serviços executados na Escola Alpha

\begin{tabular}{|c|c|c|}
\hline $\begin{array}{l}\text { Código de Serviço (Fonte: } \\
\text { Catálogo de Serviços FDE) }\end{array}$ & S13.06 & S14 \\
\hline $\begin{array}{l}\text { Ficha de Serviço (Fonte: } \\
\text { Catálogo de Serviços FDE) }\end{array}$ & Vidro liso transparente & Pintura \\
\hline $\begin{array}{l}\text { Número OmniClass (Fonte: } \\
\text { OmniClass Table 33: } \\
\text { Disciplines) }\end{array}$ & $33-414600$ & $33-415600$ \\
\hline $\begin{array}{l}\text { Título OmniClass (Fonte: } \\
\text { OmniClass - Table 33: } \\
\text { Disciplines) }\end{array}$ & Serviços de vidraçaria & Serviços de pintura \\
\hline $\begin{array}{l}\text { Material(is) (Fonte: Catálogo } \\
\text { de Serviços FDE) }\end{array}$ & vidro & Pintura \\
\hline $\begin{array}{l}\text { Etapa (Fonte: Catálogo de } \\
\text { Serviços FDE) }\end{array}$ & Vidros e chapas & Pintura \\
\hline $\begin{array}{l}\text { Descrição (Fonte: Catálogo de } \\
\text { Serviços FDE) }\end{array}$ & $\begin{array}{c}\text { - Vidro plano, transparente, incolor, de faces paralelas e planas. Isento } \\
\text { de distorções óticas, com espessura uniforme e massa homogênea. } \\
\text { • Espessura } 3 \text { a } 6 \mathrm{~mm} \text {. } \\
\text { - Massa de assentamento tipo "de vidraceiro" (à base de óleo de } \\
\text { linhaça e gesso). }\end{array}$ & $\begin{array}{c}\text { - Acabamento final para dar proteção contra intempéries, } \\
\text { umidade, sujeira e desgastes às paredes, conservação de } \\
\text { elementos metálicos, evitando a corrosão e conservação de } \\
\text { elementos de madeira, evitando a absorção de água e de } \\
\text { umidade, proporcionando também o embelezamento das } \\
\text { superfícies. }\end{array}$ \\
\hline $\begin{array}{l}\text { Protótipo Comercial (Fonte: } \\
\text { Catálogo de Serviços FDE) }\end{array}$ & $\begin{array}{l}\text { •Vidro:-GUARDIAN-SAINT-GOBAIN/CEBRACE } \\
\text {-Massa:-MASVI-VEDACON }\end{array}$ & 0 \\
\hline $\begin{array}{l}\text { Aplicação (Fonte: Catálogo de } \\
\text { Serviços FDE) }\end{array}$ & $\begin{array}{l}\text { - Vedação de portas e janelas, em locais que não estabeleçam a } \\
\text { obrigatoriedade do uso de vidro de segurança ou a necessidade de } \\
\text { garantir privacidade. }\end{array}$ & 0 \\
\hline $\begin{array}{l}\text { Execução (Fonte: Catálogo de } \\
\text { Serviços FDE) }\end{array}$ & 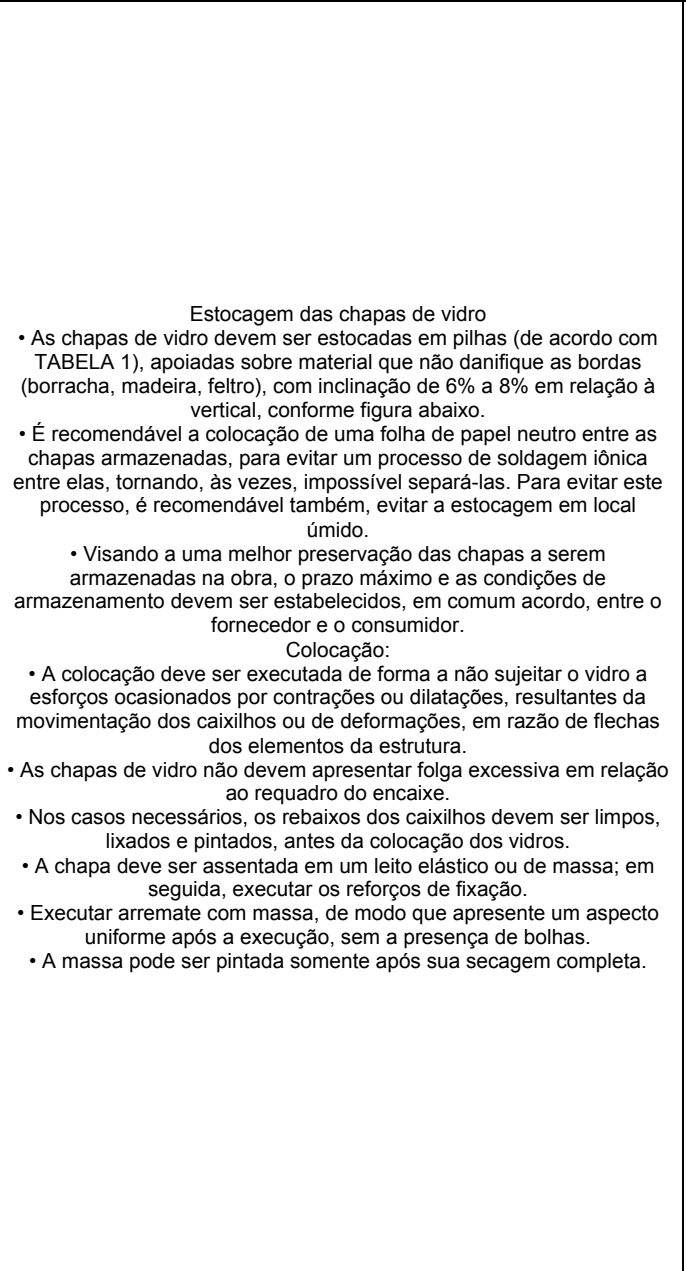 & 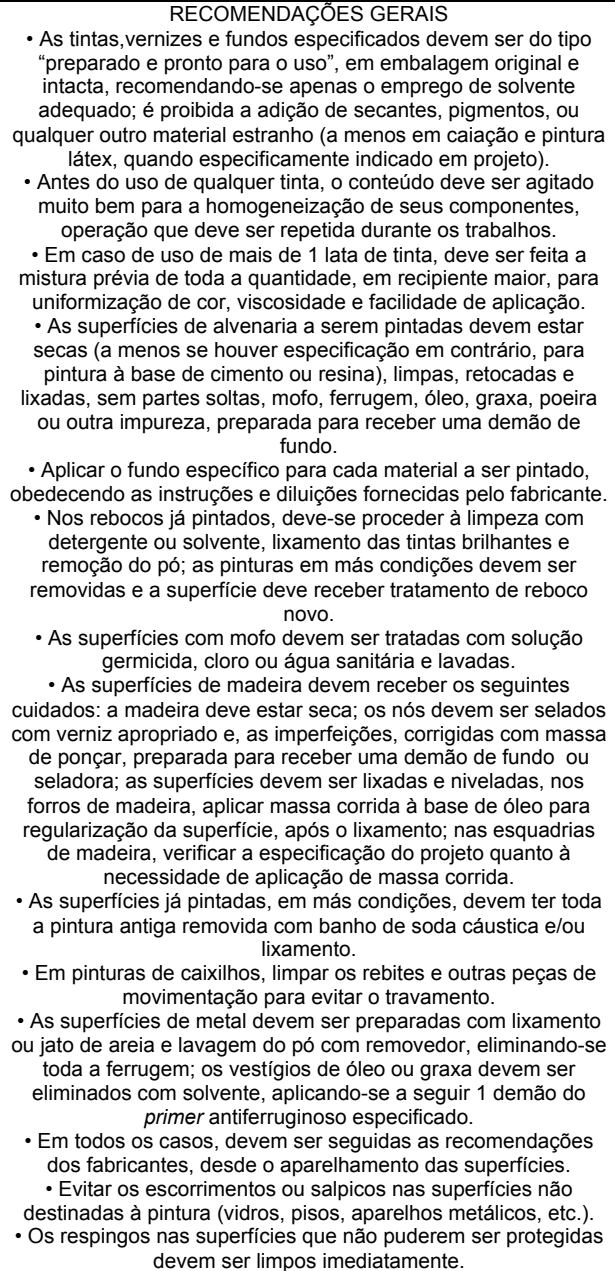 \\
\hline
\end{tabular}

Continua... 
...Continuação

\begin{tabular}{|c|c|c|}
\hline $\begin{array}{l}\text { Fichas da Etapa (Fonte: } \\
\text { Catálogo de Serviços FDE) }\end{array}$ & 0 & $\begin{array}{c}\text { Ficha S14.01 - Caiação } \\
\text { Ficha S14.02 - Massa corrida/acrílica } \\
\text { Ficha S14.03 - Massa corrida/óleo } \\
\text { Ficha S14.04 - Massa corrida/PVA } \\
\text { Ficha S14.05 - Silicone } \\
\text { Ficha S14.06 - Tinta acrilica } \\
\text { Ficha S14.07 - Tinta acrilica para piso } \\
\text { Ficha S14.08 - Tinta alumínio } \\
\text { Ficha S14.09- - Tinta esmalte sintético } \\
\text { Ficha S14.10 - Tinta grafite } \\
\text { Ficha S14.11 - Tinta látex/PVA } \\
\text { Ficha S14.12 - Tinta a óleo } \\
\text { Ficha S14.13 - Tinta mineral impermeável } \\
\text { Ficha S14.14 - Verniz acrílico } \\
\text { Ficha S14.15 - Verniz sintético } \\
\text { Ficha S14.16 - Resina poliureânica } \\
\text { Ficha S14.17 - Galvanização } \\
\text { Ficha S14.18 - Fundos para metais } \\
\text { Ficha S14.19 - Fundos para madeira } \\
\text { Ficha S14.20 - Fundos para alvenaria, reboco, concreto e gesso }\end{array}$ \\
\hline $\begin{array}{l}\text { Fichas de Referência (Fonte: } \\
\text { Catálogo de Serviços FDE) }\end{array}$ & 0 & 0 \\
\hline $\begin{array}{l}\text { Recebimento (Fonte: Catálogo } \\
\text { de Serviços FDE) }\end{array}$ & $\begin{array}{l}\text { - O serviço pode ser recebido se atendidas as condições de projeto, } \\
\text { fornecimento dos materiais e execução.Vidro } \\
\text { - As chapas devem ser isentas de distorçôes óticas e/ou defeitos de } \\
\text { fabricaçấo. } \\
\text { - Não devem apresentar bolhas, cavidade, manchas, deformação de } \\
\text { imagem, ranhuras, ondulações, empenos, defeitos de corte e outros. } \\
\text { Massa } \\
\text { - Deve apresentar-se seca, sem deformação ou fissuras. Caso a massa } \\
\text { não apresente consistência indicada, após } 20 \text { dias de sua aplicação, a } \\
\text { mesma deverá ser substituida. }\end{array}$ & 0 \\
\hline $\begin{array}{l}\text { Serviços (Fonte: Catálogo de } \\
\text { Serviços FDE) }\end{array}$ & $\begin{array}{l}\text { 14.01 VIDROS } \\
\text { 14.01.002 VIDRO LISO COMUM INCOLOR }-E=3 \mathrm{MM} \\
\text { 14.01.004 VIDRO LISO COMUM INCOLOR }-\mathrm{E}=4 \mathrm{MM} \\
\text { 14.01.006 VIDRO LISO COMUM INCOLOR }-\mathrm{E}=5 \mathrm{MM} \\
14.01 .008 \text { VIDRO LISO COMUM INCOLOR }-\mathrm{E}=6 \mathrm{MM} \\
\end{array}$ & 0 \\
\hline $\begin{array}{l}\text { Serviços Incluídos no Preço } \\
\text { (Fonte: Catálogo de Serviços } \\
\text { FDE) }\end{array}$ & $\begin{array}{c}14.01 .00214 .01 .00414 .01 .00614 .01 .008 \\
\text { • Fornecimento dos materiais e execução do serviço, inclusive } \\
\text { emassamento. }\end{array}$ & 0 \\
\hline $\begin{array}{l}\text { Critérios de Medição (Fonte: } \\
\text { Catálogo de Serviços FDE) }\end{array}$ & $\begin{array}{l}14.01 .00214 .01 .00414 .01 .00614 .01 .008 \\
\cdot \mathrm{m}^{2} \text { - pela área real dos caixilhos, deduzindo-se as áreas de chapas de } \\
\text { vedação ou de qualquer outra natureza ou finalidade. }\end{array}$ & 0 \\
\hline Legislação & 0 & 0 \\
\hline Normas & $\begin{array}{l}\text {-NBR } 7199 \text { - Projeto, execução e aplicações de vidros na construção } \\
\text { civil. } \\
\text { - NBR } 11706 \text { - Vidros na construção civil. } \\
\text { • NBR NM } 293 \text { - Terminologia de vidros planos e dos componentes } \\
\text { acessórios a sua - aplicação. } \\
\text { • NBR NM } 294 \text { - Vidro float. }\end{array}$ & 0 \\
\hline $\begin{array}{l}\text { Data (Fonte: Catálogo de } \\
\text { Serviços FDE) }\end{array}$ & 18/7/2006 & $20 / 7 / 2002$ \\
\hline $\begin{array}{l}\text { Revisão (Fonte: Catálogo de } \\
\text { Serviços FDE) }\end{array}$ & 2 & 1 \\
\hline
\end{tabular}

0 = não há informação disponível para o campo.

Fonte: Acervo da pesquisadora. Elaborado com base em especifcações disponíveis em FDE (2014).

No Quadro 23, são apresentadas propriedades atribuídas a ambientes, a saber: código FDE, nome da ficha FDE, número e termo OmniClass correspondentes (OCCS, 2012), conjunto arquitetônico no qual o ambiente está inserido, caracterização do ambiente, orientações para sua localização em projeto, 
área prevista, pé direito mínimo, proporção (relação entre profundidade e altura), ocupação prevista, carga acidental correspondente, orientações para o fechamento superior do ambiente, especificação de acabamentos de paredes, especificação de acabamentos de pisos, orientações qualitativas referentes ao conforto ambiental, classificação acústica, quantidade, tipo e especificação de luminárias, potência do conjunto, nível de iluminamento pertinente, área de iluminação natural mínima, área de ventilação natural mínima, orientações para controle solar, especificação de instalações de elétrica (interruptores, tomadas, sensores e pontos para chuveiro), instalações de lógica, instalações de telefonia, instalações de segurança, instalações para circuitos de televisão, instalações para comunicação interna, especificações de componentes (tais como: gradis, esquadrias, portas, soleiras, entre outros), instalações hidrossanitárias (vasos sanitários, válvulas de descarga, torneiras, e mictórios, entre outros), especificações de componentes de acessibilidade (por exemplo: barras de segurança, pisos tácteis), requisitos e instalações de segurança, legislação e normas técnicas citadas, data da elaboração da ficha de diretrizes e respectiva versão.

Quadro 23. Exemplo de organização das especificações técnicas, correspondentes a ambientes da Escola Alpha

\begin{tabular}{|c|c|c|c|}
\hline $\begin{array}{l}\text { Código de Ficha do Ambiente (Fonte: Quadro } \\
\text { Resumo Características Ambientais FDE) }\end{array}$ & 07B & $12 \mathrm{~B}$ & 17ATPA \\
\hline $\begin{array}{l}\text { Ficha de Ambiente (Fonte: Quadro Resumo } \\
\text { Características Ambientais FDE) }\end{array}$ & $\begin{array}{c}\text { Conjunto Sanitário } \\
\text { Administrativo M2 - M3 - M5 - } \\
\text { M6. }\end{array}$ & $\begin{array}{l}\text { Sala de Informática M4 - } \\
\text { M5 - M6. }\end{array}$ & Conjunto Sanitário Alunos M1 e M4. \\
\hline $\begin{array}{l}\text { Número OmniClass (Fonte: OmniClass Table 13: } \\
\text { Spaces by function) }\end{array}$ & $13-231700$ & $13-311711$ & $13-231700$ \\
\hline $\begin{array}{l}\text { Título OmniClass (Fonte: OmniClass - Table 13: } \\
\text { Spaces by function) }\end{array}$ & Sanitário. & $\begin{array}{l}\text { Laboratório de } \\
\text { Computação. }\end{array}$ & Sanitário. \\
\hline $\begin{array}{l}\text { Conjunto Arquitetônico (Fonte: Quadro Resumo } \\
\text { Características Ambientais FDE) }\end{array}$ & Direção/ Administração. & Pedagógico. & Vivência. \\
\hline $\begin{array}{l}\text { Caracterização do Ambiente (Fonte: Ficha } \\
\text { Ambiente FDE) }\end{array}$ & Higiene pessoal. & $\begin{array}{l}\text { Inclusão digital e social } \\
\text { dos alunos, professores } \\
\text { e funcionários das escolas } \\
\text { da rede pública estadual. }\end{array}$ & Higiene pessoal. \\
\hline $\begin{array}{l}\text { Orientações para Localização (Fonte: Ficha } \\
\text { Ambiente FDE) }\end{array}$ & $\begin{array}{l}\text { Localização para atendimento } \\
\text { ao conjunto Direção/ } \\
\text { Administração. Garantir } \\
\text { acesso autônomo de pessoas } \\
\text { com deficiência física ou } \\
\text { mobilidade reduzida. Localizar } \\
\text { de modo a racionalizar as } \\
\text { descidas de ramais de esgoto, } \\
\text { evitando conflitos com o } \\
\text { sistema estrutural. O projeto } \\
\text { deve assegurar que no } \\
\text { pavimento administrativo } \\
\text { esteja contemplado pelo } \\
\text { menos um sanitário acessível } \\
\text { com entrada independente. }\end{array}$ & $\begin{array}{l}\text { Concentrar horizontal e/ou } \\
\text { verticalmente os } \\
\text { ambientes } \\
\text { administrativos, uso } \\
\text { múltiplo, sala de leitura e } \\
\text { sala de informática de } \\
\text { forma a racionalizar a } \\
\text { rede de distribuição } \\
\text { lógica. Localização } \\
\text { estratégica considerando } \\
\text { facilidade d } \\
\text { e acesso e minimizando } \\
\text { a distância entre a central } \\
\text { de distribuição lógica } \\
\text { (rack de informática) e o } \\
\text { ponto de consolidação de } \\
\text { trabalho. Prever desnível } \\
\text { para evitar a entrada de } \\
\text { água. }\end{array}$ & $\begin{array}{l}\text { No mínimo, um conjunto acessível com entrada } \\
\text { independente, junto à Quadra de Esportes; } \\
\text { no mínimo um conjunto acessível com entrada } \\
\text { independente, em cada pavimento. }\end{array}$ \\
\hline Área $\left(\mathrm{m}^{2}\right)$ (Fonte: Ficha Ambiente FDE) & 25,92 & 77,76 & 51,84 \\
\hline $\begin{array}{l}\text { Pé Direito Mínimo }(\mathrm{m}) \text { (Fonte: Ficha Ambiente } \\
\text { FDE) }\end{array}$ & 2,5 & 3 & 2,5 \\
\hline $\begin{array}{l}\text { Proporção do Ambiente (Fonte: Ficha Ambiente } \\
\text { FDE) }\end{array}$ & 0 & $\begin{array}{c}\text { Profundidade ` } 3^{*} \mathrm{~h} \\
\text { (incluídas saliências e } \\
\text { projeções). }\end{array}$ & 0 \\
\hline Ocupação (Fonte: Ficha Ambiente FDE) & 0 & 27 & 0 \\
\hline $\begin{array}{l}\text { Carga Acidental Prevista }\left(\mathrm{Kgf} / \mathrm{m}^{2}\right) \text { (Fonte: Quadro } \\
\text { Resumo Características Ambientais FDE) }\end{array}$ & 200 & 500 & 200 \\
\hline $\begin{array}{l}\text { Orientações para Fechamento Superior (Fonte: } \\
\text { Ficha Ambiente FDE) }\end{array}$ & Laje & Laje & Laje \\
\hline
\end{tabular}




\section{...Continuação}

\begin{tabular}{|c|c|c|c|}
\hline $\begin{array}{l}\text { Orientações para Paredes (Fonte: Ficha Ambiente } \\
\text { FDE) }\end{array}$ & $\begin{array}{l}\text { Material liso, impermeável e } \\
\text { resistente a frequentes } \\
\text { lavagens. }\end{array}$ & $\begin{array}{l}\text { Acabamento } \\
\text { impermeável. }\end{array}$ & $\begin{array}{c}\text { Material liso, impermeável e resistente a frequentes } \\
\text { lavagens. }\end{array}$ \\
\hline $\begin{array}{l}\text { Orientações para Pisos (Fonte: Ficha Ambiente } \\
\text { FDE) }\end{array}$ & $\begin{array}{c}\text { Piso antiderrapante, } \\
\text { impermeável, de fácil } \\
\text { higienização e resistente a } \\
\text { ácidos. } \\
\end{array}$ & $\begin{array}{l}\text { Piso impermeável,de fácil } \\
\text { higienização, resistente a } \\
\text { alto tráfego. }\end{array}$ & $\begin{array}{l}\text { Piso antiderrapante, impermeável, de fácil } \\
\text { higienização e resistente a ácidos. }\end{array}$ \\
\hline $\begin{array}{l}\text { Orientações Qualitativas de Conforto Ambiental e } \\
\text { Ergonomia (Fonte: Ficha Ambiente FDE) }\end{array}$ & $\begin{array}{l}\text { Para o Sanitário Familiar } \\
\text { (acessível): } \\
\text { Prever área livre, externa ao } \\
\text { sanitário, com dimensões } \\
\text { mínimas de } \varnothing=1,50 \mathrm{~m} \text { para } \\
\text { manobra de cadeira de rodas, } \\
\text { permitindo rotação de } 360^{\circ} ; \\
\text { Prever área de transferência e } \\
\text { de aproximação para bacia } \\
\text { sanitária e trocador com } \\
\text { dimensões mínimas de } 0,80 \mathrm{~m} \\
\text { x } 1,20 \mathrm{~m} \text {; e área de manobra } \\
\text { permitindo rotação de } 180^{\circ} \\
(1,50 \mathrm{~m} \times 1,20 \mathrm{~m}) .\end{array}$ & $\begin{array}{c}\text { Não posicionar o } \\
\text { ambiente em fachadas de } \\
\text { alta insolação ou prever } \\
\text { anteparos de proteção. } \\
\text { Concentrar horizontal e/ou } \\
\text { verticalmente os } \\
\text { ambientes } \\
\text { administrativos, uso } \\
\text { múltiplo e sala de } \\
\text { informática de forma a } \\
\text { racionalizar a rede de } \\
\text { distribuição lógica. } \\
\text { Localização estratégica } \\
\text { considerando a facilidade } \\
\text { de acesso e minimizando } \\
\text { a distância entre a central } \\
\text { de distribuição lógica } \\
\text { (rack de informática) e o } \\
\text { ponto de consolidação de } \\
\text { trabalho. }\end{array}$ & $\begin{array}{c}\text { Boxe para bacia sanitária comum: prever área livre, } \\
\text { mínima de } \varnothing=0,60 \mathrm{~m} \text {; considerar largura livre } \\
\text { mínima de } 0,80 \mathrm{~m} \text {. } \\
\text { - Para o Sanitário Acessível: prever área livre, } \\
\text { externa ao sanitário, com dimensões mínimas de } \varnothing \\
=1,50 \mathrm{~m} \text { para manobra de cadeira de rodas, } \\
\text { permitindo rotação de } 360^{\circ} ; \text { prever área de } \\
\text { transferência e de aproximação para bacia sanitária } \\
\text { com dimensões mínimas de } 0,80 \mathrm{~m} \times 1,20 \mathrm{~m} \text { e área } \\
\text { de manobra permitindo rotação de } 180^{\circ}(1,50 \mathrm{~m} \times \\
1,20 \mathrm{~m}) \text {. }\end{array}$ \\
\hline $\begin{array}{l}\text { Classificação Acústica (Fonte: Quadro Resumo } \\
\text { Caracteristicas Ambientais FDE) }\end{array}$ & Pouco Exigente. & Resguardado. & Pouco Exigente. \\
\hline $\begin{array}{l}\text { Quantidade de Luminárias (Fonte: Quadro } \\
\text { Resumo Características Ambientais FDE) }\end{array}$ & 3 & 12 & 4 \\
\hline Tipo de lluminação (Fonte: Ficha Ambiente FDE) & Fluorescente & Fluorescente & Fluorescente \\
\hline $\begin{array}{l}\text { Especificação das Luminárias (Fonte: Ficha } \\
\text { Ambiente FDE) }\end{array}$ & $\begin{array}{l}\text { Luminária aberta com refletor } \\
\text { para lâmpada fluorescente. }\end{array}$ & $\begin{array}{l}\text { Luminária sobrepor com } \\
\text { refletor e aletas. }\end{array}$ & $\begin{array}{l}\text { Luminária aberta com refletor para lâmpada } \\
\text { fluorescente. }\end{array}$ \\
\hline $\begin{array}{l}\text { Referência Luminária (Fonte: Ficha Ambiente } \\
\text { FDE) }\end{array}$ & (in & IL-60 & ( \\
\hline $\begin{array}{l}\text { Potência do Conjunto/ Luminária (Fonte: Ficha } \\
\text { Ambiente FDE) }\end{array}$ & $2 \times 32 W$ & $2 \times 32 W$ & $2 \times 32 W$ \\
\hline $\begin{array}{l}\text { Nível Mínimo de lluminamento (lux) (Fonte: Ficha } \\
\text { Ambiente FDE) }\end{array}$ & 100 & 300 & 150 \\
\hline $\begin{array}{l}\text { Área de lluminação Natural Mínima (Fonte: Ficha } \\
\text { Ambiente FDE) }\end{array}$ & 1/10 área piso. & $1 / 5$ área piso. & 1/10 área piso. \\
\hline $\begin{array}{l}\text { Área Ventilação Natural Mínima (Fonte: Ficha } \\
\text { Ambiente FDE) }\end{array}$ & $1 / 20$ área piso. & 1/10 área piso. & $1 / 20$ área piso. \\
\hline $\begin{array}{l}\text { Controle Solar Para Luz Direta e } \\
\text { Ofuscamento(Fonte: Ficha Ambiente FDE) }\end{array}$ & 0 & Sim & 0 \\
\hline $\begin{array}{l}\text { Quantidade de Interruptores Bipolares (Fonte: } \\
\text { Ficha Ambiente FDE) }\end{array}$ & 3 & 3 & 0 \\
\hline $\begin{array}{l}\text { Quantidade de Sensores de Presença (Fonte: } \\
\text { Ficha Ambiente FDE) }\end{array}$ & 0 & 0 & 0 \\
\hline $\begin{array}{l}\text { Quantidade de Tomadas no padrão NBR } 14.136 \\
2 \mathrm{P}+\mathrm{T} \text { baixa, 10A/110V (Fonte: Ficha Ambiente } \\
\text { FDE) }\end{array}$ & 0 & 34 & 0 \\
\hline $\begin{array}{l}\text { Quantidade de Tomadas no padrão NBR } 14.136 \\
2 \mathrm{P}+\mathrm{T} \text { baixa, 20A/220V (Fonte: Ficha Ambiente } \\
\text { FDE) }\end{array}$ & 0 & 0 & 0 \\
\hline $\begin{array}{l}\text { Quantidade de Tomadas no padrão NBR } 14.136 \\
\text { 2P+T média 10A/110V (Fonte: Ficha Ambiente } \\
\text { FDE) }\end{array}$ & 0 & 0 & 0 \\
\hline $\begin{array}{l}\text { Quantidade de Tomadas no padrão NBR } 14.136 \\
\text { 2P+T média 20A/110V (Fonte: Ficha Ambiente } \\
\text { FDE) }\end{array}$ & 0 & 0 & 0 \\
\hline $\begin{array}{l}\text { Quantidade de Tomadas no padrão NBR } 14.136 \\
2 \mathrm{P}+\mathrm{T} \text { média } 20 \mathrm{~A} / 220 \mathrm{~V} \text { (Fonte: Ficha Ambiente } \\
\text { FDE) }\end{array}$ & 0 & 0 & 0 \\
\hline $\begin{array}{l}\text { Quantidade de Tomadas no padrão NBR } 14.136 \\
2 \mathrm{P}+\mathrm{T} \text { alta } 10 \mathrm{~A} / 110 \mathrm{~V} \text { (Fonte: Ficha Ambiente FDE) }\end{array}$ & 0 & 2 & 0 \\
\hline $\begin{array}{l}\text { Quantidade de Tomadas no padrão NBR } 14.136 \\
2 \mathrm{P}+\mathrm{T} \text { alta } 10 \mathrm{~A} / 210 \mathrm{~V} \text { (Fonte: Ficha Ambiente FDE) }\end{array}$ & 0 & 0 & 0 \\
\hline $\begin{array}{l}\text { Ponto de Energia para Chuveiro Elétrico } 2 \mathrm{P}+\mathrm{T} \text {, } \\
220 \mathrm{~V} \text { - com resistência blindada } 6,5 \mathrm{~kW}, \mathrm{~h}=2,20 \mathrm{~m} \\
\text { do piso (Fonte: Ficha Ambiente FDE) }\end{array}$ & 0 & 0 & 0 \\
\hline $\begin{array}{l}\text { Normas Técnicas citadas na Ficha Ambiente } \\
\text { FDE(Fonte: Ficha Ambiente FDE) }\end{array}$ & 0 & $\begin{array}{l}\text { NBR } 5410 \text { - Instalações } \\
\text { elétricas de baixa tensão. }\end{array}$ & 0 \\
\hline Pontos de Lógica (Fonte: Ficha Ambiente FDE) & 0 & 1 & 0 \\
\hline $\begin{array}{l}\text { Pontos para Telefone (Fonte: Ficha Ambiente } \\
\text { FDE) }\end{array}$ & 0 & 0 & 0 \\
\hline $\begin{array}{l}\text { Pontos para Telefone Público Externo ao } \\
\text { Ambiente (Fonte: Ficha Ambiente FDE) }\end{array}$ & 0 & 0 & 0 \\
\hline $\begin{array}{l}\text { Ponto Para Equipamento de Controle de Acesso e } \\
\text { Segurança (Fonte: Ficha Ambiente FDE) }\end{array}$ & 0 & 1 & 0 \\
\hline Ponto para TV (Fonte: Ficha Ambiente FDE) & 0 & 1 & 0 \\
\hline $\begin{array}{l}\text { Ponto para Equipamento de Comunicação Interna } \\
\text { (Fonte: Ficha Ambiente FDE) }\end{array}$ & 0 & 1 & 0 \\
\hline $\begin{array}{l}\text { Ponto para Interfone Elevador (Fonte: Ficha } \\
\text { Ambiente FDE) }\end{array}$ & 0 & 0 & 0 \\
\hline $\begin{array}{l}\text { Ponto de Acionamento de Cigarra (Fonte: Ficha } \\
\text { Ambiente FDE) }\end{array}$ & 0 & 0 & 0 \\
\hline Esquadria (Fonte: Ficha Ambiente FDE) & Especificar. & Especificar. & Especificar. \\
\hline Material Esquadria (Fonte: Ficha Ambiente FDE) & Ferro. & Ferro. & Ferro \\
\hline Ventilação Cruzada (Fonte: Ficha Ambiente FDE) & 0 & Sim. & 0 \\
\hline Gradil (Fonte: Ficha Ambiente FDE) & 0 & TP-03 & 0 \\
\hline Peitoril (Fonte: Ficha Ambiente FDE) & Especificar. & Especificar. & Especificar. \\
\hline Porta (Fonte: Ficha Ambiente FDE) & Especificar. & Especificar. & Especificar. \\
\hline Material Porta (Fonte: Ficha Ambiente FDE) & Madeira. & Ferro. & Madeira. \\
\hline
\end{tabular}

Continua... 
...Continuação

\begin{tabular}{|c|c|c|c|}
\hline $\begin{array}{l}\text { Quantidade de Portas (Fonte: Ficha Ambiente } \\
\text { FDE) }\end{array}$ & 3 & 1 & 12 ou 13 \\
\hline Largura da Porta (m) (Fonte: Ficha Ambiente FDE) & $2 \times 0,72 / 1 \times 0,92$ (acessível). & 0,82 & 0,82/ 0,62 (boxe)/ 0,92 (boxe acessível). \\
\hline Soleira Rampada (Fonte: Ficha Ambiente FDE) & Especificar. & Especificar. & Especificar. \\
\hline $\begin{array}{l}\text { Sinalização Permanente (Fonte: Ficha Ambiente } \\
\text { FDE) }\end{array}$ & Sim & $\operatorname{Sim}$ & Sim \\
\hline $\begin{array}{l}\text { Quantidade de Murais (Fonte: Ficha Ambiente } \\
\text { FDE) }\end{array}$ & 0 & 0 & 0 \\
\hline $\begin{array}{l}\text { Especificação de Murais (Fonte: Ficha Ambiente } \\
\text { FDE) }\end{array}$ & 0 & 0 & 0 \\
\hline $\begin{array}{l}\text { Quantidade de Lousas (Fonte: Ficha Ambiente } \\
\text { FDE) }\end{array}$ & 0 & 1 & 0 \\
\hline $\begin{array}{l}\text { Especificação de Lousas (Fonte: Ficha Ambiente } \\
\text { FDE) }\end{array}$ & 0 & QB-01 & 0 \\
\hline $\begin{array}{l}\text { Quantidade de Ventiladores de Parede (Fonte: } \\
\text { Ficha Ambiente FDE) }\end{array}$ & 0 & 2 & 0 \\
\hline $\begin{array}{l}\text { Especificação de Ventiladores de Parede (Fonte: } \\
\text { Ficha Ambiente FDE) }\end{array}$ & 0 & $\mathrm{VN}-02$ & 0 \\
\hline $\begin{array}{l}\text { Quantidade de Lavatórios Convencionais (Fonte: } \\
\text { Ficha Ambiente FDE) }\end{array}$ & 4 & 0 & 2 \\
\hline $\begin{array}{l}\text { Especificações de Lavatórios Convencionais } \\
\text { (Fonte: Ficha Ambiente FDE) }\end{array}$ & LT-07 & 0 & $\begin{array}{c}\text { lavatório com torneira antivandalismo / três usuários } \\
\text { (LT-06)/ lavatório com torneira antivandalismo / três } \\
\text { a quatro usuários (LT-06). }\end{array}$ \\
\hline $\begin{array}{l}\text { Quantidade de Bacias Sanitárias Convencionais } \\
\text { (Fonte: Ficha Ambiente FDE) }\end{array}$ & 4 & 0 & 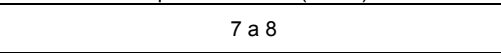 \\
\hline $\begin{array}{l}\text { Especificações de Bacias Sanitárias } \\
\text { Convencionais (Fonte: Ficha Ambiente FDE) }\end{array}$ & $\mathrm{H} 6.02$ & 0 & $\mathrm{H} 6.02$ \\
\hline $\begin{array}{l}\text { Quantidade de Válvulas de Descarga (Fonte: } \\
\text { Ficha Ambiente FDE) }\end{array}$ & 4 & 0 & 7 a 8 \\
\hline $\begin{array}{l}\text { Especificação de Válvulas de Descarga (Fonte: } \\
\text { Ficha Ambiente FDE) }\end{array}$ & $\mathrm{H} 2.07$ & 0 & $\mathrm{H} 6,14$ \\
\hline $\begin{array}{l}\text { Quantidade de Torneiras de Lavagem para Uso } \\
\text { Restrito (Fonte: Ficha Ambiente FDE) }\end{array}$ & 3 & 0 & 4 \\
\hline $\begin{array}{l}\text { Especificações de Torneiras de Lavagem para Uso } \\
\text { Restrito (Fonte: Ficha Ambiente FDE) }\end{array}$ & $\mathrm{H} 6.15$ & 0 & $\mathrm{H} 6.15$ \\
\hline $\begin{array}{l}\text { Quantidade de Conjuntos de Lavatórios e Bacias } \\
\text { Acessíveis, com Barras de Apoio (Fonte: Ficha } \\
\text { Ambiente FDE) }\end{array}$ & 1 & 0 & 2 \\
\hline $\begin{array}{l}\text { Especificações de Lavatórios e Bacias Acessíveis, } \\
\text { com Barras de Apoio (Fonte: Ficha Ambiente FDE) }\end{array}$ & LT-03 & 0 & $\begin{array}{c}\text { (BR-03) um lavatório de canto com torneira de mesa } \\
\text { com acionamento por alavanca } \\
1 \text { bacia sanitária }(0,43 \mathrm{~m} \text { h } 0,45 \mathrm{~m}) \text { com válvula de } \\
\text { descarga }(\mathrm{H} 2.07) \text { e barras de apoio lateral e } \\
\text { posterior. }\end{array}$ \\
\hline Mictórios (Fonte: Ficha Ambiente FDE) & 0 & 0 & Um (para quatro usuários). \\
\hline $\begin{array}{l}\text { Especificação dos Mictórios(Fonte: Ficha } \\
\text { Ambiente FDE) }\end{array}$ & 0 & 0 & MT-04 \\
\hline $\begin{array}{l}\text { Quantidade de Ralos Sifonados (Fonte: Ficha } \\
\text { Ambiente FDE) }\end{array}$ & 3 & 0 & 6 \\
\hline $\begin{array}{l}\text { Quantidade de Barras de Apoio com Fixação } \\
\text { Lateral (Fonte: Ficha Ambiente FDE) }\end{array}$ & 2 & 0 & 4 \\
\hline $\begin{array}{l}\text { Especificação de Barras de Apoio com Fixação } \\
\text { Lateral (Fonte: Ficha Ambiente FDE) }\end{array}$ & BR-04 & 0 & BR-04 \\
\hline $\begin{array}{l}\text { Outros Componentes ou Aspectos Específicos } \\
\text { (Fonte: Ficha Ambiente FDE) }\end{array}$ & $\begin{array}{c}\text { Trocador Acessível BR-05/ } 1 \\
\text { Papeleira Louça, } 1 \\
\text { Saboneteira Louça, } 1 \\
\text { Dispensador de Toalha, } 1 \\
\text { Dispensador de Sabonete } \\
\text { líquido - por conjunto. }\end{array}$ & $\begin{array}{l}\text { Ficha de exigências para } \\
\text { instalações elétricas }\end{array}$ & $\begin{array}{c}\text { Sete a oito papeleiras de louça (H6.01). Para } \\
\text { lavatórios: um espelho por cuba e uma barra de } \\
\text { apoio } \\
\text { com fixação lateral/por lavatório. Dois dispensadores } \\
\text { de papel toalha, } \\
\text { dois dispensadores de sabonete líquido (sanitários } \\
\text { acessíveis). Bebedouro (BB-01) com um filtro para } \\
\text { água (FT-02). } \\
\text { BR-04 barra de apoio com fixação lateral. } \\
\text { DV-01 divisória de granilite / lateral aberta. } \\
\text { DV-03 divisória de granilite / frontal. } \\
\text { DV-04 divisória de granilite / anteparo. } \\
\text { EF- esquadria de ferro a especificar. } \\
\text { EP- espelho a especificar. } \\
\end{array}$ \\
\hline $\begin{array}{l}\text { Segurança Patrimonial (Fonte: Ficha Ambiente } \\
\text { FDE) }\end{array}$ & 0 & $\begin{array}{c}\text { Sujeito à invasão. } \\
\text { Necessário maior nível de } \\
\text { segurança. Prever } \\
\text { sistemas de trancas ou } \\
\text { fechaduras especiais nas } \\
\text { portas. } \\
\end{array}$ & ( \\
\hline $\begin{array}{l}\text { Instalação de Alarme de Segurança Patrimonial } \\
\text { (Fonte: Ficha Ambiente FDE) }\end{array}$ & 0 & 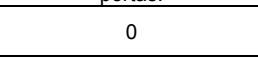 & 0 \\
\hline $\begin{array}{l}\text { Instalação de Alarme de Incêndio (Fonte: Ficha } \\
\text { Ambiente FDE) }\end{array}$ & 0 & 0 & 0 \\
\hline $\begin{array}{l}\text { Central de Alarme de Sanitário Acessível Isolado } \\
\text { para Caso de Queda (se houver) (Fonte: Ficha } \\
\text { Ambiental FDE) }\end{array}$ & 0 & 0 & 0 \\
\hline $\begin{array}{l}\text { Botão para Acionamento de Alarme de Sanitário } \\
\text { Acessível Isolado para Caso de Queda (se houver) } \\
\text { (Fonte: Ficha Ambiental FDE) }\end{array}$ & 1 & 0 & 2 \\
\hline $\begin{array}{l}\text { Central de Alarme para Segurança Patrimonial - } \\
\text { CAS (Fonte: Ficha Ambiente FDE) }\end{array}$ & 0 & 0 & 0 \\
\hline $\begin{array}{l}\text { Central de Comunicação Interna - CCL (Fonte: } \\
\text { Ficha Ambiental FDE) }\end{array}$ & 0 & 0 & 0 \\
\hline $\begin{array}{l}\text { Central de Distribuição de Lógica - DL (Fonte: } \\
\text { Ficha Ambiental FDE) }\end{array}$ & 0 & 0 & 0 \\
\hline Data (Fonte: Ficha Ambiente FDE) & jun/10 & out/12 & jun/10 \\
\hline Implantação (Fonte: Ficha Ambiente FDE) & $\mathrm{jul} / 10$ & out/12 & $\mathrm{jul} / 10$ \\
\hline
\end{tabular}

0 = não há informação disponível para o campo.

Fonte: Acervo da pesquisadora. Elaborado com base em especifcações disponíveis em FDE (2014). 
Além das diretrizes de projeto apresentadas, foram organizados, especificamente, os requisitos de acessibilidade (ABNT, 2015), conforme apresentado no Quadro 24. Nele, são processados os seguintes dados: código FDE para o ambiente ou componente, nome da ficha, ambiente a que se refere, número OmniClass, título OmniClass, conjunto arquitetônico no qual está inserido, caracterização do ambiente, normas técnicas pertinentes, tipo de iluminação, níveis de iluminamento, instalações e requisitos de acessibilidade. 
Quadro 24. Exemplo de organização das especificações técnicas correspondentes às diretrizes de acessibilidade em ambientes, para a Escola Alpha

\begin{tabular}{|c|c|c|}
\hline \\
\hline $\begin{array}{l}\text { Código de Ficha do Ambiente } \\
\text { (Fonte: Quadro Resumo } \\
\text { Características Ambientais FDE) }\end{array}$ & 24 & 24 \\
\hline $\begin{array}{l}\text { Ficha de Ambiente (Fonte: Quadro } \\
\text { Resumo Características Ambientais } \\
\text { FDE) }\end{array}$ & $\begin{array}{l}\text { Circulação Horizontal e Vertical M1 - M2 - M3 - M4 - M5 - } \\
\text { M6. }\end{array}$ & Circulação Horizontal e Vertical M1 - M2 - M3 - M4 - M5 - M6. \\
\hline Ambiente & Pisos. & Escadas. \\
\hline $\begin{array}{l}\text { Número OmniClass (Fonte: } \\
\text { OmniClass Table 13: Spaces by } \\
\text { function) }\end{array}$ & 23-15 1700 & $13-231113$ \\
\hline $\begin{array}{l}\text { Título OmniClass (Fonte: OmniClass } \\
\text { - Table 13: Spaces by function) }\end{array}$ & Pisos. & Escadas. \\
\hline $\begin{array}{l}\text { Conjunto Arquitetônico (Fonte: } \\
\text { Quadro Resumo Características } \\
\text { Ambientais FDE) }\end{array}$ & Circulação. & Circulação. \\
\hline $\begin{array}{l}\text { Caracterização do Ambiente (Fonte: } \\
\text { Ficha Ambiente FDE) }\end{array}$ & $\begin{array}{l}\text { Os pisos devem ser resistentes a tráfego intenso, serem } \\
\text { regulares, contínuos, estáveis e antiderrapantes, de modo a } \\
\text { oferecer segurança sob qualquer condição de uso (ver } \\
\text { também ficha: Acessibilidade ao Edifício). }\end{array}$ & 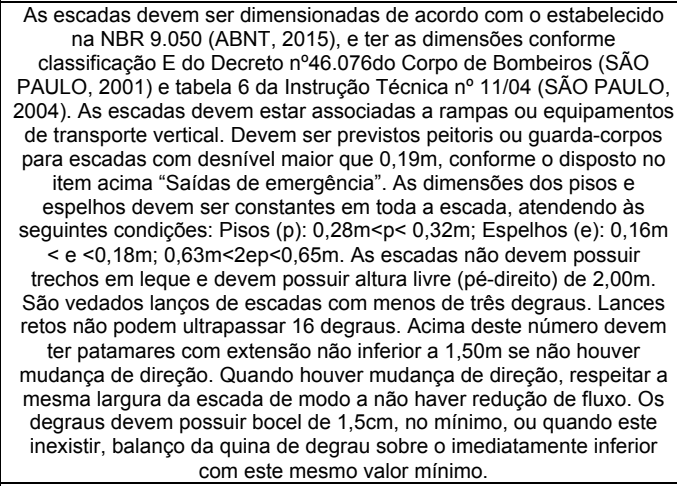 \\
\hline $\begin{array}{l}\text { Normas Técnicas citadas na Ficha } \\
\text { Ambiente FDE (Fonte: Ficha } \\
\text { Ambiente FDE) }\end{array}$ & $\begin{array}{l}\text { Decreto Estadual } n^{\circ} 46.076 \text { do Corpo de Bombeiros (SÃO } \\
\text { PAULO, 2001). }\end{array}$ & $\begin{array}{l}\text { Decreto Estadual n } 46.076 \text { do Corpo de Bombeiros (SÃO PAULO, } \\
\text { 2001). NBR } 9050 \text { (ABNT, 2015). Instrução Técnica n 11/04 - Corpo } \\
\text { de Bombeiros (SÂO PAULO, 2004). }\end{array}$ \\
\hline $\begin{array}{l}\text { Tipo de lluminação (Fonte: Ficha } \\
\text { Ambiente FDE) }\end{array}$ & $\begin{array}{l}\text { Prever sempre que possível iluminação e ventilação natural } \\
\text { em corredores. lluminação natural obrigatória nas } \\
\text { circulações verticais. Iluminação artificial: Fluorescente } \\
\text { (áreas internas); Conforme orientação do projeto (áreas } \\
\text { externas). Nível de iluminamento: Áreas internas - } 150 \text { lux; } \\
\text { Áreas externas - variável. Nos corredores, prever luz de } \\
\text { vigia a cada 10,80m obrigatória próxima aos quadros de } \\
\text { distribuição. Prever luz de vigia obrigatória nos acessos } \\
\text { inferiores, superiores e nos patamares das escadas e } \\
\text { rampas. Prever iluminação de emergência conforme NBR } \\
\text { 10.898 (ABNT, 2013) e de acordo com a Instrução Técnica } \\
n^{\circ} 18 / 04 \text { - Corpo de Bombeiros (SÃO PAULO, 2004), } \\
\text { atendendo ainda aos requisitos da NBR } 9050 \text { (ABNT, 2015). }\end{array}$ & $\begin{array}{l}\text { Prever sempre que possível iluminação e ventilação natural em } \\
\text { corredores. Iluminação natural obrigatória nas circulações verticais. } \\
\text { Iluminação artificial: Fluorescente (áreas internas); conforme orientação } \\
\text { do projeto (áreas externas). Nível de iluminamento: áreas internas - } \\
150 \text { lux; áreas externas - variável. Nos corredores, prever luz de vigia a } \\
\text { cada } 10,80 m \text { obrigatória próxima aos quadros de distribuição. Prever } \\
\text { luz de vigia obrigatória nos acessos inferiores, superiores e nos } \\
\text { patamares das escadas e rampas. Prever iluminação de emergência } \\
\text { conforme NBR } 10.898 \text { (ABNT, 2013) e de acordo com a Instrução } \\
\text { Técnica nº } 18 / 04 \text { - Corpo de Bombeiros (SÃO PAULO, 2004), } \\
\text { atendendo ainda aos requisitos da NBR } 9.050 \text { (ABNT, 2015). }\end{array}$ \\
\hline $\begin{array}{l}\text { Nivel Mínimo de lluminamento (lux) } \\
\text { (Fonte: Ficha Ambiente FDE) }\end{array}$ & 150 & 150 \\
\hline
\end{tabular}

Continua... 


\begin{tabular}{|c|c|c|}
\hline $\begin{array}{l}\text { Sinalização Permanente (Fonte: } \\
\text { Ficha Ambiente FDE) }\end{array}$ & $\begin{array}{c}\text { Prever sinalização orientando as rotas de saída conforme } \\
\text { NBR 13.434-2 (ABNT, 2004), NBR } 9.077 \text { (ABNT, 2001), } \\
\text { NBR 10.898 (ABNT, 2013) e de acordo com a Instrução } \\
\text { Técnica nº 20/04 do Corpo de Bombeiros (SÃO PAULO, } \\
\text { 2001). Prever alarmes sonoros e visuais nas saídas de } \\
\text { emergência conforme requisitos da NBR } 9.050 \text { (ABNT, } \\
\text { 2015). Prever sinalização de equipamentos de proteção } \\
\text { contra incêndio atendendo ao Decreto No } 46.076 \text { do Corpo } \\
\text { de Bombeiros (SÃO PAULO, 2001). A sinalização de } \\
\text { emergência deve possuir acabamento fotoluminescente. A } \\
\text { sinalização das áreas de circulação deve atender às } \\
\text { orientações constantes na ficha Acessibilidade ao Edifício, } \\
\text { tais como: sinalização indicadora de escadas, rampas, } \\
\text { elevadores; indicadora dos andares; faixas sinalizadoras de } \\
\text { degraus e pilares; aplicação de piso tátil de alerta e } \\
\text { direcional; entre out as. Ver também: NBR } 9.050 \text { (ABNT, } \\
\text { 2015). }\end{array}$ & $\begin{array}{l}\text { Prever sinalização orientando as rotas de saída conforme NBR 13.434- } \\
2 \text { (ABNT, 2004), NBR } 9.077 \text { (ABNT, 2001), NBR } 10.898 \text { (ABNT, 2013) } \\
\text { e de acordo com a Instrução Técnica n²0/04 do Corpo de Bombeiros } \\
\text { (SÃO PAULO, 2001). Prever alarmes sonoros e visuais nas saídas de } \\
\text { emergência conforme requisitos da NBR } 9.050 \text { (ABNT, 2015). Prever } \\
\text { sinalização de equipamentos de proteção contra incêndio atendendo } \\
\text { ao Decreto No } 46.076 \text { do Corpo de Bombeiros (SÃO PAULO, 2001). A } \\
\text { sinalização de emergência deve possuir acabamento fotoluminescente. } \\
\text { A sinalização das áreas de circulação deve atender às orientações } \\
\text { constantes na ficha Acessibilidade ao Edifício, tais como: sinalização } \\
\text { indicadora de escadas, rampas, elevadores; indicadora dos andares; } \\
\text { faixas sinalizadoras de degraus e pilares; aplicação de piso tátil de } \\
\text { alerta e direcional; entre outras. Ver também: NBR 9.050 (ABNT, } \\
\text { 2015). }\end{array}$ \\
\hline Instalações & $\begin{array}{l}\text { Iluminação autônoma de emergência. Luz de vigia. } \\
\text { Luminárias fixadas em perfilados ou diretamente na laje, } \\
\text { conforme solução de projeto. } \\
\text { Hidrantes, extintores e botoeiras de alarme, conforme } \\
\text { solução de projeto. } \\
\text { Ralos sifonados e canaletas, conforme solução de projeto. } \\
\text { Elevadores, conforme solução adotada em projeto - detalhar } \\
\text { em projeto as } \\
\text { instalações elétricas necessárias conforme o equipamento a } \\
\text { ser instalado. }\end{array}$ & $\begin{array}{c}\text { Iluminação autônoma de emergência. Luz de vigia. } \\
\text { Luminárias fixadas em perfilados ou diretamente na laje, conforme } \\
\text { solução de projeto. } \\
\text { Hidrantes, extintores e botoeiras de alarme, conforme solução de } \\
\text { projeto. } \\
\text { Ralos sifonados e canaletas, conforme solução de projeto. } \\
\text { Elevadores, conforme solução adotada em projeto - detalhar em } \\
\text { projeto as } \\
\text { instalações elétricas necessárias conforme o equipamento a ser } \\
\text { instalado. }\end{array}$ \\
\hline $\begin{array}{l}\text { Acessibilidade (Fonte: Ficha } \\
\text { Ambiente FDE) }\end{array}$ & 0 & $\begin{array}{l}\text { Prever corrimãos duplos de ambos os lados de escadas a uma altura } \\
\text { constante de } 0,92 \mathrm{~m} \text {, sem interrupção nos patamares. Os corrimãos } \\
\text { devem prolongar-se pelo menos } 0,30 \mathrm{~m} \text { antes do início e após o } \\
\text { término da escada, sem interferir com as áreas de circulação. Quando } \\
\text { a largura for superior a } 2,20 \mathrm{~m} \text { utilizar corrimão intermediário, } \\
\text { garantindo largura livre mínima de } 1,20 \mathrm{~m} \text { e máxima de } 1,80 \mathrm{~m} \text { entre } \\
\text { corrimãos. Ver NBR } 9.050 \text { (ABNT, 2015) e Instrução Técnica n } \text { no }^{\circ} 11 / 04 \text { - } \\
\text { Corpo de Bombeiros (SÃO PAULO, 2004). }\end{array}$ \\
\hline
\end{tabular}

0 = não há informação disponível para o campo.

Fonte: Acervo da pesquisadora. Elaborado a partir de especifcações disponíveis em FDE (2014) e conforme a NBR 9050:2015 (ABNT, 2015).

Para a modelagem na plataforma do Banco de Dados, os ambientes foram separados por grupos. Os critérios para a organização adotados foram: o tipo de uso pretendido e os respectivos requisitos.

Cada ambiente, modelado geometricamente, pode ser relacionado às listas de componentes para a serem inseridos, conforme o exemplo apresentado na Figura 72. 


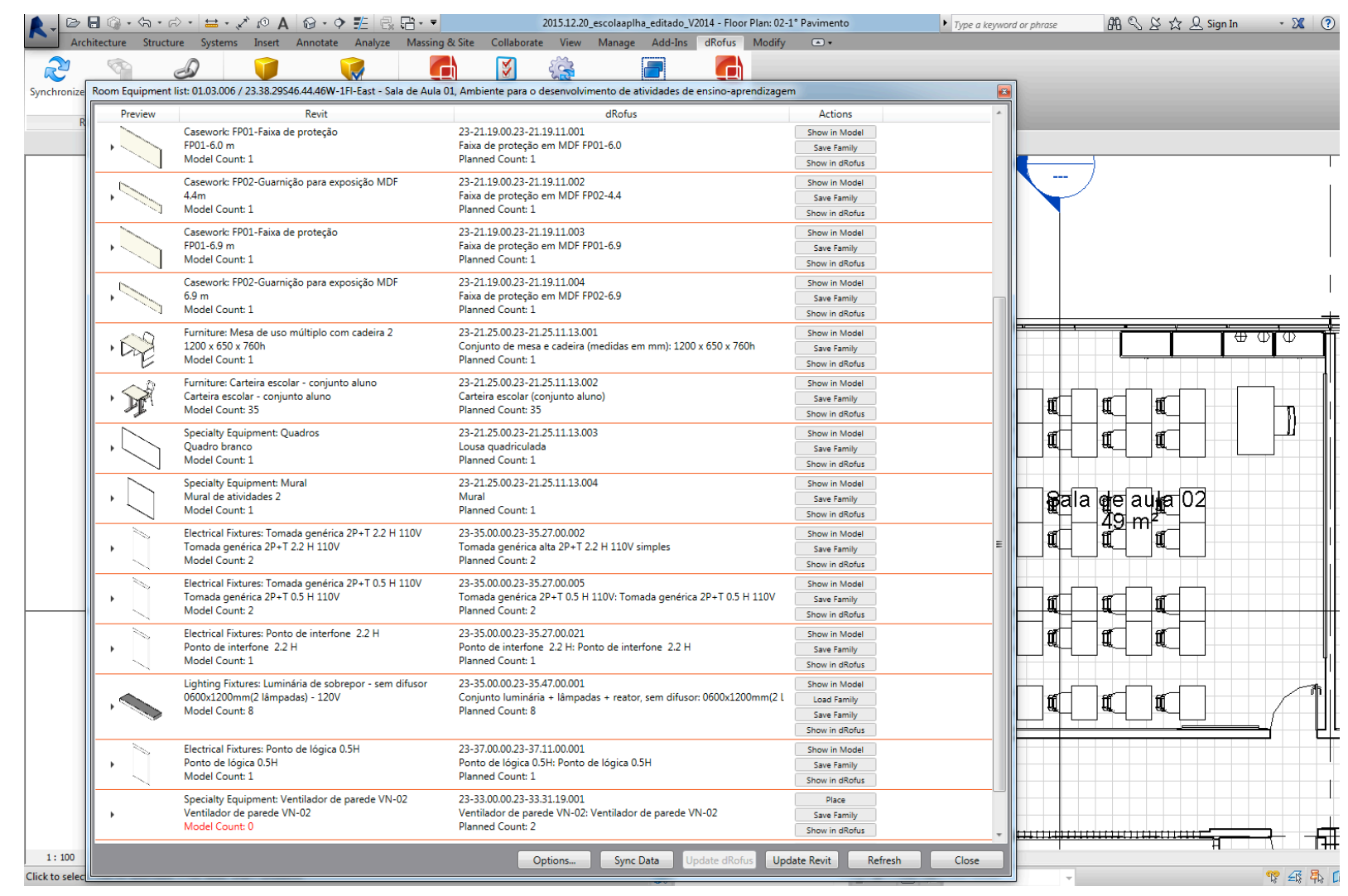

Figura 72. Exemplo de compatibilização entre os componentes especificados na ficha de ambientes e o projetado Fonte: Acervo da pesquisadora.

A relação estabelecida entre os componentes especificados e os modelados é importante para a verificação do atendimento aos requisitos, conforme é apresentado na Figura 73. Dentre os aspectos que podem ser verificados e atualizados, estão: especificações, quantidades, custo, responsável pelo projeto e grupo para orçamento. Além disso, pode-se verificar se o componente apresenta pendências quanto ao desempenho esperado (destacados por meio de ícone à esquerda da referência). 


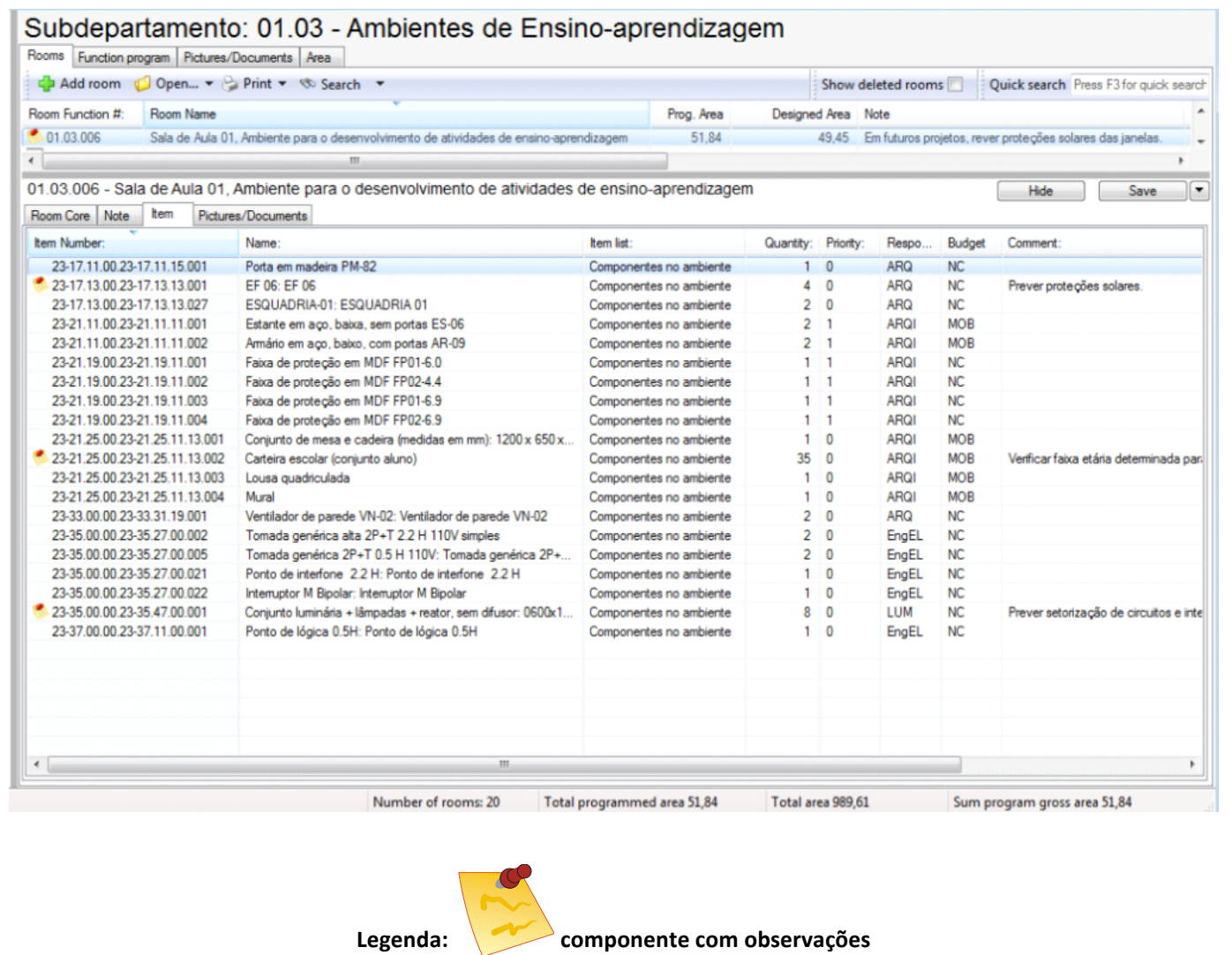

Figura 73. Lista de componentes especificados para uma sala de aula.

Fonte: Acervo da pesquisadora.

Por sua vez, a consulta ao componente referenciado pode permitir a visualização do custo total de unidades inseridas no empreendimento, quantidade e distribuição nos ambientes, conforme o exemplo apresentado na Figura 74. 


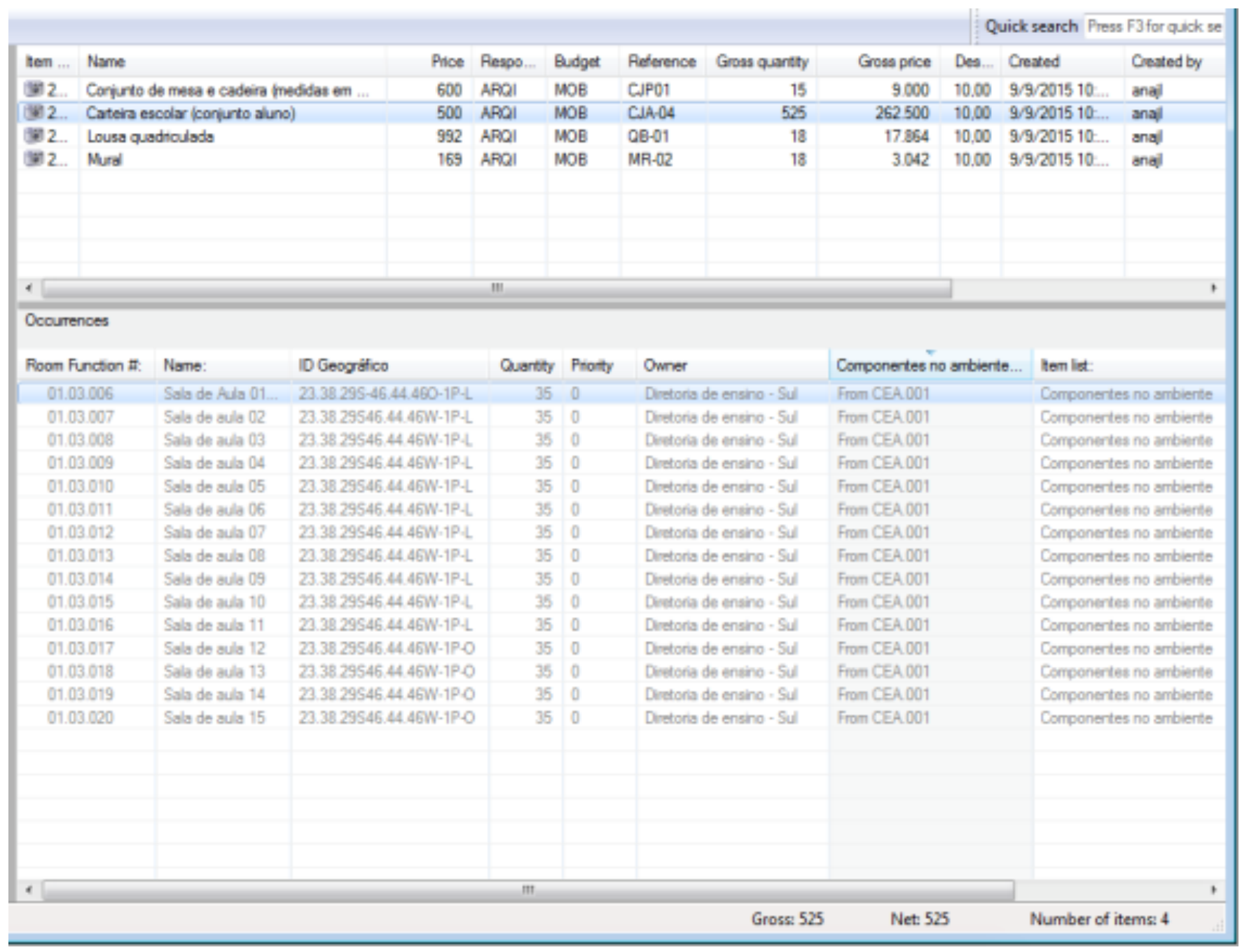

Figura 74. Exemplo de ambiente modelado e lista de componentes sincronizada com o Banco de Dados

Fonte: Acervo da pesquisadora.

Para a consulta à localização, o resultado da pesquisa pode destacar, visualmente, o componente no modelo tridimensional. No exemplo apresentado na Figura 75, o componente conjunto-aluno (carteiras escolares) foi selecionado, ressaltando todos os elementos tridimensionais do modelo que correspondem a essa relação. No Apêndice $D$, pode ser verificada a ficha de especificações para o componente 'carteira escolar - conjunto-aluno'. 


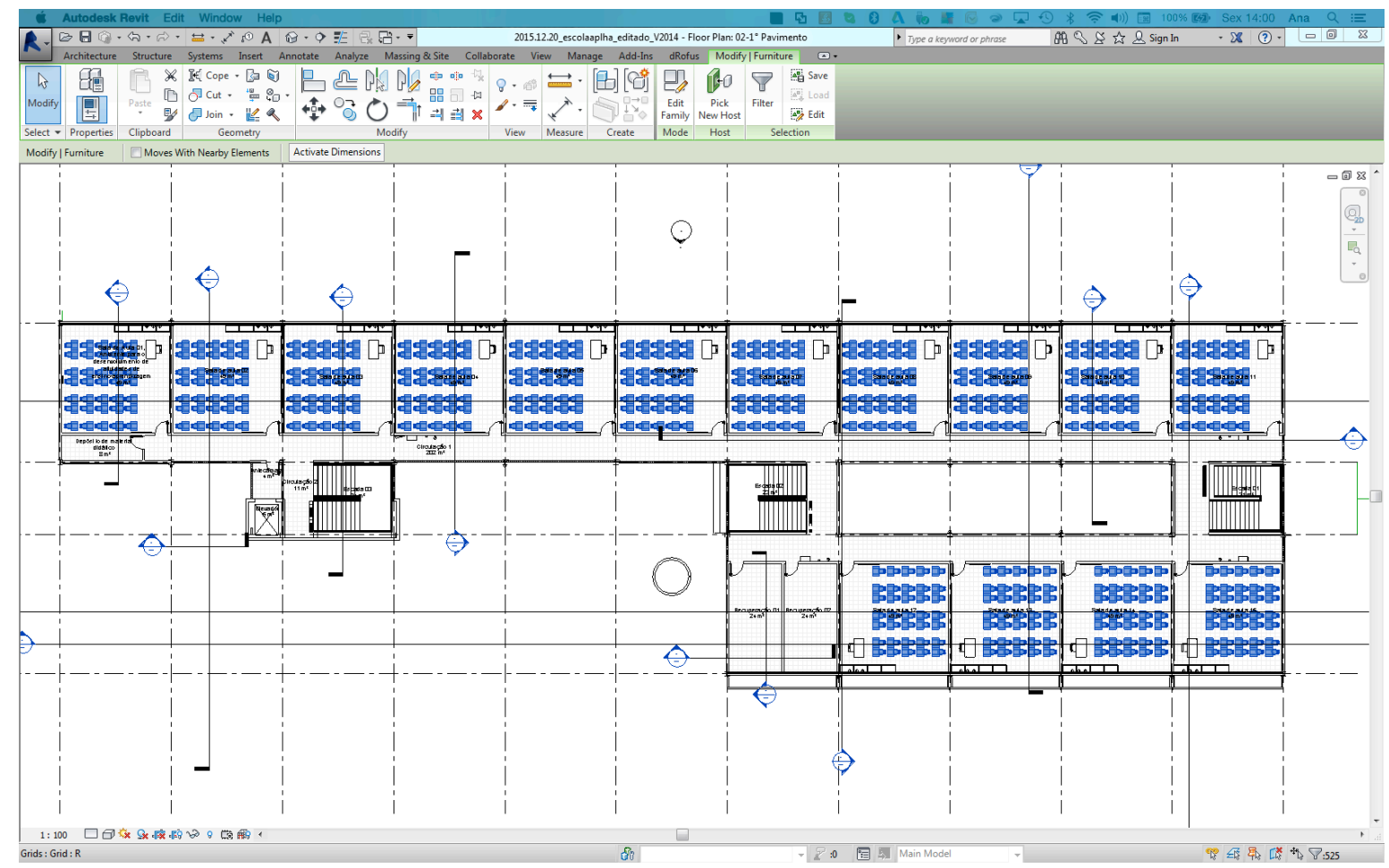

Figura 75. Exemplo de componente inserido no modelo, sincronizado com o Banco de Dados

Fonte: Acervo da pesquisadora.

Considerando que a Escola Alpha e seus componentes integram um portfólio de ativos imobiliários, a determinação dos responsáveis por seu gerenciamento é uma informação importante. Desta forma, pode-se determinar a que unidade administrativa cada elemento modelado pertence, conforme o apresentado na Figura 76. 


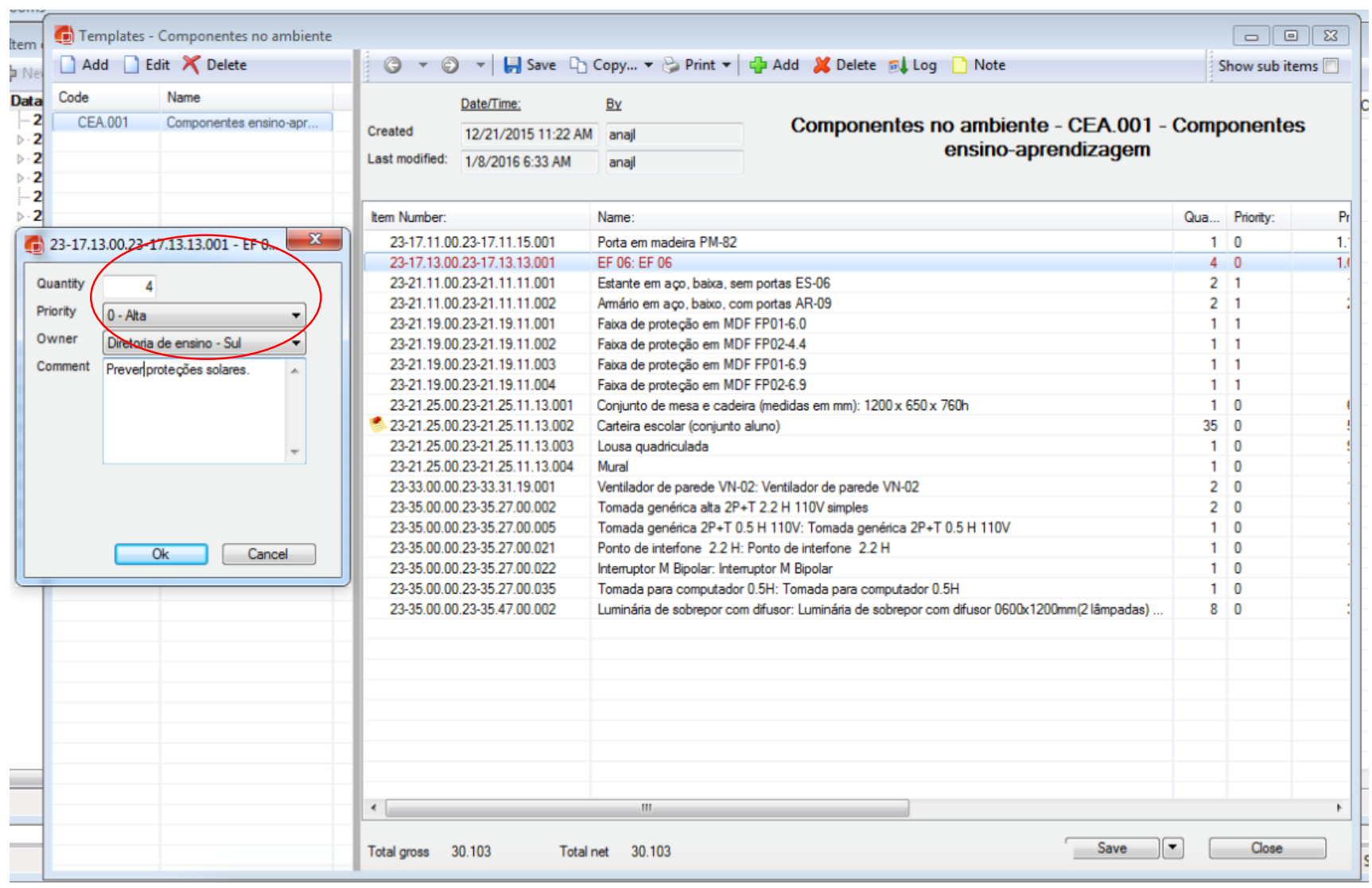

Figura 76. Exemplo de componente atribuído a uma unidade administrativa Fonte: Acervo da pesquisadora.

As informações, que podem estar disponíveis para toda a rede, foram organizadas pela gerência administrativa (por Diretoria de ensino, no caso apresentado). Esta abordagem permite pesquisas de aspectos críticos, considerando diferentes tipos de filtro, como, por exemplo, tipo de uso, pavimento, edificação, orientação da fachada e gerência administrativa, entre outros critérios de busca.

Para as telas que contêm os requisitos para ambientes, inicialmente, foram identificados os usos previstos em projeto. Os ambientes determinados pelo programa de necessidades foram então organizados por conjunto funcional.

Conjuntos de requisitos compartilhados por ambientes, com usos em comum, são atribuídos a estes espaços geométricos, conforme o indicado na Figura 77. 


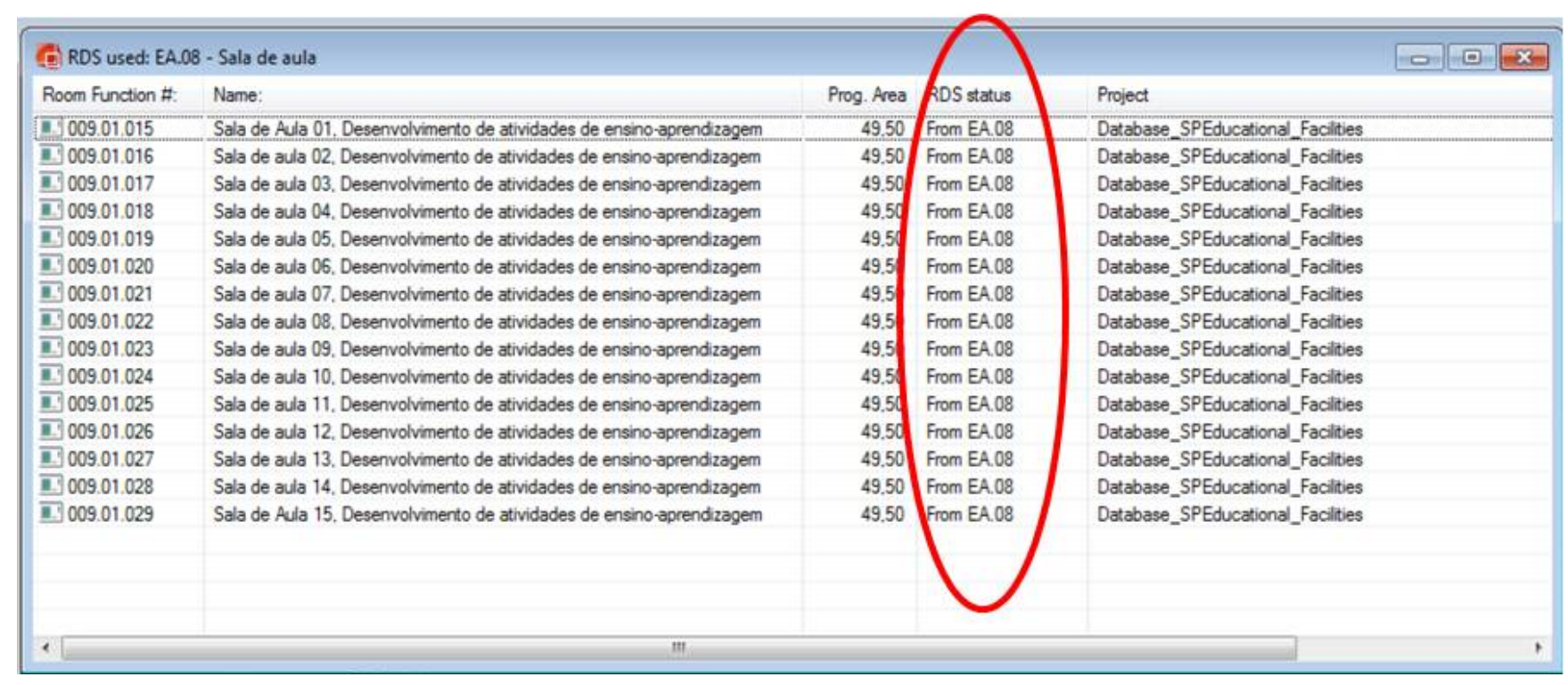

Figura 77. Exemplo de lista de ambientes que compartilham fichas de requisitos para o projeto Fonte: Acervo da pesquisadora.

Para cada conjunto funcional, podem sem ser visualizadas características, tais como localização dos ambientes, áreas especificadas e áreas projetadas, bem como eventuais notas, relacionadas a aspectos críticos pendentes, conforme é apresentado na Figura 78. 
Ambiente

\begin{tabular}{|l|}
\hline Sala de aula \\
\hline Referência OMNICLASS: 13-31.13.15 \\
Conjunto Arquitetônico \\
\hline Pedagógico \\
\hline
\end{tabular}

Caracterização:

Ambiente para o desenvolvimento de

atividades de ensino e aprendizagem.

\section{Requisitos de localização: \\ Prever espaço para a distribuição e \\ a instalação dos itens de mobiliário e de \\ equipamentos, de modo a permitir leiaute \\ flexivel.}

\begin{tabular}{|l|}
\hline $\begin{array}{l}\text { Fechamento Superior: laje. } \\
\text { Acabamento: pintura. }\end{array}$ \\
\hline
\end{tabular}

Paredes: alvenaria.

Revestimento: argamassa.

Acabamento: pintura bege lavável.

Acabamento de piso: piso cerâmico.

Dimensōes: $0,30 \times 0,30 \mathrm{~m}$, alto tráfego.

Renovação de ar:

minima, por àrea $\left(\mathrm{L} / \mathrm{s}^{*} \mathrm{~m}^{2}\right)$, conforme a

ASHRAE 62.1:2010

(ANSI/ASHRAE, 2013a): 0,60

minima, por pessoa ( $\mathrm{L} / \mathrm{s}^{*}$ pessoa), conforme a

ASHRAE 62.1:2010

(ANSI/ASHRAE, 2013a): 7,40

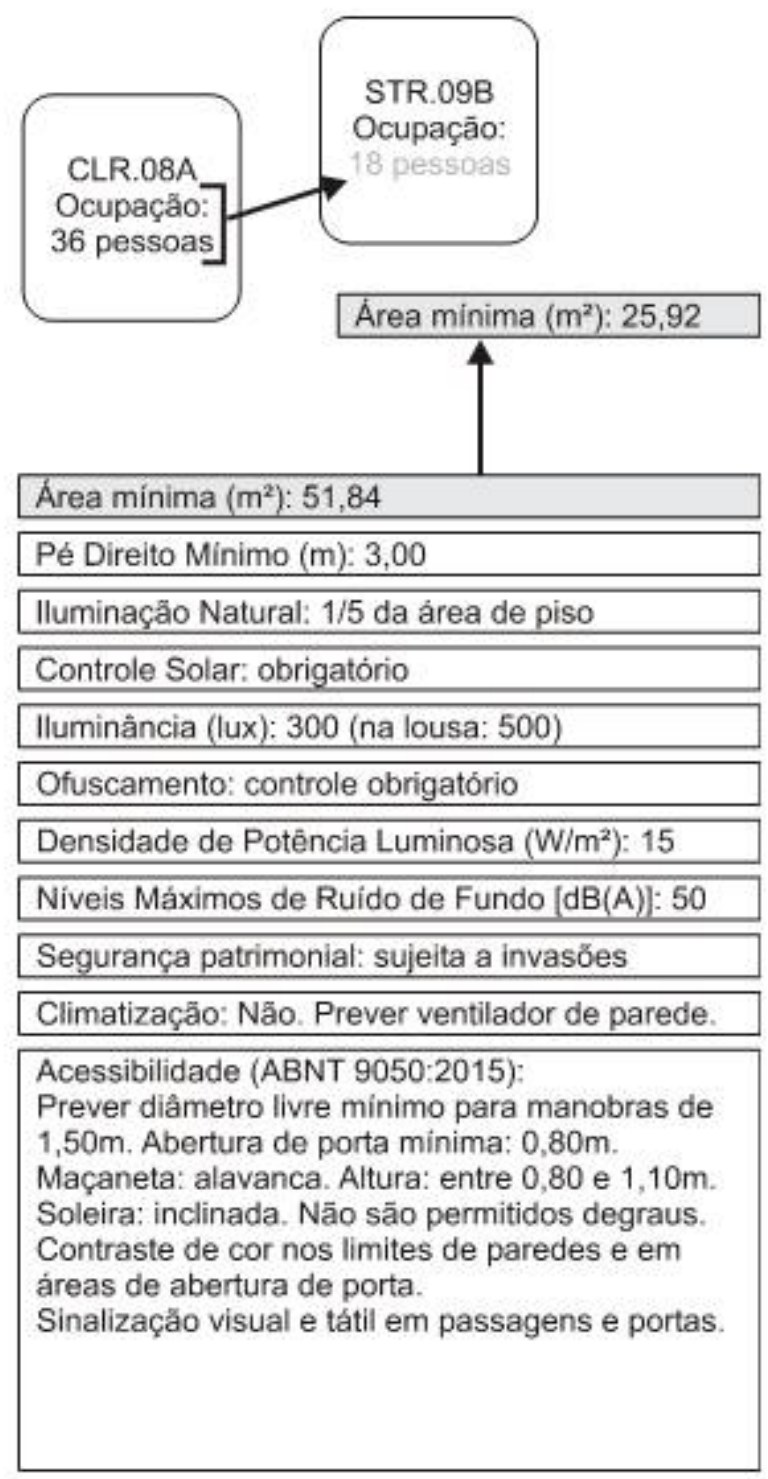

Figura 78. Exemplo de propriedades configuradas em fichas técnicas de ambiente Fonte: Elaborado pela pesquisadora, com base em informações de: FRANÇA (2011); FDE (2014).

A configuração das propriedades em Fichas de Ambientes permite a configuração de fichas derivadas, conforme o exemplo apresentado na Figura 79. Tal recurso possibilita a revisão das propriedades referentes a um ambiente específico, sempre que for pertinente. 


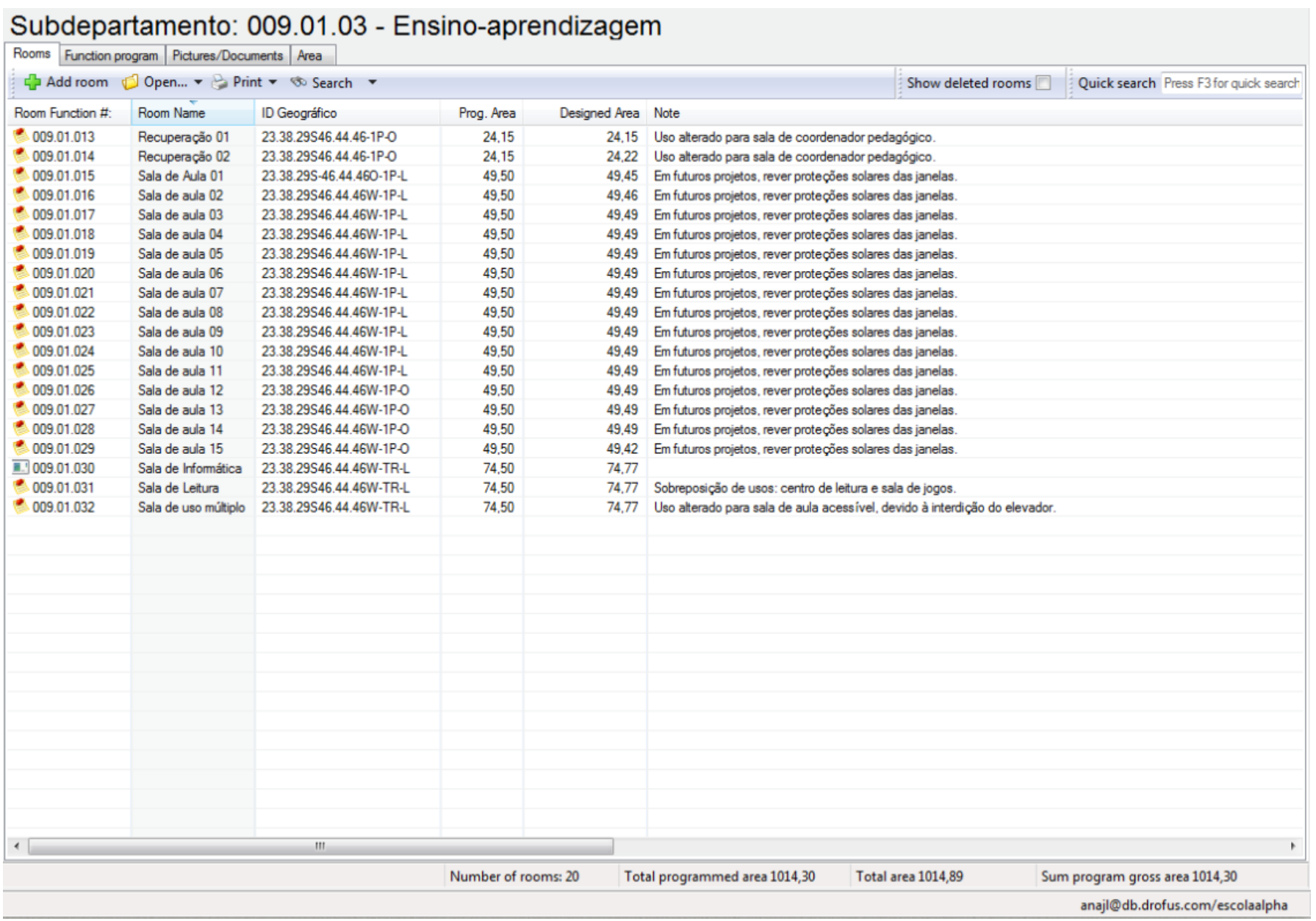

Figura 79. Exemplo de lista de ambientes organizado por conjunto funcional

Fonte: Acervo da pesquisadora.

Desta forma, podem ser visualizados facilmente todos os ambientes que apresentaram aspectos críticos, quando em uso, conforme o exemplo apresentado na Figura 80. Uma vez tendo sido selecionado o ambiente na lista, a informação referente ao comentário encontra-se em destaque no campo amarelo. 


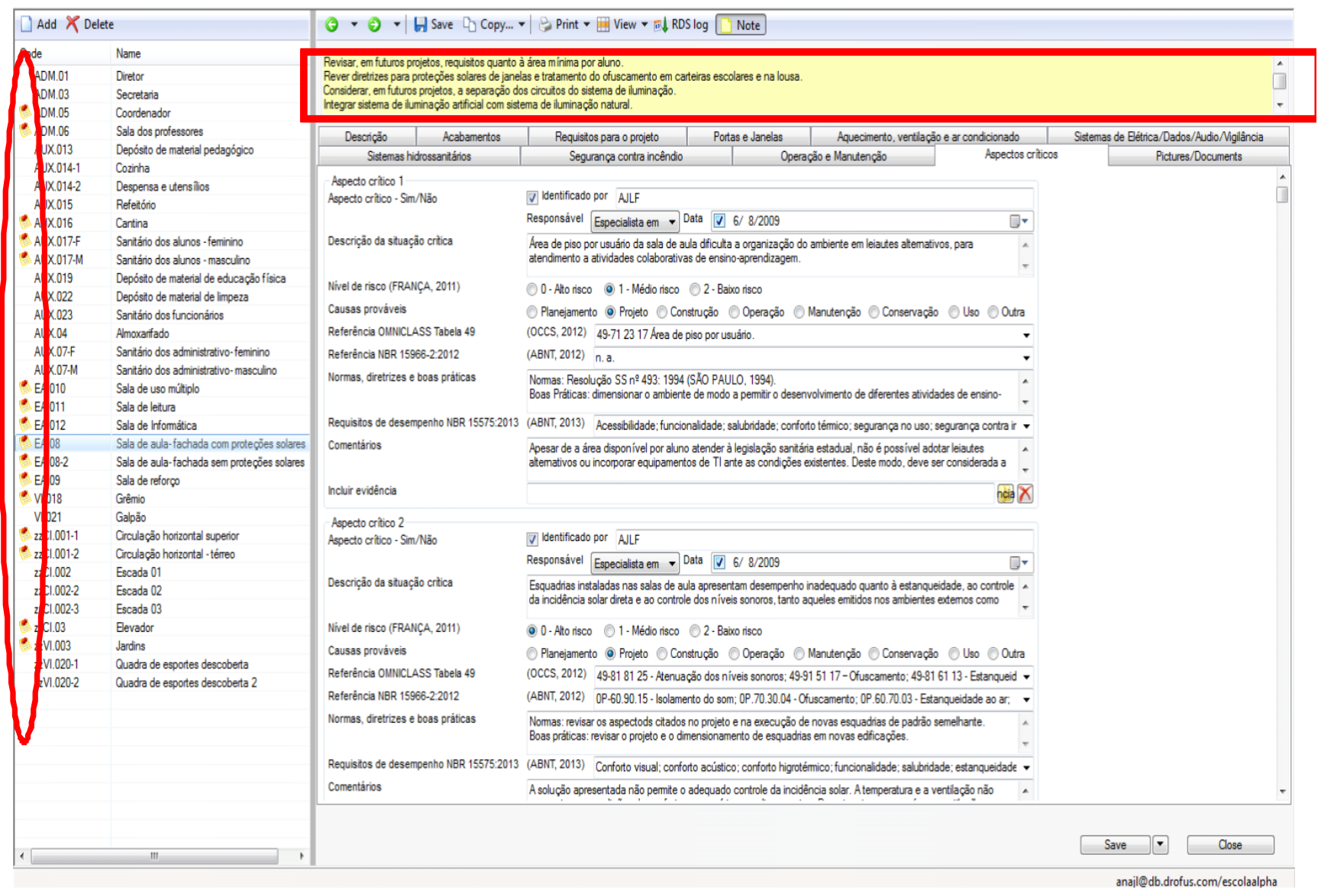

Figura 80. Exemplo de visualização de lista de ambientes para a Escola Alpha Fonte: Acervo da pesquisadora.

Para cada ambiente, foram configurados os requisitos de desempenho em função do respectivo uso. Para a determinação destes requisitos, foram consideradas as especificações constantes da ficha de ambiente FDE, complementados com propriedades necessárias à verificação do desempenho das soluções de projeto (por exemplo, características térmicas de materiais, que são necessárias para a elaboração de simulações termoenergéticas).

Também foram incorporados às fichas de ambientes os requisitos identificados como pertinentes, com base nos resultados da APO (FRANÇA, 2011).

Na Figura 81, é apresentado um exemplo de interface gráfica para a ficha técnica de ambiente. 


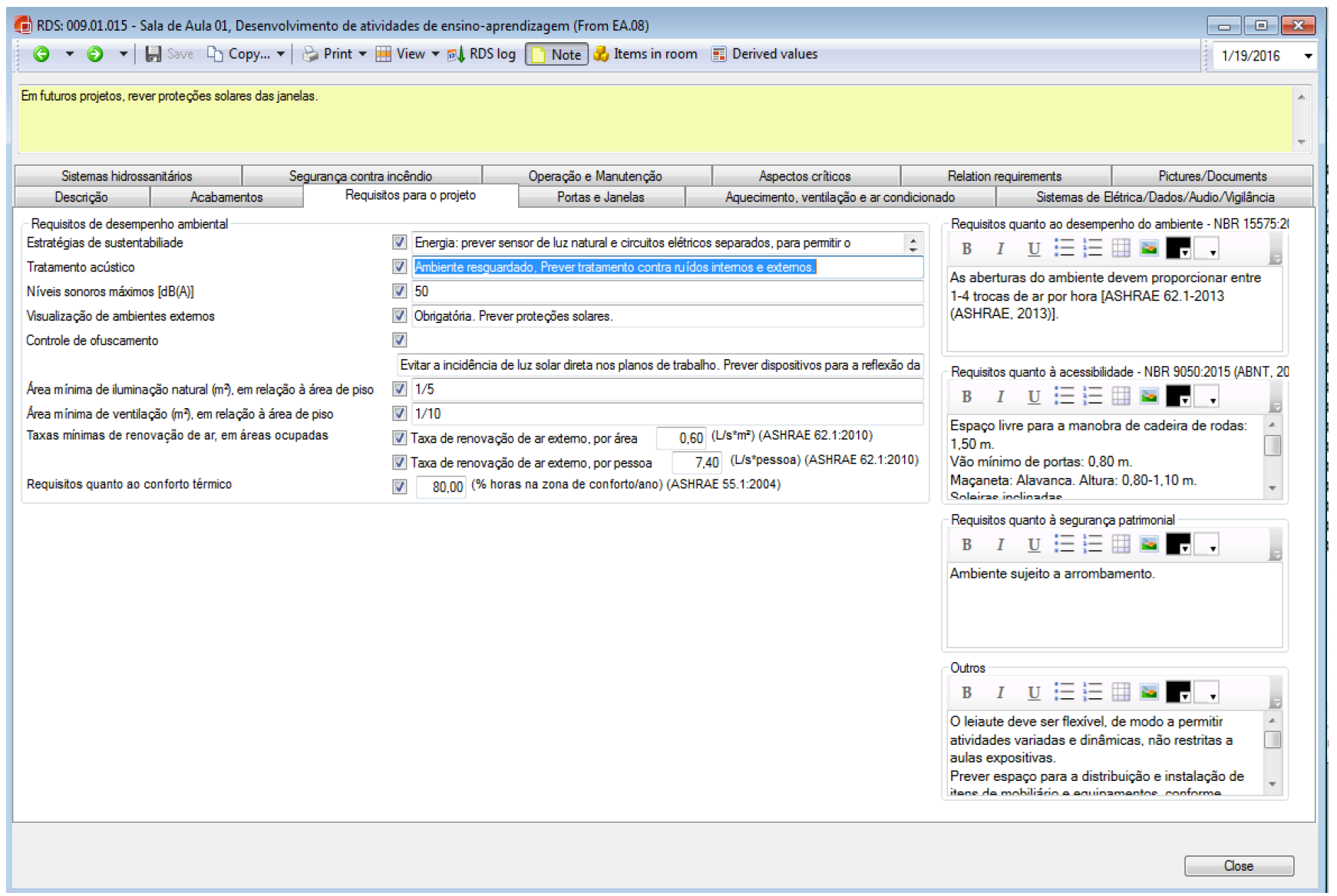

Figura 81. Aspecto da interface gráfica referente às informações relacionadas ao ambiente.

Fonte: Acervo da pesquisadora.

Para a organização das informações, foram configuradas as seguintes telas:

- Descrição - informações gerais do ambiente;

- Informações de projeto - especificações para paredes, pisos, acabamentos e requisitos de desempenho para 0 ambiente (ANSI/ASHRAE, 2004; ABNT; 2013; ANSI/ASHRAE, 2013a; ABNT; 2015);

- Janelas e portas - requisitos para a especificação e o dimensionamento destes componentes;

- Sistemas elétricos, de dados, de mídia, de vigilância e de AVAC requisitos para a especificação e o dimensionamento desses componentes;

- Segurança contra incêndio - requisitos para o dimensionamento de ambientes, a especificação e a quantificação dos componentes; 
- Operação e manutenção - Orientações para atividades de operação e manutenção. Documentação de atividades de manutenção;

- Aspectos críticos - Aspectos críticos relacionados ao ambiente, identificados pela aplicação de APOs, processos de comissionamento ou reportados por usuários ou atores do processo; e

- Área para o armazenamento de evidências (documentos e fotografias) para a comprovação dos aspectos críticos.

Nas Figuras 81 e 82, são apresentados exemplos de relatórios gerado para uma Ficha de Ambiente, referentes às telas de operação e de reporte de aspectos críticos.

Como um exemplo, na Figura 82 estão relatadas as informações correspondentes às diretrizes gerais de projeto e os requisitos de desempenho, correspondentes ao ambiente sala de aula.

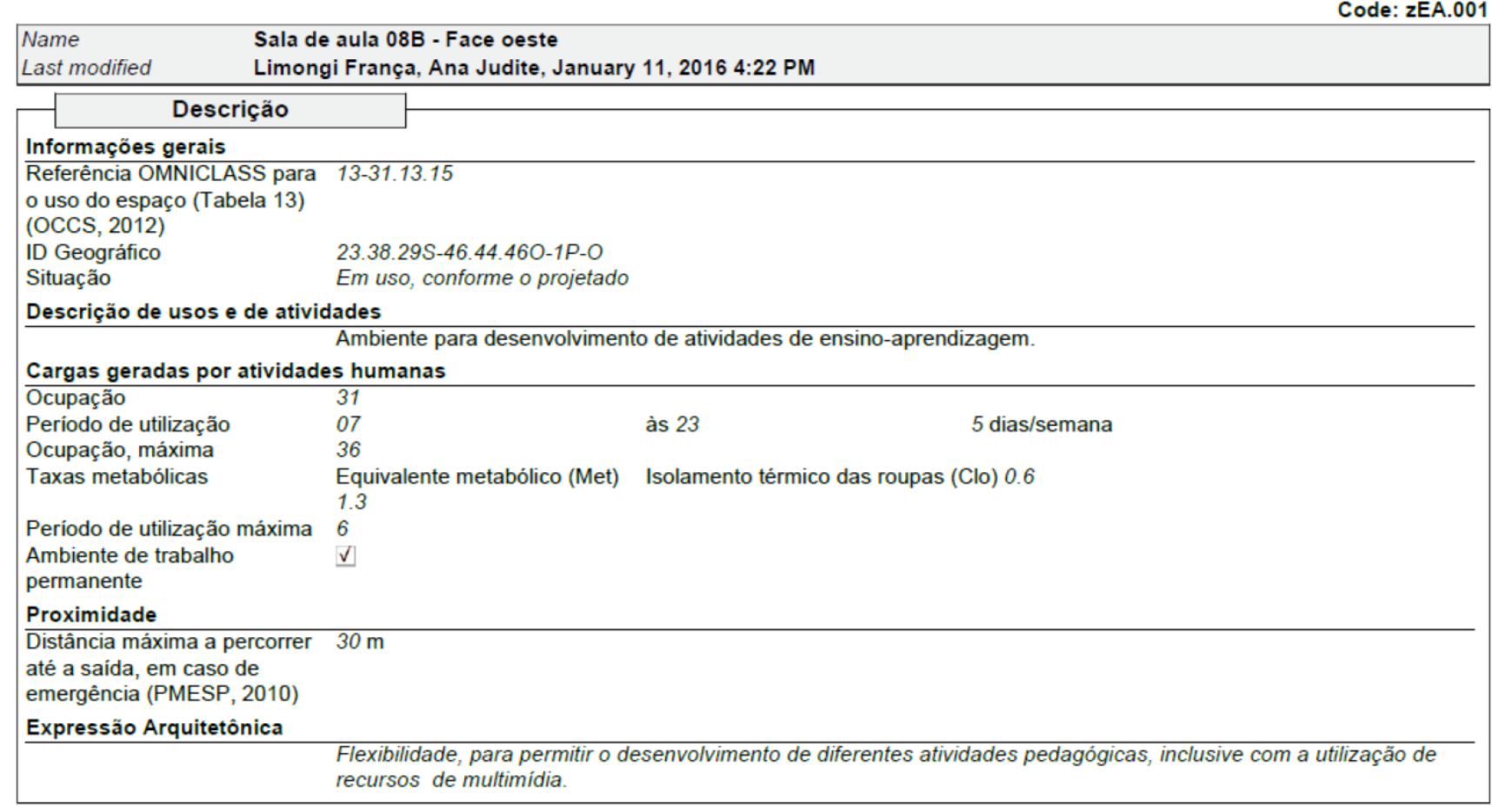

Figura 82. Exemplo de ficha de ambiente gerada a partir da plataforma de Banco de Dados Diretrizes de projeto e requisitos de desempenho correspondentes ao ambiente sala de aula. Fonte: Acervo da pesquisadora. 
$\mathrm{Na}$ Figura 83 são apresentadas as especificações correspondentes ao ambiente sala de aula, referentes a especificações de sistemas prediais.

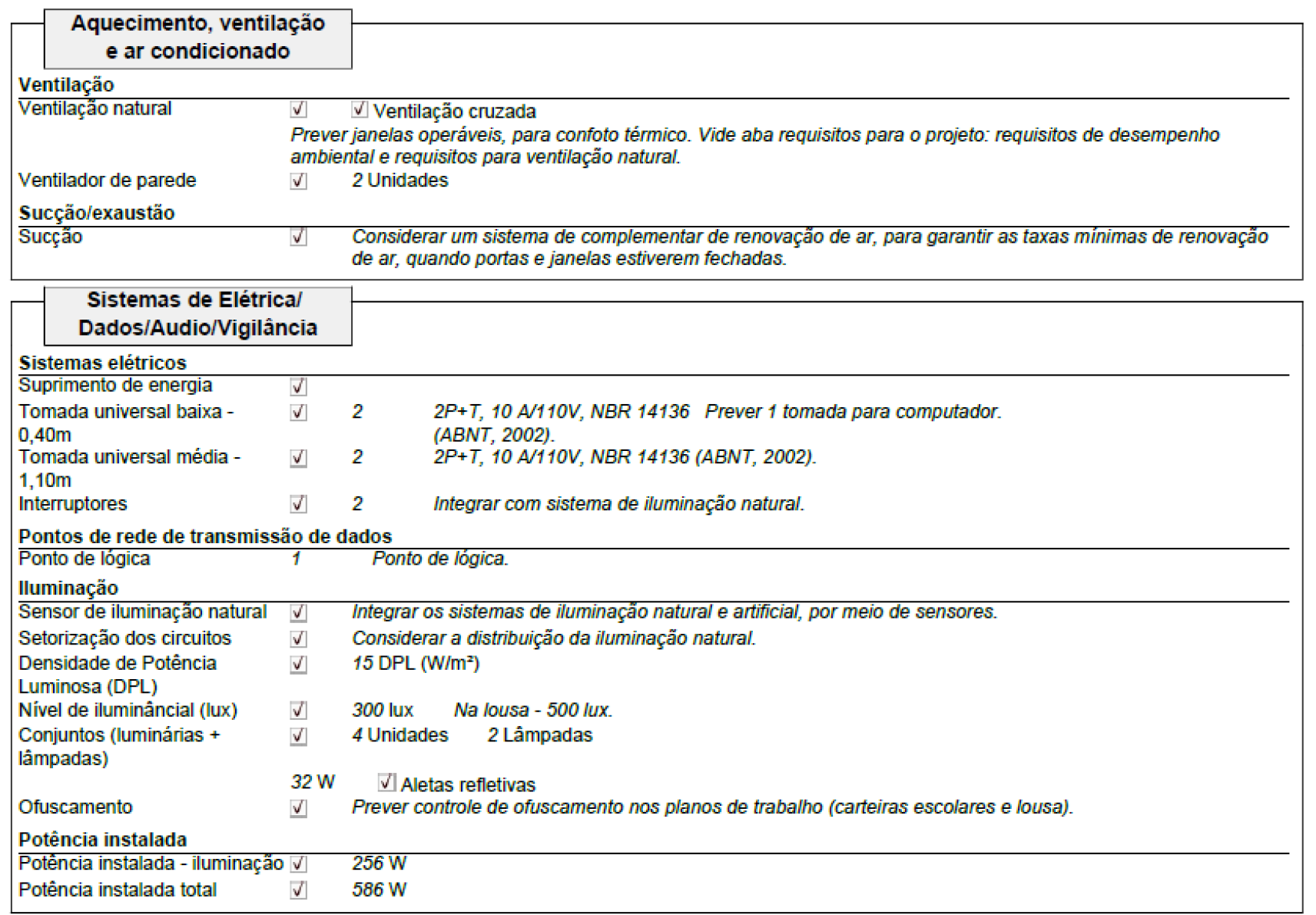

Figura 83. Exemplo de ficha de ambiente gerada a partir da plataforma de Banco de Dados Especificações e critérios de desempenho para sistemas prediais. Fonte: Acervo da pesquisadora.

O Apêndice A apresenta a lista de propriedades configuradas para o ambiente. No Apêndice $B$, podem ser consultadas as diretrizes de projeto para a Escola Alpha, organizadas em fichas de ambientes, geradas por meio da plataforma de Banco de Dados.

Para a conferência e a validação dos objetivos determinados para o empreendimento, também podem ser consultados os requisitos do proprietário e as premissas de projeto, disponíveis para acesso na interface gráfica de especificações 
de ambiente, conforme o apresentado na Figura 84.

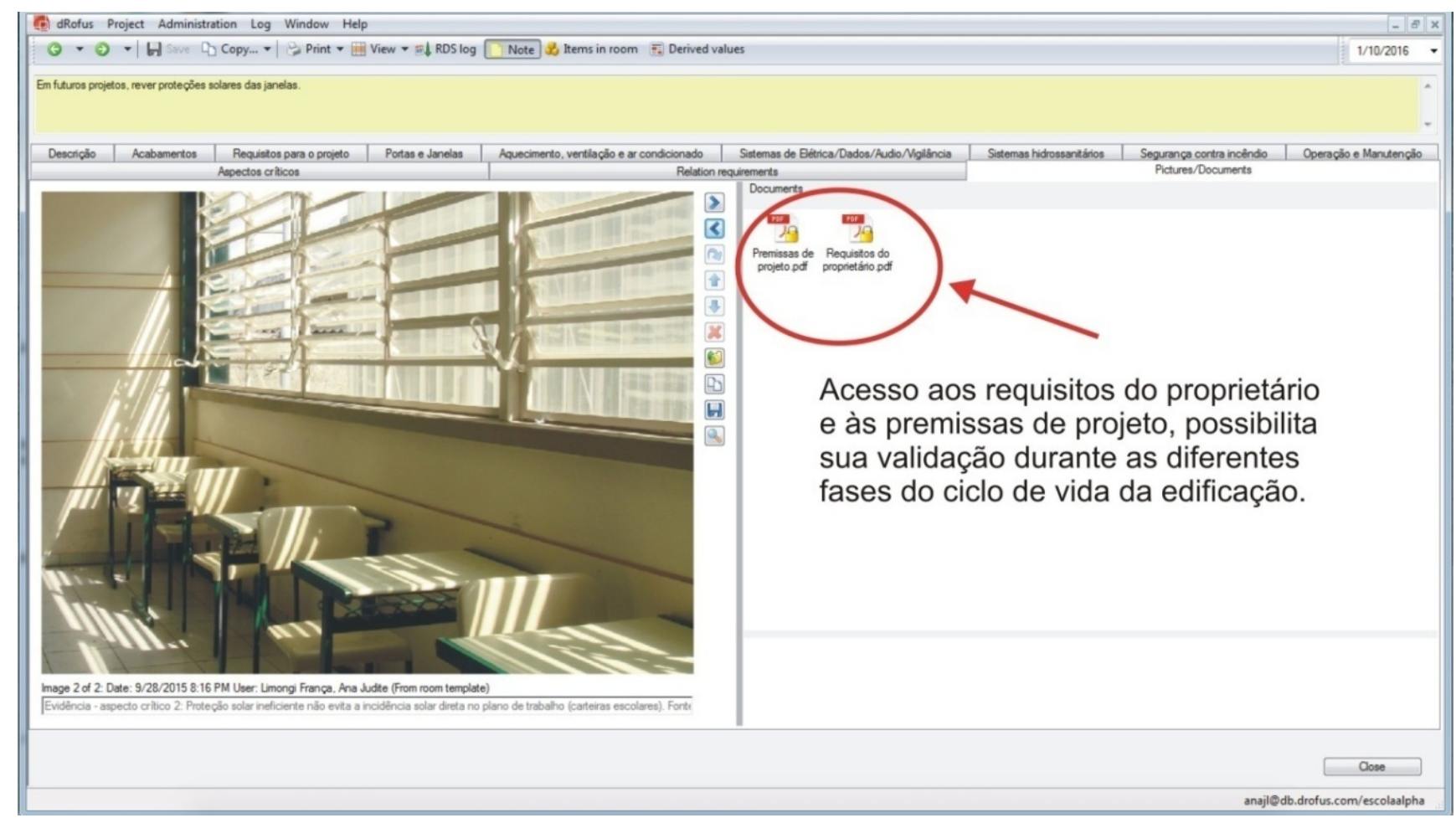

Figura 84. Exemplo de interface gráfica para acesso às premissas de projeto e aos requisitos do proprietário Fonte: Acervo da pesquisadora.

Com base na modelagem das informações na plataforma do Banco de Dados e nos procedimentos para a verificação das condições de ocupação e operação do construído, é possível realizar diagnósticos para aferir os níveis de adequação aos requisitos iniciais do empreendimento.

As informações relacionadas a estes aspectos críticos identificados também devem ser modeladas no Banco de Dados, de modo a permitir futuras análises, conforme o apresentado no Quadro 25. 
Quadro 25. Informações modeladas para a ocorrência

\begin{tabular}{|c|c|}
\hline Componente & Nome do componente. \\
\hline ID Geográfico & $\begin{array}{l}\text { Localização geográfica: } \\
\text { latitude - longitude-pavimento-localização. }\end{array}$ \\
\hline Modelo & $\begin{array}{l}\text { Modelo determinado pelo fabricante ou referência FDE, se produto não } \\
\text { industrializado. }\end{array}$ \\
\hline Material & Materia(is) predominantes do componente. \\
\hline Ambiente & Ambiente onde está localizado. \\
\hline Referência OMNICLASS (Tabela 23) & Referência da terminologia OMNICLASS correspondente ao componente. \\
\hline Identificado por & Atribuição da responsabilidade pelo cadastramento da ocorrência. \\
\hline Identificado em & Data de identificação da ocorrência. \\
\hline Descrição da ocorrência & Descrição dos aspectos críticos identificados. \\
\hline $\begin{array}{l}\text { Requisitos de desempenho } \\
\text { relacionados } \\
\text { (ABNT, 2013) }\end{array}$ & $\begin{array}{l}\text { Requisitos de desempenho relacionados à ocorrência, conforme a norma NBR } \\
15.575: 2013 \text {. }\end{array}$ \\
\hline Nível de risco & $\begin{array}{l}\text { Avaliação do nível de risco do , a saber (FRANÇA, 2011): } \\
\begin{array}{l}\text { 0- } \\
\text { física do usuário. } \\
\text { 1- Médio risco - dificulta o uso e expõe o usuário a uma condição de perigo; } \\
\text { 2- Baixo risco - necessita ser adequado às normas técnicas e diretrizes de } \\
\text { boas práticas, mas não interfere nas condições de uso/não expõe o } \\
\text { usuário a perigo. }\end{array}\end{array}$ \\
\hline
\end{tabular}

Fonte: Acervo da pesquisadora.

Assim sendo, uma tela para a inclusão de resultados da análise de desempenho dos ambientes foi prevista, para posterior análise e comparação entre edificações, para embasar decisões quanto à revisão das diretrizes, conforme o apresentado na Figura 85. 


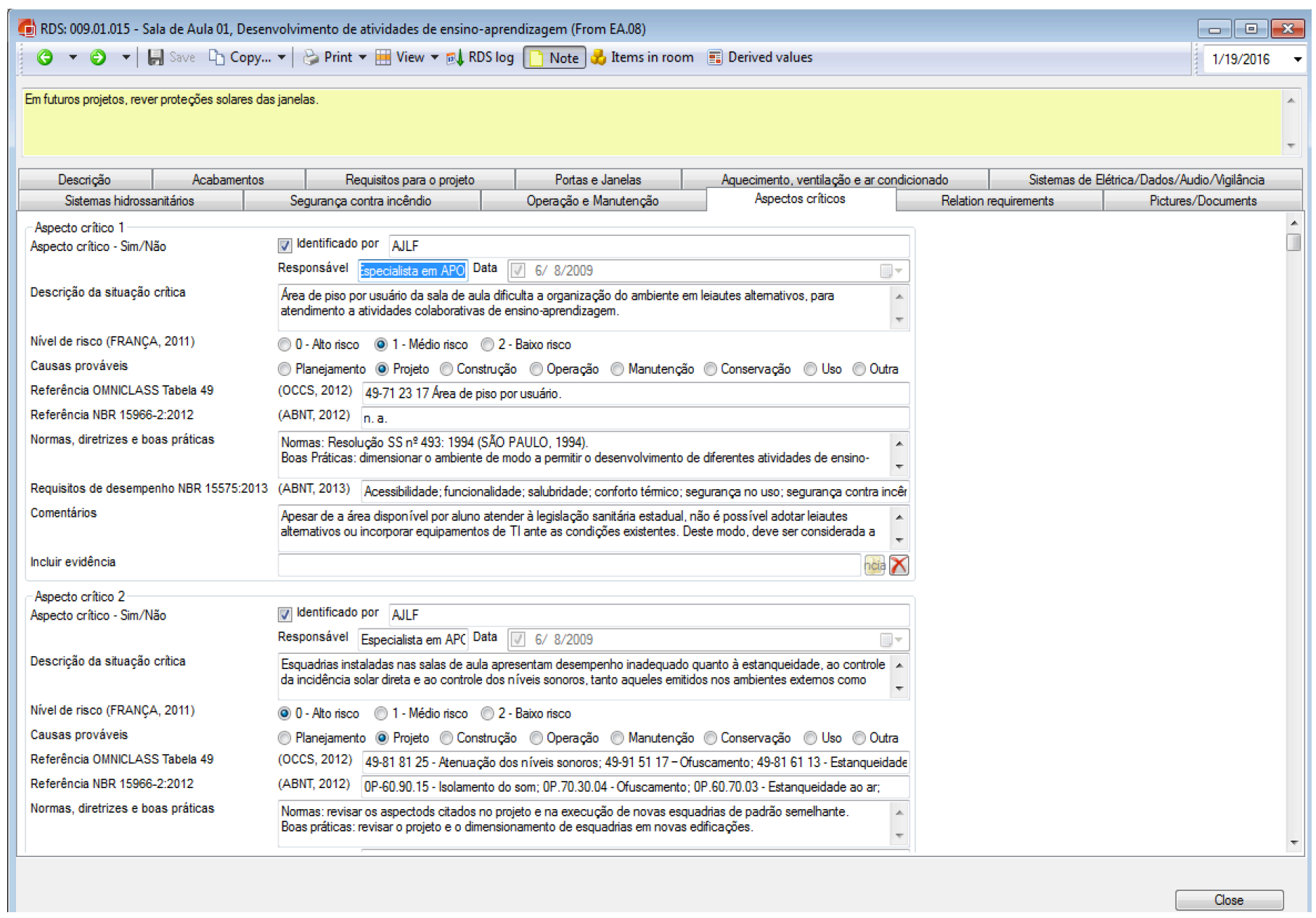

Figura 85. Exemplo de tela para a inserção dos aspectos críticos identificados, relacionados a um ambiente Fonte: Acervo da pesquisadora.

O relatório de aspectos críticos gerado para os ambientes da Escola Alpha, é apresentado no Apêndice $C$.

Como exemplo, a Figura 86 mostra o modelo tridimensional elaborado para uma sala de aula e seus componentes. 


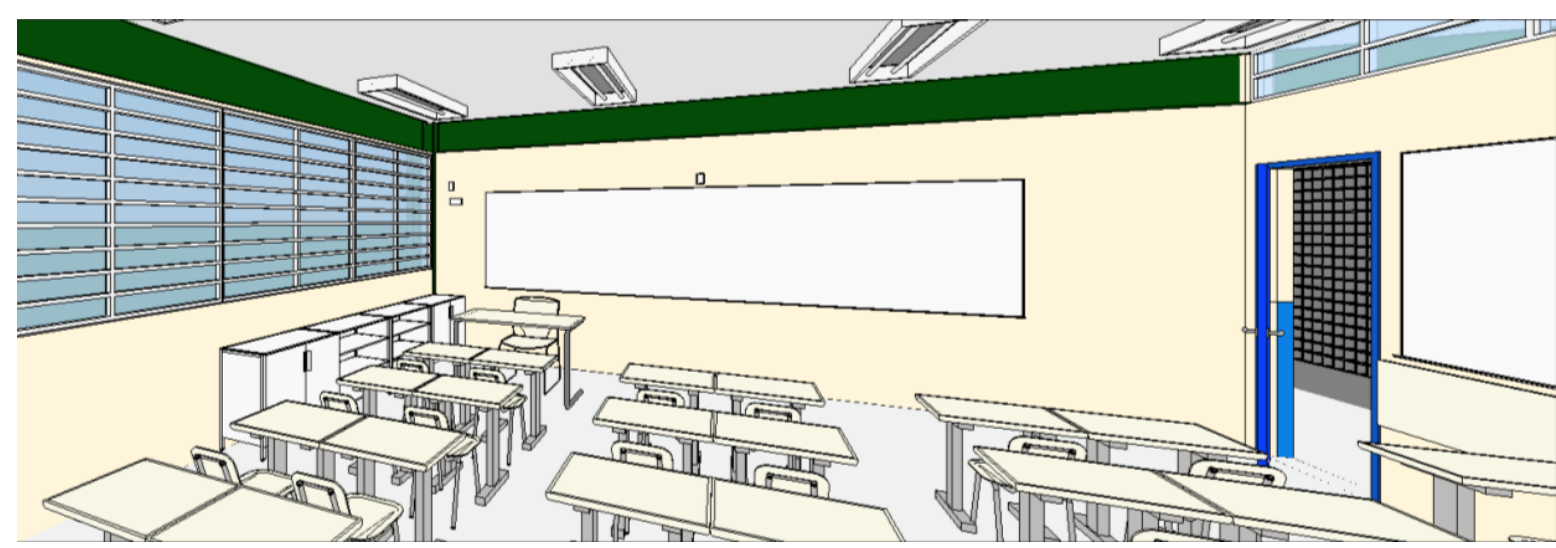

Figura 86. Modelo tridimensional elaborado para uma sala de aula. Fonte: Acervo da pesquisadora.

A validação dos resultados quanto ao desempenho desse ambiente permitiu identificar aspectos críticos, por exemplo, relacionados ao controle da incidência solar sobre as janelas (Foto 5).

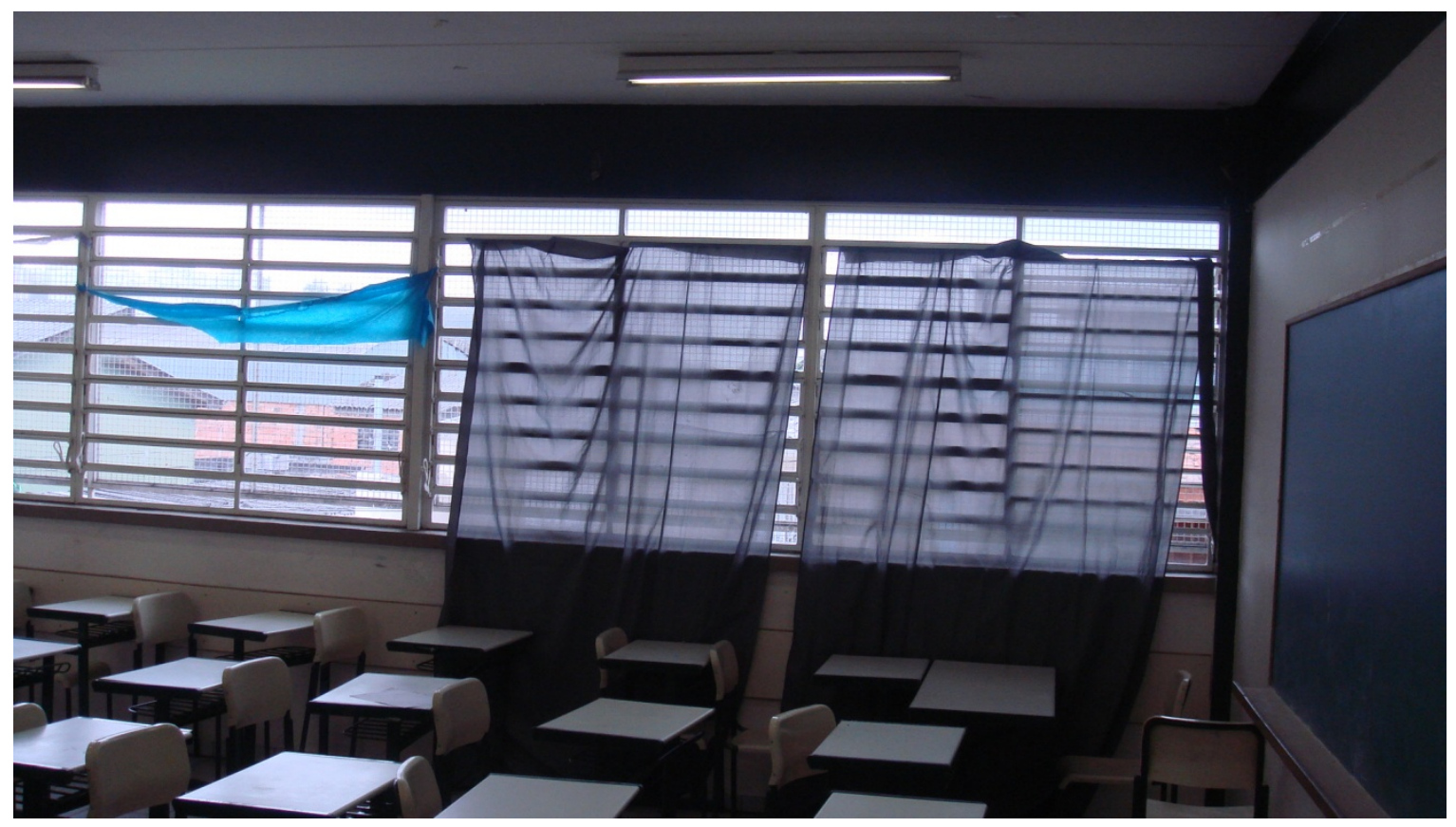

Foto 5. Evidência da instalação de elemento improvisado, fixado à janela, para controle de incidência solar

Fonte: Acervo da pesquisadora.

Além disso, foi possível evidenciar o desempenho inadequado das fechaduras instaladas na porta da sala de aula, conforme o apresentado na Foto 6. 


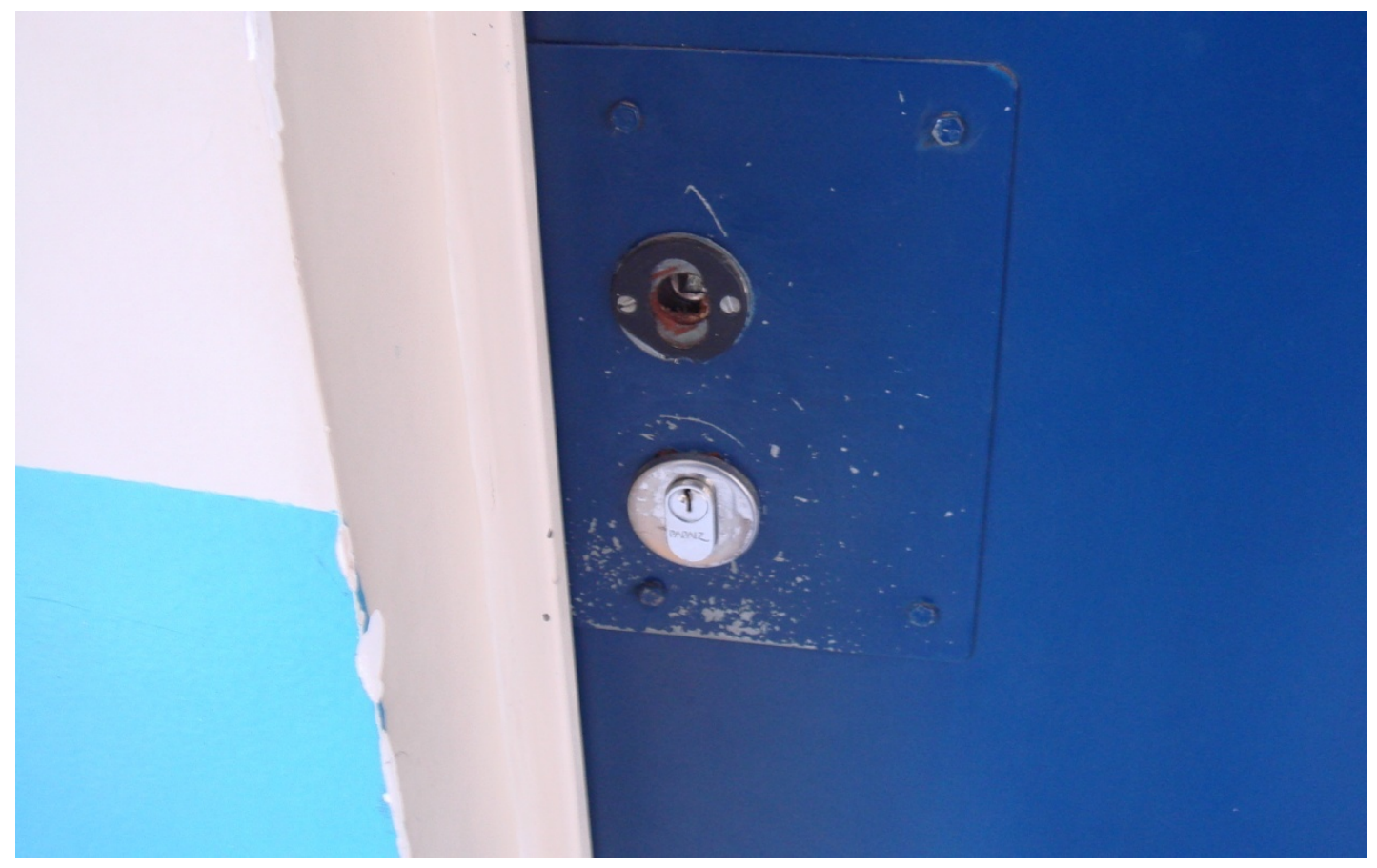

Foto 6. Evidência do desempenho inadequado de fechadura

Fonte: Acervo da pesquisadora.

A Figura 87 apresenta um exemplo de componente (Ventilador VN-02), que foi especificado para o projeto da Escola Alpha (ver Apêndice C). Porém, o equipamento, destacado em projeto, não se encontrava instalado. 


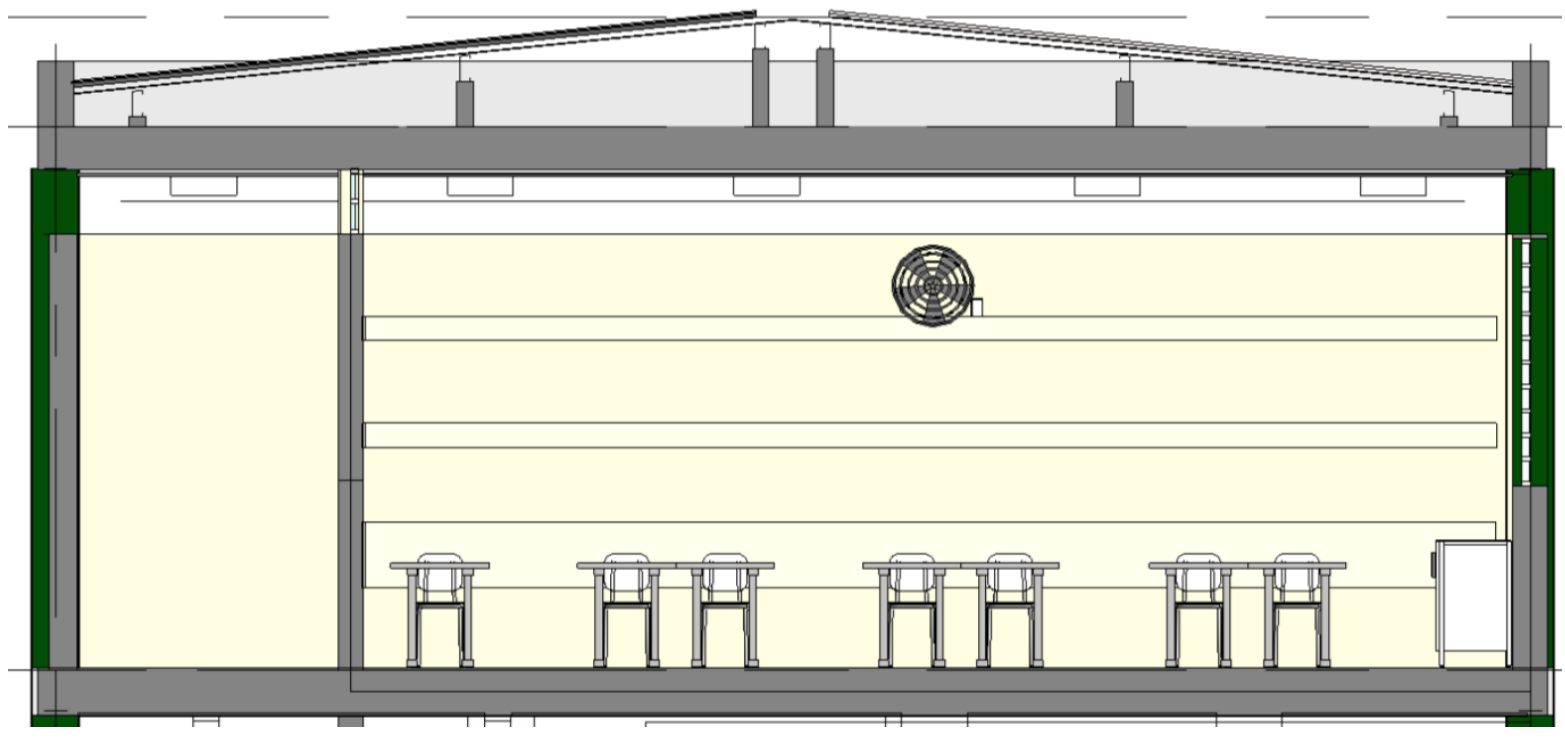

Figura 87. Exemplo de especificação não compatível com o executado Ventilador (VN-02) não instalado nas salas de aula. Fonte: Acervo da pesquisadora.

Aspectos relacionados à manutenção predial, como por exemplo, a troca necessária de lâmpadas queimadas (Foto 7) e a perda da integridade de tomadas de energia (Fotos 7 e 8) também foram digitalizadas e integradas ao Banco de Dados, o que permite, inclusive, posteriores análises estatísticas.

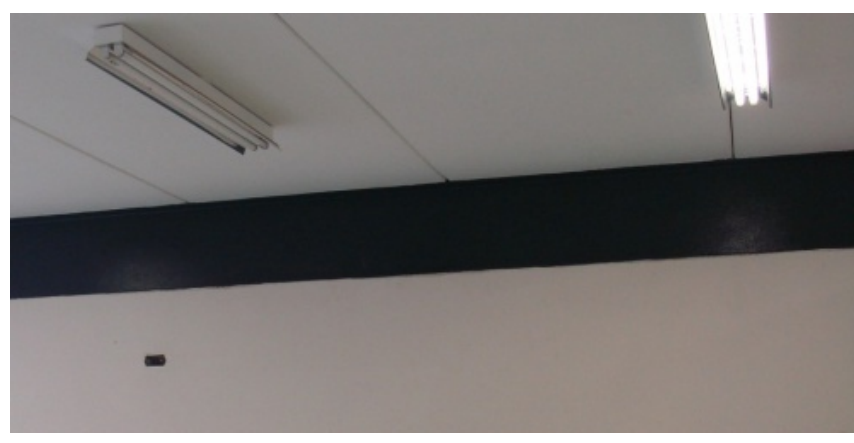

Foto 7. Evidências relacionadas à manutenção predial em ambiente da Escola Alpha Tomada danificada e lâmpada queimada Fonte: Acervo da pesquisadora.

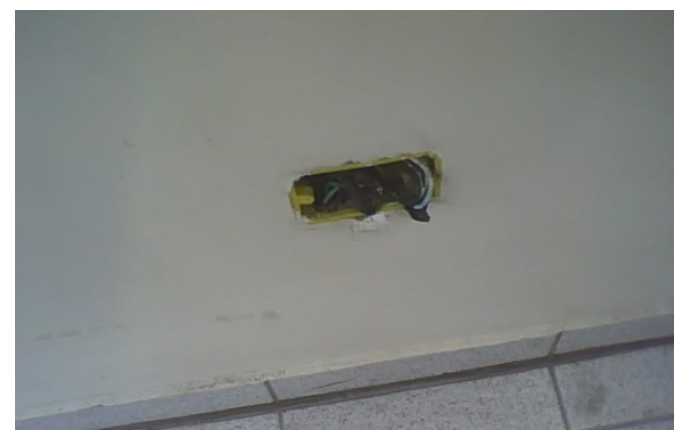

Foto 8. Evidência relacionada à manutenção predial em ambiente da Escola Alpha Tomada danificada Fonte: Acervo da pesquisadora.

Não só o comportamento dos componentes, como também o resultado de seu desempenho em conjunto com os demais elementos construtivos do ambiente, 
devem ser avaliados, como é o caso da evidência apresentada na Foto 9, na qual se observa a junção entre o piso e o pilar metálico sem o tratamento adequado, o que potencializa a corrosão deste último.

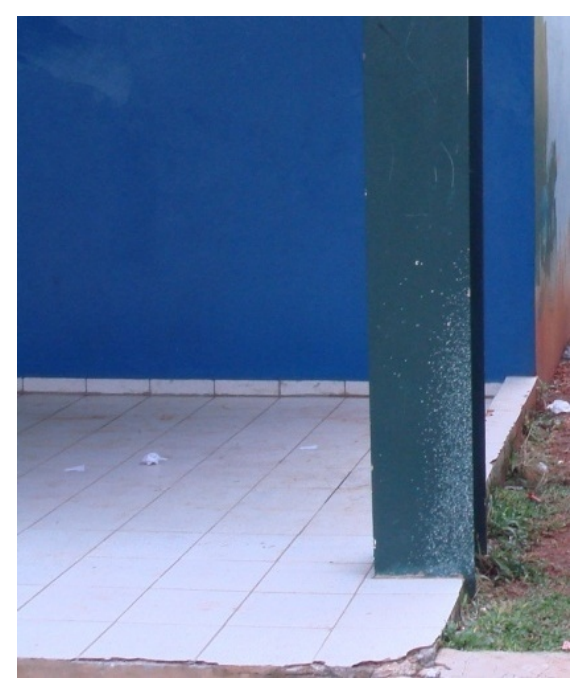

Foto 9. Exemplo de detalhamento estrutural a ser revisto: pilar metálico em contato direto com o piso cerâmico Fonte: Acervo da pesquisadora.

Outra situação importante dessa abordagem é a identificação, nos casos dos componentes executados sob medida para a edificação (e, por conseguinte, sem histórico de validação anterior), de modo a verificar sua adequação ao uso proposto, eventuais riscos aos usuários. Considerando esse diagnóstico, é possível verificar a conveniência de repetição da solução em projetos futuros. As Fotos 10 e 11 apresentam exemplos de soluções que não fazem parte do catálogo dos componentes homologados. 


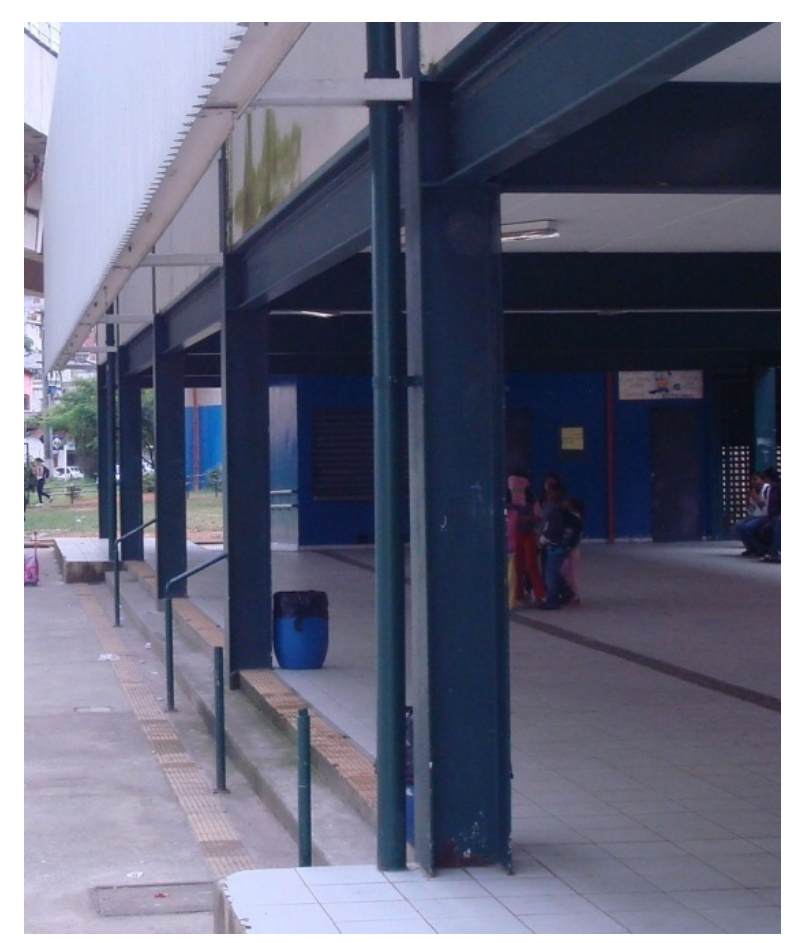

Foto 10. Exemplo de corrimão tubular desenvolvido sob medida para o projeto

Fonte: Acervo da pesquisadora.

No caso da Foto 10, observa-se que o corrimão não apresenta desempenho adequado, pois houve o descolamento de peças, impossibilitando seu uso. Além disso, as partes restantes representam risco à integridade do usuário. Portanto, esse elemento deve ser sujeito a uma revisão projetual, caso se pretenda replicá-lo.

A Foto 11 apresenta um detalhe da situação de risco potencial ao usuário, pois, além dos problemas mencionados com o componente corrimão, a altura e a quantidade de degraus não estão de acordo com o projeto. Além disso, a sinalização tátil não identifica adequadamente os obstáculos (ABNT, 2015). 


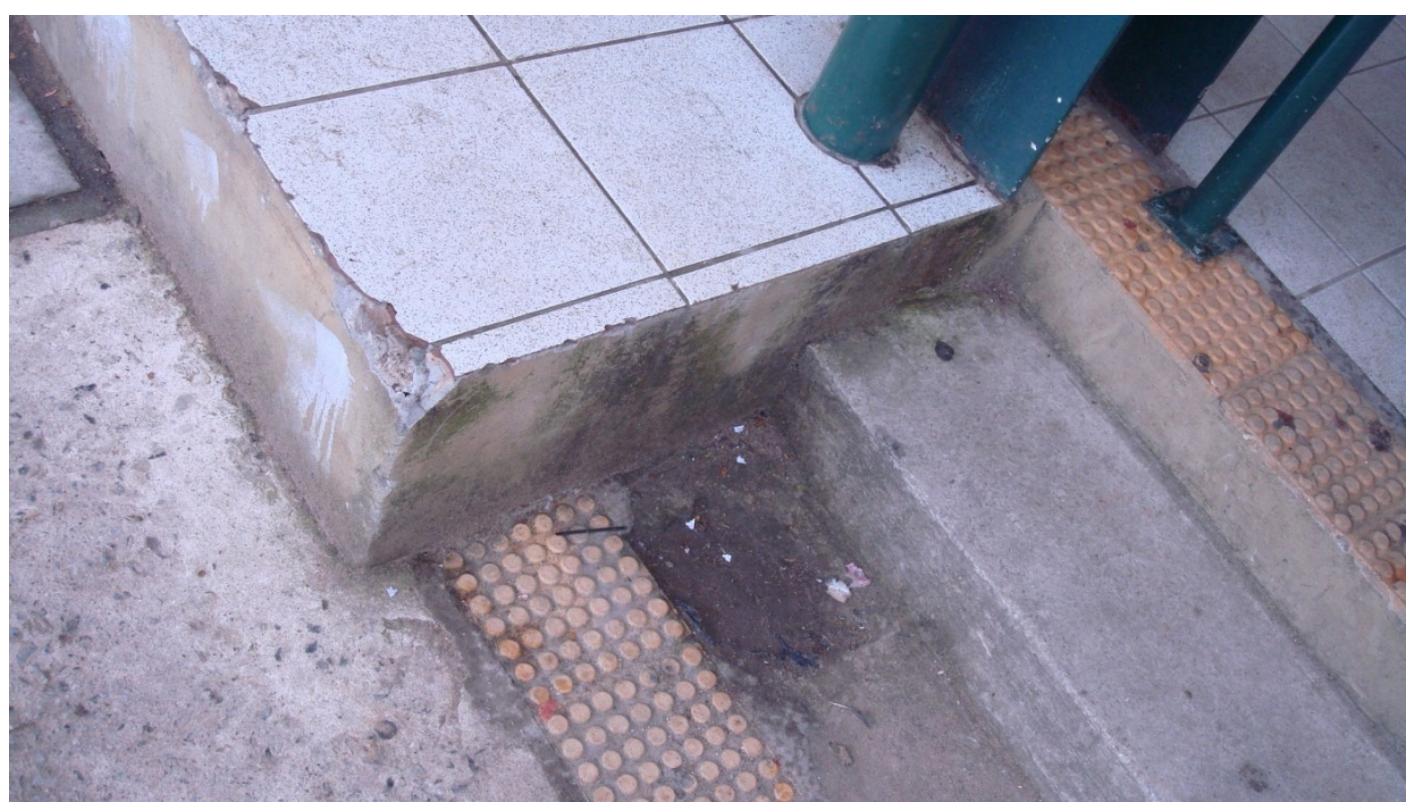

Foto 11. Evidência de situação existente em desacordo com o previsto em projeto (degraus)

Além disso, observa-se a falta corrimão e o piso tátil não sinaliza adequadamente o obstáculo, potencializando os riscos à integridade do usuário. Fonte: Acervo da pesquisadora.

Na Figura 88, é apresentada uma renderização do projetado, para os componentes mencionados.

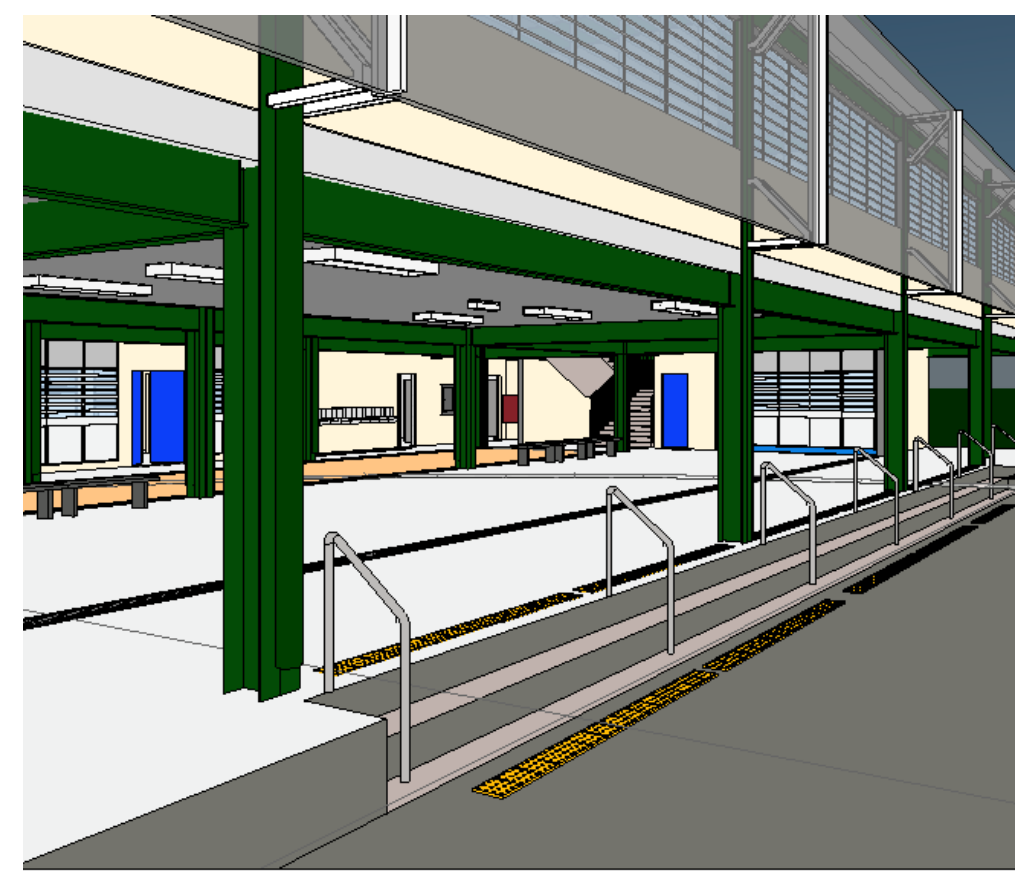

Figura 88. Exemplo de componente modelado projetado sob medida, que apresentou desempenho insatisfatório Fonte: Acervo da pesquisadora 
Componentes previstos no programa de necessidades, em desacordo com o projeto, também podem ser identificados por meio da solução proposta, como é o caso do exaustor da cozinha, apresentado no Quadro 26.

Quadro 26. Exemplo de informações modeladas - ocorrência associada ao uso inadequado

\begin{tabular}{|l|l|}
\hline Componente & Exaustor \\
\hline ID Geográfico & $28.28 .29 \mathrm{~S}-46.44 .46 \mathrm{~W}-1 \mathrm{~F}-\mathrm{E}$ \\
\hline Modelo & - \\
\hline Material & Concreto /revestimento cerâmico \\
\hline Localização & Cozinha \\
\hline Referência OMNICLASS (tabela 23) & 23 -11.29.13.11 \\
\hline Identificado por & Especialista - APO \\
\hline Identificado em & jun/2009 \\
\hline Descrição da ocorrência & $\begin{array}{l}\text { O exaustor não se encontrava em funcionamento, à época dos levantamentos } \\
(2009) .\end{array}$ \\
\hline Requisitos de desempenho críticos & $\begin{array}{l}\text { Renovação de ar compatível com os equipamentos para cocção instalados. } \\
\text { (ABNT, 2013) }\end{array}$ \\
\hline Nível de risco & 0 \\
\hline
\end{tabular}

Fonte: Acervo da pesquisadora.

$\mathrm{Na}$ Figura 89, é apresentado o componente 'exaustor' modelado, em conformidade com o programa de necessidades do ambiente.

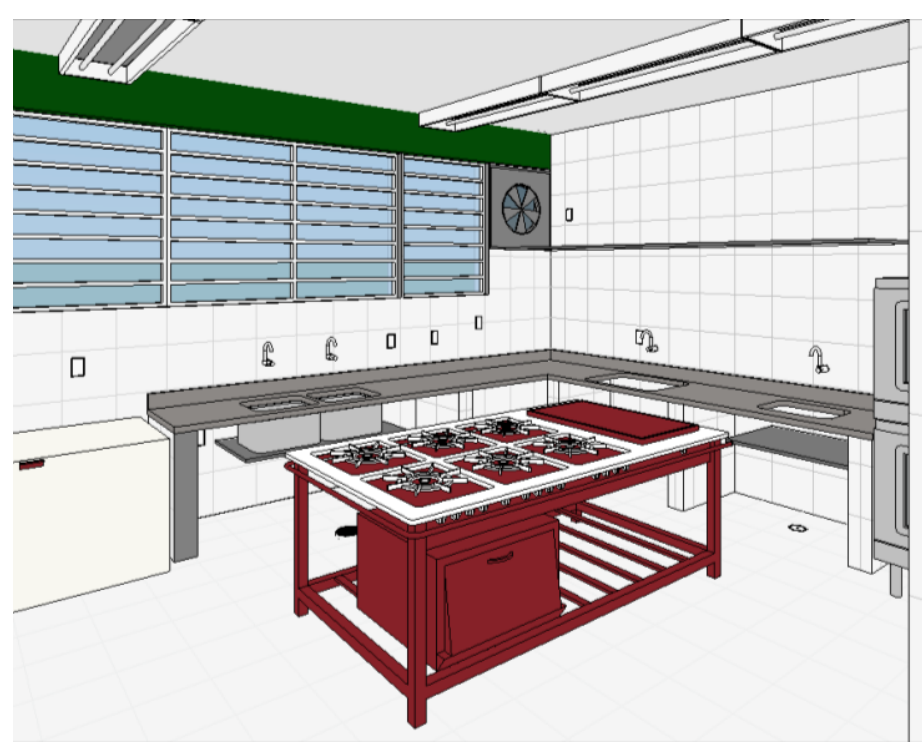

Figura 89. Modelagem do componente exaustor (EX-01)

Fonte: Acervo da pesquisadora 
$\mathrm{Na}$ Foto 12, verifica-se que o vão foi executado e o componente instalado, conforme o projeto. Apesar disso, o exaustor não estava em operação no ambiente, à época dos levantamentos (2009).

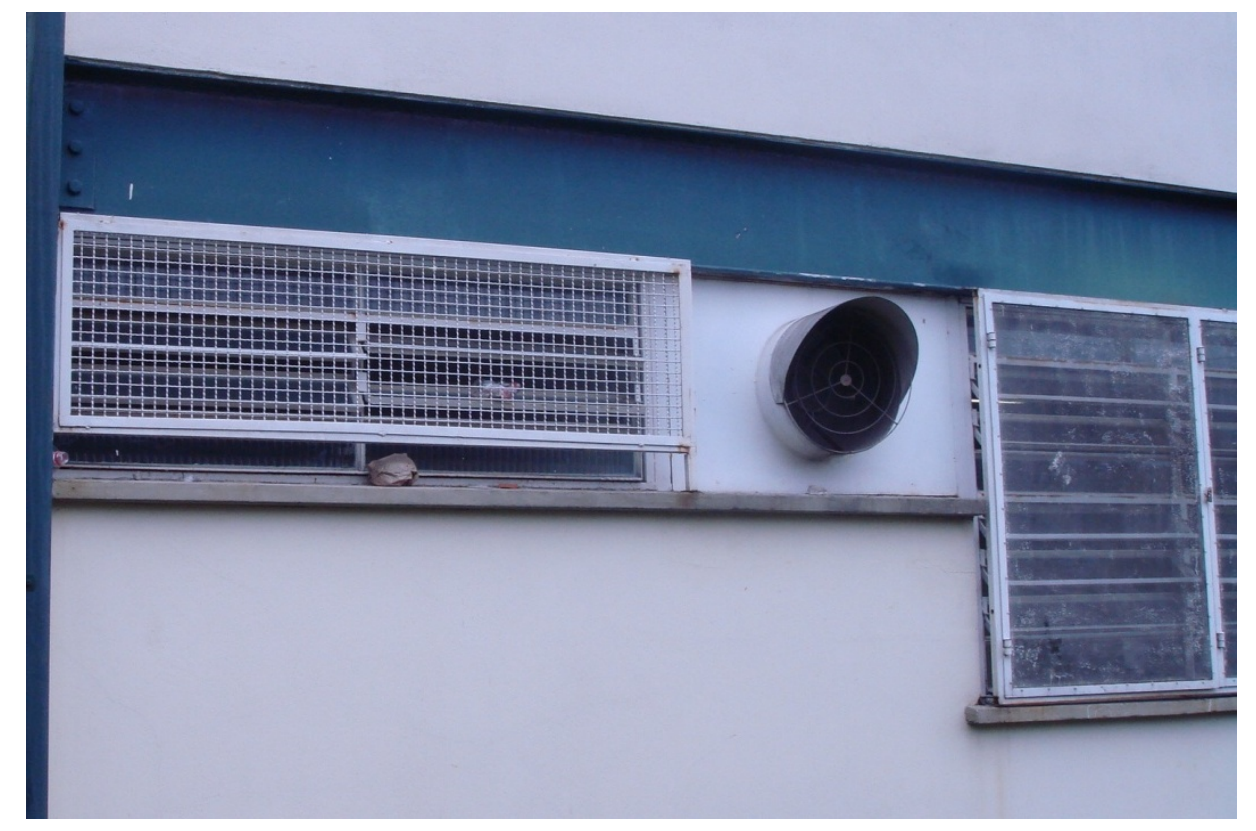

Foto 12. Evidência de ocorrência associada ao componente exaustor (EX-01)

Fonte: Acervo da pesquisadora

No Quadro 27, é apresentado um exemplo de informações modeladas, correspondentes a um aspecto crítico, relacionado ao uso não previsto de um componente. 
Quadro 27. Exemplo de informações modeladas - ocorrência associada ao uso inadequado

\begin{tabular}{|l|l|}
\hline Componente & Banco de concreto \\
\hline ID Geográfico & $28.28 .29 \mathrm{~S}-46.44 .46 \mathrm{~W}-1 \mathrm{~F}-\mathrm{C}$ \\
\hline Modelo & BC-17 \\
\hline Material & Concreto /revestimento cerâmico \\
\hline Localização & Circulação \\
\hline Referência OMNICLASS (tabela 23) & 23 -11.29.13.11 \\
\hline Identificado por & Especialista - APO \\
\hline Identificado em & jun/2009 \\
\hline Descrição da ocorrência & $\begin{array}{l}\text { Uso inadequado do banco como obstáculo para a prática de skate levou à quebra } \\
\text { do revestimento cerâmico, com permanência de partes cortantes. }\end{array}$ \\
\hline Requisitos de desempenho críticos & Segurança no uso, manutenibilidade, conforto tátil. \\
\hline (ABNT, 2013) & \begin{tabular}{l} 
\\
\hline Nível de risco
\end{tabular} \\
\hline
\end{tabular}

Fonte: Acervo da pesquisadora.

A Foto 13 corresponde à evidência relacionada ao referido aspecto crítico, também disponível na plataforma de dados.

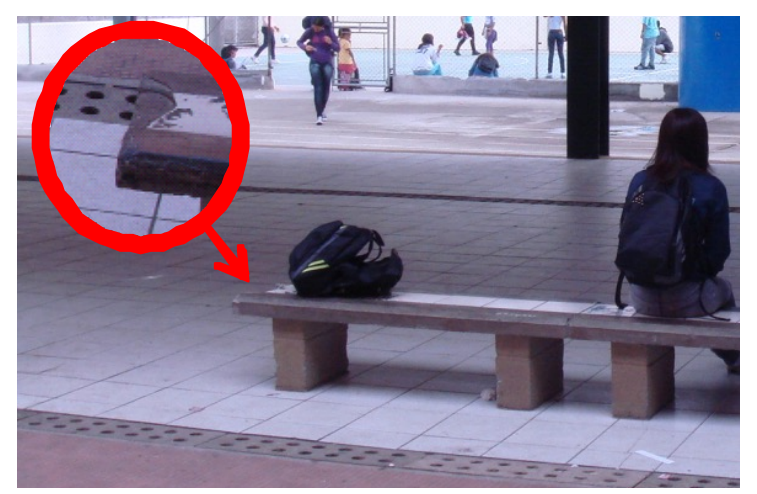

Foto 13. Evidência de ocorrência associada ao componente banco (BC-17)

Fonte: Acervo da pesquisadora

Dentre as evidências passíveis de inclusão, para consultas no Banco de Dados, além das fotos correspondentes a situações críticas, estão também resultados tabulados de questionários aplicados a usuários e resultados de avaliações técnicas, conforme o exemplo apresentado na Figura 90. 
Escola Alpha - Resultados obtidos em relação ao conforto ambiental em sala de aula. Questionários aplicados aos alunos da $8{ }^{\mathrm{a}}$ série.

1. Dê a sua opinião sobre a luz do sol em sua sala de aula - considere a carteira escolar e a lousa.

2. De que maneira você ouve o que a sua professora fala?

3. Dê a sua opinião sobre a temperatura de sua sala de aula nos dias frios.

4. Dê a sua opinião sobre a temperatura de sua sala de aula nos dias quentes.

4. Dê a sua opinião sobre a ventilação em sua sala de aula.

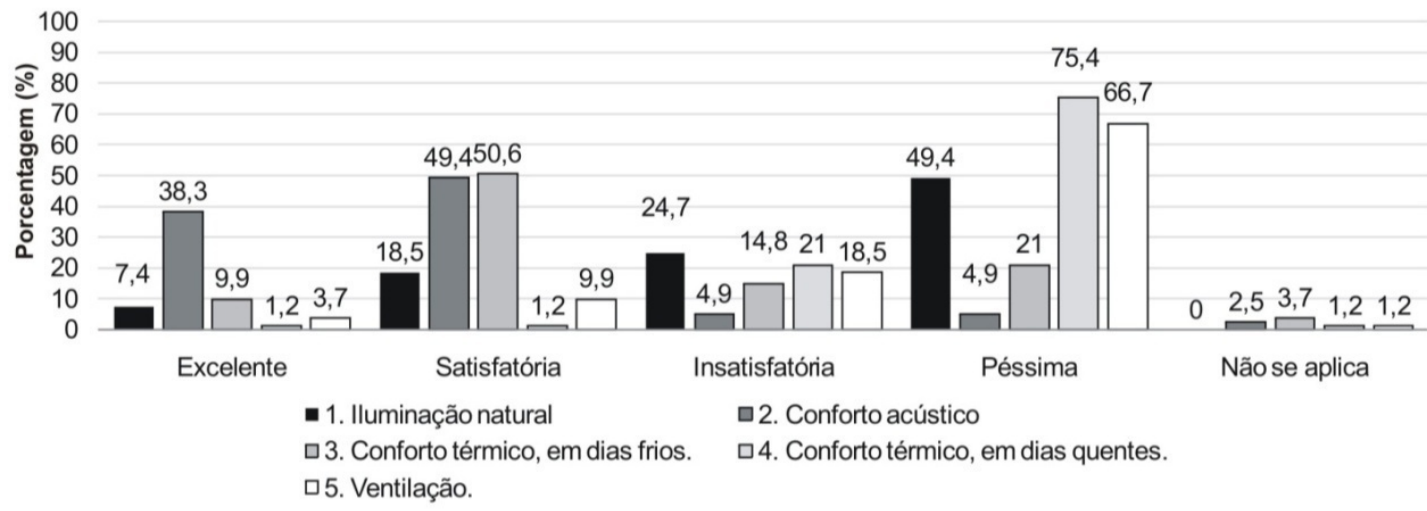

Número de respondentes

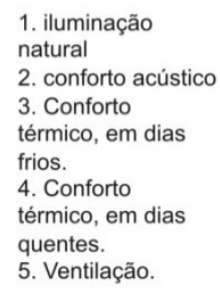

Excelente
6
31
8
1
3

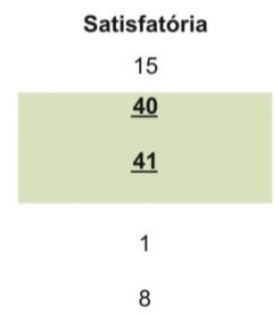

Legenda: Moda

Insatisfatória
20
4
12
17
15

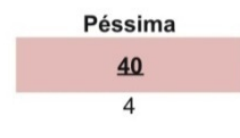

Não se aplica

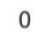

2

17

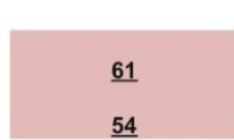

3

1

1

Figura 90. Exemplo de evidência de aspectos críticos identificados por meio da aplicação de questionários, durante processo de APO Fonte: Acervo da pesquisadora

Por fim, quanto aos aspectos importantes relacionados à modelagem, devese ressaltar que, quando se trabalha em ambiente colaborativo, é necessário que se registre o histórico das alterações. Uma vez que as informações são acessadas e editadas por vários atores, é importante que possa ser verificado quando uma modificação foi feita e quem é o respectivo responsável. 
Na Figura 91, é apresentado um exemplo de pesquisa, para verificação de listas de alterações, relacionadas a uma ficha de diretrizes para ambiente. Dentre os aspectos que podem ser verificados, estão: a alteração, a data em que foi realizada e o responsável. Também podem ser atribuídas permissões de edição ou de leitura dos dados das fichas. Sendo assim, é possível consultar as recomendações anteriores, para uma propriedade relacionada ao modelo.

\begin{tabular}{|c|c|c|c|}
\hline Field & $\begin{array}{l}\text { Descrição - Informaçöes gerais - Referência } \\
\text { OMNiCLASS para o uso do espaço (Tabela 13) (OCCS, } \\
\text { 2012) }\end{array}$ & Event & \\
\hline $\begin{array}{l}\text { Old value } \\
\text { New value }\end{array}$ & $13-31.13 .15$ & $\begin{array}{l}\text { Date } \\
\text { Modified by }\end{array}$ & $\begin{array}{l}\text { September 25, } 2015 \text { 4:29 PM } \\
\text { anajl }\end{array}$ \\
\hline $\begin{array}{l}\text { Field } \\
\text { Old value } \\
\text { New value }\end{array}$ & $\begin{array}{l}\text { Descriçäo - Informaçöes gerais - } 10 \text { Geográfico } \\
\text { 23.38.29S-46.44.46W-1F-E }\end{array}$ & $\begin{array}{l}\text { Event } \\
\text { Date } \\
\text { Modified by }\end{array}$ & $\begin{array}{l}\text { September 25, } 2015 \text { 4:29 PM } \\
\text { anajl }\end{array}$ \\
\hline Field & $\begin{array}{l}\text { Descrição - Cargas geradas por atividades humanas - } \\
\text { Ocupaçăo }\end{array}$ & Event & \\
\hline $\begin{array}{l}\text { Old value } \\
\text { New value }\end{array}$ & 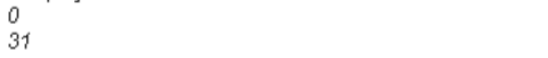 & $\begin{array}{l}\text { Date } \\
\text { Modified by }\end{array}$ & $\begin{array}{l}\text { September 25, } 2015 \text { 4:29 PM } \\
\text { anajl }\end{array}$ \\
\hline Field & $\begin{array}{l}\text { Acabamentos - Vedos - Equipamentos fixados em } \\
\text { fechamentos verticais }\end{array}$ & Event & \\
\hline $\begin{array}{l}\text { Old value } \\
\text { New value }\end{array}$ & $\begin{array}{l}\text { No } \\
\text { Yes }\end{array}$ & $\begin{array}{l}\text { Date } \\
\text { Modified by }\end{array}$ & $\begin{array}{l}\text { September 25, } 2015 \text { 4:38 PM } \\
\text { anajl }\end{array}$ \\
\hline
\end{tabular}

Figura 91. Exemplo de pesquisa para a verificação de alterações referentes a uma ficha de ambiente.

Fonte: Acervo da pesquisadora.

Considerando os procedimentos e os recursos apresentados, verifica-se ser possível modelar e gerenciar a informação de um conjunto de edificações, ao longo de seu ciclo de vida, com a participação dos diversos atores responsáveis pelo processo.

A solução proposta é particularmente interessante, pois a informação está disponível em rede e pode ser acessada remotamente. Os dados são consultados e editados de modo praticamente autoexplicativo, sem que seja necessário que membros da equipe, não envolvidos com a etapa de desenvolvimento do projeto, acessem programas complexos de modelagem tridimensional. 


\subsection{PROPOSIÇÃO DE INDICADORES PARA VERIFICAÇÃO DE DESEMPENHO}

Considerando a análise das práticas de Gestão da Qualidade, apresentadas no Capítulo 2, verifica-se que os resultados obtidos consistem em subsídios para o processo de melhoria contínua de um projeto. Com base nesse diagnóstico, é feita a proposição de ações corretivas, visando à realimentação do processo. Para tanto, no contexto dos métodos e técnicas estabelecidos para a aplicação da pesquisa APO (ORNSTEIN et al., 2009; 2012), pode-se interpretar o "consumidor", como o usuário, relacionar as "expectativas do cliente" com o programa de necessidades e as metas de desempenho, pertinentes a cada ambiente. De modo análogo, devem ser considerados os requisitos de desempenho (ABNT, 2013) como parâmetros de qualidade, a serem observados quando da avaliação do especialista (FRANÇA, 2011).

No Gráfico 3, é apresentado um exemplo de comparação entre as edificações avaliadas, considerando os aspectos críticos, por critério de desempenho.

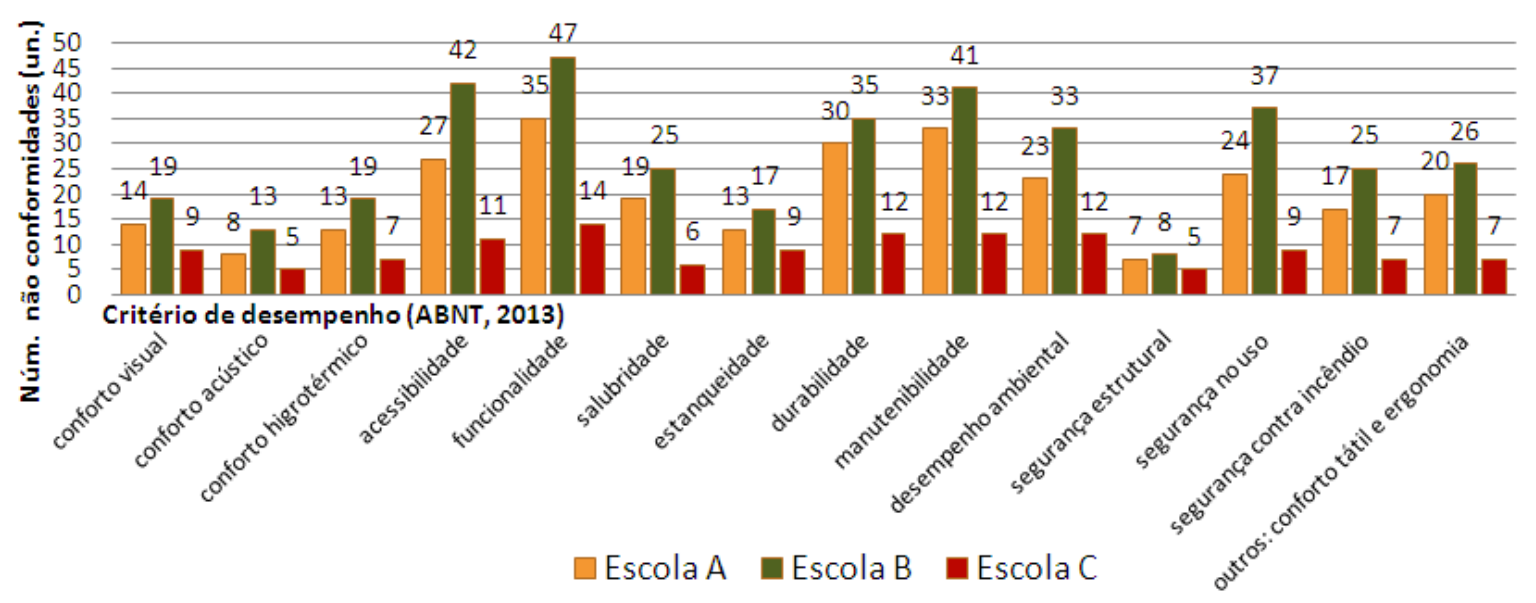

Gráfico 3. Número de não conformidades quanto ao desempenho (ABNT, 2013)

identificadas nos estudos de caso objeto de aplicação de APO (FRANÇA, 2011). Dados do levantamento correspondentes a 2009. Fonte: Acervo da pesquisadora.

Este tipo de análise comparativa entre edificações é necessária para a tomada de decisões estratégicas no contexto do portfólio de ativos e só pode ser analisada adequadamente caso as informações estejam tabuladas, de acordo com 
critérios comuns, bem como estejam disponíveis para avaliação dos stakeholders. Portanto, a modelagem da informação deve ser integrada e acessível, para que se faça possível a gestão do conhecimento organizacional.

É importante que os aspectos críticos possam ser apresentados como uma matriz elaborada para a análise de resultados, considerando os aspectos de interesse para a tomada de decisões, tais como: avaliação de falhas potenciais, possíveis causas de falhas, possíveis consequências de falhas, descrição da ocorrência, desempenho aferido, severidade/risco, frequência de ocorrência da falha, probabilidade de deteç̧ão, nível de gravidade das consequências, ações corretivas e atribuição de responsabilidades, entre outros aspectos, conforme o apresentado no Quadro 28. Para efeito da correlação com a terminologia que, usualmente, é adotada para a aplicação de APOs, interpreta-se como "falha" o aspecto crítico identificado.

Com base em pesquisas ao Banco de Dados, pela aplicação de filtros, é possível fazer comparações quanto à gravidade, nível de risco e frequência de ocorrência de um determinado aspecto crítico, inclusive considerando os resultados obtidos, para diferentes edificações.

Por meio dessa abordagem, pode-se realizar uma análise objetiva quanto à relevância das ocorrências. Esta apresentação do diagnóstico permite que sejam estabelecidos responsáveis pela correção de situações não conformes. Assim, são determinados, de modo objetivo as ações corretivas pertinentes e os responsáveis por sua implantação. 
Quadro 28. Exemplo de matriz de diagnóstico de aspectos críticos referentes à Escola Alpha

\begin{tabular}{|c|c|c|c|c|}
\hline Item & 2 & 2 & 2 & 2 \\
\hline Componente FDE & Esquadria de Ferro. & Esquadria de Ferro. & Esquadria de Ferro. & Esquadria de Ferro. \\
\hline Ambiente & 8B- Sala de Aula. & 8B- Sala de Aula. & 8B- Sala de Aula. & 8B- Sala de Aula. \\
\hline Cód. do Ambiente & EF-06 & EF-06 & EF-06. & EF-06. \\
\hline $\begin{array}{l}\text { Descrição da } \\
\text { Situação }\end{array}$ & Ferrugem. & $\begin{array}{l}\text { Dificuldade de fechamento das } \\
\text { partes móveis. }\end{array}$ & $\begin{array}{c}\text { infiltrações e queixas de } \\
\text { desconforto durante os dias frios. }\end{array}$ & $\begin{array}{c}\text { Incidência de raios solares } \\
\text { diretos sobre as carteiras } \\
\text { escolares e a lousa. }\end{array}$ \\
\hline Falhas Potenciais & Baixa resistência à corrosão. & $\begin{array}{c}\text { Emperramento do mecanismo de } \\
\text { abertura }\end{array}$ & $\begin{array}{l}\text { baixa eficiência no controle da } \\
\text { água e do vento. }\end{array}$ & $\begin{array}{l}\text { Impossibilidade de controle dos } \\
\text { níveis de iluminação. }\end{array}$ \\
\hline $\begin{array}{l}\text { Possíveis Causas } \\
\text { das Falhas }\end{array}$ & $\begin{array}{l}\text { Especificação de material com } \\
\text { baixa resistência à umidade, } \\
\text { falta de manutenção da pintura, } \\
\text { causando a perda da } \\
\text { integridade da camada } \\
\text { anticorrosão. }\end{array}$ & $\begin{array}{l}\text { Dificuldade no controle de qualidade } \\
\text { das esquadrias, execução de } \\
\text { elementos com variação } \\
\text { dimensional/fora de esquadro. }\end{array}$ & $\begin{array}{l}\text { Dificuldade no controle de } \\
\text { qualidade das esquadrias, } \\
\text { execução de elementos com } \\
\text { variação dimensional/fora de } \\
\text { esquadro. }\end{array}$ & $\begin{array}{c}\text { Dimensionamento inadequado } \\
\text { das proteções solares em } \\
\text { projeto. }\end{array}$ \\
\hline $\begin{array}{c}\text { Possíveis } \\
\text { Consequências das } \\
\text { Falhas } \\
\end{array}$ & $\begin{array}{l}\text { Redução da vida útil do } \\
\text { componente. }\end{array}$ & Desconforto térmico. & $\begin{array}{c}\text { Desconforto térmico, danos às } \\
\text { alvenarias e outros elementos } \\
\text { construtivos. }\end{array}$ & Desconforto visual. \\
\hline $\begin{array}{l}\text { Descrição da } \\
\text { Ocorrência }\end{array}$ & Perfis metálicos danificados. & $\begin{array}{c}\text { Avaliação crítica do aspecto pelos } \\
\text { usuários. }\end{array}$ & $\begin{array}{c}\text { Frestas entre partes móveis, } \\
\text { marcas de infiltração nas } \\
\text { alvenarias. }\end{array}$ & $\begin{array}{l}\text { Avaliação crítica do aspecto } \\
\text { pelos usuários. }\end{array}$ \\
\hline $\begin{array}{c}\text { Normas técnicas a } \\
\text { observar }\end{array}$ & NBR15.575 (ABNT,2013). & NBR15.575 (ABNT,2013). & NBR15.575 (ABNT,2013). & NBR15.575 (ABNT,2013). \\
\hline $\begin{array}{l}\text { Requisitos de } \\
\text { desempenho }\end{array}$ & Durabilidade. & Estanqueidade, conforto térmico. & $\begin{array}{l}\text { Durabilidade, manutenibilidade, } \\
\text { estanqueidade. }\end{array}$ & Conforto visual. \\
\hline Ações Corretivas & $\begin{array}{l}\text { Revisão de detalhamento do } \\
\text { componente EF16 no catálogo } \\
\text { de especificações. Elaboração } \\
\text { de manutenção preventiva e } \\
\text { corretiva no sistema de pintura, } \\
\text { Verificar a possibilidade de } \\
\text { especificação de esquadrias em } \\
\text { materiais resistentes à } \\
\text { corrosão. }\end{array}$ & $\begin{array}{l}\text { Revisão de detalhamento do } \\
\text { componente EF16 no catálogo de } \\
\text { especificações. Se possível, } \\
\text { considerar componentes com } \\
\text { produção industrializada, que } \\
\text { apliquem procedimentos de controle } \\
\text { de qualidade à sua linha de } \\
\text { produção. }\end{array}$ & $\begin{array}{l}\text { Revisão de detalhamento do } \\
\text { componente EF16 no catálogo de } \\
\text { especificações. Se possível, } \\
\text { considerar componentes com } \\
\text { produção industrializada, que } \\
\text { apliquem procedimentos de } \\
\text { controle de qualidade à sua linha } \\
\text { de produção. }\end{array}$ & $\begin{array}{c}\text { Instalação de proteções } \\
\text { solares adequadamente } \\
\text { dimensionadas nas esquadrias } \\
\text { existentes. }\end{array}$ \\
\hline Severidade/ Risco & 5 & 5 & 5 & 8 \\
\hline $\begin{array}{c}\text { Freq. de } \\
\text { Ocorrência }\end{array}$ & 10 & 8 & 8 & 10 \\
\hline Responsável & FDE. & FDE. & FDE. & $\begin{array}{l}\text { Equipe de projeto de } \\
\text { arquitetura. }\end{array}$ \\
\hline
\end{tabular}

Fonte: Adaptado de FRANÇA, ORNSTEIN (2014, p. 1.821).

É possível observar que, a um mesmo componente, podem ser atribuídas diferentes situações críticas que, por sua vez, estão relacionadas aos respectivos responsáveis e causas. Esta apresentação de resultados permite a fácil identificação de situações recorrentes, bem como possibilita uma avaliação qualitativa e quantitativa da pertinência quanto à revisão de especificações.

Os exemplos apresentados demonstram a importância da incorporação do processo sistemático, de forma a gerenciar e manter atualizadas as informações referentes ao desempenho das edificações e de seus componentes. Isso pressupõe a homologação de componentes no Banco de Dados, validados à luz das experiências pregressas, avaliadas em edificações de tipologia construtiva semelhante. 
A implantação do processo proposto possibilita a realização de consultas de informações (por exemplo, por endereço, por nome, por região), a fim de identificar aspectos reincidentes relacionados ao desempenho das edificações objeto de estudo

Além disso, a abordagem proposta permite maior clareza na apresentação de resultados, o que contribui para criar oportunidades para a flexibilização do projeto de ambientes e componentes.

Deste modo, pretende-se prover meios para a reflexão sobre a relevância das informações geográficas na leitura e interpretação das informações referentes ao grupo de edificações escolares, objeto de estudo. Nesse caso, além do monitoramento do desempenho, as análises das situações recorrentes podem ser consultadas para a elaboração de futuros projetos semelhantes, para a determinação das ações de operação e manutenção, ou ainda, para a revisão das diretrizes de projeto determinadas pela FDE em determinadas localidades, em função, por exemplo, de especificidades socioculturais ou de características climáticas regionais.

\subsection{DEFINIÇÃO DE INDICADORES DE DESEMPENHO}

Para a avaliação do desempenho de uma edificação, é importante que sejam determinados indicadores que permitam a análise comparativa. Para tal, dentre os aspectos relevantes para a verificação da produtividade, estão: custo, tempo despendido, modificações elaboradas e deficiências identificadas. Dentre estes, tempo e custo são mais usualmente avaliados, embora os aspectos críticos incorporados ao projeto, tais como: desempenho inadequado de componentes, bem como uso diferente do planejado (aspectos que são identificáveis durante a fase de uso/operação) são, usualmente, desconsiderados nas análises elaboradas (POCOCK; LIU; KIM, 1997, apud JACOSKI; LAMBERTS, 2003).

Diferentes stakeholders podem ter entendimentos distintos quanto ao nível de prioridade dos aspectos críticos (FEIFER, 2011), de modo que os critérios decisórios possam variar, em função da fase do ciclo de vida e da disciplina em questão.

Sendo assim, é preciso tornar o processo decisório objetivo, por meio da adoção de instrumentos de gestão da qualidade do ambiente construído, como por 
exemplo, sistemas de indicadores (FRANÇA; ORNSTEIN, 2015).

Dentre as vantagens de sua adoção estão: o monitoramento do atendimento de metas e a identificação de aspectos relevantes para a elaboração de benchmarks, para a comparação entre edificações com características em comum.

Sistemas de indicadores vêm sendo adotados, nacional e internacionalmente, com o objetivo de avaliar, tanto a qualidade do ambiente construído como das atividades da construção civil. A determinação de um sistema de indicadores de desempenho deve possibilitar a avaliação mensurável, objetiva, rastreável e auditável das condições em determinado ambiente, o que inclui análises de custobenefício referente às ações a eles relacionadas (OECD, 1993). Sendo assim, devese permitir que determinada propriedade seja mensurada e avaliada de modo a fornecer informações relevantes, relacionadas a determinado ambiente,

São exemplos de referenciais que apresentam critérios para que se verifique o desempenho do ambiente construído: Leadership in Energy and Environmental Design - LEED (USGBC, 2009) e Haute Qualité Environnementale - HQE (CERTIVÉA, 2012) e Building Research Establishment Environmental Assessment Methodology - BREAM (BRE, 2011), entidades estas que propõem boas práticas de gestão da qualidade ambiental da edificação.

Apesar de se proporem a aferir a qualidade ambiental do ambiente construído, estes exemplos diferem na abordagem e na importância dada aos diferentes critérios de desempenho (SILVA, 2007; AULICINO, 2008; DEGANI, 2010, GALVÃO, 2012).

No Brasil, o referencial AQUA (CARDOSO, 2007) apresenta critérios para a avaliação do desempenho ambiental, determinados com base nas diretrizes apresentadas no referencial francês HQE (CERTIVÉA, 2012), adaptadas às necessidades e à realidade regional.

Também merecem menção as abordagens que se dedicam a identificar os indicadores-chave de desempenho, ou seja, métricas referentes ao desempenho de características construtivas e de operação, como por exemplo, o consumo de energia (NEW BUILDINGS INSTITUTE, 2014).

Dentre outros objetivos, tais indicadores podem ser utilizados para monitorar custos, avaliar o desempenho das ações de operação e manutenção, avaliar a satisfação dos clientes e comparar o desempenho entre diferentes projetos. Para 
que isso seja possível, o processo de avaliação deve ser consistente, mensurável e auditável (GALANEZ-ÁLVAREZ, 2013).

Sistemas de indicadores podem ser ainda elaborados para avaliar a qualidade e a produtividade das atividades de construção (COSTA et al., 2005). Também podem ser destinados à análise de um determinado aspecto de interesse. Labaki et al. (2007), por exemplo, propõem indicadores de eficiência energética para escolas estaduais em Campinas, pela análise, na fase de projeto, do desempenho de elementos construtivos no contexto do projeto, por simulação computacional.

Sendo assim, deve ser investigado o nível de atendimento de um projeto, produto ou ambiente construído, em relação a objetivos predeterminados. Por isso, é necessário definir instrumentos para a identificação de aspectos não previstos ou a serem melhorados, que devem fornecer dados que permitam a consolidação de um Banco de Dados para referência (VOORDT; WEGEN, 2005).

É importante destacar que os aspectos pertinentes à investigação devem ser determinados em função dos objetivos específicos de um projeto ou um sistema de gestão.

Na Figura 92, é apresentada a configuração proposta para o Banco de Dados, para permitir a inclusão de diferentes edificações, constituindo assim o portfólio da organização. 


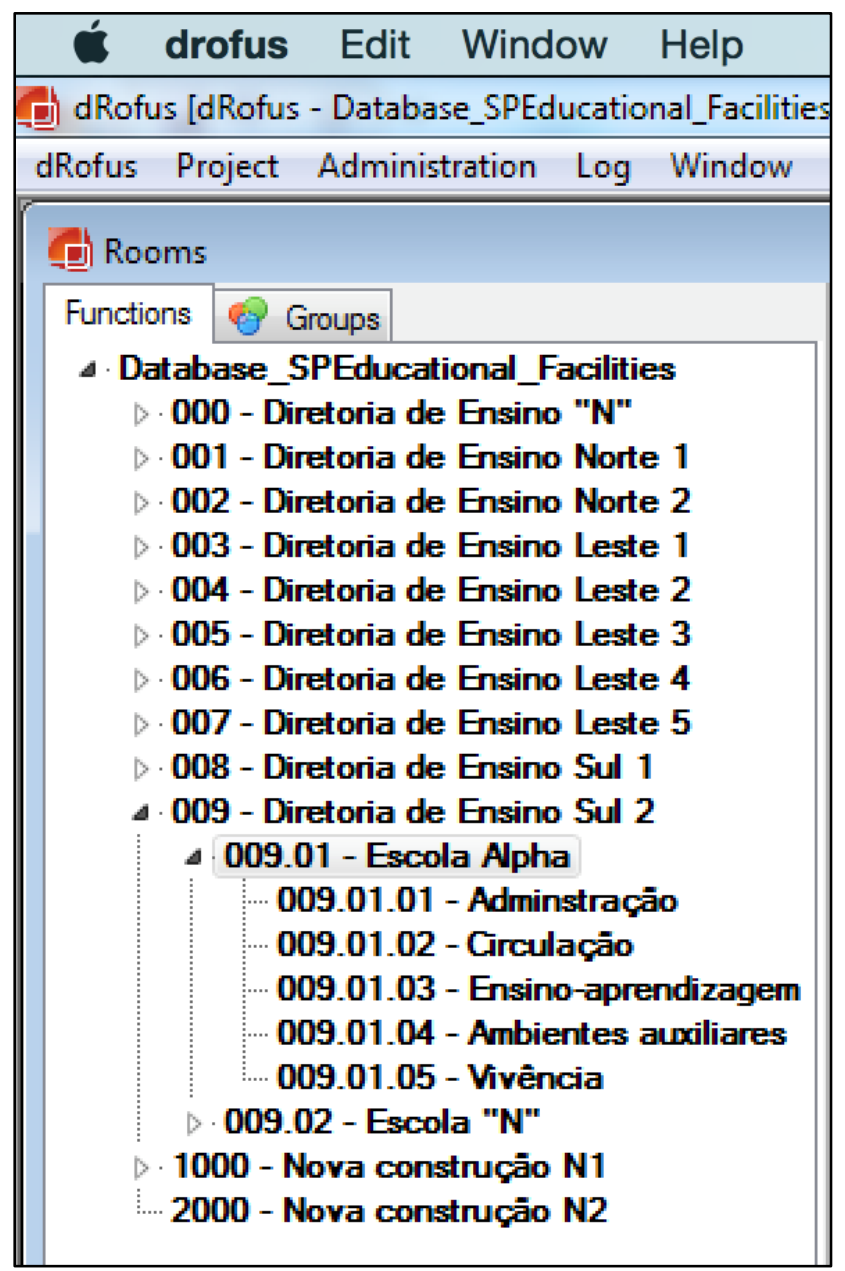

Figura 92. Exemplo de inclusão de informações relacionadas a diferentes edificações no BD. Fonte: Acervo da pesquisadora.

As informações correspondentes a todos os edifícios modelados podem ser pesquisadas juntas ou separadamente. As condições de acesso a esses dados podem ser atribuídas a diferentes atores, conforme a fase do ciclo de vida na qual se encontra a edificação e a conveniência da organização.

Considerando o contexto apresentado, é proposto um sistema de indicadores que possa ser adotado para avaliação do desempenho das edificações de tipologia padronizada em uso, bem como para a revisão das diretrizes de projeto adotadas para futuras construções e para requalificação das existentes.

A abordagem proposta permite, além de associar diferentes aspectos críticos a um mesmo componente (conforme o apresentado na Figura 93), identificar para um determinado aspecto crítico, os respectivos componentes, serviços e ambientes 
relacionados.

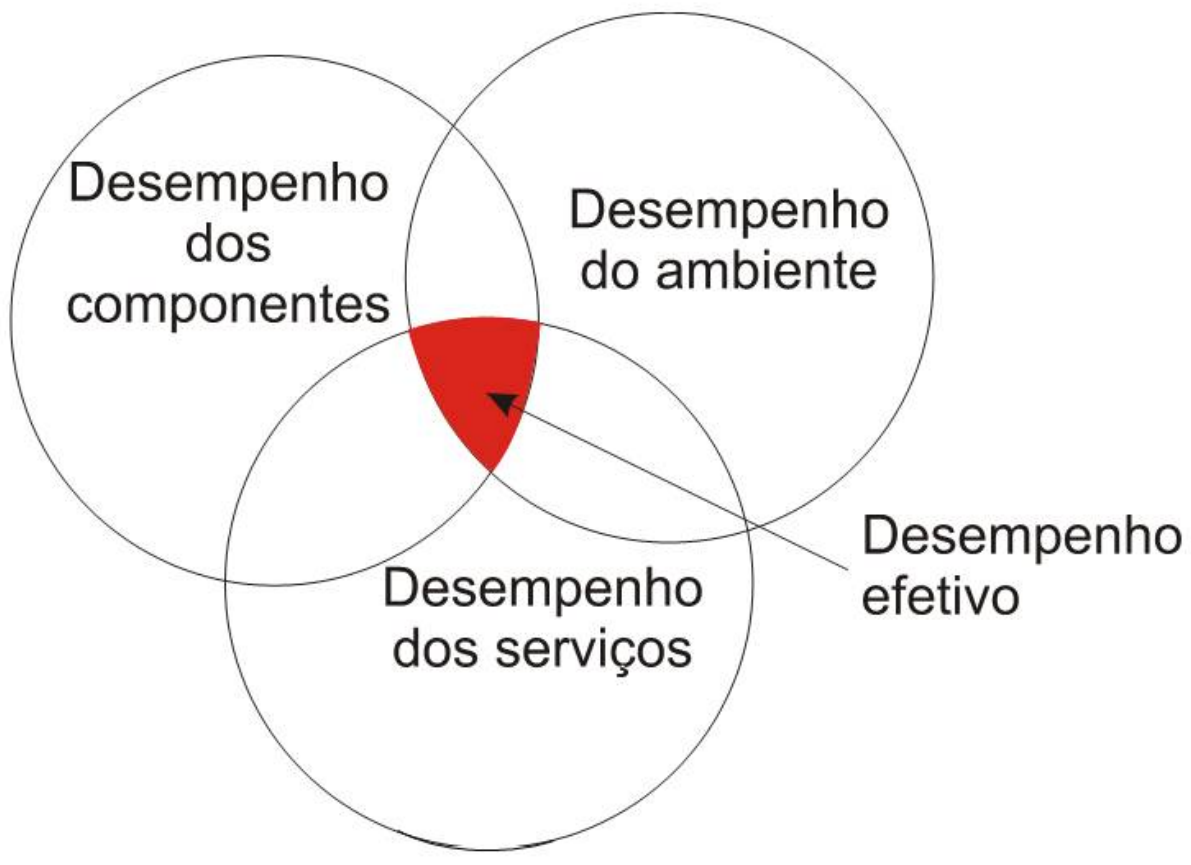

Figura 93. Conceituação de desempenho efetivo Fonte: Acervo da pesquisadora.

Este entendimento é pertinente à incorporação dos conceitos da NBR 15.575 (ABNT, 2013), que determina os requisitos de desempenho de um conjunto arquitetônico, não se restringindo ao desempenho de um determinado componente ou sistema construtivo, o que ocorre atualmente na abordagem proposta pela FDE, por meio da adoção do Catálogo de Especificações (Disponível em: <http://www.fde.sp.gov.br/PORTAL_FDE>. Acesso em 20abr. 2014).

Considerando este conceito, são apresentados, por exemplo, os requisitos de desempenho efetivo atribuídos à sala de aula (CBIC, 2013):

a) ser estanque à chuva, ao vento e à poluição atmosférica;

b) prover condições de conforto térmico compatíveis com o desempenho das funções atribuídas ao ambiente;

c) prover níveis de ventilação adequados;

d) prover condições de conforto visual (níveis de iluminância adequados, controle de ofuscamento); 
e) ser funcional para o uso previsto (aulas expositivas e atividades educativas), permitindo flexibilidade de leiaute;

f) apresentar condições de acessibilidade;

g) adotar elementos e sistemas construtivos que façam uso racional dos materiais e que apresentem impacto ambiental reduzido no meio ambiente.

h) permitir a limpeza eficiente das superfícies, dos elementos construtivos e mobiliário;

i) possibilitar a manutenção necessária à preservação de sua vida útil;

j) prover condições de conforto acústico, tais como propagação sonora adequada e isolamento dos ruídos externos à escola e de ambientes vizinhos, de modo a possibilitar atividades, tais como: aulas expositivas e leitura;

k) oferecer condições de segurança no uso; e

l) proporcionar condições de segurança contra incêndio: material não combustível, garantir a fuga dos usuários no caso de uma ocorrência.

Desta forma, o processo de análise proposto permite que o atendimento aos requisitos de desempenho sejam avaliados, considerando o ambiente nos quais estão inseridos, bem como relacionados aos sistemas construtivos, seus elementos e componentes.

De modo a determinar métricas para a comparação entre projetos, foram identificados três grupos de parâmetros, aplicáveis com objetivos distintos, a saber: avaliar o desempenho de componentes e sistemas construtivos; avaliar o nível de adequação dos ambientes de um empreendimento, considerando o uso previsto; e avaliar o desempenho global do empreendimento, frente a outras edificações com características semelhantes.

Sendo assim, os indicadores são apresentados (sejam eles atribuídos aos componentes e sistemas construtivos ou globais - atribuídos ao ambiente ou ao empreendimento como um todo), de modo que possam ser identificadas as edificações de um conjunto, que apresentem melhor ou pior desempenho, sob determinado aspecto de interesse para, mediante um aprofundamento da análise, 
isolar e identificar as variáveis responsáveis por tal condição).

Com base na análise das matrizes de diagnóstico, constituídas à luz dos resultados obtidos durante o processo de APO aos estudos de caso e das boas práticas determinadas pelos sistemas de gestão da qualidade ambiental (CARDOSO, 2007; DEGANI, 2010; GALVÃO, 2012), foram determinados os seguintes indicadores específicos, aplicáveis a componentes e sistemas construtivos (FRANÇA; ORNSTEIN, 2015):

a) frequência de quebra ou dano (número de ocorrências/ total de unidades); número de não conformidades, quanto ao desempenho - a ser considerado por critério de desempenho pertinente (ABNT, 2013);

a) frequência de medidas de manutenção preventiva (ocorrências/ total de unidades instaladas);

b) frequência de medidas de manutenção corretiva (ocorrências/ por total de unidades instaladas);

c) vida útil (vida útil efetiva/ vida útil prevista, em anos);

d) custo (valor unitário/ unidade instalada); produção/instalação (total de unidades/ período de tempo); e

e) volume de resíduos gerados $\left(\mathrm{m}^{3} /\right.$ ano); disponibilidade de fornecedores homologados (total).

Para a avaliação do desempenho esperado para o ambiente, por sua vez, são destacadas as seguintes características (FRANÇA; ORNSTEIN, 2015):

a) nível de iluminância no plano de trabalho (Lux) (ABNT, 1992);

b) nível de conforto acústico [dB(A)] (ABNT, 1987);

c) nível de conforto térmico (total de horas/ano na zona de temperatura operativa aceitável) (ABNT, 2013);

d) nível de adequação ao uso previsto (total de não conformidades/ total de ambientes com mesmo uso) (ABNT, 2013);

e) taxa de renovação de ar (ANSI/ASHRAE, 2013a); e

f) Densidade de Potência Luminosa (W/m2) (ANSI/ASHRAE, 2013b). 
Por sua vez, ao se considerar a edificação como um todo, é apresentado um conjunto de indicadores globais, pertinente ao atendimento de metas e à comparação entre edificações com características semelhantes, podem ser citados os seguintes indicadores:
a) eficiência energética;
b) consumo de água eficiente;
c) racionalização quanto à geração de resíduos da construção e demolição (RDC);
d) redução de custos de execução e manutenção;
e) redução de prazo de execução;
f) minimização de ações de manutenção;
g) aumento da vida útil; e
h) aumento da segurança dos trabalhadores e usuários.

Para sua quantificação, são propostas as seguintes propriedades, a serem calculadas para o período anual:
a) custo de execução (valor em reais, por $\mathrm{m}^{2}$ );
b) consumo de energia $\left(\mathrm{kWh} / \mathrm{m}^{2}\right)$ (ANSI/ASHRAE, 2013b);
c) consumo de água $\left(\mathrm{m}^{3} /\right.$ usuário equivalente a tempo completo - ETC) (OECD, 2008);
d) volume de resíduos gerado $\left(\mathrm{m}^{3}\right)$;
e) emissões de dióxido de carbono $\left(\mathrm{Kg} \mathrm{CO} 2 / \mathrm{m}^{2}\right)$ (OECD, 2008);
f) taxa de demanda por manutenção (total de ocorrências);
g) tempo dedicado a atividades de manutenção (total de horas trabalhadas);
h) custo das atividades de manutenção (valor total, em reais); e
i) taxa de acidentes relacionados a atividades de manutenção (total de ocorrências).

Com base nos indicadores propostos, é necessário determinar, considerando as características de projeto, quais os critérios de desempenho pretendidos para os 
ambientes, componentes e sistemas construtivos, em função dos usos previstos e de características específicas, como por exemplo, localização geográfica, tecnologia construtiva e níveis de vulnerabilidade social (que são associados a ações de vandalismo). Sendo assim, os parâmetros a serem adotados para determinado grupo de edificações, deverão ser submetidos a uma etapa inicial de validação de métricas, a fim de assegurar que permitam a avaliação dos aspectos estratégicos referentes a seu desempenho.

Para a obtenção dos dados necessários às análises, podem ser considerados os seguintes instrumentos: questionários, entrevistas e atividades de grupos focais; inspeção visual; medições; análise dos documentos de projeto; análise de faturas relacionadas ao consumo da edificação em operação (por exemplo, energia, água, compras); questionários; simulações e ensaios.

Para que os resultados obtidos possam ser modelados, de modo a possibilitar a gestão da informação da construção, é preciso que haja consistência da terminologia utilizada, tanto para a classificação dos produtos e serviços (OCCS, 2012), como no que diz respeito às características identificadas (ABNT, 2012). O objetivo das referidas normas é permitir a padronização da terminologia dos produtos da construção civil, de modo a possibilitar sua consulta pelos diversos agentes da cadeia construtiva. No Quadro 29, é apresentado um exemplo de classificação da informação e análise da recorrência de falhas, de modo a permitir o posterior rastreamento dos resultados.

Quadro 29. Exemplo de classificação da informação e de análise de recorrência de falha

\begin{tabular}{|c|c|c|c|c|}
\hline Item & 1 & 2 & 3 & 4 \\
\hline Elemento & $\begin{array}{l}\text { Portas de acesso às salas } \\
\text { de aula }\end{array}$ & Esquadrias de fachada & Fechaduras & $\begin{array}{l}\text { Sistema de drenagem de } \\
\text { pisos (corredores) }\end{array}$ \\
\hline $\begin{array}{l}\text { Código OMNICLASS } \\
\text { (OCCS, 2012) }\end{array}$ & 23-17 1115 & $23-17131323$ & 23-17 19112111 & $23-112121$ \\
\hline $\begin{array}{c}\text { Produto } \\
\text { OMNICLASS* (OCCS, } \\
\text { 2012) }\end{array}$ & Porta de madeira genérica & $\begin{array}{c}\text { Janela com caixilho em } \\
\text { perfil metálico }\end{array}$ & Fechadura para portas & Drenagem de pisos \\
\hline $\begin{array}{l}\text { Aspecto crítico } \\
\text { relacionado a }\end{array}$ & componente & sistema construtivo & componente & componente \\
\hline
\end{tabular}


...Continuação

\begin{tabular}{|c|c|c|c|c|}
\hline Comentários & $\begin{array}{l}\text { Resistência insuficiente da } \\
\text { folha de fechamento. }\end{array}$ & $\begin{array}{c}\text { Baixa resistência à } \\
\text { corrosão, emperramento } \\
\text { do mecanismo de } \\
\text { abertura, baixa eficiência } \\
\text { no controle da água, do } \\
\text { vento e dos níveis de } \\
\text { iluminação. }\end{array}$ & $\begin{array}{c}\text { Resistência insuficiente } \\
\text { de componentes tais } \\
\text { como dobradiças e } \\
\text { fechaduras. }\end{array}$ & $\begin{array}{l}\text { Caimento inadequado, } \\
\text { escoamento insuficiente. } \\
\text { Acúmulo de água em } \\
\text { corredores, áreas externas e } \\
\text { sanitários. }\end{array}$ \\
\hline $\begin{array}{l}\text { Descrição da } \\
\text { situação }\end{array}$ & Quebras e empenamento. & $\begin{array}{l}\text { Corrosão, emperramento } \\
\text { de partes móveis, frestas } \\
\text { entre componentes. }\end{array}$ & Quebra. & Empoçamento de água. \\
\hline $\begin{array}{l}\text { Falhas potenciais } \\
\text { (FRANÇA, } \\
\text { ORNSTEIN, 2014) }\end{array}$ & $\begin{array}{l}\text { Resistência insuficiente do } \\
\text { material especificado ao } \\
\text { uso efetivo. Não } \\
\text { atendimento ao } \\
\text { desempenho esperado, } \\
\text { quanto ao conforto } \\
\text { térmico, conforto acústico, } \\
\text { estanqueidade e } \\
\text { segurança. }\end{array}$ & $\begin{array}{l}\text { Baixa eficiência no } \\
\text { controle da água e do } \\
\text { vento, impossibilidade de } \\
\text { controle dos níveis de } \\
\text { iluminação. }\end{array}$ & $\begin{array}{l}\text { Desempenho em } \\
\text { desacordo quanto à } \\
\text { durabilidade. } \\
\text { Consequência: } \\
\text { travamento e } \\
\text { movimentação } \\
\text { inadequados. }\end{array}$ & $\begin{array}{c}\text { Acúmulo de água em áreas } \\
\text { de circulação. Degradação } \\
\text { de elementos construtivos, } \\
\text { devido à exposição } \\
\text { frequente e prolongada à } \\
\text { água. Crítico para a } \\
\text { segurança no uso, devido ao } \\
\text { risco de escorregamento e à } \\
\text { salubridade. }\end{array}$ \\
\hline $\begin{array}{l}\text { Código NBR 15.965- } \\
2 \text { (ABNT, 2012) }\end{array}$ & $\begin{array}{c}\text { OP.60.40.23/ OP.60.50.02/ } \\
\text { OP.60.50.23/ OP.60.50.10 }\end{array}$ & $\begin{array}{c}\text { OP.60.70.03/ OP.60.70.05/ } \\
\text { OP.60.50.08 }\end{array}$ & $\begin{array}{c}\text { OP.60.40.23/ } \\
\text { OP.60.50.02/ } \\
\text { OP.60.50.23 }\end{array}$ & OP.50.40.12 \\
\hline $\begin{array}{l}\text { Termos NBR 15.965- } \\
2 \text { (ABNT, 2012) }\end{array}$ & $\begin{array}{l}\text { Resistência ao ataque } \\
\text { intencional/ Resistência ao } \\
\text { mal uso/ Durabilidade } \\
\text { mecânica/ Resistência ao } \\
\text { apodrecimento. }\end{array}$ & $\begin{array}{l}\text { Estanqueidade ao ar/ } \\
\text { Penetração de água/ } \\
\text { Resistência à corrosão. }\end{array}$ & $\begin{array}{l}\text { Resistência ao ataque } \\
\text { intencional/ } \\
\text { Resistência ao mal } \\
\text { uso/ Durabilidade } \\
\text { mecânica. }\end{array}$ & Caimento. \\
\hline $\begin{array}{c}\text { Possíveis causas das } \\
\text { falhas }\end{array}$ & Especificação & Execução & Especificação & Execução \\
\hline Est. de caso A & 1 & 1 & 1 & 1 \\
\hline Est. de caso B & 1 & 1 & 1 & 1 \\
\hline Est. de caso C & 1 & 1 & 1 & 0 \\
\hline $\begin{array}{c}\text { Taxa de recorrência } \\
(0-1)\end{array}$ & 1,00 & 1,00 & 1,00 & 0,67 \\
\hline
\end{tabular}

* Tradução nossa. Adaptado de OCCS, 2012.

Fonte: FRANÇA; ORNSTEIN (2015, pp. 6-7).

A validação contínua dos resultados se faz necessária, visto que se pretende que as diretrizes de projeto sejam atualizadas de modo recorrente, inclusive para incorporar atualizações quanto às referências normativas e boas práticas.

Na Figura 94, é apresentado um exemplo do menu configurado para os indicadores de desempenho no banco de dados, de modo a permitir sua consulta pelos diferentes atores responsáveis, tanto pelo processo de produção do edifício como pela gestão de facilidades. 


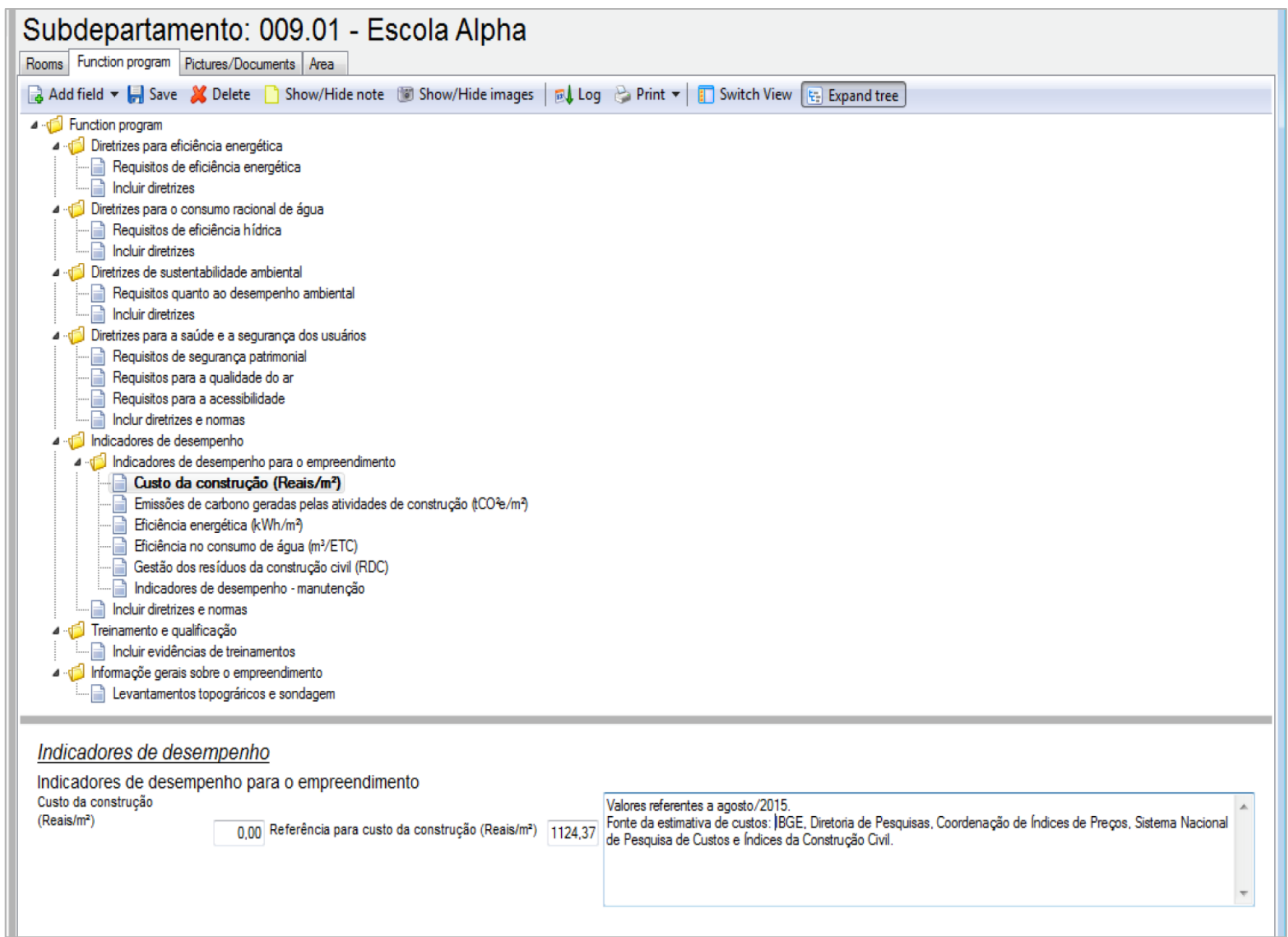

Figura 94. Exemplo de menu configurado no Banco de Dados para a determinação dos requisitos do proprietário No qual é feita a inclusão de indicadores, como referências de desempenho. Fonte: Acervo da pesquisadora

A Figura 95 apresenta o processo contínuo de avaliação de desempenho e atualização de diretrizes, considerando a análise de indicadores. 


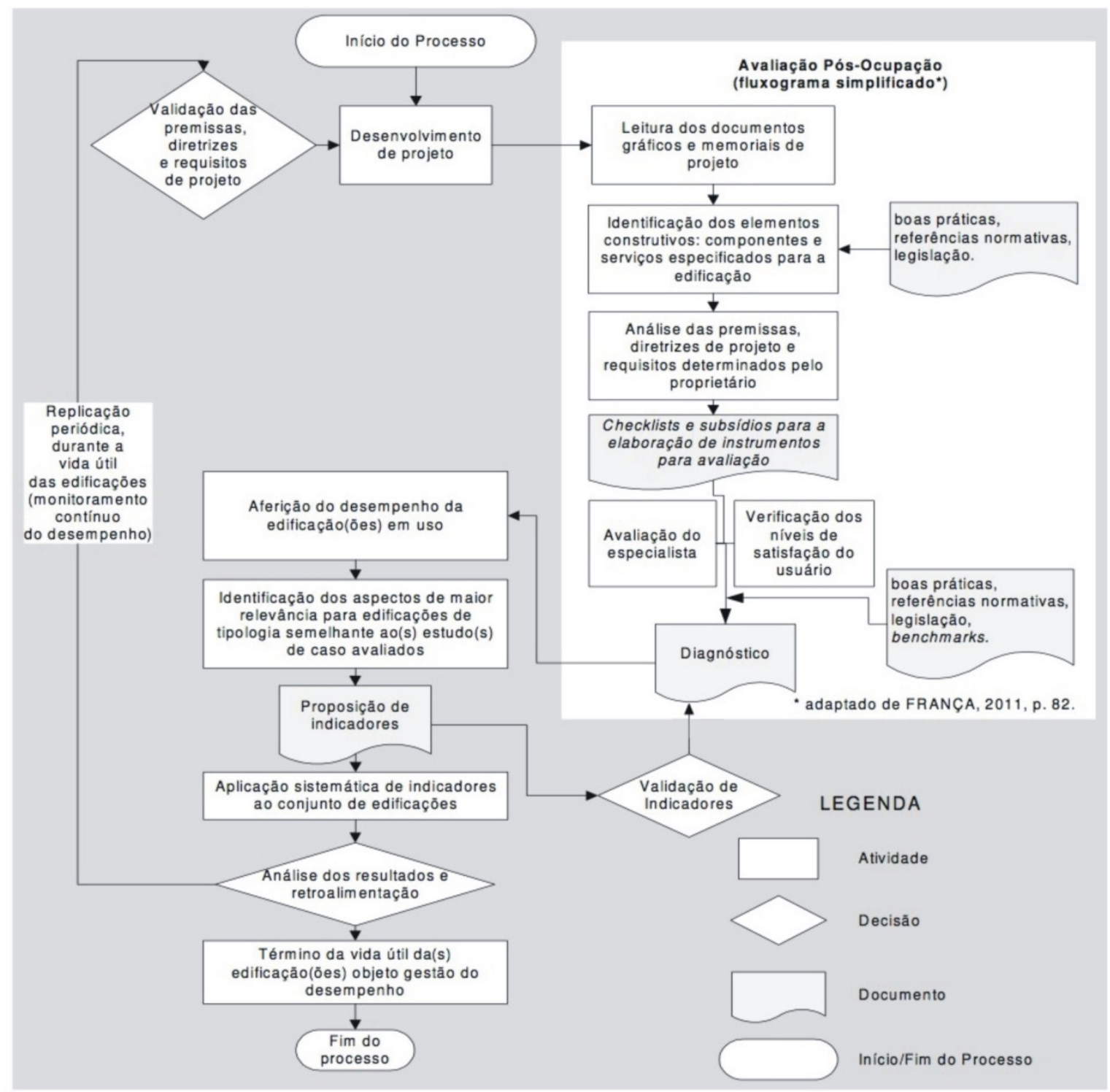

Figura 95. Processo para a consolidação de um sistema de indicadores para edificações de tipologia construtiva semelhante Fonte: FRANÇA; ORNSTEIN (2015, p. 9).

Desta forma, tanto os responsáveis pela manutenção quanto os auditores do desempenho da edificação devem ter acesso à informação regularmente coletada, referente às características do ambiente construído sob a influência do usuário. Por sua vez, projetistas, proprietários e gestores devem proceder à verificação do desempenho do projeto e à revisão das diretrizes (NEWBUILDINGS INSTITUTE, 2014). 


\subsection{SIMULAÇÃO DO DESEMPENHO EM PROJETO - OPORTUNIDADES E LIMITAÇÕES TÉCNICAS}

Uma das vantagens de se elaborar um protótipo digital da edificação é a possibilidade que sejam realizadas, desde as etapas iniciais do projeto, simulações computacionais, para verificar o desempenho das soluções propostas (Capítulo 5).

Desta forma, com base no modelo tridimensional da Escola Alpha, foram realizadas verificações dessa possibilidade. Para a simulação, foi utilizada a ferramenta disponível no programa computacional Revit v. 2014, com o objetivo de verificar as condições de conforto previstas para edificação.

Observou-se que essa função não utiliza para os cálculos os dados atribuídos aos materiais, relacionados a seu desempenho térmico. Em lugar disso, encontra-se disponível um menu simplificado, com características genéricas para os componentes da envoltória, conforme informações apresentadas na Figura 96.

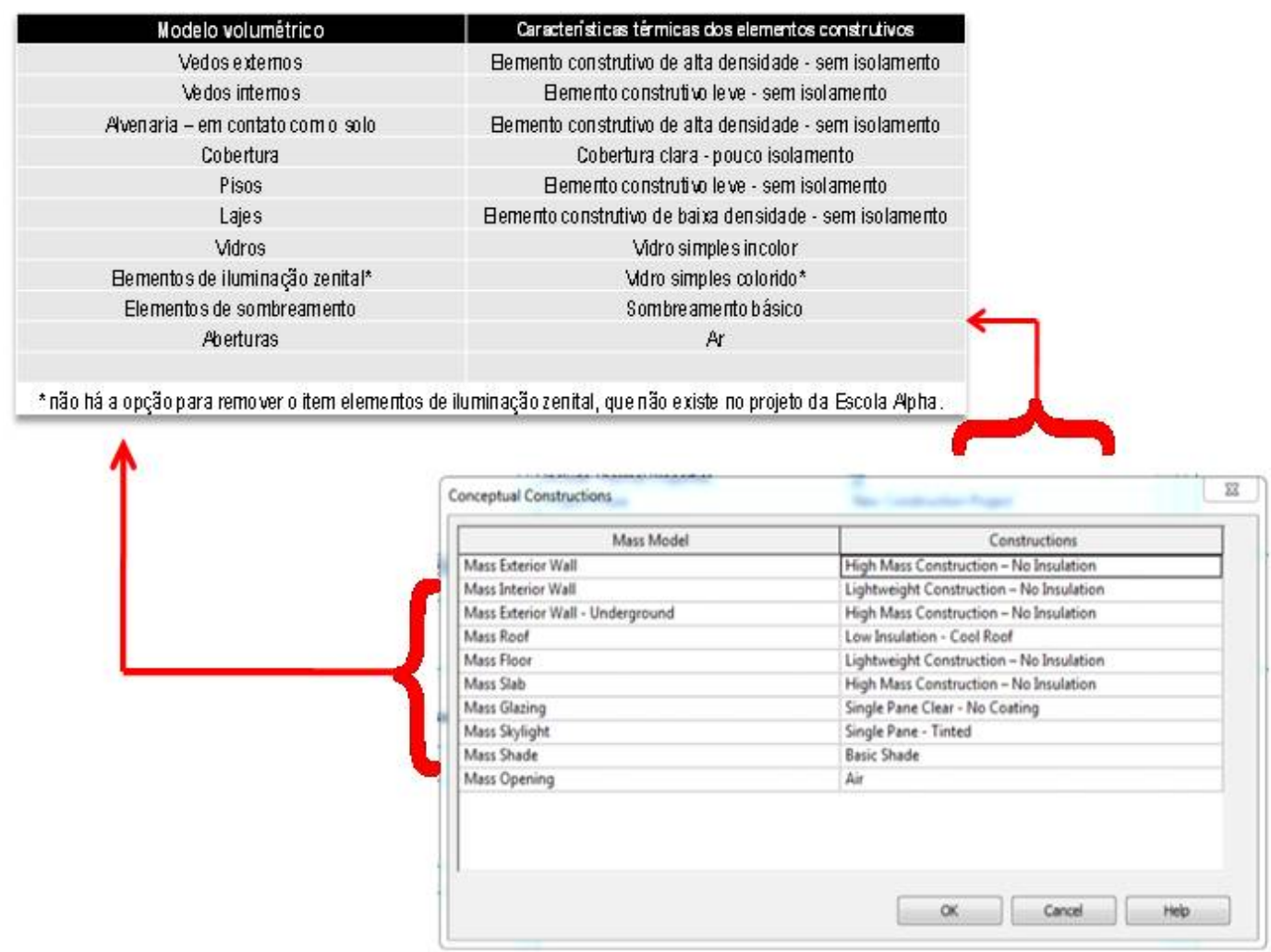

Figura 96. Menu disponível no programa computacional Revit v. 2014 para a elaboração de análises de desempenho da envoltória Fonte: Acervo da pesquisadora. 
Outro aspecto fundamental para a realização da simulação é a confiabilidade do arquivo climático. A ferramenta do programa apresenta a opção de seleção da cidade onde o projeto está localizado. Entretanto, não permite o controle sobre o arquivo climático. $\mathrm{Na}$ análise do relatório de temperaturas médias diurnas, gerado para a localização "São Paulo", destacam-se as altas temperaturas verificadas durante os meses de inverno, não compatíveis com o perfil climático local, conforme o apresentado no Gráfico 4.

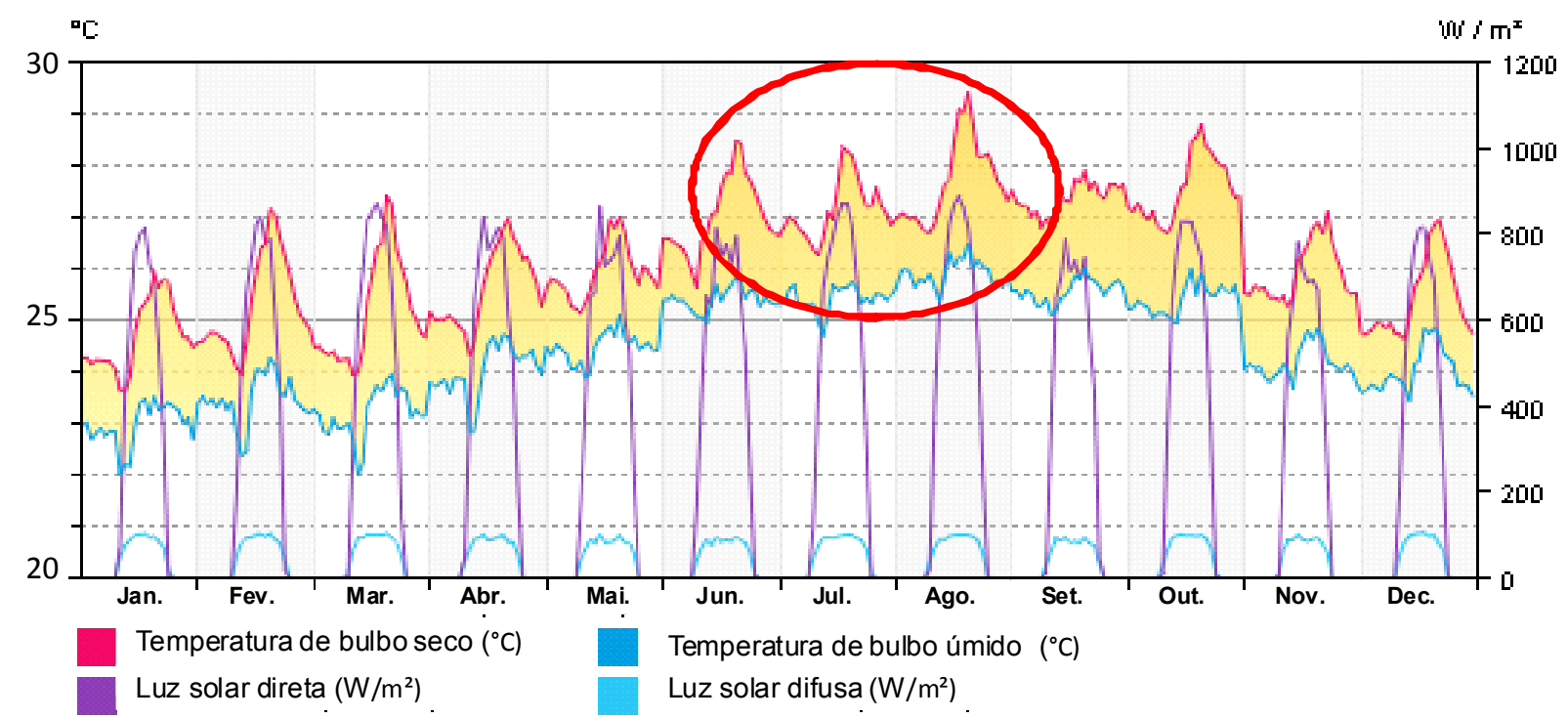

Gráfico 4. Temperaturas médias diurnas utilizadas na simulação

Gerado utilizando o programa computacional Autodesk Revit v. 2014. Fonte: Acervo da pesquisadora.

Assim sendo, entende-se que o relatório de temperaturas gerado, cujos resultados são apresentados no Gráfico 5, não apresenta os níveis de precisão necessários para embasar as decisões de projeto. 


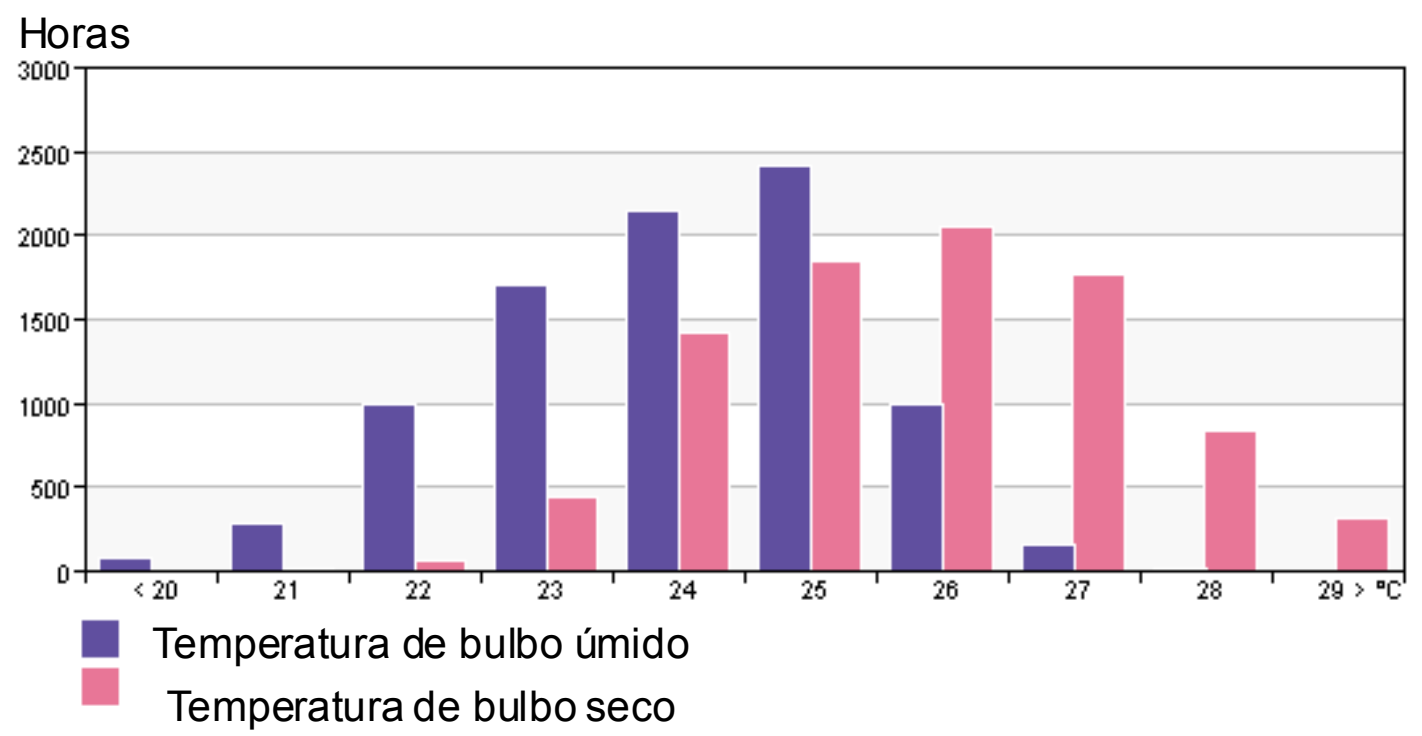

Gráfico 5. Relatório de temperaturas internas (anual) Gerado a partir do programa computacional Autodesk Revit v. 2014. Fonte: Acervo da pesquisadora.

Uma segunda verificação considerada foi a exportação das informações modeladas para a simulação em um programa computacional específico. Para tanto, foi utilizado o DesignBuilder Software v.4, uma interface gráfica para a realização de simulações por meio do EnergyPlus v.8.3.

A exportação em formato IFC mostrou-se restrita à informação geométrica do modelo, não tendo sido incluídas, portanto, as características dos materiais quanto a seu comportamento térmico.

Na Figura 97 é apresentado o aspecto do modelo elaborado, utilizando o programa Revit, v. 2014, submetido ao processo de exportação. Para a exportação, foi utilizado o formato gbXML (Open Green Building eXtensible Markup Language), visto que o processo de exportação disponível, à época da pesquisa, para o formato IFC, a partir do Revit, v. 2014, não previa a inclusão de parâmetros relacionados às propriedades térmicas, que são necessários às análises termoenergéticas. 


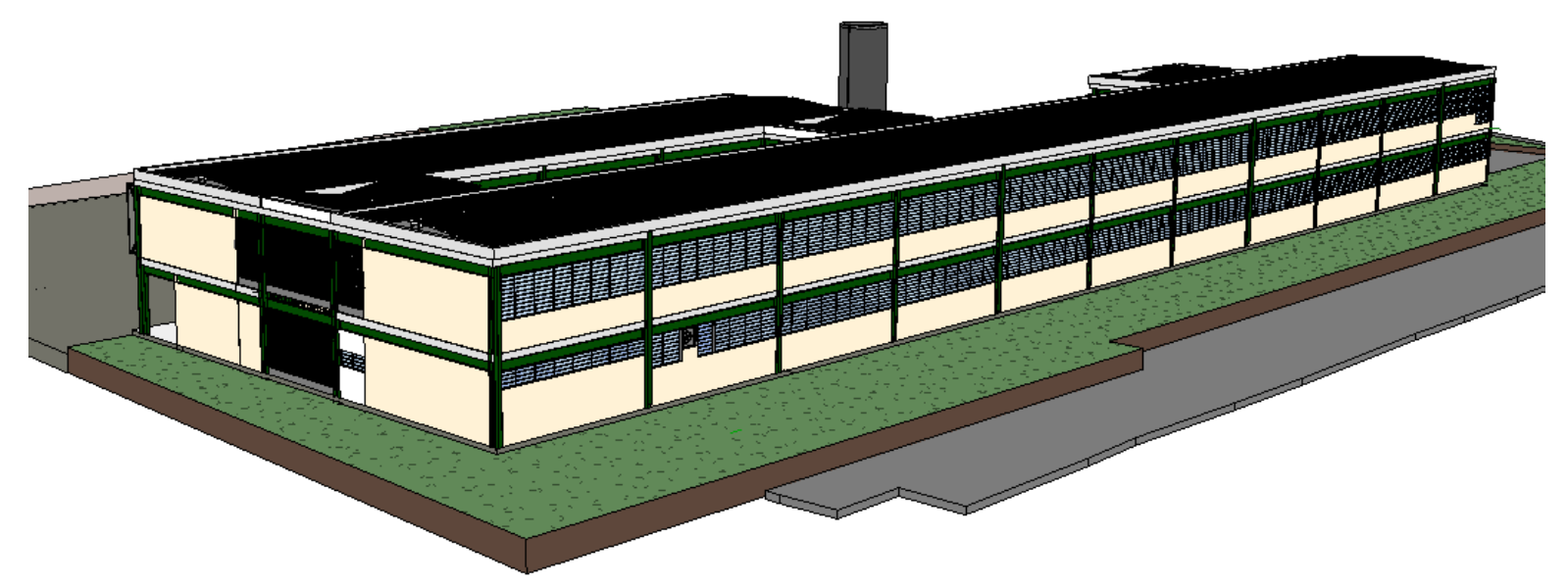

Figura 97. Aspecto do modelo exportado Fonte: Acervo da pesquisadora.

Outro aspecto crítico para a exportação da geometria foi a leitura incorreta de elementos construtivos no programa de simulação. Nas Figuras 98, 99 e 100, são destacados elementos que não foram reconhecidos corretamente quando importados.

No caso da Figura 98, ainda que haja espaço entre as zonas térmicas, as áreas das paredes faltantes são lidas, como divisórias internas, estando, deste modo, adequadas ao fluxo térmico, embora a geometria esteja incorreta. 


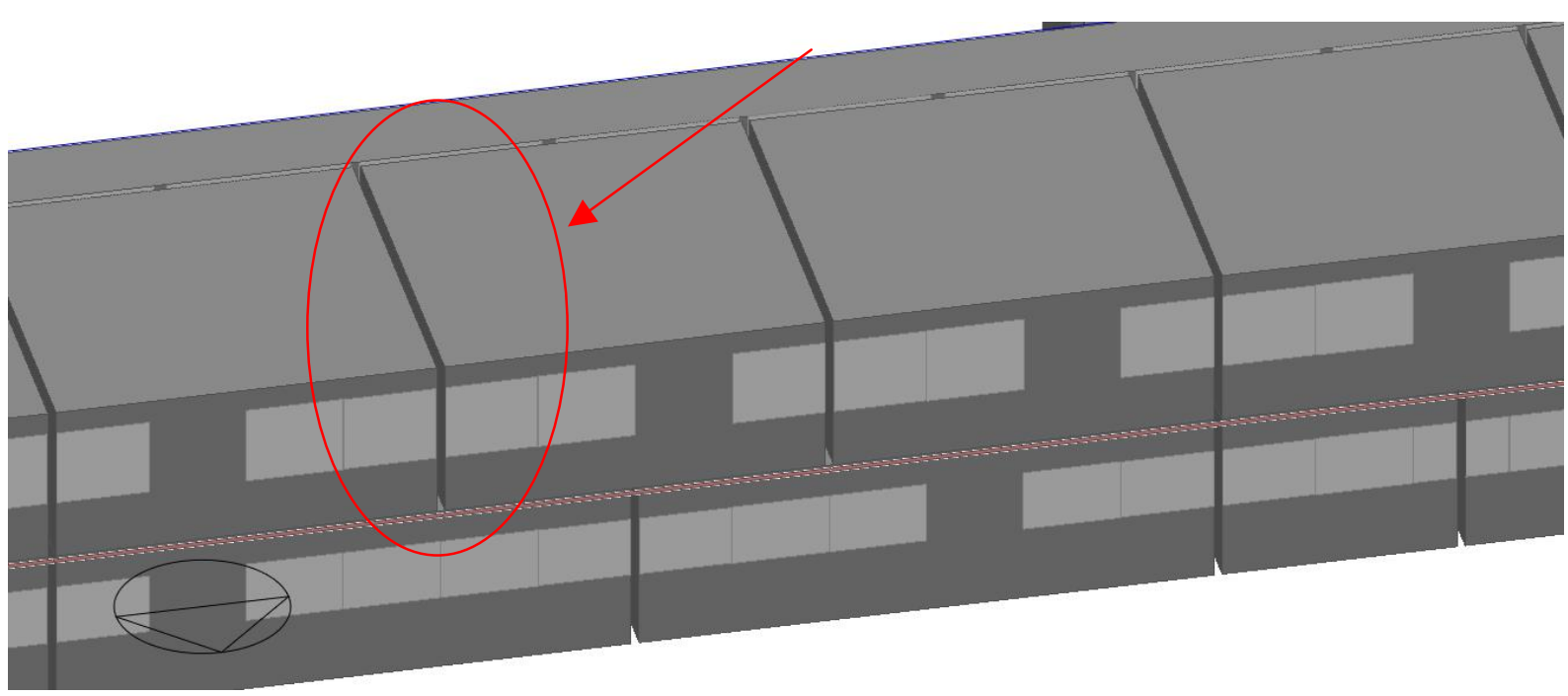

Figura 98. Exemplo de falta de elementos construtivos de divisão interna entre ambientes Fonte: Acervo da pesquisadora.

Na Figura 99, elementos de sombreamento do tipo 'cobogó' não tiveram sua geometria exportada, e a área onde estavam localizados foi lida como um conjunto de janelas simples.

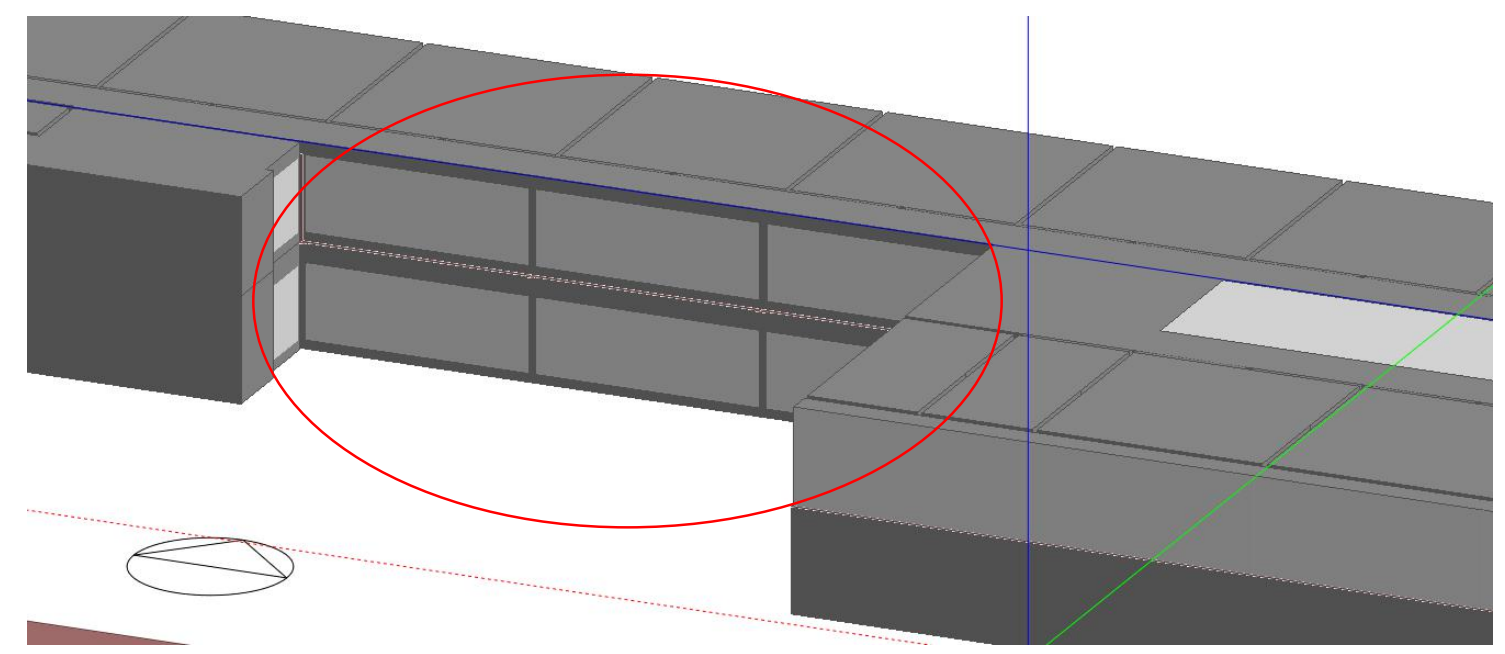

Figura 99. Exemplo de falta de elementos construtivos com geometria alterada (cobogós)

Fonte: Acervo da pesquisadora.

Muitas aberturas foram exportadas de modo incorreto ou, simplesmente, não foram exportadas, como se pode notar que aconteceu com as janelas da fachada, conforme o destacado na Figura 100. 


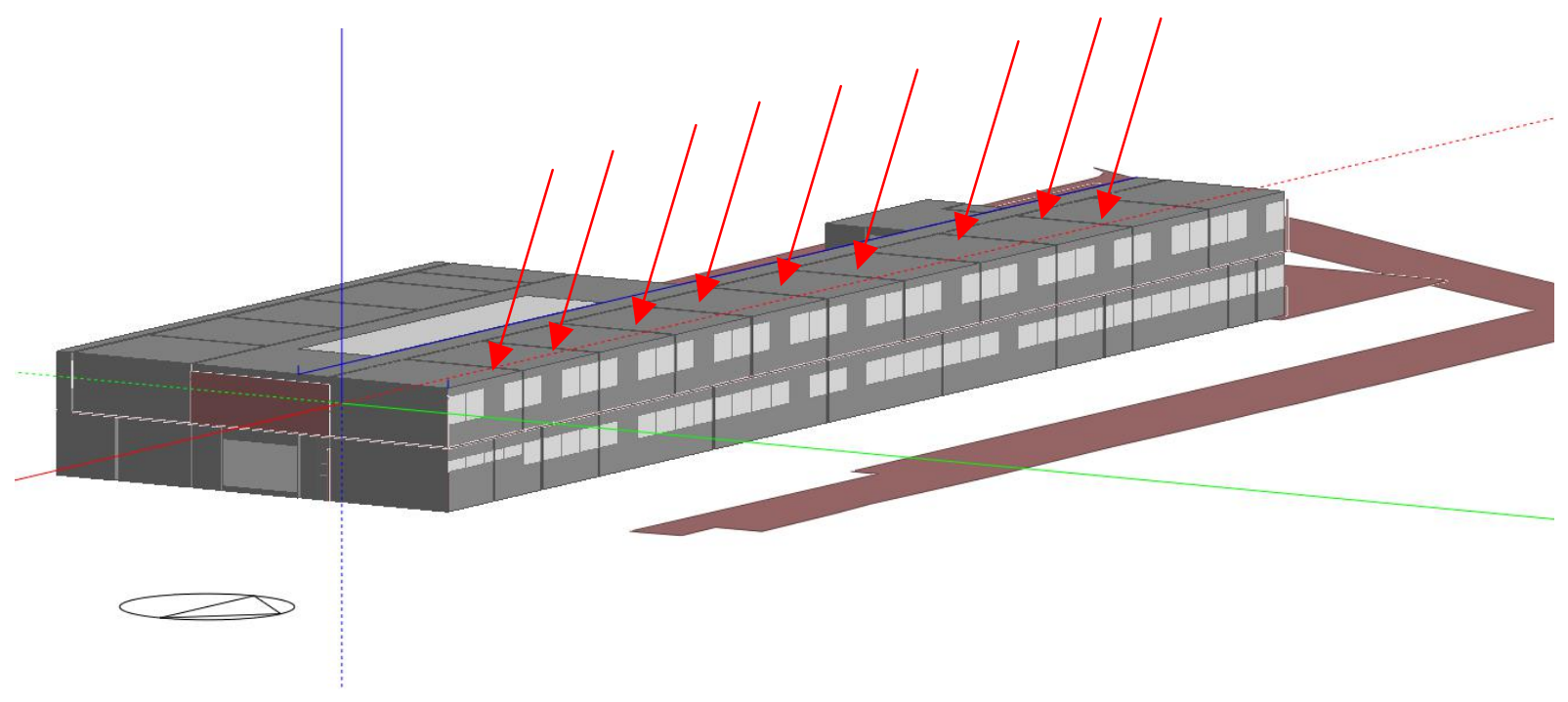

Figura 100. Exemplo de falta de elementos construtivos (janelas) Fonte: Acervo da pesquisadora..

Outra área projetada como cobogó foi exportada, como uma superfície meramente visual, sem nenhuma função ou propriedade térmica (Figura 101).

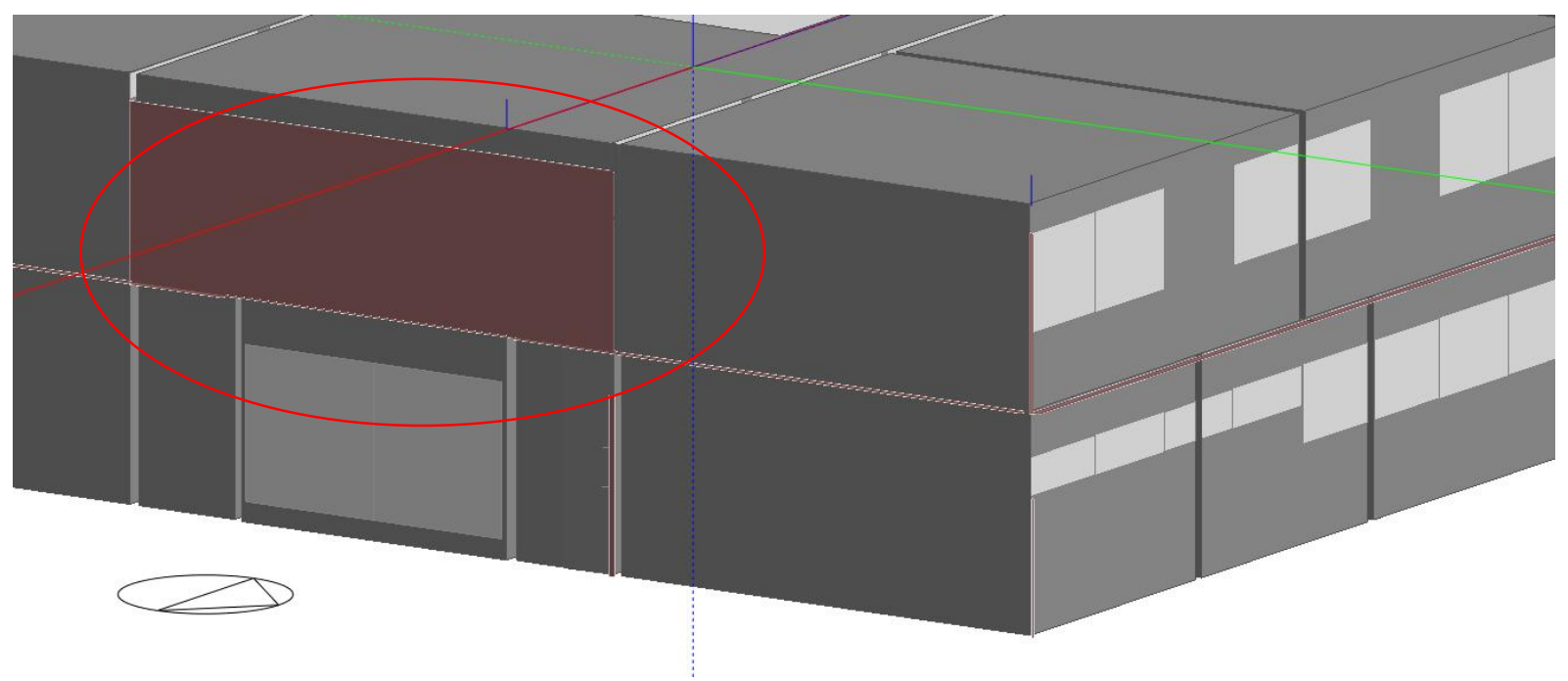

Figura 101. Exemplo de elemento exportado com características diferentes das modeladas Fonte: Acervo da pesquisadora.

Após um processo de validação e ajuste do modelo, foi conduzida uma simulação das condições de conforto térmico do projeto proposto. Para essa tarefa, foi utilizado o programa computacional DesignBuilder v. 4. 
No Gráfico 6, são apresentados os resultados referentes ao comportamento térmico, simulado para a Sala de Aula 15 da escola Alpha, para uma semana típica de verão.

Desde que a simulação computacional apresente resultados consistentes, a possibilidade de simular o desempenho de conforto ambiental consiste em uma das vantagens de se adotar este recurso para o processo de projeto.

Sala 15 - semana típica verão

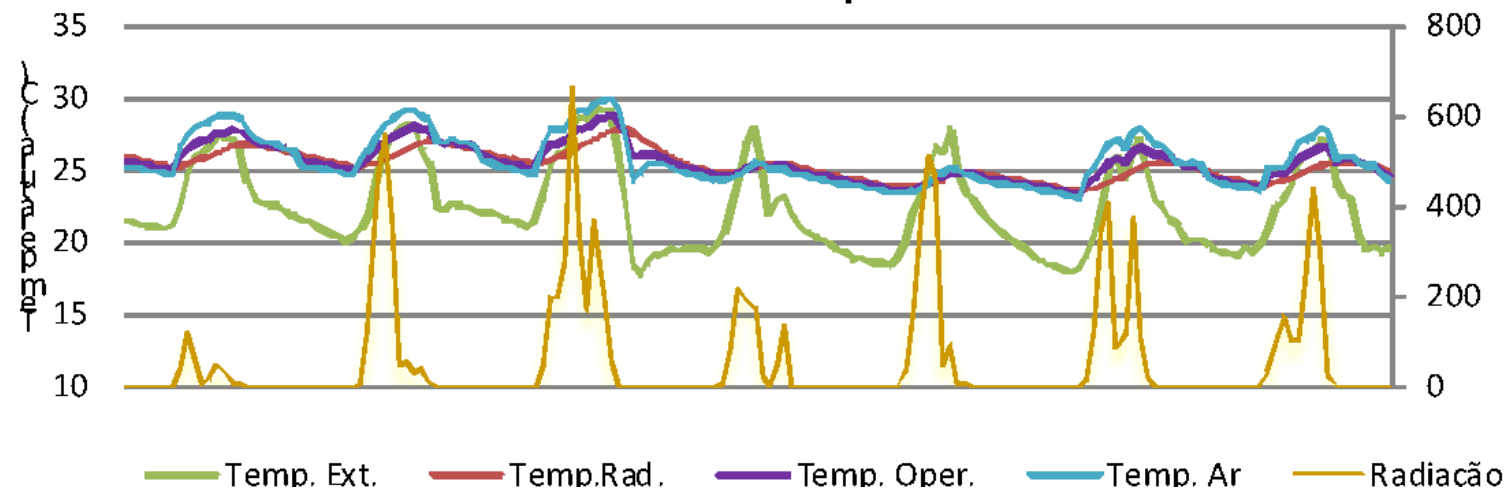

Gráfico 6. Escola Alpha - Comportamento térmico da Sala de Aula 15

Semana típica de verão Fonte: Acervo da pesquisadora.

Ao se considerar a análise dos resultados, é possível incorporar alterações de projeto ainda nas etapas preliminares (o que representa impacto reduzido e baixo custo), de modo a contribuir para a melhora do desempenho da edificação quando construída.

Portanto, embora o recurso de simulação termoenergética integrada ao modelo BIM seja muito relevante no contexto da modelagem da informação do projeto, não foi possível, à época da pesquisa (2015), extrair informações confiáveis quanto ao desempenho térmico, utilizando o mesmo programa computacional adotado para a modelagem da geometria.

A importação das informações para um programa especializado em simulação termoenergética, embora possível, apresentou a necessidade de que fosse feita uma validação dos dados e propriedades importados. Também foi preciso retrabalho, para a correção de elementos geométricos. 
Deste modo, o processo de análise de desempenho verificado mostrou-se semiautomatizado. Uma vez que, para a atualização dos recursos disponíveis desses programas, são considerados aspectos de interoperabilidade, sugere-se que sejam repetidas verificações no futuro, utilizando versões mais recentes dos programas computacionais, de modo a identificar possíveis saneamentos dos aspectos críticos mencionados.

\subsection{POSSIBILIDADES DE ANÁLISES, UTILIZANDO INFORMAÇÕES GEORREFERENCIADAS}

Conforme o discutido no Capítulo 4, georreferenciar a informação modelada pode ser um recurso muito importante para análise de desempenho de um portfólio de edificações. Isso pode ser feito em relação à edificação ou, em um nível mais aprofundado, para a análise de condições de ambientes e localização de componentes. A Figura 102 apresenta um exemplo de busca de um ambiente no modelo, por meio da utilização de sua informação geográfica.

Para a presente pesquisa, foi atribuído um código, denominado ID Geográfico, para cada ambiente, o que permite a localização do prédio, do pavimento e do setor em que uma determinada situação está localizada. 


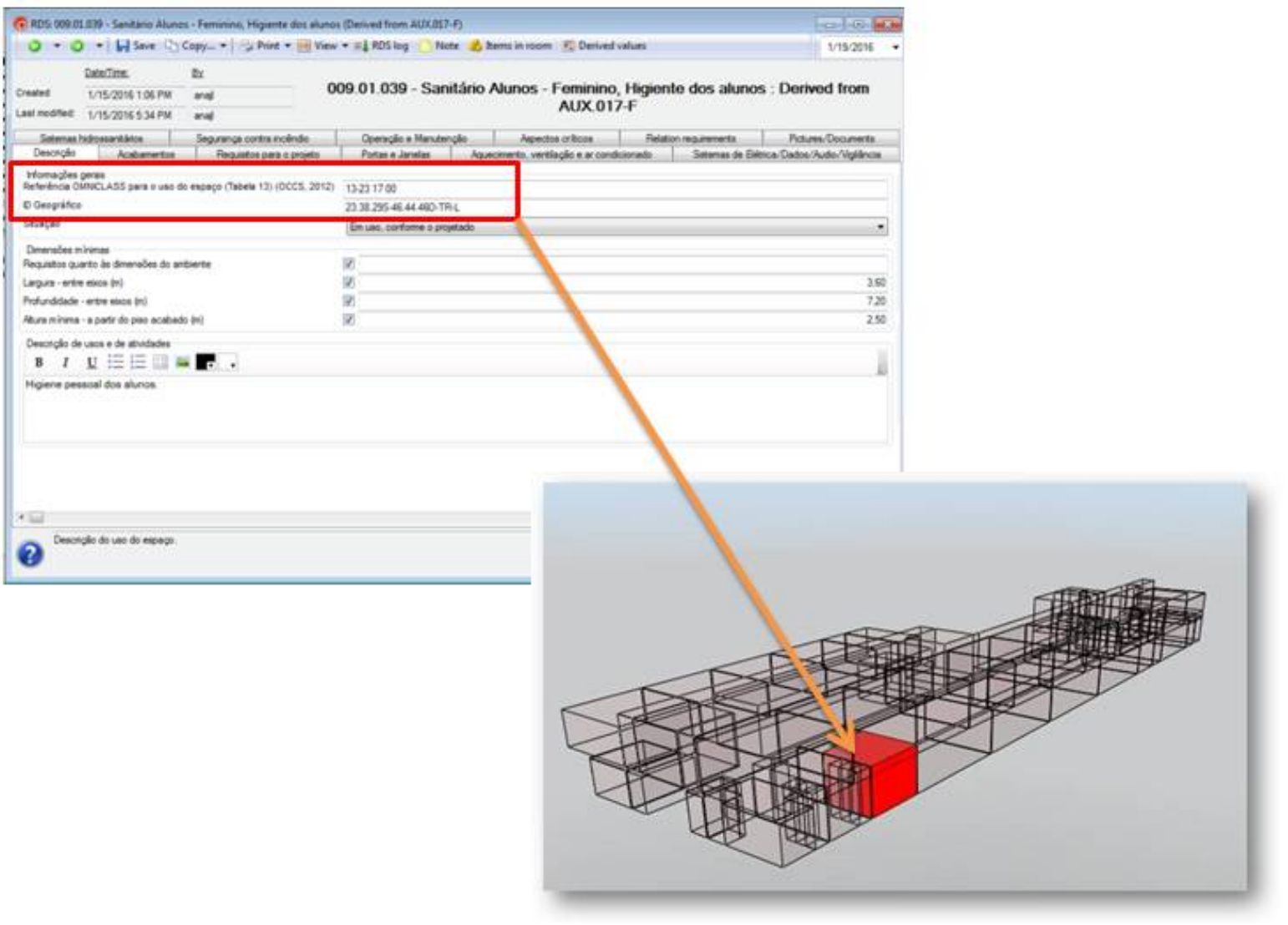

Figura 102. Exemplo de pesquisa utilizando a localização geográfica como critério Fonte: Acervo da pesquisadora.

Na Figura 103, é apresentada a localização da Escola Alpha, inserida em um sistema SIG (para tal, foi utilizado o programa computacional Terraview V. 4.2.2). 


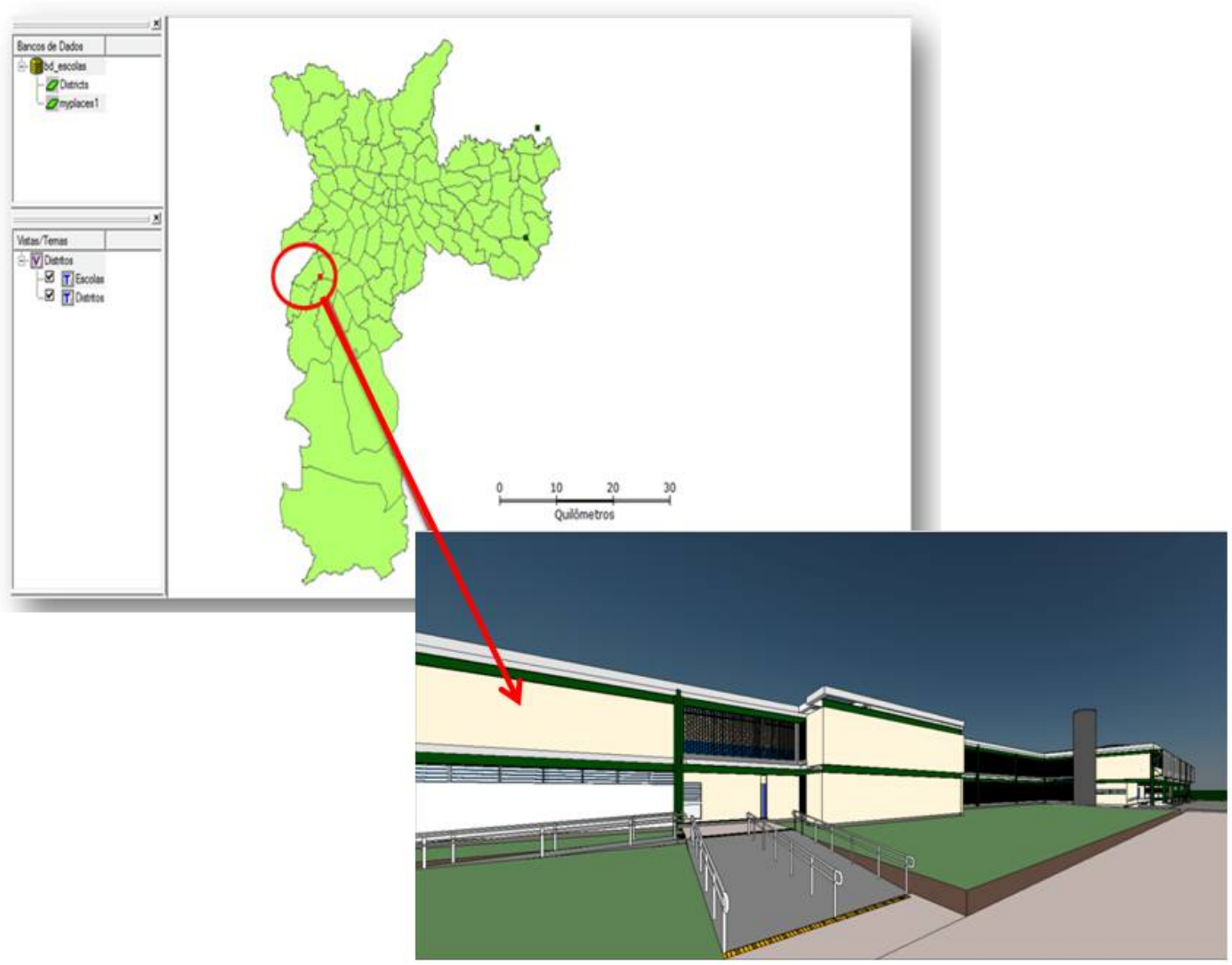

Figura 103. Escola Alpha: localização geográfica determinada por meio do software Terraview V. 4.2.2 e modelo relacionado Fonte: Acervo da pesquisadora.

Por meio da utilização deste recurso de georreferenciamento, um estudo de caso pode ser relacionado a tabelas que contenham os dados processados, o que permite a aplicação de filtros e consultas, que permitem utilizar sua localização, como um critério para a análise de ocorrências, conforme o exemplo apresentado na Figura 104. 


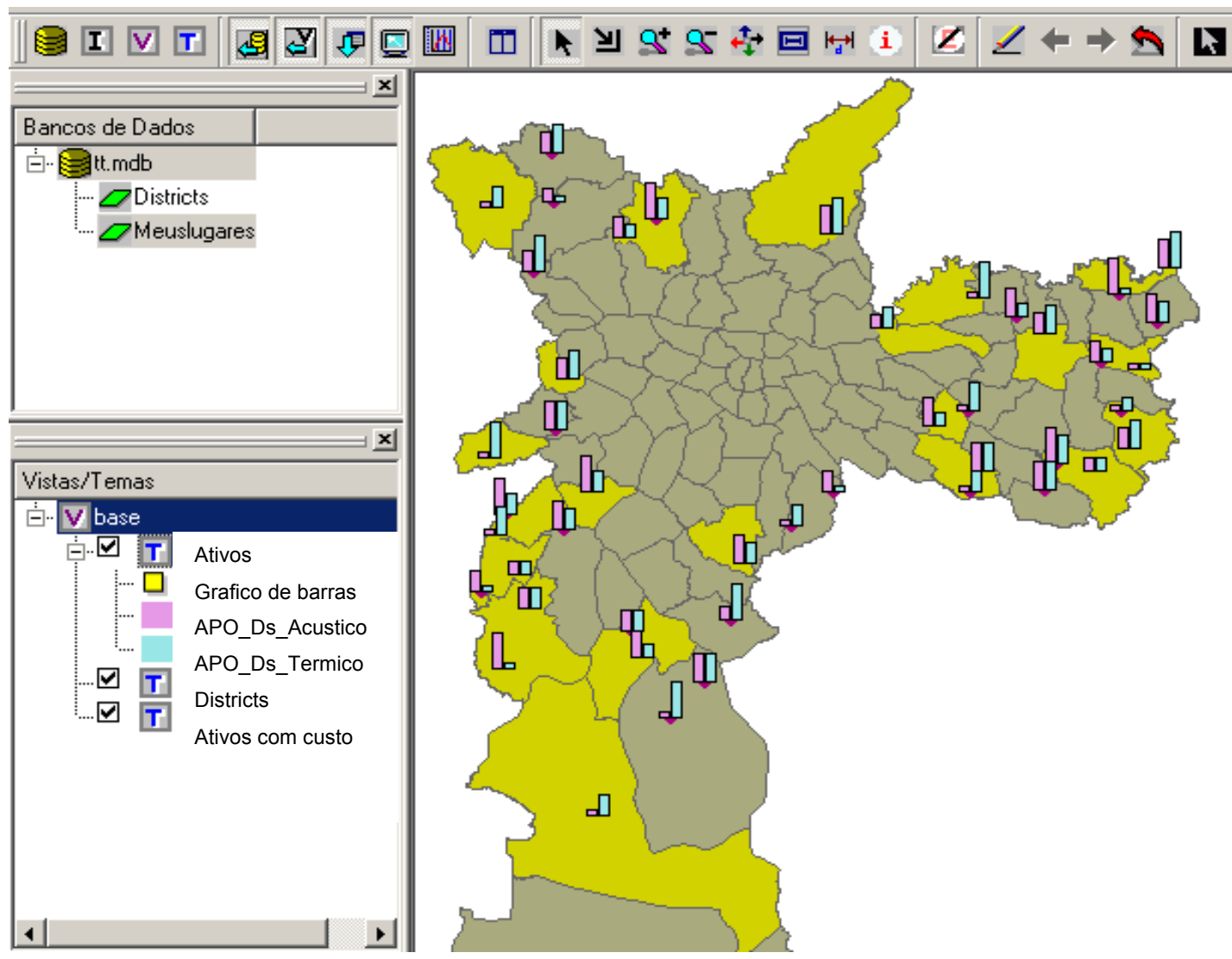

Figura 104. Exemplo de análise comparativa referente a resultados de desempenho de edificações do portfólio Imagem gerada por meio do programa computacional Terraview V. 4.2.2 Fonte: Acervo da pesquisadora.

No contexto do portfólio de ativos, esse recurso é de grande relevância. Por exemplo, pesquisas relacionadas ao desempenho de uma determinada esquadria podem ser filtradas considerando a proximidade do litoral. Do mesmo modo, componentes sujeitos à quebra podem ser pesquisados, conforme sua distribuição geográfica, para a identificação de áreas de vulnerabilidade quanto às ações de vandalismo.

Desta forma, as diretrizes de projeto podem ser atualizadas constantemente, de modo sistemático e eficiente. 


\subsection{OUTROS ASPECTOS DE INTEROPERABILIDADE ENFRENTADOS DURANTE O PROCESSO DE MODELAGEM}

Ao longo do desenvolvimento da pesquisa (início em 2012 e término em 2015) houve a necessidade de adaptar e atualizar os recursos tecnológicos, tanto em relação ao hardware como quanto ao conjunto de programas computacionais utilizados (Apêndice E).

O modelo tridimensional começou a ser elaborado no programa Autodesk Revit, versão 2012. Entretanto, até a conclusão da modelagem, o modelo foi importado para as versões 2013 e 2014 deste programa computacional.

No entanto, a versão 2014 do programa Revit não apresentou compatibilidade com o sistema operacional Windows XP que inicialmente era utilizado, o que obrigou que fosse feita sua atualização para o Windows 7 .

Também foram realizados testes para utilização da versão 2016. Nesse caso, os resultados não foram satisfatórios, pois o modelo apresentou inconsistências na visualização dos elementos modelados.

Outro aspecto crítico foi a exportação e a importação entre o programa de modelagem tridimensional e o Banco de Dados. A opção nativa do programa Revit, v. 2014, para a exportação do Banco de Dados (em formato ODBC - Open Database Conectivity), não permite a edição de informações e de tabelas fora do ambiente do programa.

A consequência disso é que estas informações podem ser exportadas para um Banco de Dados. Porém, não podem ser alteradas e importadas novamente.

Isso é crítico por ser uma função fundamental para o desenvolvimento da pesquisa, que é realizada considerando a gestão da informação, ao longo do ciclo de vida do empreendimento.

Em razão desse aspecto, foi necessário identificar outras possibilidades para a interoperabilidade. Dentre as informações que se pretendia incorporar à modelagem da informação, estavam os resultados aferidos, referentes ao desempenho em uso da edificação.

Verificou-se, como possibilidade para a exportação e a importação de informações, a utilização de um programa a ser instalado no Revit, v. 2014, o plug-in 
DB Link, desenvolvido para a instalação no programa computacional Revit, para a versão correspondente. Entretanto, esse recurso também apresentava limitações quanto aos dados que poderiam ser importados (vide Anexo C).

Nesse caso, a edição das informações deveria ser feita pelo usuário final, por meio da configuração de um Banco de Dados externo. Para os testes, utilizou-se o programa MS Access, conforme o apresentado na Figura 105.

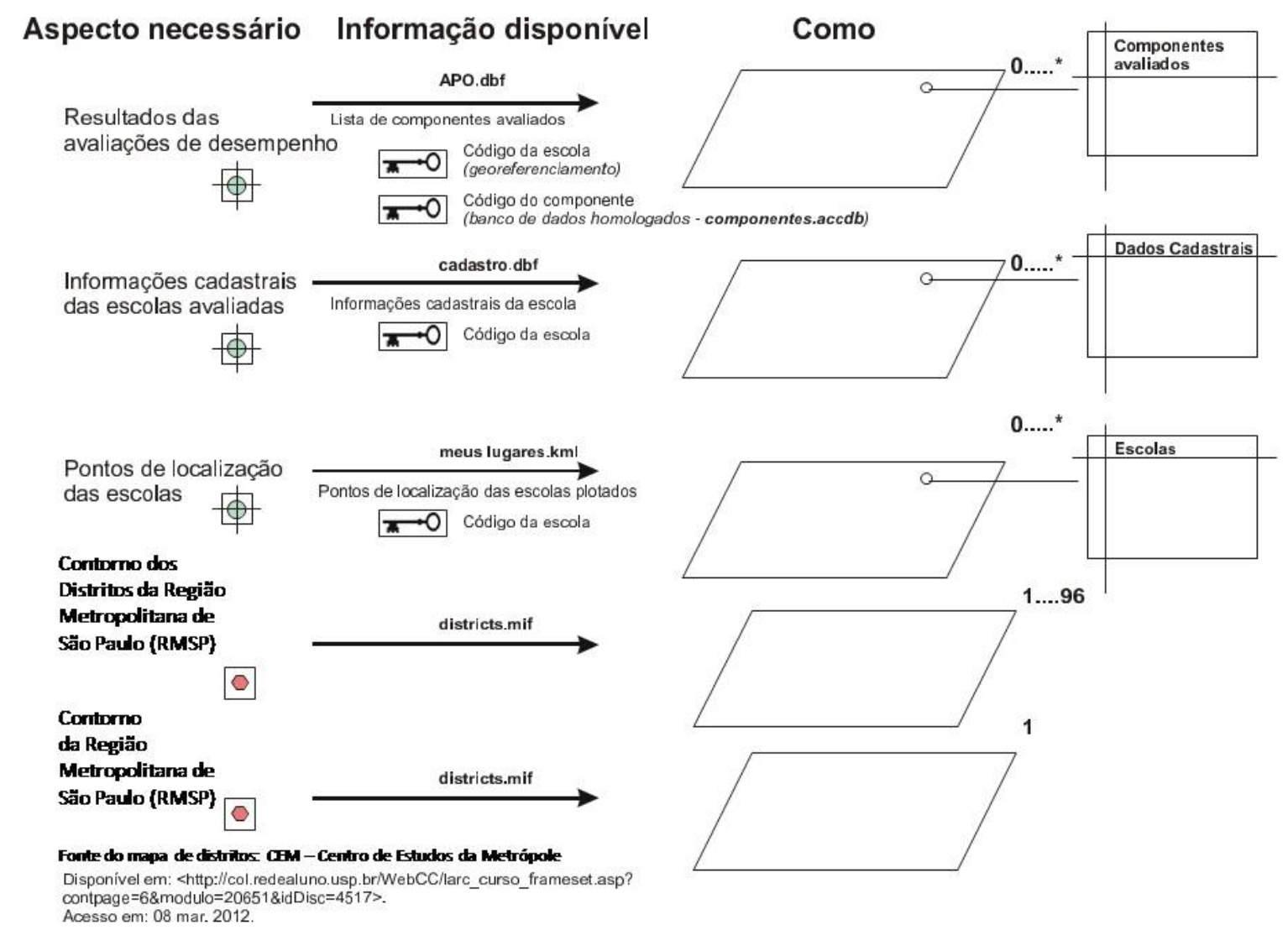

Figura 105. Níveis de organização das informações - configuração inicial Fonte: Acervo da pesquisadora.

A Autodesk descontinuou o suporte educacional durante o período da pesquisa (2014), de modo que não foi possível testar versões posteriores do plug-in DB Link.

Para sanar estes aspectos críticos, optou-se, após exaustiva pesquisa de campo, por utilizar a plataforma de Banco de Dados SQL dRofus v. 1.8, que se mostrou eficiente para o gerenciamento das informações do projeto. 
A abordagem da questão da compatibilidade entre equipamentos, programas computacionais e suas versões é de importância crucial para a viabilidade da modelagem da informação durante o ciclo de vida da edificação, bem como para a gestão do portfólio de ativos.

Espera-se que a informação possa ser gerida, de modo integrado, durante a vida útil esperada para o edifício. Também projetistas e demais envolvidos são obrigados contratualmente a manter, durante anos, seus registros de projeto.

Usualmente, as soluções oferecidas pelas empresas detentoras dos programas de autoria para a modelagem da informação não permitem que arquivos modelados ou importados para versões mais recentes possam ser acessados por meio de suas versões anteriores.

Por esse motivo, é preciso planejar o processo de modelagem, considerando a exportação de seus produtos para formatos abertos, de modo que as equipes envolvidas não fiquem reféns de atualizações ou de políticas de descontinuidade de programas computacionais.

Por fim, para que o Banco de Dados seja de fato um recurso utilizável, ele deve: permitir o acesso permanente e dinâmico à informação, ser de fácil manutenção, e, permitir seu uso por meio de programas computacionais, independente da versão disponível e do contexto utilizado, sem que ocorra perda da consistência semântica. 


\section{CONCLUSÕES E CONSIDERAÇÕES FINAIS}

Dado o apresentado por meio da presente pesquisa, pôde-se apreender que a modelagem da informação consiste em um processo único que torna possível o gerenciamento das informações de um empreendimento, com o objetivo de embasar decisões durante o ciclo de vida da edificação (conceituação, projeto, construção, operação e manutenção e reconstrução).

Nesse sentido, a BIM não é uma ferramenta ou um conjunto de ferramentas, ou de aplicativos, mas, sim, deve ser vista no contexto dos processos relacionados ao ciclo de vida do empreendimento, de modo a permitir o trabalho integrado das equipes multidisciplinares e o acesso às informações consistentes, relativas a um ou mais empreendimentos.

Um dos processos básicos adotados para a modelagem da informação é a alimentação sistemática de propriedades a um Banco de Dados, composto por tabelas associadas aos componentes modelados em 3D. Estas informações geométricas são desenvolvidas e validadas durante a fase de projeto. Ao final desta etapa, o resultado será um protótipo digital do empreendimento.

Assim sendo, o produto do processo de projeto passa a ser um Banco de Dados, com documentos de 2D gerados sob demanda, em lugar de ser um conjunto de desenhos e memoriais descritivos. Para tanto, deve ser entendido como parte de um contexto maior, no qual as soluções de construção continuam acessíveis e passíveis de avaliação, durante o uso da edificação, gerando conhecimento sobre seu desempenho, embasando, finalmente, de modo transparente, o processo de aprendizado contínuo.

As informações a serem modeladas vão depender dos usos pretendidos para a edificação. Devem também permitir a análise e a comparação de resultados entre as diferentes edificações de um portfólio.

Por meio de pesquisas feitas às informações dessas tabelas, serão tomadas as decisões estratégicas pelo proprietário e pelos demais stakeholders (relacionadas a aspectos como: custos, prazos de execução, ações de manutenção, entre outros).

Isso posto, fica claro que o processo de modelagem em 3D (com o uso do Revit - Autodesk, por exemplo ou de outros programas de autoria disponíveis no 
mercado), corresponde a apenas uma parte do sistema de modelagem da informação. Assim sendo, muitos atores, que precisarão tomar decisões, ao longo do ciclo de vida do empreendimento, não saberão - nem precisarão saber - operar um programa computacional para modelagem em 3D. Eles vão acessar programas que permitam o tratamento e a consulta aos dados e propriedades (a saber: Excel, Acess, MySql, MS Project, entre outros).

Por exemplo: a equipe de compras irá gerar quantitativos e orçamentos. Por sua vez, a equipe de manutenção gerará listas de equipamentos e atividades de manutenção para check-lists.

Usualmente, um gestor de facilidades ou um comprador da construtora não irá operar o programa computacional para a modelagem em 3D. Mesmo que saiba e a ele tenha acesso, não seria eficiente operar um modelo tridimensional para tomar decisões quanto às tarefas de manutenção e compras, por exemplo. Sendo assim, a solução adotada deve prever a interoperabilidade entre os programas adotados para a modelagem e os usados pelas demais equipes.

O entendimento fragmentado da natureza da BIM pelos gestores pode representar perdas de conhecimento e financeiras importantes durante o processo, e os efeitos negativos desta compartimentação da modelagem de informações tornam-se mais críticos durante a fase de uso e operação da edificação.

Por isso, os resultados de processos de Avaliação Pós-Ocupação ou de comissionamento devem ser modelados em uma solução que preveja acesso em rede, para serem consultados pelos stakeholders.

Sendo assim, é preciso compreender o processo de projeto e da construção de um empreendimento no contexto do sistema de gestão dos ativos de uma entidade - seja ela uma empresa pública ou privada. Podendo, portanto, beneficiarse das lições aprendidas e das boas práticas, a fim de obter melhores níveis de eficiência, tanto em relação ao ambiente construído como no que diz respeito aos recursos financeiros empregados.

De nada adianta um diagnóstico feito à exaustão, se a informação não chegar aos stakeholders - ou estiver disponível de forma incompleta ou inconsistente. $\mathrm{O}$ método proposto sugere transparência na apresentação das informações e permite a adequada acessibilidade a ela. Também permite que seja constituído um banco de conhecimento, não apenas um repositório de dados, de modo a efetivamente 
possibilitar o aprendizado organizacional.

Para a análise dos dados, por meio da implantação de um sistema de indicadores, pode-se aferir, de forma estruturada e continuada, o desempenho das edificações e de seus componentes, para criar um banco dinâmico de dados dos componentes homologados.

Sendo assim, nos casos em que as corporações administrem múltiplas edificações de tipologia semelhante, a edificação e seus processos inerentes devem ser entendidos, como parte de um contexto maior, no qual o desempenho de cada componente pode ter efeitos no desempenho do conjunto de ativos da empresa. Para que isso aconteça, é necessária a reestruturação dos processos, de modo a rever as práticas tradicionais de produção e de gestão do ambiente construído.

Essa abordagem integrada pode contribuir para a diminuição de riscos quanto à especificação das soluções de projeto, ainda não validadas, por meio das simulações de desempenho, utilizando a prototipagem digital. Sendo assim, também contribui para a flexibilização de soluções arquitetônicas.

A proposição apresentada difere da atual prática adotada pelos gestores dos estudos de caso considerados para a pesquisa, que é baseada na determinação de diretrizes de projeto e de componentes previamente homologados, sem que ocorra a validação sistemática do resultado obtido pelo conjunto de componentes e sistemas efetivamente utilizados para cada projeto, considerando as especificidades locais (tais como: localização geográfica, características climáticas e aspectos sociais da área que irá receber a edificação).

Uma vez que as decisões de projeto são guiadas por informações, ter conhecimento acerca do desempenho real dos elementos e sistemas construtivos e suas relações é importante para que se possa obter uma edificação eficiente. A abordagem proposta permite maior clareza na apresentação de resultados, o que contribui para criar oportunidades para a flexibilização do projeto de ambientes e dos componentes construtivos.

Assim sendo, mais do que aspectos necessários à gestão da informação, a presente tese propõe que sejam adotadas práticas para a gestão do conhecimento. Desta forma, pode-se utilizar a tecnologia como meio para a promoção do conhecimento e da inovação, aspectos necessários para que se promova, efetivamente o aprendizado e a melhoria contínuos. 
Ao iniciar a presente pesquisa, partimos da hipótese de que é possível estabelecer um processo sistemático para a gestão do conhecimento, pela adoção de procedimentos para avaliação de edificações que apresentam tipologia construtiva similar e da modelagem das informações obtidas, de modo a incrementar a qualidade do ambiente construído.

Considerando os métodos e técnicas pertinentes à avaliação sistemática e continuada de edificações em uso, cujos sistemas construtivos e programas de necessidades são semelhantes, verificamos ser factível tornar mais integrado e eficaz seu processo de planejamento, projeto, construção e uso.

Também é possível otimizar investimentos, a fim de prover edificações com maior qualidade, do ponto de vista ambiental e funcional, durante a vida útil da edificação.

Por conseguinte, verifica-se a confirmação da hipótese inicial, que supõe ser possível promover a gestão do conhecimento quanto ao desempenho do ambiente construído, em organizações que administram edificações padronizadas. Para que isso seja obtido, devem-se incorporar aos processos inerentes à produção e à operação dos ativos, procedimentos sistemáticos para avaliação de edificações de tipologia construtiva similar.

Deste modo, a pesquisa desenvolvida apresenta contribuições para promover a gestão do conhecimento e, consequentemente, do aprendizado, de modo a:

- criar um banco dinâmico de dados dos componentes homologados, que incorpore os benefícios da experiência pregressa referente ao projeto, à construção e à ocupação de edificações de tipologia construtiva semelhante;

- dar suporte à inclusão, neste $\mathrm{BD}$, de informações referentes a experiências passadas, boas práticas e recursos tecnológicos;

- sistematizar a documentação e a comunicação de aspectos críticos; e, desta feita; e

- constituir a memória organizacional e a transferência eficiente do conhecimento, pelas partes envolvidas no processo (FRANÇA; ORNSTEIN, 2015). 
Verifica-se que organizações de diferentes naturezas podem se beneficiar do proposto, desde que desempenhem atividades de operação e gestão de um conjunto de edificações com características em comum. Por conseguinte, embora a discussão tenha sido proposta considerando o caso das escolas públicas paulistas, ressalta-se sua aplicabilidade às organizações públicas e privadas que, da mesma forma, sejam responsáveis por gerir um portfólio de ativos imobiliários.

Com base nos resultados apresentados na presente tese, foram identificados aspectos merecedores de continuidade em pesquisas futuras, a saber:

- consolidação do Banco de Dados, pela aplicação da metodologia proposta a um conjunto de edificações em uso e monitoramento dos resultados, de modo a constituir um portfólio de ativos para a análise;

- desenvolvimento das funcionalidades de georreferenciamento para a modelagem de informações no contexto de portfólio de ativos;

- integração das fichas ambientais com as informações referentes aos sistemas prediais em operação, por meio de recursos de automação, para monitoramento do desempenho de um conjunto de edificações; e

- aprofundamento da pesquisa quanto aos recursos de exportação em formato IFC, com vistas à interoperabilidade entre os programas utilizados para simulações de desempenho.

Também dada a necessidade da revisão dos processos relacionados ao ciclo de vida da edificação, é importante a difusão dos conceitos apresentados na presente pesquisa no meio acadêmico, de modo a contribuir para a revisão de paradigmas e promoção de boas práticas para a gestão do conhecimento.

Dado o impacto da matéria nos processos tradicionais adotados pela indústria da construção civil, recomenda-se que sejam elaboradas pesquisas, de modo a consolidar o arcabouço teórico necessário para orientar os possíveis atores participantes dos processos inerentes à produção e à operação do ambiente construído. 


\section{REFERÊNCIAS}

ABEL, J.; LENNERTS, K. Where does CAFM really help? Current fields of application and future trends according to system users. In: Proceedings of $\mathrm{CIB}$ W78's 22nd International Conference on Information Technology in Construction, CIB Publication 304, ISBN 3-86005-478-3. Dresden, 2005.

ABIKO, Alex Kenya; ORNSTEIN, Sheila Walbe (orgs.). Inserção urbana e Avaliação Pós-Ocupação [APO] da habitação de interesse social. São Paulo: FAUUSP, 2002. [Coletânea Habitare/FINEP, 1].

ABNT - ASSOCIAÇÃO BRASILEIRA DE NORMAS TÉCNICAS. NBR 10.152 Níveis de ruído para conforto acústico. Rio de Janeiro: ABNT, 1987. ABNT - ASSOCIAÇÃO BRASILEIRA DE NORMAS TÉCNICAS. NBR 7.199 Projeto, execução e aplicações de vidros na construção civil. Rio de Janeiro: Associação Brasileira de Normas Técnicas, 1988.

ABNT - ASSOCIAÇÃO BRASILEIRA DE NORMAS TÉCNICAS. NBR 5.413 lluminância de interiores. Rio de Janeiro: Associação Brasileira de Normas Técnicas, 1992.

ABNT - ASSOCIAÇÃO BRASILEIRA DE NORMAS TÉCNICAS. NBR 13.531 Elaboração de projetos de edificações: atividades técnicas. ABNT: Rio de Janeiro, 1995.

ABNT - ASSOCIAÇÃO BRASILEIRA DE NORMAS TÉCNICAS. NBR 5.674 Manutenção de edificações: procedimento. Rio de Janeiro: Associação Brasileira de Normas Técnicas, 1999.

ABNT - ASSOCIAÇÃO BRASILEIRA DE NORMAS TÉCNICAS. NBR 10.151 Avaliação do ruído em áreas habitadas, visando o conforto da comunidade. Rio de Janeiro: Associação Brasileira de Normas Técnicas, 2000.

ABNT - ASSOCIAÇÃO BRASILEIRA DE NORMAS TÉCNICAS. NBR 9.077 Saídas de emergência em edifícios. Rio de Janeiro: Associação Brasileira de Normas Técnicas, 2001.

ABNT - ASSOCIAÇÃO BRASILEIRA DE NORMAS TÉCNICAS. NBR 8.800 Projetos e execução de estruturas de aço e de estruturas mistas de açoconcreto em edifícios. Rio de Janeiro: Associação Brasileira de Normas Técnicas, 
2003.

ABNT - ASSOCIAÇÃO BRASILEIRA DE NORMAS TÉCNICAS. NBR 5.410 Instalações elétricas de baixa tensão. Rio de Janeiro: Associação Brasileira de Normas Técnicas, 2004a.

ABNT - ASSOCIAÇÃO BRASILEIRA DE NORMAS TÉCNICAS. NBR 13.434-2 Sinalização de segurança contra incêndio e pânico. Parte 2 - símbolos e suas formas, dimensões e cores. Rio de Janeiro: Associação Brasileira de Normas Técnicas, 2004b.

ABNT - ASSOCIAÇÃO BRASILEIRA DE NORMAS TÉCNICAS. NBR 15.215-1 lluminação natural [Parte 1: conceitos básicos e definições]. Rio de Janeiro: Associação Brasileira de Normas Técnicas, 2004c.

ABNT - ASSOCIAÇÃO BRASILEIRA DE NORMAS TÉCNICAS. NBR 15.215-2 Iluminação natural [Parte 2: procedimentos de cálculo para a estimativa da disponibilidade de luz natural]. Rio de Janeiro: Associação Brasileira de Normas Técnicas, 2004d.

ABNT - ASSOCIAÇÃO BRASILEIRA DE NORMAS TÉCNICAS. NBR 15.215-3 Iluminação natural [Parte 3: procedimentos de cálculo para a determinação da iluminação natural em ambientes internos]. Rio de Janeiro: Associação Brasileira de Normas Técnicas, $2004 \mathrm{e}$.

ABNT - ASSOCIAÇÃO BRASILEIRA DE NORMAS TÉCNICAS. NBR 15.215-4 Iluminação natural [Parte 4: verificação experimental das condições de iluminação interna de edificações - método de medição]. Rio de Janeiro: Associação Brasileira de Normas Técnicas, $2004 \mathrm{f}$.

ABNT - ASSOCIAÇÃO BRASILEIRA DE NORMAS TÉCNICAS. NBR 15.220-1 Desempenho térmico de edificações. Partes 1 e 2. Rio de Janeiro: Associação Brasileira de Normas Técnicas, 2005a.

ABNT - ASSOCIAÇÃO BRASILEIRA DE NORMAS TÉCNICAS. Projeto 02:135.01005 [Revisão da NBR 10152]: Medição e avaliação de ruído em ambientes internos. CB-02, Comitê Brasileiro de Construção Civil, CE-02: 135.01, Comissão de Estudos de Desempenho Acústico de Edificações. São Paulo, 2005b.

ABNT - ASSOCIAÇÃO BRASILEIRA DE NORMAS TÉCNICAS. NBR 15.965-1 Sistema de classificação da informação da construção. Parte1: Terminologia e estrutura. ABNT: Rio de Janeiro, 2011. 
ABNT - ASSOCIAÇÃO BRASILEIRA DE NORMAS TÉCNICAS. NBR 15.965-2 Sistema de classificação da informação da construção. Parte 2: Características dos objetos da construção. Rio de Janeiro: ABNT, 2012.

ABNT - ASSOCIAÇÃO BRASILEIRA DE NORMAS TÉCNICAS. NBR 15.575-1 Edifícios habitacionais - Desempenho.[Parte 1: requisitos gerais].Rio de Janeiro: Associação Brasileira de Normas Técnicas, 2013.

ABNT - ASSOCIAÇÃO BRASILEIRA DE NORMAS TÉCNICAS. NBR 9.050 Acessibilidade a edificações, mobiliário, espaços e equipamentos urbanos. Rio de Janeiro: Associação Brasileira de Normas Técnicas, 2015.

ABNT/ ISO - ASSOCIAÇÃO BRASILEIRA DE NORMAS TÉCNICAS; INTERNATIONAL ORGANIZATION FOR STANDARDIZATION. ABNT NBR/ISO 9.000. Sistemas de gestão da qualidade - Fundamentos e vocabulário. Rio de Janeiro: ABNT, 2005.

ABNT/ ISO - ASSOCIAÇÃO BRASILEIRA DE NORMAS TÉCNICAS; INTERNATIONAL ORGANIZATION FOR STANDARDIZATION. ABNT NBR/ISO 9.001. Sistemas de gestão da qualidade - Requisitos. Rio de Janeiro: ABNT, 2008.

ABNT/ISO - ASSOCIAÇÃO BRASILEIRA DE NORMAS TÉCNICAS/ INTERNATIONAL ORGANIZATION FOR STANDARDIZATION. NBR 12.006-2 Construção da informação - organização da informação da construção. Parte 2: estrutura para a classificação da informação. Rio de Janeiro: ABNT, 2010.

ABRAMOVICZ, Tatiana; ORNSTEIN, Sheila Walbe. A gestão da qualidade no projeto; sob a ótica da habitação. In: IV WBGPPCE 2004 - Workshop Brasileiro de Gestão do Processo de Projeto na Construção de Edifícios. Rio de Janeiro, 2004.

ADDOR, Mirian (coord.). Estruturação do escritório de projeto para a implantação do BIM. Guia ASBEA de boas práticas em BIM. Fascículo 1. São Paulo: ASBEA, 2013.

ADDOR, Mirian (coord.). Fluxo de projetos em BIM: planejamento e execução. Guia ASBEA de boas práticas em BIM. Fascículo 2. São Paulo: ASBEA, 2015.

AGC - ASSOCIATED GENERAL CONTRACTORS OF AMERICA. Contractors' Guide to BIM. Edition One. AGC of America, 2006.

AHANKOOB, Alireza; MANLEY, Karen; STEINHARDT, Dale. The application of 
building information modeling to enhance organizational learning. In: Proceedings of The Construction, Building and Real Estate Research Conference of the Royal Institution of Chartered Surveyors - RICS COBRA AUBEA. London: RICS - Royal Institution of Chartered Surveyors, 2015.

AIA - The American Institute of Architects. Integrated project delivery: a guide. California: The American Institute of Architects, 2007.

AIA - The American Institute of Architects. Document E202 - Building Information Modeling protocol exibhit. San Francisco: AIA, 2008.

AIA - THE AMERICAN INSTITUTE OF ARCHITECTS. AIA guide do building life cycle assessment in practice. Washington: The American Institute of Architects, 2010.

ALVES, Taís da C. L.; FORMOSO, Carlos Torres. ALVES, T.C.L.; FORMOSO, C.T. Guidelines for managing physical flows in construction sites. In: Annual Conference of The International Group For Lean Construction, 8, Brighton, 2000. Artigo técnico. Brighton, UK. 2000.. Science and Technology Policy Research, 2000. AMOR, Robert; OWEN, Robert. Beyond BIM - it's not the end of the road. AECBytes $\begin{array}{lllll}\text { Viewpoint. } & \mathrm{n} . & 58 . & 2011 . & \text { Disponível em: }\end{array}$ <http://www.aecbytes.com/viewpoint/2011/issue_58.html>. Acesso em 15 jan. 2015. ANDERY, Paulo; CAMPOS, Cintia; ARANTES, Eduardo Marques. Desenvolvimento de um termo de referência para o gerenciamento de projetos integrados em uma instituição pública. In: Gestão e Tecnologia, v. 7, n 1, São Carlos: GTP, 2012, pp. 38-61.

ANDERY, Paulo Roberto Pereira; ARANTES, Eduardo Marques. Revisitando as extranets de projeto: uma análise dos processos de projeto. In: Revista Ambiente Construído, v. 15, n. 4, p.149-164, out./dez. 2015. Porto Alegre: ANTAC, 2015.

ANDRADE, Max Lira Veras X. de; RUSCHEL, Regina Coeli. BIM: conceitos, cenário das pesquisas publicadas no Brasil e tendências. In: Simpósio Brasileiro de Qualidade do Projeto no Ambiente Construído 2009. São Carlos, Brasil, 2009. p. 602-613.

ANSI/ASHRAE- AMERICAN NATIONAL STANDARDS INSTITUTE/ AMERICAN SOCIETY OF HEATING, REFRIGERATING AND AIR-CONDITIONING ENGINEERS. Standard 55.1. Thermal environmental conditions for human occupancy. Atlanta: ASHRAE, 2004. 
ANSI/ASHRAE- AMERICAN NATIONAL STANDARDS INSTITUTE/ AMERICAN SOCIETY OF HEATING, REFRIGERATING AND AIR-CONDITIONING ENGINEERS. Standard 0-2005. The commissioning process. Atlanta: ASHRAE, 2005.

ANSI/ASHRAE- AMERICAN NATIONAL STANDARDS INSTITUTE/ AMERICAN SOCIETY OF HEATING, REFRIGERATING AND AIR-CONDITIONING ENGINEERS. Standard 62.1. Ventilation for acceptable indoor air quality. Atlanta: ASHRAE, 2013a.

ANSI/ASHRAE- AMERICAN NATIONAL STANDARDS INSTITUTE/ AMERICAN SOCIETY OF HEATING, REFRIGERATING AND AIR-CONDITIONING ENGINEERS. Standard 90.1-Energy Standard for Buildings Except Low-Rise Residential Building. Atlanta: ASHRAE, 2013b.

ANTÓN, Laura Álvarez; DÍAZ, Joaquín. Integration of LCA and BIM for sustainable construction. International Journal of Social, Behavioral, Educational, Economic and Management Engineering. V. 8, n. 5. World Academy of Science, Engineering and Technology, 2014, p. 1356-1360. Disponível em: <http://www.waset.org/Publication/99982119>. Acesso em 03 abr. 2015.

ANTONIOLI, Paulo Eduardo; GRAÇA, Moacyr Eduardo Alves. Subsídios conceituais para o planejamento de sistemas de gerenciamento de facilidades em edificações produtivas. Boletim Técnico da Escola Politécnica da USP, Departamento de Engenharia de Construção Civil; BT/PCC/358. São Paulo: EPUSP, 2004. 26p.

ANVISA - Agência Nacional de Vigilância Sanitária. Norma Regulamentadora NR 17. Ergonomia. Regulamentada pela Portaria Ministério do Trabalho e Previdência Social - MTPS n. 3.751 , de 23 de novembro de 1990.

ANVISA - Agência Nacional de Vigilância Sanitária. Portaria MS n. ${ }^{0}$ 3.523. Ministério da Saúde. D.O.U. - Diário Oficial da União, Poder Executivo, de 31 de agosto de 1998.

ASHRAE - AMERICAN SOCIETY OF HEATING, REFRIGERATING AND AIRCONDITIONING ENGINEERS. An Introduction to Builiding Information Modeling (BIM). A guide for ASHRAE Members. Revised. Atlanta: ASHRAE, 2009.

ASHURST, Colin; DOHERTY, Neil; PEPPARD, Joe. Improving the impact of it develompent projects: the benefits realization capability model. In: European Journal of Information Systems, 17. London: Palgrave Macmillan, 2008, pp. 1-40. 
AUGENBROE, Godfried; SANGUINETTI, Paola ; EASTMAN, Charles. Courthouse energy evaluation: BIM and simulation model interoperability in concept design. In: International IBPSA Conference 11. Glasgow, Scotland, 2009. p. 1922-1929.

AULICINO, P. Análise de métodos de avaliação de sustentabilidade do ambiente construído: o caso dos conjuntos habitacionais. Dissertação (mestrado). São Paulo: Escola Politécnica da Universidade de São Paulo, 2008.

AUTODESK. BIM's return on investment. AutoDesk White Paper. AUTODESK, 2007. Disponível em: <http://images.autodesk.com/adsk/files/bim_roi_jan07_1_.pdf >. Acesso em 22 jul. 2013.

AUTODESK. The advantages of BIM for government building performance analysis. AutoDesk White Paper. AUTODESK, 2009. Disponível em: $<$ http://images.autodesk.com/adsk/files/the_advantages_of_bim_govt_building_final. pdf>. Acesso em 22 jul. 2013.

AZHAR, Salman, et al.. Building information modeling for sustainable design and LEED rating analysis. In: Automation in Construction v. 20. London: Elsevier B. V., 2011, pp. 217-224.

AZHAR, Salman; BROWN, Justin; FAROOQUI, Riswan.BIM-based Sustainability Analysis: An Evaluation of Building Performance Analysis Software. In: Proceedings of the 45th ASC, 2009.Disponivel em: < http://ascpro.ascweb.org/chair/paper/CPRT125002009.pdf>. Acesso em 12 jun. 2012.

BALDAUF, Juliana Parise; FORMOSO, Carlos Torres; MIRON, Luciana Inês Gomes. Modelagem de requisitos de clientes em empreendimentos habitacionais de interesse social com o uso de BIM. In: Ambiente Construído, v. 13, n. 3. Porto Alegre: ANTAC, 2013, pp. 177-195.

BARBOSA, Maria Beatriz et al. Avaliação Pós-Ocupação da Escola Estadual

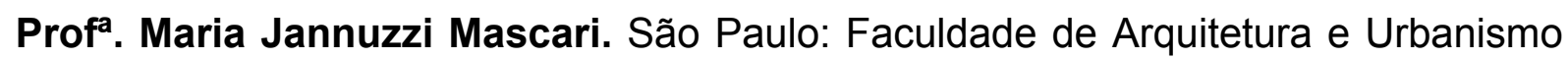
da Universidade de São Paulo, 2008. (trabalho final para a disciplina de pósgraduação AUT 5.805).

BASSETTE, Fábio Luiz Franzin; MORAIS, Marcelo de; RUSCHEL, Regina Coeli. Quantificação por meio de Modelagem de Informação da Construção: uma avaliação do aplicativo QUANTITY TAKEOFF. In: Encontro Nacional de Tecnologia do Ambiente Construído, 2012, Juiz de Fora. ENTAC: Encontro Nacional de 
Tecnologia do Ambiente Construído. Porto Alegre: ANTAC, 2012. p. 1151-1158.

BAZJANAC, Vladmir; CRAWLEY, Drury B.. The implementation of Industry Foundation Classes in Simulation tools for building industry. In: Building'97 Simulation Conference. Prague, 1997. Disponível em: <http:// eetd.lbl.gov/node/52077>. Acesso em: 22 mai. 2013.

BBSR - BUNDESINSTITUT FÜR BAU-, STADT-, UND RAUMFORSCHUNG. BIMLeitfaden Für Deutschland. Information und ratgeber. München: BBSR, 2013. Disponível em:

http://www.bbsr.bund.de/BBSR/DE/FP/ZB/Auftragsforschung/3Rahmenbedingungen/ 2013/BIMLeitfaden/Endbericht.pdf?_blob=publicationFile\&v=2>. Acesso em 22 abr. 2015.

BCA - BUILDING AND CONSTRUCTION AUTHORITY. Singapore BIM Guide. Version 2. Singapore: BCA, 2012. Disponível em: < https://corenet.gov.sg/media/586132/Singapore-BIM-Guide_V2.pdf>. Acesso em 21 abr. 2015.

BEBER, Michele; SCHEER, Sergio; WILLE, Silvio A. de C.. Uso da tecnologia da informação como auxiliadora da gestão da comunicação em escritórios de arquitetura. In: III Encontro de Tecnologia de Informação e Comunicação na Construção Civil - TIC. Anais. Porto Alegre: TIC, 2007.

BECERIK-GERBER, Burcin; JAZIZADEH, Farrokh; LI, Nan; CALIS, Gulben. Application areas and data requirements for BIM-enabled facilities management. In: Journal of Construction Engineering and Management. ASCE, 2012, pp. 431442.

BERARD, Ole; KARLSHOEJ, Jan. Information delivery manuals to integrate building product information into design. In: Journal of Information Technology in Construction. ITcon, v. 17, 2012, pp. 64-74.

BERTEZINI, Ana Luisa; MELHADO, Silvio Burrattino. Métodos de avaliação de projeto de arquitetura na construção de edifícios sob a ótica da gestão da qualidade. In: Boletim Técnico da Escola Politécnica da USP, Departamento de Engenharia de Construção Civil; BT/PCC/448. São Paulo: EPUSP, 2007.

BETIN, Marcos E. J. Quality in Latin America. In: JURAN, Joseph Moses (coord.). Juran`s quality control handbook. 5th ed. New York: McGraw-Hill, 1998, p. 11621177. 
BHAVNANI, Suresh K.; JOHN, Bonnie E.. From sufficient to efficient usage: an analysis of estrategic knowledge. CHI 97- Conference on Human Factors in Computing Systems. Atlanta, 1997.

BIC - INSTITUTE FOR BIM IN CANADA. IBC 100-2014 Bim Contract Appendix. OTTAWA: BIC, 2014a.

BIC - INSTITUTE FOR BIM IN CANADA. IBC 201-2014 LOD, Authorized Uses and Model Element Table. OTTAWA: BIC, 2014b.

BIMFORUM. Level of development specification for building information modeling. AGC, 2015. Disponível em: <https://bimforum.org>. Acesso em 13 abr. 2015.

BORGES, Carlos A. M.; SABBATINI, Fernando H. O conceito de desempenho de edificações e a sua importância para o setor da construção civil no Brasil. São Paulo: Edusp, 2008.

BPMN - BUSINESS PROCESS MODEL AND NOTATION. Business Process Model and Notation. BPMN.org, 2004. Disponível em: <http: //www.bpmn.org>. Acesso em 03 fev. 2015.

BRASIL. Parâmetros nacionais de qualidade para a educação infantil. Brasília: Ministério da Educação/Secretaria de Educação Básica, 2006. Disponível em: $<$ http://portal.mec.gov.br>. Acesso em 5 mai. 2010.

BRE - BUILDING RESEARCH ESTABLISHIMENT. BREEAM new construction: non domestic buildings. Technical manual. United Kingdom, BRE Global Ltd., 2011.

BSI - Britsh Standards Institute. BS 3.811 - Glossary of terms used in terotechnology. United Kingdom: BSI, 1993.

BSI - British Standards Institution. BS PD7.503 - Knowledge management in construction. London: BSI, 2003.

BSI - The British Standards Institution. BS 1.192 - Collaborative production of architectural, engineering and construction information. Code of practice. London: BSI, 2007. BSI - THE BRITISH STANDARDS INSTITUTIONT. PAS 55-1Asset Management. London: BSI, 2008.

BSI - The British Standards Institution. PAS1.192-2 - Specification for information management for the capital/delivery phase of construction projects using building information modelling. Corrigendum 1. London: BSI, 2013. 
BSI - The British Standards Institution. PAS1.192-3 - Specification for information management for the operational phase of assets using building information modelling. London: BSI, 2014.

BUDDEN, Richard. GIS and information management on Crossrail C122 bored tunnels contract. In: Atkins Technical Journal, v. 6. Atkins Global, 2011. Disponível em: $\quad<\quad$ http://www.atkinsglobal.com/ /media/Files/A/AtkinsGlobal/Attachments/sectors/rail/library-docs/technical-papers/gis-and-informationmanagement-on-crossrail-c122-bored-tunnels-contract.pdf>. Acesso em 20 set. 2015.

BUILDINGSMART. Industry Foundation Classes Release 4 (IFC 4). buildingSMART, 2013. Disponível em: < http://www.buildingsmarttech.org/ifc/lFC4/final/html/>. Acesso em 02 dez. 2014.

BUILDINGSMART. About buildingSMART. buildingSMART, 2014a. Disponível em: <http://www.buildingsmart.org>. Acesso em 25 jan. 2015.

BUILDINGSMART. General questions about buildingSMART, IAI, and IFC. buildingSMART, 2014b. Disponível em: < http://www.buildingsmarttech.org/implementation/faq/faq-general-questions >. Acesso em 10 jun. 2014.

CÂMARA, Gilberto, et al. (eds.). Introdução à ciência da geoinformação. Ministério da Ciência e Tecnologia. Instituto Nacional de Pesquisas Espaciais. São José dos Campos: INPE, 2001.

CARDOSO. F. F. (Coord.). Referencial técnico de certificação "Edifícios do setor de serviços - Processo AQUA". Escritórios e edifícios escolares. São Paulo: FCAV, 2007.

CASTANHO, Mirian Dardes de Almeida. Processos e procedimentos de projeto na Era BIM: um exemplo prático. In: Autodesk University Brasil 2012. Autodesk, 2012. Disponível em: <http://static-wd.autodesk.net/content/dam/au/Brasil2014/documents/materialapoio/2012/AUBR-15_Apresenta\%C3\%A7\%C3\%A3o.pdf>. Acesso em 20 mai. 2015.

CBIC - CÂMARA BRASILEIRA DA INDÚSTRIA DA CONSTRUÇÃO. Desempenho de edificações para atendimento à norma ABNT NBR 15.575/2013. Câmara brasileira da indústria da construção. Fortaleza: Gadioli Cipolla Comunicação, 2013. CERTIVÉA. Guide pratique du referentiel pour la qualité environnementale des bâtiments. Bâtiments tertiaires. Paris: Certivéa, 2012. Acesso em 12 mai. 2015. 
CHECCUCCI, Érica de Sousa; PEREIRA, Ana Paula Carvalho; AMORIM, Arivaldo Leão de. Uma visão da difusão e apropriação do paradigma BIM no Brasil. In: Gestão \& Tecnologia de Projeto. v. 1, n. 8 São Paulo, 2013. p. 19-39.

CHECCUCCI, Érica de Sousa. Ensino-aprendizagem de BIM nos cursos de graduação em engenharia civil e o papel da expressão gráfica neste contexto. Tese (doutorado Multi-institucional e Multidisciplinar em Difusão do Conhecimento) Universidade Federal da Bahia. Faculdade de Educação, Salvador, 2014.

CHEN, Injazz J.. Planning for ERP systems: analysis and future trend. In: Business Process Management Journal, v. 7, $\mathrm{n}^{\circ}$ 5. MCB University Press, 2001, pp. 374-386. Disponível em: < http://cis.csuohio.edu/ ichen/ERP.pdf>. Acesso em 12 mai. 2015. CHEN, Peter. Entity-relationship model - toward a unified view of data. ACM Transactions on Database Systems, Vol. 1, No. 1. March 1976. p. 9-36. Disponível em: < http://csc.lsu.edu/news/erd.pdf >. Acesso em 10 mai. 2012.

CHENG, Jack C. P.; LU, Qiqi. A review of the efforts and roles of the public sector for BIM adoption worldwide. In: Journal of Information Technology in Construction. IT Con Vol. 20, PP. 442-478. Disponível em: < http://www.itcon.org/data/works/att/2015_27.content.01088.pdf>. Acesso em 04 set. 2015.

CHENG, Jack C. P.; MA, Lauren Y. H. A BIM-basede system for demolition and renovation waste estimation and planning. In: Waste Management. Volume 33, Issue 6. Elsevier, 2013, p. 1.539-1.551.

CIE - COMMISSION INTERNATIONALE DE L'ÉCLAIRAGE. Discomfort glare in the interior working environment. France: Bureau Central de la CIE, 1983.

COELHO, Sergio Salles; NOVAES, Celso Carlos. Modelagem de informações para construção (BIM) e ambientes colaborativos para gestão de projetos na construção civil. In: Anais do VIII Workshop nacional degestão do processo de projetos na construção de edifícios, São Paulo, 2008.

CONSENSUSDOCS. ConsensusDocs 301 - Building Information Modeling (BIM) Addendum - 2008, Revised 2011. Arlington: ConsensusDocs, 2011.

CONTIER, Luiz Augusto. Caminho sem volta: um novo olhar. In: Seminário Estadual BIM. Florianópolis: Governo de Santa Catarina, 2014. Disponível em: http://www.spg.sc.gov.br/index.php/visualizar-biblioteca/acoes/comite-de-obraspublicas/seminario-bim/20-luizaugustocontier/file. Acesso em 20 set. 2014. 
CORREAA, Marcus Viníncius Granadeiro; RUSCHEL, Regina Coeli. Tendências da colaboração em arquitetura, engenharia e construção. In: FABRICIO, Márcio Minto; ORNSTEIN, Sheila Walbe (orgs.). Qualidade no Projeto de edifícios. $1^{\text {a }}$. ed. São Carlos/Porto Alegre: RIMA/ANTAC, 2010, p. 119-136.

COSTA, Dayana B.; et al. Sistema de Indicadores para benchmarking na construção civil: manual de utilização. Núcleo Orientado para a Inovação da Edificação. UFRGS: Porto Alegre, 2005.

CPIC - CONSTRUCTION PROJECT INFORMATION COMITEE. CPIX - BIM assessment form. 24 fev. 2011. Disponível em: < http://www.cpic.org.uk/wpcontent/uploads/2013/06/cpix_-_bim_assessment_form_ver_1.0.pdf>. Acesso em 21 jan. 2015.

CRESPO, Cláudia Campos; RUSCHEL, Regina Coeli. Ferramentas BIM: Um Desafio Para a Melhoria no Ciclo de Vida do Projeto. III Encontro de Tecnologia de Informação e Comunicação na Construção Civil. Porto Alegre, ANTAC: 2007.

CROSSRAIL. Crossrail route maps. London: CROSSRAIL, 2014. Disponível em: <http://www.crossrail.co.uk/route/maps/>. Acesso em 20 set. 2014.

DALKIR, Kimz. Knowledge Management in theory and practice. Oxford: Elsevier Butterworth-Heinemann, 2005.

DDC - NEW YORK CITY DEPARTMENT OF DESIGN AND CONSTRUCTION. BIM guidelines. New York: DDC, 2012. Disponível em: < http://www.nyc.gov/html/ddc/downloads/pdf/DDC_BIM_Guidelines.pdf>. Acesso em 12 mai. 2015.

DECONCIC - Departamento da Indústria da Construção. Cadeia produtiva da construção: estimativas do investimento em obras, do PIB e do emprego. São Paulo, FIESP, 2015.2 Disponível em: <http://az545403.vo.msecnd.net/uploads/2015/07/indicadores_1-tri2015_construbusiness.pdf>. Acesso em 20 set. 2015.

DEGANI, C. M.. Modelo de gerenciamento de sustentabilidade de facilidades construídas. Tese (doutorado). Escola Politécnica da Universidade de São Paulo. Departamento de Engenharia Civil. São Paulo: Escola Politécnica da Universidade de São Paulo, 2010.

DEMING, William Edwards. Out of the Crisis. Cambridge, Massachusetts: MIT Center for Advanced Professional Services, 1986. 
DEMING, William Edwards. Qualidade: a revolução da administração. Tradução de Clave Comunicações e Recursos Humanos. Rio de Janeiro: Marques-Saraiva, 1990.

DEPARTMENT FOR BUSINESS, INNOVATION AND SKILLS. Government Construction Strategy. United Kingdom, 2011a. Disponível em: <<https://www.gov.uk/government/publications/government-construction-strategy>. Acesso em 8 set. 2012.

DEPARTMENT FOR BUSINESS, INNOVATION AND SKILLS. Strategy Paper for the Government Construction Client Group From the BIM Industry Working Group. United Kingdom, 2011b. Disponível em: < http://www.bimtaskgroup.org/wpcontent/uploads/2012/03/BIS-BIM-strategy-Report.pdf >. Acesso em 8 set. 2012.

DEPARTMENT FOR BUSINESS, INNOVATION AND SKILLS. Government Construction Strategy. One Year On Report and Action Plan Update. United Kingdom, 2012.

Disponível

em:

<https://www.gov.uk/government/publications/government-construction-strategy>.

Acesso em 10 jan. 2013.

DEPARTMENT OF TRADE AND INDUSTRY.Rethinking construction: the reporto f the Construction Task Force. London: Crown Copyright, 1998.

DNIT - DEPARTAMENTO NACIONAL DE INFRAESTRUTURA DE TRANSPORTES. Relatório de Gestão do Exercício de 2011. Brasília: DNIT, 2012. Disponível em: < http://www.dnit.gov.br/download/institucional/relatorio-degestao/relatorio-de-gestao-2011-vf-25-04-impresso.pdf>. Acesso em 12 mai. 2015.

DOM - Diretoria de Obras Militares do Exército Brasileiro. BIMNET EB - a rede BIM do Exército Brasileiro. Brasília: DOM, 2014. Disponível em: < http://www.dom.eb.mil.br/?page_id=316>. Acesso em 20 mai. 2015.

DOM - DIRETORIA DE OBRAS MILITARES DO EXÉRCITO BRASILEIRO. O que é OPUS. Brasília: DOM, $2015 . \quad$ Disponível em: <http://www.dom.eb.mil.br/?page_id=312>. Acesso em 10 jan. 2015.

DURAN, Mônica G.; Esteves, Ricardo G (coord.). Especificações da edificação escolar: ambientes/distribuição/mobiliário. Fundação para o Desenvolvimento da Educação, 2006.

EASTMAN, Chuck et al. BIM handbook - a guide to building information modeling for owners, managers, designers, engineers and contractors. $2^{\text {nd }}$. ed. 
New Jersey: John Wiley \& Sons, 2011.

EB - EXÉRCITO BRASILEIRO. Módulo de solicitação de obras do Sistema OPUS. In: Noticiário do Exército. Encarte do NE $n^{\circ}$ 10.536. Brasília: Centro de Comunicação Social do Exército, 2008. Disponível em: <http://www.eb.mil.br/c/document_library/get_file?uuid=a4372ae0-df64-4532-9718ab3f86577159\&groupld=16541>. Acesso em 20 mai. 2015.

EGAN, John. Foreword by John Egan. In: DEPARTMENT OF TRADE AND INDUSTRY. Rethinking construction: the reporto f the Construction Task Force. London: Crown Copyright, 1998.

ELALI, Gleice Azambuja. Processo projetual e estresse ambiental: explorando aspectos que podem influenciar a relação usuário-ambiente. In: FABRICIO, Márcio Minto; ORNSTEIN, Sheila Walbe (orgs.). Qualidade no Projeto de edifícios. $1^{\mathrm{a}}$. ed. São Carlos/Porto Alegre: RIMAIANTAC, 2010, p. 59-74.

ERDC/CERL - U. S. ARMY ENGINEER RESEARCH AND DEVELOPMENT RESEARCH CENTER/ CONSTRUCTON ENGINEERING RESEARCH LABORATORY. Construction Operations Building Information Exchange (COBie): requirements definition and pilot implementation standard. Washington: ERDC/CERL, 2007.

ESRI - ENVIRONMENTAL SYSTEMS RESEARCH INSTITUTE. Building interior space data model. ESRI, 2010. Disponível em: <downloads2.esri.com /support /TechArticles/Building_Interior_Space_Data_Model.pdf>. Acesso em 20 mai. 2015. EVO - EFFICIENCY VALUATION ORGANIZATION. International Performance Measurement and Verification Protocol-IPMVP. EVO: 2010. Disponível em: <http://www.evo-world.org/>. Acesso em 15 out. 2012.

FABRICIO, Márcio Minto. Projeto Simultâneo na construção de edifícios. Tese (doutorado). São Paulo: Escola Politécnica, Universidade de São Paulo, 2002.

FABRICIO, Márcio Minto; MELHADO, Silvio Burratino. Impactos da tecnologia da informação no conhecimento e métodos projetuais. In: Seminário de Tecnologia de Informação e Comunicação na Construção Civil, 1., 2002, Paraná, Brasil, 2002, p. 37-46.

FABRICIO, Márcio Minto; MELHADO, Sílvio Burratino. Fatores de competitividade e a Engenharia Simultânea na Construção de Edifícios. In: IV Congresso Brasileiro de Gestão e Desenvolvimento de produtos. Gramado, RS. 2003. 
FABRICIO, Márcio Minto; ORNSTEIN, Sheila Walbe; MELHADO, Silvio Burrattino. Conceitos de qualidade no projeto de edifícios. In: FABRICIO, Márcio Minto; ORNSTEIN, Sheila Walbe (orgs.). Qualidade no projeto de edifícios. $1^{\text {a }}$. ed. São Carlos/Porto Alegre: RIMA/ANTAC, 2010, p. 5-22.

FAGUNDES, J. L.; TRISKA, R.; MENDES JUNIOR, R.. A gestão da informação no contexto de gerenciamento de projetos. In: Tecnologia da Informação e Comunicação na Construção Civil - TIC. São Paulo: TIC, 2005.

FDE - FUNDAÇÃO PARA O DESENVOLVIMENTO DA EDUCAÇÃO. Roteiro para a conservação de edifícios escolares da rede pública de ensino do Estado de São Paulo. São Paulo: FDE, 2008.

FDE - FUNDAÇÃO PARA O DESENVOLVIMENTO DA EDUCAÇÃO. Catálogos técnicos sobre ambientes e distribuição; mobiliário; componentes; serviços; normas de apresentação de projetos; arquitetura e paisagismo; instalações prediais, segurança, estrutura e outros. Disponível em: <http://www.fde.sp.gov.br/PORTAL_FDE>. Acesso em 20 abr. 2014

FEIFER, L. 786: Sustainability indicators in buildings: identifying key performance indicators. In: PLEA Proceedings 2011- 27th Conference on Passive and Low Energy Architecture. BELGIUM, Louvain-la-Neuve: PLEA, 2011. p. 133-138. FERREIRA, Avany de Francisco; MELLO, Mirela Geiger de (orgs.). Arquitetura escolar paulista: estruturas pré-fabricadas. São Paulo: Fundação para o Desenvolvimento da Educação, 2006.

FERREIRA, Clarice S. C.; SALGADO, Mônica Santos. Impacto da ISO 9.001:2000 nos aspectos gerenciais dos escritórios de arquitetura: estudos de caso em empresas certificadas. Gestão e Tecnologia de Projetos, vol. 2, nº 1, maio, 2007. Disponível em: <http://www.arquitetura.eesc.usp.br/gestaodeprojetos/>. Acesso em 3 fev. 2013.

FERREIRA, Edilberto. Plano de Preparação da Base de Dados Georreferenciada de Imóveis do Exército. In: Geolivre Conference. Brasília: DOM, 2009.

FERREIRA, Sergio Leal. Da engenharia simultânea ao modelo de informações de construção (BIM): contribuição das ferramentas ao processo de projeto e produção e vice-versa. In: Workshop Brasileiro de Gestão do Processo de Projeto na Construção de Edifícios, 2007, Curitiba: Workshop Brasileiro de Gestão do Processo de Projeto na Construção de Edifícios, 2007. 
FIESP - FEDERAÇÃO DAS INDÚSTRIAS DO ESTADO DE SÃO PAULO. Construção: estimativas do investimento em obras, do PIB e do emprego. $1^{\circ}$ trimestre/2015. 02 de julho de 2015. São Paulo: FIESP, 2015. Disponível em: < http://az545403.vo.msecnd.net/uploads/2015/07/indicadores_1-tri-

2015_construbusiness.pdf>. Acesso em 03 ago. 2015.

FISCHER, Martin. Formalizing construction knowledge for concurrent performancebased design. In: Intelligent computing in engineering and architecture. $13^{\text {th }}$ EGICE Workshop, 2006. Ascona: Springer-Verlag Berlin Heidelberg, 2006, pp. 186205.

FLEMMING, Ulrich. Mismatched metaphor: user vs system model in computer-aided drafting. In: Design Studies, Volume 18 (4) Elsevier - Oct 1, 1997.

FORMOSO, Carlos Torres et al. Gestão da qualidade na Construção Civil: estratégias e melhorias de processo em empresas de pequeno porte. In: Inovação, Gestão da Qualidade \& Produtividade e Disseminação do Conhecimento na Construção Habitacional. Coletânea Habitare, v.2, 2003. Disponível em:<http://www.habitare.org.br/publicacao_coletanea2.aspx>. Acesso em 3 fev. 2013.

FRANÇA, Ana Judite Galbiatti Limongi. Ambientes contemporâneos para o ensino-aprendizagem: Avaliação Pós-Ocupação aplicada a três edifícios escolares públicos, situados na Região Metropolitana de São Paulo. Dissertação (Mestrado). São Paulo, FAUUSP: 2011.

FRANÇA, Ana Judite Galbiatti Limongi; ORNSTEIN, Sheila Walbe. Impactos da Tecnologia da Informação (TI) em ambientes escolares: o caso de três escolas públicas situadas na Região Metropolitana de São Paulo. In: I Simpósio Brasileiro de Qualidade do Projeto no Ambiente Construído e XI Workshop Brasileiro de Gestão do Processo de Projeto na Construção de Edifícios. São Carlos: Associação Nacional de Tecnologia do Ambiente Construído - ANTAC, 2009.

FRANÇA, Ana Judite Galbiatti Limongi; ORNSTEIN, Sheila Walbe. Conforto visual em salas de aula: o caso das escolas estaduais recém-construídas, situadas na Região Metropolitana de São Paulo. In: XIII Encontro Nacional de Tecnologia do Ambiente Construído. Avanços científicos e impactos da pesquisa em tecnologia do ambiente construído: como avaliar? Porto Alegre: ANTAC, 2010a, v. 1, p. 404414. 
FRANÇA, Ana Judite Galbiatti Limongi; ORNSTEIN, Sheila Walbe. Maintenance in educational facilities. Three public schools in São Paulo, Brazil. In: CIB W070 International Conference in Facilities Management. FM in the Experience Economy, 2010, São Paulo. CIB W070 Conference in Facilities Management. São Paulo: CIB International Council for Research and Innovation in Building and Construction, 2010b, v. 1, p. 697-707.

FRANÇA, Ana Judite Galbiatti Limongi; ORNSTEIN, Sheila Walbe. Técnicas de gestão da qualidade aplicadas ao diagnóstico de Avaliação Pós-Ocupação (APO). In: Encontro Nacional de Tecnologia do Ambiente Construído- ENTAC, 2014. v. 1. p. $1814-1823$.

FRANÇA, Ana Judite Galbiatti Limongi; ORNSTEIN, Sheila Walbe. Subsídios para a criação de um sistema de indicadores de desempenho em edificações. In: IV Simpósio Brasileiro de Qualidade do Projeto no Ambiente Construído - SBQP 2015. v. 1. Viçosa: ANTAC, 2015.

FRANÇA, Ana Judite Galbiatti Limongi; ORNSTEIN, Sheila Walbe; ONO, Rosária. Mapas de diagnóstico: procedimentos de Avaliação Pós-Ocupação (APO) voltados à qualidade de projeto. In: 20 Simpósio Brasileiro de Qualidade do Projeto no Ambiente Construído / X Workshop Brasileiro de Gestão do Projeto na Construção de Edifícios, 2011. Rio de Janeiro: Associação Nacional de Tecnologia do Ambiente Construído / ProArq - FAU - UFRJ, 2011. v. 1. p. 297-307.

FREITAS, Márcia Regina de; RUSCHEL, Regina Coeli. Validação de aplicativo comercial visando a inforporação da realidade aumentada a um modelo de Avaliação Pós-Ocupação. In: Ambiente Construído, v. 15, n. 2. Porto Alegre: ANTAC, 2015, pp. 97-112.

FULGENCIO, Paulo Cesar. Glossário Vade Mecum: administração pública, ciências contábeis, direito, economia, meio ambiente. Rio de Janeiro: Mauad Editora, 2007. p. 64.

GALANEZ-ÁLVAREZ, B. Project Sponsor Group Handbook. V. 2. United Kingdon: University of Oxford, 2013.

GALVÃO, Walter José Ferreira. Roteiro para diagnóstico do potencial de reabilitação para edifícios de apartamentos antigos. Tese (Doutorado) Faculdade de Arquitetura e Urbanismo da USP, 2012.

GALVÃO, Walter José Ferreira ; Ornstein, Sheila W. ; ORNSTEIN,Sheila Walbe ; 
Ono, Rosaria . A Avaliação Pós-Ocupação em empreendimentos habitacionais no Brasil: da reabilitação aos novos edifícios. In: Simone Barbosa Villa; Sheila Walbe Ornstein. (Org.). Qualidade ambiental na habitação. Avaliação Pós-Ocupação. 1 ed. São Paulo: Oficina de Textos, 2013, v. 1, p. 37-52.

GESC - Governo do Estado de Santa Catarina. Termo de referência para desenvolvimento de projetos com o uso de Modelagem da Informação da Construção - BIM. Florianópolis: Governo do Estado de Santa Catarina, 2014.

GIACAGLIA, Marcelo Eduardo; LARA, Arthur Hunold; MOURA, Norberto Corrêa da Silva. Digital manufacturing terminology in the product and the construction industries. In: Arquiteturarevista, v. 7, n. 2. São Leopoldo: UNISINOS, 2011, pp. 172-181. Disponível em: <http://revistas.unisinos.br>. Acesso em 10 dez. 2014.

GOES, Renata Heloisa Tonissi Buschenelli; SANTOS, Eduardo Toledo. Design coordination with building information modeling: a case of study. In: CIB W78-W102 2011: International Conference. Sophia Antipolis: CSTB, 2011, p.1-10.

GRAÇA. Valéria A. C. A integração dos aspectos de conforto ambiental no projeto de escolas: uso da metodologia axiomática e de exemplos simplificados. Tese (doutorado). Universidade Estadual de Campinas - UNICAMP. Faculdade de Arquitetura e Urbanismo. Campinas: 2008.

GREEN, Stuart D. The dark side of lean construction: exploitation and ideology. Proceedings IGLC. Seventh Annual Conference of thelnternational Group for Lean Construction - IGLC-7. Berkeley, 1999.

GROTTI, Thaís Molon. Aferição de instrumentos para Avaliação Pós-Ocupação: O caso das escolas de ensino fundamental e a satisfação dos alunos de menor faixa etária. São Paulo: Faculdade de Arquitetura e Urbanismo da Universidade de São Paulo e Fundação de Amparo à Pesquisa do Estado de São Paulo, 2009.

GSA - U. S. General Services Administration. The building comissioning guide. Washington: GSA Public Buildings Service, 2005.

GSA - UNITED STATES GENERAL SERVICES ADMINISTRATION. GSA BIM guide 02 - spatial program validation - appendices. Draft. Washington: GSA, 2006. Disponível em < http://www.gsa.gov/ >. Acesso em 05 jun. 2015.

GSA - UNITED STATES GENERAL SERVICES ADMINISTRATION. GSA BIM guide 01- BIM overview. Draft. Washington: GSA, 2007a. Disponível em < http://www.gsa.gov/ >. Acesso em 05 jun. 2015. 
GSA - UNITED STATES GENERAL SERVICES ADMINISTRATION. U. S. Courts design guide. Washington: Judicial Conference of the United States, 2007b. Disponível em < http://www.gsa.gov/graphics/pbs/Courts_Design_Guide_07.pdf>. Acesso em 05 jun. 2015.

GSA - UNITED STATES GENERAL SERVICES ADMINISTRATION. Statement of intention to support building information modeling with open standards. Washington: GSA, 2008. Disponivel em <http://www.gsa.gov/portal/mediald/227131/fileName/Statement_of_IntentionBIM_FINAL.action>. Acesso em 20 abr. 2015.

GSA - UNITED STATES GENERAL SERVICES ADMINISTRATION. GSA BIM guide 03 - 3D laser scanning. Draft. Washington: GSA, 2009a. Disponível em < http://www.gsa.gov/ >. Acesso em 05 jun. 2015.

GSA - UNITED STATES GENERAL SERVICES ADMINISTRATION. GSA BIM guide 04 - 4D phasing. Washington: GSA, 2009b. Disponível em < http://www.gsa.gov/ >. Acesso em 05 jun. 2015.

GSA - UNITED STATES GENERAL SERVICES ADMINISTRATION. GSA BIM guide 08 - facility management. volume 1 . Washington: GSA, 2012. Disponível em < http://www.gsa.gov/ >. Acesso em 05 jun. 2015.

GSA - UNITED STATES GENERAL SERVICES ADMINISTRATION. Background and history. Washington: GSA, 2015a. Disponível em < http://www.gsa.gov/portal/category/21354>. Acesso em 05 jun. 2015. GSA - UNITED STATES GENERAL SERVICES ADMINISTRATION. GSA BIM guide 02 - spatial program validation. Washington: GSA, 2015b. Disponível em < http://www.gsa.gov/ >. Acesso em 05 jun. 2015.

GSA - UNITED STATES GENERAL SERVICES ADMINISTRATION. GSA BIM guide 05 - energy performance. Washington: GSA, 2015c. Disponível em < http://www.gsa.gov/ >. Acesso em 05 jun. 2015.

HAINES, Mary et al. A follow-up study of effects of chronic aircraft noise exposure on child stress responses and cognition. UK: International Epidemiological Association, 2001.

HACKMAN, J. Richard; WAGEMAN, Ruth. Total quality management: empirical, conceptual, and practical issues. Administrative Science Quarterly. Vol. 40, Issue 2. June, Ithaca: Cornell University. 1995. p.309-342. 
HARTMANN, Timo. 4D models to support safe planning of hospital renovations. In: Proceedings of the CIB W78-W102 International Conference. Sophia Antipolis: CIBW, 2011, pp. 1-10.

HINO, Maurício Kenji. Qualidade do projeto de empreendimentos habitacionais de interesse social: proposta utilizando o conceito de desempenho. Boletim Técnico da Escola Politécnica da USP, Departamento de Engenharia de Construção Civil; BT/PCC/303. São Paulo: EPUSP, 2001. 20 p.

HIROTA, Ercília Hitomi; FORMOSO, Carlos Torres. Barriers to management innovations: communicating meanings.In: International Group for Lean Construction Conference, 9., 2001. ARTIGO TéCNICO, 2001, Singapore, 2001. p.379-390.

HKIBIM - HONG KONG INSTITUTE OF BUILDING INFORMATION MODELLING. BIM project specification. Rev. 3. Hong Kong: HKIBIM, 2011.

HM GOVERNMENT. Construction 2025. Industrial strategy: government and industry in partnership. London: HM Government, 2013. Disponível em: <https://www.gov.uk/government/uploads/system/uploads/attachment_data/file/2100 99/bis-13-955-construction-2025-industrial-strategy.pdf>. Acesso em 20 mai. 2015. HOFFMANN, Terry. Building automation and control systems. In: TEICHOLZ, Eric (Ed.). Technology for facility managers: the impacto f cutting-edge technology on facility management. IFMA Foundation. New Jersey: John Wiley \& Sons, Inc., 2013. HOUAISS, Antonio. Dicionário Houaiss da língua portuguesa. $2^{a}$. ed. Rio de Janeiro: Editora Objetiva, 2002.

HURTADO, Kimberly A.. BIM contract negotiation and risk allocation. AGC'S Building Information Modeling Education Program, v.4. Arlington: The Associated General Contractors of America, 2010.

HVAM, Lars. A procedure for building product models, robotics and computerintegrated manufacturing. In: Robotics and Computer-Integrated Manufacturing, v. 15. London: Elsevier, 1999, pp. 77-87.

IAM - THE INSTITUTE OF ASSET MANAGEMENT. Leveraging the relationship between BIM and asset management. Bristol: IAI, 2013. Disponível em: <http://www.theiam.org>. Acesso em 20 jun. 2015.>

IBRAHIM, Magdy; KRAWCZYK, Robert. The level of knowledge of CAD objects within the building information model. In: ACADIA22 - Connecting Crossroads of 
Digital Discourse. Muncie: Ball State University, 2003.

IFMA - International Facility Management Association. FM Glossary. IFMA, 2014a. Disponível em: <https://community.ifma.org/fmpedia/w/fmpedia/3178>. Acesso em 20 mai. 2015.

IFMA - International Facility Management Association. What is facility management. IFMA, 2014b. Disponível em: <http://www.ifma.org/about/what-isfacility-management>. Acesso em 20 mai. 2015.

ICC - International Code Council. International Plumbing Code. New Jersey: International Code Council, 2012.

IMAI, César. A participação dos usuários nos processos avaliativos: metodologias e resultados. In: VILLA, Simone Barbosa; ORNSTEIN, Sheila Walbe (orgs.). Qualidade ambiental na habitação: Avaliação Pós-Ocupação. São Paulo: Oficina de Textos, 2013.

IRWIN, Daniel. Crossrail: future-proofing railway asset management. The AGI Asset Management SIG Event. Milton Keynes, 2014.

ISHIKAWA, K.. Guide to quality control. 2nd rev. english ed. Tokyo: Asian Productivity Organization, 1982.

ISO - INTERNATIONAL ORGANIZATION FOR STANDARDIZATION. ISO 6.241. Performance standards in buildings: principles for their preparation. London: 1984. ISO - INTERNATIONAL ORGANIZATION FOR STANDARDIZATION. ISO 15.686-3. Building and constructed assets - service life planning - Part 3: Performance audits and reviews. London, 2002.

ISO - INTERNATIONAL ORGANIZATION FOR STANDARDIZATION. ISO 31.000. Risk management - principles and guidelines. London, 2009.

ISO - INTERNATIONAL ORGANIZATION FOR STANDARDIZATION. ISO 15.686-1. Building and constructed assets - service life planning - Part 1: General principles. London, 2011.

ISO - INTERNATIONAL ORGANIZATION FOR STANDARDIZATION. ISO 15.686-2.

Building and constructed assets - service life planning - Part 2: Service life prediction procedures. London, 2012.

ISO - INTERNATIONAL ORGANIZATION FOR STANDARDIZATION. ISO 16.739. Industry Foundation Classes (IFC) for data sharing in the construction and facility management industries. 2013. 
ISO - INTERNATIONAL ORGANIZATION FOR STANDARDIZATION. ISO 15.686-4. Building and constructed assets - service life planning - Part 4: Service life planning using building information modeling. London, 2014a.

ISO - INTERNATIONAL ORGANIZATION FOR STANDARDIZATION. ISO 55.000. Asset management - overview, principles and terminology. London, 2014b. ISO - INTERNATIONAL ORGANIZATION FOR STANDARDIZATION. ISO 55.001. Asset management - management systems - requirements. London, 2014c. ISO - INTERNATIONAL ORGANIZATION FOR STANDARDIZATION. ISO 55.002. Risk management - management systems - guidelines for the application of ISO 55.001. London, 2014d.

ISO/IEC - INTERNATIONAL ORGANIZATION FOR STANDARDIZATION; INTERNATIONAL ELETROTECHNICAL COMMISSION. ISO/IEC 31010. Risk Management - Risk Assessment Techniques. London, 2009.

ISSA, Maíra P. Avaliação Pós-Ocupação:procedimentos para a aplicação em escolas. Relatório Final de Iniciação Científica. São Paulo: Faculdade de Arquitetura e Urbanismo da Universidade de São Paulo e Fundação de Amparo à Pesquisa do Estado de São Paulo, 2008.

JACOSKI, Claudio Alcides; LAMBERTS, Roberto. Desenvolvimento de protótipo IFC/XML para integração da informação em projetos de edificações. In: III Workshop Brasileiro de Gestão do Processo de Projeto na Construção de Edifícios. Anais do III Workshop Brasileiro de Gestão do Processo de Projeto na Construção de Edifícios. Belo Horizonte: UFMG, 2003.

JERNIGAN, Finith. Big BIM, little BIM: the practical approach to building information modeling. Integrated practice done the right way! 2nd. ed. Salisbury: 4Site Press, 2008.

JESUS, Ana Cáudia Nascimento; CARDOSO, Francisco Ferreira. Análise crítica da implementação do PSQ - setor de obras do programa QUALIHAB. Boletim Técnico da Escola Politécnica da USP, Departamento de Engenharia de Construção Civil; BT/PCC/445. São Paulo: EPUSP, 2006. 21p.

JOSEPHSON, P. E.. Causes of defects in construction - a study of seven building projects in Sweden. Department of Management of Construction and Facilities. Chalmers University of Technology, 1998.

JURAN, Joseph Moses. The quality improvement process. In: JURAN, Joseph 
Moses (coord.). Juran`s quality control handbook. 5th ed. New York: McGraw-Hill, 1998, p. 124-196.

KARLSHØJ, Jan. Statements and Guidelines. buildingSMART, 2014. Disponível em: <http://iug.buildingsmart.org/resources/statements-and-guidelines>. Acesso em 12 mai. 2015.

KASSEM, Mohamed; LEUSIN, Sergio R. Amorim. BIM- Building Information Modeling no Brasil e na União Européia. Brasília: MDIC/MOPG, 2015. Disponível em: $\quad$ http://sectordialogues.org/sites/default/files/acoes/documentos/bim.pdf>. Acesso em 20 out. 2015.

KEADY, Robert A.. Financial impact and analysis of equpment inventories. Washington D. C.: U. S. General Services Administration, 2009.

KELLER, Chris. CAFM/IWMS - Balancing tecnology, processes and objetives. In: TEICHOLZ, Eric (Ed.). Technology for facility managers: the impacto $f$ cuttingedge technology on facility management. IFMA Foundation. New Jersey: John Wiley \& Sons, Inc., 2013.

KENDRA, Silvia. Building Information Management at the Smithsonian Institution. In: Proceedings Envirnomental Systems Research Insitute - ESRI. Kenton Williams: Smithsonian Institution, 2009.

KENDRA, Sylvia. Defining BIM for project execution. Washington: Smithsonian Institution, 2015.

KENDRA, Sylvia; HELLER, Barbara. Smithsonian Facilities: technology planning \& information management. Campus FM Technology, 2011.

KERZNER, Harold. Gerenciamento de projetos: uma abordagem sistêmica para planejamento, programação e controle. Tradução João Gama e Joyce Prado. $10^{a}$ edição norte-americana. São Paulo: Editora Blucher, 2011

KIM, Inham. Development of Open BIM based design environment for improving design productivity. In: ITM and IUG Meetings, 2014. Stockholm: buildingSMART, 2014. Disponível em:< http://iug.buildingsmart.org/resources/itm-and-iug-meetings2014-stockholm/plenarymeetings/BIM\%20Project\%20in\%20Korea_\%20InhanKim.pdf>. Acesso em 12 mai. 2015.

KIVINIEMI, Arto. Requirements management interface to building product models. CIFE Technical Report \#161. Stanford University. Stanford: CIFE, 2015. 
KOSKELA, Lauri. Application of the New Production Philosophy to construction. CIFE Technical Report n. 72. Stanford University, 1992. Disponível em: <http://www.ce.berkeley.edu/ tommelein/Koskela-TR72.pdf>. Acesso em 20 mai. 2015.

KOSKELA, Lauri. Making-do - The eighth category of waste. In: 12th Annual Conference of the International Group for Lean Construction, 3-5 August 2004, Helsingor: 2004.2 Disponível em: <http://usir.salford.ac.uk/9386/1/2004_Making_do_the_eighth_category_of_waste.pdf >. Acesso em 26 mai. 2015.

KOWALTOWSKI, Doris Catharine Cornelie Knatz. Arquitetura escolar: o projeto do ambiente de ensino. São Paulo: Oficina de Textos, 2011.

KOWALTOWSKI, Doris Catharine Cornelie Knatz; DELIBERADOR, M. S.. O processo de projeto de arquitetura escolar no Estado de São Paulo: caracterização e possibilidades de intervenção. In: $1^{\circ}$ Workshop GAE-PROLUGAR-SEL: O lugar do pátio escolar no sistema de espaços livres, 2010, Rio de Janeiro, RJ, 2010.

KOWALTOWSKI, Doris Catharine Cornelie Knatz; PIÑA, Silvia A. Mikami Gonçalves. Avaliação da funcionalidade de prédio escolar da rede pública: o caso de Campinas. In: VI Encontro Nacional e III Encontro Latino-Americano sobre Conforto no Ambiente Construído. São Pedro: ENCAC, 2001, p. 1-8.

KOWALTOWSKI, Doris Catharine Cornelie Knatz et al. Métodos e instrumentos de avaliação de projetos destinados à habitação social. In: VILLA, Simone Barbosa; ORNSTEIN, Sheila Walbe (orgs.). Qualidade ambiental na habitação: Avaliação Pós-Ocupação. São Paulo: Oficina de Textos, 2013.

KRYGIEL, Eddy; NIES, Bradley. Green BIM: Successful Sustainable Design with Building Information Modeling. $1^{\text {st }}$. ed. Indianapolis, Wiley Publishing Inc.: 2008.

KUNZ, John; FISCHER, Martin. Virtual design and construction: themes, case studies and implementation suggestions. CIFE Working Paper n ${ }^{\circ}$ 097, version 14. Stanford: Stanford Univesity, 2012.

KYMMELL, Willem. Building information modeling: planning and managing construction projects with 4D CAD and simulations. United States: The McGraw-Hill Companies, 2008.

LABAKI, L. C. et al. Indicadores de eficiência energética e conforto ambiental em escolas da rede pública de Campinas, SP. In: ENCAC 2007 - IX Encontro Nacional 
e V Latino-americano de conforto no ambiente construído, 2007, Ouro Preto: ANTAC, 2007. v. 1. p. 2112-2113.

LAINE, Tuomas ; HÄNNINEN , Reijo ; KAROLA , Antti. Benefits of bim in the thermal performance management. Building Performance Simulation Association Conference and Exhibition 10, Beijing, China, 2007.

LAY, Maria Cristina Dias; REIS, Antônio Tarcísio da Luz. O papel de espaços abertos comunais na avaliação de desempenho de conjuntos habitacionais. Ambiente Construído, Porto Alegre, v.2, n.3, p. 25- 39, 2002.

LEE, Bo-Cing, CHUANG, Tien-Hsiang, WU, I-Chen. Design and implementation of an interactive GUI for BIM systems. In: International Conference on Construction Applications of Virtual Reality. CONVR, 2011. Disponível em: < http://www2.kuas.edu.tw/prof/kwu/docs/cp024.pdf>. Acesso em 15 jan. 2015.

LEE, Chang. Towards BIM guide 2.0: the current status of BIM guides development in South Korea. In: buildingSMART International Meeting 2014. Toronto: buildingSMART, $2014 . \quad$ Disponivel em:< http://iug.buildingsmart.org/resources/international-meetings-2014-toronto/p07guidelines/bim-guides-in-korea>. Acesso em 12 mai. 2015.

LEE, Chang; SACKS, Rafael; EASTMAN, Charles M.. Specifying parametric building object behavior $(\mathrm{BOB})$ for a building information modeling system. In: Automation in Construction. v. 5. London: Elsevier B. V., 2006, pp. 758-776. Disponível em: < http://www.sciencedirect.com/science/article/pii/S0926580505001445>. Acesso em 10 mai. 2014.

LEINSTER, Frank. Mastering organization knowledge flow: how to make knowledge sharing work. Cary, North Carolina: SAS Institute Inc., 2010.

LEITE, Luiz Ricardo Pereira. APO promovidas pela prefeitura de São Paulo: estudo de caso do Programa 3R. In: VILLA, Simone Barbosa; ORNSTEIN, Sheila Walbe (orgs.). Qualidade ambiental na habitação: Avaliação Pós-Ocupação. São Paulo: Oficina de Textos, 2013.

LEITE, Fernanda et al.. Analysis of modeling effort and impact of different levels of detail in building information models. In: Automation in Construction, v. 20. London: Elsevier B. V., 2011, pp. 601-609.

LIEBICH, Thomas. IFC model implementation guide. Version 2.0. buildingSMART Model Support Group, 2009. Disponível em: <http://www.buildingsmart- 
tech.org/downloads/accompanying-

documents/guidelines/IFC2x\%20Model\%20Implementation\%20Guide\%20V2-

Ob.pdf>. Acesso em 13 mar. 2014.

LIMA, Danubia; FABRICIO, Márcio Minto; FIRMINO, Rodrigo José. Uso da tecnologia da informação e comunicação em licenciamento de projetos residenciais municipais: estudo de caso e propostas de implementação de TICs. In: III Encontro de Tecnologia de Informação e Comunicação na Construção Civil - TIC. Anais. Porto Alegre: TIC, 2007.

LISBOA FILHO, Jugurta. Projeto conceitual de banco de dados geográficos através da reutilização de esquemas, utilizando padrões de análise e um framework conceitual Tese (doutorado). Porto Alegre: Universidade Federal do Rio Grande do Sul, 2000.

LISBOA FILHO, Jugurta. Estruturação e modelagem de banco de dados (2a. ed).Curitiba: Fator GIS, 2001.

LISBOA FILHO, Jugurta; IOCHPE, Cirano. Introdução a sistemas de informa;ões geográficas com ênfase em banco de dados. In: 10 ${ }^{\text {a }}$ Escuela de Ciencias Informáticas. Departamento de Computación, Universidad de Buenos Aires, Argentina. Buenos Aires, Universidad de Buenos Aires: 1996.

LOVE, Peter E. D. et al.. A benefits realization management building information modeling framework for asset owners. In: Automation in Construction, v. 37. London: Elsevier B. V., 2014, pp. 1-10.

LOVE, Peter E. D. et al.. A systems information model for managing electrical, control, and instrumental assets. In: Built Environment Project and Asset Management. v.5, issue 3. Emerald Group Publishing Limited., 2015, pp. 278-289. Disponível em: < http://dx.doi.org/10.1108/BEPAM-03-2014-0020>. Acesso em 19 jun. 2015.

LOWE, Richard H.; MUNCEY, Jason M.. ConsensusDOCS 301 BIM Addendum. In: Construction Lawer, v. 29. $\mathrm{n}^{\circ}$ 1, winter. The American Bar Association, 2009. Disponivel em: <https://www.consensusdocs.org/News/Download/d2458cb3-5ba44e2d-bb1d-9fb400cfd2fc?name=ABA-Winter-09-ConsensusDOCS-301-BIM-

Addendum-Lowe-and-Muncey.pdf >. Acesso em 01 jun. 2015.

LUCAS, Jason; BULBUL, Taynel; THABET, Walid. A pilot model for a proof of concept healthcare facility information management prototype. In: Journal of 
Information Technology in Construction. ITcon, v. 18, PP. 67-97. Disponível em: < http://www.itcon.org/cgi-bin/works/Show?2013_5>. Acesso em 18 fev. 2015.

LUCIANO, Evandro; LUCIANO, Edimara. Contribuições da tecnologia da informação e comunicação na gestão da qualidade em empresas de construção civil. In: Tecnologia de Informação e Comunicação na Construção Civil, 2. São Paulo, SP, 2005.

MALMKVIST, Mikael. BIM in swedish transport administration -Trafikverket. In: ITM and IUG Meetings, 2013. Munich: buildingSMART, 2013. Disponível em: <http://iug.buildingsmart.org/resources/itm-and-iug-meetings-2013-munich>. Acesso em 12 mai. 2015.

MALLORY-HILL, Shauna; PREISER, Wolfgang F. E.; WATSON, Chris. Introduction to building performance evaluation: milestones in evolution. In: MALLORY-HILL, Shauna; PREISER, Wolfgang F. E.; WATSON, Chris (eds.). Enhancing Building Performance. Oxford: Blackwell Publishing Ltd., 2012.

MANZIONE, Leonardo. Proposição de uma estrutura conceitual de gestão do processo de projeto colaborativo com o uso do BIM. Tese (Doutorado) - Escola Politécnica, Universidade de São Paulo, São Paulo, 2013.

MANZIONE, Leonardo, et al.. Challenges for implementation of a new model of collaborative desing management: analyzing the impact of human factor. In: CIB W096 Proceedings. Vienna: CIB W096, 2011a, p. 256-266.

MANZIONE, Leonardo, et al. Desenvolvimento e aplicação de indicadores de desempenho na análise e melhoria da gestão do fluxo de informações do processo de projeto em BIM. In: V Encontro de Tecnologia de Informação e Comunicação na Construção. Salvador: TIC, 2011b.

MANZIONE, Leonardo; MELHADO, Silvio Burrattino. Design process maturity level: the four interfaces. In: CIB78 International Conference 2015 Proceedings. Rotterdam: CIB, 2015.

MCGRAW-HILL. The Business Value of BIM in North America. New York: MCGRAW-HILL Construction, 2012. Disponível em: <http://bimforum.org/wpcontent/uploads/2012/12/MHC-Business-Value-of-BIM-in-North-America-2007-2012SMR.pdf > . Acesso em 28 mai. 2015.

MCGRAW-HILL. The business value of BIM for construction in major global markets: how contractors around the world are driving innovation with Building 
Information Modeling. SmartMarket Report. New York: MCGRAW-HILL Construction, 2014.

MELHADO, Silvio Burrattino. O plano da qualidade dos empreendimentos e a engenharia simultânea na construção de edifícios. In: Encontro Nacional de Engenharia de Produção - ENEGEP, 19: anais. Rio de Janeiro: UFRJ/ABEPRO, 1999.

MELHADO, Silvio Burrattino. A qualidade na construção de edifícios e o tratamento das interfaces entre os sistemas de gestão dos diversos agentes. In: Encontro Nacional de Tecnologia do Ambiente Construído. 8. Salvador, 26 a 28 abril/2000. ENTAC 2000: anais (CD-ROM). Salvador: UFBA, 2000.

MELHADO, Silvio Burrattino. Gestão, cooperação e integração para um novo modelo voltado a qualidade do processo de projeto na construção de edifícios. Tese (Livre- docência). Escola Politécnica da Universidade de São Paulo. São Paulo: EPUSP, 2001.

MELHADO, Silvio Burrattino (org.). Coordenação de projetos de edificações. São Paulo: O Nome da Rosa, 2005.

MELHADO, Silvio Burrattino; MESQUITA, Maria Julia de Moraes. Gestão do ciclo de vida do empreendimento: estratégias para eficiência e eficácia com base na interface operação - concepção. In: IV Simpósio Brasileiro de Gestão e Economia da Construção. Anais. Porto Alegre, 2005, apud SANCHES, lara Del'Arco, FABRICIO, Márcio Minto. Projeto para manutenção. Anais do VIII Workshop Brasileiro. Gestão do Processo de Projetos na Construção de Edifícios, 2008. MELHADO, Silvio Burrattino; MESQUITA, Maria Julia de Moraes. Project management: towards an emphasis in conception-operation interface. In: CIB W107 Construction in Developing Economies International Symposium, 2006, Santiago. Proceedings of the CIB W107 Construction in Developing Economies International Symposium Construction in Developing Economies: New Issues and Challenges. Santiago: PUC - Chile, 2006.

MENDES, Nitton Paulo Raimundo. Modelo virtual exploratório: proposta de uma ferramenta de vendas para o mercado imobiliário residencial. Dissertação (mestrado). São Paulo: Escola Politécnica da Universidade de São Paulo, 2012. MESQUITA, Maria Julia de Moraes. Subsídios para o planejamento da qualidade em edifícios do segmento hoteleiro. Tese (Doutorado). São Paulo: Escola 
Politécnica, Universidade de São Paulo, 2007.

MESEGUER, Alvaro Garcia. Controle e garantia da qualidade na construção. São Paulo: Sinduscon, 1991.

METRÔ - COMPANHIA DO METROPOLITANO DE SÃO PAULO. Relatório de sustentabilidade. São Paulo: METRÔ, 2012. Disponível em: < http://www.metro.sp.gov.br/metro/sustentabilidade/pdf/relatorio-sustentabilidade2012.pdf>. Acesso em Acesso em 12 mai. 2015.

MOECKEL, Alexandre. Modelagem de processos de desenvolvimento em ambiente de engenharia simultânea: implementações com as tecnologias workflow e BSCW. Dissertação (mestrado). Curitiba: Centro Federal de Educação Tecnológica do Paraná (CEFET-PR), 2000.

MONTEIRO, Ari. Projeto para produção de vedações verticais em alvenaria em uma ferramenta CAD/BIM. São Paulo: Escola Politécnica da Universidade de São Paulo, 2011.

MOTA, Marco Antonio Nascimento da; RODRIGUES, Rubens. Utilização da metodologia BIM na Sede da Petrobrás em Santos. In: Autodesk University Brasil 2012. São Paulo: Autodesk, 2012.

MOTA, Marco Antonio Nascimento da. Sede da Petrobrás em Santos. In: II Seminário BIM SindusCon/SP. São Paulo, SindusCon, 2011. Disponível em: <http://www.sindusconsp.com.br/downloads/eventos/2011/bim/Rubens-

Rodrigues.pdf>. Acesso em 20 set. 2014.

NAMBU, Liliane C.. Aferição de instrumentos para a avaliação de desempenho de edifícios escolares de ensino fundamental: do programa de necessidades à pós-ocupação. Relatório Final de Iniciação Científica. São Paulo: FAUUSP/CNPq, 2010.

NASCIMENTO, Alexandre Fitzner do. Plano de Preparação da Base de Dados Georreferenciada de Imóveis do Exército. In: Geolivre Conference. Brasília: DOM, 2009.

NASCIMENTO, Alexandre Fitzner do; LÜKE, Washington Gultenberg. Gestão da informação da infraestrutura e edifições no setor público. In: III Seminário de Modelagem da Informação da Construção SindusCon SP. São Paulo: Sinduscon, 2012.

NASCIMENTO, Luiz Antonio; SANTOS, Eduardo Toledo. A contribuição da 
tecnologia da informação ao processo de projeto na construção civil. In: Workshop Brasileiro de Gestão do Processo de Projeto 1. São Carlos, SP, 2001. 5 p. NASCIMENTO, Luiz Antonio; SANTOS, Eduardo Toledo. A indústria da construção na era da informação. In: Ambiente Construído, v. 3, n. 1. Porto Alegre: ANTAC, 2003, pp. 69-81.

NEW BUILDINGS INSTITUTE. Key performance indicators for commercial buildings. $\quad \mathrm{NBI}, \quad 2014.2$ Disponível em: < http://newbuildings.org/sites/default/files/What_is_a_KPI_1.pdf>. Acesso em: 20 mar. 2015.

NIBS - NATIONAL INSTITUTE OF BUILDING SERVICES. Information exchange projects. NIBS, 2015a. Disponível em: <https://www.nibs.org/?page=bsa_infoexchange>. Acesso em 13 mai. 2015. NIBS - NATIONAL INSTITUTE OF BUILDING SERVICES. National BIM Standard - United States: transforming the building supply chain through open and interoperable information exchanges. NIBS, 2015b. Disponível em: < https://www.nationalbimstandard.org/nbims-us>. Acesso em 13 mai. 2015.

NIST - NATIONAL INSTITUTE OF STANDARDS AND TECHNOLOGY. Cost Analysis of inadequate interoperability in the U. S. Capital Facilities Industry. NIST GCR 04-867. Gaithersburg: NIST, 2004. Disponível em: < http://www.nist.gov/el/>. Acesso em 20 jun. 2015.

NONAKA, Ikujiro; TAKEUCHI, Hirotaka. Criação de conhecimento na empresa: como as empresas japonesas geram a dinâmica da inovação. Rio de Janeiro: Campus, 1997.

NOSYKO AS. Drofus administration guide. Version 1.8. Oslo: Nosyko AS, 2015. Disponível em: < http://www.drofus.no/ >. Acesso em 05 jun. 2015.

NOVASKI, Mariana. Segurança contra incêndio em edifícios escolares. Relatório final de Iniciação Científica. São Paulo: Faculdade de Arquitetura e Urbanismo da Universidade de São Paulo, Conselho Nacional de Desenvolvimento Científico e Tecnológico, 2010.

OAKLAND, John S. Statistical process control. 5th ed. Burlington: ButterworthHeinemann, 2003.

OECD - ORGANIZATION FOR ECONOMIC COOPERATION AND DEVELOPMENT. OECD Core set of indicators for environmental performance reviews. A synthesis 
report by the Group on the State of the Environment. In: Environment Monographs, n.83, 1993. Disponível em: <http:// http://indicators.ucdavis.edu/waf/biblio/oecd-coreset-indicators-environmental-performance-reviews-synthesis-report-group-state>. Acesso em: 10 mar. 2015.

OECD - ORGANIZATION FOR ECONOMIC COOPERATION AND DEVELOPMENT. OECD Glossary of statistical therms. OECD, 2008. Disponível em: <http:// stats.oecd.org/glossary/>. Acesso em: 10 mar. 2015.

OHIO DAS - OHIO DEPARTMENT OF ADMINISTRATIVE SERVICES. State of Ohio Building Information Modeling Protocol. Columbus: OHIO DAS, 2011.

OLATUNJI, Oluwole Alfred. Views on building information modelling, procurement and contract management. In: Proceedings of the Institution of Civil Engineers. Management, Procurement and Law, v. 167; issue MP3. ICE Publishing, 2014, pp. 117-126.

Disponível em: http://www.icevirtuallibrary.com/doi/abs/10.1680/mpal.13.00011?journalCode=jmapl> . Acesso em 22 jun. 2015.

OLATUNJI, Oluwole Alfred; SHER, Willy. Implications of BIM: model ownership and other matters arising. In: Proceedings of CIB W113 - Law and Dispute Resolution. $18^{\text {th }}$ CIB World Building Congress. Salford, CIBW, 2010, pp. 453-463. OLIVEIRA, Djalma de Pinho Rebouças de. Sistemas, organização e métodos: uma abordagem gerencial. 21ª . ed. São Paulo: Atlas, 2013.

OLIVEIRA, Ludmila Cabizuca Carvalho Ferreira de. Características e particularidades das ferramentas BIM: reflexos da implantação recente em escritórios de arquitetura. Dissertação (mestrado). Universidade Federal de Santa Catarina. Florianópolis, 2011.

OLIVEIRA, Otávio José de. Modelo de gestão para pequenas empresas de projeto de edifícios. 2005. Tese (doutorado) - Escola Politécnica, University of São Paulo, São Paulo, 2005.2 Disponível em: <http://www.teses.usp.br/teses/disponiveis/3/3146/tde-15062005-112500/>. Acesso em: 2015-10-06.

OMG - OBJECT MANAGEMENT GROUP. Business process model and notation (BPMN). OMG, 2011. Disponível em: < http://www.omg.org/spec/BPMN/2.0/PDF/>. Acesso em 15 fev. 2015.

OCCS - OMNICLASS CONSTRUCTION CLASSIFICATION SYSTEM. Introduction 
and user's guide. 2006. Disponível em: <http://www.omniclass.org>. Acesso em 10 set. 2012.

OCCS - OMNICLASS CONSTRUCTION CLASSIFICATION SYSTEM. Tables 11-49. OMNICLASS, 2012. Disponível em: <http:// www.omniclass.org>. Acesso em: 11 jun. 2015.

OHNUMA, Daniel Kamekichi; CARDOSO, Francisco Ferreira. Modelo de processos para a gestão de subempreiteiros: estudo de casos em empresas construtoras de edifícios. Boletim Técnico da Escola Politécnica da Usp. Departamento de Engenharia de Construção Civil, BT / PCC/441. São Paulo: Epusp, 2006. 24 p.

OPENBIM. OpenBIM Network. United Kingdom, 2012. Disponível em <http://www.openbim.org>. Acesso em 15 jan. 2015.

ORNSTEIN, Sheila Walbe. Desempenho do ambiente construído, interdisciplinaridade e arquitetura. São Paulo: Faculdade de Arquitetura e Urbanismo da USP, 1996.

ORNSTEIN, Sheila Walbe et al. Performance evaluation of a psychiatric facility in São Paulo, Brasil. Facilities, v. 27, p.152-167, London, 2006.

ORNSTEIN, Sheila Walbe et al. Improving the quality of school facilities through building performance assessment: Educational Reform and School Building Quality in Sao Paulo, Brazil. In: Journal of Educational Administration, v. 47, 2009, p. 350-367.

ORNSTEIN, Sheila Walbe et al. Post-Occupancy Evaluation in Brazil. Its impact on professional practice. In: Shauna Mallory-Hill; Wolfgang F.E. Preiser; Chris Watson. (Org.). Enhancing Building Perfomance. 1 ed. New York: Wiley-Blackwell, 2012, v. 1, p. 247-258.

ORNSTEIN, Sheila Walbe; MOREIRA, Nanci Saraiva. Evaluating school facilities in Brazil. In: PEB Exchange, n. ${ }^{\circ} 62$, February. Paris: Organisation for Economic and Co-Operation Development [OECD], 2008, p. 1-7. Disponível em: <http://www.oecd.org/searchResult/>. Acesso em 20 jun. 2009.

ORNSTEIN, Sheila Walbe; ONO, Rosaria. Post-Occupancy Evaluation and design quality in Brazil: concepts, approaches and an example of application. Architectural engineering and design management, v. 6, p. 48-67, 2010.

OWEN et al.. Challenges for integrated design and delivery solutions. Architectural Engineering and Design Management. Special Issue: Integrated Design and 
Delivery Solutions. pp. 232-240, 2010. Disponível em: < http://www.tandfonline.com/doi/abs/10.3763/aedm.2010.IDDS1\#.ViffqCvAFhF>. Acesso em 26 mai. 2015.

OXMAN, Rivka. Performance based Design: Current Practices and Research Issues. In: IJAC International Journal of Architectural Computing. Vol. 6 Issue 1 pp. 1-17. 2008.

OXMAN, Rivka. Theory and Design in the First Digital Age. In: Design Studies, Vol. 27 No. 3 pp. 229 - 265. 2006.

OZAN, Onder Ozener; CLAYTON, Mark J.; NOME, Carlos Alejandro. BIM to CAFM: An investigation of Adapting a Building Information Model to a Legacy Computer Aided Facility Management. In: CIB W78 25th International Conference on Information Technology in Construction. São Paulo, 2009.

PALERMO, Carolina. Avaliação da qualidade no projeto de HIS: uma parceria com a Cohab/SC. In: VILLA, Simone Barbosa; ORNSTEIN, Sheila Walbe (orgs.). Qualidade ambiental na habitação: Avaliação Pós-Ocupação. São Paulo: Oficina de Textos, 2013.

PANIZZA, Alexandre; RUSCHEL, Regina. Avaliação da competência para colaboração em cad associada à utilização da tecnologia da informação no desenvolvimento do projeto. Tecnologia de Informação e Comunicação na construção Civil 2, São Paulo, SP, 2005. 10 p.

PMI - PROJECT MANAGEMENT INSTITUTE. A guide to the project management body of knowledge. PMBOK Guide, $4^{\text {th }}$. ed. Pennsylvania: PMI, 2008.

POCOCK, James B.; LIU, Liang Y.; KIM, Michael K.. Impact of management approach on project interaction and performance. In: Journal of construction engineering and management. v. 123, Issue 4, p. 441-418, United States: American Society of Civil Engineers, 1997.

POLTRONIERI, Julyane P. Procedimentos para a avaliação de desempenho das etapas de planejamento e de projeto de escolas do ensino fundamental e médio. Relatório final de Iniciação Científica. São Paulo: Faculdade de Arquitetura e Urbanismo da Universidade de São Paulo, Conselho Nacional de Desenvolvimento Científico e Tecnológico, 2008.

PREISER, Wolfgang F. E.; VISCHER, Jacqueline C.. In: PREISER, Wolfgang F. E.; VISHER, Jacqueline C. (eds.). Evolution of building performance evaluation: an 
introduction. Assessing building performance. Oxford: Elseviser ButterworthHeinemann, 2005, p. 3-14.

PREISER, Wolfgang Friedrich Ernst (ed.). Building evaluation. New York: Plenum Press, 1989.

PREISER, Wolfgang Friedrich Ernst; SCHRAMM, Ulrich. A conceptual framework for building performance evaluation. In: PREISER, Wolfgang Friedrich Ernst; VISCHER, Jacqueline C.(eds.). Assessing building performance. Oxford: Elseviser Butterworth-Heinemann, 2005, cap. 2, p. 15-26.

REINHARDT, Jan; WIDLEY, Jonathan. BIM process, adoption, and integration. AGC'S Building Information Modeling Education Program, v.4. Arlington: The Associated General Contractors of America, 2010.

RHEINGANTZ, Paulo Afonso. Abordagem experiencial, qualidade do projeto, qualidade do lugar e cultura na atualidade. In: FABRICIO, Márcio Minto; ORNSTEIN, Sheila Walbe (orgs.). Qualidade no projeto de edifícios. $1^{a}$ ed. São Carlos/Porto Alegre: RIMA/ANTAC, 2010, p. 60-75.

RIBA - ROYAL INSITUTE OF BRITISH ARCHITECTS. BIM overlay to the RIBA outline plan of work. London: RIBA Publishing, 2012.

RIST, Tobin. A path to BIM-based LCA for whole-buildings. Master thesis. Norwegian University of Science and Technology (NTNU). Department of Civil and Tranport Engineering. Trondheim: NTNU, 2011.

RODRIGUES, Rubens. A modelagem tridimensional na Petrobrás. In: II Seminário BIM SindusCon/SP. São Paulo, SindusCon, 2011. Disponível em: <http://www.sindusconsp.com.br/downloads/eventos/2011/bim/RubensRodrigues.pdf>. Acesso em 20 set. 2014.

ROE, Adrew; REINA, Peter. Learnng to share is tougher than anyone anticipated. Industry fragmentation impedes automantion. In: Engineering News Record. 247. New York: MCGRAW-HILL Construction, 2001. Disponível em: < http://enr.construction.com/features/technologyEconst/archives/010813c.asp>.

Acesso em: 28 mai. 2015.

ROMAN, Humberto; BONIN, Luis Carlos (eds.). Normalização e certificação na construção habitacional. Coleção Habitare. Porto Alegre: Associação Nacional de Tecnologia do Ambiente Construído, 2003.

ROMANO, Fabiane Vieira. Modelo de referência para o gerenciamento do 
processo de projeto integrado de edificações. Tese (doutorado). Florianópolis Universidade Federal de Santa Catarina, 2003.

ROMERO, Juliana Maria; SCHEER, Sérgio. Potencial da implementação da BIM no processo de aprovação de projetos de edificação na Prefeitura Municipal de Curitiba. In: IX Workshop Brasileiro de Gestão do Processo de Projeto na Construção de Edifícios. Simpósio Brasileiro de Qualidade de Projeto no Ambiente Construído - SBQP. São Carlos: EESCUSP, 2009.

ROMÉRO, Marcelo de Andrade; ORNSTEIN, Sheila Walbe (eds.). Avaliação PósOcupação: métodos e técnicas aplicadas à habitação social. Porto Alegre: Associação Nacional de Tecnologia do Ambiente Construído, 2003.

RUSCHEL, Regina Coeli et al. Building Information Modeling para projetistas. In: FABRICIO, Márcio Minto; ORNSTEIN, Sheila Walbe (orgs.). Qualidade no Projeto de edifícios. $1^{a}$. ed. São Carlos/Porto Alegre: RIMA/ANTAC, 2010, p. 137-162.

SABOL, Louise A.. Building information modeling. In: TEICHOLZ, Eric (Ed.). Technology for facility managers: the impacto f cutting-edge technology on facility management. IFMA Foundation. New Jersey: John Wiley \& Sons, Inc., 2013.

SABOL, Louise. Supporting project reviews and delivery. Smithsonian Institution, 2015.

SALES, Adriano de Alencar; RUSCHEL, Regina Coeli. BIM no suporte à Avaliação Pós-Ocupação. In: XV Encontro Nacional de Tecnologia do Ambiente Construído - ENTAC 2014 - Anais. Maceió: ANTAC, 2014, pp. 1773-1783.

SALGADO, Mônica Santos. Arquitetura centrada no usuário ou no cliente? Uma relfexão sobre a qualidade do projeto. In: FABRICIO, Márcio Minto; ORNSTEIN, Sheila Walbe (orgs.). Qualidade no Projeto de edifícios. $1^{\text {a }}$. ed. São Carlos/Porto Alegre: RIMA/ANTAC, 2010a, p. 23-33.

SALGADO, Mônica Santos. Implementation of a quality management system in architecture offices: case studies at Rio de Janeiro. Proceedings of CIB W070 Facilities Management and Assets Maintenance. São Paulo: CIB W070, 2010b.

SANTOS, Luiz Augusto dos; MELHADO, Silvio Burrattino. Diretrizes para elaboração de planos da qualidade em empreendimentos da construção civil. In: Boletim Técnico da Escola Politécnica da USP, Departamento de Engenharia de Construção Civil; BT/PCC/377. São Paulo: EPUSP, 2004.

SÃO PAULO (Estado). Resolução SS n. 493 de 08 de setembro de 1994. Aprova 
norma técnica que dispõe sobre a elaboração de projetos de edificação de escolas de $1^{\circ}$ e $2^{\circ}$ graus no âmbito Estado de São Paulo. São Paulo: Secretaria do Estado da Saúde, 1994.

SÃO PAULO (Estado). Decreto Estadual n. 46.076 de 31 de agosto de 2001. Regulamento de segurança contra incêndio das edificações e áreas de risco, Corpo de Bombeiros da Polícia Militar do Estado de São Paulo. São Paulo: Polícia Militar do Estado de São Paulo, 2001. Disponível em: <http://www.ccb.polmil.sp.gov.br>. Acesso em 1 dez. 2008.

SÃO PAULO (Estado). Instruções Técnicas 1-22. São Paulo:Polícia Militar do Estado de São Paulo, 2004. Disponível em: <http://www.ccb.polmil.sp.gov.br>. Acesso em 1 dez. 2008.

SÃO PAULO (Município). Código de obras e edificações - COE. LEI n. ${ }^{\circ}$ 11.228/92. D.O.M.: Diário Oficial do Município, 23 de setembro de 1992.

SCHEER, Sergio et al.. Collaborative CAD modeling process analysis to support teamwork for building design. In: Gestão e Tecnologia de Projetos, v. 4, $n^{\circ} 1$. Porto Alegre: ANTAC, 2009, pp.124-135.

SCHEER , Sérgio; et al. Impactos do uso do sistema CAD geométrico e do uso do sistema CAD-BIM no processo de projeto em escritórios de arquitetura. In: Workshop Brasileiro de Gestão do Processo de Projetos na Construção de Edifícios 7. Curitiba, PR, 2007. 7 p.

SCHEER, Sergio; AYRES FILHO, Cervantes Gonçalves. Abordando BIM em níveis de modelagem. In: IX Workshop Brasileiro de Gestão do Processo de Projeto na Construção de Edifícios. Simpósio Brasileiro de Qualidade de Projeto no Ambiente Construído - SBQP. São Carlos: EESCUSP, 2009.

SCHEER, Sérgio; BOLLMANN, Caroline; STUMM, Silvana B.. Engenharia colaborativa: uma visão para a engenharia simultânea e o uso de ambientes colaborativos para arquitetura e engenharia civil. In: Seminário de Tecnologia da Informação e Comunicação na Construção Civil, 2., 2005, SÃO PAULO, SP, 2005, São Paulo, SP, 2005. 1 CD-ROOM.

SCHLEUSNER, Greg. IFC in design. In: Journal of the National Institute of Building Sciences, v. 2, ${ }^{\circ} 3$. Washington: NIBS, 2014, pp. 21-24.

SEBASTIAN, Rizal. Breaking through the business and legal barriers of the open collaborative processes based on Building Information Modeling (BIM). In: 
Proceedings of CIB W113 - Law and Dispute Resolution. $18^{\text {th }}$ CIB World Building Congress. Salford, CIBW, 2010, pp.166-186.

SECOVI/SP - SINDICATO DAS EMPRESAS DE COMPRA, VENDA, LOCAÇÃO E ADMINISTRAÇÃO DE IMÓVEIS RESIDENCIAIS E COMERCIAIS DE SÃO PAULO. Manuais de escopo para a contratação de projetos e serviços para a indústria imobiliária. 14 volumes. São Paulo: SECOVI/SP, 2006. Disponível em: <http://www.manuaisdeescopo.com.br/Manuais>. Acesso em 20 out. 2015.

SEDERA, Darshana, ROSEMANN, Michael, GABLE, Guy. Using performance measurement models for benefit realization with enterprise systems - the Queensland Gonvernment approach (case study). In: Proceedings of The $\mathbf{9}^{\text {th }}$ European Conference on Information Systems. Bled: Global Co-Operation In the New Millenium, 2001, pp. 837-847.

SENATE PROPERTIES. BIM Requirements. V. 7. Finland, Senate Properties, 2007. Disponível em:

http://www.tocoman.com/sites/default/files/webfm/user/BIM_2007_Vol_7_Quantity_ta ke-off_R1_0.pdf>. Acesso em 12 mai. 2015.

SERAPIÃO, Fernando. Estrutura pré-fabricada marca nova etapa das escolas paulistas: metal e PVC também são novidade. In: ProjetoDesign. São Paulo: Arco Editorial, out. 2004, p. 58-59.

SI - SMITHSONIAN INSTITUTION. Building Information Modeling practice development for the Smithsonian Institution. Design + Construction Strategies. Smithsonian Institution, 2014.

SI - SMITHSONIAN INSTITUTION. Smithsonian BIM execution plan, v.1. Smithsonian Institution, 2015.

SILVA, Maria Angélica Covelo; SOUZA, Roberto de. Gestão do processo do projeto de edificações. São Paulo: O Nome da Rosa, 2003.

SILVA, Vanessa Gomes. Indicadores de sustentabilidade de edifícios: estado da arte e desafios para desenvolvimento no Brasil. In: Revista Ambiente Construído. Porto Alegre: ANTAC, 2007; v. 7, n. 1. p.47-66.

SOUZA, Livia L. Alves; AMORIM, Sérgio R. Leusin; LYRIO, Arnaldo de Magalhães. Impactos do Uso do BIM em estricórios de arquitetura: oportunidades no mercado imobiliário. In: Gestão da Tecnologia de Projetos; v. 4, n² 2, novembro de 2009. 
SOUZA, Flávia; MELHADO, Silvio. A importância do sistema de informação para a gestão das empresas de projeto. In: Gestão \& Tecnologia de Projetos 2008; v. 3, 2008. Disponível em: <http://www.iau.usp.br/gestaodeprojetos/>. Acesso em jan. 2015

SSI - SWEDISH STANDARDS INSTITUTE. Bygghandlingar 90: byggsektorns rekommendationer för redovisning av byggprojekt. Stockholm : SIS Förlag $A B$, Swedish Standards Institute, 2008.

STATSBYGG. Statsbygg Building Information Modelling Manual. Version 1.2.1. Oslo: Statsbygg, 2013. Disponível em: < http://www.statsbygg.no/Files/publikasjoner/manualer/StatsbyggBIM-manual-ver1-21eng-2013-12-17.pdf>. Acesso em 22 abr. 2015.

SUCCAR, Bilal. Building information modelling framework: A research and delivery foundation for industry stakeholders. In: Automation in Construction, 18(3), London: Elsevier B. V., 2009, pp. 357-375.

SUCCAR, Bilal. Building Information Modelling Maturity Matrix. In: UNDERWOOD, Jason; ISIKDAG, Umit (eds.). Handbook of Research on Building Information Modelling and Construction Informatics: Concepts and Technologies: Information Science Reference, IGI Publishing, 2010a.

SUCCAR, Bilal. The Five Components of BIM Performance Measurement. In: 2010 CIB World Congress. Salford, United Kingdom, 2010b.

SUCCAR, Bilal; SHER W.; WILLIAMS A.. An integrated approach to BIM competency assessment, acquisition and application. In: Automation in Construction. Australia, 2013.

SULLIVAN, Kenneth T. Quality Management Programs in the Construction Industry: Best Value Compared with Other Methodologies.Journal of Management in Engineering.American Society of Civil Engineers. p. 210-219. ASCE, 2011.

TANG, Llewellyn et al.. Overload of information or lack of high value information: lessons learnt from construction. In: Proceedings of the $9^{\text {th }}$ European Conference on knowledge Mangement and Evaluation. Southampton: ECKM, 2008.

TAYLOR, Malcolm. Crossrail: a case study in BIM. In: Lake Constance 5D Conference. Constance: Hochschule Konstanz University of Applied Sciences, 2013. Disponível em: <http://www.5d-initiative.eu/Inhalte/Crossrail.pdf>. Acesso em 22 set. 2015. 
TAYLOR, Malcolm. Crossrail and the world of BIM. In: Construction Manager. The Chartered Institute of Building - ClOB, 2014a. Disponível em: < http://www.construction-manager.co.uk/client_media/pdfcontent/July_CM.pdf>. Acesso em 13 jun. 2015.

TAYLOR, Malcolm. Special fetaure: BIM the Crossrail way. In: BIM Today. Cheshire: Adjacent Digital Politics Ltda., 2014b.

TAYLOR, Malcolm. Moving London Forward. Crossrail: a case study in project information management. In: GeoBIM Geospatial World Forum. Lisboa: Geospatial World $2015 . \quad$ Forum, Disponível <http://www.geospatialworldforum.org/speaker/SpeakersImages/Malcolm\%20Taylor. pdf>. Acesso em 22 set. 2015.

TEICHOLZ, Eric (Ed.). Geographic Information Systems (GIS) for facility management. Houston: IFMA Foundation, 2010.

TEICHOLZ, Eric (Ed.). Technology for facility managers: the impact of cuttingedge technology on facility management. IFMA Foundation. New Jersey: John Wiley \& Sons, Inc., 2013.

THOMAZ, Ercio. Tecnologia, gerenciamento e qualidade na construção. São Paulo: Editora Pini, 2001.

THOMAZONI, Andrea D'Angelo Leitner et al. Avaliação Pós-Ocupação da E. E. Hélio Helene (União de Vila Nova III). São Paulo: Faculdade de Arquitetura e Urbanismo da Universidade de São Paulo, 2007. (trabalho final para a disciplina de pós-graduação AUT 5805).

TOBIN, John. Proto-Building: To BIM is to build. 28 mai. 2008. Disponível em: <http://www.aecbytes.com/buildingthefuture/2008/ProtoBuilding.html>. Acesso em: 19 de ago. 2013.

TZORTZOPOULOS, Patrícia; FORMOSO, Carlos Torres. Modelo de gestão do processo de desenvolvimento de produto na construção habitacional. In: Inovação, Gestão da Qualidade \& Produtividade e Disseminação do Conhecimento na Construção Habitacional. Coletânea Habitare, v.2, 2003. Disponível em:<http://www.habitare.org.br/publicacao_coletanea2.aspx>. Acesso em 3 fev. 2013.

UE - UNIÃO EUROPEIA. Regulamento (EU) N³05/2011 do Parlamento Europeu e do Conselho. In: Jornal Oficial da União Européia. Luxemburgo: EUR-Lex, 2011. 
Disponível

em:

http://eur-lex.europa.eu/legal-

content/en/TXT/?uri=CELEX:32011R0305>. Acesso em 20 mai. 2015.

UE - UNIÃO EUROPEIA. Diretiva 2014/24/EU do Parlamento Europeu e do Conselho, de 26 de fevereiro de 2014, relatiova aos contratos públicos e que revoga a Diretiva 2004/18/CE . In: Jornal Oficial da União Européia. L 94. Luxemburgo: EUR-Lex, 2014. Disponível em: <http://eur-lex.europa.eu/legalcontent/pt/TXT/PDF/?uri=OJ:L:2014:094:FULL\&from=pt>. Acesso em 20 mai. 2015. USC - UNIVERSITY OF SOUTHERN CALIFORNIA. Building Information modeling (BIM) guidelines. Version 1.6. Los Angeles: USC Capital Construction Development and Facilities Management Services, 2012.

USGBC - UNITED STATES GREEN BUILDING COUNCIL. LEED 2009 Reference Guide for New Construction and Major Renovation. USGBC, 2009.

VA - DEPARTMENT OF VETERANS AFFAIRS. The VA BIM guide. Washington DC: U. S. Department of Veterans Affairs, 2010. Disponível em: <http://www.cfm.va.gov/til/bim/BIMguide/downloads/VA-BIM-Guide.pdf>. Acesso em 20 abr. 2014.

VILLA, Simone Barbosa. Multimétodos em Avaliação Pós-Ocupação e sua aplicabilidade para o mercado imobiliário habitacional. In: VILLA, Simone Barbosa; ORNSTEIN, Sheila Walbe (orgs.). Qualidade ambiental na habitação: Avaliação Pós-Ocupação. São Paulo: Oficina de Textos, 2013.

VOLK, Rebeca; STENGEL, Julian, SCHULTMANN, Frank. Building information modeling (BIM) for existing buildings - literature review and future needs. In: Automation in Construction, n. 38, 2014, pp 109-127.

VOORDT, Theo M. Van der; WEGEN, Herman B. Van. Architecture in use: an introduction to the programming, design and evaluation of buildings. The Neederlands: THTHO Publishers, 2005.

WITTS JR., William. Roles of geographic information systems in facility management. In: TEICHOLZ, Eric (Ed.). Technology for facility managers: the impact of cuttingedge technology on facility management. IFMA Foundation. New Jersey: John Wiley \& Sons, Inc., 2013.

WIX, Jeff; KARLSHØJ, Jan. Information delivery manual: guide to components and development methods. Revised by Jan Karlshøj. buildingSMART International, 2010. 
<http://iug.buildingsmart.org/idms/development/IDMC_004_1_2.pdf>. Acesso em 13 mar. 2014.

WIX, Jeffrey. Quick guide to Business Process Modeling Notation. buildingSMART, 2007. Disponível em: < http://iug.buildingsmart.org/idms/methodsand-guides/QuickGuideToBPMN.pdf/view>. Acesso em 15 fev. 2015.> WOODHOUSE; John. Setting a good standard in asset management. In: Assets. The Institute of Asset Management Magazine. March, 2011. Disponível em: <https://theiam.org>. Acesso em 15 jan. 2015.

YAMASHITA, Jun-ichi et al.. Japan Chapter Status Report. Report for Toronto Meetings. In: buildingSMART International Meeting 2014. Toronto: buildingSMART, $2014 \quad$ Disponivel em:< http://iug.buildingsmart.org/resources/international-meetings-2014-toronto/chapterreports/chapter-report-japan>. Acesso em 12 mai. 2015.

YIN, Robert K. Estudo de caso: planejamento e métodos. Tradução Daniel Grassi. $3^{\mathrm{a}}$ ed. Porto Alegre: Bookman, 2005.

ZANCHETTA, Carlo et al.. II performance based building design per La qualità edilizia: dalla normalizazione alla LEAN construction. In: Journal of Technology for Architecture and Environment -Techne. Journal of SITdA - Società Italiana della Tecnologia dell'Architettura. Issue 8. Firenze: Firenze University Press, 2014, pp. 6269.

ZEGARRA, Sofía Lilianne Villagarcía ; CARDOSO, Francisco Ferreira. Gestão de materiais em empresas construtoras de edifícios: gestão dos fluxos de informações. In: Boletim Técnico da Escola Politécnica da USP, Departamento de Engenharia de Construção Civil; BT/PCC/280. São Paulo: EPUSP, 2001. 


\section{WEBSITES}

ANTAC - ASSOCIAÇÃO NACIONAL DE TECNOLOGIA DO AMBIENTE CONSTRUÍDO. Disponível em: <http://www.antac.org.br/>. Acesso em 15 dez. 2015. BPMN - BUSINESS PROCESS MODEL AND NOTATION. Disponível em: http://www.bpmn.org>. Acesso em 21 fev. 2015.

BUILDINGSMART. Disponível em: <http://www.buildingsmart-tech.org/>. Acesso em 6 ago. 2015.

BUSINESS PROCESS MODELING NOTATION. Disponível em: <www.BPMN.org>. Acesso em 5 mar. 2014.

CPIC - CONSTRUCTION PROJECT INFORMATION COMITEE. Disponível em: < http://www.cpic.org.uk>. Acesso em 21 jan. 2015.

CROSSRAIL. Disponível em: <http://www.crossrail.co.uk/>. Acesso em 22 set. 2015. EVO - EFFICIENCY VALUATION ORGANIZATION. Disponível em: <http://www.evo-world.org/>. Acesso em 15 out. 2012.

FUNDAÇÃO PARA O DESENVOLVIMENTO DA EDUCAÇÃO. Disponível em: $<$ http://fde.sp.gov.br>. Acesso em 20 abr. 2014.

GRUPO DE PESQUISA QUALIDADE E DESEMPENHO NO AMBIENTE CONSTRUÍDO.

Disponível

em:

<http://dgp.cnpq.br/buscaoperacional/detalhegrupo.jsp?grupo=0067604LW6DNHQ>. Acesso em 19 out. 2014.

NUTAU - NUCLEO DE PESQUISA EM TECNOLOGIA DA ARQUITETURA E URBANISMO DA UNIVERSIDADE DE SÃO PAULO. Disponível em: <http://www.usp.br/nutau/nutau.html>. Acesso em 15 dez. 2015.

OMNICLASS CONSTRUCTION CLASSIFICATION SYSTEM. Disponível em: $<$ http://www.omniclass.org>. Acesso em 21 set. 2015.

ORGANISATION FOR ECONOMIC CO-OPERATION AND DEVELOPMENT. Disponível em:<http://www.oecd.org/>. Acesso em 2 fev. 2015.

REDE BIM BRASIL. Disponível em: <www.redebimbrasil.org>. Acesso em 13 set. 2015.

WBDG - WHOLE BUILDING DESIGN GUIDE. Disponível em: <https://www.wbdg.org/>. Acesso em 22 set. 2015. 


\section{APÊNDICES}


APÊNDICE A - LISTA DE PROPRIEDADES CONFIGURADAS PARA A FICHA DE AMBIENTE NA PLATAFORMA DE BANCO DE DADOS

As seguintes informações foram modeladas para a composição da ficha de ambiente:

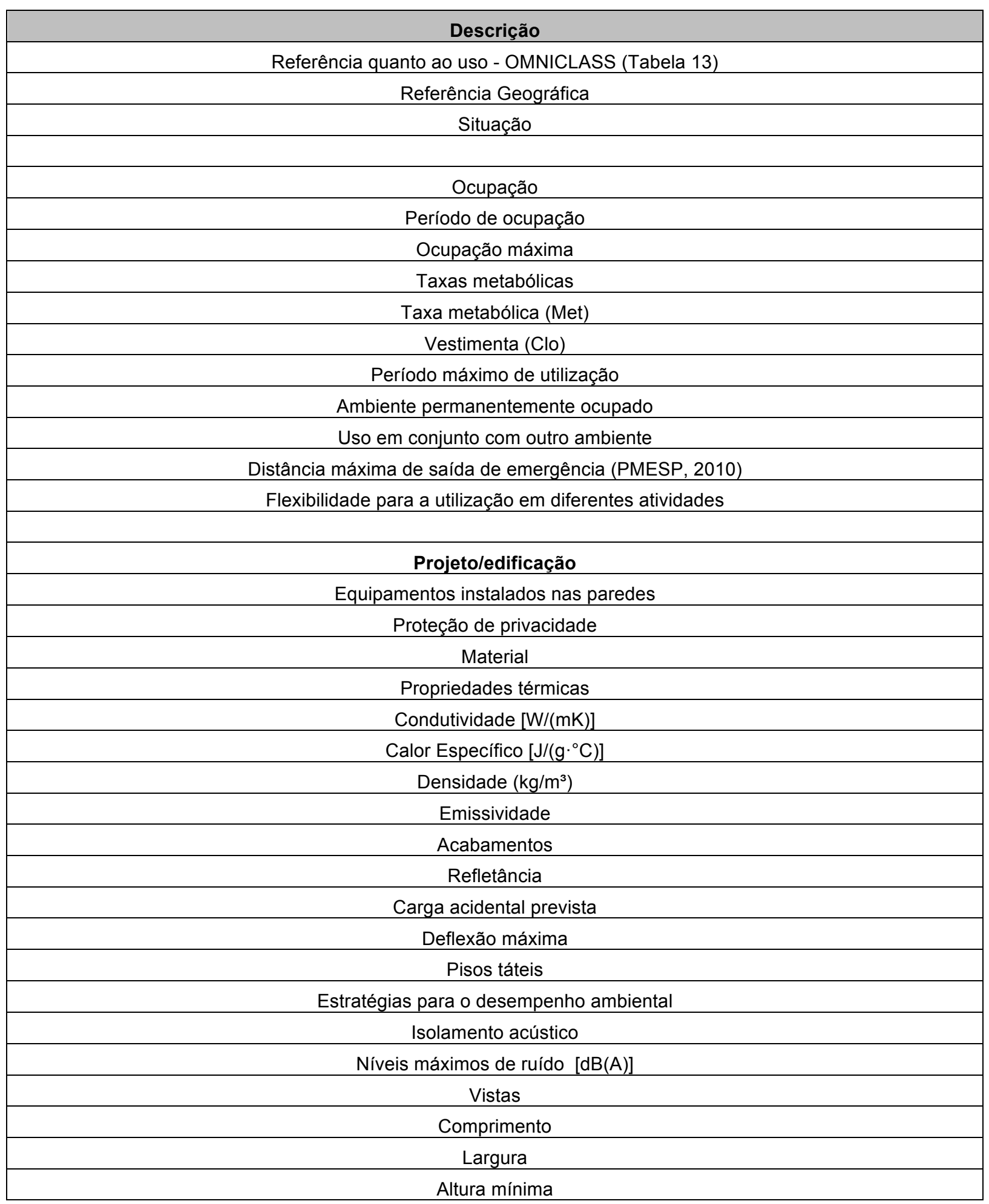




\begin{tabular}{|c|}
\hline Área mínima de iluminação natural \\
\hline Dispositivo para controle de ofuscamento \\
\hline Área mínima de ventilação \\
\hline Taxas mínimas de renovação de ar, em áreas ocupadas \\
\hline $\begin{array}{l}\text { Taxa de renovação de ar, considerando a área do ambiente }\left(\mathrm{L} / \mathrm{s}^{*} \mathrm{~m}^{2}\right) \text { [ASHRAE 62.1:2013 (ANS } \\
\text { 2013a] }\end{array}$ \\
\hline $\begin{array}{l}\text { Taxa de renovação de ar, considerando a ocupação do ambiente (L/s*pessoa) [ASHRAE } 62 . \\
\text { (ANSI/ASHRAE, 2013a)] }\end{array}$ \\
\hline Requisitos de conforto térmico \\
\hline Quantidade mínima de horas na Zona de Conforto (\%/ano) [ASHRAE 55.1:2004 (ANSI/ASHR/ \\
\hline Janelas e portas \\
\hline Vão mínimo de porta [NBR 9050:2015 (ABNT, 2015)] \\
\hline Tipo de abrertura de porta \\
\hline Vidros nas portas \\
\hline Soleiras inclinadas \\
\hline Proteção \\
\hline Mecanismo de travamento \\
\hline Mecanismo de fechamento \\
\hline direção da abertura \\
\hline Material da porta \\
\hline Porta de segurança \\
\hline Porta de baia de sanitário \\
\hline Iluminação natural \\
\hline Sem janelas \\
\hline Pode se aberta ou fechada \\
\hline Requisitos do mecanismo de abertura da janela \\
\hline Controles de incidência solar \\
\hline Cortinas/persianas \\
\hline Parapeito \\
\hline Altura mínima do parapeito \\
\hline Barras de proteção/segurança \\
\hline Material da estrutura \\
\hline Especificação do vidro \\
\hline Tomada simples - Fornecimento normal de energia \\
\hline Fornecimento prioritário, em caso de falta de energia \\
\hline Eletrocalhas acessíveis \\
\hline Suprimento de energia \\
\hline Tomada de eletricidade NBR 14136 (ABNT, 2002) 2P+T, Altura: 0,40 m, $10 \mathrm{~A} / 110 \mathrm{~V}$ \\
\hline Tomada de eletricidade NBR 14136 (ABNT, 2002) 2P+T, Altura: 0,40 m, 20 A/220V \\
\hline Tomada de eletricidade NBR 14136 (ABNT, 2002) 2P+T, Altura: $1.10 \mathrm{~m}, 10 \mathrm{~A} / 110 \mathrm{~V}$ \\
\hline Tomada de eletricidade NBR 14136 (ABNT, 2002) 2P+T, Altura: 1,10 m, $20 \mathrm{~A} / 110 \mathrm{~V}$ \\
\hline Tomada de eletricidade NBR 14136 (ABNT, 2002) 2P+T, Altura: 1,10 m, $20 \mathrm{~A} / 220 \mathrm{~V}$ \\
\hline Tomada de eletricidade NBR 14136 (ABNT, 2002) 2P+T, Altura: $2.20 \mathrm{~m}, 10 \mathrm{~A} / 110 \mathrm{~V}$ \\
\hline
\end{tabular}




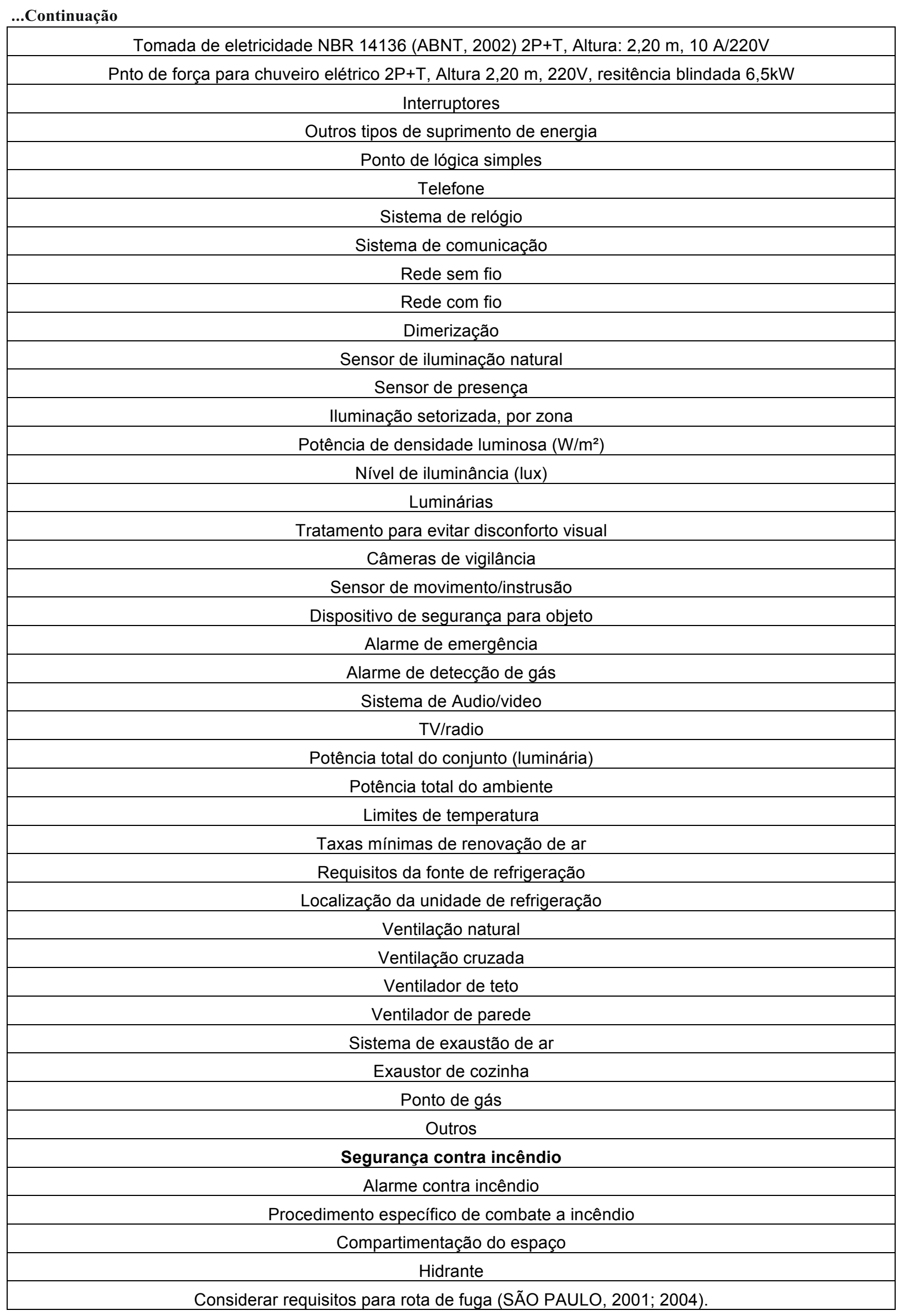




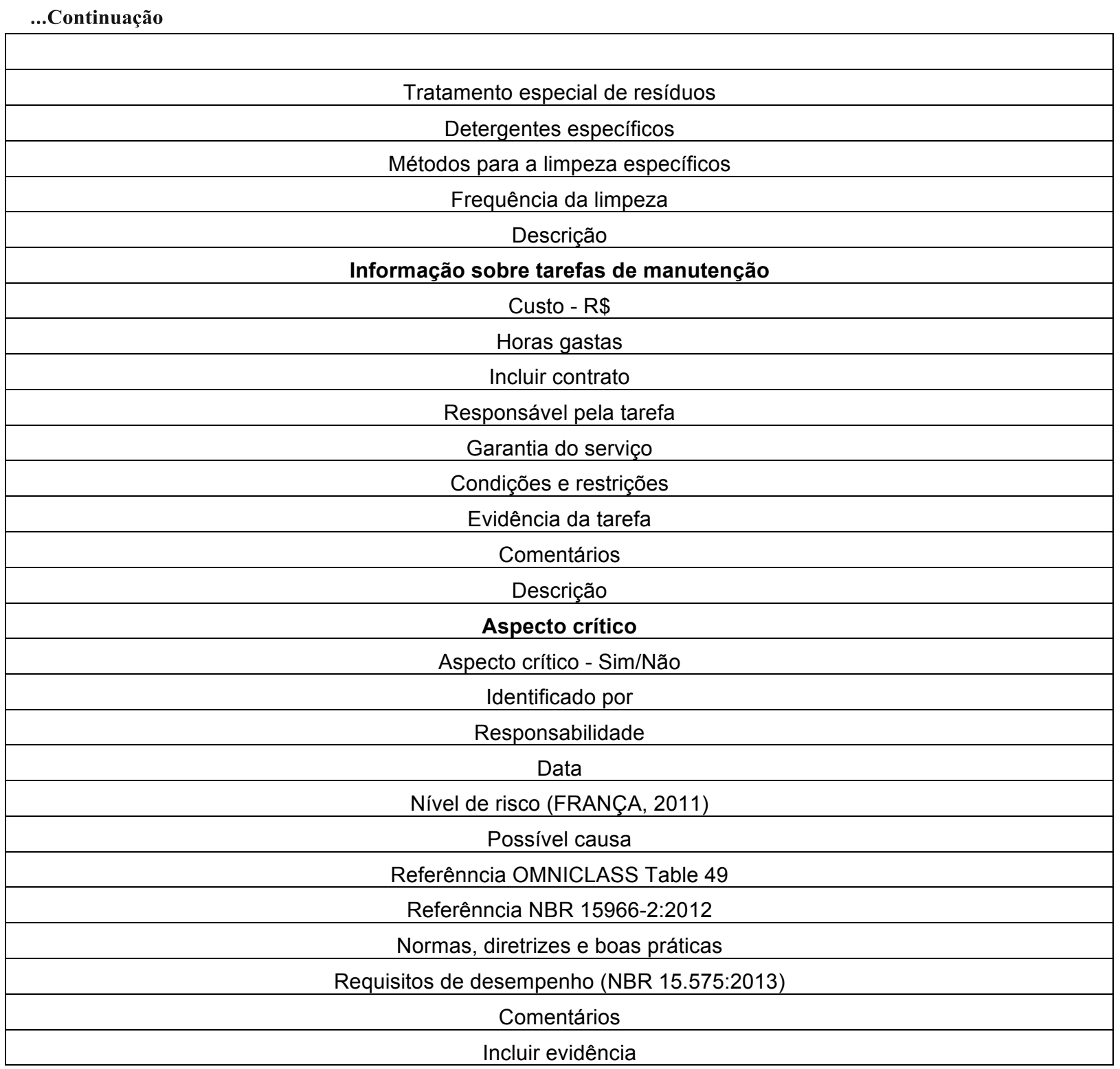


APÊNDICE B - EXEMPLOS DE FICHAS DE DIRETRIZES DE PROJETO PARA AMBIENTES, ELABORADAS POR MEIO DA PLATAFORMA DE BANCO DE DADOS DROFUS V. 1.8 PARA A ESCOLA ALPHA 
Status: Derived from ADM.05

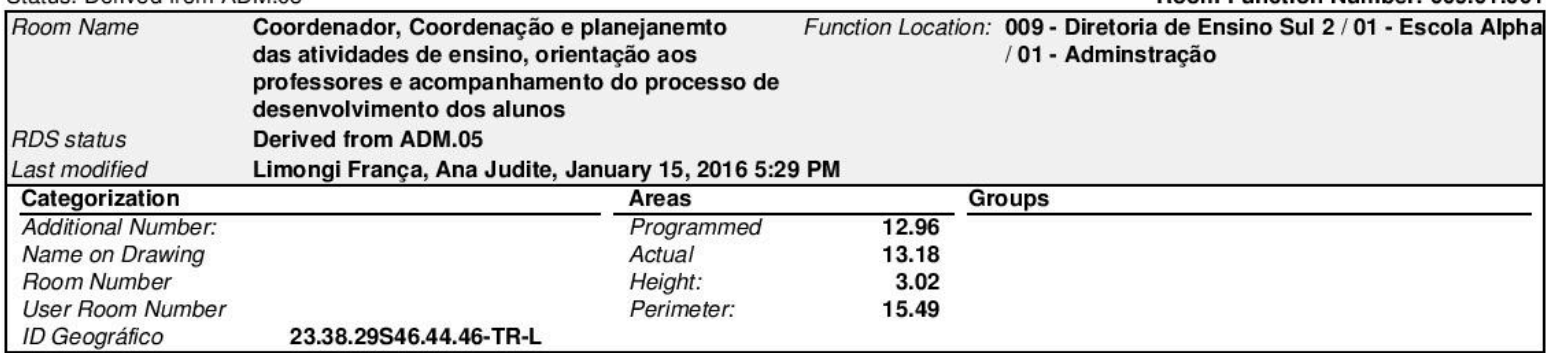

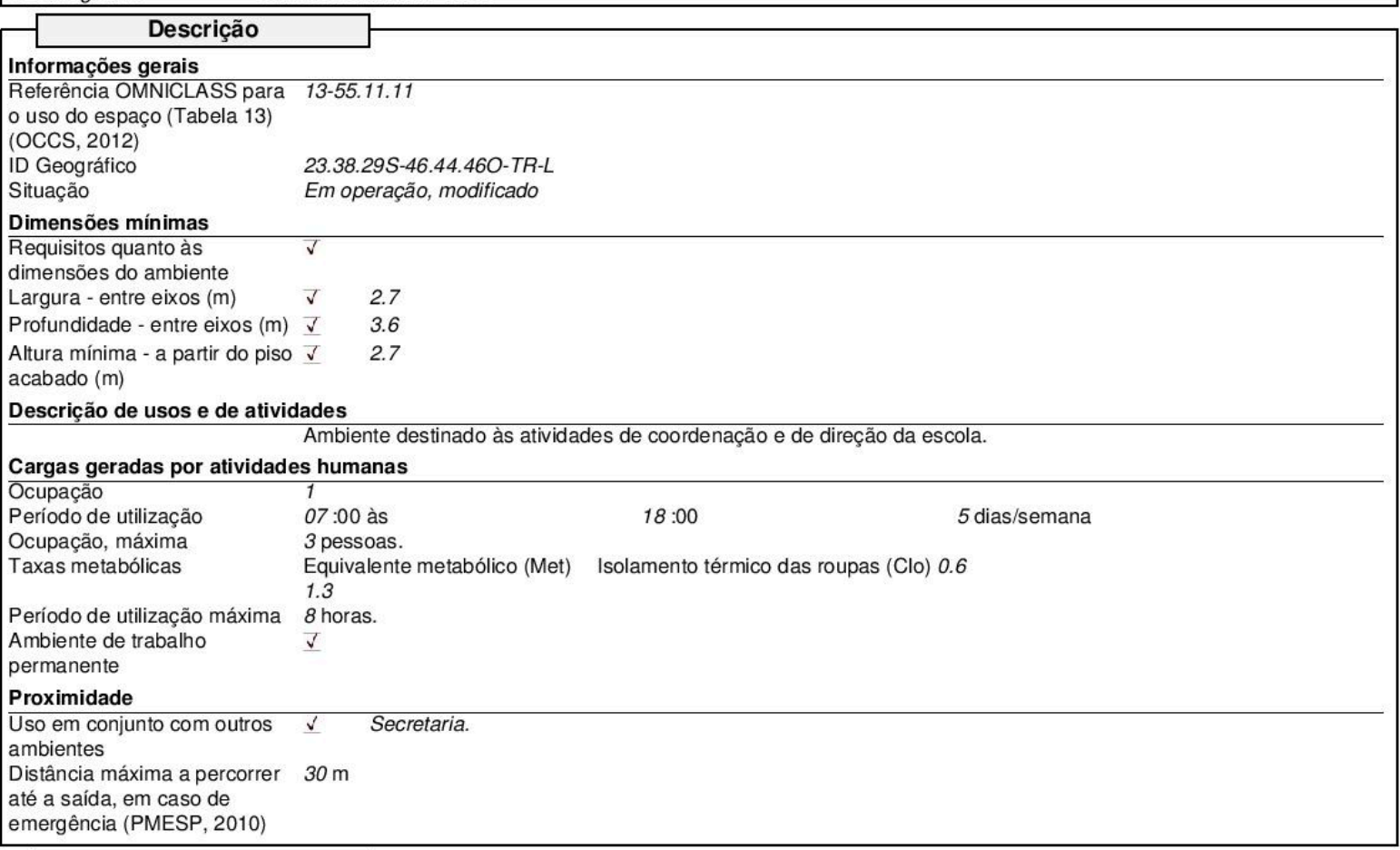

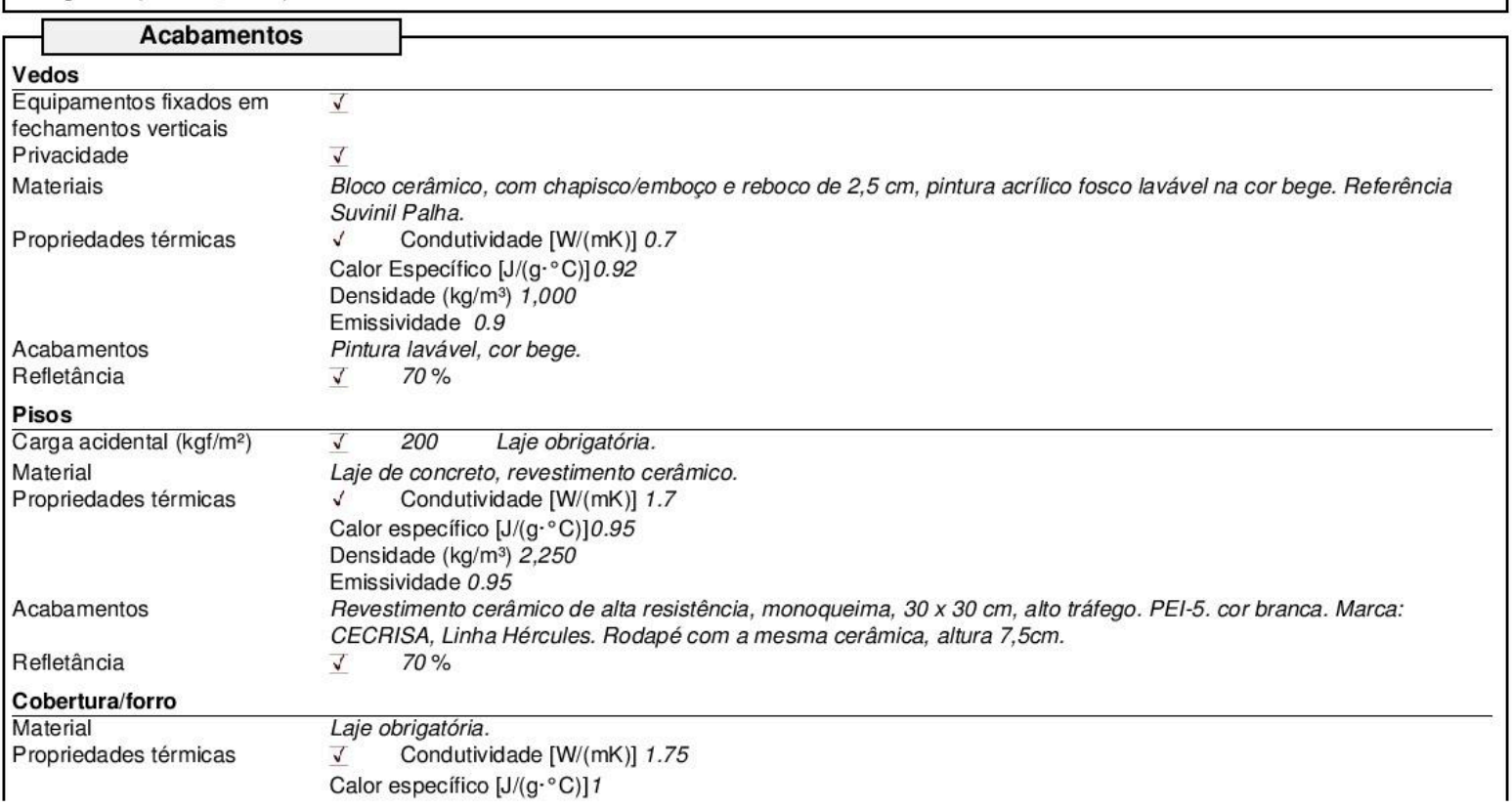




\section{Diretrizes de projeto para}

Status: Derived from ADM.05

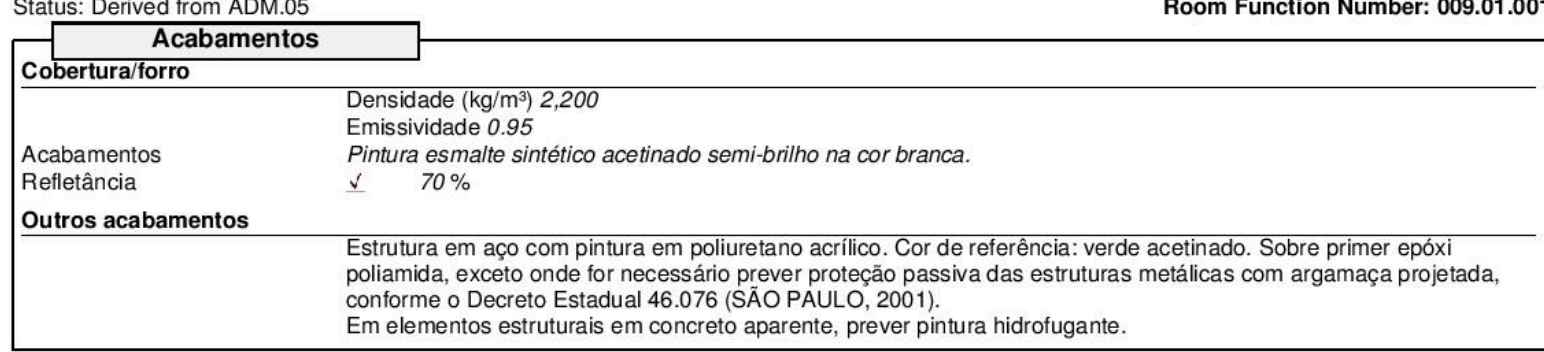

\section{Requisitos para o projeto}

Requisitos de desempenho ambiental

Estratégias de sustentabilidade $\checkmark \quad$ Energia: prever sensor de luz natural e circuitos elétricos separados, para permitir o acionamento parcial da iluminação artificial. Especificar lâmpadas fluorecentes T5 com reatores eletrônicos. Iluminação natural: controle solar para evitar ofuscamento e ganhos térmicos indesejados.

Materiais: somente componentes em madeira que tenham certificação de procedência. É obrigatória a apresentação de Documento de Origem Florestal.

Especificar, preferencialmente, componentes com, no mínimo, 25\% de material reciclado pós-consumo. Somente é permitida a utilização de tintas, selantes, impermeabilizantes, adesivos, vernizes e mastiques com

Tratamento acústico

Níveis sonoros máximos

$[\mathrm{dB}(\mathrm{A})]$

Visualização de ambientes

externos

Controle de ofuscamento

Área mínima de iluminação

natural $\left(\mathrm{m}^{2}\right)$, em relação à área

de piso

Área mínima de ventilação

$\left(\mathrm{m}^{2}\right)$, em relação à área de piso

Taxas mínimas de renovação $\checkmark$ Taxa de renovação de ar externo, por área

de ar, em áreas ocupadas

$\checkmark$ Taxa de renovação de ar externo, por pessoa

Requisitos quanto ao conforto $\checkmark \quad 80$ (\% horas na zona de conforto/ano) [ASHRAE 55.1:2004 (ANSI/ASHRAE, 2004)].

térmico

Requisitos quanto ao desempenho do ambiente - NBR 15.575:2013 (ABNT, 2013)

As aberturas do ambiente devem proporcionar entre 1-4 trocas de ar por hora [ASHRAE 62.1-2013 (ASHRAE, 2013)].

Requisitos quanto à acessibilidade - NBR 9.050:2015 (ABNT, 2015)

Espaço livre para a manobra de cadeira de rodas: $1,50 \mathrm{~m}$

Vão mínimo de portas: $0,80 \mathrm{~m}$.

Maçaneta: Alavanca. Altura: 0,80-1,10 m.

Soleiras inclinadas.

Degraus e desníveis não são permitidos.

Contraste de cor para destaque de aberturas e limites de piso.

Acessos devem ter sinalização visual e tátil.

Requisitos quanto à segurança patrimonial

Ambiente sujeito a arrombamento, necessário nível prever dispositivos de seguraça.

Outros

Prever espaço para 02 mesas, 04 cadeiras fixas, 02 cadeiras giratórias, 02 armários, 01 arquivo e 01 rack para TV

televisor de $21^{\prime \prime}$

$\mathrm{O}$ ambiente deve ser sinalizado.

\begin{tabular}{|c|c|c|}
\hline \multicolumn{2}{|c|}{ Portas e Janelas } & \\
\hline \multicolumn{3}{|l|}{ Portas } \\
\hline $\begin{array}{l}\text { Vão livre mínimo [NBR } \\
\text { 9050:2015 (ABNT, 2015)] }\end{array}$ & $\checkmark$ & $0.8 \mathrm{~m}$ \\
\hline Janelas para visualização & $\checkmark$ & \\
\hline Soleira inclinada & $\checkmark$ & Não são permitidos degraus de desníveis. \\
\hline Dispositivos de proteção & $\checkmark$ & Antivandalismo. \\
\hline Janelas & & \\
\hline $\begin{array}{l}\text { Requisitos de iluminação } \\
\text { natural }\end{array}$ & $\checkmark$ & Em paredes externas. \\
\hline
\end{tabular}




\section{Diretrizes de projeto para Ambientes}

\begin{tabular}{|c|c|}
\hline Status: Derived from ADM.05 & \multirow[t]{2}{*}{ Room Function Number: 009.01.0 } \\
\hline Portas e Janelas & \\
\hline \multicolumn{2}{|l|}{ Janelas } \\
\hline $\begin{array}{l}\text { Com dispositivos para abertura } \\
\text { e fechamento }\end{array}$ & $\begin{array}{l}\text { O usuário deve controlar as aberturas para ventilação natural. Considerar a especificação de um sistema de } \\
\text { exaustão para assegurar níveis mínimos de renovação de ar. (ANVISA, 1998). }\end{array}$ \\
\hline $\begin{array}{l}\text { Requisitos de mecanismos de } \\
\text { abertura }\end{array}$ & \\
\hline Dispositivos de controle solar & \\
\hline Parapeito & \\
\hline Gradis de segurança & \\
\hline Material da estrutura da janela & Pintura esmalte, na cor branca, sobre base antioxidante. \\
\hline $\begin{array}{l}\text { Requisitos para a especificação } \\
\text { do vidro }\end{array}$ & Vidro comum, $3 \mathrm{~mm}$ \\
\hline
\end{tabular}

\begin{tabular}{|c|c|c|}
\hline $\begin{array}{l}\text { Aquecimer } \\
\text { e ar cor }\end{array}$ & & \\
\hline Ventilação & & \\
\hline Ventilação natural & $\begin{array}{l}\frac{\checkmark}{\text { Preve }} \\
\text { ambie }\end{array}$ & $\begin{array}{l}\text { Ventilação cruzada } \\
\text { janelas operáveis, para confoto térmico. Vide aba requisitos para o projeto: requisitos de desempenho } \\
\text { tal e requisitos para ventilação natural. }\end{array}$ \\
\hline
\end{tabular}

\begin{tabular}{|c|c|c|}
\hline \multicolumn{2}{|c|}{$\begin{array}{l}\text { Sistemas de Elétrica/ } \\
\text { Dados/Audio/Vigilância }\end{array}$} & \\
\hline \multicolumn{3}{|l|}{ Sistemas de iluminação } \\
\hline Sensor de iluminação natural & $\checkmark$ & \multirow{2}{*}{ Integrar os sistemas de iluminação natural e artificial, por meio de sensores. } \\
\hline Setorização dos circuitos & $\checkmark$ & \\
\hline $\begin{array}{l}\text { Densidade de Potência } \\
\text { Luminosa (DPL) }\end{array}$ & $\checkmark$ & $\begin{array}{l}12 \mathrm{DPL}\left(\mathrm{W} / \mathrm{m}^{2}\right) \text { (ANSI/ASHRAE, } \\
2013 \mathrm{~b})\end{array}$ \\
\hline Nível de iluminâncial (lux) & $\checkmark$ & $\begin{array}{l}300 \text { lux [NBR 5.413:1992 (ABNT, } \\
1992)] .\end{array}$ \\
\hline $\begin{array}{l}\text { Conjuntos (luminárias + } \\
\text { lâmpadas) }\end{array}$ & $\checkmark$ & 2 Unidades 2 Lâmpadas \\
\hline & $32 \mathrm{~W}$ & \multirow{2}{*}{$\begin{array}{l}\qquad \sqrt{ } \text { Aletas refletivas } \\
\text { Prever controle de ofuscamento nos planos de trabalho. (CIE, 1983). }\end{array}$} \\
\hline Ofuscamento & $\checkmark$ & \\
\hline \multicolumn{3}{|l|}{ Sistemas elétricos } \\
\hline $\begin{array}{l}\text { Tomada universal baixa - } \\
0,40 \mathrm{~m}\end{array}$ & $\checkmark$ & $\begin{array}{l}2 P+T, 10 A / 110 V, N B R 14136 \text { Prever } 2 \text { tomadas para computador. } \\
\text { (ABNT, 2002). }\end{array}$ \\
\hline $\begin{array}{l}\text { Tomada universal média - } \\
1,10 \mathrm{~m}\end{array}$ & $\checkmark$ & $\begin{array}{l}2 P+T, 10 A / 110 V, N B R 14136 \\
(A B N T, 2002)\end{array}$ \\
\hline Ponto de força - 2,20 m & $\bar{z}$ & \\
\hline Interruptores & $\checkmark$ & Bipolar. Integrar com sistema de iluminação natural. \\
\hline \multicolumn{3}{|l|}{ Potência instalada } \\
\hline Potência instalada - iluminação & $\checkmark$ & $128 \mathrm{~W}$ \\
\hline Potência instalada total & $\checkmark$ & $708 \mathrm{~W}$ \\
\hline \multicolumn{3}{|c|}{ Pontos de rede de transmissão de dados } \\
\hline $\begin{array}{l}\text { Ponto de lógica } \\
\text { Ponto de telefone }\end{array}$ & \multicolumn{2}{|c|}{$\begin{array}{l}1 \\
1\end{array}$} \\
\hline \multicolumn{3}{|l|}{ Audio/Video } \\
\hline Sistema de TV/Radio & $\sqrt{v}$ & Ponto para televisor. \\
\hline
\end{tabular}

\section{Sistemas hidrossanitários}

Sistema predial de água fria

Sanitários

Outros

Sistemas hidrossanitários nã̃o estão previstos para o ambiente.

Segurança contra incêndio

Outros

\section{Operação e Manutenção}

Limpeza

Especificação de detergentes $\checkmark \checkmark \quad$ Somente produtos de limpeza neutros e não abrasivos.

Procedimentos de limpeza $\quad \bar{v} \quad$ Limpeza de piso com pano úmido e esfregão. Não lavar com água corrente.

Frequencia da limpeza $\quad \checkmark \quad$ Toda troca de turno. 


\section{Diretrizes de projeto para}

Database_SPEducational_Facilities

\section{Ambientes}

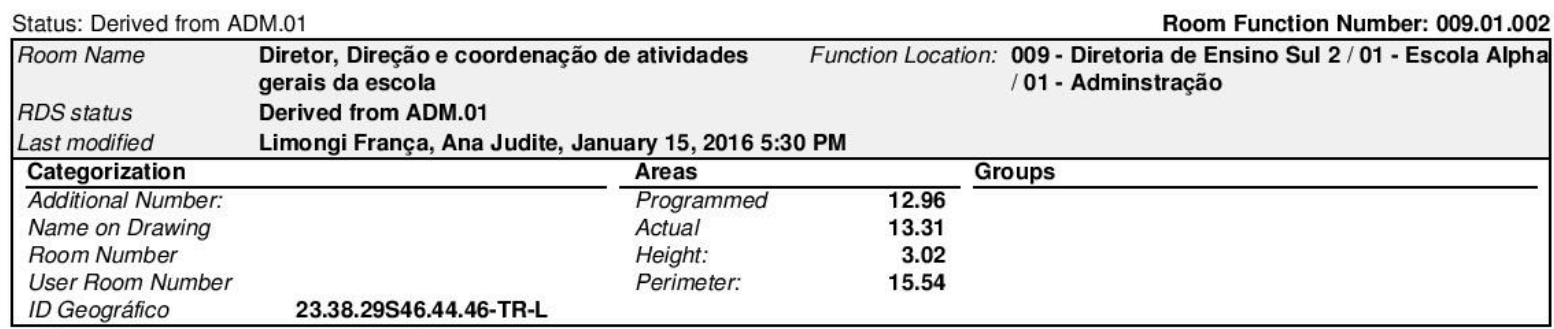

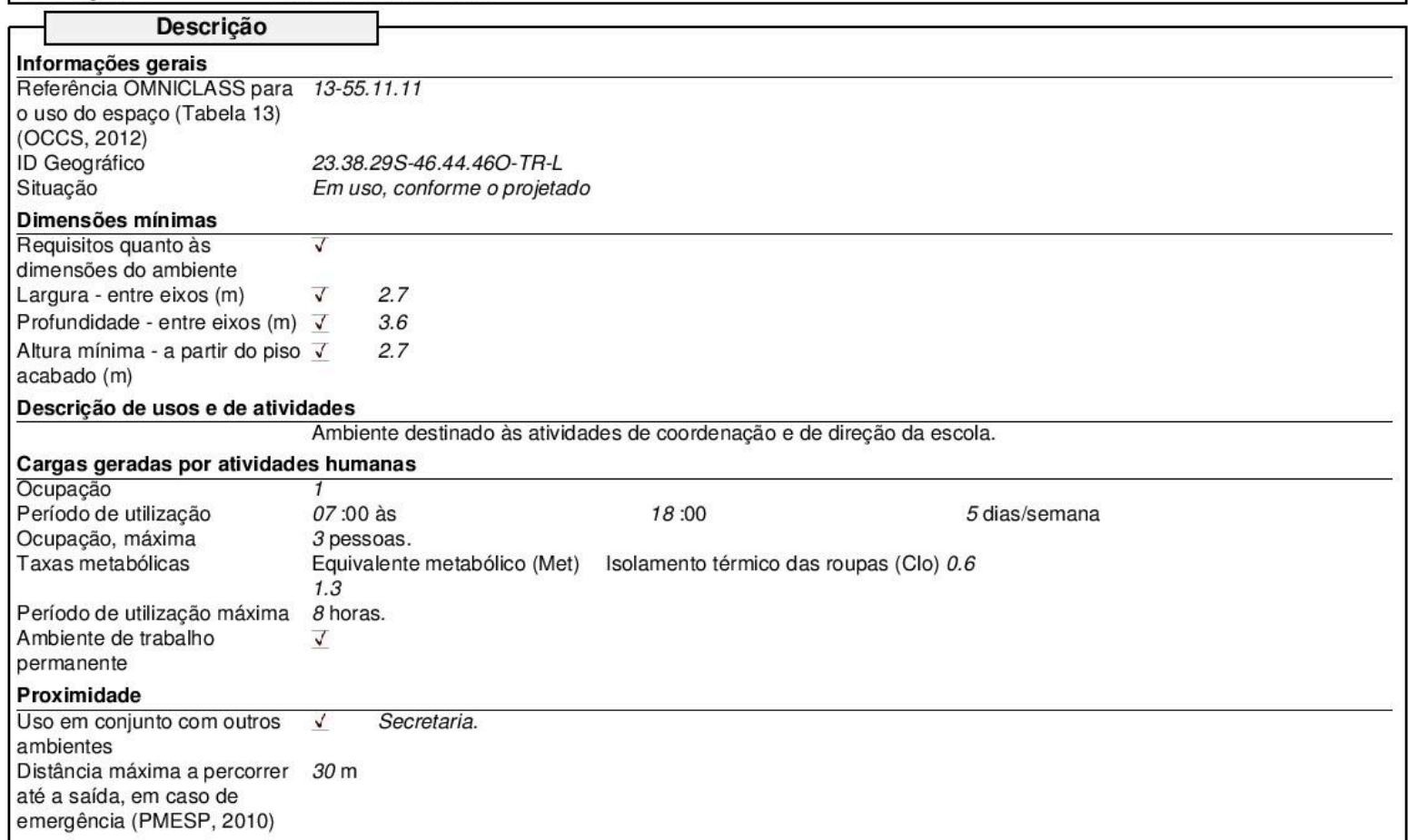

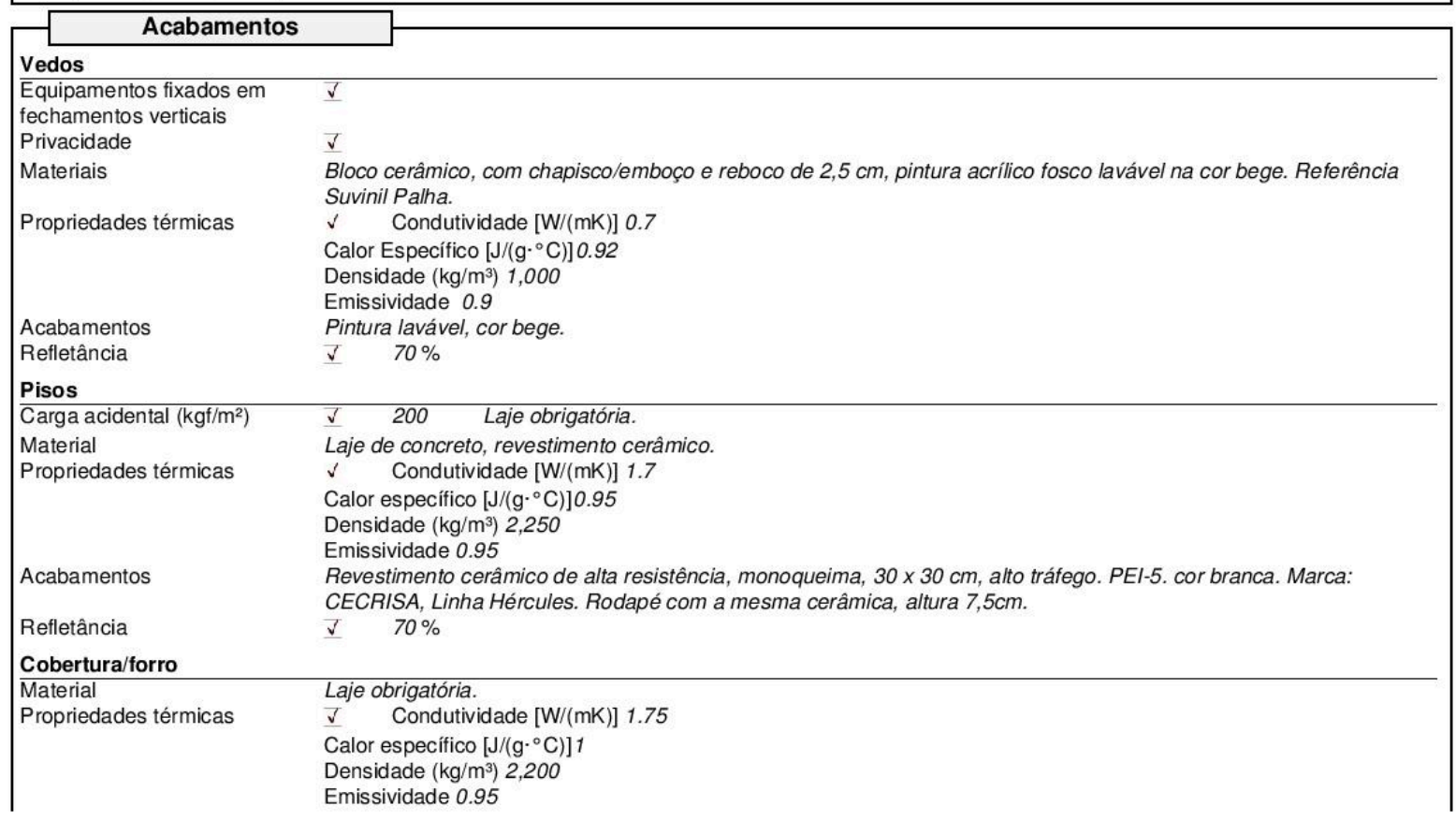




\section{Diretrizes de projeto para Ambientes}

Database SPEducational Facilities

Room Function Number: 009.01.002

Status: Derived from ADM.01

\section{Acabamentos}

Cobertura/forro

Acabamentos Pintura esmalte sintético acetinado semi-brilho na cor branca.

Refletância

Outros acabamentos

Estrutura em aço com pintura em poliuretano acrílico. Cor de referência: verde acetinado. Sobre primer epóx poliamida, exceto onde for necessário prever proteção passiva das estruturas metálicas com argamaça projetada, conforme o Decreto Estadual 46.076 (SÃO PAULO, 2001).

Em elementos estruturais em concreto aparente, prever pintura hidrofugante.

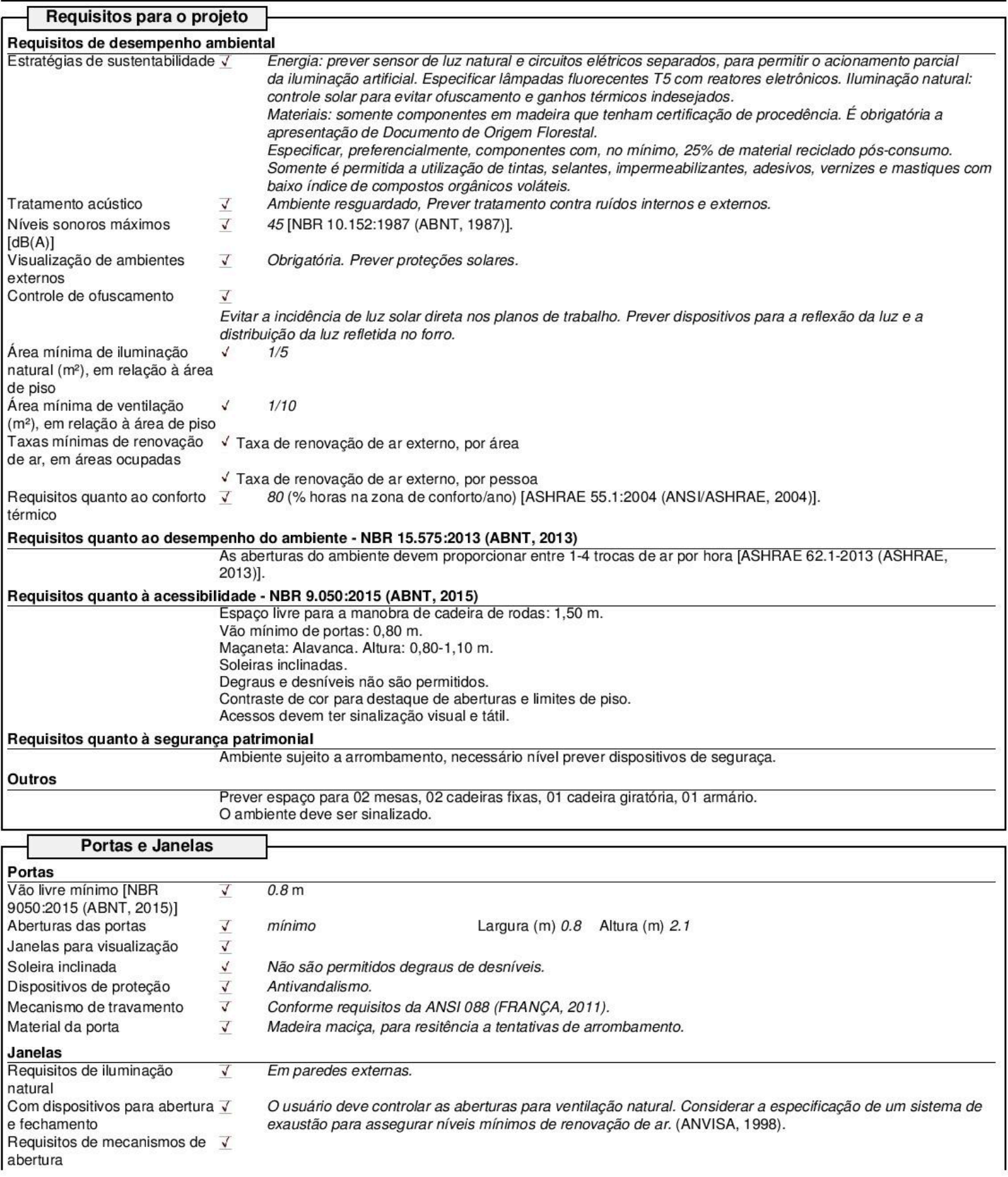


Diretrizes de projeto para Ambientes

Status: Derived from ADM.01

Room Function Number: 009.01.002

Janelas

Dispositivos de controle solar

Parapeito

Gradis de segurança

Material da estrutura da janela $v$

Requisitos

do vidro

Pintura esmalte, na cor branca, sobre base antioxidante.

Vidro comum, $3 \mathrm{~mm}$

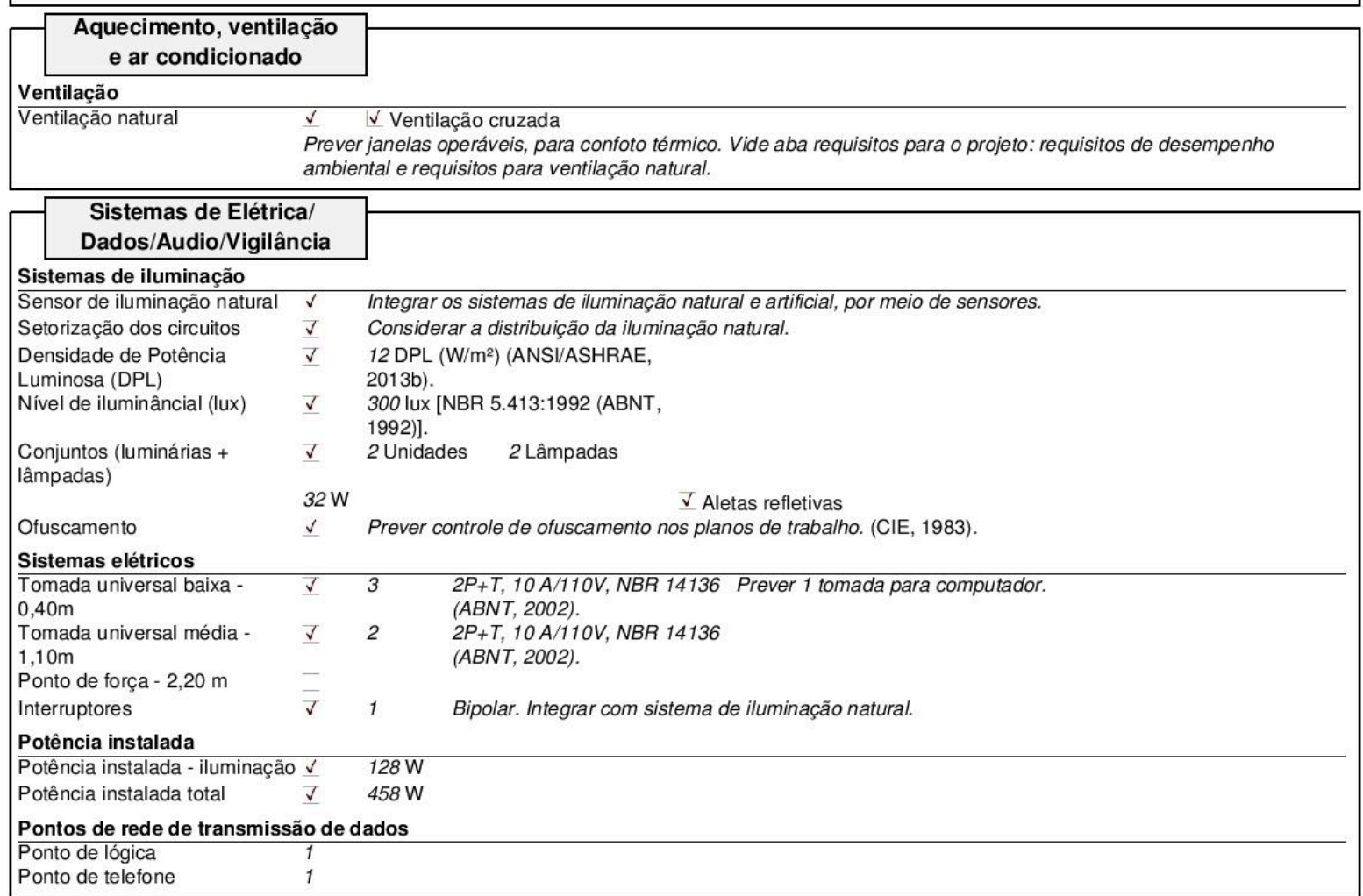

\section{Sistemas hidrossanitários}

Sistema predial de água fria

Sanitários

Outros

Sistemas hidrossanitários não estão previstos para o ambiente.

\section{Seguranca contra incêndio}

Outros

Considerar requisitos para evacuação de emergência (SAO PAULO, 2001; 2004).

Operação e Manutenção

Limpeza

Especificação de detergentes $\sqrt{ } \quad$ Somente produtos de limpeza neutros e não abrasivos.

Procedimentos de limpeza $\quad$ v Limpeza de piso com pano úmido e esfregão. Não lavar com água corrente.

Frequencia da limpeza $\quad \checkmark \quad$ Toda troca de turno. 
Status: Derived from ADM.06

Room Function Number: 009.01.003

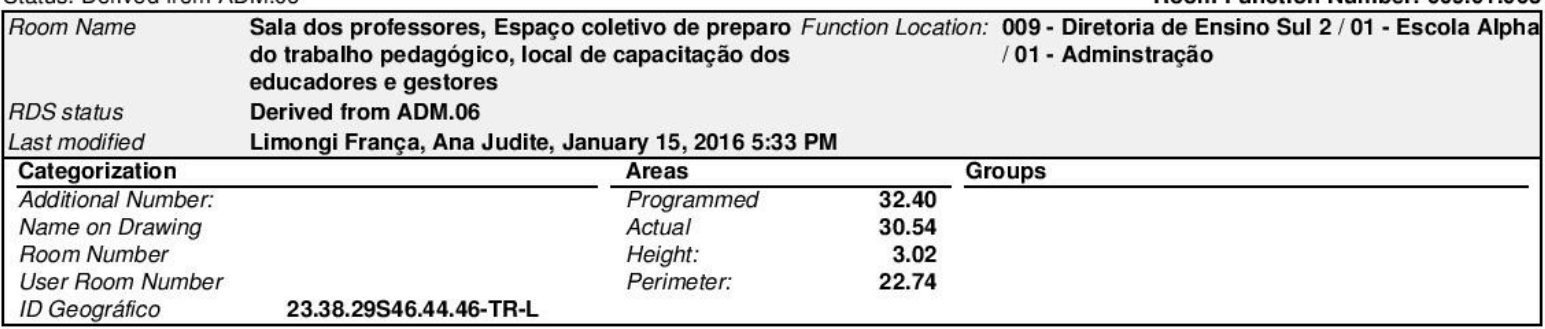

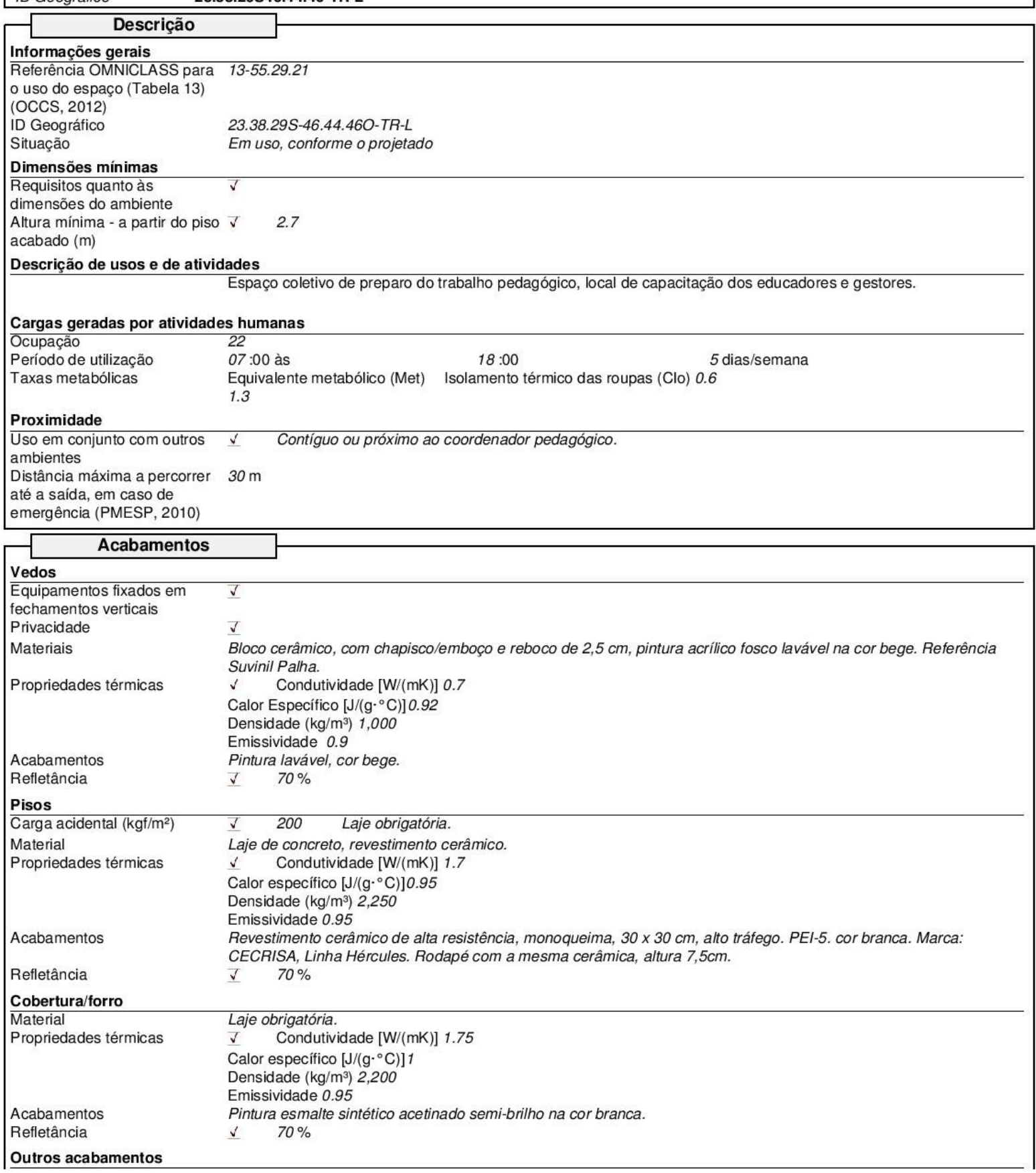


Status: Derived from ADM.06

Room Function Number: 009.01.003

\section{Acabamentos \\ Outros acabamentos}

Estrutura em aço com pintura em poliuretano acrílico. Cor de referência: verde acetinado. Sobre primer epóxi poliamida, exceto onde for necessário prever proteção passiva das estruturas metálicas com argamaça projetada, conforme o Decreto Estadual 46.076 (SÃO PAULO, 2001).

Em elementos estruturais em concreto aparente, prever pintura hidrofugante.

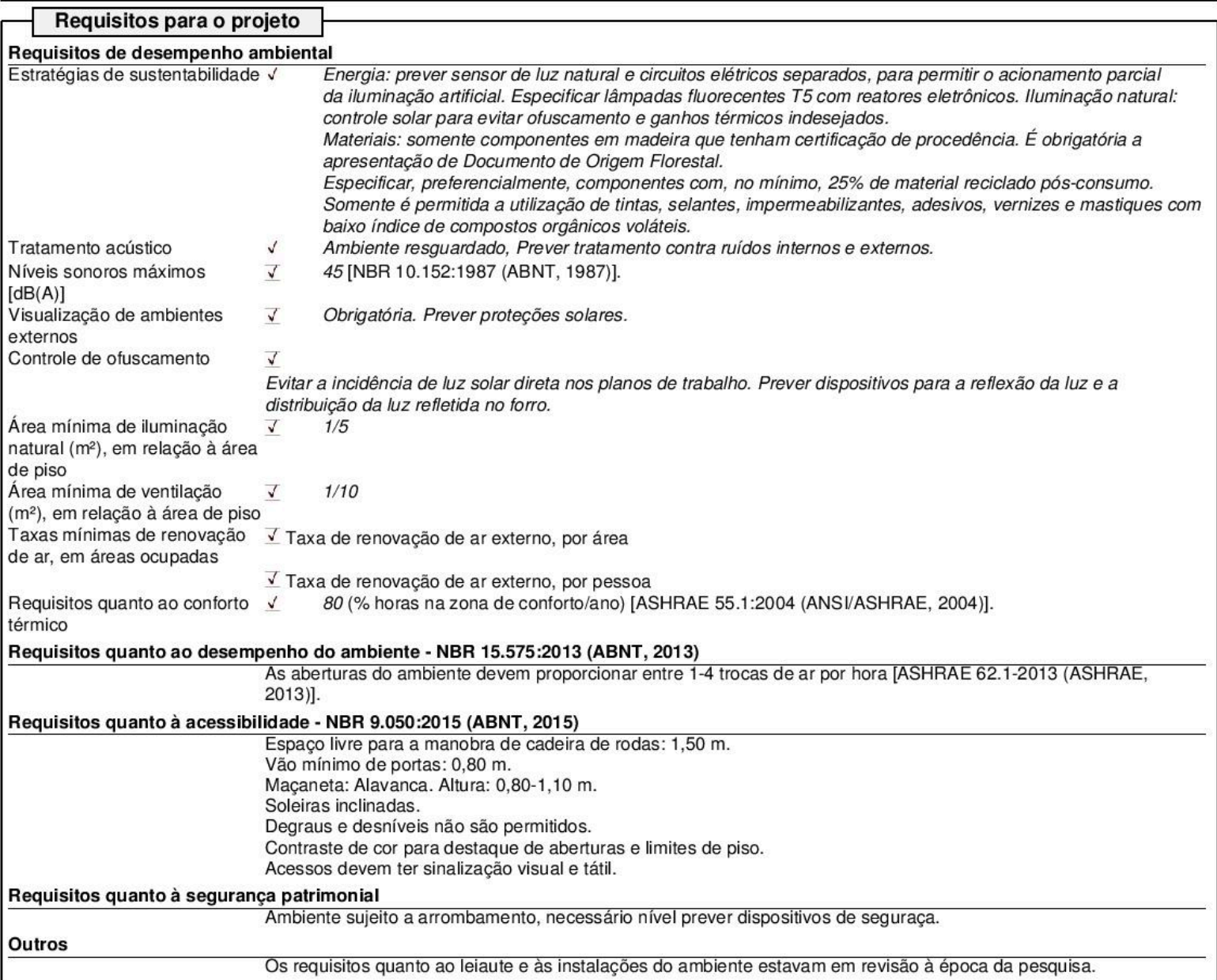

\section{Portas e Janelas}

Portas

Vão livre mínimo [NBR

9050:2015 (ABNT, 2015)

Aberturas das portas

Janelas para visualização

Soleira inclinada

Dispositivos de proteção

Mecanismo de travamento

Material da porta

S requisitos quanto ao leiaute e às instalações do ambiente estavam em revisão à época da pesquisa.

Janelas

Requisitos de iluminação $\quad \checkmark \quad$ Em paredes externas.

natural

Com dispositivos para abertura $\overrightarrow{ }$

e fechamento

Requisitos de mecanismos de

abertura

Dispositivos de controle solar

Parapeito

Gradis de segurança

$0.8 \mathrm{~m}$

Material da estrutura da janela -

Pintura esmalte, na cor branca, sobre base antioxidante. 
Diretrizes de projeto para Ambientes

Status: Derived from ADM.06

Room Function Number: 009.01.003

Janelas

Portas e Janelas

Requisitos para a especificação $v^{\prime}$ Vidro comum, $3 \mathrm{~mm}$.

do vidro

\begin{tabular}{|c|c|c|}
\hline \multicolumn{2}{|c|}{$\begin{array}{c}\text { Aquecimento, ventilação } \\
\text { e ar condicionado }\end{array}$} & \\
\hline Ventilação & & \\
\hline
\end{tabular}

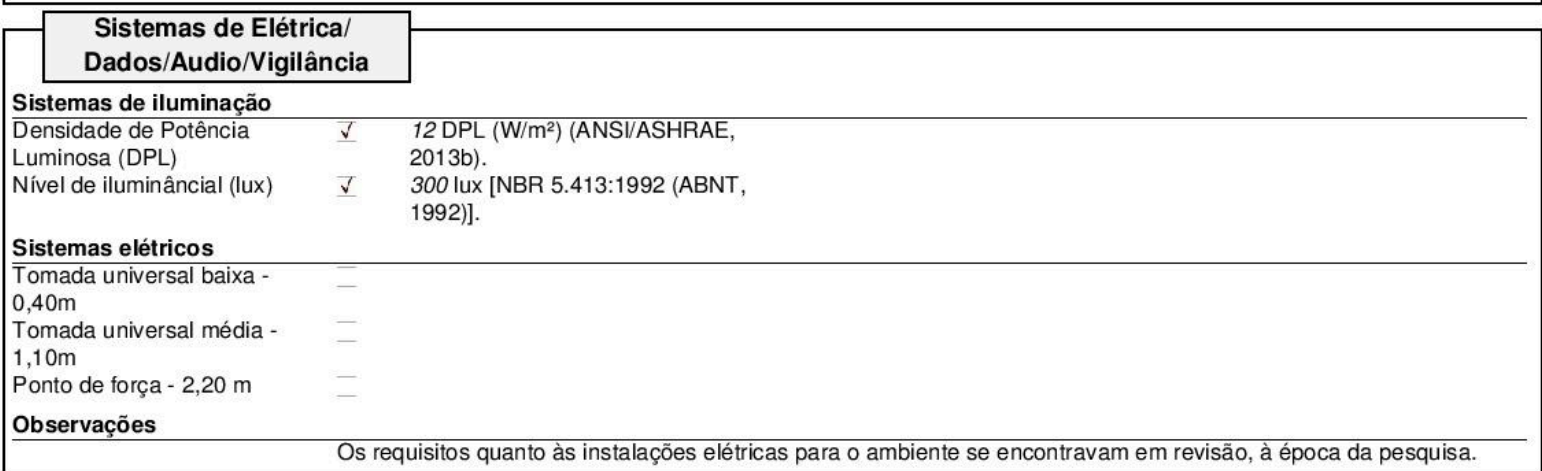

Sistemas hidrossanitários

Sistema predial de água fria

Sanitários

Outros

Os requisitos quanto aos sistemas hidrossanitários para o ambiente se encontravam em revisão, à época da pesquisa.ara o ambiente.

\section{Segurança contra incêndio}

Outros

Considerar requisitos para evacuação de emergência (SAO PAULO, 2001; 2004).

Operação e Manutenção

impeza

Especificação de detergentes $\checkmark \checkmark$ Somente produtos de limpeza neutros e não abrasivos.

Procedimentos de limpeza $\quad \checkmark \quad$ Limpeza de piso com pano úmido e esfregão. Não lavar com água corrente.

Frequencia da limpeza $\quad \checkmark \quad$ Toda troca de turno. 


\section{Diretrizes de projeto para}

Database_SPEducational_Facilities Ambientes

\begin{tabular}{|c|c|c|}
\hline Status: From ADM.03 & \multicolumn{2}{|r|}{ Room Function Number: 009.01.004 } \\
\hline Room Name & $\begin{array}{l}\text { Secretaria, Desenvolvimento de atividades } \\
\text { administrativas }\end{array}$ & $\begin{array}{l}\text { Function Location: } 009 \text { - Diretoria de Ensino Sul } 2 \text { / } 01 \text { - Escola Alpha } \\
\text { / } 01 \text { - Adminstração }\end{array}$ \\
\hline RDS status & From ADM.03 & \\
\hline Categorization & Areas & Groups \\
\hline Additional Number: & Programmed & 64.30 \\
\hline Name on Drawing & Actual & 46.20 \\
\hline Room Number & Height: & 3.02 \\
\hline
\end{tabular}

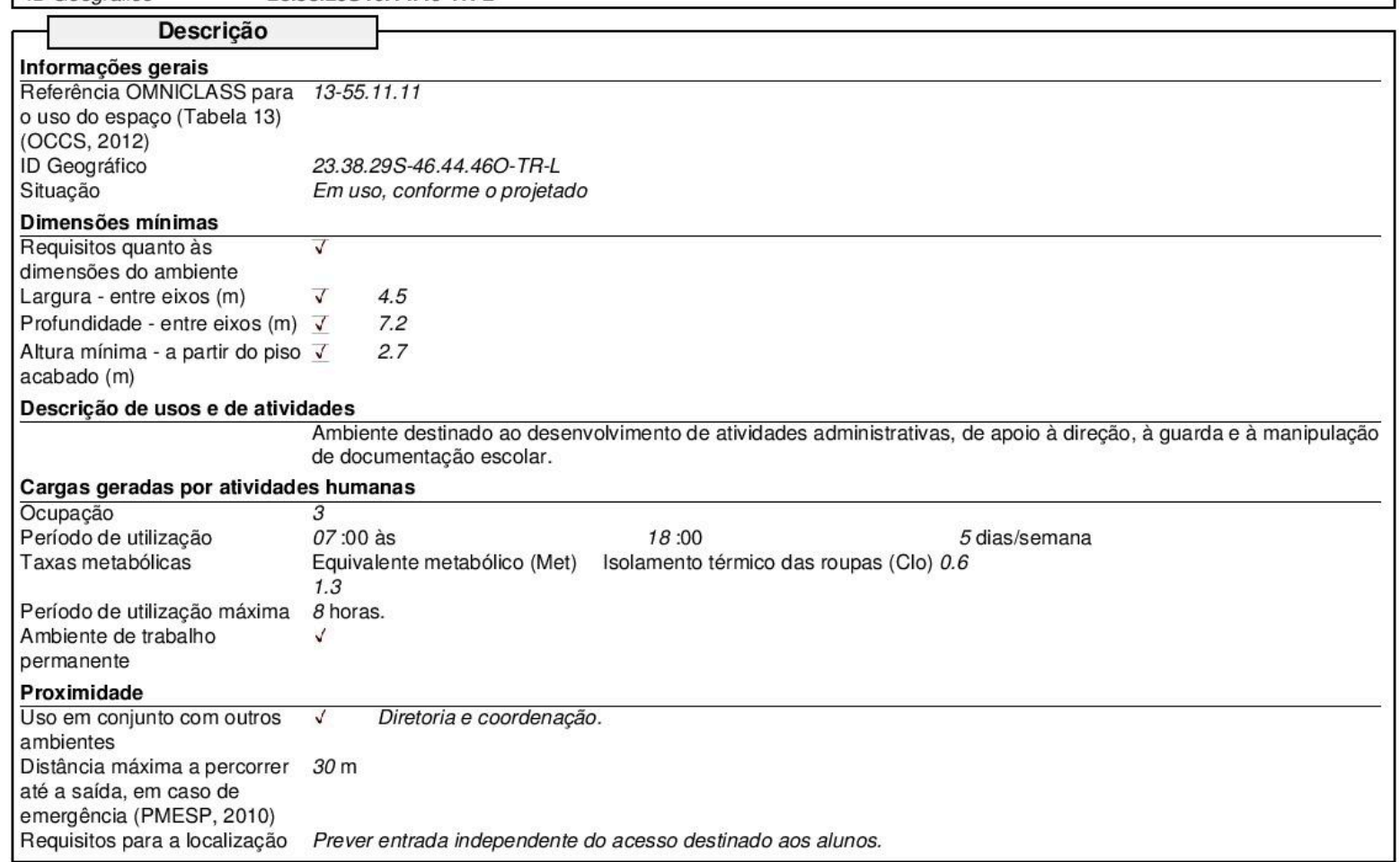

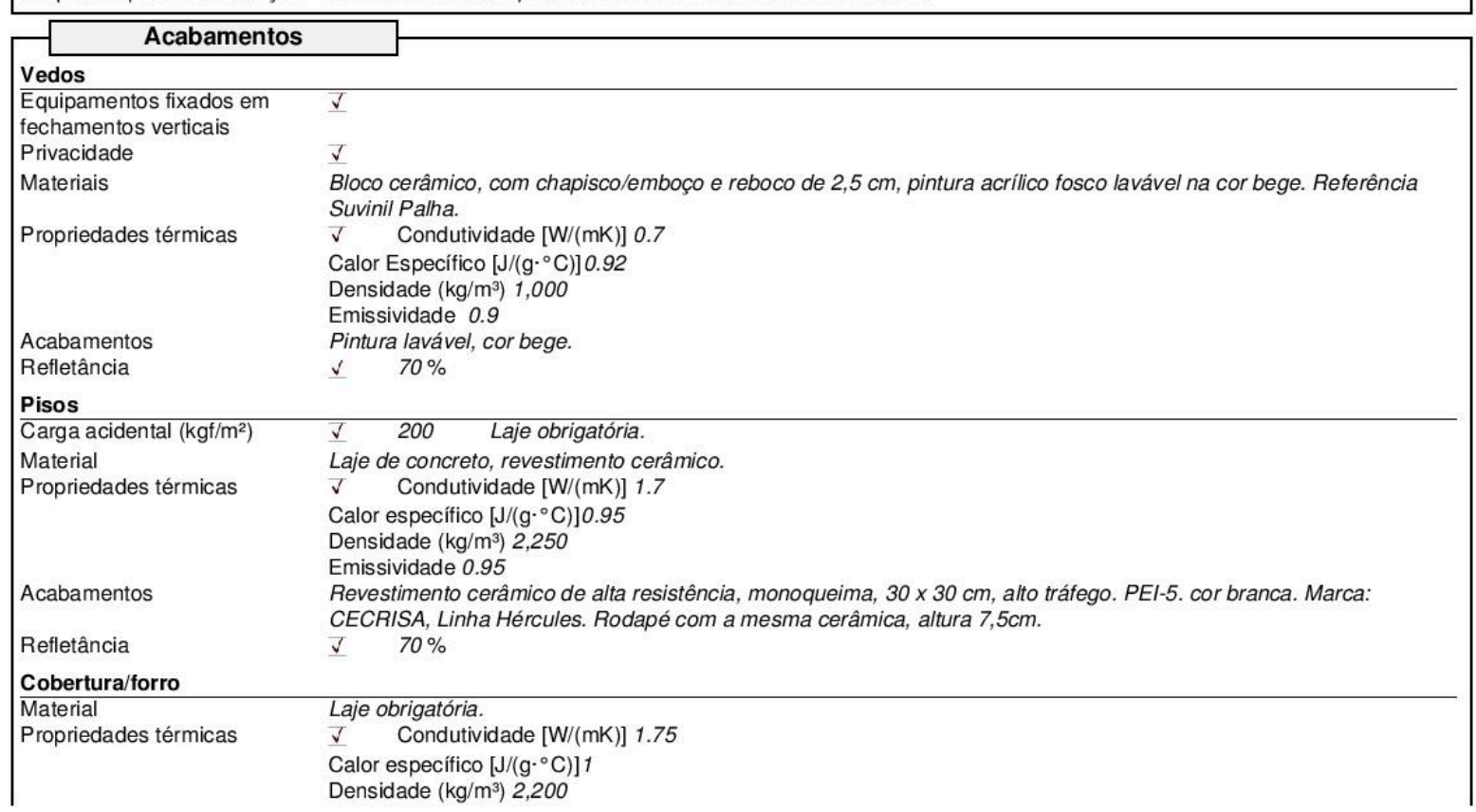




\section{Diretrizes de projeto para Ambientes}

Database SPEducational Facilities

Room Function Number: 009.01.004

Status: From ADM.03

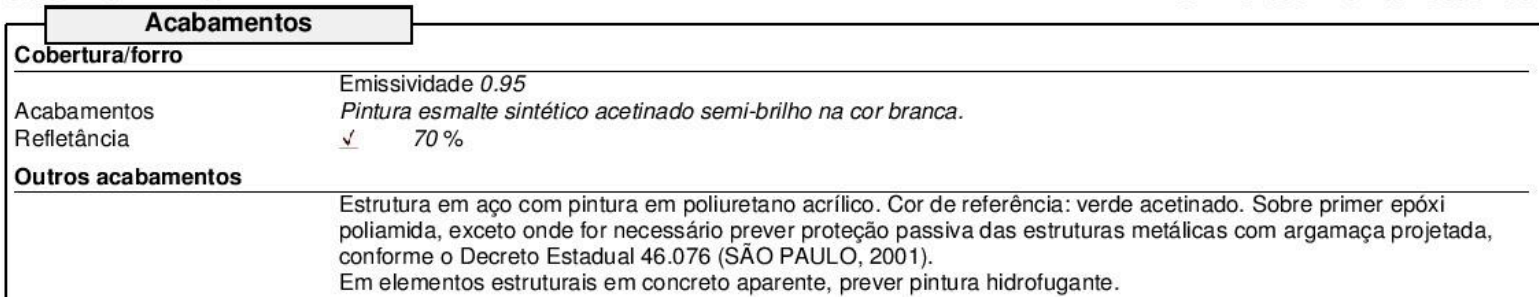

\section{Requisitos para o projeto}

Requisitos de desempenho ambienta

Estratégias de sustentabilidade $\checkmark$ Energia: prever sensor de luz natural e circuitos elétricos separados, para permitir o acionamento parcial da iluminação artificial. Especificar lâmpadas fluorecentes $T 5 \mathrm{com}$ reatores eletrônicos. Iluminação natural: controle solar para evitar ofuscamento e ganhos térmicos indesejados.

Materiais: somente componentes em madeira que tenham certificação de procedência. É obrigatória a apresentação de Documento de Origem Florestal.

Especificar, preferencialmente, componentes com, no mínimo, 25\% de material reciclado pós-consumo. Somente é permitida a utilização de tintas, selantes, impermeabilizantes, adesivos, vernizes e mastiques com baixo índice de compostos orgânicos voláteis.

Tratamento acústico

Níveis sonoros máximos

$[\mathrm{dB}(\mathrm{A})]$

Visualização de ambientes

$\begin{array}{ll}\checkmark & \text { Ambiente resguardado, Prever tratam } \\ \checkmark & 45[\text { [NBR 10.152:1987 (ABNT, 1987)] }\end{array}$

externos

Controle de ofuscamento

$\checkmark \quad$ Obrigatória. Prever proteções solares.

Área mínima de iluminação

Evitar a incidência de luz solar direta nos planos de trabalho. Prever dispositivos para a reflexão da luz e a distribuição da luz refletida no forro.

natural $\left(\mathrm{m}^{2}\right)$, em relação à área

de piso

Área mínima de ventilação $\quad \checkmark \quad 1 / 10$

$\left(\mathrm{m}^{2}\right)$, em relação à área de piso

Taxas mínimas de renovação $\checkmark$ Taxa de renovação de ar externo, por área

de ar, em áreas ocupadas

Requisitos quanto a conforto $\checkmark$ Taxa de renovação de ar externo, por pessoa

térmico

Requisitos quanto ao desempenho do ambiente - NBR 15.575:2013 (ABNT, 2013)

As aberturas do ambiente devem proporcionar entre 1-4 trocas de ar por hora [ASHRAE 62.1-2013 (ASHRAE, 2013)].

Requisitos quanto à acessibilidade - NBR 9.050:2015 (ABNT, 2015)

Espaço livre para a manobra de cadeira de rodas: $1,50 \mathrm{~m}$

Vão mínimo de portas: 0,80 m.

Maçaneta: Alavanca. Altura: 0,80-1,10 m.

Soleiras inclinadas.

Degraus e desníveis não são permitidos.

Contraste de cor para destaque de aberturas e limites de piso.

Acessos devem ter sinalização visual e tátil.

Requisitos quanto à segurança patrimonial

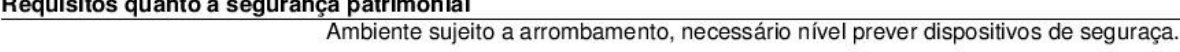

Outros

Prever espaço para 05 mesas, 02 cadeiras fixas, 03 cadeiras giratórias, 03 armários, 02 estantes e 06 arquivos para pastas suspensas.

O ambiente deve ser sinalizado.

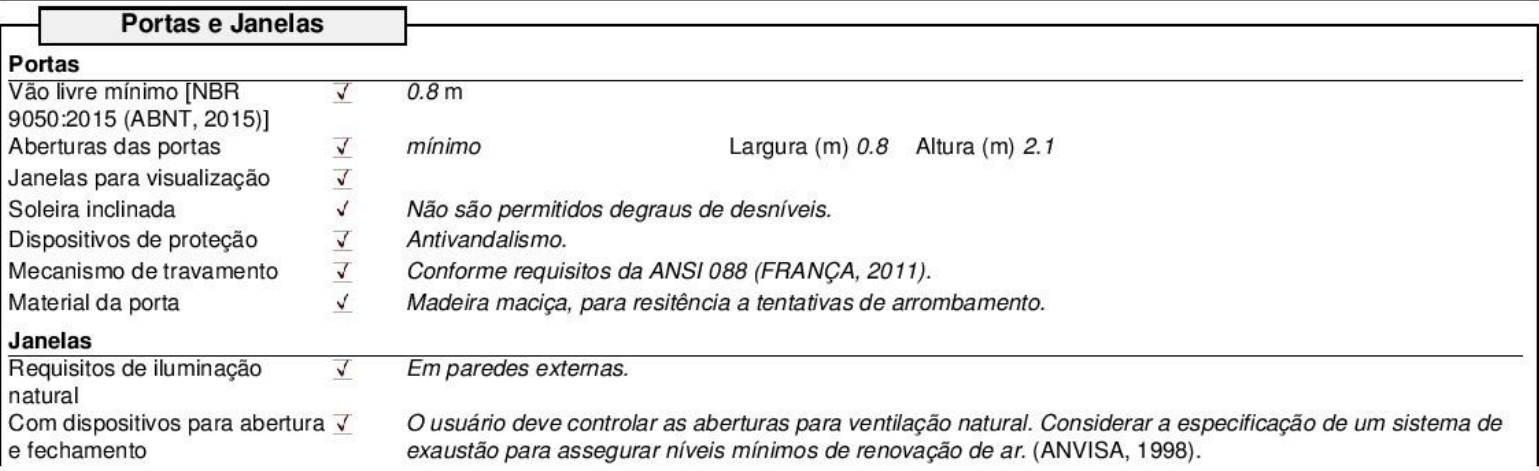


Status: From ADM.03

\begin{tabular}{|c|c|c|}
\hline \multicolumn{2}{|l|}{ Portas e Janelas } & \\
\hline Janelas & & \\
\hline $\begin{array}{l}\text { Requisitos de mecanismos de } \\
\text { abertura }\end{array}$ & & \\
\hline Dispositivos de controle solar & $\checkmark$ & \\
\hline Parapeito & $\checkmark$ & \\
\hline Gradis de segurança & $\bar{v}$ & \\
\hline Material da estrutura da janela & $\vec{v}$ & Pintura esmalte, na cor branca, sobre base antioxidante. \\
\hline $\begin{array}{l}\text { Requisitos para a especificação } \\
\text { do vidro }\end{array}$ & & Vidro comum, 3mm. \\
\hline
\end{tabular}

Room Function Number: 009.01.004 do vidro

\begin{tabular}{|c|c|c|}
\hline \multicolumn{2}{|c|}{$\begin{array}{l}\text { Aquecimento, ventilação } \\
\text { e ar condicionado }\end{array}$} & \\
\hline Ventilação & & \\
\hline Ventilação natural & Preve & $\begin{array}{l}\checkmark \text { Ventilação cruzada } \\
\text { janelas operáveis, para confoto térmico. Vide aba requisitos para o projeto: requisitos de desempenho } \\
\text { ital e requisitos para ventilação natural. }\end{array}$ \\
\hline
\end{tabular}

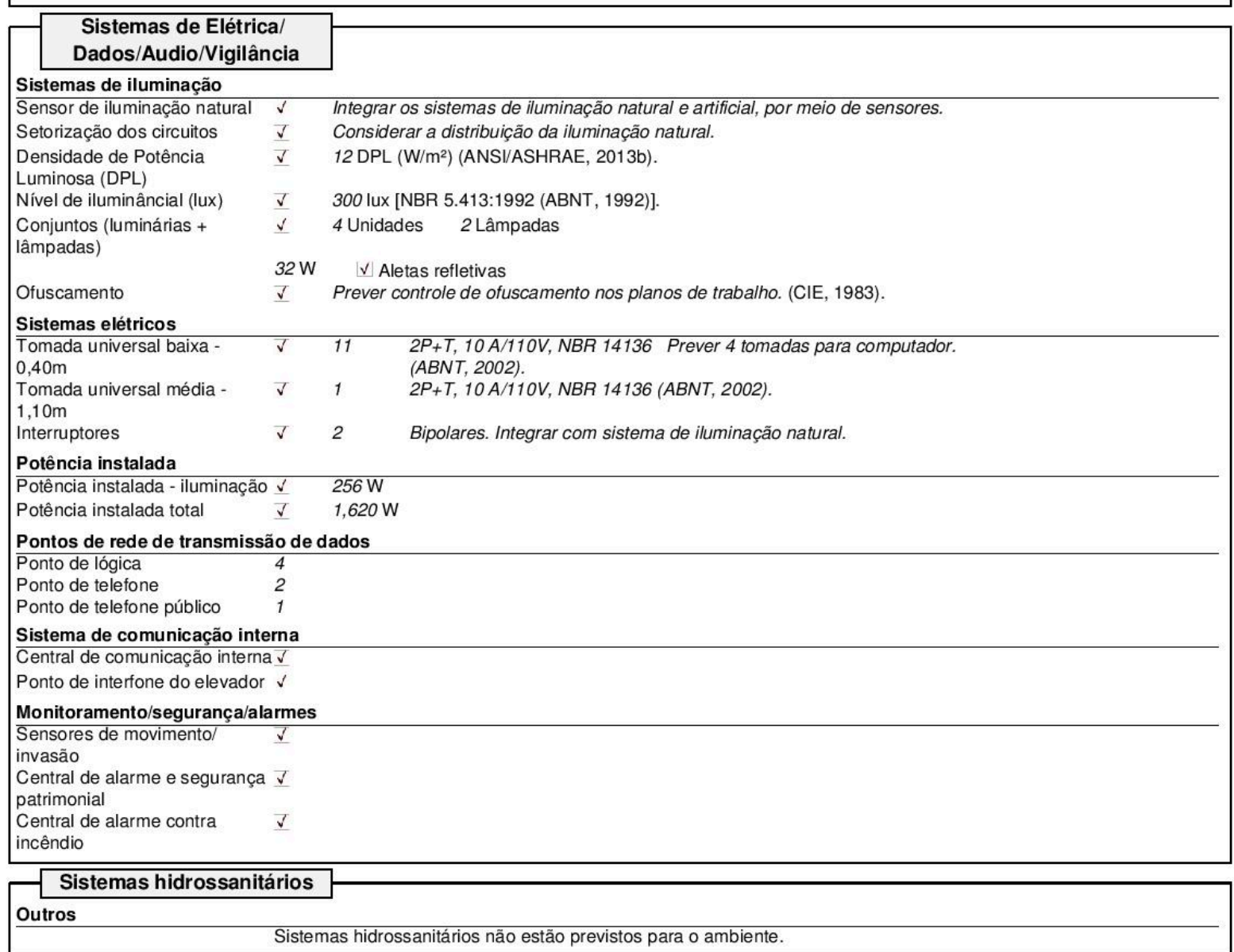

\section{Segurança contra incêndio}

Equipamentos para segurança contra incêndio

Alarme contra incêndio -

conforme Decreto Estadual N ${ }^{\circ}$

46.076 (SAO PAULO, 2001)

Outros

Considerar requisitos para evacuação de emergência (SAO PAULO, 2001; 2004).

Operação e Manutenção
Limpeza
Especificação de detergentes $\checkmark \quad \checkmark \quad$ Somente produtos de limpeza neutros e não abrasivos.


H MELHORIA CONTÍNUA APLICADA A

Database_SPEducational_Facilities

Status: From ADM. 03

Operação e Manutenção

Limpeza

Procedimentos de limpeza $\quad \checkmark \quad$ Limpeza de piso com pano úmido e esfregão. Não lavar com água corrente.

Frequencia da limpeza $\quad \checkmark \quad$ Toda troca de turno.
Diretrizes de projeto para Ambientes

Room Function Number: 009.01.004 


\section{Diretrizes de projeto para}

Database_SPEducational_Facilities

Ambientes

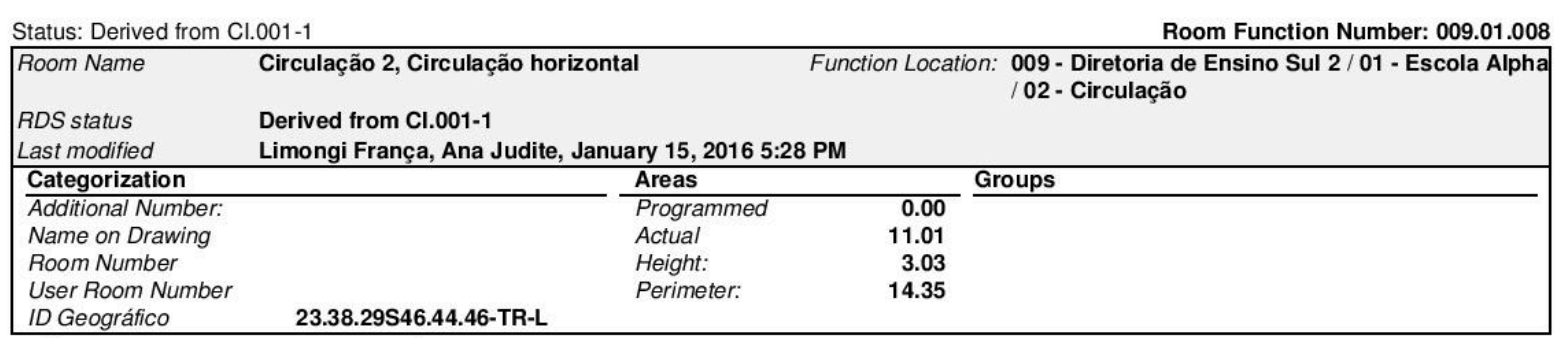

\begin{tabular}{|ll|}
\hline \multicolumn{2}{|c|}{ Descrição } \\
Informações gerais \\
\hline Referência OMNICLASS para & $13-851111$ \\
o uso do espaço (Tabela 13) & \\
(OCCS, 2012) & \\
ID Geográfico & 23.38.29S-46.44.46O-1P-C \\
Situação & Em uso, conforme o projetado
\end{tabular}

Descrição de usos e de atividades

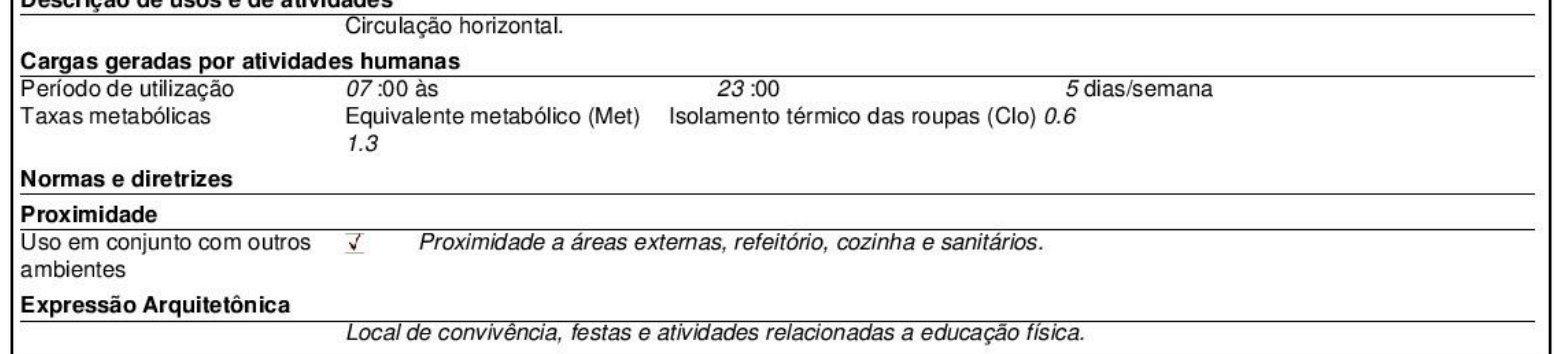

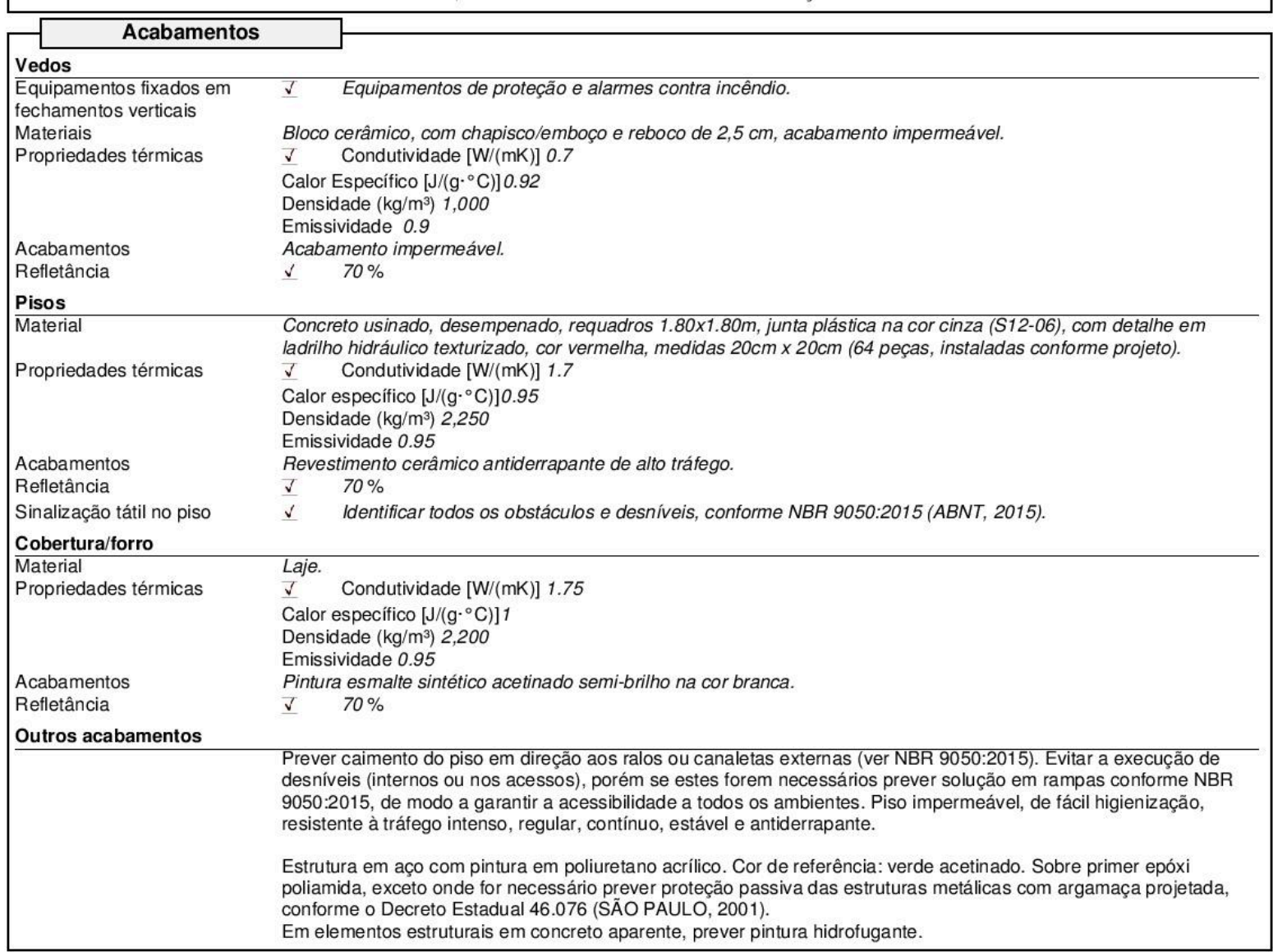




\section{Diretrizes de projeto para Ambientes}

Status: Derived from Cl.001-1

Room Function Number: 009.01.008

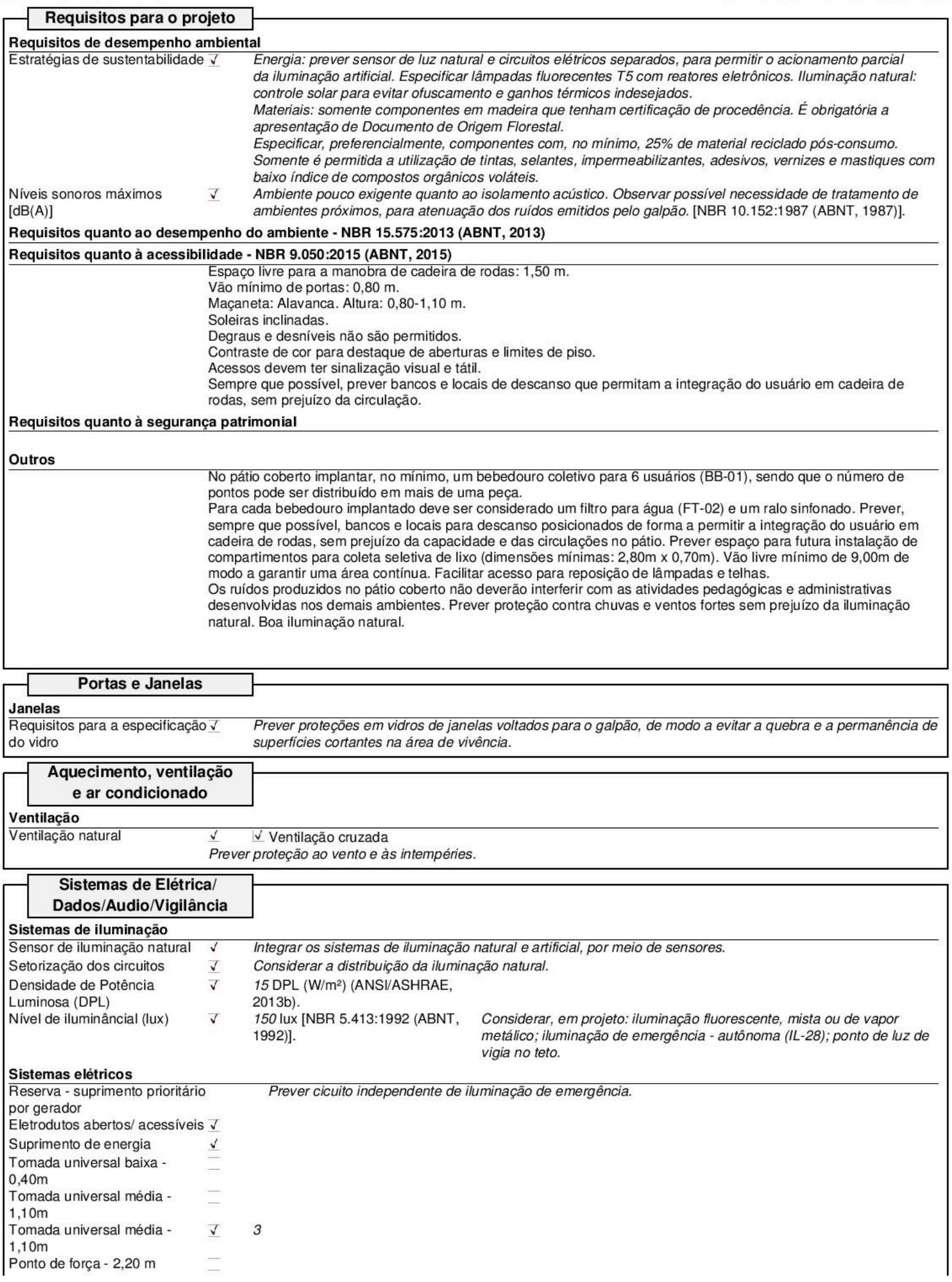




\section{Diretrizes de projeto para}

Database_SPEducational_Facilities Ambientes

Status: Derived from Cl.001-1

Room Function Number: 009.01.008

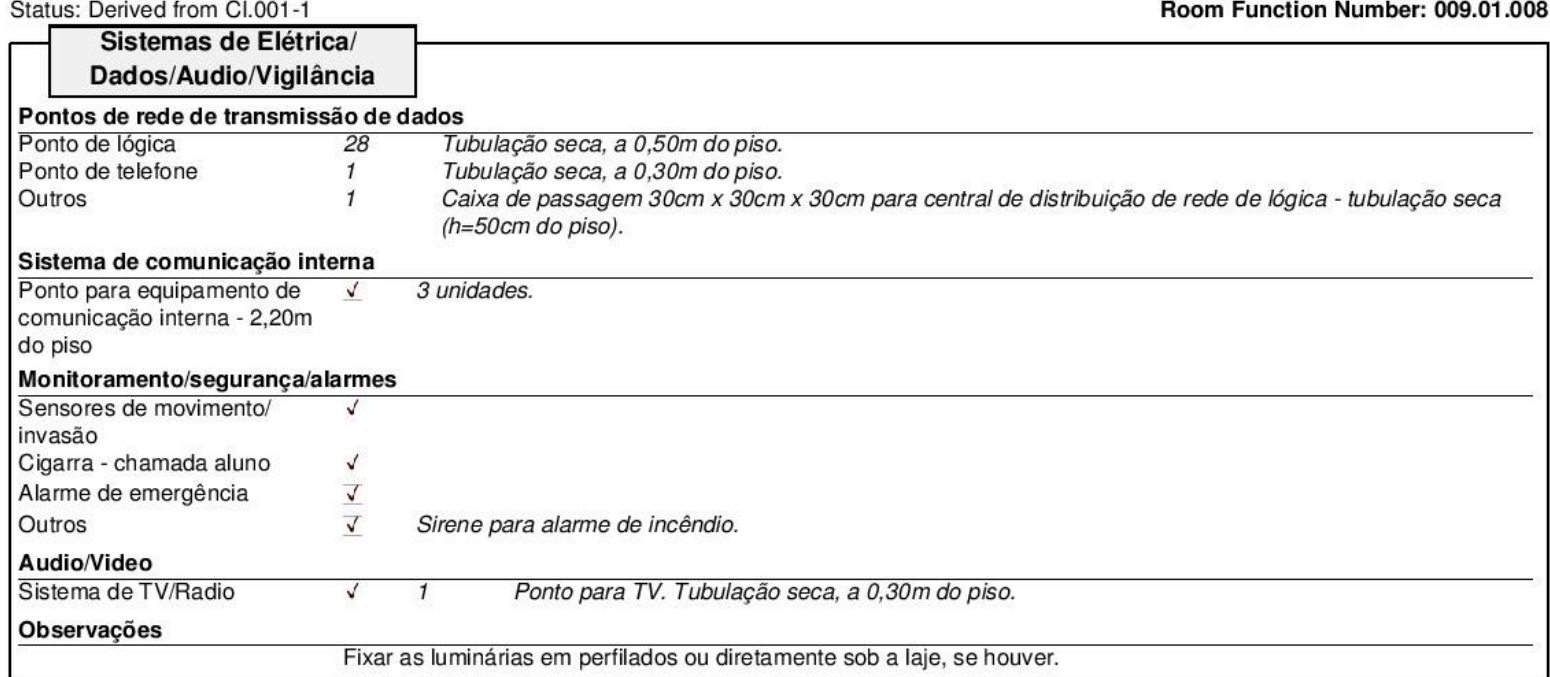

\section{Sistemas hidrossanitários}

Sistema predial de água fria

Dispositivos antivandalismo $\quad \sqrt{ } \quad$ Todos os metais e componentes hidrossanitários.

Sanitários

Filtragem de água $\quad \checkmark \quad$ No mínimo 06 bebedouros coletivos (BB-01).

Ralos

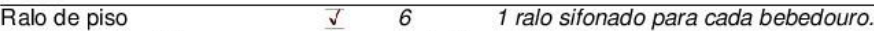

Ralos com requisitos $\quad \checkmark \quad$ Ralo linear para sistema de drenagem do galpão.

específicos

Outros

Prever caimento em direção aos ralos ou canaletas externas.

\section{Segurança contra incêndio}

Equipamentos para segurança contra incêndio

Alarme contra incêndio - $\underline{\checkmark}$ Devidamente sinalizados, conforme o Decreto 46.076 (SÄO PAULO, 2001).

conforme Decreto Estadual N

46.076 (SÄO PAULO, 2001)

Extintores $\quad \checkmark \quad$ Devidamente sinalizados, conforme o Decreto 46.076 (SÃO PAULO, 2001).

Hidrantes $\quad \checkmark \quad$ Devidamente sinalizados, conforme o Decreto 46.076 (SÃO PAULO, 2001).

Outros

Considerar requisitos para evacuação de emergência.

Prever sinalização orientando rotas de saída, sistema de iluminação de emergência e luz de vigia (SÃO PAULO, 2001; 2004).

\section{Operação e Manutenção}

\section{Resíduos}

Programa de reciclagem $\checkmark$

Prever espaço para futura instalação de compartimentos para a coleta seletiva.

Dimensões mínimas: $2,80 \mathrm{~m} \times 0,70 \mathrm{~m}$.

Limpeza

Especificação de detergentes $\checkmark \quad$ Somente produtos de limpeza neutros e não abrasivos.

Procedimentos de limpeza $\quad \checkmark \quad$ Pisos podem ser lavados. Nesse caso, utilizar somente água de reúso.

Frequencia da limpeza $\quad \checkmark \quad$ Toda troca de turno. 


\section{Diretrizes de projeto para Ambientes}

Database SPEducational Facilities

Room Function Number: 009.01.013

Status: From EA.09-1

\begin{tabular}{|c|c|c|}
\hline $\begin{array}{l}\text { RDS status } \\
\text { Last modified }\end{array}$ & $\begin{array}{l}\text { Recuperação 01, Atividades de ensino- } \\
\text { aprendizagem complementares } \\
\text { From EA.09-1 } \\
\text { Limongi França, Ana Judite, January 16, } 20168: 5\end{array}$ & $\begin{array}{l}\text { Function Location: } 009 \text { - Diretoria de Ensino Sul 2 / } 01 \text { - Escola Alpha } \\
\qquad / 03 \text { - Ensino-aprendizagem } \\
3 \text { AM }\end{array}$ \\
\hline Additional Number: & Programmed & Ambientes de Ensino- \\
\hline Name on Drawing & Actual & aprendizagem \\
\hline Room Number & Height: & 3 \\
\hline User Room Number & Perimeter: & 20.92 \\
\hline
\end{tabular}

\section{Descrição}

Informacões gerais

Referência OMNICLASS para 13-31.13.15

o uso do espaço (Tabela 13)

(OCCS, 2012)

ID Geográfico 23.38.29S-46.44.46O-1P-O

Situação Em operação, modificado

Dimensões mínimas

Requisitos quanto às

dimensões do ambiente

Largura - entre eixos $(m) \quad \checkmark \quad 7.2$

Profundidade - entre eixos $(\mathrm{m}) \quad \checkmark \quad 3.6$

Altura mínima - a partir do piso $\checkmark \quad 3$

acabado $(\mathrm{m})$

Descrição de usos e de atividades

Ambiente para desenvolvimento de atividades de ensino-aprendizagem de reforço.

Cargas geradas por atividades humanas

Ocupação 16

Período de utilização $\quad 07: 00$ às

Ocupação, máxima 17 pessoas.

$23: 00 \quad 5$ dias/semana

Taxas metabólicas $\quad$ Equivalente metabólico (Met) Isolamento térmico das roupas (Clo) 0.6

1.3

permanente

Proximidade

Uso em conjunto com outros $\quad \checkmark \quad$ Salas de aula.

ambientes

Distância máxima a percorrer $30 \mathrm{~m}$

até a saída, em caso de

emergência (PMESP, 2010)

Expressão Arquitetônica

Flexibilidade, para permitir o desenvolvimento de diferentes atividades pedagógicas, inclusive com a utilização de
recursos de multimídia.

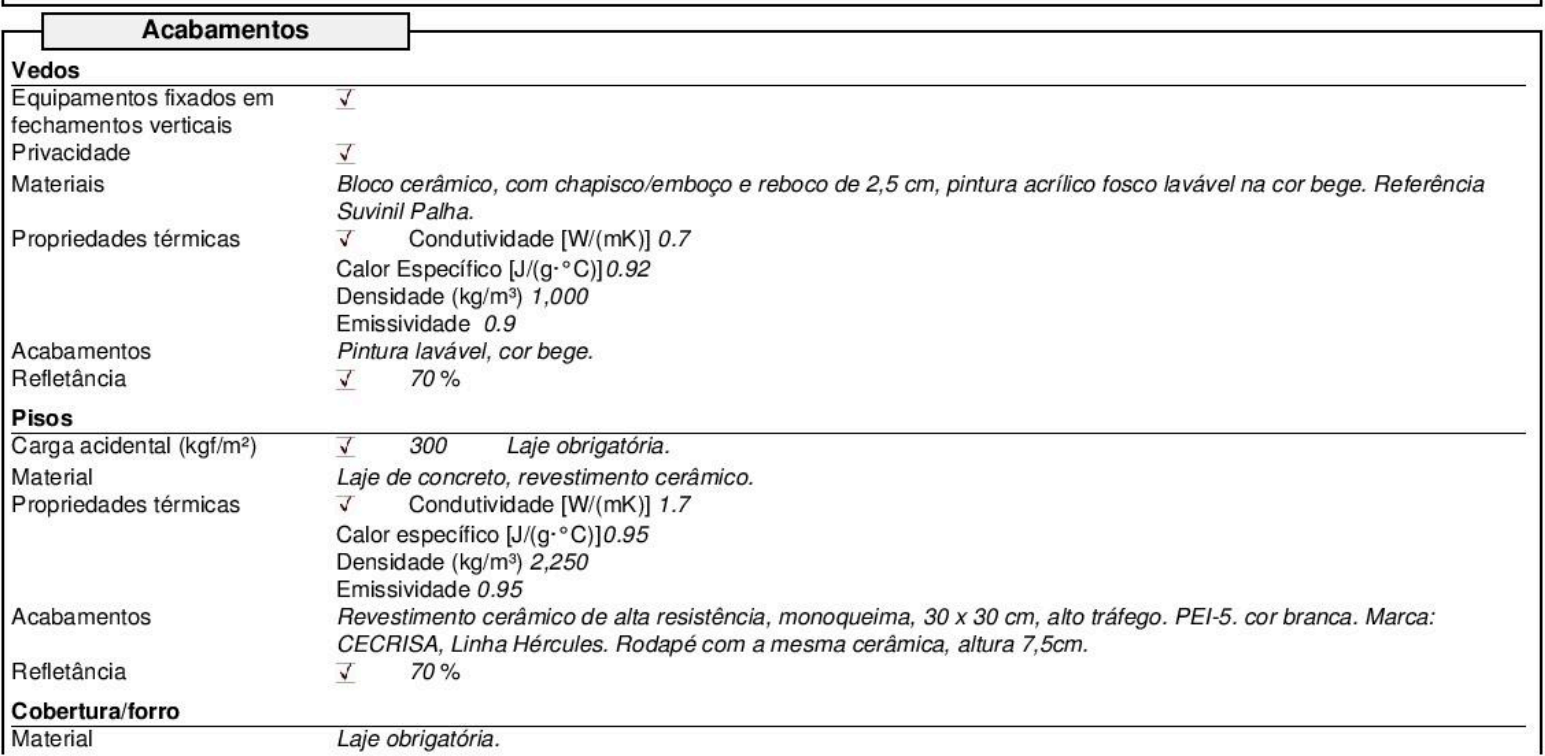


Status: From EA.09-1

Room Function Number: 009.01.013

Cobertura/forro

Propriedades térmicas

\begin{tabular}{ll}
\hline Propriedades térmicas & $\checkmark$ \\
& Calor específico $\left[\mathrm{J} /\left(\mathrm{g} \cdot{ }^{\circ} \mathrm{C}\right)\right] 1$ \\
& Densidade $\left(\mathrm{kg} / \mathrm{m}^{3}\right) 2,200$ \\
& Emissividade 0.95 \\
Acabamentos & Pintura esmalte sintético acetinado semi-brilho na cor branca. \\
Refletância & $\checkmark \quad 70 \%$
\end{tabular}

Refletância

$\checkmark \quad 70 \%$

Outros acabamentos

Estrutura em aço com pintura em poliuretano acrílico. Cor de referência: verde acetinado. Sobre primer epóxi poliamida, exceto onde for necessário prever proteção passiva das estruturas metálicas com argamaça projetada, conforme o Decreto Estadual 46.076 (SÃO PAULO, 2001).

Em elementos estruturais em concreto aparente, prever pintura hidrofugante.

Requisitos para o projeto
Requisitos de desempenho ambiental
Estratégias de sustentabilidade $\checkmark$

Energia: prever sensor de luz natural e circuitos elétricos separados, para permitir o acionamento parcial da iluminação artificial. Especificar lâmpadas fluorecentes T5 com reatores eletrônicos. Iluminação natural: controle solar para evitar ofuscamento e ganhos térmicos indesejados.

Materiais: somente componentes em madeira que tenham certificação de procedência. É obrigatória a apresentação de Documento de Origem Florestal.

Especificar, preferencialmente, componentes com, no mínimo, 25\% de material reciclado pós-consumo. Somente é permitida a utilização de tintas, selantes, impermeabilizantes, adesivos, vernizes e mastiques com

Tratamento acústico baixo indice de compostos orgânicos voláteis.

Níveis sonoros máximos

$[\mathrm{dB}(\mathrm{A})]$

Visualização de ambientes

externos

Ambiente resguardado, Prever tratamento contra ruídos internos e externos. 50 [NBR 10.152:1987 (ABNT, 1987)].

$\checkmark \quad$ Obrigatória. Prever proteções solares.

Evitar a incidência de luz solar direta nos planos de trabalho. Prever dispositivos para a reflexão da luz e a distribuição da luz refletida no forro. Considerar, como planos de trabalho, as carteiras escolares e a lousa.

Área mínima de iluminação $\checkmark \quad 1 / 5$

natural $\left(\mathrm{m}^{2}\right)$, em relação à área

de piso

Área mínima de ventilação $\quad \checkmark \quad 1 / 10$

$\left(\mathrm{m}^{2}\right)$, em relação à área de piso

Taxas mínimas de renovação $\checkmark$ Taxa de renovação de ar externo, por área

de ar, em áreas ocupadas

$\checkmark$ Taxa de renovação de ar externo, por pessoa

Requisitos quanto ao conforto $\quad \checkmark \quad 80$ (\% horas na zona de conforto/ano) [ASHRAE 55.1:2004 (ANSI/ASHRAE, 2004)].

térmico

Requisitos quanto ao desempenho do ambiente - NBR 15.575:2013 (ABNT, 2013)

As aberturas do ambiente devem proporcionar entre 1-4 trocas de ar por hora [ASHRAE 62.1-2013 (ASHRAE, 2013)].

Requisitos quanto à acessibilidade - NBR 9.050:2015 (ABNT, 2015)

Espaço livre para a manobra de cadeira de rodas: $1,50 \mathrm{~m}$

Vão mínimo de portas: $0,80 \mathrm{~m}$.

Maçaneta: Alavanca. Altura: 0,80-1,10 m.

Soleiras inclinadas.

Degraus e desniveis não são permitidos.

Contraste de cor para destaque de aberturas e limites de piso.

Acessos devem ter sinalização visual e tátil.

Requisitos quanto à segurança patrimonial

Ambiente sujeito a arrombamento.

Outros

O leiaute deve ser flexível, de modo a permitir atividades variadas e dinâmicas, não restritas a aulas expositivas.

Prever espaço para a distribuição e instalação de itens de mobiliário e equipamentos, conforme leiaute sugerido.

A profundidade do ambiente deve ser menor ou igual a 3 vezes a distância entre piso e forro acabados (incluídas

saliências e projeções).

$\mathrm{O}$ ambiente deve ser sinalizado.

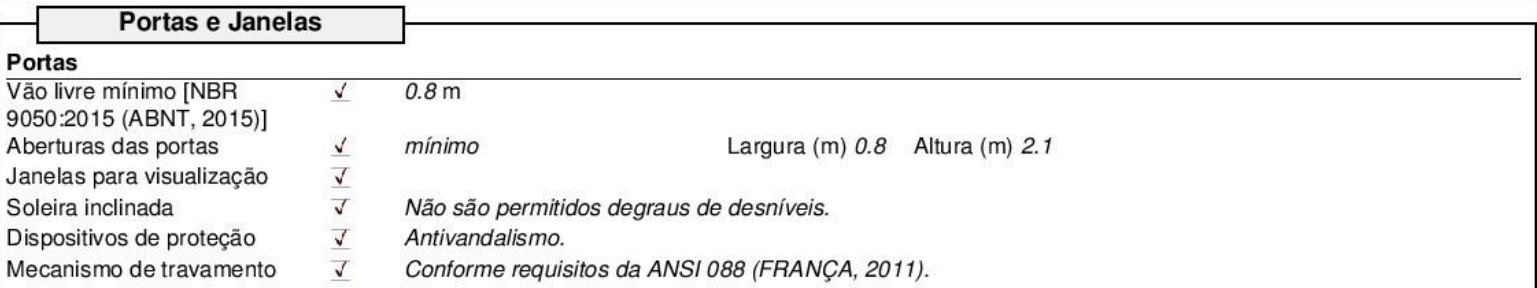




\section{Diretrizes de projeto para Ambientes}

\begin{tabular}{|c|c|c|}
\hline Status: From EA.09-1 & & Room Function Number: 009.01.0 \\
\hline$-\sqrt{\text { Portas e Janelas }}$ & & \\
\hline Portas & & \\
\hline Material da porta & $\checkmark$ & $\begin{array}{l}\text { Madeira. Em ambientes semiabertos, especificar apenas componentes em madeira maciça. Nesses casos, } \\
\text { portas com enchimento sarrafeado não são permitidas. }\end{array}$ \\
\hline Janelas & & \\
\hline $\begin{array}{l}\text { Requisitos de iluminação } \quad \checkmark \\
\text { natural }\end{array}$ & $\checkmark$ & Em paredes externas. \\
\hline $\begin{array}{l}\text { Requisitos de mecanismos de } \checkmark \\
\text { abertura }\end{array}$ & $\checkmark$ & \\
\hline Dispositivos de controle solar $\checkmark$ & $\checkmark$ & \\
\hline Parapeito & $\checkmark$ & \\
\hline Material da estrutura da janela $\checkmark$ & $\checkmark$ & Pintura esmalte, na cor branca, sobre base antioxidante. \\
\hline $\begin{array}{l}\text { Requisitos para a especificação } \checkmark \\
\text { do vidro }\end{array}$ & & Vidro comum, $3 \mathrm{~mm}$ \\
\hline
\end{tabular}

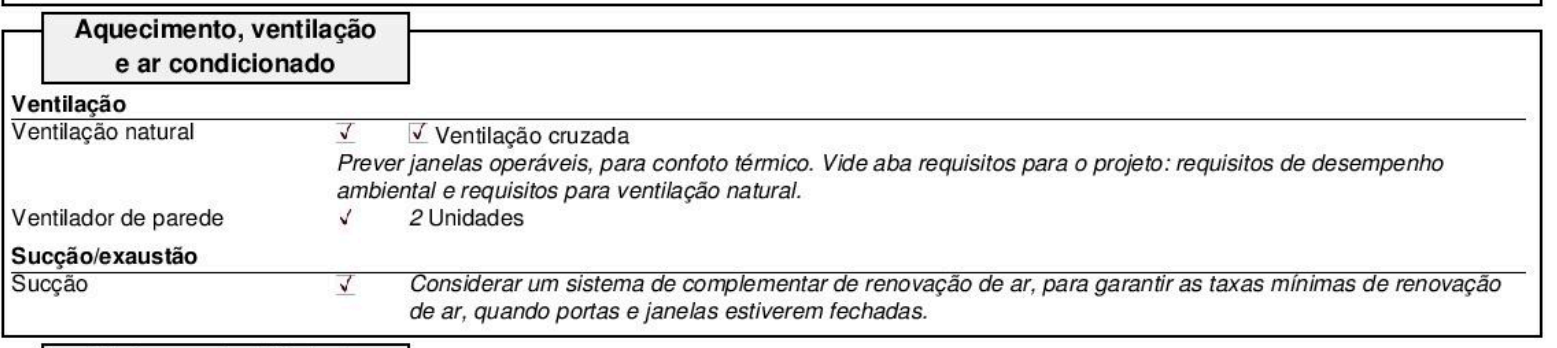

\begin{tabular}{|c|c|c|}
\hline \multicolumn{2}{|c|}{$\begin{array}{l}\text { Sistemas de Elétrica/ } \\
\text { Dados/Audio/Vigilância }\end{array}$} & \\
\hline \multicolumn{3}{|l|}{ Sistemas de iluminação } \\
\hline Sensor de iluminação natural & $\checkmark$ & \\
\hline Setorização dos circuitos & $\checkmark$ & Considerar a distribuição da iluminação natural. \\
\hline $\begin{array}{l}\text { Densidade de Potência } \\
\text { Luminosa (DPL) }\end{array}$ & $\checkmark$ & $15 \mathrm{DPL}\left(\mathrm{W} / \mathrm{m}^{2}\right)$ (ANSI/ASHRAE, 2013b). \\
\hline Nível de iluminâncial (lux) & $\checkmark$ & $\begin{array}{l}300 \text { lux [NBR 5.413:1992 (ABNT, Na lousa - } 500 \text { lux. } \\
\text { 1992)]. }\end{array}$ \\
\hline $\begin{array}{l}\text { Conjuntos (luminárias + } \\
\text { lâmpadas) }\end{array}$ & $\checkmark$ & 4 Unidades 2 Lâmpadas \\
\hline & $32 \mathrm{~W}$ & \multirow{2}{*}{$\begin{array}{l}\nabla \text { Aletas refletivas } \\
\text { Prever controle de ofuscamento nos planos de trabalho (carteiras escolares e lousa). (CIE, 1983). }\end{array}$} \\
\hline Ofuscamento & $\checkmark$ & \\
\hline \multicolumn{3}{|l|}{ Sistemas elétricos } \\
\hline Suprimento de energia & $\checkmark$ & \multirow{2}{*}{$\begin{array}{ll} & \\
2 & \\
& \\
& (A B N T, 10 \mathrm{~A} / 110 \mathrm{~V}, \mathrm{NBR} 14136 \text { Prever } 1 \text { tomada para computador. } \\
& 2 P+T, 10 \mathrm{~A} / 110 \mathrm{~V}, \mathrm{NBR} 14136(A B N T, 2002) .\end{array}$} \\
\hline $\begin{array}{l}\text { Tomada universal baixa - } \\
0,40 \mathrm{~m}\end{array}$ & $\checkmark$ & \\
\hline $\begin{array}{l}\text { Tomada universal média - } \\
1,10 \mathrm{~m}\end{array}$ & $\checkmark$ & $2 \quad 2 P+T, 10 A / 110 V, N B R 14136(A B N T, 2002)$ \\
\hline Interruptores & $\checkmark$ & 2 Integrar com sistema de iluminação natural. \\
\hline \multicolumn{3}{|l|}{ Potência instalada } \\
\hline Potência instalada - iluminação & $\checkmark$ & $256 \mathrm{~W}$ \\
\hline Potência instalada total & $\checkmark$ & $586 \mathrm{~W}$ \\
\hline \multicolumn{3}{|c|}{ Pontos de rede de transmissão de dados } \\
\hline Ponto de lógica & 1 & Ponto de lógica. \\
\hline \multirow{2}{*}{\multicolumn{3}{|c|}{$\begin{array}{l}\text { Sistemas hidrossanitários } \\
\text { Outros }\end{array}$}} \\
\hline & & \\
\hline \multicolumn{3}{|r|}{ Sistemas hidrossanitários não estão previstos para o ambiente. } \\
\hline \multirow{2}{*}{\multicolumn{3}{|c|}{$\begin{array}{l}\text { Segurança contra incêndio } \\
\text { Outros }\end{array}$}} \\
\hline & & \\
\hline \multicolumn{3}{|r|}{ Considerar requisitos para evacuação de emergência (SAOO PAULO, 2001; 2004). } \\
\hline \multicolumn{3}{|c|}{$\begin{array}{l}\text { Operação e Manutenção } \\
\text { Limpeza }\end{array}$} \\
\hline \\
\hline Especificação de detergentes & $\vec{v}$ & \multirow{3}{*}{$\begin{array}{l}\text { Somente produtos de limpeza neutros e não abrasivos. } \\
\text { Limpeza de piso com pano úmido e esfregão. Não lavar com água corrente. } \\
\text { Toda troca de turno. }\end{array}$} \\
\hline Procedimentos de limpeza & $v$ & \\
\hline Frequencia da limpeza & $\checkmark$ & \\
\hline
\end{tabular}




\section{Diretrizes de projeto para}

Database_SPEducational_Facilities

\section{Ambientes}

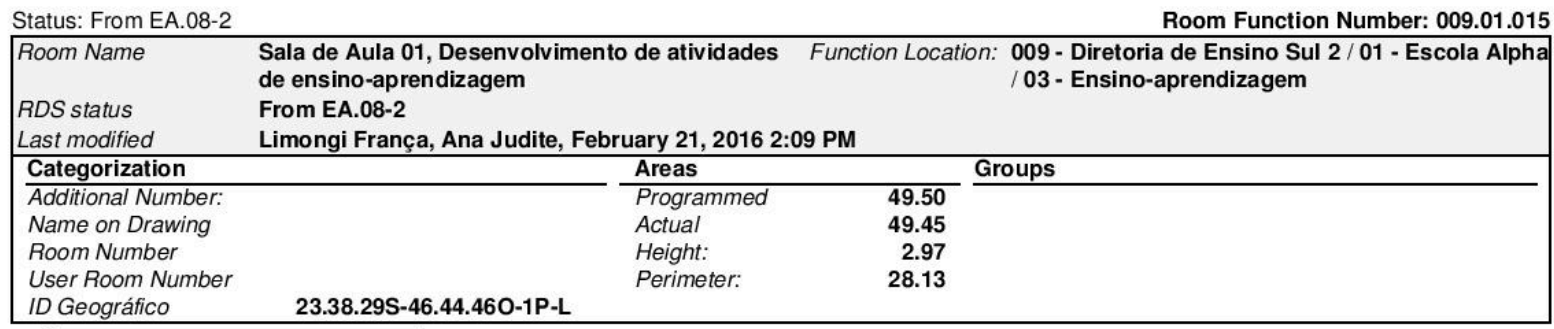

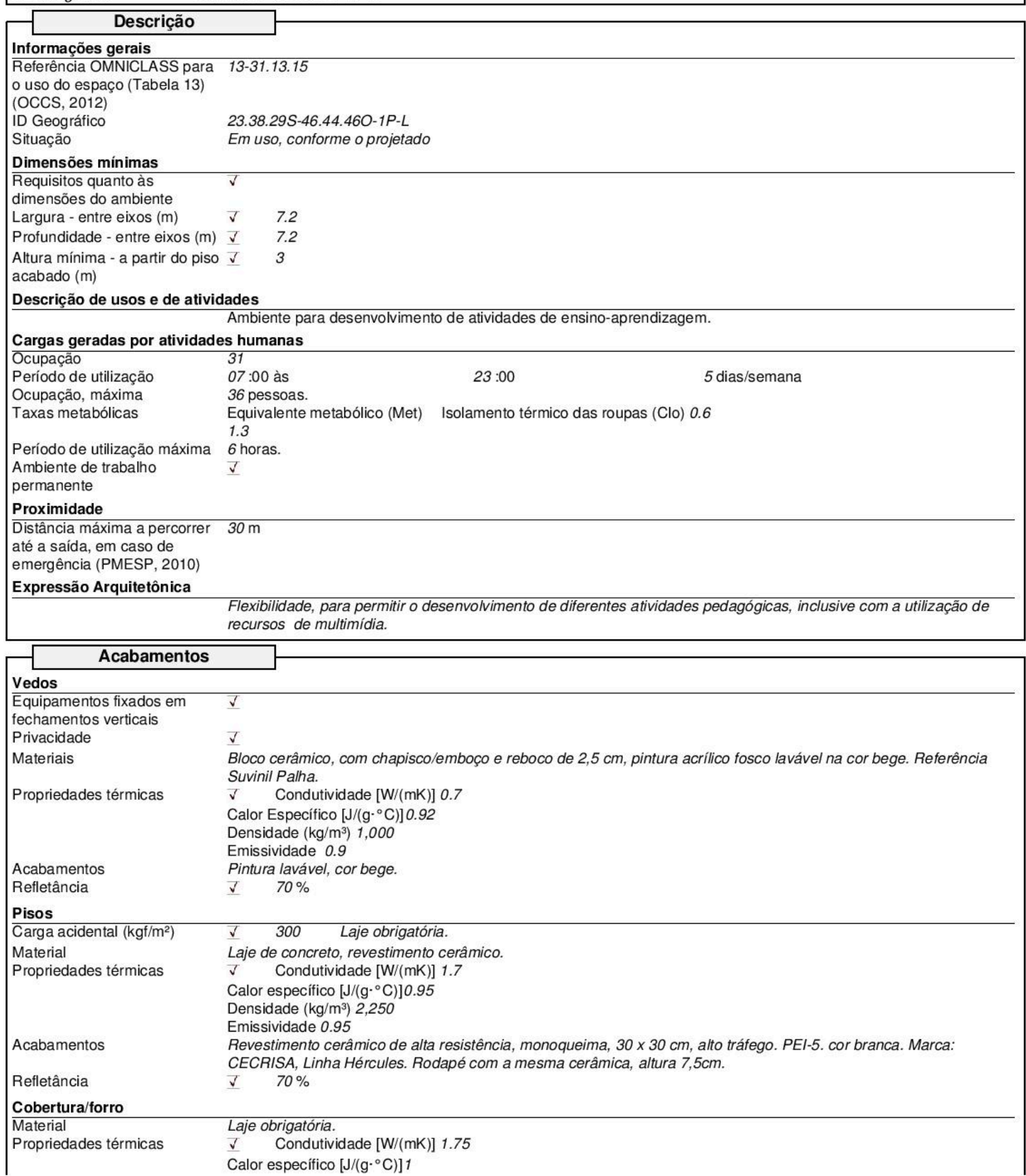




\section{Diretrizes de projeto para Ambientes}

Database SPEducational Facilities

Room Function Number: 009.01.015

Status: From EA.08-2

\begin{tabular}{|l|}
\hline \multicolumn{1}{|c|}{ Acabamentos } \\
Acabamentos
\end{tabular}

\section{Requisitos para o projeto}

Requisitos de desempenho ambienta

Estratégias de sustentabilidade $\checkmark$ Energia: prever sensor de luz natural e circuitos elétricos separados, para permitir o acionamento parcial da iluminaç̃o artificial. Especificar lâmpadas fluorecentes T5 com reatores eletrônicos. Iluminação natural: controle solar para evitar ofuscamento e ganhos térmicos indesejados.

Materiais: somente componentes em madeira que tenham certificação de procedência. É obrigatória a apresentação de Documento de Origem Florestal.

Especificar, preferencialmente, componentes com, no mínimo, 25\% de material reciclado pós-consumo. Somente é permitida a utilização de tintas, selantes, impermeabilizantes, adesivos, vernizes e mastiques com

Tratamento acústico baixo índice de compostos orgânicos voláteis.

Níveis sonoros máximos Ambiente resguardado, Prever tratamento contra ruídos internos e externos.

$[\mathrm{dB}(\mathrm{A})]$

Visualização de ambientes

externos

Controle de ofuscamento

$\checkmark \quad 50$ [NBR 10.152:1987 (ABNT, 1987)].

$\checkmark \quad$ Obrigatória. Prever proteções solares.

Área mínima de iluminação

natural $\left(\mathrm{m}^{2}\right)$, em relação à área

de piso

Área mínima de ventilação $\quad \checkmark \quad 1 / 10$

$\left(\mathrm{m}^{2}\right)$, em relação à área de piso

Taxas mínimas de renovação $\checkmark$ Taxa de renovação de ar externo, por área

de ar, em áreas ocupadas

$\checkmark$ Taxa de renovação de ar externo, por pessoa

Requisitos quanto ao conforto $\checkmark \quad 80$ (\% horas na zona de conforto/ano) [ASHRAE 55.1:2004 (ANSI/ASHRAE, 2004)].

térmico

Requisitos quanto ao desempenho do ambiente - NBR 15.575:2013 (ABNT, 2013)

As aberturas do ambiente devem proporcionar entre 1-4 trocas de ar por hora [ASHRAE 62.1-2013 (ASHRAE, 2013)].

Requisitos quanto à acessibilidade - NBR 9.050:2015 (ABNT, 2015)

Espaço livre para a manobra de cadeira de rodas: $1,50 \mathrm{~m}$

Vão mínimo de portas: $0,80 \mathrm{~m}$

Maçaneta: Alavanca. Altura: $0,80-1,10 \mathrm{~m}$

Soleiras inclinadas.

Degraus e desniveis não são permitidos.

Contraste de cor para destaque de aberturas e limites de piso.

Acessos devem ter sinalização visual e tátil.

Requisitos quanto à segurança patrimonial

Ambiente sujeito a arrombamento.

Outros

O leiaute deve ser flexível, de modo a permitir atividades variadas e dinâmicas, não restritas a aulas expositivas.

Prever espaço para a distribuição e instalação de itens de mobiliário e equipamentos, conforme leiaute sugerido.

A profundidade do ambiente deve ser menor ou igual a 3 vezes a distância entre piso e forro acabados (incluídas

saliências e projeções)

\begin{tabular}{|c|c|c|}
\hline \multicolumn{2}{|c|}{ Portas e Janelas } & \\
\hline Portas & & \\
\hline $\begin{array}{l}\text { Vão livre mínimo [NBR } \\
\text { 9050:2015 (ABNT, 2015)] }\end{array}$ & $\checkmark$ & $0.8 \mathrm{~m}$ \\
\hline Aberturas das portas & $\checkmark$ & Largura $(\mathrm{m}) 0.8 \quad$ Altura $(\mathrm{m}) 2.1$ \\
\hline Janelas para visualização & $\checkmark$ & \\
\hline Soleira inclinada & $\checkmark$ & Não são permitidos degraus de desníveis. \\
\hline Dispositivos de proteção & $\checkmark$ & Antivandalismo. \\
\hline Mecanismo de travamento & $\checkmark$ & Conforme requisitos da ANSI 088 (FRANÇA, 2011). \\
\hline Material da porta & $\checkmark$ & $\begin{array}{l}\text { Madeira. Em ambientes semiabertos, especificar apenas componentes em madeira maciça. Nesses casos, } \\
\text { portas com enchimento sarrafeado não são permitidas. }\end{array}$ \\
\hline
\end{tabular}


Status: From EA.08-2

\begin{tabular}{|c|c|c|}
\hline \multicolumn{2}{|l|}{ Portas e Janelas } & \\
\hline Janelas & & \\
\hline $\begin{array}{l}\text { Requisitos de iluminação } \\
\text { natural }\end{array}$ & $\checkmark$ & Em paredes externas. \\
\hline $\begin{array}{l}\text { Com dispositivos para abertura } \\
\text { e fechamento }\end{array}$ & $\checkmark$ & $\begin{array}{l}\text { O usuário deve controlar as aberturas para ventilação nath } \\
\text { exaustão para assegurar níveis mínimos de renovação de }\end{array}$ \\
\hline $\begin{array}{l}\text { Requisitos de mecanismos de } \\
\text { abertura }\end{array}$ & & \\
\hline Dispositivos de controle solar & $\checkmark$ & \\
\hline Parapeito & $\checkmark$ & \\
\hline $\begin{array}{l}\text { Material da estrutura da janela } \\
\text { Requisitos para a especificacão }\end{array}$ & $\begin{array}{l}\checkmark \\
\checkmark\end{array}$ & $\begin{array}{l}\text { Pintura esmalte, na cor branca, sobre base antioxidante. } \\
\text { Vidro comum, } 3 \mathrm{~mm} \text {. }\end{array}$ \\
\hline
\end{tabular}

Requisitos para a especificaçäo $\checkmark$ Vidro comum, $3 \mathrm{~mm}$.

do vidro

\begin{tabular}{|c|c|c|}
\hline \multicolumn{2}{|c|}{$\begin{array}{c}\text { Aquecimento, ventilação } \\
\text { e ar condicionado }\end{array}$} & \\
\hline \multicolumn{3}{|c|}{ Ventilação } \\
\hline \multirow[t]{2}{*}{ Ventilação natural } & $\checkmark$ & $\checkmark$ Ventilação cruzada \\
\hline & & $\begin{array}{l}\text { rjanelas operáveis, para confoto térmico. Vide aba requisitos para o projeto: requisitos de desempenho } \\
\text { ntal e requisitos para ventilação natural. }\end{array}$ \\
\hline Ventilador de parede & $\checkmark$ & 2 Unidades \\
\hline \multicolumn{3}{|l|}{ Sucção/exaustão } \\
\hline
\end{tabular}

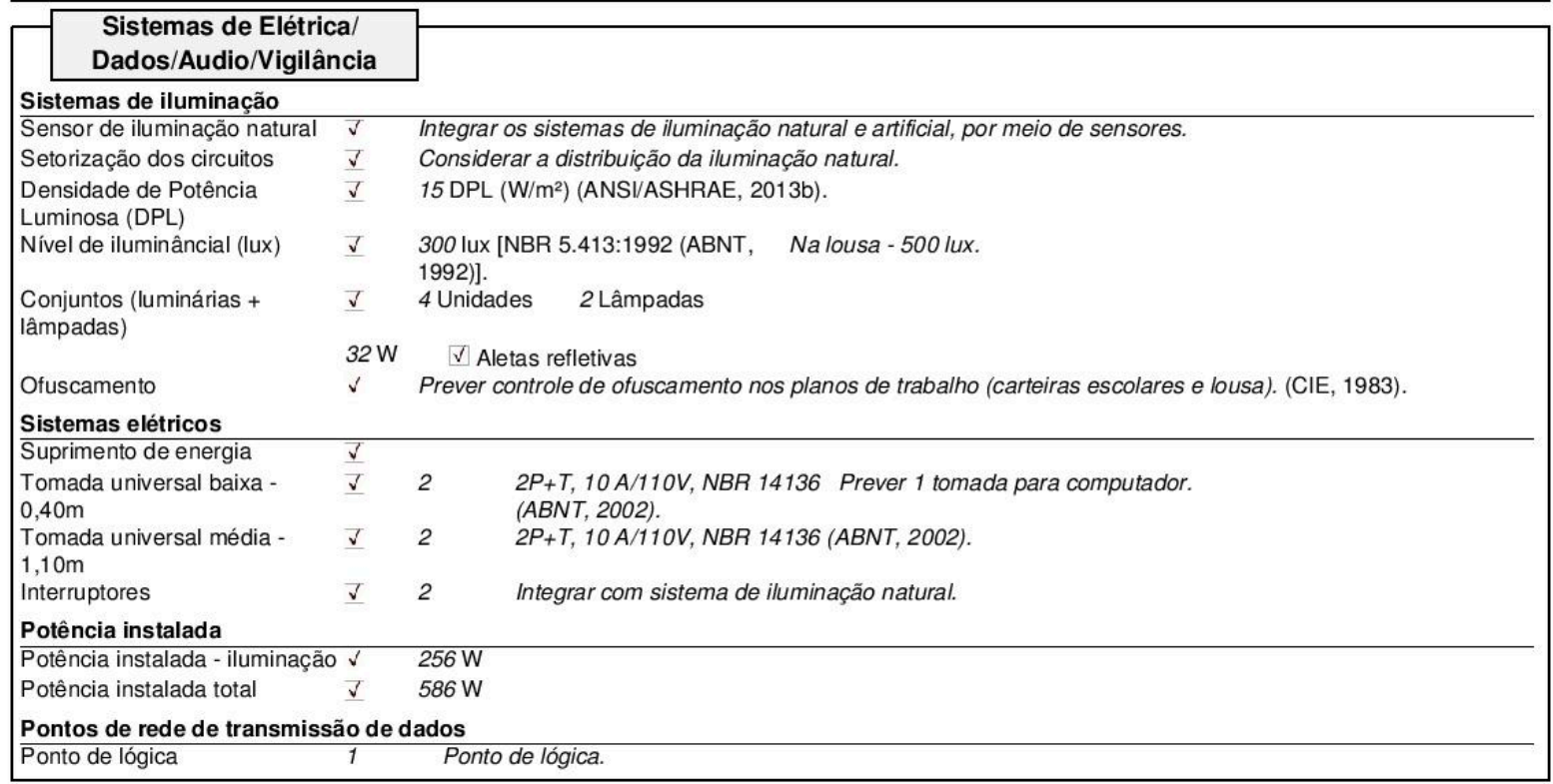

\section{Sistemas hidrossanitários}

Outros

Sistemas hidrossanitários não estão previstos para o ambiente.

\section{Segurança contra incêndio}

Outros

Considerar requisitos para evacuação de emergência (SAO PAULO, 2001; 2004).

Operação e Manutenção

\section{Resíduos}

\begin{tabular}{ll}
\hline Programa de reciclagem & $\checkmark$ \\
& Prever lixeiras para a separação do lixo orgânico e lixo reciclável. Promover atividades educativas para conscientizar
\end{tabular} os alunos sobre o programa de reciclagem e sua importância ambiental.

Limpeza

Especificação de detergentes $\quad \checkmark \quad$ Somente produtos de limpeza neutros e não abrasivos.

Procedimentos de limpeza $\quad \checkmark \quad$ Limpeza de piso com pano úmido e esfregão. Não lavar com água corrente.

Frequencia da limpeza $\quad \frac{\checkmark}{} \quad$ Toda troca de turno. 


\section{Diretrizes de projeto para Ambientes}

Database SPEducational Facilities

Room Function Number: 009.01.030

Status: From EA.012

\begin{tabular}{|llll|}
\hline Room Name & Sala de Informática, Inclusão digital e social & Function Location: 009 - Diretoria de Ensino Sul 2 / 01 - Escola Alpha \\
/ 03 - Ensino-aprendizagem & & \\
RDS status & From EA.012 & Areas & \\
Last modified & Limongi França, Ana Judite, January 15, 2016 5:33 PM & Groups \\
\hline Categorization & & Programmed & 74.50 \\
\hline Additional Number: & & Actual & $\mathbf{7 4 . 7 7}$ \\
Name on Drawing & & Height: & 3 \\
Room Number & & Perimeter: & 35.34 \\
User Room Number & $23.38 .29 S 46.44 .46 W-T R-L$ & & \\
ID Geográfico & & \\
\hline
\end{tabular}

\section{Descrição}

Informaç̃es gerais

Referência OMNICLASS para 13-13.11.99

o uso do espaço (Tabela 13)

(OCCS, 2012)

ID Geográfico 23.38.29S-46.44.46O-TR-L

Situação Em uso, conforme o projetado

Dimensões mínimas

Requisitos quanto às

dimensões do ambiente

Largura - entre eixos $(m) \quad \checkmark \quad 7.2$

Profundidade - entre eixos $(\mathrm{m}) \quad \checkmark \quad 7.2$

Altura mínima - a partir do piso $\checkmark \quad 3$

acabado $(\mathrm{m})$

Descrição de usos e de atividades

Inclusão digital e social dos alunos, professores e funcionários das escolas da rede pública estadual.

Cargas geradas por atividades humanas

Ocupação 35

Período de utilização $\quad 07: 00$ às

Ocupação, máxima $\quad 36$ pessoas.

$23: 00 \quad 5$ dias/semana

Taxas metabólicas

Equivalente metabólico (Met) Isolamento térmico das roupas (Clo) 0.6

Equi 1.3

Período de utilização máxima 6 horas.

Ambiente de trabalho $\checkmark$

permanente

Proximidade

Uso em conjunto com outros $\checkmark$ Ambientes administrativos, sala de uso múltiplo, sala de leitura e sala de uso múltiplo.

ambientes

Proximidade a/distância de

outros ambientes

Concentrar horizontal e/ou verticalmente os ambientes administrativos, uso múltiplo, sala de leitura esala de informática de forma a racionalizar a rede de distribuição lógica. Localização estratégica considerando facilidade de acesso e minimizando a distância entre a central de distribuição lógica (rack de informática) e o ponto de

Distância máxima a percorrer $30 \mathrm{~m}$ consolidação de trabalho. Prever desnivel para evitar a entrada de águas pluviais.

até a saída, em caso de

emergência (PMESP, 2010)

Expressão Arquitetônica

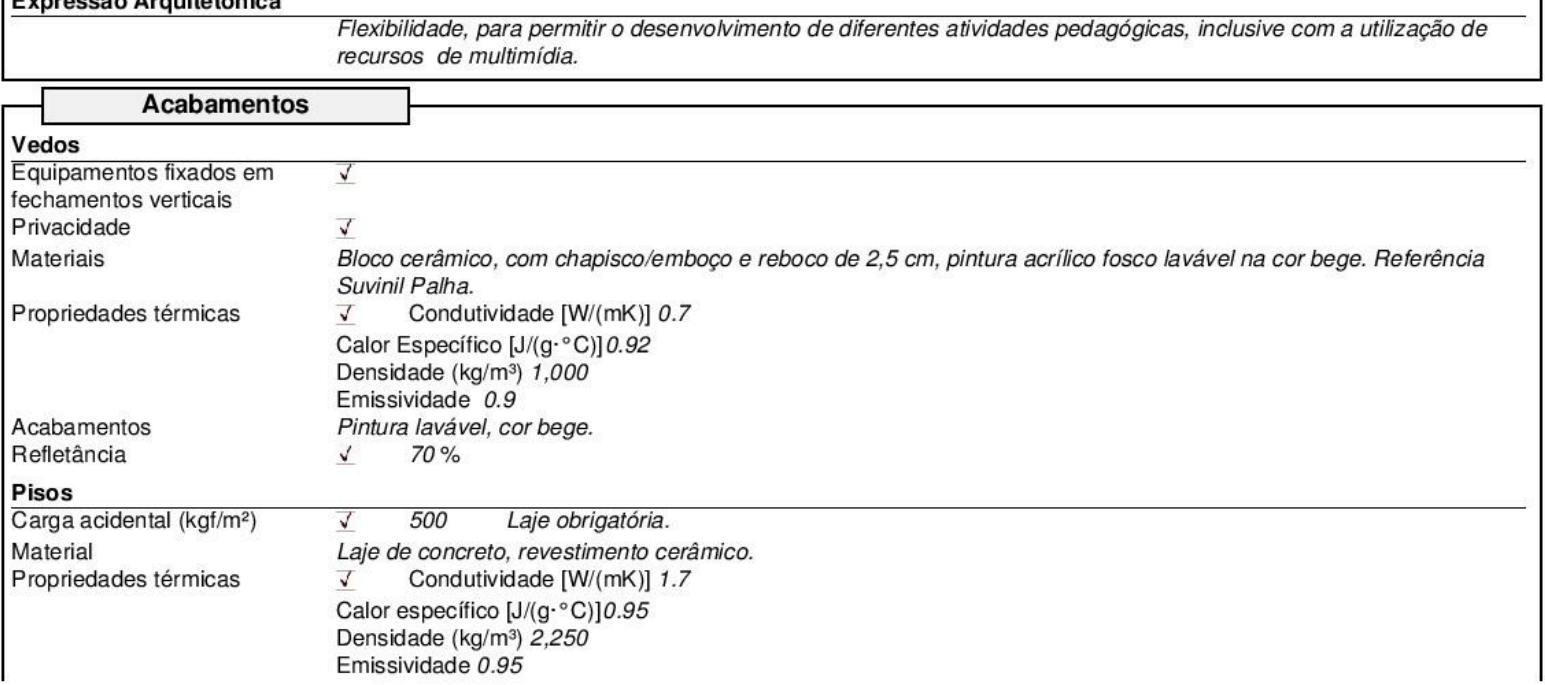




\section{Diretrizes de projeto para}

Status: From EA.012

Room Function Number: 009.01.030

\begin{tabular}{|ll|}
\hline \multicolumn{1}{|c|}{ Acabamentos } \\
Pisos
\end{tabular}

\section{Requisitos para o projeto}

Requisitos de desempenho ambiental

Estratégias de sustentabilidade $\checkmark \quad$ Energia: prever sensor de luz natural e circuitos elétricos separados, para permitir o acionamento parcial da iluminação artificial. Especificar lâmpadas fluorecentes T5 com reatores eletrônicos. Iluminação natural: controle solar para evitar ofuscamento e ganhos térmicos indesejados. Materiais: somente componentes em madeira que tenham certificação de procedência. É obrigatória a apresentação de Documento de Origem Florestal.

Especificar, preferencialmente, componentes com, no mínimo, $25 \%$ de material reciclado pós-consumo. Somente é permitida a utilização de tintas, selantes, impermeabilizantes, adesivos, vernizes e mastiques com baixo índice de compostos orgânicos voláteis.

Tratamento acústico $\checkmark \quad$ Ambiente resguardado, Prever tratamento contra ruídos internos e externos.

Níveis sonoros máximos

$[\mathrm{dB}(\mathrm{A})]$

Visualização de ambientes

externos

$\checkmark \quad 45$ [NBR 10.152:1987 (ABNT, 1987)].

Controle de ofuscamento

$\checkmark$ Obrigatória. Prever proteções solares.

$\checkmark$

Evitar a incidência de luz solar direta nos planos de trabalho. Prever dispositivos para a reflexão da luz e a distribuição da luz refletida no forro. Considerar, como planos de trabalho, as telas dos computadores, as carteiras escolares e a lousa.

Área mínima de iluminação $\quad \underline{v} 1 / 5$

natural $\left(\mathrm{m}^{2}\right)$, em relação à área

de piso

Área mínima de ventilação $\quad \checkmark \quad 1 / 10$

$\left(\mathrm{m}^{2}\right)$, em relação à área de piso

Taxas mínimas de renovação $\checkmark$ Taxa de renovação de ar externo, por área

de ar, em áreas ocupadas

$\checkmark$ Taxa de renovação de ar externo, por pessoa

Requisitos quanto ao conforto $\checkmark \quad 80$ (\% horas na zona de conforto/ano) [ASHRAE 55.1:2004 (ANSI/ASHRAE, 2004)].

térmico

Requisitos quanto ao desempenho do ambiente - NBR 15.575:2013 (ABNT, 2013)

As aberturas do ambiente devem proporcionar entre 1-4 trocas de ar por hora [ASHRAE 62.1-2013 (ASHRAE, 2013)].

Requisitos quanto à acessibilidade - NBR 9.050:2015 (ABNT, 2015)

Espaço livre para a manobra de cadeira de rodas: $1,50 \mathrm{~m}$

Vão mínimo de portas: $0,80 \mathrm{~m}$.

Maçaneta: Alavanca. Altura: 0,80-1,10 m.

Soleiras inclinadas.

Degraus e desníveis não são permitidos.

Contraste de cor para destaque de aberturas e limites de piso.

Acessos devem ter sinalização visual e tátil.

Requisitos quanto à segurança patrimonial

Ambiente sujeito a invasão. Necessário maior nível de segurança. Prever sistemas de trancas ou fechaduras especiais nas portas. Prever sistemas de controle de acesso e de alarme.

Outros

Não posicionar o ambiente em fachadas de alta insolação ou prever anteparos de proteção. Ventilação cruzada obrigatória através de caixilhos situados na parede oposta à das janelas.

A profundidade do ambiente deve ser menor ou igual a 3 vezes a distância entre piso e forro acabados (incluídas saliências e projeções).

$\mathrm{O}$ ambiente deve ser sinalizado.

Portas e Janelas




\section{Diretrizes de projeto para Ambientes}

Status: From EA.012

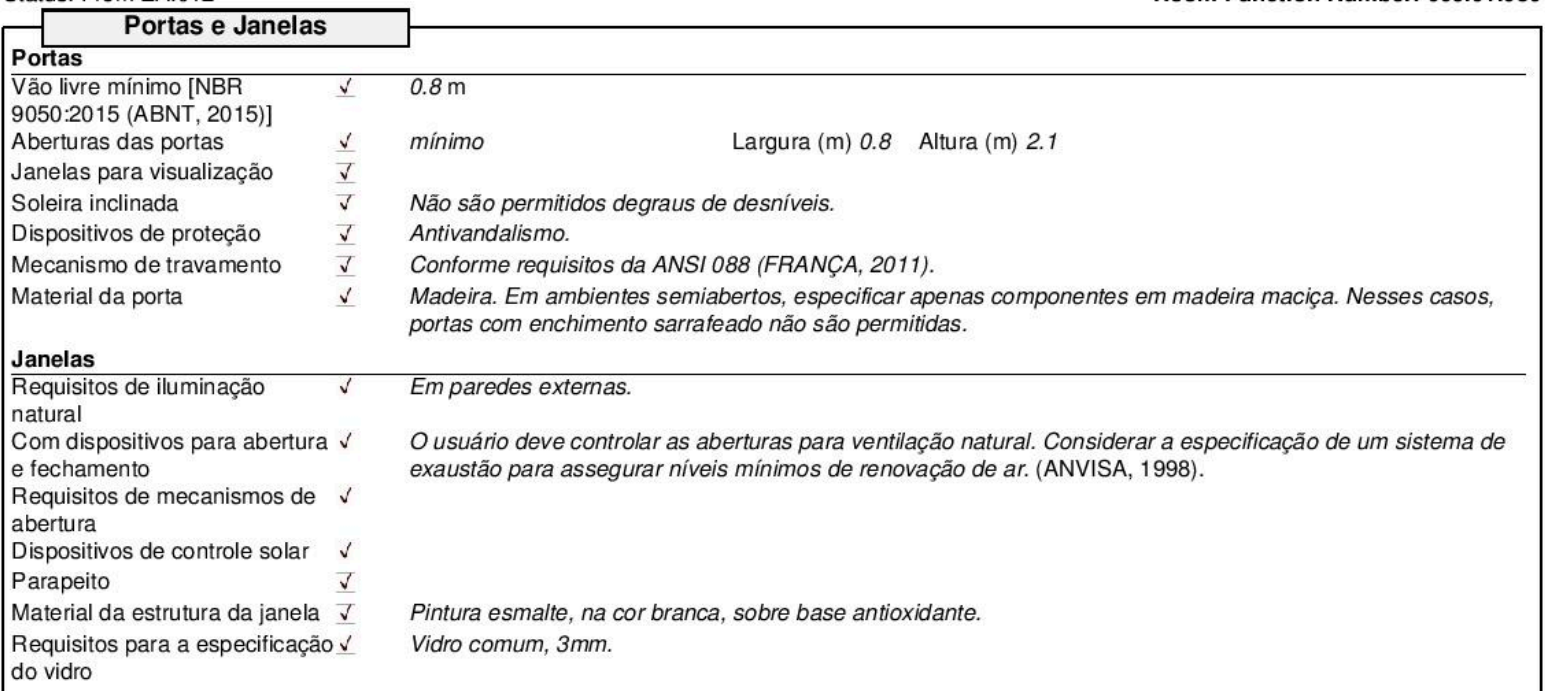

\begin{tabular}{|c|c|c|}
\hline \multicolumn{2}{|c|}{$\begin{array}{l}\text { Aquecimento, ventilação } \\
\text { e ar condicionado }\end{array}$} & \\
\hline \multicolumn{3}{|l|}{ Ventilação } \\
\hline Ventilação natural & $\begin{array}{l}\mathrm{V} \\
\text { Preve } \\
\text { ambie }\end{array}$ & $\begin{array}{l}\checkmark \text { Ventilação cruzada } \\
\text { janelas operáveis, para confoto térmico. Vide aba requisitos para o projeto: requisitos de desempenho } \\
\text { ttal e requisitos para ventilação natural. }\end{array}$ \\
\hline Ventilador de parede & $\checkmark$ & 2 Unidades \\
\hline \multicolumn{3}{|l|}{ Sucção/exaustão } \\
\hline
\end{tabular}

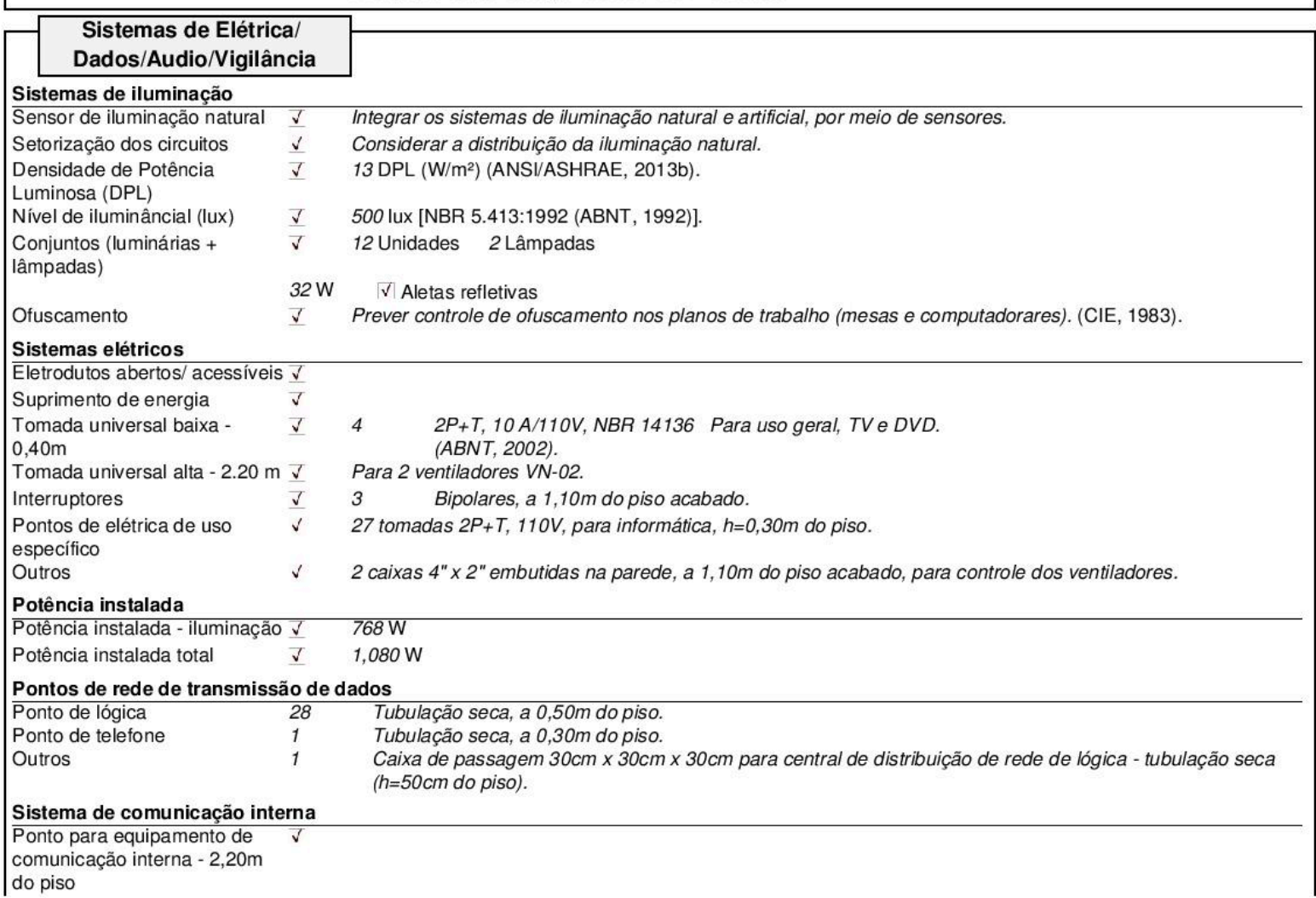


Diretrizes de projeto para Ambientes

Room Function Number: 009.01.030

Status: From EA.012

Sistemas de Elétrica/

Dados/Audio/Vigilância

Monitoramento/segurança/alarmes

Sensores de movimento/ $\checkmark$

invasão

Alarme de emergência

Outros

Audio/Video

$\checkmark$ Ponto para equipamento de controle de acesso e segurança - tubulação seca ( $h=2,20 \mathrm{~m}$ do piso acabado).

Sistema de TV/Radio $\quad \checkmark \quad 1 \quad$ Ponto para TV. Tubulação seca, a 0,30m do piso.

Observações

As instalações para os computadores e demais equipamentos de informática devem ser exclusivas. Não é permitido o compartilhamento de eletrodutos, caixas de distribuição e de passagem com outros circuitos. Etiquetas para a identificação dos circuitos devem ser fixadas na parte interna da tampa do quadro de distrbuição.

Observar disposições apresentadas pela NBR 5410:2004 (ABNT, 2004) Instalações elétricas de baixa tensão.

\section{Sistemas hidrossanitários}

Outros

Sistemas hidrossanitários não estẫo previstos para o ambiente.

Segurança contra incêndio

Outros

Considerar requisitos para evacuação de emergência (SÄO PAULO, 2001; 2004).

\section{Operação e Manutenção}

Limpeza

Especificação de detergentes $\checkmark \checkmark \quad$ Somente produtos de limpeza neutros e não abrasivos.

Procedimentos de limpeza $\quad \frac{v}{v} \quad$ Limpeza de piso com pano úmido e esfregão. Não lavar com água corrente.

Frequencia da limpeza $\quad \checkmark \quad$ Toda troca de turno. 


\section{Diretrizes de projeto para Ambientes}

Room Function Number: 009.01.031

Status: From EA.011

\begin{tabular}{|c|c|c|}
\hline Room Name & \multicolumn{2}{|c|}{$\begin{array}{lc}\begin{array}{l}\text { Sala de Leitura, Desenvolvimento de atividades } \\
\text { pedagógicas complementares }\end{array} & \text { Function Location: } 009 \text { - Diretoria de Ensino Sul } 2 \text { / } 01 \text { - Escola Alpha } \\
/ 03-\text { Ensino-aprendizagem }\end{array}$} \\
\hline Last modified & \multicolumn{2}{|l|}{ Limongi França, Ana Judite, January 15, 2016 5:33 PM } \\
\hline Additional Number: & Programmed & Ambientes de Ensino- \\
\hline Name on Drawing & Actual & aprendizagem \\
\hline Room Number & Height: & 3 \\
\hline User Room Number & Perimeter: & 35.34 \\
\hline
\end{tabular}

\section{Descrição}

Informacões gerais

Referência OMNICLASS para 13-31.17.11

o uso do espaço (Tabela 13)

(OCCS, 2012)

ID Geográfico 23.38.29S-46.44.46O-TR-L

Situação Em operação, modificado

Dimensões mínimas

Requisitos quanto às

dimensões do ambiente

Largura - entre eixos $(m) \quad \checkmark \quad 7.2$

Profundidade - entre eixos $(\mathrm{m}) \quad \checkmark \quad 7.2$

Altura mínima - a partir do piso $\checkmark \quad 3$

acabado $(\mathrm{m})$

Descrição de usos e de atividades

Atendimento às atividades curriculares como consulta e empréstimo de livros, leitura, pesquisa e trabalhos em grupo. Acervo de livros, revistas, jornais e outros meios de informação e comunicação, tais como jogos, mapas, entre outros.

Cargas geradas por atividades humanas

Ocupação

Período de utilização $\quad 27: 00$ às

Ocupação, máxima 27 pessoas.

Taxas metabólicas $\quad$ Equivalente metabólico (Met) Isolamento térmico das roupas (Clo) 0.6

Período de utilização máxima 6 horas.

Ambiente de trabalho

permanente

Proximidade

Uso em conjunto com outros $\quad \checkmark \quad$ Ambientes administrativos, sala de uso múltiplo, sala de uso múltiplo e sala de informática.

ambientes

Proximidade a/distância de

outros ambientes

Concentrar horizontal e/ou verticalmente os ambientes administrativos, uso múltiplo, sala de leitura e

sala de informática de forma a racionalizar a rede de distribuição lógica. Localização estratégica minimizando a

distância entre a central de distribuição lógica (rack de informática) e para ser utilizada como espera para o usuário

Distância máxima a percorrer $30 \mathrm{~m}$

da sala de informática.

até a saída, em caso de

emergência (PMESP, 2010)

Expressão Arquitetônica

Flexibilidade, para permitir o desenvolvimento de diferentes atividades pedagógicas, inclusive com a utilização de recursos de multimídia.

\begin{tabular}{|ll|}
\hline \multicolumn{1}{|c|}{ Acabamentos } \\
Vedos
\end{tabular}




\section{Diretrizes de projeto para}

Status: From EA.011

Room Function Number: 009.01.031

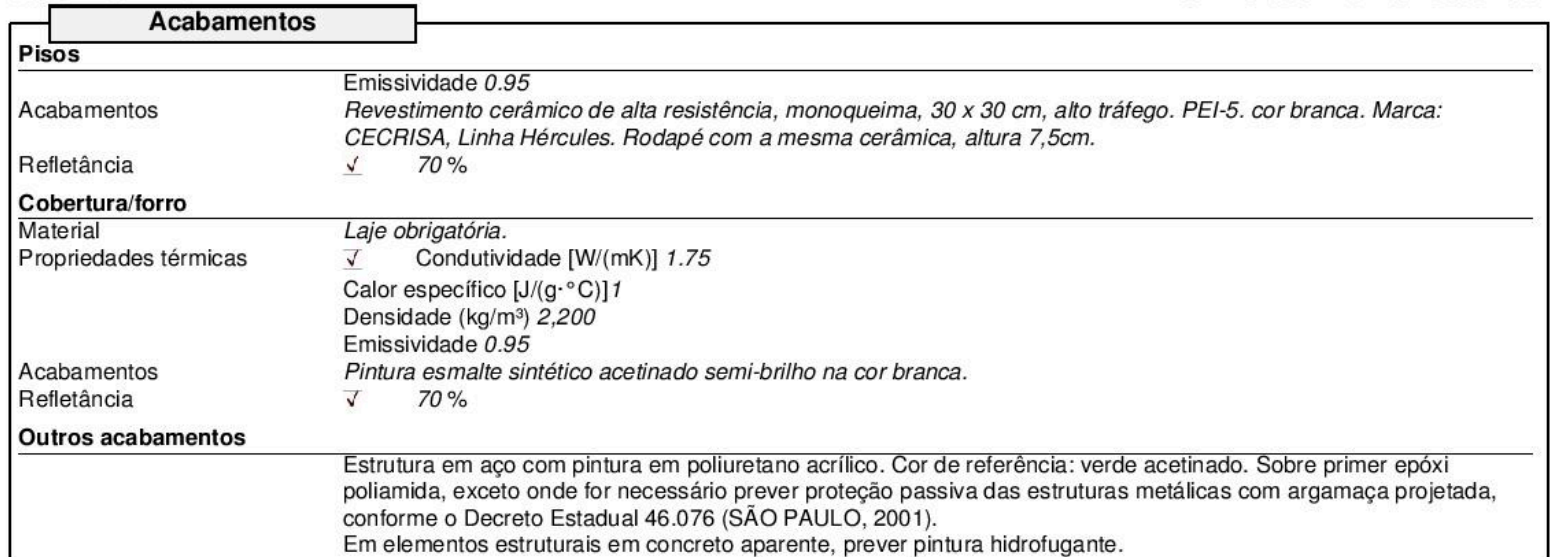

Requisitos para o projeto

Requisitos de desempenho ambiental

Estratégias de sustentabilidade $\checkmark \quad$ Energia: prever sensor de luz natural e circuitos elétricos separados, para permitir o acionamento parcial da iluminação artificial. Especificar lâmpadas fluorecentes T5 com reatores eletrônicos. Iluminação natural: controle solar para evitar ofuscamento e ganhos térmicos indesejados.

Materiais: somente componentes em madeira que tenham certificação de procedência. É obrigatória a apresentação de Documento de Origem Florestal.

Especificar, preferencialmente, componentes com, no mínimo, $25 \%$ de material reciclado pós-consumo.

Somente é permitida a utilização de tintas, selantes, impermeabilizantes, adesivos, vernizes e mastiques com baixo índice de compostos orgânicos voláteis.

Tratamento acústico

$\checkmark \quad$ Ambiente resguardado, Prever tratamento contra ruídos internos e externos.

Níveis sonoros máximos

45 [NBR 10.152:1987 (ABNT, 1987)].

$[\mathrm{dB}(\mathrm{A})]$

Visualização de ambientes

externos

$$
\checkmark \quad 45 \text { [NBR 10.152:1987 (ABNT, 1987)]. }
$$

Controle de ofuscamento

$$
\sqrt{ }
$$

Evitar a incidência de luz solar direta nos planos de trabalho. Prever dispositivos para a reflexão da luz e a distribuição da luz refletida no forro. Considerar, como planos de trabalho, as carteiras escolares, lousas e telas de equipamentos de multimídia.

Área mínima de iluminação $\checkmark \quad 1 / 5$

natural $\left(\mathrm{m}^{2}\right)$, em relação à área

de piso

Área mínima de ventilação $\quad$ v $\quad$ 1/10

$\left(\mathrm{m}^{2}\right)$, em relação à área de piso

Taxas mínimas de renovação $\checkmark$ Taxa de renovação de ar externo, por área

de ar, em áreas ocupadas

$\checkmark$ Taxa de renovação de ar externo, por pessoa

Requisitos quanto ao conforto $\sqrt{ } \quad 80$ (\% horas na zona de conforto/ano) [ASHRAE 55.1:2004 (ANSI/ASHRAE, 2004)].

térmico

Requisitos quanto ao desempenho do ambiente - NBR 15.575:2013 (ABNT, 2013)

As aberturas do ambiente devem proporcionar entre 1-4 trocas de ar por hora [ASHRAE 62.1-2013 (ASHRAE, 2013)].

Requisitos quanto à acessibilidade - NBR 9.050:2015 (ABNT, 2015)

Espaço livre para a manobra de cadeira de rodas: $1,50 \mathrm{~m}$.

Vão mínimo de portas: $0,80 \mathrm{~m}$.

Maçaneta: Alavanca. Altura: 0,80-1,10 m.

Soleiras inclinadas.

Degraus e desniveis não são permitidos.

Contraste de cor para destaque de aberturas e limites de piso.

Acessos devem ter sinalização visual e tátil.

Requisitos quanto à segurança patrimonial

\section{Outros}

Ambiente sujeito a arrombamento. Prever gradis e sistema de alarme.

Não posicionar o ambiente em fachadas de alta insolação ou prever anteparos de proteção. Ventilação cruzada obrigatória através de caixilhos situados na parede oposta à das janelas.

A profundidade do ambiente deve ser menor ou igual a 3 vezes a distância entre piso e forro acabados (incluídas saliências e projeções).

O ambiente deve ser sinalizado.

Portas e Janelas




\section{Diretrizes de projeto para} Ambientes

Status: From EA.011

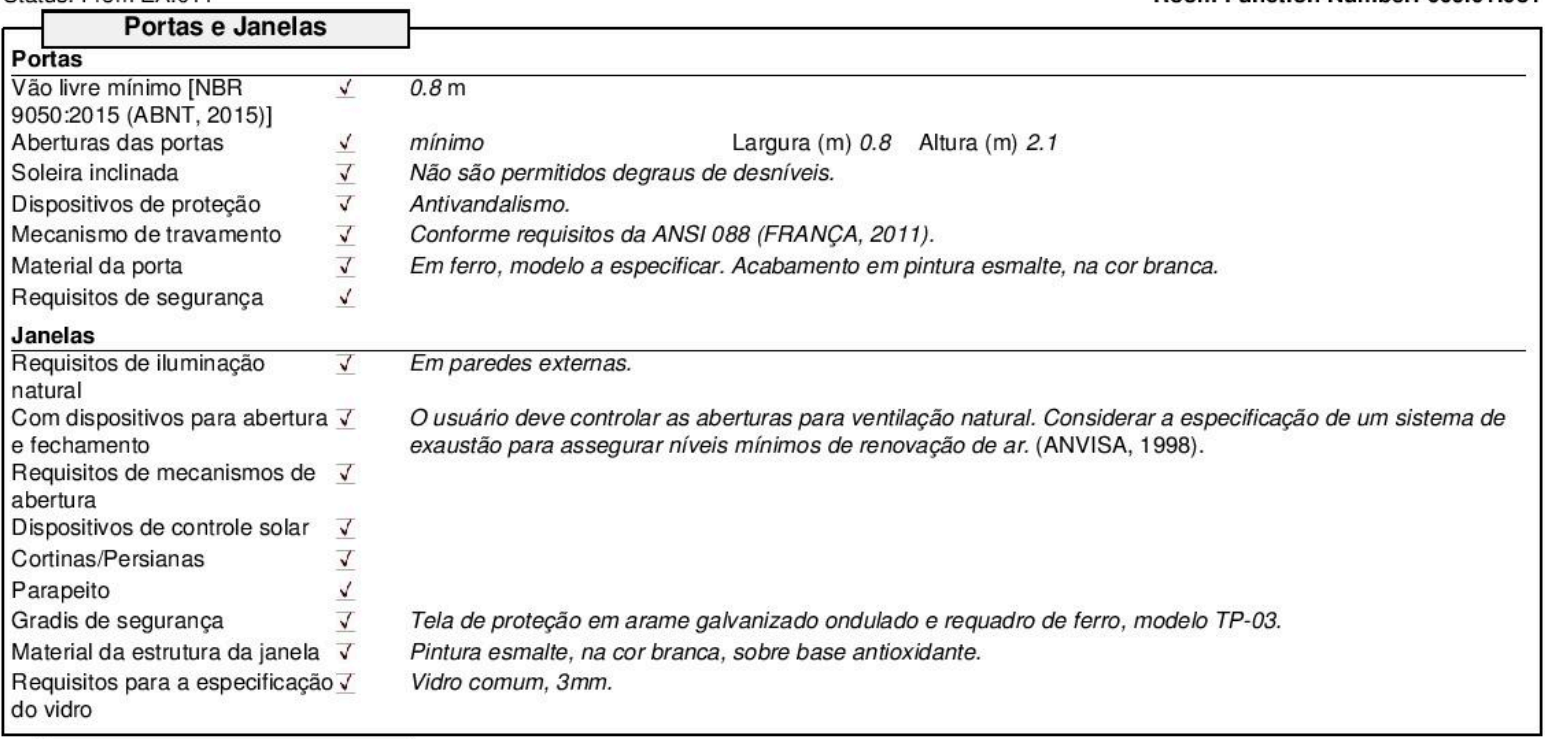

do vidro

Pintura esmalte, na cor branca, sobre base antioxidante.

e ar condicionado

Ventilação

Ventilação natural

$\checkmark$ Ventilação cruzada

Prever janelas operáveis, para confoto térmico. Vide aba requisitos para o projeto: requisitos de desempenho

Ventilador de parede ambiental e requisitos para ventilação natural.

Sucção/exaustão

Sucção $\checkmark \quad 2$ Unidades

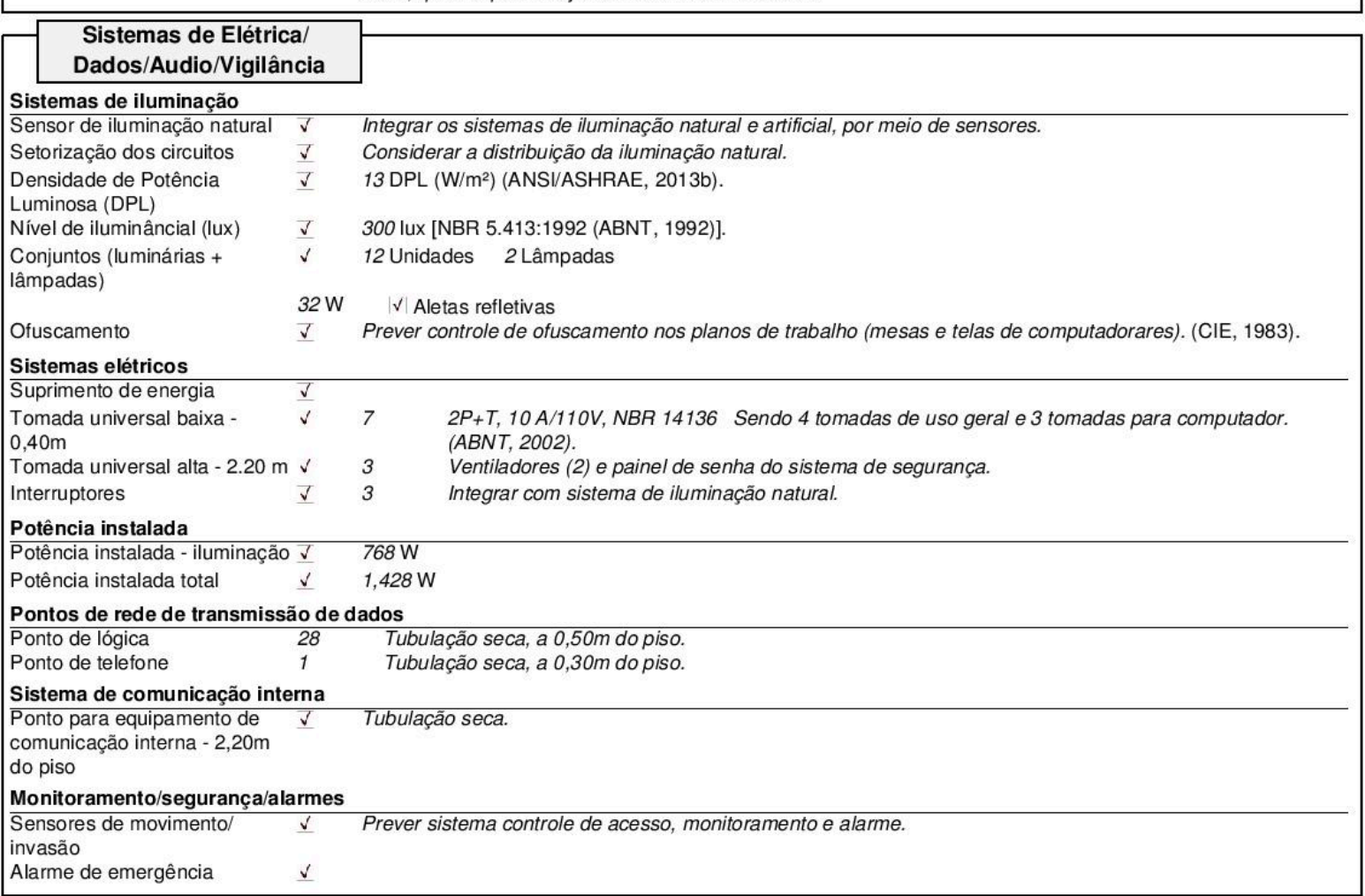


H MELHORIA CONTINUAA APLICADA A

Database_SPEducational_Facilities

Status: From EA.011

Room Function Number: 009.01.031

Diretrizes de projeto para

Ambientes

Outros

Sistemas hidrossanitários não estão previstos para o ambiente

Segurança contra incêndio

Outros

Considerar requisitos para evacuação de emergência (SAO PAULO, 2001; 2004).

\section{Operação e Manutenção}

\section{Limpeza}

Especificação de detergentes $\checkmark \checkmark \quad$ Somente produtos de limpeza neutros e não abrasivos.

Procedimentos de limpeza $\quad \checkmark \quad$ Limpeza de piso com pano úmido e esfregão. Não lavar com água corrente.

Frequencia da limpeza $\quad \bar{v}$ Toda troca de turno. 


\section{Diretrizes de projeto para Ambientes}

Room Function Number: 009.01.032

Status: From EA.011

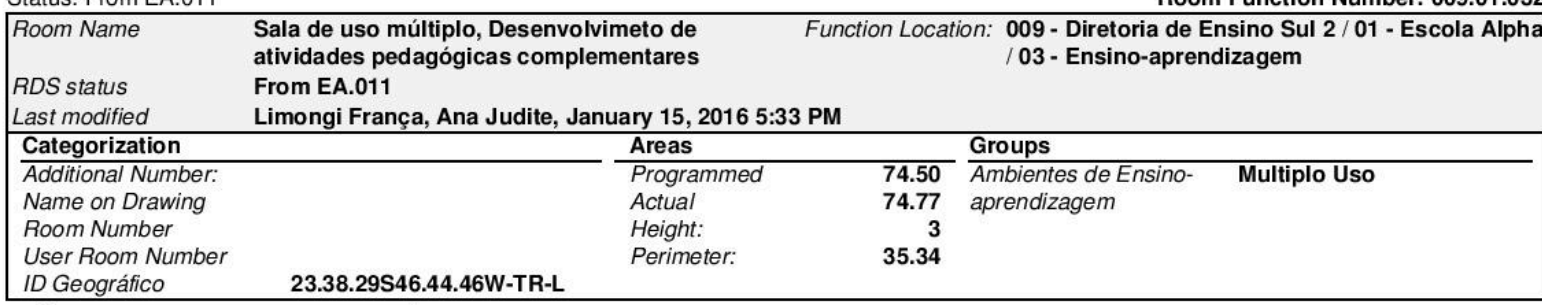

\begin{tabular}{|lll|}
\hline \multicolumn{3}{|c|}{ Descrição } \\
\cline { 2 - 3 } Informações gerais \\
\hline Referência OMNICLASS para & $13-31.17 .1$ \\
o uso do espaço (Tabela 13) \\
(OCCS, 2012) & \\
ID Geográfico & $23.38 .29 S$ \\
Situação & Em operaç \\
Dimensões mínimas & \\
\hline $\begin{array}{l}\text { Requisitos quanto às } \\
\text { dimensões do ambiente }\end{array}$ & $\checkmark$ \\
Largura - entre eixos (m) & $\checkmark$ & 7.2 \\
Profundidade - entre eixos (m) & $\checkmark$ & 7.2 \\
Altura mínima - a partir do piso & $\checkmark$ & 3
\end{tabular}

- a partir do piso $\sqrt{ } \quad 3$

acabado $(\mathrm{m})$

Descrição de usos e de atividades

Atendimento às atividades curriculares como consulta e empréstimo de livros, leitura, pesquisa e trabalhos em grupo. Acervo de livros, revistas, jornais e outros meios de informação e comunicação, tais como jogos, mapas, entre outros.

Cargas geradas por atividades humanas

Ocupação

Período de utilização

Ocupação, máxima 27 pessoas.

Taxas metabólicas $\quad$ Equivalente metabólico (Met) Isolamento térmico das roupas (Clo) 0.6

1.3

Período de utilização máxima 6 horas.

Ambiente de trabalho

permanente

Proximidade

Uso em conjunto com outros $\checkmark \quad \checkmark \quad$ Ambientes administrativos, sala de uso múltiplo, sala de uso múltiplo e sala de informática.

ambientes

Proximidade ardistanc

outros ambientes

Concentrar horizontal e/ou verticalmente os ambientes administrativos, uso múltiplo, sala de leitura e sala de informática de forma a racionalizar a rede de distribuição lógica. Localização estratégica minimizando a distância entre a central de distribuição lógica (rack de informática) e para ser utilizada como espera para o usuário da sala de informática.

Distância máxima a percorrer $30 \mathrm{~m}$

até a saída, em caso de

emergência (PMESP, 2010)

Expressão Arquitetônica

Flexibilidade, para permitir o desenvolvimento de diferentes atividades pedagógicas, inclusive com a utilização de recursos de multimídia.

\begin{tabular}{|ll|}
\hline \multicolumn{1}{|c|}{ Acabamentos } \\
Vedos
\end{tabular}




\section{Diretrizes de projeto para}

Status: From EA.011

Room Function Number: 009.01.032

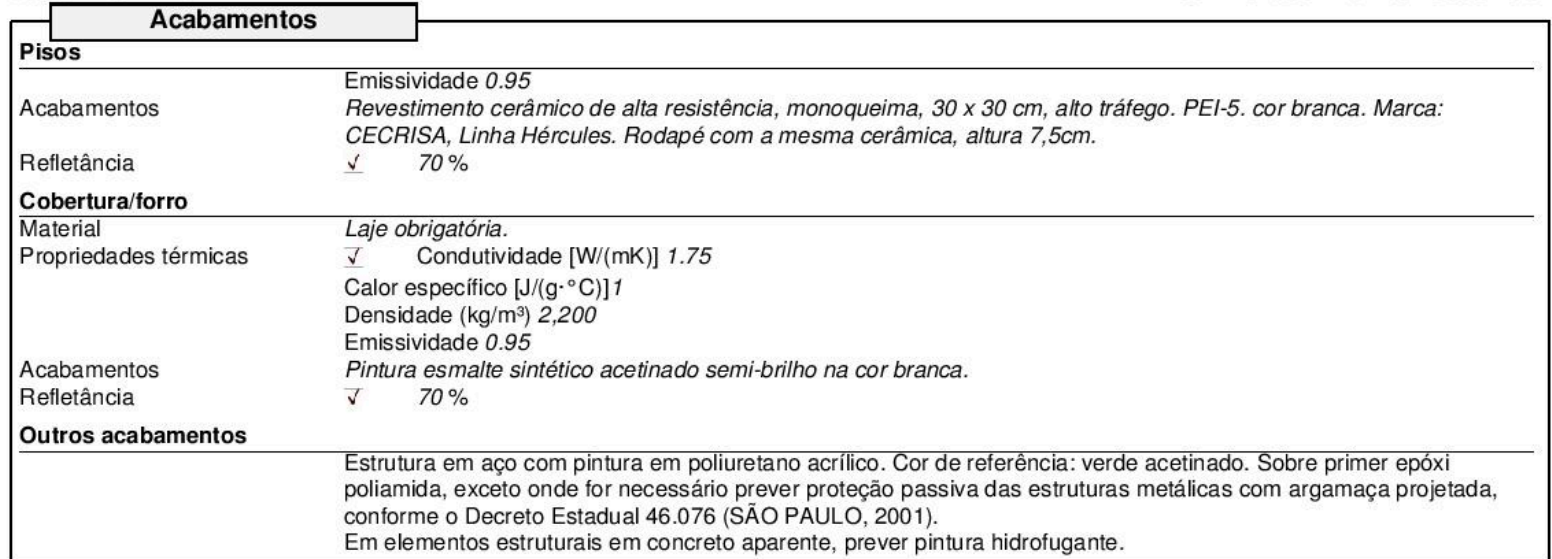

Requisitos para o projeto

Requisitos de desempenho ambiental

Estratégias de sustentabilidade $\checkmark \quad$ Energia: prever sensor de luz natural e circuitos elétricos separados, para permitir o acionamento parcial da iluminação artificial. Especificar lâmpadas fluorecentes T5 com reatores eletrônicos. Iluminação natural: controle solar para evitar ofuscamento e ganhos térmicos indesejados.

Materiais: somente componentes em madeira que tenham certificação de procedência. É obrigatória a apresentação de Documento de Origem Florestal.

Especificar, preferencialmente, componentes com, no mínimo, $25 \%$ de material reciclado pós-consumo.

Somente é permitida a utilização de tintas, selantes, impermeabilizantes, adesivos, vernizes e mastiques com baixo índice de compostos orgânicos voláteis.

Tratamento acústico

$\checkmark \quad$ Ambiente resguardado, Prever tratamento contra ruídos internos e externos.

Níveis sonoros máximos

45 [NBR 10.152:1987 (ABNT, 1987)].

$[\mathrm{dB}(\mathrm{A})]$

Visualização de ambientes

externos

$$
\checkmark \quad 45 \text { [NBR 10.152:1987 (ABNT, 1987)]. }
$$

Controle de ofuscamento

$$
\checkmark
$$

Evitar a incidência de luz solar direta nos planos de trabalho. Prever dispositivos para a reflexão da luz e a distribuição da luz refletida no forro. Considerar, como planos de trabalho, as carteiras escolares, lousas e telas de equipamentos de multimídia.

Área mínima de iluminação $\checkmark \quad 1 / 5$

natural $\left(\mathrm{m}^{2}\right)$, em relação à área

de piso

Área mínima de ventilação $\quad$ v $\quad 1 / 10$

$\left(\mathrm{m}^{2}\right)$, em relação à área de piso

Taxas mínimas de renovação $\checkmark$ Taxa de renovação de ar externo, por área

de ar, em áreas ocupadas

$\checkmark$ Taxa de renovação de ar externo, por pessoa

Requisitos quanto ao conforto $\sqrt{ } \quad 80$ (\% horas na zona de conforto/ano) [ASHRAE 55.1:2004 (ANSI/ASHRAE, 2004)].

térmico

Requisitos quanto ao desempenho do ambiente - NBR 15.575:2013 (ABNT, 2013)

As aberturas do ambiente devem proporcionar entre 1-4 trocas de ar por hora [ASHRAE 62.1-2013 (ASHRAE, 2013)].

Requisitos quanto à acessibilidade - NBR 9.050:2015 (ABNT, 2015)

Espaço livre para a manobra de cadeira de rodas: $1,50 \mathrm{~m}$.

Vão mínimo de portas: $0,80 \mathrm{~m}$.

Maçaneta: Alavanca. Altura: 0,80-1,10 m.

Soleiras inclinadas.

Degraus e desniveis não são permitidos.

Contraste de cor para destaque de aberturas e limites de piso.

Acessos devem ter sinalização visual e tátil.

Requisitos quanto à segurança patrimonial

\section{Outros}

Ambiente sujeito a arrombamento. Prever gradis e sistema de alarme.

Não posicionar o ambiente em fachadas de alta insolação ou prever anteparos de proteção. Ventilação cruzada obrigatória através de caixilhos situados na parede oposta à das janelas.

A profundidade do ambiente deve ser menor ou igual a 3 vezes a distância entre piso e forro acabados (incluídas saliências e projeções).

O ambiente deve ser sinalizado.

Portas e Janelas




\section{Diretrizes de projeto para Ambientes}

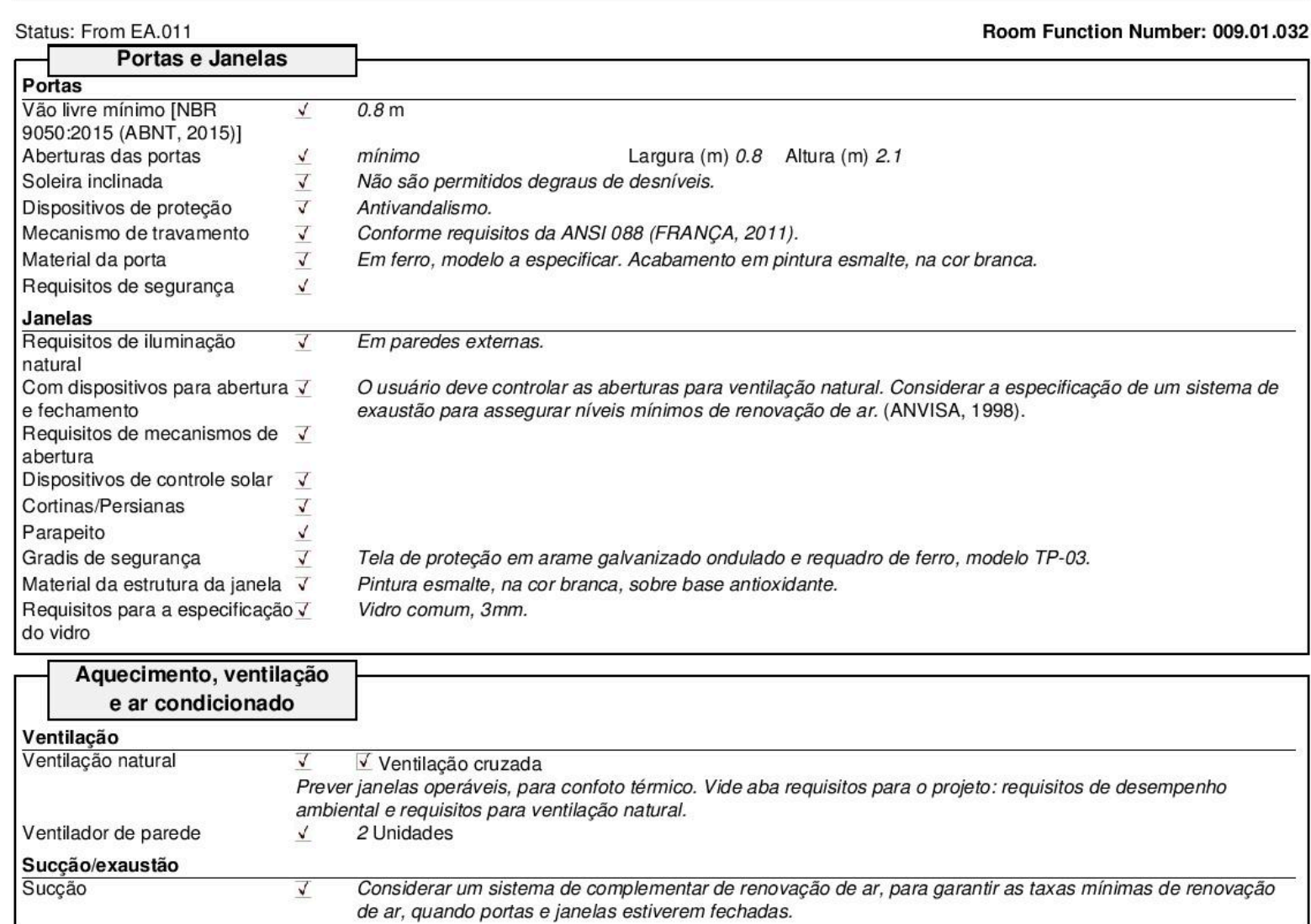

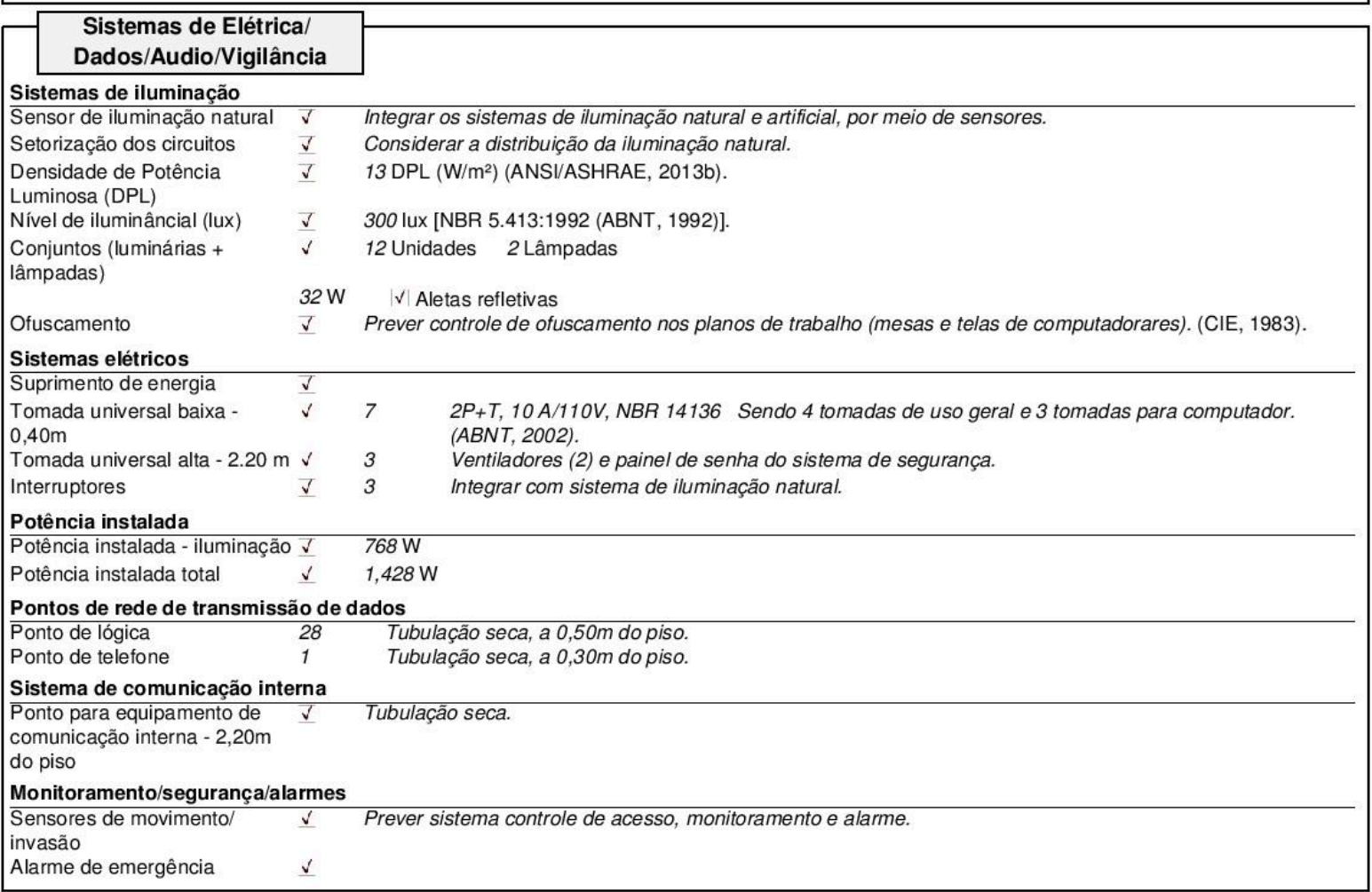


H. MELHORIA CONTÍNUA APLICADA A

Database_SPEducational_Facilities

\section{Diretrizes de projeto para}

Ambientes

Status: From EA.011

Room Function Number: 009.01.032

Sistemas hidrossanitários

Outros

Sistemas hidrossanitários não estão previstos para o ambiente.

Segurança contra incêndio

Outros

Considerar requisitos para evacuação de emergência (SAO PAULO, 2001; 2004).

\section{Operação e Manutenção}

\section{Limpeza}

Especificação de detergentes $\checkmark \checkmark \quad$ Somente produtos de limpeza neutros e não abrasivos.

Procedimentos de limpeza $\quad \checkmark \quad$ Limpeza de piso com pano úmido e esfregão. Não lavar com água corrente.

Frequencia da limpeza $\quad \bar{v}$ Toda troca de turno. 


\section{Diretrizes de projeto para} Ambientes

Database SPEducational Facilities

Room Function Number: 009.01.033

Status: From AUX.04

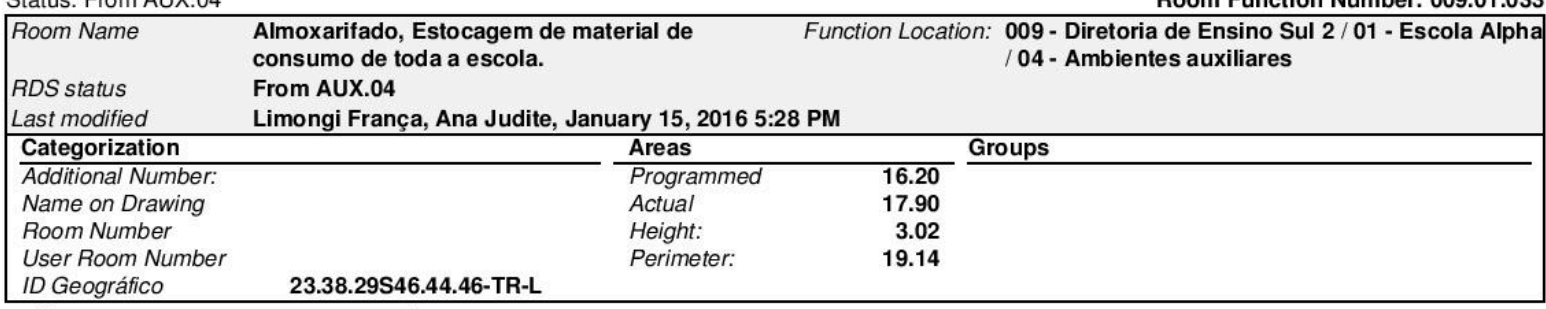

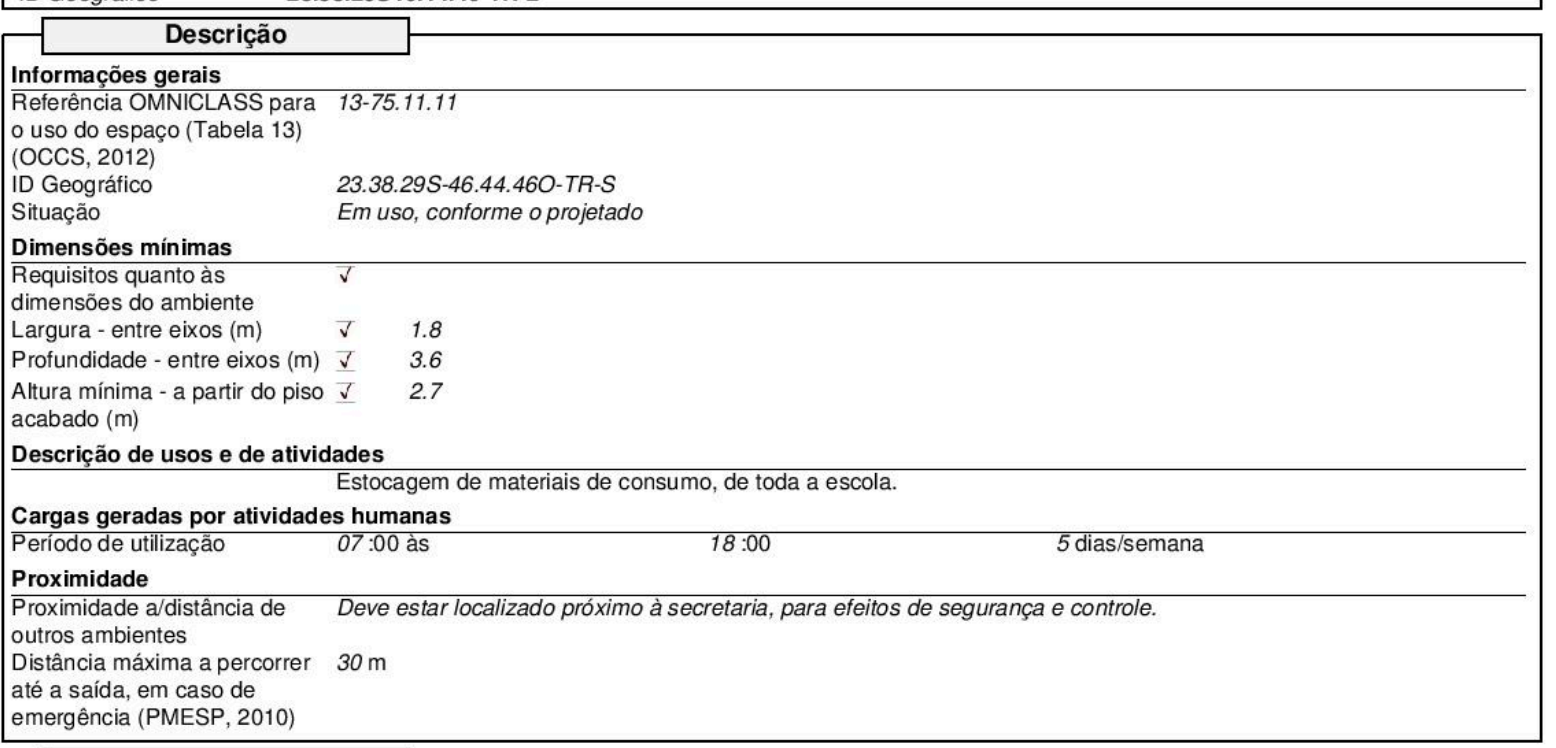

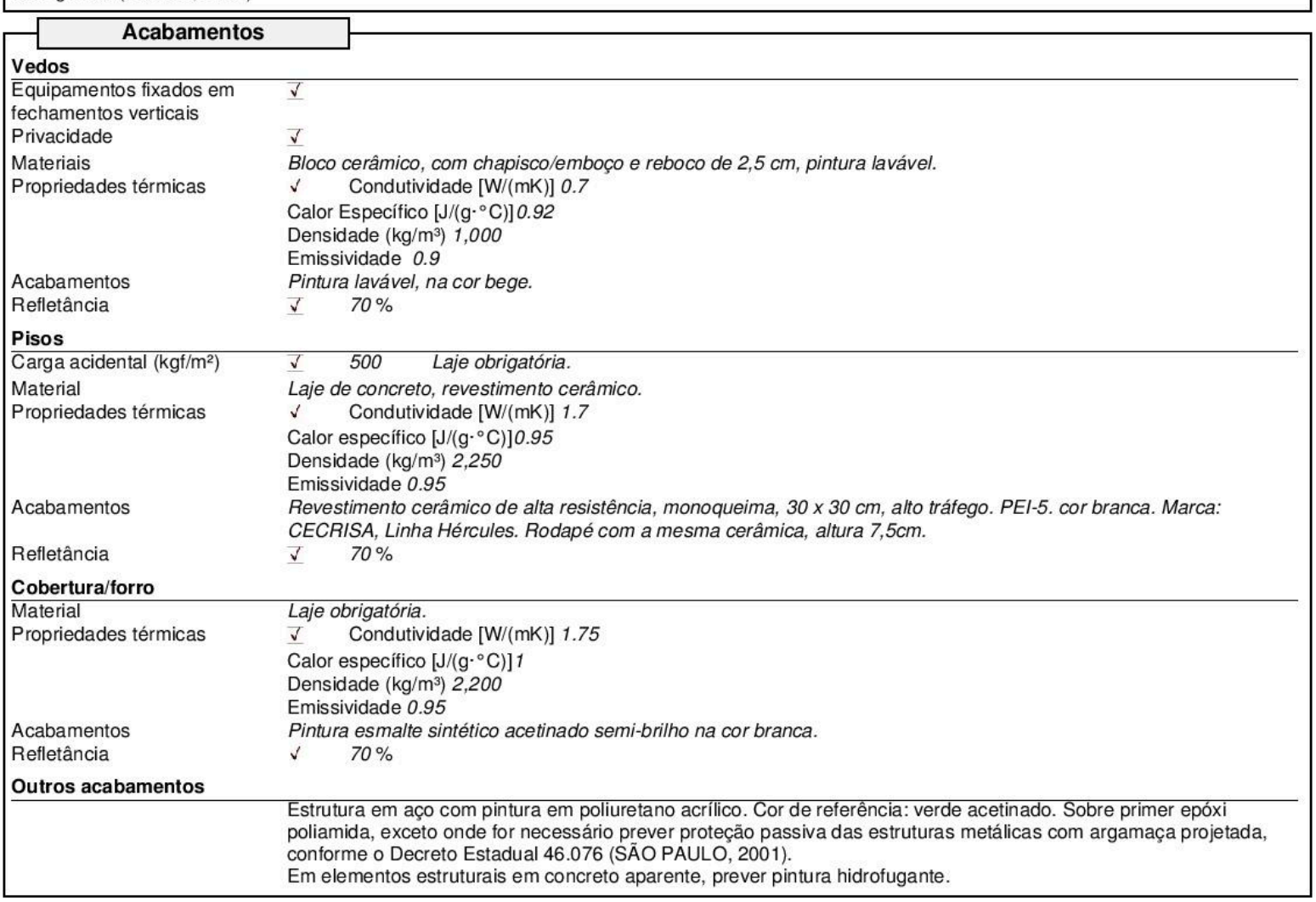


Diretrizes de projeto para Ambientes

Status: From AUX.04

Room Function Number: 009.01.033

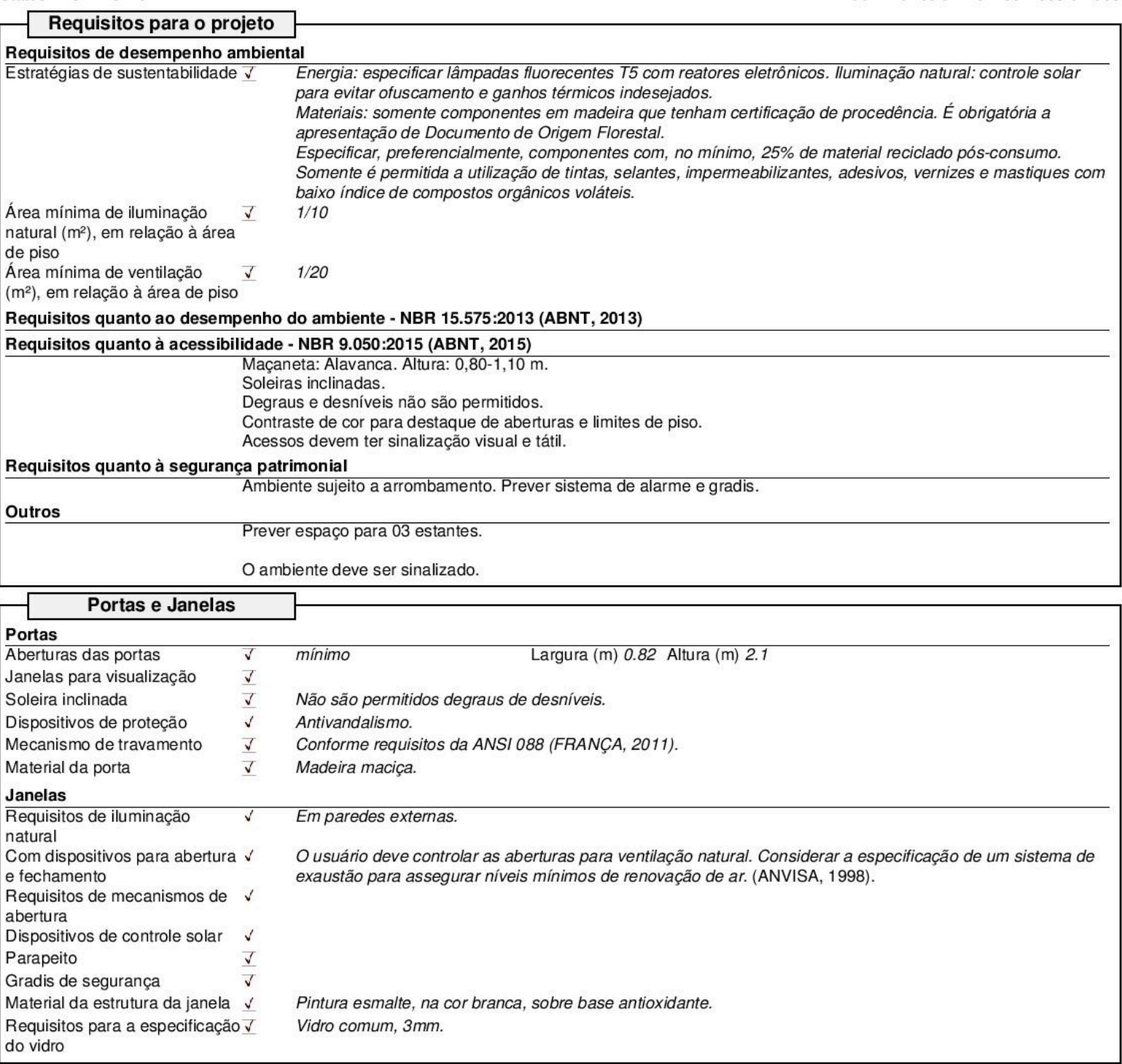

do vidro

\begin{tabular}{|c|c|c|}
\hline \multicolumn{2}{|c|}{$\begin{array}{l}\text { Aquecimento, ventilação } \\
\text { e ar condicionado }\end{array}$} & \\
\hline Ventilação & & \\
\hline Ventilação natural & $\begin{array}{l}\checkmark \\
\text { Preve } \\
\text { ambi }\end{array}$ & $\begin{array}{l}\text { V Ventilação cruzada } \\
\text { janelas operáveis, para confoto térmico. Vide aba requisitos para o projeto: requisitos de desempenho } \\
\text { ttal e requisitos para ventilação natural. }\end{array}$ \\
\hline
\end{tabular}

\begin{tabular}{|c|c|c|}
\hline $\begin{array}{l}\text { Sistemas de Elé } \\
\text { Dados/Audio/Vig }\end{array}$ & & \\
\hline Sistemas de iluminação & & \\
\hline Sensor de presença & $\sqrt{ }$ & \\
\hline Nível de iluminâncial (lux) & $\checkmark$ & 150 lux [NBR 5.413:1992 (ABNT, 1992)]. \\
\hline $\begin{array}{l}\text { Conjuntos (luminárias + } \\
\text { lâmpadas) }\end{array}$ & $\checkmark$ & 1 Unidades 2 Lâmpadas \\
\hline Ofuscamento & $\checkmark$ & Prever controle de ofuscamento nos planos de trabalho. (CIE, 1983). \\
\hline Sistemas elétricos & & \\
\hline
\end{tabular}




\section{Diretrizes de projeto para} Ambientes

Status: From AUX.04

Room Function Number: 009.01.033

Sistemas de Elétrica

Dados/Audio/Vigilância

Sistemas elétricos

Tomada universal média - $\quad \checkmark \quad 1 \quad 2 P+T, 10$ A/110V, NBR 14136 (ABNT, 2002).

$1,10 \mathrm{~m}$

Bipolar

Potência instalada

Potência instalada - iluminação $\sqrt{\checkmark} 64 \mathrm{~W}$

Pontos de rede de transmissão de dados

Ponto de lógica

Ponto de telefone

1
1

Monitoramento/segurança/alarmes

Sensores de movimento/

invasão

Sistemas hidrossanitários

Outros

Não foram previstas instalações hidrossanitárias no ambiente.

\section{Segurança contra incêndio}

Outros

Considerar requisitos para evacuação de emergência (SÁO PAULO, 2001; 2004).

Operação e Manutenção

Limpeza

Especificação de detergentes $\checkmark \checkmark \quad$ Somente produtos de limpeza neutros e não abrasivos.

Procedimentos de limpeza $\quad \checkmark \quad$ Ambiente pode ser lavado com água. Nesse caso, utilizar somente água de reúso.

Frequencia da limpeza $\quad \checkmark \quad$ Toda troca de turno. 


\section{Diretrizes de projeto para}

Database_SPEducational_Facilities Ambientes

Status: Derived from AUX.016

\begin{tabular}{|c|c|c|}
\hline $\begin{array}{l}\text { Room Name } \\
\text { RDS status } \\
\text { Last modified }\end{array}$ & $\begin{array}{l}\text { Cantina, Espaço para o preparo e venda de } \\
\text { lanches para os usuários da escola } \\
\text { Derived from AUX.016 } \\
\text { Limongi França, Ana Judite, January 15, } 20165: 28\end{array}$ & $\begin{array}{l}\text { Function Location: } 009 \text { - Diretoria de Ensino Sul 2 / } 01 \text { - Escola Alpha } \\
\qquad / 04 \text { - Ambientes auxiliares } \\
8 \mathrm{PM}\end{array}$ \\
\hline Additional Number: & Programmed & 16.20 \\
\hline Name on Drawing & Actual & 16.28 \\
\hline Room Number & Height: & 3 \\
\hline User Room Number & Perimeter: & 16.34 \\
\hline
\end{tabular}

\section{Descrição}

Informaçoes gerais

Referência OMNICLASS para 13-57 13 15 31

o uso do espaço (Tabela 13)

(OCCS, 2012)

ID Geográfico 23.38.29S-46.44.46O-TR-O

Situação Construído, não utilizado

Dimensões mínimas

Requisitos quanto às

dimensões do ambiente

Largura - entre eixos $(m) \quad \checkmark \quad 4.5$

Profundidade - entre eixos $(\mathrm{m}) \quad \checkmark \quad 3.6$

Altura mínima - a partir do piso $\sqrt{ } \quad 3$

acabado $(\mathrm{m})$

Descrição de usos e de atividades

Preparo e venda de lanches aos usuários da escola.

Cargas geradas por atividades humanas

Ocupaçăo 1

Ambiente de trabalho

$07: 00$ às $\quad 18: 00$

5 dias/semana

permanente

Proximidade

Uso em conjunto com outros

ambientes

Proximidade a/distância de Deve abrir diretamente para o galpão.

outros ambientes

Distância máxima a percorrer $30 \mathrm{~m}$

até a saída, em caso de

emergência (PMESP, 2010)

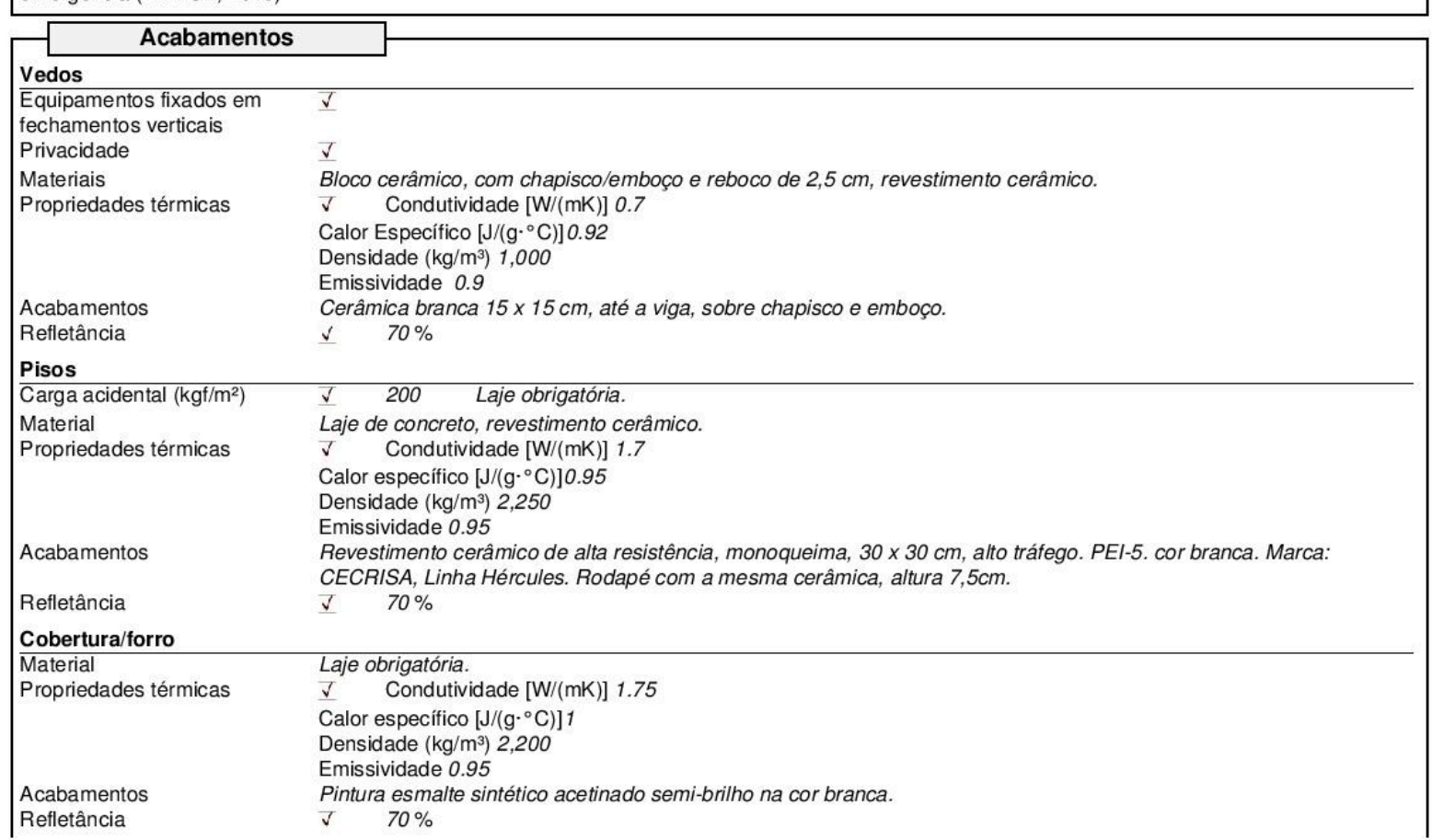




\section{Diretrizes de projeto para Ambientes}

Status: Derived from AUX.016

Acabamentos

Outros acabamentos

Observar o caimento dos pisos, em direção aos ralos.

Prever rodapés arredondados no piso, em todo o ambiente.

As paredes devem ser revestidas com material liso, impermeável e resistente a frequentes lavagens.

O piso deve ser anti-derrapante, impermeável, de fácil higienização e resistente a ácidos.

Estrutura em aço com pintura em poliuretano acrílico. Cor de referência: verde acetinado. Sobre primer epóxi

poliamida, exceto onde for necessário prever proteção passiva das estruturas metálicas com argamaça projetada,

conforme o Decreto Estadual 46.076 (SÃO PAULO, 2001).

Em elementos estruturais em concreto aparente, prever pintura hidrofugante.

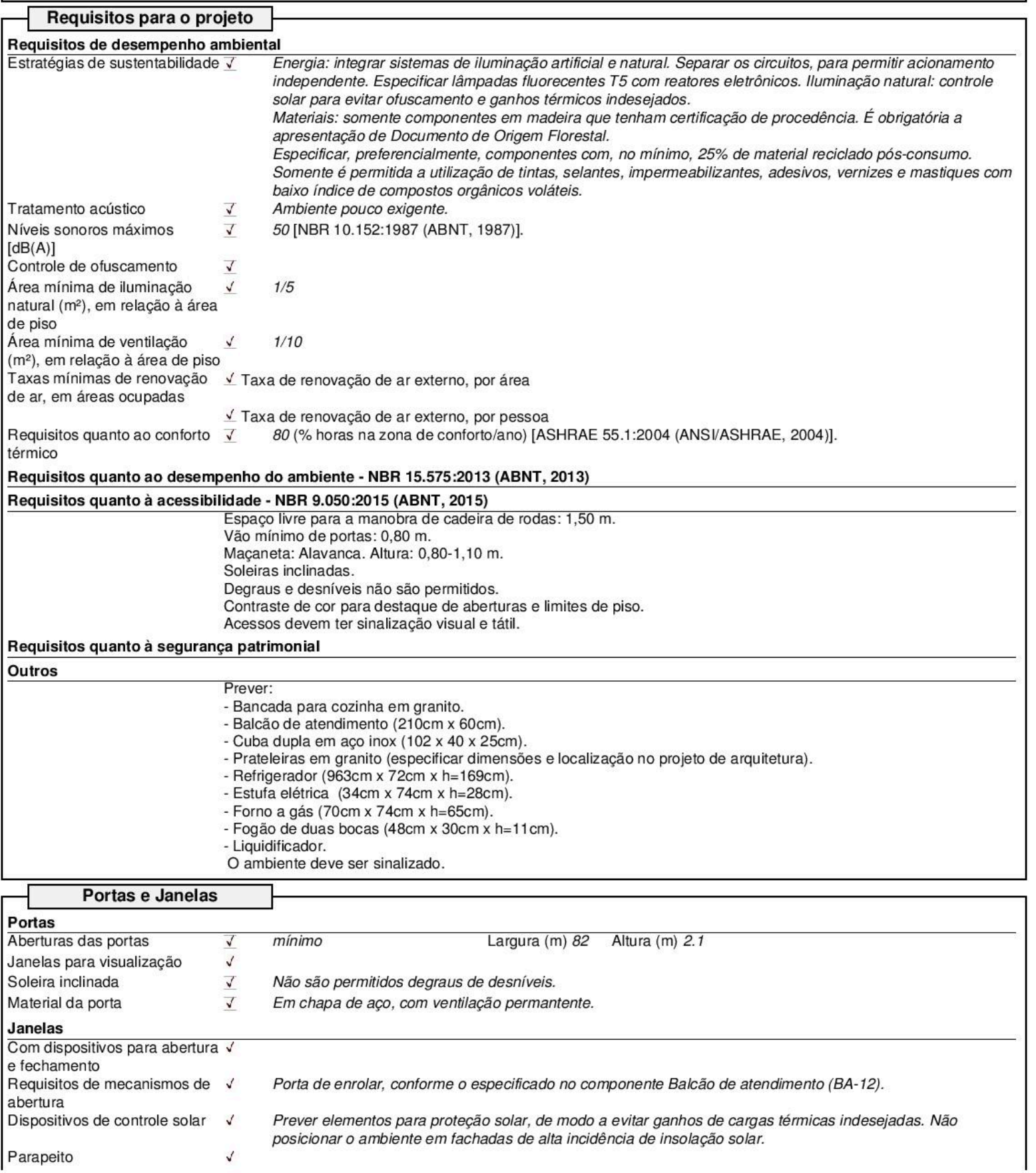


Diretrizes de projeto para Ambientes

Status: Derived from AUX.016

Room Function Number: 009.01.034

Portas e Janelas

Janelas

Material da estrutura da janela $\checkmark \quad$ Pintura esmalte, na cor branca, sobre base antioxidante. Prever telas metálicas removíveis, do tipo

mosquiteiro.

Requisitos para a especificação $\checkmark \quad$ Vidro comum, $3 \mathrm{~mm}$

do vidro

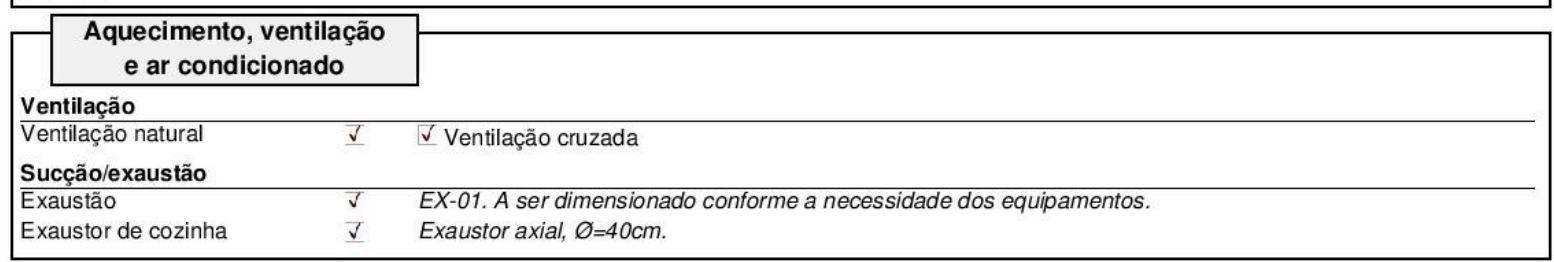

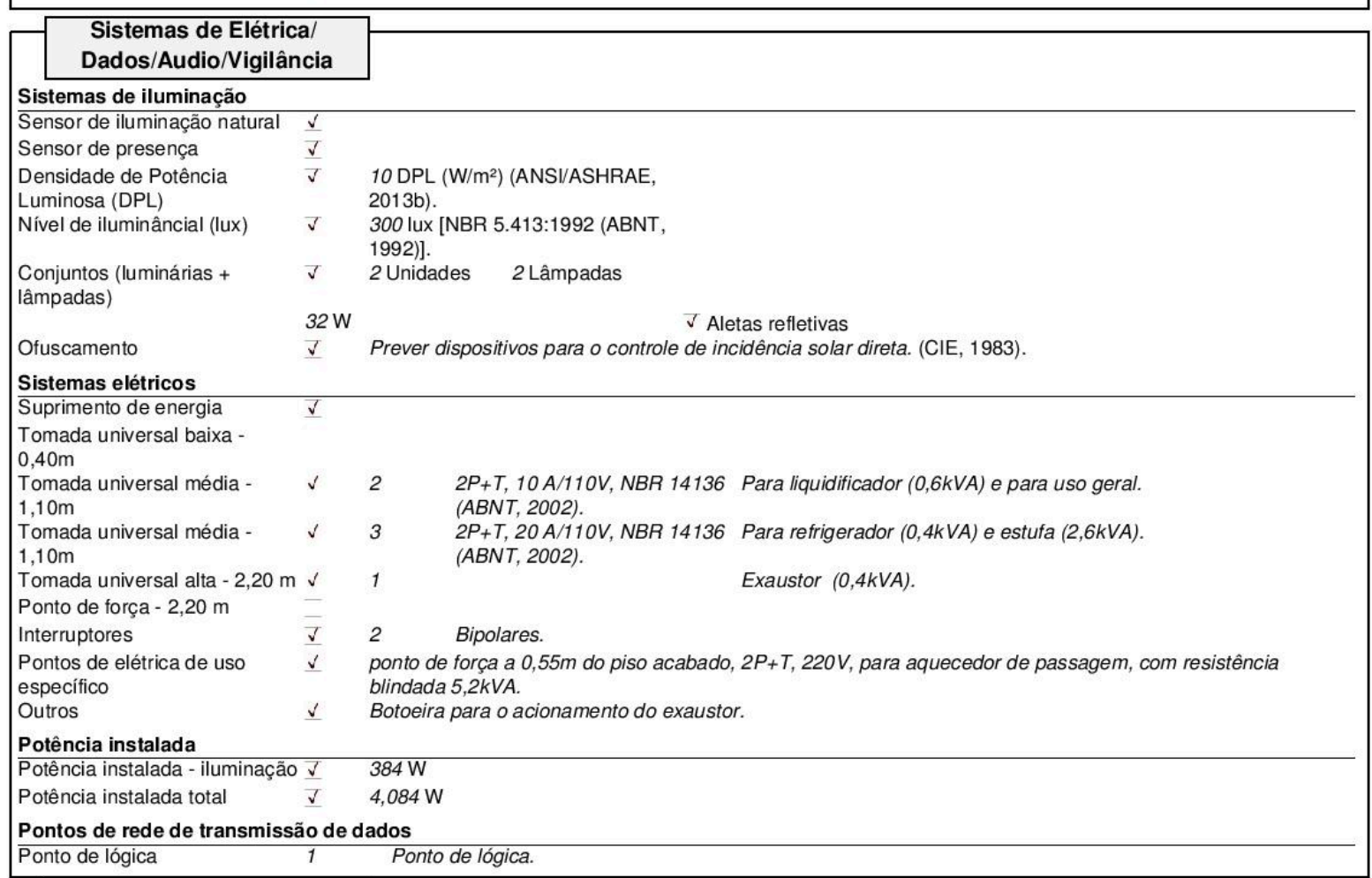

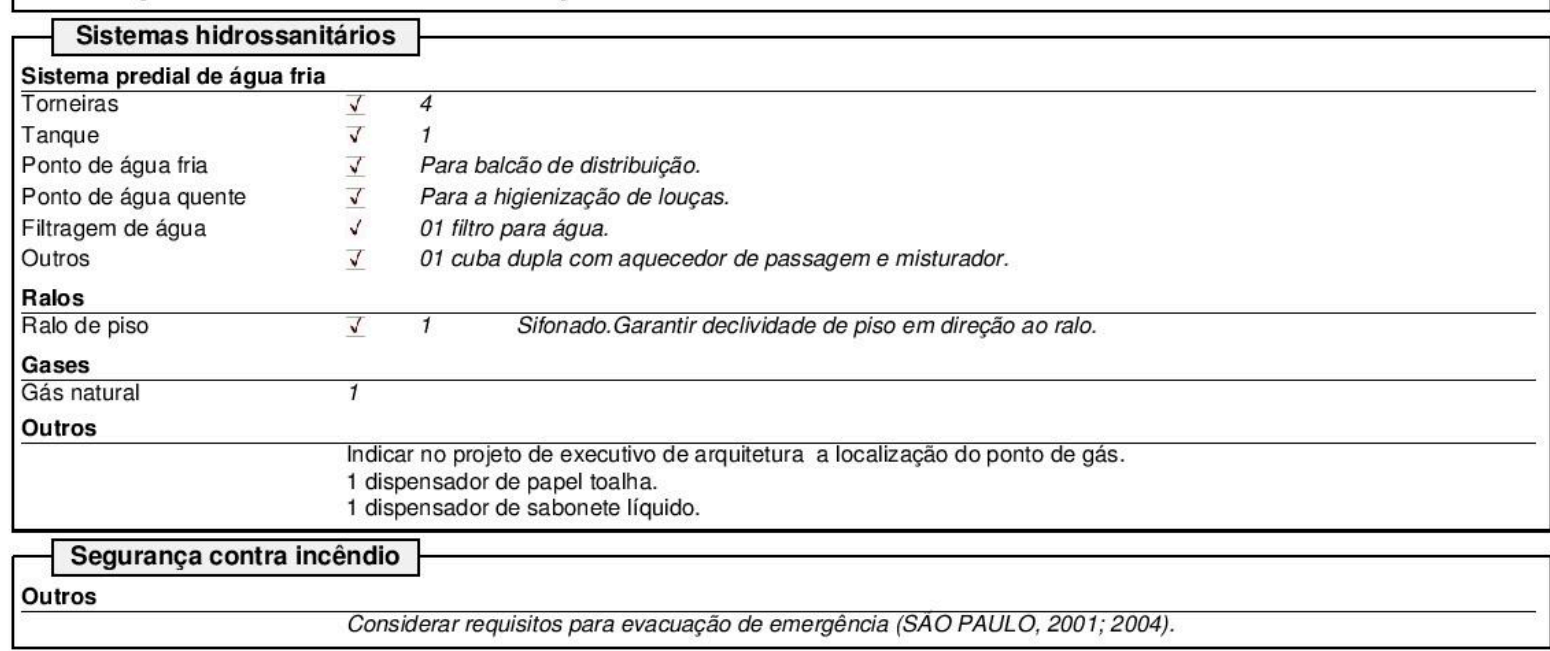


H MELHORIA CONTÍNUA APLICADA A

Database_SPEducational_Facilities

Status: Derived from AUX.016

\section{Diretrizes de projeto para} Ambientes

Operação e Manutenção

Room Function Number: 009.01.034

Limpeza

Especificação de detergentes $\checkmark \quad$ Somente produtos de limpeza neutros e não abrasivos.

Procedimentos de limpeza $\quad \checkmark \quad$ Lavar e desinfetar pisos, paredes e equipamentos hidrossanitários. 


\section{Diretrizes de projeto para}

Database_SPEducational_Facilities

\section{Ambientes}

\begin{tabular}{|c|c|c|}
\hline Status: Derived from A & UX.014-1 & Room Function Number: 009.01.035 \\
\hline Room Name & $\begin{array}{l}\text { Cozinha, Preparo de alimentos para os usuários } \\
\text { da escola }\end{array}$ & $\begin{array}{l}\text { Function Location: } 009 \text { - Diretoria de Ensino Sul } 2 \text { / } 01 \text { - Escola Alpha } \\
\text { / } 04 \text { - Ambientes auxiliares }\end{array}$ \\
\hline RDS status & Derived from AUX.014-1 & \\
\hline Categorization & Areas & Groups \\
\hline Additional Number: & Programmed & 28.35 \\
\hline Name on Drawing & Actual & 25.40 \\
\hline Room Number & Height: & 3.02 \\
\hline
\end{tabular}

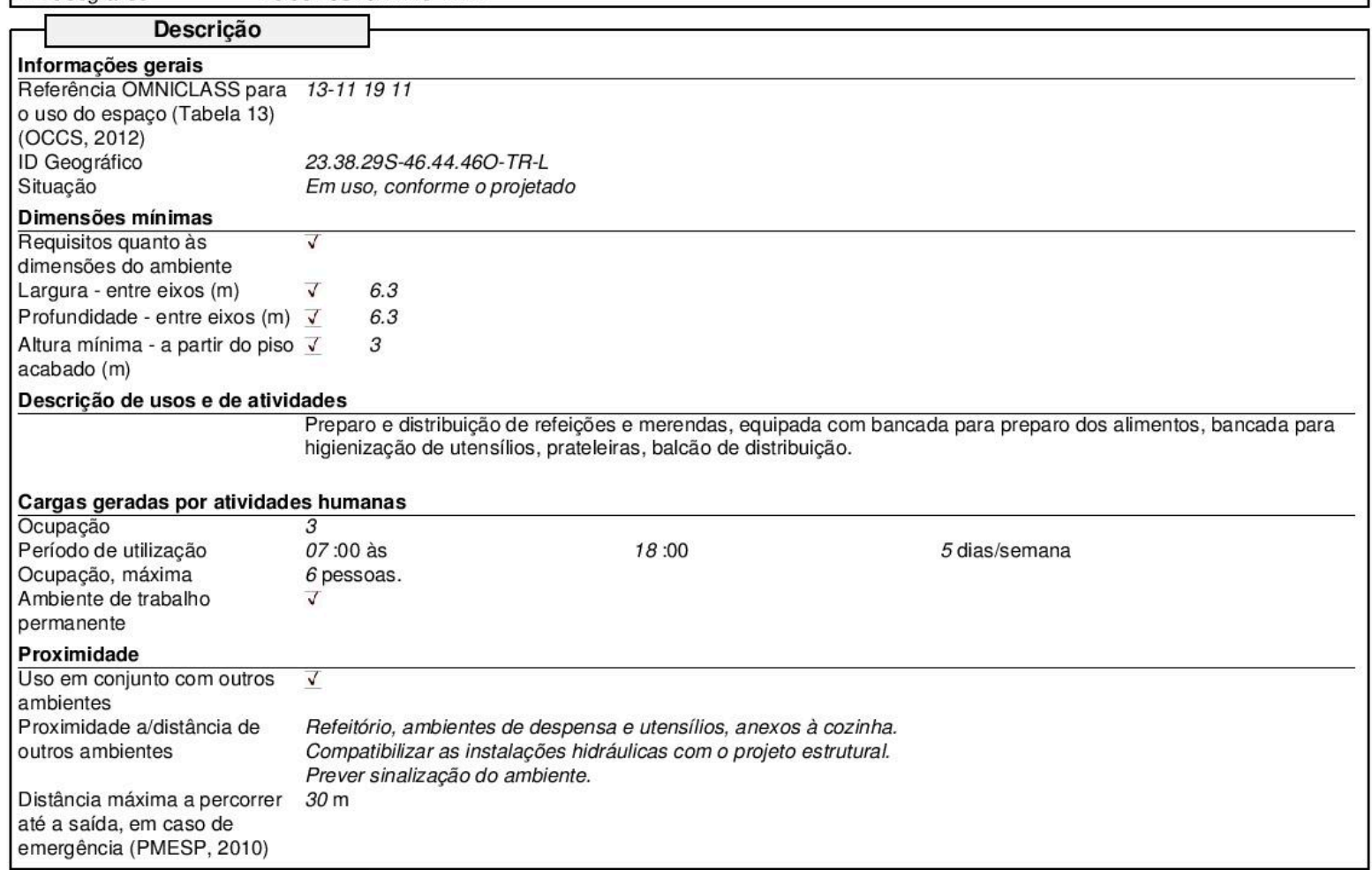

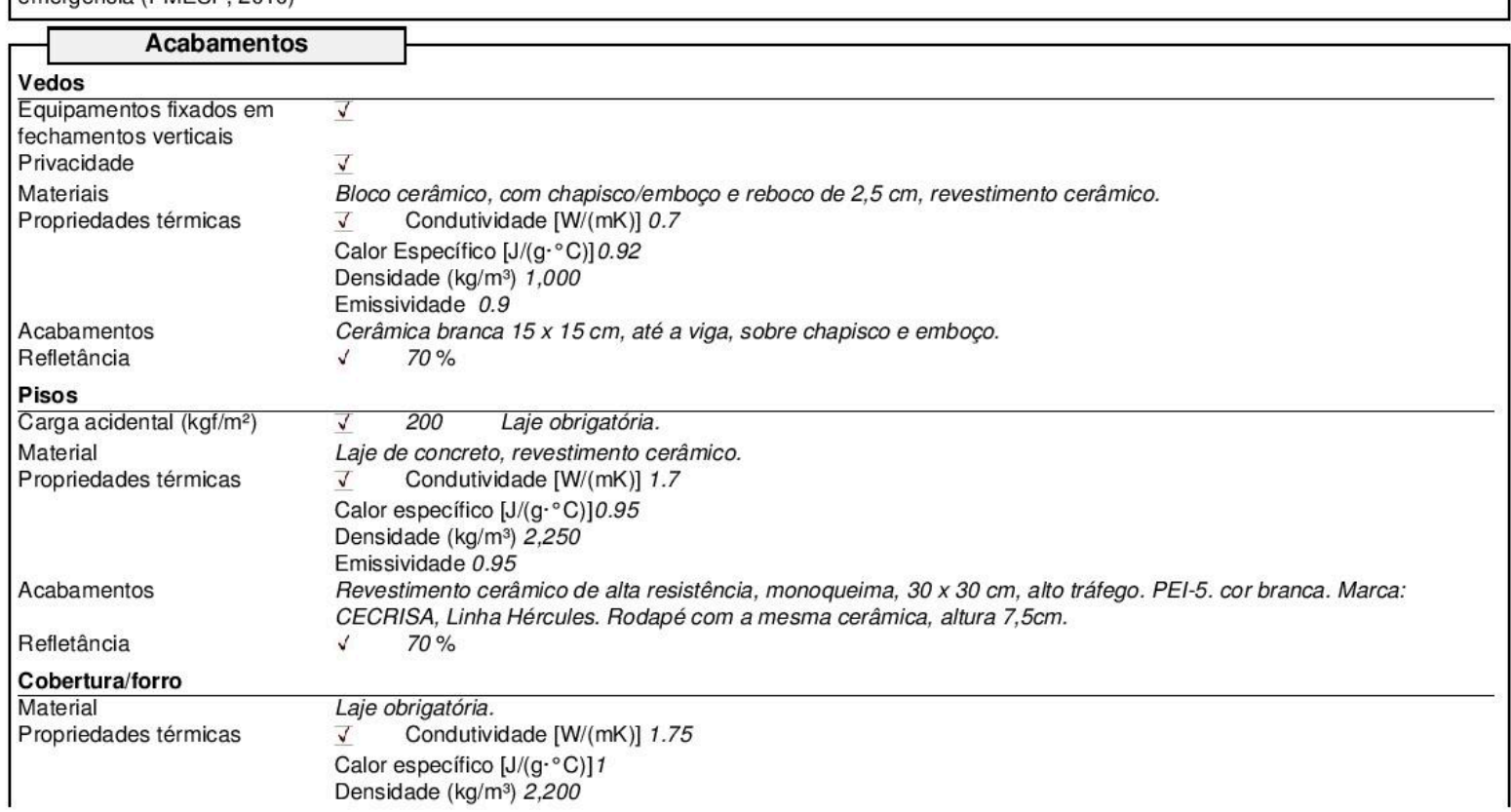




\section{Diretrizes de projeto para Ambientes}

Database_SPEducational_Facilities

Room Function Number: 009.01.035

Status: Derived from AUX.014-1

\begin{tabular}{|ll}
\hline \multicolumn{1}{|c|}{ Acabamentos } \\
\hline Cobertura/forro & Emissividade 0.95 \\
Acabamentos & Pintura esmalte sintético acetinado semi-brilho na cor branca. \\
Refletância & $\checkmark \quad 70 \%$ \\
Outros acabamentos & Observar o caimento dos pisos, em direção aos ralos. \\
& Prever rodapés arredondados no piso, em todo o ambiente. \\
& As paredes devem ser revestidas com material liso, impermeável e resistente a frequentes lavagens. \\
& O piso deve ser anti-derrapante, impermeável, de fácil higienizaçäo e resistente a ácidos. \\
& Estrutura em aço com pintura em poliuretano acrílico. Cor de referência: verde acetinado. Sobre primer epóxi \\
& poliamida, exceto onde for necessário prever proteção passiva das estruturas metálicas com argamaça projetada, \\
& conforme o Decreto Estadual 46.076 (SÃO PAULO, 2001). \\
& Em elementos estruturais em concreto aparente, prever pintura hidrofugante.
\end{tabular}

Requisitos para o projeto

Requisitos de desempenho ambiental

Estratégias de sustentabilidade $\sqrt{ } \quad$ Energia: integrar sistemas de iluminação artificial e natural. Separar os circuitos, para permitir acionamento independente. Especificar lâmpadas fluorecentes T5 com reatores eletrônicos. lluminação natural: controle solar para evitar ofuscamento e ganhos térmicos indesejados.

Materiais: somente componentes em madeira que tenham certificação de procedência. É obrigatória a apresentação de Documento de Origem Florestal.

Especificar, preferencialmente, componentes com, no mínimo, 25\% de material reciclado pós-consumo. Somente é permitida a utilização de tintas, selantes, impermeabilizantes, adesivos, vernizes e mastiques com baixo índice de compostos orgânicos voláteis.

Tratamento acústico

$\checkmark$ Ambiente pouco exigente.

Niveis sonoros máximos 50 [NBR 10.152:1987 (ABNT, 1987)]

$[\mathrm{dB}(\mathrm{A})]$

Controle de ofuscamento

Área mínima de iluminação

natural $\left(\mathrm{m}^{2}\right)$, em relação à área

de piso

Área mínima de ventilação $\quad \checkmark \quad 2 / 3$

$\left(\mathrm{m}^{2}\right)$, em relação à área de piso

Taxas mínimas de renovação $\checkmark$ Taxa de renovação de ar externo, por área

de ar, em áreas ocupadas

Requisitos quanto ao conforto $\checkmark \quad 80$ (\% horas na zona de conforto/ano) [ASHRAE 55.1:2004 (ANSI/ASHRAE, 2004)].

térmico

Requisitos quanto ao desempenho do ambiente - NBR 15.575:2013 (ABNT, 2013)

As aberturas do ambiente devem proporcionar entre 15-60 trocas de ar por hora [ASHRAE 62.1-2013 (ASHRAE, 2013)].

Requisitos quanto à acessibilidade - NBR 9.050:2015 (ABNT, 2015)

Espaço livre para a manobra de cadeira de rodas: $1,50 \mathrm{~m}$.

Vão mínimo de portas: $0,80 \mathrm{~m}$

Maçaneta: Alavanca. Altura: 0,80-1,10 m.

Soleiras inclinadas.

Degraus e desniveis não são permitidos.

Contraste de cor para destaque de aberturas e limites de piso.

Acessos devem ter sinalização visual e tátil.

Requisitos quanto à segurança patrimonial

Outros

Prever:

Bancada para cozinha em granito

- Balcão de distribuição em granito - $L=350 \mathrm{~cm}$.

- Balcão de devolução em granito - $L=700 \mathrm{~cm}$.

- Cuba em aço inox $(60 \times 50 \times 30 \mathrm{~cm})$.

- Cuba em aço inox $(50 \times 40 \times 25 \mathrm{~cm})$

- Cuba dupla em aço inox $(102 \times 40 \times 25 \mathrm{~cm})$

- Cuba em aço inox $(50 \times 40 \times 25 \mathrm{~cm})$, com torneira de mesa.

- Fogão industrial de 4 bocas, com circulação nos quatro lados.

- Espaço para futura instalação do forno, junto ao fogão, com medidas aproximadas de $104 \mathrm{~cm} \times 94 \mathrm{~cm}$ e altura de

$132 \mathrm{~cm}$.

- Prever abrigo externo para botijões de gás.

- Espaço para refrigerador industrial de 02 portas, com medidas aproximadas de: $127 \mathrm{~cm} \times 73 \mathrm{~cm}$ e altura de $90 \mathrm{~cm}$.

- Prever espaço para a circulação de carro para transporte de caldeirões, com dimensões aproximadas de $50 \mathrm{~cm} x$ $80 \mathrm{~cm}$ e altura de $80 \mathrm{~cm}$.

O ambiente deve ser sinalizado

\begin{tabular}{|lllll|}
\hline \multicolumn{3}{|c|}{ Portas e Janelas } & & \\
\hline Portas & & & \\
\hline Aberturas das portas & $\checkmark$ & mínimo & Largura $(\mathrm{m}) 1.4$ & Altura $(\mathrm{m}) 2.1$ \\
Janelas para visualização & $\mathrm{V}$ & & & \\
\hline
\end{tabular}




\section{Diretrizes de projeto para}

Database_SPEducational_Facilities Ambientes

Status: Derived from AUX.014-1

Room Function Number: 009.01.035

Portas

Soleira inclinada $\quad \checkmark \quad$ Não são permitidos degraus de desníveis.

Material da porta $\quad \bar{v} \quad$ Em chapa de aço, com ventilação permantente.

Janelas

Requisitos de iluminação $\quad \checkmark \quad$ Em paredes externas.

natural

Com dispositivos para abertura $\checkmark \quad$ O usuário deve controlar as aberturas para ventilação natural. Considerar a especificação de um sistema de

e fechamento

exaustão para assegurar níveis mínimos de renovação de ar. (ANVISA, 1998).

Dispositivos de controle solar $\checkmark \quad$ Prever elementos para proteção solar, de modo a evitar ganhos de cargas térmicas indesejadas. Não

Parapeito

posicionar o ambiente em fachadas de alta incidência de insolação solar.

Material da estrutura da janela $\checkmark$

Requisitos para a especificação $\checkmark$

do vidro

Pintura esmalte, na cor branca, sobre base antioxidante. Prever telas metálicas removíveis, do tipo mosquiteiro.

Vidro comum, $3 \mathrm{~mm}$

\begin{tabular}{|c|c|c|}
\hline \multicolumn{2}{|c|}{$\begin{array}{c}\text { Aquecimento, ventilação } \\
\text { e ar condicionado }\end{array}$} & \\
\hline Ventilação & & \\
\hline Ventilação natural & $\checkmark$ & $\checkmark$ Ventilação cruzada \\
\hline Exaustão & J & EX-01. A ser dimensionado conforme a necessidade dos equipamentos. \\
\hline Exaustor de cozinha & $\checkmark$ & Exaustor axial, $\varnothing=40 \mathrm{~cm}$ \\
\hline
\end{tabular}

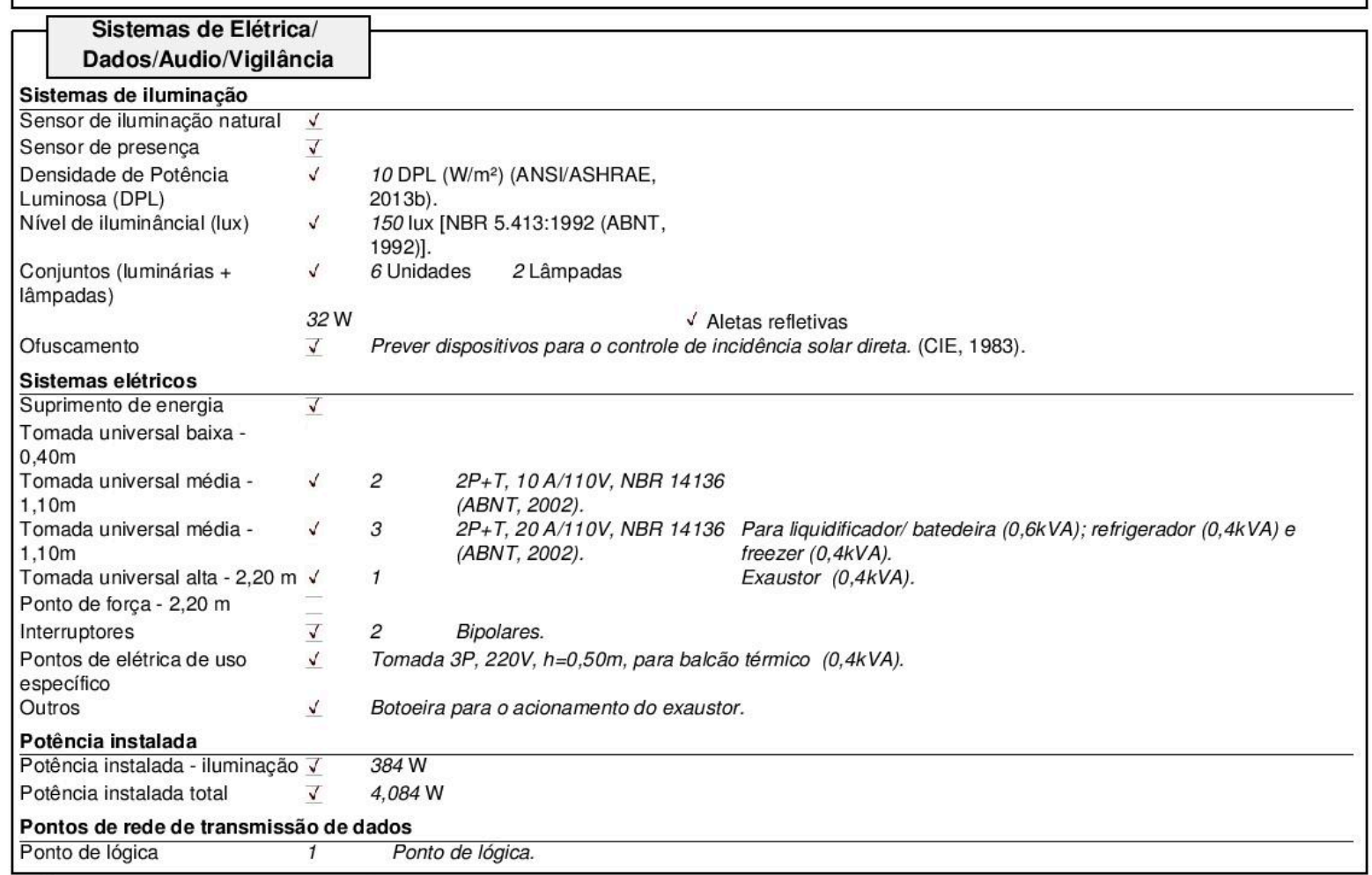

\begin{tabular}{|c|c|c|}
\hline \multicolumn{2}{|c|}{ Sistemas hidrossanitários } & \\
\hline \multicolumn{3}{|c|}{ Sistema predial de água fria } \\
\hline Torneiras & $\checkmark$ & 4 \\
\hline Ponto de água fria & $\checkmark$ & Para balcão de distribuição. \\
\hline Filtragem de água & $\vec{v}$ & 02 filtros para água. \\
\hline Outros & $\checkmark$ & $\begin{array}{l}01 \text { Cuba simples com torneira de parede; } 01 \text { Cuba simples com torneira de parede ou com torneira de mesa; } \\
01 \text { cuba dupla com aquecedor de passagem e misturador; } 01 \text { lavatório individual, sem coluna. }\end{array}$ \\
\hline Gases & & \\
\hline
\end{tabular}


Diretrizes de projeto para Ambientes

Status: Derived from AUX.014-1

Room Function Number: 009.01.035

Sistemas hidrossanitários

Gáses natural

Outros

Prever regulador de pressão e válvula esférica junto ao fogão. Indicar no projeto de executivo de arquitetura a localização do ponto de gás.

1 dispensador de papel toalha.

1 dispensador de sabonete líquido.

Segurança contra incêndio

Outros

Considerar requisitos para evacuação de emergência (SAO PAULO, 2001; 2004).

Operação e Manutenção

Limpeza

Especificação de detergentes $\checkmark \quad$ Somente produtos de limpeza neutros e não abrasivos.

Procedimentos de limpeza $\quad \checkmark \quad$ Lavar e desinfetar pisos, paredes e equipamentos hidrossanitários. 


\section{Diretrizes de projeto para}

Database_SPEducational_Facilities

\section{Ambientes}

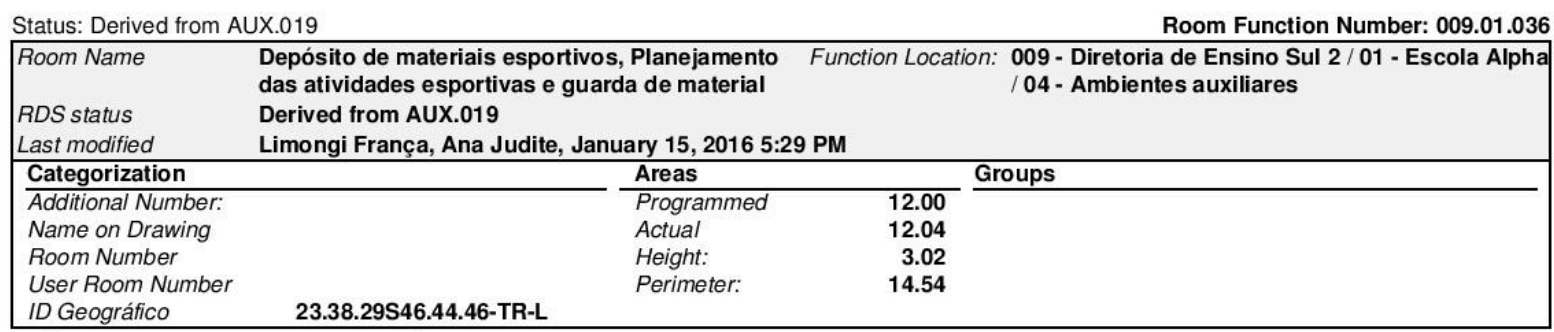

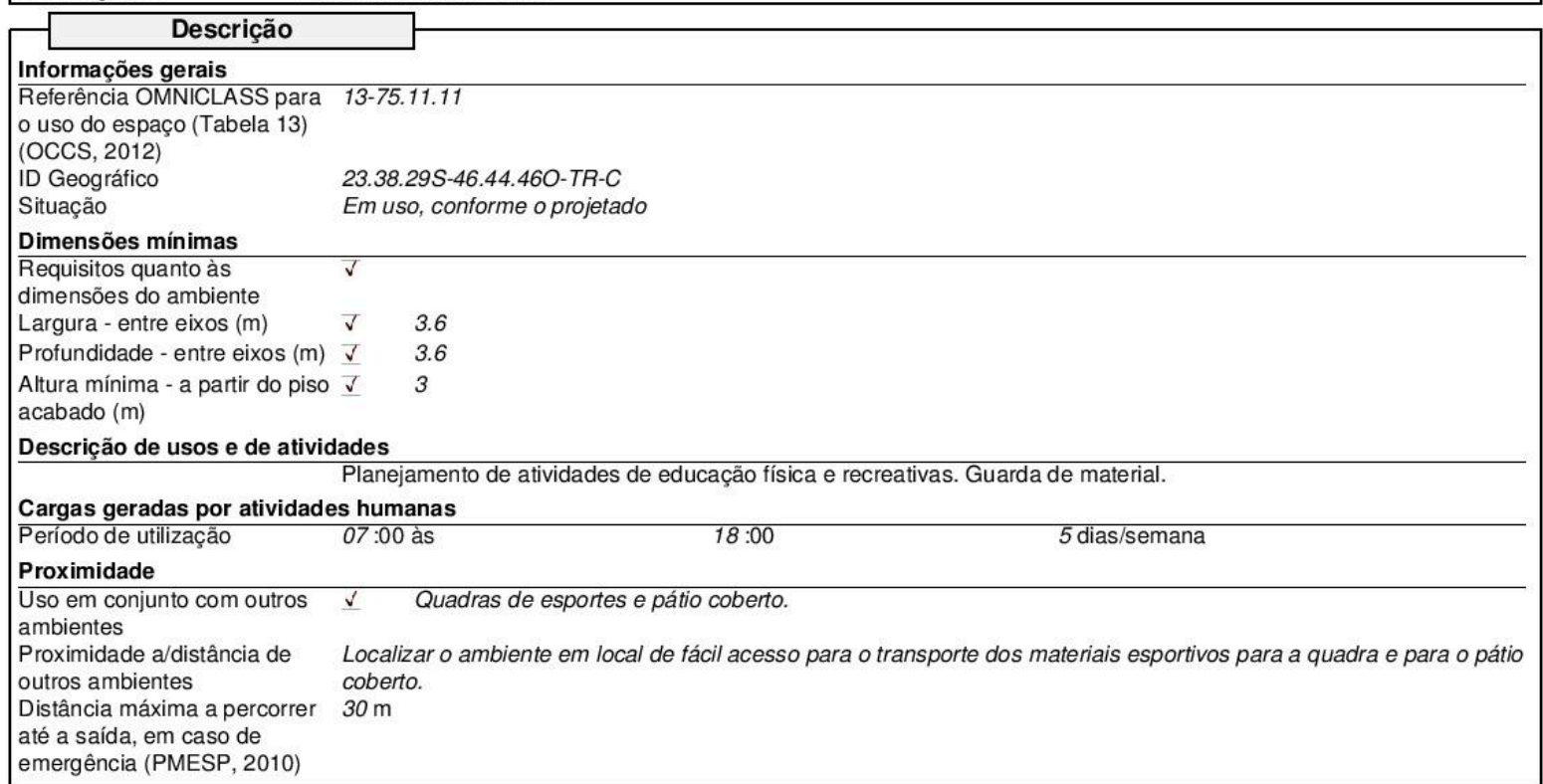

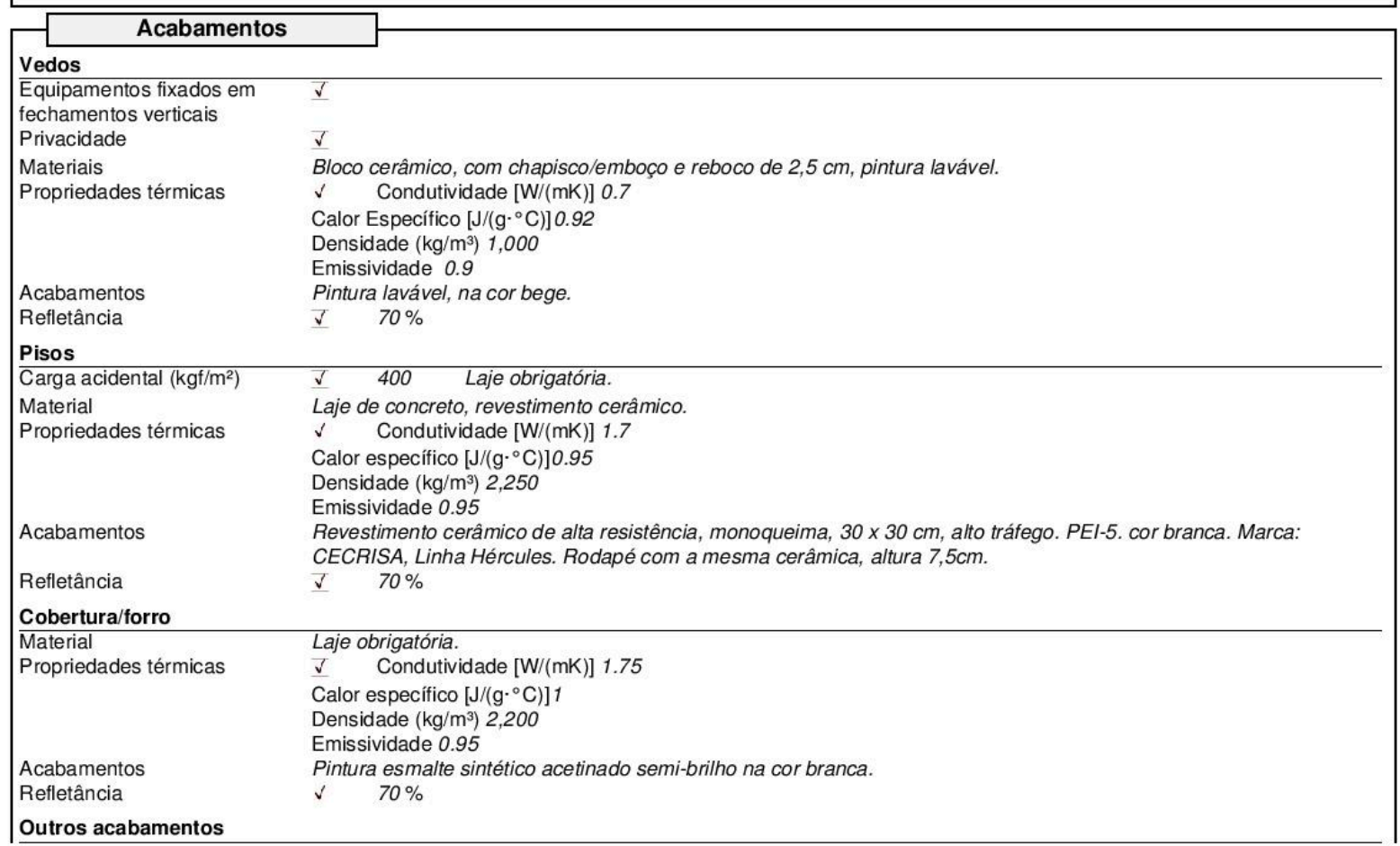




\section{Diretrizes de projeto para Ambientes}

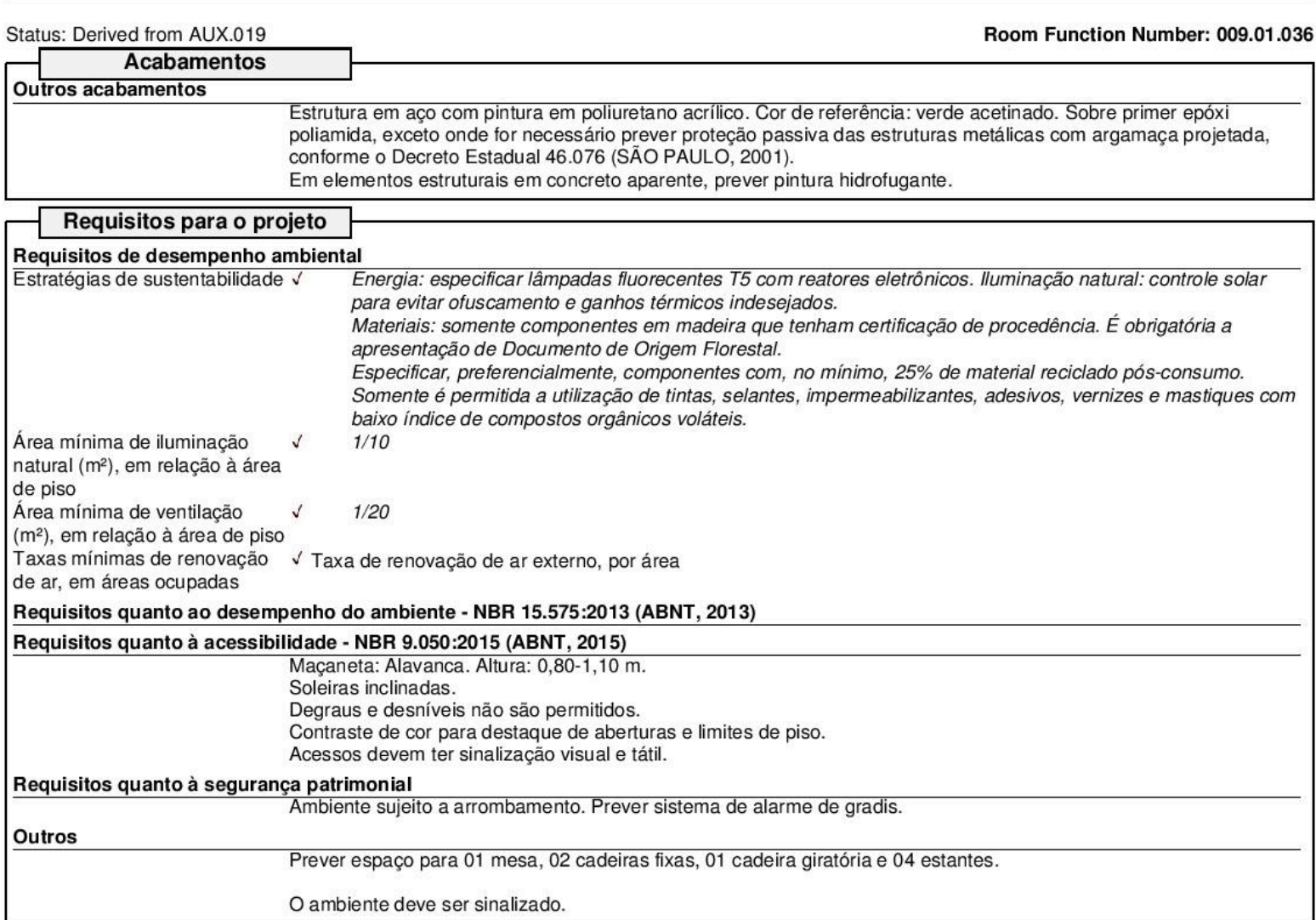

\begin{tabular}{|c|c|c|}
\hline \multicolumn{2}{|l|}{ Portas e Janelas } & \\
\hline \multicolumn{3}{|l|}{ Portas } \\
\hline Aberturas das portas & $\checkmark$ & Largura $(\mathrm{m}) 0.82$ Altura $(\mathrm{m}) 2.1$ \\
\hline Janelas para visualização & $\bar{v}$ & \\
\hline Dispositivos de proteção & $\checkmark$ & Antivandalismo. \\
\hline Mecanismo de travamento & $\checkmark$ & Conforme requisitos da ANSI 088 (FRANÇA, 2011). \\
\hline Material da porta & $\checkmark$ & Madeira maciça. \\
\hline $\begin{array}{l}\text { Requisitos de iluminação } \\
\text { natural }\end{array}$ & $\checkmark$ & Em paredes externas. \\
\hline $\begin{array}{l}\text { Com dispositivos para abertura } \\
\text { e fechamento }\end{array}$ & $\checkmark$ & $\begin{array}{l}\text { O usuário deve controlar as aberturas para ventilação natural. Considerar a especificação de um sistema de } \\
\text { exaustão para assegurar níveis mínimos de renovação de ar. (ANVISA, 1998). }\end{array}$ \\
\hline $\begin{array}{l}\text { Requisitos de mecanismos de } \\
\text { abertura }\end{array}$ & $\checkmark$ & \\
\hline Dispositivos de controle solar & $\checkmark$ & \\
\hline
\end{tabular}

\begin{tabular}{|c|c|c|}
\hline \multicolumn{2}{|c|}{$\begin{array}{l}\text { Aquecimento, ventilação } \\
\text { e ar condicionado }\end{array}$} & \\
\hline Ventilação & & \\
\hline Ventilação natural & $\begin{array}{l}\text { Preve } \\
\text { Prombie }\end{array}$ & $\begin{array}{l}\checkmark \text { Ventilação cruzada } \\
\text { janelas operáveis, para confoto térmico. Vide aba requisitos para o projeto: requisitos de desempenho } \\
\text { ttal e requisitos para ventilação natural. }\end{array}$ \\
\hline
\end{tabular}

\begin{tabular}{|c|c|}
\hline $\begin{array}{c}\text { Sistemas de Elétrica/ } \\
\text { Dados/Audio/Vigilância }\end{array}$ \\
Sistemas de iluminação \\
\hline Sensor de presença & $\checkmark$
\end{tabular}


Status: Derived from AUX.019

Room Function Number: 009.01.036

Sistemas de Elétrica/

Dados/Audio/Vigilância

Sistemas de iluminação

Densidade de Potência $\checkmark \checkmark$ 9DL $\left(\mathrm{W} / \mathrm{m}^{2}\right)$ (ANSI/ASHRAE,

Luminosa (DPL) 2013b).

Nível de iluminâncial (lux) 는 $\quad 150$ lux [NBR 5.413:1992 (ABNT,

Conjuntos (luminárias + $\quad \checkmark \quad 1$ Unidades 2 Lâmpadas

lâmpadas

Ofuscamento

$32 \mathrm{~W}$

Sistemas elétricos

Tomada universal baixa -

$0,40 \mathrm{~m}$

Tomada universal média - $\quad \checkmark \quad 1 \quad 2 P+T, 10$ A/110V, NBR 14136

$1,10 \mathrm{~m}$

Ponto de força - 2,20 m

Interruptores

(ABNT, 2002).

Potência instalada

Potência instalada - iluminação $\checkmark \quad 64 \mathrm{~W}$

Pontos de rede de transmissão de dados

Ponto de lógica 1

Ponto de telefo

Monitoramento/segurança/alarmes

Sensores de movimento

invasão

\section{Sistemas hidrossanitários}

Sistema predial de água fria

Sanitários

Outros

Não foram previstas instalações hidrossanitárias no ambiente.

\section{Segurança contra incêndio}

Outros

Considerar requisitos para evacuação de emergência (SAO PAULO, 2001; 2004).

Operação e Manutenção

Limpeza

Especificação de detergentes $\quad \checkmark \quad$ Somente produtos de limpeza neutros e não abrasivos.

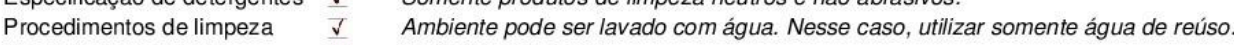

Frequencia da limpeza $\quad \checkmark \quad$ Toda troca de turno 
Status: Derived from AUX.013

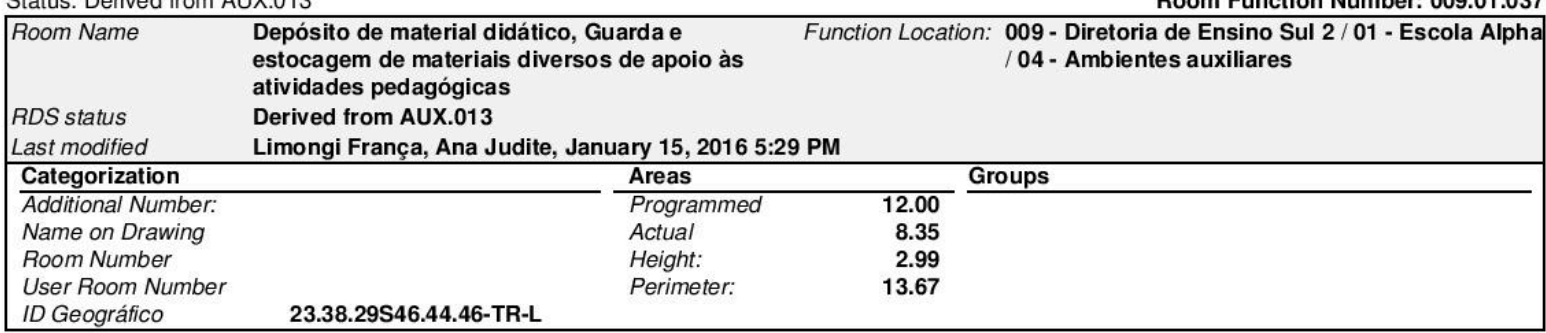

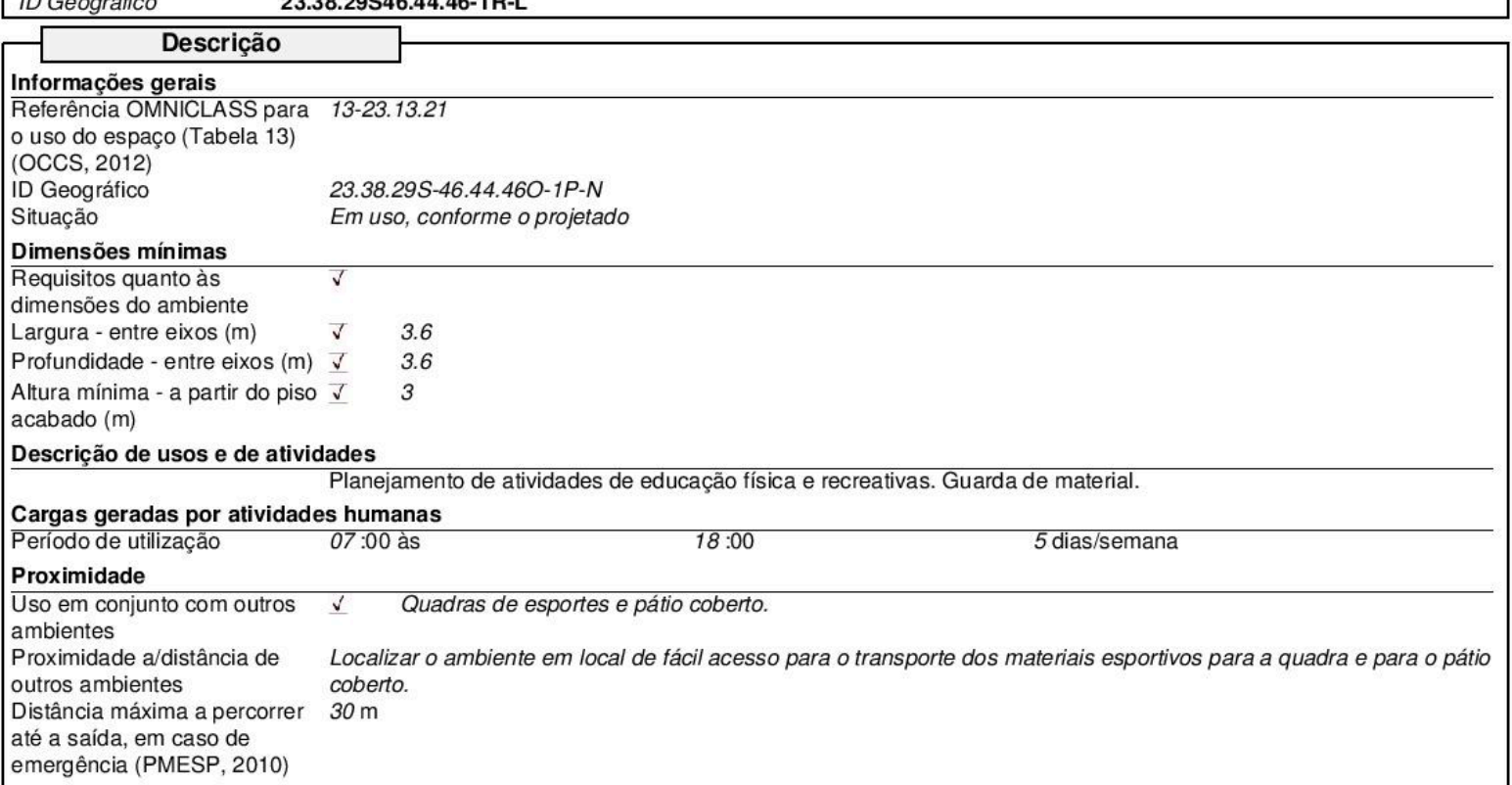

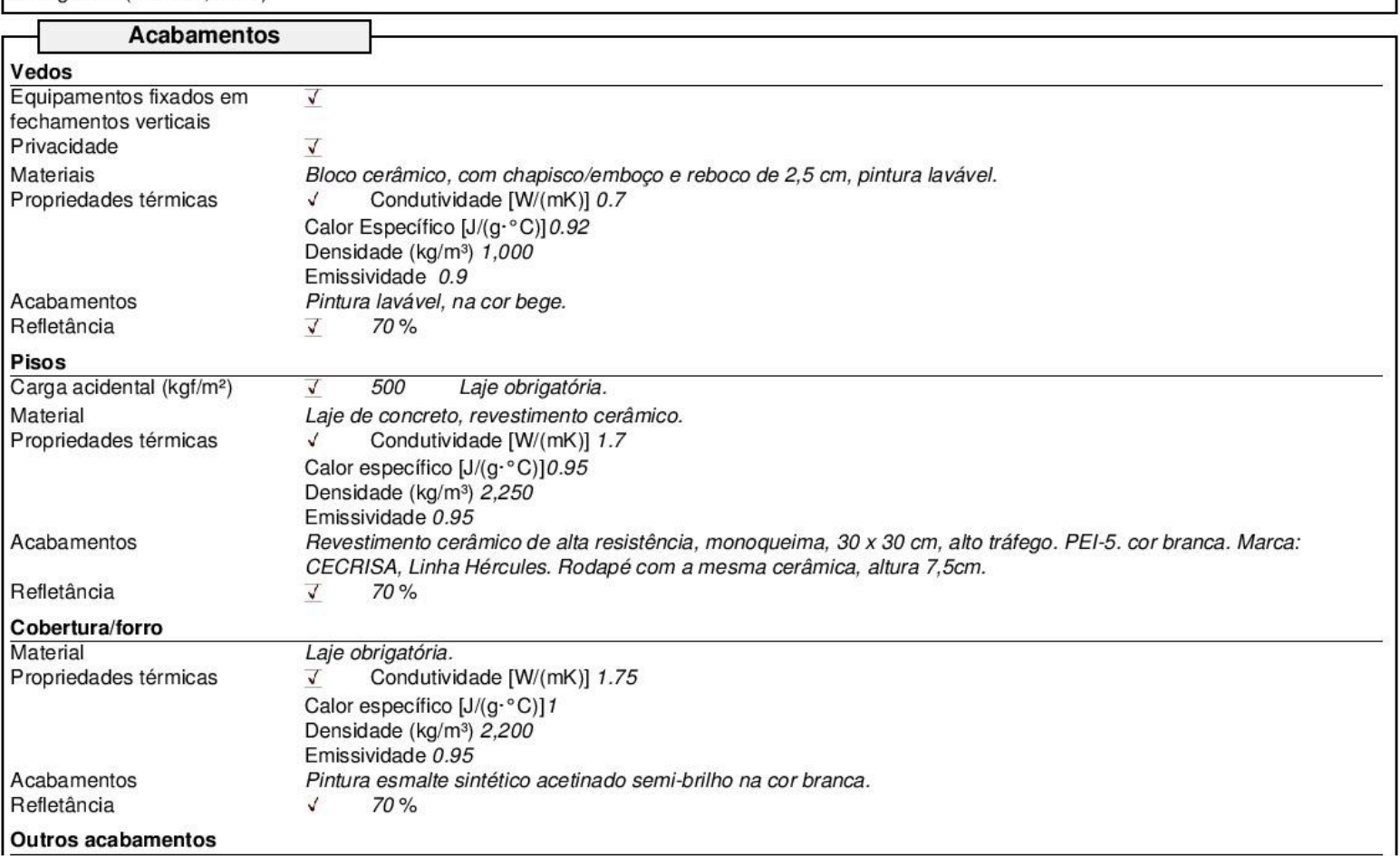


Status: Derived from AUX.013

\section{Acabamentos Outros acabamentos}

Room Function Number: 009.01.037

\begin{tabular}{ll} 
Outros acabamentos & \\
\hline & Estrutura em aço com pintura em poliuretano acrílico. Cor de referência: verde acetinado. Sobre primer epóxi \\
poliamida, exceto onde for necessário prever proteção passiva das estruturas metálicas com argamaça projetada, \\
conforme o Decreto Estadual 46.076 (SÃO PAULO, 2001). \\
Em elementos estruturais em concreto aparente, prever pintura hidrofugante.
\end{tabular}

\section{Requisitos para o projeto}

Requisitos de desempenho ambiental

Estratégias de sustentabilidade $\checkmark$ Energia: especificar lâmpadas fluorecentes T5 com reatores eletrônicos. Iluminação natural: controle solar para evitar ofuscamento e ganhos térmicos indesejados.

Materiais: somente componentes em madeira que tenham certificação de procedência. É obrigatória a

apresentação de Documento de Origem Florestal.

Especificar, preferencialmente, componentes com, no mínimo, 25\% de material reciclado pós-consumo

Somente é permitida a utilização de tintas, selantes, impermeabilizantes, adesivos, vernizes e mastiques com baixo índice de compostos orgânicos voláteis.

Área mínima de iluminação $\quad \checkmark \quad 1 / 10$

natural $\left(\mathrm{m}^{2}\right)$, em relação à área

de piso

Área mínima de ventilação $\quad \checkmark \quad 1 / 20$

$\left(\mathrm{m}^{2}\right)$, em relação à área de piso

Taxas mínimas de renovação $\checkmark$ Taxa de renovação de ar externo, por área

de ar, em áreas ocupadas

Requisitos quanto ao desempenho do ambiente - NBR 15.575:2013 (ABNT, 2013)

Requisitos quanto à acessibilidade - NBR 9.050:2015 (ABNT, 2015)

Maçaneta: Alavanca. Altura: 0,80-1,10 m.

Soleiras inclinadas.

Degraus e desníveis não são permitidos.

Contraste de cor para destaque de aberturas e limites de piso.

Acessos devem ter sinalização visual e tátil.

Requisitos quanto à segurança patrimonial

Ambiente sujeito a arrombamento. Prever sistema de alarme de gradis.

Outros

Prever espaço para 01 mesa, 02 cadeiras fixas, 01 cadeira giratória e 04 estantes.

O ambiente deve ser sinalizado.

\begin{tabular}{|c|c|c|}
\hline \multicolumn{2}{|l|}{ Portas e Janelas } & \\
\hline \multicolumn{3}{|l|}{ Portas } \\
\hline Janelas para visualização & $\checkmark$ & \\
\hline Dispositivos de proteção & $\checkmark$ & Antivandalismo. \\
\hline Mecanismo de travamento & $\checkmark$ & Conforme requisitos da ANSI 088 (FRANÇA, 2011). \\
\hline Material da porta & $\checkmark$ & Madeira maciça. \\
\hline $\begin{array}{l}\text { Com dispositivos para abertura } \\
\text { e fechamento }\end{array}$ & $\checkmark$ & $\begin{array}{l}\text { O usuário deve controlar as aberturas para ventilação natural. Considerar a especificação de um sistema de } \\
\text { exaustão para assegurar níveis mínimos de renovação de ar. (ANVISA, 1998). }\end{array}$ \\
\hline $\begin{array}{l}\text { Requisitos de mecanismos de } \\
\text { abertura }\end{array}$ & $\checkmark$ & \\
\hline Dispositivos de controle solar & v & \\
\hline
\end{tabular}

\begin{tabular}{|c|c|c|}
\hline \multicolumn{2}{|c|}{$\begin{array}{l}\text { Aquecimento, ventilação } \\
\text { e ar condicionado }\end{array}$} & \\
\hline \multicolumn{3}{|r|}{ (1) } \\
\hline Ventilação natural & $\begin{array}{l}\bar{\checkmark} \\
\text { Preve } \\
\text { ambie }\end{array}$ & $\begin{array}{l}\checkmark \text { Ventilação cruzada } \\
\text { janelas operáveis, para confoto térmico. Vide aba requisitos para o projeto: requisitos de desempenho } \\
\text { ttal e requisitos para ventilação natural. }\end{array}$ \\
\hline
\end{tabular}

\begin{tabular}{|l|c|}
\hline $\begin{array}{c}\text { Sistemas de Elétrica/ } \\
\text { Dados/Audio/Vigilância }\end{array}$ & \\
Sistemas de iluminação & \\
\hline Sensor de presença & $\checkmark$
\end{tabular}




\section{Diretrizes de projeto para}

Database_SPEducational_Facilities Ambientes

Status: Derived from AUX.013

Room Function Number: 009.01.037

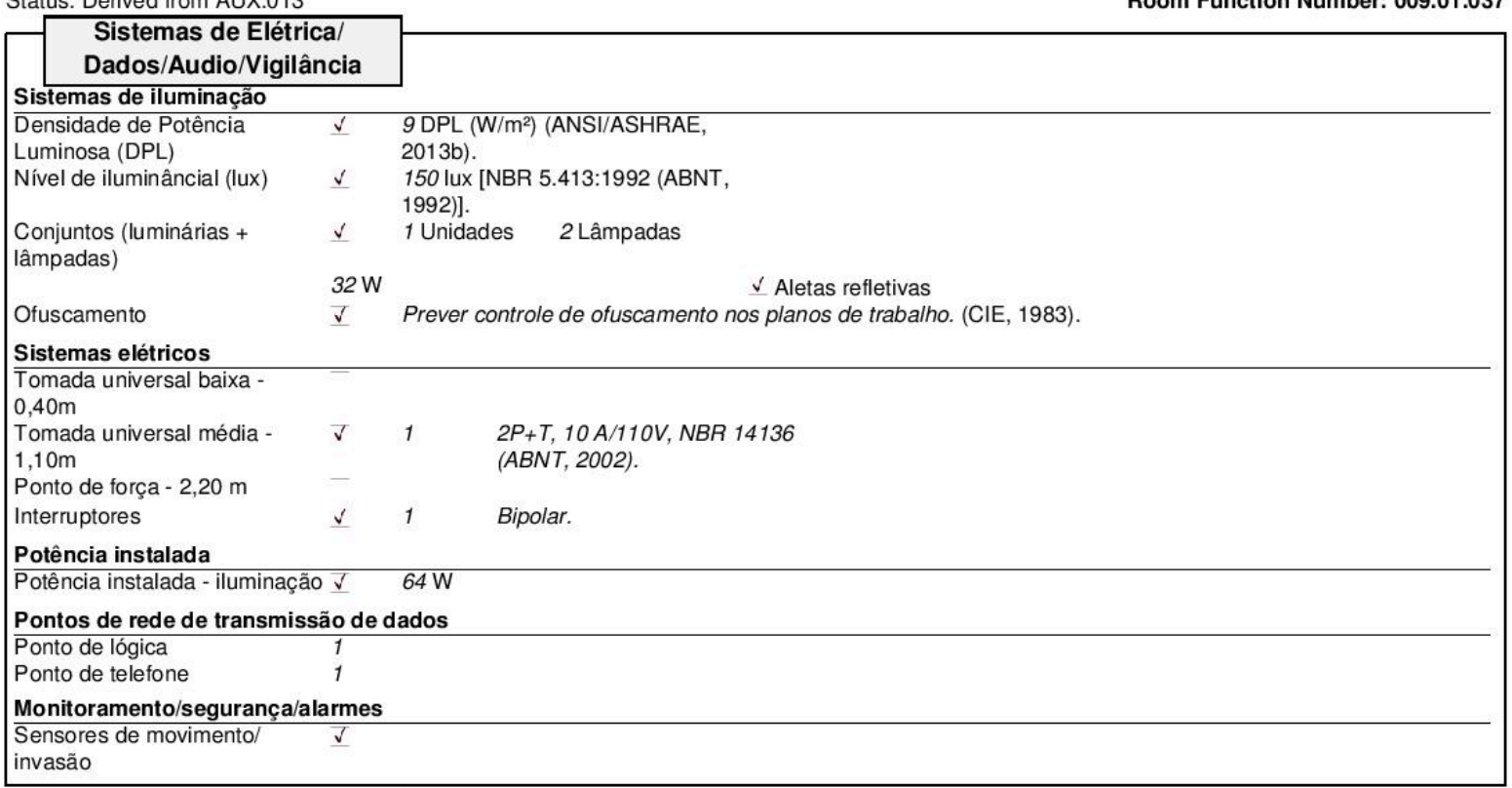

\section{Sistemas hidrossanitários}

Sistema predial de água fria

Sanitários

Outros

Não foram previstas instalações hidrossanitárias no ambiente.

\section{Segurança contra incêndio}

Outros

Considerar requisitos para evacuação de emergência (SAO PAULO, 2001; 2004).

Operação e Manutenção

Limpeza

Especificação de detergentes $\checkmark \checkmark \quad$ Somente produtos de limpeza neutros e não abrasivos.

Procedimentos de limpeza $\quad \bar{v} \quad$ Ambiente pode ser lavado com água. Nesse caso, utilizar somente água de reúso.

Frequencia da limpeza $\quad \checkmark \quad$ Toda troca de turno. 


\section{Diretrizes de projeto para}

Database_SPEducational_Facilities

\section{Ambientes}

\begin{tabular}{|c|c|c|}
\hline Status: Derived from A & UX.014-2 & $\begin{array}{rr}\text { Room Function Number: 009.01.038 } \\
\end{array}$ \\
\hline Room Name & $\begin{array}{l}\text { Despensa, Guarda e estocagem de mantimentos, } \\
\text { equipada de estrados e prateleiras }\end{array}$ & $\begin{array}{l}\text { Function Location: } 009 \text { - Diretoria de Ensino Sul 2 / } 01 \text { - Escola Alpha } \\
\qquad / 04 \text { - Ambientes auxiliares }\end{array}$ \\
\hline RDS status & Derived from AUX.014-2 & \\
\hline Categorization & Areas & Groups \\
\hline Additional Number: & Programmed & 11.00 \\
\hline Name on Drawing & Actual & 10.07 \\
\hline Room Number & Height: & 3.02 \\
\hline
\end{tabular}

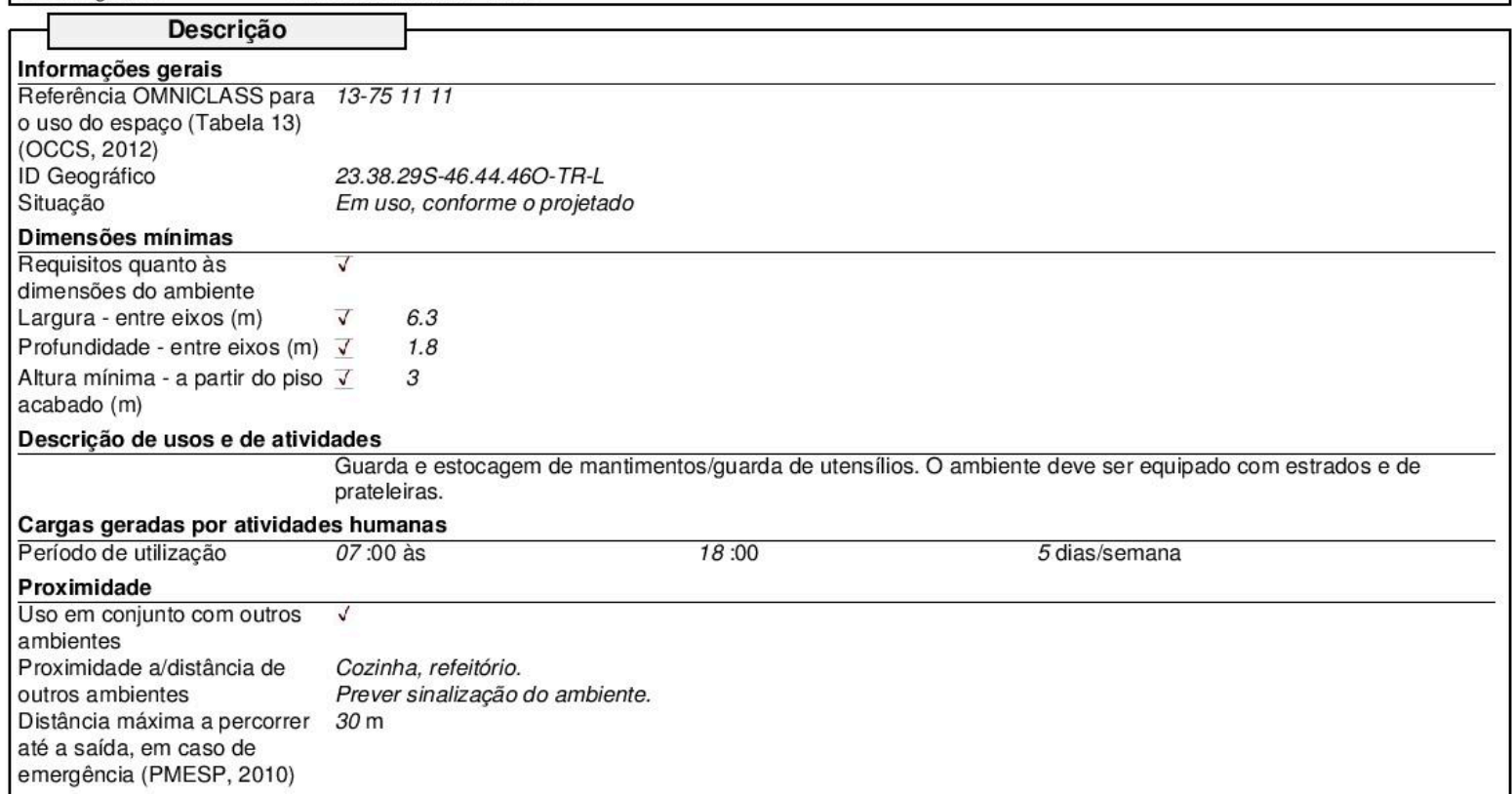

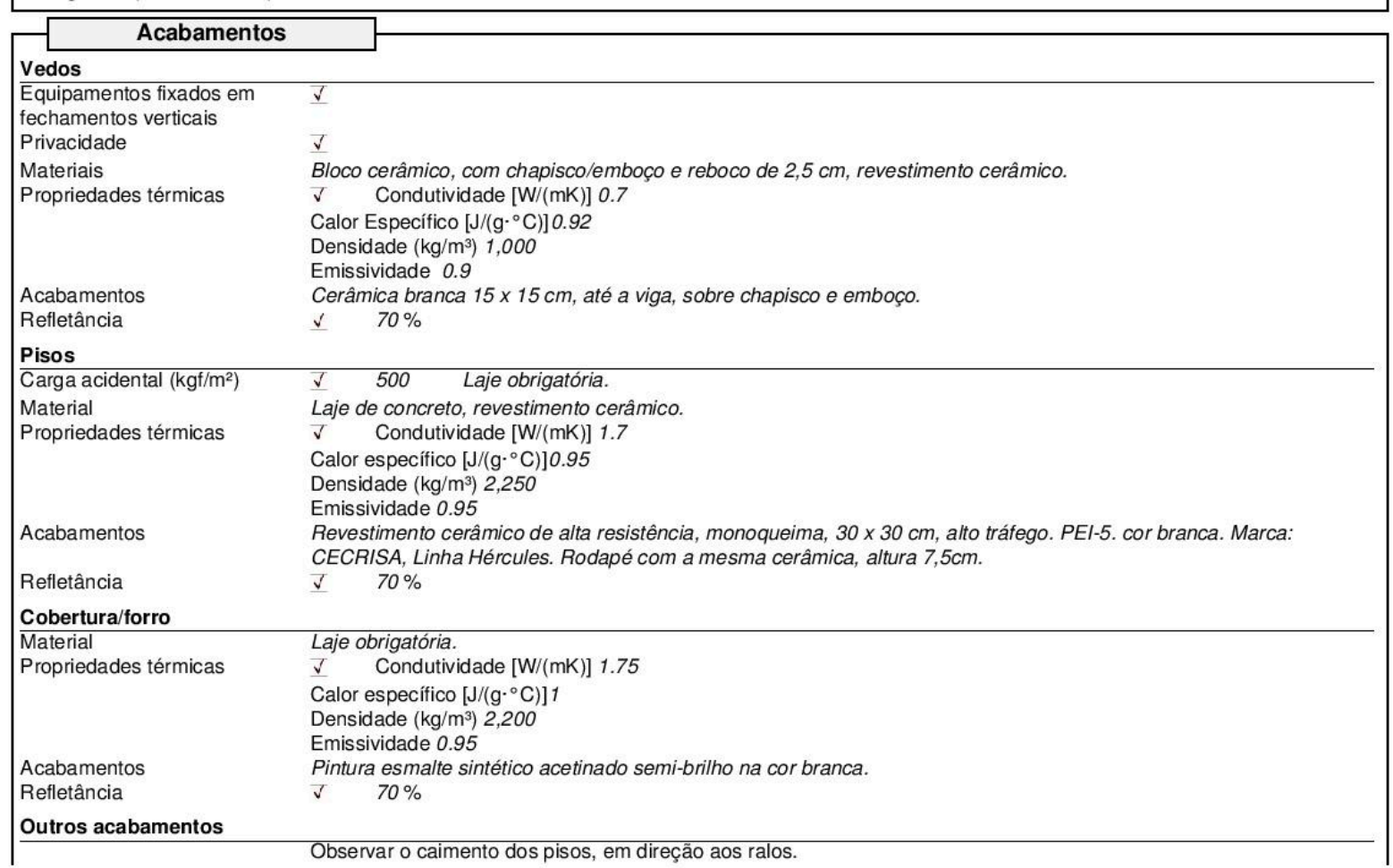




\section{Diretrizes de projeto para Ambientes}

Status: Derived from AUX.014-2

\begin{tabular}{ll}
\hline Acabamentos & \\
\hline Outros acabamentos & Prever rodapés arredondados no piso, em todo o ambiente. \\
As paredes devem ser revestidas com material liso, impermeável e resistente a frequentes lavagens. & O piso deve ser anti-derrapante, impermeável, de fácil higienização e resistente a ácidos. \\
& Estrutura em aço com pintura em poliuretano acrílico. Cor de referência: verde acetinado. Sobre primer epóxi \\
poliamida, exceto onde for necessário prever proteção passiva das estruturas metálicas com argamaça projetada, \\
conforme o Decreto Estadual 46.076 (SÃO PAULO, 2001). \\
Em elementos estruturais em concreto aparente, prever pintura hidrofugante.
\end{tabular}

Requisitos para o projeto

Requisitos de desempenho ambiental

Estratégias de sustentabilidade $\checkmark \quad$ Energia: Especificar lâmpadas fluorecentes T5 com reatores eletrônicos. Iluminação natural: controle solar para evitar ofuscamento e ganhos térmicos indesejados.

Materiais: somente componentes em madeira que tenham certificação de procedência. É obrigatória a apresentação de Documento de Origem Florestal.

Especificar, preferencialmente, componentes com, no mínimo, 25\% de material reciclado pós-consumo. Somente é permitida a utilização de tintas, selantes, impermeabilizantes, adesivos, vernizes e mastiques com baixo índice de compostos orgânicos voláteis. Tratamento acústico $\quad \checkmark \quad$ Ambiente pouco exigente

Controle de ofuscamento

Área mínima de iluminação

natural $\left(\mathrm{m}^{2}\right)$, em relação à área

de piso

Área mínima de ventilação $\quad \checkmark \quad 1 / 2$

$\left(\mathrm{m}^{2}\right)$, em relação à área de piso

Taxas mínimas de renovação $\checkmark$ Taxa de renovação de ar externo, por área

de ar, em áreas ocupadas

Requisitos quanto ao conforto $\checkmark \quad 80$ (\% horas na zona de conforto/ano) [ASHRAE 55.1:2004 (ANSI/ASHRAE, 2004)].

térmico

Requisitos quanto ao desempenho do ambiente - NBR 15.575:2013 (ABNT, 2013)

As aberturas do ambiente devem proporcionar entre 15-60 trocas de ar por hora [ASHRAE 62.1-2013 (ASHRAE, 2013)].

Requisitos quanto à acessibilidade - NBR 9.050:2015 (ABNT, 2015)

Vão mínimo de portas: $0,80 \mathrm{~m}$

Maçaneta: Alavanca. Altura: $0,80-1,10 \mathrm{~m}$

Soleiras inclinadas.

Degraus e desníveis não são permitidos.

Contraste de cor para destaque de aberturas e limites de piso.

Acessos devem ter sinalização visual e tátil.

Requisitos quanto à segurança patrimonial

Outros

Prever estrados de polipropileno para prateleira de despensa $(25 \times 50 \times 2,5 \mathrm{~cm})$. Quantificar e indicar suas

características no projeto executivo.

Prever prateleiras em granilite para o ambiente de guarda de utensílios, $L=55 \mathrm{~cm}$.

$\mathrm{O}$ ambiente deve ser sinalizado.

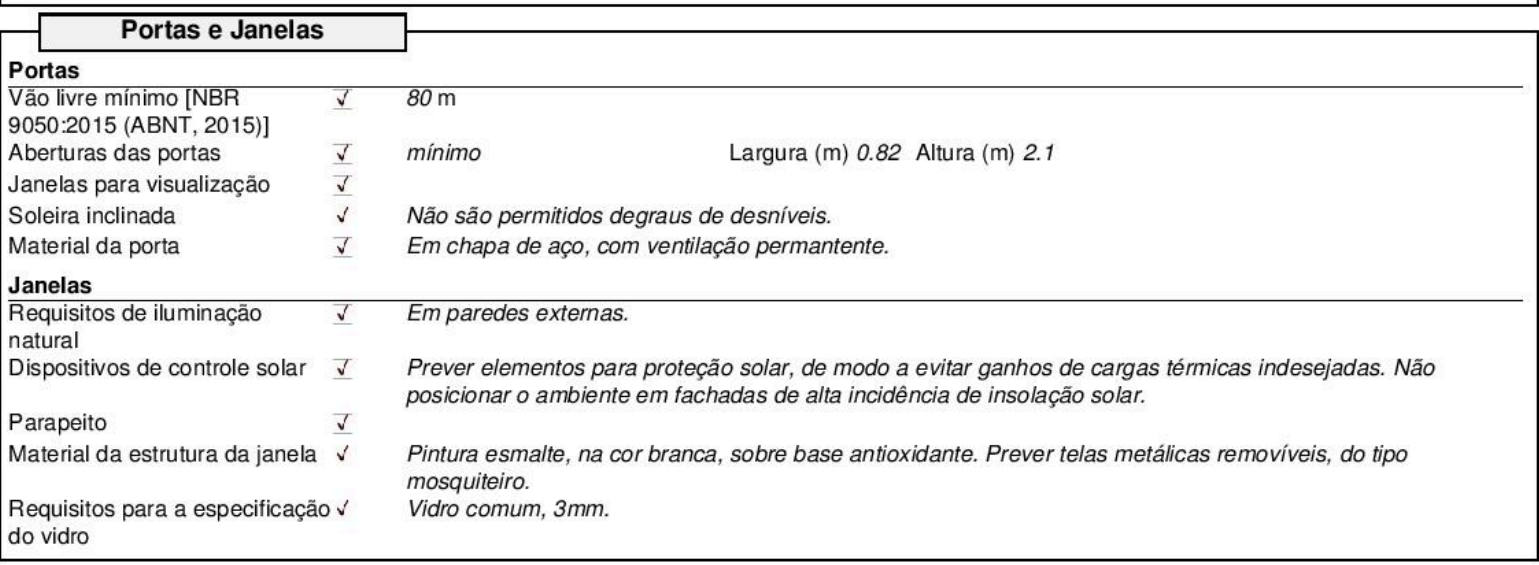

Sistemas de Elétrica

Dados/Audio/Vigilância

Sistemas de iluminação

Sensor de iluminação natural $\sqrt{ }$

Sensor de presença 
Diretrizes de projeto para Ambientes

Status: Derived from AUX.014-2

Room Function Number: 009.01.038

Sistemas de Elétrica/

Dados/Audio/Vigilância

Sistemas de iluminação

Densidade de Potência $\quad \checkmark \quad 10 \mathrm{DPL}\left(\mathrm{W} / \mathrm{m}^{2}\right)$ (ANSI/ASHRAE,

Luminosa (DPL) 2013b).

Nível de iluminâncial (lux) $\quad \checkmark \quad 150$ lux [NBR 5.413:1992 (ABNT,

Conjuntos (luminárias + $\quad \checkmark \quad 3$ Unidades 2 Lâmpadas

lâmpadas

$32 \mathrm{~W}$

$\checkmark$ Aletas refletivas

Sendo: 1 luminária destinada à área de guarda de utensilios e 2 para atendimento à área da despensa.

Sistemas elétricos

Tomada universal baixa -

$0,40 \mathrm{~m}$

Tomada universal média -

$1,10 \mathrm{~m}$

Tomada universal média -

$1,10 \mathrm{~m}$

Ponto de força - $2,20 \mathrm{~m}$

Interruptores

Bipolares, caso os ambientes estinados à despensa e à guarda de utensílios sejam separados. Se integrados, 1 interruptor bipolar é suficiente.

Potência instalada

Potência instalada - iluminação $\checkmark \quad 192 \mathrm{~W}$

Pontos de rede de transmissão de dados

Ponto de lógica $1 \quad$ Ponto de lógica.

Observações

Sistemas hidrossanitários

Gases

Gás natural 1

Outros

Não estão previstas instalações hidrossanitárias neste ambiente.

Segurança contra incêndio

Outros

Considerar requisitos para evacuação de emergência (SAO PAULO, 2001; 2004).

\section{Operação e Manutenção}

\section{Limpeza}

Especificação de detergentes $\checkmark \quad$ Somente produtos de limpeza neutros e não abrasivos.

Procedimentos de limpeza $\quad \checkmark \quad$ Lavar e desinfetar pisos, paredes e equipamentos hidrossanitários. 


\section{Diretrizes de projeto para Ambientes}

Database_SPEducational_Facilities

Room Function Number: 009.01.039

Status: Derived from AUX.017-F

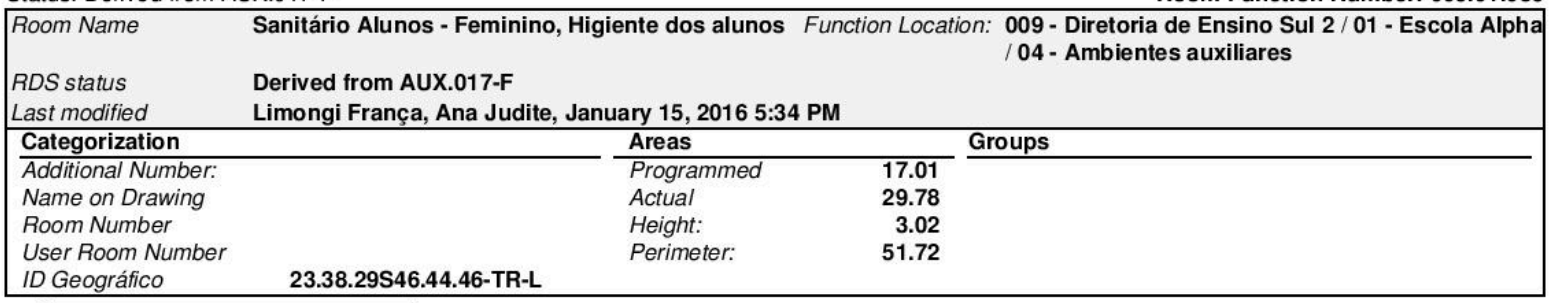

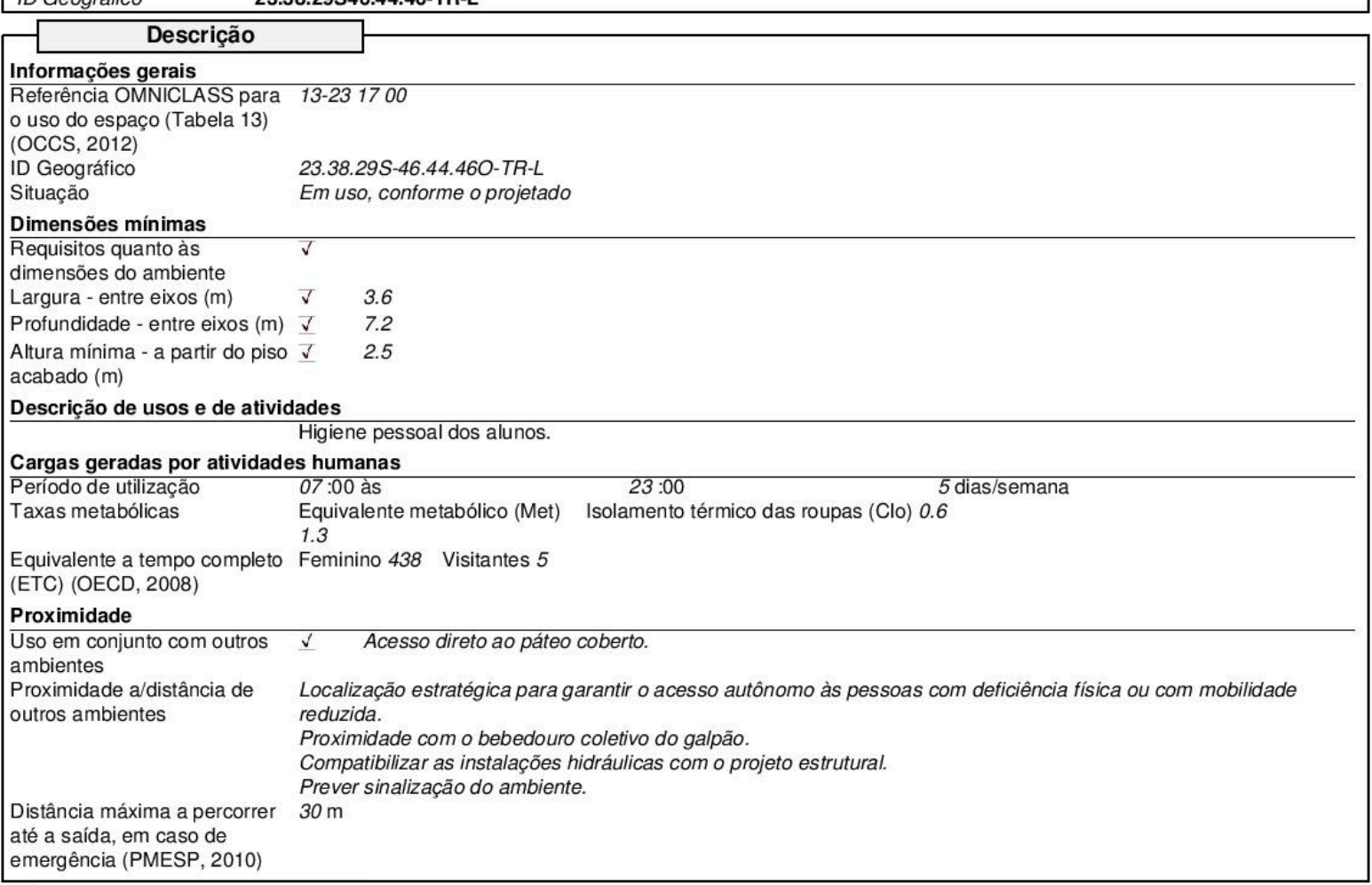

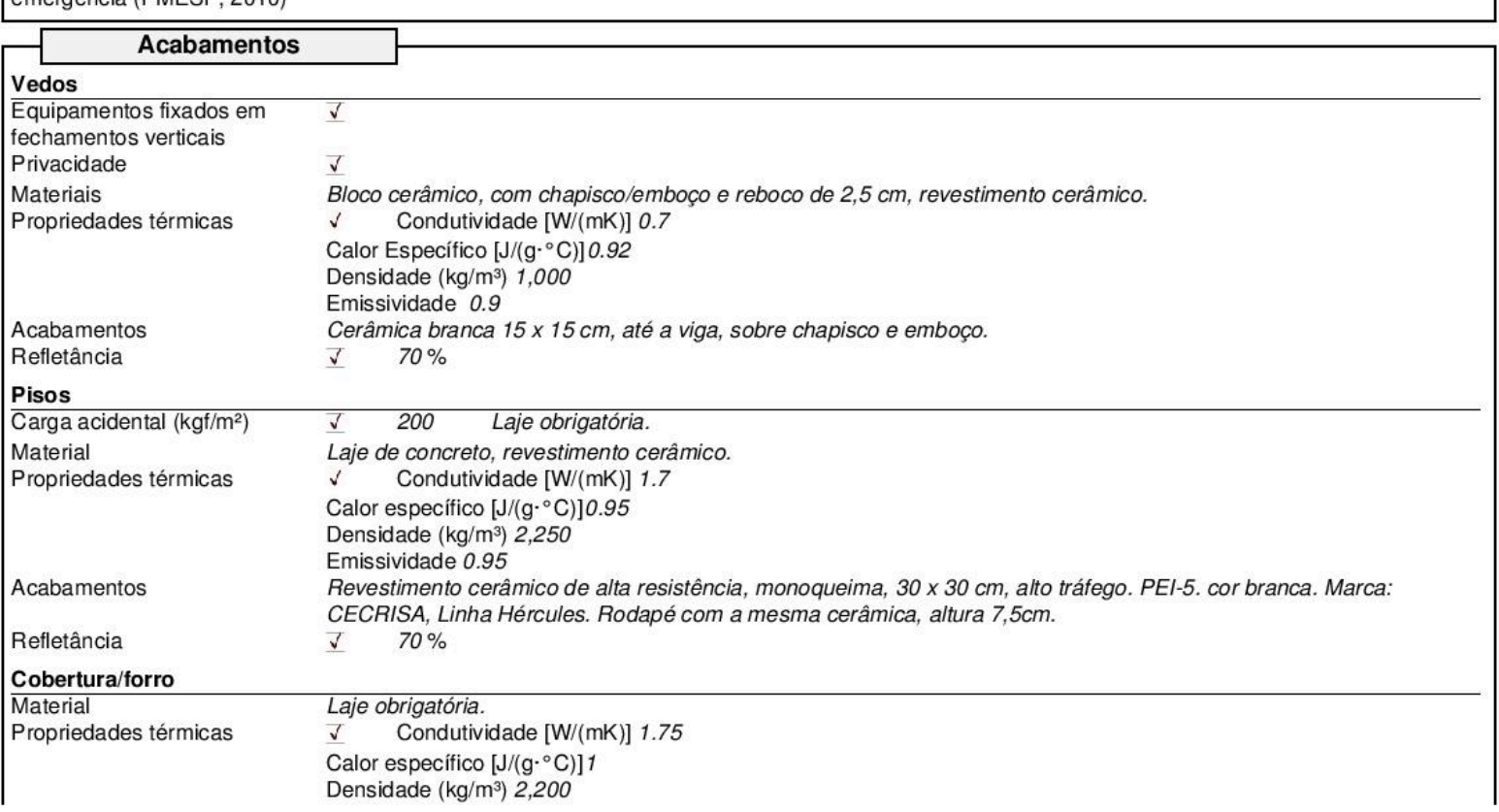




\section{Diretrizes de projeto para}

Database_SPEducational_Facilities Ambientes

Status: Derived from AUX.017-F

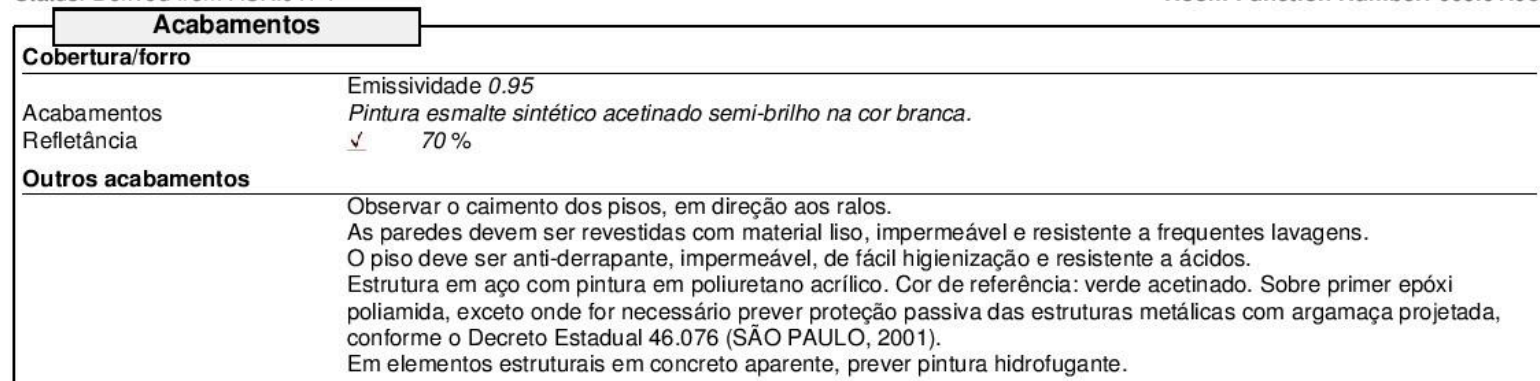

Requisitos para o projeto

Requisitos de desempenho ambiental

Estratégias de sustentabilidade $\checkmark$ Energia: prever sensores de presença para evitar que as lâmpadas permaneçam acesas quando 0 ambiente não está sendo utilizado. Especificar lâmpadas fluorecentes T5 com reatores eletrônicos. Iluminação natural: controle solar para evitar ofuscamento e ganhos térmicos indesejados.

Materiais: somente componentes em madeira que tenham certificação de procedência. É obrigatória a

apresentação de Documento de Origem Florestal.

Especificar, preferencialmente, componentes com, no mínimo, 25\% de material reciclado pós-consumo.

Somente é permitida a utilização de tintas, selantes, impermeabilizantes, adesivos, vernizes e mastiques com baixo índice de compostos orgânicos voláteis.

Tratamento acústico $\quad$ Ambiente pouco exigente.

Área mínima de iluminação $\quad \checkmark \quad 1 / 10$

natural $\left(\mathrm{m}^{2}\right)$, em relação à área

de piso

Área mínima de ventilação $\quad \checkmark \quad 1 / 20$

$\left(\mathrm{m}^{2}\right)$, em relação à área de piso

Requisitos quanto ao desempenho do ambiente - NBR 15.575:2013 (ABNT, 2013)

Requisitos quanto à acessibilidade - NBR 9.050:2015 (ABNT, 2015)

No mínimo 1 conjunto acessível com entrada independente, junto à Quadra de Esportes;

no mínimo 1 conjunto acessível com entrada independente, em cada pavimento.

Prever área de transferência e de aproximação para bacia sanitária com dimesões mínimas

Espaço livre para a manobra de cadeira de rodas: $1,50 \mathrm{~m}$.

Vão mínimo de portas: $0,80 \mathrm{~m}$.

Maçaneta: Alavanca. Altura: 0,80-1,10 m.

Soleiras inclinadas.

Degraus e desníveis não são permitidos.

Contraste de cor para destaque de aberturas e limites de piso.

Acessos devem ter sinalização visual e tátil.

Requisitos quanto à segurança patrimonial

Outros

Prever sinalização.

\begin{tabular}{|c|c|c|}
\hline \multicolumn{2}{|l|}{ Portas e Janelas } & \\
\hline \multicolumn{3}{|l|}{ Portas } \\
\hline $\begin{array}{l}\text { Vão livre mínimo [NBR } \\
\text { 9050:2015 (ABNT, 2015)] }\end{array}$ & $\checkmark$ & $0.8 \mathrm{~m}$ \\
\hline Janelas para visualização & $\checkmark$ & \\
\hline Soleira inclinada & $\checkmark$ & Não são permitidos degraus de desniveis. \\
\hline Dispositivos de proteção & $\checkmark$ & Antivandalismo. \\
\hline Porta de boxe sanitário & $\checkmark$ & Dimensões da porta de boxe $=62 \mathrm{~cm}$. Dimensões da porta de boxe acessível $=82 \mathrm{~cm}$ \\
\hline \multicolumn{3}{|l|}{ Janelas } \\
\hline $\begin{array}{l}\text { Requisitos de iluminação } \\
\text { natural }\end{array}$ & $\checkmark$ & Em paredes externas. \\
\hline $\begin{array}{l}\text { Com dispositivos para abertura } \\
\text { e fechamento }\end{array}$ & $\checkmark$ & $\begin{array}{l}\text { O usuário deve controlar as aberturas para ventilação natural. Considerar a especificação de um sistema de } \\
\text { exaustão para assegurar níveis mínimos de renovação de ar. (ANVISA, 1998). }\end{array}$ \\
\hline
\end{tabular}

do vidro

\begin{tabular}{|c|c|c|}
$\begin{array}{c}\text { Aquecimento, ventilação } \\
\text { e ar condicionado }\end{array}$ \\
Ventilação
\end{tabular}


Status: Derived from AUX.017-F

Room Function Number: 009.01.039

\begin{tabular}{|l|c|c|}
$\begin{array}{c}\text { Aquecimento, ventilação } \\
\text { e ar condicionado }\end{array}$ & \\
Ventilação & $\checkmark$ & $\checkmark$ Ventilação cruzada \\
\hline Ventilação natural & $\checkmark$ &
\end{tabular}

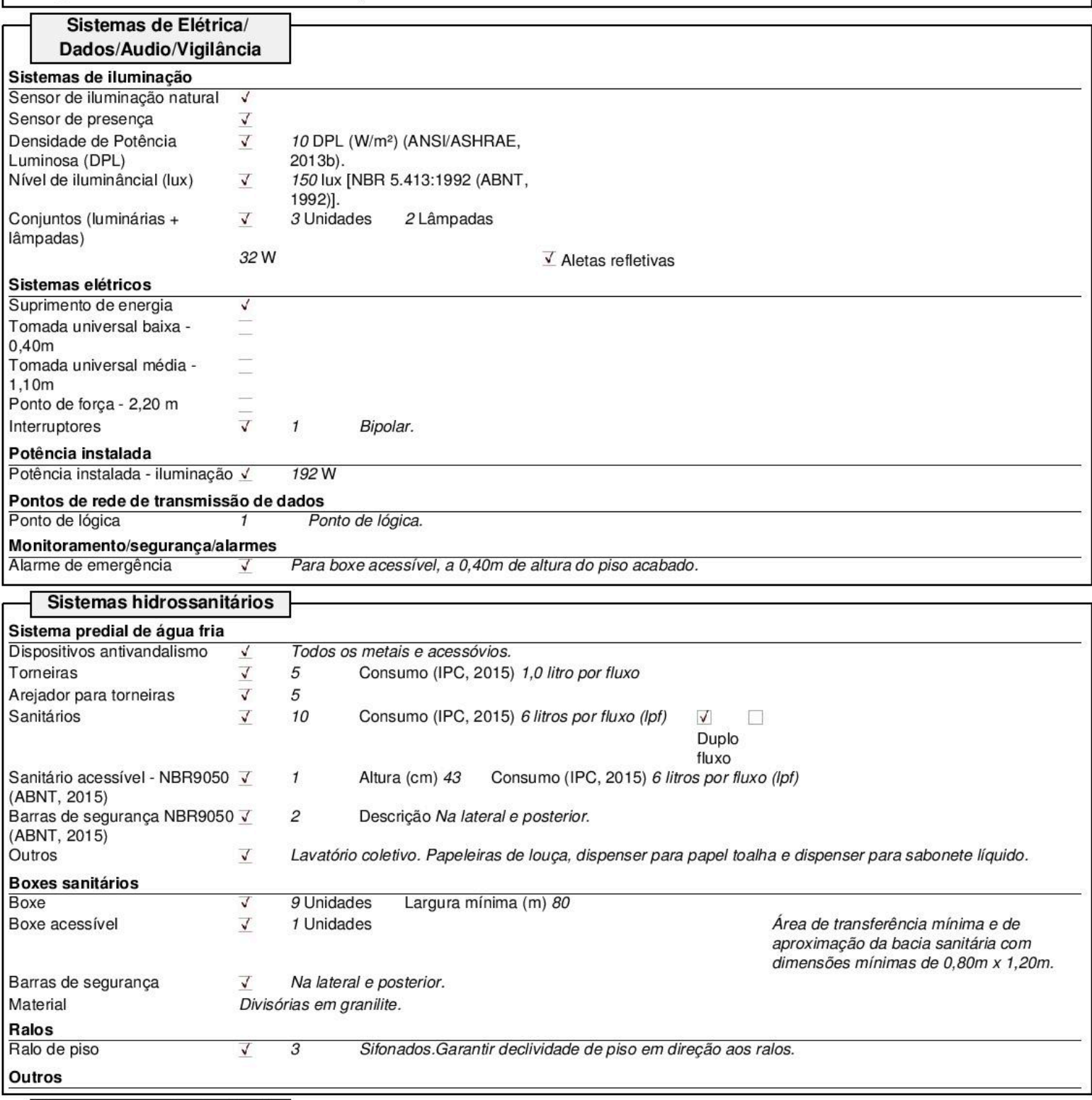

\section{Segurança contra incêndio}

Outros

Considerar requisitos para evacuação de emergência (SÄO PAULO, 2001; 2004).

\section{Operação e Manutenção}

Especificação de detergentes $\checkmark$ Somente produtos de limpeza neutros e não abrasivos.

Procedimentos de limpeza $\quad v \quad$ Lavar e desinfetar pisos, paredes e equipamentos hidrossanitários. 


\section{Diretrizes de projeto para}

Database_SPEducational_Facilities

\section{Ambientes}

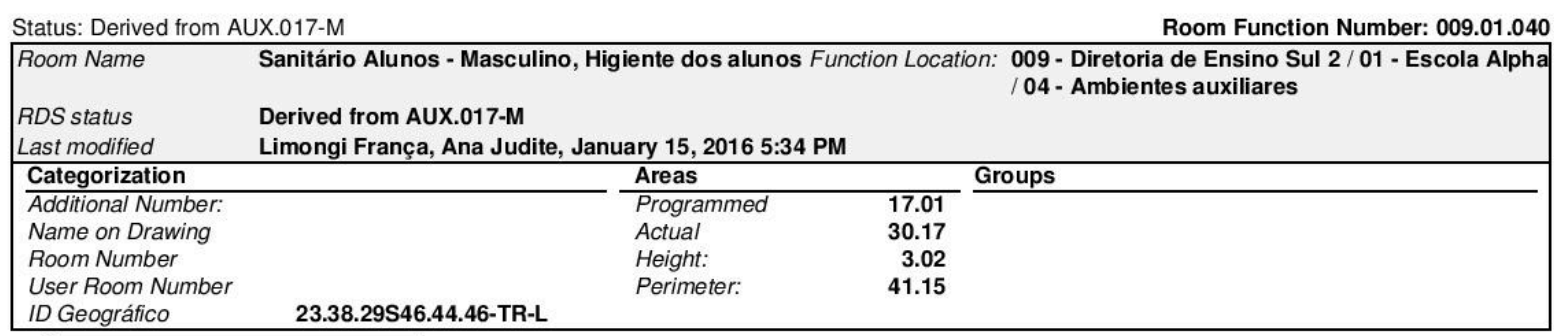

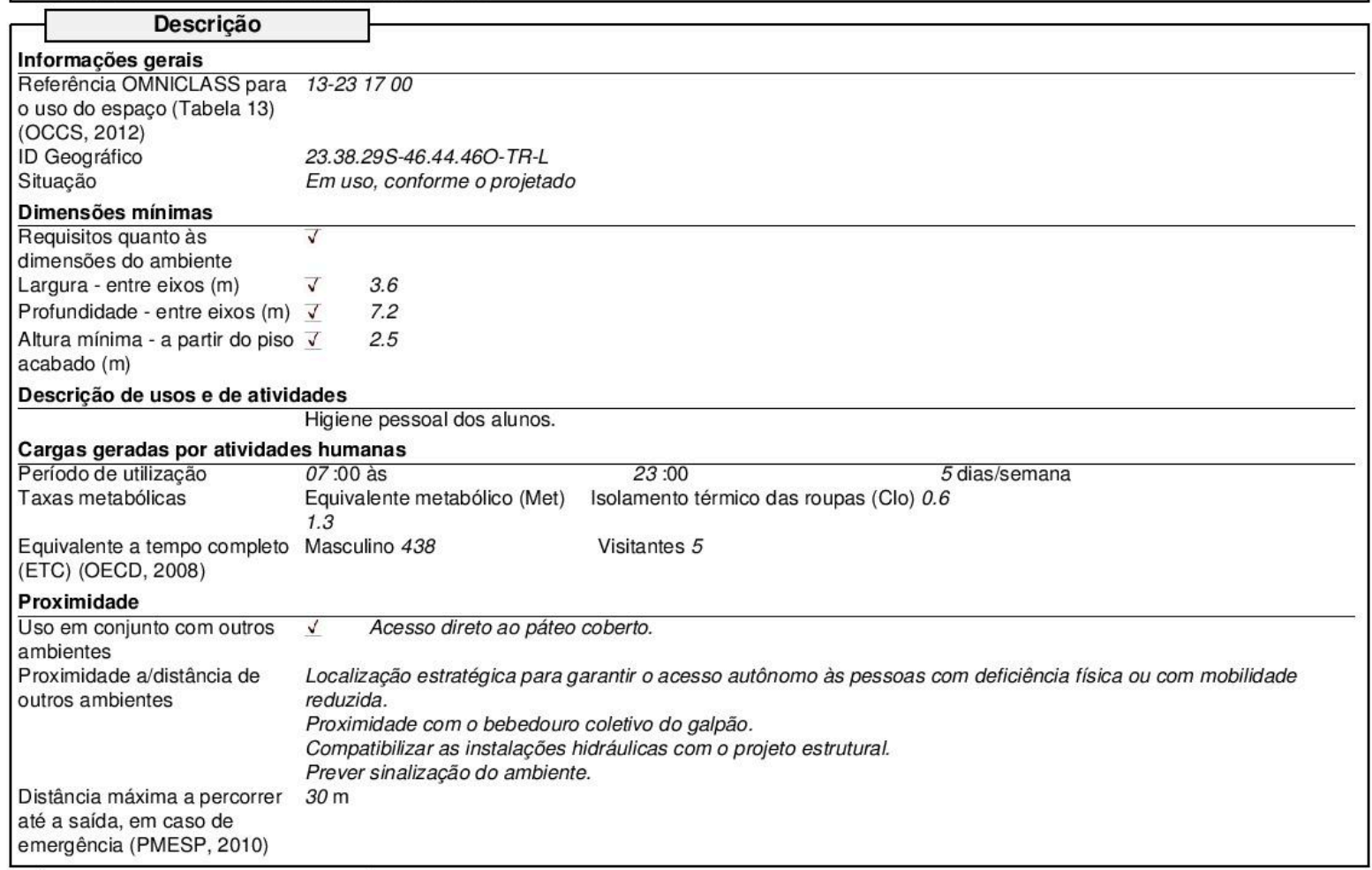

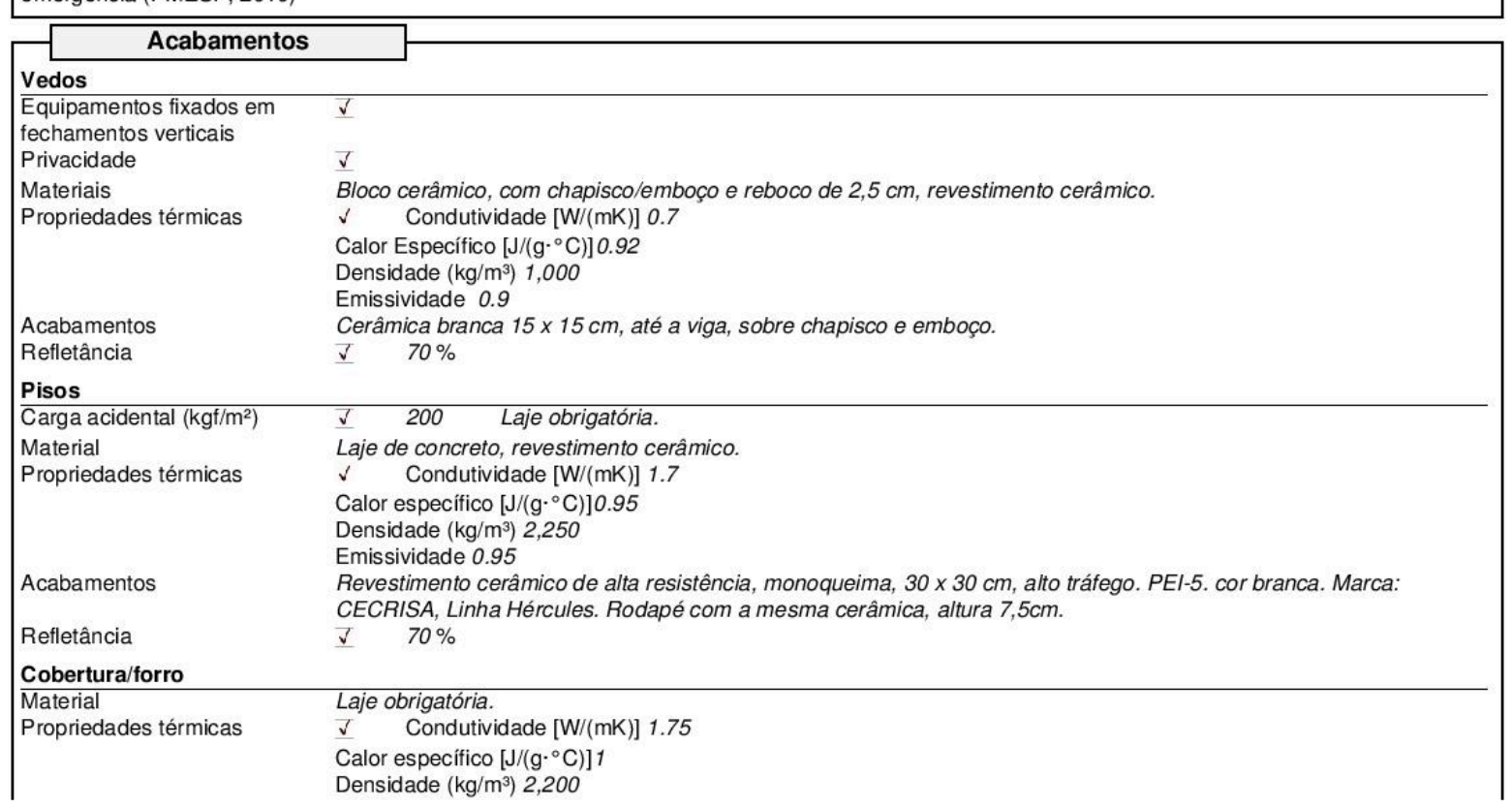




\section{Diretrizes de projeto para Ambientes}

Database SPEducational Facilities

Room Function Number: 009.01.040

Status: Derived from AUX.017-M

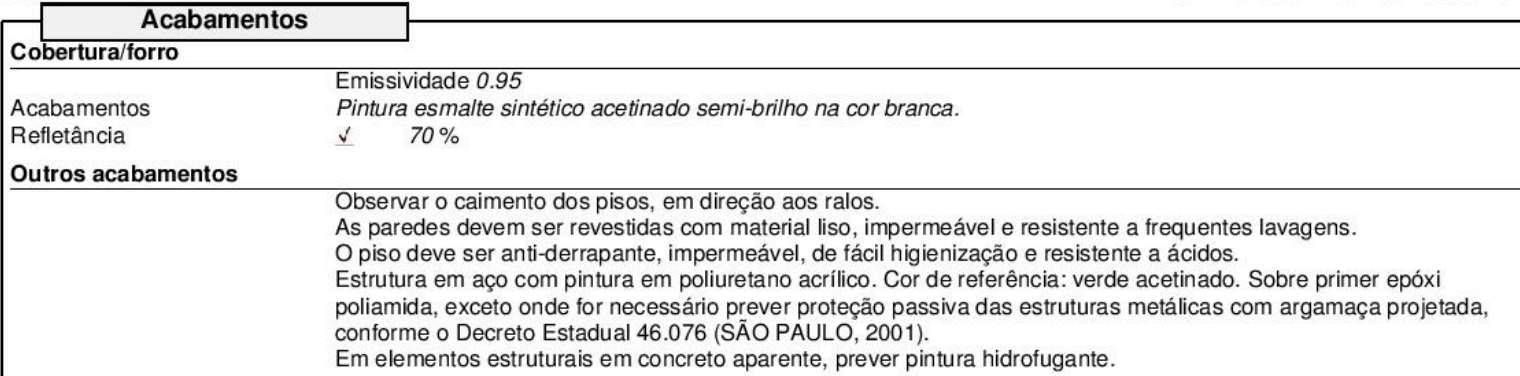

Requisitos para o projeto

Requisitos de desempenho ambiental

Estratégias de sustentabilidade $\vec{\checkmark}$ Energia: prever sensores de presenç para evitar que as lâmpadas permaneçm acesas quando o ambiente não está sendo utilizado. Especificar lâmpadas fluorecentes T5 com reatores eletrônicos. Iluminação natural: controle solar para evitar ofuscamento e ganhos térmicos indesejados.

Materiais: somente componentes em madeira que tenham certificação de procedência. É obrigatória a apresentação de Documento de Origem Florestal.

Especificar, preferencialmente, componentes com, no mínimo, $25 \%$ de material reciclado pós-consumo. Somente é permitida a utilização de tintas, selantes, impermeabilizantes, adesivos, vernizes e mastiques com baixo índice de compostos orgânicos voláteis.

Tratamento acústico $\quad \checkmark \quad$ Ambiente pouco exigente.

Área mínima de iluminação $\checkmark \quad$ 1/10

natural $\left(\mathrm{m}^{2}\right)$, em relação à área

de piso

Área mínima de ventilação $\quad \checkmark \quad$ 1/20

$\left(\mathrm{m}^{2}\right)$, em relação à área de piso

Requisitos quanto ao desempenho do ambiente - NBR 15.575:2013 (ABNT, 2013)

Requisitos quanto à acessibilidade - NBR 9.050:2015 (ABNT, 2015)

No mínimo 1 conjunto acessível com entrada independente, junto à Quadra de Esportes:

no mínimo 1 conjunto acessível com entrada independente, em cada pavimento.

Prever área de transferência e de aproximação para bacia sanitária com dimesões mínimas

Espaço livre para a manobra de cadeira de rodas: $1,50 \mathrm{~m}$.

Vão mínimo de portas: $0,80 \mathrm{~m}$.

Maçaneta: Alavanca. Altura: 0,80-1,10 m.

Soleiras inclinadas.

Degraus e desníveis não são permitidos.

Contraste de cor para destaque de aberturas e limites de piso.

Acessos devem ter sinalização visual e tátil.

Requisitos quanto à segurança patrimonial

Outros

Prever sinalização.

\begin{tabular}{|c|c|c|}
\hline \multicolumn{2}{|l|}{ Portas e Janelas } & \\
\hline \multicolumn{3}{|l|}{ Portas } \\
\hline $\begin{array}{l}\text { Vão livre mínimo [NBR } \\
9050: 2015 \text { (ABNT, 2015)] }\end{array}$ & $\checkmark$ & $0.8 \mathrm{~m}$ \\
\hline Aberturas das portas & $\checkmark$ & Largura $(\mathrm{m}) 0.8$ \\
\hline Janelas para visualização & $\checkmark$ & \\
\hline Soleira inclinada & $\checkmark$ & Não são permitidos degraus de desniveis. \\
\hline Dispositivos de proteção & $\bar{v}$ & Antivandalismo. \\
\hline Mecanismo de travamento & $\checkmark$ & Conforme requisitos da ANSI 088 (FRANÇA, 2011). \\
\hline Material da porta & $\checkmark$ & $\begin{array}{l}\text { Madeira. Em ambientes semiabertos, especificar apenas componentes em madeira maciça. Nesses casos, } \\
\text { portas com enchimento sarrafeado não são permitidas. }\end{array}$ \\
\hline Porta de boxe sanitário & $\checkmark$ & Dimensões da porta de boxe $=62 \mathrm{~cm}$. Dimensões da porta de boxe acessível $=82 \mathrm{~cm}$ \\
\hline \multicolumn{3}{|l|}{ Janelas } \\
\hline $\begin{array}{l}\text { Requisitos de iluminação } \\
\text { natural }\end{array}$ & $\checkmark$ & Em paredes externas. \\
\hline $\begin{array}{l}\text { Com dispositivos para abertura } \\
\text { e fechamento } \\
\text { Parapeito }\end{array}$ & $\checkmark$ & $\begin{array}{l}\text { O usuário deve controlar as aberturas para ventilação natural. Considerar a especificação de um sistema de } \\
\text { exaustão para assegurar níveis mínimos de renovação de ar. (ANVISA, 1998). }\end{array}$ \\
\hline Material da estrutura da janela & $\frac{v}{v}$ & Pintura esmalte, na cor branca, sobre base antioxidante. \\
\hline $\begin{array}{l}\text { Requisitos para a especificação } \\
\text { do vidro }\end{array}$ & & Vidro comum, $3 \mathrm{~mm}$. \\
\hline
\end{tabular}

do vidro

Aquecimento, ventilação

e ar condicionado

Ventilação 


\section{Diretrizes de projeto para}

Database_SPEducational_Facilities Ambientes

Status: Derived from AUX.017-M

Room Function Number: 009.01.040

Ventilação

Aquecimento, ventilação

e ar condicionado

Ventilação natural

$\checkmark \quad \checkmark$ Ventilação cruzada

\section{Sistemas de Elétrica/}

Dados/Audio/Vigilância

Sistemas de iluminação

Sensor de iluminação natural $\checkmark$

Sensor de presença

Densidade de Potência

Luminosa (DPL)

v

Nível de iluminâncial (lux) $\quad \checkmark \quad 150$ lux [NBR 5.413:1992 (ABNT,

$10 \mathrm{DPL}\left(\mathrm{W} / \mathrm{m}^{2}\right)$ (ANSI/ASHRAE,

lâmpadas)

3 Unidades 2 Lâmpadas

$32 \mathrm{~W} \quad \checkmark$ Aletas refletivas

Sistemas elétricos

Suprimento de energia

Tomada universal baixa -

$0,40 \mathrm{~m}$

Tomada universal média -

$1,10 \mathrm{~m}$

Ponto de força - 2,20 m

Interruptores

Potência instalada

Potência instalada - iluminação $\checkmark \quad 192 \mathrm{~W}$

Pontos de rede de transmissão de dados

Ponto de lógica 11 Ponto de lógica.

Monitoramento/segurança/alarmes

Alarme de emergência $\quad \checkmark \quad$ Para boxe acessível, a 0,40m de altura do piso acabado.

\section{Sistemas hidrossanitários}

Sistema predial de água fria

Dispositivos antivandalismo $\quad \checkmark \quad$ Todos os metais e acessóvios.

Torneiras $\quad \underline{v} 5$

Arejador para torneiras $\quad \checkmark \quad 5$

Mictórios $\quad$ v 6

Restritor de fluxo para mictórios $\bar{v} \quad 6$

Sanitários $\quad \checkmark \quad 4$

Consumo (IPC, 2015) 1,0 litro por fluxo

Consumo (IPC, 2015) 4 litros por fluxo (Ipf)

Mictório coletivo (MT-04).

Consumo (IPC, 2015) 6 litros por fluxo (Ipf)

Sanitário acessível - NBR9050 $\checkmark \quad 1 \quad$ Altura (cm) $43 \quad$ Consumo (IPC, 2015) 6 litros por fluxo (Ipf)

(ABNT, 2015)

Barras de segurança NBR9050 $\checkmark 2$ Descrição Na lateral e posterior.

(ABNT, 2015)

Outros

$\checkmark \quad$ Lavatório coletivo. Papeleiras de louça, dispenser para papel toalha e dispenser para sabonete líquido.

Boxes sanitários

Boxe

$\checkmark 9$ Unidades

Boxe acessivel

$\checkmark \quad 1$ Unidades

Largura mínima (m) 80

Barras de segurança

$\checkmark \quad$ Na lateral e posterior.

Área de transferência mínima e de

aproximação da bacia sanitária com Material Divisórias em granilite.

Ralos

Ralo de piso

Outros

\begin{tabular}{|l|} 
Segurança contra incêndio \\
Outros Considerar requisitos para evacuação de emergência (SAO PAULO, 2001; 2004).
\end{tabular}

\section{Operação e Manutenção}

\section{Limpeza}

Especificação de detergentes $\checkmark$ Somente produtos de limpeza neutros e não abrasivos.

Procedimentos de limpeza $\quad \checkmark \quad$ Lavar e desinfetar pisos, paredes e equipamentos hidrossanitários. 


\section{Diretrizes de projeto para Ambientes}

Database SPEducational Facilities

Room Function Number: 009.01.042

Status: Derived from AUX.07-F

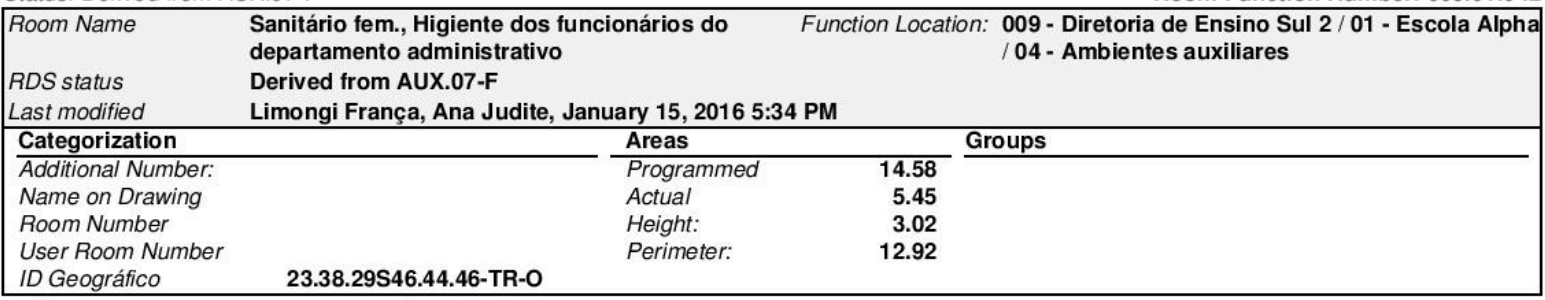

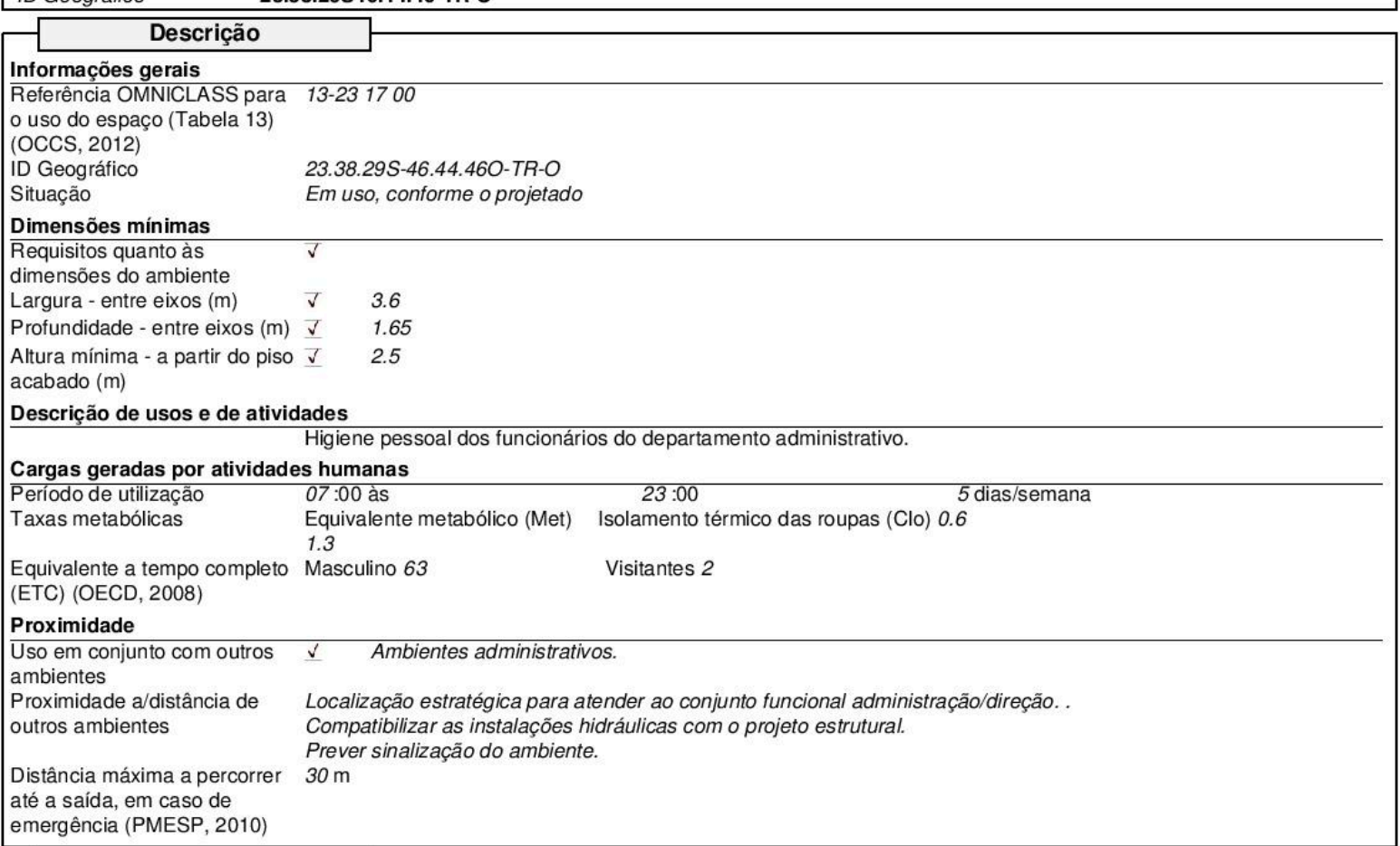

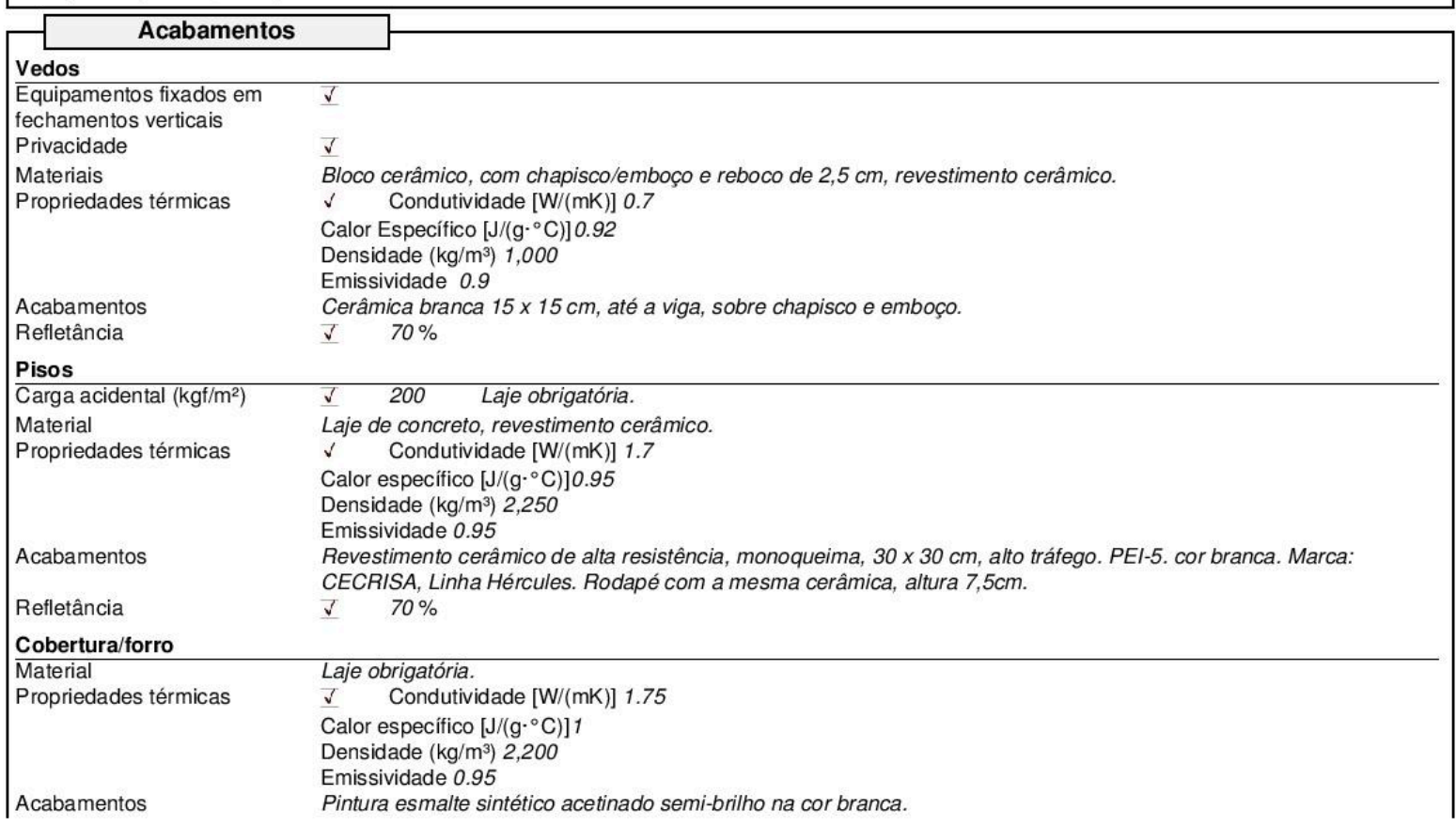




\section{Diretrizes de projeto para}

\begin{tabular}{|l} 
Status: Derived from AUX.07-F \\
\begin{tabular}{|l} 
Acabamentos \\
Cobertura/forro
\end{tabular} \\
\hline Outros acabamentos
\end{tabular}

\section{Requisitos para o projeto \\ Requisitos de desempenho ambiental}

Estratégias de sustentabilidade $\checkmark$ Energia: prever sensores de presença para evitar que as lâmpadas permaneçam acesas quando $o$ ambiente não está sendo utilizado. Especificar lâmpadas fluorecentes T5 com reatores eletrônicos. Iluminação natural: controle solar para evitar ofuscamento e ganhos térmicos indesejados.

Materiais: somente componentes em madeira que tenham certificação de procedência. É obrigatória a apresentação de Documento de Origem Florestal.

Especificar, preferencialmente, componentes com, no mínimo, 25\% de material reciclado pós-consumo. Somente é permitida a utilização de tintas, selantes, impermeabilizantes, adesivos, vernizes e mastiques com

Tratamento acústico $\quad \checkmark \quad$ Ambiente pouco exigente.

Área mínima de iluminação $\quad \underline{v} \quad 1 / 10$

natural $\left(\mathrm{m}^{2}\right)$, em relação à área

de piso

Área mínima de ventilação $\quad \checkmark \quad 1 / 20$

$\left(\mathrm{m}^{2}\right)$, em relação à área de piso

Requisitos quanto ao desempenho do ambiente - NBR 15.575:2013 (ABNT, 2013)

Requisitos quanto à acessibilidade - NBR 9.050:2015 (ABNT, 2015)

No mínimo 1 conjunto acessível com entrada independente.

Prever área de transferência e de aproximação para bacia sanitária com dimesões mínimas

Espaço livre para a manobra de cadeira de rodas: $1,50 \mathrm{~m}$.

Vão mínimo de portas: $0,80 \mathrm{~m}$.

Maçaneta: Alavanca. Altura: 0,80-1,10 m.

Soleiras inclinadas.

Degraus e desníveis não são permitidos.

Contraste de cor para destaque de aberturas e limites de piso.

Acessos devem ter sinalização visual e tátil.

Requisitos quanto à segurança patrimonial

Outros

Prever sinalização.

Portas e Janelas

Portas

\begin{tabular}{lll}
\hline Vão livre mínimo [NBR & $\checkmark$ & $0.8 \mathrm{~m}$
\end{tabular}

9050:2015 (ABNT, 2015)]

Aberturas das portas

Janelas para visualização

Soleira inclinada

Dispositivos de proteção

Mecanismo de travamento

Material da porta

mínimo

Largura $(\mathrm{m}) 0.8 \quad$ Altura $(\mathrm{m}) 2.1$

portas com enchimento sarrafeado não são permitidas.

Janelas

Requisitos de iluminação $\quad \checkmark \quad$ Em paredes externas.

natural

Com dispositivos para abertura

e fechamento

Parapeito

O usuário deve controlar as aberturas para ventilação natural. Considerar a especificação de um sistema de exaustão para assegurar níveis mínimos de renovação de ar. (ANVISA, 1998).

Material da estrutura da janela $\checkmark \quad$ Pintura esmalte, na cor branca, sobre base antioxidante.

Requisitos para a especificação $\checkmark$ Vidro comum, $3 \mathrm{~mm}$

do vidro

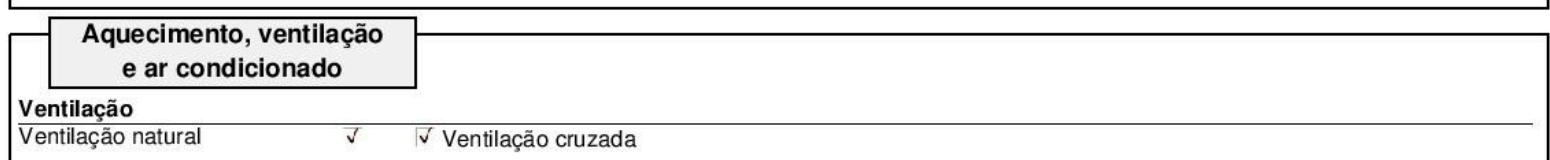


Status: Derived from AUX.07-F

Room Function Number: 009.01.042

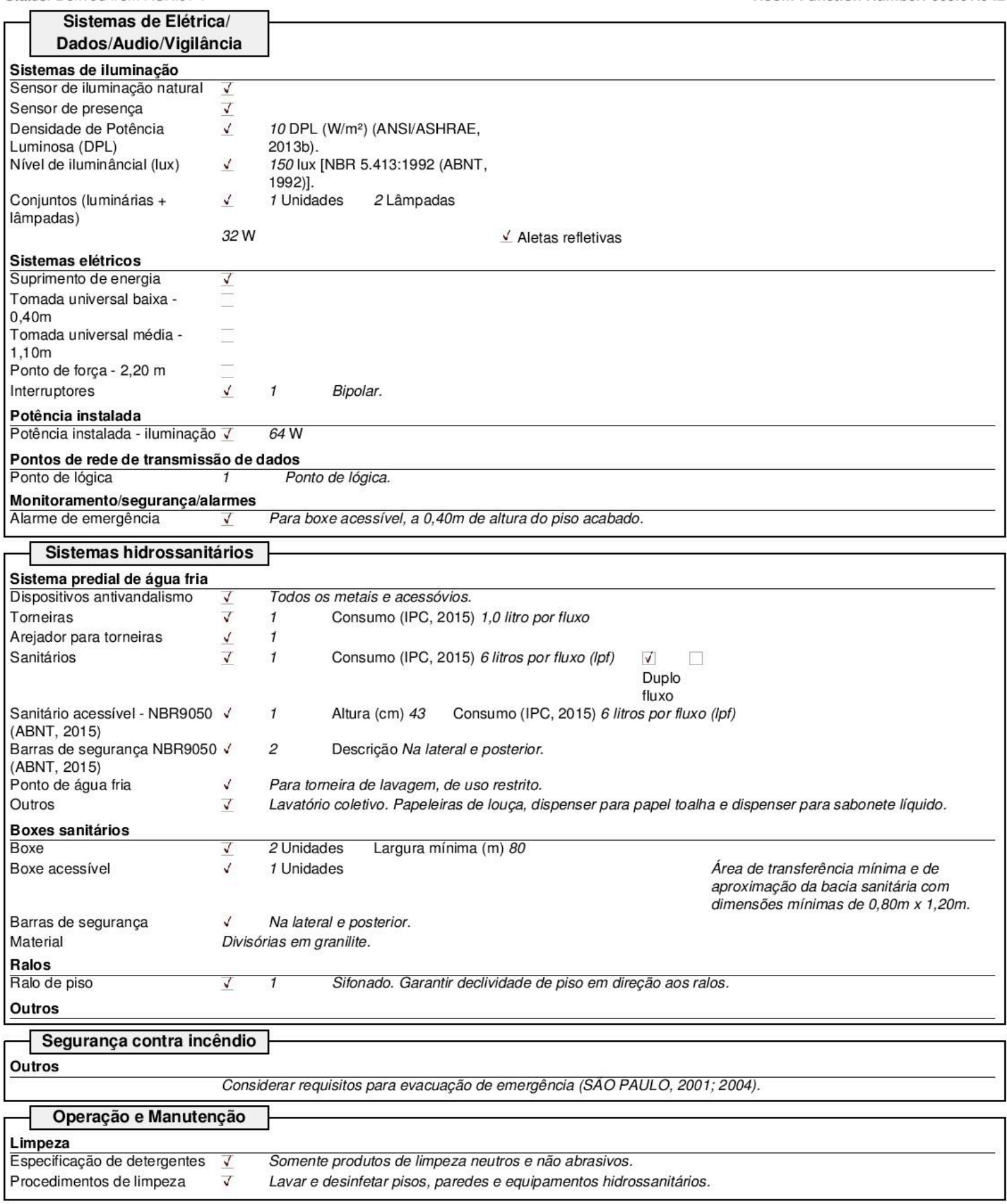




\section{Diretrizes de projeto para}

Database_SPEducational_Facilities

\section{Ambientes}

\begin{tabular}{|c|c|c|}
\hline Status: Derived from A & UX.07-M & Room Function Number: 009.01 .043 \\
\hline Room Name & $\begin{array}{l}\text { Sanitário masc., Higiente dos funcionários do } \\
\text { departamento administrativo }\end{array}$ & $\begin{array}{l}\text { Function Location: } 009 \text { - Diretoria de Ensino Sul } 2 \text { / } 01 \text { - Escola Alpha } \\
\text { / } 04 \text { - Ambientes auxiliares }\end{array}$ \\
\hline RDS status & Derived from AUX.07-M & \\
\hline Categorization & Areas & Groups \\
\hline Additional Number: & Programmed & 14.58 \\
\hline Name on Drawing & Actual & 5.41 \\
\hline Room Number & Height: & 3.02 \\
\hline
\end{tabular}

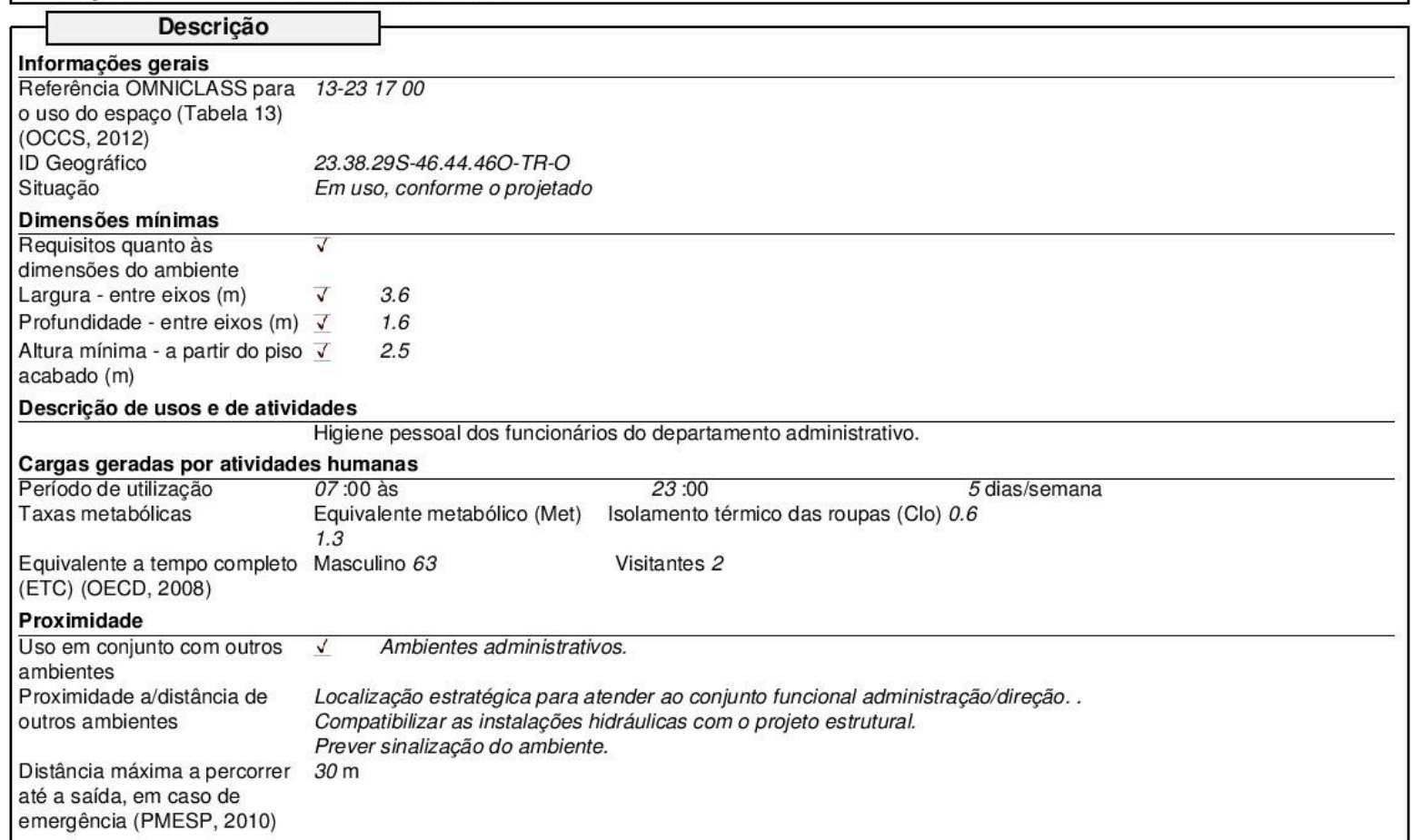

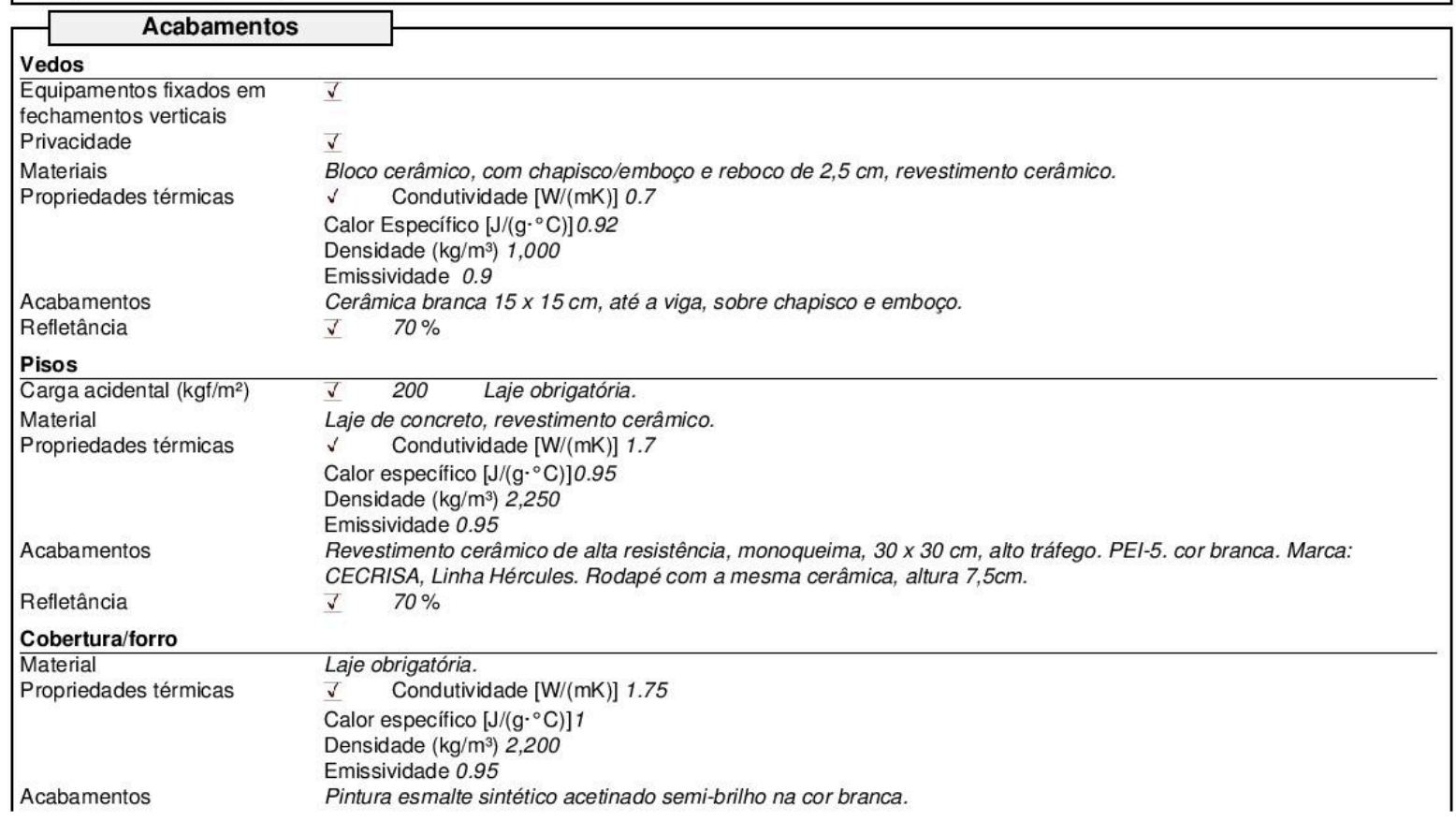




\section{Diretrizes de projeto para Ambientes}

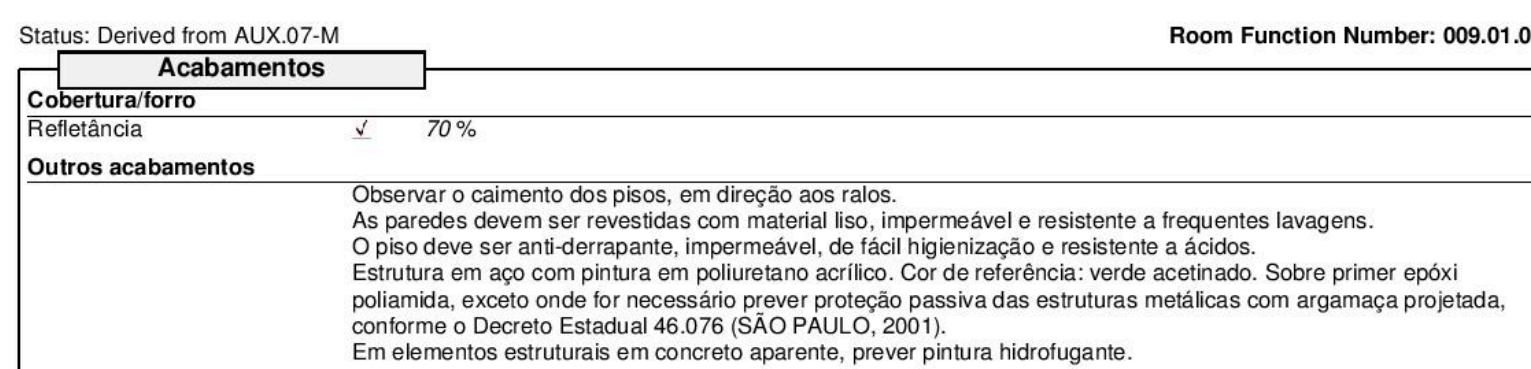

\section{Requisitos para o projeto}

Requisitos de desempenho ambienta

Estratégias de sustentabilidade $\checkmark \quad$ Energia: prever sensores de presença para evitar que as lâmpadas permaneçam acesas quando $o$ ambiente não está sendo utilizado. Especificar lâmpadas fluorecentes T5 com reatores eletrônicos. lluminação natural: controle solar para evitar ofuscamento e ganhos térmicos indesejados.

Materiais: somente componentes em madeira que tenham certificação de procedência. É obrigatória a apresentação de Documento de Origem Florestal.

Especificar, preferencialmente, componentes com, no mínimo, 25\% de material reciclado pós-consumo.

Somente é permitida a utilização de tintas, selantes, impermeabilizantes, adesivos, vernizes e mastiques com

Tratamento acústico $\quad \checkmark \quad$ Ambiente pouco exigente.

Área mínima de iluminação $\quad \checkmark \quad 1 / 10$

natural $\left(\mathrm{m}^{2}\right)$, em relação à área

de piso

Área mínima de ventilação $\quad \checkmark \quad 1 / 20$

$\left(\mathrm{m}^{2}\right)$, em relação à área de piso

Requisitos quanto ao desempenho do ambiente - NBR 15.575:2013 (ABNT, 2013)

Requisitos quanto à acessibilidade - NBR 9.050:2015 (ABNT, 2015)

No mínimo 1 conjunto acessível com entrada independente.

Prever área de transferência e de aproximação para bacia sanitária com dimesões mínimas

Espaço livre para a manobra de cadeira de rodas: $1,50 \mathrm{~m}$.

Vão mínimo de portas: $0,80 \mathrm{~m}$.

Maçaneta: Alavanca. Altura: 0,80-1,10 m.

Soleiras inclinadas.

Degraus e desniveis não são permitidos.

Contraste de cor para destaque de aberturas e limites de piso.

Acessos devem ter sinalização visual e tátil.

Requisitos quanto à segurança patrimonial

Outros
Prever sinalização.

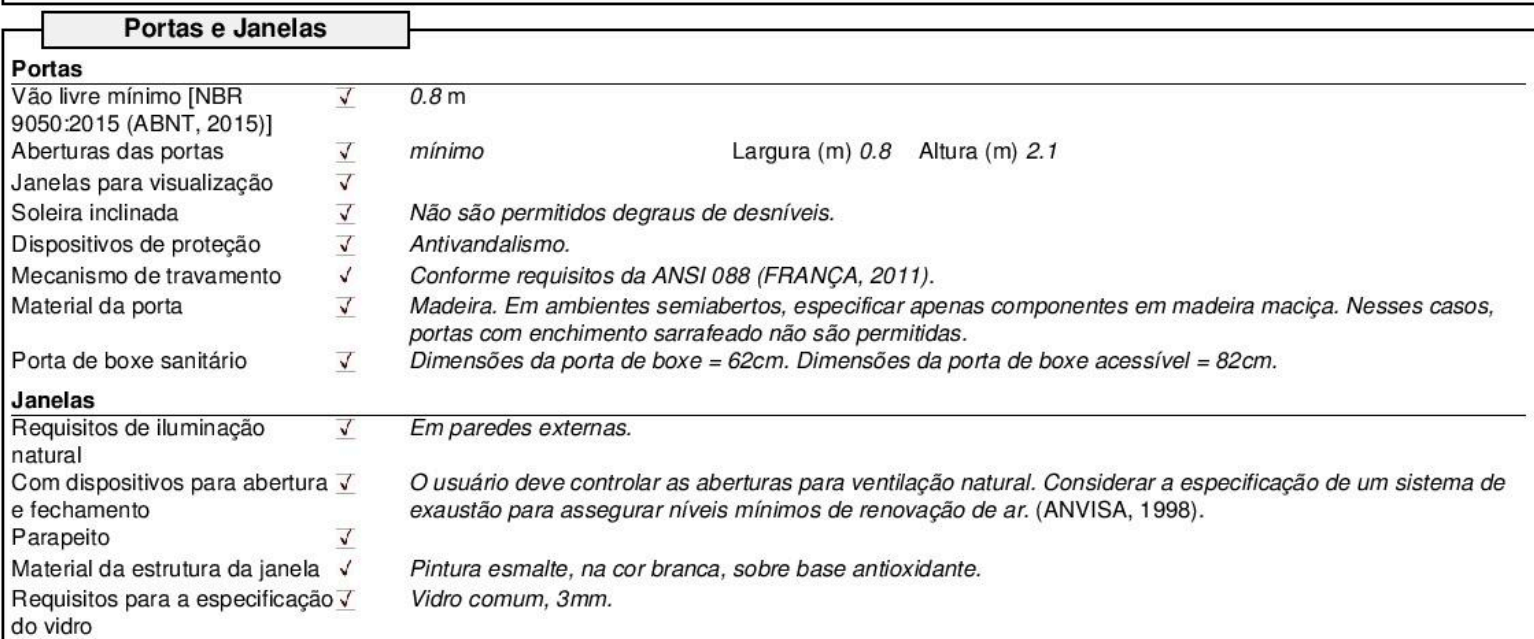

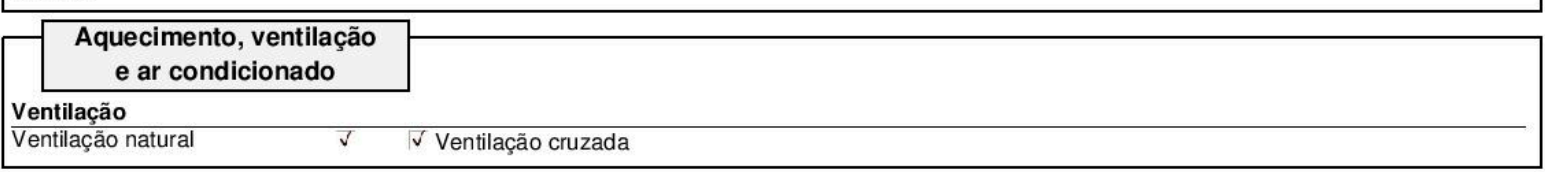


Status: Derived from AUX.07-M

Room Function Number: 009.01.043

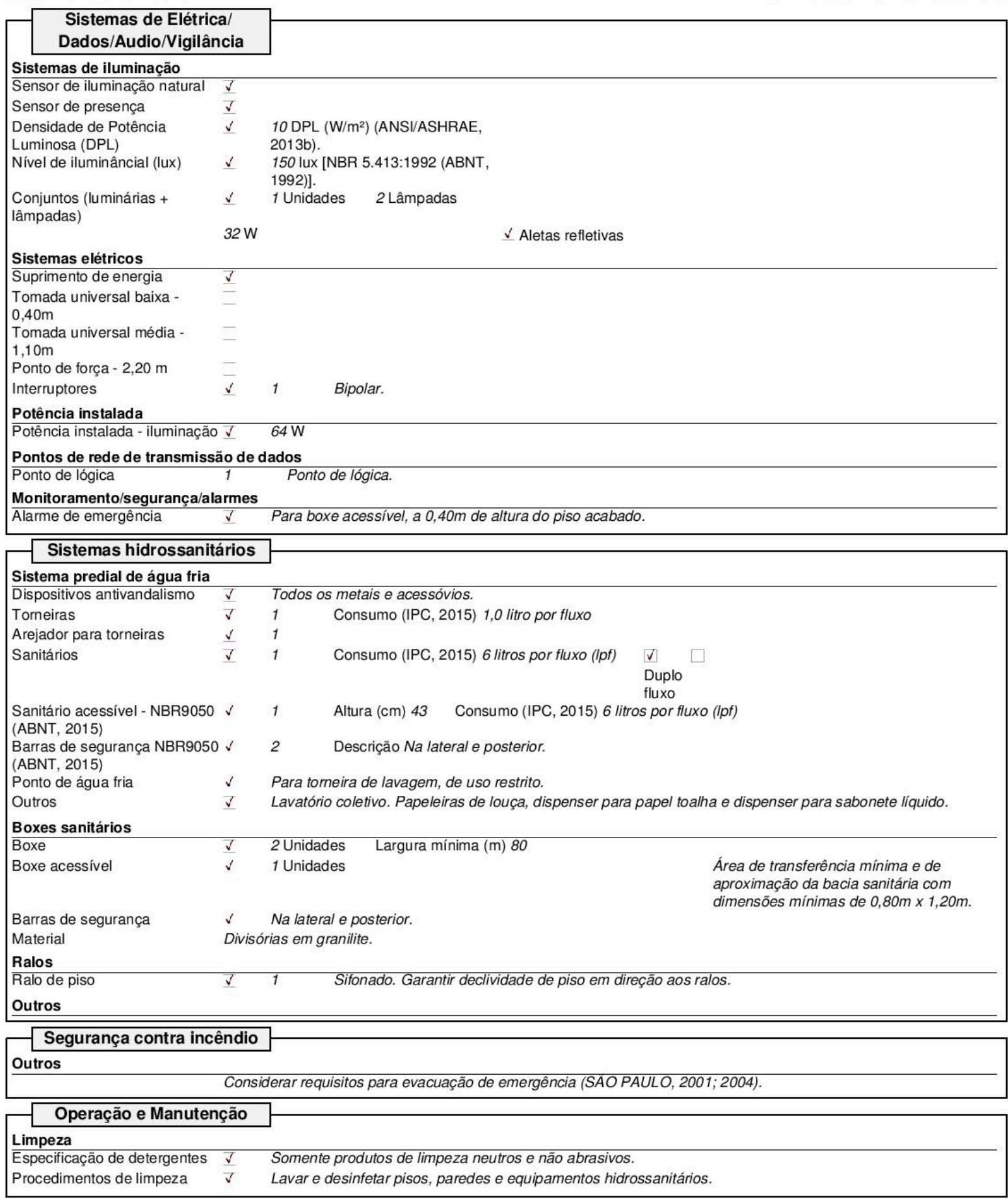




\section{Diretrizes de projeto para Ambientes}

Database_SPEducational_Facilities

Room Function Number: 009.01.044

Status: Derived from AUX.023

Vestiário funcionários, Higiene dos funcionários Function Location: 009 - Diretoria de Ensino Sul $2 / 01$ - Escola Alph

\begin{tabular}{|llll|}
\hline Room Name & Vestiário funcionários, Higiene dos funcionários & $\begin{array}{c}\text { Function Location: } 009 \text { - Diretoria de Ensino Sul 2 / 01 - Escola Alpha } \\
\text { / 04 - Ambientes auxiliares }\end{array}$ \\
RDS status & $\begin{array}{l}\text { Derived from AUX.023 } \\
\text { Last modified }\end{array}$ & Limongi França, Ana Judite, January 15, 2016 5:34 PM & \\
\hline Categorization & & Areas & Groups \\
\hline Additional Number: & & Programmed & 12.96 \\
Name on Drawing & Actual & 7.79 \\
Room Number & & Height: & 2.96 \\
User Room Number & & Perimeter: & 12.74 \\
ID Geográfico & 23.38.29S46.44.46-TR-S & & \\
\hline
\end{tabular}

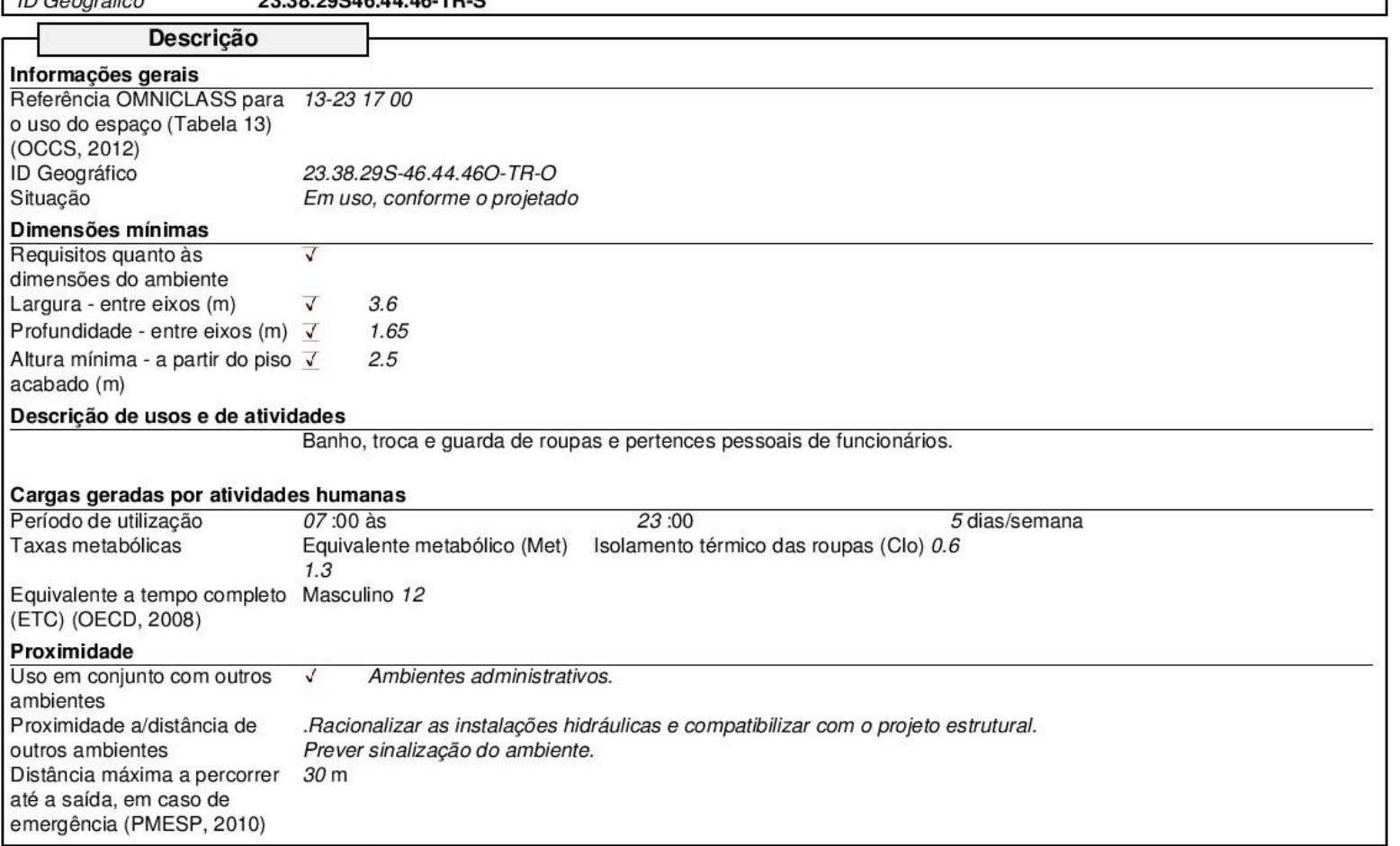

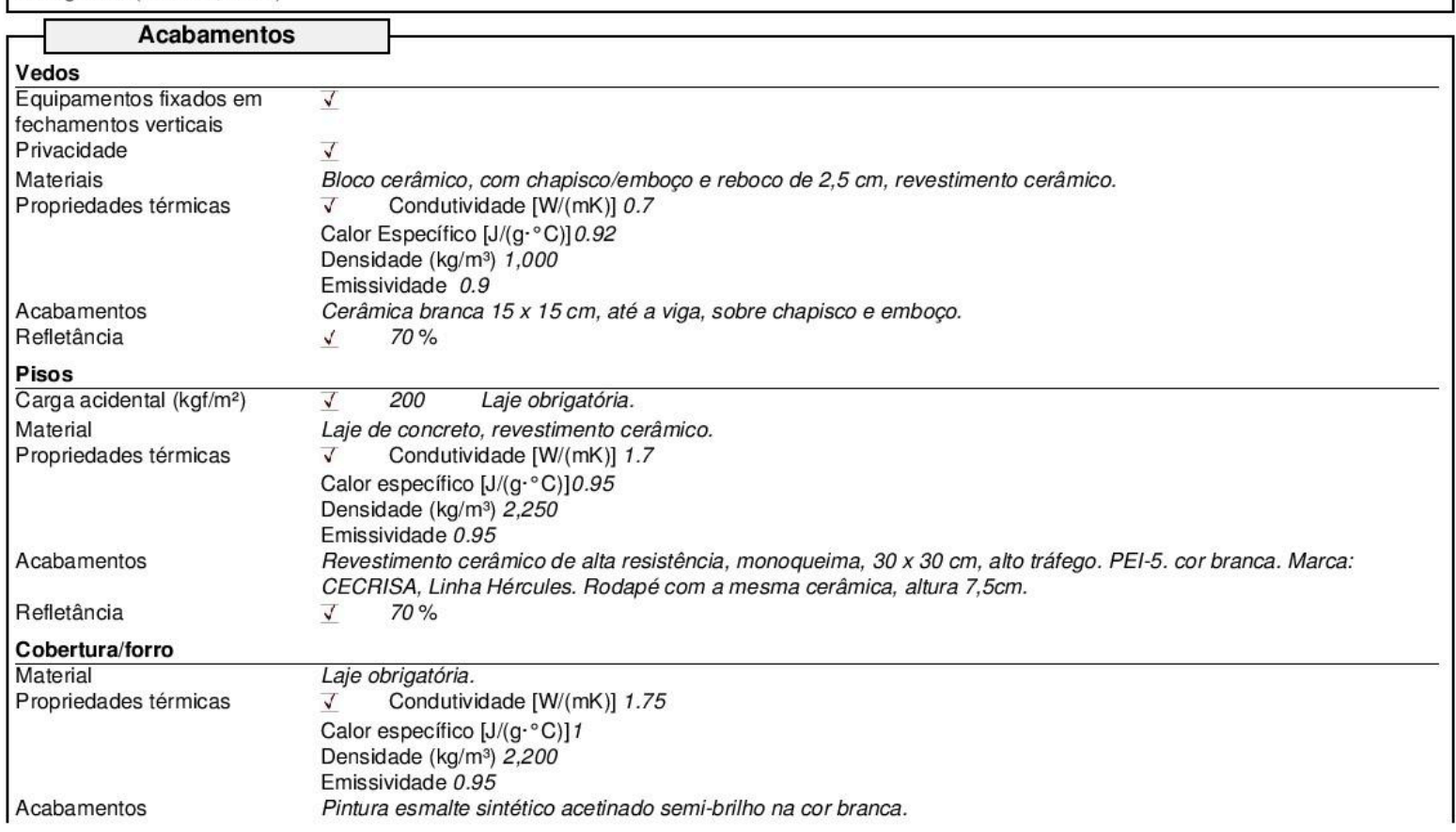




\section{Diretrizes de projeto para}

\begin{tabular}{|l|l|l|l}
\hline \multicolumn{1}{|c|}{ Acabamentos } \\
Coftatus: Derived from AUX.023
\end{tabular}

\section{Requisitos para o projeto \\ Requisitos de desempenho ambiental}

Estratégias de sustentabilidade $\checkmark \quad$ Energia: prever sensores de presença para evitar que as lâmpadas permaneçam acesas quando 0 ambiente não está sendo utilizado. Especificar lâmpadas fluorecentes T5 com reatores eletrônicos. Iluminação natural: controle solar para evitar ofuscamento e ganhos térmicos indesejados.

Materiais: somente componentes em madeira que tenham certificação de procedência. É obrigatória a apresentação de Documento de Origem Florestal.

Especificar, preferencialmente, componentes com, no mínimo, 25\% de material reciclado pós-consumo.

Somente é permitida a utilização de tintas, selantes, impermeabilizantes, adesivos, vernizes e mastiques com

Tratamento acústico baixo índice de compostos orgânicos voláteis.

Area minima de iluminação $\quad \checkmark \quad$ 1/10

natural $\left(m^{2}\right)$, em relação à área

de piso

Área mínima de ventilação $\quad \checkmark \quad 1 / 20$

$\left(\mathrm{m}^{2}\right)$, em relação à área de piso

Requisitos quanto ao desempenho do ambiente - NBR 15.575:2013 (ABNT, 2013)

Requisitos quanto à acessibilidade - NBR 9.050:2015 (ABNT, 2015)

Requisitos quanto à segurança patrimonial

Outros

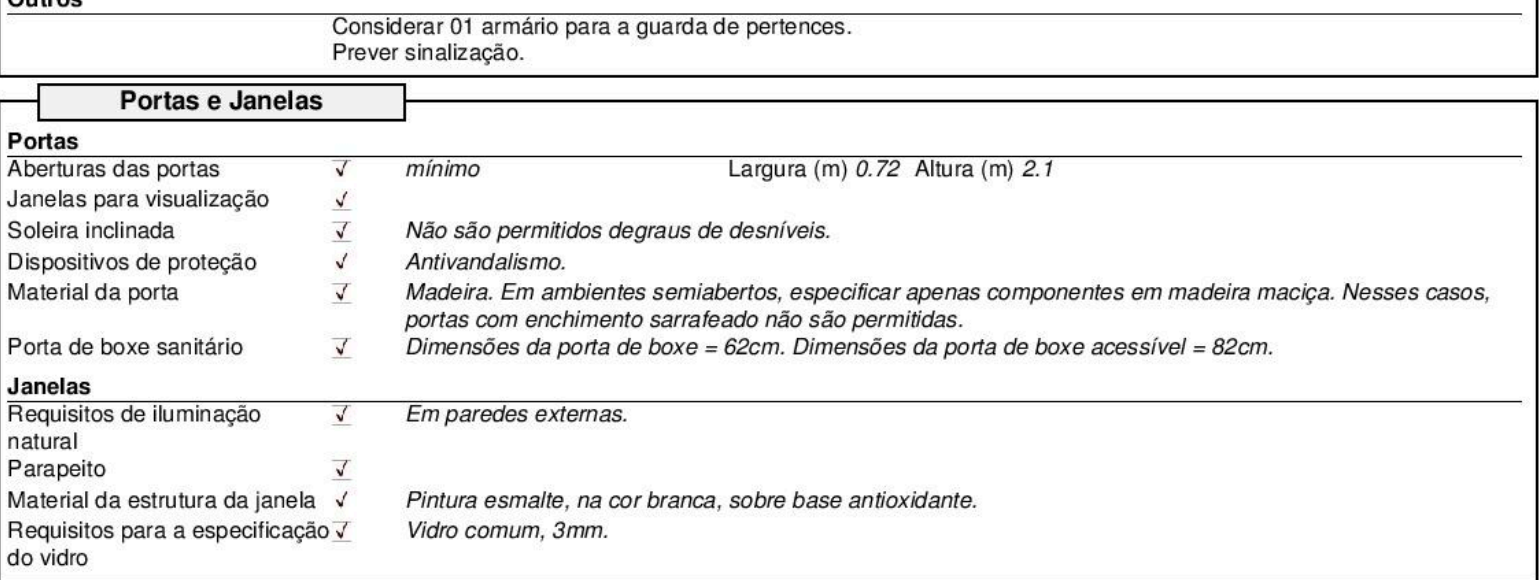

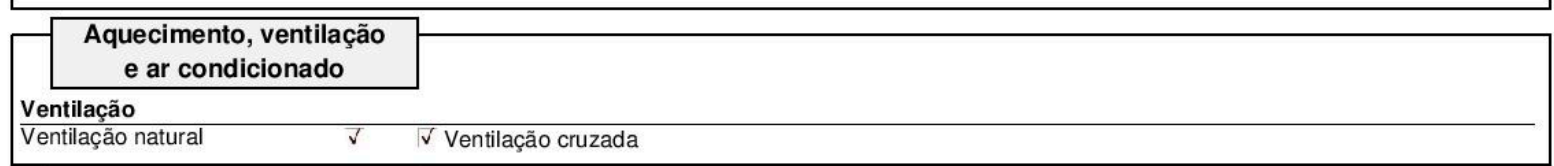

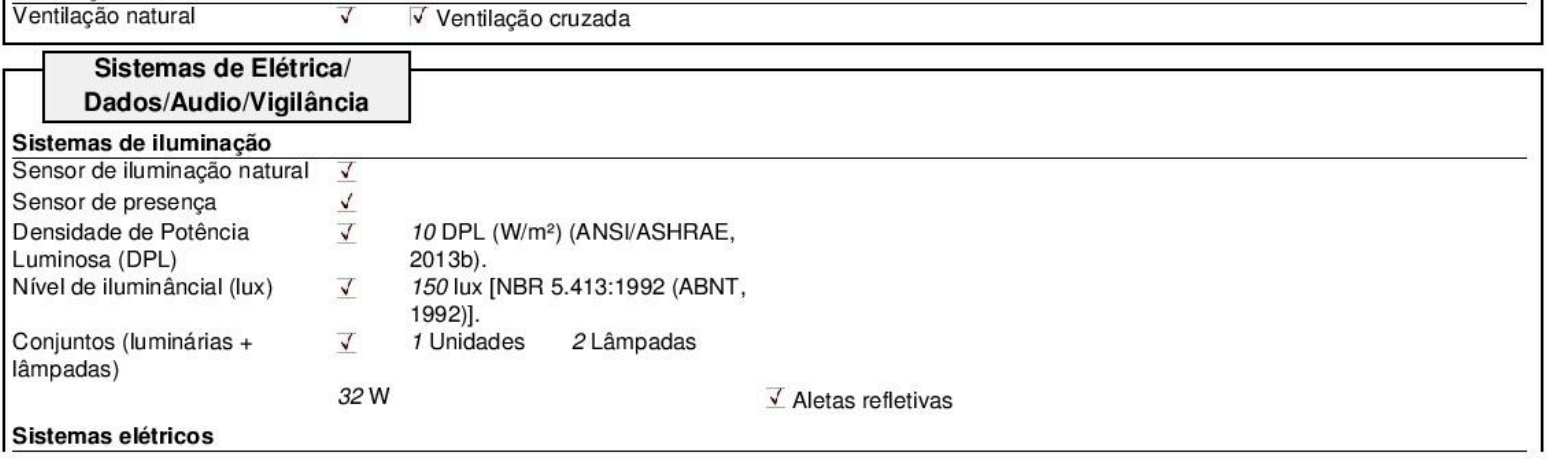


Status: Derived from AUX.023

Room Function Number: 009.01.044

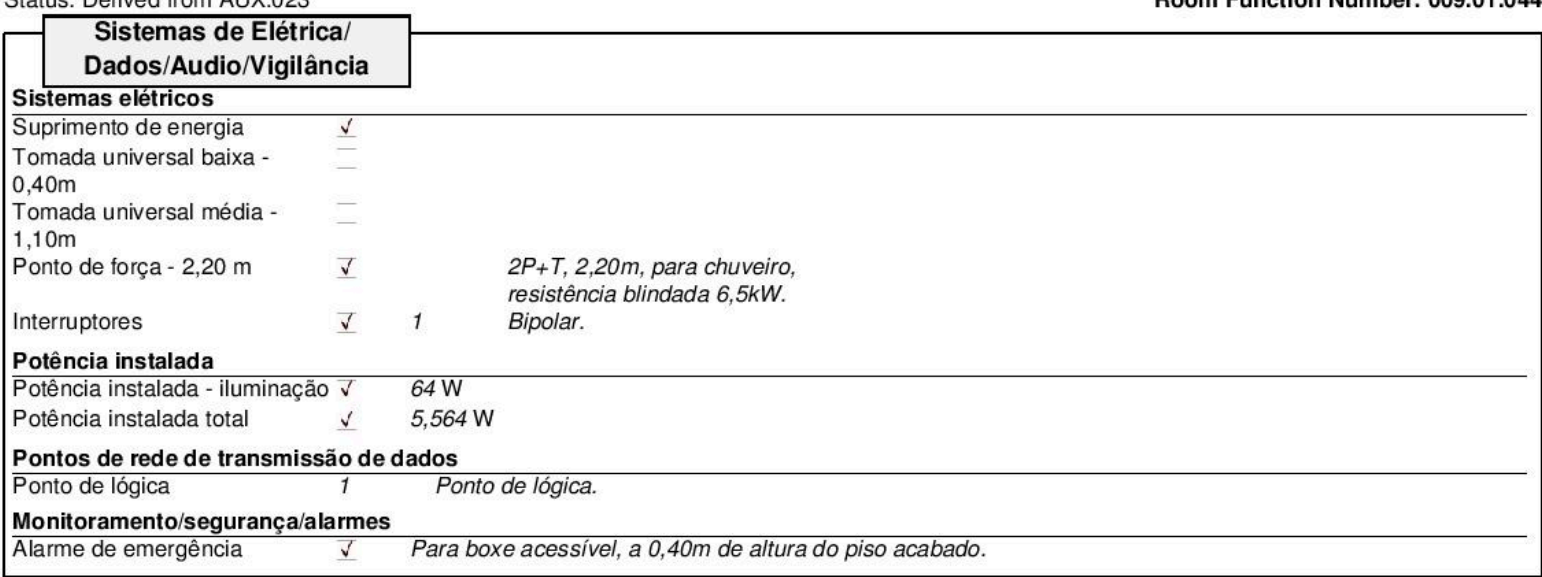

Sistemas hidrossanitários

\begin{tabular}{|c|c|c|c|c|c|}
\hline \multicolumn{6}{|l|}{ Sistema predial de água fria } \\
\hline Dispositivos antivandalismo & $\checkmark$ & \multicolumn{4}{|c|}{ Todos os metais e acessóvios. } \\
\hline Torneiras & $\checkmark$ & 1 & \multicolumn{3}{|c|}{ Consumo (IPC, 2015) 1,0 litro por fluxo } \\
\hline Arejador para torneiras & $\checkmark$ & 1 & & & \\
\hline Chuveiros & $\checkmark$ & 1 & \multirow[t]{2}{*}{ Consumo (IPC, 2015) } & \multicolumn{2}{|c|}{9,5 litros por minuto(lpm) a 80 psi } \\
\hline $\begin{array}{l}\text { Restritor de fluxo para } \\
\text { chuveiros }\end{array}$ & $\checkmark$ & 1 & & & \\
\hline Sanitários & $\checkmark$ & 1 & Consumo (IPC, 2015) & 6 litros por fluxo (lpf) & $\begin{array}{l}\text { v } \\
\text { Duplo } \\
\text { fluxo }\end{array}$ \\
\hline
\end{tabular}

Sanitário acessível - NBR9050 $\checkmark \quad 1 \quad$ Altura (cm) $43 \quad$ Consumo (IPC, 2015) 6 litros por fluxo (Ipf)

(ABNT, 2015)

Barras de segurança NBR9050 v 2 Descrição Na lateral e posterior.

(ABNT, 2015)

Ponto de água fria $\quad \checkmark \quad$ Para torneira de lavagem, de uso restrito.

Outros $\quad \checkmark \checkmark \quad$ Lavatório coletivo. Papeleiras de louça, dispenser para papel toalha e dispenser para sabonete líquido.

Boxes sanitários

Boxe $\quad \frac{\checkmark}{v} \quad 2$ Unidades Largura mínima $(\mathrm{m}) 80 \quad$ Área de transferência mínima e de

$\begin{array}{lll}\text { Boxe acessivel } & 1 \text { Unidades } & \text { Area de transferencia mínima e de } \\ \text { aproximação da bacia sanitária com }\end{array}$

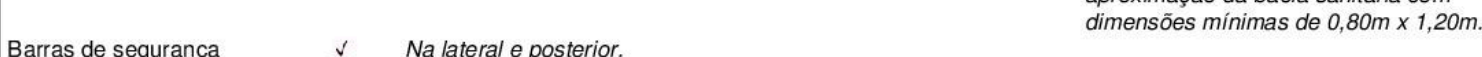

Material Divisórias em granilite.

Ralos

Ralo de piso $\quad \checkmark \quad 2 \quad$ Sifonados. Garantir declividade de piso em direção aos ralos.

Outros

Segurança contra incêndio

Outros

Considerar requisitos para evacuação de emergência (SAO PAULO, 2001; 2004).

\section{Operação e Manutenção}

Limpeza

Especificação de detergentes $\checkmark \checkmark \quad$ Somente produtos de limpeza neutros e não abrasivos.

Procedimentos de limpeza $\quad \checkmark \quad$ Lavar e desinfetar pisos, paredes e equipamentos hidrossanitários. 
Diretrizes de projeto para

Database_SPEducational_Facilities Ambientes

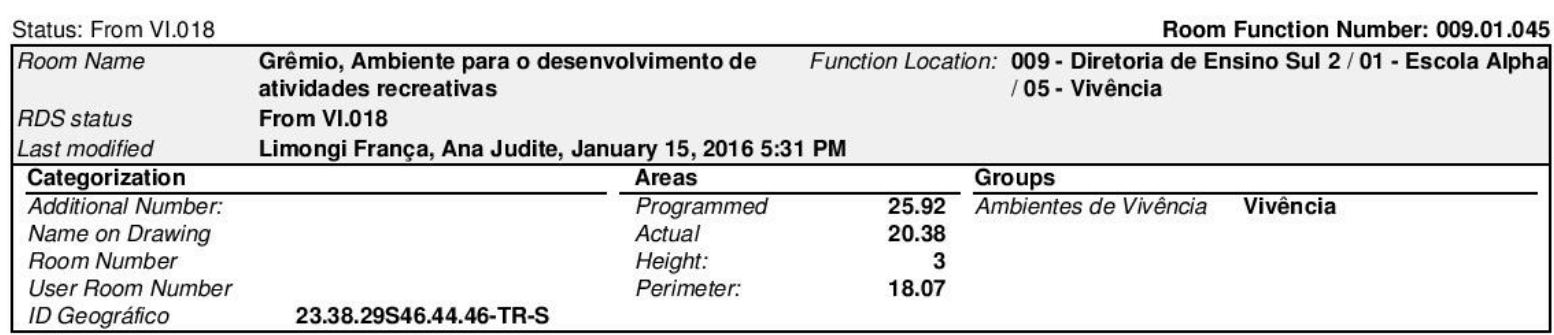

\begin{tabular}{|c|c|}
\hline Descrição & \\
\hline \multicolumn{2}{|l|}{ Informações gerais } \\
\hline \multicolumn{2}{|l|}{$\begin{array}{l}\text { o uso do espaço (Tabela 13) } \\
\text { (OCCS. 2012) }\end{array}$} \\
\hline \multicolumn{2}{|l|}{ ID Geográfico } \\
\hline Situação & \\
\hline \multicolumn{2}{|l|}{ Dimensões mínimas } \\
\hline $\begin{array}{l}\text { Requisitos quanto às } \\
\text { dimensões do ambiente }\end{array}$ & $\checkmark$ \\
\hline Largura - entre eixos (m) & $\checkmark$ \\
\hline Profundidade - entre eixos $(\mathrm{m})$ & $\checkmark$ \\
\hline Altura mínima - a partir do piso & $\checkmark$ \\
\hline
\end{tabular}

acabado $(\mathrm{m})$

Descrição de usos e de atividades

Local para desenvolvimento de atividades recreativas, sociais e culturais dos alunos.

Cargas geradas por atividades humanas

Ocupação 12

Periodo de utilização

$23: 00$

5 dias/semana

Taxas metabólicas $\quad$ Equivalente metabólico (Met) Isolamento térmico das roupas (Clo) 0.6

Proximidade

Uso em conjunto com outros $\checkmark$ Galpão.

ambientes

Proximidade a/distância de Localizado de forma a permitir fácil acesso para os alunos, próximo ao pátio coberto.

outros ambientes

Distância máxima a percorrer $30 \mathrm{~m}$

até a saída, em caso de

emergência (PMESP, 2010)

Expressão Arquitetônica

\begin{tabular}{|c|c|}
\hline Acabamentos & \\
\hline \multicolumn{2}{|l|}{ Vedos } \\
\hline Privacidade & $\bar{v}$ \\
\hline \multirow[t]{2}{*}{ Propriedades térmicas } & $\checkmark \quad$ Condutividade $[\mathrm{W} /(\mathrm{mK})] 0.7$ \\
\hline & $\begin{array}{l}\text { Calor Específico }\left[\mathrm{J} /\left(\mathrm{g} \cdot{ }^{\circ} \mathrm{C}\right)\right] 0.92 \\
\text { Densidade }\left(\mathrm{kg} / \mathrm{m}^{3}\right) 1,000 \\
\text { Emissividade } 0.9\end{array}$ \\
\hline Refletância & $\checkmark \quad 70 \%$ \\
\hline \multicolumn{2}{|l|}{ Pisos } \\
\hline Carga acidental $\left(\mathrm{kgf} / \mathrm{m}^{2}\right)$ & $\begin{array}{lll} & 300 & \text { Laje obrigatória. }\end{array}$ \\
\hline Material & Laje de concreto, revestimento cerâmico. \\
\hline Propriedades térmicas & $\checkmark \quad$ Condutividade $[\mathrm{W} /(\mathrm{mK})] 1.7$ \\
\hline & $\begin{array}{l}\text { Calor específico }\left[\mathrm{J} /\left(\mathrm{g} \cdot{ }^{\circ} \mathrm{C}\right)\right] 0.95 \\
\text { Densidade }\left(\mathrm{kg} / \mathrm{m}^{3}\right) 2,250 \\
\text { Emissividade } 0.95\end{array}$ \\
\hline Refletância & $\checkmark \quad 70 \%$ \\
\hline Cobertura/forro & \\
\hline Material & Laje obrigatória. \\
\hline Propriedades térmicas & $\begin{array}{l}\checkmark \quad \text { Condutividade }[\mathrm{W} /(\mathrm{mK})] 1.75 \\
\text { Calor específico }\left[\mathrm{J} /\left(\mathrm{g} \cdot{ }^{\circ} \mathrm{C}\right)\right] 1 \\
\text { Densidade }\left(\mathrm{kg} / \mathrm{m}^{3}\right) 2,200 \\
\text { Emissividade } 0.95\end{array}$ \\
\hline
\end{tabular}


Status: From VI.018

Room Function Number: 009.01.045

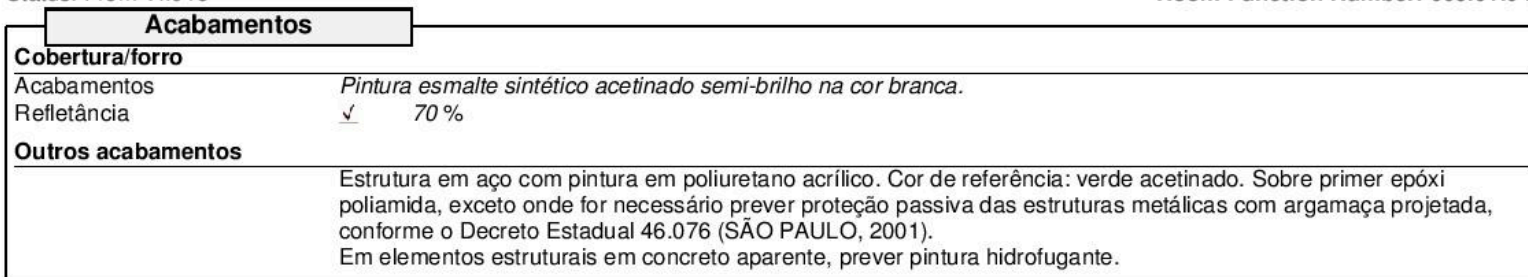

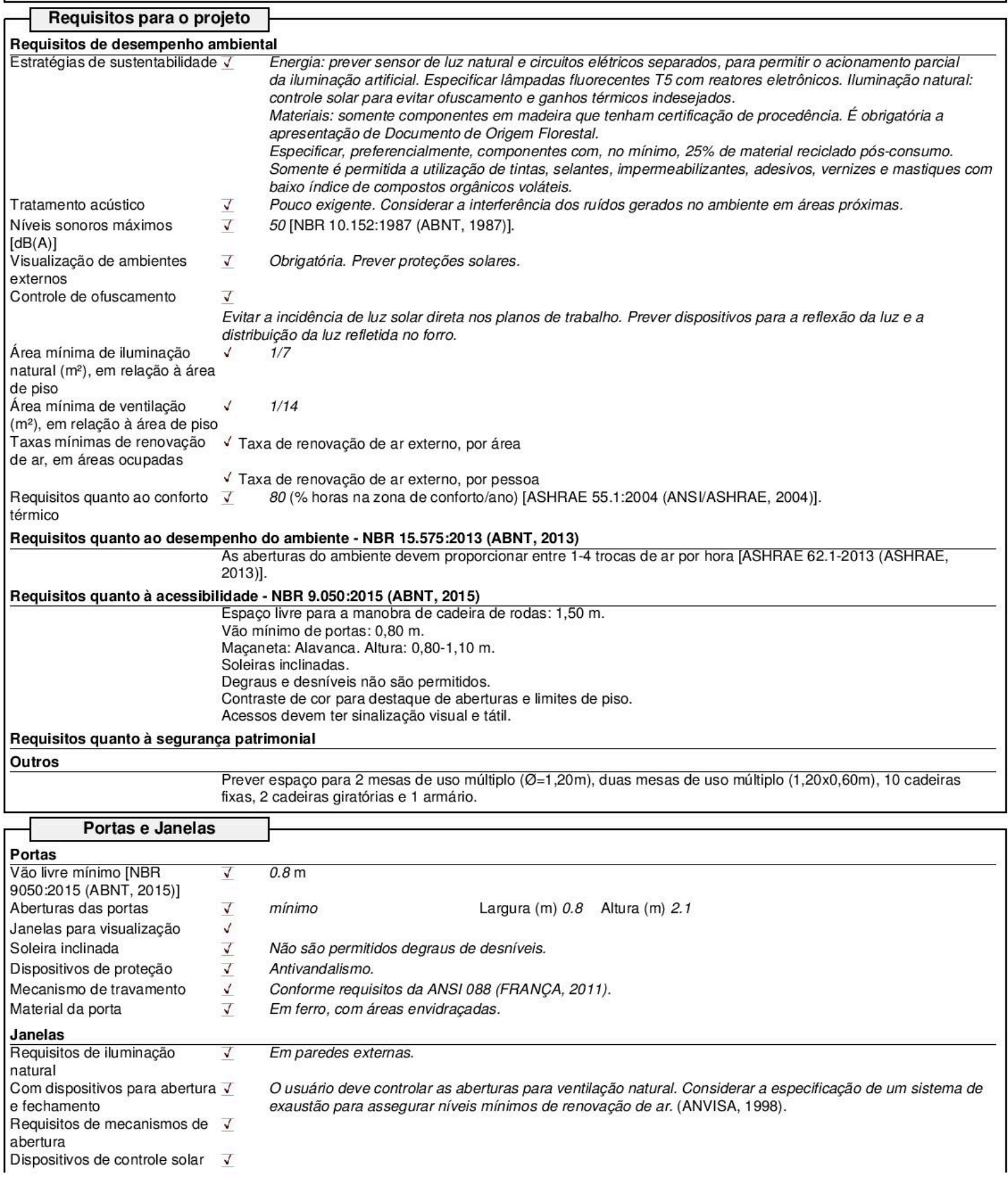


Diretrizes de projeto para Ambientes

Status: From VI.018

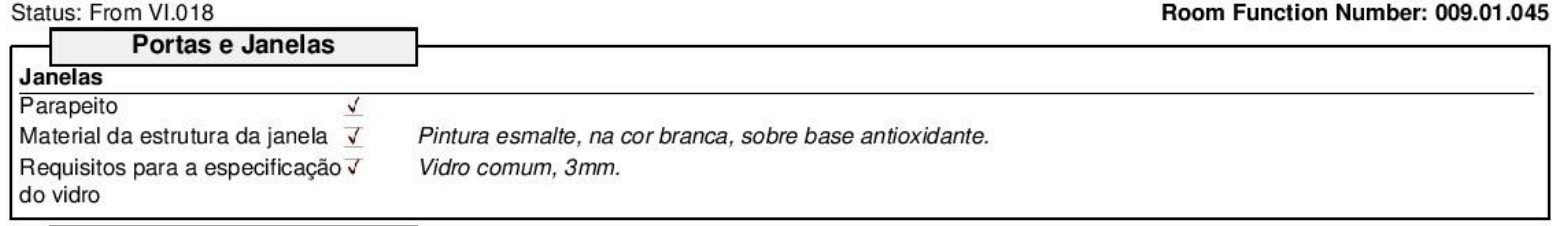

do vidro

\begin{tabular}{|c|c|c|}
\hline \multicolumn{2}{|c|}{$\begin{array}{l}\text { Aquecimento, ventilação } \\
\text { e ar condicionado }\end{array}$} & \\
\hline \multicolumn{3}{|l|}{ Ventilação } \\
\hline Ventilação natural & $\begin{array}{l}\checkmark \\
\text { Preve } \\
\text { ambie }\end{array}$ & $\begin{array}{l}\checkmark \text { Ventilação cruzada } \\
\text { janelas operáveis, para confoto térmico. Vide aba requisitos para o projeto: requisitos de desempenho } \\
\text { ntal e requisitos para ventilação natural. }\end{array}$ \\
\hline Sucção/exaustão & & \\
\hline Sucção & $\checkmark$ & $\begin{array}{l}\text { Considerar um sistema de complementar de renovação de ar, para garantir as taxas mínimas de renovação } \\
\text { de ar, quando portas e janelas estiverem fechadas. }\end{array}$ \\
\hline
\end{tabular}

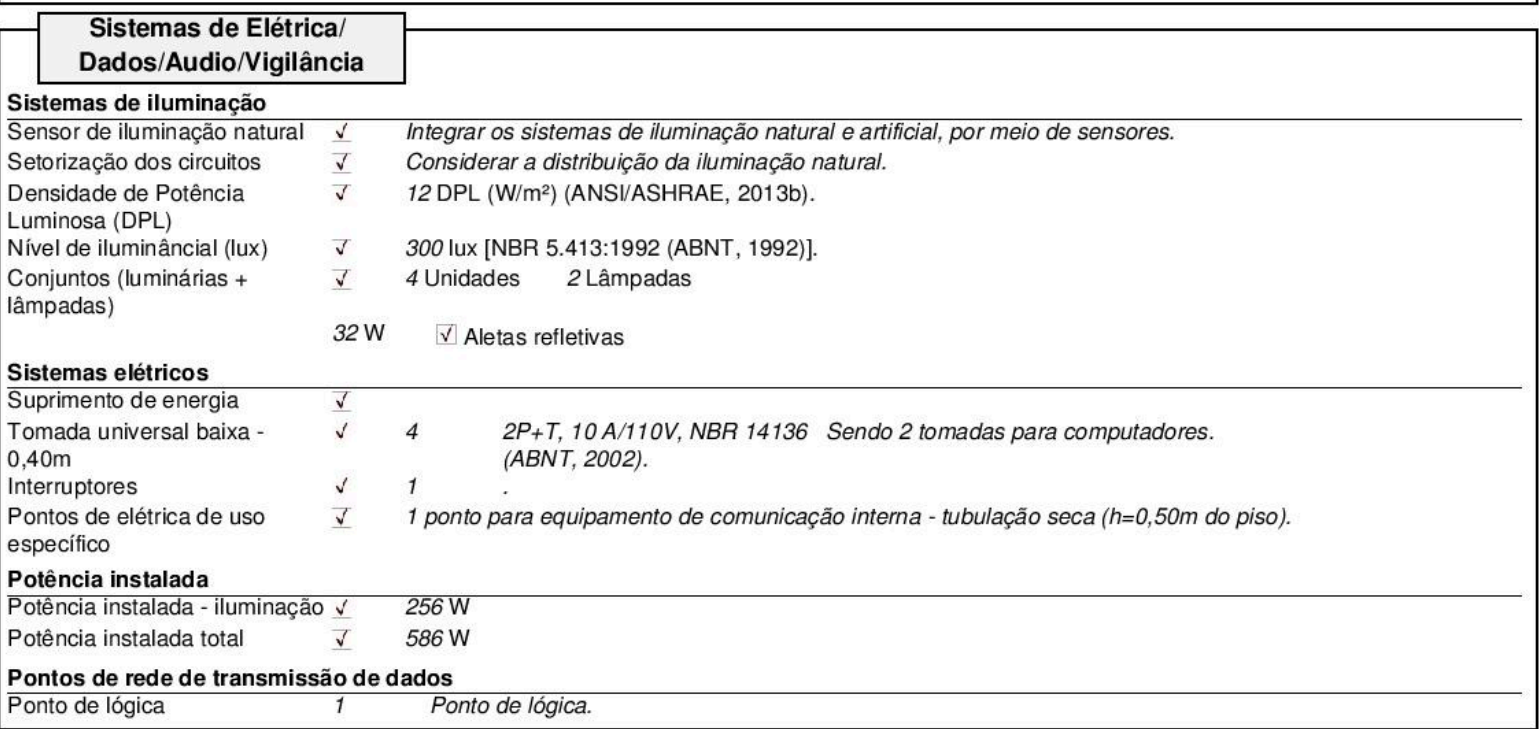

\section{Sistemas hidrossanitários}

Outros

Sistemas hidrossanitários não estão previstos para o ambiente.

\section{Segurança contra incêndio}

Outros

Considerar requisitos para evacuação de emergência (SAO PAULO, 2001; 2004).

\section{Operação e Manutenção}

Limpeza

Especificação de detergentes $\checkmark \checkmark \quad$ Somente produtos de limpeza neutros e não abrasivos.

Procedimentos de limpeza $\quad \bar{v} \quad$ Limpeza de piso com pano úmido e esfregão. Não lavar com água corrente.

Frequencia da limpeza $\quad \checkmark \quad$ Toda troca de turno. 
Diretrizes de projeto para

Database_SPEducational_Facilities Ambientes

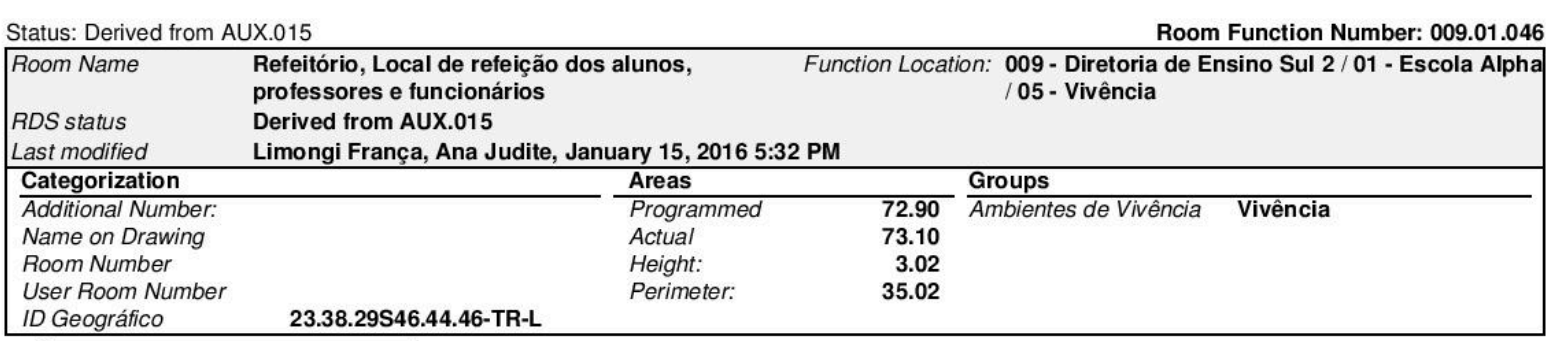

\begin{tabular}{|c|c|}
\hline Descrição & \\
\hline \multicolumn{2}{|l|}{ Informações gerais } \\
\hline \multirow{2}{*}{\multicolumn{2}{|c|}{$\begin{array}{l}\text { Referência OMNICLASS para } 13-11192149 \\
\text { o uso do espaço (Tabela 13) } \\
\text { (OCCS, 2012) }\end{array}$}} \\
\hline & \\
\hline ID Geográfico & 23.38.29S-46.44.46O-TR-L \\
\hline Situação & Em uso, conforme o projetado \\
\hline \multicolumn{2}{|l|}{ Dimensões mínimas } \\
\hline $\begin{array}{l}\text { Requisitos quanto às } \\
\text { dimensões do ambiente }\end{array}$ & $\checkmark$ \\
\hline Largura - entre eixos $(\mathrm{m})$ & 8.1 \\
\hline Profundidade - entre eixos $(\mathrm{m})$ & 9 \\
\hline $\begin{array}{l}\text { Altura mínima - a partir do piso } \\
\text { acabado }(\mathrm{m})\end{array}$ & 3 \\
\hline \multicolumn{2}{|c|}{ Descrição de usos e de atividades } \\
\hline & $\begin{array}{l}\text { Local de refeição dos usuários da escola. Também deverá ser utilizado como local de reuniões para atividades extra- } \\
\text { curriculares. }\end{array}$ \\
\hline \multicolumn{2}{|c|}{ Cargas geradas por atividades humanas } \\
\hline Ocupação & \multirow{3}{*}{$\begin{array}{l}72 \\
07: 00 \text { às } \\
3 \text { horas. }\end{array}$} \\
\hline Período de utilização & \\
\hline Período de utilização máxima & \\
\hline \multicolumn{2}{|c|}{ Normas e diretrizes } \\
\hline & Também poderá ser utilizado fora do horário de aulas, para atividades extra-curriculares. \\
\hline \multicolumn{2}{|l|}{ Proximidade } \\
\hline $\begin{array}{l}\text { Uso em conjunto com outros } \\
\text { ambientes }\end{array}$ & v $\quad$ Ambientes de vivência. \\
\hline $\begin{array}{l}\text { Proximidade a/distância de } \\
\text { outros ambientes }\end{array}$ & $\begin{array}{l}\text { - Bebedouros. } \\
\text { - Lavatórios. }\end{array}$ \\
\hline Distância máxima a percorrer & $30 \mathrm{~m}$ \\
\hline $\begin{array}{l}\text { emergencla (PMESP, 2010) } \\
\text { Requisitos para a localização }\end{array}$ & Deve abrir diretamente para o páteo descoberto. \\
\hline \multicolumn{2}{|l|}{ Acabamentos } \\
\hline \multicolumn{2}{|l|}{ Vedos } \\
\hline $\begin{array}{l}\text { Equipamentos fixados em } \\
\text { fechamentos verticais }\end{array}$ & $\checkmark$ \\
\hline Privacidade & 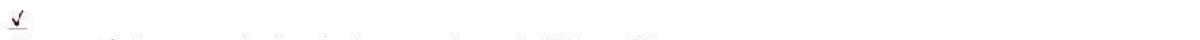 \\
\hline Materiais & Bloco cerâmico, com chapisco/emboço e reboco de $2,5 \mathrm{~cm}$, pintura. \\
\hline Propriedades térmicas & $\checkmark \quad$ Condutividade $[\mathrm{W} /(\mathrm{mK})] 0.7$ \\
\hline & Calor Específico $\left[\mathrm{J} /\left(\mathrm{g} \cdot{ }^{\circ} \mathrm{C}\right)\right] 0.92$ \\
\hline & Densidade $\left(\mathrm{kg} / \mathrm{m}^{3}\right) 1,000$ \\
\hline & Emissividade 0.9 \\
\hline Acabamentos & Pintura, com tinta lavável, cor bege. $O$ acabamento deve ser impermeável e resistente a lavagens frequentes. \\
\hline Refletância & v $70 \%$ \\
\hline Pisos & \\
\hline Carga acidental $\left(\mathrm{kgf} / \mathrm{m}^{2}\right)$ & $\begin{array}{lll} & 400 \quad \text { Laje obrigatória. }\end{array}$ \\
\hline Material & Laje de concreto, revestimento cerâmico. \\
\hline Propriedades térmicas & $\checkmark \quad$ Condutividade $[\mathrm{W} /(\mathrm{mK})] 1.7$ \\
\hline & Calor específico $\left[\mathrm{J} /\left(\mathrm{g} \cdot{ }^{\circ} \mathrm{C}\right)\right] 0.95$ \\
\hline & Densidade $\left(\mathrm{kg} / \mathrm{m}^{3}\right) 2,250$ \\
\hline & Emissividade 0.95 \\
\hline Acabamentos & $\begin{array}{l}\text { Revestimento cerâmico de alta resistência, monoqueima, } 30 \text { × } 30 \mathrm{~cm} \text {, alto tráfego. PEI-5. cor branca. Marca: } \\
\text { CECRISA, Linha Hércules. Rodapé com a mesma cerâmica, altura } 7,5 \mathrm{~cm} \text {. }\end{array}$ \\
\hline Refletância & $\checkmark \quad 70 \%$ \\
\hline Cobertura/forro & \\
\hline $\begin{array}{l}\text { Material } \\
\text { Propriedades térmicas }\end{array}$ & $\begin{array}{l}\text { Laje de concreto. } \\
\text { Condutividade }[\mathrm{W} /(\mathrm{mK})] 1.75\end{array}$ \\
\hline
\end{tabular}




\section{Diretrizes de projeto para}

Status: Derived from AUX.015

Cobertura/forro

\section{Cobertura/forro}

s

Calor específico $\left[\mathrm{J} /\left(\mathrm{g} \cdot{ }^{\circ} \mathrm{C}\right)\right]$

Densidade $\left(\mathrm{kg} / \mathrm{m}^{3}\right) 2,200$

Emissividade 0.95

Acabamentos $\quad$ Pintura esmalte sintético acetinado semi-brilho na cor branca.

Refletância

$\checkmark \quad 70 \%$

Outros acabamentos

Observar o caimento dos pisos, em direção aos ralos.

Prever rodapés arredondados no piso, em todo o ambiente.

As paredes devem ser revestidas com material liso, impermeável e resistente a frequentes lavagens.

O piso deve ser anti-derrapante, impermeável, de fácil higienização e resistente a ácidos.

Estrutura em acco com pintura em poliuretano acrílico. Cor de referência: verde acetinado. Sobre primer epóxi

poliamida, exceto onde for necessário prever proteção passiva das estruturas metálicas com argamaça projetada,

conforme o Decreto Estadual 46.076 (SÃO PAULO, 2001).

Em elementos estruturais em concreto aparente, prever pintura hidrofugante.

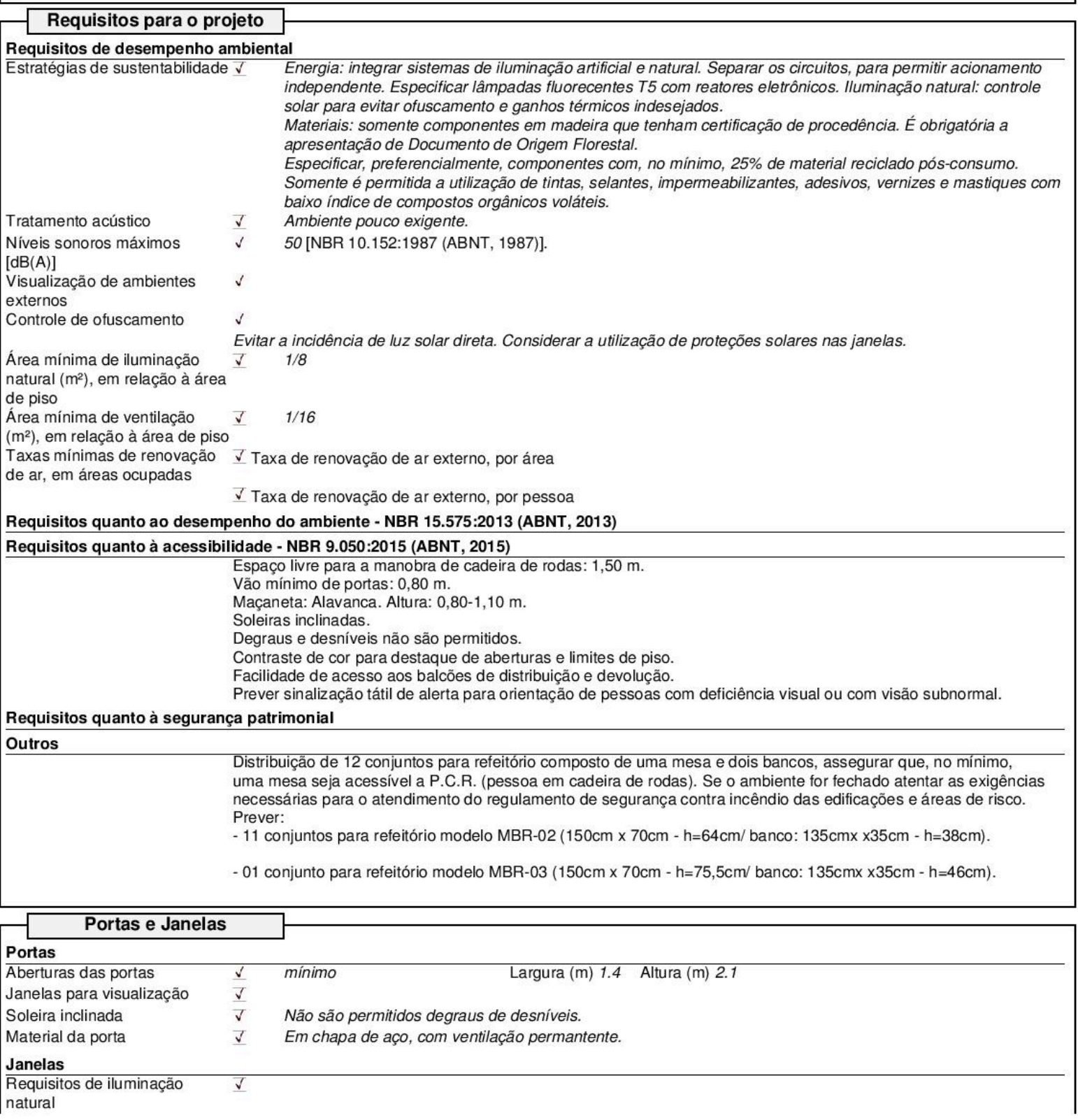




\section{Diretrizes de projeto para Ambientes}

Status: Derived from AUX.015

Room Function Number: 009.01.046

\begin{tabular}{|l|l|}
\hline \multicolumn{2}{|c|}{ Portas e Janelas } \\
Janelas
\end{tabular}

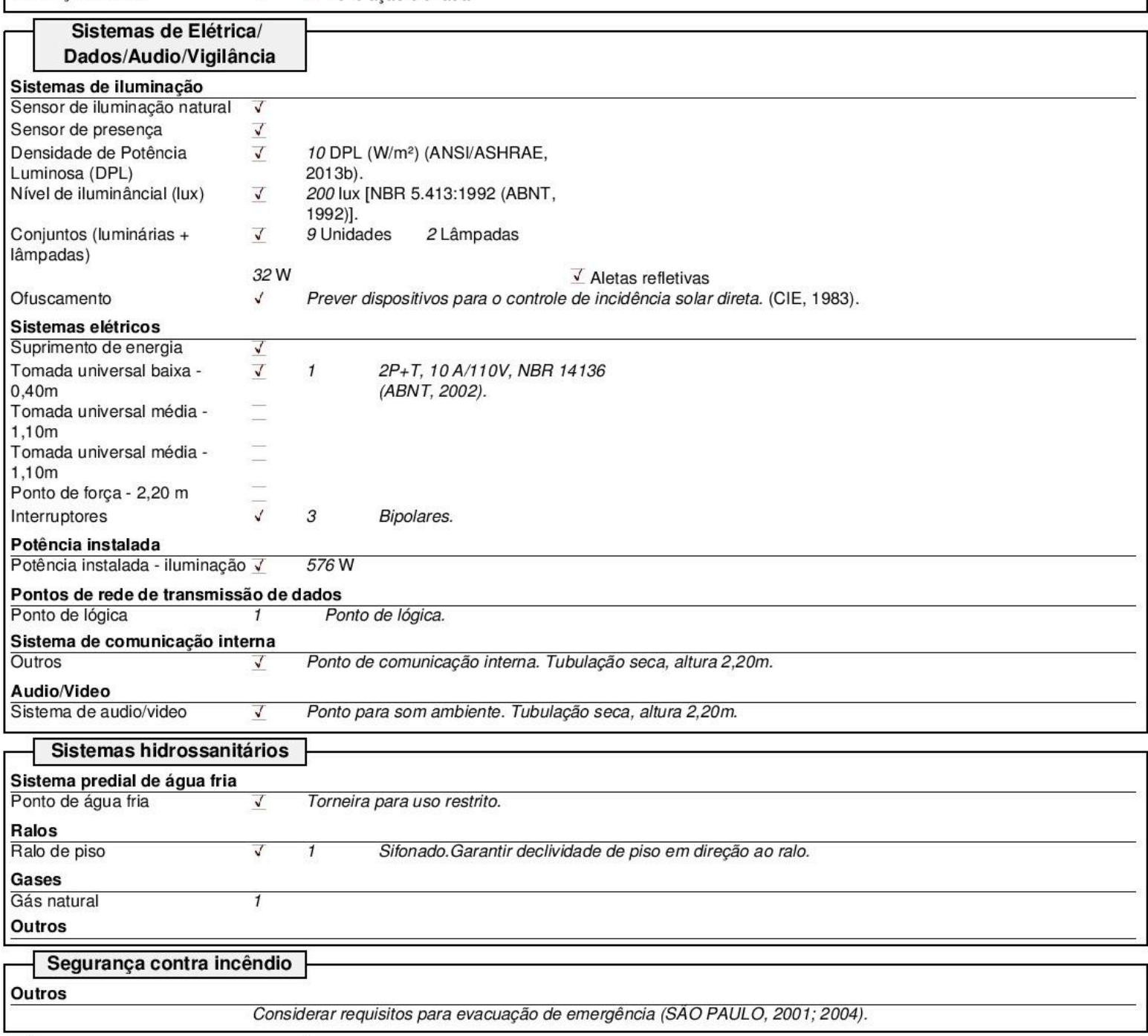

\section{Operação e Manutenção}

Limpeza

Especificação de detergentes $\checkmark \checkmark \quad$ Somente produtos de limpeza neutros e não abrasivos.

Procedimentos de limpeza $\quad \checkmark \quad$ Lavar e desinfetar pisos, paredes e equipamentos hidrossanitários. 
Diretrizes de projeto para Ambientes

\begin{tabular}{|c|c|c|c|}
\hline Status: From VI.020-1 & \multicolumn{3}{|c|}{ Room Function Number: 009.01.047 } \\
\hline Room Name & $\begin{array}{l}\text { Quadra de esportes 1, Desenvolvimento de } \\
\text { atividades esportivas }\end{array}$ & $\begin{aligned} \text { Function Location: } & 009-\text { Diretoria de } \\
& \text { / } 05 \text { - Vivência }\end{aligned}$ & isino Sul 2 / 01 - Escola Alpha \\
\hline RDS status & From VI.020-1 & & \\
\hline Categorization & Areas & Groups & \\
\hline Additional Number: & Programmed & Ambientes de Vivência & Ambientes Esportivos \\
\hline Name on Drawing & Actual & 0.00 & \\
\hline ID Geográfico & 23.38.29S46.44.46-TR-O & & \\
\hline
\end{tabular}

\section{Descrição}

Informaç̃es gerais

Referência OMNICLASS para 13-31 1913 Quadra de esportes ao ar livre

o uso do espaço (Tabela 13)

(OCCS, 2012)

ID Geográfico 23.38.29S-46.44.46O-TR-O

Situação Em uso, conforme o projetado

Dimensões mínimas

Requisitos quanto às

dimensões do ambiente

Largura - entre eixos $(\mathrm{m})$

Profundidade - entre eixos $(\mathrm{m}) \quad \checkmark \quad 30$

Descrição de usos e de atividades

Desenvolvimento de atividades esportivas, jogos, exercícios físicos, festas e reuniões recreativas.

Cargas geradas por atividades humanas

$\begin{array}{llll}\text { Período de utilização } & 07: 00 \text { às } & 23: 00 & 5 \text { dias/semana }\end{array}$

Normas e diretrizes

Eventualmente, pode ser utilizado fora do horário de funcionamento da escola.

Prever:

- Poste para rede de voleibol QE-02.

- Traves para futebol de salão QE-03.

- Tabelas de basquete QE-025 ou QE-37.

Opcionais:

- Arquibancadas (QE-11; QE-16; QE-17; QE-19).

Proximidade

Uso em conjunto com outros $\quad \checkmark \quad$ Integrar 0 ambiente a espaços externos e a jardins.

ambientes

Proximidade a/distância de Prever fácil acesso ao páteo coberto e ao depósito de material para educação física.

outros ambientes Deve ter acesso independente, para uso fora do horário de aulas, de modo a preservar a segurança dos demais

Deve ter acesso in

Localizá-lo próximo a sanitário acessível e a bebedouros.

Requisitos para a localização Localizar o ambiente afastado de ambientes destinados a atividades de ensino-aprendizagem ou administrativos,

pois é gerador de ruído.

Expressão Arquitetônica

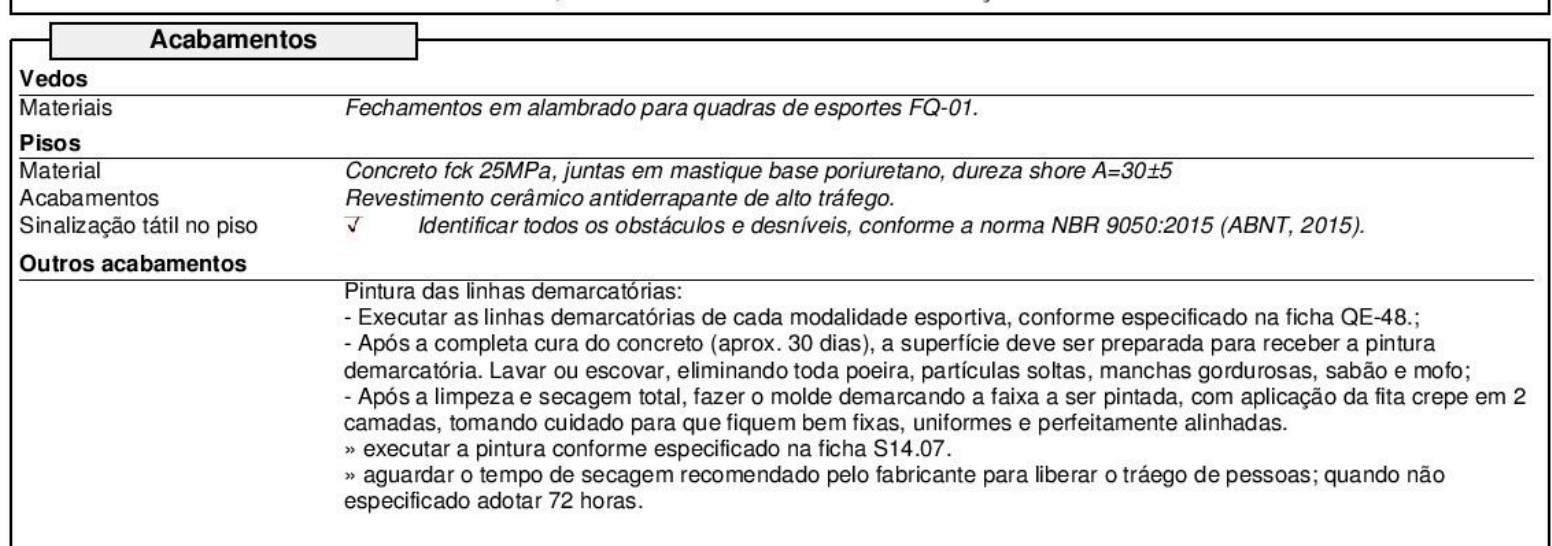

Requisitos para o projeto

Requisitos de desempenho ambiental

Estratégias de sustentabilidade $\checkmark$ Energia: prever circuitos elétricos separados, para permitir o acionamento parcial da iluminação artificial. Materiais: somente componentes em madeira que tenham certificação de procedência. É obrigatória a apresentação de Documento de Origem Florestal. 


\section{Diretrizes de projeto para Ambientes}

Status: From VI.020-1

Room Function Number: 009.01.047

Requisitos para o projeto

Requisitos de desempenho ambienta

Especificar, preferencialmente, componentes com, no mínimo, $25 \%$ de material reciclado pós-consumo.

Somente é permitida a utilização de tintas, selantes, impermeabilizantes, adesivos, vernizes e mastiques com baixo índice de compostos orgânicos voláteis.

Níveis sonoros máximos $\quad \checkmark \quad$ Ambiente gerador de ruídos. Prever afastamento das áreas destinadas ao ensino-aprendizagem e às $[\mathrm{dB}(\mathrm{A})]$ atividades administrativas da edificação. Se necessário, considerar tratamento acústico. [NBR 10.152:1987 (ABNT, 1987)].

Requisitos quanto ao desempenho do ambiente - NBR 15.575:2013 (ABNT, 2013)

Prover acessibilidade a pessoas de mobilidade reduzida e observar a segurança no uso quanto ao piso e aos equipamentos esportivos.

Requisitos quanto à acessibilidade - NBR 9.050:2015 (ABNT, 2015) Acesso universal ao ambiente, sanitários bebedouros e arquibancadas, conforme o preconizado na norma NBR 9050:2015(ABNT, 2015)

Requisitos quanto à segurança patrimonial

\begin{tabular}{ll} 
Outros & Prever uso da quadra independente da operação da escola, de modo a preservar sua privacidade e segurança. \\
\hline Orientação em relação ao eixo longitudinal Norte-Sul com variação máxima de $15^{\circ}$.
\end{tabular}

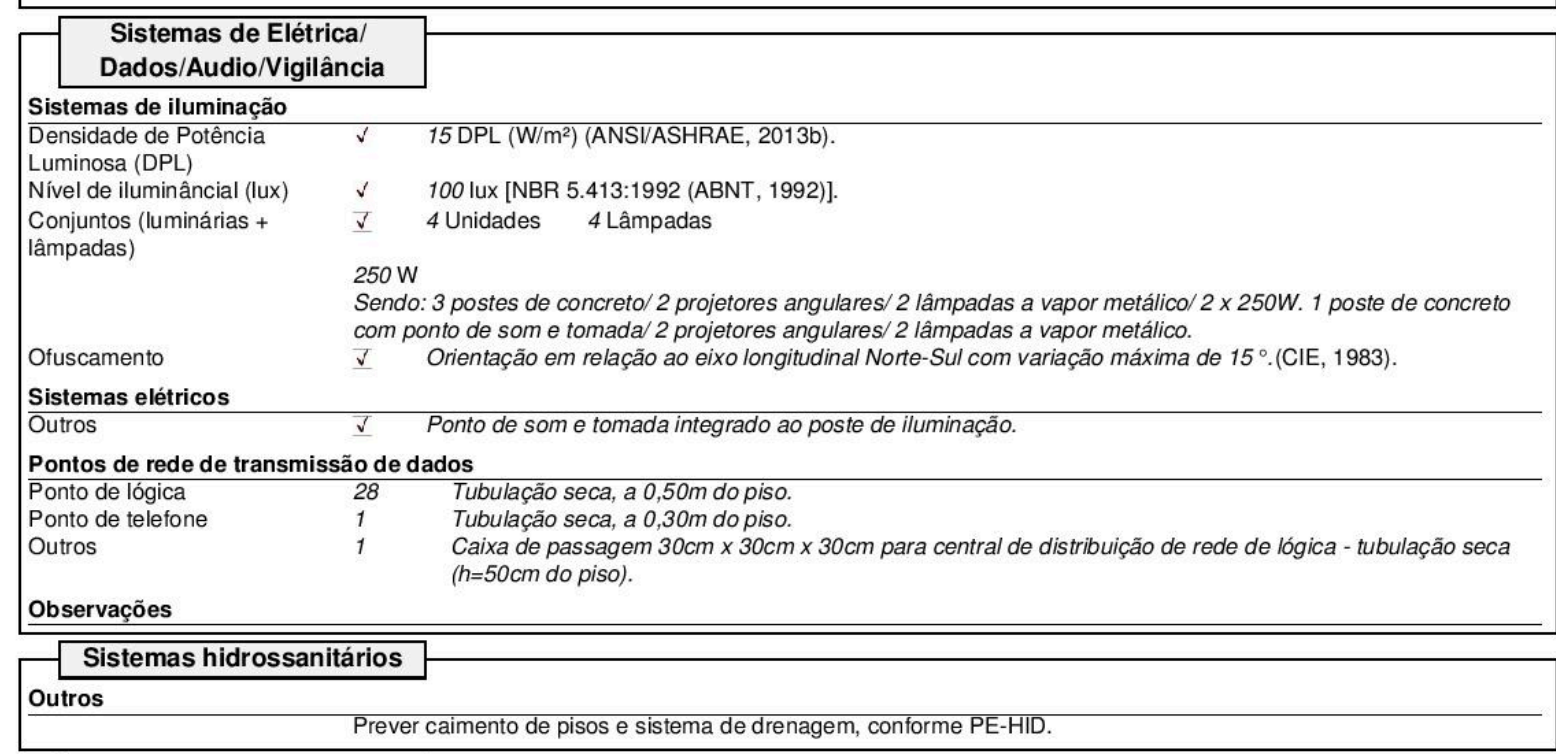

\section{Segurança contra incêndio}

Outros

Considerar requisitos para evacuação de emergência.

Prever sinalização orientando rotas de saída (SÃO PAULO, 2001; 2004).

\section{Operação e Manutenção}

Limpeza

Especificação de detergentes $\checkmark \checkmark \quad$ Somente produtos de limpeza neutros e não abrasivos.

Procedimentos de limpeza $\quad \bar{v} \quad$ Pisos podem ser lavados. Nesse caso, utilizar somente água de reúso. 
APÊNDICE C - RELATÓRIO DE ASPECTOS CRÍTICOS IDENTIFICADOS NA ESCOLA ALPHA, ELABORADO POR MEIO DA PLATAFORMA DE BANCO DE DADOS DROFUS V. 1.8 
MELHORIA CONTÍNUA APLICADA A

Database_SPEducational_Facilities

Status: Derived from ADM.05

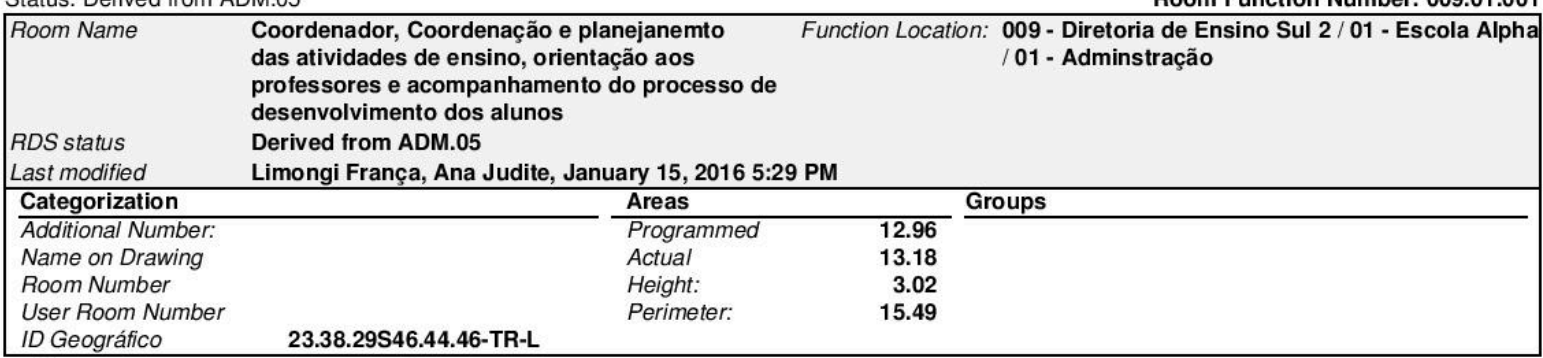

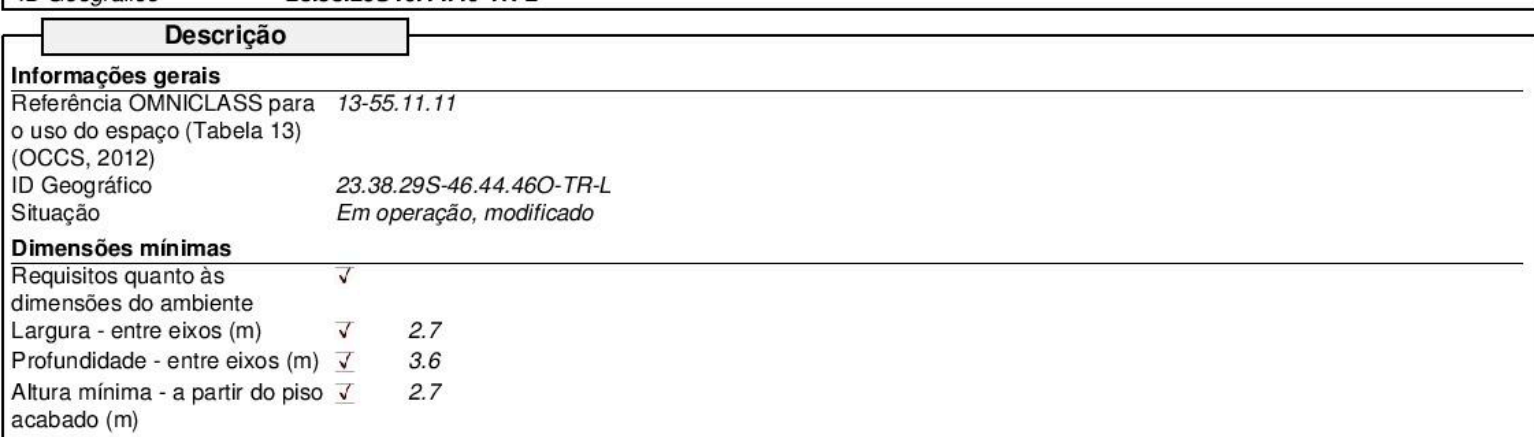

\begin{tabular}{|c|c|}
\hline Aspectos críticos & \\
\hline \multicolumn{2}{|l|}{ Aspecto crítico 1} \\
\hline Aspecto crítico - Sim/Não & $\begin{array}{ll}\checkmark & \text { Identificado por } A J L F\end{array}$ \\
\hline & Responsável Especialista em APO Data June 8, 2009 \\
\hline Nível de risco (FRANÇA, 2011) & 1 - Médio risco \\
\hline Referência NBR 15966-2:2012 ( & (ABNT, 2012) OP.60.30.02 - Limitações funcionais. \\
\hline $\begin{array}{l}\text { Normas, diretrizes e boas } \\
\text { práticas }\end{array}$ & Boas práticas: manter em operação os ambientes contemplados no programa de necessidades. \\
\hline $\begin{array}{l}\text { Requisitos de desempenho } \\
\text { NBR } 15575: 2013\end{array}$ & (ABNT, 2013) Funcionalidade; ergonomia. \\
\hline
\end{tabular}


酒 Database SPEducational Facilities

Status: Derived from ADM.05
Relatório de aspectos críticos: Ambientes

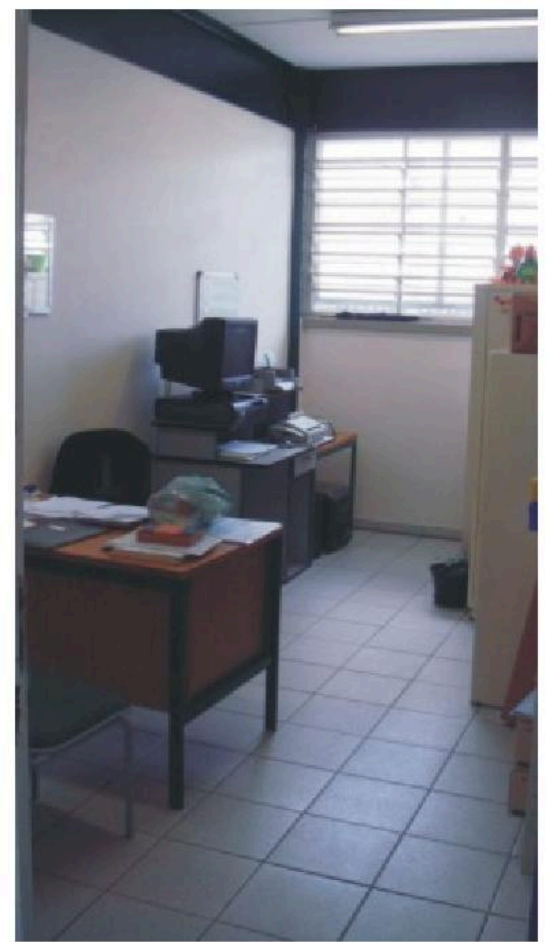

Room Function Number: 009.01.001

Evidência - aspecto crítico 1: sala projetada para uso do coordenador teve uso alterado para sala do vide-diretor. Fonte: Acervo da pesquisadora.

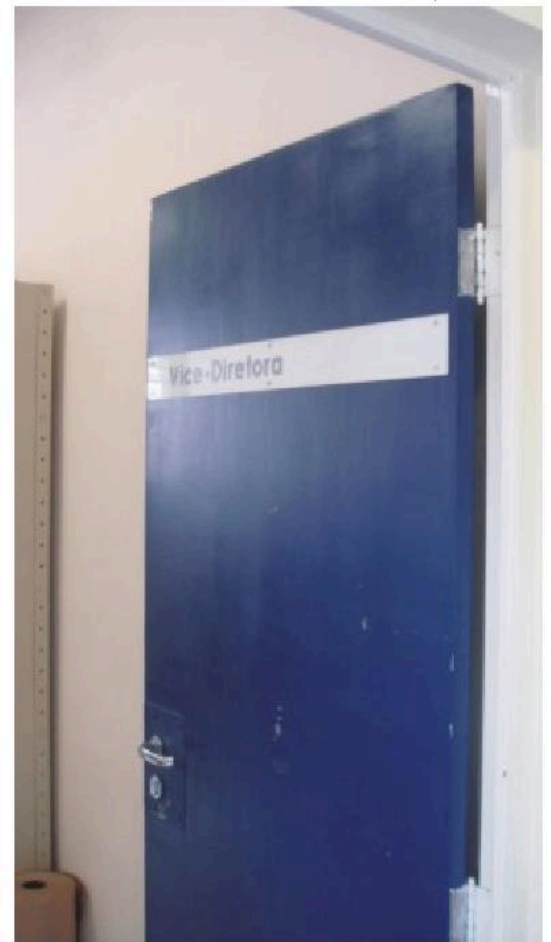

Evidência - aspecto crítico 1: sala projetada para uso do coordenador teve uso alterado para sala da vide-diretora. Fonte: Acervo da pesquisadora. 
Relatório de aspectos críticos: Ambientes

Status: Derived from ADM.06

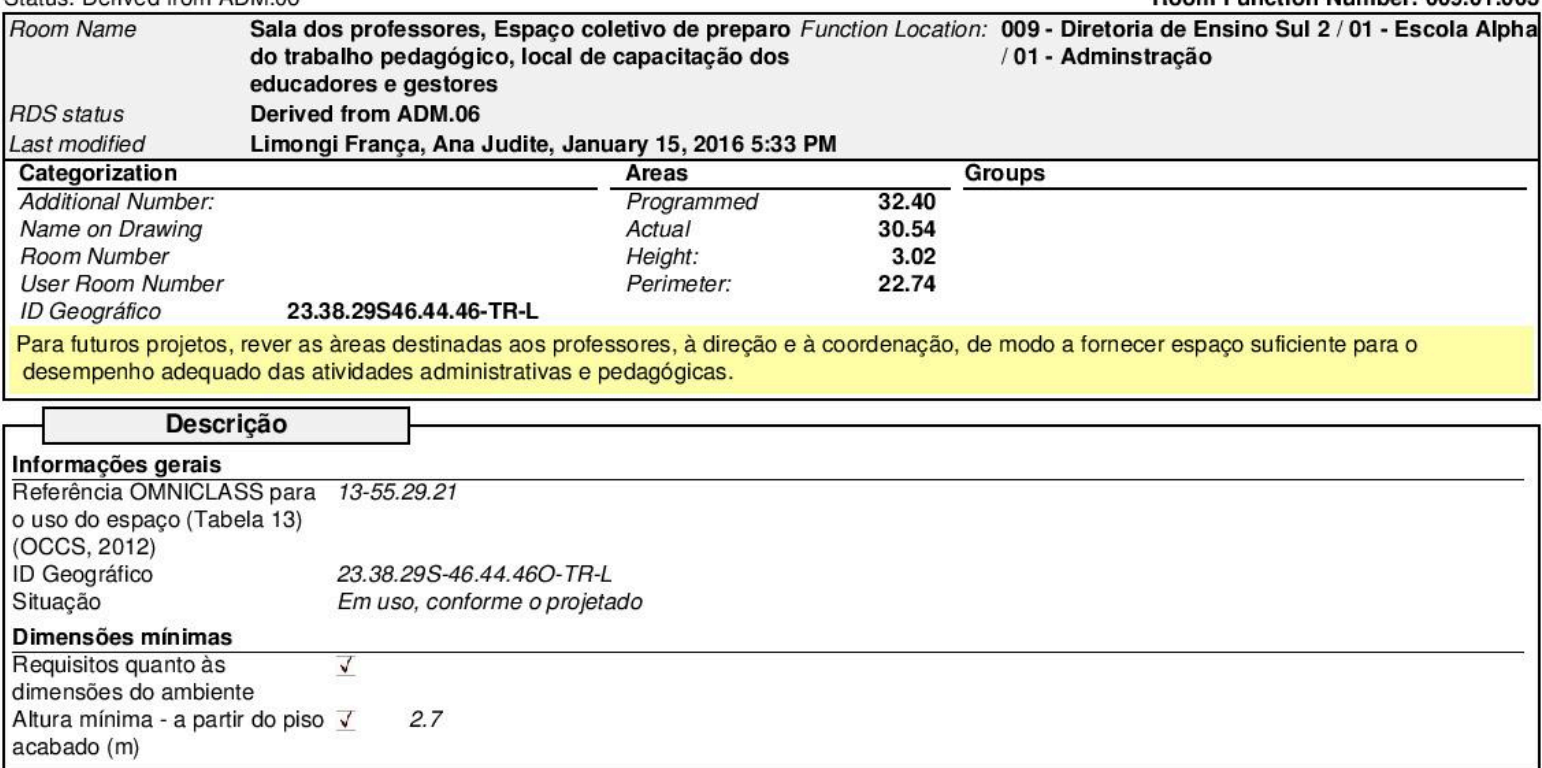

acabado $(\mathrm{m})$

\section{Aspectos críticos}

\section{Aspecto crítico}

Aspecto crítico - Sim/Não $\checkmark$ Identificado por AJLF

Responsável Especialista em APO Data June 8, 2009

Descrição da situação crítica A área destinada à sala dos professores é insuficiente para o desempenho de todas as atividades previstas,

ocasionando situações críticas quanto aos espaços de circulação e de trabalho dos usuários.

Causas prováveis

Referência OMNICLASS $\quad$ (OCCS, 2012) 49-812113 - Limitações funcionais.

Tabela 49

Referência NBR 15966-2:2012 (ABNT, 2012) OP.60.30.02 - Limitações funcionais.

Normas, diretrizes e boas Boas práticas: avaliar os requisitos para o dimensionamento do ambiente, de modo a permitir o desempenho das

atividades necessárias à prática docente.

Requisitos de desempenho (ABNT, 2013) Acessibilidade, funcionalidade; ergonomia.

NBR 15575:2013 

MELHORIA CONTINNUA APLICADA A
EDIFICACOOES DE TIPOLOGIA PADRONIZADA Database_SPEducational_Facilities
Relatório de aspectos críticos: Ambientes

Status: Derived from Cl.001-1

\begin{tabular}{|c|c|c|}
\hline Room Name & Circulação 2, Circulação horizontal & $\begin{array}{l}\text { Function Location: } 009 \text { - Diretoria de Ensino Sul } 2 \text { / } 01 \text { - Escola Alpha } \\
\text { / } 02 \text { - Circulação }\end{array}$ \\
\hline RDS status & Derived from $\mathrm{Cl} .001-1$ & \\
\hline Last modified & Limongi França, Ana Judite, January 15, 2016 5:2 & 3 PM \\
\hline Additional Number: & Programmed & 0.00 \\
\hline Name on Drawing & Actual & 11.01 \\
\hline Room Number & Height: & 3.03 \\
\hline $\begin{array}{l}\text { User Room Number } \\
\text { ID Geográfico }\end{array}$ & 23.38.29S46.44.46-TR-L & 14.35 \\
\hline
\end{tabular}

Descrição

Informações gerais

Referência OMNICLASS para 13-851111

o uso do espaço (Tabela 13)

(OCCS, 2012)

ID Geográfico 23.38.29S-46.44.46O-1P-C

Situação Em uso, conforme o projetado

Expressão Arquitetônica

Local de convivência, festas e atividades relacionadas a educação física.

Aspectos crítico

Aspecto crítico 1

Aspecto crítico - Sim/Não $\quad$ I $\quad$ Identificado por AJLF

Responsável Especialista em APO Data September 8, 2009

Descrição da situação crítica Falta de mangueira e de peças de engate em hidrantes. Falta de sinalização e de extintores, alarme sem condições de uso.

Nível de risco (FRANÇA, 2011) 0 - Alto risco

Causas prováveis Conservação

Referência OMNICLASS $\quad$ (OCCS, 2012) 49-41318313- Cronograma de manutenção; 49-8141 13 - Resistência ao mal uso; 49 -81 41 00 -

Tabela $49 \quad$ Propriedades de durabilidade.

Referência NBR 15966-2:2012 (ABNT, 2012) OP.30.10.35.02 - Cronograma de manutenção; OP.60.50.02 - Resistência ao mal uso; OP.60.50.00 -

Propriedades de durabilidade.

Normas, diretrizes e boas $\quad$ Normas técnicas: Decreto Estadual n 46.076:2001 (São Paulo, 2001); Instruções Técnicas do Corpo de Bombeiros

práticas da Polícia Militar (São Paulo, 2004); Manual de orientação à prevenção e ao combate a incêndio nas escolas (FDE, 2009).

Boas práticas: Manter hidrantes em condições de uso, conforme o projeto.

Requisitos de desempenho (ABNT, 2013) Acessibilidade; funcionalidade; durabilidade; manutenibilidade; desempenho ambiental; segurança no

NBR 15575:2013 uso; segurança contra incêndio; conforto tátil; ergonomia.

Comentários Realizar manutenção nos hidrantes e dos alarmes de incêndio da edificação e providenciar para que sejam mantidos

Aspecto crítico 2

\begin{tabular}{lll}
\hline Aspecto crítico - Sim/Não & $\checkmark$ & Identificado por AJLF \\
& Responsável Especialista em APO Data September 8, 2009
\end{tabular}

Descrição da situação crítica Instalações elétricas adaptadas e/ou sem manutenção adequada. Comprometimento da funcionalidade devido à falta de componentes; quantificação e distribuição insuficientes provocam adaptações em desacordo com o projeto; obstrução das caixas para a passagem de fiação com elementos estranhos (por exemplo: pedaços de papel, embalagens)

Nível de risco (FRANÇA, 2011) 0 - Alto risco

Causas prováveis Manutenção

Referência OMNICLASS ～(OCCS, 2012) 49-41318313 - Cronograma de manutenção; 49-8121 13 - Limitações funcionais.

Tabela 49

Referência NBR 15966-2:2012 (ABNT, 2012) OP.30.10.35.02 - Cronograma de manutenção; OP.60.30.02 - Limitações funcionais.

Normas, diretrizes e boas Normas técnicas: NBR 5410:1997 (ABNT, 1997); Decreto Estadual no 46.076 (SẤO PAULO, 2001); Manual de práticas orientação à prevenção e ao combate a incêndio nas escolas (FDE,2009).

Boas práticas: Realizar manutenção periódica e preventiva nas instalações.

Elaborar o projeto de instalações de forma a permitir fácil adequação, em função de necessidades específicas.

Requisitos de desempenho (ABNT, 2013) Funcionalidade; durabilidade; manutenibilidade; desempenho ambiental; segurança no uso; segurança NBR 15575:2013 contra incêndio.

Comentários Realizar manutenção corretiva nas instalações elétricas.

Aspecto crítico 3

Aspecto crítico - Sim/Não

$\checkmark \quad$ Identificado por $A J L F$

Responsável Especialista em APO Data September 8, 2009

Descrição da situação crítica Dificuldades para manter as paredes limpas ocasionaram a demarcação de uma barra em tinta esmalte nas áreas de circulação, em desacordo com o projeto.

Nível de risco (FRANÇA, 2011) 2 - Baixo risco

Causas prováveis Projeto

Referência OMNICLASS $\quad$ (OCCS, 2012) 49-41318313-Cronograma de manutenção; 49-8141 13 - Resistência ao mal uso; 49 -81 41 00 -

Tabela $49 \quad$ Propriedades de durabilidade.

Referência NBR 15966-2:2012 (ABNT, 2012) OP.30.10.35.02 - Cronograma de manutenção; OP.60.50.02 - Resistência ao mal uso; OP.60.50.00 -

Propriedades de durabilidade.

Normas, diretrizes e boas $\quad$ Normas técnicas: NBR 15575:2013 (ABNT, 2013); ISO 15686-1:2000 (ISO, 2000).

práticas Boas práticas: Especificar tintas laváveis, a fim de facilitar a limpeza das paredes. 
MELHORIA CONTÍNUA APLICADA A

Database_SPEducational_Facilities

\section{Relatório de aspectos críticos: Ambientes}

Status: Derived from Cl.001-1

Room Function Number: 009.01.008

\section{Aspectos críticos}

Aspecto crítico 3

Requisitos de desempenho (ABNT, 2013) conforto visual; funcionalidade; salubridade; durabilidade; manutenibilidade; desempenho ambiental.

Comentários

Avaliar, para futuros projetos, acabamentos que apresentem desempenho adequado para as áreas de circulação intensa. Especificar tintas que facilitem a remoção de sujeira. Preparar adequadamente as superfícies. Apagar rapidamente vestígios de vandalismo.

A specto crítico 4

\begin{tabular}{llll}
\hline Aspecto crítico - Sim/Não & $\checkmark$ & Identificado por AJLF \\
& Responsável Especialista em APO Data June 8, 2009
\end{tabular}

Descrição da situação crítica Infiltrações e vazamentos potencializando o processo de corrosão das estruturas metálicas e a deterioração dos elementos de vedação.

Nível de risco (FRANÇA, 2011) 0 - Alto risco

Causas prováveis Manutenção

Referência OMNICLASS $\quad$ (OCCS, 2012) 49-41318313-Cronograma de manutenção; 49-8141 13 - Resistência ao mal uso; $49-814100$ -

Tabela 49 Propriedades de durabilidade; 49-8121 13 - Limitações funcionais.

Referência NBR 15966-2:2012 (ABNT, 2012) OP.30.10.35.02 - Cronograma de manutenção; OP.60.50.02 - Resistência ao mal uso; OP.60.50.00 -

Propriedades de durabilidade; OP.60.30.02 - Limitaçōes funcionais.

Normas, diretrizes e boas $\quad$ Normas técnicas: NBR 15575:2013 (ABNT, 2013); ISO 15686-1:2000 (ISO, 2000).

práticas

Boas práticas: Manter as calhas em condições adequadas de uso.

(ABNT, 2013) Funcionalidade; salubridade; estanqueidade; durabilidade; manutenibilidade; desempenho ambiental.

NBR 15575:2013

Comentários Realizar manutenção nas calhas, tanto de natureza preventiva quanto corretiva.

Aspecto crítico - Sim/Não $\quad \checkmark \quad$ Identificado por AJLF

Responsável Especialista em APO Data June 8, 2009

Descrição da situação crítica Falta de bebedouros nos locais previstos em projeto.

Nível de risco (FRANÇA, 2011) 1 - Médio risco

Causas prováveis

Referência OMNICLASS $\quad$ (OCCS, 2012) 49-8121 13- Limitações funcionais.

Tabela 49

Referência NBR 15966-2:2012 (ABNT, 2012) OP.60.30.02 - Limitações funcionais.

Normas, diretrizes e boas Normas técnicas: Resolução SS nº 493:1994 (SÃO PAULO, 1994).

práticas

Boas práticas: Manter pelo menos, um bebedouro em funcionamento para cada cem alunos, conforme o previsto em projeto.

Requisitos de desempenho (ABNT, 2013) Acessibilidade; funcionalidade; durabilidade; manutenibilidade.

NBR 15575:2013

Comentários

Instalar bebedouros em conformidade com o projeto.

Aspecto crítico 6

Aspecto crítico - Sim/Não $\checkmark \quad$ Identificado por $A J L F$

Responsável Especialista em APO Data June 8, 2009

Descrição da situação crítica Caimento inadequado, escoamento insuficiente causando acúmulo de água nos corredores e nas áreas externas.

Nível de risco (FRANÇA, 2011) 0 - Alto risco

Causas prováveis Construção

Referência OMNICLASS （OCCS, 2012) 49-91 2317 - Sistema de drenagem; 49-81 2113 - Limitações funcionais.

Tabela 49

Referência NBR 15966-2.2012 (ABNT, 2012) OP.70.06.01 - Sistemas de águas residuais; OP.60.30.02 - Limitações funcionais.

Normas, diretrizes e boas

práticas

Normas técnicas: NBR5626:92 (ABNT, 1992); NBR 10844:89 (ABNT, 1989); NBR 8160:99 (ABNT, 1999). Boas práticas: respeitar as especificações de projeto quanto ao caimento de pisos e à vazão do sistema de drenagem.

Requisitos de desempenho (ABNT, 2013) Acessibilidade; funcionalidade; salubridade; estanqueidade; durabilidade; manutenibilidade;

NBR 15575:2013

Comentários desempenho ambiental; segurança estrutural; segurança no uso.

Verificar critérios de dimensionamento e de execução do sistema. Implantar medidas de operação e manutenção compatíveis com o especificado quanto a materiais e sistemas. A manutenção preventiva pode reduzir custos a longo prazo.

Aspecto crítico 7

Aspecto crítico - Sim/Não $\quad \checkmark$ Identificado por AJLF

Responsável Especialista em APO Data June 8, 2009

Descrição da situação crítica Falta de/danos a componentes; trancamento de portas com a utilização de cadeados.

Nível de risco (FRANCA, 2011) 0 - Alto risco

Causas prováveis Operação

Referência OMNICLASS (OCCS, 2012) 49-8121 13 - Limitações funcionais; 49-614145 - Acesso de manutenção.

Tabela 49

Referência NBR 15966-2:2012 (ABNT, 2012) OP.60.30.02 - Limitações funcionais; OP.40.20.18 - Acesso de manutenção.

Normas, diretrizes e boas Normas técnicas: NBR 5410:97 (ABNT, 1997); Decreto Estadual n0 46.076:2001 (ABNT, 2001); Manual de

práticas orientação à prevenção e ao combate a incêndio nas escolas (FDE, 2009).

Boas práticas: permitir acesso imediato às instalações para manutenção e emergências.

Requisitos de desempenho (ABNT, 2013) Acessibilidade; funcionalidade; salubridade; durabilidade; manutenibilidade; segurança no uso;

NBR 15575:2013 conforto tátil; ergonomia.

Comentários Desbloquear as portas dos quadros. Para futuros projetos, considerar localização das instalações de modo que estejam visíveis das áreas administrativas e menos expostas a atos de vandalismo.

Aspecto crítico 8

Aspecto crítico - Sim/Não $\quad \checkmark \quad$ Identificado por $A J L F$ 
MELHORIA CONTÍNUA APLICADA A

告

Database SPEducational Facilities
Relatório de aspectos críticos: Ambientes

Status: Derived from Cl.001-1

Room Function Number: 009.01.008

\section{Aspectos críticos} Aspecto crítico 8

Responsável Especialista em APO Data June 8, 2009

Nível de risco (FRANÇA, 2011) 1 - Médio risco

Causas prováveis Manutenção

Referência OMNICLASS (OCCS, 2012) 49-41 318313 - Cronograma de manutenção; 49-8141 13 - Resistência ao mal uso; $49-814100$ -

Tabela $49 \quad$ Propriedades de durabilidade.

Referência NBR 15966-2:2012 (ABNT, 2012) OP.30.10.35.02 - Cronograma de manutenção; OP.60.50.02 - Resistência ao mal uso; OP.60.50.00 -

Propriedades de durabilidade.

Normas, diretrizes e boas $\quad$ Normas técnicas: NBR 15575:2013 (ABNT, 2013); ISO 15686-1:2000 (ISO, 2000).

$\begin{array}{ll}\text { poáticas prática } & \\ \text { corretiva. }\end{array}$

(ABNT, 2013) Conforto visual; conforto acústico; conforto higrotérmico; funcionalidade; salubridade; estanqueidade;
durabilidade; manutenibilidade; desempenho ambiental; segurança estrutural; segurança no uso.

NBR 15575:2013

Comentários Realizar manutenção corretiva nas alvenarias. Apagar rapidamente vestígios de vandalismo e pichações. Avaliar causas de açõe de vandalismo e determinar estratégias para o seu controle.

Evidência - aspecto crítico 1: hidrante, alarme de incêndio e sinalização danificados. Fonte: Acervo da pesquisadora. 
H MELHORIA CONTINUA APLICADA A

Database_SPEducational_Facilities

Status: Derived from Cl.001-1
Relatório de aspectos críticos:

Ambientes

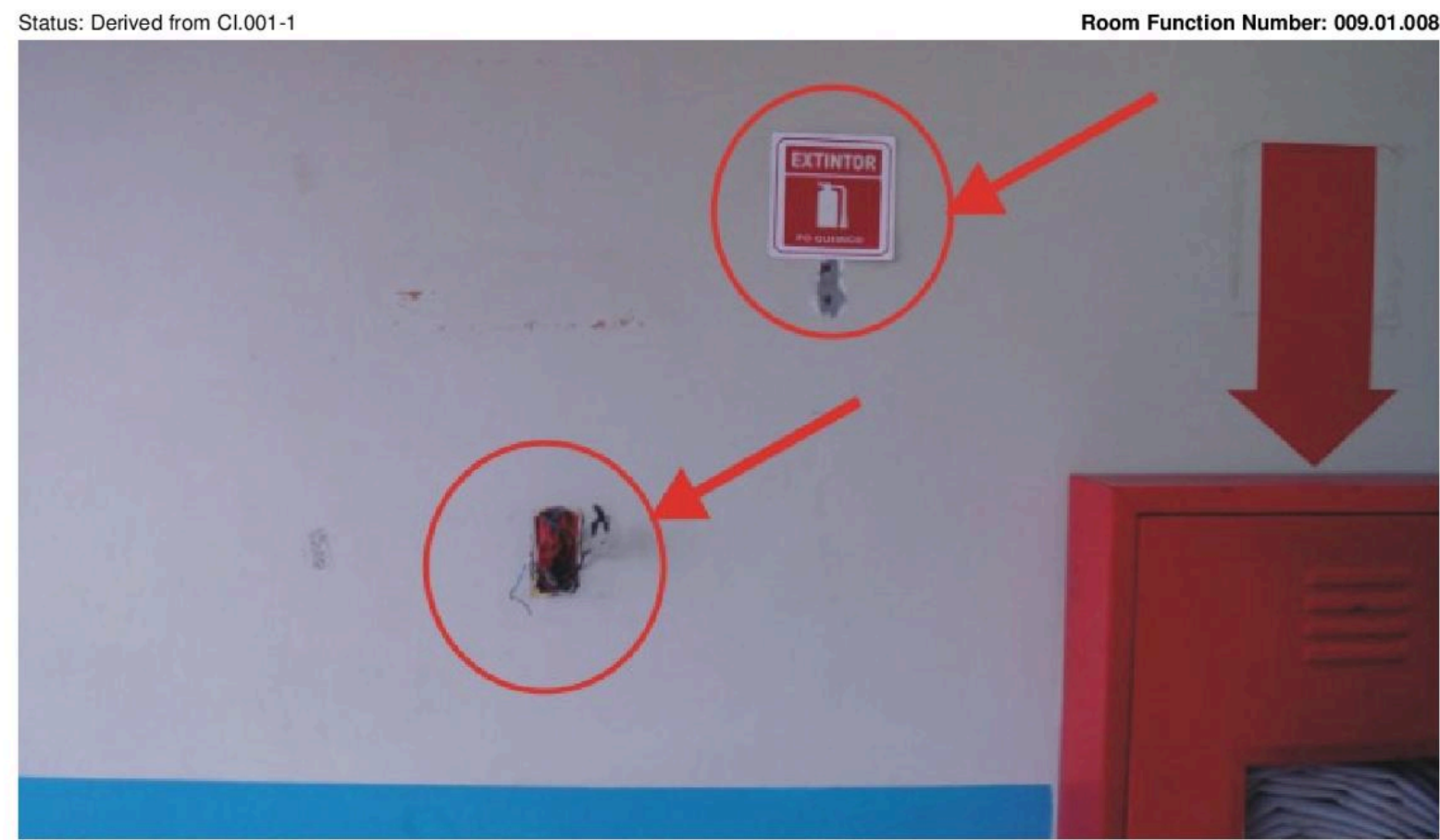

Evidência - aspectos críticos 1 e 2: falta de extintor e respectivo suporte. Fonte: Acervo da pesquisadora.

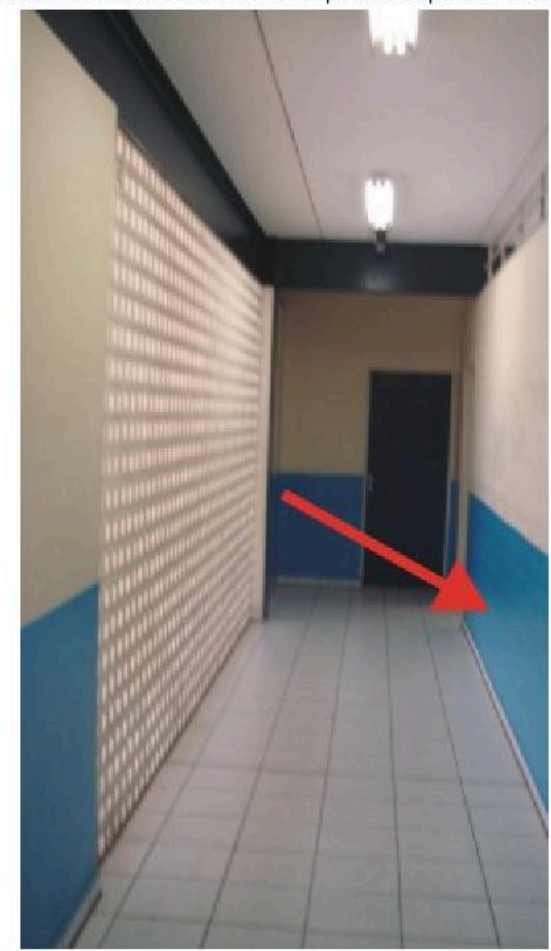

Evidência - aspectos crítico 3: repintura das áreas de circulação, com a adoção de um barrado em tinta esmalte, em desacordo com o projeto. Fonte: Acervo da pesquisadora. 
贯

MELHORIA CONTÍNUA APLICADA A Database_SPEducational_Facilities

Status: Derived from Cl.001-1
Relatório de aspectos críticos: Ambientes

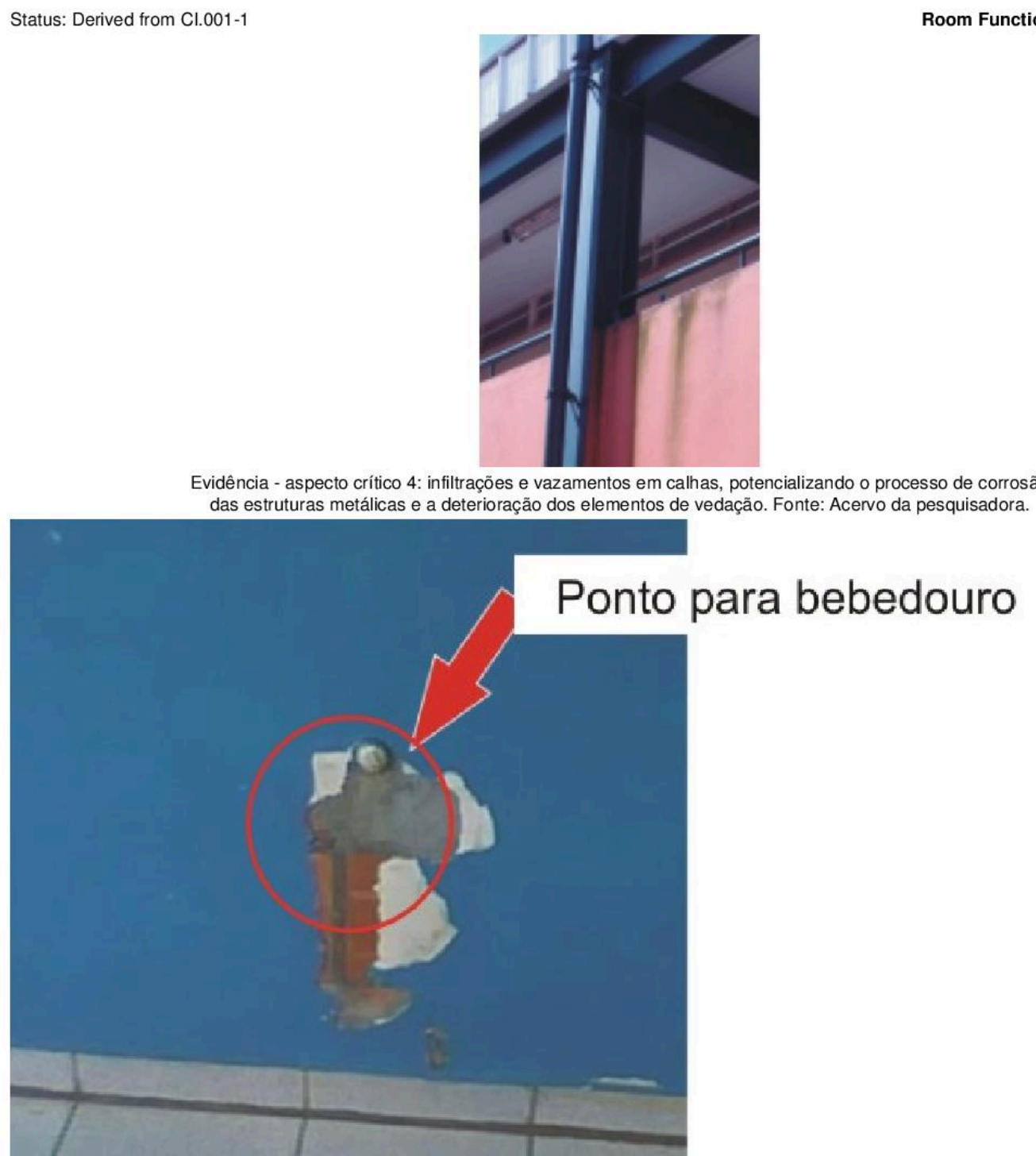

Evidência - aspectos crítico 5: falta de bebedouro em área de circulação. Fonte: Acervo da pesquisadora. 
7 MELHORIA CONTINUA APLICADA A

Database_SPEducational_Facilities

Status: Derived from Cl.001-1
Relatório de aspectos críticos:

Ambientes

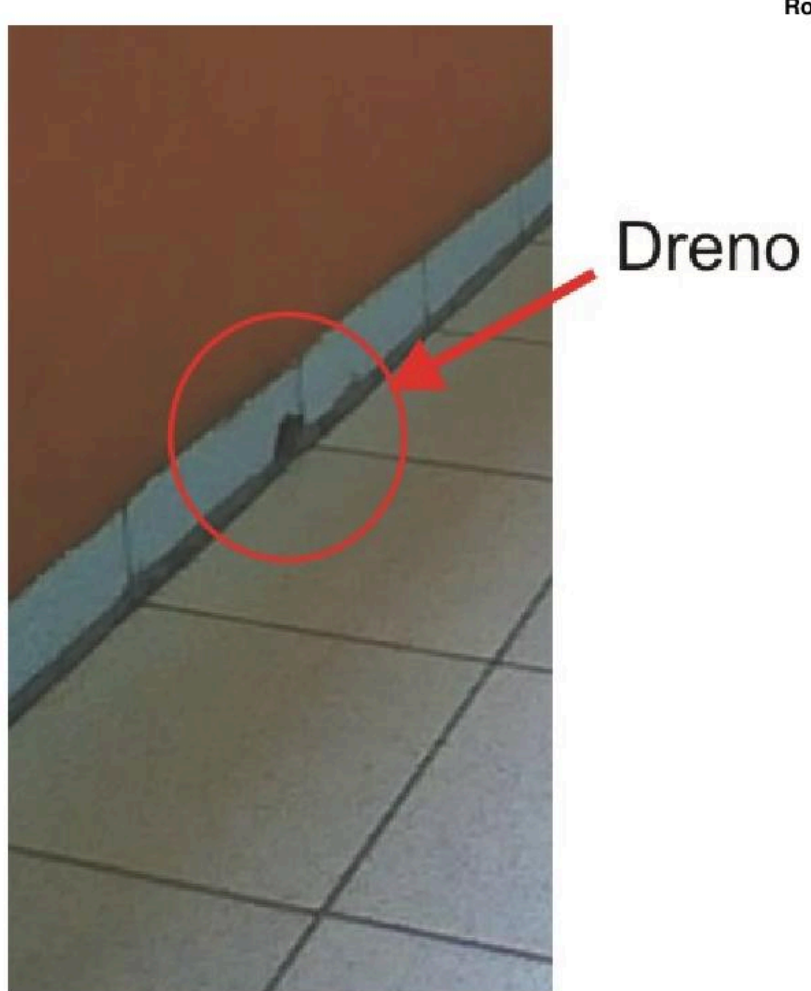

Room Function Number: 009.01.008

Evidência - aspectos crítico 6: drenos instalados em área de circulação semi-externa insuficientes para o escoamento das águas pluviais. Fonte: Acervo da pesquisadora.

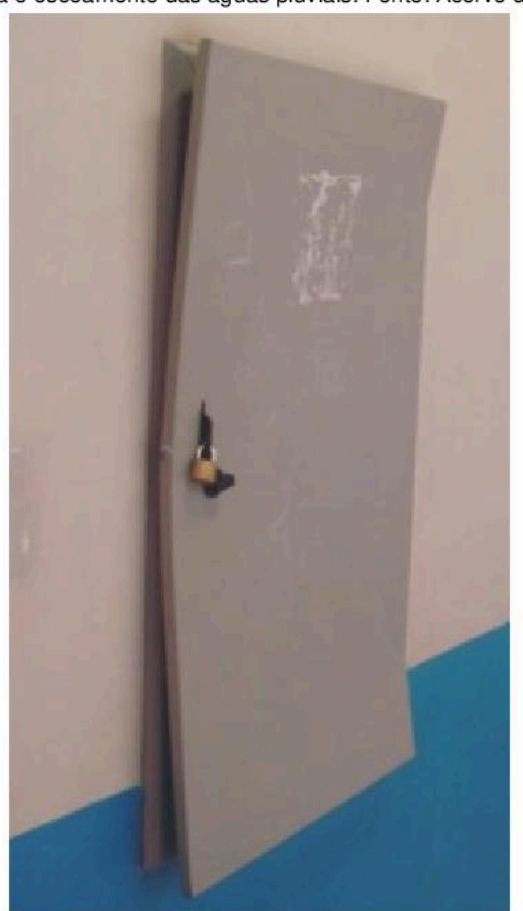

Evidência - aspectos crítico 7: quadro de distribuição de energia danificado e trancado. Fonte: Acervo da pesquisadora. 
H MELHORIA CONTINUA APLLCADA A Database SPEducational Facilities

Status: Derived from Cl.001-1

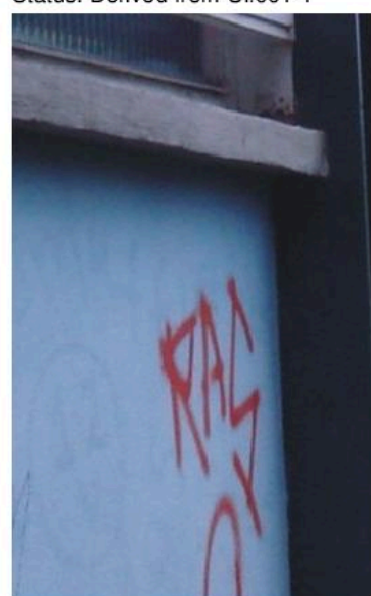

Relatório de aspectos críticos: Ambientes
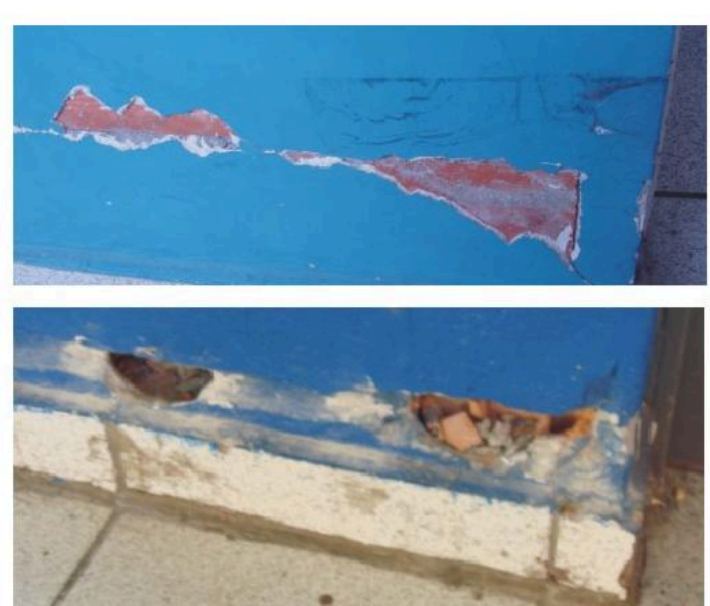

Evidência - aspecto crítico 8: alvenarias danificadas. Fonte: Acervo da pesquisadora.
Room Function Number: 009.01.008

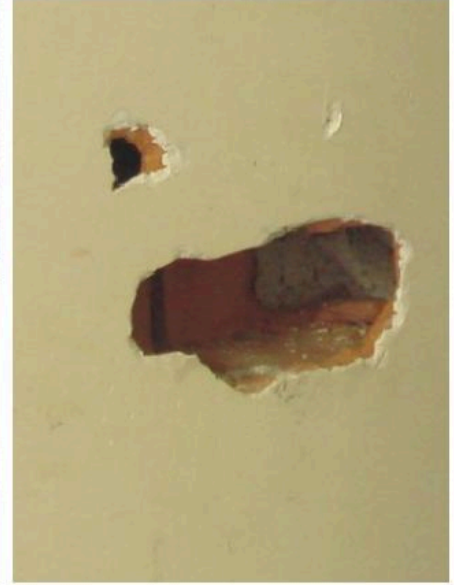




\section{Relatório de aspectos críticos: Ambientes}

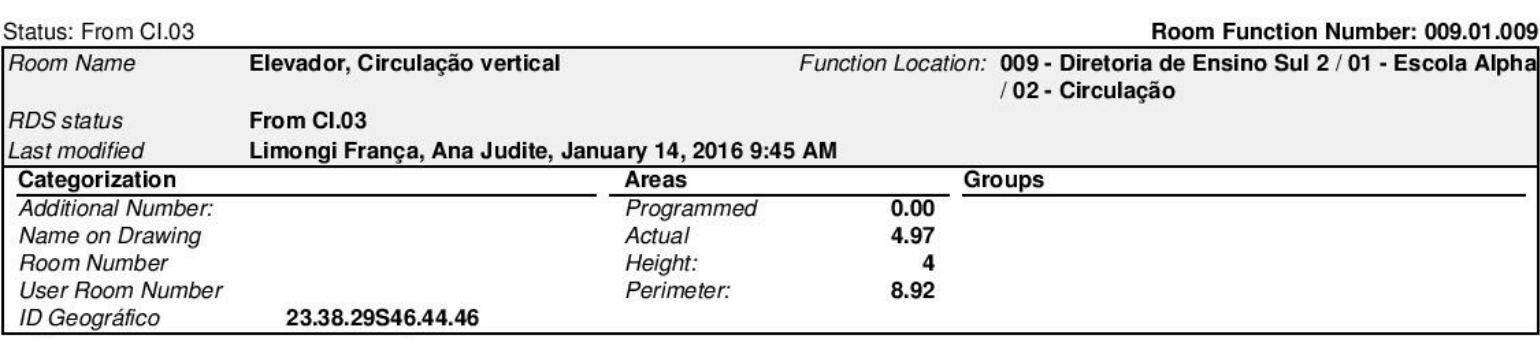

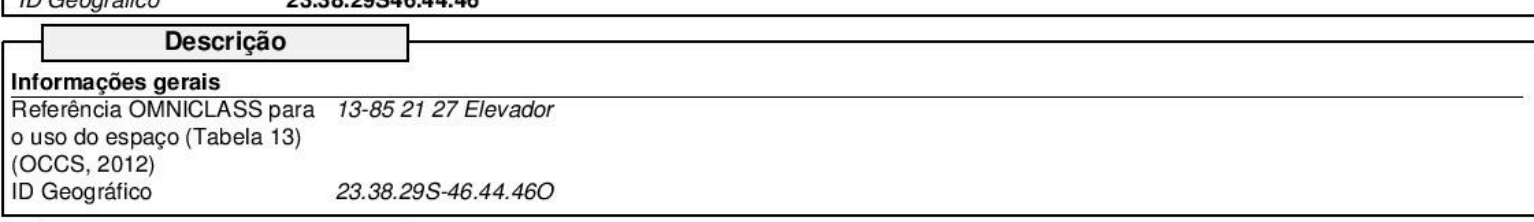

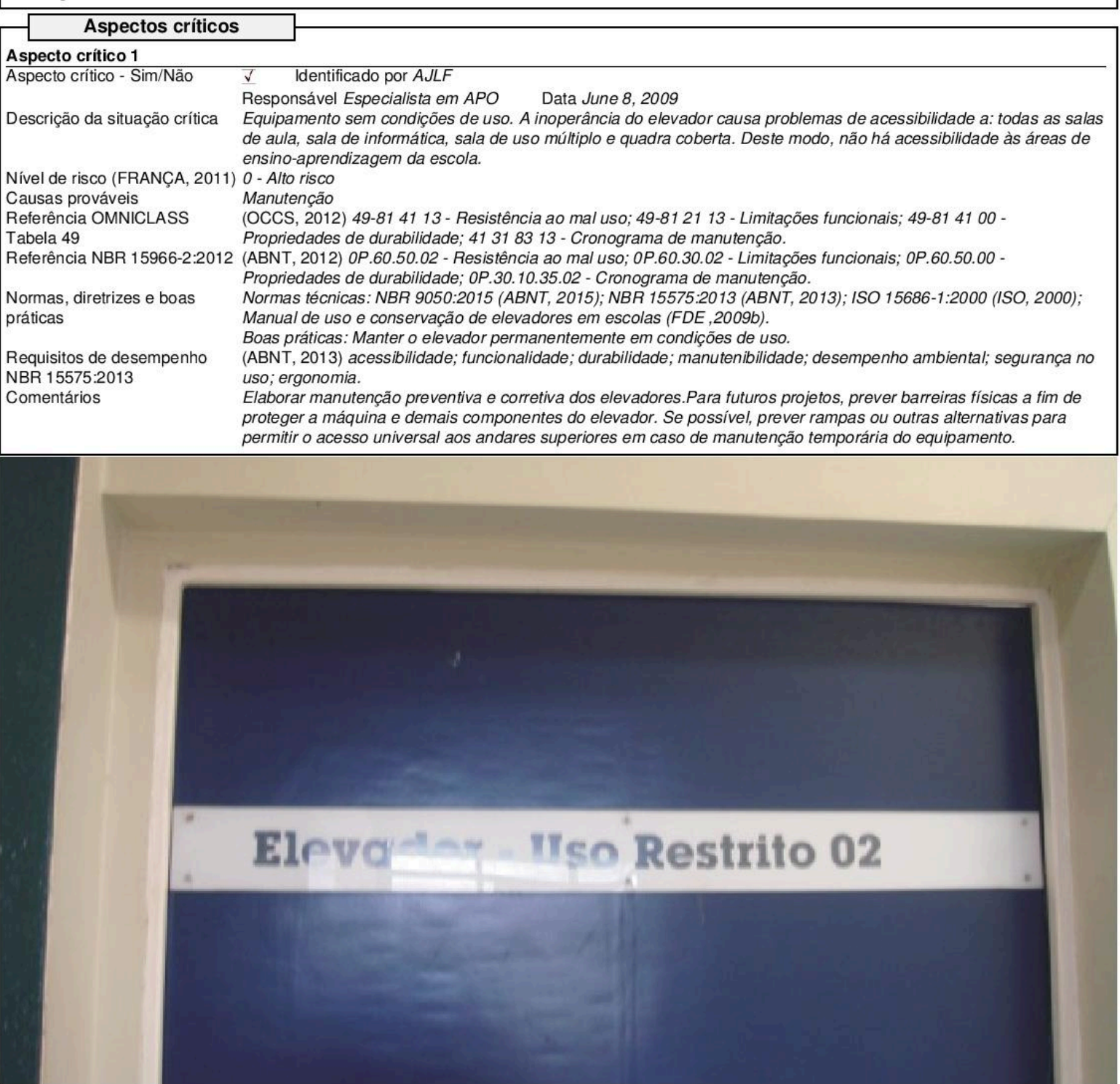

Evidência - aspecto crítico 1: acesso ao elevador trancado. Equipamento fora de operação. Fonte: Acervo da pesquisadora. 
Relatório de aspectos críticos: Ambientes

Status: Derived from $\mathrm{Cl} .002-2$

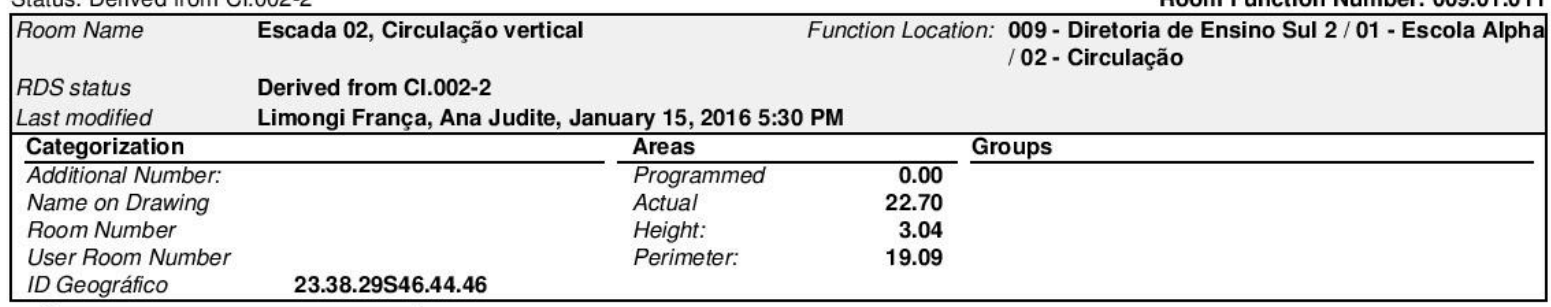

Descrição

Informações gerais

Referência OMNICLASS para 13-852111

o uso do espaço (Tabela 13)

(OCCS, 2012)

ID Geográfico 23.38.29S-46.44.460

Situação Em uso, conforme o projetado

Expressão Arquitetônica

Local de convivência, festas e atividades relacionadas a educação física.

Aspectos críticos

Aspecto crítico 1

Aspecto crítico - Sim/Não $\quad$ Identificado por AJLF

Responsável Especialista em APO Data September 8, 2009

Descrição da situação crítica Obstrução de rota de fuga pelo trancamento de gradis; acúmulo de mobiliário em manutenção, potencialmente combustive, sob escada de estrutura metálica.

Nivel de risco (FRANÇA, 2011) 0 - Alto risco

Causas prováveis Uso

Referência OMNICLASS (OCCS, 2012) 49-41318313 - Cronograma de manutenção; 49-8121 13 - Limitações funcionais.

Tabela 49

Referência NBR 15966-2:2012 (ABNT, 2012) OP.30.10.35.02 - Cronograma de manutenção; OP.60.30.02 - Limitações funcionais.

Normas, diretrizes e boas Normas técnicas: Decreto Estadual n²6.076:2001 (São Paulo, 2001); Instruções Técnicas do Corpo de Bombeiros da Polícia Militar (São Paulo, 2004); Manual de orientação à prevenção e ao combate a incêndio nas escolas (FDE, 2009).

Boas práticas: Manter hidrantes em condições de uso, conforme o projeto.

Requisitos de desempenho (ABNT, 2013) Acessibilidade; funcionalidade; durabilidade; manutenibilidade; segurança no uso; segurança contra NBR 15575:2013 incêndio.

Comentários

Realizar manutenção nos hidrantes e dos alarmes de incêndio da edificação e providenciar para que sejam mantidos em condiçōes permanentes de uso.

Aspecto crítico 2

Aspecto crítico - Sim/Não

$\checkmark \quad$ Identificado por $A J L F$

Responsável Especialista em APO Data June 8, 2009

Descrição da situação crítica Elevação dos trilhos dos gradis em relação ao nível do piso, causando um obstáculo em potencial, em desacordo com o projeto.

Nível de risco (FRANÇA, 2011) 0 - Alto risco

Causas prováveis Construção

Referência OMNICLASS (OCCS, 2012) 49-8121 13 - Limitações funcionais.

Tabela 49

Referência NBR 15966-2:2012 (ABNT, 2012) OP.60.30.02 - Limitações funcionais.

Normas, diretrizes e boas $\quad$ Normas técnicas: NBR 9050:2015 (ABNT, 2015); NBR 15575:2013 (ABNT, 2013); ISO 15686-1:2000 (ISO, 2000 ).

práticas

Requisitos de desempenho (ABNT, 2013) Acessibilidade; funcionalidade; durabilidade; manutenibilidade; segurança no uso; segurança contra

NBR 15575:2013 incêndio; conforto tátil; ergonomia.

Comentários Rebaixar o trilho do gradil nivelando-o ao piso acabado. 
MI MELHORIA CONTINUA APLICADA A

Database_SPEducational_Facilities

Status: Derived from Cl.002-2
Relatório de aspectos críticos: Ambientes

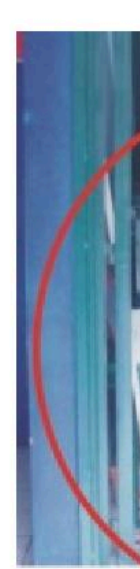

Room Function Number: 009.01.011

Evidência - aspecto crítico 1: gradil trancado, obstruíndo rota de fuga. Acúmulo de material potencialmente combustível sob escada de estrutura metálica. Fonte: Acervo da pesquisadora.

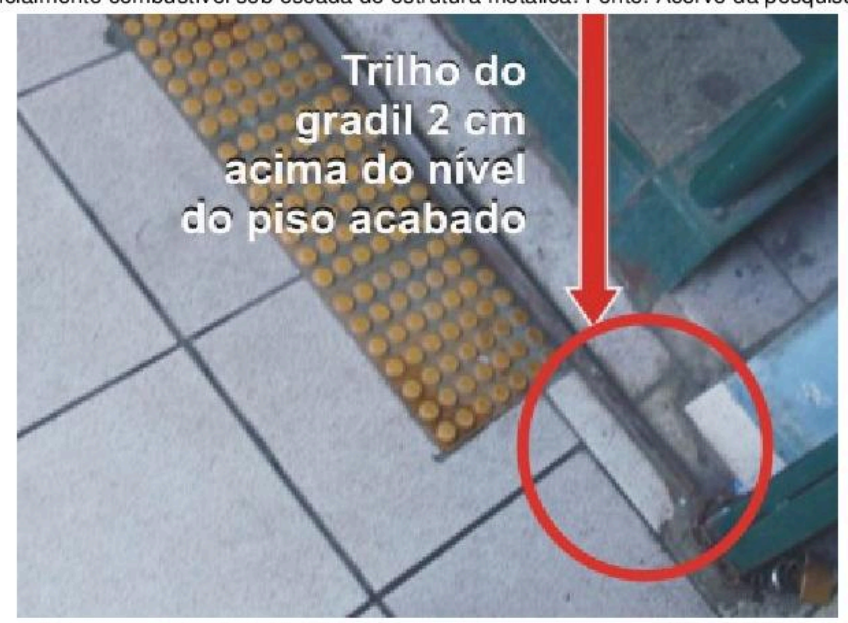

Evidência - aspecto crítico 2: desnível em piso de rota de fuga, causado por trilho de gradil. Fonte: Acervo da pesquisadora. 

MELHORIA CONTINUAA APLICADA A
EDIFICACOCES DE TIPOLOGIA PADRONIZADA

Database_SPEducational_Facilities
Relatório de aspectos críticos: Ambientes

\begin{tabular}{|c|c|c|c|}
\hline Status: From EA.09-1 & & \multicolumn{2}{|r|}{ Room Function Number: 009.01.013 } \\
\hline Room Name & $\begin{array}{l}\text { Recuperação 01, Atividades de ensino- } \\
\text { aprendizagem complementares }\end{array}$ & Function Local & $\begin{array}{l}\text { ion: } 009 \text { - Diretoria de Ensino Sul } 2 \text { / } 01 \text { - Escola Alpha } \\
\text { / } 03 \text { - Ensino-aprendizagem }\end{array}$ \\
\hline RDS status & From EA.09-1 & & \\
\hline Categorization & Areas & & Groups \\
\hline Additional Number: & Programmed & 24.15 & Ambientes de Ensino- \\
\hline Name on Drawing & Actual & 24.15 & aprendizagem \\
\hline Room Number & Height: & 3 & \\
\hline
\end{tabular}

Uso alterado para sala de coordenador pedagógico.

\section{Informacões gerais}

Referência OMNICLASS para 13-31.13.15

o uso do espaço (Tabela 13)

(OCCS, 2012)

ID Geográfico 23.38.29S-46.44.46O-1P-O

Situação Em operação, modificado

Dimensões mínimas

Requisitos quanto às

dimensões do ambiente

Largura - entre eixos $(\mathrm{m})$

Profundidade - entre eixos $(\mathrm{m}) \quad \bar{v} \quad 3.6$

Altura mínima - a partir do piso $\checkmark \quad 3$

acabado $(\mathrm{m})$

Expressão Arquitetônica

Flexibilidade, para permitir o desenvolvimento de diferentes atividades pedagógicas, inclusive com a utilização de recursos de multimídia.

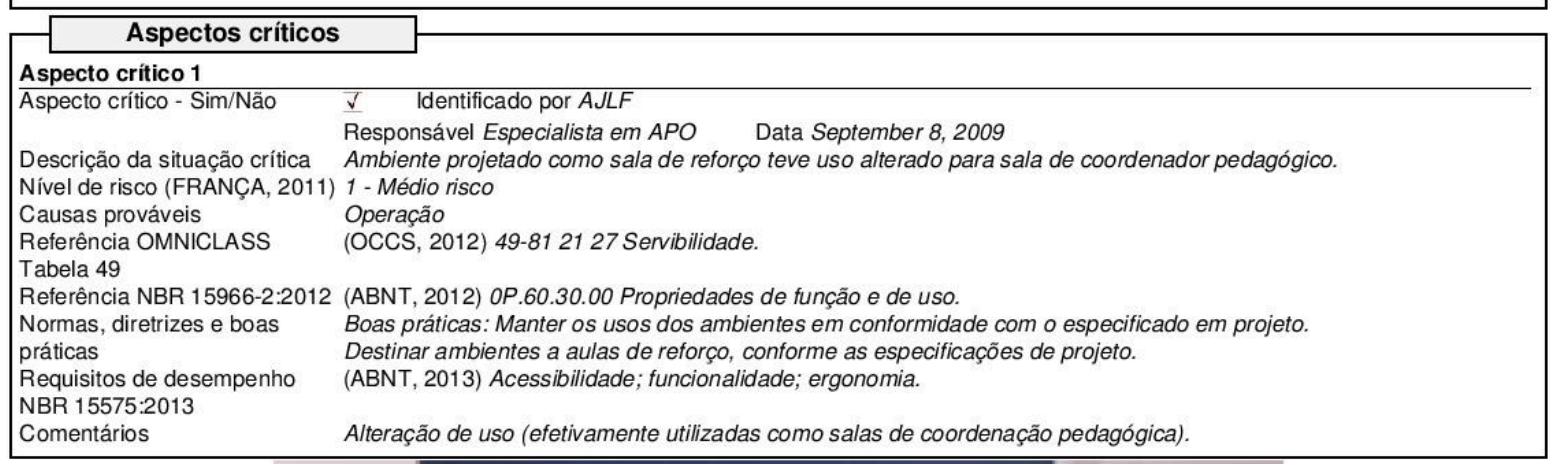

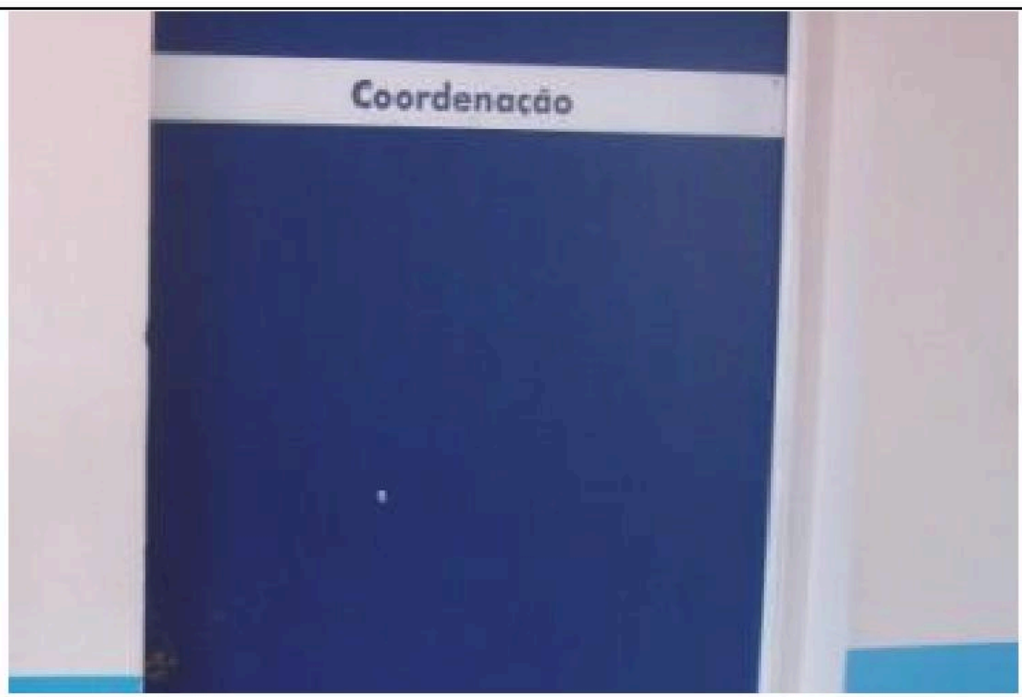

Evidência - aspecto crítico 1: ambiente projetado como sala de reforço efetivamente utilizado como sala do coordenador pedagógico. Fonte: Acervo da pesquisadora. 
Relatório de aspectos críticos: Ambientes

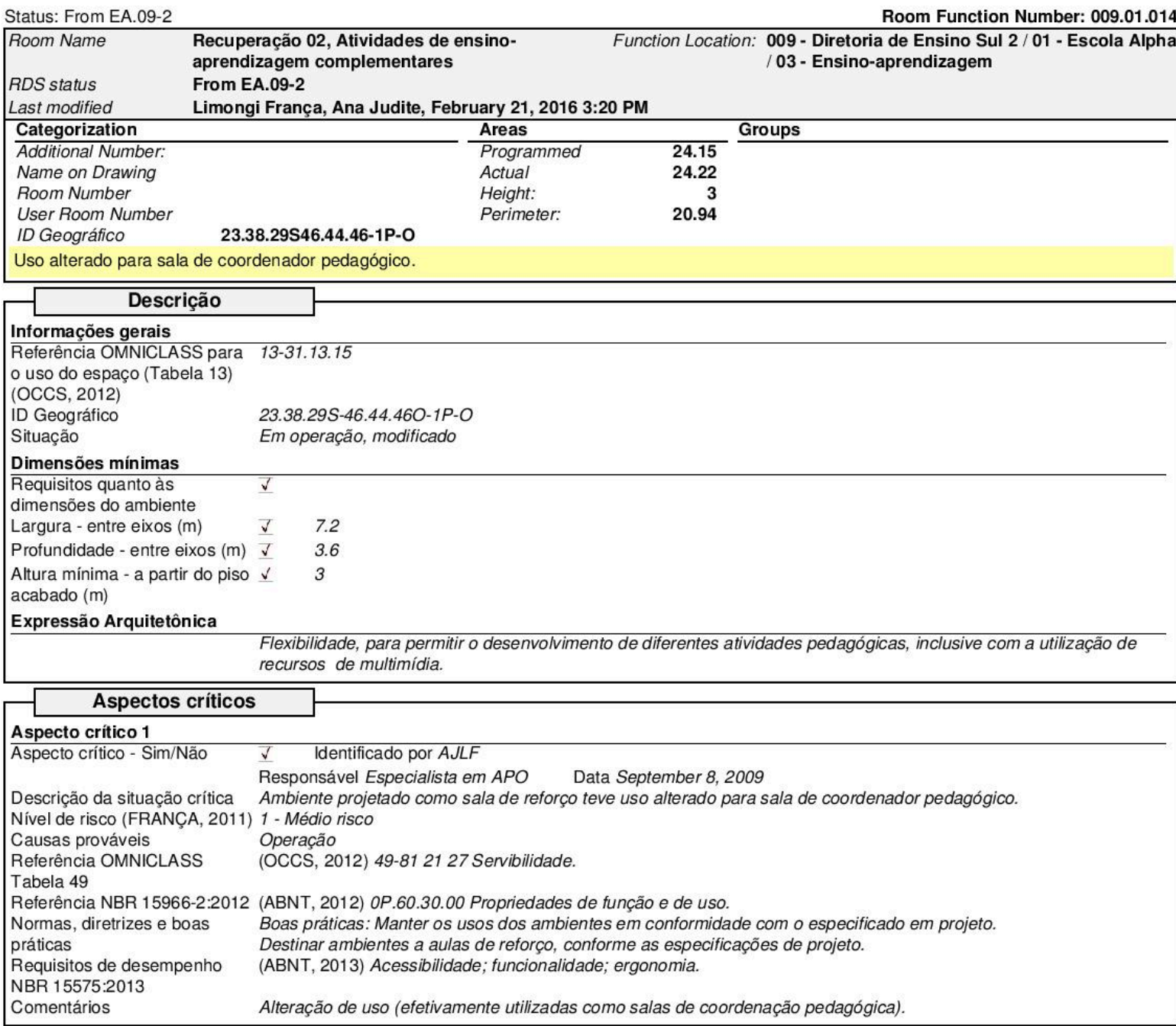


Relatório de aspectos críticos: Ambientes

Status: From EA.08-2

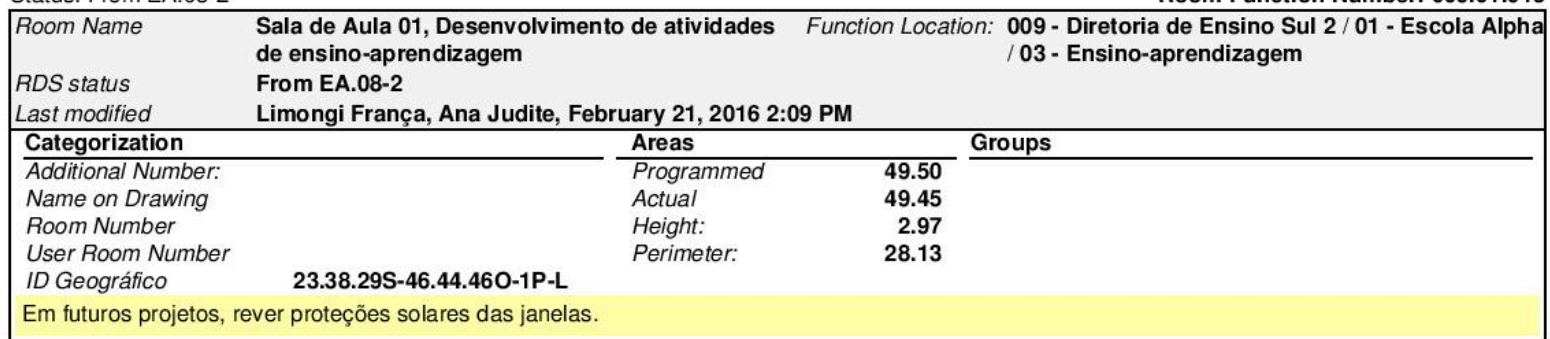

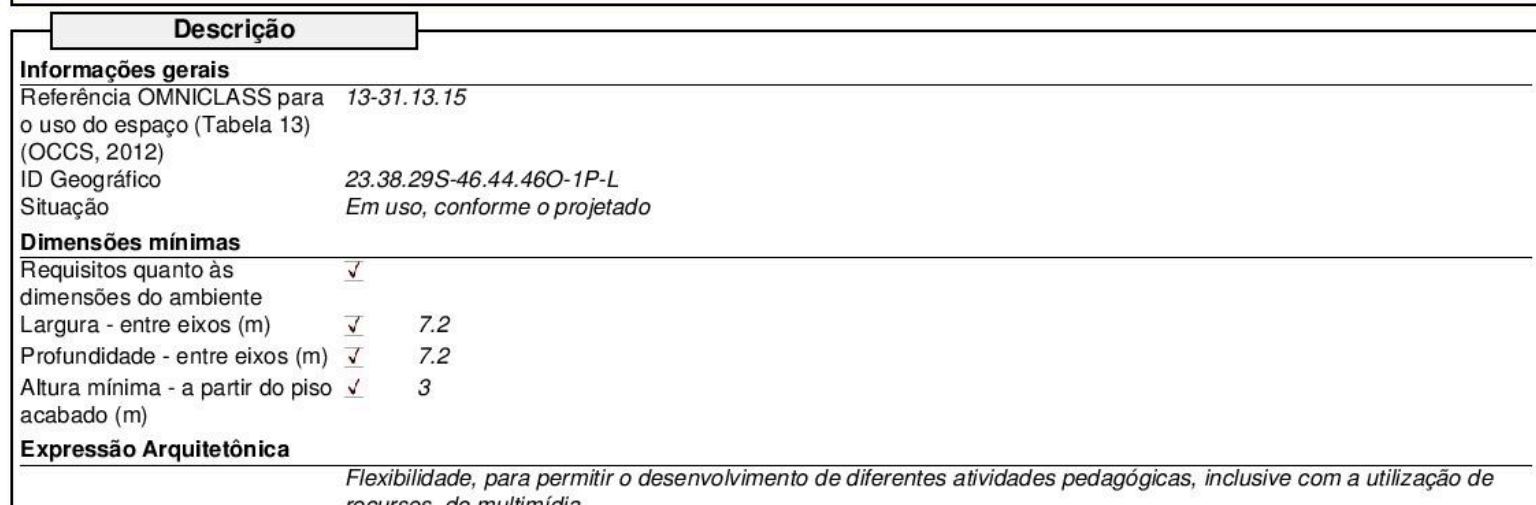
recursos de multimídia.

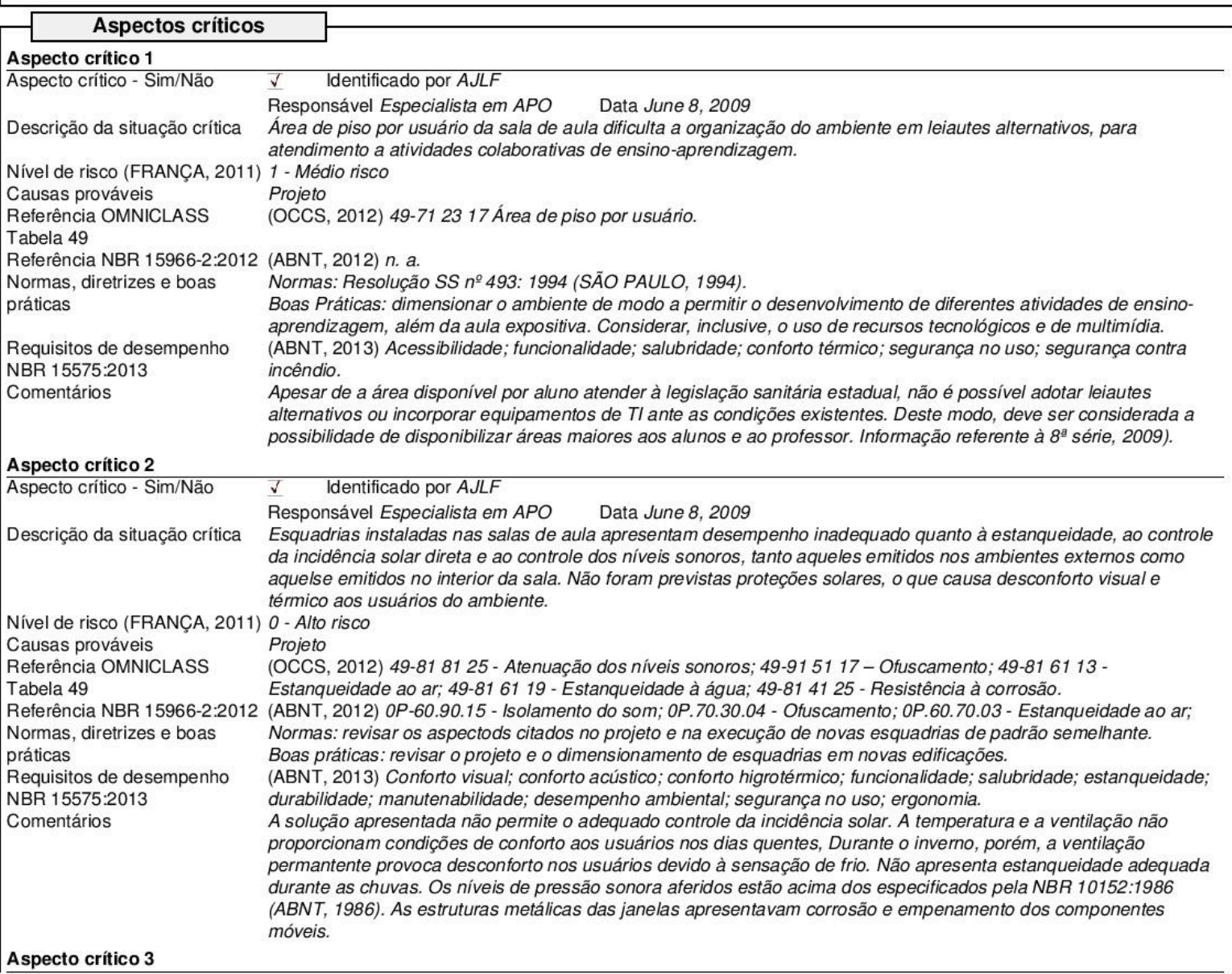




\section{Relatório de aspectos críticos:} Ambientes

Status: From EA.08-2

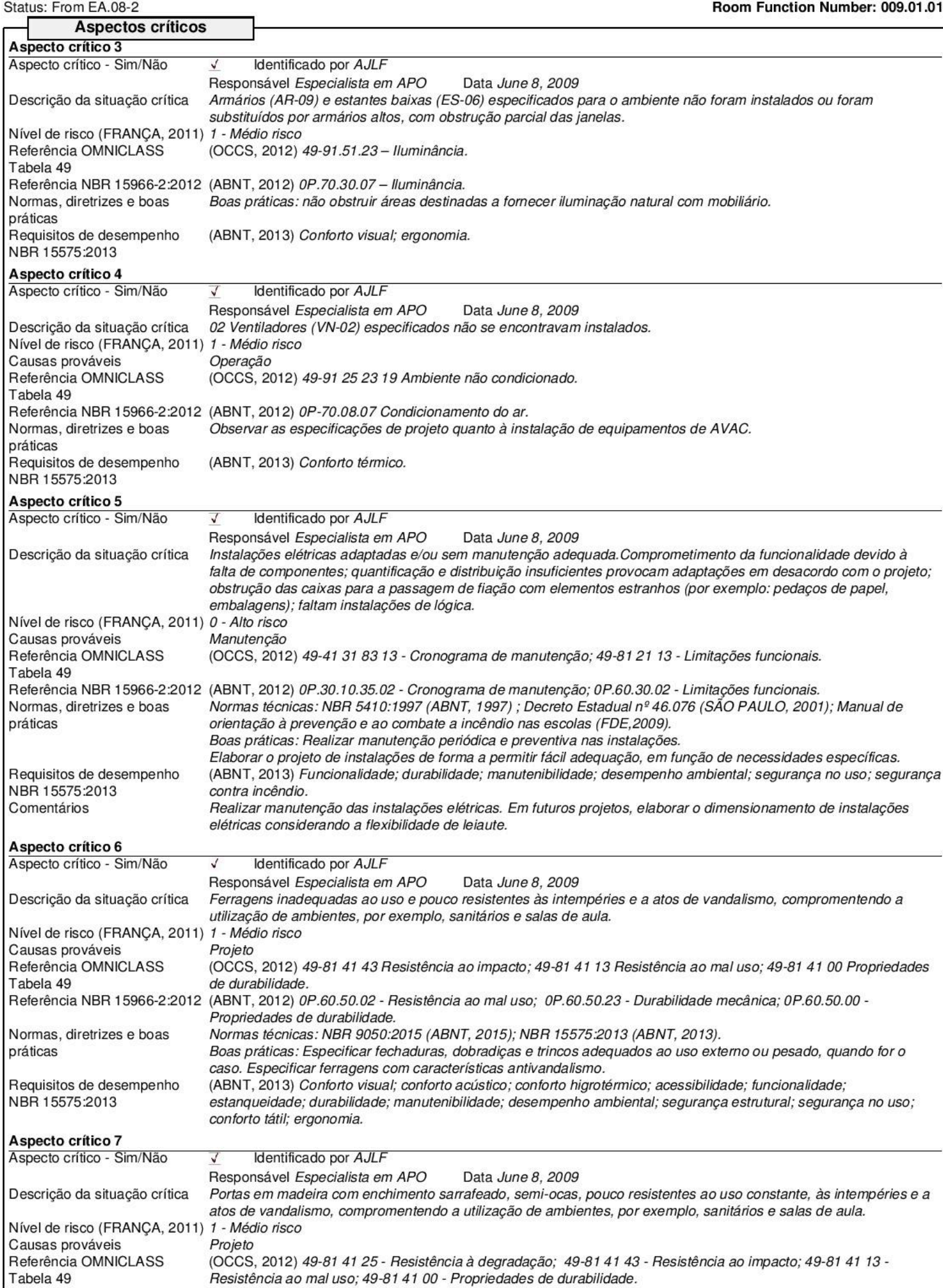


MELHORIA CONTÍNUA APLICADA A

불 Database SPEducational Facilities
Relatório de aspectos críticos: Ambientes

Status: From EA.08-2

Room Function Number: 009.01.015

\section{Aspectos críticos \\ Aspecto crítico 7}

Referência NBR 15966-2:2012 (ABNT, 2012) OP.60.50.02 - Resistência ao mal uso; OP.60.50.23 - Durabilidade mecânica; OP.60.50.00 -

Propriedades de durabilidade.

Normas, diretrizes e boas $\quad$ Normas técnicas: NBR 9050:2015 (ABNT, 2015); NBR 15575:2013 (ABNT, 2013); ISO 15686-1:2000 (ISO, 2000).

práticas

Requisitos de desempenho (ABNT, 2013) Especificar portas adequadas ao uso externo ou pesado, quando for o caso. estanqueidade; durabilidade; manutenibilidade; desempenho ambiental; segurança estrutural; segurança no uso; segurança contra incêndio; conforto tátil; ergonomia.

Comentários Substituir portas por itens com características compatíveis ao uso. Para futuras escolas, rever os critérios para a especificação de portas.

Aspecto crítico 8

\begin{tabular}{llcl}
\hline Aspecto crítico - Sim/Não & $\checkmark$ & Identificado por AJLF \\
& Responsável Especialista em APO Data August 6, 2009
\end{tabular}

Descrição da situação crítica Falta de interruptores nas salas de aula. O acionamento é feito por meio de um quadro geral para o andar. Não e possível acionar parcialmente as luminárias de uma sala de aula.Os quadros nos quais é previsto o acionamento ficam trancados à chave.

Nível de risco (FRANÇA, 2011) 1 - Médio risco

Causas prováveis Projeto

Referência OMNICLASS ～(OCCS, 2012) 49-91 5147 - Controles de iluminação; 49-91 8121 - Eficiência energética.

Rela 49 (ABNT, 2012) OP.70.30.19 - Controles de iluminação; OP.70.60.06 - Eficiência energética.

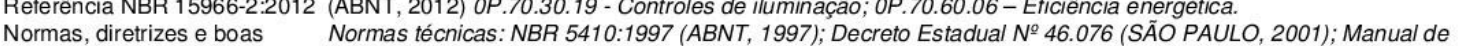
práticas Normas técnicas: NBR 5410:1997 (ABNT, 1997); Decreto Estadual № 46.076 (SÃO PAULO, 2001); Manual
orientação à prevenção e ao combate a incêndio nas escolas (FDE, 2009); NBR 5413:1992 (ABNT, 1992). Boas práticas: Realizar manutenção periódica e preventiva nas instalações.

Elaborar o projeto de instalações de forma a permitir o fácil acesso e o controle dos níveis de iluminamento, em função de atividades pedagógicas específicas.

Requisitos de desempenho (ABNT, 2013) conforto visual; conforto higrotérmico; acessibilidade; funcionalidade; durabilidade; manutenibilidade; NBR 15575:2013 Comentários desempenho ambiental; segurança no uso; segurança contra incêndio; ergonomia.

Adotar medidas para permitir o controle dos niveis de iluminamento nas salas de aula. Prover fácil acesso às instalações elétricas dos quadros, em caso de emergência. Em futuros projetos, incluir controles acessíveis aos professores e dimensionar os circuitos considerando o leiaute previsto.

Aspecto crítico 9

Aspecto crítico - Sim/Não $\checkmark \quad$ Identificado por $A J L F$

Responsável Especialista em APO Data August 6, 2009

Descrição da situação crítica Falta/quebra de componentes; falta de mobiliário adequado (conjunto aluno) para alunos de baixa estatura.

Nível de risco (FRANÇA, 2011) 1 - Médio risco

Causas prováveis Manutenção

Referência OMNICLASS ～(OCCS, 2012) 49-814113-Resistência ao mal uso; 49-413183 13 - Cronograma de manutenção; $49-8121$ 13 -

Tabela $49 \quad$ Limitações funcionais.

Referência NBR 15966-2:2012 (ABNT, 2012) OP.60.50.02 - Resistência ao mal uso; 0P.30.10.35.02 - Cronograma de manutenção; OP.60.30.02 Limitações funcionais.

Normas, diretrizes e boas $\quad$ Normas técnicas: NBR 9050:2015 (ABNT, 2015); Especificações da Edificação Escolar: Ambientes/ Distribuição/ práticas Mobiliário (FDE, 2006).

Boas práticas: Manter o mobiliário escolar em plena condição de uso.

Requisitos de desempenho (ABNT, 2013) conforto visual; conforto higrotérmico; acessibilidade; funcionalidade; durabilidade; manutenibilidade; NBR 15575:2013 desempenho ambiental; segurança no uso; segurança contra incêndio; ergonomia.

Comentários Realizar substituição eficiente em caso de desgaste ou vandalismo. Em escolas que atendam alunos dos Ciclos I e II, providenciar mobiliário adequado aos alunos de baixa estatura.

Aspecto crítico 10 Aspecto crítico - Sim/Não $\checkmark \quad$ Identificado por $A J L F$

Responsável Especialista em APO Data August 6, 2009

Descrição da situação crítica Falta de elementos de sinalização previstos em projeto (devido a quebra/ remoção); elaboração de sinalização improvisada, em desacordo com o projeto.

Nível de risco (FRANÇA, 2011) 2 - Baixo risco

Causas prováveis Uso

Referência OMNICLASS (OCCS, 2012) 49-814113 - Resistência ao mal uso; 49-8141 00 - Propriedades de durabilidade; $49-8121$ 13 -

Tabela $49 \quad$ Limitaçōes funcionais.

Referência NBR 15966-2:2012 (ABNT, 2012) OP.60.50.02 - Resistência ao mal uso; 0P.60.50.00 - Propriedades de durabilidade; OP.60.30.02 -

Limitações funcionais.

, diretrizes e boas

práticas

Norma técnica: NBR 9050:2015.

Boas práticas: Manter os elementos de comunicação visual e sinalização em condiçães de uso.

$\begin{array}{ll}\text { NBR 15575:2013 } & \text { (ABNT, 2013) Acessibilidade; func } \\ \text { uso; segurança contra incêndio. }\end{array}$

Comentários Rever as especificações para a sinalização dos ambientes, considerando soluções mais resistentes a vandalismo. 
7 MELHORIA CONTÍNUA APLICADA

Database_SPEducational_Facilities

Status: From EA.08-2

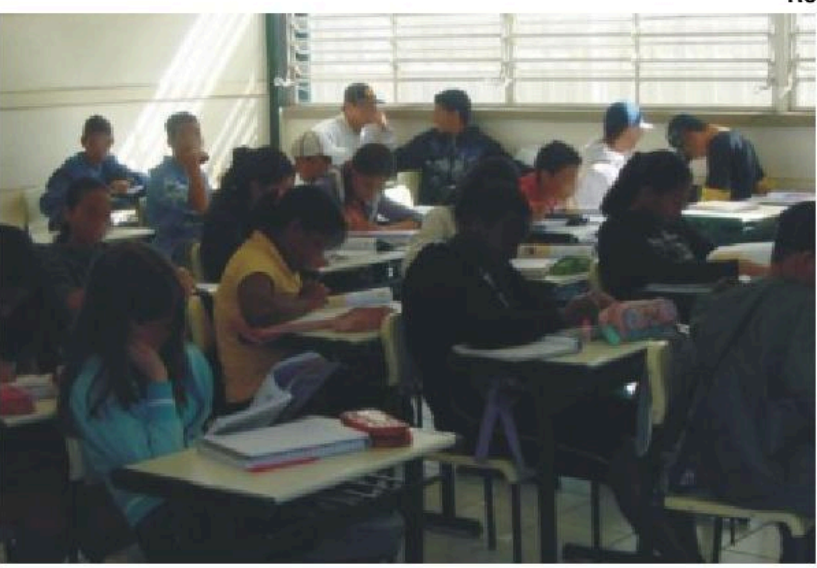

Evidência - aspecto crítico 1: dimensionamento da sala de aula $\left(1,2 \mathrm{~m}^{2} /\right.$ aluno $)$ dificulta a realização de atividades de ensino-aprendizagem colaborativas. Fonte: Acervo da pesquisadora.

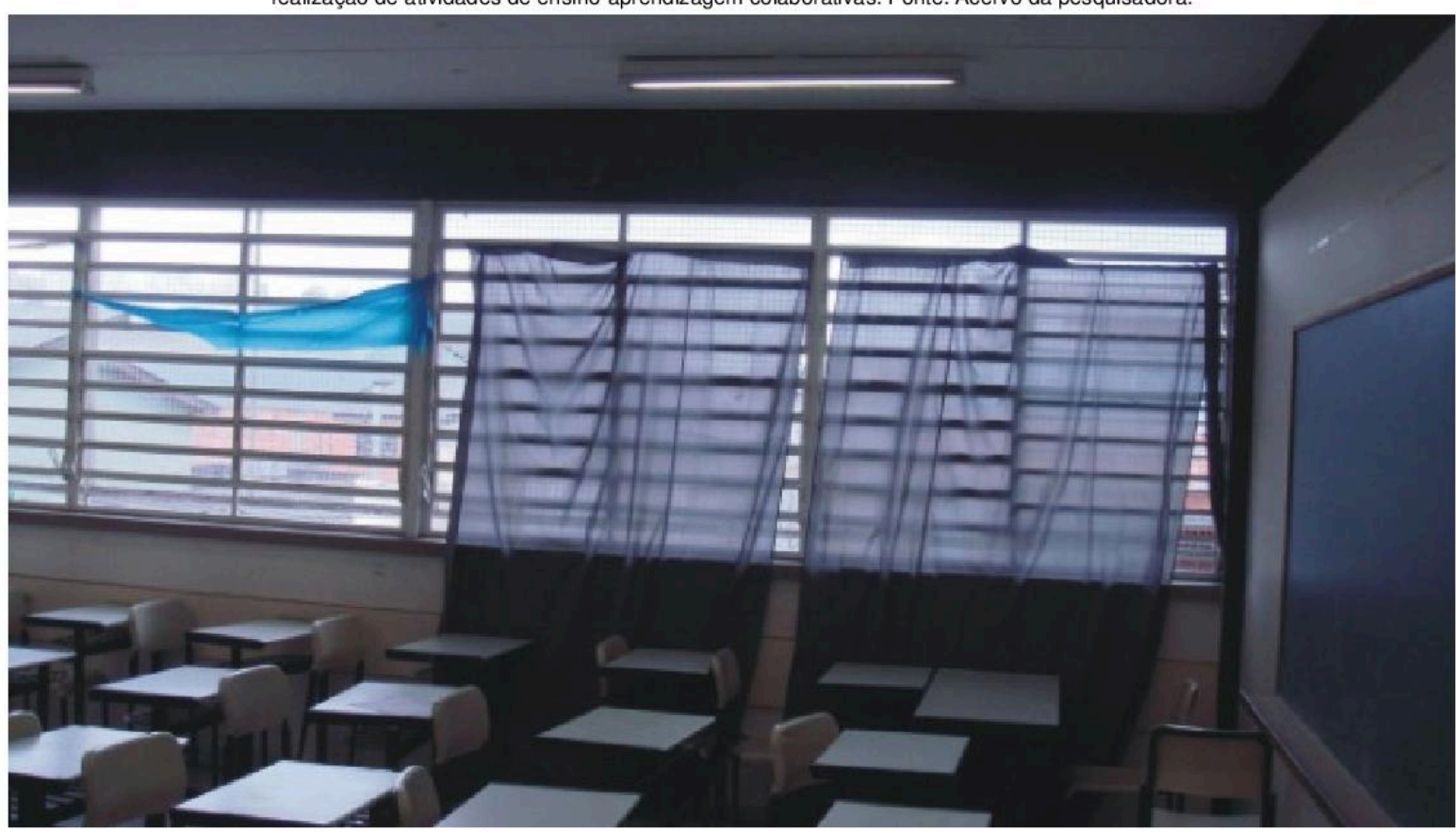

Evidência - aspecto crítico 2: falta de elementos de proteção solar nas janelas causa a incidência solar direta no plano de trabalho (carteiras escolares). Fonte: Acervo da pesquisadora. 
酒

MELHORIA CONTÍNUA APLICADA A

Database SPEducational Facilitio

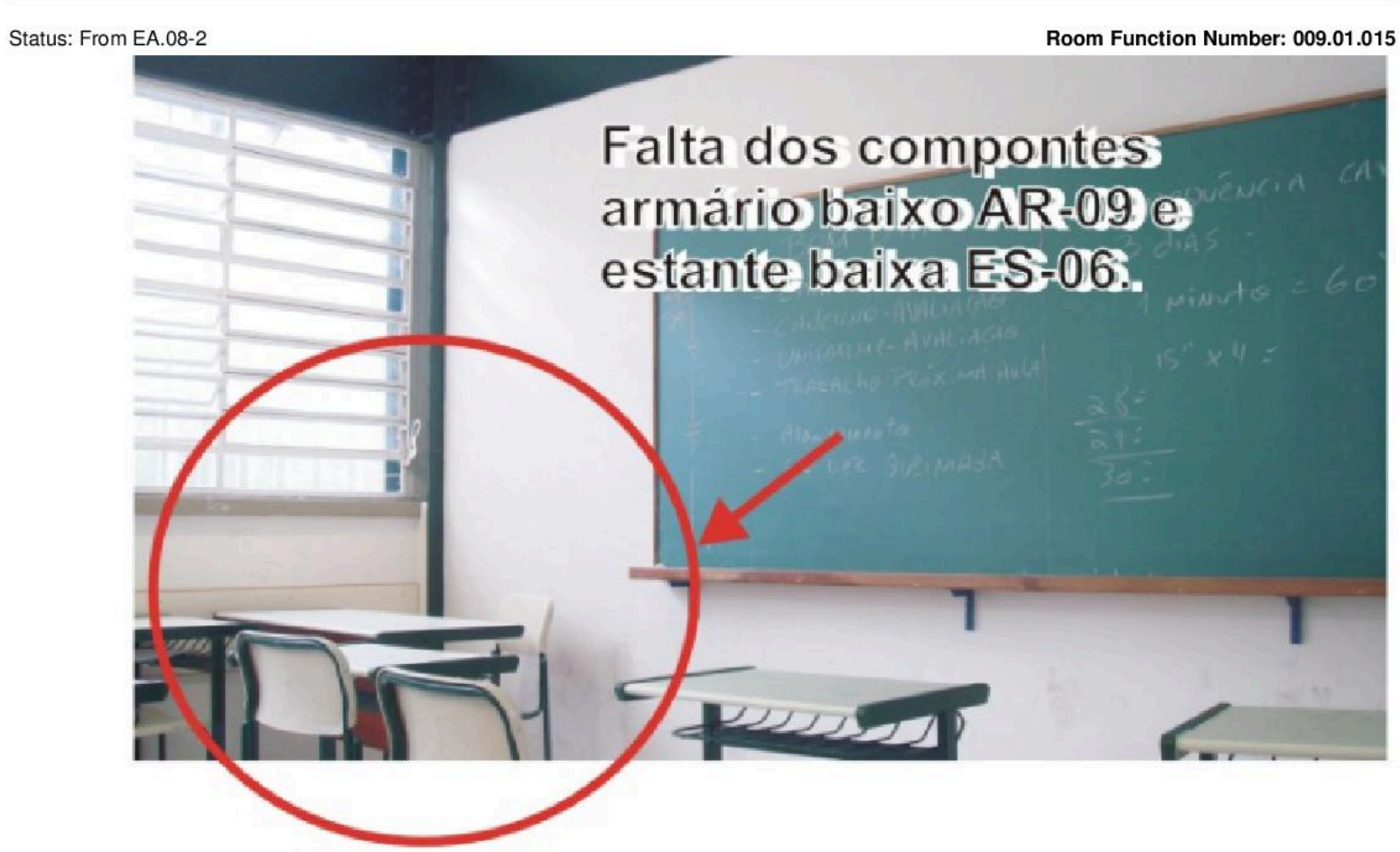

Relatório de aspectos críticos: Ambientes

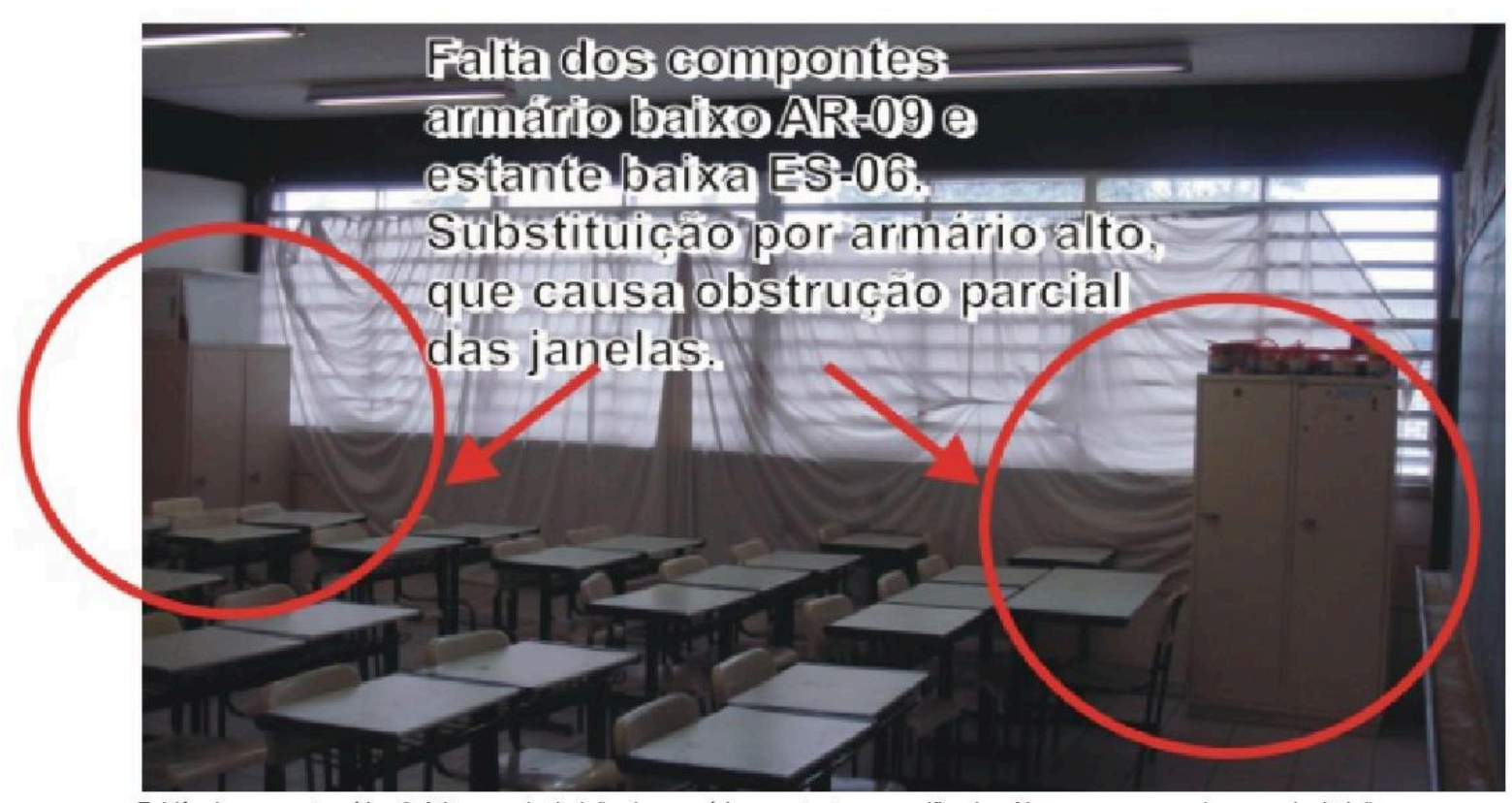

Evidência - aspecto crítico 3: falta ou substituição dos armários e estantes especificados. Nos casos em que houve substituição pelos armários altos, a iluminação natural foi prejudicada pela obstrução parcial das janelas. Fonte: Acervo da pesquisadora. 
Relatório de aspectos críticos:

Database_SPEducational_Facilities Ambientes

Status: From EA.08-2

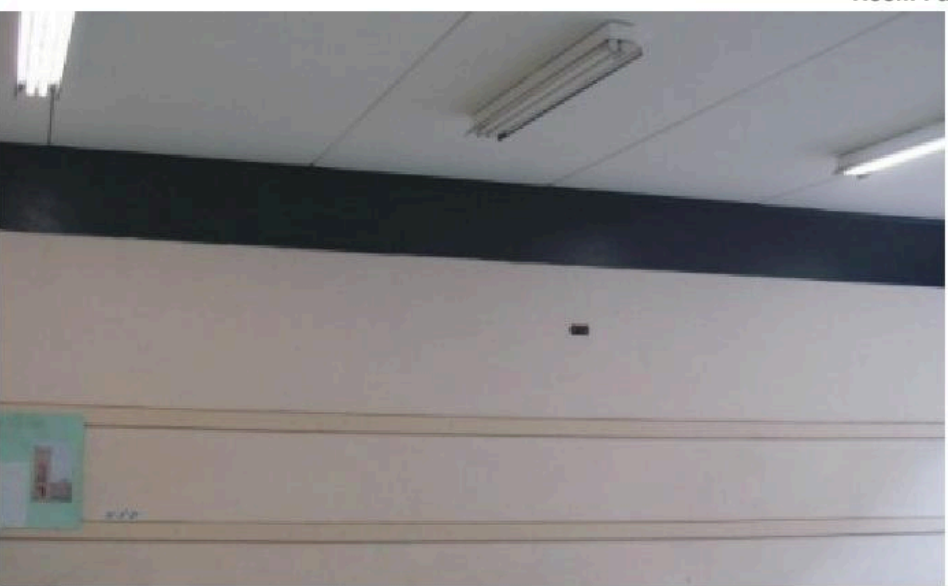

Room Function Number: 009.01.015

Evidência - aspecto crítico 4: falta de ventiladores VN-02. Nenhuma das unidades especificadas para as salas de aula estavam instaladas à época dos levantamentos (2009). Fonte: Acervo da pesquisadora.

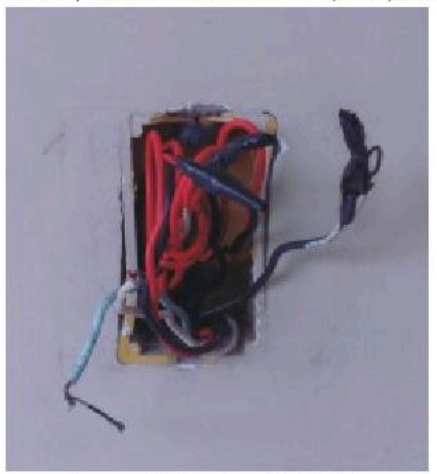

Evidência - aspecto crítico 5: comprometimento da funcionalidade de tomadas devido à falta de componentes; quantificação e distribuição insuficientes; faltam instalações de lógica. Fonte: Acervo da pesquisadora.

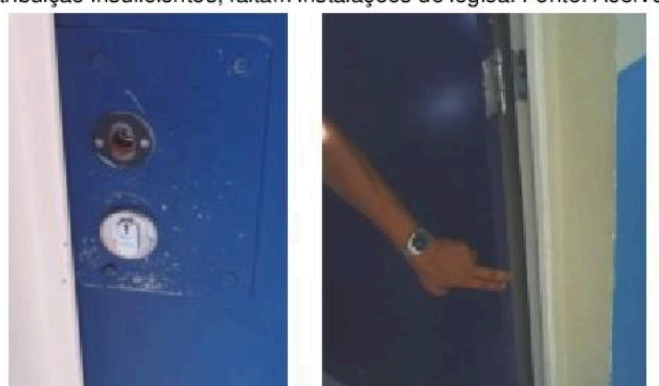

Evidência - aspecto crítico 6: Resistência insuficiente de componentes tais como dobradiças e fechaduras. Fonte: Acervo da pesquisadora.

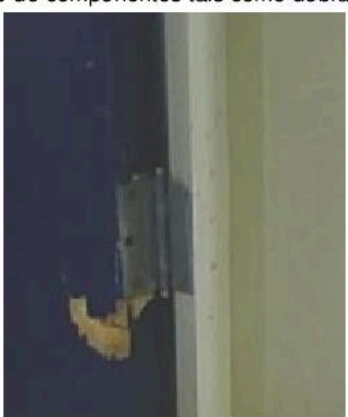

Evidência - aspecto crítico 7: Resistência insuficiente de porta em área semiexposta e em ambiente sujeito a arrombamento. Fonte: Acervo da pesquisadora. 
酒 Database_SPEducational_Facilities

Status: From EA.08-2
Relatório de aspectos críticos: Ambientes

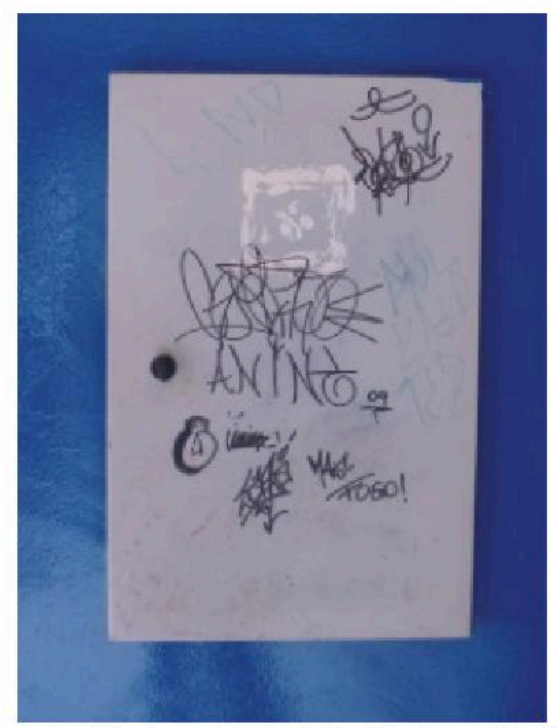

Room Function Number: 009.01.015

Evidência - aspecto crítico 8: quadros de distribuição de energia utilizados para o acionamento de luminárias nas salas de aulas. Fonte: Acervo da pesquisadora.

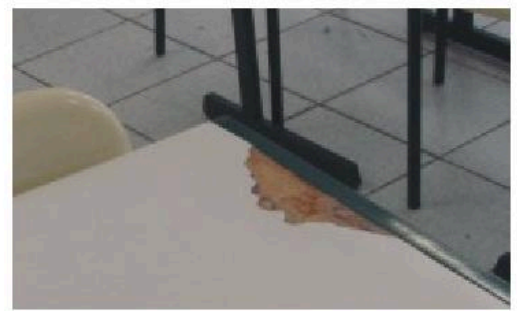

Evidência - aspecto crítico 9: Carteiras escolares danificadas. Fonte: Acervo da pesquisadora.
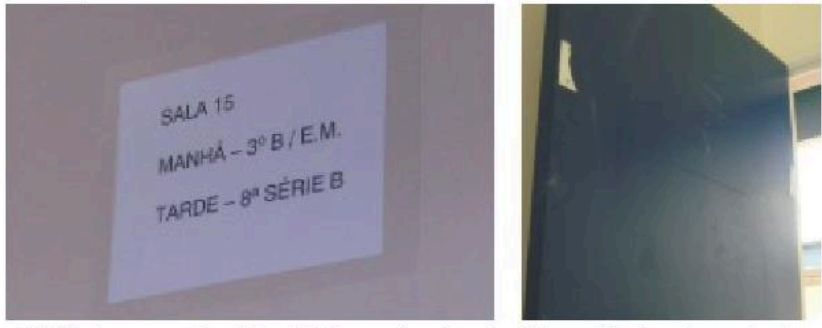

Evidência - aspecto crítico 10: Comunicação visual de ambientes improvisada. Sinalização prevista em projeto danificada. Fonte: Acervo da pesquisadora. 
Relatório de aspectos críticos: Database_SPEducational_Facilities Ambientes

\begin{tabular}{|c|c|c|c|}
\hline Status: From EA.08 & & & Room Function Number: 009.01.029 \\
\hline Room Name & $\begin{array}{l}\text { Sala de Aula 15, Desenvolvimento de atividades } \\
\text { de ensino-aprendizagem }\end{array}$ & Function Location: & $\begin{array}{l}009 \text { - Diretoria de Ensino Sul } 2 \text { / } 01 \text { - Escola Alpha } \\
\text { / } 03 \text { - Ensino-aprendizagem }\end{array}$ \\
\hline RDS status & From EA.08 & & \\
\hline Last modified & Limongi França, Ana Judite, January 16, $20168: 4$ & 5 AM & \\
\hline Categorization & Areas & & aroups \\
\hline Additional Number: & Programmed & 49.50 & \\
\hline Name on Drawing & Actual & 49.42 & \\
\hline Room Number & Height: & 2.99 & \\
\hline User Room Number & Perimeter: & 28.12 & \\
\hline ID Geográfico & 23.38.29S46.44.46W-1P-O & & \\
\hline
\end{tabular}

Em futuros projetos, rever proteções solares das janelas.

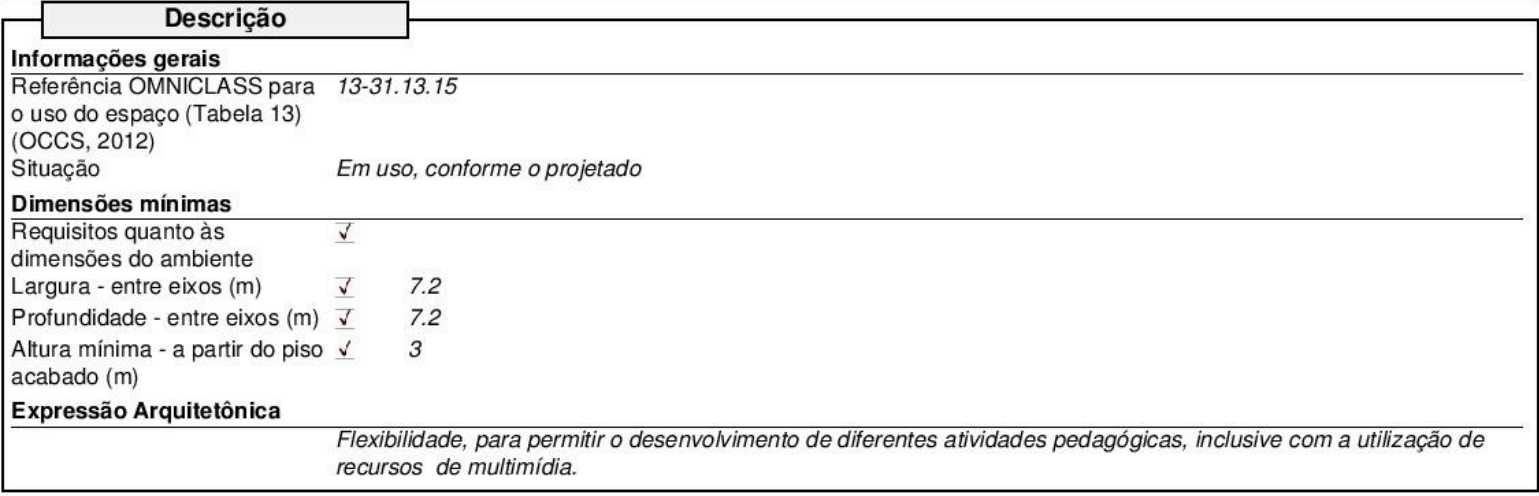

Aspectos críticos

Aspecto crítico 1

Aspecto crítico - Sim/Não $\quad \checkmark \quad$ Identificado por AJLF

Responsável Especialista em APO Data June 8, 2009

Descrição da situação crítica Área de piso por usuário da sala de aula dificulta a organização do ambiente em leiautes alternativos, para atendimento a atividades colaborativas de ensino-aprendizagem.

Nível de risco (FRANÇA, 2011) 1 - Médio risco

Causas prováveis Projeto

Referência OMNICLASS $\quad$ (OCCS, 2012) 49-712317 Área de piso por usuário.

Tabela 49

Referência NBR 15966-2:2012 (ABNT, 2012) n. a.

Normas, diretrizes e boas Normas: Resolução SS nº 493: 1994 (SÃO PAULO, 1994).

práticas

$\begin{array}{ll}\text { Requisitos de desempenho } & \text { (ABNT, 2013) Acessibilidade; funcionalidade; salubridade; conforto térmico; segurança no uso; segurança contra }\end{array}$

NBR 15575:2013 incêndio.

Comentários Apesar de a área disponivel por aluno atender à legislação sanitária estadual, não é possível adotar leiautes alternativos ou incorporar equipamentos de $\mathrm{Tl}$ ante as condições existentes. Deste modo, deve ser considerada a possibilidade de disponibilizar áreas maiores aos alunos e ao professor. Informação referente à $8^{\mathrm{a}}$ série, 2009).

Aspecto crítico 2

Aspecto crítico - Sim/Não $\checkmark \quad$ Identificado por $A J L F$

Responsável Especialista em APO Data June 8, 2009

Descrição da situação crítica Esquadrias instaladas nas salas de aula apresentam desempenho inadequado quanto à estanqueidade, ao controle da incidência solar direta e ao controle dos níveis sonoros, tanto aqueles emitidos nos ambientes externos como aquelse emitidos no interior da sala. As proteções solares instaladas não apresentam eficiência adequada em períodos nos quais a incidência solar se dá com ângulos maiores (período entre 11:00 e 14:00), o que causa desconforto visual e térmico aos usuários do ambiente.

Nível de risco (FRANÇA, 2011) 0 - Alto risco

Causas prováveis Projeto

Referência OMNICLASS ～(OCCS, 2012) 49-81 8125 - Atenuação dos níveis sonoros; 49-9151 17 - Ofuscamento; 49 -81 6113 -

Tabela 49 Estanqueidade a0 ar; 49-816119 - Estanqueidade à água; $49-814125$ - Resistência à corrosão.

Referência NBR 15966-2:2012 (ABNT, 2012) OP-60.90.15 - Isolamento do som; OP.70.30.04 - Ofuscamento; OP.60.70.03 - Estanqueidade ao ar;

Normas, diretrizes e boas Normas: revisar os aspectods citados no projeto e na execução de novas esquadrias de padrão semelhante.

práticas

Requisitos de desempenho

NBR 15575:2013

Comentários Boas práticas: revisar o projeto e o dimensionamento de esquadrias em novas edificaçôes.

(ABNT, 2013) Conforto visual; conforto acústico; conforto higrotérmico; funcionalidade; salubridade; estanqueidade; durabilidade; manutenibilidade; desempenho ambiental; seguranç no uso; ergonomia.

A solução apresentada não permite o adequado controle da incidência solar. A temperatura e a ventilação não proporcionam condições de conforto aos usuários nos dias quentes, Durante o inverno, porém, a ventilação permantente provoca desconforto nos usuários devido à sensação de frio. Não apresenta estanqueidade adequada durante as chuvas. Os níveis de pressão sonora aferidos estão acima dos especificados pela NBR 10152:1986 (ABNT, 1986). As estruturas metálicas das janelas apresentavam corrosão e empenamento dos componentes

Aspecto crítico 3 
MELHORIA CONTÍNUA APLICADA A
Relatório de aspectos críticos: Ambientes

Status: From EA.08

Room Function Number: 009.01.029

\section{Aspectos críticos}

Aspecto crítico - Sim/Não

Descrição da situação crítica

Identificado por $A J L F$

Responsável Especialista em APO Data June 8, 2009

substituídos por armários altos, com obstrução parcial das janelas.

Referência OMNICLASS (OCCS, 2012) 49-91.51.23-Iluminância.

Tabela 49

Referência NBR 15966-2:2012 (ABNT, 2012) OP.70.30.07 - Iluminância.

Normas, diretrizes e boas $\quad$ Boas práticas: não obstruir áreas destinadas a fornecer iluminação natural com mobiliário.

práticas

Requisitos de desempenho (ABNT, 2013) Conforto visual; ergonomia.

NBR 15575:2013

\section{Aspecto crítico 4}

\begin{tabular}{lll}
\hline Aspecto crítico - Sim/Não & $\checkmark$ & Identificado por AJLF \\
& Responsável Especialista em APO Data June 8, 2009
\end{tabular}

Descrição da situação crítica 02 Ventiladores (VN-02) especificados não se encontravam instalados.

Nível de risco (FRANÇA, 2011) 1 - Médio risco

Causas prováveis Operação

Referência OMNICLASS $\quad$ (OCCS, 2012) 49-91252319 Ambiente não condicionado.

Tabela 49

Referência NBR 15966-2:2012 (ABNT, 2012) OP-70.08.07 Condicionamento do ar.

Normas, diretrizes e boas Observar as especificações de projeto quanto à instalação de equipamentos de AVAC.

práticas

Requisitos de desempenho (ABNT, 2013) Conforto térmico.

NBR 15575:2013

Aspecto crítico 5

Aspecto crítico - Sim/Não $\quad \checkmark \quad$ Identificado por $A J L F$

Responsável Especialista em APO Data June 8, 2009

Descrição da situação crítica Instalações elétricas adaptadas e/ou sem manutenção adequada. Comprometimento da funcionalidade devido à falta de componentes; quantificação e distribuição insuficientes provocam adaptações em desacordo com o projeto; obstrução das caixas para a passagem de fiação com elementos estranhos (por exemplo: pedaços de papel, embalagens); faltam instalações de lógica.

Nível de risco (FRANÇA, 2011) 0 - Alto risco

Causas prováveis Manutenção

Referência OMNICLASS （OCCS, 2012) 49-41318313 - Cronograma de manutenção; 49-8121 13 - Limitações funcionais.

Tabela 49

Referência NBR 15966-2:2012 (ABNT, 2012) OP.30.10.35.02 - Cronograma de manutenção; OP.60.30.02 - Limitações funcionais.

Normas, diretrizes e boas Normas técnicas: NBR 5410/1997 (ABNT, 1997); Decreto Estadual no 46.076 (SÂO PAULO, 2001); Manual de práticas orientação à prevenção e ao combate a incêndio nas escolas (FDE,2009).

Boas práticas: Realizar manutenção periódica e preventiva nas instalações.

Elaborar o projeto de instalações de forma a permitir fácil adequação, em função de necessidades específicas.

Requisitos de desempenho (ABNT, 2013) Funcionalidade; durabilidade; manutenibilidade; desempenho ambiental; segurança no uso; segurança NBR 15575:2013 contra incêndio.

Comentários Realizar manutenção das instalações elétricas. Em futuros projetos, elaborar o dimensionamento de instalações elétricas considerando a flexibilidade de leiaute.

Aspecto crítico 6

Aspecto crítico - Sim/Não $\checkmark \quad$ Identificado por $A J L F$

Responsável Especialista em APO Data June 8, 2009

Descrição da situação crítica Ferragens inadequadas ao uso e pouco resistentes às intempéries e a atos de vandalismo, compromentendo a utilização de ambientes, por exemplo, sanitários e salas de aula.

Nível de risco (FRANÇA, 2011) 1 - Médio risco

Causas prováveis Projeto

Referência OMNICLASS ～(OCCS, 2012) 49-814143 Resistência ao impacto; 49-814113 Resistência ao mal uso; $49-8141$ 00 Propriedades

Tabela 49 de durabilidade.

Referência NBR 15966-2:2012 (ABNT, 2012) OP.60.50.02 - Resistência ao mal uso; OP.60.50.23 - Durabilidade mecânica; OP.60.50.00 -

Propriedades de durabilidade.

Normas, diretrizes e boas $\quad$ Normas técnicas: NBR 9050:2015 (ABNT, 2015); NBR 15575:2013 (ABNT, 2013).

práticas Boas práticas: Especificar fechaduras, dobradiças e trincos adequa

Requisitos de desempenho (ABNT, 2013) Conforto visual; conforto acústico; conforto higrotérmico; acessibilidade; funcionalidade;

NBR 15575:2013 estanqueidade; durabilidade; manutenibilidade; desempenho ambiental; segurança estrutural; segurança no uso; conforto tátil; ergonomia.

Aspecto crítico 7

Aspecto crítico - Sim/Não $\checkmark \quad$ Identificado por $A J L F$

Responsável Especialista em APO Data June 8, 2009

Descrição da situação crítica Portas em madeira com enchimento sarrafeado, semi-ocas, pouco resistentes ao uso constante, às intempéries e a atos de vandalismo, compromentendo a utilização de ambientes, por exemplo, sanitários e salas de aula.

Nível de risco (FRANÇA, 2011) 1 - Médio risco

Causas prováveis Projeto

Referência OMNICLASS ～(OCCS, 2012) 49-814125 - Resistência à degradação; 49-814143 - Resistência ao impacto; $49-8141$ 13 -

Tabela 49

Resistência ao mal uso; 49-8141 00 - Propriedades de durabilidade. 


\section{Relatório de aspectos críticos:} Ambientes

Status: From EA.08

Room Function Number: 009.01.029

\section{Aspectos críticos}

Aspecto crítico 7

Referência NBR 15966-2:2012 (ABNT, 2012) OP.60.50.02 - Resistência ao mal uso; OP.60.50.23 - Durabilidade mecânica; 0P.60.50.00 -

Propriedades de durabilidade.

Normas, diretrizes e boas $\quad$ Normas técnicas: NBR 9050:2015 (ABNT, 2015); NBR 15575:2013 (ABNT, 2013); ISO 15686-1:2000 (ISO, 2000).

práticas

Boas práticas: Especificar portas adequadas ao uso externo ou pesado, quando for o caso.

Requisitos de desempenho (ABNT, 2013) conforto visual; conforto acústico; conforto higrotérmico; acessibilidade; funcionalidade; salubridade;

estanqueidade; durabilidade; manutenibilidade; desempenho ambiental; segurança estrutural; segurança no uso;

segurança contra incêndio; conforto tátil; ergonomia.

Comentários Substituir portas por itens com características compatíveis ao uso. Para futuras escolas, rever os critérios para a especificação de portas.

Aspecto crítico 8

\begin{tabular}{lll}
\hline Aspecto crítico - Sim/Não & $\checkmark$ & Identificado por AJLF \\
& Responsável Especialista em APO Data August 6, 2009
\end{tabular}

Descrição da situação crítica Falta de interruptores nas salas de aula. O acionamento é feito por meio de um quadro geral para o andar. Não é possível acionar parcialmente as luminárias de uma sala de aula.Os quadros nos quais é previsto o acionamento ficam trancados à chave.

Nível de risco (FRANÇA, 2011) 1 - Médio risco

Causas prováveis Projeto

Referência OMNICLASS $\quad$ (OCCS, 2012) 49-9151 47 - Controles de iluminação; 49-91 8121 - Eficiência energética.

Tabela 49 NBR 15966-2.2012 (ABNT, 2012) OP 70.3019 - Controles de iluminação; OP 70.60 .06 - Eficiência energética.

Normas, diretrizes e boas Normas técnicas: NBR 5410:1997 (ABNT, 1997); Decreto Estadual № 46.076 (SÃO PAULO, 2001); Manual de

práticas orientação à prevenção e ao combate a incêndio nas escolas (FDE, 2009); NBR 5413:1992 (ABNT, 1992). Boas práticas: Realizar manutenção periódica e preventiva nas instalações.

Elaborar o projeto de instalações de forma a permitir o fácil acesso e o controle dos niveis de iluminamento, em função de atividades pedagógicas específicas.

Requisitos de desempenho (ABNT, 2013) conforto visual; conforto higrotérmico; acessibilidade; funcionalidade; durabilidade; manutenibilidade; NBR 15575:2013 desempenho ambiental; segurança no uso; segurança contra incêndio; ergonomia.

Comentários Adotar medidas para permitir o controle dos níveis de iluminamento nas salas de aula. Prover fácil acesso às instalações elétricas dos quadros, em caso de emergência. Em futuros projetos, incluir controles acessíveis aos professores e dimensionar os circuitos considerando o leiaute previsto.

Aspecto crítico 9

Aspecto crítico - Sim/Não $\checkmark \quad$ Identificado por $A J L F$

Responsável Especialista em APO Data August 6, 2009

Descrição da situação crítica Falta/quebra de componentes; falta de mobiliário adequado (conjunto aluno) para alunos de baixa estatura.

Nível de risco (FRANÇA, 2011) 1 - Médio risco

Causas prováveis

Referência OMNICLASS (OCCS, 2012) 49-814113 - Resistência ao mal uso; 49-41318313 - Cronograma de manutenção; $49-812113$ -

Tabela $49 \quad$ Limitações funcionais.

Referência NBR 15966-2:2012 (ABNT, 2012) OP.60.50.02 - Resistência ao mal uso; 0P.30.10.35.02 - Cronograma de manutenção; OP.60.30.02 Limitações funcionais.

Normas, diretrizes e boas $\quad$ Normas técnicas: NBR 9050:2015 (ABNT, 2015); Especificações da Edificação Escolar: Ambientes/ Distribuição/

práticas

Mobiliário (FDE, 2012).

Boas práticas: Manter o mobiliário escolar em plena condição de uso.

Requisitos de desempenho (ABNT, 2013) conforto visual; conforto higrotérmico; acessibilidade; funcionalidade; durabilidade; manutenibilidade; NBR 15575:2013 desempenho ambiental; segurança no uso; segurança contra incêndio; ergonomia.

Comentários Realizar substituição eficiente em caso de desgaste ou vandalismo. Em escolas que atendam alunos dos Ciclos I e II, providenciar mobiliário adequado aos alunos de baixa estatura.

Aspecto crítico 10

Aspecto crítico - Sim/Não $\quad \frac{\checkmark}{\text { Identificado por AJLF }}$ I

Descrição da situação crítica Falta de elementos de sinalização previstos em projeto (devido a quebra/ remoção); elaboração de sinalização improvisada, em desacordo com o projeto.

Nível de risco (FRANÇA, 2011) 2 - Baixo risco

Causas prováveis

Referência OMNICLASS (OCCS, 2012) 49-814113 - Resistência ao mal uso; 49-8141 00 - Propriedades de durabilidade; $49-812113$ -

Tabela $49 \quad$ Limitaçôes funcionais.

Referência NBR 15966-2:2012 (ABNT, 2012) OP.60.50.02 - Resistência ao mal uso; OP.60.50.00 - Propriedades de durabilidade; OP.60.30.02 Limitações funcionais.

Normas, diretrizes e boas Norma técnica: NBR 9050:2015.

práticas

Requisitos de desempenho (ABNT, 2013) Acessibilidade; funcionalidade; durabilidade; manutenibilidade; desempenho ambiental; segurança no

NBR 15575:2013 uso; segurança contra incêndio.

Comentários Rever as especificações para a sinalização dos ambientes, considerando soluções mais resistentes a vandalismo. 
MELHORIA CONTINUAA APLICADA A Database SPEducational Facilities

Status: From EA.08
Relatório de aspectos críticos: Ambientes

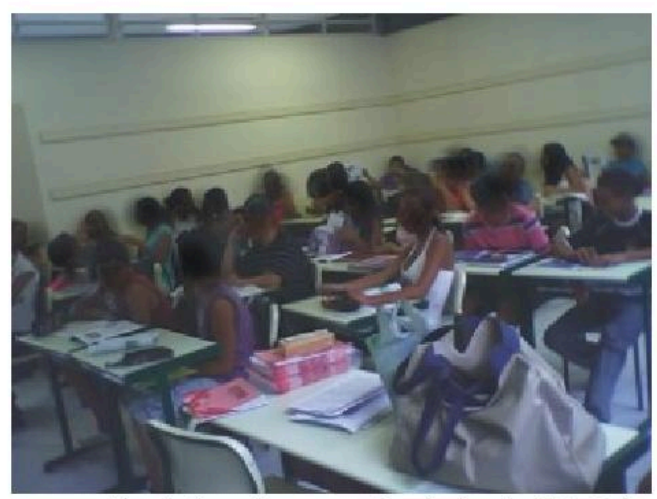

Evidência - aspecto crítico 1: dimensionamento da sala de aula ( $1,2 \mathrm{~m}^{2} /$ aluno) dificulta a realização de atividades de ensino-aprendizagem colaborativas. Fonte: Acervo da pesquisadora.

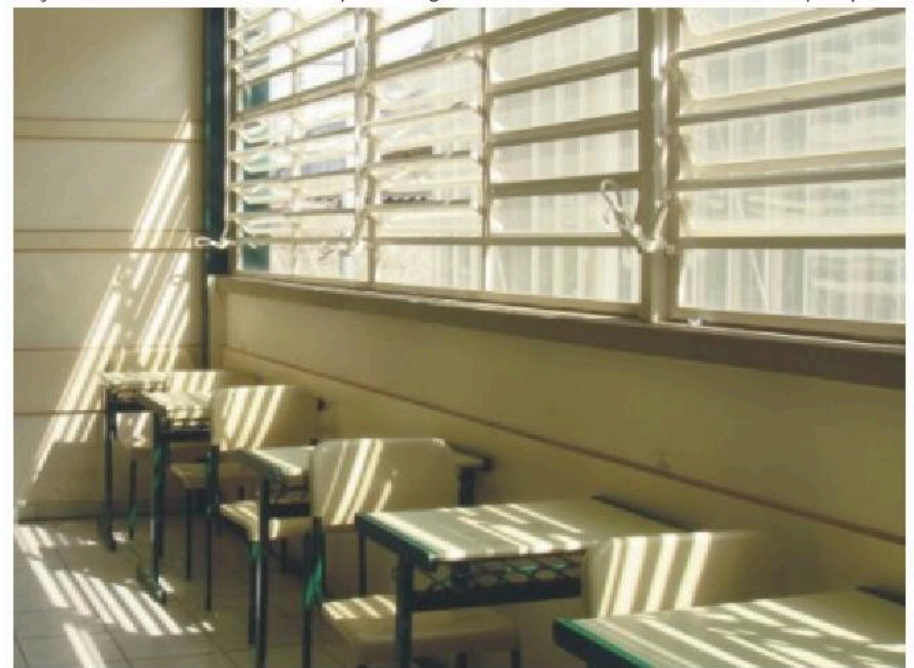

Evidência - aspecto crítico 2: proteção solar ineficiente não evita a incidência solar direta no plano de trabalho (carteiras escolares). Fonte: Acervo da pesquisadora.

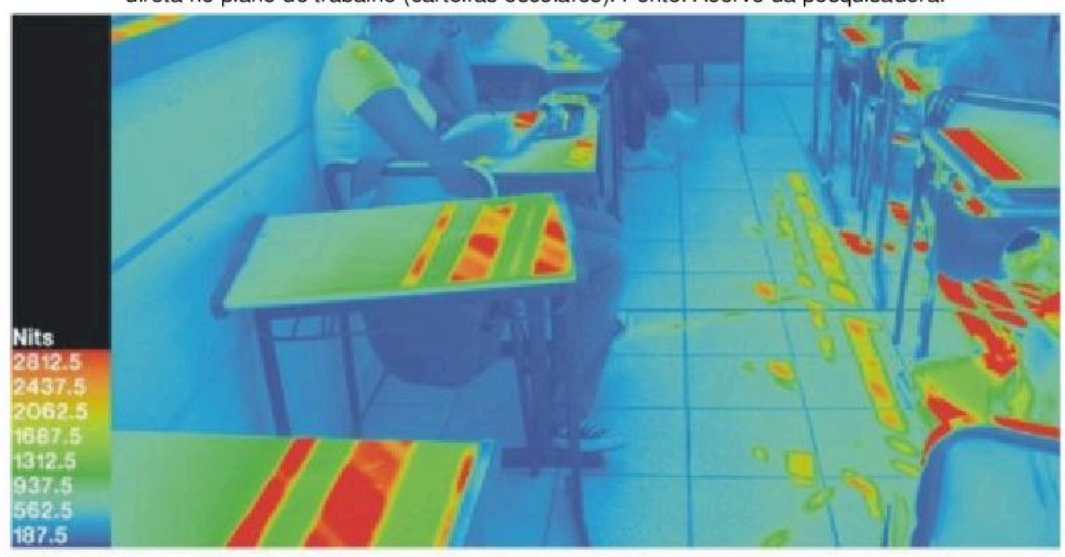

Condiçöes de contraste e de ofuscamento na Sala de Aula 15 - Escola Alpha. Levantamento realizado em:

Data: $13 / 05 / 2009$

Hora: 14:00

Condiçöes de céu: Parcialmente encoberto.

Evidência - aspecto crítico 2: a análise das condições de luminância, elaborada a partir de fotografias do ambiente, evidenciaram os efeitos negativos do brilho excessivo e baixos níveis de contraste, o que impacta o desempenho das atividades escolares (areas críticas em vermelho). Fonte: Acervo da pesquisadora. 
MELHORIA CONTÍNUA APLICADA A

蘛

Database_SPEducational_Facilities
Relatório de aspectos críticos: Ambientes

Status: From EA.08

Escola Alpha - Resultados obtidos em relação ao conforto ambiental em sala de aula. Questionários aplicados aos alunos da $8^{\mathrm{a}}$ série.

1. Dê a sua opiniảo sobre a luz do sol em sua sala de aula - considere a carteira escolar e a lousa.

2. De que maneira você ouve o que a sua professora fala?

3. Dê a sua opiniăo sobre a temperatura de sua sala de aula nos dias frios.

4. Dê a sua opiniăo sobre a temperatura de sua sala de aula nos dias quentes.

4. Dê a sua opiniăo sobre a ventilação em sua sala de aula.

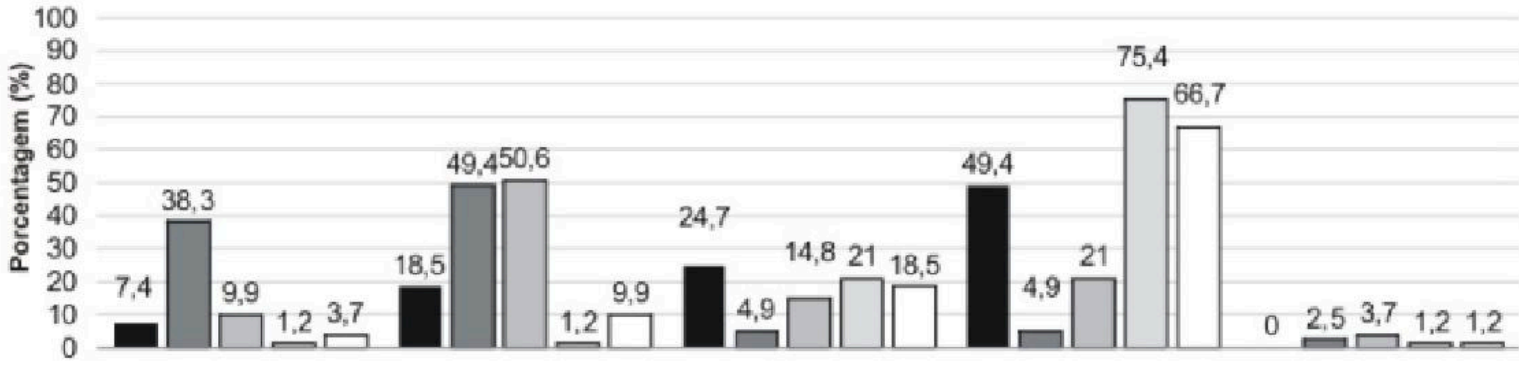

Excelente

Satisfatória

Insatisfatónia

Péssima

Não se aplica

- 1. Iluminaçãonatural

⒉ Confortoacústico

口3. Conforto térmico, em dias frios. $\square$ 4. Confortotérmico, em dias quentes.

口5. Ventilação.

Número de respondentes

1. iluminaçào

natural

2. conforto acústico

3. Conforto

têrmico, em dias

frios.

4. Conforto

térmico, em dias

quentes.

5. Ventilaçăo.

Excelente
6
31
8
1
3

Legenda: Moda

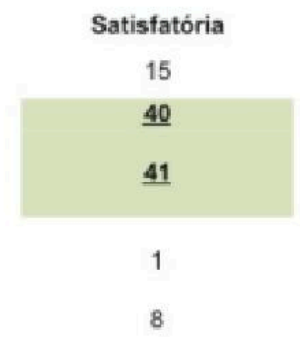

Insatisfatória

20

12

17

15

Dados referentes ao 1 - semestre de 2009.

Evidência - aspectos críticos 2 e 4: resultados de questionários aplicados aos alunos demonstram insatisfação dos usuários em relação às condições de conforto ambiental, a saber: lluminação natural $-24,7 \%$ (20 respondentes) assinalaram a opção insatisfatória e 49,4\% (40 respondentes) indicaram a opção péssima. Conforto térmico em dias quentes - $21 \%$ ( 17 respondentes) assinalaram a opção insatisfatória e $75,4 \%$ (61 respondentes) indicaram a opção péssima. Ventilação - $18,5 \%$ (15 respondentes) assinalaram a opção insatisfatória e 66,7\% (54 respondentes) indicaram a opção péssima. Fonte: Acervo da pesquisadora. 
Relatório de aspectos críticos: Ambientes

Status: From EA.08

Room Function Number: 009.01.029

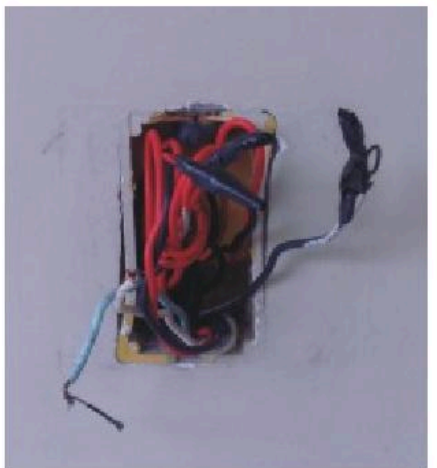

Evidência - aspecto crítico 5: comprometimento da funcionalidade de tomadas devido à falta de componentes:

quantificação e distribuição insuficientes; faltam instalações de lógica. Fonte: Acervo da pesquisadora.

Evidência - aspecto crítico 7: Resistência insuficiente de porta em área semiexposta e em ambiente sujeito a arrombamento. Fonte: Acervo da pesquisadora. 
MELHORIA CONTÍNUA APLICADA A

Database_SPEducational_Facilities

Status: From EA.08
Relatório de aspectos críticos: Ambientes
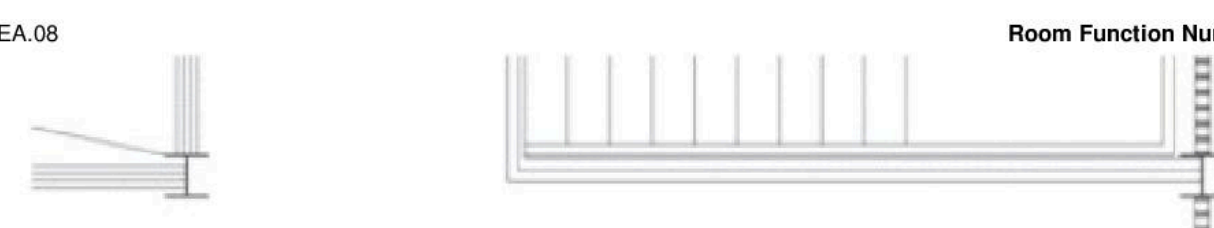

umber: 009.01.029

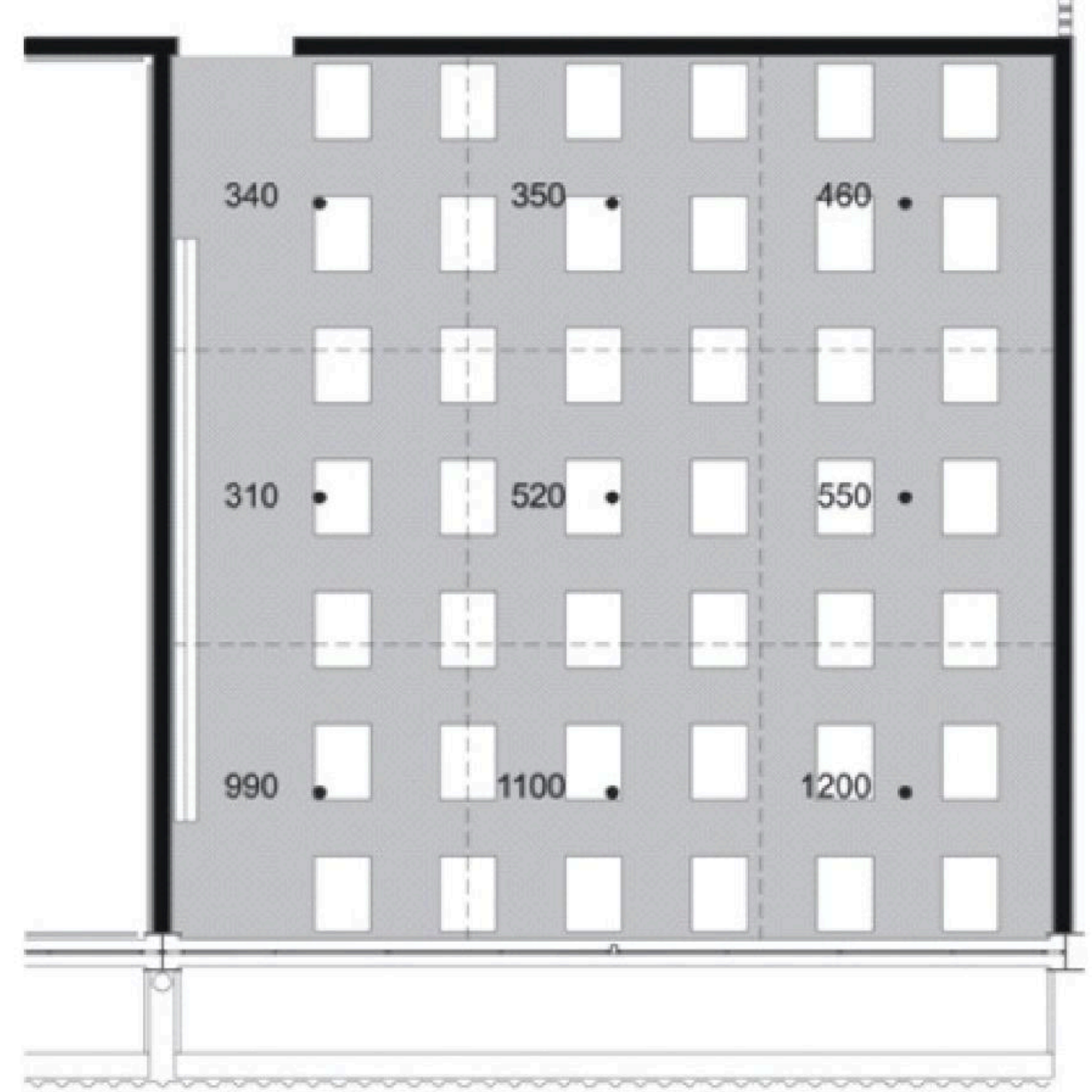

\section{Niveis de lluminância (Lux)}

Evidência - aspecto crítico 8: medições dos níveis de iluminância (lux), realizadas na sala de aula 15, conforme NBR:15215-4 (ABNT, 2004). Data da medição:13/05/2009. Horário: 14:00. Os níveis aferidos superam o preconizado pela NBR 5413:1992. É recomendada a setorização dos circuitos do sistema de iluminação artificial, de modo a permitir o desligamento independente de parte das luminárias, para maior eficiência energética. Fonte: Acervo da pesquisadora. 
MELHORIA CONTINUA APLICADA A

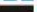

Database_SPEducational_Facilities

Status: From EA.08

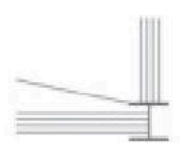

Relatório de aspectos críticos: Ambientes

Room Function Number: 009.01.029

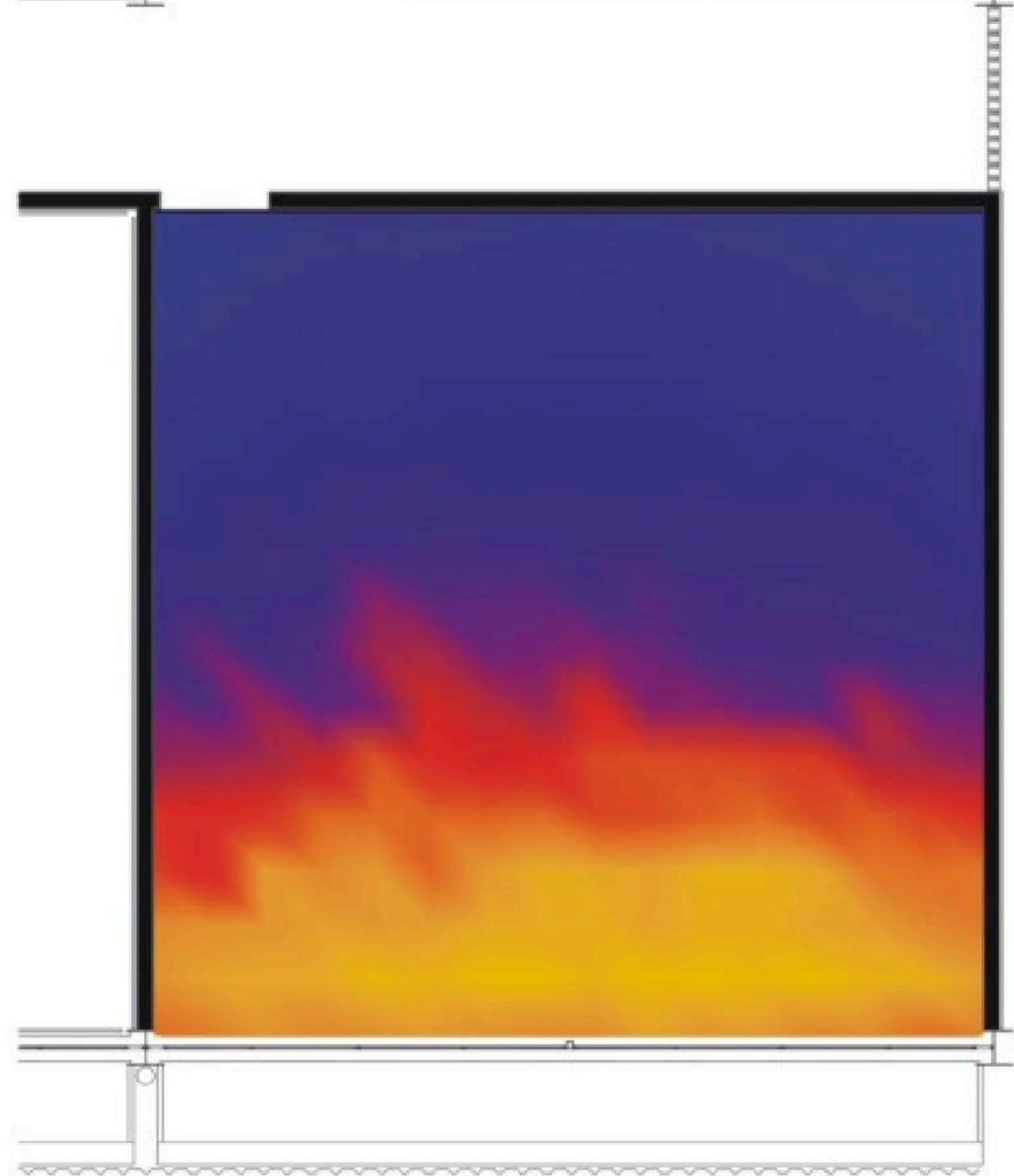

Escola Alpha - Autonomia de iluminaçåo natural (\% de horas por ano). Intervalo considerado: 7:00 às 18:00.

lluminância no plano de trabalho: 300 lux.

Simulaçăo elaborada utilizando o programa computacional Daysim. Fonte: Acervo da pesquisadora.

Evidência - aspecto crítico 8: simulação para verificação da autonomia de luz natural demonstra que é recomendável o desligamento das luminárias próximas às janelas, em $70 \%$ das horas anuais em que o ambiente é utilizado (ambiente de referência: sala de aula 15). Para tal, é necessária a setorização dos circuitos do sistema de iluminação artificial, de modo a permitir o desligamento independente de parte das luminárias, para maior eficiência energética. Fonte: Acervo da pesquisadora. 
Relatório de aspectos críticos: Ambientes

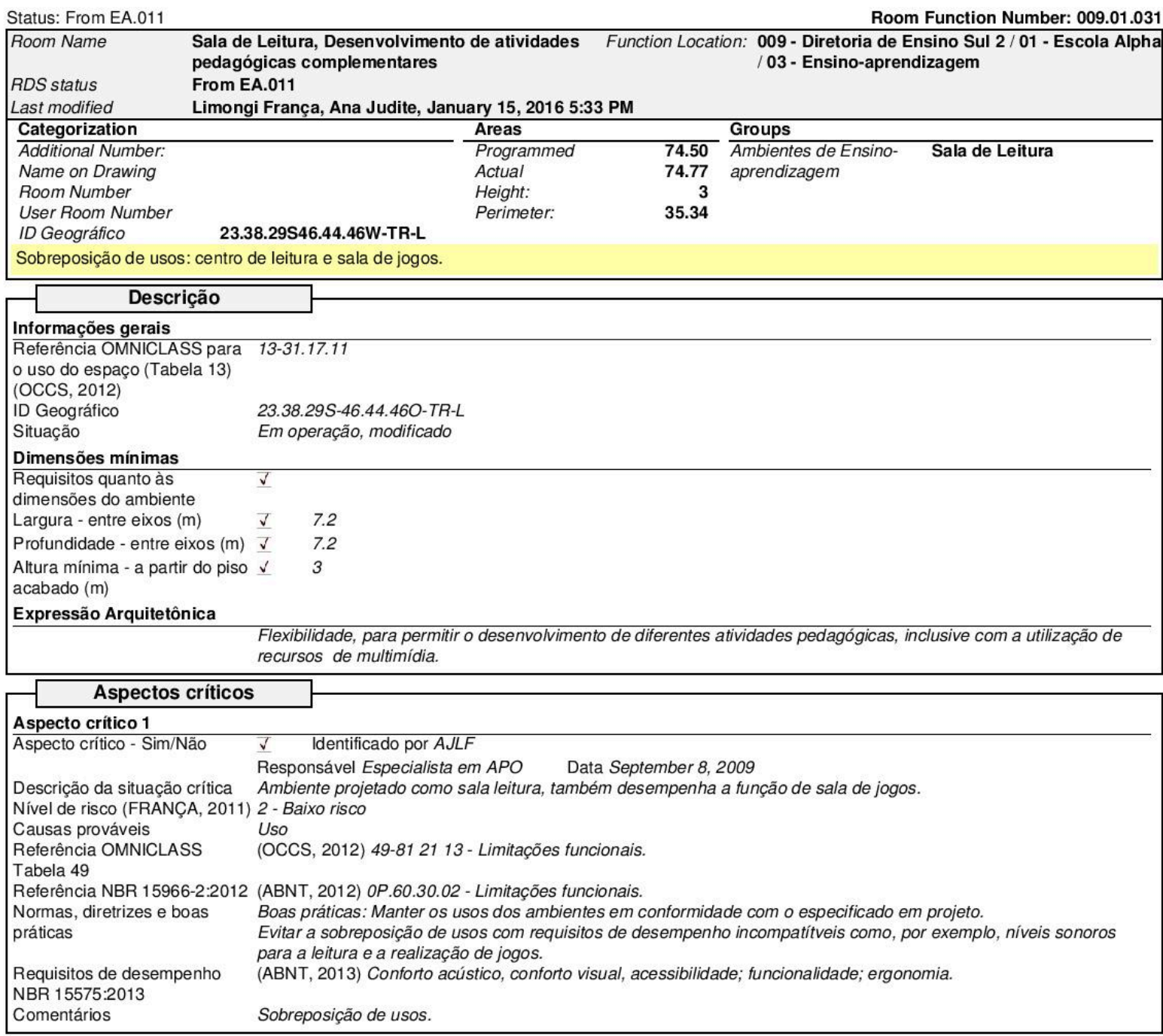


Relatório de aspectos críticos: Ambientes

Status: From EA.011

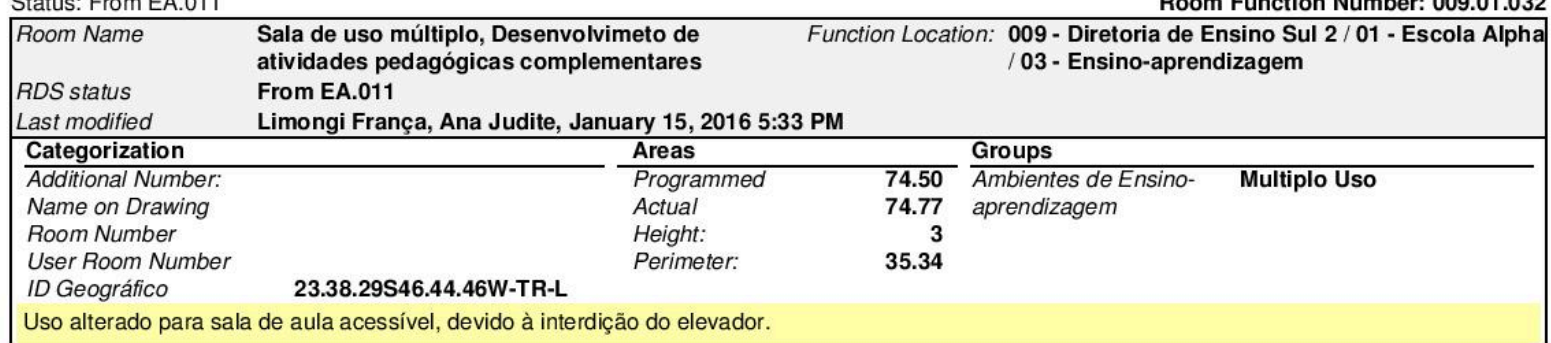

Uso alterado para sala de aula acessível, devido à interdição do elevador.

Informações gerais

Descrição

Referência OMNICLASS para 13-31.17.11

o uso do espaço (Tabela 13)

(OCCS, 2012

ID Geográfico 23.38.29S-46.44.46O-TR-L

Situação Em operação, modificado

Dimensões mínimas

Requisitos quanto às

dimensões do ambiente

Largura - entre eixos $(\mathrm{m}) \quad \checkmark \quad 7.2$

Profundidade - entre eixos $(\mathrm{m}) \quad \bar{v} \quad 7.2$

Altura mínima - a partir do piso $\checkmark \quad 3$

acabado $(\mathrm{m})$

Expressão Arquitetônica

Flexibilidade, para permitir o desenvolvimento de diferentes atividades pedagógicas, inclusive com a utilização de recursos de multimídia.

\begin{tabular}{ll|l}
\hline \multicolumn{1}{c|}{ Aspectos críticos } & \\
\cline { 2 - 3 } Aspecto crítico 1 & & \\
\hline Aspecto crítico - Sim/Não & $\checkmark$ & Identificado por AJLF \\
& Responsável Especialista em APO Data September 8, 2009
\end{tabular}

Descrição da situação crítica Ambiente projetado como sala leitura, também desempenha a função de sala de jogos.

Nível de risco (FRANÇA, 2011) 2 - Baixo risco

Causas prováveis Uso

Referência OMNICLASS $\quad$ (OCCS, 2012) 49-812113- Limitações funcionais.

Tabela 49

Referência NBR 15966-2:2012 (ABNT, 2012) OP.60.30.02 - Limitações funcionais.

Normas, diretrizes e boas Boas práticas: Manter os usos dos ambientes em conformidade com o especificado em projeto.

práticas

Evitar a sobreposição de usos com requisitos de desempenho incompatítveis como, por exemplo, níveis sonoros para a leitura e a realização de jogos.

Requisitos de desempenho (ABNT, 2013) Conforto acústico, conforto visual, acessibilidade; funcionalidade; ergonomia.

NBR 15575:2013

Comentários

Sobreposição de usos. 
MELHORIA CONTÍNUA APLICADA A

tabase_SPEducational_Facilities

\section{Relatório de aspectos críticos: Ambientes}

Room Function Number: 009.01.03

Status: Derived from AUX.016

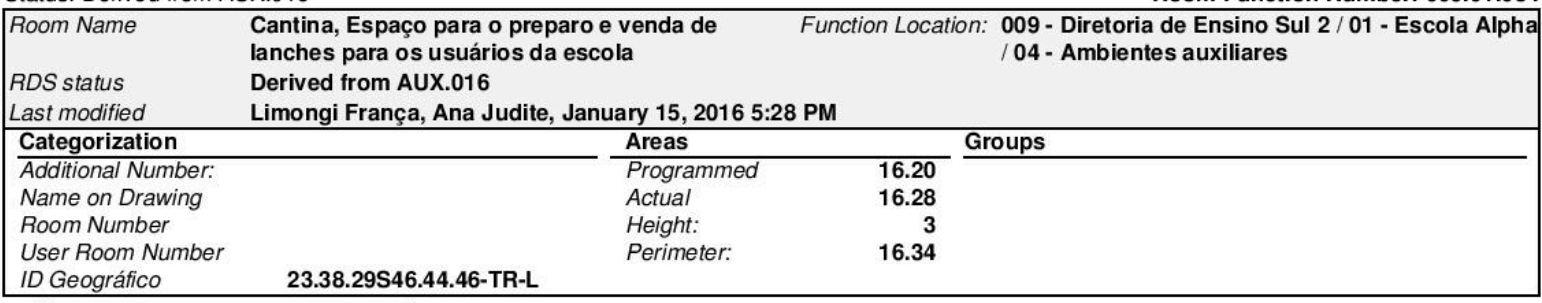

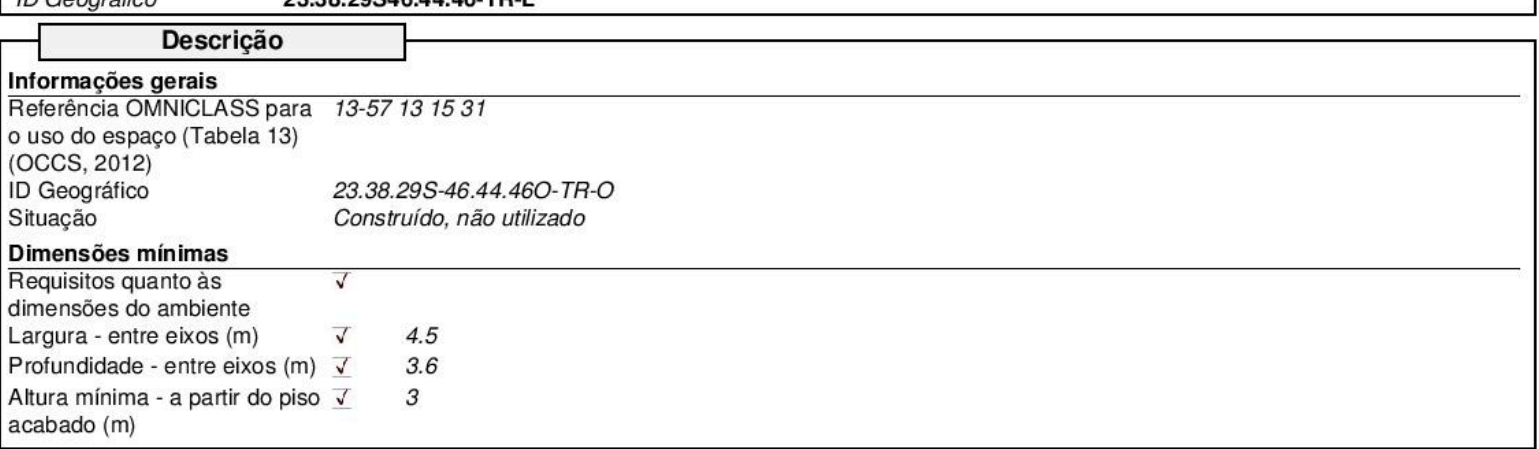

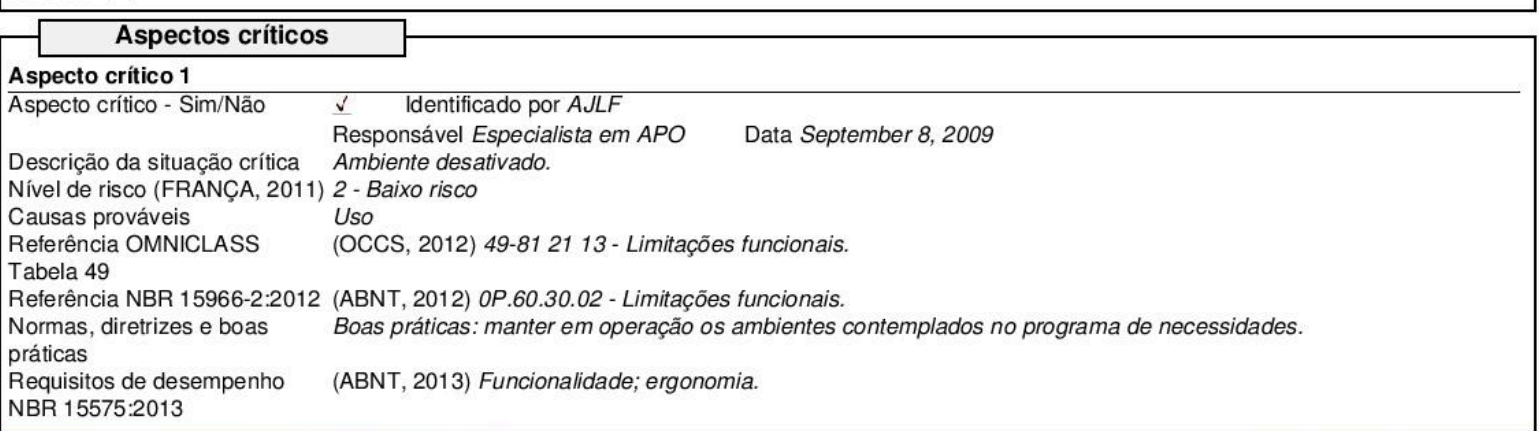

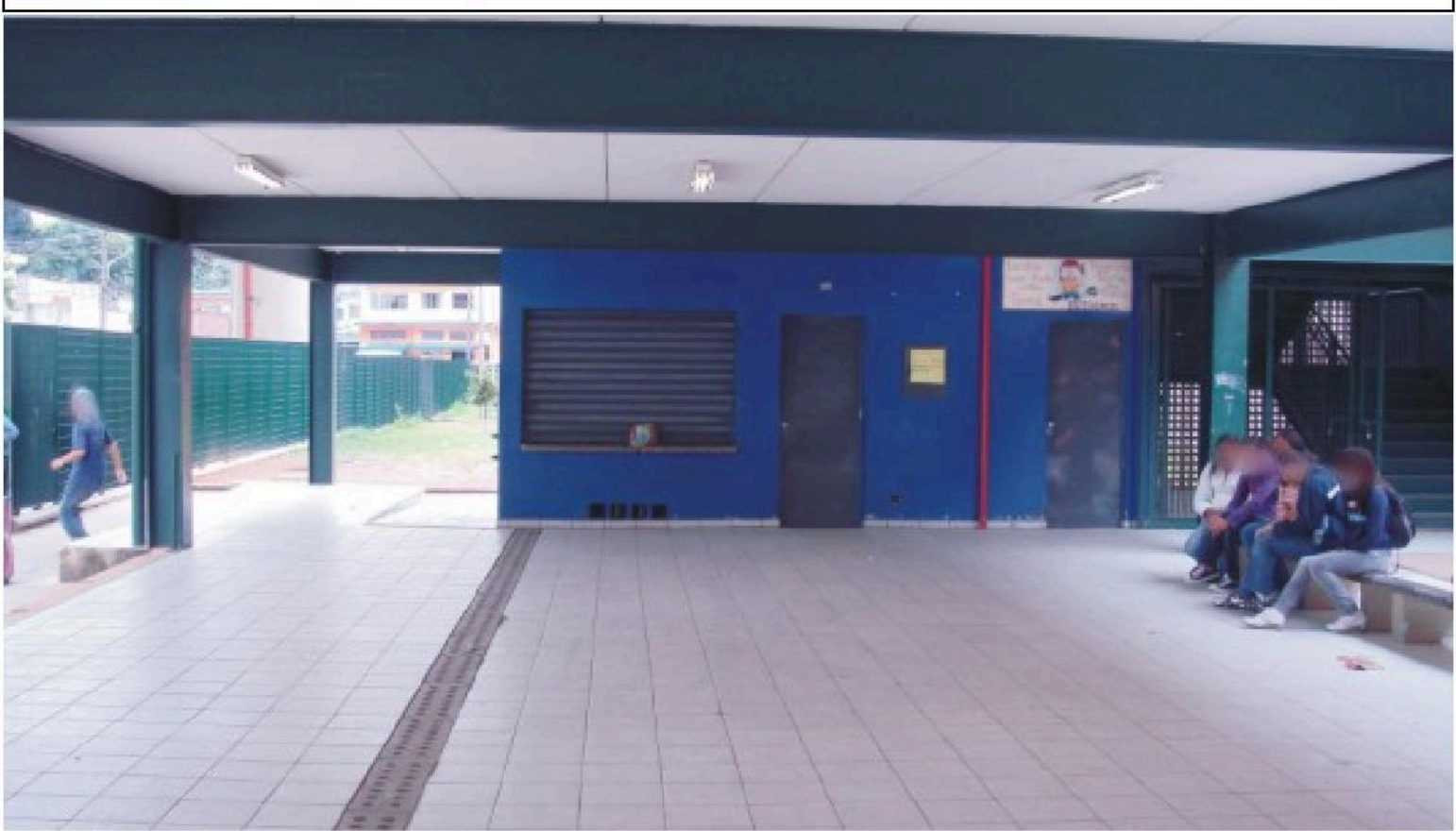

Evidência - aspecto crítico 1: à época dos levantamentos (2009), a Cantina se encontrava desativada. Fonte: Acervo da pesquisadora. 

MELHORIA CONTINUA APLICADA A
EDIFICACOES DE TIPOLOGIA PADRONIZADA Database_SPEducational_Facilities
Relatório de aspectos críticos: Ambientes

Status: Derived from AUX.017-F

Room Function Number: 009.01.039

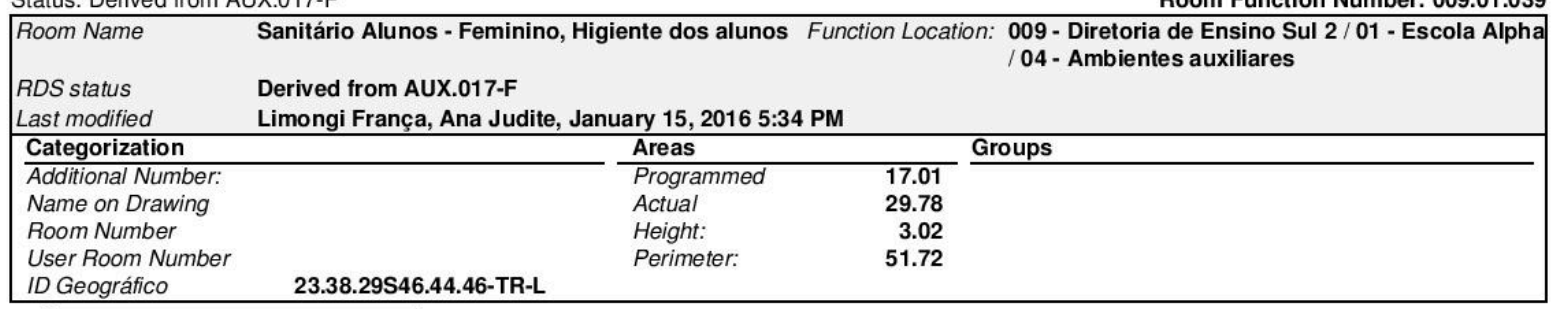

\section{Descrição}

Informações gerais

Referência OMNICLASS para $13-231700$

o uso do espaço (Tabela 13)

(OCCS, 2012)

23.38.29S-46.44.46O-TR-L

Situação Em uso, conforme o projetado

Dimensões minimas

Requisitos quanto às

dimensões do ambiente

Largura - entre eixos $(\mathrm{m})$

Profundidade - entre eixos $(\mathrm{m}) \quad \checkmark \quad 7.2$

Altura mínima - a partir do piso $\checkmark \quad 2.5$

acabado $(\mathrm{m})$

Aspectos criticos

Aspecto crítico 1

Aspecto crítico - Sim/Não $\quad \checkmark \quad$ Identificado por $A J L F$

Responsável Especialista em APO Data September 8, 2009

Descrição da situação crítica Falta de louças, metais e portas. Falta de porta no sanitário destinado a pessoas com deficiência.

Nível de risco (FRANÇA, 2011) 0 - Alto risco

Causas prováveis Operação

Referência OMNICLASS $\quad$ (OCCS, 2012) 49-91 2325 - Componentes hidrossanitários; 49-81 4113 - Resistência ao mal uso ; $49-812113$ -

Tabela 49 Limitaçổes funcionais; 49-814100-Propriedades de durabilidade.

Referência NBR 15966-2:2012 (ABNT, 2012) OP.60.50.02 - Resistência ao mal uso; OP.60.30.02 - Limitações funcionais; OP.60.50.00 -

$\begin{array}{ll}\begin{array}{l}\text { Normas, diretrizes e boas } \\ \text { práticas }\end{array} & \text { Normas técnicas: NBR9050:2015 (ABNT, 2015); NBR 15575:2013 (ABNT, } 201 \text { (A) pras práticas: realizar manutenção periódica e preventiva nas instalaços. } \\ & \text { Apagar vestígios de vandalismo, como forma de reduzir futuros incidentes. }\end{array}$

Requisitos de desempenho (ABNT, 2013) Acessibilidade; funcionalidade; salubridade; estanqueidade; durabilidade; manutenibilidade;

NBR 15575:2013 desempenho ambiental; segurança no uso; conforto tátil; ergonomia.

Comentários Reformar e manter os sanitários em condições de uso. Implantar programas para a redução de vandalismo e realizar trabalhos de conscientização junto à comunidade. Especificar linhas de metais antivandalismo. 
MELHORIA CONTÍNUA APLICADA A
EDIFICAÇOES DE TIPOLOGIA PADRONIZADA

Database_SPEducational_Facilities
Relatório de aspectos críticos: Ambientes

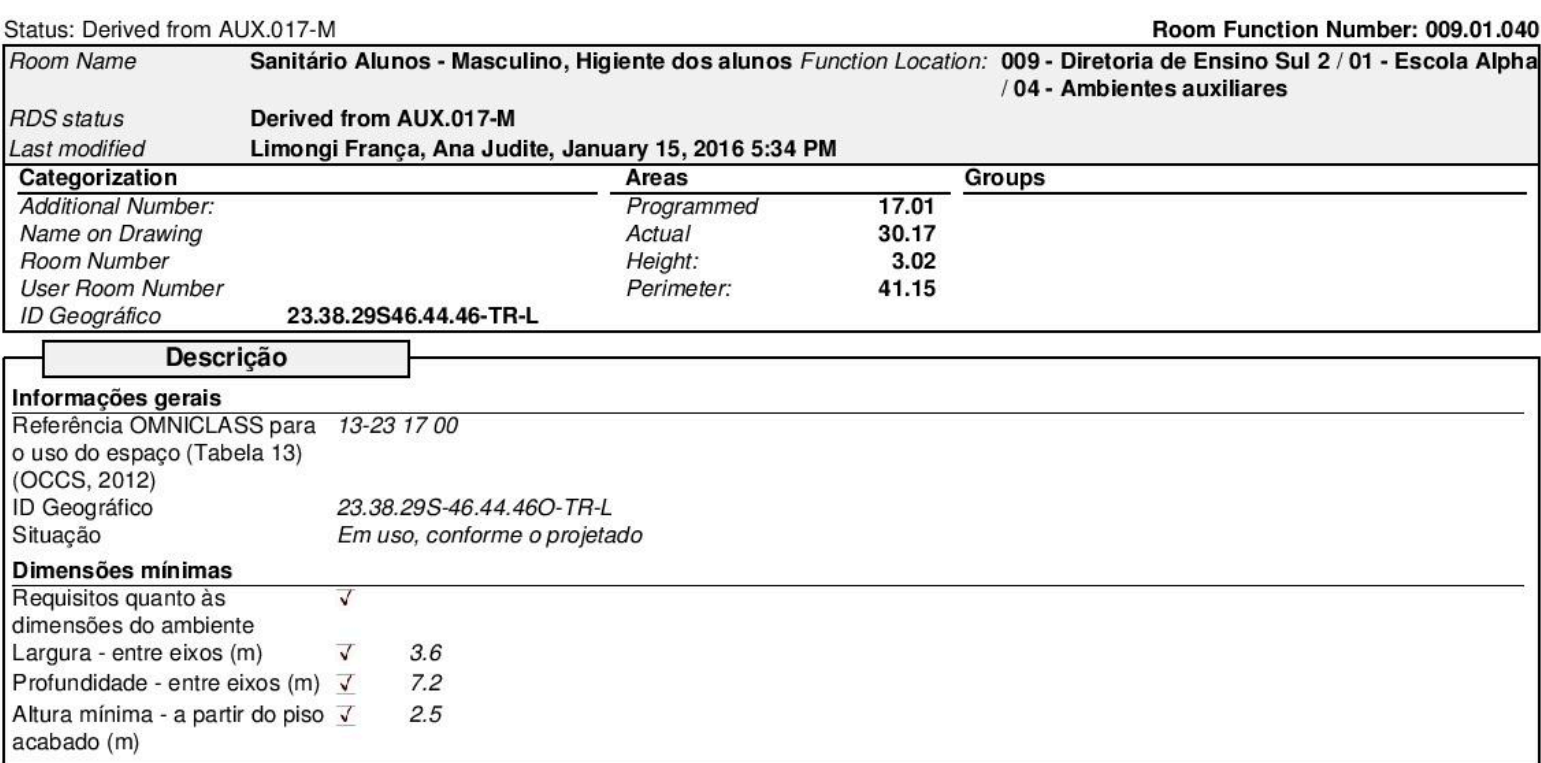

acabado $(\mathrm{m})$

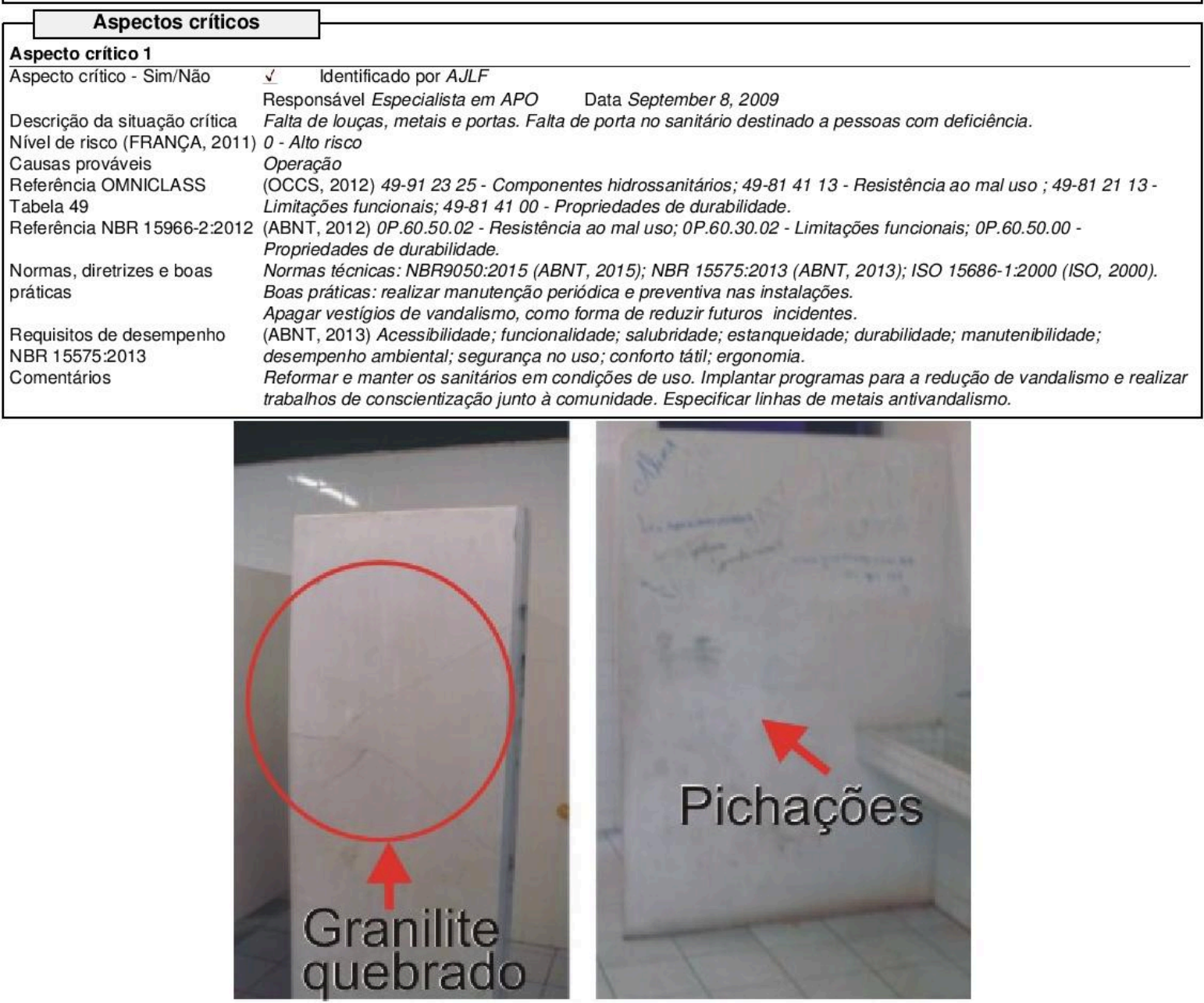

Evidência - aspecto crítico 1: componentes danificados por ações de vandalismo, no sanitário dos alunos. Fonte: Acervo da pesquisadora. 
Relatório de aspectos críticos:

Database_SPEducational_Facilities

\section{Ambientes}

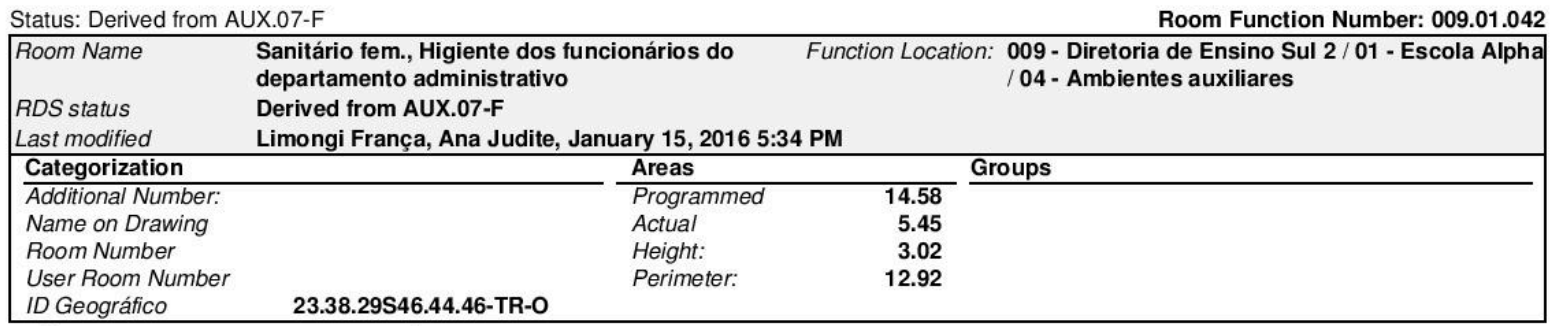

\section{ID Geográfico}

\section{Descrição}

Informações gerais

Referência OMNICLASS para $13-231700$

o uso do espaço (Tabela 13)

(OCCS, 2012)

ID Geográfico 23.38.29S-46.44.460-TR-O

Situação Em uso, conforme o projetado

Dimensões minimas

Requisitos quanto às

dimensões do ambiente

Largura - entre eixos $(\mathrm{m})$

Profundidade - entre eixos $(\mathrm{m}) \quad \checkmark \quad 1.65$

Altura mínima - a partir do piso $\checkmark \quad 2.5$

acabado $(\mathrm{m})$

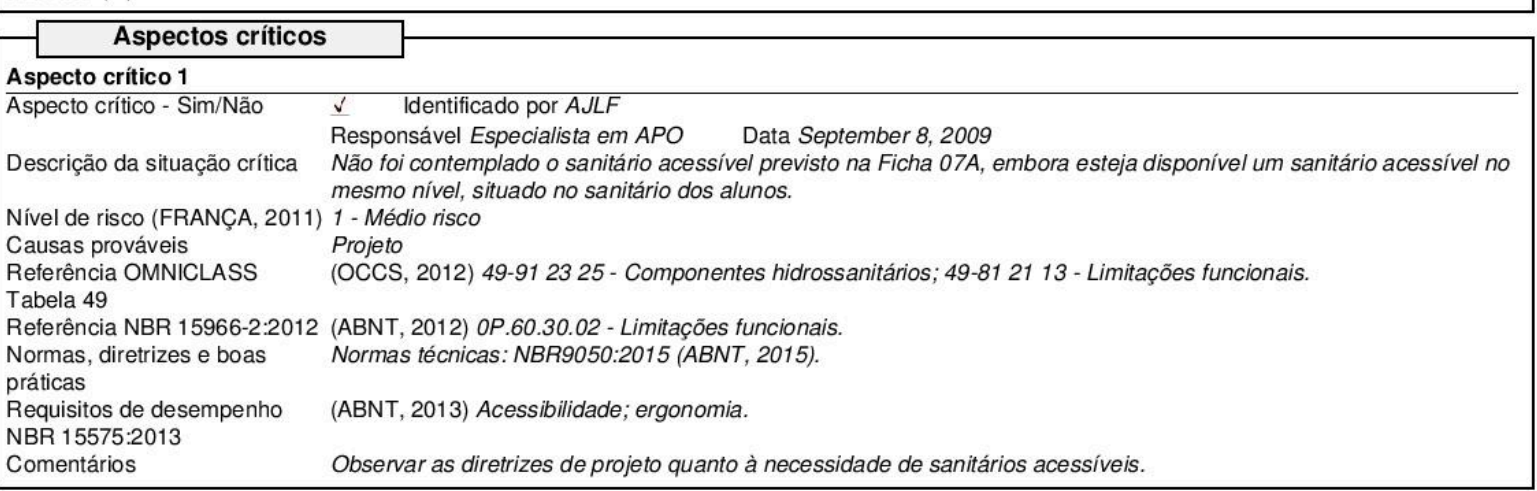


Relatório de aspectos críticos: Ambientes

Status: Derived from AUX.07-M

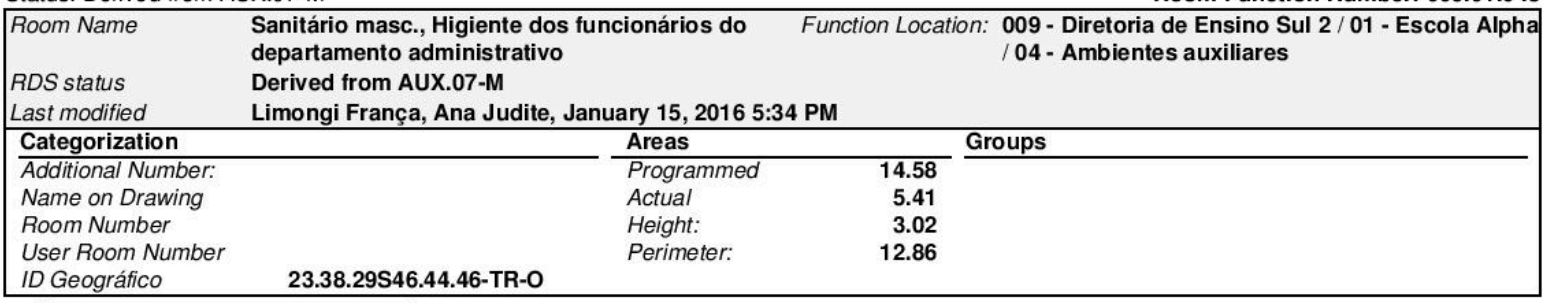

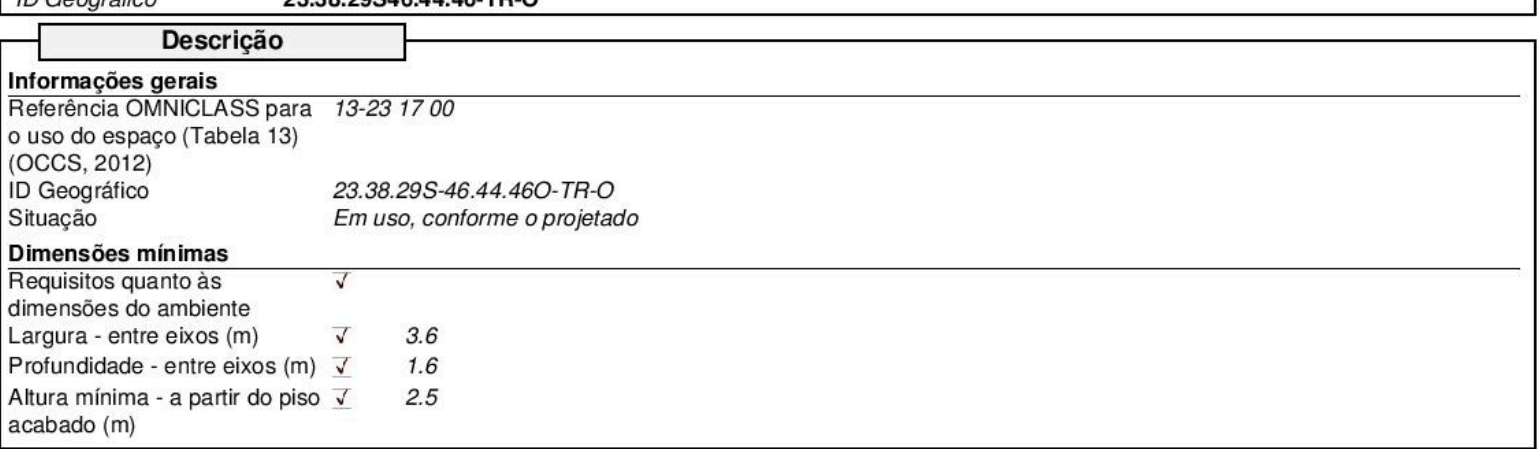

acabado $(\mathrm{m})$

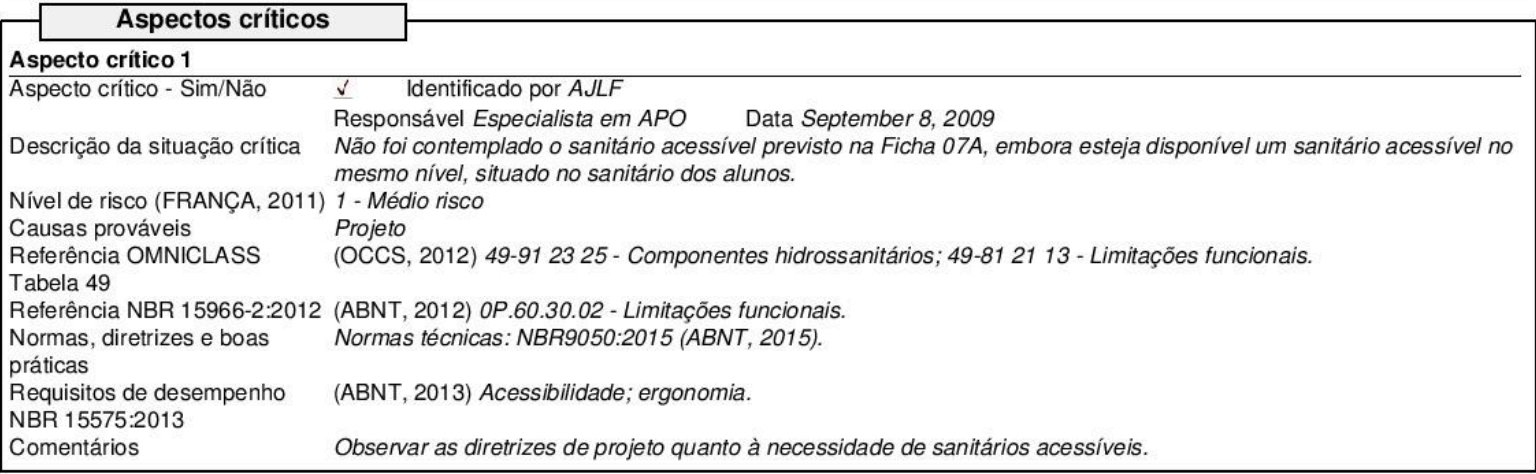


Relatório de aspectos críticos:

Database_SPEducational_Facilities Ambientes

\begin{tabular}{|c|c|c|}
\hline Status: Derived from $A$ & UX.023 & Room Function Number: 009.01.044 \\
\hline RDS status & Derived from AUX.023 & \\
\hline Last modified & Limongi Franca, Ana Judite, January 15, 2016 5:3 & 4 PM \\
\hline Additional Number: & Programmed & 12.96 \\
\hline Name on Drawing & Actual & 7.79 \\
\hline Room Number & Height: & 2.96 \\
\hline
\end{tabular}

Informaçoes gerais

Referência OMNICLASS para $13-231700$

o uso do espaço (Tabela 13)

(OCCS, 2012)

ID Geográfico 23.38.29S-46.44.460-TR-O

Situação Em uso, conforme o projetado

Dimensões mínimas

Requisitos quanto às

dimensões do ambiente

Largura - entre eixos $(\mathrm{m})$

Profundidade - entre eixos $(\mathrm{m}) \quad \checkmark \quad 1.65$

Altura mínima - a partir do piso $\checkmark \quad 2.5$

acabado $(\mathrm{m})$

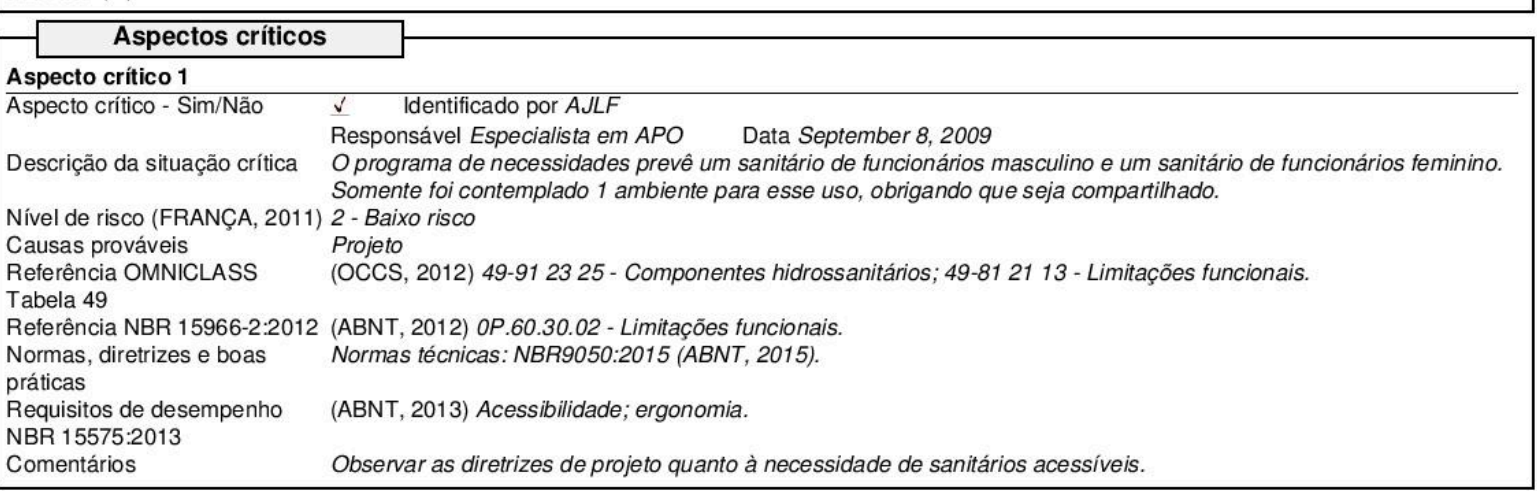


MELHORIA CONTÍNUA APLICADA A Database_SPEducational_Facilities

\section{Relatório de aspectos críticos: Ambientes}

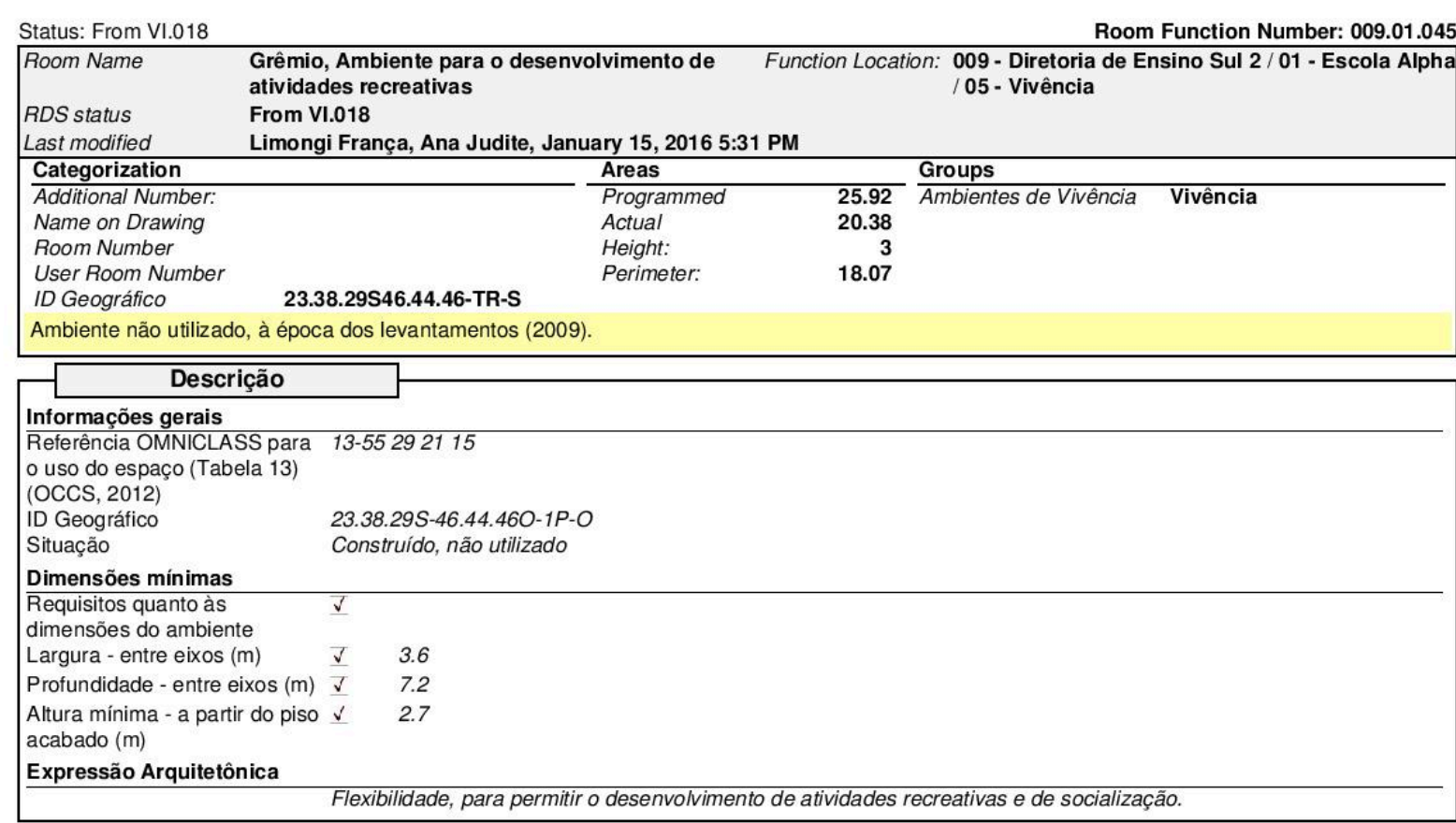

\begin{tabular}{|c|c|}
\hline Aspectos críticos & \\
\hline \multicolumn{2}{|l|}{ Aspecto crítico 1} \\
\hline Aspecto crítico - Sim/Não & Identificado por $A J L F$ \\
\hline & Responsável Especialista em APO Data September 8, 2009 \\
\hline Causas prováveis & Uso \\
\hline $\begin{array}{l}\text { Referência OMNICLASS } \\
\text { Tabela } 49\end{array}$ & (OCCS, 2012) 49-81 2113 - Limitações funcionais. \\
\hline $\begin{array}{l}\text { Normas, diretrizes e boas } \\
\text { práticas }\end{array}$ & Boas práticas: Manter os usos dos ambientes em conformidade com o especificado em projeto. \\
\hline $\begin{array}{l}\text { Requisitos de desempenho } \\
\text { NBR } 15575: 2013\end{array}$ & (ABNT, 2013) Acessibilidade; funcionalidade; ergonomia. \\
\hline Comentários & Avaliar motivos para a não utilização da Sala do Grêmio. Rever diretrizes para projetos futuros. \\
\hline
\end{tabular}
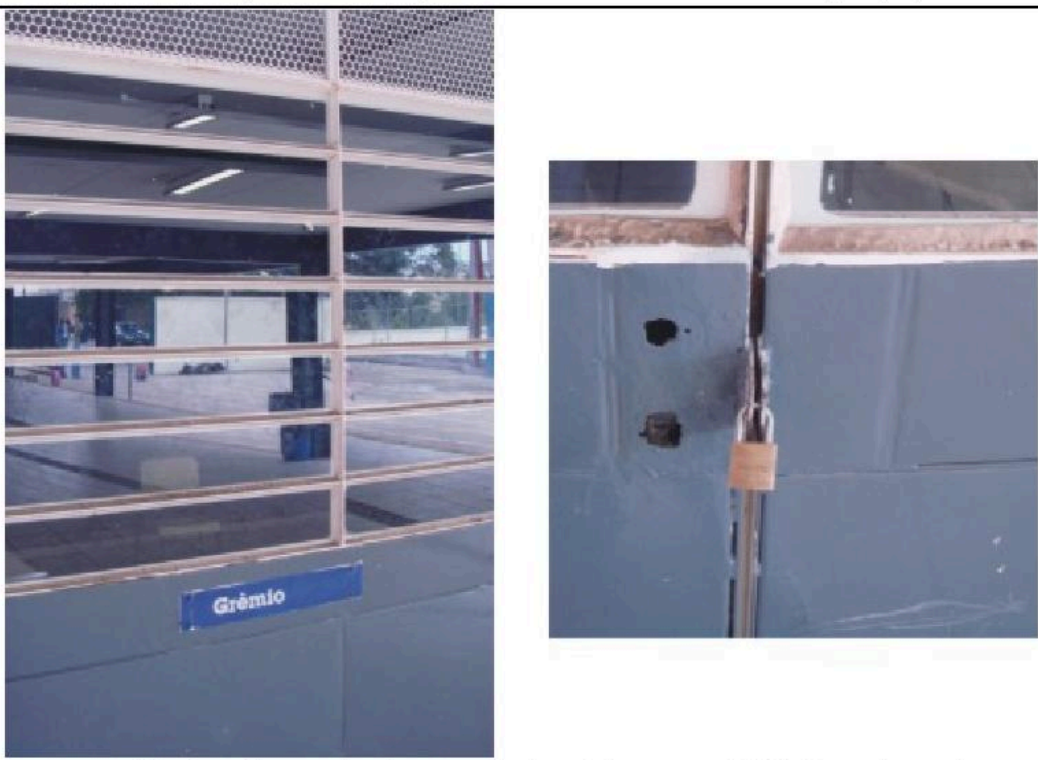

Evidência - aspecto crítico 1: ambiente projetado como sala do grêmio sem uso (2009). Fonte: Acervo da pesquisadora. 
Relatório de aspectos críticos:

Database SPEducational Facilities Ambientes

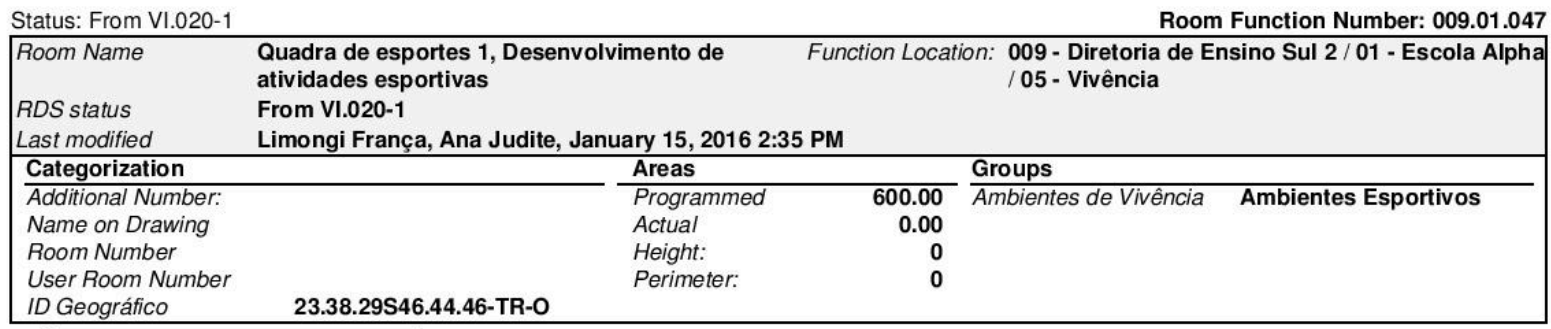

\section{Descrição}

Informações gerais

Referência OMNICLASS para 13-31 1913 Quadra de esportes ao ar livre

o uso do espaço (Tabela 13)

(OCCS, 2012)

23.38.29S-46.44.46O-TR-O

Situação Em uso, conforme o projetado

Dimensões mínimas

Requisitos quanto às $\quad \checkmark \quad$ Área $600 \mathrm{~m}^{2}$

dimensões do ambiente

Largura - entre eixos $(\mathrm{m})$

Profundidade - entre eixos $(\mathrm{m}) \quad \checkmark \quad 30$

Expressão Arquitetônica

Local de convivência, festas e atividades relacionadas a educação física.

\begin{tabular}{ll}
\multicolumn{1}{|c|}{ Aspectos críticos } \\
Aspecto crítico 1 \\
\hline Aspecto crítico - Sim/Não $\quad \checkmark \quad$ Identificado por AJLF
\end{tabular}

$\begin{array}{llll}\text { Aspecto crítico - Sim/Não } & \checkmark & \text { Identificado por AJLF } & \\ & \text { Responsável Especialista em APO Data September 8, } 2009\end{array}$

Descrição da situação crítica Falta de portão, furos no alambrado, trinco danificado.

Nível de risco (FRANÇ, 2011) 1 - Médio risco

Causas prováveis Manutenção

Referência OMNICLASS (OCCS, 2012) 49-8141 13 - Resistência ao mal uso ; 49-81 21 13 - Limitações funcionais; 49 -81 4100 -

Propriedades de durabilidade.

Referência NBR 15966-2:2012 (ABNT, 2012) OP.60.50.02 - Resistência ao mal uso; OP.60.30.02 - Limitaç̃es funcionais; OP.60.50.00 -

Propriedades de durabilidade.

Normas, diretrizes e boas $\quad$ Normas técnicas: NBR 9050:2015 (ABNT, 2015); NBR 15575:2013 (ABNT, 2013); ISO 1686-1:2000 (ISO, 2000)

práticas

Boas práticas: providenciar manutenção corretiva para os elementos de fechamento da quadra. Exercer a territorialidade, apagando

Requisitos de desempenho (ABNT, 2013) Acessibilidade; funcionalidade; durabilidade; manutenibilidade; segurança no uso; segurança contra

NBR 15575:2013 incêndio; conforto tátil; ergonomia.

Comentários Elaborar um plano de manutenção eficiente, de modo a manter a funcionalidade do alambrado da quadra.

Aspecto crítico 2

Aspecto crítico - Sim/Não $\quad \checkmark \quad$ Identificado por $A J L F$

Responsável Especialista em APO Data September 8, 2009

Descrição da situação crítica A proximidade entre a quadra de esportes e as janelas das salas de aula gera niveis sonoros inadequados durante as aulas.

Nível de risco (FRANÇA, 2011) 1 - Médio risco

Causas prováveis Projeto

Referência OMNICLASS $\quad$ (OCCS, 2012) 49-81 8125 - Atenuação dos niveis sonoros; 49-8121 13 - Limitações funcionais.

Tabela 49

Referência NBR 15966-2:2012 (ABNT, 2012) OP-60.90.15 - Isolamento do som; OP.60.30.02 - Limitaç̃es funcionais.

Normas, diretrizes e boas Boas práticas: para a implantação do edifício, tirar proveito da distribuição dos ambientes, a fim de afastar áreas

práticas destinadas a atividades ruidosas dos ambientes de ensino.

Requisitos de desempenho (ABNT, 2013) Conforto visual; conforto acústico; acessibilidade; funcionalidade

NBR 15575:2013

Comentários 
H. MELHORIA CONTÍNUA APLICADA A

Database_SPEducational_Facilities

Status: From VI.020-1

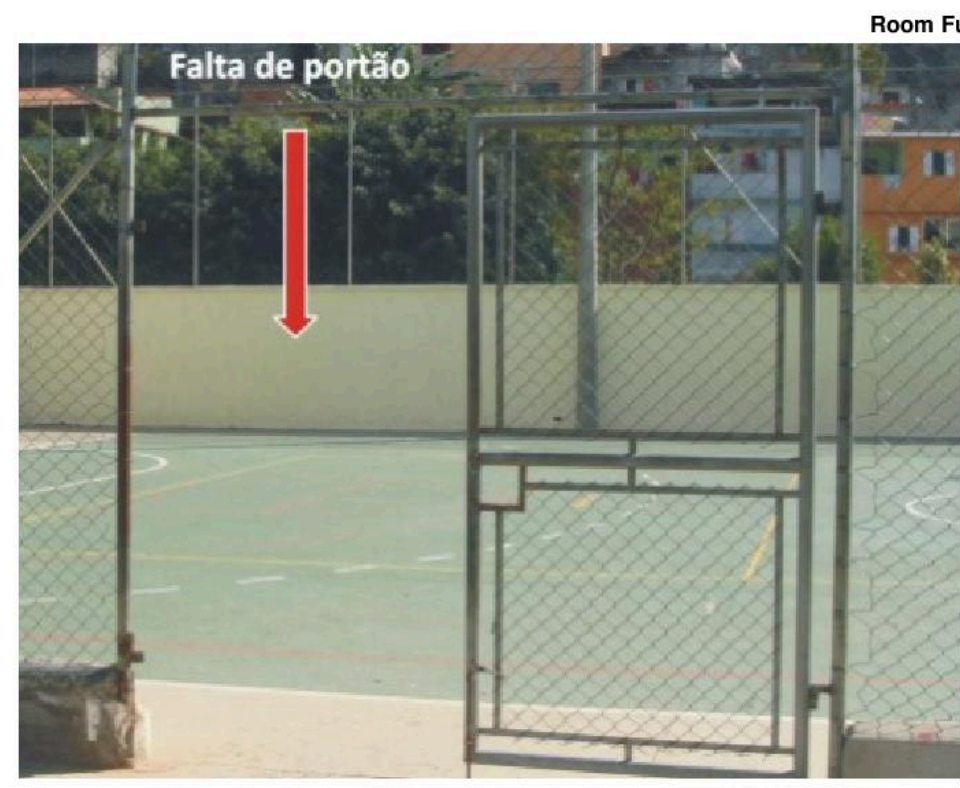

Evidência - aspecto crítico 1: falta de portão na Quadra 1. Fonte: Acervo da pesquisadora.

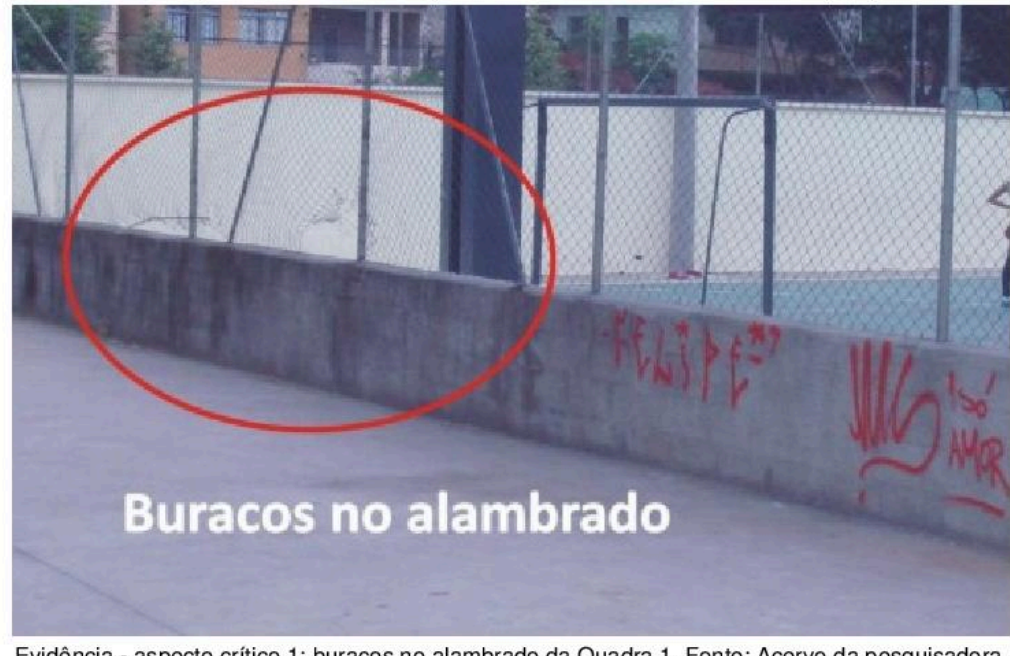

Evidência - aspecto crítico 1: buracos no alambrado da Quadra 1. Fonte: Acervo da pesquisadora.

Relatório de aspectos críticos:

Ambientes

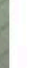

oom Function Number: 009.01.047 
HI MELHORIA CONTÍNUA APLICADA A Database_SPEducational_Facilities

Status: From VI.020-1

Salas de aula

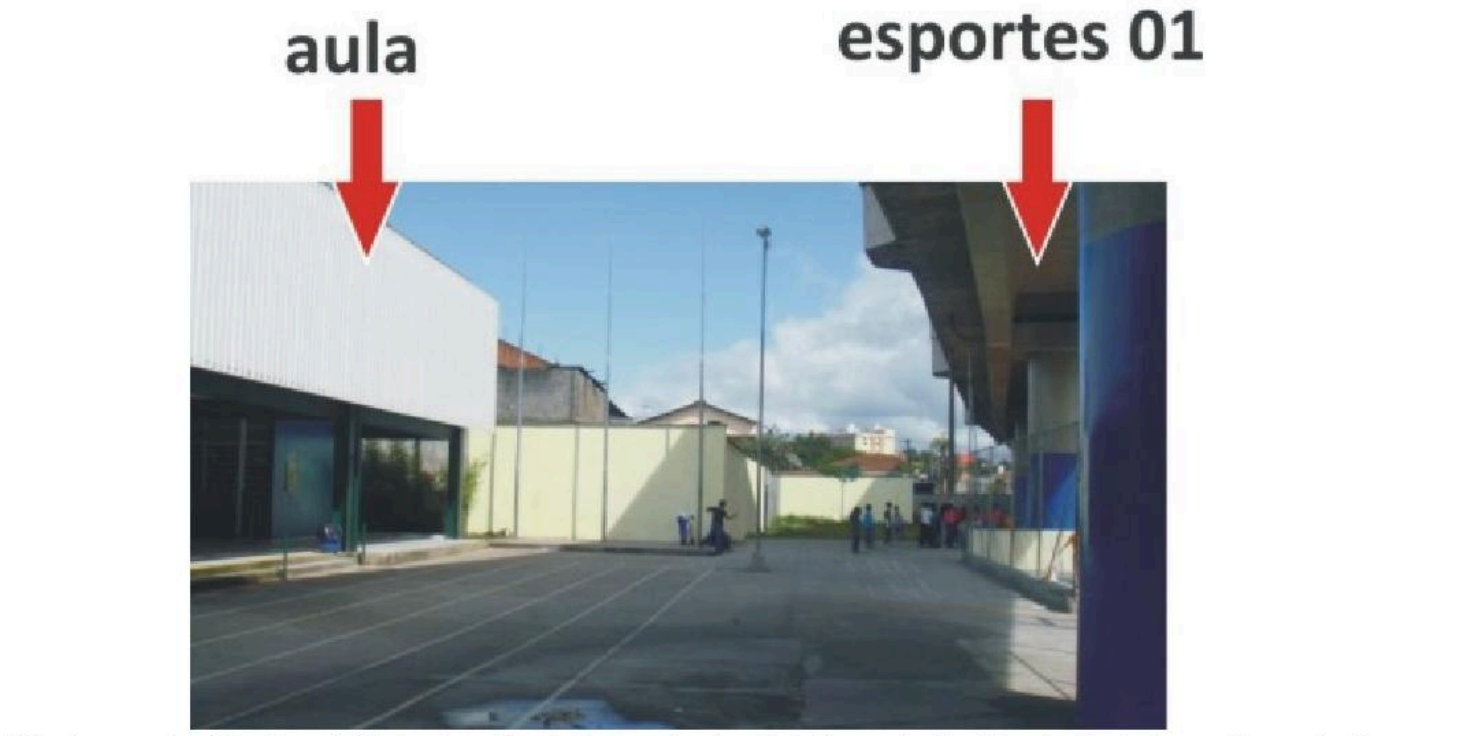
Ambientes

Relatório de aspectos críticos: Quadra de

Room Function Number: 009.01.047

Evidência - aspecto crítico 2: proximidade entre a Quadra 1 e as salas de aula da face oeste da edificação. Fonte: Acervo da pesquisadora. 
MELHORIA CONTÍNUA APLICADA A

Database_SPEducational_Facilities
Relatório de aspectos críticos: Ambientes

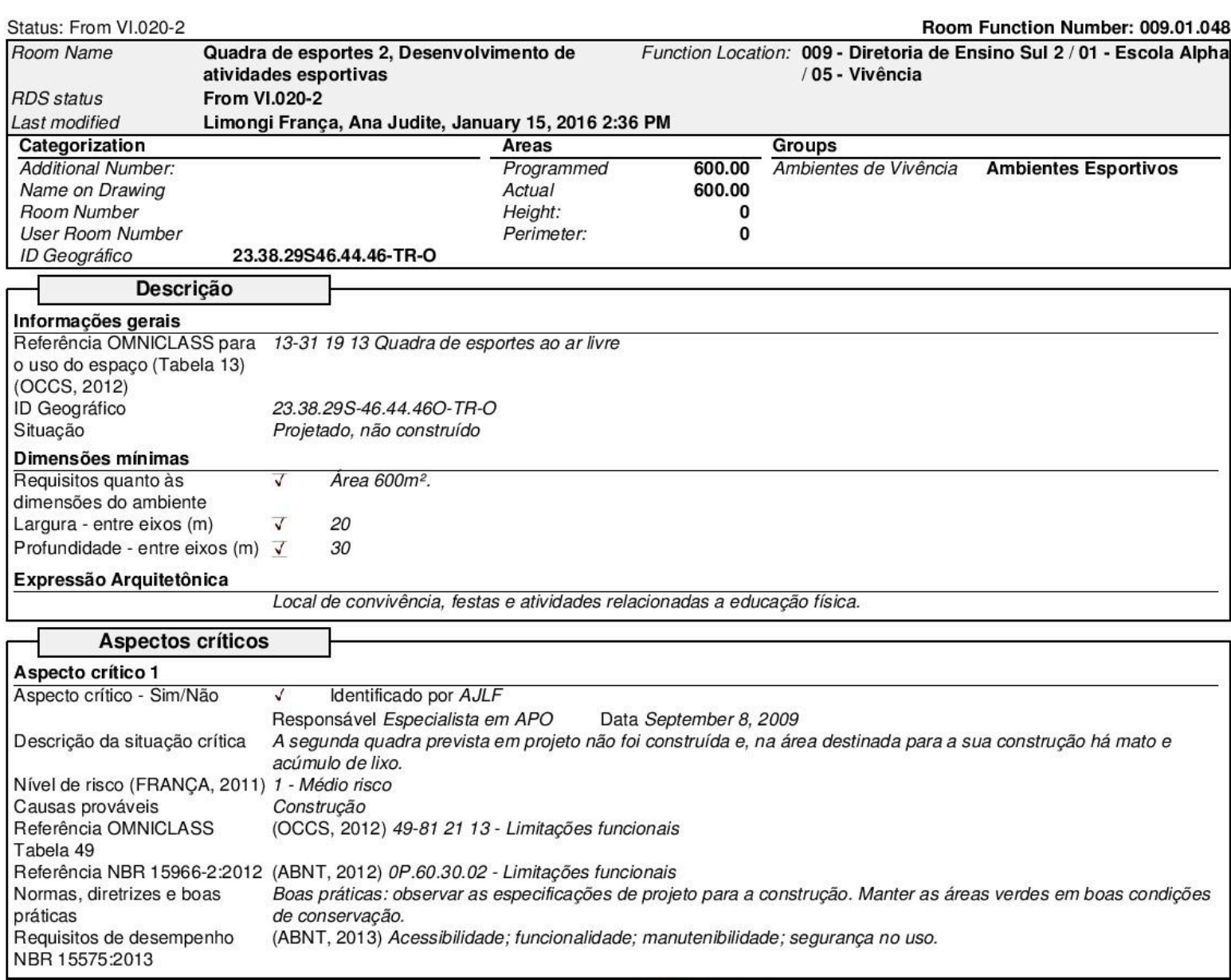

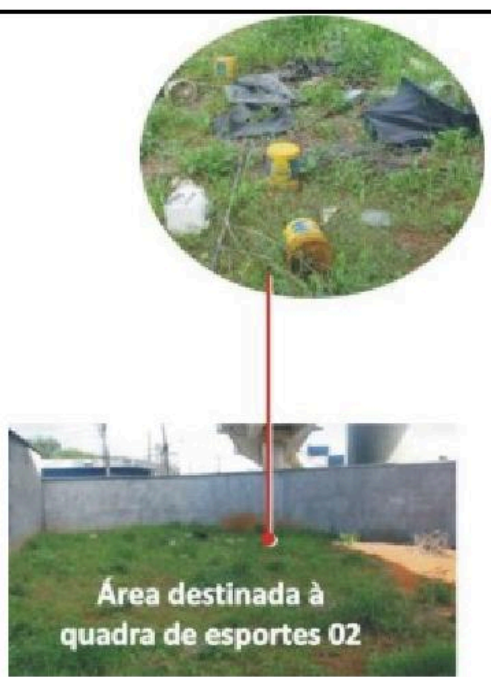

Evidência - aspecto crítico 1: a quadra 2, prevista em projeto, não foi construída. Em seu lugar, há acúmulo de lixo, proícia à proliferação de pragas. Fonte: Acervo da pesquisadora. 
MELHORIA CONTÍNUA APLICADA A atabase SPEducational Facilities
Relatório de aspectos críticos: Ambientes

Room Function Number: 009.01.049

Status: From VI.003

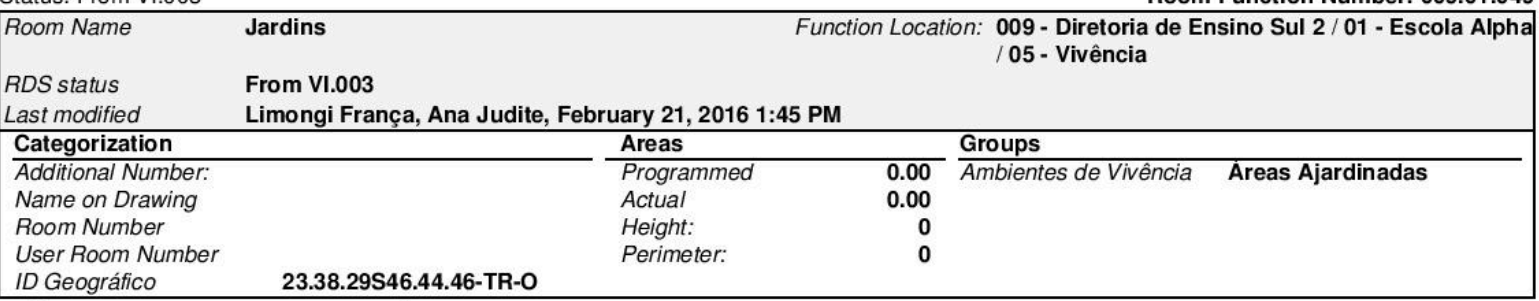
Descrição

Informações gerais

Referência OMNICLASS para 13-3111 00 Áreas de recreação nẫo destinadas à prática de esportes

o uso do espaço (Tabela 13)

(OCCS, 2012)

ID Geográfico 23.38.29S-46.44.460-TR

Situação Em operação, modificado

Aspectos críticos

Aspecto crítico 1

Aspecto crítico - Sim/Não $\quad \checkmark \quad$ Identificado por AJLF

Responsável Especialista em APO Data June 8, 2009

Descrição da situação crítica Não há áreas livres permeáveis integradas às áreas sociais, que possam ser utilizadas para o lazer, a socialização e o aprendizado. As áreas ajardinadas estão confinadas aos recuos obrigatórios e apresentam acúmulo de lixo.

Nível de risco (FRANÇA, 2011) 1 - Médio risco

Causas prováveis Manutenção

Referência OMNICLASS $\quad$ (OCCS, 2012) 49-8121 13- Limitações funcionais; 49-41318313-Cronograma de manutenção.

Tabela 49

Referência NBR 15966-2:2012 (ABNT, 2012) OP.60.30.02 - Limitações funcionais; OP.30.10.35.02 - Cronograma de manutenção.

Normas, diretrizes e boas Boas práticas: avaliar, desde as fases iniciais do projeto, a integração das áreas livres permeáveis aos demais práticas NBR 15575:2013 manutenibilidade; desempenho ambiental.

Comentários Elaborar e implementar um projeto de paisagismo que permita integrar melhor este aspecto ao edifício.

Aspecto crítico 2

Aspecto crítico - Sim/Não $\quad \checkmark \quad$ Identificado por AJLF

Responsável Especialista em APO Data June 8, 2009

Descrição da situação crítica Danos ou falta de componentes, possibilidando a entrada e saída indevida de pessoas, inclusive de alunos.

Nível de risco (FRANÇA, 2011) 0 - Alto risco

Causas prováveis Manutenção

Referência OMNICLASS (OCCS, 2012) 49-8141 13-Resistência ao mal uso ; 49-81 21 13 - Limitações funcionais; 49 -81 41 00 -

Tabela 49

Propriedades de durabilidade.

Referência NBR 15966-2:2012 (ABNT, 2012) OP.40.20.08.Grau

Normas, diretrizes e boas Normas técnicas: NBR 9050:2015 (ABNT, 2015); NBR 15575:2013 (ABNT, 2013); ISO 1686-1:2000 (ISO, 2000).

práticas

Boas práticas: manter as circulações e rotas de fuga em boas condições de acessibilidade e segurança. Exercer a territorialidade, apagando rapidamente os vestígios de vandalismo.

Requisitos de desempenho (ABNT, 2013) Acessibilidade; funcionalidade; durabilidade; manutenibilidade; segurança no uso; segurança contra NBR 15575:2013 incêndio; conforto tátil; ergonomia

Comentários Elaborar um plano de manutenção eficiente, de modo a manter os gradis em condições permanentes de utilização.

Aspecto crítico 3

Aspecto crítico - Sim/Não

$\checkmark \quad$ Identificado por $A J L F$

Responsável Especialista em APO Data June 8, 2009

Descrição da situação crítica Poucas torneiras disponíveis para a limpeza. Falta de torneiras previstas em projeto.

Nível de risco (FRANÇA, 2011) 2 - Baixo risco

Referência OMNICLASS (OCCS, 2012) 49-912311- Sistema doméstico de água fria; 49-81 2113 - Limitações funcionais.

Tabela 49

Referência NBR 15966-2:2012 (ABNT, 2012) OP.70.06.01 - Sistemas domésticos de água fria; OP.60.30.02 - Limitações funcionais.

Normas, diretrizes e boas NT: NBR 5626:92 (ABNT, 1992).

práticas Boas práticas: prever torneiras

Requisitos de desempenho (ABNT, 2013) acessibilidade; funcionalidade; salubridade; durabilidade; manutenibilidade; segurança no uso;

NBR 15575:2013 conforto tátil; ergonomia.

Comentários Prever a distribuição estratégica dos pontos de água para a limpeza e a irrigação de jardins. Projetar as torneiras para de modo a dificultar roubo ou vandalismo.

Aspecto crítico 4

Aspecto crítico - Sim/Não $\quad \checkmark \quad$ Identificado por $A J L F$

Responsável Especialista em APO Data June 8, 2009

Descrição da situação crítica Desrespeito aos elementos de divisa pelas construções vizinhas: elaboração de furos, aproveitamento irregular dos muros; pichações, trincas e buracos nos muros.

Nível de risco (FRANÇA, 2011) 1 - Médio risco

Causas prováveis Operação 
HI MELHORIA CONTINUUA APLICADA A

Database_SPEducational_Facilities
Relatório de aspectos críticos: Ambientes

Status: From VI.003

Room Function Number: 009.01.049

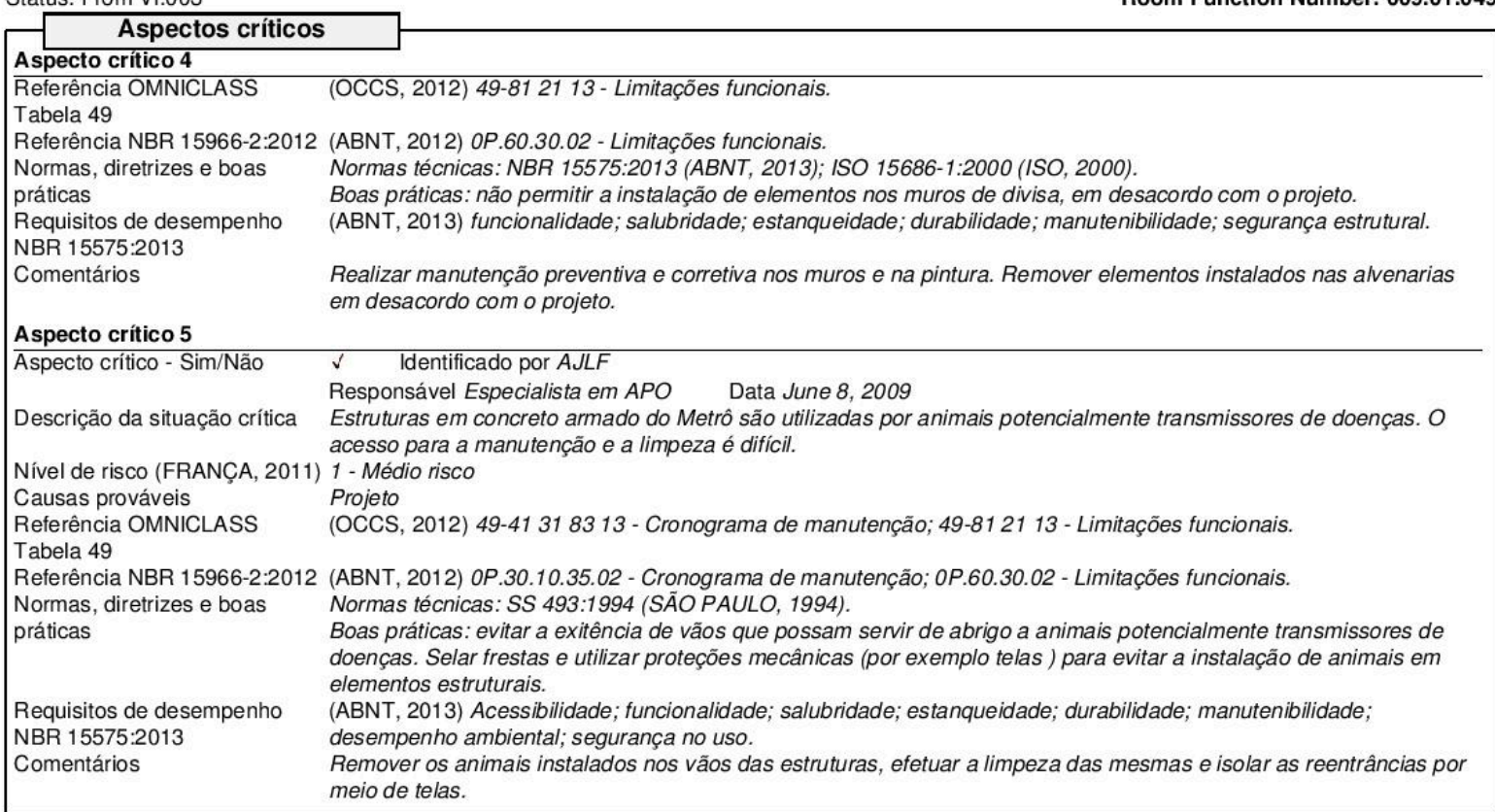

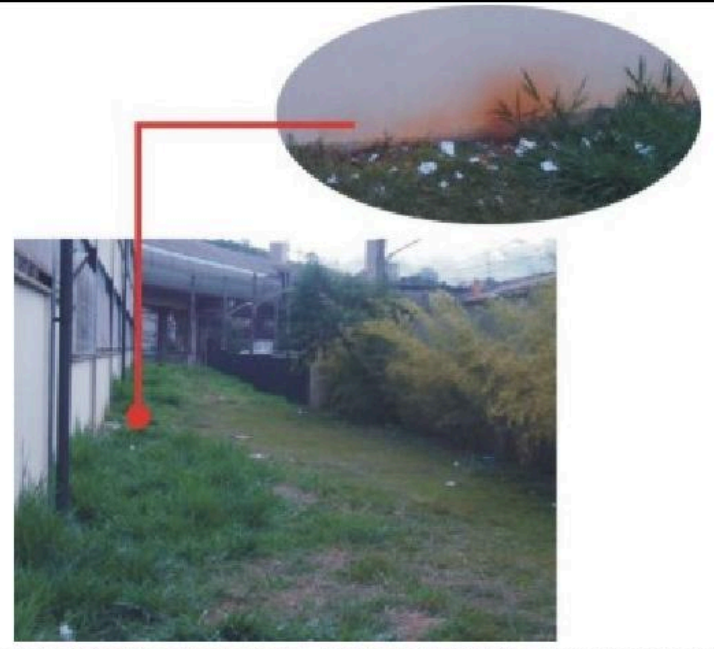

Evidência - aspecto crítico 1: acúmulo de lixo em áreas vegetadas. Fonte: Acervo da pesquisadora. 


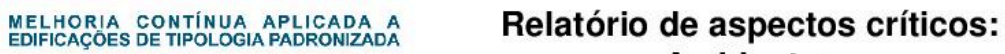

Database SPEducational Facilities

\section{Ambientes}

Status: From VI.003

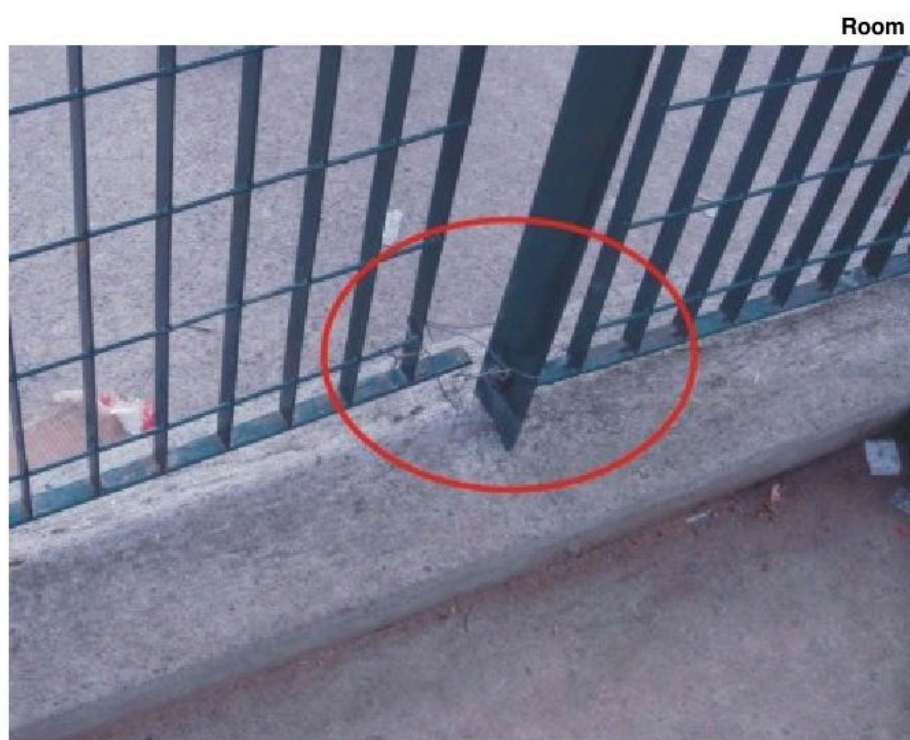

Room Function Number: 009.01.049

Evidência - aspecto crítico 2: danos a gradis, possibiltando a entrada e a saída indevidas à edificação. Fonte: Acervo da pesquisadora.

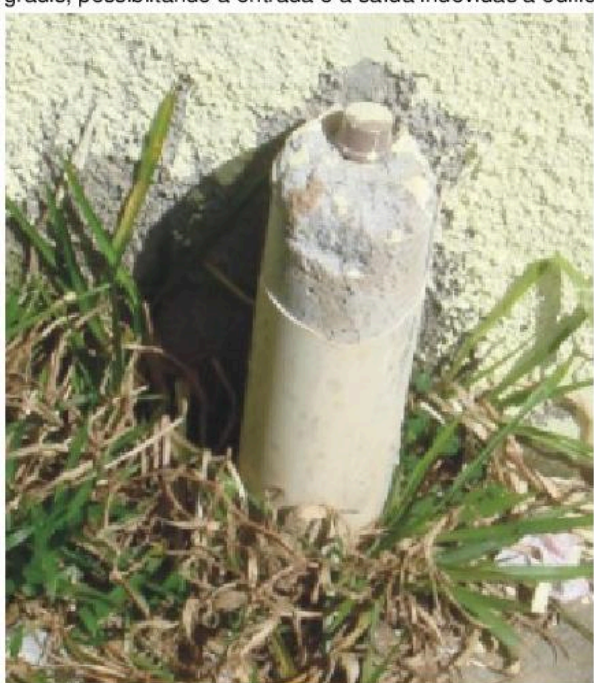

Evidência - aspecto crítico 3: falta de torneiras previstas em projeto. Fonte: Acervo da pesquisadora.
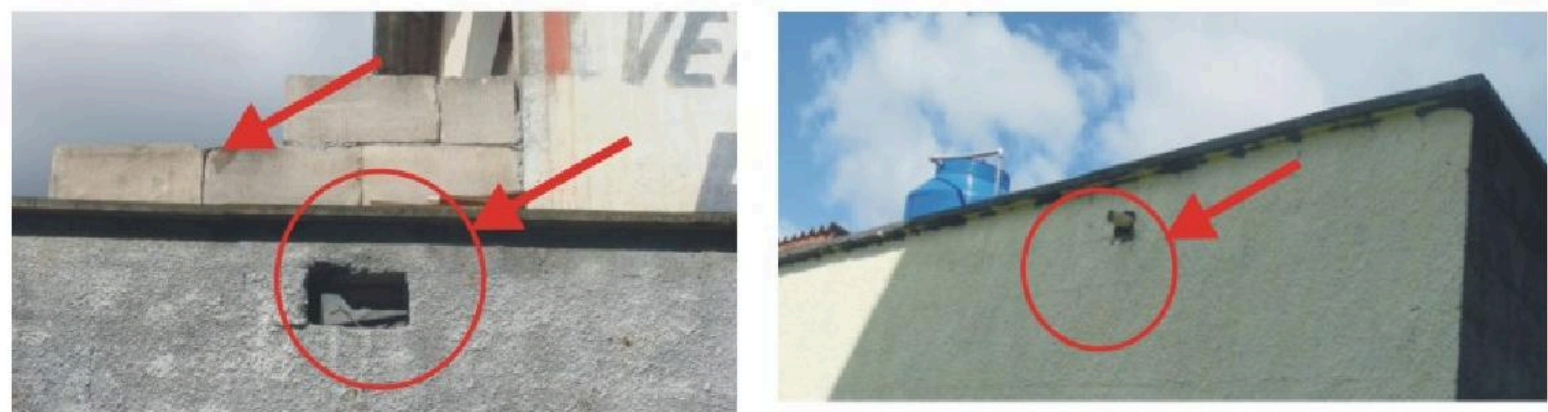

Evidência - aspecto crítico 4: desrespeito aos elementos de divisas pelas construções vizinhas. Fonte: Acervo da pesquisadora. 
H1 MELHORIA CONTINUA APLICADA A

Database_SPEducational_Facilities

Status: From VI.003
Relatório de aspectos críticos:

Ambientes

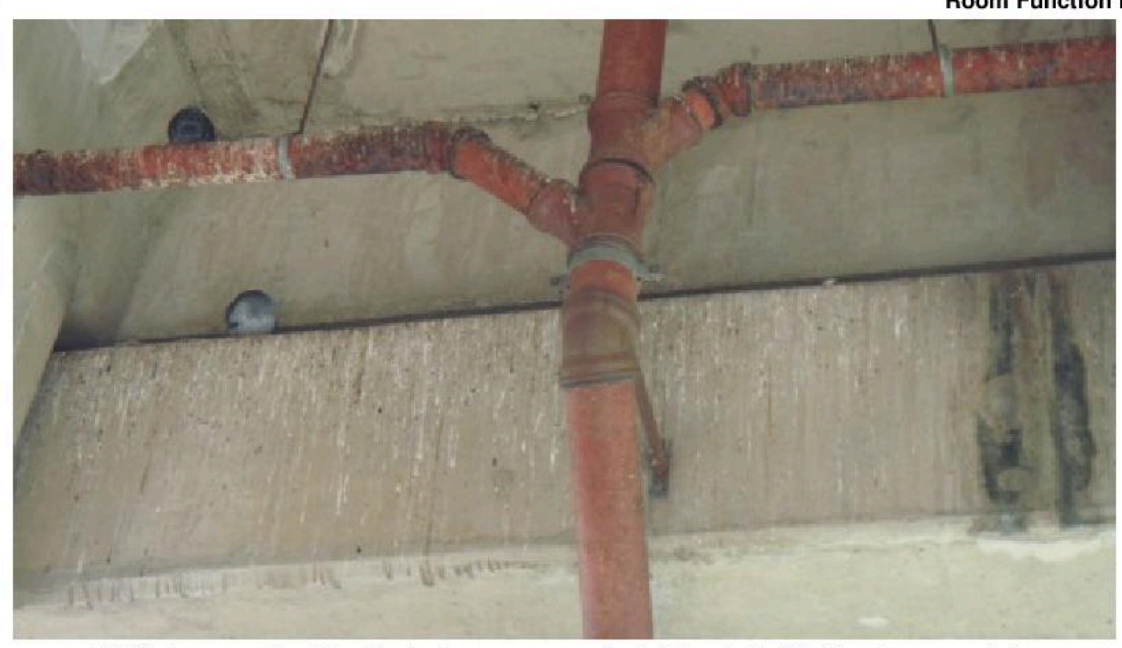

Evidência - aspecto crítico 5: estruturas em concreto da linha do Metrô utilizadas como abrigo por animais potencialmente transmissores de doenças. Fonte: Acervo da pesquisadora. 
MELHORIA CONTINUA APLICADA A H Database_SPEducational_Facilities
Relatório de aspectos críticos: Componentes

\begin{tabular}{|c|c|c|c|}
\hline & & & Item Number 23-21.19.00.23-21.19.13.0 \\
\hline $\begin{array}{l}\text { Item name } \\
\text { Last modified }\end{array}$ & $\begin{array}{l}\text { Balcão de atendimento em granito com porta de } \\
\text { enrolar: } 210 \mathrm{~cm} \times 60 \mathrm{~cm} \\
\text { Limongi França, Ana Judite, January 9, } 2016 \text { 3:1 }\end{array}$ & $\begin{array}{l}\text { Function Location: } \\
4 \text { PM }\end{array}$ & $\begin{array}{l}\text { 23-21.19.00 - Casework / 23-21.19.13 - Custom } \\
\text { General Casework }\end{array}$ \\
\hline \multicolumn{2}{|r|}{ Linumyin } & \multicolumn{2}{|l|}{ Other } \\
\hline \multicolumn{4}{|c|}{ Descrição } \\
\hline \multicolumn{4}{|c|}{$\begin{array}{l}\text { Função do componente } \\
\text { Balcão de atendimento e porta basculante de acionamento manual, composta de sistema completo de contrapeso para acionamento manual; } \\
\text { caixa lateral para o contrapeso em chapa dobrada de aço galvanizado, e=1,6mm; travessão superior em chapa dobrada de aço galvanizado, } \\
e=1,6 \mathrm{~mm} \text {; folha da porta constituída de: chapa lisa de aço galvanizado, e=1,6mm; requadro em tubo de aço galvanizado a fogo (40x80mm, } \\
e=1,2 \mathrm{~mm}) ; \text { montantes verticais em tubo de aço galvanizado a fogo (40x40mm, e=1,2mm); mata-juntas em perfi s " } \mathrm{L} \text { " }(1 / 2 \text { " } x 1 / 8 \text { ") e barra chata } \\
(3,18 \mathrm{~mm} \text { e=3mm); fita vedadora ("escova") com base rígida de polipropileno e fios semiflexíveis, para vedação da fresta no trecho junto ao eixo } \\
\text { de basculação onde não existe mata-junta; protetor para o trilho e trava para o portão na posição, aberto: chapa dobrada de aço galvanizado, } \\
\text { e=1,2mm, conforme detalhe; portas-cadeado em chapa de aço galvanizado a fogo, e=3mm. } \\
\text { Fonte das especificações: FDE, } 2014 \text {. }\end{array}$} \\
\hline \multicolumn{4}{|c|}{$\begin{array}{l}\text { Referência OMNICLASS } \\
22-123640 \text { Balcôes em pedra }\end{array}$} \\
\hline \multicolumn{4}{|c|}{ Materiais } \\
\hline \multicolumn{4}{|c|}{ corumbá ou cinza andorinha, $(\mathrm{e}=2 \mathrm{~cm})$, com testeira, conforme detalhe. } \\
\hline \multicolumn{4}{|c|}{ 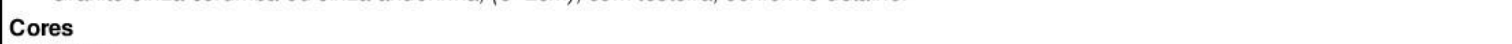 } \\
\hline \multicolumn{4}{|c|}{$\begin{array}{l}\text { Informação para identificação - ID } \\
\text { BA12_15_10_14.pdf }\end{array}$} \\
\hline $\begin{array}{l}\text { Vida útil } \\
\quad 10 \text { anos }\end{array}$ & & & \\
\hline
\end{tabular}

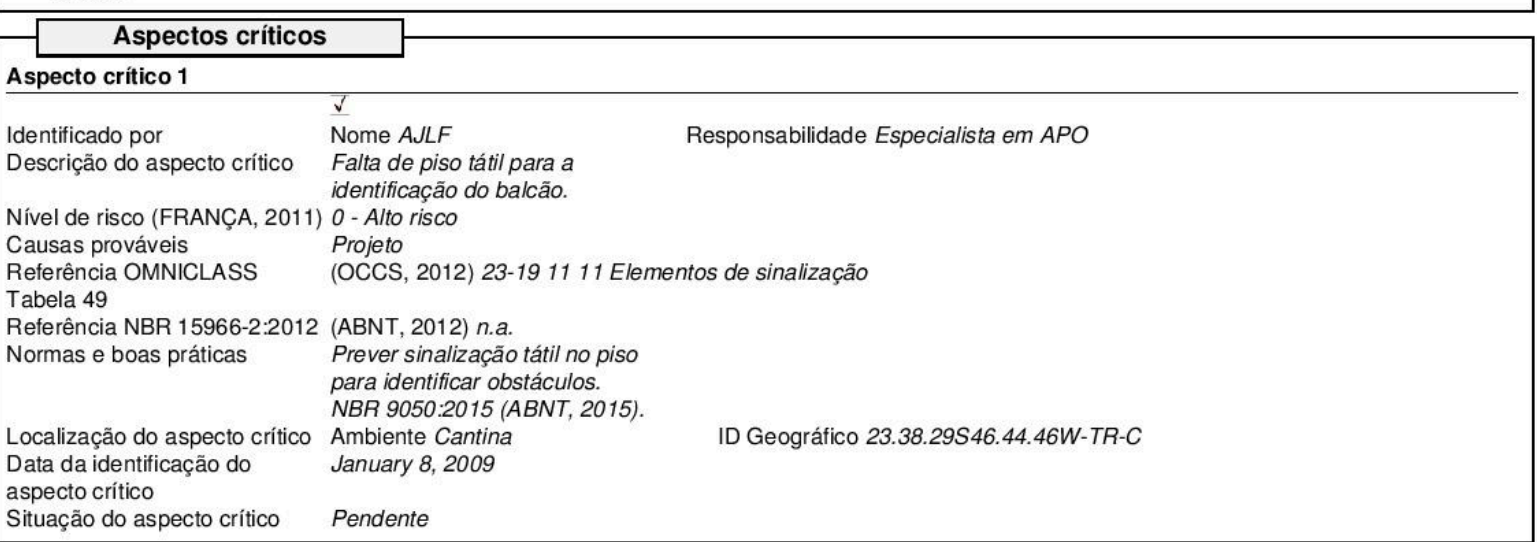

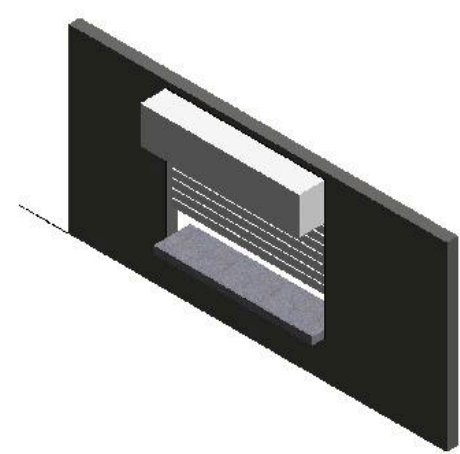

Imagem obtida a partir do modelo tridimensional, elaborado por utilizando o programa Revit 2014. Fonte: Acervo da pesquisadora. 


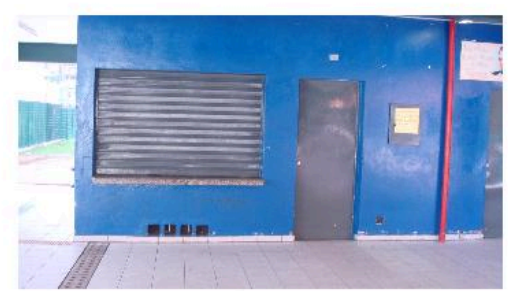

Item Number 23-21.19.00.23-21.19.13.002

Evidência de aspecto crítico: Balcão BA-02 não apresenta sinalização tátil no piso, para identificação de obstáculo. Fonte: Acervo da pesquisadora.

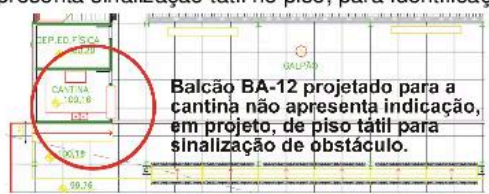

Evidência de aspecto crítico: Planta do pavimento térreo não apresenta indicação de sinalização tátil no piso, para o balcão BA-12. Detalhe da planta 0059199_01APE0200_01.dwg. Fonte: Acervo da FDE. 
MELHORIA CONTÍNUA APLICADA A Hin

Database_SPEducational_Facilities

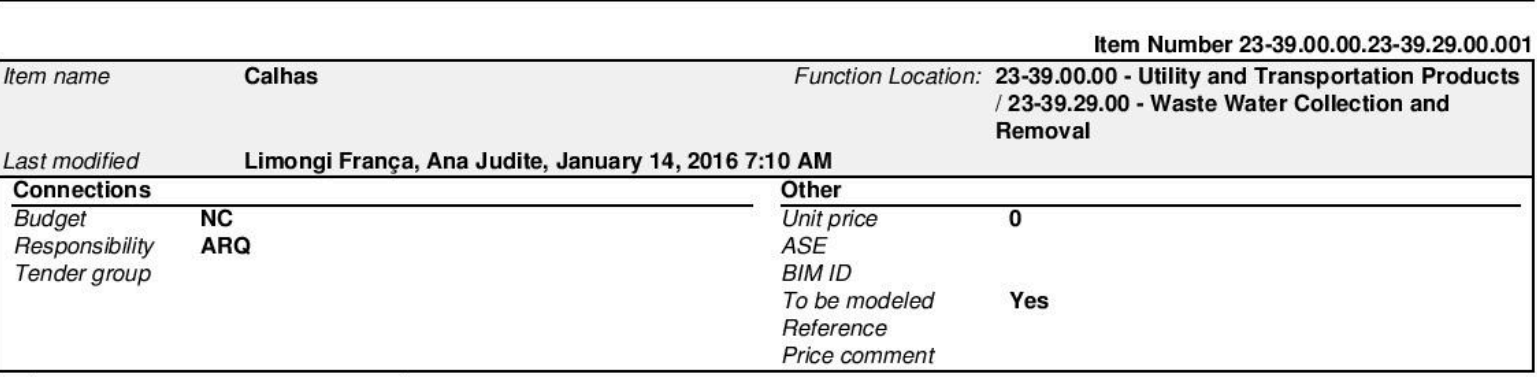

Descrição

Função do componente

Coleta de águas pluviais

Referência OMNICLASS

22-22 1400 Sistema de drenagem de águas pluviais

Materiais

PVC.

Acabamento

Pintura esmalte.

Cores

Verde colonial.

Vida útil

20 anos

\begin{tabular}{|c|c|}
\hline Aspectos críticos & \\
\hline Aspecto crítico 1 & \\
\hline & $\checkmark$ \\
\hline Identificado por & Responsabilidade Especialista em APO \\
\hline Nível de risco (FRANÇA, 2011) & 0 - Alto risco \\
\hline Causas prováveis & Planejamento \\
\hline $\begin{array}{l}\text { Referência OMNICLASS } \\
\text { Tabela } 49\end{array}$ & (OCCS, 2012) 49-91 8115 Eficiência quanto ao consumo de água. \\
\hline Referência NBR 15966-2:2012 & (ABNT, 2012) OP.70.60.06.03 Eficiência da água. \\
\hline Normas e boas práticas & $\begin{array}{l}\text { Captar e reutilizar as águas } \\
\text { pluviais no empreendimento. }\end{array}$ \\
\hline Situação do aspecto crítico & Pendente \\
\hline
\end{tabular}

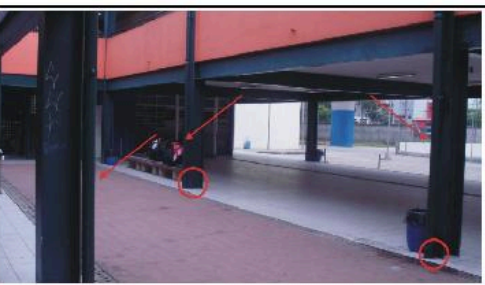

Evidência - aspecto crítico 1: sistema de coleta de águas pluviais - as águas das chuvas não são direcionadas para reúso. Fonte: Acervo da pesquisadora. 
MELHORIA CONTÍNUA APLICADA A

ㅂ.

Database_SPEducational_Facilities
Relatório de aspectos críticos: Componentes

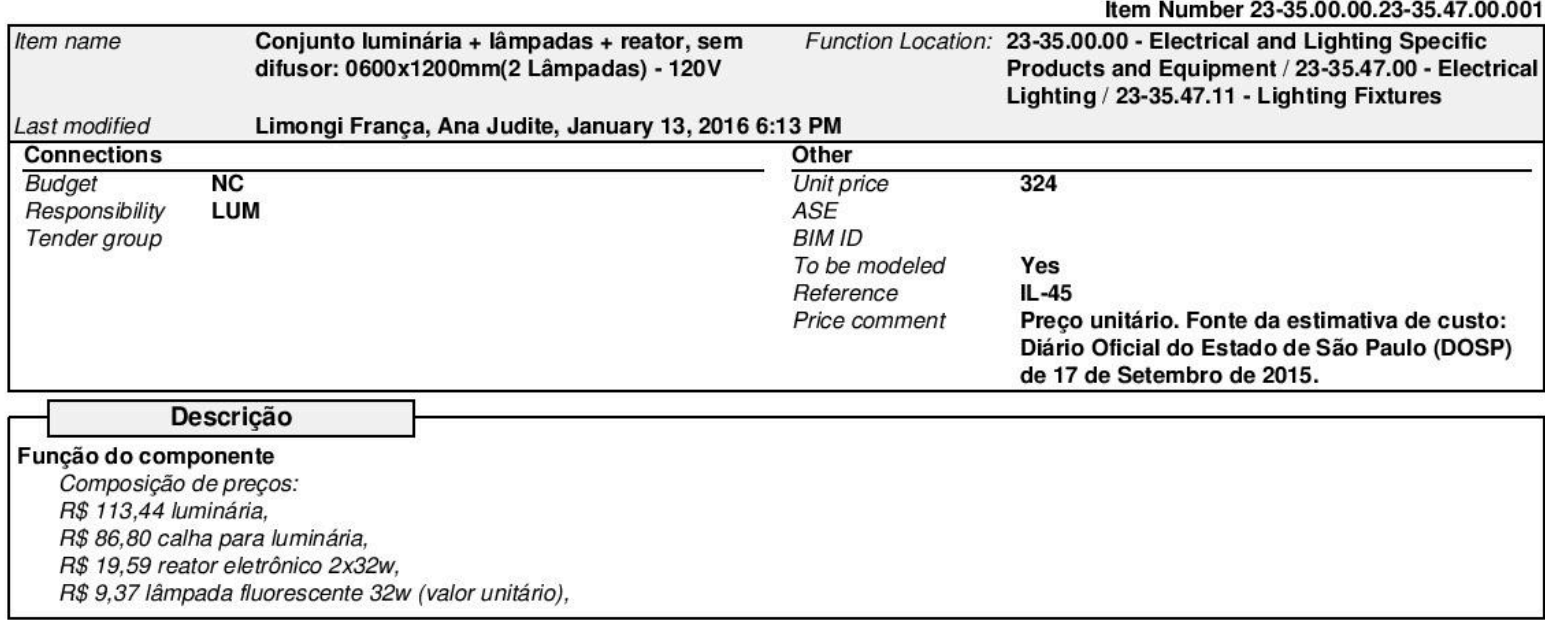

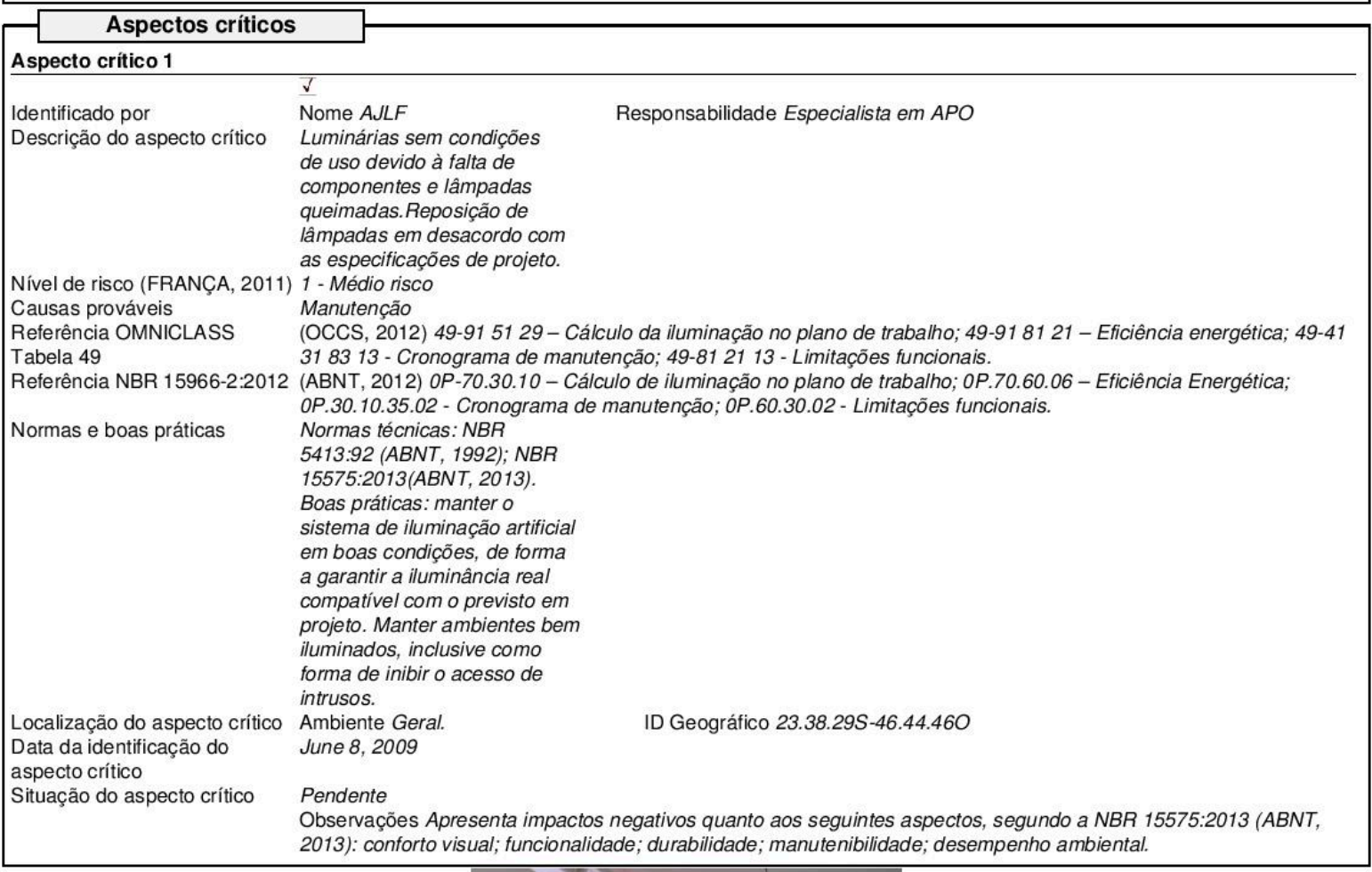

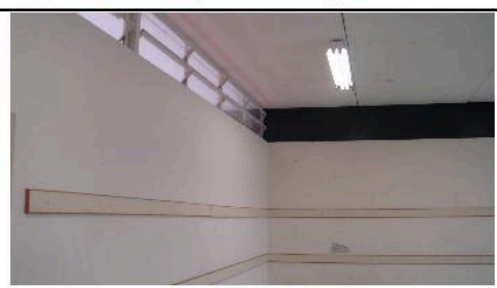

Luminária IL-45 instalada na Escola Alpha. Fonte: Acervo da pesquisadora. 
Relatório de aspectos críticos: Componentes

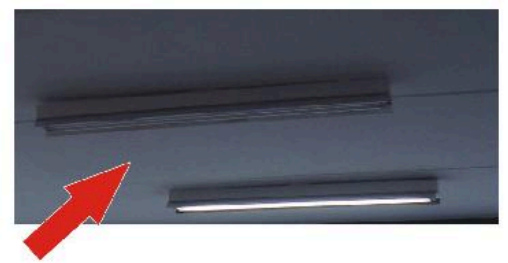

Item Number 23-35.00.00.23-35.47.00.001

Evidência - aspecto crítico 1: exemplo de luminária com lâmpadas queimadas, instalada em sala de aula. Fonte: Acervo da pesquisadora. 
MELHORIA CONTÍNUA APLICADA A atabase SPEducational Facilities
Relatório de aspectos críticos: Componentes

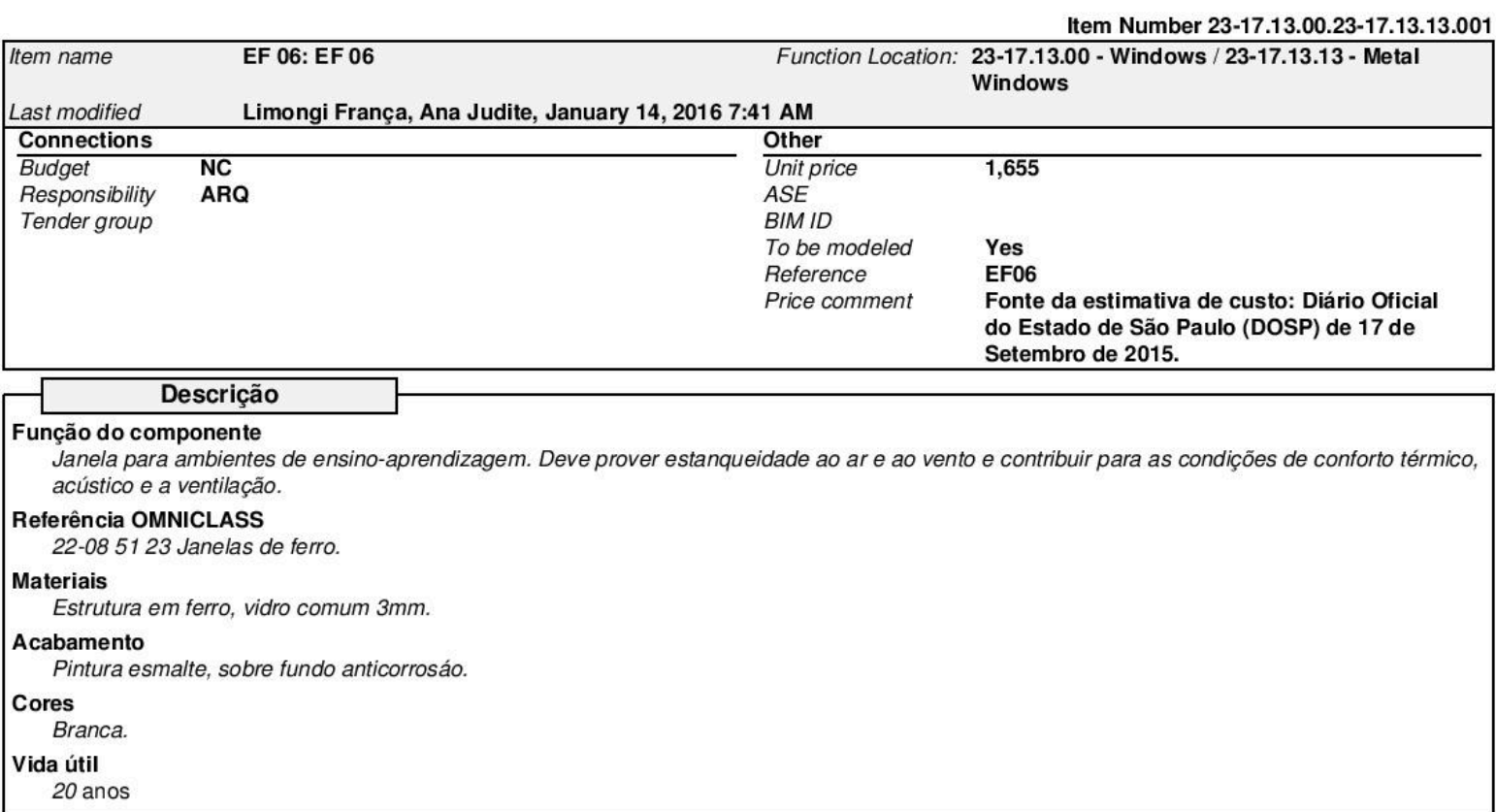

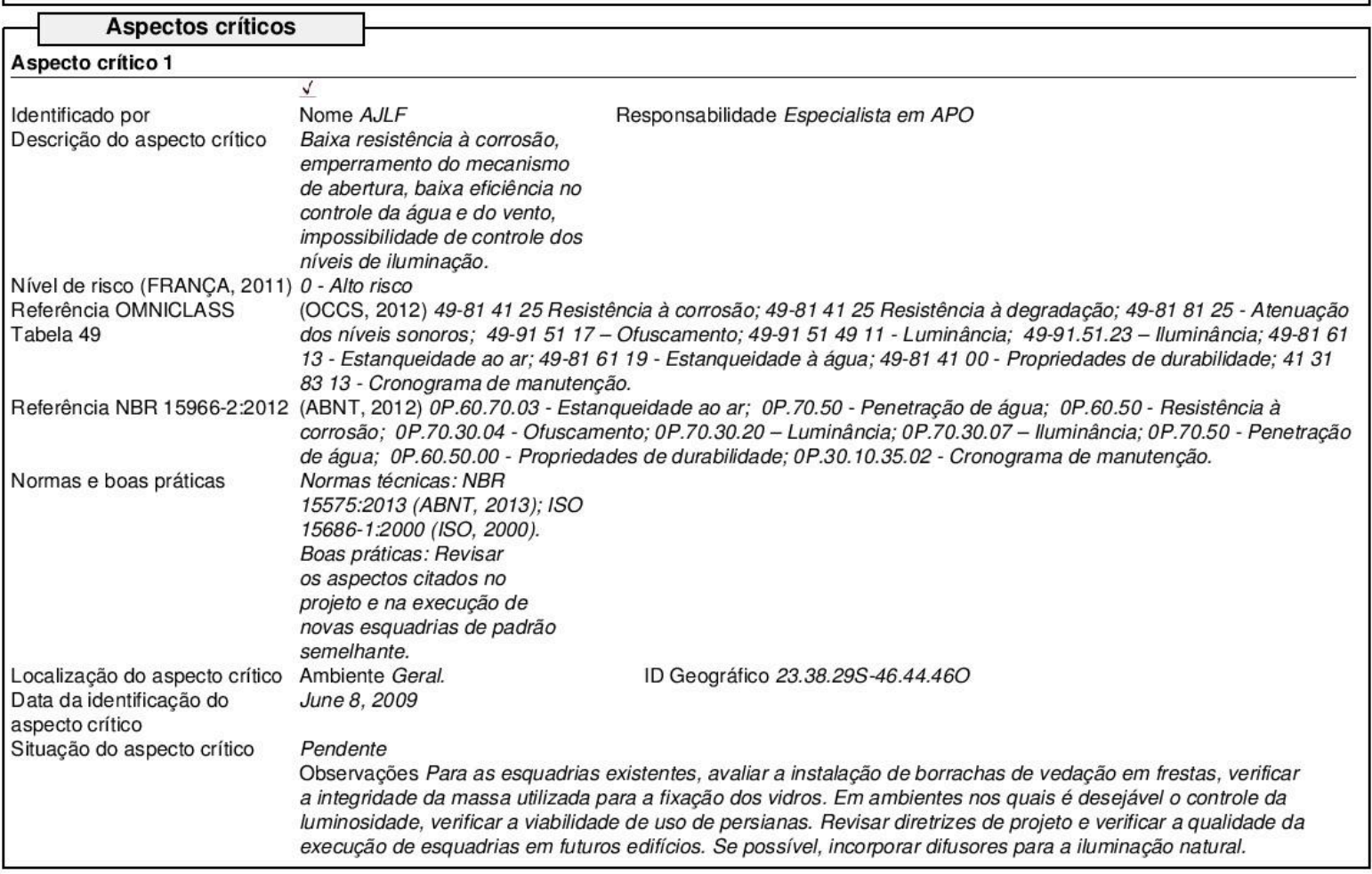


Relatório de aspectos críticos:

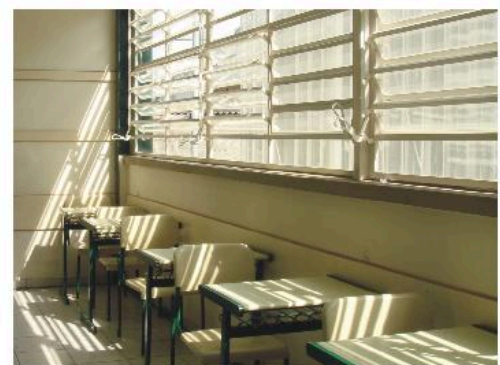

Item Number 23-17.13.00.23-17.13.13.001

Evidëncia - aspecto crítico 1: esquadria EF-06 não apresenta desempenho adequado quanto à estanqueidade à água e ao vento; ao controle da incidência de luz solar direta e à usabilidade, devido ao emperramento de partes móveis. Fonte: Acervo da pesquisadora.

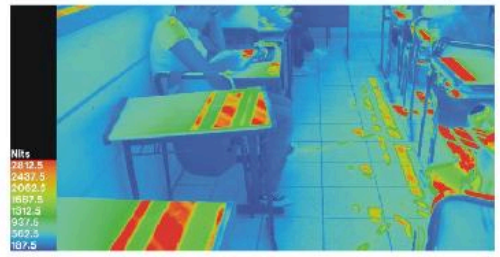

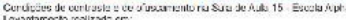

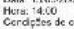

Evidëncia - aspecto crítico 1: esquadria EF-06 não apresenta desempenho adequado quanto à estanqueidade à água e ao vento; ao controle da incidência de luz solar direta. A análise elaborada para as condições de ofuscamento demonstra condição de desconforto no plano de trabalho (áreas críticas em vermelho). Renderização de imagem HDR, utilizando o programa Radiance. Fonte: Acervo da pesquisadora. 
Relatório de aspectos críticos: Componentes

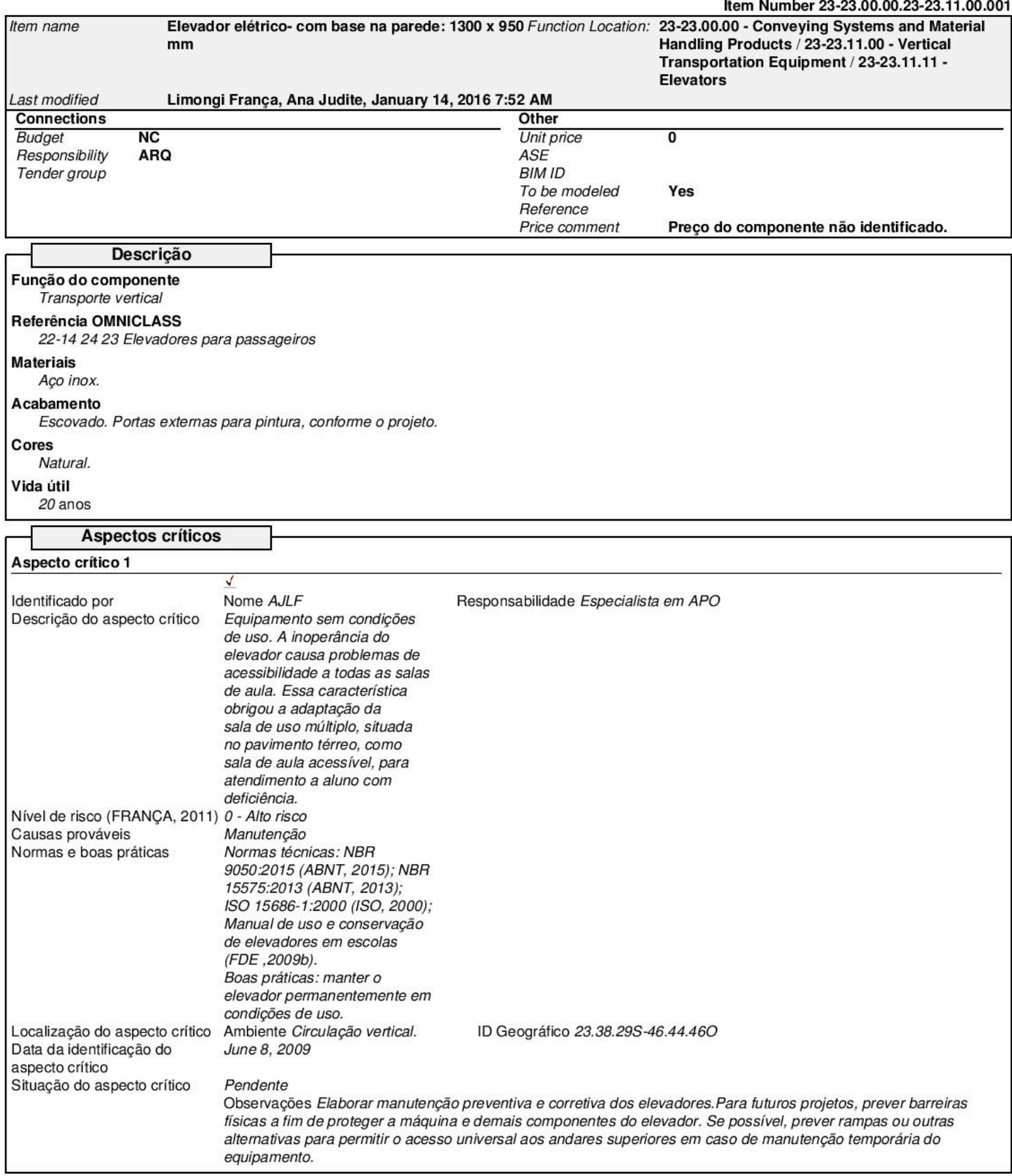


MELHORIA CONTÍNUA APLICADA A H Database_SPEducational_Facilities
Relatório de aspectos críticos: Componentes

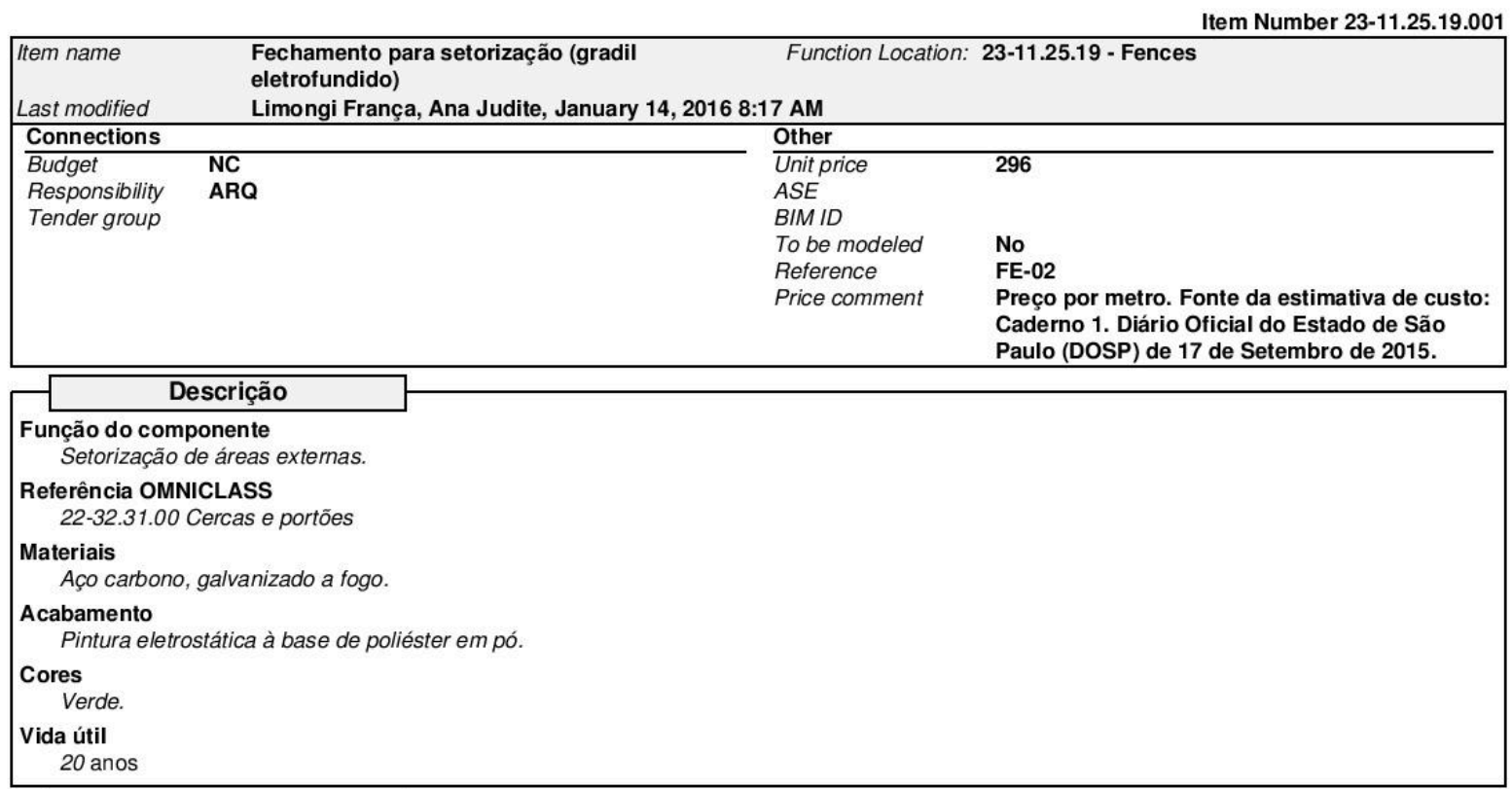

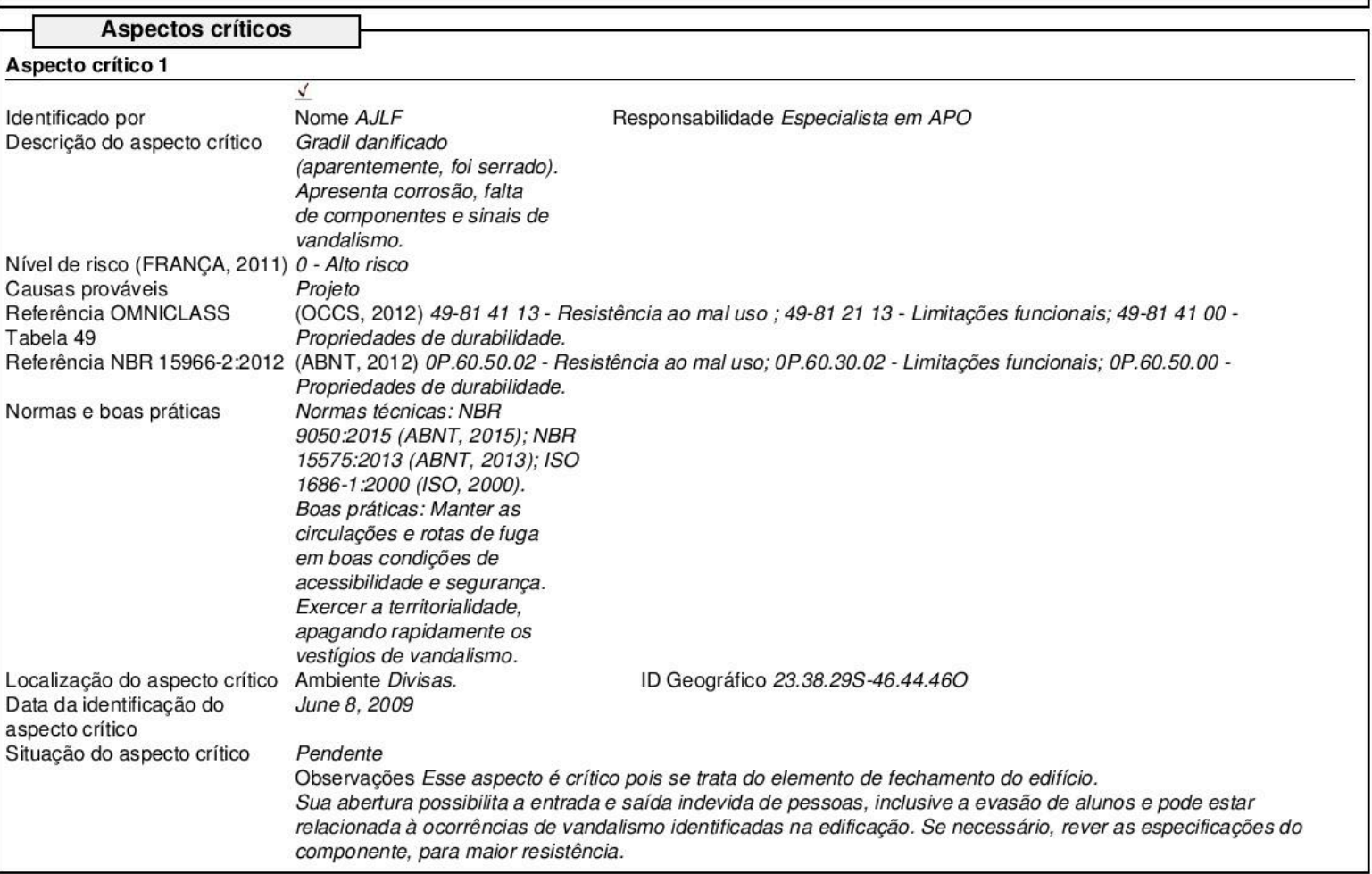


H MELHORIA CONTÍNUA APLICADA A Database_SPEducational_Facilities
Relatório de aspectos críticos: Componentes

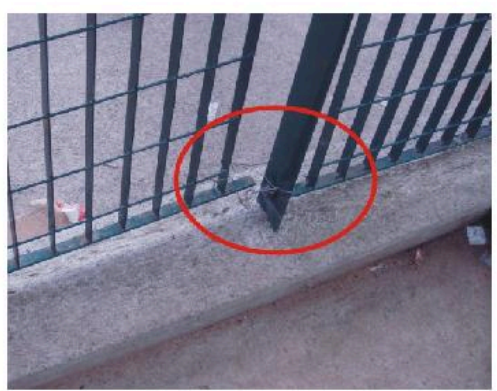

Item Number 23-11.25.19.001

Evidência - aspecto crítico 1: gradil para o fechamento externo da edificação danificado (aparentemente, foi serrado). Fonte: Acervo da pesquisadora. 

MELHORIA CONTINUA APLICADA A Database_SPEducational_Facilities
Relatório de aspectos críticos: Componentes

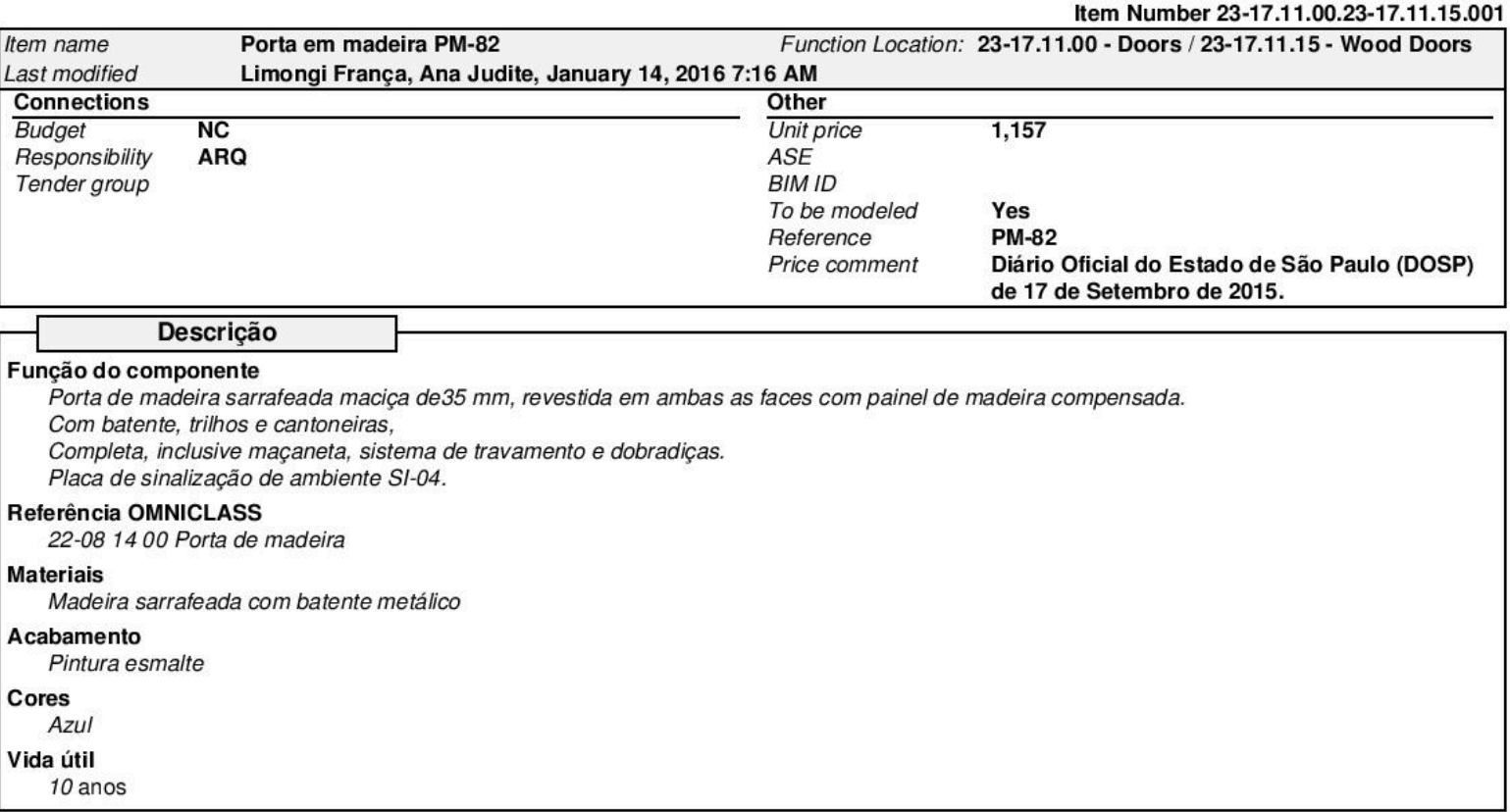

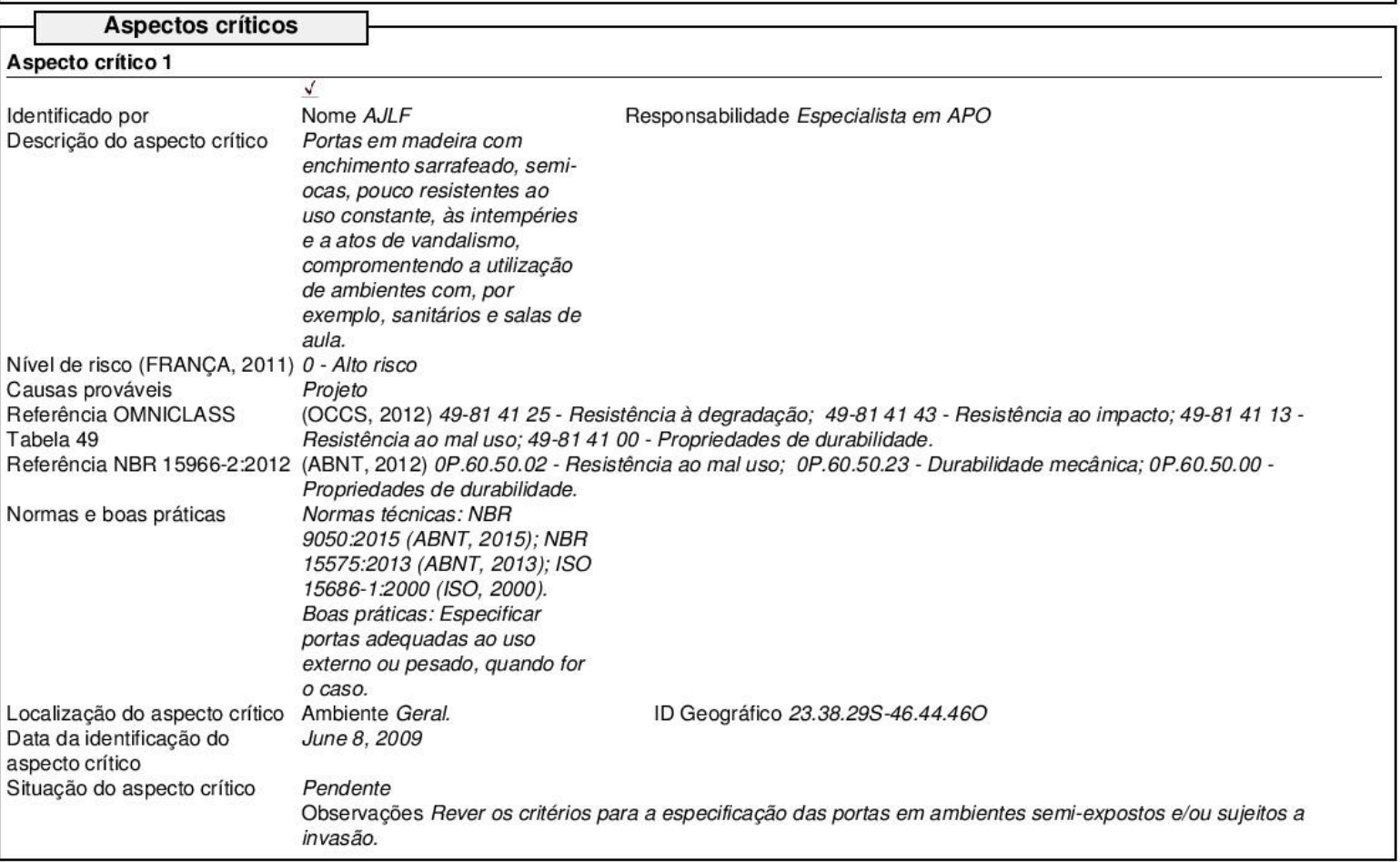


H MELHORIA CONTÍNUA APLICADA A Database_SPEducational_Facilities
Relatório de aspectos críticos: Componentes

Item Number 23-17.11.00.23-17.11.15.001

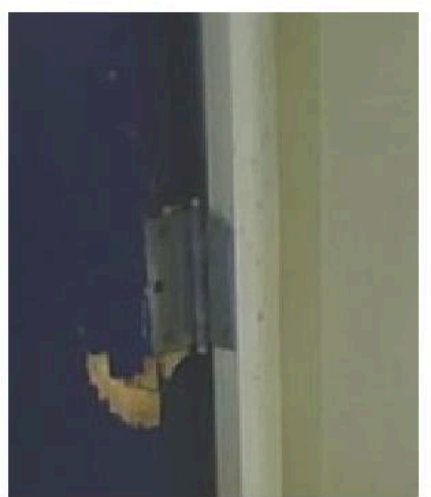

Evidência- aspecto crítico 1: porta danificada. Fonte: Acervo da pesquisadora. 
MELHORIA CONTINUA APLICADA A Hi Database_SPEducational_Facilities
Relatório de aspectos críticos: Componentes

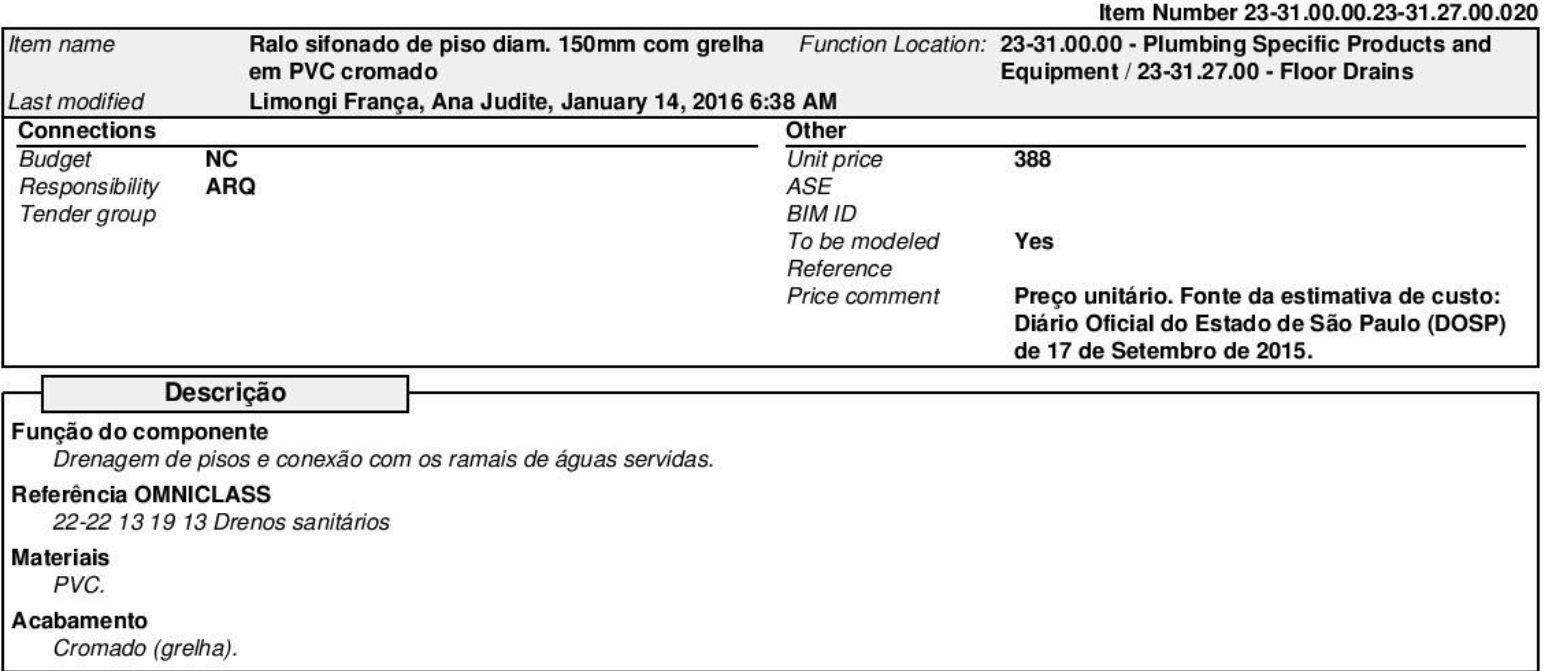

\section{Aspectos críticos}

\section{Aspecto crítico 1}

Descrição do aspecto crítico Vazão insuficiente em ralos

e caimento inadequado de

pisos dificultam a drenagem,

causando acúmulo de

água em corredores, áreas

externas e sanitários, caimento

inadequado, dimensionamento

e localização de ralos

insuficientes.

Referência OMNICLASS $\quad$ (OCCS, 2012) 49-91 2317 - Sistema de drenagem; 49-81 21 13 - Limitações funcionais.

Tabela 49

Referência NBR 15966-2:2012 (ABNT, 2012) OP.70.06.01 - Sistemas de águas residuais; OP.60.30.02 - Limitações funcionais.

Normas e boas práticas

Normas técnicas: NBR5626:92

(ABNT, 1992); NBR 10844:89

(ABNT, 1989); NBR 8160:99

(ABNT, 1999).

Boas práticas: Respeitar

especificações de projeto

quanto ao caimento de pisos.

Realizar manutenção periódica

e preventiva nas instalaçōes.

Localização do aspecto crítico Ambiente Geral.

ID Geográfico 23.38.29S-46.44.460

Data da identificação do

June 8, 2009

aspecto crítico

Situação do aspecto crítico

Pendente

Observações Verificar critérios de dimensionamento e execução do sistema. Implantar medidas de operação e

manutenção compatíveis com o especificado quanto a materiais e sistemas. A manutenção preventiva pode reduzir

custos a longo prazo.

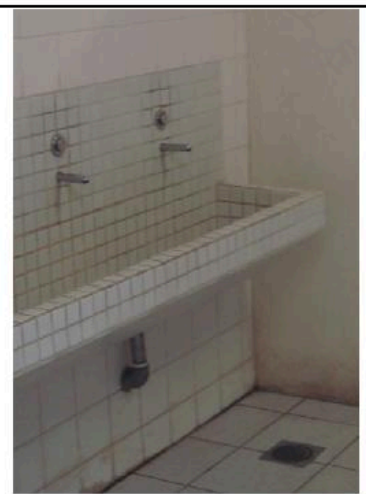

Evidência - aspecto crítico 1: sistema de drenagem deficiente no sanitário feminino dos alunos caimento de piso inadequado não direciona a água para o ralo. Fonte: acervo da pesquisadora. 
MELHORIA CONTÍNUA APLICADA A

atabase_SPEducational_Facilities
Relatório de aspectos críticos: Componentes

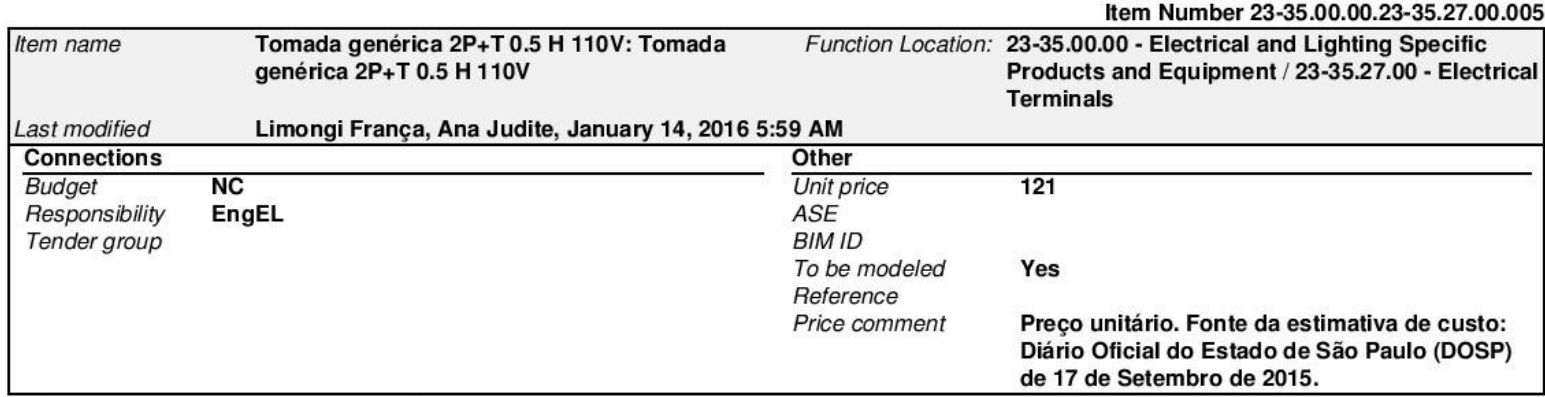

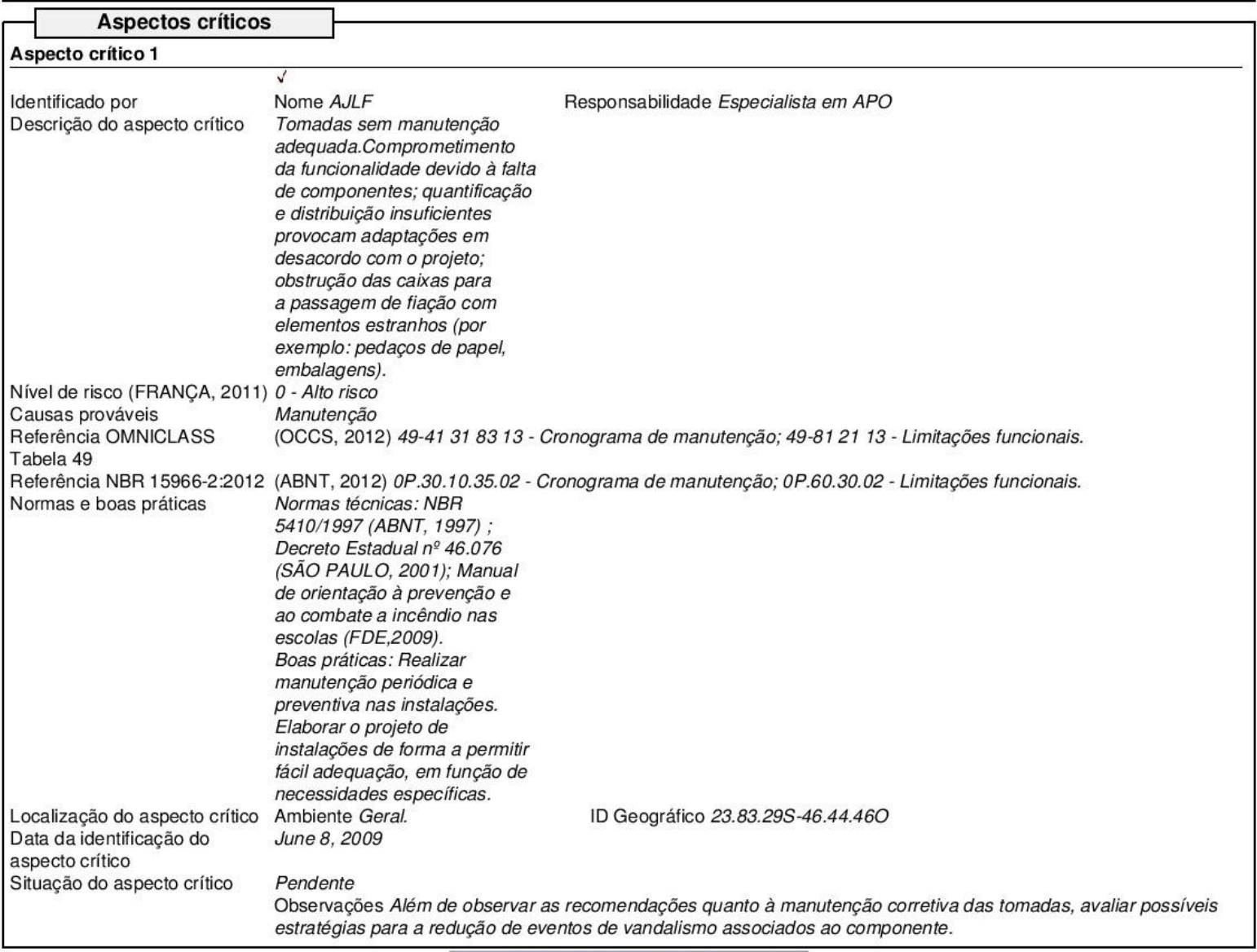

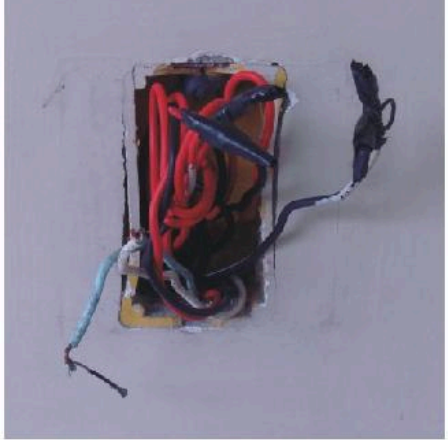

Evidência - aspecto crítico 1: tomada sem condições de uso devido à falta de componetes. Fonte: Acervo da pesquisadora. 
MELHORIA CONTINUAA APLICADA A Hit Database_SPEducational_Facilities
Relatório de aspectos críticos: Componentes

\begin{tabular}{|c|c|c|c|}
\hline $\begin{array}{l}\text { Item name } \\
\text { Last modified }\end{array}$ & $\begin{array}{l}\text { Ventilador de parede VN-02: Ventilador de parede } \\
\text { VN-02 } \\
\text { Limongi França, Ana Judite, January 13, } 20161: 3\end{array}$ & Function Location: & $\begin{array}{l}\text { 23-33.00.00 - HVAC Specific Products and } \\
\text { Equipment / 23-33.31.19 - Fans }\end{array}$ \\
\hline Connections & & Other & \\
\hline \multicolumn{4}{|c|}{ Descrição } \\
\hline \multicolumn{4}{|c|}{$\begin{array}{l}\text { Função do componente } \\
\text { Ventilador } R \$ 125,99 \\
\text { Instalação } R \$ 10,12 .\end{array}$} \\
\hline
\end{tabular}

Aspectos críticos

\section{Aspecto crítico 1}

Identificado por

Descrição do aspecto crítico Os ventiladores especificados

Responsabilidade Especialista em APO

em projeto não se encontravam

instalados.

Nível de risco (FRANÇA, 2011) 1 - Médio risco

Causas prováveis Operação

Referência OMNICLASS $\quad$ (OCCS, 2012) 49-8121 13 - Limitações funcionais;

Tabela 49

Referência NBR 15966-2:2012 (ABNT, 2012) OP.60.30.02 - Limitações funcionais.

Normas e boas práticas Observar as especificações de projeto

Localização do aspecto crítico Ambiente Salas de aula, sala do ～ID Geográfico 23.38.29S-46.44.46O

grêmio, salas de refoço, sala de uso

multiplo, sala de leitura.

Data da identificação do June 8, 2009

aspecto crítico

Situação do aspecto crítico Pendente

Observações $A$ falta do equipamento impacta negativamente nas condições de conforto higrotérmico dos usuários.

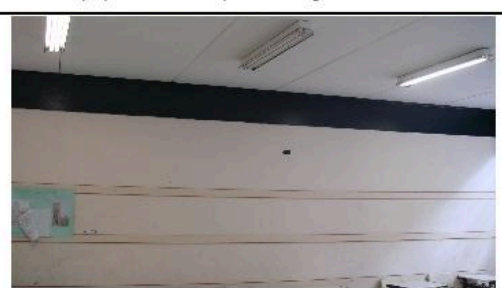

Evidência - aspecto crítico 1: exemplo de ambiente no qual foi previsto ponto de energia para instalação do ventilador e o equipamento não foi instalado. Fonte: Acervo da pesquisadora 
APÊNDICE D - EXEMPLOS DE FICHA DE ESPECIFICAÇÕES DE COMPONENTES 
MELHORIA CONTÍNUA APLICADA A Database_SPEducational_Facilities
Ficha de componente Balcão de atendimento BA-12

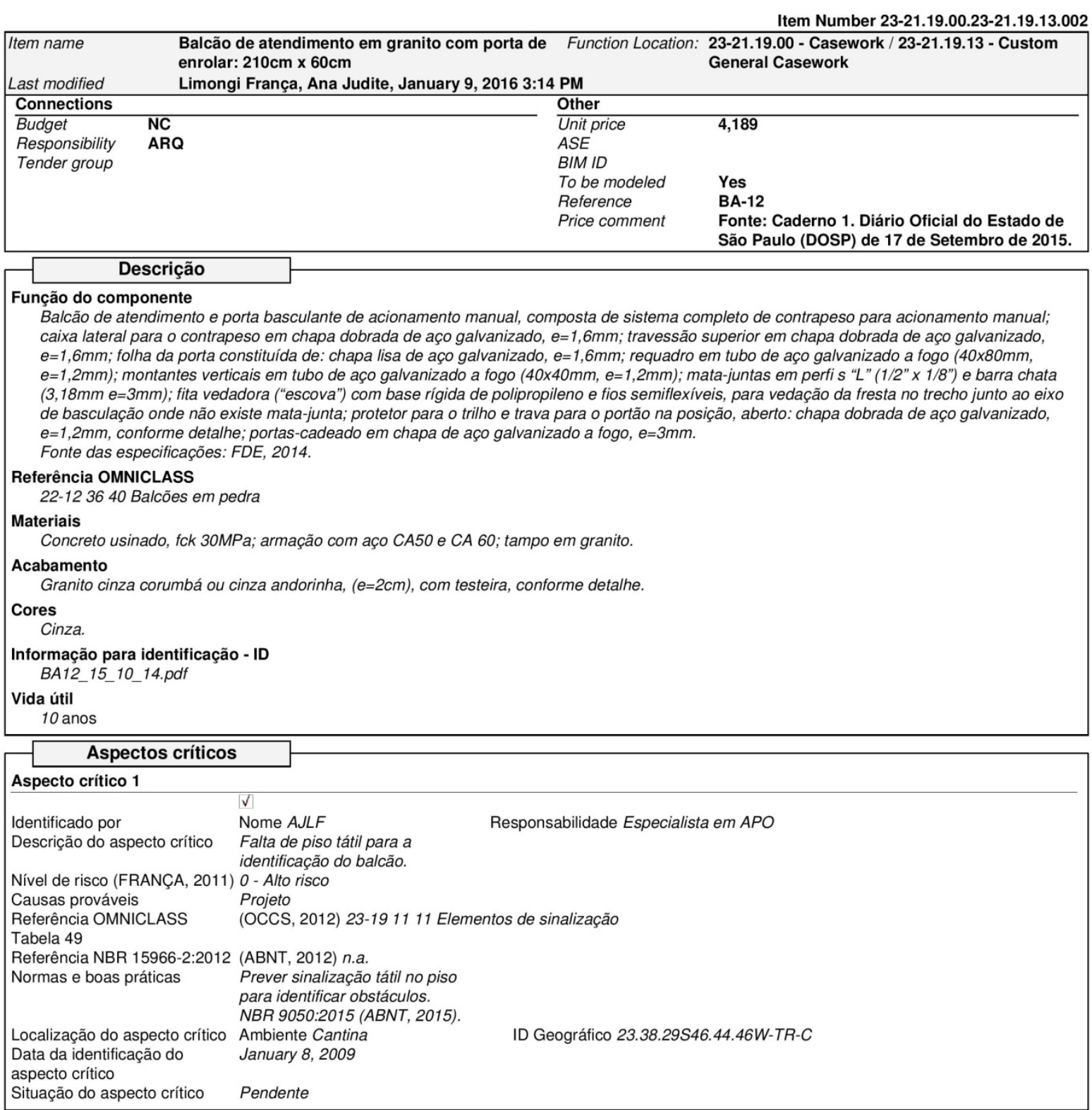

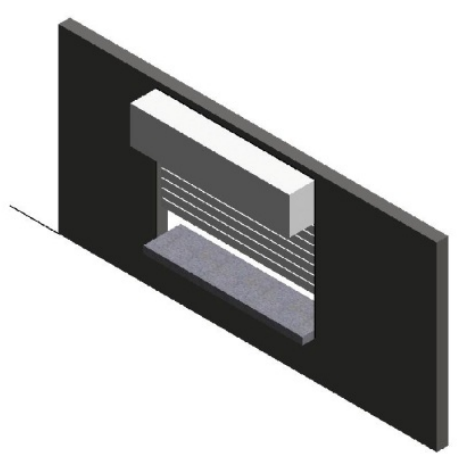

Imagem obtida a partir do modelo tridimensional, elaborado por utilizando o programa Revit 2014. Fonte: Acervo da pesquisadora 
Ficha de componente

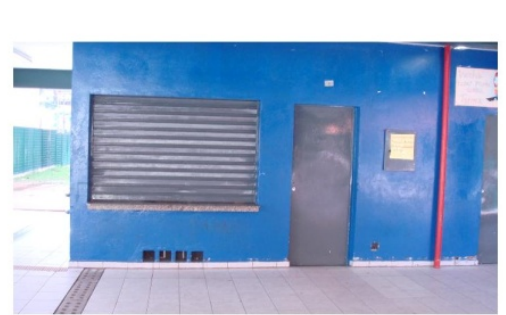

Item Number 23-21.19.00.23-21.19.13.002

Evidência de aspecto crítico: Balcão BA-02 não apresenta sinalização tátil no piso, para identificação de obstáculo. Fonte: Acervo da pesquisadora.

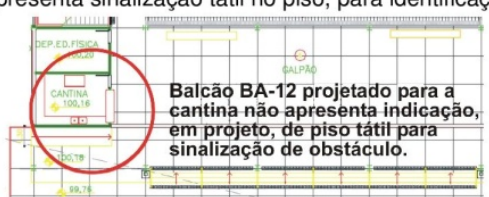

Evidência de aspecto crítico: Planta do pavimento térreo não apresenta indicação de sinalização tátil no piso, para o balcão BA-12. Detalhe da planta 0059199_01APE0200_01.dwg. Fonte: Acervo da FDE. 

MELHORIA CONTÍNUA APLICADA A
EDIFICAÇOEES DE TIPOLOGIA PADRONIZADA

Database SPEducational Facilities
Ficha de componente

Carteira escolar (conjunto aluno) CJA-04

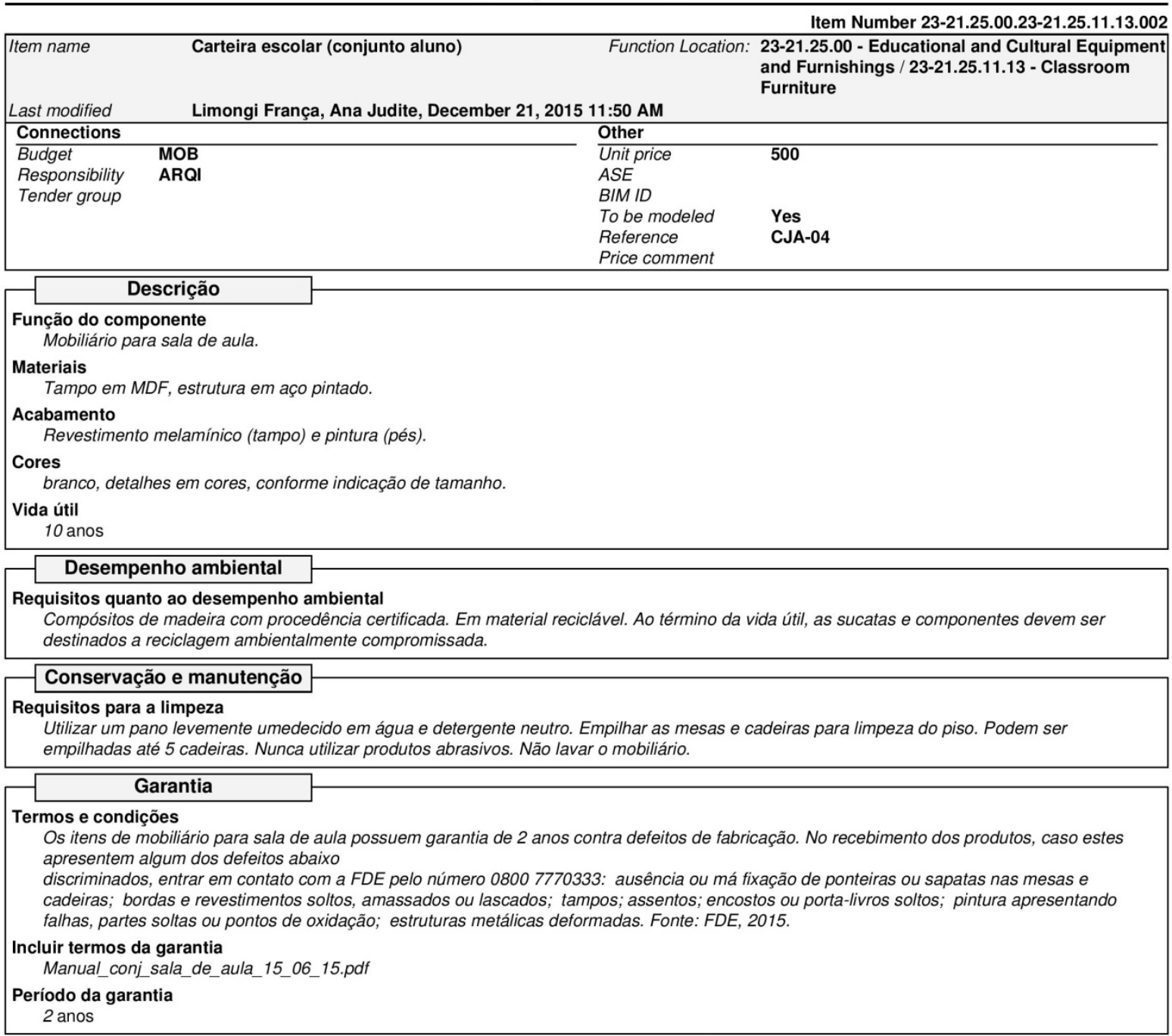

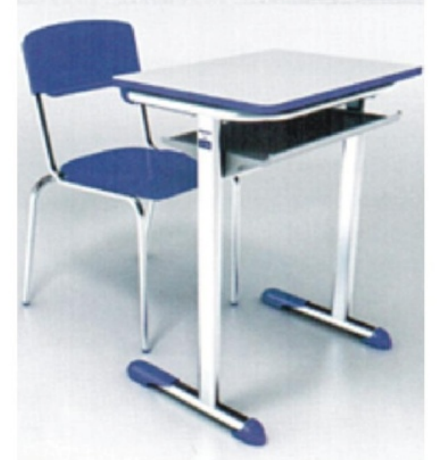

Fonte da imagem: Acervo FDE (FDE, 2014) 
MELHORIA CONTINUUA APLICADA A

Ficha de componente Lousa quadriculada QB-01

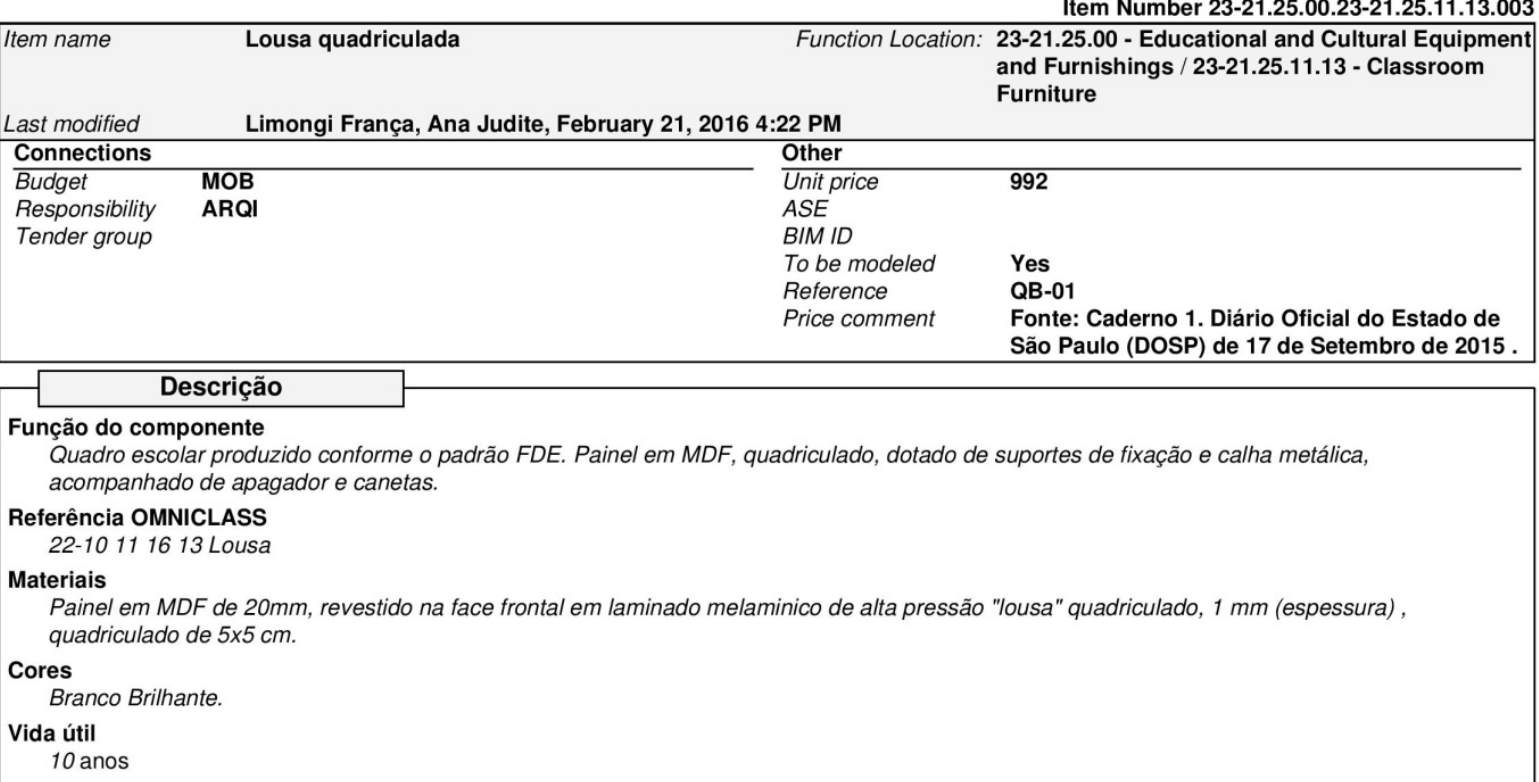

Entrega/Instalação

Informações para a instalação 34.85

\section{Garantia}

Termos e condições

Dois anos contra defeitos de fabricação. Fixar Etiqueta auto adesiva vinílica ou de alumínio com informações impressas de forma permanente, do tamanho mínimo $80 \mathrm{~mm}$ x $40 \mathrm{~mm}$, a ser fi xada na parte posterior do painel, contendo:

-Nome do fornecedor;

-Nome do fabricante;

-Logomarca do fabricante;

-Endereço / telefone do fornecedor;

-Data de fabricação (mês/ano);

№ do contrato;

- Garantia até__ _ (24 meses após a data da nota fiscal de entrega),

Código FDE do móvel.

Período da garantia

$$
2 \text { anos }
$$

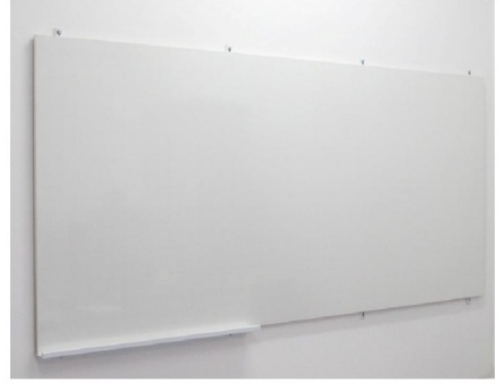

Fonte da imagem: Acervo FDE (FDE, 2004). 
APÊNDICE E - CONSIDERAÇÕES SOBRE OS RECURSOS TECNOLÓGICOS E AS FERRAMENTAS COMPUTACIONAIS UTILZADAS

\section{Recursos utilizados para a pesquisa}

\begin{tabular}{|c|c|c|c|}
\hline \multicolumn{2}{|c|}{ Início da pesquisa (2012) } & \multicolumn{2}{|c|}{ Término da pesquisa (2015) } \\
\hline \multicolumn{4}{|l|}{ Hardware } \\
\hline \multicolumn{2}{|c|}{ Computador de uso pessoal } & \multicolumn{2}{|c|}{ Computador de uso pessoal } \\
\hline Processador & Intel i7-2,7GHz & Processador & Intel i7-2,7GHz \\
\hline Memória RAM & $\begin{array}{l}16 \text { GB Total, usados } 3 \text { GB pelo } \\
\text { Windows XP }\end{array}$ & Memória RAM & 16 GB Total, usados 3 GB pelo Windows 7 \\
\hline Armazenamento & Memória Flash 512 GB & Armazenamento & Memória Flash 512 GB \\
\hline Placa de vídeo & $\begin{array}{l}\text { NVIDIA GE FORCE GT 650m- } \\
\text { 1024MB }\end{array}$ & Placa de vídeo & NVIDIA GE FORCE GT 650m-1024MB \\
\hline Monitor & $15^{\prime \prime}$, resolução 2880 x 1800 & Monitor & $15^{\prime \prime}$, resolução 2880 x 1800 \\
\hline Monitor & $21,5^{\prime \prime}$ resolução & Monitor & 21,5" resolução \\
\hline \multicolumn{4}{|c|}{ Sistema operacional } \\
\hline \multicolumn{2}{|c|}{ Microsoft Windows XP Pro 32 bits, SP3 } & \multicolumn{2}{|c|}{ Microsoft Windows 77 Ultimate 64 bits } \\
\hline
\end{tabular}

\begin{tabular}{|c|c|c|c|}
\hline \multicolumn{2}{|l|}{ Início da pesquisa (2012) } & \multicolumn{2}{|l|}{ Término da pesquisa (2015) } \\
\hline $\begin{array}{l}\text { Programas } \\
\text { computacionais }\end{array}$ & Uso & Programas computacionais & Uso \\
\hline \multirow[t]{2}{*}{$\begin{array}{l}\text { Mozilla Fire Fox } \\
\text { (navegador de internet) }\end{array}$} & \multirow{2}{*}{$\begin{array}{l}\text { Captura da lista de } \\
\text { endereços das escolas } \\
\text { objeto de análise. }\end{array}$} & \multirow[t]{2}{*}{$\begin{array}{l}\text { Mozilla Fire Fox (navegador de } \\
\text { internet) }\end{array}$} & $\begin{array}{l}\text { Captura da lista de endereços } \\
\text { das escolas objeto de análise. }\end{array}$ \\
\hline & & & $\begin{array}{l}\text { Acesso ao Banco de Dados e } \\
\text { compilação de relatórios. }\end{array}$ \\
\hline Google Earth & $\begin{array}{l}\text { Localização de endereços } \\
\text { e visualização de imagens } \\
\text { aéreas - localização de } \\
\text { endereços nas imagens } \\
\text { aéreas. }\end{array}$ & Google Earth & $\begin{array}{l}\text { Localização de endereços e } \\
\text { visualização de imagens aéreas } \\
\text { - localização de endereços nas } \\
\text { imagens aéreas. }\end{array}$ \\
\hline Terraview V. 4.2.2 & Geoprocessamento. & Terraview V. 4.2.2 & Geoprocessamento. \\
\hline Microsoft Access 2007 & $\begin{array}{l}\text { Configuração e edição de } \\
\text { tabelas. Configuração de } \\
\text { colunas para } \\
\text { compatibilização com o } \\
\text { programa Terraview. }\end{array}$ & Autodesk Revit 2014 & $\begin{array}{l}\text { Modelagem tridimensional e } \\
\text { configuração paramétrica. }\end{array}$ \\
\hline
\end{tabular}




\begin{tabular}{|c|c|c|c|}
\hline Autodesk Revit 2012 & $\begin{array}{l}\text { Modelagem } \\
\text { tridimensional e } \\
\text { configuração } \\
\text { paramétrica. }\end{array}$ & dRofus v. 1.8 & $\begin{array}{l}\text { Plataforma de Banco de Dados } \\
\text { MySQL. }\end{array}$ \\
\hline DB Link v. 2012 (plug-in) & $\begin{array}{l}\text { Exportação e importação } \\
\text { de informações entre os } \\
\text { programas Revit e Access. }\end{array}$ & Solibri Model Checker & $\begin{array}{l}\text { Verificação e validação do } \\
\text { modelo. }\end{array}$ \\
\hline Microsoft Excel 2007 & $\begin{array}{l}\text { Elaboração de planilhas e } \\
\text { tratamento de dados. }\end{array}$ & \multirow[t]{2}{*}{ Excel 2007} & \multirow[t]{2}{*}{$\begin{array}{l}\text { Elaboração de planilhas e } \\
\text { tratamento de dados. }\end{array}$} \\
\hline Microsoft Access 2007 & $\begin{array}{l}\text { Configuração e edição de } \\
\text { tabelas. Configuração de } \\
\text { colunas para } \\
\text { compatibilização com o } \\
\text { programa Terraview. }\end{array}$ & & \\
\hline
\end{tabular}


APÊNDICE F - INFORMAÇÕES UTILIZADAS PARA A MODELAGEM:

Os seguintes documentos foram utilizados para a modelagem das informações na plataforma de Banco de Dados e para a elaboração do modelo tridimensional:

\begin{tabular}{|c|c|c|}
\hline Nome do arquivo & Conteúdo & Data \\
\hline 1A.Diretor.pdf & Ficha técnica de ambiente & $10 / 2008$ \\
\hline 2A.Vice-diretor.pdf & Ficha técnica de ambiente & $10 / 2008$ \\
\hline 3C.Secretaria.pdf & Ficha técnica de ambiente & $10 / 2008$ \\
\hline 4B.Almoxarifado.pdf & Ficha técnica de ambiente & $10 / 2008$ \\
\hline 5B.Coordenação.pdf & Ficha técnica de ambiente & $10 / 2008$ \\
\hline 7A.Conjunto Sant. Adm.pdf & Ficha técnica de ambiente & $10 / 2008$ \\
\hline 8B.Sala de Aula.pdf & Ficha técnica de ambiente & $06 / 2010$ \\
\hline 9B.Sala de Reforço.pdf & Ficha técnica de ambiente & $06 / 2010$ \\
\hline 11A.Sala de Leitura-M4-M5-M6.pdf & Ficha técnica de ambiente & $12 / 2008$ \\
\hline 12B.Sala de Informática.pdf & Ficha técnica de ambiente & $10 / 2008$ \\
\hline 13A.Depósito Mat. Ped..pdf & Ficha técnica de ambiente & $10 / 2008$ \\
\hline 14A.Cozinha, Despensa.pdf & Ficha técnica de ambiente & $10 / 2008$ \\
\hline 15B.Refeitório.pdf & Ficha técnica de ambiente & $10 / 2008$ \\
\hline 16A.Cantina.pdf & Ficha técnica de ambiente & $10 / 2008$ \\
\hline 17A.Conjunto Sanit. Alunos.pdf & Ficha técnica de ambiente & $10 / 2008$ \\
\hline 18B.Gêmio.pdf & Ficha técnica de ambiente & $10 / 2008$ \\
\hline 19B. Dep. Mat. Ed. Física.pdf & Ficha técnica de ambiente & $10 / 2008$ \\
\hline 20C.Espaço Multiesportivo.pdf & Ficha técnica de ambiente & $10 / 2008$ \\
\hline 21A. Pátio Coberto.pdf & Ficha técnica de ambiente & $10 / 2008$ \\
\hline 22A. Dep. Mat. Limpeza.pdf & Ficha técnica de ambiente & $10 / 2008$ \\
\hline 23A.Conj. Sanit. Func..pdf & Ficha técnica de ambiente & $10 / 2008$ \\
\hline 24.Circulação horizontal e vertical.pdf & Ficha técnica de ambiente & $10 / 2008$ \\
\hline 25. Acessibilidade ao edifício.pdf & Ficha técnica de ambiente & $10 / 2008$ \\
\hline Fluxograma.pdf & Ficha técnica de ambiente & $10 / 2008$ \\
\hline Programas arquitetônicos.pdf & Ficha técnica de ambiente & $10 / 2008$ \\
\hline
\end{tabular}




\begin{tabular}{|c|c|c|}
\hline 0059199_01APE0100_01.dwg & $\begin{array}{l}\text { Projeto de arquitetura executivo - Levantamento } \\
\text { Topográfico }\end{array}$ & $06 / 2005$ \\
\hline 0059199_01APE0200_01.dwg & Projeto de arquitetura executivo - Implantação & 06/2005 \\
\hline 0059199_01APE0300_01.dwg & Projeto de arquitetura executivo - Pavimento Térreo & $06 / 2005$ \\
\hline 0059199_01APE0400_01.dwg & $\begin{array}{l}\text { Projeto de arquitetura executivo - Primeiro pavimento } \\
\text { e detalhes construtivos }\end{array}$ & $06 / 2005$ \\
\hline 0059199_01APE0500_01.dwg & $\begin{array}{l}\text { Projeto de arquitetura executivo - Planta de cobertura } \\
\text { e detalhes construtivos }\end{array}$ & $06 / 2005$ \\
\hline 0059199_01APE0600_01.dwg & Projeto de arquitetura executivo - Cortes & $06 / 2005$ \\
\hline 0059199_01APE0700_01.dwg & Projeto de arquitetura executivo - Cortes & $06 / 2005$ \\
\hline 0059199_01APE0800_01.dwg & $\begin{array}{l}\text { Projeto de arquitetura executivo - Cortes e detalhes } \\
\text { construtivos }\end{array}$ & $06 / 2005$ \\
\hline 0059199_01APE0900_01.dwg & Projeto de arquitetura - Elevações & $06 / 2005$ \\
\hline 0059199_01APE01000_01.dwg & $\begin{array}{l}\text { Projeto de arquitetura executivo - Planta da cozinha e } \\
\text { detalhes construtivos }\end{array}$ & $06 / 2005$ \\
\hline 0059199_01APE01100_01.dwg & $\begin{array}{l}\text { Projeto de arquitetura executivo - Escada e detalhes } \\
\text { construtivos }\end{array}$ & $06 / 2005$ \\
\hline 0059199_01APE01200_01.dwg & $\begin{array}{l}\text { Projeto de arquitetura executivo - Escada e detalhes } \\
\text { construtivos }\end{array}$ & $06 / 2005$ \\
\hline 0059199_01APE01300_01.dwg & $\begin{array}{l}\text { Projeto de arquitetura executivo - Detalhes } \\
\text { construtivos }\end{array}$ & $06 / 2005$ \\
\hline 0059199_01APE0100_01.dwg & $\begin{array}{l}\text { Projeto de arquitetura executivo - Detalhes } \\
\text { construtivos }\end{array}$ & $06 / 2005$ \\
\hline 0059199_01TLT0201_01.dwg & Levantamento planialtimétrico e cadastral & não fornecida \\
\hline 0059199_01TLT0201_02.dwg & Levantamento planialtimétrico e cadastral & não fornecida \\
\hline Ana_Limongi_Dissertação.pdf & Diagnóstico de APO & $05 / 2011$ \\
\hline
\end{tabular}

Fonte das fichas técnicas <http://www.fde.sp.gov.br/PORTAL_FDE>. Acesso em 8 out. 2010.

Fonte dos projetos: Acervo da FDE.

Fonte do diagnóstico de APO: FRANÇA, 2011.

Fonte: Acervo da pesquisadora. 
ANEXOS 
ANEXO A - EXEMPLO DE FICHA TÉCNICA DE AMBIENTE MODELO FDE

Diretor

CONJUNTO FUNCIONAL

PROGRAMA ARQUITETÔNICO

MÓDULO BÁSICO

DATA
Direção / Administração

Ciclo I - Ciclo II - Ensino Médio

M1 - M2 - M3 - M4 - M5 - M6

Outubro / 2008

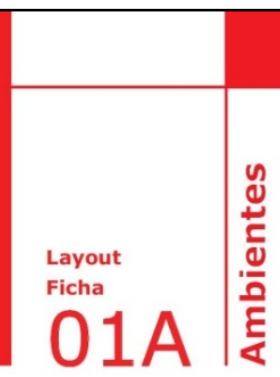

Área $\quad 9,72 \mathrm{~m}^{2}$

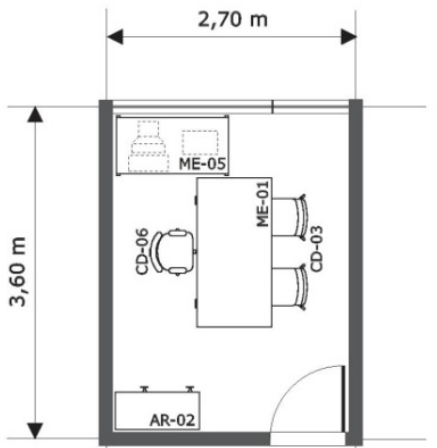

Escala $1: 75$ 


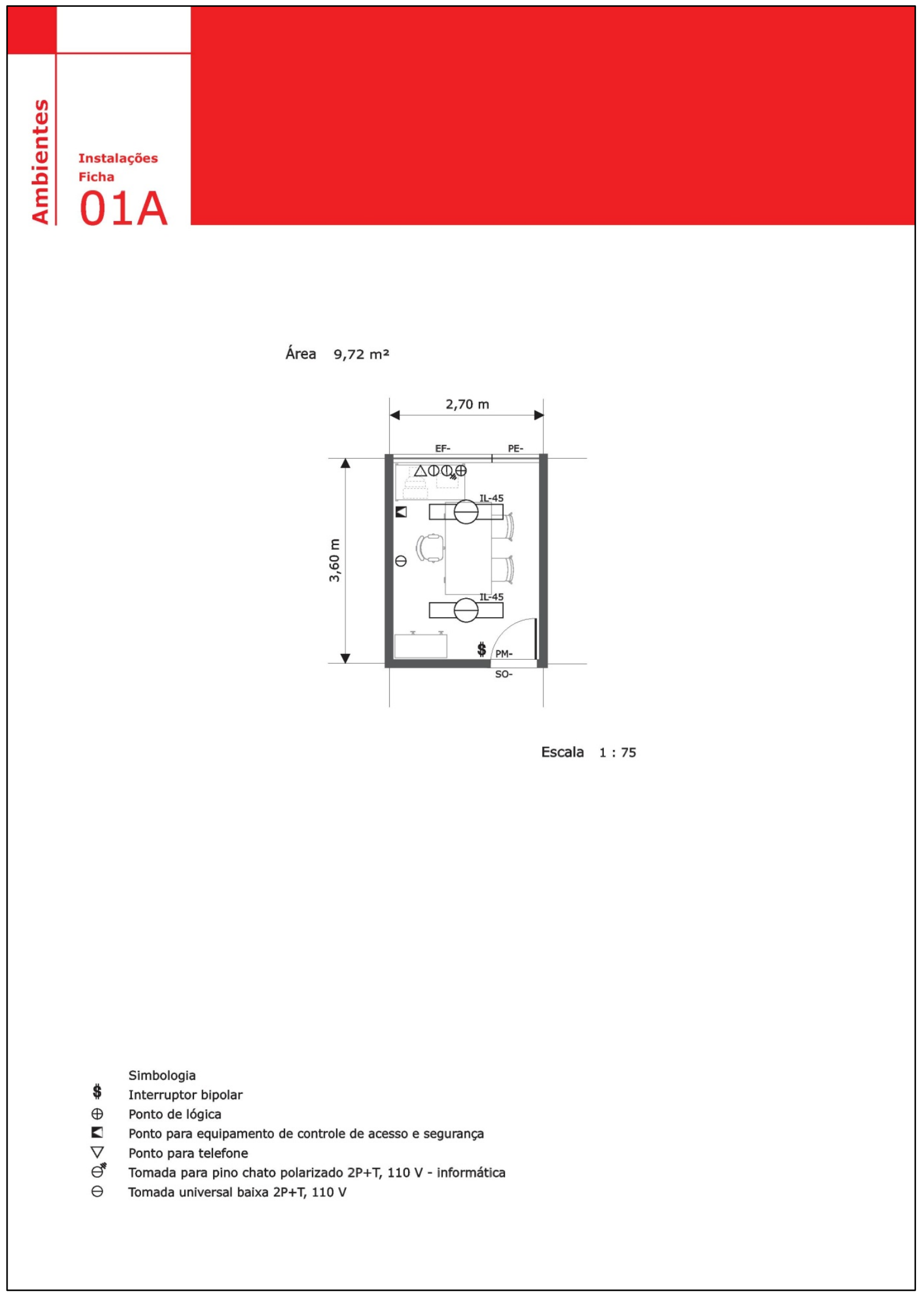




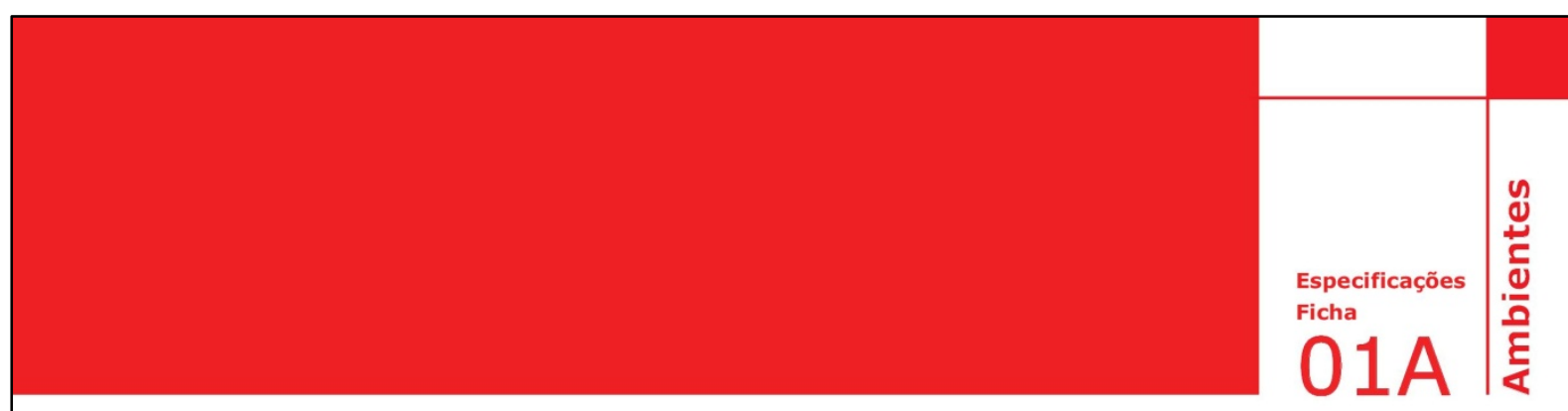

CARACTERIZAÇÃo DO AMBIENTE

- Direção e coordenação das atividades gerais da escola.

\section{DIRETRIZES PARA PROJETO}

- Ambiente localizado próximo à secretaria.

- Ambiente sujeito a invasão sendo necessário maior nível de segurança.

- Requisitos a considerar:

- Prever espaço para 02 mesas, 02 cadeiras fixas, 01 cadeira giratória.

- Prever local para 01 armário.

- Prever sinalização do ambiente.

\section{EXIGÊNCIAS AMBIENTAIS}

- Pé direito mínimo: 2,70m.

- Área de iluminação natural mínima: $1 / 5$ da área de piso.

- Área de ventilação natural mínima: $1 / 10$ da área de piso.

- A profundidade do ambiente em relação ao posicionamento dos caixilhos não poderá ser superior a três

vezes seu pé direito, incluída na profundidade a projeção de saliências ou cobertura.

- Laje obrigatória.

- Iluminação fluorescente.

- Nível mínimo de iluminamento: 300 lux.

- Carga acidental a ser prevista: $200 \mathrm{kgf} / \mathrm{m}^{2}$.

- Classificação acústica: privativo.

\section{INSTALAÇÕES}

1 interruptor bipolar ( $h=1,10 \mathrm{~m}$ do piso)

2 tomadas universais baixas $2 \mathrm{P}+\mathrm{T}, 110 \mathrm{~V}$ ou de acordo com a tensão local ( $\mathrm{h}=0,30 \mathrm{~m}$ do piso)

1 tomada para pino chato polarizado $2 \mathrm{P}+\mathrm{T}, 110 \mathrm{~V}$ - informática $(\mathrm{h}=0,30 \mathrm{~m}$ do piso)

2 luminárias / lâmpadas fluorescentes / 2 × 32W (IL-45)

1 ponto para telefone - tubulação seca ( $h=0,30 \mathrm{~m}$ do piso)

1 ponto de lógica - tubulação seca ( $h=0,50 \mathrm{~m}$ do piso)

1 ponto para equipamento de controle de acesso e segurança - tubulação seca ( $h=2,20 \mathrm{~m}$ do piso)

\section{COMPONENTES A SEREM INDICADOS EM PROJETO}

EF- esquadria de ferro a especificar

IL-45 luminária aberta com refletor para lâmpada fluorescente - $2 \times 32 \mathrm{~W}$

PE- peitoril a especificar

$\begin{array}{ll}\text { PE- } & \text { peitoril a especificar } \\ \text { PM- } & \text { porta a especificar }(L=82 \mathrm{~cm})\end{array}$

$\begin{array}{ll}\text { PM- } & \text { porta a especificar }(L=82 c h \\ \text { RS- } & \text { sinalização a especificar }\end{array}$

SO- $\quad$ soleira rampada a especificar

\section{MOBILIÁRIO E EQUIPAMENTOS}

Quantidade Código Discriminação

01 AR-02 armário de aço $/ 2$ portas $(90 \mathrm{~cm} \times 40 \mathrm{~cm}-\mathrm{h}=160 \mathrm{~cm})$

01 BD-01 bandeira nacional

01 BD-02 bandeira paulista

02 CD-03 cadeira fixa $(40 \mathrm{~cm} \times 38 \mathrm{~cm}-\mathrm{h}=44 \mathrm{~cm})$

01 CD-06 cadeira giratória para diretor $(46 \mathrm{~cm} \times 44 \mathrm{~cm}-\mathrm{h}=$ variável)

01 ME-01 mesa escrivaninha / 6 gavetas $(160 \mathrm{~cm} \times 80 \mathrm{~cm}-\mathrm{h}=74 \mathrm{~cm})$

01 ME-05 mesa de uso múltiplo $(120 \mathrm{~cm} \times 60 \mathrm{~cm}-\mathrm{h}=72 \mathrm{~cm})$

$01 *$ impressora

* equipamentos a serem atendidos através de projetos específicos da FDE/SEE. 
ANEXO B - LISTA DE CLASSES IFC DISPONÍVEIS PARA EXPORTAÇÃO, POR MEIO DO PROGRAMA AUTODESK REVIT V. 2014

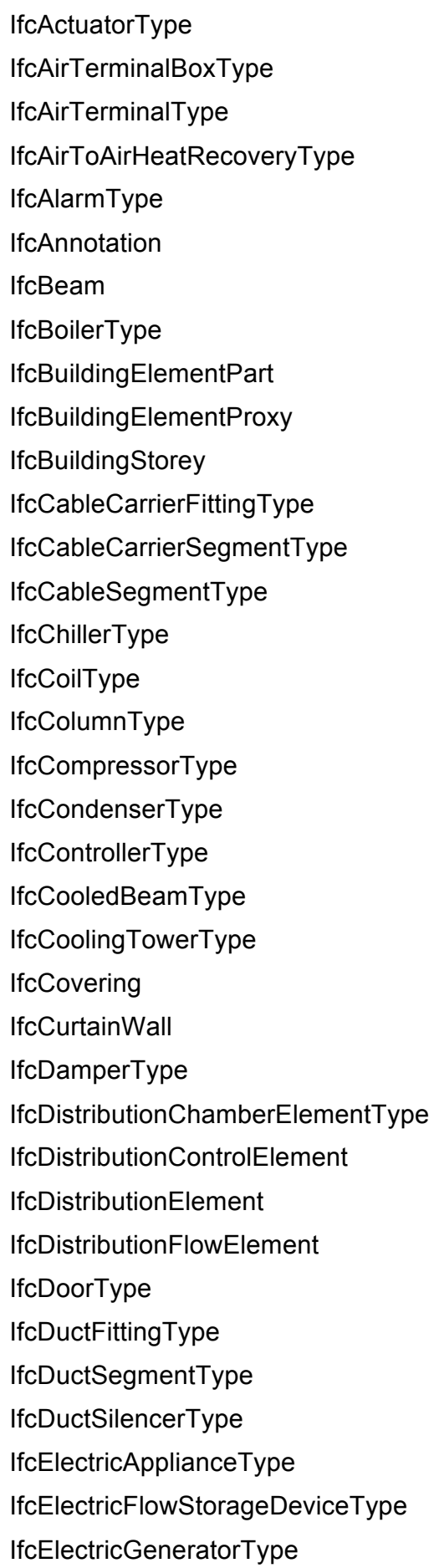

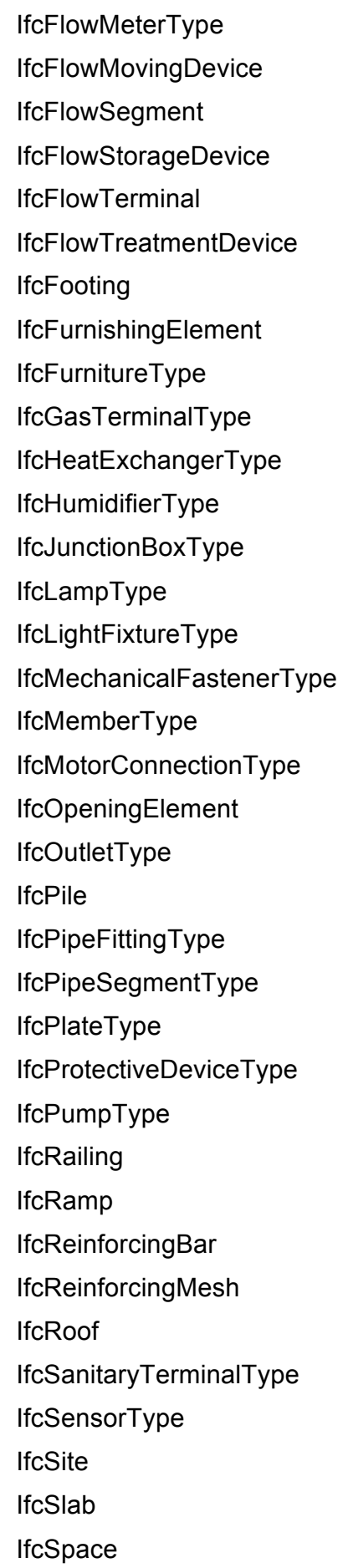


IfcElectricHeaterType

IfcElectricMotorType

IfcElectricTimeControlType

IfcElementAssembly

IfcEnergyConversionDevice

IfcEvaporativeCoolerType

IfcEvaporatorType

IfcFanType

IfcFastenerType

IfcFilterType

IfcFireSuppressionTerminalType

IfcFlowController

IfcFlowFitting

IfcFlowInstrumentType
IfcSpaceHeaterType

IfcStackTerminalType

IfcStair

IfcSwitchingDeviceType

IfcSystemFurnitureElementType

IfcTankType

IfcTransformerType

IfcTransportElementType

IfcTubeBundleType

IfcUnitaryEquipmentType

IfcValveType

IfcWall

IfcWasteTerminalType

IfcWindowType

Disponível em: <https://knowledge.autodesk.com/support/revit-products/learn-explore/caas/CloudHelp/cloudhelp/2016/ENU/RevitDocumentPresent/files/GUID-EE6COCF8-7671-4DCC-B0C7-EEA7513C90A9-htm.html>. Acesso em 04 nov. 2015. 


\section{ANEXO C - LISTA dE TABELAS QUE NÃO SÃO IMPORTADAS PELO PLUG-IN DB LINK}

Lista de tabelas não suportadas pelo plug-in DB Link V. 2014.

\section{Tables that do not support importing}

AnalyzesAsTypeEnums AreaLoadOnSlab AssemblyCodes CaseworkOnWall Categories ConditionTypeEnums CurtainWallPanelOnRoof CurtainWallPanelOnWall DoorWall DuctSystemTypeEnums EaveCutterTypeEnums ElectricalPhaseConfigurationEnums ElectricalPhaseEnums ElectricalSystemEnums ElementLevel ElementPhase GenericModelOnRoof GenericModelOnWall InstanceUsageEnums LightingFixtureOnCeiling LightingFixtureOnWall LineLoadOnBeam LoadClassificationTypeEnums MaterialQuantities MechanicalEquipmentOnWall NeutralModeEnums OmniClassNumbers OpeningOnFloor OpeningOnWall Openings PipeFlowStateEnums PipeSystemTypeEnums PlumbingFixtureOnWall PowerFactorStateTypeEnums RebarLayoutEnums RebarOnColumn RebarOnFloor RebarOnFoundation RebarOnFraming RebarOnWall RebarStyleEnums\&nb sp; RevitDBLinkInfo RoomAssociations RoomFromToAssociations RoomTags ServiceTypeEnums SpaceAssociations SpaceTypeEnums WallUsageEnums WindowWall WiringTypeEnums 